

\section{PARADIGMAS ANTAGÔNICOS: ARQUITETURA E ARTE CONTEMPORÂNEA NO MOMA DE NOVA YORK E NO PALAIS DE TOKYO DE PARIS}

\section{OPPOSING PARADIGMS: ARCHITECTURE AND CONTEMPORARY ART AT THE MOMA NEW YORK AND AT THE PALAIS DE TOKYO PARIS}

Tese apresentada ao Programa de Pós-Graduação da Faculdade de Arquitetura e Urbanismo da Universidade de São Paulo para obtenção do título de Doutora em Arquitetura e Urbanismo Área de Concentração: Projeto, Espaço e Cultura Orientador: Prof. Dr. Agnaldo Aricê Farias

Exemplar revisado e alterado em relação à versão original, sob responsabilidade da autora e anuência do orientador. A versão original, em formato digital, ficará arquivada na Biblioteca da Faculdade. 
Autorizo a reprodução e divulgação total ou parcial deste trabalho, com exceção dos apêndices, por qualquer meio convencional ou eletrônico, para fins de estudo e pesquisa, desde que citada a fonte.

Catalogação na Publicação

Serviço Técnico de Biblioteca

Faculdade de Arquitetura e Urbanismo da Universidade de São Paulo

Pontes, Ana Paula Gonçalves

Paradigmas Antagônicos: arquitetura e arte contemporânea no MoMA de Nova York e no Palais de Tokyo de Paris / Ana Paula Pontes; orientador Agnaldo Farias. - São Paulo, 2021. 660p.

Tese (Doutorado) - Faculdade de Arquitetura e Urbanismo da Universidade de São Paulo. Área de concentração: Projeto, Espaço e Cultura.

1. Arte Contemporânea. 2. Arquitetura Contemporânea. 3. Museus de Arte. 4. Exposições de Arte. I. Farias, Agnaldo Aricê, orient. II. Título.

Elaborado eletronicamente através do formulário disponivel em: $<$ http://www.fau.usp.br/fichacatalografica/> 
Nome: PONTES, Ana Paula Gonçalves.

Título: Paradigmas Antagônicos: arquitetura e arte contemporânea no MoMA de Nova York e no Palais de Tokyo de Paris. Tese (Doutorado em Arquitetura e Urbanismo) - Faculdade de Arquitetura e Urbanismo da Universidade de São Paulo, São Paulo, 2021.

Aprovado em 12/11/2021

Banca Examinadora

Prof. Dr. Agnaldo Aricê Caldas Farias

Instituição: FAU-USP

Julgamento: APROVADO

Profa. Dra. Ana Maria da Silva Araujo Tavares

Instituição: ECA-USP

Julgamento: APROVADO

Prof. Dr.Luiz Camillo Dolabella Portella Osório de Almeida

Instituição: PUC-Rio

Julgamento: APROVADO

Profa. Dra. Maria Paula Piazza Recena

Instituição: FAU-UFRGS / EXTERNO

Julgamento: APROVADO

Prof. Dr. João Masao Kamita

Instituição: PUCRJ / EXTERNO

Julgamento: APROVADO 

À SAUDOSA MEMÓRIA DE ANDRÉ STOLARSKI. 
Agradeço ao meu orientador, Agnaldo Farias, não apenas pela orientação instigante e precisa, mas também pelo estímulo para que esta tese existisse. O disparo inicial, que merece ser relatado, ocorreu no início de 2014, num encontro casual na sala de embarque do aeroporto Santos Dumont. Enquanto tomávamos café, o professor discorria animadamente sobre a estratégia que acabara de usar para convencer o público numa palestra sobre a importância de conhecer a fundo seu campo de atuação - remetendo-se à extrema erudição musical de certos roqueiros. Não pude deixar de me emocionar com a semelhança de seu modo de falar com a do querido amigo André Stolarski, que falecera havia menos de um ano em decorrência de um câncer. Os dois haviam sido muito próximos desde a adolescência de André, que fora convidado por Agnaldo para dirigir o departamento de design do MAM do Rio de Janeiro quando ele assumiu o cargo de curador da instituição, no fim dos anos 1990. Acabei juntando-me a eles em 1999, colaborando com a realização de projetos expográficos no museu, $o$ que marcou uma virada na minha vida profissional e pessoal. Mudei-me de São Paulo para o Rio de Janeiro, onde permaneci por dez anos, e aprendi desde então a trabalhar com diferentes instituições de arte e artistas contemporâneos, o que me motivou a prosseguir com minha formação acadêmica na pós-graduação.

Sob o impacto da saudade do amigo em comum, soou-me como bombástica a singela pergunta lançada por Agnaldo na hora da despedida: "E você, quando vai fazer seu doutorado?" Voei com o eco daquela ideia que, apesar de óbvia, estava soterrada em meio a outros planos. O enfático professor ainda arrematou com um torpedo, que li ao pousar em São Paulo: "E tem que ser logo!” Foi a centelha que me fez dar início ao processo de preparação para voltar como doutoranda à Faculdade de Arquitetura e Urbanismo da Universidade de São Paulo (FAUUSP), escola em que me graduei e à qual também sou grata pelo acolhimento e apoio.

Estendo os agradecimentos a diversas organizações e pessoas que me deram o suporte necessário para esta empreitada: 
À Faculdade de Arquitetura e Urbanismo da Universidade Presbiteriana Mackenzie (FAU Mackenzie), pelo incentivo e suporte para integrar esta pesquisa às atividades de docência.

Ao João Masao Kamita - com quem sigo dialogando desde a orientação no mestrado na PUC-Rio - e à Marta Bogéa, pelos comentários precisos na banca de qualificação.

À Patrícia Pereira Martins, pela interlocução e intensa troca de ideias ao longo de todo o trabalho, envolvidas em amizade e parceria em artigos, pesquisas e viagens.

A Ana Gabriela Godinho Lima, Pedro Puntoni e Rodrigo Mindlin Loeb, pelo acolhimento no Instituto Brasiliana e pelo apoio à realização de diversas atividades que impulsionaram esta pesquisa.

A Elizabeth Diller, Rebecca Lamarche-Vadel, Olivier Cinqualbre, Carlito Carvalhosa (in memorian) e Stéphane Maupin, pelas entrevistas concedidas.

À Anna Helena Villela, pela convivência nas atividades desta pós-graduação e parceria certeira nos projetos que desenvolvemos juntas.

À Elaine Ramos, pelo luxuoso apoio no projeto gráfico desta tese, e à Julia Paccola Nogueira, que lhe deu assistência na diagramação.

À Letícia Becker Savastano, pela cuidadosa revisão de texto, que propiciou um ótimo diálogo.

À Fanny Feigenson Grinfeld, pela participação entusiasmada nas viagens e demais atividades que fomentaram esta pesquisa e aos participantes dos Roteiro dos Museus em Nova York (2017), Paris (2018) e Londres (2019): Amanda Suzuki Locatelli, Ana Luisa Motta, Beatriz Karpuk, Bruna Lima Caracciolo, Carolina Madrid da Silva Prado, Claudia Getschko, Flávia Gallo, Gabriel Granado, Gabriela Queiroz Dantas da Silva, Gabrielle Maussen, Jose Carlos Navarro, Julia Getschko, Luca Corazza, Luiza Corte Bachert, Maria Victoria Rudge Leite, Mônica Fraga, Sheila Dryzun, Stephanie Loureiro Fantinato e ainda Gabriela Guerra e Thatiane Marah Pimentel Colognese, que gentilmente contribuíram para a transcrição de uma entrevista.

A Georgia Lemes e Isabela Trindade, pelo apoio como estagiárias de pesquisa. 
Ao Guilherme Wisnik, pela generosa disposição em compartilhar sua biblioteca e reunir pessoas em torno de discussões sobre arte, arquitetura e vida.

A amigos e colegas que me apoiaram de modo direto ou indireto, oferecendo dicas de pesquisa, comentários sobre meus textos, empréstimos de livros, auxílio com traduções e oportunidades de trabalho, recebendo-me em suas casas e escritórios e cobrindo minhas ausências em outras atividades: Aline Zorzo, Amanda Landeiro, Ana Maria Fasanella, Bertrand Beau, Camila Goulart, Caroline Fretin, Catherine Otondo, Celina Olga, Chris Andreacola, Daniela Getlinger, Denise Polônio, Edna Timbó, Felipe Rodrigues, Francesco Perrota-Bosch, Graziella Betting, Gustavo Moura, Heloísa Espada, Jayme Costa Pinto, Jorge Pereira, Joséphine Poirot-Delpech, Julio Vieira, Larissa Graça, Lia Soares, Lilian Tone, Lucas Fehr, Lucia Basto, Marcelo Barbosa, Marina Grinover, Marina Person, Mário Figueroa, Mayra Rodrigues, Mirtes Oliveira, Paula Signorelli, Raquel Ferreira, Ruth Verde Zein, Silvio Oksman, Tânia Rocha Pitta, Teresa Lima, Vico Iasi, Victor Kenji e Valentina Moimas.

Ao meu pai (in memorian), à minha mãe e à minha irmã, pelo carinho e apoio constantes, e às famílias Rosa de Moura e Barreto Lima, pelos braços sempre abertos.

E, por fim, ao Vini Barreto, por todo o amor e companheirismo, e aos nossos filhos, que compartilham conosco as dores e as delícias de nossa família combo. 


Esta pesquisa tem por objetivo investigar as tensões entre projetos arquitetônicos para edifícios destinados a exposições de arte e propostas artísticas contemporâneas que operam transformações nesses espaços, sob a mediação da moldura institucional, oferecendo subsídios para a reflexão sobre projetos de edifícios de museus e centros de arte. Para isso, foram eleitos como objetos de estudo duas instituições que exemplificam paradigmas considerados antagônicos de concepção institucional e arquitetônica para espaços de arte. Uma delas é o Museu de Arte Moderna de Nova York - Moma, com uma longa história de intervenções arquitetônicas desde o projeto de Philip Goodwin e Edward Stone de 1939, e que culmina nas duas últimas expansões e reformas: a inaugurada em 2004, com projeto do japonês Yoshio Taniguchi, e a completada em 2019, com projeto liderado pelo escritório estadunidense Diller Scofidio + Renfro. Investigou-se o desenvolvimento de um modelo de espaço expositivo idealizado e supostamente neutro praticado pelo museu desde os seus anos iniciais, que se estabeleceu como uma referência onipresente para espaços de arte moderna e contemporânea no ocidente e foi posteriormente nomeado por Brian O'Doherty de "cubo branco". A segunda é o Palais de Tokyo de Paris, "local de criação contemporânea", uma kunsthalle implantada em um edifício histórico deteriorado, com projeto arquitetônico do escritório francês Lacaton \& Vassal inaugurado em duas etapas, em 2002 e 2012. Analisou-se criticamente a proposta de oferecer para a arte contemporânea ambientes sem acabamentos como contraponto ao padrão "cubro branco". Partindo da análise cruzada de exposições e espaços arquitetônicos nessas duas instituições, a hipótese é a de que a contenção demandada para locais destinados a abrigar exposições de arte contemporânea não implique necessariamente numa ambientação genérica ou anódina, mas que, ao contrário, seja compatível com arquiteturas e configurações expográficas que tornem perceptíveis as condições particulares de seus respectivos contextos de inserção, valorizados como inputs para concepções artísticas.
Arte Contemporânea; arquitetura contemporânea; museus de arte; exposições de arte; expografia; cubo branco; момA; Palais de Tokyo. 

This research aims to investigate the tensions between architectural projects for art exhibition buildings and contemporary art proposals that operate spatial transformations under the mediation of a given institutional framework, offering reflection subsidies for museums and art centers designs. The institutions chosen as case studies exemplify antagonistic paradigms of both institutional conception and architectural design for art spaces. The first one is the Museum of Modern Art in New York - MOMA, with a long history of architectural interventions since the 1939 Philip Goodwin and Edward Stone project, that culminates in the last expansion and renovation proposals: one by the Japanese architect Yoshio Taniguchi, inaugurated in 2004, and the other by the North American office Diller Scofidio + Renfro, completed in 2019. The research investigates the development of an idealized and supposedly neutral model for exhibition spaces practiced by момА since its early years, that became ubiquitous reference for modern and contemporary art spaces in Western culture and was later named by Brian O'Doherty as the "white cube". The second case is the Palais de Tokyo in Paris, "site for contemporary arts", a kunsthalle housed in a ruined historic building, designed by the French office Lacaton \& Vassal and inaugurated in two stages, in 2002 and 2012. The proposal to maintain low finishing environments for contemporary art exhibitions is critically evaluated as a counterpoint to the "white cube" standard. Based on cross-analysis of exhibitions and architectural spaces practiced by these institutions, the hypothesis is that the moderation required for contemporary art exhibitions venues does not necessarily implies on a generic or anodyne setting, on the contrary, this condition may be consistent with architectures and exhibition designs that enhance and/or highlight particular conditions of their respective contexts as valuable inputs for artistic conception.
Contemporary art; contemporary architecture; art museums; art exhibitions; exhibition design; white cube; мома; Palais de Tokyo. 
NEGOCIAÇÕES ENTRE ARQUITETURA, ARTE CONTEMPORÂNEA E INSTITUIÇÃO: PROJETO EXPOGRÁFICO PARA AS MOSTRAS DE ANRI SALA NO INSTITUTO MOREIRA SALLES

INSTITUIÇÕES E ARQUITETURA DIANTE DA CONQUISTA DO “ESPAÇO REAL” PELA ARTE CONTEMPORÂNEA

O MOMA E O PALAIS DE TOKYO COMO PARADIGMAS

EDIFÍCIOS, INSTITUIÇÕES E EXPOSIÇÕES EM PERSPECTIVA HISTÓRICA

IMPASSES, DESAFIOS E POTENCIALIDADE PARA A ARQUITETURA

\section{QUANDO 0 CONTEMPORÂNEO} ERA MODERNO: 0 MOMA COMO CÂNONE

1.1 ANOS DE FORMAÇÃO: 1929 A 1948

1.1.1 UM MUSEU DE ARTE “CONTEMPORÂNEA” NO INÍCIO DO SÉCULO XX 66

1.1.2 UM MODO DE EXPOR ESTETIZADO EM CONTEXTOS PROVISÓRIOS

1.1.3 TORPEDO EM EXPOSIÇÃO

1.1.4 ARQUITETURA (DE COMPROMISSO) COMO REPRESENTAÇÃO DO MODERNO: A PRIMEIRA SEDE PRÓPRIA

1.1.5 CONVERGÊNCIA ENTRE EXPOGRAFIA E ARQUITETURA 106

1.1.6 DIVERSIFICAÇÃO DE PRÁTICAS EXPOGRÁFICAS EM ÉPOCA DE POLITIZAÇÃO 110

1.1.7 NACIONALISMO À AMERICANA 123

1.1.8 OUTROS MODOS DE EXPOR ARTE MODERNA

1.1.9 CONFLITOS INSTITUCIONAIS E A CONSOLIDAÇÃO DA VANGUARDA NORTE AMERICANA

1.2 EXPANSÃO E CONSOLIDAÇÃO: 1949 A 1968

1.2.1 SOB NOVA DIREÇÃO

1.2.2 UM NOVO JARDIM MODERNO COMO “CORAÇÃO" DO MUSEU

1.2.3 A VALORIZAÇÃO DA COLEÇÃO

1.2.4 A LEGITIMAÇÃO DO MODERNISMO ESTADUNIDENSE 


\section{O MOMA ENTRE ENCONTROS E DESENCONTROS COM A ARTE CONTEMPORÂNEA}

2.20 MOMA EM TURBULÊNCIA: 1969 E 70

2.2.1 SOB PROTESTOS 208

2.2.2 O LENTO ACOLHIMENTO A INSTALAÇÕES 217

2.2.3 ARTE CONCEITUAL E OS LIMITES INSTITUCIONAIS 224

2.3 À MARGEM DAS CONVENÇÕES: ANOS 1960 E 1970

2.3.1 ESPAÇOS ALTERNATIVOS COMO LABORATÓRIOS DA ARTE CONTEMPORÂNEA 233

2.3.2 PS1 COMO ANTI-MUSEU: A INSTITUCIONALIZAÇÃO DO ALTERNATIVO 242

2.3.3 O CONCEITO DE CUBO BRANCO COMO CRÍTICA AO MUSEU MODERNISTA 253

2.4 MOMA E AS INICIATIVAS PONTUAIS DE ATUALIZAÇÃO: ANOS 1970 A 90256

2.4.1 ARTE CONTEMPORÂNEA EM DOSES CONTROLADAS 256

2.4.2 O FLERTE COM O PÓS MODERNO NA EXPANSÃO DOS ANOS 80

2.4.3 ARTISTAS NO PAPEL DE CURADORES 276

2.4.4 A ASSIMILAÇÃO DAS INSTALAÇÕES 281

2.5 MOMA E PS1: O ENCONTRO DE DOIS PARADIGMAS OPOSTOS NO FIM DO SÉCULO XX

2.5.1 A CONSOLIDAÇÃO DO PS1 COMO MODELO PARA A ARTE CONTEMPORÂNEA 291

2.5.2 UMA FUSÃO INESPERADA 299 
3.1 A EXPANSÃO DA VIRADA DO MILÊNIO: 1996 A 2004

3.1.1 A CONCEITUAÇÃO DE UM MUSEU CONTEMPORÂNEO

3.1.2 ESPAÇO CRÍTICO E CELEBRATÓRIO 328

3.1.3 O PROCESSO DE ESCOLHA DE UMA PROPOSTA ARQUITETÔNICA 331

3.1.4 O PROJETO VENCEDOR DE TANIGUCHI

3.1.5 UM PROCESSO “EXTRAORDINÁRIO" PARA O DESENVOLVIMENTO DO PROJETO 347

3.1.6 ESPAÇOS DA ARTE NO NOVO PROJETO 350

3.1.7 RECEPÇÃO CRÍTICA EM 2004

3.1.8 ARTE CONTEMPORÂNEA NO NOVO MOMA 371

3.2 A MAIS RECENTE EXPANSÃ0: 2014 A 2019

3.2.1 RENOVAÇÃO CURATORIAL 396

3.2.2 AS RAZÕES DA ESCOLHA DO ESTÚDIO DILLER SCOFIDIO + RENFRO 402

3.2.3 RECEPÇÃO E CIRCULAÇÃO NA AMPLIAÇÃO DE DILLER SCOFIDIO + RENFRO E GENSLER

3.2.4 GALERIAS DE EXCEÇÃO PARA A ARTE

3.2.5 NEUTRALIDADE, FLEXIBILIDADE E A EXPRESSÃO ARQUITETÔNICA NOS ESPAÇOS DE ARTE

3.2.6 ARTE NAS ÁREAS INTERSTICIAIS DO MUSEU 436

3.2.7 A NOVA APRESENTAÇÃO DA COLEÇÃO 445

$\begin{array}{ll}\text { 3.2.8 EXPOSIÇÕES TEMPORÁRIAS } & 467\end{array}$

3.2.9 RECEPÇÃO CRÍTICA EM 2019

3.2.10 UM TERRITÓRIO ABERTO 


\section{O PALAIS DE TOKYO EA ARQUITETURA DO MUNDANO 487}

4.1 UM PALÁCIO PARA A ARTE MODERNA NA FRANÇA: ANOS 1930 A 1970491

4.1.1 UM EDIFÍCIO ANACRÔNICO 492

4.1.2 MUSEUS EM CONFLITOS DE IDENTIDADE 498

4.2 O PALAIS DE TOKYO COMO “LOCAL DE CRIAÇÃO CONTEMPORÂNEA": ANOS 2000 A 2010

\begin{tabular}{lll}
\hline 4.2.1 UM PROJETO COMPARTILHADO & 512
\end{tabular}

4.2.2 O IDEAL DE LIBERDADE: A PRAÇA E O FUN PALACE 533

4.2.3 NO DOMÍNIO DA ARTE 544

4.2.4 MATURIDADE OU INSTITUCIONALIZAÇÃO? 556

4.2.5 O QUE HÁ DE ESPECÍFICO PARA A ARTE CONTEMPORÂNEA NO PALAIS DE TOKYO

\section{CONCLUSÃO}

O CUBO BRANCO COMO REFERÊNCIA CULTURAL 580

O LUGAR DA AUTORIA NA ARQUITETURA DESTINADA À ARTE

ARQUITETURA, INSTITUIÇÃO E ARTE NA CONTEMPORANEIDADE $\quad 588$

\begin{tabular}{ll}
\hline EM TEMPO & 591 \\
\hline
\end{tabular}

REFERÊNCIAS

\begin{tabular}{ll}
\hline APÊNDICES & 617
\end{tabular}

APÊNDICE A: ENTREVISTA COM ELIZABETH DILLER. 617

APÊNDICE B: ENTREVISTA COM REBECCA LAMARCHE-VADEL 623

APÊNDICE C: ENTREVISTA COM OLIVIER CINQUALBRE $\quad 635$

APÊNDICE D: ENTREVISTA COM CARLITO CARVALHOSA $\quad 642$ 

INTRODUÇÃO 

Esta pesquisa tem por objetivo investigar as tensões no encontro entre projetos arquitetônicos para edifícios destinados a exposições de arte e propostas artísticas contemporâneas que operam transformações nesses espaços, sob a mediação da moldura institucional. Para isso, foram eleitos dois objetos que exemplificam paradigmas de concepção institucional e arquitetônica para espaços de arte. Um deles é o moma de Nova York - estabelecido como museu de arte moderna e vinculado a uma coleção -, que representa um modelo de espaço expositivo idealizado e supostamente neutro, conhecido como "cubo branco". O outro é o Palais de Tokyo de Paris, "local de criação contemporânea" - dedicado apenas a eventos temporários e situado, portanto, no campo da kunsthalles -, que assume que a arte pode conviver com a ambiência "contaminada" pelas marcas de usos e desusos do edifício histórico em que se situa.

Antes de abordar os aspectos conceituais que estruturam esta tese, considero relevante contextualizar a motivação inicial da pesquisa e sua relação com minha experiência atuando como arquiteta no Brasil, em duas principais frentes. De um lado, como colaboradora em projetos e obras de museus e edifícios culturais realizados por equipe de arquitetura brasileiras e estrangeiras e, de outro, como realizadora de projetos expográficos para exposições de arte, na mediação entre as propostas de artistas, as perspectivas de curadores e as condições institucionais e dos espaços arquitetônicos que recebem esses eventos temporários. A partir dessa experiência, veio a percepção de um certo descompasso entre propostas arquitetônicas para edifícios destinados à arte e os modos como artistas interagem com esses espaços na montagem de suas exposições. Surgiu daí o interesse em somar à vivência empírica o estudo de fatores determinantes na concepção e utilização de espaços de museus e centros de arte contemporânea, tendo como base o tripé: arquitetura, arte e instituição. No preâmbulo a seguir, apresento um relato profissional que, embora distante dos exemplos apresentados como objetos de análise nesta tese, determinaram o olhar para os temas que procurei investigar ao longo da pesquisa, tendo como foco o embate entre trabalhos de arte e os espaços arquitetônicos das instituições em que se inserem.

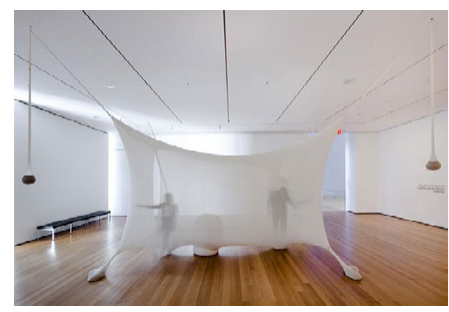

0.1 Ernesto Neto, Navadenga, MoMA, Nova York, 2010. Fonte: https://artemais. wordpress.co m/2010/02/22/ernestoneto-no-moma-nova-york-com-navedenga/

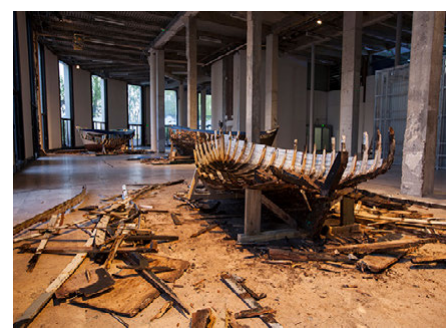

0.2 Héctor Zamora, Ordem e Progresso, Palais de Tokyo, Paris, 2016. Fonte: https://Isd.com.mx/artwork/ especiales1/\#iLightbox[image_ carousel_1]/14 
NEGOCIAÇÕES ENTRE ARQUITETURA, ARTE CONTEMPORÂNEA E INSTITUIÇÃO: PROJETO EXPOGRÁFICO PARA AS MOSTRAS DE ANRI SALA NO INSTITUTO MOREIRA SALLES

Atuando na elaboração de projetos expográficos de mostras de arte em diversas instituições brasileiras desde 1999, percebo que cada um deles se desenvolve segundo uma dinâmica própria, delineada em função da natureza dos trabalhos, da quantidade de artistas e obras, do perfil das instituições, de seus curadores e equipes, da condição dos espaços e, em grande medida, por contar ou não com a participação direta de artistas em sua elaboração. Projetos para exposições que apresentam apenas obras preexistentes, pertencentes a coleções e realizadas por artistas que não participam do processo de sua elaboração - muitas vezes por não estarem mais vivos - são concebidos levando em conta a leitura curatorial e a natureza dos espaços expositivos, geralmente pré-delimitados pela instituição, dentro de uma determinada arquitetura. O processo torna-se mais complexo e imprevisível quando a exposição é destinada a um artista contemporâneo que toma o espaço como matéria de seu trabalho, como exemplifica o caso da mostra Anri Sala: o momento presente, realizada pelo Instituto Moreira Salles (IMS) em duas montagens, no Rio de Janeiro em 2016 e em São Paulo em 2017-18.

Fui convidada por Heloísa Espada, curadora do IMS, para realizar o projeto expográfico dessa mostra, ${ }^{1}$ anunciada como um evento de grande importância, dada a projeção do albanês Anri Sala (1974-) na cena internacional. Sua obra ilustra bem o cruzamento de diversos meios de expressão que caracteriza boa parte da arte contemporânea. Com formação inicial em cinema, Sala expande esse meio relacionando imagens em movimento, sons e espaço arquitetônico, gerando assim experiências imersivas para o público.

A primeira reunião com o artista e a curadora foi realizada em setembro de 2015, na sede carioca do IMs, conhecida como casa da Gávea, onde teria início a exposição. Os dois já haviam se encontrado previamente no estúdio do artista em Berlim e elaborado uma seleção de obras - incluindo fotografias, objetos e, principalmente, videoinstalações sonoras que demandavam
1 Cf. Pontes, Ana Paula. Projeto Expográfico para Anri Sala: o Momento Presente. APP.arq. Disponível em: $<$ https://www. app.arq.br/anri-sala $>$. Acesso em: 14 jan. 2021. 
uma interação entre o som e os espaços arquitetônicos. Tais definições haviam sido tomadas considerando as características muito particulares da casa e uma distribuição preliminar dos trabalhos pelas salas destinadas à exposição. Logo de saída, ficou evidente que aquele projeto expográfico seria sobretudo "dele" - ou seja, tratado como sua obra - e que meu papel não seria, como em outras ocasiões, o de desenhar a ocupação do espaço e a disposição de obras junto à curadoria, mas, principalmente, o de mediar a interlocução entre o artista, a arquitetura existente e a instituição, e, ainda, o de compatibilizar as demandas artístico-arquitetônicas com as necessidades das demais disciplinas técnicas. Mesmo tendo as decisões principais da exposição definidas de antemão, a mediação mostrou-se intensa do início ao fim do processo, dadas as alterações que o artista propôs na forma de ocupar os espaços, a complexidade das instalações sonoras e o elevado nível de exigência na qualidade da execução de cada item.

Havia um visível encantamento de Anri Sala com a arquitetura da casa, que, distante dos moldes convencionais de museus e galerias, é um espaço ao mesmo tempo desafiador e instigante para a montagem de exposições. Projetada por Olavo Redig de Campos e rodeada por jardins desenhados por Roberto Burle Marx, a casa foi construída no início dos anos 1950 para abrigar a família do empresário e embaixador Walter Moreira Salles e seus frequentes eventos políticos e sociais. Organizados ao redor de um pátio central, os ambientes internos integram-se visualmente ao exterior por meio de grandes superfícies envidraçadas e adquirem unicidade pelo uso de elementos característicos do vocabulário modernista brasileiro - como treliças, brises e venezianas. Alguns deles são empregados de forma a ressaltar o caráter palaciano da residência - como a coleção de azulejos portugueses revestindo inteiramente uma sala de estar e um plano de cobogó em escala monumental na varanda contígua.

Entre as principais missões do IMS está a preservação e a difusão de fotografia - além de música, literatura, artes visuais e cinema - e, como exposições de obras em papel requerem limitações severas, especialmente quanto aos níveis de luminosidade, as condições abertas de sua sede carioca se impuseram 


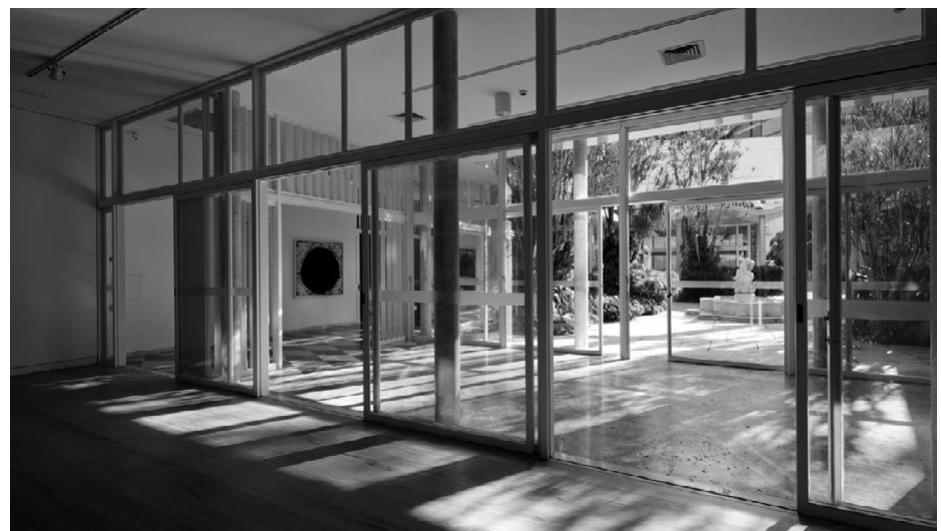

tivesse sido abafada, resultando, segundo ele, numa "sensação o claustrofóbica". ${ }^{3}$ Com uma prestigiada carreira que vem se desenvolvendo, desde os anos 1960, a partir de relações de suas obras com o espaço ao redor, Serra comentou sobre a exposição carioca: "achei que cabia a mim dispor meu trabalho em relação à casa original, não em relação à casa alterada." ${ }^{4} \mathrm{O}$ IMS acatou sua solicitação de resgatar as qualidades de transparência e integração visual entre ambientes interiores e exteriores, interrompendo a programação expositiva na casa enquanto realizava uma obra significativa de recuperação do edifício. ${ }^{5}$ Dada a articulação da exposição com o lugar - considerada pela curadora como uma intervenção site-specific -, a exposição foi nomeada Richard Serra: Desenhos na casa da Gávea. O evento representou um impulso para explorar outras possibilidades expográficas, de modo a preservar, sempre que possível, as qualidades arquitetônicas originais da casa, valorizando-a não apenas como um dos artefatos mais importantes do acervo da instituição, mas como elemento fundamental de sua identidade.

Quando Anri Sala foi conhecê-la no ano seguinte, a casa da Gávea estava em plena forma, ou seja, muito próxima de sua condição arquitetônica original. Sua intenção de potencializar a experiência do público por meio da arquitetura transparente e luminosa do lugar precisava, no entanto, ser compatibilizada com a necessidade de controle sobre a iluminação e o desempenho acústico das obras audiovisuais, várias delas realiza-
0.5 Vista da exposição Desenhos na Casa da Gávea, de Richard Serra, IMS, Rio de Janeiro, 2014. Foto: Cristiano Mascaro/IMS. Fonte: https://ims.com.br/2019/09/27/ duas-decadas-de-ims-rio/
3 PONTUAL, Jorge. Entrevista com Richard Serra. In: Starte, Rio de Janeiro: Globonews, 2014.

4 Instituto Moreira SALles. Richard Serra: Desenhos na casa da Gávea. IMS. Disponível em: <https://ims.com.br/exposicao/ richard-serra-desenhos-na-casa-da-gavea-ims-rio/>. Acesso em: 14 jan. 2021.

5 Ver artigo a respeito, de nossa autoria: PonTEs, Ana Paula. Arquitetura para Arte Contemporânea: Longe da Neutralidade. Cadernos de pós-graduação em arquitetura e urbanismo, v. 17, n. 2, p. 151-170, 2017.

\section{4-25}




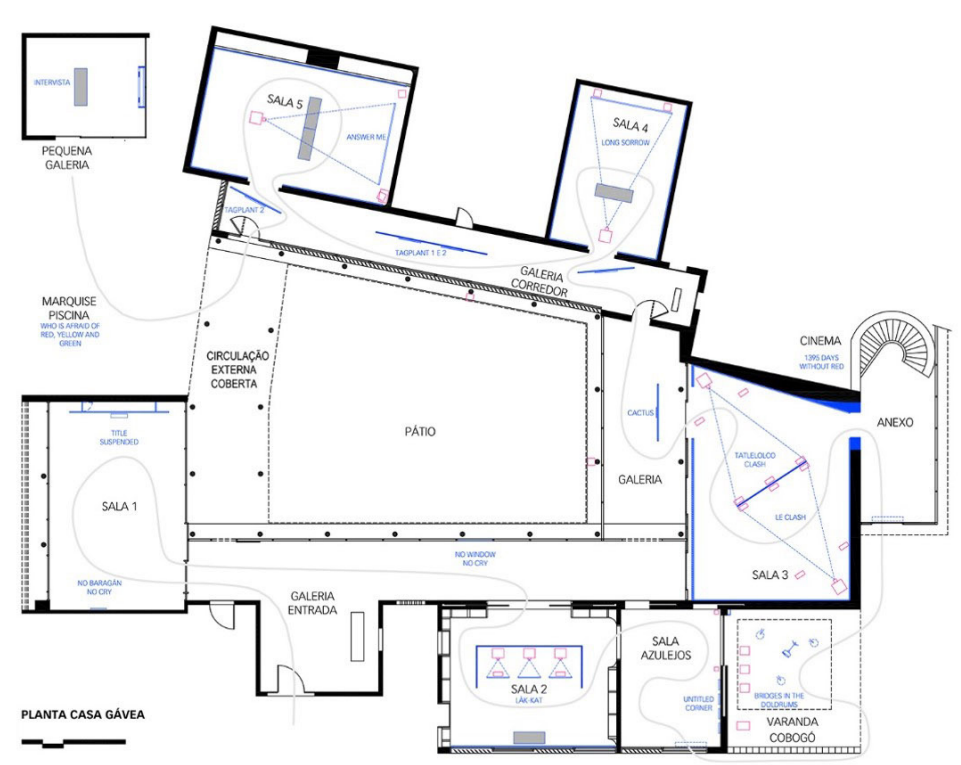

0.6 Planta do Projeto Expográfico da mostra Anri Sala: o momento presente, IMS, Rio de Janeiro, 2014. Desenho: Arq. Ana Paula Pontes. das com projeções. Daí a decisão, tomada de antemão com a curadora, de apresentar as videoinstalações sonoras nas salas mais isoladas e dispor fotografias e objetos nos ambientes mais abertos e transparentes, evitando, assim, criar bloqueios desnecessários à fruição da arquitetura.

Além dessas definições de ordem mais prática, um dos aspectos primordiais do "partido" de sua montagem - já que podemos tratá-la como arquitetônica - foi a alteração do percurso de visitação da casa, com a introdução de um desvio no trajeto tradicional que rodeava o pátio central, com a abertura de um acesso à área externa pela sala dos azulejos, levando à passagem pela varanda dos cobogós e ao retorno ao interior por um ambiente anexo à próxima sala expositiva. No relato do artista, vemos como a ideia se desenvolveu a partir de seu encontro com a casa:

Quando fiz a primeira visita, fiquei muito impressionado com a beleza do lugar, tanto da casa quanto do verde que a cerca. Em nossas primeiras conversas, pensamos numa coreografia possível, numa trajetória possível dos visitantes pelos dife- 
rentes espaços. E na interação entre a parte mais interna da casa e a parte intermediária, em que estamos no lado de dentro no corredor, mas também enxergamos a parte externa, e também a parte externa em si. Ou seja, não como recompor essas áreas, pois são belas como estão, como foram criadas pelo arquiteto, mas como atravessá-las e compor a trajetória possível do visitante. ${ }^{6}$

Essa interação entre interior e exterior da casa foi explorada em diversas obras da exposição, uma delas justamente no desvio do percurso, onde foi localizada a instalação sonora Bridges in the Doldrums (2016). O contato inicial com a obra se dava na chegada à sala dos azulejos - que continha também oito fotografias da série Untitled (corner) (2004) - onde o visitante podia ouvir a gravação de um clarinete, um trombone e um saxofone executando uma composição de Anri Sala (em colaboração com o músico húngaro-estadunidense Andre Vida), realizada a partir de colagens de trechos - "pontes" - de 74 músicas de variadas épocas, lugares e estilos musicais. ${ }^{7} \mathrm{Na}$ varanda dos cobogós, a mesma composição era reproduzida em baixa frequência, por meio de amplificadores instalados no interior de quatro tambores - três deles pendurados de cabeça para baixo e um apoiado no piso - que, junto com o som emitido por um subwoofer, faziam vibrar os pares de baquetas acoplados em cada um deles, que pareciam estar tocando sem a ajuda de um instrumentista. Não era possível ouvir nitidamente todos os sons ao mesmo tempo, uma vez que as fontes sonoras ficavam em ambientes distintos, e a conexão se completava visualmente por uma esquadria de vidro e pela memória das sensações distintas acumuladas em cada um dos espaços.

Outras obras também foram apresentadas de modo propositadamente fragmentado no espaço da casa, como a videoinstalação Long Sorrow (2005). Num dos ambientes mais fechados (originalmente um dormitório), uma projeção audiovisual mostrava o músico estadunidense Jemeel Moondoc executando uma improvisação de jazz estando pendurado do lado de fora do $18^{\circ}$ andar de um edifício habitacional modernista de Berlim, enquanto no pátio externo da casa, sem contato nem visual nem sonoro com o ambiente da projeção do filme, era reproduzido
6 Entrevista com Anri Sala in: INSTITUTO MOREIRA SALLES. Anri Sala: O Momento Presente. IMS. Disponível em: <https://ims. com.br/exposicao/anri-sala-o-momento-presente/>. Acesso em: 14 jan. 2021.

7 Conforme texto da curadoria: "ponte musical” é o "termo usado para denominar a parte da música que faz a transição entre o tema principal e o fim, com melodia e ritmo significativamente diferentes do restante da composição”. Cf. Heloísa Espada. A memória como matéria Prima. In: INsTituTo Moreira SAlles. Anri Sala: $O$ momento presente. Rio de Janeiro e São Paulo: Instituto Moreira Salles, 2016, p. 19-21. 

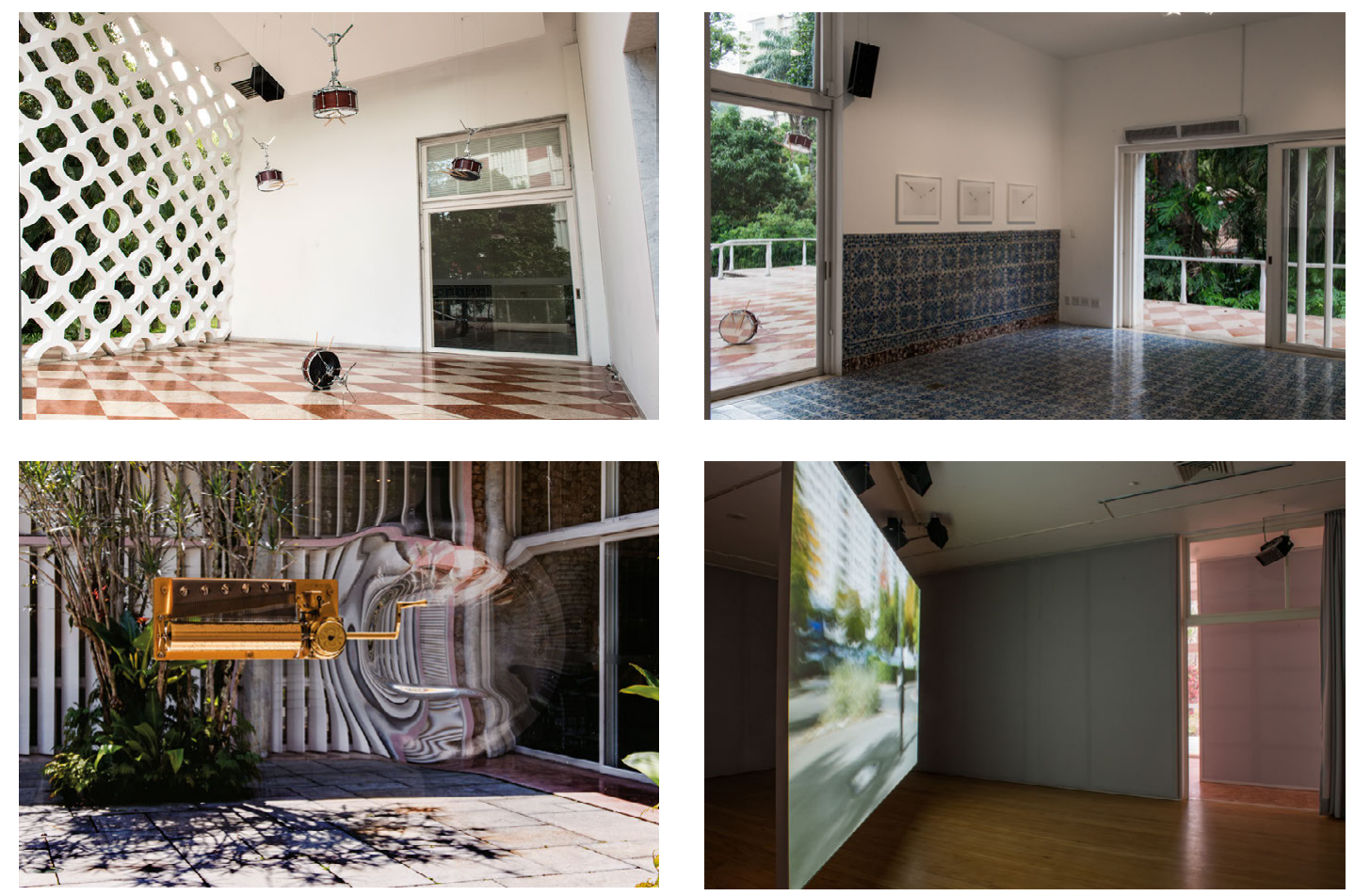

0.7 e 0.8 Anri Sala, Bridges in the Doldrums, exposição Anri Sala: 0 momento presente, IMS, Rio de Janeiro, 2016. Foto 7: Vicente de Mello/IMS. Foto 8: Foto: Paulo Jabur/IMS.

0.9 Anri Sala, No Window No Cry (Olavo Redig de Campos, Instituto Moreira Salles, Rio de Janeiro), exposição Anri Sala: o momento presente, IMS, Rio de Janeiro, 2016. Foto: Vicente de Mello/IMS.

0.10 Vista da exposição Anri Sala: 0 momento presente, IMS, Rio de Janeiro, 2016. Foto: Paulo Jabur/IMS. o som de uma outra improvisação realizada pelo músico em 2006, em diálogo com a performance original.

Numa esquadria ao redor do mesmo pátio, um dos vidros transparentes foi substituído por outro especialmente produzido com um trecho côncavo, para permitir o movimento da mão do visitante girando a manivela de uma caixa de música ali acoplada, que tocava a música Should I Stay or Should I Go, da banda inglesa The Clash. Enfatizando a relação com a arquitetura - usada então como instrumento musical - a obra recebeu, como em outras montagens, um subtítulo referente ao lugar de sua instalação - nesse caso No Window No Cry (Olavo Redig de Campos, Instituto Moreira Salles, Rio de Janeiro) (2016). A mesma música comparecia ainda em duas projeções audiovisuais - Le Clash (2010) e Tlatelolco Clash (2011) - apresentadas simultaneamente em faces opostas de uma tela suspensa na diagonal de uma outra sala. 
Para que o som das instalações pudesse ser reproduzido em alto volume e boa qualidade, sem que os ambientes fossem efetivamente isolados com portas, cortinas e corredores segregando demais os espaços, as quatro salas que receberam videoinstalações tiveram as paredes revestidas com material para absorção acústica, além de painéis soltos diante das entradas, criando um elemento de identidade da montagem. No caso de um plano de vidro que limitava uma das salas com projeções, a solução para controlar o vazamento de luz e som foi a construção de um painel acústico delgado com a mesma espessura da esquadria e um pouco mais afastado dela, criando um diálogo respeitoso com esse elemento arquitetônico.

Todas essas soluções foram adotadas para engajar o público na experiência sensorial da exposição, enfatizando o encontro de sons e imagens com o edifício existente. A respeito dessa dimensão da poética de Sala, a curadora observou, no texto do catálogo da mostra, que "o foco na relação dos trabalhos com a casa se apoia na percepção de que a arquitetura, como a música, é uma poderosa âncora de conexão com o presente.” Tal entrelaçamento com o edifício não significou, no entanto, uma mera submissão do artista ao lugar ou uma integração harmônica com a arquitetura, pois sua atitude envolveu tanto a valorização quanto a subversão das características da casa. Sala provocou um estranhamento capaz de aguçar a consciência da presença do visitante naquele espaço específico, evidenciando a tensão entre sua constituição residencial e seu uso institucional. Os desdobramentos dessa abordagem sobre a casa na relação entre arte, arquitetura e espectador foram explicitados em mais um de seus relatos:

Ainda sentimos bastante o ambiente doméstico, mas ao mesmo tempo percebemos que ela agora está inserida em uma estrutura mais institucional. E essa estrutura institucional moldou a forma com que a casa é usada nessa segunda vida. Senti que deveria reequilibrar um pouco as coisas. Aproveitar, é claro, o convite de usar esta bela casa como possibilidade e oportunidade de mostrar minha obra, mas ao mesmo tempo fazer isso exibindo ou encenando a casa de um modo diferente, 8 EsPADA, op. cit., p. 15 . 
um pouco mais parecido com o que era antes. Algo mais próximo do doméstico e mais distante do institucional. ${ }^{9}$

O público acostumado a frequentar o IMs do Rio de Janeiro certamente notou a variação na forma de circular pelos espaços, a presença intrigante dos sons vindos de dentro e de fora e as novas perspectivas sobre a casa da Gávea provocadas pela intervenção de Anri Sala. O que nem mesmo um visitante mais especializado tem condição de perceber ao transitar por uma exposição depois de pronta são os embates que acontecem nos bastidores ao longo da elaboração e da produção de cada evento, que, nesse caso, foram abundantes.

A aparente simplicidade de abrir a porta de uma das salas para o exterior e deixar o público circular por um pequeno trecho do lado de fora esconde a sequência de dificuldades que se impuseram entre a vontade do artista e as responsabilidades da instituição, que foram se avolumando desde os momentos iniciais do projeto até o fim da exposição. Em primeiro lugar, o espaço da varanda nunca havia sido usado para expor obras e havia planos vagos de instalar ali um café ou de usá-lo pelos educadores para reunir visitantes. Vencida a resistência de várias instâncias do instituto para além da curadoria, foi a vez de enfrentar outros problemas práticos. Para mitigar a fuga de ar condicionado, a solução adotada foi instalar cortinas de ar acima das portas, mas, em caso de chuva, a passagem precisava ser temporariamente fechada, para evitar que o público escorregasse no piso de mármore molhado. Foi levantado em seguida o risco de que os tambores sofressem danos durante ventanias e tempestades, o que demandou o desenvolvimento de um sistema de capas plásticas, cintas e lastros, de modo a manter as peças secas e firmes no lugar. Para instalar e desinstalar tudo isso com rapidez, uma equipe recebeu um treinamento específico para atuar não apenas em caso de intempéries, mas duas vezes ao dia, na abertura e no fechamento da mostra, contando com um funcionário especialmente dedicado a tomar conta da obra. Por fim, uma plataforma abaixo do teto

9 Conversa com Anri Sala in: INSTITUTO MOREIRA SALLES, Anri Sala: O Momento Presente, IMS, op. cit. precisou ser construída para apoiar equipamentos de som e possibilitar a instalação de finos cabos de aço que suspendiam e alimentavam eletricamente os tambores. Foi então necessário 
submeter a intervenção, ainda que temporária, à aprovação do IPHAN (Instituto do Patrimônio Histórico e Artístico Nacional), órgão responsável pelo tombamento da casa em 2006.

Mesmo com todas essas medidas, nem todos os problemas puderam ser antecipados. Em função das demandas de Anri Sala em controlar cada detalhe dos espaços e suportes expográficos e da complexidade técnica das instalações, muitas outras questões se apresentaram como desafios para o projeto e para as equipes de curadoria e produção do IMs, que não contava com orçamento ilimitado para a mostra. Itens não previstos tiveram que ser incluídos, como a troca do carpete bege na ala dos antigos dormitórios - instalado há muito tempo - por um de cor cinza que o artista considerava mais condizente com seu trabalho. Outros elementos habitualmente usados nas obras de Sala tiveram que ser substituídos por soluções nacionais e não industriais, como os painéis de lã de PET e tecido, desenvolvidos com o apoio do consultor de acústica, Marcos Holtz, para desempenhar efeito similar às espumas produzidas da Alemanha, que tinham custos de importação inviáveis.

Uma intensa troca de mensagens com seus assistentes, as equipes do IMs e empresas especializadas locais foi necessária para definir cada item - como a especificação de equipamentos de áudio e vídeo, o desenho dos suportes de telas de projeção e monitores de vídeo e a definição dos diferentes tons de cinza para pintura e tecidos dos painéis de cada sala. Ainda que o layout da exposição não tenha sofrido alterações significativas desde o início do processo, o projeto expográfico continuou sendo desenvolvido ao longo de quase um ano até a conclusão da versão executiva.

Durante a montagem, novas dificuldades se apresentaram, como a reprovação pelo artista da qualidade da tela suspensa que recebia projeção dos dois lados, que precisou ser refeita na última hora. Para diminuir a entrada de luz que interferia numa das projeções, uma cortina teve que ser encomendada às pressas para cobrir uma das passagens. Com a diferença de temperatura entre o ambiente interno com ar condicionado e o exterior com clima geralmente muito quente do Rio de Janeiro, o produto usado habitualmente para colar a caixa de música no vidro não se mostrou eficiente, o que levou a equipe 


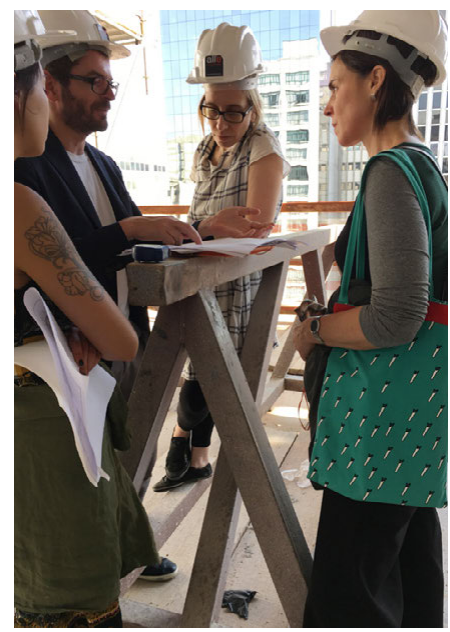

0.11 Tiê Higashi, Anri Sala, Heloísa Espada e Ana Paula Pontes em reunião realizada na sala em construção do edifício do IMS de São Paulo, 2016.

0.12 Vista da exposição Corpo a Corpo, IMS, São Paulo, 2017. Foto: Pedro Vanucchi. Fonte: http://www. pedrovannucchi.com/site/busca_en.php

$10 \mathrm{O}$ projeto foi selecionado a partir de um concurso fechado de arquitetura realizado em 2011.

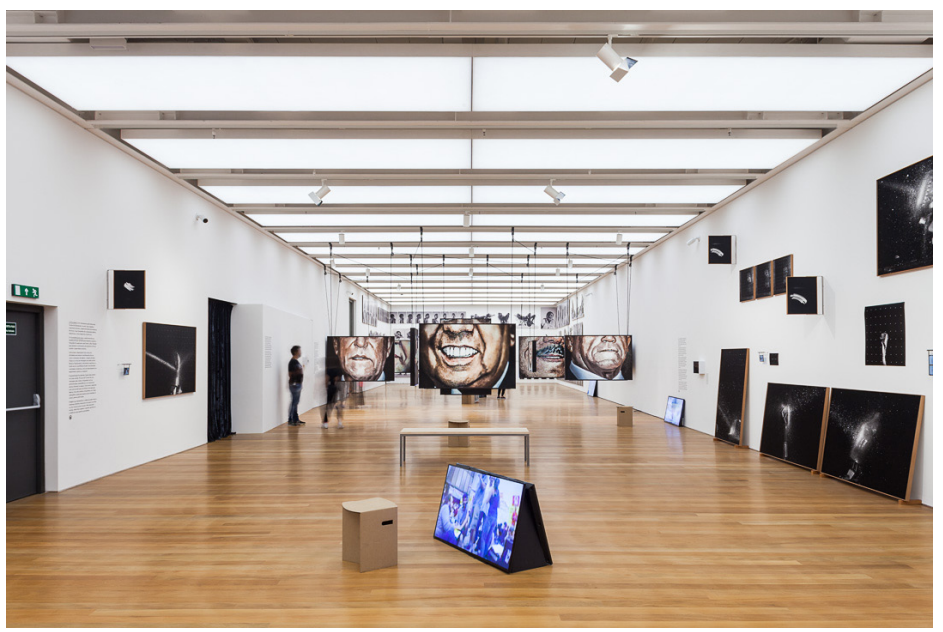

de produção a percorrer com urgência diversas lojas de materiais de construção da cidade em busca de um determinado tipo de parafuso para uma fixação alternativa. Assim que os equipamentos de áudio começaram a ser testados durante a montagem, o instituto teve ainda que enfrentar uma série de reclamações dos moradores vizinhos, que, fazendo coro com os funcionários administrativos, incomodavam-se com aqueles sons dissonantes de instrumentos de sopro e tambores tocando o dia todo, que o artista queria manter em alto volume. Apesar dos sobressaltos, a montagem chegou ao fim com todos os envolvidos satisfeitos com o resultado.

Logo depois da inauguração, em setembro de 2016, uma nova reunião com o artista foi organizada em São Paulo para tratar do projeto da segunda montagem da mostra, prevista para o ano seguinte. A condição da arquitetura ali era bastante distinta, não apenas porque a sede do IMs na Avenida Paulista é uma obra concebida especialmente para este fim - com projeto do escritório paulistano Andrade Morettin Arquitetos -, mas também porque o edifício estava ainda em construção naquele momento. ${ }^{10}$ Apesar disso, Anri Sala fez questão de discutir as ideias do projeto no próprio espaço, que consistia então apenas na estrutura, sem qualquer vedação para o exterior. Sendo assim, as reuniões se desenrolaram parte no escritório do IMS do outro 

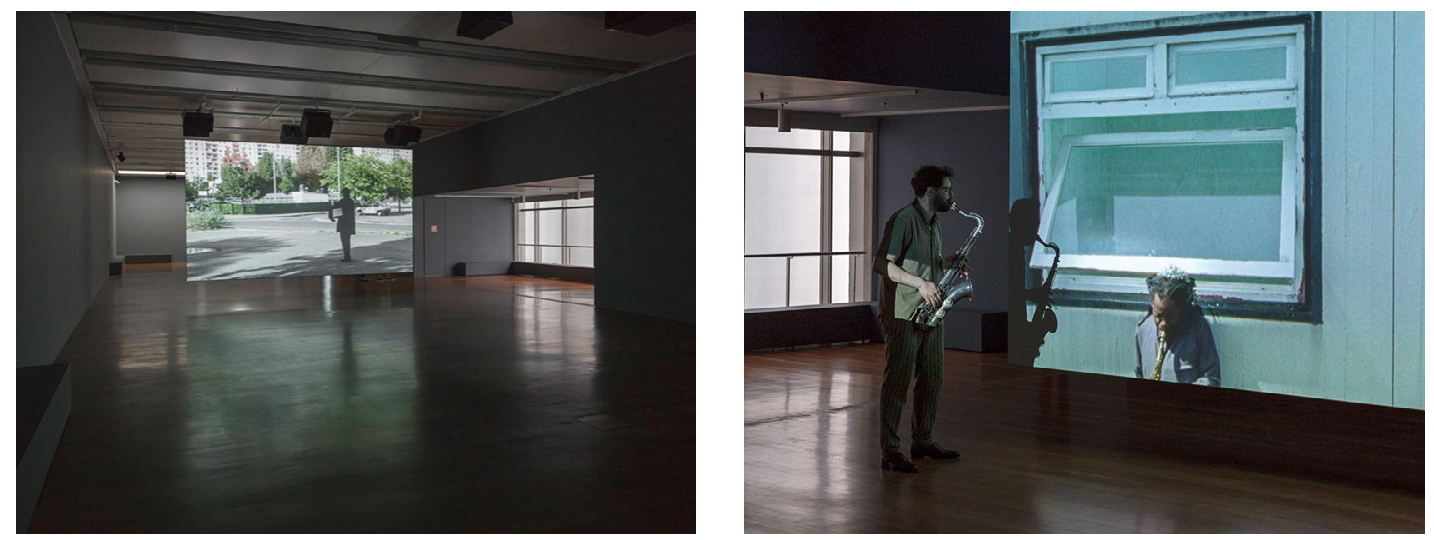

0.15 e 0.16 Vista da exposição Anri Sala: 0 momento presente com performance de Andre Vida, 7ํ Pavimento, IMS, São Paulo, 2017. Foto: Renato Parada/IMS.

11 Memorial do projeto in: ANDRADE MoretTIN ARQUiTetos. IMS São Paulo. Andrade Morettin. Disponível em: <https://www. andrademorettin.com.br/projetos/ ims/>. Acesso em: 14 jan. 2021. 12 Ibidem. percepção do tempo muito particulares". ${ }^{11}$ Se o partido buscou criar um museu "de caráter marcante, que proporcione uma experiência única e pessoal para quem o visita”, a percepção da especificidade do lugar não incluiu os ambientes expositivos, que deveriam ser, segundo seus autores, "generosos", "flexíveis" e com o "ambiente controlado, com as condições ideais para acomodar o acervo e as mais diferentes modalidades de exposição." ${ }^{12}$ Chama a atenção nessa afirmação a intenção de não questionar a necessidade de isolar completamente os espaços museológicos da agitação da cidade e a aceitação dessa configuração como "ideal". Afinal, a especificidade dos espaços expositivos - justamente o que os distancia de paradigmas pré-concebidos - é frequentemente tomada como ponto de partida para o engajamento das propostas artísticas com o espaço arquitetônico, como vimos na exploração de Anri Sala dos espaços nada genéricos, ideais ou supostamente neutros da casa da Gávea.

A natureza isolada dos ambientes expositivos do novo edifício de São Paulo representava, portanto, uma condição muito distinta da encontrada no Rio de Janeiro. Ainda que algumas obras se repetissem nos dois casos, as duas montagens teriam diferenças expressivas. Na galeria contínua do sétimo andar, seriam expostas as cinco videoinstalações que estavam distribuídas em quatro salas da casa na montagem anterior. Ao invés de subdividir o espaço, o artista preferiu fechar apenas um dos ambientes ao fundo para a obra Làk-kat 3.o (Brazi- 


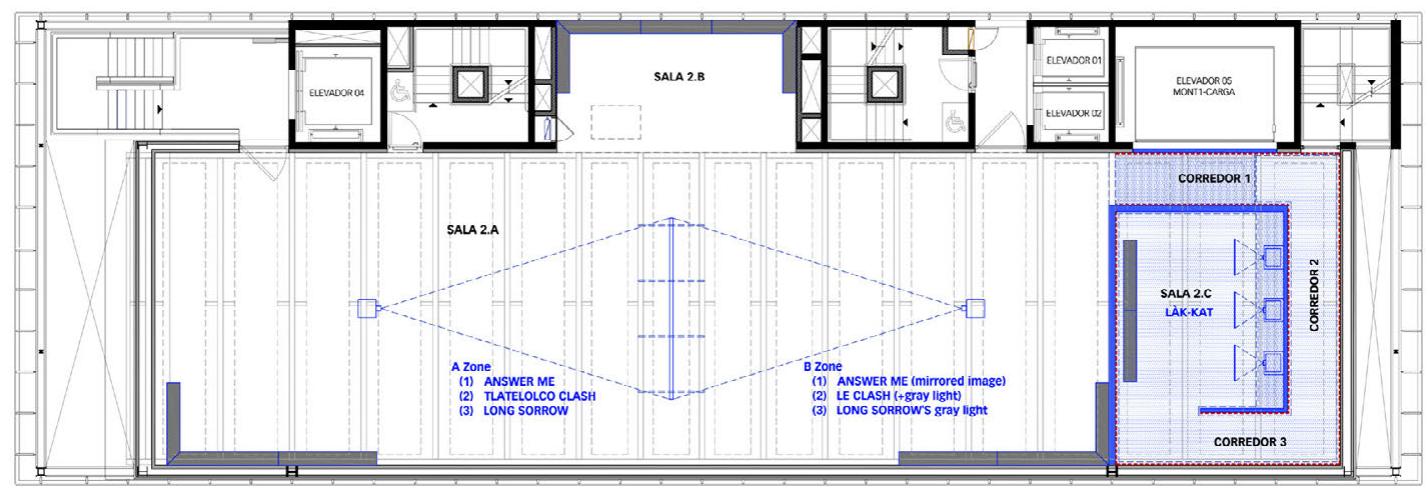

PLANTA 70. PAVIMENTO

lian Portuguese/Portuguese/Angolan Portuguese) (2016) - uma videoinstalação mostrando crianças senegalesas num ambiente escuro, repetindo, em uólofe, palavras relativas a gradações de claridade luminosa e, em seguida, de tonalidades de pele. A mesma imagem era repetida em três telas suspensas pequenas, cada uma legendada numa tradução distinta para a língua portuguesa, demandando maior concentração do visitante e um ambiente mais escuro. Para atingir o isolamento sonoro esperado no amplo salão contínuo da galeria, foi preciso executar praticamente uma obra civil, com espessas paredes feitas de várias camadas de gesso recheadas com lã mineral, e, em vez de portas que bloqueariam o fluxo dos visitantes, foi construído um longo corredor revestido com material absorvente, projetadas novamente com o apoio da consultoria de acústica. $\mathrm{O}$ artista queria ainda ocultar os painéis e vigas brancas do teto com um plano escuro, o que gerou a preocupação de bloquear não apenas as grelhas de ar condicionado, como também os detectores de fumaça e chuveiros automáticos do sistema de combate a incêndio. Com a anuência dos bombeiros, foi instalado um forro de tecido cinza escuro que cumpria a função de rebaixar a luminosidade sem oferecer riscos ao conforto e à segurança do edifício. Depois de construídas paredes e forros, o som continuava vazando, o que demandou a aplicação de espuma expandida para fechar todas as pequenas frestas de ar entre o interior e o exterior da sala.
0.17 Planta do Projeto Expográfico da mostra Anri Sala: o momento presente, 7ํ Pavimento, IMS, São Paulo, 2017. Desenho: Arq. Ana Paula Pontes.

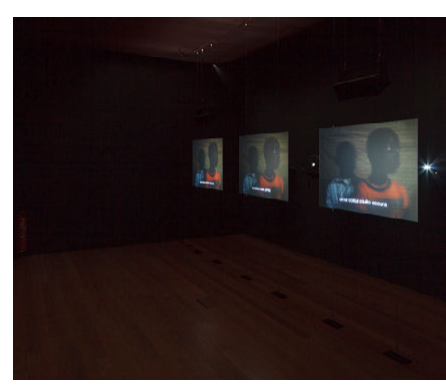

0.18 Làk-kat 3.0 (Brazilian Portuguese) Portuguese/Angolan Portuguese) (2016), exposição Anri Sala: o momento presente, IMS, São Paulo, 2017. Foto: Renato Parada/IMS.

\section{4-35}




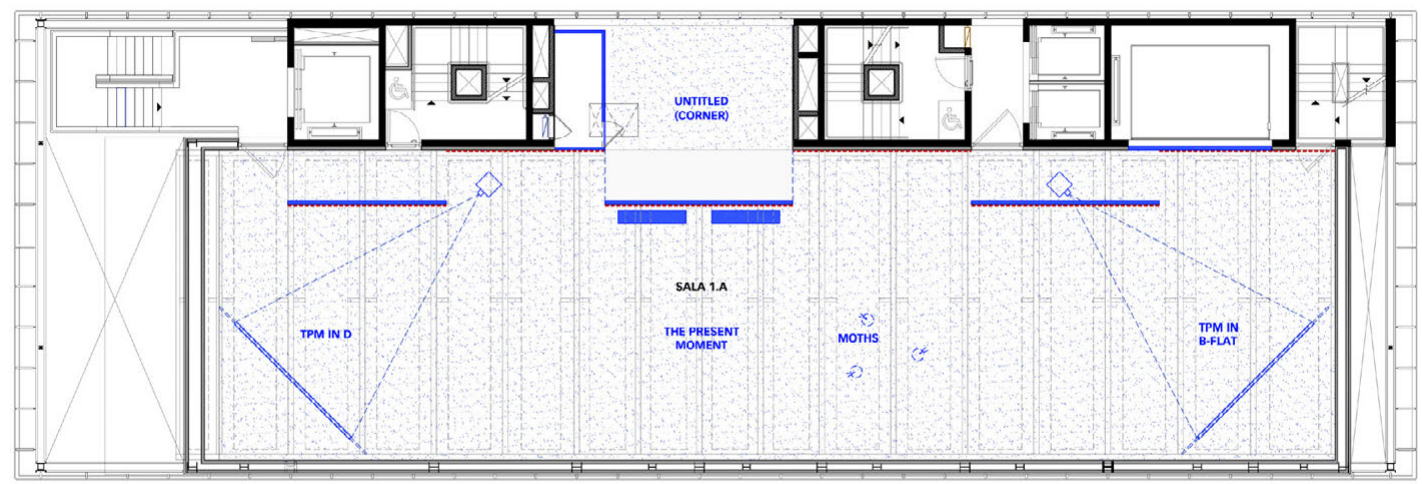

PLANTA 8O. PAVIMENTO

A amplitude das novas galerias, em contraste com a escala doméstica das salas da casa da Gávea, permitiu que a tela de projeção tivesse uma dimensão maior e pudesse ser vista com mais distância. Se essa condição ajudava a valorizar a presença dos filmes no espaço, não havia, por outro lado, possibilidade de um entrelaçamento com a arquitetura desse edifício que incluísse uma expansão para além dos limites muito definidos do interior da galeria. Sendo assim, a comparação entre as duas montagens permite refletir sobre a articulação entre o que seria o "núcleo duro" sempre presente dessas videoinstalações e a situação arquitetônica variável de acordo com cada local, que faz com que as obras se desdobrem em inúmeras versões. Ou seja, esse tipo de obra não se define como autônoma, pois depende de sua situação como exposição, no diálogo com cada um dos espaços arquitetônicos preexistentes.

Na mostra de São Paulo, havia ainda a videoinstalação composta por The Present Moment (in D) e The Present Moment (in $B$-flat), de 2014 - que dava título à mostra e não fora apresentada na montagem anterior -, ocupando praticamente toda a outra galeria destinada à mostra, no oitavo e último pavimento expositivo. Duas telas suspensas instaladas nos cantos opostos da sala exibiam os braços dos músicos de um sexteto de cordas tocando notas isoladas extraídas de uma composição romântica de Schönberg - Verkläte Nacht Op. 4 [Noite transfigurada], de 1899 -, submetida por Sala ao método serialista dodecafônico
0.22 Planta do Projeto Expográfico da mostra Anri Sala: o momento presente, 8ํ Pavimento, IMS, São Paulo, 2017. Desenho: Arq. Ana Paula Pontes. 
13 Natalie Bell. Passado imperfeito e futuro presente. In: INSTITUTO Moreira Salles, Anri Sala: $O$ momento presente, 2016, op. cit., p. 143 . desenvolvido décadas mais tarde pelo mesmo músico austríaco. As novas sequências geradas pelo artista eram reproduzidas transitando pelos diversos alto-falantes dispostos no teto, acumulando-se em alguns momentos em pontos específicos, tensionando o espaço com o som. Como afirmou a curadora Natalie Bell, que colaborara na realização da exposição de Anri Sala no New Museum de Nova York (2016), a instalação "produz a sensação de estarmos suspensos em meio a partituras que explodiram, vagando entre as notas de uma música ou orbitando em uma espiral sem saída." ${ }^{13}$

Nessa videoinstalação, havia necessidades especiais quanto à qualidade sonora, o que demandou que muitas das superfícies da galeria fossem tratadas acusticamente com materiais absorventes, incluindo o piso de madeira, que foi todo revestido com carpete. As diversas aberturas que pontuavam uma das longas paredes num ritmo aleatório apareceram como um incômodo para Sala, que imaginava um espaço limpo para essa obra. Para atenuar a presença das portas, a solução desenvolvida no projeto expográfico foi ocultá-las com a construção de um corredor descontínuo formado por uma sequência de três painéis delgados, que recebiam também material absorvente e revestimento em tecido. A posição dos painéis foi definida junto com o artista a partir de uma série de estudos, até se chegar a um determinado ritmo que tivesse relação com os pontos focais de som produzidos pela instalação. O painel mais central funcionava ainda para limitar o ambiente da saleta anexa - onde foram expostas as fotografias da série Untitled (corner) - mantida com a esquadria aparente e aplicação de filme sobre o vidro, como na galeria do outro andar, mas com as paredes pintadas de branco, em contraste com o cinza claro do salão aberto. No mesmo salão, foram também expostas as obras Moth in B-Flat (2015) e Moth in $D$ (2015), feitas por três tambores invertidos pendurados no teto com as baquetas tocando a partir de equipamentos que reproduziam em baixa frequência as notas das videoinstalações, como na obra exposta no Rio de Janeiro, Bridges in the Doldrums.

Com as equipes locais mais familiarizadas com as demandas e o modo de trabalhar assertivo e exigente do artista, o 
projeto para a mostra paulistana foi desenvolvido mais rapidamente, chegando a uma versão pré-executiva após dois meses de trabalho, um ano antes da abertura da exposição, prevista para o fim de 2017. Todavia, imprevistos de ordem maior fizeram com que o projeto tivesse que ser revisado poucos meses antes da abertura da mostra. A apenas uma semana da inauguração da nova sede do IMS, agendada para 21 de agosto de 2017, os convidados e a imprensa foram surpreendidos com a notícia de que o evento seria adiado, para possibilitar que a obra do edifício, iniciada em 2013, fosse completada adequadamente, antes da chegada do público. A sede paulistana foi enfim inaugurada no dia 20 de setembro do mesmo ano, com cada uma das três galerias ocupada por uma exposição diferente. Um mês de atraso não necessariamente causa grande impacto em obras convencionais, mas pode tumultuar o funcionamento de uma instituição voltada a um programa de exposições temporárias. Esse tipo de evento dura geralmente em torno de três meses e é planejado com pelo menos um ano de antecedência, tendo que conciliar a agenda de artistas e curadores, a disponibilidade de empréstimos de coleções, o agenciamento de espaços e orçamentos das montagens.

No esforço de acomodação da programação a partir do adiamento, a solução encontrada pelo IMS para a mostra de Anri Sala - que aconteceria em seguida às exposições de inauguração - foi transferir a instalação de The Present Moment do oitavo para o sexto pavimento. Não parecia difícil fazer uma adaptação do projeto expográfico, já que as salas são muito semelhantes: as únicas diferenças são na parede menor próxima à entrada - aprumada no oitavo andar e inclinada no sexto - e no comprimento da sala - com de 37 metros no pavimento superior e 34 no inferior. $\mathrm{O}$ artista, no entanto, tinha se programado para afinar o projeto de sonorização dessa instalação durante uma breve janela de tempo que teria na companhia do designer de som francês Olivier Goinard durante a montagem de uma outra exposição em Sydney, e tinha urgência em revisar o projeto expográfico, que serviria de base para o posicionamento dos equipamentos que produziriam a experiência sonora.

Mais uma vez, todos os envolvidos tiveram que se adaptar à disponibilidade do artista para trabalhar no intervalo de suas 
frequentes viagens e montagens de exposições em diversos lugares do mundo. Durante o período de preparação das duas mostras no Brasil, o artista apresentou, além das exposições no New Museum de Nova York (de fevereiro a abril de 2016) e no Observatory Hill Rotunda de Sydney (de outubro a novembro de 2018), mais duas exposições na Cidade do México - no Museu Tamayo (de setembro de 2017 a janeiro de 2018) e na galeria Kurimanzutto (setembro a outubro de 2017).

Mesmo estando num momento desfavorável para me dedicar ao projeto - viajava a Tbilisi e Amsterdã, para apresentar artigos em seminários do ICOM - tive que realizar reuniões à distância com a equipe do IMs e estudar alternativas ao projeto para solucionar às pressas o impasse dentro dos prazos requeridas pelo artista. Conhecendo bem a lógica de Sala a essa altura do projeto, percebi que o impacto da mudança de andar não seria tão insignificante, uma vez que, com a redução do comprimento da sala, perdia-se um espaço importante justamente na entrada, o que resultava na necessidade de alterar a posição dos painéis, cuja distribuição ritmada tinha sido cuidadosamente estudada com ele. Ao receber o resultado da análise, $\mathrm{o}$ artista de fato considerou que as alterações seriam bastante graves, pois, além do problema da entrada, haveria uma dificuldade de conciliar a posição das caixas de som com as vigas do teto onde estariam fixadas. Numa intensa troca de mensagens por e-mail, Sala ainda insistiu para que a instalação voltasse para o oitavo pavimento, mantendo o projeto expográfico como definido antes, mas a decisão não pôde ser revertida pelo instituto, em função de compromissos assumidos para acomodar outros eventos da programação.

Se, apesar do desgaste, conseguiu-se por fim adequar o projeto às condições arquitetônicas ligeiramente distintas do sexto pavimento, não foi possível a Anri Sala se adaptar aos adiamentos propostos em função do atraso da obra, pois, para equalizar a distribuição do som da instalação The Present Moment, era necessário dedicar dias de trabalho do artista e de Goinard no próprio espaço, mas suas agendas já estavam tomadas nos meses seguintes. A solução, bastante incomum, foi inaugurar a exposição em duas etapas: a galeria do sexto andar abriu ao público em 12 de dezembro de 2017, próximo à data progra- 
mada desde o início, e a do sétimo foi adiada para 23 de janeiro de 2018, tendo a mostra sido encerrada em 25 de março desse ano. Esse descompasso de datas foi, possivelmente, o único indício que o público teve da trama de questões enfrentadas na articulação entre os diversos agentes que determinaram a realização da exposição. Ainda que em parte ocultas, as tensões entre arte, arquitetura e instituição são um aspecto indissociável desses trabalhos.

Sabemos que, para quem não visitou pessoalmente uma exposição como essas, é impossível ter uma noção concreta da experiência, dada a mobilização de diversas fontes sensoriais sintonizadas com o lugar. Mesmo com a profusão cada vez maior de registros documentais - em vídeos, fotos e textos - a percepção de um evento temporário de arte só pode acontecer com a presença física no espaço, determinada necessariamente pela arquitetura. As exposições de Anri Sala tratadas aqui colocam essa questão em primeiro plano, como explicita a declaração do artista:

Arquitetura é a moldura do som. Ela contém o som. Uma exposição não serve apenas para mostrar obras editadas na origem, mas também para mostrá-las no lugar onde pertencem: o aqui e agora; a visita, que é o destino final. Espero que o espectador e ouvinte tenha a forte sensação de estar aqui e agora. ${ }^{14}$

Diante das reflexões suscitadas por essa experiência, resta a incômoda questão para a arquitetura: se o espaço expositivo tem como função oferecer-se à exploração de artistas - no limite da sua subversão -, em que medida é oportuno para uma instituição dedicada à arte contemporânea contar com um edifício projetado especificamente para esse fim?

\section{INSTITUIÇÕES E ARQUITETURA DIANTE DA CONQUISTA DO "ESPAÇO REAL" PELA ARTE CONTEMPORÂNEA}

$\mathrm{Na}$ arte contemporânea, a dissolução de fronteiras entre as formas de expressão tradicionais - pintura, escultura, fotografia - e da inclusão de outros - teatro, cinema etc -, obras 

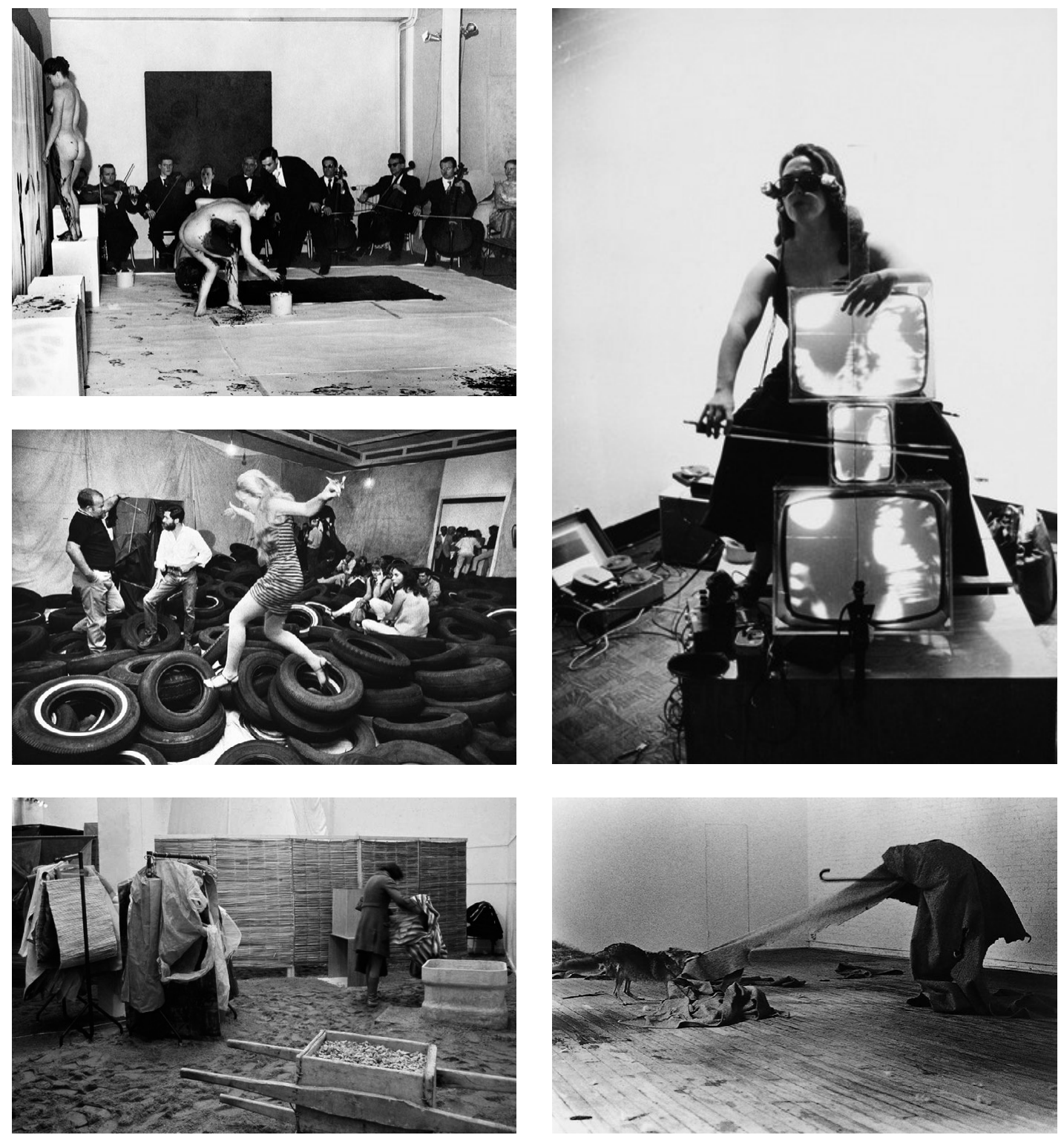
como happenings, environments, performances, land art, body art, instalações e videoarte exploraram novas possibilidades de combinar diversos meios, estimulando outros sentidos além da visão, num movimento de aproximação entre arte e vida, no mundo real. Tal dissolução de limites engendrou uma nova concepção de espectador, que deixou de ser alguém que contempla uma obra acabada - um observador passivo - para se tornar alguém que participa dela, completando-a. A participação desse espectador se dá em seu encontro público com a obra de arte, o que implica sua presença física no lugar específico em que essa acontece. A dimensão arquitetônica dos espaços concebidos para a arte contemporânea é assumida, portanto, como parte integrante dessa experiência. Nos museus e centros de arte as exposições configuram esses espaços de encontro, que apresentam tanto coleções de modo mais ou menos estático - pela geralmente longa duração de suas montagens -, quanto eventos temporários mais dinâmicos, que interagem de modos variados e imprevistos com a arquitetura existente.

A arquitetura, por sua vez, adquiriu, desde meados do século $\mathrm{xx}$, grande protagonismo em edifícios públicos e privados destinados à arte - tanto para a criação de instituições quanto para a ampliação, reforma ou construção de novas sedes de instituições existentes -, tendo, com frequência, sua identidade associada à assinatura de arquitetos internacionalmente celebrados. Uma linhagem de museus que, por sua exuberância plástica e o destaque em seus respectivos contextos, passaram então a ser identificados como "espetaculares", tendo como ícones o Guggenheim de Frank Lloyd Wright (Nova York, 1959) e o de Frank Gehry (Bilbao, 1997) e o Centro Pompidou de Piano \& Rogers (Paris, 1977). O fenômeno não se restringe aos centros urbanos mais afluentes, mas comparece ainda em cidades relativamente mais periféricas, como ilustram os exemplos locais do Museu de Arte Contemporânea de Oscar Niemeyer (Niterói, 1996) e, mais recentemente, a Fundação Iberê Camargo de Álvaro Siza (Porto Alegre, 2008).

A possibilidade de adquirirem, assim como o seu conteúdo, o status de "arte", fizeram com que edifícios dedicados a esse programa tenham se tornado especialmente atraentes no mundo contemporâneo e quase obrigatórios no currículo de um
0.23 Yves Klein e participantes em sua apresentação Anthropométries de l'Époque Bleue, Galerie Internationale d'Art Contemporain, Paris, 1960. Foto: Harry Shunk and Janos Kender/The Getty Research Institute. Fonte: http:// www.yvesklein.com/fr/photographies/ view/468/yves-klein-s-performanceyanthropometries-of-the-blueperiody $/$ ? of $=79$

0.24 Charlotte Moorman apresentando a obra de Nam June Paik Concerto for TV Cello and Videotapes, Galeria Bonino, Nova York, 1971. Foto: Peter Moore. Fonte: https://fotografia.folha.uol.com.br/ galerias/51477-helio-oiticica-em-nova-york

0.25 Allan Kaprow (ao centro, com barba) e participantes em sua instalação Yard, Pasadena Art Museum, 1967. Foto: Julian Wasser/The Getty Research Institute. Fonte: https:// www.nytimes.com/2009/09/13/arts/ design/13johnson.html

0.26 Hélio Oiticica, Eden, Whitechapel Gallery, Londres 1969. Fonte: https://fotografia.folha.uol.com.br/ galerias/51477-helio-oiticica-em-nova-york

0.27 Joseph Beuys em sua performance I Like America and America Likes Me, René Block Gallery, Nova York, 1974. Fonte: https://www.wikiart.org/en/joseph-beuys/ i-like-america-and-america-likes-me

\section{2-43}



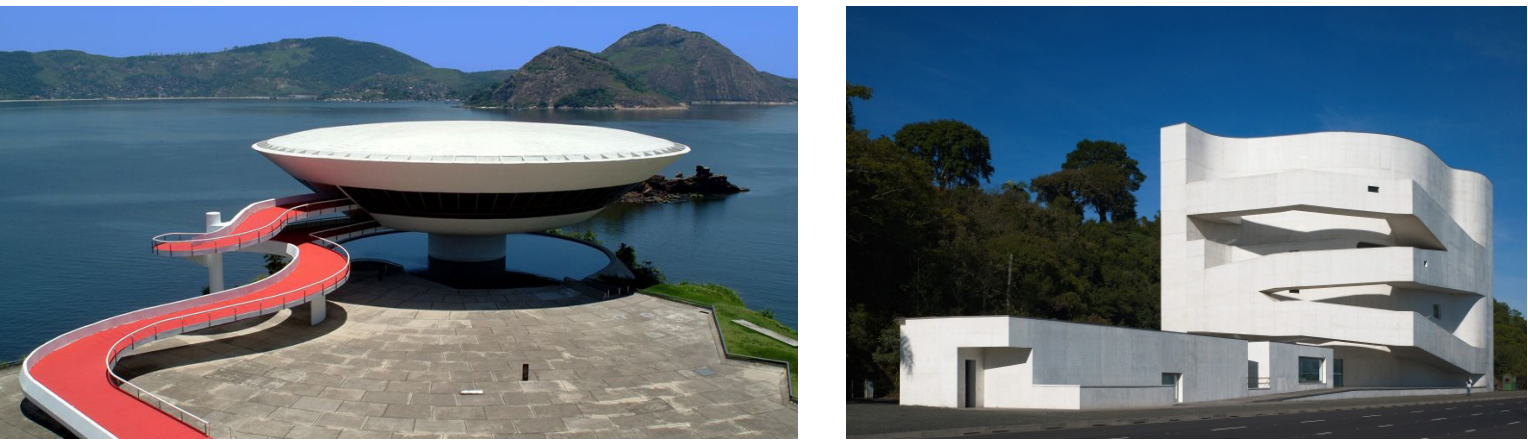

0.28 Museu de Arte Contemporânea (MAC), projeto de Oscar Niemeyer de 1996, Niterói, s.d. Fonte: http://cidadedeniteroi. com/2016/06/15/cidade-mac-niteroireabre-apos-reforma-inedita-mirandoseus-20-anos/

0.29 Fundação Iberê Camargo (FIC), projeto de Álvaro Siza de 2008, Porto Alegre, s.d. Fonte: https://www.guiadasartes. com.br/rio-grande-do-sul/porto-alegre/ fundacao-ibere-camargo
15 Como é o caso de Otília Arantes. Cf. ArAntes, Otília B. F.. Os Novos Museus. Novos Estudos CEBRAP, n. 31, p. 161-169, 1991. profissional que tenha seu nome associado ao chamado star system da arquitetura internacional. Dada a visibilidade que esses edifícios vieram a adquirir - frequentemente integrando estratégias de marketing vinculadas a projetos de renovação urbana - e a proporcional valorização da autoria dos respectivos projetos - que atraem por si só mais visitantes para as instituições -, tais obras arquitetônicas são frequentemente reconhecidas pela crítica como expressão de conceitos fortes, particularmente distintivos. Há toda uma discussão que aborda os museus contemporâneos sob o ponto de vista sociológico, ${ }^{15}$ mas o interesse aqui é focar na relação entre arquitetura e as artes visuais, no encontro físico de ambas nos espaços institucionais.

Diferentemente da arte, que pode operar sem demandas apriorísticas para sua expressão, a arquitetura lida normalmente com uma amplitude bem maior de restrições para a sua realização - incluindo orçamento, legislação, programa de necessidades, tempo de execução e viabilidade técnica. A própria mobilização simbólica que os edifícios destinados à arte produzem conta com uma liberdade apenas aparente, pois dependem, necessariamente, do perfil das respectivas instituições responsáveis por sua encomenda, execução e operação. Quando detentoras de uma coleção, qualificando-se como museu, instituições de arte costumam atuar no sentido de favorecer as obras de seu acervo, mas não deixam de ter suas contingências quando classificadas como kunsthalles, realizando apenas exposições temporárias. Em ambos os casos, sua identidade será moldada de acordo com fatores variados, como o recorte histórico e de meios de 
expressão da arte que fomentam, a variedade de público ao qual se dirigem, o local onde se situam e, em grande medida, a natureza de suas fontes de financiamento.

No que se refere especificamente à concepção arquitetônica de espaços destinados à produção artística contemporânea, foi relevante para esta pesquisa observar alguns impasses diante da conquista do "espaço real" pela arte. O crítico alemão Robert Kudielka (1945-) tratou das consequências para as instituições do interesse da arte contemporânea em atuar no "espaço real" - que ganhou impulso a partir dos anos 1960 e 70 -, em oposição à espacialidade da arte moderna, de valorização das "relações intrínsecas" das obras, consideradas de modo autônomo, independente do contexto exterior. ${ }^{16}$ Tal relaxamento da lógica formal interna das obras teria levado à sua dependência de uma delimitação espacial externa capaz de garantir a coesão necessária à "experiência" que se pretenderia promover. O autor descreveu como alguns artistas contemporâneos com trabalhos muito diversos compartilhariam de uma pré-condição básica para a realização de suas instalações: a necessidade de contar com

[...] um invólucro ou recipiente nos quais elas se organizam e dentro dos quais elas podem lograr um efeito, [...] pois apenas o apoio de uma moldura preexistente permite manter a organização de um modo tão aberto, que um espaço de vivência autêntico, experimentável ao se transitar dentro dele, passa a existir. Dentro desse espaço o observador pode dispor, sem instrução prévia e até certo ponto, de um olhar contemplativo. Entrar e imergir, em vez de defrontar e ficar diante de algo é a forma como se pode descrever as regras do jogo estético do environment e da instalação. ${ }^{17}$

Seria esperado que a concepção dos museus de arte contemporânea sofresse os impactos dessa nova relação espacial colocada pela produção, pois, se cada instalação precisa de uma delimitação espacial para acontecer, torna-se difícil a convivência de dois trabalhos distintos num mesmo ambiente. Segundo Kudielka, isso teria resultado na quase inevitabilidade de parcelamento do espaço, visando a criação de salas individualizadas para cada obra. Talvez seja essa uma das razões para a persistên-
16 Cf. Kudielka, Robert. Objetos da Observação - Lugares da Experiência. Novos Estudos CEBRAP, v. 82, p. 167-178, 2008.

17 Ibidem, p.174. 

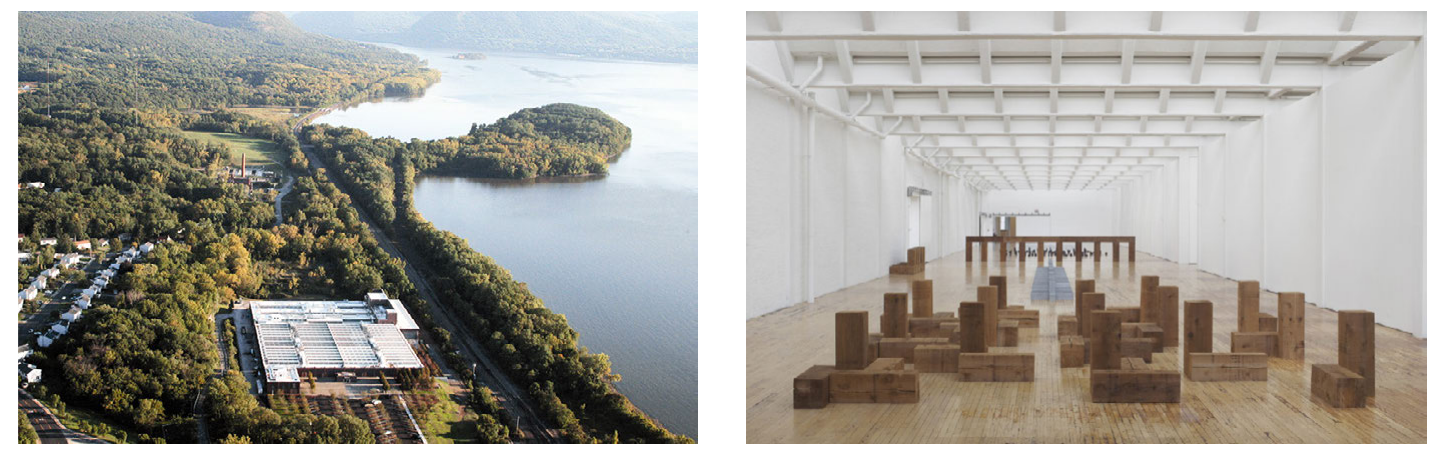

0.30 Dia:Beacon, projeto de OpenOffice e Robert Irwin de 2003, Beacon, s.d.

0.31 Vista da instalação de Carl Andre, Sculpture as Place, 1958-2010, Dia:Beacon, Beacon, 2014- 2015. Foto: Bill Jacobson Studio. Fonte: https://www. diaart.org/exhibition/exhibitions-projects/ carl-andre-sculpture-as-place-19582010exhibition

18 Onde hoje está instalada permanentemente a obra do estadunidense Walter de Maria, The Broken Kilometer (1979), pertencente ao acervo da Dia Foundation.

19 Ibidem, p.177.

20 Constituído à época pelos arquitetos Alan Koch, Lyn Rice, Galia Solomonoff e Linda Taalman.

21 Não se nota ali o alto custo da obra, que, de acordo com Hal Foster, chegou a 50 milhões de dólares. Cf. Foster, Hal, At Dia:Beacon: Fetishistic Minimalist, London Review of Books, v. 25, n. 11, 2003, n.p. cia do "cubo branco" nos espaços expositivos, acompanhado da "caixa preta" para a exibição de audiovisuais. O autor apontou também para a dificuldade de obter área suficiente para conservar e expor nos edifícios dos museus os acervos em expansão, constituídos por obras que ocupam grande espaço físico. Daí que um dos poucos consensos a respeito das qualidades espaciais desejáveis às instituições de arte contemporânea seria a demanda por espaços de grande escala.

Tal necessidade explicaria o surgimento de diversos exemplos de apropriação de edifícios industriais desativados para a exibição de arte, como a sede da Dia Arts Foundation em Beacon, inaugurada em 2003. Concebida para abrigar uma coleção particular dedicada à arte dos anos 60 até hoje, incluindo obras importantes de artistas ligados ao minimalismo, a fundação instalou-se em 1978 num edifício comercial de finais do século XIX no Soho ${ }^{18}$ e nos anos 1980, mantendo-se em Nova York, passou a ocupar também um edifício de lofts no Chelsea. Localizado a pouco mais de uma hora de distância dali, num edifício de dimensões muito mais amplas, a nova sede da fundação - denominada Dia:Beacon - seria "o maior espaço de exposição do mundo, destinado a uma arte que é espaço-dependente e espaço-determinante", ${ }^{19}$ e sua arquitetura refletiria explicitamente a relação pretendida entre os espaços expositivos e as obras. No projeto realizado pelos arquitetos do OpenOffice ${ }^{20}$ e pelo artista Robert Irwin (1928-), a adaptação do edifício existente resultou numa ambiência bastante severa e discreta, ${ }^{21}$ procurando manter seu aspecto industrial, 
que estaria em sintonia com a estética do minimalismo. Na opinião do crítico estadunidense Hal Foster (1955-), porém, essa calculada coerência entre a arte exposta e o tratamento dado à arquitetura seria problemática:

o que era uma reciprocidade tensa entre arte e arquitetura, como na estética original da Dia, tornou-se uma tautologia, como agora na Dia:Beacon, e se isso não for exatamente um retrocesso, é pelo menos uma contenção.

Sem dúvida, esse arranjo pode ser considerado perfeitamente adequado: o que poderia ser mais apropriado, depois das pinturas da vida moderna nos museus nacionais e das obras abstratas em cubos brancos, do que instalações minimalistas em galpões industriais? No entanto, o problema reside justamente nessa conformidade, pois ela reduz a pressão que a arte exerce sobre a arquitetura, e o que se esperaria é que as instituições realçassem essas contradições em vez de eliminá-las por meio do projeto arquitetônico. ${ }^{22}$

Foster parece apontar para um beco sem saída para a arquitetura de museus de arte contemporânea, pois um espaço "adequado demais" ao tipo de obra que vai receber tenderia a anular as possibilidades de tensão que a obra visaria provocar em seu interior. Nesse sentido, a moldura institucional e arquitetônica - o "cenário" fabril e austero do Dia:Beacon - seria tão pesada e convencional para o minimalismo quanto havia sido o estéril "cubo branco" do мома para a arte moderna.

Voltando aos exemplos apontados por Kudielka, uma outra resposta da arquitetura às demandas da arte contemporânea de escala e de flexibilidade e, ainda, à difícil questão de "onde dispor espaços artísticos completos, que não podem se apresentar ou estar pendurados juntos ou na companhia do trabalho de outros expositores" ${ }^{23}$ seria o Schaulager na Basiléia. Este "armazém de exposições" da Fundação Laurenz, projeto do escritório suíço Herzog \& De Meuron e também aberto em 2003, combina as condições de reserva técnica às de apreciação do público, num layout modular de vastas dimensões. Mesmo que essa flexibilidade amplie as possibilidades de configuração espacial, o resultado seria ainda a subdivisão em salas que
22 Foster, Hal, O complexo ArteArquitetura, São Paulo: Cosac Naify Edições, 2015, p. 141-142.

23 KUDIELKA, op. cit., p.177. 

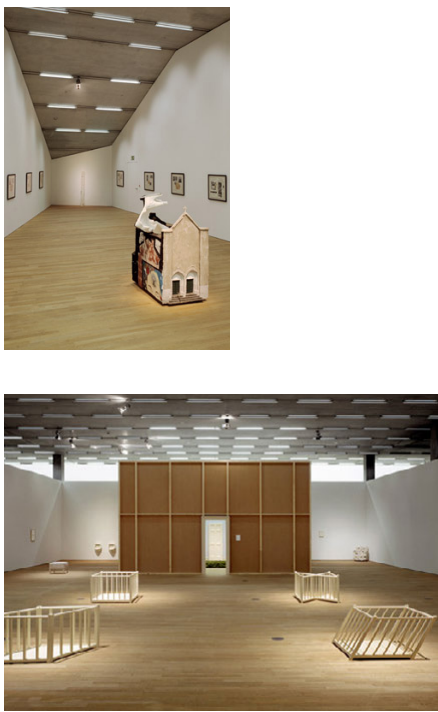

0.32 Vista da instalação de Carl Andre, Sculpture as Place, 1958-2010, Dia:Beacon, Beacon, 2014-2015. Foto: Bill Jacobson Studio. Fonte: https://www. diaart.org/exhibition/exhibitions-projects/ carl-andre-sculpture-as-place-19582010exhibition

0.33 Vistas da exposição Robert Gober. Work 1976-2007, Laurenz Foundation, Basel, 2007. Foto: Tom Bisig. Fonte: https://www.inexhibit.com/mymuseum/ schaulager-basel-herzog-de-meuron/

0.34 Plantas da Laurenz Foundation em Basel, projeto de Herzog \& De Meuron de 2003. Fonte: https:// www.inexhibit.com/mymuseum/ schaulager-basel-herzog-de-meuron/

24 KudielKA, op. cit., p.177.

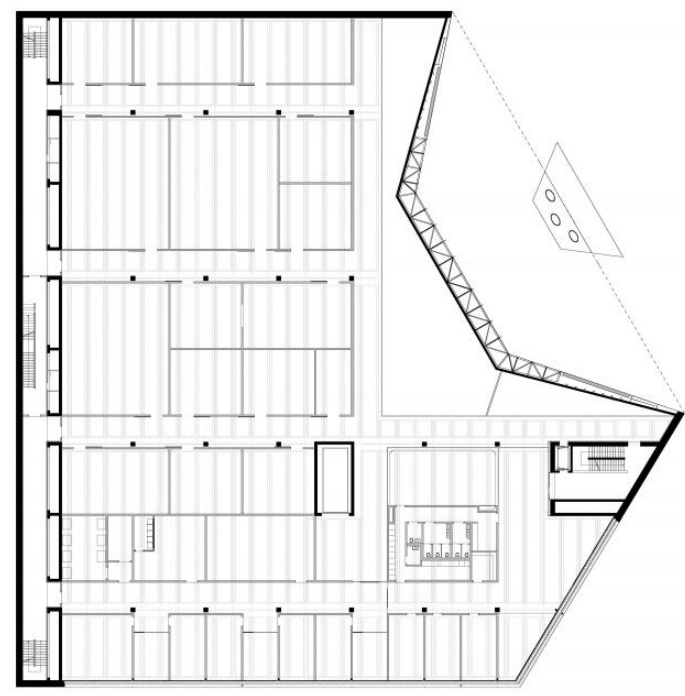

compartilham das mesmas características de ambientação presentes no "cubo branco". Trata-se, assim como o Dia: Beacon, de um local pensado para abrigar principalmente uma coleção de obras criadas anteriormente, ali remontadas para armazenagem e exposição, mas provavelmente não tão propício para ser explorado por artistas para intervenções concebidas especificamente para o local.

O autor questionou, por fim: "não seria o caso de se pensar que, com a transformação do objeto da observação em lugar da experiência, a dimensão histórica do tempo perdeu o seu significado primário de contato com a arte?" ${ }^{24}$ e indagou ainda se seria viável ou pertinente para os museus prosseguir com a missão que desempenharam para a arte moderna - a de constituir coleções que permitam ao público e pesquisadores entrar em contato com a experiência da arte, com toda a especificidade espacial da produção contemporânea.

Além das dificuldades de conciliar escala, flexibilidade e possibilidades de isolar os trabalhos entre si em coleções com um recorte conhecido, a arquitetura para as instituições de arte contemporânea enfrenta ainda questões mais complexas, as que envolvem a demanda por instigar a produção futura e/ou 
realizar exposições temporárias, pois, além do grau de incerteza inerente ao fato de as obras ainda não existirem, é preciso considerar a imensa diversidade dos caminhos trilhados na arte atual, que incluem manifestações tão diversas entre si como instalações, performances, audiovisuais, objetos escultóricos e até mesmo pinturas e outros suportes bidimensionais.

Para investigas essas questões, esta pesquisa adotou como premissa compreender edifícios concebidos para abrigar arte contemporânea não como obras de arquitetura acabadas em si mesmas, mas como polos de articulação entre as instituições responsáveis por sua encomenda e gestão e os trabalhos de arte que irão ocupá-las com as exposições. Considerou-se que o tipo de ocupação a que se destinam seus projetos implica numa condição espacial que não se limita à disciplina arquitetônica, mas se imbrica com a ambiência gerada por cada nova exposição a ser organizada por outros atores, num momento posterior à conclusão da construção dos edifícios. Tal condição mostra-se especialmente crítica nos casos em que as instituições se dedicam à programação de mostras de arte contemporânea nas quais artistas atuam diretamente no espaço, tomando-o como sua própria matéria artística.

No debate sobre a necessidade de configurar tais espaços expositivos de modo contido - sinalizando uma espécie de disputa entre os campos da arte e da arquitetura -, persiste a sombra do paradigma da suposta neutralidade - o "cubo branco", disseminado como padrão para exposições de arte moderna. A hipótese a ser verificada nesta tese é a de que tal contenção demandada para a arquitetura de espaços destinados a abrigar exposições de arte contemporânea não implique necessariamente numa ambientação genérica ou anódina, mas que, ao contrário, seja compatível com arquiteturas e configurações expográficas que tornem perceptíveis as condições particulares de seus respectivos contextos de inserção. Ao evidenciar sua história institucional, seu entorno urbano e sua esfera sócio cultural, edifícios destinados à produção artística atual oferecem oportunidades de diálogo com o chamado "mundo real" mais efetivas do que espaços configurados de modo idealizado e padronizado, impermeáveis às condições específicas em que se encontram. 
Em busca de testar tais pressupostos, a pesquisa teve como foco investigar de que forma se relacionam, de um lado, as condicionantes que definem a materialização desses edifícios e, de outro, a exploração de seus espaços por agentes variados ao longo do tempo, revelando os conflitos entre a natureza mais estática da arquitetura e o dinamismo das exposições de arte contemporânea. Seria possível estabelecer parâmetros para a conceber edifícios capazes de potencializar a experiência com a arte produzida no momento presente e ainda antecipar as necessidades da produção artística no futuro? Haveria meios de conciliar a imediatez e a imprevisibilidade da arte contemporânea com a lentidão da arquitetura, com seu tempo alongado entre a concepção inicial e a concretização, tendo como expectativa uma duração por décadas?

\section{O MOMA E O PALAIS DE TOKYO COMO PARADIGMAS}

Para investigar essas questões, o caminho adotado nesta tese foi, ao invés de construir um inventário das diversas abordagens arquitetônicas que hoje se apresentam para espaços de arte, eleger instituições dedicadas à arte contemporânea configuradas a partir de projetos recentes, associados a perspectivas consideradas paradigmáticas e a princípio antagônicas de espaços de arte. O primeiro caso escolhido para estudo foi o Museu de Arte Moderna de Nova York - MomA -, que conta com uma rica história de intervenções arquitetônicas, culminando nas duas últimas expansões e reformas: a inaugurada em 2004, com projeto do japonês Yoshio Taniguchi e a concluída em 2019 com projeto liderado pelo escritório estadunidense Diller Scofidio + Renfro. O interesse em investigar a concepção dos projetos arquitetônicos e dos espaços expositivos desde o início da história dessa instituição está na observação do desenvolvimento de um modo de expor ancorado na suposição de neutralidade do ambiente expositivo, que, adotado e difundido em grande medida pelo próprio MOMA, veio a se estabelecer como uma referência tanto central quanto longeva para espaços de arte moderna e contemporânea no ocidente - inclusive no Brasil, sede desta pesquisa. 


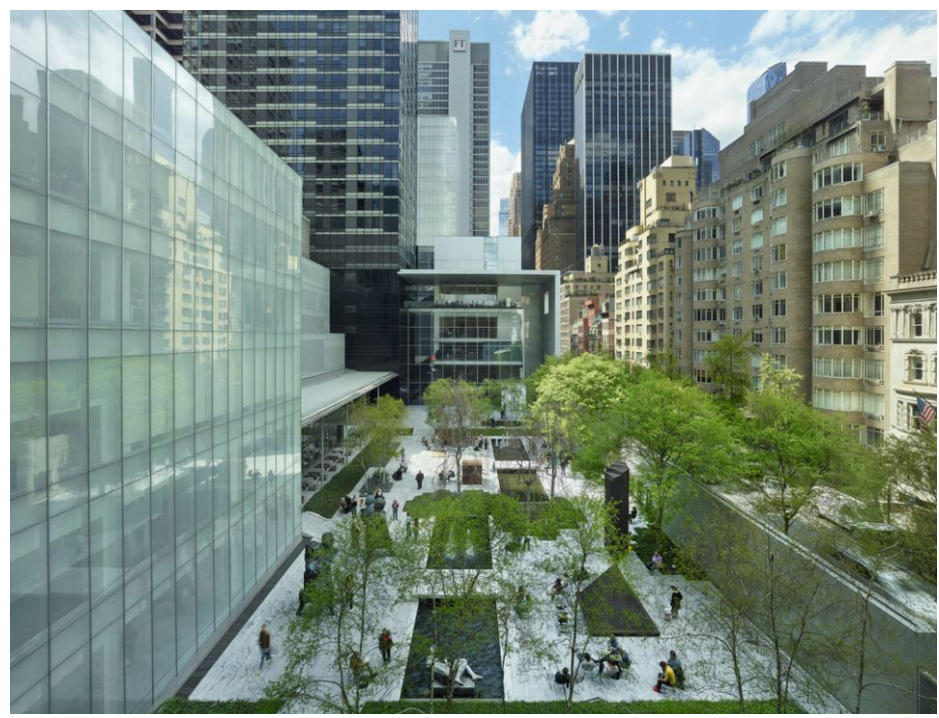

Uma ambiência discreta o suficiente para não criar "distrações" na percepção das obras de arte corresponderia, idealmente, a salas geometricamente regulares com superfícies lisas, homogêneas e de coloração sóbria, sem contato com o exterior e com iluminação artificialmente controlada, nas quais as obras seriam dispostas afastadas umas das outras, de modo a garantir o foco individual em cada uma. Tal é a configuração que ficou conhecida como "cubo branco", expressão cunhada nos anos 1970 pelo crítico e artista estadunidense Brian O'Doherty, que buscou identificar a configuração "pristina" desse modo de expor com uma ideologia em favor da sacralização da linhagem abstrata da arte moderna. ${ }^{25} \mathrm{~A}$ leitura que o autor fez da relação entre os modos de expor com o desenvolvimento da arte do século $\mathrm{xx}$ foi a referência teórica inicial para as reflexões desta tese.

A trajetória do MомA mostrou-se especialmente rica para iluminar essas questões, não apenas por ter a instituição incorporado as práticas contemporâneas à arte moderna como seu propósito central, mas também pelo fato de ter investido pesadamente em arquitetura a partir da construção da primeira sede moderna em 1939 - reformada e ampliada diversas vezes

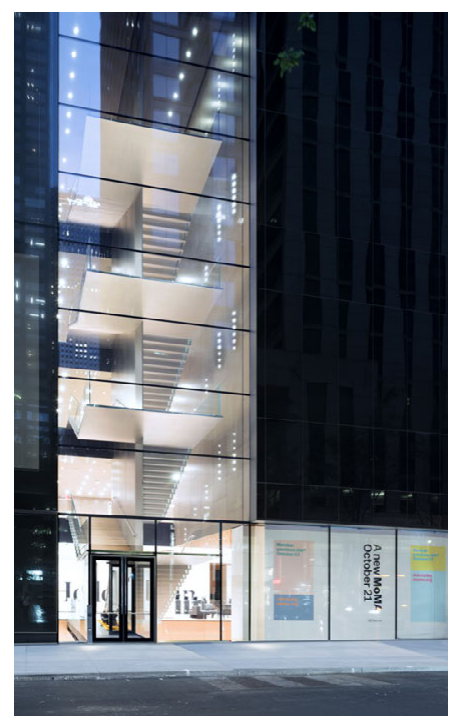

0.35 Vista do jardim de esculturas do MoMA, projeto de Yochio Taniguchi, Nova York, 2004. Foto: Timothy Hursley. Fonte: http://www.timothyhursley.com/moma/ oqg06058m4qz6hoz4skr11c01cmpj7

0.36 Fachada do MoMA, projeto de Diller Scofidio + Renfro, Nova York, 2019. Foto: Foto: Iwan Baan. Fonte: Cortesia de Diller Scofidio + Renfro.

25 O'DOHERTY, Brian. No Interior do Cubo Branco: a ideologia do espaço da arte. São Paulo: Martins Fontes, 2002.

\section{$50-51$}


desde então. Além disso, o museu nova-iorquino foi palco de um vultoso número de exposições - mais de 5.000 delas com amplo material disponível para consulta pública em seu website -, muitas das quais marcantes para a "arte de seu tempo". $\mathrm{O}$ interesse central da tese será investigar como os recentes projetos de arquitetura para a instituição procuraram responder às demandas da arte contemporânea, bem como os modos pelos quais propostas artísticas atuais vêm confrontando os espaços do museu.

Se ainda se sustenta como referência para espaços de arte, mesmo em casos destinados à produção atual, o paradigma da suposta neutralidade do espaço expositivo passou a conviver com outras abordagens para a arquitetura de museus e centros de arte contemporânea desde a intensificação, a partir dos anos 1960, dos questionamentos ao sistema vigente da arte por seus próprios realizadores, os artistas. Para construir um contraponto, o segundo caso escolhido para estudo foi o Palais de Tokyo de Paris, um "local de criação contemporânea" implantado em edifício histórico deteriorado com projeto do escritório francês Lacaton \& Vassal e inaugurado em duas etapas, em 2002 e 2012. O partido do projeto exemplifica a abordagem que vem orientando a atuação da dupla ao longo de toda a carreira - a de realizar intervenções estratégicas para atualizar estruturas obsoletas, tirando partido das propriedades duradouras dos edifícios existentes e promovendo a liberdade de utilização dos espaços arquitetônicos aliada à máxima economia de recursos. $\mathrm{O}$ alinhamento dessa postura com a premência atual de valorização da sustentabilidade econômica, social e ambiental - foi um dos fatores que contribuíram para que a dupla fosse laureada em 2021 com o Pritzker Architecture Prize - prêmio conferido em vida a profissionais de arquitetura pelo conjunto da obra. Ao invés de recuperar e renovar o edifício histórico destinado ao centro, então em precário estado de conservação, o projeto de intervenção para o Palais de Tokyo consistiu em realizar apenas obras de infraestrutura e acessibilidade, mantendo a materialidade crua da construção existente - destituída de seus acabamentos em função de obras anteriores não concluídas. A proposta era oferecer a artistas e curadores a oportunidade de "completar" 


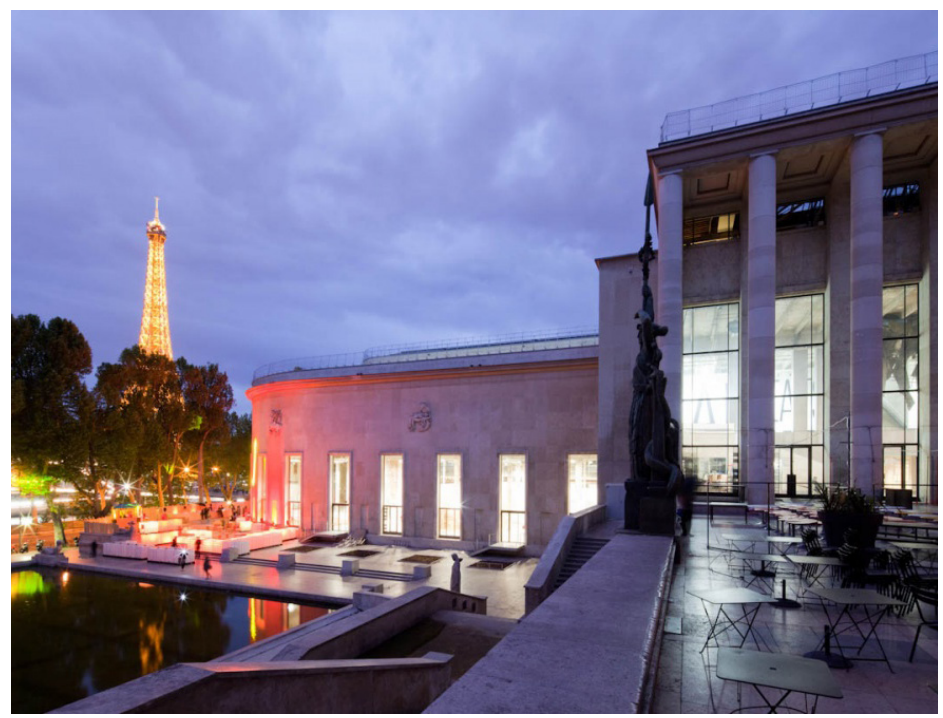

o espaço conforme cada evento e transformá-lo ao longo do tempo, independente do controle da arquitetura, criando uma sobreposição de histórias e narrativas e dando continuidade ao ambiente urbano no espaço interior. Ainda que as fontes de pesquisa relativas às exposições do Palais de Tokyo sejam bem menos estruturadas que no exemplo do момА, o interesse em investigar esse caso está na explicitação da negociação entre os trabalhos de arte e o espaço que ocupam, dado que a ambiência proposta por sua arquitetura se afasta da padronização idealizada, ao apresentar suas falhas construtivas e as marcas de sua história como indícios concretamente perceptíveis do "mundo real".

O estudo de dois objetos a princípio antagônicos não teve como intenção promover uma comparação direta entre eles, o que não seria pertinente, dadas suas condições institucionais essencialmente distintas. Em primeiro lugar, o Palais de Tokyo não tem como proposta colecionar arte, mas dedicar-se exclusivamente a eventos temporários - o que faz com que que esteja situado no campo da kunsthalle, não do museu. Tal condição tem impacto significativo no modo como esses espaços são geridos, e, consequentemente, nas possibilidades de organi-
0.37 Fachada do Palais de Tokyo, projeto de renovação de Lacaton \& Vassal de 2002 e 2012, Paris, s.d. Fonte: https:// www.palaisdetokyo.com/en/list/ requests-proposals 
zação das exposições e atuação de artistas. Em segundo lugar, o museu de Nova York é uma instituição privada, enquanto o Palais de Tokyo, embora não seja financiado apenas com recursos públicos, está vinculado ao Ministério da Cultura da França, gestor de uma ampla rede estatal de instituições culturais e museus. Além disso, o Palais de Tokyo é muito mais recente, tendo sido concebido no final da década de 1990, quando a arte contemporânea já estava madura e contava com uma ampla gama de referências de arquiteturas dedicadas a esse programa, muitas delas bastante divergentes do modelo supostamente neutro associado à história do MOMA, fundado em 1929. Por fim, o Palais de Tokyo não contou com vultosos recursos na sua implantação, mas com uma soma mínima para ocupar uma parcela do enorme edifício em desuso, o que configura uma condicionante forte para a intervenção arquitetônica.

Por outro lado, a análise dos dois casos num mesmo corpo de pesquisa permite observar como se desenvolveu a arquitetura nas principais instituições de arte moderna e contemporânea na França e nos EUA, dois dos países que disputaram o protagonismo na narrativa da arte ocidental durante boa parte do século xx. Foi justamente para ser a primeira sede do Museu Nacional de Arte Moderna da França - o MNAM - que o Palais de Tokyo foi construído em 1937, tendo sido esvaziado quatro décadas depois, quando a instituição se transferiu para o Centro Georges Pompidou, um projeto referencial não apenas como centro cultural, mas como um dos principais pontos de inflexão da arquitetura contemporânea em geral. Mais de duas décadas se passaram até que o edifício do Palais de Tokyo recuperasse um papel significativo como instituição de cultura, sediando atualmente um dos maiores e mais importantes centros dedicados à arte contemporânea na Europa. O MомA, por sua vez, realizou suas principais reformas e expansões permanecendo no mesmo endereço, procurando sustentar a identidade moderna e, ao mesmo tempo, buscando participar ativamente do cenário da arte contemporânea, mantendo-se, ainda que de forma diluída, como uma instituição referencial no cenário internacional atual. 
Para organizar essas discussões, esta tese adotou um encadeamento cronológico estruturado em quatro capítulos, sendo os três primeiros dedicados ao MомA, que tem uma trajetória mais longa - de nove décadas -, e o quarto e último ao Palais de Tokyo, que ainda não completou 20 anos. Por tratarem das relações entre arte e arquitetura no momento mais recente em cada uma das duas instituições, os dois últimos capítulos concentram o principal foco de interesse da pesquisa. As referências teóricas relacionadas à história e à crítica da arte e da arquitetura não foram tratadas de modo independente, mas entremeadas à sequência temporal das exposições e projetos arquitetônicos nos dois casos. Como consequência disso, não foram contempladas as múltiplas formas com que a produção de arte contemporânea e arquitetura de museus se desenvolveu no mundo, com as inúmeras especificidades de cada região e cultura. O recorte limitou-se ao contexto ocidental, especificamente o estadunidense e europeu, a partir de eventos artísticos e projetos arquitetônicos que repercutiram mais diretamente na concepção e utilização dos espaços de arte das instituições em questão.

É preciso observar, porém, que o estudo das exposições encontra dificuldades inerentes à condição temporária desses eventos. Dada a impossibilidade de reviver a experiência direta das obras instaladas nos respectivos espaços depois de sua desmontagem, contamos apenas com o acesso sabidamente incompleto e mediado por uma documentação muitas vezes escassa e dispersa. Registros dos projetos expográficos são muito úteis para o entendimento das montagens, mas são bastante raros de encontrar, sendo que nem sempre chegam a ser realizados, pois o planejamento das exposições é, muitas vezes, feito somente com o auxílio de maquetes ou mesmo com instruções fornecidas diretamente no espaço, sem que sejam documentados. Outra fonte importante para a compreensão dos espaços expositivos é a documentação fotográfica das montagens, também dificilmente disponibilizada nos materiais publicados pelas instituições, que normalmente privilegiam 
0.38 Equipe de curadoria do departamento Drawings and Prints trabalhando na maquete do projeto da exposição Betye Saar: The Legends of Black Girl's Window, MoMA, Nova York, 2019. Cena do vídeo Gave Away the Secret (S2, E2) | AT THE MUSEUM. Fonte: https://www.youtube. com/watch? $\mathrm{v}=3 \mathrm{JhPAQehsmU}$
26 Por serem consideradas essenciais na compreensão da discussão desta tese, serão apresentadas junto ao texto uma grande quantidade de imagens. Os casos de fotografias e desenhos sem indicação de créditos correspondem aos que não tiveram a autoria localizada ao longo desta pesquisa. Todas as imagens que têm como fonte $w e b$ sites foram acessadas nos meses de junho e julho de 2021.

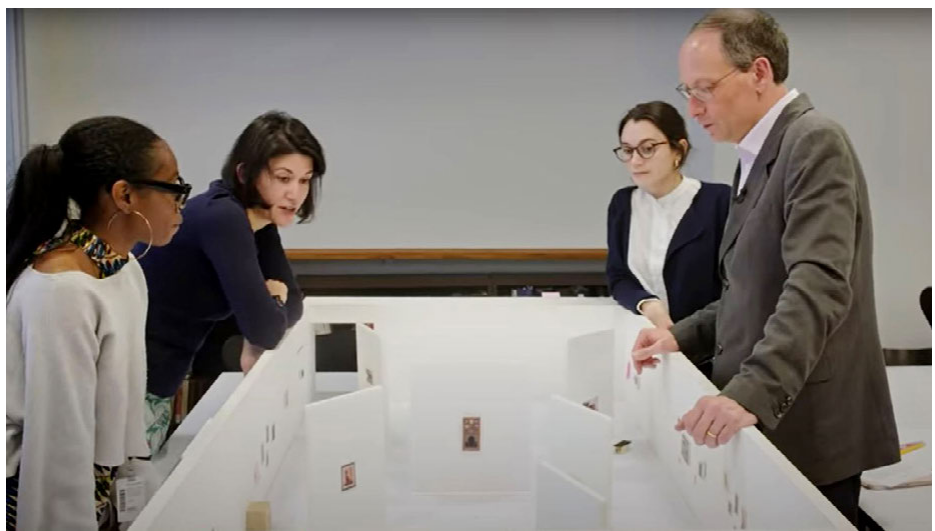

a apresentação individual das obras de arte nos catálogos impressos, preparados em geral antes de as exposições ficarem prontas. Jornais, revistas e sites de internet, por sua vez, costumam publicar fotos das exposições em suas reportagens, realizadas em geral após as inaugurações, constituindo uma boa fonte de informação visual para o entendimento das montagens, embora o contexto dessas análises nem sempre seja bem estruturado. Em todos os casos estudados, os registros fotográficos foram considerados indispensáveis para a compreensão visual das montagens das exposições em relação com os espaços das respectivas instituições, podendo ser acompanhados de análises críticas, depoimentos de artistas e curadores, press-releases das instituições, plantas do projeto expográfico e documentários audiovisuais, conforme a disponibilidade em cada caso. ${ }^{26}$

A tese se inicia com o capítulo intitulado Quando o Contemporâneo era Moderno: o мома como cânone, tendo como foco as quatro primeiras décadas de funcionamento do MoмA, de 1929 a 1968. Esse período compreende um ciclo que tem início com a formação e consolidação de um modelo de museu de arte moderna entre as décadas de 1920 a 1940 - sob liderança de seu primeiro diretor, Alfred Barr Jr. -, passa por seu apogeu nos anos 1950 - durante a gestão de René D'Harnoncourt - e se encerra com o distanciamento de suas práticas com relação à "arte de seu tempo" ao longo dos anos 1960, prenunciando 
a crise que se acentuaria a seguir. $O$ recuo no tempo permite observar a origem de aspectos institucionais que permanecem como questões no museu ainda hoje, impactando a maneira de apresentar a arte e de configurar a arquitetura de sua sede. São eles: a segmentação das diversas disciplinas artísticas em função da estrutura multidepartamental - tendo a Bauhaus como matriz -; os dilemas envolvendo a ênfase em exposições temporárias ou na promoção da coleção; as tentativas de equilibrar a presença de obras estrangeiras e nacionais e de artistas consagrados e iniciantes e, ainda, o empenho em constituir uma identidade moderna capaz de acompanhar as transformações da arte contemporânea.

O exame dos modos de expor então desenvolvidos pelo MомA apoiou-se sobretudo na leitura de Mary Anne Staniszewsky, que mostrou como, dentre os vários experimentos expográficos realizados nesses "anos de laboratório", prevaleceria o modo estetizado que Barr adotara para as exposições de arte moderna, no qual a suposta neutralidade do espaço da galeria contribuiria para a valorização da apreciação individual de cada obra. ${ }^{27}$ Serão analisados os nexos entre as questões institucionais e os projetos arquitetônicos realizados para o MOMA no período - a primeira sede de Goodwin e Stone, de 1939, e as várias ampliações de Phillip Johnson dos anos 1950 e 1960, todas elas vinculadas à promoção pelo museu do chamado International Style. ${ }^{28}$ Ao longo deste e dos demais capítulos sobre o MомA, foi fonte essencial da pesquisa a página do website do museu Exhibition History, que disponibiliza documentação sobre todas as exposições realizadas pela instituição ao longo de sua história, contendo press-releases, listas de obras, fotos das montagens e, muitas vezes, catálogos das mostras. ${ }^{29}$ Para as exposições montadas há mais de 25 anos, a instituição permite a consulta a uma documentação ainda mais completa em seus arquivos, entre os quais foram examinados os desenhos de alguns projetos expográficos.

O segundo capítulo, intitulado O мома entre encontros $e$ desencontros com a arte contemporânea, compreende as três últimas décadas do século xx, de 1969 a 2000. Antes de abordar os acontecimentos diretamente relacionados ao museu nova-iorquino, serão apresentadas algumas das vertentes experi-
27 Cf. STANiszewski, Mary Anne. The Power of Display: a history of exhibition at the Museum of Modern Art. Cambridge. Londres: The MIT Press, 1998.

28 Wallach, Alan. The Museum of Modern Art: The Past's Future, Journal of Design History, v. 5, n. 3 , p. 207-215, 1992.

29 The Museum of Modern ART. Exhibition History. MOMA. Disponível em: $<$ https://www. moma.org/calendar/exhibitions/ history>. Acesso em: 27 mar. 2021. 
mentais da arte que, ao longo da década de 1960, provocaram uma ruptura com paradigmas modernistas, dando origem ao ciclo histórico da arte contemporânea - que perdura até hoje. Exemplos de obras e exposições de artistas dos EuA e de outras partes do mundo serão entremeados com a apresentação de conceitos-chave como campo ampliado, instalação, site-specific e crítica institucional, referenciais para a discussão sobre novos modos de produzir, expor e comercializar arte que questionaram tanto seu estatuto de objeto quanto os padrões expositivos convencionais sustentados pelo sistema estabelecido.

A partir dessa contextualização, serão retomados os eventos diretamente relacionados ao MомA, investigando de que modo a ruptura com os paradigmas modernistas da arte daquele momento impactaram a relação da instituição com a produção contemporânea e com a configuração arquitetônica de seus espaços desde 1969 - ano em que o museu foi tomado por tensões provocadas pela insatisfação de artistas -, até 2000 - quando o museu buscava se reaproximar de modo mais assertivo das práticas contemporâneas. Dos últimos trinta anos do século $\mathrm{xx}$, foram escolhidos para análise programas e exposições que pontuaram a lenta inserção da arte contemporânea no museu, especialmente nas décadas de 1970 e 80 , quando o foco da instituição foi dirigido sobretudo para a consolidação do aspecto canônico da coleção de arte moderna e para o aprofundamento da forma estetizada de sua apresentação, sob a liderança do diretor e curador William Rubin. Será avaliado, ainda, o projeto de expansão da sede realizado por César Pelli em 1984, observando sua articulação com a visão institucional e artística do мома daquela época.

A investigação sobre esse período será centrada nos modos como as novas formas de interação da arte com os espaços de exposição vincularam-se ao descrédito com relação à configuração "pristina" das galerias convencionais de arte moderna. A análise dessas questões, de interesse central para esta tese, apoiou-se principalmente na crítica elaborada por Brian O'Doherty nos anos 1970 e no contexto em que o autor cunhou a expressão "cubo branco", associando-a uma ideologia. ${ }^{30}$

Em paralelo aos eventos do MoмA, será examinado o uni30 O'DOHERTY, 2012, op. cit. verso dos espaços alternativos de arte de Nova York e a funda- 
ção em 1976 do PS1 - um grande centro de arte contemporânea instalado num edifício deteriorado de uma antiga escola. Concebido como um "anti-museu" por Alanna Heis, o PS1 oferece um contraponto importante para a reflexão sobre modelos institucionais e arquitetônicos para espaços de arte, sendo especialmente relevante para esta pesquisa, tendo em vista sua fusão com o MомA a partir de 1999.

O terceiro capítulo, intitulado O MомA enfrenta o contemporâneo, trata das duas primeiras décadas do século xxI, retomando alguns eventos desde 1996, ano em que, sob a direção de Glenn Lowry, o museu iniciou um movimento de reaproximação das práticas contemporâneas que envolveram duas expansões de sua sede, num intervalo de quinze anos. Será analisado como, num primeiro momento, o protagonismo desse processo foi dado à arquitetura, por meio da ampla mobilização do museu em torno de debates e de um concurso de projetos, sob a condução de Terence Riley, então diretor do Departamento de Arquitetura e Design. Será examinado como a escolha do projeto de Yoshio Taniguchi, inaugurado em 2004, revelou, por outro lado, o entendimento do MомA de que a expressão arquitetônica não deveria se sobrepor à da arte, especialmente no interior das galerias, desenhadas de acordo com o padrão convencional e discreto praticado no museu. Considerando o grande átrio central como o lugar em que a arquitetura se desenvolveu de modo mais desimpedido, serão estudadas algumas propostas artísticas que interagiram com esse espaço, explorando seu potencial atrativo com a realização de exposições de peças escultóricas e pictóricas e, sobretudo, de instalações, vídeo instalações e performances - muitas das quais sob a curadoria de Klaus Biesenbach, que viera do PS1.

No momento seguinte, o Mома conduziu o processo de reaproximação com as práticas contemporâneas movido principalmente por uma renovação da abordagem curatorial, tendo como consequência o projeto de reforma e expansão liderado por Diller Scofidio + Renfro, realizado em colaboração com o escritório Gensler e concluído em 2019. As principais demandas para a arquitetura foram então a ampliação e a flexibilização das galerias da coleção, para permitir aos curadores arranjos 
31 Foster, Hal. O complexo ArteArquitetura. São Paulo: Cosac Naify Edições, 2015. que dissolvessem a linearidade das montagens anteriores e promovessem, assim, uma visão mais multicultural e interdisciplinar da arte. Será avaliado como, mais uma vez, o projeto manteve a maior parte das galerias com a ambientação convencional, inserindo em meio a elas, porém, um conjunto de espaços com características de exceção, criando novas possibilidades de articulação visual entre as galerias expositivas e dessas com a cidade. Serão observados, além da intervenção arquitetônica, os modos como os diversos setores do edifício foram ocupados pela arte, tanto pelas exposições da coleção, como pelas mostras temporárias e pelas instalações site-specific comissionadas para a ocasião da reinauguração. A reflexão sobre a interação dos dois projetos realizados no MoMA neste início do século XXI com as formas de apresentação da arte e com o discurso e o modo de funcionamento da instituição tiveram como referência as críticas de Hal Foster, ${ }^{31}$ bem como as de outros autores que publicaram artigos na imprensa, além da consulta aos arquivos do museu, das visitas ao edifício e suas exposições. Foram realizadas ainda pela autora entrevistas com a arquiteta Elizabeth Diller, em que se discutiu o papel da arquitetura no contexto institucional do момА, е com o artista brasileiro Carlito Carvalhosa, que relatou sua experiência de realizar uma exposição no museu em 2011.

Encerrando a tese, o quarto e último capítulo, intitulado $O$ Palais de Tokyo e arquitetura do mundano, trata da concepção e do funcionamento desse centro de arte contemporânea de Paris, de 1999 até 2018, e da origem do edifício em que foi instalado. Inaugurado em 1937, como sede do Museu Nacional de Arte Moderna da França, o Palais de Tokyo acabou sendo desocupado quatro décadas depois, quando o museu foi transferido para o Centro Georges Pompidou. Será investigada a articulação entre a proposta curatorial instaurada por Jérome Sans e Nicolas Bourriaud e o projeto arquitetônico de Lacaton \& Vassal na elaboração de espaços destinados à arte contemporânea, afirmando a materialidade crua do edifício deteriorado e a abertura à sua transformação pela arte, como contraposição aos espaços anódinos do tradicional modelo "cubo branco". A constante reiteração, tanto pelos arquitetos quanto pelos dirigentes do centro, de que o princípio norteador do Palais 
de Tokyo seria o da liberdade artística, será confrontada com a argumentação de Boris Groys de que a arte contemporânea revelaria a ambiguidade do conceito de liberdade individual - encarnada pelo artista -, em seu atrito com a esfera pública domínio do curador, operando em nome da instituição. ${ }^{32}$ Uma das principais fontes de pesquisa deste capítulo foi a publicação do centro, Palais no. $15,{ }^{33}$ edição que contém um histórico da construção do edifício, elaborado por Jean Baptiste Minnaert, e diversas entrevistas com arquitetos, curadores e artistas que realizaram exposições no Palais de Tokyo, dentre as quais foram examinadas as que interagiram de modo mais direto com a arquitetura. Outra referência importante foi a entrevista realizada pela autora com uma das curadoras do centro, Rebecca Lamarche-Vadel, abordando o papel da arquitetura na elaboração das exposições e o jogo entre os códigos museais e a ideia de "instituição", elucidando assim o modo como os espaços do edifício são gerenciados.

\section{IMPASSES, DESAFIOS E POTENCIALIDADE PARA A ARQUITETURA}

Com esse percurso pelos projetos arquitetônicos e exposições das duas instituições, espera-se compreender alguns caminhos para problematizar a tensão entre arte, arquitetura e instituição na reflexão sobre projetos de edifícios de museus e centros de arte no momento contemporâneo. Vemos que uma das características da arte contemporânea é engajar-se no espaço e na relação com o espectador, dependendo mais da moldura institucional do que das características físicas museológicas, cuja subversão é muitas vezes a razão de ser da obra. Podemos, de fato, encontrar obras instaladas tanto em espaços arquitetônicos especificamente destinados à arte quanto em qualquer outro - é sobretudo sua designação por artistas e instituições que o tornarão um "espaço da arte". Se, para boa parte dos artistas contemporâneos, não há uma configuração "ideal" definida de antemão para a instalação de seus trabalhos, em que devem se balizar arquitetas e arquitetos para criar espaços expositivos mais favoráveis a uma ampla gama de experimentações? Dada a natureza propositiva da arquitetura,
32 Groys, Boris. Politics of Installation. E-flux, n. Journal \#02, p. 1-8, 2009.

33 PALAIS DE TOKYO. Palais 15: Histoire du Palais de Tokyo depuis 1937, Paris: Palais de Tokyo, 2012. 
que implica prever, e, até certo ponto, determinar formas de uso, é importante que a concepção de novos museus e centros de arte contemporânea parta da compreensão dos impasses, desafios e potencialidades na utilização dos espaços institucionais pela arte. 


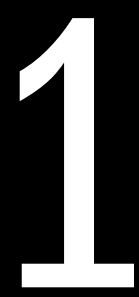

QUANDO 0

CONTEMPORÂNEO

ERA MODERNO:

O MoMA COMO

CÂNONE 

Esta tese parte do reconhecimento da posição paradigmática ocupada pelo Museu de Arte Moderna de Nova York - conhecido pelo acrônimo MOMA - como referência incontornável de instituição de arte do século xx, que incluiu o desenvolvimento de um modo específico de apresentá-la ao público por meio de suas exposições e da arquitetura de sua sede. ${ }^{34}$ Entre os fatores que o levaram a essa condição estão: os atores - uma reunião singular de figuras influentes não apenas no âmbito social, político e econômico, como também no meio intelectual ligado às artes -; o ambicioso e bem definido objetivo - o de instaurar o "gosto" pelo moderno na cultura estadunidense, e, a partir dela, expandi-lo para além-fronteiras -; a realização de um número expressivo de exposições emblemáticas, a maioria muito bem documentada e, ainda, a formação de uma das mais abrangentes coleções de arte moderna do mundo.

O sucesso do empreendimento pode ser medido pela associação do MOMA à formação e difusão de uma visão canônica para a arte moderna, que consolidou sua sólida e profunda influência no cenário artístico mundial, pelo menos até a década de 1950, superando em muito as altas pretensões iniciais de seus fundadores. A partir da década seguinte, no entanto, os desdobramentos da arte contemporânea começaram a colocar em xeque o prestígio desse cânone, alvo de questionamentos cada vez mais intensos, o que, somado ao crescimento expressivo do circuito artístico em que surgiram novos museus, centros de arte e galerias, fez о мома chegar ao fim dos anos 1960 com uma proeminência diluída, apesar de sua robustez institucional, ou talvez justamente por isso.

Apoiando-se no cruzamento da vasta historiografia disponível com a análise de fontes primárias obtidas nos arquivos do MOMA,$^{35}$ este capítulo é dedicado às quatro primeiras décadas de funcionamento do museu. A investigação que aqui se inicia percorrerá toda a tese, procurando compreender o papel da arquitetura na articulação tanto com a produção da arte de seu tempo quanto com a visão institucional, especialmente nos espaços em que se encontram com o público: as exposições.
34 Diversos museus de arte moderna nos EUA adotaram para si o acrônimo MOMA, do mesmo modo que no Brasil foi adotado o acrônimo MAM, em geral acompanhado das siglas referentes aos locais onde se situam. Ao longo desta tese, sua utilização se referirá especificamente ao Moma de Nova York, salvo indicação específica.

35 A partir de 2018, o мома, por meio de seu departamento The Museum of Modern Art Archives, passou a disponibilizar em seu website, na sessão Exhibition History, boa parte do material referente às exposições realizadas pelo museu, incluindo listas de artistas e obras, comunicados de imprensa, catálogos e registros fotográficos da maioria das montagens, fontes essenciais para esta pesquisa. Foram consultados também documentos em papel armazenados nos arquivos no museu, especialmente desenhos dos projetos expográficos relativos às exposições estudadas. Cf. THe Museum of Modern ART. Exhibition History. MOMA. Disponível em: <https://www. moma.org/calendar/exhibitions/ history>. Acesso em: 27 mar. 2021. 
Eventos temporários, ainda que por vezes de longa duração, a exposições e sua organização espacial em relação com a arquitetura podem iluminar as várias formas com que se procurou configurar nos museus as narrativas da história da arte e suas conexões com a produção contemporânea em diferentes épocas. O MOMA, por conjugar pioneirismo na associação entre museu e a "arte de seu tempo", investimento contínuo em arquitetura, abundância e disponibilidade de documentação de exposições e, evidentemente, por sua referida influência, mostrou-se objeto especialmente fecundo para esta pesquisa. Sem a pretensão de esmiuçar cada um dos eventos abordados, a análise se desenvolverá de modo cronológico tendo como foco a formação e a consolidação de um padrão expográfico que se manteve referencial para exposições de arte mesmo após o encerramento do ciclo histórico do modernismo, confrontando-o com os respectivos contextos da produção artística, do desenvolvimento institucional e das transformações das condições arquitetônicas da sede do museu.

\subsubsection{UM MUSEU DE ARTE "CONTEMPORÂNEA” NO INÍCIO DO SÉCULO XX}

Era crescente nos EUA o interesse em promover a produção da arte atual quando membros da alta sociedade nova-iorquina decidiram fundar, em 1929, o Museum of Modern Art (MOMA). Ainda era considerada ousada a ideia de criar uma instituição associando tão assertivamente os dois termos: museu e arte moderna. Mesmo em Paris, então capital da arte moderna e tão rica em museus, artistas contemporâneos contavam apenas com o Musée des Artistes Vivants, posteriormente Musée du Luxembourg, que, como apontou o historiador da arte Jesùs Pedro Lorente (1963-), era apertado e retrógrado, ainda atrelado aos padrões acadêmicos. Além disso, era dedicado apenas a artistas de nacionalidade francesa, pois a arte

36 Cf. LORENTE, Jesùs Pedro. The Museums of Contemporary Art: Notion and Development. Surrey; Burlington: Ashgate Publishing, 2011, p. 128. realizada por pessoas estrangeiras ficava alocada no Musée du Jeu de Paume, no Jardim das Tulherias, onde também se localizava o Musée de l'Orangerie, que abrigava as enormes Nymphéas de Monet. ${ }^{36}$ 


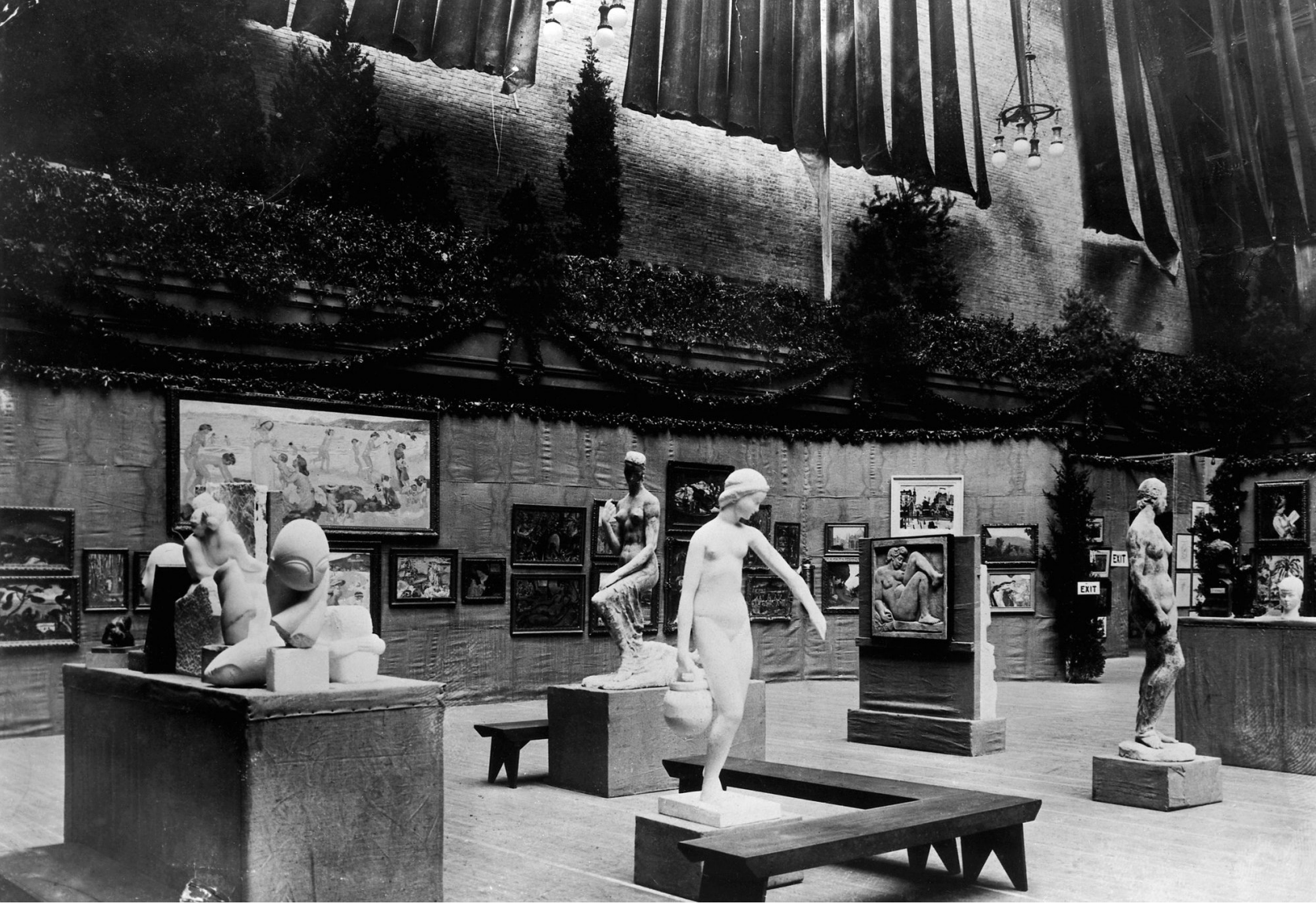

Diversas instituições e organizações independentes já vinham se articulando para trazer ao novo continente a arte moderna produzida na Europa desde finais do século xIX e, simultaneamente, fomentar a produção de artistas locais. Embora a produção de vanguarda ainda encontrasse certa resistência em meios mais conservadores, a marca de aproximadamente 88 mil visitantes alcançada em 1913 pela montagem da exposição The Armory Show em Nova York evidenciava que a atração pela arte moderna já não se restringia apenas ao pequeno círculo elitizado que podia frequentar museus europeus ou colecionar obras de arte. ${ }^{37}$ Organizada pela Associação dos Pintores e Escultores Americanos, a exposição tinha 1300 obras de 308 artistas, dos quais dois terços estadunidenses e um terço de origem europeia - como Pablo Picasso, Henri Matisse,
1.1 Vista da International Exhibition of Modern Art (The Armory Show), Nova York, 1913. Fonte: https://static01.nyt.com/ images/2012/10/28/arts/JP-ARMORY1/ JP-ARMORY1-super Jumbo.jpg

37 A exposição alcançou ainda o número aproximado de $188 \mathrm{mil}$ na montagem de Chicago, mais 13 mil na de Boston. Cf. Altshuler, Bruce (Ed.). Salon to Biennial. Exhibitions That Made Art History: 1893-1959. Londres, Nova York: Phaidon, 2008, p. 153. 


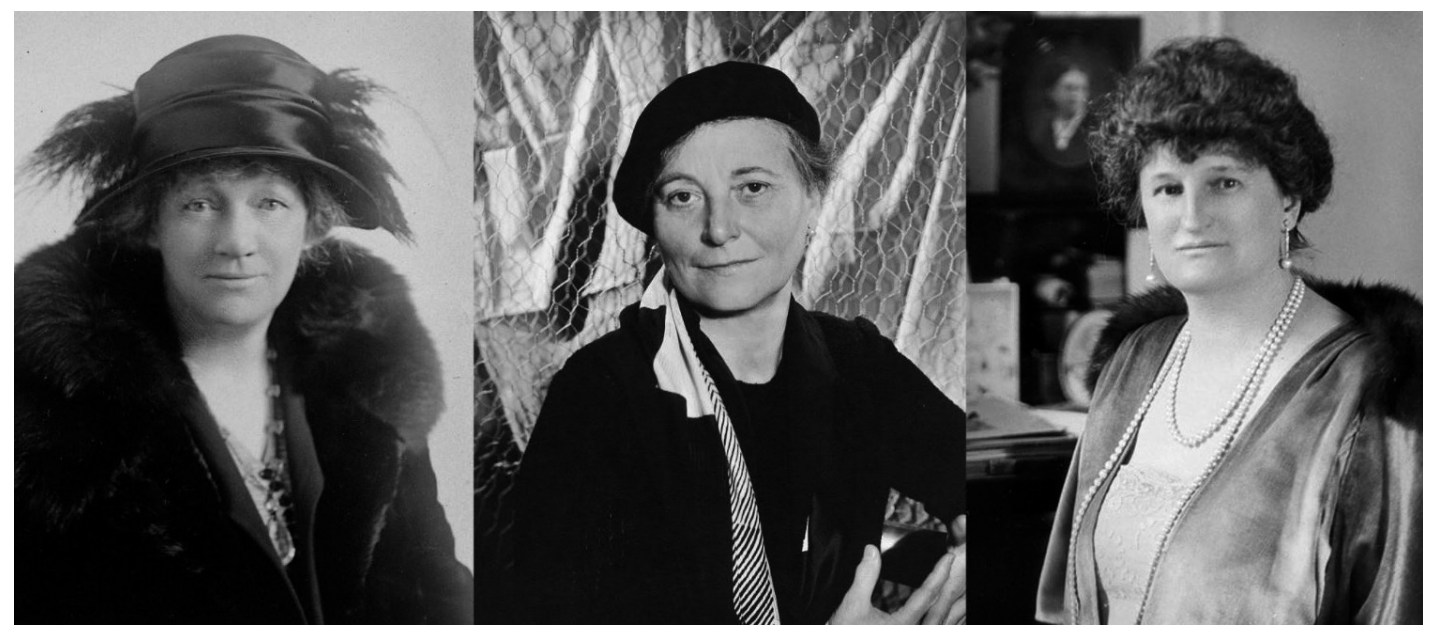

1.2 As fundadoras do MoMA: Lillie P. Bliss, c. 1924; Mary Quinn Sullivan e Abby Aldrich Rockefeller, 1922. Fonte: https://www.moma.org/ interactives/moma_through_time/1920/ three-women-have-a-vision/
38 As fundadoras eram chamadas de "The Ladies", duas das quais frequentemente referidas em publicações pelo sobrenome de seus maridos, Mrs. Cornelius J (Mary Quinn) Sullivan e Mrs. John D. (Abby Aldrich) Rockefeller, Jr, ao modo usual da época. Tendo falecido solteira em 1931, Lillie P. Bliss era a única a ser chamada pelo próprio nome.

39 Criada em 1862 como Buffalo Fine Arts Academy.
Marcel Duchamp, Paul Gauguin, Paul Cézanne e Vincent Van Gogh, as estrelas da mostra. Além de ter ampliado o interesse do público para essa produção, o evento impulsionou a formação de importantes coleções de arte moderna, como a que viria a inaugurar a formação do acervo do MoMA em 1934, deixada em testamento por Lillie P. Bliss, uma das fundadoras do museu junto a Mary Quinn Sullivan e Abby Aldrich Rockefeller. ${ }^{38}$

Para realizar a empreitada, as três colecionadoras convidaram membros da alta sociedade com interesses afins para formar o conselho do museu, o chamado board of trustees. A presidência ficou a cargo de A. Conger Goodyear, empresário e colecionador de arte moderna, que havia ocupado a direção de uma das mais antigas instituições de arte dos EUA, a Albright Art Gallery de Buffalo. ${ }^{39}$ Além de Frank Crowninshield - jornalista da revista estadunidense Vanity Fair e influente no meio artístico - e de Josephine Boardman Crane - patrona da progressista Dalton School -, foi convidado o empresário do setor de investimentos Paul Sachs, que atuava ao mesmo tempo como professor do departamento de Belas Artes de Harvard, ministrando um curso sobre de história da arte e museus.

Ao contrário do que divulgavam suas campanhas de marketing, o MoMA não foi uma novidade absoluta enquanto instituição dedicada à arte moderna, embora tenha sido pioneiro 
ao incorporar a designação a seu nome.$^{40}$ Seu traço mais original era a conexão íntima de seus membros com o mundo dos negócios, o que lhe permitiu atrair grupos influentes da política e das finanças com estratégias tipicamente comerciais, independente do universo dos artistas, que não tiveram participação na formação inicial do museu. Além disso, entre as instituições locais, apenas a Albright Art Gallery e o Metropolitan Museum eram consideradas relevantes pelo conselho, que almejava construir um museu que viesse a se equiparar aos grandes museus europeus. ${ }^{41}$

Embora os vínculos com a alta sociedade tenham sido desde sempre vitais para o MOMA, a consistência de seu projeto e o sucesso que alcançou devem-se em grande medida à liderança intelectual de Alfred $\mathrm{H}$. Barr Jr., que havia sido aluno de Paul Sachs em Harvard e era professor no curso que criara de história da arte moderna no Wellesley College quando foi nomeado o primeiro diretor do museu, com apenas 27 anos de idade. Entre suas principais referências para a concepção de um museu de arte moderna estavam as experiências do De Stijl, do Construtivismo Russo e sobretudo da Bauhaus, com sua ênfase na integração entre as diversas disciplinas artísticas e dessas com o universo dos objetos comuns, além da articulação da produção com o ensino. Vem daí a estruturação multi-departamental criada por Barr, que é até hoje a marca do момА, integrando as disciplinas mais afeitas ao ambiente museológico tradicional das belas artes - como a pintura e a escultura - ao contexto artístico mais amplo da criação moderna - que incluía manifestações como arquitetura, design, fotografia e cinema. ${ }^{42}$

A identidade do museu e o funcionamento dessa estrutura, no entanto, não estavam dados desde o início, e sua consolidação como a referência que veio a se tornar foi um processo tão experimental quanto o da própria arte moderna, atravessado por intensas disputas, tanto no âmbito institucional quanto no artístico. O principal debate interno girava em torno do que definiria com mais propriedade o perfil de uma instituição dedicada à "arte de seu tempo": assumir-se como uma kunsthalle - dedicando-se apenas a exposições temporárias -, ou tornar-se um museu propriamente dito - conservando
40 Nos textos de Barr lançados na ocasião do lançamento do MoMA, foram elencadas diversas cidades menores que Nova York da Europa e dos EUA cujos museus já tinham exposições permanentes de arte moderna (Estocolmo, Weimar, Dusseldorf, Essen, Manheim, Lyons, Rotterdam, The Hague, Detroit, Chicago, Cleveland, Providence e Worcester). Eram referências para a fundação do Moma museus de cidades maiores que acolhiam a produção mais recente, como o Musée du Luxembourg em Paris, a Tate Gallery em Londres e a NationalGalerie em Berlim. Cf. Alfred Barr, A New Art Museum e A New Museum , in: SANDLER, Irving; NEWMan, Amy (Orgs.). Defining Modern Art: Selected Writings of Alfred Barr, Jr. . Nova York: Harry N. Abrams, 1986.

41 LORENTE, op. cit., p. 149.

42 O MoмA foi o primeiro museu a integrar as "belas artes" do século xx às artes aplicadas. Cf. HuNTER, Samuel. Introduction. In: The Museum of Modern Art, New York, 8a. edição. Nova York: Harry N. Abrams e The Museum of Modern Art, 1984, p. 8-41. 
uma coleção que inevitavelmente se tornaria histórica. Não havia então um consenso sobre como equilibrar a presença de obras de mestres consagrados, produzidas então na Europa, com o incentivo à produção atual de artistas estadunidenses, considerada ainda incipiente. Questões como essas, que ainda hoje desafiam as instituições dedicadas à arte contemporânea, estavam sendo enfrentadas pela primeira vez no contexto da arte moderna. A seguir, será investigada como a montagem institucional do MOMA articulou-se ao modo como o museu configurou seus espaços arquitetônicos e expográficos entre 1929 e 1968, definindo um padrão que se espraiou pelo mundo, vindo a se tornar hegemônico.

\subsubsection{UM MODO DE EXPOR ESTETIZADO EM CONTEXTOS PROVISÓRIOS}

Seguindo o tempo geralmente lento da arquitetura, levou dez anos para que o мома pudesse se instalar num edifício projetado e construído como sede própria, tendo em 1929 iniciado suas atividades num imóvel alugado no $12^{-} \mathrm{a}$ andar de um edifício comercial - o Heckscher Building -, localizado na esquina da $5^{\mathrm{a}}$ Avenida com a Rua $57 \cdot{ }^{43}$ Em contraste com a tradição de monumentalidade das sedes das instituições da época dedicadas às "belas-artes", a situação tinha coerência com um certo espírito de informalidade que se buscava para um museu de arte moderna, voltado não aos tesouros do passado, como o Metropolitan Museum, mas à "arte de seu tempo". Apesar das limitações inerentes à adaptação a imóveis pré-existentes destinados a outros usos, as condições espaciais e as soluções expositivas adotadas pelo MoMA em sua primeira década de funcionamento tiveram impacto duradouro não apenas da definição de um modelo expositivo particular quanto em certas

43 MAM e MASP de São Paulo também abriram as portas em um imóvel comercial - ambos no edifício Guilherme Guinle, conhecido como "prédio dos Diários Associados", à Rua 7 de Abril, 230, no centro da cidade de São Paulo -, respectivamente em 1947 e 1953. soluções arquitetônicas adotadas em sua sede moderna no endereço definitivo.

A primeira exposição do museu, definida pelas fundadoras, foi Cézanne, Gauguin, Seurat, Van Gogh, apresentando artistas que, embora já não representassem mais a última vanguarda, ainda não tinham conquistado plena aceitação nem 
do público, nem dos museus tradicionais. ${ }^{44}$ Com 98 obras, a mostra foi considerada um sucesso, tendo recebido $47 \mathrm{mil}$ pessoas nos 30 dias em que esteve em cartaz - a maior visitação para um evento de arte moderna desde o The Armory Show. ${ }^{45}$ Barr teria preferido inaugurar o museu com obras de artistas estadunidenses, aos quais foi dedicada a segunda mostra - Paintings by Nineteen Living Americans -, com 105 obras de artistas selecionados pelo conselho e não tão bem recebida. A terceira exposição - Painting in Paris -, com 99 obras de 26 artistas como Braque, Chagal, Giorgio de Chirico, Matisse, Miró e Picasso, superou o sucesso da primeira, com mais de $5^{8}$ mil visitantes. ${ }^{46}$ Realizadas num período de menos de quatro meses, essas três exposições iniciais são uma boa amostra da direção que Barr pretendia dar ao museu e dos embates que teria que enfrentar.

Para o jovem diretor, era importante estabelecer um sentido de paridade entre obras pioneiras da arte moderna de finais do século xIX e a produção das vanguardas então mais recentes do século $\mathrm{xx}$, assim como entre artistas estadunidenses e europeus. Seu rigoroso critério de "qualidade" e o perfil internacionalista do museu renderam por muitas décadas críticas ferozes da comunidade local de artistas, que, embora numericamente bem representada nas exposições - e, posteriormente, nas aquisições -, sentia-se desprestigiada em comparação ao peso dado à produção da "Escola de Paris", que ainda contava com maior preferência do público. Segundo o historiador da arte Sam Hunter (1923-2014), embora Barr mantivesse uma certa distância temporal para julgar uma obra de maneira mais definitiva, suas opções eram ousadas, considerando o contexto hostil do público estadunidense para com a arte de vanguarda e as limitações do campo crítico de então. ${ }^{47}$

Embora não tenha sido o responsável por escolher as obras das exposições iniciais, foi Barr quem definiu o modo como seriam expostas no espaço do museu. Em livro referencial para este tese sobre as exposições do момA, The Power of Display, a historiadora da arte Mary Anne Staniszewski (1954-) apontou como novidade esse modo de expor, que se tornaria mais tarde tão convencional: a instalação das obras separadas umas das outras, alinhadas à altura dos olhos, posicionadas contra

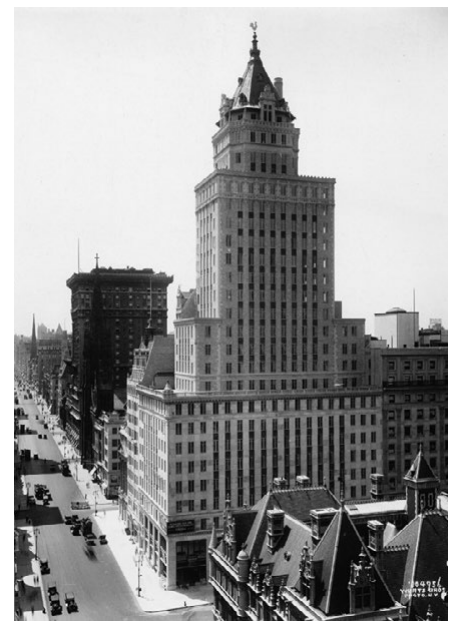

1.3 The Heckscher Building na Quinta Avenida, projeto de Warren \& Wetmore, Nova York, 1921. Foto: Wurts Bros. Fonte: https://digitalcollections.nypl. org/items/510d47e2-f1f7-a3d9-e040e00a18064a99

44 O Metropolitan ainda não colecionava obras do final do século XIX. Cf. LORENTE, op. cit., p. 145.

45 Cf. Hunter, op. cit., p. 12.

46 Cf. LOREnTE, op. cit, p. 150.

47 Cf. Hunter, op. cit, p. 13. 
48 Cf. Staniszewsky, Mary Anne. The Power of Display: a history of exhibition at the Museum of Modern Art. Cambridge, Londres: The MIT Press, 1998, p. 61.

49 Cf. GrassKamp, Walter. The white wall - on the prehistory of the 'white cube'. Oncurating: Curating critique, p. 78-90, 2011, p. $80-81$.

50 Vale ressalvar que, se estúdios de artistas se caracterizam pelo despojamento - no sentido de serem oficinas de trabalho, em geral desprovidos de elementos decorativos -, são, em boa parte dos casos, espaços visualmente bastante carregados, com acúmulo de materiais, obras prontas e em processo de realização, sem a organização que caracteriza espaços expositivos destinados ao público. 51 Ibidem, p.87. Tradução nossa. um fundo discreto (tecido de cor clara), organizadas sequencialmente por familiaridade conceitual e estética criteriosa (cronologia, artistas, escolas) e, um pouco mais tarde, com legendas explicativas. ${ }^{48}$

Diversos desses aspectos já vinham, no entanto, sendo explorados em ambientes expositivos europeus e estavam conectados ao recente desenvolvimento da arquitetura moderna. O historiador da arte Walter Grasskamp (1950-) identificou dois fatores decisivos para o estabelecimento dessa nova linguagem expográfica, que teriam começado a se delinear em datas e locais distintos, entre 1870 e 1900 , especialmente na Alemanha e na Áustria. ${ }^{49}$ Em primeiro lugar, o abandono das paredes decoradas e com cores fortes - nos moldes das luxuosas residências burguesas - e, em segundo, a preferência por dispor as obras lado a lado, não mais em diversas alturas preenchendo toda a superfície vertical. Segundo o autor, enquanto a disposição de obras em uma única fileira tinha se tornado comum na Europa na década de 1930, havia ainda muito debate e resistência quanto ao uso de paredes não decoradas nos museus de arte, embora esse padrão já conquistasse também boa aceitação.

Outros fatores de naturezas distintas são apontados por Grasskamp como origens da consolidação das paredes brancas como padrão expositivo no século xx. Entre eles, estariam a necessidade de superfícies claras para potencializar o rendimento da recém-criada iluminação artificial, o reconhecimento das vantagens de exibir as obras em condições óticas mais próximas aos despojados estúdios dos artistas onde haviam sido realizadas, ${ }^{50}$ a facilidade e economia para adaptar os espaços para receber exposições temporárias, as mudanças no gosto decorativo burguês impulsionadas pela difusão da arquitetura moderna, e principalmente a incompatibilidade das obras abstratas do Expressionismo contra fundos visualmente carregados de informação. Ainda segundo o autor, "a parede branca do museu foi também um pré-requisito para o abandono da moldura, antes tão indispensável para criar uma separação entre pintura e decoração". ${ }^{51}$

Se o modelo não foi inteiramente criado por Barr, a expansão global de sua influência dependeu da adoção consistente 
por ele dessas novas técnicas expográficas alemãs, com as quais tinha tido contato em sua temporada de viagens pela Europa em $1927-28,{ }^{52}$ e de sua intrincada articulação com a assertiva e bem-sucedida política de difusão de uma determinada visão da arte moderna, construída e sustentada pelas exposições e publicações realizadas pelo MoмA.

Como relatou Staniszewski, tanto Barr quanto Philip Johnson (1906-2005), colega do círculo de Harvard ligado às artes, ${ }^{53}$ haviam visitado o Landesmuseum de Hannover, onde se impressionaram com a avançada expografia do artista e arquiteto russo El Lissitzky (1890-1941) para o Abstract Cabinet, de 1927. Dedicada à arte moderna, esta sala continha uma série de dispositivos interativos e visualmente ativos, como painéis deslizantes e superfícies de parede "drapeadas" com faces alternadamente pretas e brancas. No entanto, segundo Johnson, entre os vários experimentos que Barr estava fazendo naquele momento, a referência que acabou adotando foi a expografia mais sóbria do Folkwang Museum da cidade de Essen, no qual as pinturas estavam expostas à altura dos olhos contra um fundo de algodão cru, considerada tonalidade mais discreta possível e não tão luminosa quanto o branco. ${ }^{54}$ Além de vincular-se a experiências especificamente expográficas, a adoção desse tipo de ambiência mais austera também deve muito à profunda admiração que Barr desenvolvera pela linguagem de determinados mestres da arquitetura moderna europeia de então, como Le Corbusier, J. J. P. Oud, Mies van der Rohe e sobretudo Walter Gropius, sendo esse último o autor de sua obra favorita, o edifício da Bauhaus de Dessau, de 1926.

Barr estudara com afinco as realizações da escola alemã antes de visitá-la, por meio das numerosas publicações que as difundiam para além das fronteiras de seu país, e conhecera também o projeto de sua sede, cujas fotografias constavam na mostra Machine-Age Exposition, realizada num espaço comercial de Nova York em 1927, poucos meses antes de partir em viagem pela Europa. Sobre os quatro dias em que esteve lá, Barr relatou: "Eu tinha me preparado com grande antecipação para a Bauhaus e senti que ela tinha correspondido às minhas expectativas". ${ }^{55} \mathrm{~A}$ experiência havia sido seminal para seu entendimento da importância da unidade estilística
52 Nessa viagem, financiada por Paul Sachs, Barr esteve na Inglaterra, Holanda, Alemanha e Rússia. Cf. KANTOR, Sybil Gordon, Alfred $\mathrm{H}$. Barr, Jr. and the Intellectual Origins of the Museum of Modern Art, Londres, Nova York: The MIT Press, 2002.

53 Philip Johnson, que era muito próximo a Alfred Barr, viria a se tornar arquiteto apenas mais tarde, graduando-se na Escola de Design de Harvard entre 1940 e 1943.

54 STANISZEWSKI, op. cit., p. 64. 55 Alfred Barr apud KanTOR, op. cit., p.155. 
1.4 Vista do Abstract Cabinet, projeto de El Lissitzky, Landesmuseum, Hannover, 1927-28. Fonte: https://www.jstor.org/ stable/10.5749/futuante.12.2.0013

1.5 Vista do Folkwang Museum, Essen, ca. 1934. Fonte: STANISZEWSKI, p.65

1.6 Edifício da Bauhaus em Dessau, projeto de Walter Gropius, 1926. Foto: Lucia Moholy. Fonte: https://99percentinvisible.org/episode/ photo-credit-negatives-bauhaus/
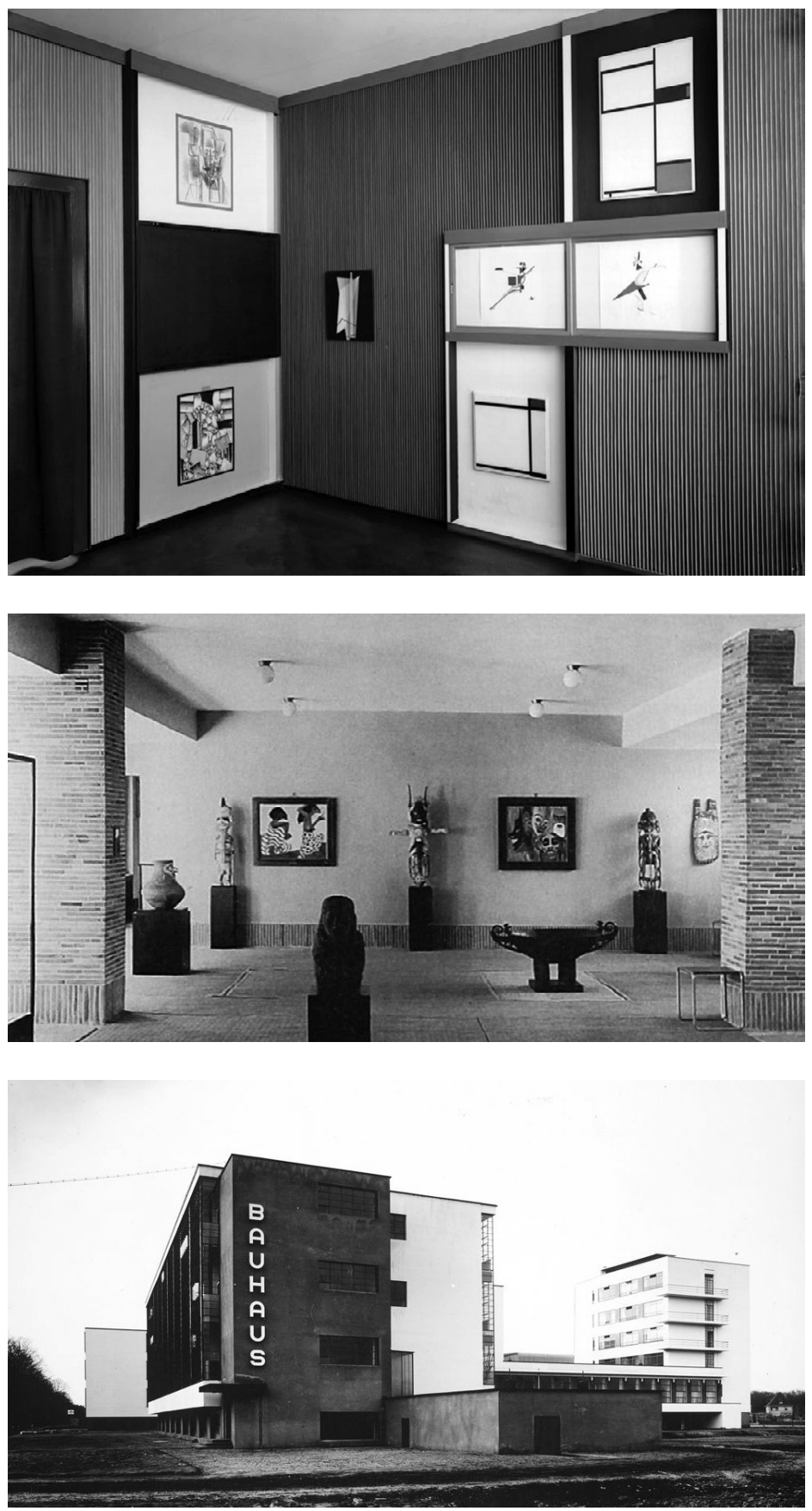
das artes para o modernismo, que estava na base da estrutura multidisciplinar da escola, referência para a estrutura departamental do museu. Sendo a arquitetura a disciplina guia da Bauhaus, sua linguagem racionalista e asséptica foi referência essencial para a construção do modelo expositivo que viria a desenvolver no Mома.

Ainda que de modo embrionário, o modelo expositivo que viria a prevalecer no museu pode ser identificado desde a primeira mostra de arte realizada pela instituição. Nos registros fotográficos das exposições Cézanne, Gauguin, Seurat, Van Gogh ${ }^{56}$ e Painting in Paris, ${ }^{57}$ observa-se que as obras estão enfileiradas lado a lado à altura dos olhos, espaçadas entre si e sustentadas contra um fundo liso e de tonalidade clara. Nota-se, nas imagens, vestígios do que parecem ser as janelas do edifício ocultadas por painéis opacos, um expediente que tanto aumenta a superfície disponível para as apoiar obras de parede quanto cria um ambiente mais artificialmente controlado para sua fruição, sem a interferência de vistas e variações de luminosidade do exterior.

As experiências expográficas estavam, como é sempre o caso, condicionadas às condições do espaço pré-existente, sendo o Heckscher Building especialmente inadequado para as atividades do museu. Sua chegada por elevadores gerava dificuldade de acesso a um grande número de visitantes e sua área de $42 \mathrm{Om}^{2}$, dividida em seis ambientes, era exígua para o programa, que continha, além das salas de exposição, uma biblioteca e escritórios para quatro membros da equipe..$^{58}$ É o que possivelmente levou ao uso até mesmo das portas como superfície para apoiar obras, resultando num tipo de "ruído" que desapareceria com o posterior aprimoramento do modelo, juntamente com outros aspectos tradicionais de ordem decorativa, como arranjos simétricos de obras, vasos de plantas e sofás.

Outras exposições deixariam mais evidente a importância que Barr conferia à arquitetura, tanto como tema curatorial integrado ao contexto da arte moderna quanto como possibilidade de representação institucional do museu numa sede própria e no espaço expositivo. Já em 1930, o jovem diretor havia solicitado ao historiador da arquitetura Henry-Russell
56 Cf. The Museum of ModerN ART. Cézanne, Gauguin, Seurat, van Gogh (Nov 7-Dec 7, 1929). MOMA. Disponível em: <https:// www.moma.org/calendar/exhibitions $/ \mathbf{1 7 6 7}$ ? locale=pt $>$. Acesso em: 26 jan. 2020.

57 Cf. The Museum of Modern ART, Painting in Paris (Jan 19-Mar 2, 1930), MOMA, disponível em: <https://www.moma.org/calendar/ exhibitions/2024>. acesso em: 26 jan. 2020.

58 Segundo Lorente, a primeira exposição ficou apertada. Cf. LORENTE, op. cit., pp. 158-9. 


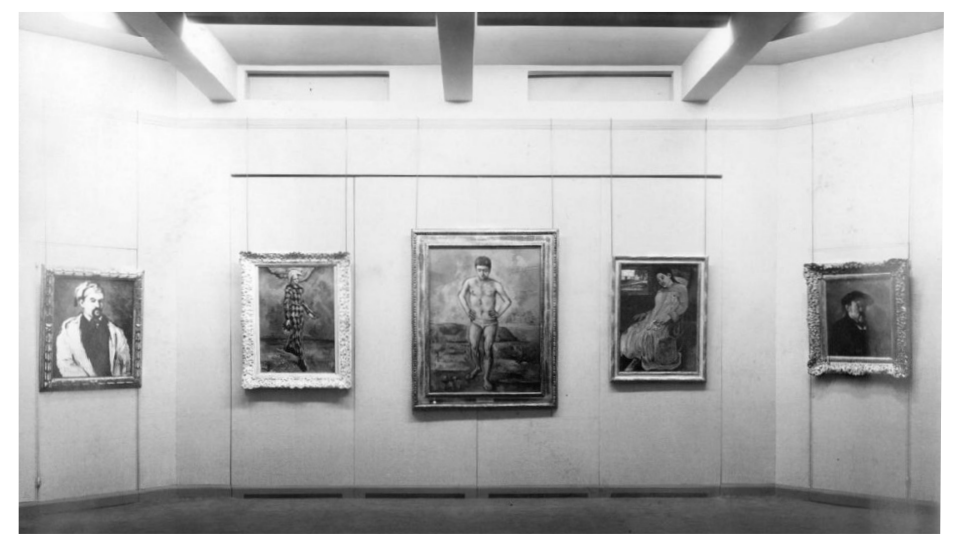

1.7 e 1.8 Vistas da exposição Cézanne, Gauguin, Seurat, Van Gogh, MoMA, Nova York, 1929. Foto: Peter A. Juley. Fonte: https://www.moma.org/calendar/ exhibitions/1767

1.9 Vista da exposição Painting in Paris, MoMA, Nova York, 1930. Foto: Peter A. Juley. Fonte: https://www.moma.org/ calendar/exhibitions/2024
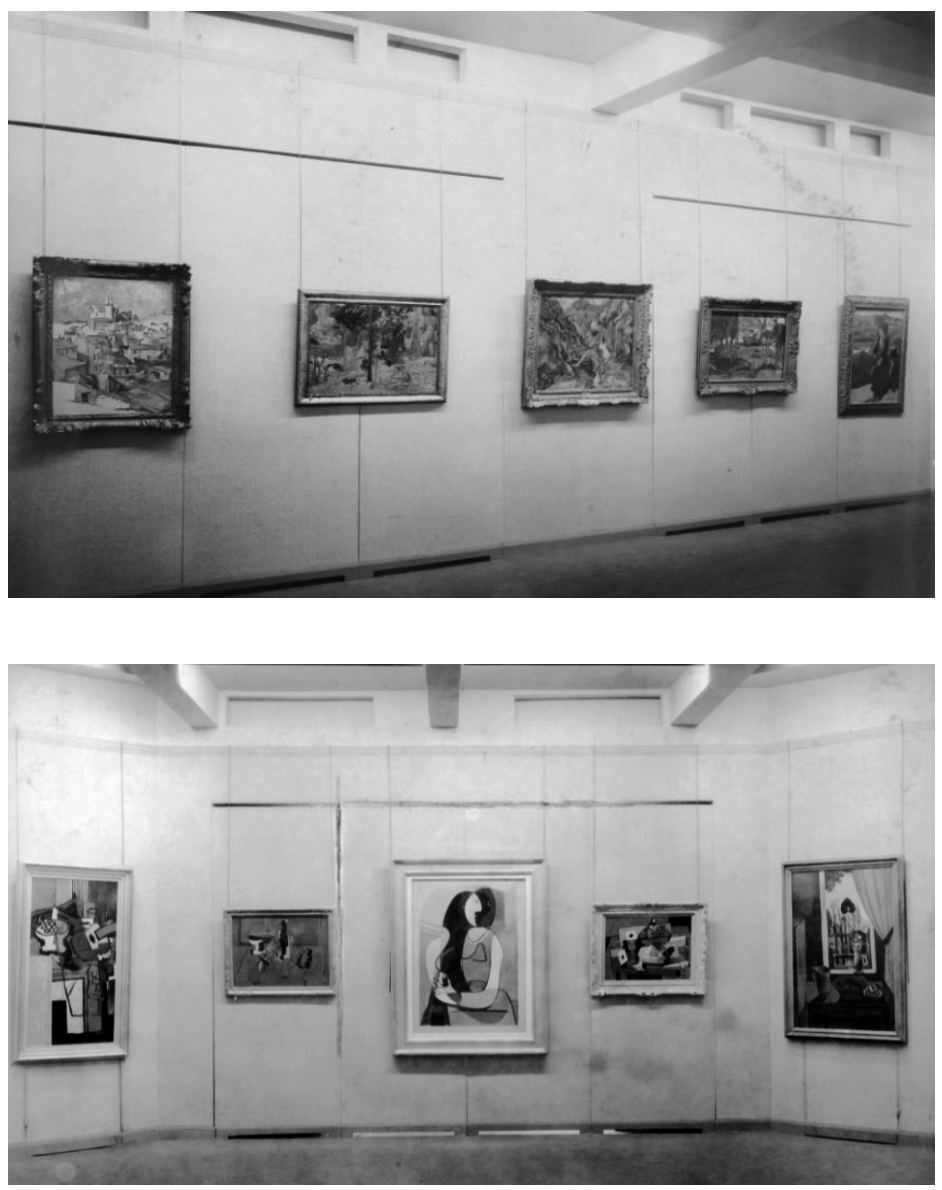
Hitchcock (1903-1987) e a seu colega Philip Johnson - o último ainda apenas um amador na área - que organizassem uma exposição dedicada à produção arquitetônica de vanguarda, buscando fomentar a introdução do já denominado International Style nos EUA, onde o movimento ainda enfrentava grande resistência do público e o antagonismo de defensores do estilo Beaux-Arts.$^{59} \mathrm{~A}$ exposição Modern Architecture: International Exhibition foi a última a ser montada no Heckscher Building, em 1932, acompanhada de um catálogo amplamente ilustrado, ${ }^{60} \mathrm{e}$ a primeira itinerante do museu, viajando por três anos pelos EUA em diferentes versões e marcando o início da legitimação do movimento no país. ${ }^{61}$ Figuravam na mostra obras dos principais mestres europeus - Le Corbusier, Mies Van der Rohe, Oud e Gropius -, e de arquitetos modernistas atuantes nos EUA - Raymond M. Hood, Howe \& Lescaze, Richard Neutra e Bowman Brothers. Apesar de não ser identificado com o Internationl Style, Frank Lloyd Wright também foi incluído na exposição, pois, como justificou Barr, sua obra teria sido seminal para a formação dos arquitetos modernos que o sucederam. ${ }^{62} \mathrm{~A}$ apresentação dos projetos continha grandes ampliações fotográficas - de iguais dimensões e regularmente dispostas nas paredes - e maquetes posicionadas em mesas no centro da sala, além de alguns poucos desenhos técnicos - donde se apreende que a mostra não era destinada apenas a profissionais da área, mas ao público em geral. Confirmando a importância da arquitetura na noção moderna de síntese das artes, formou-se em seguida o Departamento de Arquitetura do MOMA, tendo Johnson como primeiro diretor. ${ }^{63}$

Enquanto Barr encomendava a exposição a Hitchcock e Johnson, o conselho se ocupava da necessidade de ter uma sede propriamente alinhada com a arquitetura moderna, contratando em 1930 os arquitetos George Howe (1886-1955) e William Lescaze (1896-1969) para elaborar um projeto para o museu num hipotético terreno de miolo de quadra do Midtown nova-iorquino. Entre as várias versões estudadas por Howe e Lescaze, a considerada mais ousada apresentava nove blocos de galerias empilhadas em torre, rotacionados a go graus a cada pavimento e conectados por um núcleo lateral de elevadores e escadas, concebidos como "câmaras de iluminação mista",
59 Em 1931 houve uma grande exposição da Architecture League of New York que excluiu os modernistas, o que gerou em reação uma exposição dos "recusados", a primeira a introduzir o International Style nos EUA. Cf. SANDLER, op. cit.

60 Contendo ensaios de Hitchcock e Johnson e desenhos e fotos de obras dos arquitetos europeus Walter Gropius, Le Corbusier, J. J. P. Oud, Mies van der Rohe e Richard Neutra e dos estadunidenses Frank Lloyd Wright, Raymond M. Hood, Howe \& Lescaze e Bowman Brothers. Cf. The Museum of Modern ART. Modern Architecture: international exhibition. Nova York: The Museum of Modern Art, 1932.

61 Na opinião de Edward Stone, que viria a projetar a sede do MOMA de 1939 em parceria com Philip Goodwin, "a exposição fez para a arquitetura o que o Armory Show tinha feito para a pintura... Não conheço um único evento que tenha influenciado tão profundamente a arquitetura do século xx". Edward Stone apud RicciotTi, Dominic. The 1939 Building of the Museum of Modern Art: The Goodwin-Stone Collaboration. The American Art Journal, v. 17, n. 3, p. 50-76, 1985, p. 52. Tradução nossa.

62 Cf. Apresentação de Alfred Barr no catálogo da mostra, in: THE Museum OF Modern ART, Modern Architecture: international exhibition, op. cit, p. 16.

63 Philip Johnson ocupou o cargo de diretor do Departamento de Arquitetura do мома de 1932 a 34 e de 1946 a 54 . 

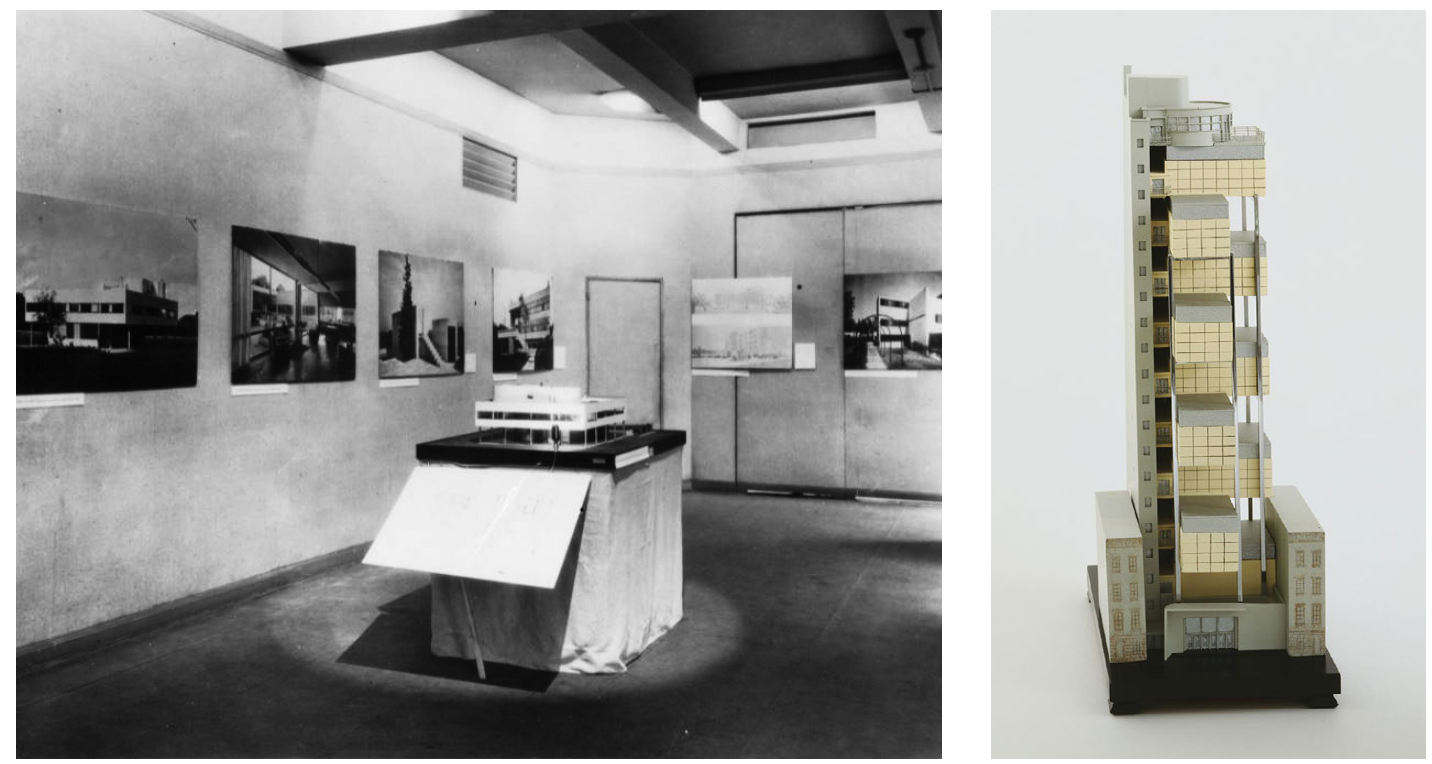

1.10 Maquete do MoMA (Scheme 4, First Variation), projeto de George Howe e William Lescaze, 1930. Fonte: https:// www.moma.org/collection/works/1017

1.11 Vista da exposição Modern Architecture: International Exhibition, MoMA, Nova York, 1932. Foto: George H. van Anda. Fonte: https://www.moma.org/ calendar/exhibitions/2044

64 Como indica a legenda da maquete exposta no MOMA em 2019. Cf. THE MUSEUM OF MODERN ART. George Howe, William Lescaze: The Museum of Modern Art, New York (Scheme 4, First Variation), 1930. МомА. Disponível em: <https://www. moma.org/collection/works/1017>. Acesso em: 27 mar. 2021. que, dotadas de dispositivos fotoelétricos, equilibrariam automaticamente as fontes de luz natural e artificial. ${ }^{64}$

De natureza altamente idealizada, o projeto logo foi arquivado diante das possibilidades concretas, porém bem mais limitadas, de instalação do museu na antiga mansão de cinco andares que pertencera ao sogro da fundadora Abby Aldrich, doada pela família Rockefeller ao MomA em 1931. Localizado no número 11 a Oeste da Rua 53, o endereço tornou-se o local definitivo do museu a partir de 1932. A passagem por mais esta sede, ainda que nunca tenha sido considerada permanente, possivelmente contribuiu para construir a identidade duradoura do MOMA, misturando a austeridade adotada por Barr - vinda das referências arquitetônicas e expográficas europeias - à atmosfera de "intimidade" proveniente das características do imóvel residencial. O museu notabilizou-se por ser um local onde espectadores poderiam ter uma relação próxima com as obras, expondo-as em ambientes de escala mais acolhedora - como os de residências de colecionadores particulares -, distanciando-se da monumentalidade dos museus tradicionais. Segundo depoimento do curador do MOMA, Kirk Varnedoe (1946-), 

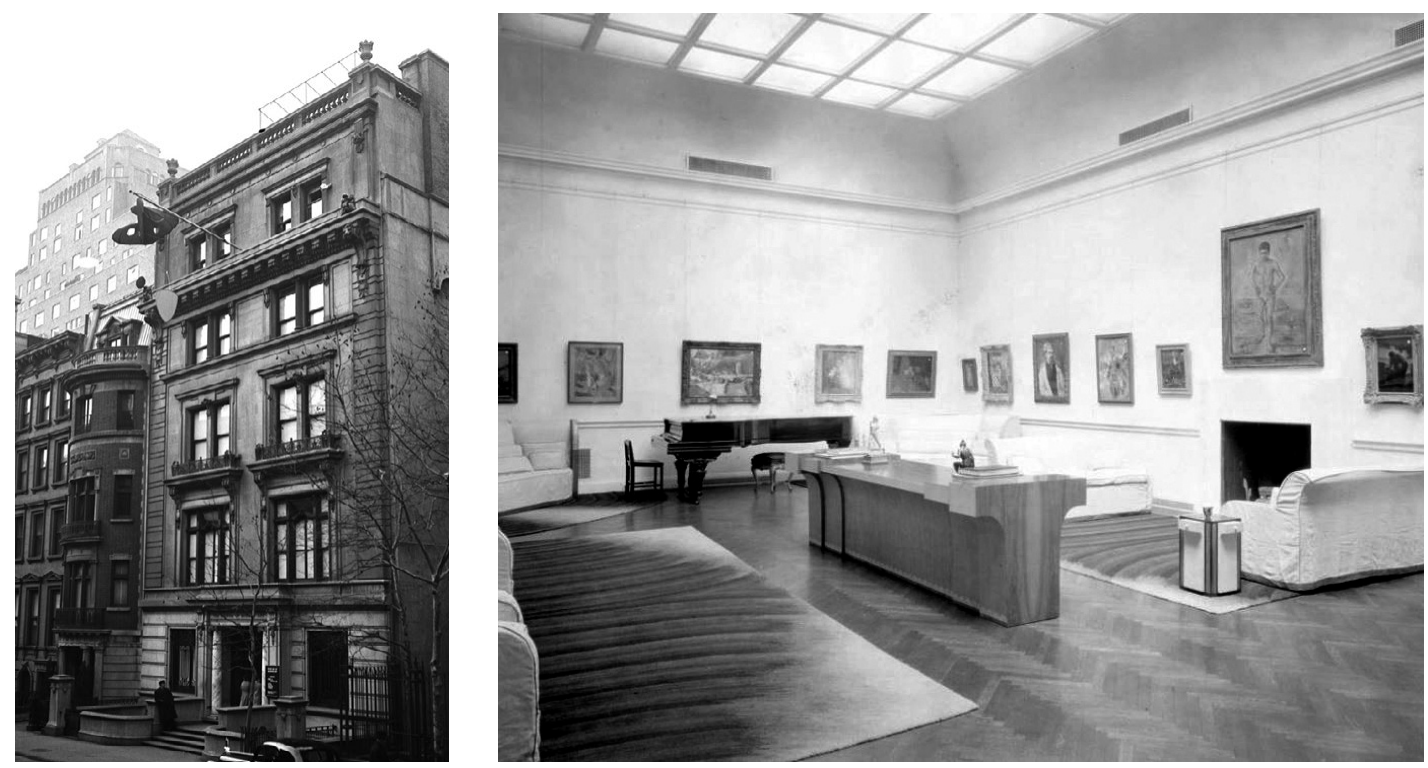

Barr acreditava firmemente que o sentido privado e subjetivo da experiência no modo de vida burguês era radical. $\mathrm{O}$ momento em que grandes pinturas de salão deixaram de ser produzidas - para ambientes específicos - e julgadas em grandes feiras, e que pinturas pequenas, espontâneas e portáteis começaram a ser feitas no Impressionismo, sendo ainda mais determinadas pela subjetividade no Pós-Impressionismo, era considerado por ele o ponto inicial de uma noção distinta da relação do indivíduo com a obra de arte. Isso teria a ver com o tipo de privacidade que para ele era simbolizada pela natureza do apartamento privado e pela janela móvel da pintura. Isso teria um significado, e ele queria que Cézanne e Van Gogh fossem vistos nesse contexto. ${ }^{65}$

Nas primeiras exposições montadas na casa em 1932, ainda é possível notar a forte presença de elementos tradicionais típicos de uma residência pertencente a uma família abastada da época - cortinas, corrimãos, rodapés, luminárias, colunas, capitéis e forros decorados -, que, perturbando a austeridade perseguida por Barr, foram sendo ocultados nas
1.12 Primeira sede do MoMA na Rua 53 em Nova York, numa townhouse doada pela família Rockefeller, década de 1930. Fonte: https://www. newyorker.com/culture/culture-desk/ the-once-and-future-moma

1.13 Vista da coleção de Lillie Bliss em seu apartamento, Nova York, ca. 1927. Fonte: https://www.moma.org/ interactives/moma_through_time/1930/ lillie-p-bliss-legacy/

65 Kirk Varnedoe. Building the Future: Museums of Modern Art in the Twenty-first Century. In: ELDERFFIELD, John (ed.). Imagining the Future of The Museum of Modern Art. Nova York: The Museum of Modern Art, 1998, p. 32. Tradução nossa. 

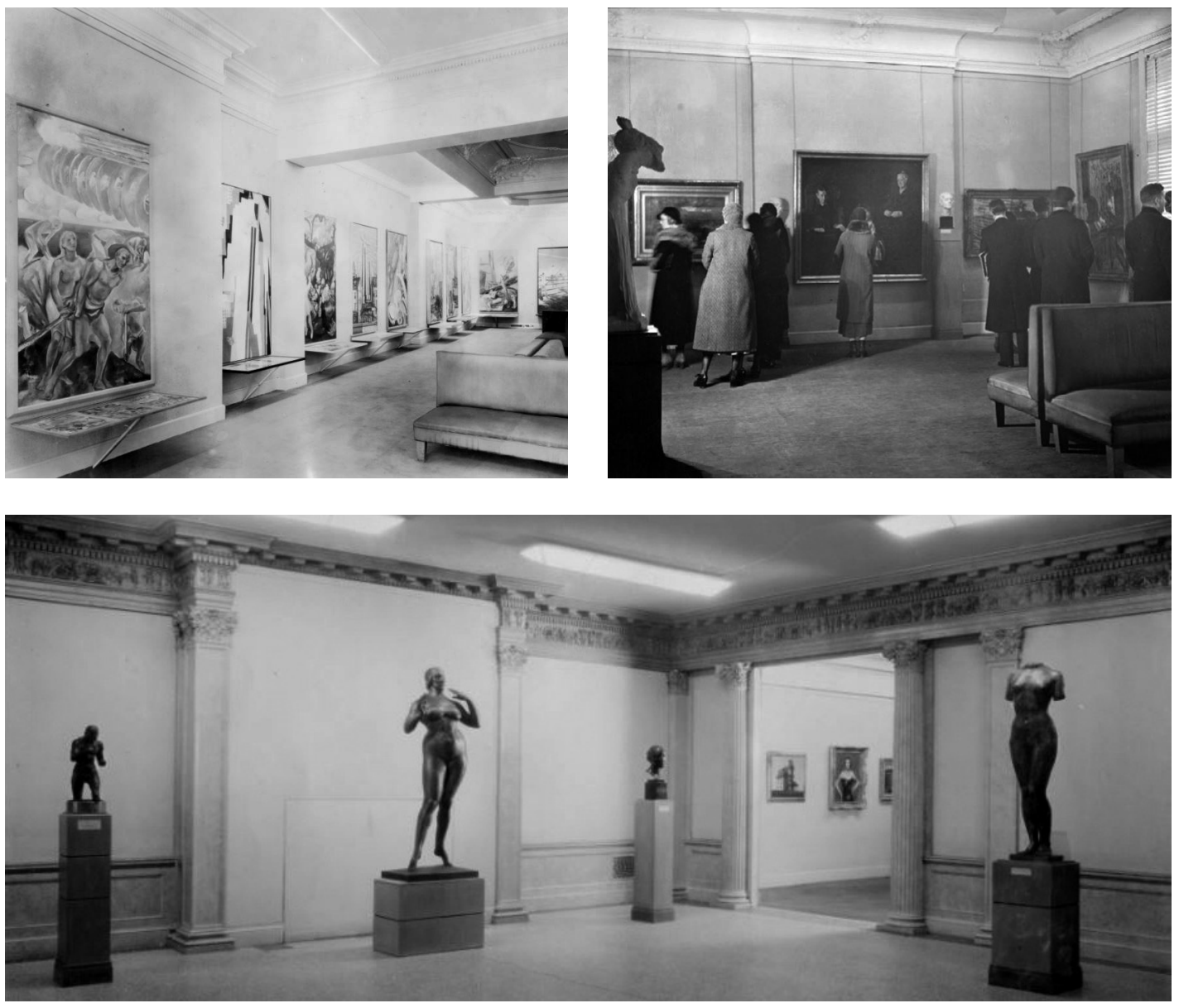

1.14 Vista da exposição Murals by American Painters and Photographers,MoMA, Nova York, 1932. Fonte: https://www.moma. org/calendar/exhibitions/2045

1.15 Visitantes na exposição American Painting and Sculpture, 1862-1932, MoMA, Nova York, 1932 - 1933. Foto: Soichi Sunami. Fonte: https://www.moma. org/calendar/exhibitions/2048

1.16 Vista da exposição Summer Exhibition: Painting and Sculpture, MoMA, Nova York, 1932. Fonte: https://www.moma.org/ calendar/exhibitions/1708 
montagens subsequentes, nos limites do que era possível no imóvel. ${ }^{66}$

Exemplo máximo desse esforço em configurar um "cenário" moderno no interior da casa tradicional foi realizado na exposição Machine Art, de 1934, com curadoria e projeto expográfico de Philip Johnson, que se tornou em 1932 o primeiro diretor do recém-criado Departamento de Arquitetura e Design. A exposição tinha um caráter original e provocador, por não conter obras de arte entendidas no sentido convencional, mas 600 objetos que não pertenciam ao universo dos museus até então, como máquinas industriais e suas peças, equipamentos domésticos e comerciais, móveis e acessórios, instrumentos científicos e objetos utilitários de uso comum, que, segundo Johnson, embora não fossem puramente ornamentais, foram escolhidos por sua "qualidade estética". ${ }^{67}$

Para valorizar esses objetos inusitadamente deslocados de seus contextos, Johnson criou uma expografia requintada, ao mesmo tempo moderna e estetizada, que ocultava os indesejáveis elementos decorativos pré-existentes, transformando de modo mais radical a ambiência da casa. Conforme relatou Staniszewski, as paredes foram revestidas e os painéis móveis construídos com uma gama diversificada de materiais - alumínio, aço inox, micarta, tecido plástico e linho belga natural - e as superfícies que recebiam pintura tinham tons pastéis de azul, rosa e cinza e em alguns pontos em tons de vermelho escuro ou de ferrugem. ${ }^{68}$ Sob o teto das salas, foram instalados forros de tecido musseline translúcido, acima dos quais foram posicionadas lâmpadas - uma solução então inovadora para criar uma iluminação homogênea com uma superfície inteiramente lisa e livre de luminárias. Para os expositores, foram utilizados suportes metálicos, prateleiras de madeira texturizada ou vidro, bancadas forradas de veludo escuro e tablados e pedestais típicos para apoiar esculturas. Segundo a autora, os elementos da montagem "revestiam elegantemente esse ambiente, conferindo-lhe uma aparência cristalina, metálica, tátil e luxuosa - e ao mesmo tempo simples, sóbria, pura e racional". ${ }^{69}$ A referência de Johnson teria sido não apenas a obra de Le Corbusier, mas sobretudo os projetos expográficos de Mies van der Rohe e Lilly Reich.
66 Cf. fotos das montagens das exposições de 1932 in: THE Museum of MOdern ART. American Painting and Sculpture, 1862-1932 (Oct 31, 1932-Feb 11, 1933). MoMA. Disponível em: <https:// www.moma.org/calendar/exhibitions $/ 2048$ ?locale $=p t>$. Acesso em: 24 jan. 2020; THE MUSEUM OF MODERN ART. Summer Exhibition: Painting and Sculpture (Jun 7-Oct 30, 1932). момA. Disponível em: <https://www.moma.org/calendar/exhibitions/1708?locale $=\mathrm{pt}>$. Acesso em: 24 jan. 2020.

67 "Alguns dirão que utilidade é mais importante que a beleza, ou que a beleza torna um objeto útil. Esta exposição foi organizada a partir do ponto de vista que considera que a utilidade é essencial, mas a aparência tem no mínimo grande validade”. Phillip Johnson. "History of Machine Art" in: BARR JR., Alfred H.; JoHnson, Phillip (Orgs.). Machine art. Nova York: The Museum of Modern Art, 1934, n.p.. Tradução nossa.

68 Cf. STANISZEWSKI, op. cit., p.154 69 STANISZEWSKI, op. cit. p.153. 

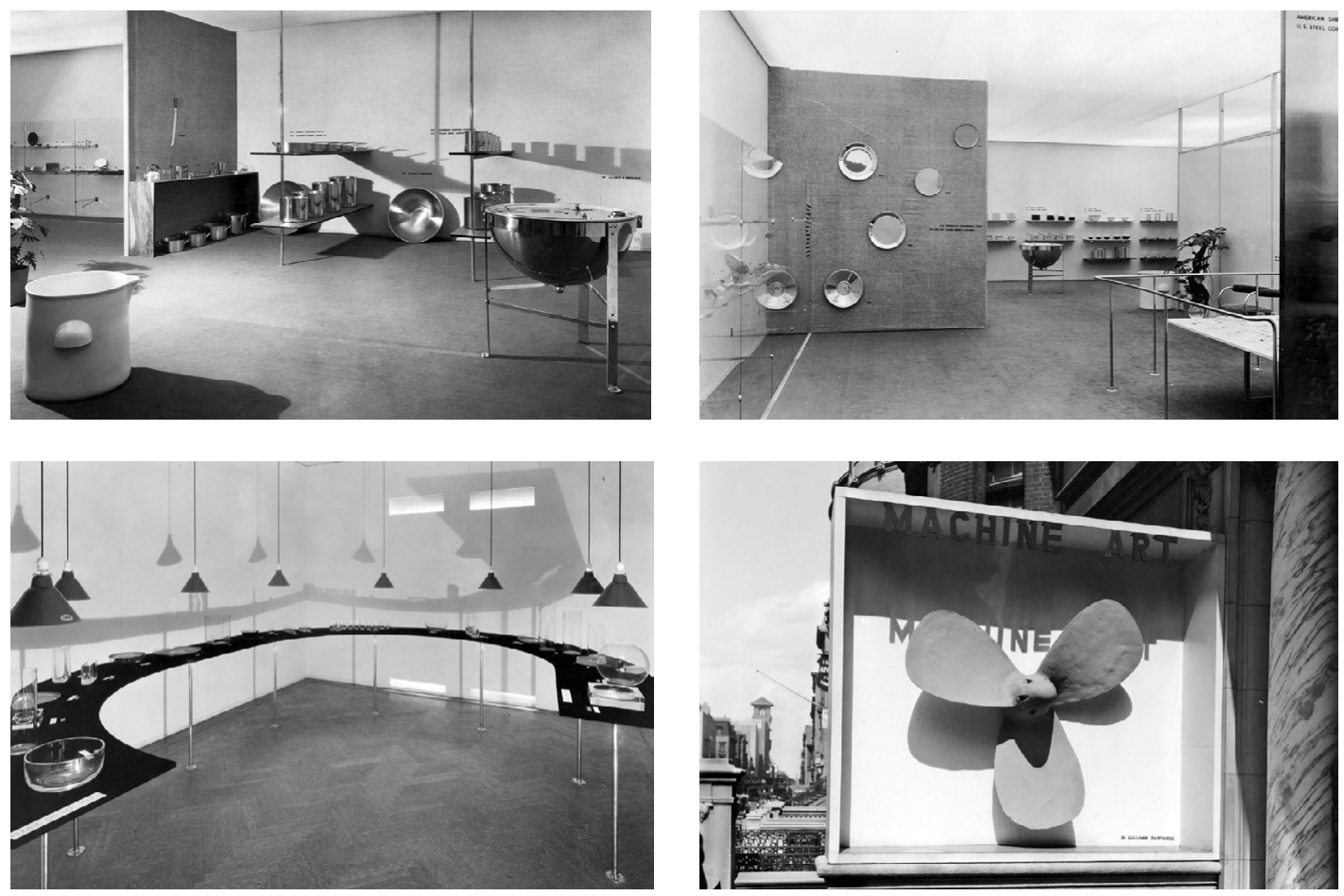

ênfase da exposição num entendimento a-histórico da cultura. O programa básico da exposição era revelar a essência atemporal dos objetos mundanos. Se o observador superasse o fato de que os objetos expostos eram louças e parafusos, a montagem oferecia um ambiente familiar e idealizado para consagrar a beleza atemporal, consoante com a mitologia moderna da arte como universal. ${ }^{70}$

Além de valorizar as peças com recursos museográficos, a montagem tinha ainda uma semelhança com os mostruários de lojas, condizente com os objetivos da exposição de ser um guia prático para os consumidores e um incentivo para os fabricantes do "bom design", ${ }^{71}$ o que levava alguns visitantes a tocar os objetos e considerá-los à venda. Com linguagem sofisticada e ao mesmo tempo familiar e acessível, a exposição foi muito bem recebida pelo público e pela crítica,

70 Ibidem, p. 158. Tradução nossa. 71 Ibidem, p. 152-161.

\section{2-83}


tendo a última ressaltado as qualidades da expografia, tratando-a como um ramo da arquitetura. O sucesso de Machine Art ecoou por muito tempo no universo do museu, atestando, na opinião de Staniszewski, o poder longevo desse tipo de ambiência estetizada como moldura para a institucionalização da cultura moderna. ${ }^{72}$ Além de ter se tornado uma referência de projeto expográfico moderno, a mostra marcou ainda o início do acervo de design do мома, que adquiriu diversos itens da exposição, sendo, segundo Hunter, o primeiro museu a colecionar esse tipo de peças contemporâneas. ${ }^{73}$

\subsubsection{TORPEDO EM EXPOSIÇÃO}

Outro fato que marcou o caráter da instituição aconteceu também em 1934, ano em que o museu se comprometeu oficialmente a constituir um acervo de arte moderna. A questão tornou-se premente a partir de 1931, quando o момA recebeu como herança a valiosa coleção da recém falecida fundadora Lillie Bliss, que havia imposto como condição para a consolidação da transferência que o museu levantasse fundos que sustentassem sua manutenção. ${ }^{74}$ Não havia, até então, um consenso sobre o perfil que a instituição deveria assumir. De um lado, membros do conselho, especialmente Goodyear, defendiam o modelo kunsthalle - no qual o fomento à arte moderna se basearia em exposições temporárias, montadas com obras

72 Ibidem, p. 159.

73 HunTER, op. cit, p. 17.

74 O espólio doado por Lillie Bliss continha 150 pinturas, gravuras e desenhos, incluindo obras de Paul Cézanne, Pierre-Auguste Renoir, Edgar Degas, Georges Seurat e Odilon Redon. Cf. THE MuseuM OF MODERN ART. Lillie P. Bliss's Legacy. MOMA. Disponível em: <https://www.moma.org/interactives/moma_through_time/1930/ lillie-p-bliss-legacy/>. Acesso em: 27 mar. 2021.

75 HunTER, op. cit., p.17. emprestadas de colecionadores, artistas ou instituições parceiras -, enquanto o outro, encabeçado por Barr, acreditava que era essencial constituir um acervo permanente, sem a qual não haveria propriamente um museu, mas apenas uma Exhibition Gallery. ${ }^{75}$

Segundo Lorente, se Barr tivesse tido pleno poder decisório, teria estabelecido desde cedo uma política seletiva para o recebimento de obras em doação e uma orientação mais ousada nas aquisições, visando obras mais experimentais. Mas a coleção acabou recebendo inicialmente doações de colecionadores particulares, que selecionavam suas aquisições não de acordo com critérios curatoriais calcados em conhecimentos mais rigorosos da História da Arte, mas motivados principalmente por gosto 


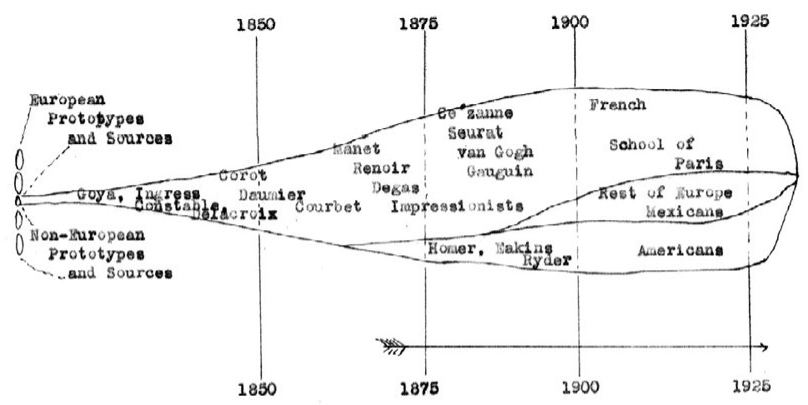

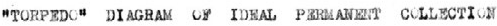

pessoal. O diretor estava, afinal, subordinado ao conselho, cujos membros chegavam até mesmo a organizar exposições. ${ }^{76}$

Foi aos poucos que Barr conquistou a confiança do conselho para implementar sua política, que tinha como um dos objetivos constituir um acervo o mais completo possível em termos de representação de artistas e escolas, orientado por seu célebre esquema conhecido como "torpedo avançando no tempo", a base do modelo canônico que viria a se tornar dominante na historiografia da arte moderna.

Em 1936, Barr teve a oportunidade de explicitar de modo mais completo seu esquema teórico ao organizar duas das principais retrospectivas de sua carreira. A primeira delas, Cubism and Abstract Art, ocupou os quatro andares do museu com 386 obras de 113 artistas, incluindo não apenas pintura e escultura, mas também fotografia, arquitetura, design industrial e gráfico, teatro e filmes, demonstrando sua concepção multidisciplinar. ${ }^{77}$ A orientação didática de Barr evidenciava-se na estrutura narrativa da exposição, reforçada por painéis e diagramas explicativos localizando artistas e movimentos - uma novidade no contexto dos museus ${ }^{78}$ e pelo catálogo com textos e imagens das obras, exibindo na capa um elaborado esquema gráfico relacionando as vertentes da produção artística moderna de 1890 a 1935.

Sua leitura, de cunho predominantemente estético, estabelecia duas principais tradições da arte abstrata, considerando mais importante a que definiu como "intelectual, estrutural,

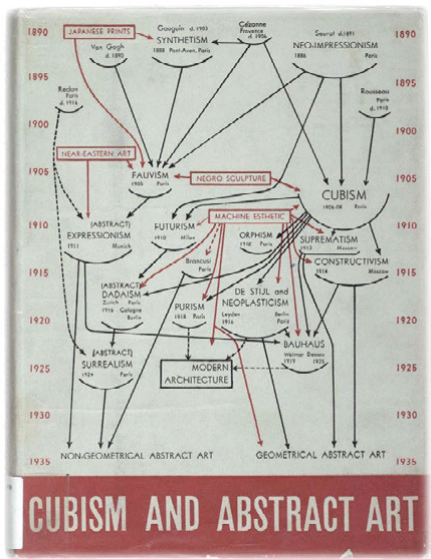

1.22 Alfred H. Barr Jr. Diagrama para a coleção permante ideal - Torped, in: Report on the Permanent Collection, MoMA, Nova York, 1933. Fonte: https://www.moma.org/interactives/ moma_through_time/1920/ starting-a-collection-from-scratch/

1.23 Capa do Catálogo da exposição Cubism and Abstract Art, MoMA, Nova York, 1936.

76 Ibidem, p. 12.

77 A exposição tinha como subtítulo as diversas disciplinas que abrangia: Painting, Sculpture, Constructions, Photography, Architecture, Industrial Art, Theatre, Films, Posters, Typography. Cf. The Museum of Modern Art. Cubism and abstract art (Mar 2Apr 19, 1936). MOMA. Disponível em: <https://www.moma.org/calendar/exhibitions $/ 2748$ ? locale $=$ pt $>$. Acesso em: 27 mar. 2021.

78 Barr tomara como referência a forma com que as legendas eram utilizadas nos museus da Rússia que visitou durante a viagem pela Europa, entre 1928-29. Cf. KANTOR, op. cit., p. 188.

\section{4-85}



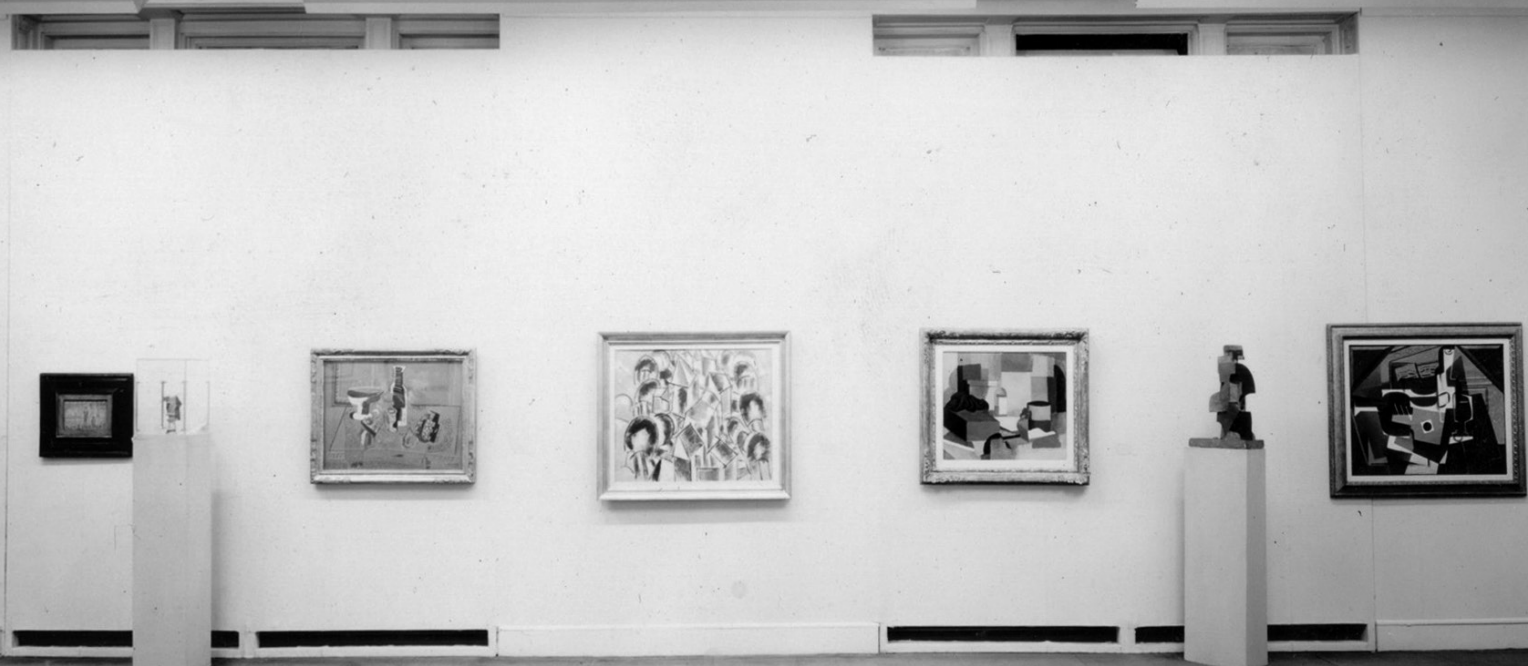

1.24 a 1.32 Vistas da exposição Cubism and Abstract Art, MoMA, Nova York, 1936. Foto: Beaumont Newhall. Fonte: https://www.moma.org/calendar/ exhibitions $/ 2748$

79 Alfred Barr in: The Museum OF MODERN ART. Cubism and abstract art, Nova York: The Museum of Modern Art, 1936, p. 19. Tradução nossa.

80 Ibidem, p.19. arquitetônica, geométrica, retilínea e clássica em sua austeridade e dependência da lógica e do cálculo", ${ }^{79}$ cuja rota partiria de Cézanne e Seurat, passaria pelo Cubismo e desembocaria nos movimentos construtivistas espalhados pelo mundo a partir da Rússia e da Holanda. A outra, considerada por ele secundária até então, seria, comparada com a primeira, "intuitiva e emocional ao invés de intelectual; orgânica e biomórfica ao invés de geométrica em suas formas; curvilínea ao invés de retilínea, decorativa ao invés de estrutural e romântica ao invés de clássica em sua exaltação ao místico, espontâneo e irracional" ${ }^{80} \mathrm{e}$ partiria das teorias de Gauguin e seu círculo, passando pelo Fauvismo de Matisse para dirigir-se então ao expressionismo abstrato das obras iniciais de Kandinsky.

Com relação à montagem, as fotos não mostram alguns elementos decorativos muito presentes em exposições anteriores na casa, como forros ornamentados, que se apresentavam agora aparentemente lisos, mesmo sem o recurso que Johnson empregara em Machine Art. Algumas janelas foram sobrepostas 

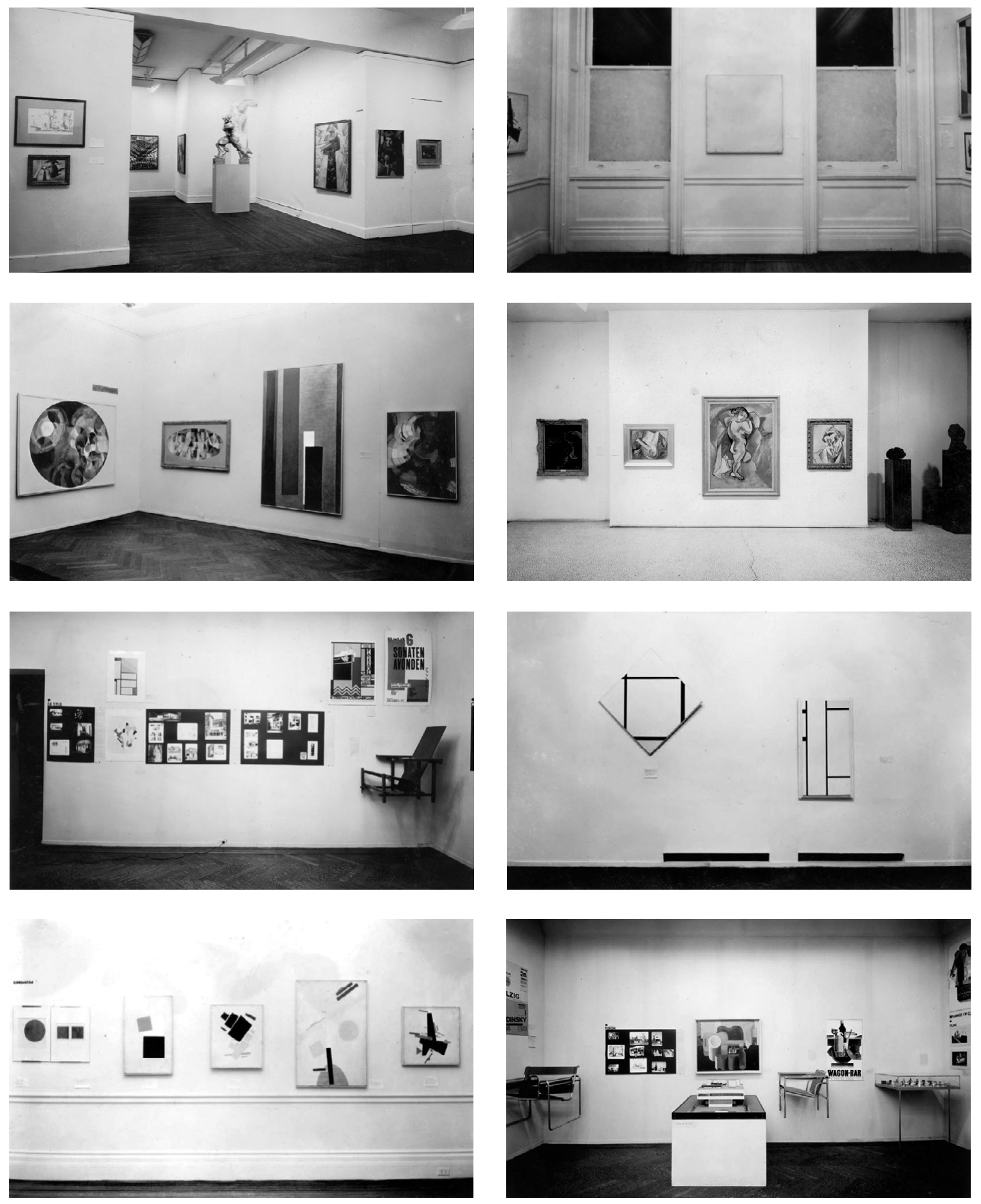
81 A parede escura da entrada parece ser a única exceção. Cf. The Museum of Modern ART. Fantastic Art, Dada, Surrealism (Dec 9, 1936-Jan 17, 1937). момA. Disponível em: $<$ https://www. moma.org/calendar/exhibitions $/ 2823$ ? locale $=\mathrm{pt}>$. Acesso em: 24 jan. 2020. por painéis, produzindo longas e contínuas superfícies planas de apoio a obras, enquanto outras continuaram à vista, com persianas ou trechos de vidro cobertos por material opaco. Permaneceram nas paredes certos barrados, cantos e rodapés frisados e, embora tenham desaparecido os tradicionais cabos de sustentação para as pinturas, algumas delas continuavam posicionadas sobre as portas. O esforço, ainda que incompleto, no sentido de tornar o espaço livre de elementos decorativos, somado a um maior espaçamento entre as obras pelo menos em algumas das salas, dão à montagem de Cubism and Abstract Art a impressão de maior arejamento em comparação a mostras de arte visualmente mais saturadas organizadas anteriormente pelo museu, embora o resultado não seja tão estetizado quanto o da exposição Machine Art.

A segunda exposição da série retrospectiva do que Barr considerava os principais movimentos da arte moderna foi Fantastic Art, Dada, Surrealism, também montada em 1936 e ocupando os quatro andares do museu. Representando 157 artistas europeus e estadunidenses com 694 obras de arte e arquitetura, a mostra incluía pinturas, esculturas, gravuras e fotografias, cobrindo um período histórico bem mais amplo - de meados do século Xv até a atualidade. Os registros fotográficos disponíveis não são tão fartos e diversificados quanto os da mostra anterior e enquadram os conjuntos de obras apenas em ângulos mais fechados, sem mostrar a configuração geral das salas expositivas. Ainda assim, eles permitem deduzir que a solução expográfica manteve-se a mesma que na mostra anterior, ${ }^{81}$ com paredes de tonalidade clara com uma única fileira de obras espaçadas entre si e à altura dos olhos. A única foto em que se percebe uma nota de dramaticidade é a que mostra o balcão de recepção junto ao início da escada, contra um fundo de tonalidade escura, em que se destacam o título da mostra e três relevos biomórficos de Jean Arp, que parecem flutuar.

O tom geral de sobriedade, que em Cubism and Abstract Art encontrava mais coerência com a linguagem das obras, produzia, no entanto, um contraste mais evidente com o conteúdo de Fantastic Art, Dada, Surrealism, especialmente se comparado ao aspecto anárquico de outras exposições organizadas por grupos de artistas ligado ao Dadaísmo e ao Surrealismo. Nas ima- 

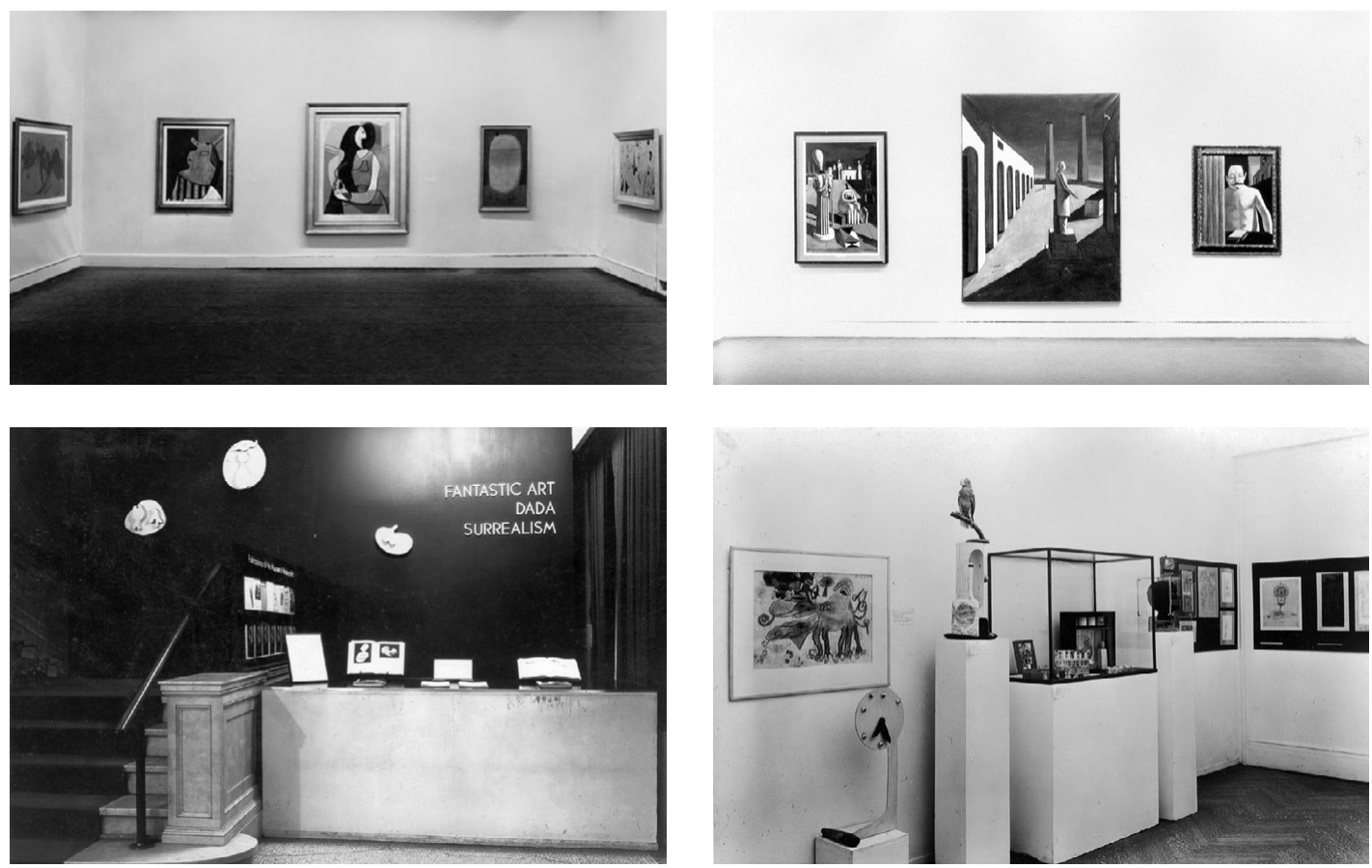

gens da Primeira Feira Internacional Dada (Erste Internationale Dada-Messe), realizada em 1920 na galeria Burchard Galerie em Berlim, vê-se obras espalhadas pelas paredes de modo aparentemente aleatório e até uma escultura suspensa no teto, criando uma atmosfera anticonvencional e provocativa. Mais desorientadora ainda seria a Exposição internacional do surrealismo (Exposition internationale du surréalisme), realizada em 1938 na Galerie des Beaux-Arts de Paris, ${ }^{82}$ na qual Marcel Duchamp transformou todo o salão em que obras de outros artistas estavam expostas com sua intervenção, que consistia em sacos de carvão suspensos no teto sobre um falso braseiro, cuja lâmpada no interior fazia com que parecesse aceso, rodeado por folhas espalhadas por todo o piso. ${ }^{83}$

Em diversas mostras ligadas às vanguardas modernas europeias, a configuração do ambiente expositivo era considerada uma oportunidade de expressão a ser explorada para potencializar a mensagem artística de cada movimento. Para

1.33 a 1.36 Vistas da exposição Fantastic Art, Dada, Surrealism, MoMA, Nova York, 1936-37. Foto: Soichi Sunami. Fonte: https://www.moma.org/calendar/ exhibitions/2823
82 Organizada por André Breton, escritor e teórico do movimento, e por Paul Éluard, poeta.

83 O caráter ambiental dessa intervenção seria retomado com força em obras desenvolvidas por outros artistas décadas mais tarde, como veremos nos capítulos seguintes desta tese. 

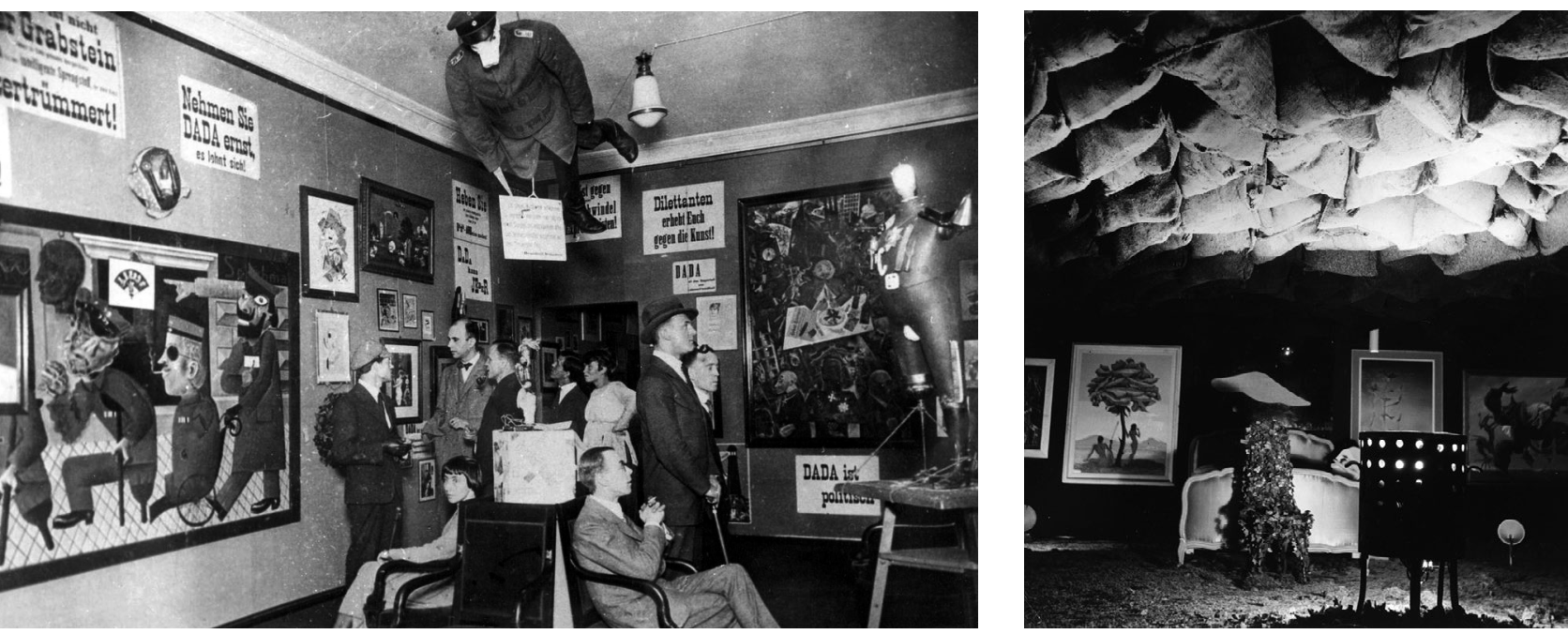

1.37 Vista da exposição Primeira Feira Internacional Dada, Burchard Galerie, Berlim, 1920. Fonte: https://www.wsj.com/articles/ dada-100-years-later-1453223133

1.38 Vista da Exposição internacionl do surrealismo, Galerie des Beaux-Arts, Paris, 1938. Foto: Roger Schall. Fonte: https:// www.moma.org/collection/works/289771

84 STANISZEWKI, op. cit., p. 71.

85 O tema será tratado com mais detalhes no Capítulo 2 desta tese. Cf. O'DOHERTY, Brian. No Interior do Cubo Branco: a ideologia do espaço da arte. São Paulo: Martins Fontes, 2002.
Staniszewski, enquanto soluções como a do Abstract Cabinet de El Lissitzky seriam claramente associadas a um movimento artístico específico - nesse caso o Construtivismo Russo -, o modelo estetizado e supostamente neutro adotado por Barr representaria a visão ideológica do modernismo como linguagem "atemporal, eterna e universal". ${ }^{84}$ A adoção constante desse padrão expositivo austero, a despeito da diversidade das tendências artísticas apresentadas, deve-se em grande medida à pronta filiação de Barr à linguagem do International Style e à sua adesão ao pensamento difundido pela Bauhaus, que considerava a arquitetura o núcleo central da síntese das artes.

Embora o debate em torno da noção de neutralidade do espaço expositivo tenha eclodido apenas décadas mais tarde, quando o ciclo histórico do modernismo chegava ao fim, vale antecipar brevemente alguns pontos, dado que estão na base da investigação dos diversos momentos percorridos por esta tese. A crítica mais profícua ao que seria a ideologia da suposta neutralidade do espaço expositivo modernista seria elaborada na década de 1970 pelo crítico e artista estadunidense Brian O’Doherty (1928-), que cunharia o termo “cubo branco" para designá-la. ${ }^{85}$ Remetendo a uma figura geométrica perfeitamente regular e a uma cor associada à noção de limpeza, a 
expressão veio a sintetizar de modo eficaz o conceito idealizado de pureza estética que estaria sendo buscado nesse tipo de espaço, tornando-se sinônimo do modo de expor arte que o MOMA definira, aprimorara e difundira.

Dado o progressivo crescimento que a instituição viveria e de sua influência sobre os museus de arte moderna de todo o mundo, o modelo viria a se disseminar até alcançar, em última instância, a condição de "padrão", sendo adotado frequentemente como "o modo correto" de expor arte. Embora a neutralidade seja uma condição conceitualmente impossível, o padrão estetizado e supostamente neutro praticado pelo MOMA tornaria-se, como afirmou Staniszewski, invisível em sua função de representação do moderno, devido à sua disseminação massiva. ${ }^{86} \mathrm{~A}$ desconfiança com relação ao poder velado que esse modo de expor teria sobre a valorização de determinada produção da arte viria a crescer em meio ao contexto geral de contestação social, política e cultural dos anos 1960 e 70, dominando o meio artístico e atingindo em cheio os museus, acusados de todo tipo de abuso de autoridade, como veremos mais adiante.

Voltando aos anos iniciais do MOMA e à observação dos registros fotográficos das exposições no imóvel da rua 53, podemos, no entanto, relativizar a afirmação de que o objetivo central de Barr para os espaços expositivos fosse atingir uma ambiência propriamente "neutra" - no sentido de algo que passasse despercebido -, pois seus esforços visavam, na medida do possível, configurar uma atmosfera moderna no edifício do museu, a despeito de arquitetura tradicional. Devido à espacialidade das exposições, o visitante, ao invés de encontrar no interior da casa a mesma linguagem eclética que dominava as fachadas, deparava-se com um ambiente progressivamente despojado, com paredes lisas cobrindo alguns dos elementos ornamentais, em contraste com a arquitetura do entorno e com a ambiência mais carregada dos museus de então. Parece mais plausível supor, portanto, que a intenção de Barr ao estruturar o espaço expositivo de modo racional e livre de ornamentações fosse a de causar um impacto, mergulhando o visitante do museu num ambiente inovador, afinado com o espírito moderno de "obra de arte total" da avançada
86 STANisZeWKy, op. cit., p. 67. 
87 A Natureza da Arte Abstrata, publicado originalmente em 1937. Cf. Shapiro, Meyer. Arte Moderna Séculos XIX e XX, São Paulo: EDUSP, 1994, p. 251-275. arquitetura que conhecera na Europa, ainda pouco desenvolvida nos EUA.

Razões de ordem prática também podem ter determinado o fato de Barr não ter investido numa ambientação tão elaborada quanto a de certas experiências expográficas ligadas às vanguardas que conhecera na Europa, como a do Abstract Cabinet - uma pequena sala concebida para longa duração, num museu com sede própria. Um arranjo mais simples era, afinal, mais condizente com o período de apenas 30 dias de duração das exposições iniciais do MoMA e com o intervalo geralmente de uma semana para desmontagem e montagem de mostras nas sedes adaptadas que o museu ocupava nos anos iniciais. Além disso, podemos imaginar que uma expografia de caráter dinâmico e interativo como a de El Lissitzky seria menos propícia que um arranjo mais sóbrio para controlar a condução do espectador pela criteriosa sequência narrativa de obras - a tradução no espaço do entendimento didático de Barr sobre a arte moderna.

Articulada ao aprimoramento do modelo expositivo, essa estrutura narrativa das exposições ganhou crescente consistência e visibilidade no MOMA, contando com a determinação de Barr em abranger as diversas nuances da produção de cada movimento e as diversas disciplinas artísticas nas mostras que realizava - como em Cubism and Abstract Art e Fantastic Art, Dada, Surrealism. A mesma orientação foi adotada posteriormente na montagem da coleção, visando "preencher as lacunas" da história da arte moderna. Foi devido a constância dessa prática, fundada então, que o museu veio a construir ao longo de sua história seu amplo acervo de obras de arte moderna, considerado um dos mais abrangentes do mundo, tanto em termos quantitativos como qualitativos.

A argumentação que Barr publicara no catálogo da exposição Cubism and Abstract Art, estruturada em torno de seu "torpedo", movimentou o debate especializado da época, sendo refutada frontalmente pelo historiador da arte Meyer Shapiro (1904-1996), que a chamou de "teoria do esgotamento e reação", dada a preponderância excessiva conferida aos fatores estilísticos, em detrimento de aspectos sociais, que, em sua visão, teriam papel central no desenvolvimento da história da arte. ${ }^{87}$ 
De acordo com o historiador da arte Irving Sandler (19252018), na época de Cubism and Abstract Art, Barr já havia, no entanto, deixado para trás a interpretação do modernismo segundo a visão estritamente "formalista" que havia abraçado no início de sua formação. ${ }^{88}$ Sem nunca ter sido entusiasta da abstração geométrica, o diretor teria organizado essa retrospectiva considerando a importância histórica da produção Cubista, mas não acreditaria que essa ainda fosse uma fonte vital para a produção atual. Naquele momento, sua aposta estaria no Surrealismo, especialmente nas obras de formas biomórficas e não geométricas como as de Jean Arp, Joan Miró e Henry Moore, que consideraria mais atuais e significativas para os novos desdobramentos da arte..$^{89}$

A discussão em torno da autonomia da arte com relação ao contexto social de sua produção imbricava-se então com a atmosfera de repressão à produção independente de vanguarda por regimes autoritários em ascensão - como o nazismo, o fascismo e o comunismo -, que consideravam subversivas obras que não se identificassem com suas respectivas ideologias. Contra a submissão da criação a justificativas políticas, Barr defendia vigorosamente a liberdade artística. Ele considerava central para o modernismo a atuação do gênio artístico individual, que em sua opinião só poderia florescer dentro de um regime democrático que permitisse a pluralidade de manifestações, ainda que de forma dependente de um mecenato ligado à elite social, como nos EuA. No texto do catálogo de Cubism and Abstract Art, Barr apresentou um tópico descrevendo as conturbadas relações entre arte abstrata e política, com a conclusão: "este ensaio e exposição podem bem ser dedicados aos pintores de quadrados e círculos (e aos arquitetos influenciados por eles) que sofreram nas mãos de filistinos com poder político." ${ }^{90}$

O conteúdo das exposições e o perfil das aquisições do MoMA durante a gestão de Barr mostram que sua postura era mais diversificada do que parecia indicar o sentido evolutivo e unidirecional de seu esquema do "torpedo avançando no tempo", pois não raro arriscava investir em obras e artistas pouco conhecidas e ainda em produções de origem popular. $\mathrm{O}$ peso que a visão formalista da arte adquiriu a partir da década de 1940 não resultou direta e unicamente de sua visão e atuação
88 Sob influência dos textos do artista e crítico Roger Fry (18661934). Cf. SANDLER, op. cit., p. 11.

89 SANDLER, op. cit., p. 25.

90 The Museum of Modern Art. Cubism and abstract art, op.cit., p. 18. Tradução nossa. 
no museu, mas articulou-se à influência da crítica elaborada por Clement Greenberg (1909-1994), que defendia o entendimento da arte moderna numa rota evolutiva mais retilínea e historicista, segundo uma interpretação essencialmente estética, valorizando não apenas a noção de autonomia, mas também a especificidade de cada meio. Segundo Sandler, a posição do crítico não corresponderia exatamente à visão mais aberta de Barr, sobre qual se baseava a política que procurava implantar no museu:

Muito cedo em sua carreira, Barr rejeitou a noção vanguardista de que a arte estava progredindo em uma direção - a afirmação que Clement Greenberg faria mais tarde. Barr substituiu o vanguardismo pela concepção de história da arte como um vasto depósito de ideias que os artistas vivos poderiam usar para novos começos, dependendo de sua visão, energia e independência. ${ }^{91}$

Desconsiderando essas diferenças, os aspectos defendidos mais por Greenberg do que por Barr são constantemente associados ao modo de expor arte moderna que o diretor implantara desde cedo no момa. Para Staniszewski, a prática de dispor as obras separadas entre si, individualizadas no campo de visão do espectador e em ambientes sóbrios, corresponderia ao objetivo de fazer com que a percepção de cada uma delas prevalecesse sobre a arquitetura e associações específicas ao local. Na opinião da autora, o recurso de rebaixar a presença visual do contexto arquitetônico corresponderia a uma intenção de neutralidade, o que desconsidera a possibilidade discutida anteriormente de que o propósito de Barr fosse o oposto, ou seja, o de gerar uma impressão impactante de modernidade num contexto arquitetônico tradicional. A desmontagem que Staniszewski faz da noção de neutralidade adota o viés alinhado à crítica ideológica de O'Doherty, associando o isolamento da obra de arte à valorização da autonomia e independência tanto da obra quanto do próprio indivíduo que se posiciona

91 SANDLER, op. cit., p. 13. Tradução nossa. frente a ela no momento da apreciação, o que traduziria valores especialmente caros à sociedade estadunidense: 
Este método estetizado, autônomo e pretensamente 'neutro' de expor criou um aparato ideológico de acomodação para a recepção do modernismo nos EUA, onde o ideal democrático liberal do indivíduo autônomo e independente nascido com direitos naturais e livre iniciativa é a fundação da mitologia do sonho americano. ${ }^{92}$

Se de fato Barr defendia esses valores, vimos que o entendimento da construção de um padrão expositivo como intenção em gerar uma ambiência específica - combinando a austeridade da arquitetura moderna e a "intimidade" do apartamento burguês -, contraria a interpretação que o associa desde o início a uma suposta neutralidade. Ou seja, o modelo expositivo que começa e se formar nos anos iniciais do мома cria intencionalmente um impacto no contexto museológico da época e é apenas mais tarde, com sua constante repetição e difusão como um padrão, inclusive para além dos muros da instituição, que pode ser percebido e possivelmente praticado enquanto propositadamente neutro. A intenção de Barr de impactar o contexto tradicional com a modernidade do museu estará presente não apenas no modelo expositivo, mas também na arquitetura da primeira sede própria do MOMA, como veremos a seguir.

\subsubsection{ARQUITETURA (DE COMPROMISSO) COMO REPRESENTAÇÃO DO MODERNO: A PRIMEIRA SEDE PRÓPRIA}

Com o crescimento do момa em meados da década de 1930, já era perceptível que as características da sede e o número de funcionários eram insuficientes para a missão pretendida, $o$ que levou o museu a adquirir, em 1936, a casa onde se encontrava e mais três imóveis adjacentes para construir uma instalação própria. Se havia um consenso entre os membros do conselho e do staff de que a arquitetura da nova sede seria central para representar a modernidade da instituição, as opiniões se dividiam sobre a escolha dos profissionais à altura de liderar a missão. Sendo o único arquiteto do board, do qual 92 STANISZEWSKI, op. cit., p. 70. 

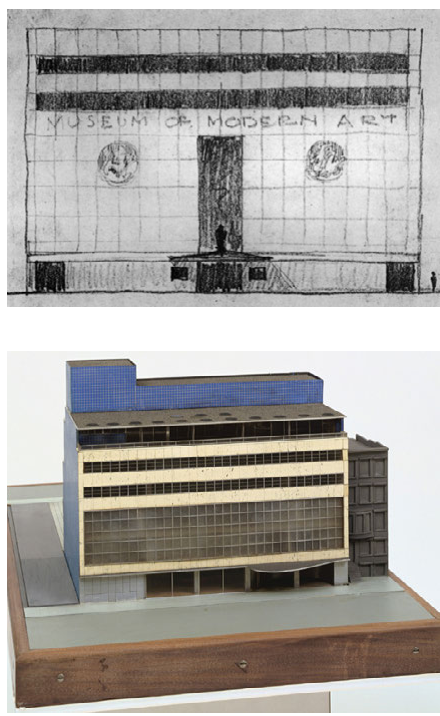

1.39 Fachada proposta para o MoMA por Philip L. Goodwin (sozinho?), 1936. Fonte: RICCIOTTI, p.61.

1.40 Maquete do MoMA, projeto de Goodwin e Stone, Nova York, 1939. Fonte: https://www.moma.org/ collection/works/82404
93 A prática de Goodwin até então caracterizava-se por uma linguagem eclética, entre o Art Déco e o Modernismo classicista, ainda vinculado à linguagem Beaux Arts. Cf. RicciotTI, op. cit., p. 62-3.

94 Barr teria aceitado também Frank Lloyd Wright ou Le Corbusier, mas nenhum deles tinha boas relações com o museu. Cf. RicCiotTi, op. cit., p. 63 . participava sobretudo por sua atuação como colecionador, Philip L. Goodwin (1885-1958) logo foi apontado com um dos nomes, a despeito de não praticar uma linguagem propriamente moderna, ${ }^{93}$ o que revela a postura controladora que a instituição assumiu desde então com relação à produção de sua própria arquitetura.

Para garantir que o edifício expressasse o espírito inovador do museu, foi acordado que outro arquiteto que dominasse a linguagem moderna fosse contratado para colaborar com o projeto. Barr ansiava que a sede no museu fosse a expressão da mais alta qualidade arquitetônica e, considerando ainda incipiente a experiência dos estadunidenses nessa área, era da firme opinião de que o projeto fosse liderado por um dos pioneiros europeus consagrados no International Style. Entre os nomes que apontou estavam J. J. P. Oud, Walter Gropius e Mies van der Rohe, sendo que apenas o último, justamente o favorito do diretor, demonstrara interesse e disponibilidade para assumir a tarefa. ${ }^{94}$ Goodwin, no entanto, recusava-se a trabalhar ao lado de um arquiteto europeu, insistindo que seu parceiro deveria ser estadunidense.

Enquanto Barr percorria a Europa entrevistando os candidatos, o conselho, sem lhe dar notícias, contratou para participar do projeto Edward Durell Stone (1902-1978), que, embora jovem, vinha obtendo reconhecimento por seus edifícios mais alinhados com o chamado International Style. Os principais apoiadores dessa decisão foram o presidente da instituição, Goodyear, e o tesoureiro do comitê de construção do museu, o empresário Nelson Rockefeller (1908-1979), cuja família era intimamente vinculada ao MомA, bem como ao Rockefeller Center, onde trabalhara Stone durante a construção. Ao voltar para Nova York e tomar conhecimento da contratação, Barr não se conformou e ainda se empenhou em reverter o fato consumado, tentando convencer o conselho a encomendar a Mies o projeto pelo menos da fachada frontal. Sem ter sua opinião acatada para uma questão que lhe era tão sensível, o diretor retirou-se do comitê de construção, negando-se a cooperar com uma decisão que considerava totalmente equivocada e potencialmente desastrosa para a imagem do museu, que, em sua opinião, desperdiçava a oportunidade preciosa 
de construir a própria sede numa linguagem moderna de alta qualidade arquitetônica. ${ }^{95}$

Observando as primeiras versões do projeto apresentadas por Goodwin, vinculadas a um modernismo classicista muito em voga nos anos 1930, vemos que a preocupação de Barr não era excessivamente alarmista, mas baseada na consciência que tinha da distância que separava o conservadorismo vigente nos EUA das experiências de vanguarda da Europa naquele momento. ${ }^{96}$ Apesar das turbulências do processo, a participação de Stone mostrou-se fundamental para colocar o projeto numa rota moderna e chegar a uma solução que, mesmo não sendo tão assertiva quanto teria preferido Barr, foi considerada muito bem-sucedida tanto pelo conselho do museu quanto pela crítica especializada da época. ${ }^{97}$

Como observou o historiador da arte Dominic Ricciotti (1939-), o edifício inaugurado em 1939 atendia em linhas gerais aos princípios definidos por Hitchcock e Johnson para o International Style, sendo eles a prevalência do volume sobre a massa, a ordenação do projeto pela regularidade ao invés da simetria e a ausência de adorno nas superfícies. ${ }^{98}$ Por outro lado, o autor apontou que a boa receptividade do projeto se deveu, em boa medida, ao fato de sua modernidade ser suavizada por um detalhamento "gracioso" nos interiores e pela estrutura compositiva tradicional da fachada. Se o aspecto fabril gerava um contraste com as casas vitorianas alinhadas ao longo da rua 53, o encaixe razoavelmente harmonioso do museu entre elas foi favorecido pela composição quase tripartite da fachada - dividida em base, corpo principal e coroamento:

Em 1939, para um público não habituado à radicalidade do International Style, o MoмA poderia parecer uma fábrica, mas seu caráter semelhante ao de um palazzo evidencia a persistência da tradição beaux-arts na América durante o advento do modernismo. Ao evocar a forma urbanística do palácio italiano, Goodwin e Stone propiciaram que seu edifício se encaixasse confortavelmente em uma paisagem urbana então puramente residencial. Desse modo, eles aprimoraram o sentimento de domesticidade do Mома e ainda contribuíram para o seu ar cosmopolita. ${ }^{99}$

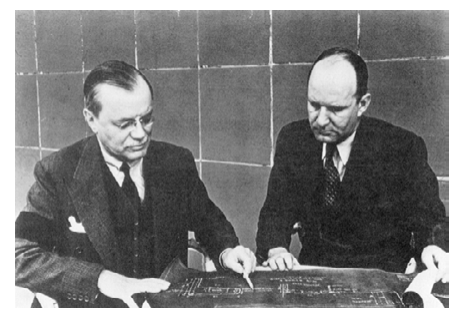

1.41 Philip L. Goodwin e Edward D. Stone olhando para os desenhos do novo ediício do MoMA, ca. 1936. Foto: MoMA. Fonte: RICCIOTTI, p.68.
95 Cf. RicciotTi, op. cit., p. 66.

96 Embora tenha sido esse o estilo adotado pelo Museu de Arte Moderna de Paris construído na mesma época, que será analisado mais adiante, no capítulo 4 desta tese.

97 Como o crítico Lewis Mumford. Cf. RicciotTi, op. cit., p. 72.

98 Cf. RicCIOTTI, op. cit., p.52-54. 99 Ibidem, p. 71. Tradução nossa. 

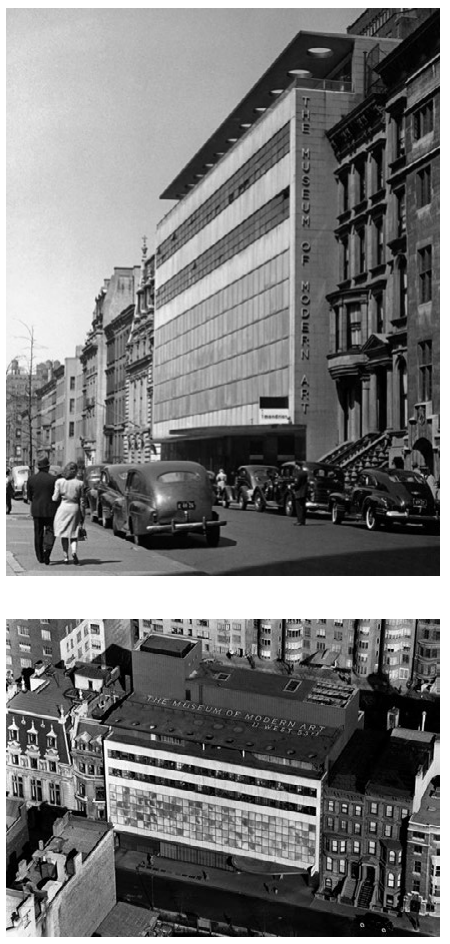

1.42 Fachada do MoMA, projeto de Goodwin e Stone, na ocasião de sua inauguração, Nova York, 1939.

Foto: George Marks. Fonte: https://www. architecturaldigest.com/story/new-yorkiconic-museum-of-modern-art-completed450-million-makeover

1.43 Edifício do MoMA, projeto de Goodwin e Stone, entre construções vizinhas, Nova York, 1939. Foto: Andreas Feininger. Fonte: https://www.nytimes. com/2014/01/14/arts/design/momasplan-to-demolish-folk-art-museum-lacksvision.html

1.44 Entrada do MoMA, projeto de Goodwin e Stone, Nova York, 1939. Fonte: https:// www.moma.org/about/who-we-are/ moma-history

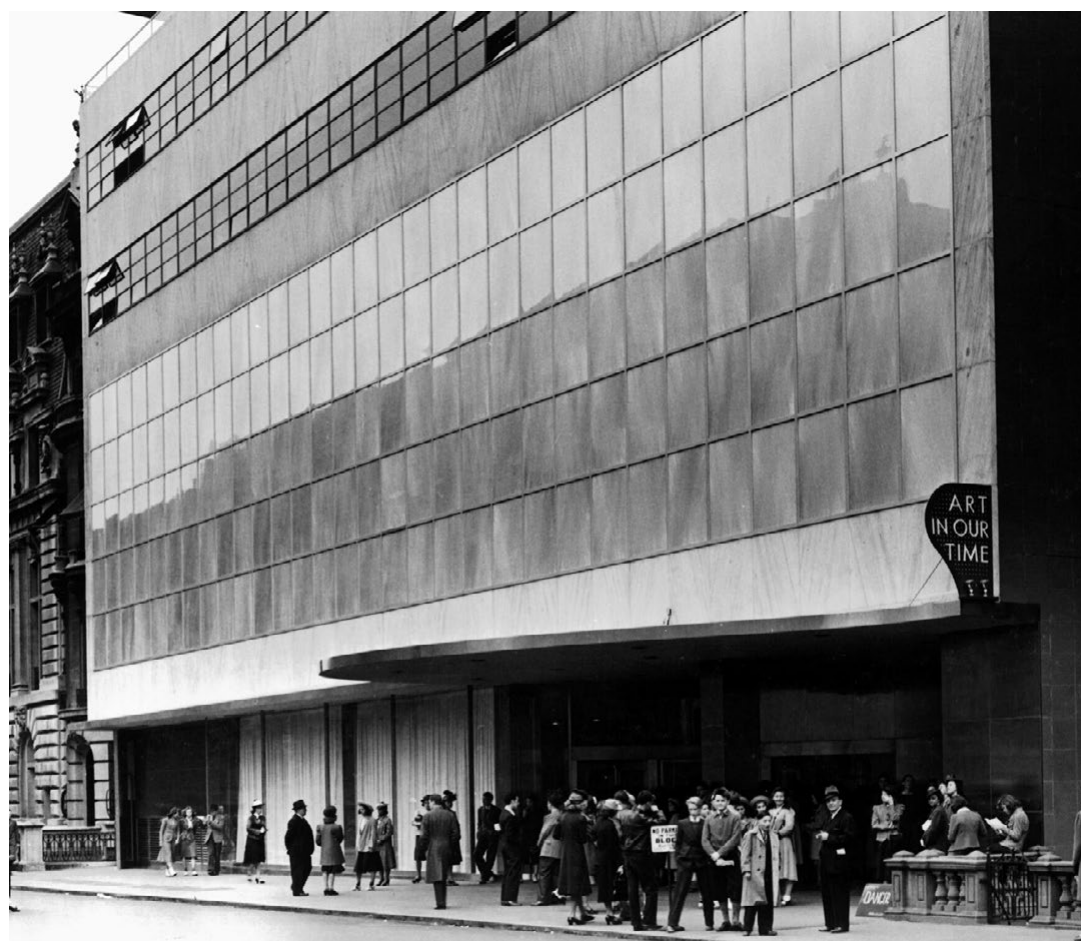

Se é possível falar em moderação com relação à arquitetura no novo edifício, é preciso observar que equipes de arquitetura, de fato treinadas nos moldes tradicionais da época, estavam longe de ter a última palavra sobre o projeto. Como é comum na relação entre escritório de arquitetura e cliente, a dupla de arquitetos estava submetida ao comitê de construção do museu, que representava os interesses de seus mantenedores e de membros do conselho, e é difícil imaginar que tivessem prestígio profissional suficiente para contrariá-los, ainda que Goodwin fosse um dos membros. Entre dirigentes do момА, havia personalidades com diferentes graus de entusiasmo com a produção da arte e da arquitetura mais avançadas da época, mas todos tinham em comum o fato de serem muito bem conectados com as estruturas tradicionais de poder na cidade, em geral avessa a radicalismos. Nas palavras de Ricciotti, "os respectivos gostos dos indivíduos do comitê interferi- 


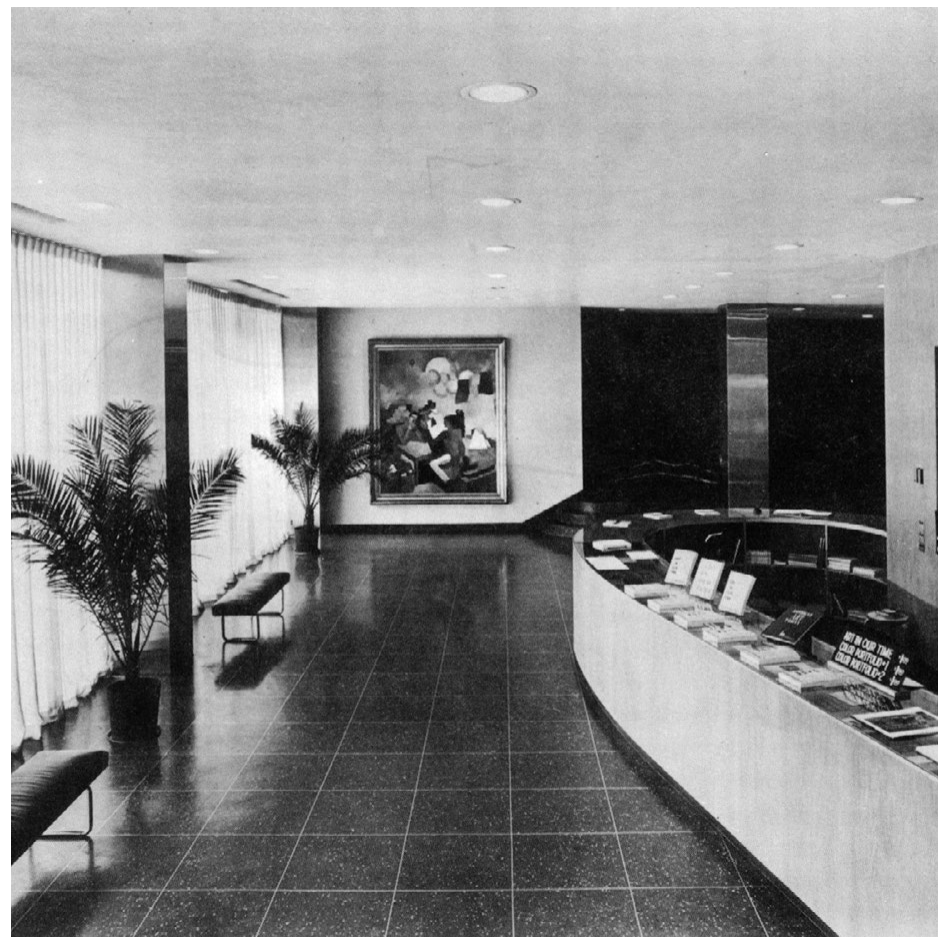

ram na produção de um edifício que, suprimindo os rigores do International Style, resultou num modernismo atenuado." ${ }^{100}$

O edifício pode ter ficado aquém das experiências mais radicais da arquitetura moderna, mas seu caráter informal era especialmente inovador no contexto dos museus da época. Ao invés de destacar-se na paisagem por uma escadaria que lhe conferisse monumentalidade, apenas uma esquadria de vidro transparente separava a calçada de seu interior, sem qualquer desnível, deixando à vista o jardim aos fundos. $\mathrm{O}$ acesso, localizado assimetricamente na fachada e sob uma marquise curva, ${ }^{101}$ era feito por uma porta giratória similar às das lojas de departamentos e edifícios comerciais, afirmando o caráter urbano do museu e a intenção de integrar-se ao fluxo cotidiano da cidade. O lobby, sem qualquer dimensão grandiosa, continha um balcão de recepção na área paralela à fachada $\mathrm{e}$ prosseguia no sentido perpendicular até o fundo, dando acesso
1.45 Saguão de entrada do MoMA com balcão de recepção, projeto de Goodwin e Stone, Nova York, 1939. Foto: Robert M. Damora. Fonte: RICCIOTTI, p.54.
100 Ibidem, p. 73. Tradução nossa.

101 Embora assimétrica com relação à largura da fachada, a entrada localizava-se no eixo de uma possível rua que seria aberta ligando o Rockefeller Center ao MomA. Cf. RicCioti, op. cit., p. 61. 


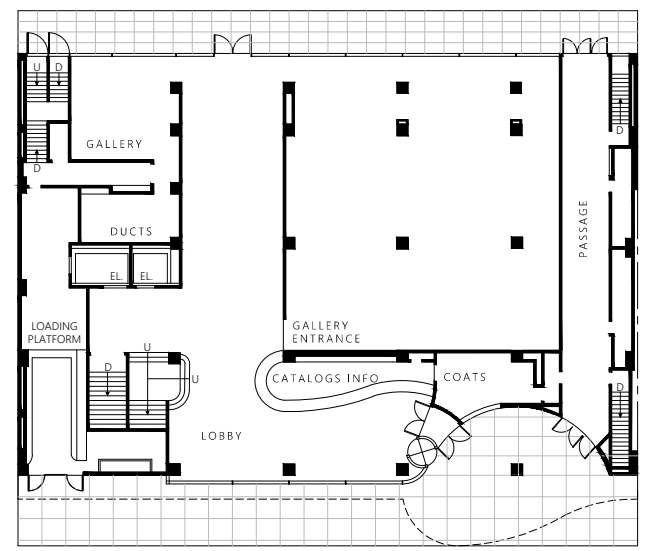

FIRST FLOOR

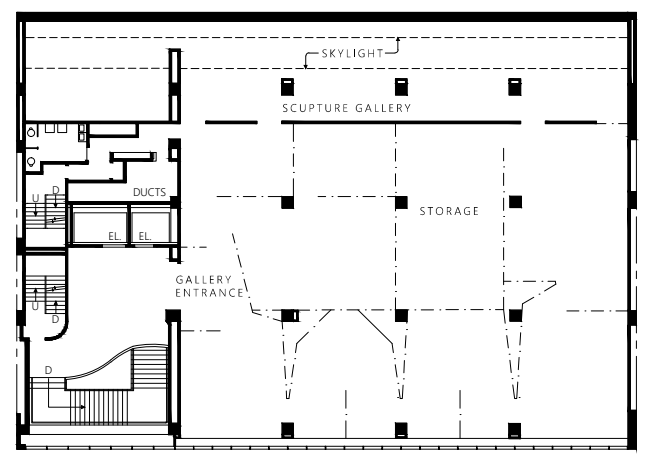

THIRD FLOOR [PAVIMENTO 3]
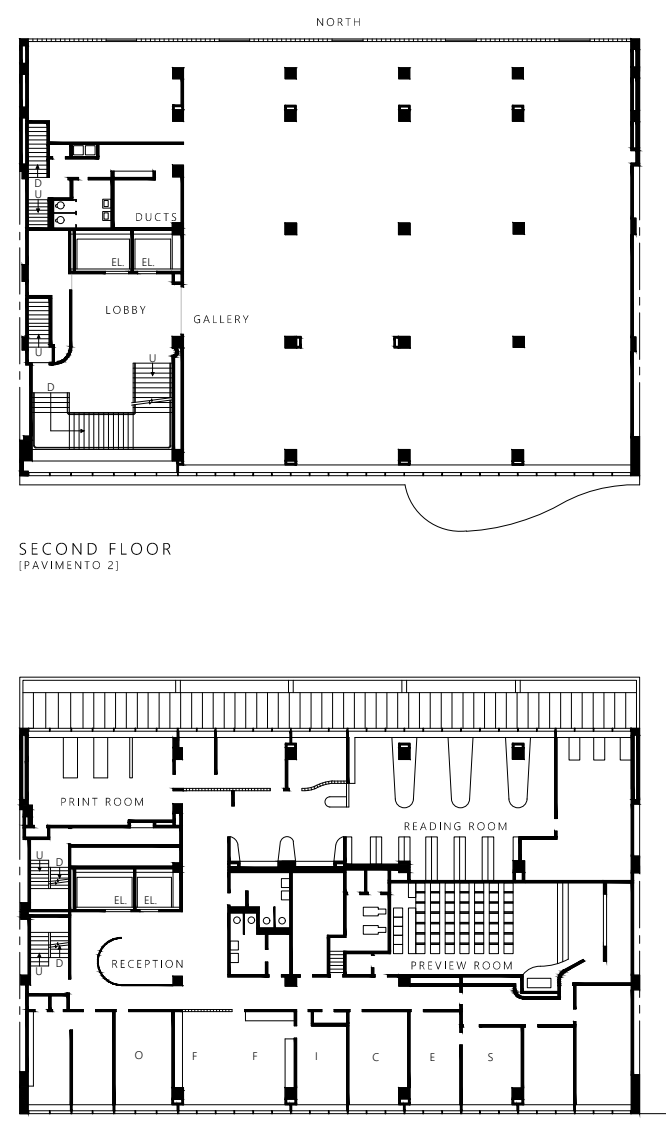

FOURTH FLOOR
[PAVIMENTO 4 ]
1.46 Plantas do edifício do MoMA, projeto de Godwin e Stone, Nova York, 1939.

Desenhos nossos baseados em RICCIOTTI, p. 56 e STONE, n.p. ao jardim de esculturas, a duas galerias expositivas menores envidraçadas para ele e ao núcleo de circulação vertical na lateral, composto por uma escadaria junto à fachada frontal e elevadores de público e de serviço. Além das áreas expositivas, que ocupavam ainda todo o segundo e o terceiro pavimentos, o programa do museu incluía uma biblioteca e escritórios de administração e curadoria (quarto e no quinto pavimentos), escritórios e ambientes de encontro reservados para os membros e conselheiros (sexto pavimento) e auditório e áreas de serviço (subsolo). 

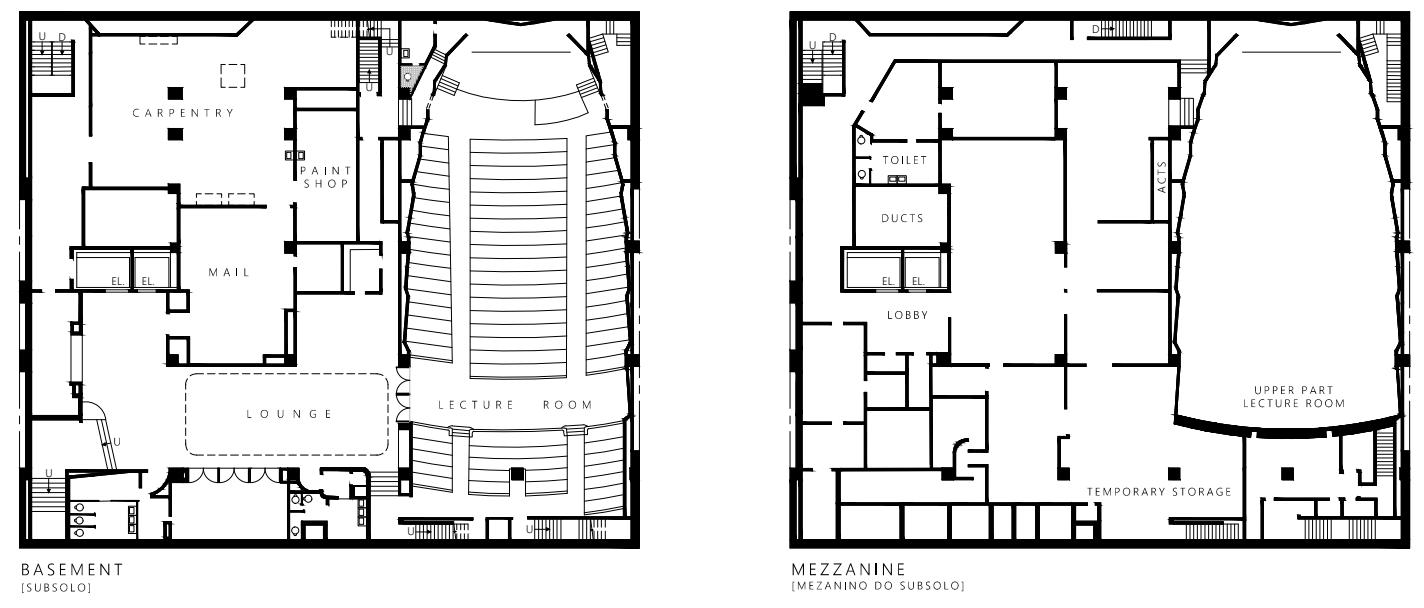

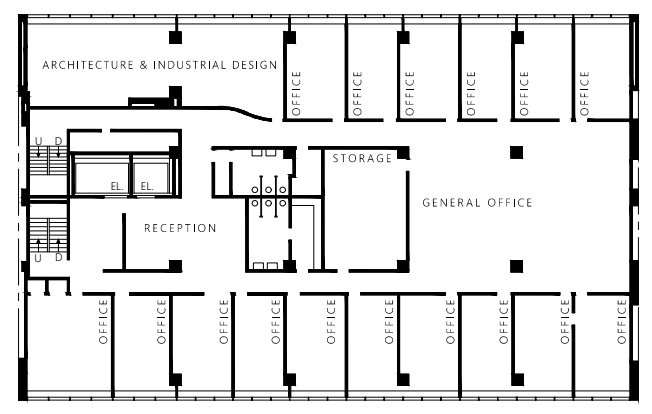

FIFTH FLOOR
SIXTH FLOOR [PAVIMENTO 6]
A concentração do bloco edificado exclusivamente na faixa dos lotes da rua 53 justifica-se não apenas por uma decisão de partido projetual, mas também pelo fato de a área voltada para a rua 54 ser inicialmente mais estreita e ter sido doada pela família Rockefeller já com a designação de "jardim de esculturas", como aponta a historiadora da arquitetura Mirka Benes. ${ }^{102}$ A doação de novas áreas que ampliaram o jardim para a dimensão final foi efetuada a menos de duas semanas da inauguração do edifício, daí sua configuração não ter sido incorporada ao projeto de Goodwin e Stone. De todo modo,
102 Cf. Benes, Mirka. Inventing a Modern Sculpture Garden in 1939 at the Museum of Modern Art.

New York, Landscape Journal, v. 13, p. 1-20, 1994. 


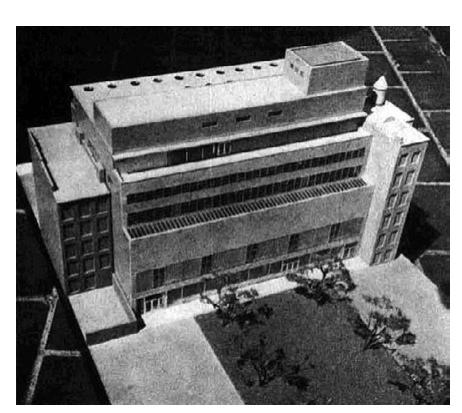

1.47 Maquete do MoMA, projeto de Goodwin e Stone, Nova York, 1937. Fonte: PETERSON, A. Everet (ed.). Art Guide Directing the World's Fair Visitor to the Better Known Art Centers of New York City, NYC Art Commission: Nova York, p. 39 apud BENES, p. 4.

1.48 Planta do jardim de esculturas do MoMA, de John McAndrew e Alfred Barr Jr., Nova York, 1939. Fonte: BENES, p. 4.

103 Cf. Coolidge, John. Patrons and Architects: Designing Art Museums in the Twentieth Century. Fort Worth: Amon Carter Museum, 1989, p. 163 .

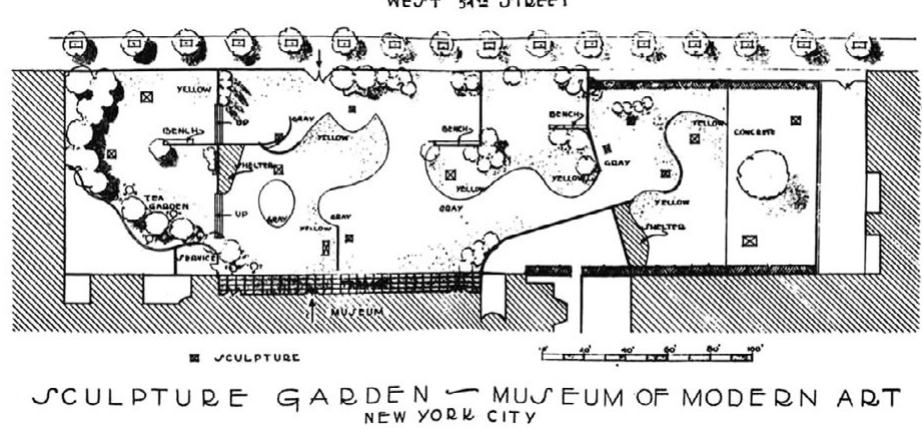

a implantação que liberava uma área aberta no lote, então novidade, viria em breve a ser uma característica marcante do International Style. Contrastando com a configuração típica dos museus de então, muitos dos quais construídos ao redor de pátios internos, o MOMA teria sido o primeiro a incorporar um jardim público de esculturas nos EUA, solução adotada posteriormente por muitos outros centros de arte. ${ }^{103}$

Com a intenção de inaugurar o jardim junto com o novo edifício, Barr e John McAndrew, então curador de arquitetura e desenho industrial do MOMA, improvisaram às pressas um arranjo paisagístico que permitisse seu uso como um local de exposições a céu aberto. Como apontou Benes, a escassez de tempo não impediu que os curadores fossem bem-sucedidos na tarefa inédita de conceituar um jardim modernista de esculturas, estabelecendo quatro parâmetros fundamentais para o seu desenvolvimento posterior. Em primeiro lugar, o abandono da configuração convencional de pátio, em favor de ambientar as esculturas num "jardim" propriamente dito. Em segundo, a opção por expor peças em pequena quantidade, favorecendo sua apreciação individual e liberando-as das paredes dos museus e dos jardins naturalistas, em consonância com as preocupações curatoriais da época. Além da abordagem museológica, a solução tinha como referência projetos de Mies van der Rohe, como o Pavilhão de Barcelona de 1929, habitados por esculturas solitárias contra planos construídos. O desenho do jardim do MомA, no entanto, não tinha o rigor geométrico do mestre alemão, mas formas orgânicas inspiradas tanto em obras do Surrealismo quanto em projetos do 
finlandês Alvar Aalto e do brasileiro Roberto Burle Marx, que já eram referência para paisagistas estadunidenses como Thomas D. Price, Thomas Church e Fletcher Steele, com os quais Barr e McAndrew já estavam familiarizados. Em terceiro lugar, a afirmação de um jardim formal configurado com elementos discretos e grandes áreas de circulação - em oposição ao jardim naturalista -, o que se popularizou a partir dos anos 1950. Em quarto, por fim, a ênfase numa relação desimpedida entre interior e exterior, como havia se desenvolvido desde os projetos de Frank Lloyd Wright e de outros arquitetos de uma geração mais recente, como Mies van der Rohe, Richard Neutra e Thomas Church. ${ }^{104}$

Novidades no modo de organizar os espaços não se restringiam à área do jardim, mas também se apresentavam nas áreas expositivas internas do edifício de Goodwin e Stone, que divergiam da tipologia tradicional dos museus, frequentemente organizados a partir de eixos de corredores e galerias enfileiradas e dispostas em torno de um grande saguão principal. Na nova sede do момA, os dois pavimentos de exposição eram configurados num salão único de planta livre, pontuado apenas por pilares posicionados segundo uma malha regular. Com área três vezes maior que no antigo imóvel, os espaços expositivos seriam subdivididos de acordo com as necessidades específicas de cada mostra, com a instalação de divisórias móveis, como nos edifícios de escritório. Essa condição de flexibilidade e indeterminação, então novidade nos museus, tornou-se posteriormente padrão para os espaços da arte, juntamente com a adoção das paredes brancas afinadas com a linguagem do International Style. ${ }^{105}$

Na configuração original, porém, as áreas expositivas não eram isoladas do exterior como vieram a se tornar posteriormente. Por insistência de Barr, que preferia iluminação natural à artificial, Goodwin e Stone substituíram o fechamento cego que haviam proposto por uma esquadria translúcida em toda a largura da fachada frontal, cobrindo tanto as galerias quanto a escada na altura dos dois pavimentos expositivos. ${ }^{106} \mathrm{~A}$ face voltada para o jardim, por sua vez, tinha no segundo pavimento um fechamento que alternava esquadrias de vidro transparente com faixas de tijolos de vidro, permitindo vistas para a cidade

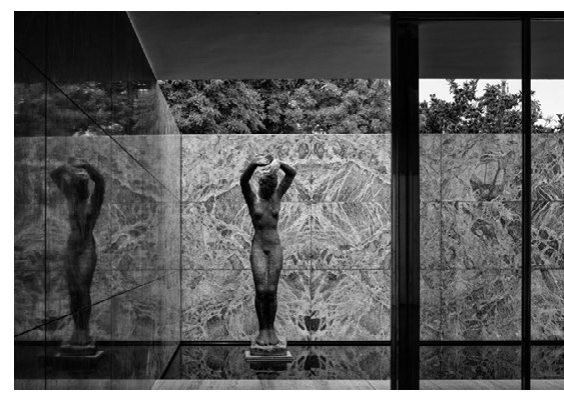

1.49 Pavilhão Barcelona, projeto de Mies van der Rohe, Barcelona, 1929. Foto: Cemal Emden. Fonte: https:// divisare.com/projects/395780-ludwigmies-van-der-rohe-cemal-emdenbarcelona-pavilion
104 O jardim foi completamente reformulado em 1953 por Phillip Johnson, como será tratado mais adiante, ainda neste capítulo da tese.

105 BENES, op. cit., p. 15-16.

106 O painel Thermolux, então novidade da indústria da construção, era constituído por duas placas de vidro transparente com uma de fibra de vidro no meio, produzindo um efeito translúcido. 
1.50 Pavimento térreo e entorno paisagístico para o Metropolitan Museum, projeto de McKim, Mead and White. Nova York, ca. 1907. Fonte: HECKSCHER, Morrison H. The Metropolitan Museum of Art: An Architetural History. The Metropolitan Museum of Art Bulletin, Summer 1995. The Metropolitan Museum of Art: Nova York, p. 44.

1.51 Fachada do MoMA voltada para a Rua 54, projeto de Goodwin e Stone, com jardim de esculturas, projeto de John McAndrew e Alfred Barr Jr., Nova York, 1939. Foto: Wurts Brothers.

Fonte: RICCIOTI, p. 58.
107 Iluminação lateral para pinturas e zenital para esculturas era o contrário do padrão museográfico tradicional, como veremos com mais detalhes no Capítulo 4 desta tese.
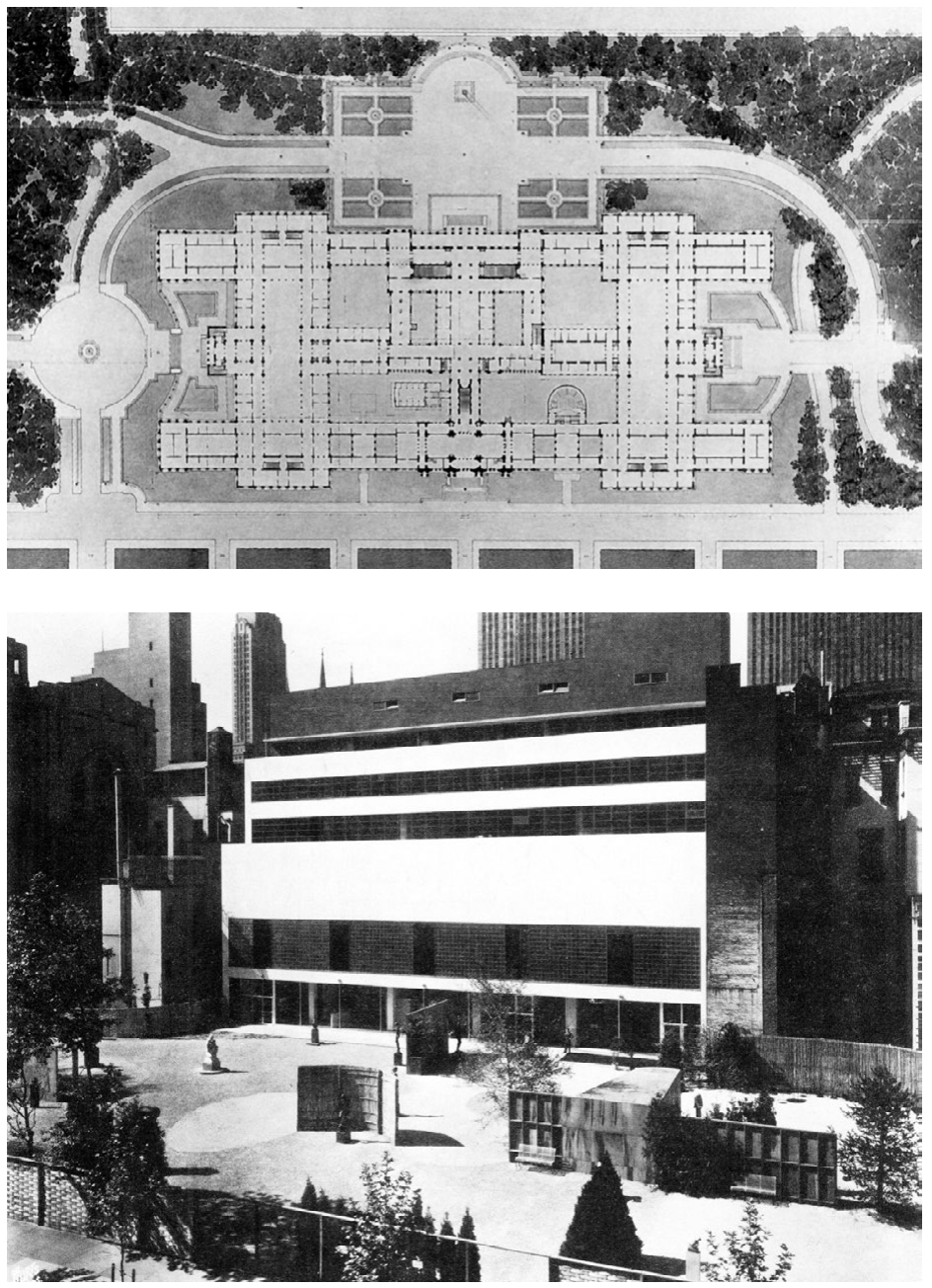

ao redor, além da iluminação natural. No terceiro pavimento, o fechamento dos fundos era cego, pois a área junto à fachada seria dedicada a esculturas, iluminadas por aberturas zenitais. ${ }^{107}$ No entanto, diante da necessidade que logo se impôs de ampliar as superfícies para exposição, foram construídos painéis opacos faceando internamente as fachadas, ocultando as aberturas para o exterior. O desejo de Barr em dotar as salas expositivas de transparência e iluminação natural foi atendido 
pelo projeto, mas não se sustentou por muito tempo, o que contribuiu para a consolidação da noção de que o padrão de expor desenvolvido no момA articulou-se desde o início a uma intenção de isolamento da arte de seu contexto arquitetônico, ou do "mundo real" exterior.

Outro aspecto que marcou a identidade do MOMA, foi a relação de "intimidade" que as condições expositivas proporcionavam entre espectador e obra foi, por sua vez, absolutamente proposital, tendo origem, como vimos, na convicção de Barr de que a escala doméstica dos apartamentos burgueses era a referência ideal para o modo de fruição da arte moderna. No novo edifício, não havia nenhum ambiente imponente, sendo os pés direitos limitados a 3,6 ou 4,2m, dimensões mais próximas às das casas vizinhas que às dos museus tradicionais. Como já ensaiado nas antigas sedes, essa condição de "intimidade" era reforçada nas montagens das exposições pela distância lateral entre as obras e seu posicionamento conforme a estatura de uma pessoa mediana, enaltecendo a experiência individual "olho a olho" com cada uma delas.

Embora tenham se originado não apenas por razões conceituais, mas também pelas necessidades práticas apontadas anteriormente, foi na nova sede que o tipo de ambiente expositivo austero, isolado e artificialmente controlado destinado às mostras de arte moderna - conhecido posteriormente como "cubo branco" - atingiu sua forma acabada. Sua prática repetiu-se à exaustão nas mostras de arte do MOMA, espraiando-se em escala global como o padrão expositivo dominante em museus e galerias de arte na mesma velocidade com que se popularizava a arte moderna.

Escrevendo sobre as transformações no modo como o MOMA foi percebido desde sua fundação até os anos 1990, o historiador da arte Alan Wallach (1942-) investigou como as diversas versões arquitetônicas adotadas como representação do museu relacionaram-se de modos distintos com uma visão do moderno como expressão de seu tempo. Na argumentação do autor, as primeiras três décadas de funcionamento do museu seriam definidas pela "utopia" ${ }^{108}$ de implantar nos EUA uma visão do moderno voltada para o futuro, da qual o edifício de Goodwin e Stone teria participação decisiva.
108 WallaCh, Alan. The Museum of Modern Art: The Past's Future. Journal of Design History, v. 5, n. 3 , p. 207-215, 1992, p. 210. 
Formado a partir da visão multidisciplinar da Bauhaus especialmente de sua arquitetura e design - e das experiências do Fauvismo, Cubismo e Surrealismo, o museu teria passado por um processo permeado por tentativas e erros, que teria resultado numa intrincada construção da história da arte moderna, capaz de justificar a estética desses movimentos como algo historicamente inevitável. Sendo o único artefato produzido deliberadamente para representar a instituição e em contraste evidente com seu contexto físico e cultural, o edifício funcionaria como um elemento unificador das diversas manifestações da arte moderna. Wallach mostra como a articulação entre o aspecto tecnológico da fachada e o ascetismo dos interiores da nova sede produziu um modo específico de se relacionar com a arte moderna, contribuindo para a sua valorização:

O edifício de Goodwin e Stone representou uma ruptura decisiva com o design convencional de museus (...). Se a fachada proclamava repúdio ao passado e exaltação de um futuro tecnológico, o interior demonstrava os meios pelos quais esse futuro poderia ser alcançado. O interior do museu foi transformado em espaços antissépticos como laboratórios - fechados, isolados, iluminados artificialmente - e ambientes aparentemente neutros, nos quais os espectadores podiam estudar obras de arte expostas como tantos espécimes isolados. Muito se falou da 'intimidade' desses espaços da galeria. No entanto, essa 'intimidade' também produziu sua própria sensação de distância. O espaço do museu - o cubo branco pelo qual o Moma ficou famoso pelo pioneirismo - contribuiu para uma nova estética da reificação, uma estética que redefiniu tanto a obra de arte quanto o espectador que foi solicitado a contemplar a obra de um modo que se aproximava do desapego científico. Nesse espaço tecnologizado, a obra de arte adquiriu sua aura utópica. ${ }^{109}$

\subsubsection{CONVERGÊNCIA ENTRE EXPOGRAFIA E ARQUITETURA}

A exposição inaugural que ocupou todo o novo edifício - Art in Our Time: 1oth Anniversary Exhibition: Painting, Sculpture, Prints 
torial de Barr. ${ }^{110}$ Embora não tenha controlado inteiramente a concepção do edifício, o diretor foi o responsável por definir como os objetos de arte seriam ali dispostos. Como apontado no catálogo, a mostra foi planejada para atrair o grande público que visitaria a Feira Mundial de Nova York. ${ }^{111}$ Enquanto outros museus da cidade expunham nessa ocasião apenas obras de artistas estadunidenses, о момА procurava equilibrar a presença deles com a dos mestres europeus, além de abranger a produção atual e a do passado recente das diversas disciplinas que correspondiam aos departamentos do museu. ${ }^{112}$

A sessão de Pintura e Escultura ocupou a maior área da exposição, sendo a única que contou com registros fotográficos disponíveis para consulta. A maioria deles mostra ângulos fechados sobre conjuntos de obras, sem revelar a configuração geral dos ambientes, que guardavam dimensões reduzidas como as da antiga casa. Poucas pistas se têm da presença das aberturas para o exterior, que se vislumbra apenas por uma faixa de tijolos de vidro ao lado da pintura de Max Beckmann, Departure (1932 e 1933-35), , e por um canto de cortina, talvez junto à esquadria, ao lado da obra de Pablo Picasso, Boy Leading a Horse (1905-06).

Digno de nota é o fato de os conjuntos de pinturas e esculturas em Art in Our Time aparecerem bem mais apartados do que na exposição Cubism and Abstract Art, pois parte das esculturas estavam dispostas no amplo jardim ou concentradas na zona especialmente dedicada a elas na faixa posterior do terceiro pavimento, dotada de iluminação zenital. Esse tipo de predeterminação espacial de acordo com os suportes convencionais da arte era comum nos museus tradicionais, estruturados segundo os procedimentos classificatórios típicos do Iluminismo. Talvez a configuração arquitetônica do novo edifício, que contava com uma área de exceção dentro da planta livre, tenha conduzido nessa exposição à segmentação espacial das disciplinas, apesar de pintura e escultura estarem incluídas num mesmo departamento. ${ }^{113}$ De todo modo, a expografia acentua a diferenciação entre os dois tipos de suporte, pois, enquanto as pinturas estão dispostas em paredes brancas e lisas, ${ }^{114}$ a área interna do terceiro pavimento onde estão as esculturas, dotada de iluminação zenital, é subdividida com cortinas drapeadas de diferentes
110 CF. The Museum of Modern ART. Art in Our Time: 1oth Anniversary Exhibition: Painting, Sculpture, Prints (May 10-Sep 30, 1939). МОмА. Disponível em: $<$ https://www.moma.org/calendar/ exhibitions $/ 2743$ ? locale $=$ pt $>$. acesso em: 5 fev. 2020.

111 Cf. The Museum of Modern ART. Art in our time: color portfolio. Nova York: The Museum of Modern Art, 1939.

112 A sessão de Pintura e Escultura era introduzida por uma pequena mostra de arte popular estadunidense e pinturas feitas por crianças. Na sessão dedicada à Arquitetura e Arte Industrial, Houses and Housing, estavam expostos projetos de habitação em diversas escalas e padrões, ao lado de peças de mobiliário e banheiros pré-fabricados e de um filme sobre a evolução dos arranha-céus. $\mathrm{O}$ departamento de Filmes contava com mostras no auditório e com a exibição de dois curta-metragem nas salas expositivas. Os departamentos ainda não formalmente estabelecidos de Artes Gráficas e Fotografia também ganharam pequenas exposições, enquanto o de Teatro e Arte comercial não foi representado na mostra.

113 Pintura e escultura permanecem até hoje num mesmo departamento, o que conflita com a não segmentação por suportes da arte contemporânea.

114 Entre as fotos disponíveis, apenas uma delas revela uma parede de tom escuro. 

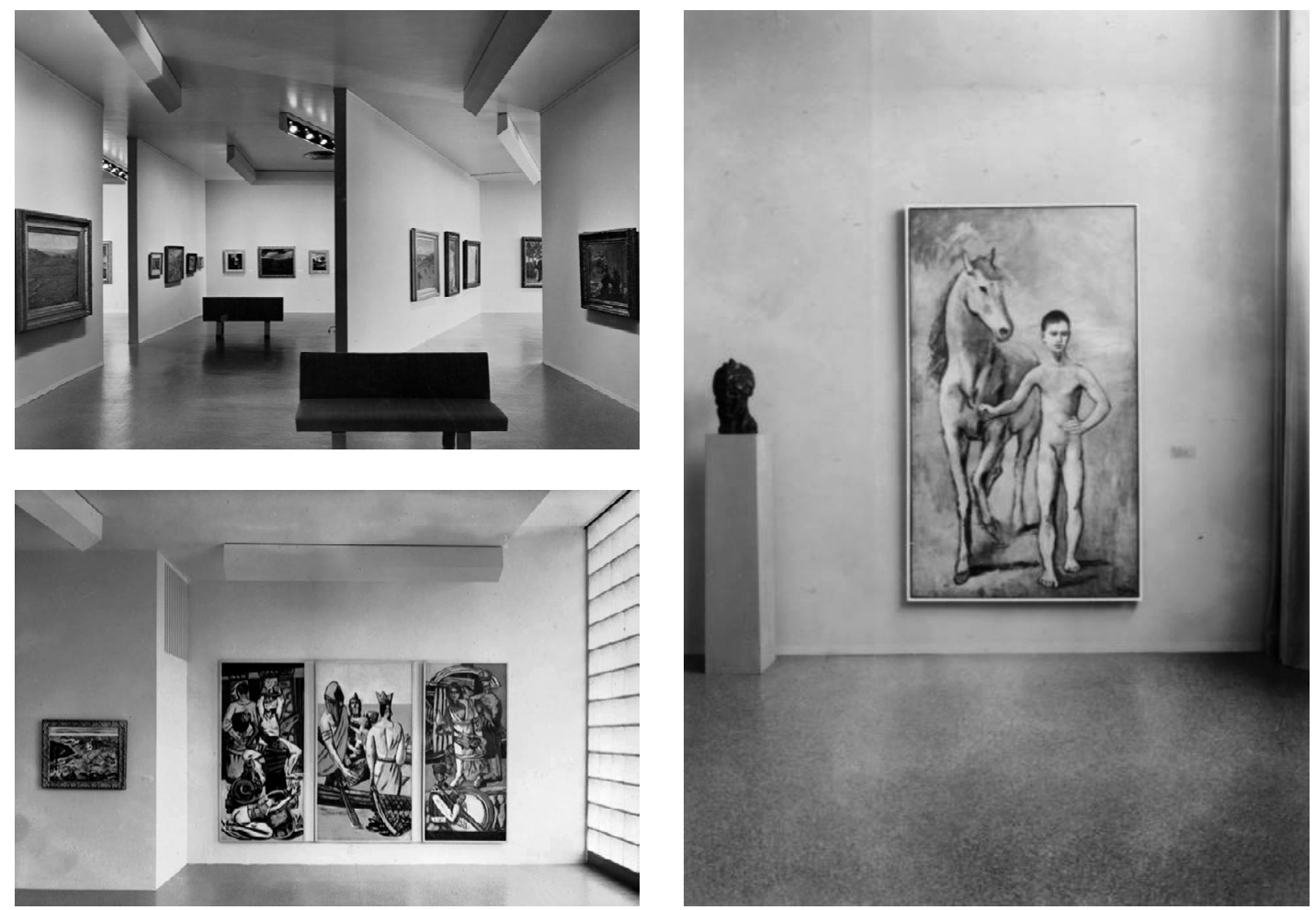

115 The Museum of Modern ART. Art in our time: color portfolio, op. cit. tons, gerando uma ambiência mais variada e menos austera. No jardim, as esculturas eram dispostas distantes umas das outras para valorizar sua percepção individual, conforme previsto no projeto paisagístico.

A estrutura multidepartamental do MомA criada por Barr visava ampliar o entendimento da arte moderna para além da pintura e da escultura, mas cada departamento era tratado de modo relativamente independente, convivendo num mesmo museu, mas não necessariamente no mesmo espaço expositivo. No catálogo de Art in Our Time, o diretor relatou sua intenção de distribuir galerias distintas para cada departamento nos andares expositivos, de modo mais ou menos permanente de acordo com a receptividade do público. ${ }^{115}$ Tal plano foi aos poucos se concretizando no museu, acompanhado pelo fortalecimento que os departamentos viveram a partir dos anos 1940, com o 

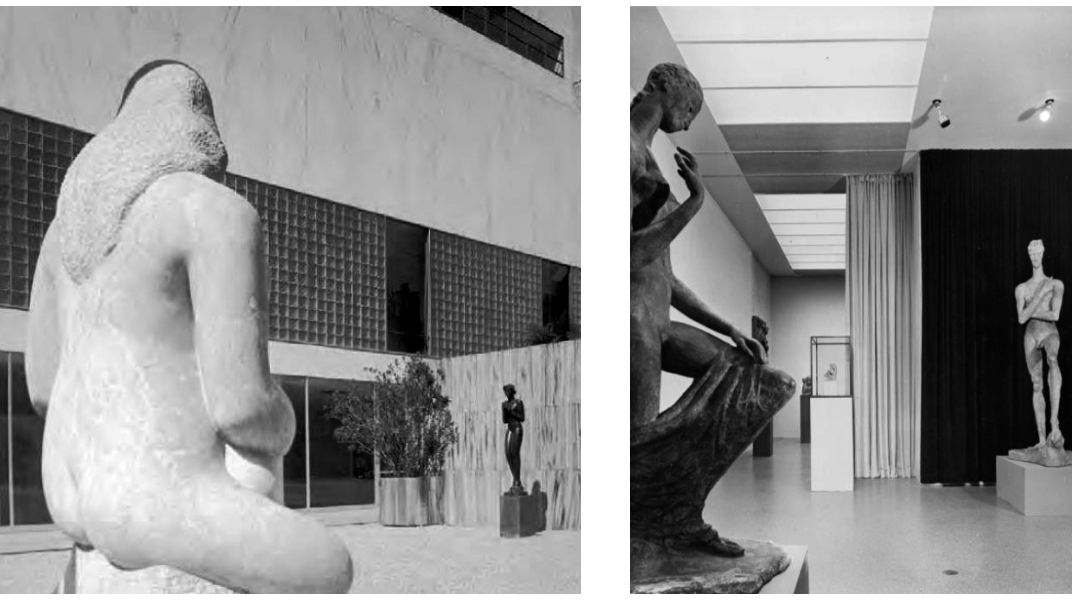

1.52 Vista da seção Painting, Sculpture, Prints da exposição Art in Our Time: 10th Anniversary Exhibition, MoMA, Nova York, 1939. Foto: Eliot Elisofon. Fonte: https:// www.moma.org/calendar/exhibitions/2743

1.53 Max Beckmann, Departure (1932 e 1933-35), na exposição Art in Our Time: 10th Anniversary Exhibition, MoMA, Nova York, 1939.Foto: Eliot Elisofon. Fonte: https://www.moma.org/calendar/ exhibitions/2743

1.54 Pablo Picasso, Boy Leading a Horse (1905-06), na exposição Art in Our Time: 10th Anniversary Exhibition, MoMA, Nova York, 1939. Foto: Soichi Sunami. Fonte: https://www.moma.org/calendar/ exhibitions/2743

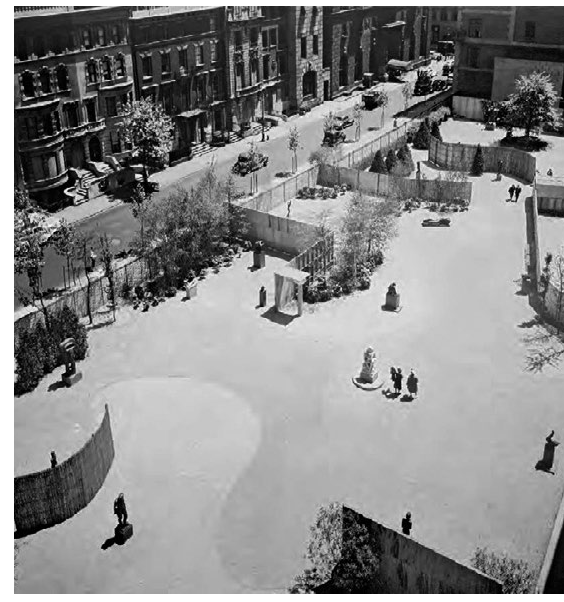

1.55 William Zorach, Mother and Child (1927-30), e Georg Kolbe, Assunta (1921) no jardim de esculturas na exposição Art in Our Time: 10th Anniversary Exhibition, MoMA, Nova York, 1939. Foto: Robert Damora. Fonte: Edward Durell Stone, The Evolution of an Architect, Horizon Press: Nova York, 1962, n.p.

1.56 Vista da seção Painting, Sculpture, Prints da exposição Art in Our Time: 10th Anniversary Exhibition, MoMA, Nova York, 1939. Foto: Robert Damora. Fonte: https://www.moma.org/calendar/ exhibitions/2743

1.57 Vista do jardim de esculturas olhando para Nordeste, Art in Our Time. Foto: Wurts Brothers. Fonte: REED, SILVER-KOHN, p. 50. 


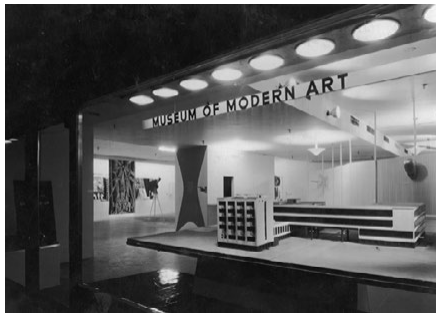

1.58 Vista da exposição Bauhaus: 1919-1928, MoMA, Nova York, 1938-39. Foto: Soichi Sunami. Fonte: https://www. moma.org/calendar/exhibitions/2735 aprofundamento de conhecimentos e fidelização de apoiadores específicos à cada área. Como veremos mais adiante, o consequente aumento da independência entre eles entraria em choque com o desdobramento da arte a partir do final da década de 1960, quando a classificação das obras por suporte passou a se tornar progressivamente problemática. A própria estrutura de funcionamento que deu força ao museu viria a se transformar num dos seus aspectos críticos na contemporaneidade.

\subsubsection{DIVERSIFICAÇÃO DE PRÁTICAS EXPOGRÁFICAS EM ÉPOCA DE POLITIZAÇÃO}

O modelo expositivo dominante nas mostras realizadas pelo departamento de Pintura e Escultura do MoMA não foi o único praticado no museu, tendo convivido durante os chamados "anos de laboratório" com uma série de experimentações com expografia, sobretudo nos departamentos de fotografia, arquitetura e design e peças etnográficas. Uma importante contribuição veio do austríaco Herbert Bayer (1900-1985), que, tendo sido aluno e professor da Bauhaus, emigrou para os EUA a convite de Barr para aplicar suas teorias expográficas na exposição Bauhaus: 1919-28. Realizada em 1938 nas instalações provisórias do мома no Rockefeller Center, no período em que o novo edifício estava em obras, a mostra foi uma grande retrospectiva do período em que a escola estivera sob a direção de Walter Gropius, que foi responsável pela curadoria.

A amplitude do escopo e a escala da exposição, que contou com 700 itens relacionados à produção de arquitetura e design das oficinas como tipografia, mobiliário, cenografia, fotografia e têxteis, além de pinturas e esculturas, são indicativas da importância da Bauhaus como referência central para o desenvolvimento do мома e de sua estrutura multidepartamental, que integrava as chamadas "belas artes" às artes aplicadas. Tratava-se da exposição mais custosa realizada pelo museu até o momento e envolvia riscos políticos, por expor obras de artistas perseguidos pelo regime nazista, que fechara a escola em 1933. Muitos objetos não puderam ser levados até os EUA, sendo representados na mostra apenas por fotografias. 


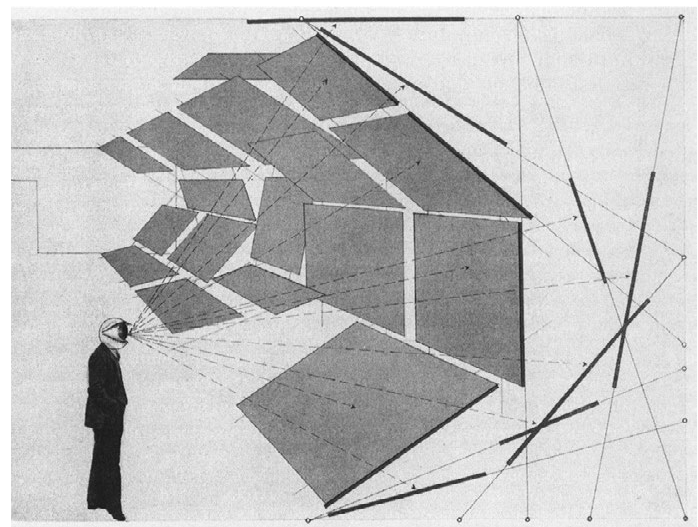

O projeto expográfico desenvolvido por Bayer empregava recursos ousados e variados, inspirados em sua teoria do "campo de visão ampliado" ${ }^{116} \mathrm{O}$ espaço do edifício, cuja arquitetura ficou oculta pela cenografia, foi subdividido num percurso contínuo, demarcado por manchas sinuosas e marcas de pegadas no piso indicando o percurso de visitação. Uma maquete do edifício da Bauhaus em Dessau foi posicionada na primeira sala, onde uma divisória curvilínea de papel corrugado sobre uma leve estrutura metálica delimitava os fluxos de entrada e saída e apoiava alguns objetos escultóricos. Diversos painéis fotográficos foram fixados em paredes, mas alguns estavam inclinados ou em posição perpendicular, ou ainda suspensos no teto, assim como bancadas de formato orgânico para apoio de objetos. As cores predominantes dos fundos eram creme, preto, branco e cinza, mas cores primárias como o vermelho e o azul marcavam presença em painéis e legendas de parede, na cor vermelha. Elementos gráficos como a impressão de um dedo apontado em escala ampliada chamavam a atenção para pontos de interesse, como o visor pelo qual o espectador via um robô rodopiante vestido com uma peça de figurino desenhada por Oskar Schlemmer. ${ }^{117}$

Todos esses elementos geravam uma impressão de modernidade distinta da austeridade das mostras de arte do момА, criando, segundo Staniszewski, "uma linguagem formal dinâmica que encenava um diálogo com o espectador, assumindo

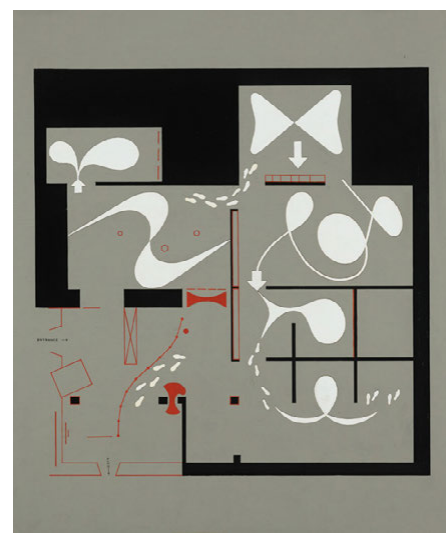

1.59 Herbert Bayer, ilustração da teoria do Campo de Visão Ampliado (1930). Fonte: BAYER, p. 277.

1.60 Herbert Bayer, planta da exposição Bauhaus 1919-1928 (1938).

Fonte: https://www.moma.org/collection/ works/287
116 Aplicado na sessão de Arquitetura e mobiliário da Deutsher Werkbund da Exposition de la Societé des Artistes Décorateurs realizada em Paris, 1930. Cf. BAYER, Herbert. Aspects of Design of Exhibitions and Museums. Curator: The Museum Journal, v. 4, p. 257-288, 1961.

117 Cf. STANISZEWSKI, op. cit., p. 144 . 

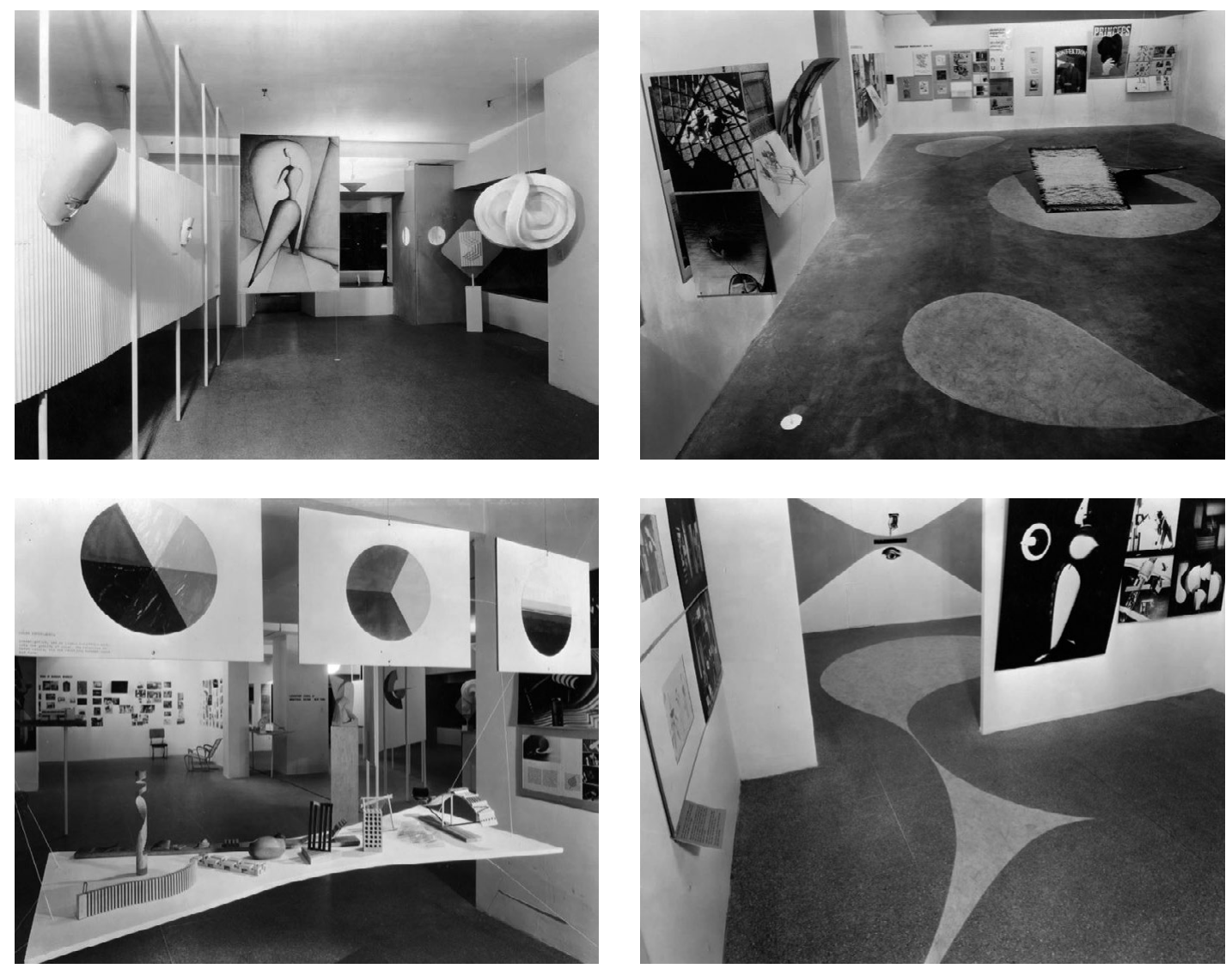

1.61 a 1.64 Vista da exposição Bauhaus 1919-1928, projeto expográfico de Herbert Bayer, MoMA, Nova York, 1939. Foto: Soichi Sunami. Fonte: https://www. moma.org/calendar/exhibitions/2735

118 Ibidem, p. 145 .

119 Ibidem, p. 145. Tradução nossa. a presença do visitante na exposição." ${ }^{118}$ No entanto, a mostra não agradou ao público e poucas das críticas publicadas na imprensa valorizaram as qualidades da montagem, que em geral foi considerada caótica, confusa, desarticulada e sem sentido. Como apontou a autora,

A arte, o design e a arquitetura da Bauhaus eram respeitados por muitos dos críticos que detestaram a exposição, mas o modo como os elementos foram arranjados - a linguagem formal da montagem - era indecifrável e de certo modo além da habilidade de assimilação do público americano. ${ }^{119}$ 
Na opinião de Staniszewski, ainda que a montagem tenha tido recepção predominantemente desfavorável, não passou despercebida ou ficou restrita ao campo especializado, mas chamou a atenção tanto da crítica quanto do público, convocado a interagir com os variados suportes. A mesma atenção havia sido dada à montagem de Machine Art, que, no entanto, havia tido uma recepção extremamente favorável. A autora elenca algumas razões para as diferentes reações às exposições, além das qualidades espaciais específicas a cada uma delas. A exposição da Bauhaus, uma instituição alemã, foi realizada numa época em que, às vésperas da II Grande Guerra, crescia o sentimento antigermânico, enquanto os itens expostos em Machine Art eram produtos da indústria americana, muitos deles disponíveis para os consumidores, com os preços de venda indicados no catálogo da mostra. Além disso, a exposição da Bauhaus tinha um caráter mais documental e didático, mostrando boa parte da produção da escola apenas por meio de fotografias, o que exigia mais do espectador do que a apreciação direta dos objetos de Machine Art, selecionados e organizados ao modo "elegante" de Johnson, segundo um critério mais facilmente assimilável de "beleza", ainda que inusitadamente aplicado a peças utilitárias.

As dificuldades na recepção enfrentadas pela exposição da Bauhaus não impediram que Bayer realizasse projetos para outras exposições do museu, organizadas pelo departamento de fotografia e com curadoria do fotógrafo e curador luxemburguês radicado nos EUA Edward Steichen (1878-1973), ${ }^{120}$ como Road to Victory, em 1942, e Airways to Peace, em 1943, ambas voltadas à temática da II Guerra Mundial. O início dos conflitos acontecera poucos meses depois da inauguração da nova sede e impactaram profundamente a atuação do MOMA, que chegou a criar uma programação especial direcionada aos soldados que voltavam feridos do combate ou que aguardavam na cidade para serem enviados ao front, além de organizar uma série de exposições temáticas ligadas à guerra. ${ }^{121}$

A exposição Road to Victory evidencia o envolvimento do MOMA com a política governamental dos EUA e com os esforços propagandísticos da guerra, e exemplifica o modo como as curadorias realizadas por Steichen faziam uso de fotogra-
120 O departamento de fotografia havia sido criado em 1940 sob a direção de Beaumont Newhall, que se afastou do museu entre 1942 e 1945 para servir à guerra, deixando suas atividades sob responsabilidade de sua esposa, Nancy Newhall. Edward Steichen, fotógrafo e tenente comandante da força naval dos EUA, foi nomeado pela Marinha para organizar Road to Victory e realizou diversas outras exposições do departamento nesse período, assumindo oficialmente o cargo de diretor em 1947. Cf. LORENTE, op. cit., p. 179; The Museum of Modern ART. Beaumont Newhall Papers. MOмA. Disponível em: $<$ https://www. moma.org/research-and-learning/ archives/finding-aids/Newhallf>. Acesso em: 5 jun. 2021.

121 Segundo Lorente, todos os museus se envolveram em esforços para "levantar o moral" dos cidadãos durante a guerra. Cf. LORENTE, op. cit., p.177. 

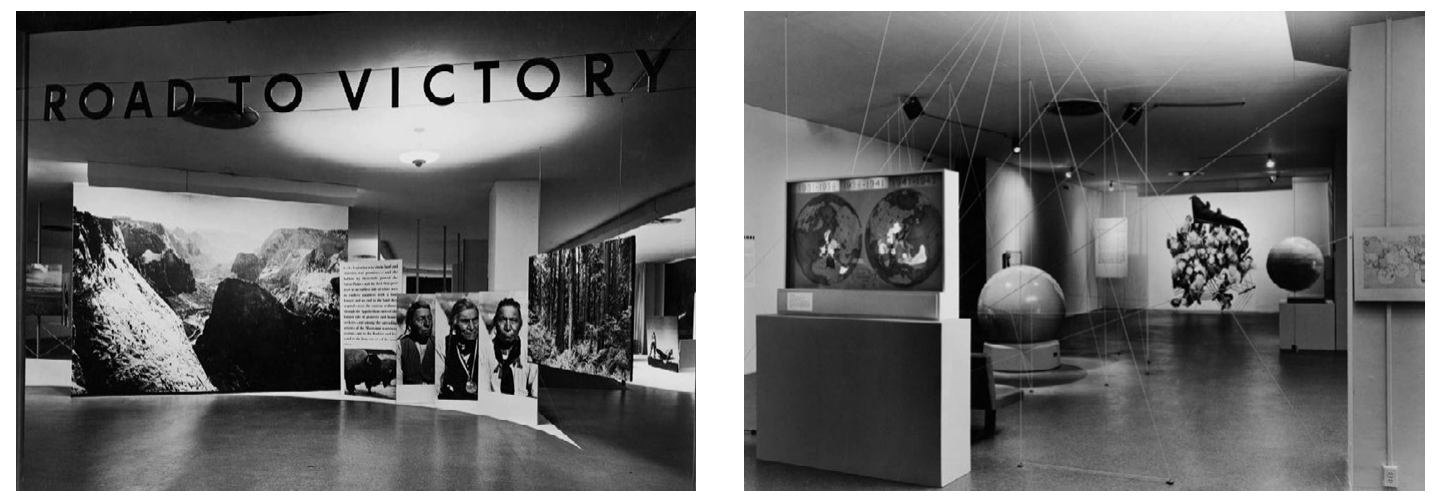

1.65 Vista da exposição Road to Victory, projeto expográfico de Herbert Bayer, MoMA, Nova York, 1942. Foto: Albert Fenn. Fonte: https://www.moma.org/calendar/ exhibitions/3038?\#installation-images

1.66 Vista da exposição Airways to Peace, projeto expográfico de Herbert Bayer, MoMA, Nova York, 1943. Foto: Samuel Gottscho. Fonte: https://www.moma.org/ calendar/exhibitions/3138
122 Principalmente do Farm Security Administration, do Army Signal Corps e do Navy Bureau of Aeronautics. Cf. The Museum of MODERN ART. Road to victory, a procession of photographs of the nation at war directed by Lt. Comdr. Edward Steichen, U.S.N.R.. Nova York: The Museum of Modern Art, 1942. fias de diversos autores em função de uma narrativa bem estruturada, articulada com o projeto expográfico. Tanto ele quanto Bayer tinham experiência na área publicitária e aplicaram fartamente essa linguagem na mostra, construindo um discurso destinado a convencer as massas da inevitabilidade da participação dos EUA nos confrontos. Os recursos persuasivos, explorando efeitos dramáticos baseados em ampliações fotográficas em diferentes formatos associadas a elementos gráficos, eram similares aos empregados em exposições como Pressa, realizada em 1928 por El Lissitzky para o pavilhão soviético na Exposição Internacional da Imprensa (Pressa), na cidade alemã de Colônia, ou na Exposição do Sindicato dos Trabalhadores da Construção (Exhibition of the Building Workers Unions), realizada em 1931 em Berlim, com curadoria de Walter Gropius e projeto expográfico do artista e designer húngaro László Moholy-Nagy (1895-1946) e do próprio Bayer. Essa linguagem mostrava-se adaptável a diferentes tipos de mensagem e era dirigida a um público mais amplo e popular, em contraste com a ambiência discreta das mostras montadas por Barr, que atraíam o grupo mais restrito de visitantes interessados em arte moderna.

As 150 imagens utilizadas em Road to Victory vinham das mesmas fontes utilizadas pelas foto-narrativas popularizadas pela imprensa, na grande maioria agências governamentais, ${ }^{122}$ ampliadas em grandes dimensões e acompanhadas por legendas sem compromisso com a realidade dos fatos, nem 


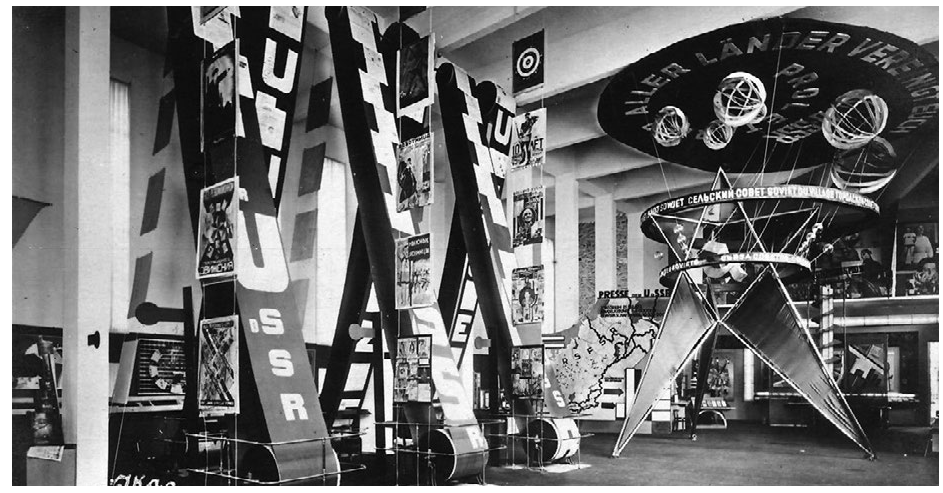

indicação de créditos para os autores. Na descrição do autor dos textos da exposição e do catálogo, o poeta e escritor Carl Sandburg (1878-1967):

A força da exposição reside acima de tudo na sequência das fotos. Cada sala é um capítulo, cada fotografia uma sentença. Segue com magnífica simplicidade e uma certa eloquência visual desde a paisagem do continente primitivo, passando pelos hábitos tradicionais dos habitantes e pelos extraordinários mecanismos de paz e guerra, até a cavalgada de homens voando, navegando, dirigindo e marchando em defesa do continente. ${ }^{123}$

A observação da maquete do projeto e das fotografias da montagem permitem compreender como Bayer deu forma a esse discurso, chamado pelos organizadores de "procissão". ${ }^{124} \mathrm{O}$ arquiteto tratou o segundo pavimento do museu como um espaço genérico, sem ressaltar especificamente suas qualidades arquitetônicas, eliminando boa parte das divisórias móveis instaladas previamente e mantendo os painéis que ocultavam a fachada frontal translúcida. ${ }^{125}$ Algumas das subdivisões do espaço foram feitas com os próprios painéis fotográficos de grandes dimensões, suspensos por cabos, apoiados diretamente no piso ou em estruturas leves, orientados em ângulos conforme seu esquema de "campo de visão". A rota de visitação, configurando um vai e vem com retas e curvas pelo salão,

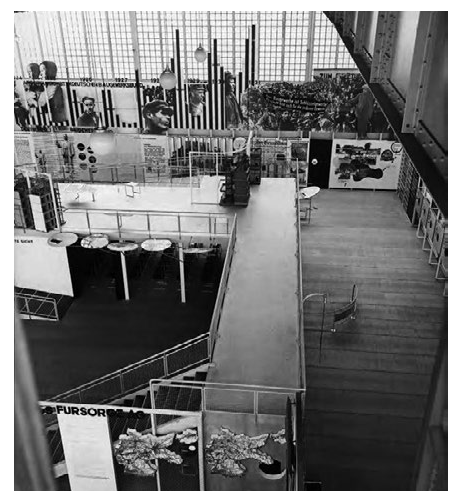

1.67 Vista da exposição Pressa no pavilhão soviético, projeto expográfico de El Lissitzky, Colônia, 1928. Fonte: STANISZEWSKI, p. 49.

1.68 Vista da Exposição do Sindicato dos Trabalhadores da Construção, projeto expográfico de Herbert Bayer, Walter Gropius e László Moholy-Nagy, Berlim, 1931. Foto: Walter Christeller. Fonte: ROCCO, p.26
123 Ibidem, p. 19-20.

124 The Museum of Modern ART. Road to Victory (May 21-Oct 4, 1942). момA. Disponível em: <https:// www.moma.org/calendar/exhibitions/3038?>. Acesso em: 26 fev. 2020.

125 A maquete e as fotos não mostram o tratamento dado à fachada voltada ao jardim, composta de planos lisos e tijolos de vidro, onde não há fotos fixadas. 


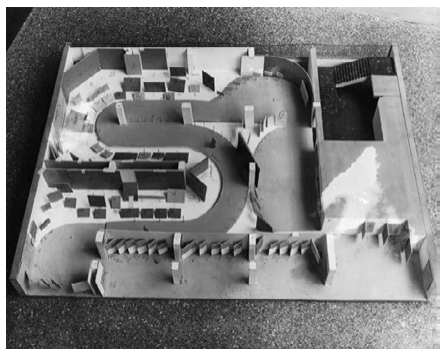

1.69 Maquete da exposição Road to Victory, projeto expográfico de Herbert Bayer, MoMA, Nova York, 1942. Fonte: https://www.moma.org/calendar/ exhibitions/3038?\#installation-images

1.70 e 1.71 Vista da exposição Road to Victory, projeto expográfico de Herbert Bayer, MoMA, Nova York, 1942. Foto: Samuel Gottscho. Fonte: https://www.moma.org/calendar/ exhibitions/3038?\#installation-images
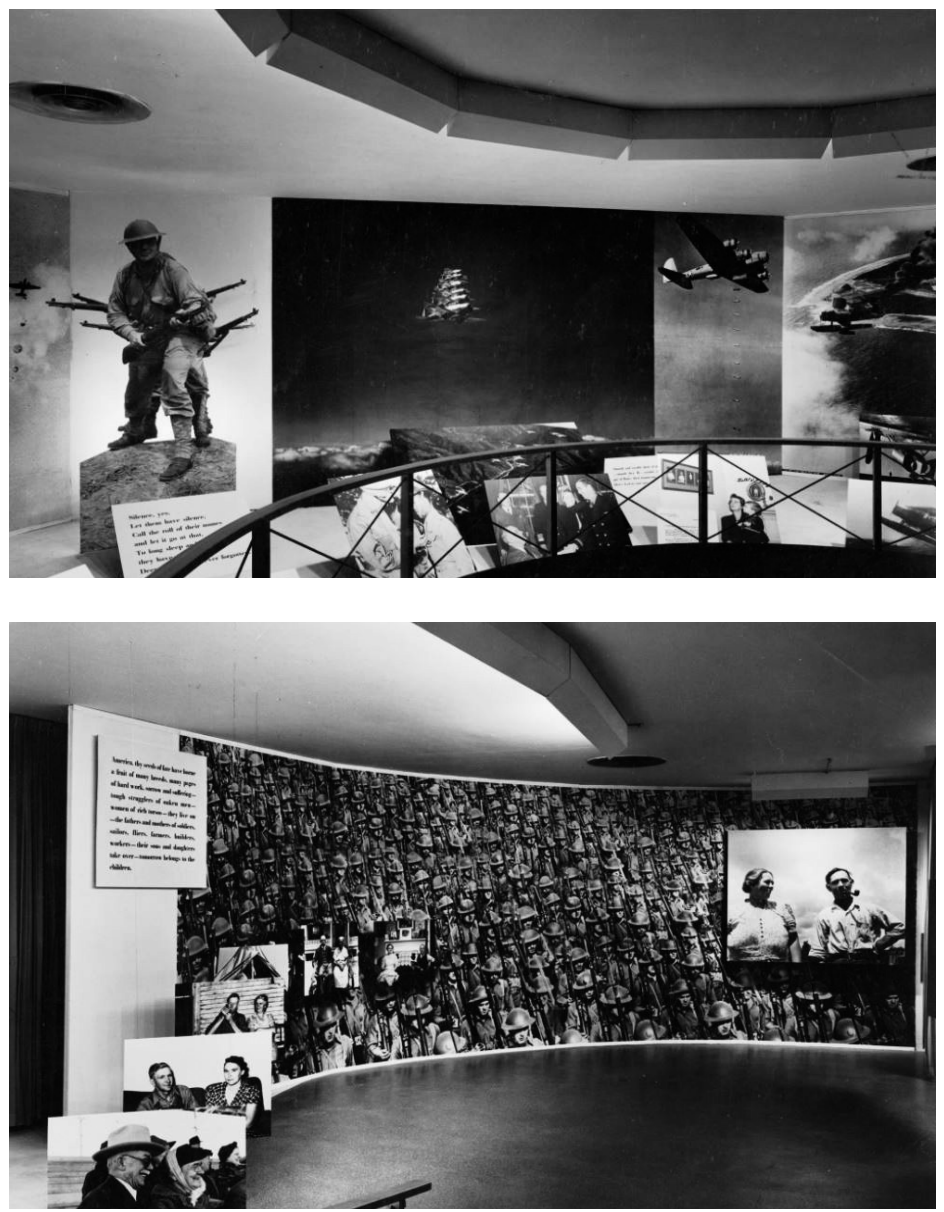

foi demarcada no piso por uma diferença de cor e trechos em nível elevado, criando um percurso bem mais controlado que na exposição da Bauhaus.

Segundo Staniszewski, Bayer considerava a expografia como "um ápice de todas as mídias e poderes de comunicação", não devendo ser considerada uma atividade autônoma, mas a ser desenvolvida em estreita sintonia com o conteúdo a ser transmitido. ${ }^{126}$ Em Road to Victory, a mensagem estava inscrita na própria rota de visitação: o caminho para a vitória. As dimensões das fotos e sua posição em relação às demais e à posição 
do visitante eram definidas em função do impacto psicológico pretendido - as imagens de paisagens eram ampliadas em grandes formatos, enquanto as de comunidades eram expostas em escala mais humana. ${ }^{127}$

A autora observou que, no contexto em que a população era dominada pela ansiedade diante das incertas consequências da guerra para o país, para os cidadãos enviados para os confrontos e suas famílias, a exposição passava uma mensagem apaziguadora, de legitimação da adesão e confiança na vitória, o que contribuiu para o grande sucesso que obteve junto ao público e à imprensa. Assumido abertamente pelo museu, o caráter persuasivo da mostra, amplamente apoiado em recursos publicitários, foi, no entanto, considerado excessivamente manipulador por historiadores e críticos. Staniszewski usou a exposição como exemplo do que o filósofo francês Roland Barthes (1915-1980) definiria mais tarde como a noção de "mito": o que purifica um fato e lhe dá justificativa. ${ }^{128}$ De fato, imagens mostrando os horrores da guerra eram censuradas na imprensa e em salas de cinema dos EUA até pouco antes do término dos combates, o que confirma que o caráter dirigido da exposição se vinculava a um posicionamento político vinculado a objetivos muito específicos e que o sucesso da transmissão da mensagem dependia da ocultação de verdades desagradáveis para o público.

Usando outros tipos de recurso expográfico, a exposição Indian Art of the United States, de $1941,{ }^{129}$ também exemplifica o envolvimento do museu com as políticas nacionais, mas a partir de uma visão curatorial e de recursos expográficos de natureza bem distinta, liderados por uma figura que viria se tornar anos depois o sucessor de Barr da direção do MOMA: René D'Harnoncourt (1901-1968). Como relatou a historiadora da arte e chefe dos arquivos do момА, Michelle Elligot, D'Harnoncourt pertencia a uma família de nobres franceses residentes na Áustria, que se viu destituída de posses com a dissolução do império Austro-húngaro em 1924. ${ }^{130} \mathrm{Em}$ busca de refazer a vida, tinha a intenção de emigrar para os EUA, mas, não tendo obtido permissão para entrar no país, mudou-se para o México em 1925. Apesar de sua formação como químico, foi sua familiaridade com as artes - como comerciante de artefatos e
127 Ibidem.

128 O raciocínio de Barthes refere-se especificamente à exposição Family of Man, que também foi organizada por Steichen, tendo itinerado por muitos países em outros formatos depois na inauguração no MOMA em 1955. STANISZEWSKI, op. cit., pp 222.

129 Cf. The Museum of Modern ART. Indian Art of the United States (Jan 22-Apr 27, 1941). MOMA. Disponível em: <https:// www.moma.org/calendar/exhibitions $/ 2998$ ? locale $=\mathrm{pt}>$. Acesso em: 5 abr. 2020.

130 Elligot, Michelle. René D'Harnoncourt and the Art of Installation. Nova York: The Museum of Modern Art, 2018. 


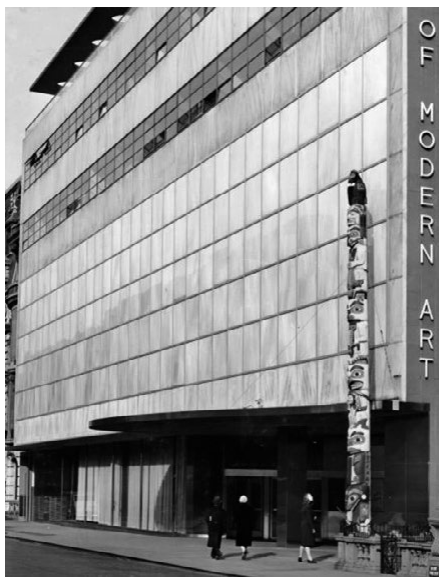

1.72 Totem de nove metros de altura criado por John e Fred Wallace (entalhadores Haida) para a exposição Indian Art of the United States, posicionado na entrada do museu, MoMA, Nova York, 1941. Foto: Albert Fenn. Fonte: https://www.moma. org/calendar/exhibitions/2998

1.73 Vista da exposição Mexican Art, The Metropolitan Museum of Art, Nova York, 1930. Fonte: STANISZEWSKI, p. 86

1.74 Vista da exposição African Negro Art, MoMA, Nova York, 1935. Foto: Soichi Sunami. Fonte: https://www.moma.org/ calendar/exhibitions/2937?locale=pt

131 A exposição itinerou por 14 cidades dos EuA. Cf. ibidem, p. 26.

132 O New Deal foi um programa de reforma e recuperação da economia implementado nos EUA entre 1933 e 1937, sob o governo do presidente estadunidense Franklin Delano Roosevelt (1882-1945).

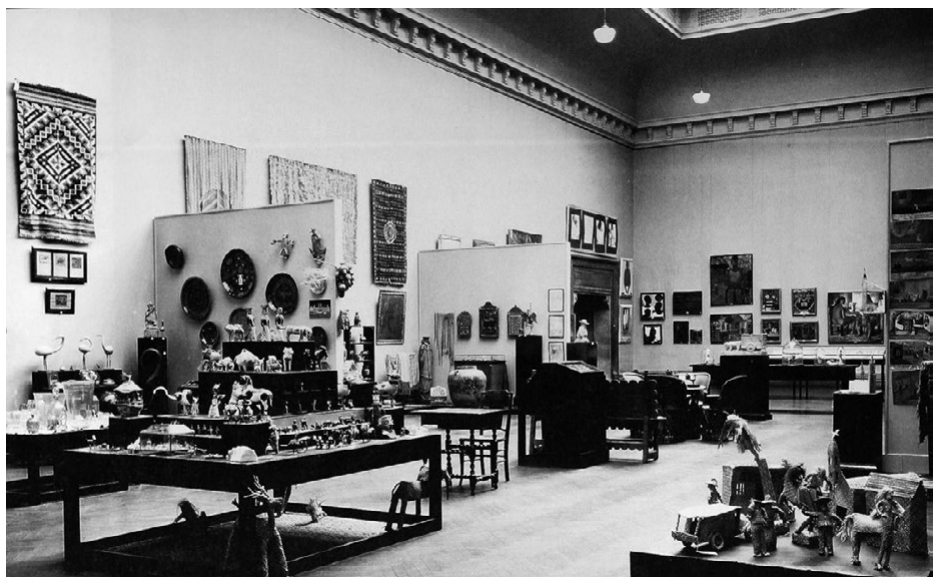

artista amador - que conduziu seu percurso profissional, aproximando-o tanto de artistas da vanguarda mexicana, quanto da cultura indígena do país, na qual tornou-se especialista. Em 1930, realizou no Metropolitan Museum of Art sua primeira grande exposição, Mexican Arts, cuja grande receptividade lhe abriu as portas para, em 1933, obter o visto de permanência nos EUA. ${ }^{131}$ Em 1936, foi convidado para integrar o Indian Arts and Crafts Board (IACB), criado sob o programa do New Deal, ${ }^{132}$ com o objetivo de promover o bem-estar econômico da população indígena dos EUA. Para estimular a comercialização de seus produtos, о IACB delegou a D' Harnoncourt e ao curador Frederick H. Douglas a organização da exposição Indian Art of the United States and Alaska, montada em 1939 na Golden Gate International Exposition em São Francisco, com a assistência do arquiteto Henry Klumb, experiente em projetos de exposições e de interiores. Também recebida com sucesso, a exposição chamou a atenção do MoмA, que decidiu repetir e ampliar o tema da exposição em sua sede, convidando a mesma equipe para organizar dois anos depois a mostra Indian Art of the United States.

Ocupando os três andares do museu - totalmente reformulados para a montagem -, a exposição reuniu aproximadamente 1000 itens, abrangendo desde objetos pré-históricos de 15 mil anos até artefatos recentes realizados pelas populações 


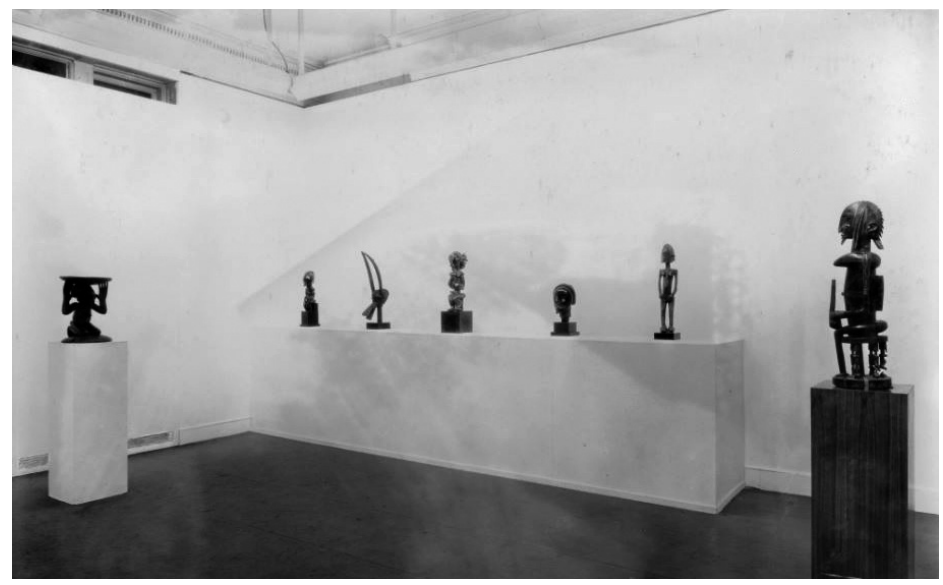

indígenas. Não foi a primeira vez que era organizada no MOMA uma exposição de caráter etnográfico, sendo a primeira delas African Negro Art, realizada em 1935 com curadoria do crítico da arte James Johnson Sweeney (1900-1986). ${ }^{133}$ No entanto, a montagem dessa última não se preocupava em informar o contexto cultural dos artefatos, apresentando-os da mesma forma que as obras modernas, valorizando apenas suas qualidades estéticas, ${ }^{134} \mathrm{em}$ consonância com o que afirmava o curador: "A arte da África negra é uma arte de escultor. Como tradição escultórica do século passado, não teve rival. É como escultura que devemos abordá-la." ${ }^{135}$

A partir do profundo envolvimento que D'Harnoncourt desenvolvera com a cultura indígena da América do Norte, sua atitude como curador contrastava com a de Sweeney. Ele acreditava que, tirando o objeto de seu contexto original e expondo-o no museu, era necessário transmitir a atmosfera cultural de seus meios de criação, com as quais se articulariam suas qualidades estéticas. Nas exposições que vinha organizando, procurava enfatizar o papel dos artefatos como evidências de uma cultura material, evocando, como apontou Elligot, "o contexto, a geografia, a história e a função de cada obra, entendendo os objetos em profundidade - e ao mesmo tempo garantindo a exposição de suas altas qualidades estéticas." ${ }^{136} \mathrm{O}$ próprio D'Harnoncourt esclarece sua abordagem:
133 The Museum of Modern Art. African Negro Art (Mar 18-May 19, 1935). момA. Disponível em: <https://www.moma.org/calendar/exhibitions/2937?locale=pt $>$. Acesso em: 5 abr. 2020.

134 Conforme Staniszewsky, nos 1940 e 50, os museus nos EUA e na Europa foram dominados por uma visão humanista universalista, contrária ao racismo e à teoria evolucionista na qual a cultura ocidental seria "superior". Daí a convivência num mesmo modo de expor dos artefatos não ocidentais ao lado dos objetos da arte moderna. STANISZEWSKI, op. cit. p. 98-99.

135 James Johnson Sweeney. The Art of Negro Africa. In: THE Museum of Modern ART. African Negro Art. Nova York: The Museum of Modern Art, 1935, p. 21. Tradução nossa.

136 Elligot, op. cit., p. 37. 


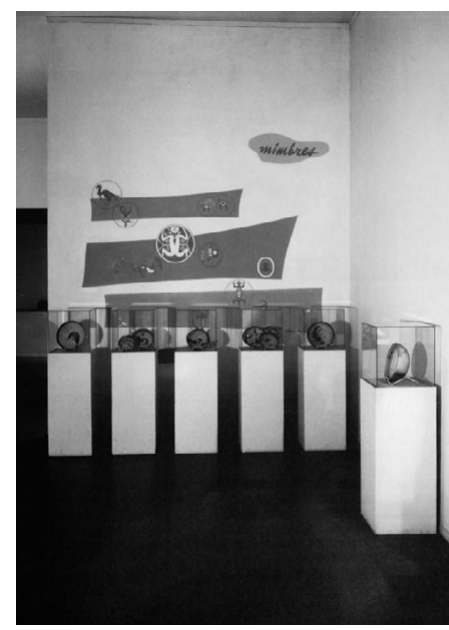

1.75 Vista da seção Mimbers Pottery na exposição Indian Arts of the United States, projeto expográfico de René d'Harnoncourt em colaboração com Henry Klumb, MoMA, Nova York, 1941. Fonte: https://www. moma.org/calendar/exhibitions/2998

1.76 Ponchos e cobertores Navajos na exposição Indian Arts of the United States, projeto expográfico de René d'Harnoncourt em colaboração Henry Klumb, MoMA, Nova York, 1941. Foto: Soichi Sunami. Fonte: https://www.moma.org/calendar/ exhibitions/2998

137 Apud ibidem, p. 30.

138 STANISZEWSKI, op. cit., p. 87.

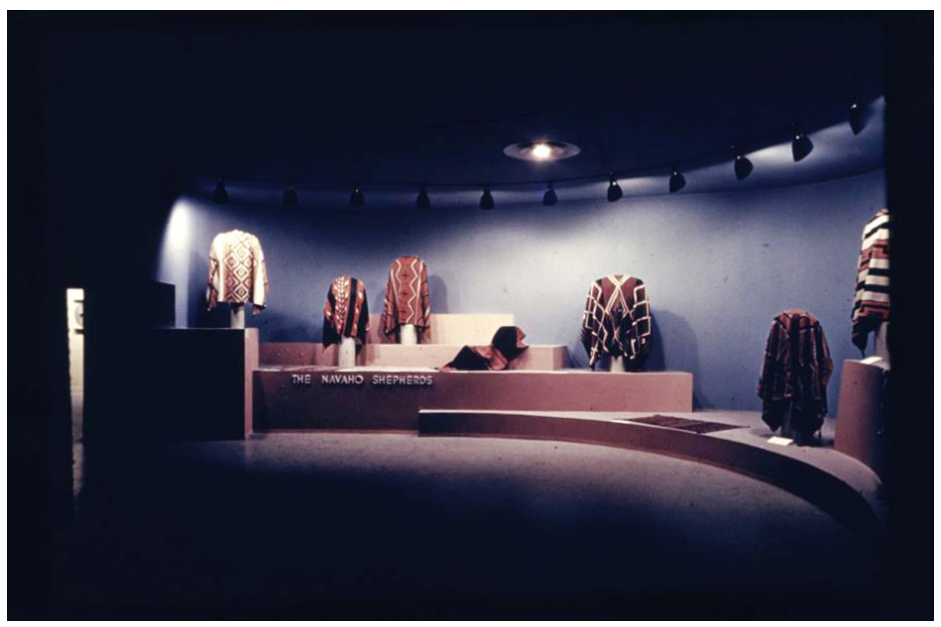

Em teoria, seria possível alcançar uma apreciação estética razoável de qualquer tipo de arte sem se preocupar muito com o seu contexto cultural. Uma boa organização de linhas, espaços, formas, tons e cores deve ser auto evidente onde quer que a encontremos. No entanto, sabemos que uma maior familiaridade com o contexto de um objeto não apenas satisfaz a curiosidade intelectual, mas de fato eleva a apreciação de seus valores estéticos. ${ }^{137}$

Ao conceber seus projetos expográficos, D'Harnoncourt iniciava desenhando meticulosamente cada peça selecionada, prosseguia com a organização dos conjuntos e estudava, por fim, as vistas das galerias, criando destaques visuais segundo o fluxo previsto de visitação, configurado como uma experiência de ordem teatral. Engajado em apresentar as complexidades de artefatos não ocidentais num museu de arte, o curador empregou técnicas expositivas diversificadas em Indian Art of the United States. Na opinião de Staniszewski, apesar de concebida como propaganda do New Deal, a mostra "continua de longe sendo a mais bem sucedida apresentação da cultura nativa norte americana e de artefatos etnográficos expostos no Museu de Ate Moderna; foi também uma das mais criativas montagens já apresentadas no MoмA." ${ }^{338}$ 

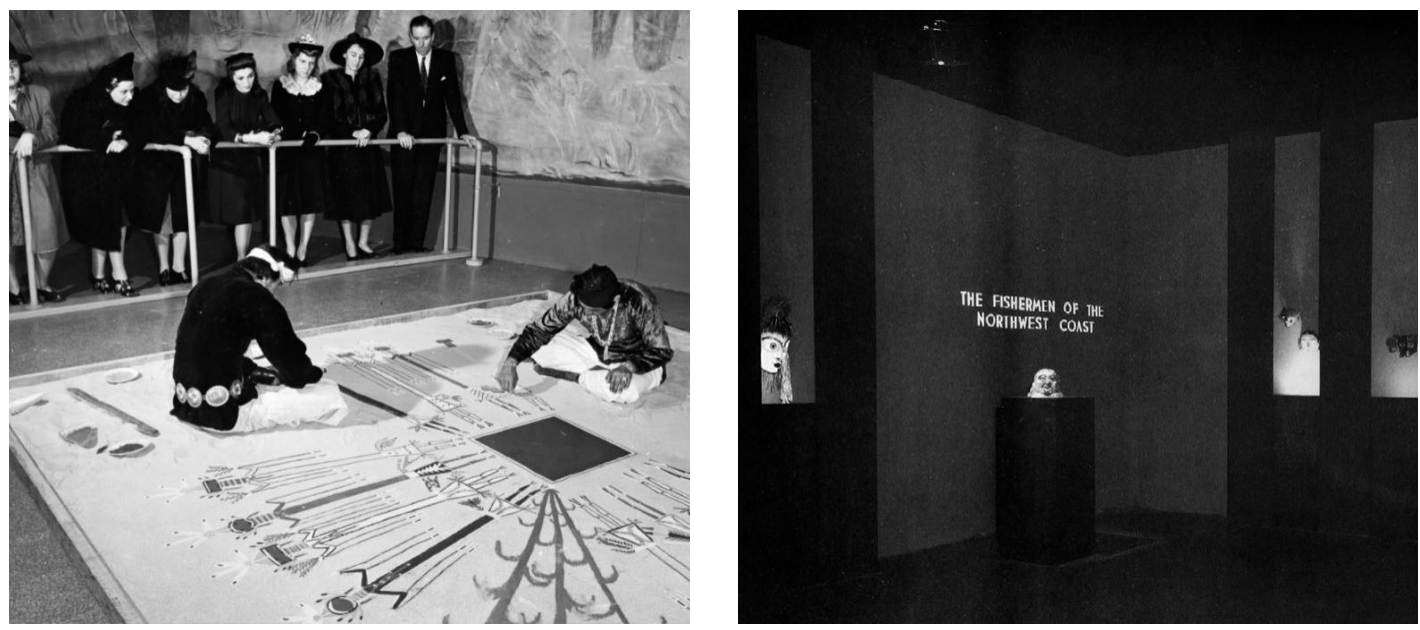

Como descreve a autora, no setor denominado Prehistoric $A r t$, que reunia itens sobre os quais não se tinha muita informação sobre o contexto específico de produção, os artefatos foram em geral expostos como objetos de arte moderna, mas com acentos visuais, como desenhos em paredes. Onde havia informação, foram realizadas elaboradas recriações abstratas dos contextos, solução empregada também na sessão Living Traditions, que dedicava uma galeria para cada grupo de povos, reunidos por critérios de afinidade. No pavimento térreo, a ambientação da sessão Indian Art for Modern Living apoiava-se num sofisticado repertório comercial, evidenciando a intenção da mostra em potencializar o valor comercial dos produtos dos povos indígenas. A mostra era pontuada ainda por áreas dedicadas à realização de práticas e rituais, adaptadas quando necessário para não ferir os princípios religiosos de origem. Apesar de a maioria das salas serem tratadas como ambientes cenográficos sem relação com o edifício, em alguns pontos a montagem se articulou com elementos da arquitetura, como as fachadas envidraçadas para o jardim, que funcionavam como fundo para certas obras.

O sucesso que D'Harnoncourt obteve com mais essa exposição aproximou-o de Nelson Rockefeller, fator determinante para que o curador firmasse vínculos cada vez maiores com o
1.77 Indígenas Navajos pintando com areia na exposição Indian Arts of the United States, MoMA, Nova York, 1941. Fonte: https://www.moma.org/calendar/ exhibitions/2998

1.78 Vista da seção Northwest Coast na exposição Indian Arts of the United States, projeto expográfico de René d'Harnoncourt em colaboração com Henry Klumb, MoMA, Nova York, 1941. Fonte: https://www. moma.org/calendar/exhibitions/2998 

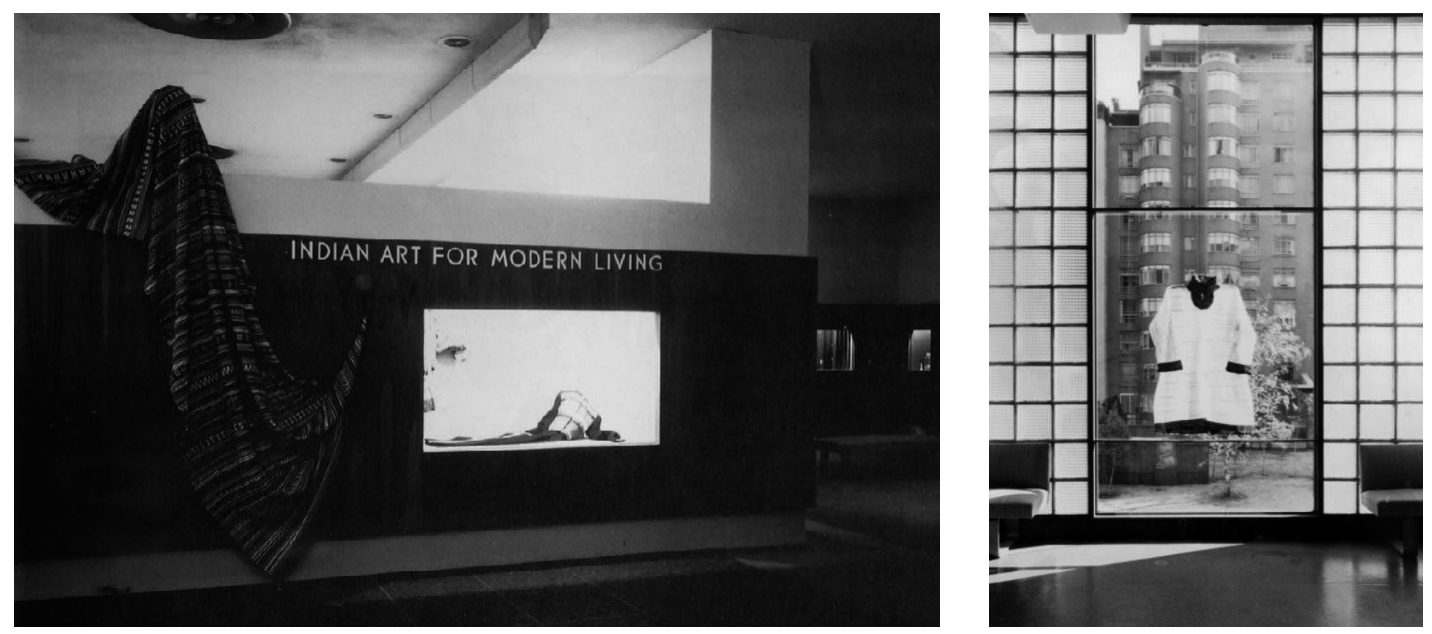

1.79 Vista da seção Indian Art for Modern Living na exposição Indian Arts of the United States, projeto expográfico de René d'Harnoncourt em colaboração Henry Klumb, MoMA, Nova York, 1941. Fonte: https://www.moma.org/calendar/ exhibitions/2998

1.80 Vista da exposição Indian Arts of the United States, projeto expográfico de René d'Harnoncourt em colaboração com Henry Klumb, MoMA, Nova York, 1941. Fonte: https://www.moma.org/calendar/ exhibitions/2998
139 A chamada "política de boa vizinhança” iniciou-se com o New Deal em 1933 e envolveu não apenas a exportação de exposições, como a de diversos museus de arte moderna, inclusive no Brasil. Cf. ToтA, Antonio Pedro. O imperialismo sedutor: a americanização do Brasil na época da segunda guerra. São Paulo: Companhia das Letras, 2000.
MOMA. Rockefeller continuava influente no museu apesar de ter deixado seu assento no conselho em 1941 para gerenciar o Office of the Coordinator of Inter-American Affairs (OCIAA), uma agência responsável por ampliar a liderança dos EUA nas Américas por meio da articulação de políticas econômicas e culturais. Rockefeller foi o responsável por estabelecer contratos do museu com a agência em prol da chamada "Política da Boa Vizinhança”, voltada para ações nos países da América Latina, especialmente México, Brasil e Argentina, que ocupavam posições estratégicas nos anos de conflito, pois interessava aos EUA assegurar que estivessem alinhados do mesmo lado do conflito. ${ }^{139}$ É nessa época que se intensifica no MOMA a prática de colecionar e expor obras de artistas desses países, e também de apoiar a criação de novos museus de arte moderna que pudessem sustentar a parceria cultural em suas próprias regiões. Acumulando boas experiências com exposições de arte indígena da América do Norte, especialmente a mexicana, D'Harnoncourt foi nomeado por Rockefeller em 1943 como diretor da sessão de arte do OCIAA e contratado pelo MOMA no ano seguinte para dirigir um novo departamento, denominado Manual Industry.

Ainda que os métodos expositivos de D'Harnoncourt procurassem respeitar e valorizar os conteúdos expostos, dife- 
renciando-se do tom ostensivamente persuasivo das mostras de Steichen e Bayer, sua atuação também se vinculava a determinados interesses políticos, que impactaram até mesmo as mostras de arte moderna do MомA, como veremos a seguir.

\subsubsection{NACIONALISMO À AMERICANA}

Embora os EUA tenham sustentado um regime democrático nos anos de conflito, o país não ficou imune ao crescimento de tendências nacionalistas, que na Europa vinham alimentando regimes autoritários desde o início da década de 1930. A questão atingia o MомA em cheio, pois, apesar de o museu ter assumido uma postura abertamente patriótica em boa parte de sua programação durante a II Guerra, suas ações haviam alimentado desde a sua fundação o descontentamento de artistas locais, que se consideravam desprestigiados diante da postura curatorial "internacionalista" do museu, dada sua valorização da arte de origem estrangeira.

Se na ocasião da inauguração da nova sede em 1939, o edifício dos estadunidenses Goodwin e Stone, embora alinhado com o International Style, tinha sido bem recebido nos círculos arquitetônicos, a exposição Art in Our Time não contara com a mesma sorte, gerando muita controvérsia no meio artístico. Entre os mais insatisfeitos estavam os artistas do grupo nova-iorquino American Abstract Artists (AAA), que, não representados na exposição, chegaram a organizar um manifesto diante do museu, distribuindo panfletos com o texto que questionava “Quão Moderno é o Museu de Arte Moderna?". ${ }^{140}$

A tensão vinha se agravando com a chegada aos EUA de muitos refugiados, entre os quais diversos artistas europeus de vanguarda que, acolhidos pelo MомA, concentraram-se em Nova York e colaboraram para que a cidade se tornasse um novo polo internacional da arte. Somado a isso, ainda em 1939 era inaugurado o Museum of Non-Objective Painting - embrião do Guggenheim Museum - que, além de expor apenas artistas europeus, era inteiramente dedicado a uma tendência da arte abstrata oposta ao do grupo AAA. ${ }^{141}$ Em meio ao acirramento dos dilemas entre arte "moderna" ou "contemporânea" e entre
140 How Modern is the Museum of Modern Art, desenhado pelo artista estadunidense Ad Reinhardt. Cf. LORENTE, op. cit., p. 167-8.

$141 \mathrm{O}$ museu contava com um grande acervo de obras de Kandinsky. 


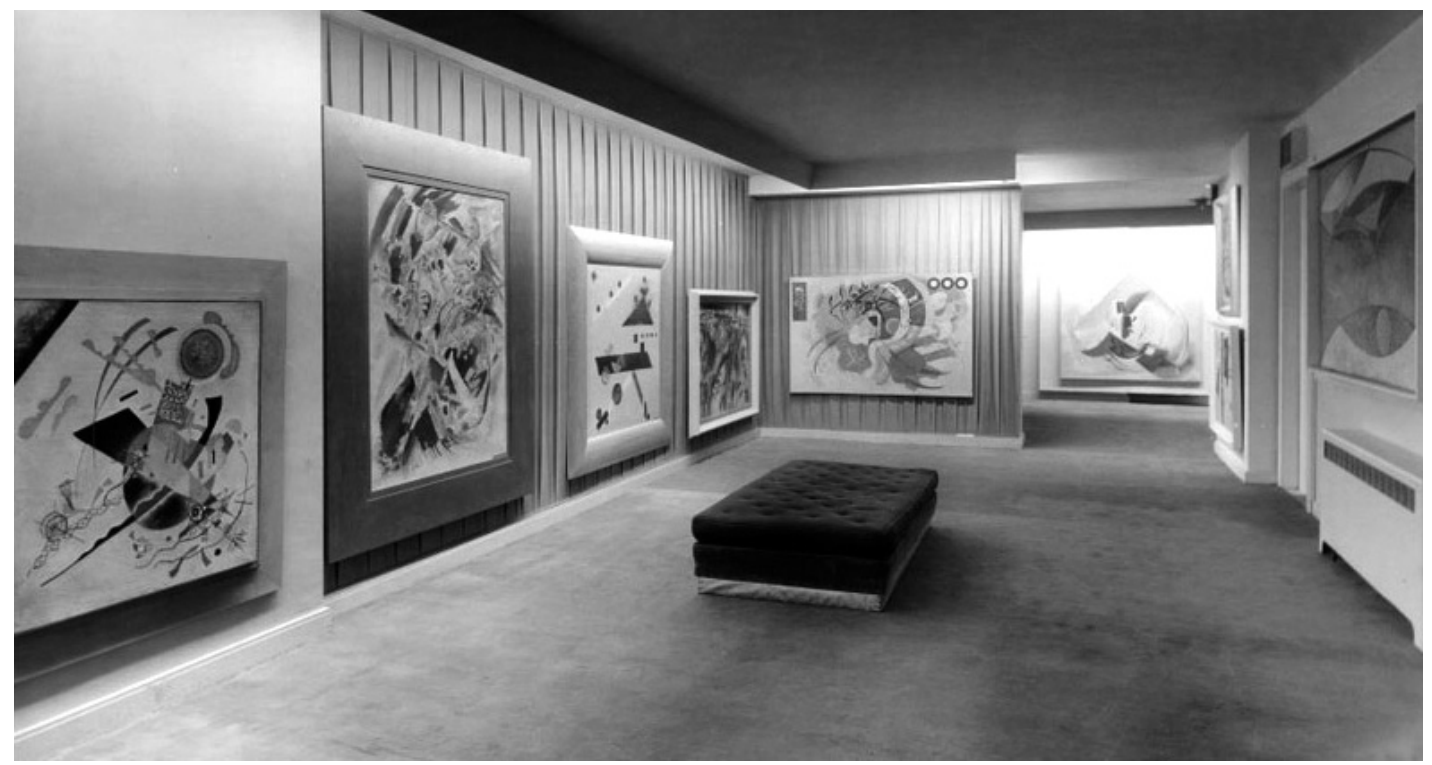

1.81 Vistas da exposição da coleção do Museum of Non-Objective Painting, Nova York, 1948. Fonte: https://www. guggenheim.org/blogs/findings/ installation-photograph-museum-of-nonobjective-painting

142 Cf. LORENTE, op. cit., p. 167.

143 Embora Miller tenha desempenhado um papel fundamental no MomA de sustentar o programa de valorização da arte contemporânea estadunidense, justamente quando essa produção atinge reconhecimento mais amplo a partir dos anos 1950, exposições de artistas de maior visibilidade já expostos por Miller passaram a ser realizadas por curadores homens, o que, para Lorente, não seria coincidência. Cf. LORENTE, op. cit., p. 201. arte europeia ou estadunidense, os artistas locais voltaram suas munições a diversos museus estabelecidos que deixavam de fora suas produções levando o MoMA a se tornar um dos alvos privilegiados de ataques. ${ }^{142}$

Assim como muitos membros do conselho, Barr, embora refutasse veementemente a argumentação nacionalista, era sensível à questão da representatividade dos artistas locais no MoMA e rebatia as críticas mostrando que, no balanço de suas mostras, havia uma presença equilibrada entre os lados. Mais que isso, o diretor empenhava-se em promover a produção estadunidense por meio das mostras realizadas por Dorothy C. Miller (1904-2003), sua assistente nomeada em 1934 especificamente para esta missão. ${ }^{143}$ Miller estreou na direção de uma exposição em 1936, com New Horizons in American Art, e trabalhara com Barr e curadores de outros departamentos na organização da primeira exposição organizada pelo museu para uma instituição internacional, justamente dedicada a difundir a produção estadunidense. Cobrindo o vasto período de 1609 a 1938 e com um escopo multidisciplinar, Trois siècles d'art aux États-Unis: peinture, sculpture, architecture, art populaire, photo- 


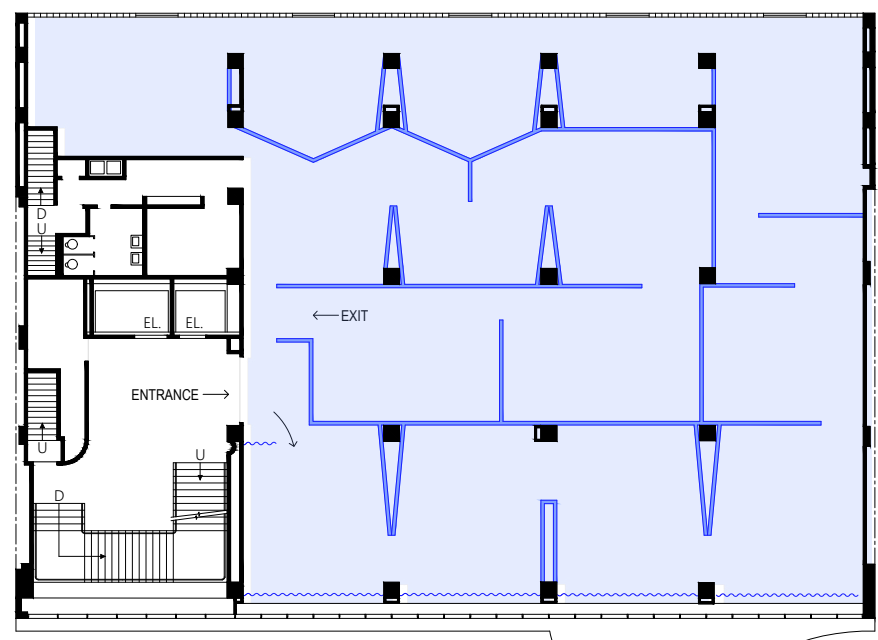

AMERICANS 1942: 18 ARTISTS FROM 9 STATES, MOMA NY, 1942 EXHIBITION LAYOUT - SECOND FLOOR [LAYOUT EXPOSITIVO - PAVIMENTO 2]

graphie, cinéma expôs 1000 itens no prestigioso Museu do Jeu de Paume, em Paris, no ano de $1938 .{ }^{144}$

Entre 1942 e 1963, Miller foi a curadora responsável por uma série de seis exposições periódicas dedicadas a artistas contemporâneos do país, sendo a primeira delas Americans 1942: 18 Artists from 9 States, ${ }^{145}$ com pinturas e esculturas de um número reduzido de artistas que ainda não tinham sido expostas em Nova York. ${ }^{146}$ Miller desenvolveu um modo original de organizar suas exposições coletivas, que antes geralmente apresentavam um número maior de artistas, representados apenas por uma única obra. ${ }^{147}$

A planta de layout de Americans 1942 mostra o segundo pavimento do museu subdividido em pequenas salas dedicadas a várias obras de um mesmo artista, mostrando que o fluxo de visitação se dava por um circuito fechado e unidirecional, similar ao esquema sugerido nos desenhos de Goodwin e Stone, com a posição alternada das passagens impedindo longas perspectivas e contendo o olhar em cada pequeno ambiente, visualmente segregado dos adjacentes. ${ }^{148}$ No desenho estão representadas linhas onduladas indicando provavelmente
1.82 Plantas do projeto expográfico de Americans, MoMA, Nova York, 1942. Desenhos nossos baseados em material de arquivo do MoMA.
144 Cf. THE Museum OF MODERN Three Centuries of American Art (May 24-Jul 31, 1938). MOMA. Disponível em: < https://www. moma.org/calendar/exhibitions/3597? locale $=\mathrm{pt}>$. Acesso em: 28 fev. 2020.

145 Cf. The Museum of Modern ART. Americans 1942: 18 Artists from 9 States (Jan 21-Mar 8, 1942). MOMA. Disponível em: <https:// www.moma.org/calendar/exhibitions $/ 3028$ ? locale $=\mathrm{pt}>$. Acesso em: 13 fev. 2020.

A planta mostra apenas a posição das divisórias, mas não indica a localização de artistas e obras.

146 Dorothy Miller dirigira antes disso a exposição Four American Travelling Shows, realizada em 1940.

147 Cf. The Museum of ModerN ART. Dorothy C. Miller Papers. MOMA. Disponível em: <https:// www.moma.org/research-and-learning/archives/finding-aids/dcmillerf>. Acesso em: 28 fev. 2020.

148 A planta mostra apenas a posição das divisórias, mas não indica a localização de artistas e obras. Cf. The Museum of Modern ART. Planta do projeto expográfico da mostra Americans 1942: 18 Artists from 9 States, 1942. 


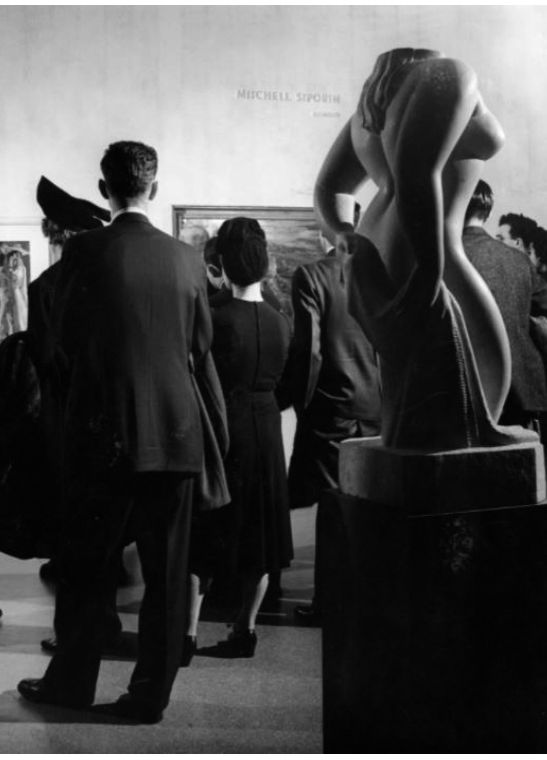

1.83 Vista da exposição Americans 1942: 18 Artists from 9 States, MoMA, Nova York, 1942. Foto: Albert Fenn. Fonte: https://www.moma.org/calendar/ exhibitions/3028

1.84 a 1.86 Vista da exposição Americans 1942: 18 Artists from 9 States, MoMA, Nova York, 1942. Fonte: https://www. moma.org/calendar/exhibitions/3028
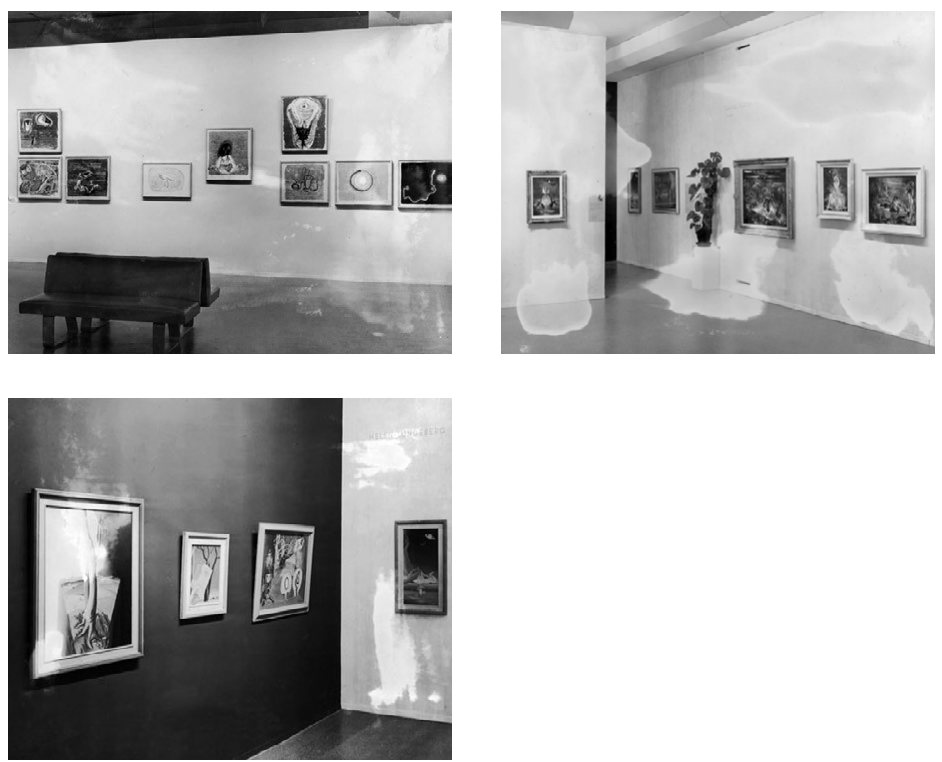

panos de cortinas cobrindo toda a fachada frontal, mas não há indicações sobre o tratamento da face voltada para o jardim. Nas fotos da montagem observa-se que apenas as esculturas são acompanhadas por etiquetas individualizadas, enquanto as pinturas são identificadas por conjuntos com um letreiro fixado no alto das paredes, indicando nome do autor e seu Estado de origem, além de um pequeno painel com uma foto e um texto de apresentação do artista, conteúdo que se repete no catálogo. As pinturas estão em geral fixadas à altura dos olhos, mas nem sempre numa única linha, sendo que algumas delas formam composições bastante dinâmicas. A maioria das paredes são de tom claro, com algumas de tom escuro, principalmente nos ambientes com esculturas, mostrando uma diferença de tratamento dada aos suportes, ainda que mais discreta que em Art in Our Time. Em contraponto ao ascetismo predominante nos ambientes, um vaso de plantas traz uma nota decorativa na passagem entre duas salas, mostrando características domésticas que mais tarde seriam eliminadas com a depuração do modelo. Ainda assim, Americans 1942 é uma boa amostra da rota de desenvolvimento do padrão 
expositivo que prevalecerá nas exposições de arte moderna do museu, independentemente da origem dos artistas e obras e de tendências distintas.

\subsubsection{OUTROS MODOS DE EXPOR ARTE MODERNA}

A prevalência do padrão discreto e "elegante" nas exposições de arte do мома não contrastava apenas com as montagens visualmente movimentadas organizadas por outros departamentos do museu, como os de fotografia, arquitetura e design e peças etnográficas. No próprio ano de 1942, um outro modo de expor arte era explorado na galeria que Peggy Guggenheim inaugurava em Nova York, Art of This Century, com projeto expográfico desenvolvido pelo arquiteto e artista austríaco Frederick Kiesler (1890-1965), que emigrou para os EUA em 1926. Com vocação de museu, a galeria localizada no 70 andar de um edifício comercial na West 57 th. Street, no 30 , tinha as duas maiores salas ocupadas por obras abstratas e surrealistas e um pequeno espaço com obras cinéticas de sua coleção permanente, além de duas outras salas menores reservadas a mostras temporárias.

Para as galerias da coleção, Kiesler elaborou um projeto que dialogava com as linguagens específicas de cada núcleo, a partir de suportes não convencionais e interativos. $\mathrm{Na}$ galeria dedicada à arte abstrata e a obras do Cubismo, uma das paredes laterais foi recoberta por uma tela sinuosa de tecido azul marinho, enquanto as telas, ao invés de apoiadas em painéis ou paredes, eram apresentadas sem molduras e suspensas por um sistema de cordas tensionadas de piso a teto, que permitiam variações de ângulo e altura. As duas laterais da galeria do Surrealismo tinham painéis côncavos de compensado de madeira, onde telas eram apoiadas com distanciadores, em ângulos diversos. Para as obras cinéticas, Kiesler desenvolveu dispositivos mecânicos acionados manualmente pelo público. Todos os ambientes eram ocupados por móveis sinuosos de madeira, que faziam as vezes de assento, mesa ou suporte de obras, dependendo da posição em que se apoiavam no piso. 

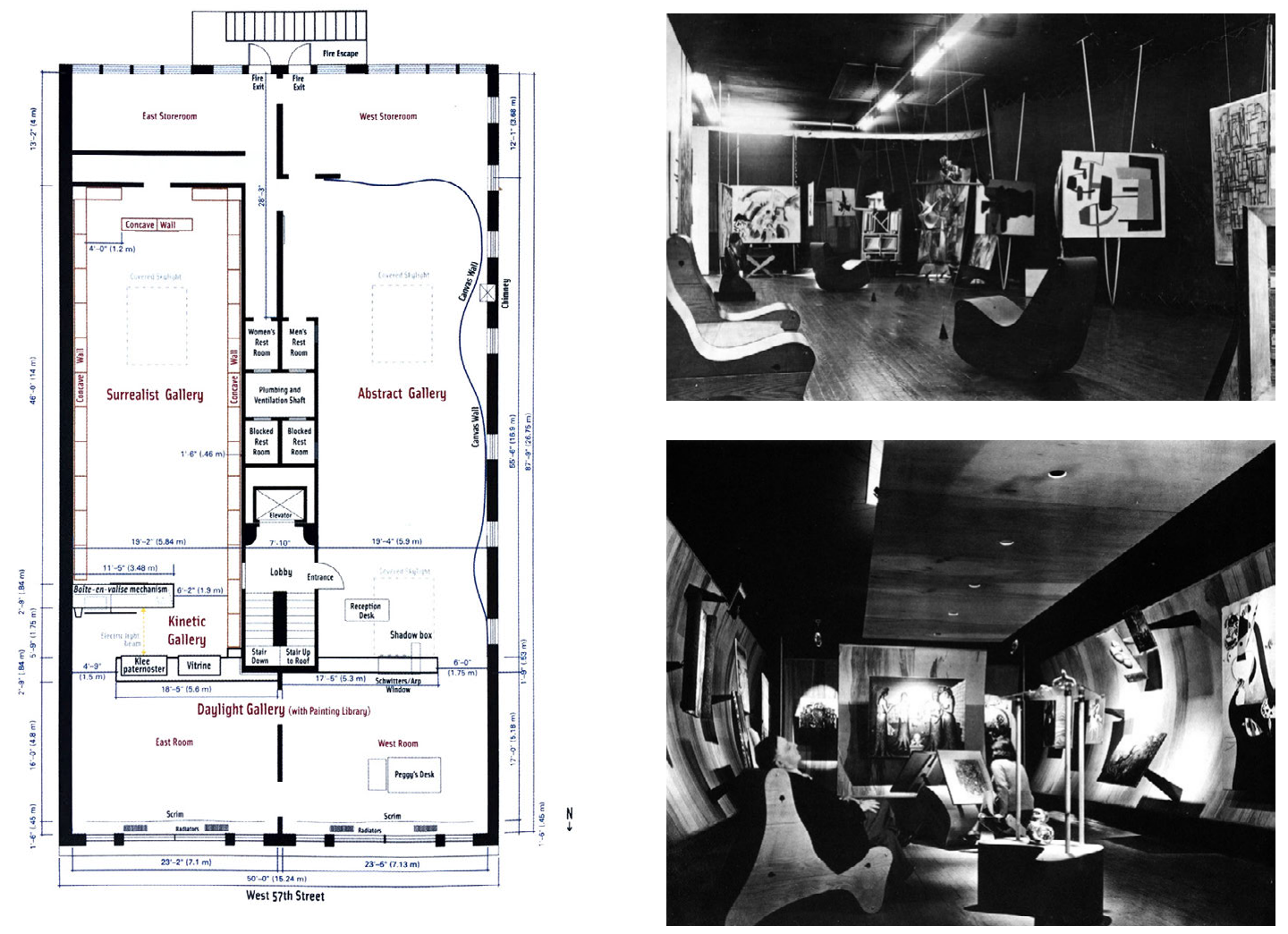

1.87 Planta do projeto expográfico da galeria Art of This Century, Nova York, 1942. Fonte: ALTSHULER, p. 312.

1.88 Vista da seção The abstract gallery na galeria Art of This Century, Nova York, 1942. Foto: K.W. Hermann. Fonte: ALTSHULER, p. 316.

1.89 Vista da seção Surrealist Gallery na galeria Art of This Century, Nova York, 1942. Foto: Berenice Abbot. Fonte: ALTSHULER, p. 319 .

1.90 Mecanismo para a obra de Marcel Duchamp La-Boîte-en-valise, na seção Kinetic Gallery na galeria Art of This Century, Nova York, 1942. Foto: K.W. Hermann. Fonte: https://doi. org/10.2307/j.ctv16qk3nf.9

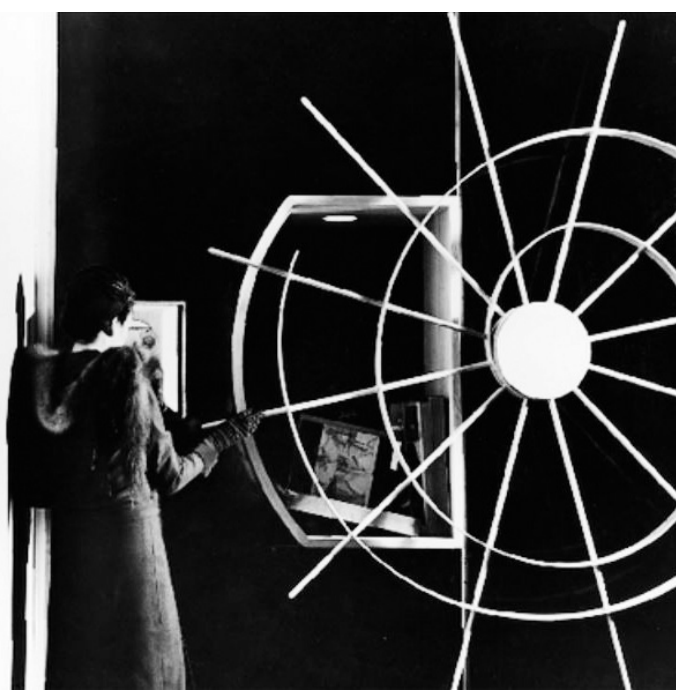




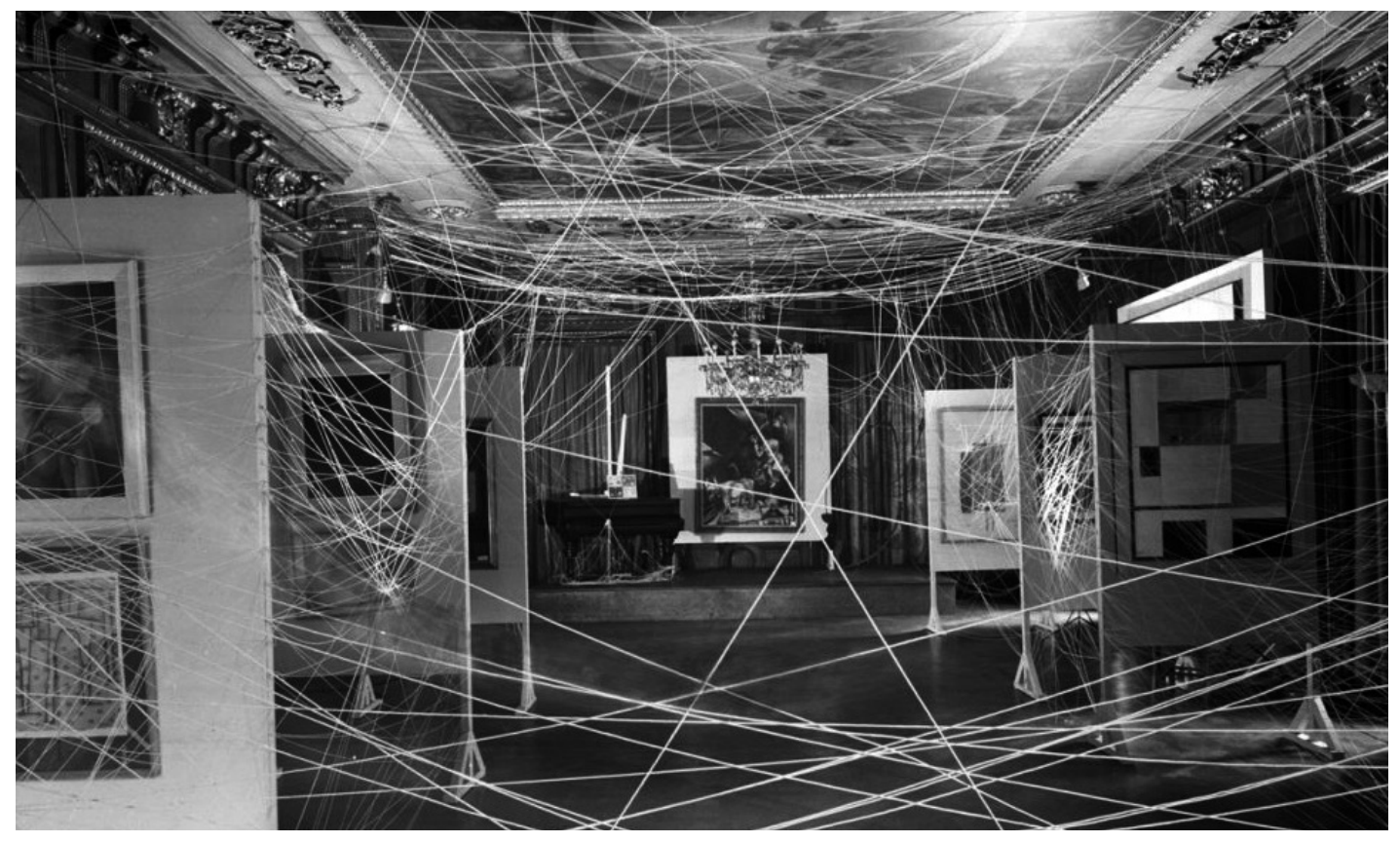

Ainda que Kiesler tenha usado soluções pouco habituais para os museus de arte da época, "procurando romper a barreira entre espectador e obra de arte", ${ }^{149}$ como apontou o historiador e crítico de arte Bruce Altschuler (1949-), o resultado ainda era uma cenografia racionalmente estruturada por um design sofisticado. De natureza distinta e bem mais provocativa era a montagem que Marcel Duchamp realizara para a exposição First Papers of Surrealism, organizada pelo líder do Surrealismo André Breton (1896-1966), inaugurada menos de uma semana antes numa mansão do século XIX, a poucas quadras de distância da galeria de Peggy Guggenheim. Duchamp criou uma teia de fios entrelaçados por todo o espaço expositivo, gerando uma ambiência que dialogava de modo mais radical com a mensagem do Surrealismo, chegando ao limite de praticamente obstruir $\mathrm{o}$ acesso de visitantes a certas obras. Cada uma a seu modo, as montagens de Kiesler e Duchamp tensionavam os espaços das galerias, conferindo-lhes status de propostas artísticas.

1.91 Vista da exposição First Papers of Surrealism com Mile String de Marcel Duchamp, Nova York, 1942. Foto: John Schift. Fonte: https://icaphila. org/miranda_posts/his-twine-marcelduchamp-and-the-limits-of-exhibitionhistory/

\section{8-129}




\subsubsection{CONFLITOS INSTITUCIONAIS E A CONSOLIDAÇÃO DA VANGUARDA ESTADUNIDENSE}

Além de fazer um contraponto com o modo de expor arte que se consolidava nо мома, a galeria Art of This Century desempenhou um papel importante ao expor artistas que viriam mais tarde a ser relacionados ao Expressionismo Abstrato, como Robert Motherwell (1915-1991) e Jackson Pollock (19121956), antes que os artistas desse grupo figurassem entre os principais protagonistas da arte estadunidense.ww Barr entusiasmou-se com os trabalhos expostos, empenhando-se em absorver a arte recente e explorar novas possibilidades com exposições temporárias no museu, em colaboração com a galeria. O diretor identificava como influências da emergência da vanguarda local o Surrealismo e exposições como as de Paul Klee (1941) e Joan Miró (1941-42), assim como outras dedicadas à arte então nomeada como primitiva: American Sources of Modern Art (1933), African Negro Art (1935) e especialmente Indian Art of the United States (1941). ${ }^{150}$ Foi em seguida que o crítico Clement Greenberg passou a atuar como vigoroso defensor da nova arte estadunidense, colaborando para conferir-lhe o status de legítima herdeira da arte europeia. ${ }^{151}$

Bem antes que essa visão se tornasse dominante e a aceitação do Expressionismo Abstrato irreversível no círculo das artes, a postura ousada de Barr em acolher a vanguarda local no Mома causou grave desconforto na ala mais conservadora do museu, liderada pelo presidente do conselho, o empresário e colecionador Stephen Clark (1882-196o), ocupante do posto desde o afastamento de Rockefeller em 1941. Embora o museu já tivesse então uma posição de maturidade e prestígio, conquistada sob a direção de Barr, nem todos os membros do conselho compartilhavam de sua disposição para apostar em exposições e aquisições de obras consideradas mais arrojadas. Ainda não se apaziguara na instituição a disputa sobre qual dos dois papéis deveriam sobressair: o de museu dedicado a uma coleção ou o de realizador de exposições temporárias. Barr vinha apostando nas duas frentes, mas

150 Cf. SANDLER, op. cit., p. 28. 151 Cf. LORENTE, op. cit., p. 173. naquele momento crescia a impressão de que os papéis eram inconciliáveis. 
Não bastasse sua adesão à produção ainda controversa do Surrealismo e da nova geração de artistas de Nova York, o diretor organizara em 1943 uma exposição sobre um pintor autodidata e fora do circuito estabelecido das artes, The Paintings of Morris Hirshfield, e uma outra exibindo caixas de engraxate, Joe Milone Shoe Shine Stand. Foi então que Clark decidiu restringir as funções de Barr à elaboração de uma publicação sobre a história da arte moderna, afastando-o da organização das exposições. $\mathrm{O}$ fato de Barr ter continuado a atuar extraoficialmente nessa área e não ter concluído sua nova missão deu a Clark a perfeita justificativa para destituí-lo da direção, deixando-o no museu sem a mesma autoridade. ${ }^{152} \mathrm{~A}$ gestão do museu passou a ser então exercida por um comitê com cinco membros, entre eles o próprio Barr e René D’Harnoncourt, tendo o último assumido o cargo de diretor em 1949. Barr permaneceu nо момА, mas só voltou a assumir formalmente um posto de maior responsabilidade no museu em 1947, o de diretor das coleções do museu, em que se manteve até sua aposentadoria, vinte anos mais tarde..$^{153}$

Quem assumiu a diretoria do Departamento de Pintura e Escultura após a saída de Barr foi seu assistente James. T. Soby, também colecionador e membro do conselho, que manteve a mesma rota do antecessor. Em 1944, Soby adquiriu para o museu uma pintura de Pollock pela qual Barr se interessara na galeria de Peggy Guggenheim - The She-Wolf, de 1943, a primeira do artista a entrar na coleção do MoMA. Quando em seguida Soby deu preferência para adquirir num leilão obras deste e de outros artistas da nova escola de Nova York, como Motherwell e Roberto Matta (1911-2002), deixando escapar obras do Impressionismo e Pós-Impressionismo, a reação da ala conservadora do conselho foi exigir uma definição clara sobre a política de aquisições, demandando que salas do museu fossem reservadas para expor a coleção, naquele momento pouco conhecida pelo público e até mesmo por membros do conselho. Sentindo-se desautorizado, Soby renunciou ao cargo, para o qual foi apontado James Johnson Sweeney. ${ }^{154}$

Em meio a troca de diretores do departamento, a exposição do acervo foi montada, sendo a maior desse tipo realizada até então no момА. The Museum Collection of Painting and

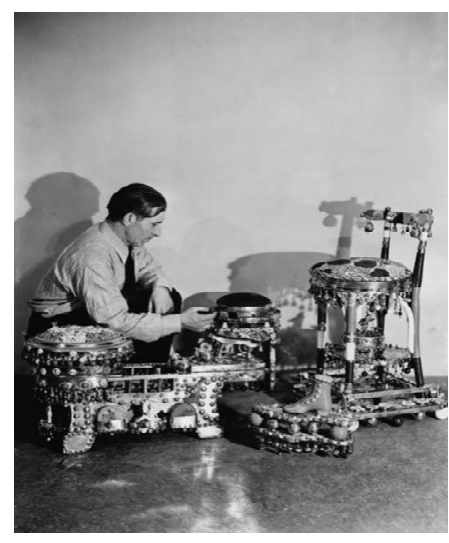

1.92 Joe Milone e seu equipamento de engraxate na exposição Joe Milone's Shoe Shine Stand, MoMA, Nova York, 1943. Foto: Soichi Sunami. Fonte: https://www. moma.org/calendar/exhibitions/3124

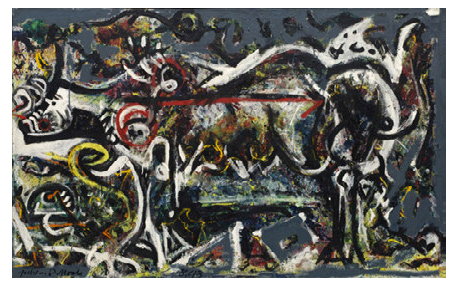

1.93 Jackson Pollock, The She-Wolf, 1943. Fonte: https://www.moma.org/collection/ works/ 78719

152 SANDLER, op. cit., pp. 28-29. 153 LORENTE, op. cit., pp. 173-5. 154 Ibidem, pp. $174^{-5}$. 

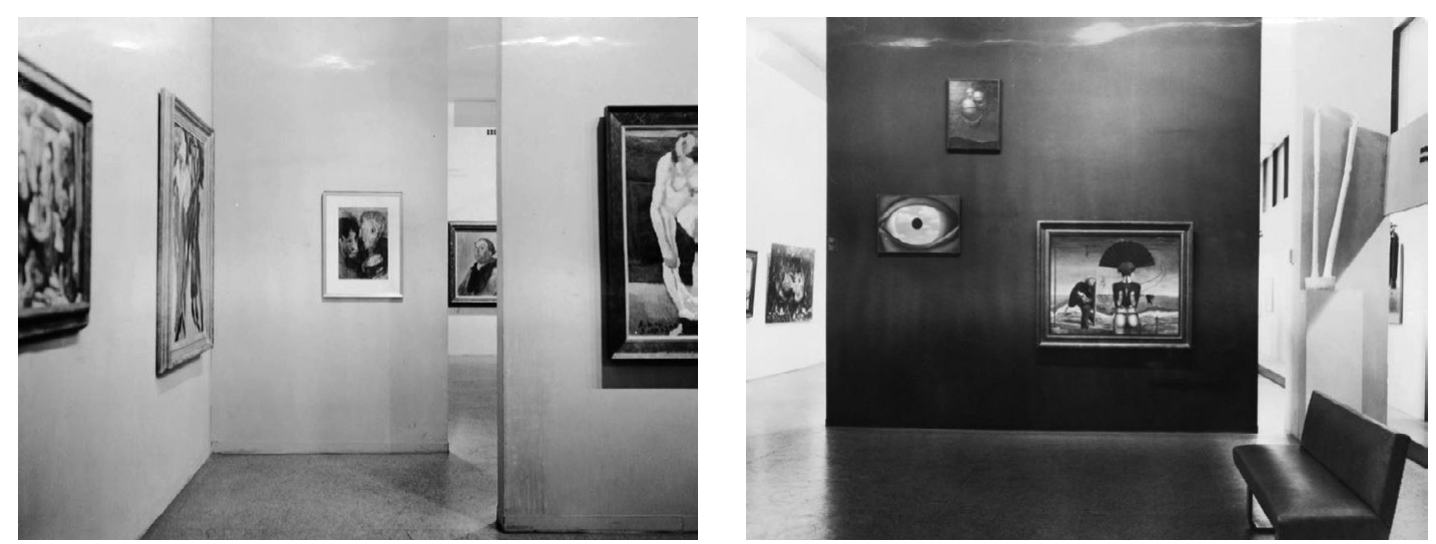

1.94 a 1.97 Vistas da exposição The Museum Collection of Painting and Sculpture, MoMA, Nova York, 1945. Fonte: https:// www.moma.org/calendar/ exhibitions/2861

155 Cf. The Museum of Modern ART. The Museum Collection of Painting and Sculpture (Jun 20, 1945-Feb 13, 1946). МОМА. Disponível em: <https://www. moma.org/calendar/exhibitions $/ 2861$ ? locale $=e n>$. Acesso em: 4 mar. 2020.

156 No press release da exposição, Barr explicou que reservou uma sala ampla para duas esculturas de grandes dimensões "para dar ao visitante a sensação do impacto que uma escultura pode provocar quando exposta num espaço amplo e bem proporcionado", explicitando as relações pretendidas entre soluções de montagem e percepção das obras (as obras em questão são do artista alemão Wilhelm Lehmbruck (1881-1919) Kneeling Woman de 1911 e Standing Youth de 1913). Ibidem.
Sculpture, organizada por Barr, ocupou todo o segundo e o terceiro pavimentos expositivos, além de áreas de circulação e o jardim, com cerca de um terço do acervo - aproximadamente 300 pinturas e 75 esculturas. ${ }^{155}$ As fotos da montagem mostram a segmentação dos andares livres em pequenas salas, com aberturas em posições alternadas, e o predomínio da setorização de zonas específicas para pinturas e esculturas (como observado em montagens anteriores), assim como sutis distinções entre os respectivos tratamentos expográficos, com maior densidade de cortinas nos locais em que se concentram esculturas. Os painéis onde se apoiavam as pinturas foram pintados em diferentes tonalidades, algumas delas bastante escuras. A esquadria Thermolux da fachada frontal, por sua vez, recebeu um painel opaco mais baixo, deixando aparente o módulo superior translúcido - uma solução de conciliação entre a necessidade de aumentar a superfície expositiva e a de dialogar com características da arquitetura do edifício. Reforçando esse aspecto, uma faixa horizontal opaca destacada do painel e fixada no alinhamento dos pilares abrigava lâmpadas por trás, iluminando homogeneamente o plano das pinturas. ${ }^{156}$

A exposição teve duração de oito meses, longa para os padrões do museu, e sua inauguração em 20 de junho de 1945 se deu em meio ao desfecho da iI Guerra. Durante o período em que os EUA estiveram envolvidos nos combates, departa- 

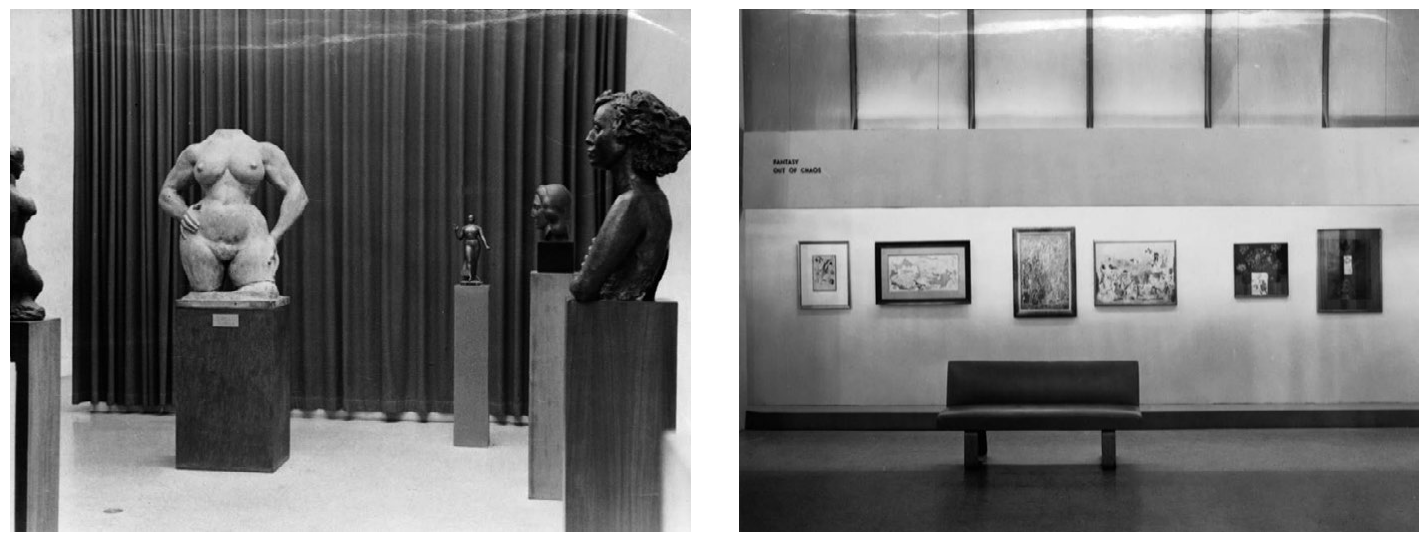

mentos que podiam colaborar de modo mais evidente com os esforços propagandísticos dirigido às massas, como o de fotografia, tinham adquirido proeminência sobre o de pintura e escultura, que nem por isso esteve imune ao clima dos conflitos, como evidencia o modo como Barr concluiu a apresentação da mostra da coleção no memorial de divulgação à imprensa, articulando sua convicção antinacionalista à sua visão da arte como produto da criação individual:

Esta coleção de arte de muitas nações é um símbolo da liberdade - liberdade do artista e por meio do artista - de cada indivíduo expressar o que lhe vem à mente sem medo de perseguição. Além da liberdade individual, ela simboliza ainda a liberdade das nações de cuidar não apenas de suas próprias obras de arte, mas também daquelas de outros povos, de modo que a arte possa promover o entendimento e a estima, contribuindo assim para acabar com o ódio e o desprezo internacionais, contra os quais estamos lutando atualmente nos campos de batalha. ${ }^{157}$

Com a conclusão da guerra, simultânea ao sucesso da exposição da já rica coleção do MOMA, diminuíram as tensões no departamento de Pintura e Escultura do Museu, mas até o fim da década o museu ainda enfrentaria controvérsias internas e externas envolvendo a aceitação da arte estadunidense de van157 Ibidem, p. 18. 
158 HUNTER, op. cit., p. 23.

159 LORENTE, op. cit., p. 188. guarda. A partir do MомA, a produção contemporânea ganhava impulso com a atuação de Sweeney à frente do Departamento de Pintura e Escultura entre 1945 e 46 e com as exposições organizadas por Miller, que passou a selecionar um número progressivamente maior de artistas da vanguarda local a partir da mostra Fourteen Americans, de $1946 .{ }^{158}$

Porém, com a exacerbação de tendências nacionalistas no ambiente da Guerra Fria, ecoava em diversos círculos artísticos e na imprensa o sentimento de que a produção associada ao Expressionismo Abstrato teria uma linguagem demasiadamente internacional, de origem europeia, e possivelmente vinculada ao comunismo, devendo, portanto, ser combatida do mesmo modo. Segundo essa visão, uma arte legitimamente patriótica seria aquela em que se reconheceriam os valores da cultura tipicamente estadunidense, como a dos pintores Regionalistas. ${ }^{159}$ Curiosamente, era justamente esse o único tipo de expressão artística admitido pelo regime soviético naquele momento - o exemplo de autoritarismo que Barr sempre considerara danoso para o desenvolvimento da arte.

Não surpreendia que a imprensa não especializada e artistas que se consideravam preteridos pelo museu desaprovassem que a arte de vanguarda conquistasse cada vez mais espaço, mas as controvérsias alcançaram outra dimensão quando o Boston Museum of Modern Art, criado em 1936 como instituição associada ao MOMA, anunciou no início de 1948 a decisão de alterar seu nome para Institute of Contemporary Art (ICA), com a justificativa de que a chamada "arte moderna", que designaria a produção europeia do final do século XIX ao início da II Guerra, distanciara-se demasiadamente do público em geral e deveria ser considerada encerrada. Parte da imprensa aproveitou a oportunidade para defender que uma nova arte local se desenvolvesse retomando a rota traçada pela produção do Romantismo e Realismo estadunidenses.

Os ataques atingiam especialmente o MOMA, cuja missão sempre fora difundir a arte moderna nos EUA e a partir dela promover o desenvolvimento da arte local. Embora o perfil do museu fosse internacionalista, desde o início incluíra a produção nacional na programação das exposições e nas aquisições. Ao final do próprio ano de 1948, foi inaugurada a 
exposição organizada por Miller, American Paintings from the Museum Collection, mostrando 150 pinturas a óleo e aquarelas produzidas por 115 artistas estadunidenses nas últimas cinco décadas, a maior parte nos últimos 25 anos, contando com 10 novas aquisições, entre as quais uma pintura de Willem de Kooning, Painting, de $1948 .{ }^{160} \mathrm{O}$ memorial de divulgação à imprensa incluía trechos de um texto de apresentação da coleção de pintura e escultura de autoria do presidente do board of trustees, John Hay Whitney (1904-1982), que manifestava seu repúdio ao controle totalitário da produção artística e o entendimento adotado pelo MoMA sobre a arte moderna desvinculada de uma noção de "estilo": "nesta coleção há muitos tipos de arte - pois, paradoxalmente, não se pode considerar a 'arte moderna' no sentido estritamente categórico ou descritivo. Ainda assim, o termo 'moderno' é válido porque sugere o progressivo e o desafiador...."161

Defendendo o caráter aberto da expressão, "moderno" seria, para Barr, apropriado para designar "os movimentos mais desafiadores, originais e ainda não assimilados em filosofia, teologia e nas artes [...], por isso usamos essa palavra para nomear o Museu de Arte Moderna”. ${ }^{162}$ Diante da incompreensão e dos ataques continuados à arte moderna publicados por setores influentes da imprensa conservadora, Barr empenhou-se em articular com o próprio ICA de Boston e o Metropolitan Museum de Nova York a redação de um manifesto conjunto, o Statement on Modern Art, publicado em 1950. O texto tratava da arte moderna e de seus valores humanistas, de seu potencial para explorar novas fronteiras, da valorização da arte estadunidense sem limitações nacionalistas, da rejeição de uma subserviência a fins sociais ou políticos e ainda da necessidade de os museus estarem receptivos à arte de seu tempo, selecionando obras recentes com critérios objetivos de qualidade, para apresentá-las ao público de modo imparcial e não dogmático.

De acordo com Sandler, o manifesto marcou uma guinada na recepção à arte moderna e à produção mais recente, que adquiriram uma nova condição de respeitabilidade nos círculos intelectualizados. Por outro lado, a chamada "arte experimental”, vista de modo geral como antipatriótica e sub-
160 O museu possuía então 300 pinturas de artistas estadunidenses. Cf. The Museum of ModerN ART. American Paintings from the Museum Collection (Dec 23, 1948Mar 13, 1949). MOMA. Disponível em: <https://www.moma.org/calendar/exhibitions $/ 285^{2}$ ?locale $=\mathrm{pt}>$. Acesso em: 7 mar. 2020.

161 John Hay Whitney in: Idem (Press release), p. 337. Tradução nossa.

162 Alfred Barr apud SANDLER; NEWMAN, op. cit., p. 32. Tradução nossa. 
1.98 Vista da exposição American Paintings from the Museum Collection, MoMA,

Nova York, 1948-49. Foto: Soichi Sunami.

Fonte: https://www.moma.org/calendar/ exhibitions/2852

1.99 Plantas do projeto expográfico de American Paintings from the Museum Collection, MoMA, Nova York, 1948. Desenhos nossos baseados em material de arquivo do MoMA.
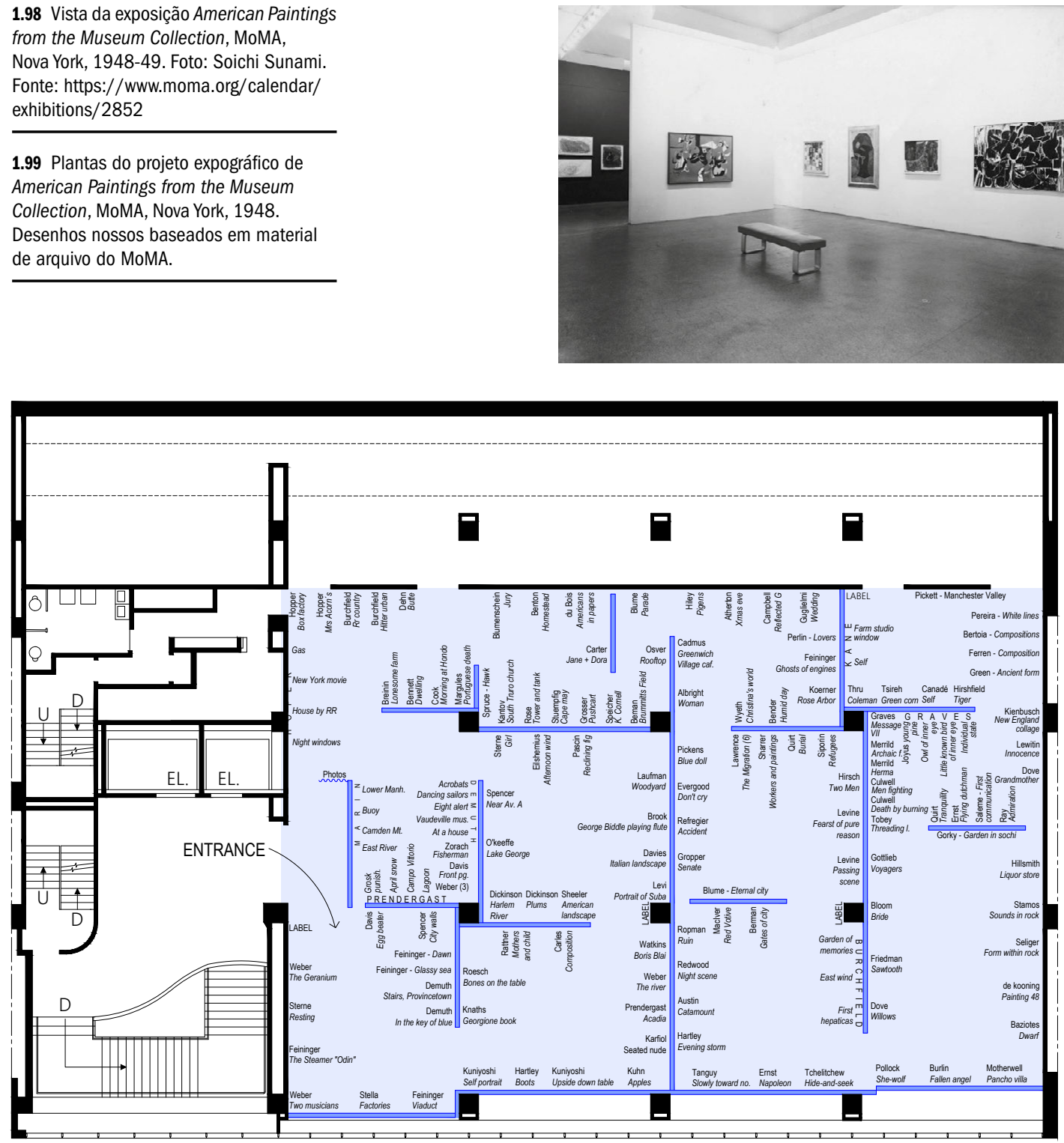

AMERICAN PAINTINGS FROM THE MUSEUM COLLECTION, MOMA NY, 1948 EXHIBITION LAYOUT - THIRD FLOOR

[LAYOUT EXPOSITIVO - PAVIMENTO 3]

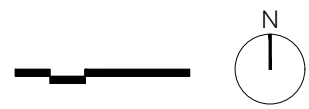


versiva, continuava ameaçada de censura por órgãos governamentais que procuravam dirigir a produção cultural do país, limitando manifestações que destoassem da mensagem nacionalista ou que pudessem ser efetivamente conectadas a movimentos comunistas. Durante toda a década de 1950, Barr manteve-se envolvido nas principais discussões públicas, defendendo que a liberdade de expressão - princípio essencial da sociedade estadunidense e condição para o desenvolvimento da arte - seria o verdadeiro antídoto tanto para o comunismo quanto para o fanatismo anticomunista que procurava combatê-lo. ${ }^{163}$

Como apontou Lorente, as disputas que o Moma enfrentou nos anos 1950 envolvendo seus próprios membros, outras instituições de arte, a imprensa e a ascensão do Expressionismo Abstrato consolidaram a instituição como um núcleo a partir do qual se desenvolveu um protótipo de museu de arte moderna, como veremos a seguir. ${ }^{164}$

\subsection{EXPANSÃO E CONSOLIDAÇÃO: 1949 A 1968}

\subsubsection{SOB NOVA DIREÇÃO}

A atuação de Alfred Barr nos anos de formação do MOMA havia sido crucial para moldar o perfil da instituição e definir um modo de expor e colecionar arte moderna, mas os conflitos institucionais internos nos anos de guerra haviam lhe custado o cargo de direção do museu em 1943. A condução do MOMA entre 1949 e 1968, fase de prosperidade que marca a consolidação e o crescimento do museu, esteve nas mãos de René D'Harnoncourt, que havia montado sua primeira exposição no museu em 1941, Indian Art of the United States, e dirigido diversos departamentos desde 1943 até chegar em 1949 ao cargo de diretor geral, como vimos.

D'Harnoncourt não tinha uma visão de arte conflitante com a de Barr, mas seu modo particular de organizar as exposições, fundindo a concepção curatorial à elaboração dos projetos expográficos, resultava em ambientes mais expressivos e sedutores, como vemos nas duas exposições que organizou
163 SANDLER, op. cit. p. 35 Tradução nossa.

164 LORENTE, op. cit., p. 197. 

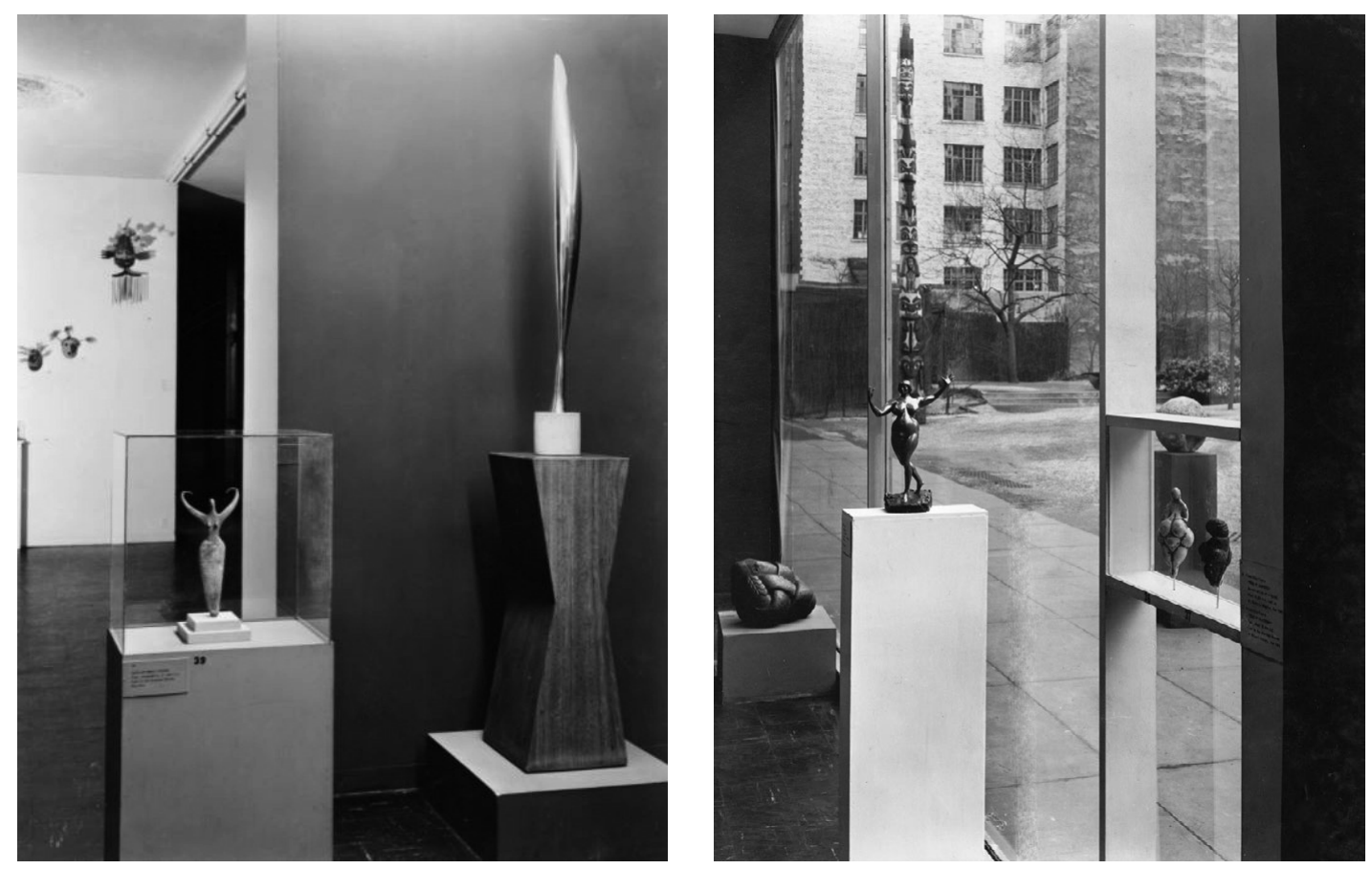

1.100 a 1.102 Vistas da exposição Timeless Aspects of Modern Art, MoMA, Nova York, 1948-49. Foto: Soichi Sunami. Fonte: https://www.moma.org/calendar/ exhibitions/2845

165 Cf. The Museum OF ModerN ART. Timeless Aspects of Modern Art (Nov 16, 1948-Jan 23, 1949). MOMA. Disponível em: < https:// www.moma.org/calendar/exhibitions $/ 2845$ ?locale $=$ pt $>$. Acesso em: 11 mar. 2020.

166 The Museum of Modern ART. Timeless Aspects of Modern Art: the first of a series of exhibitions marking the 2oth anniversary of the Museum of Modern Art, New York. Nova York: The Museum of Modern Art, 1948, n.p.. Tradução nossa. para a comemoração do vigésimo aniversário do museu. A primeira delas foi Timeless Aspects of Modern Art, inaugurada ao final de $1948,{ }^{165}$ mostrando obras de arte moderna ao lado de peças europeias, africanas e asiáticas de diversas épocas, justapostas desta vez a partir de critérios estéticos atemporais, “para lembrar que esse modo de expressão 'moderno' - como exagero, distorção e abstração - vem sendo usado por artistas desde os primórdios da civilização para dar forma a suas ideias e emoções."166

É de particular interesse desta tese observar o diálogo aberto que a exposição estabelecia com a arquitetura do edifício, tirando partido da transparência das salas expositivas do térreo: com o posicionamento de vitrines junto às esquadrias, era possível visualizar as peças tendo o jardim de esculturas ao fundo. Tal foi a importância dada a esse projeto expográfico, que a planta da montagem - raramente divulgada ao público foi impressa em grandes dimensões no painel de abertura da 

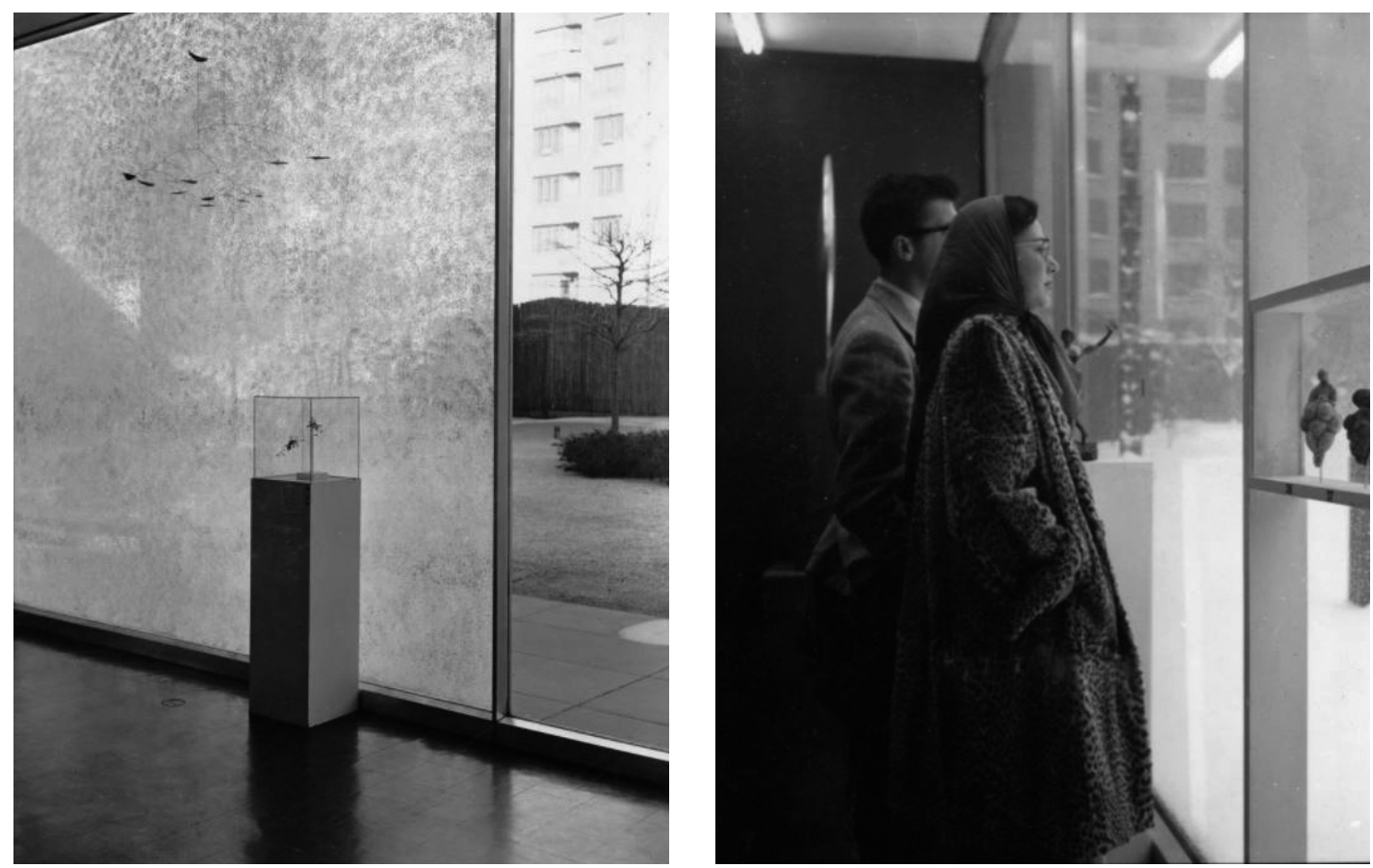

mostra, além de figurar no catálogo e no memorial de divulgação à imprensa, explicitando as relações pretendidas entre as obras e a visão geral da curadoria.

A segunda exposição comemorativa da ocasião foi Modern Art in Your Life, inaugurada em 1949, que relacionava as artes "puras" às "aplicadas", presentes em cinco vertentes modernas interconectadas: abstração geométrica, abstração orgânica, estilização geométrica, estilização orgânica e arte surrealista e fantástica. ${ }^{167}$ Neste caso também se nota como a concepção curatorial se expressa diretamente no projeto expográfico, por meio de um diagrama circular publicado no catálogo, mostrando o núcleo de pinturas e esculturas ao centro, dando acesso a cinco zonas dedicadas a obras e objetos de cada uma das tendências elencadas. Para traduzir a distribuição do diagrama na organização da galeria do terceiro andar, D'Harnoncourt criou na entrada da exposição um túnel com pé direito rebaixado e ladeado por cortinas semitransparentes, levando o visitante a
1.103 Vistas da exposição Timeless Aspects of Modern Art, MoMA, Nova York, 1948-49. Foto: Homer Page. Foto: Homer Page. Fonte: https://www.moma.org/ calendar/exhibitions/2845

167 Cf. The Museum of Modern ART. Modern Art in Your Life (Oct 5-Dec 4, 1949). МОмA. Disponível em: <https://www.moma.org/calendar/exhibitions/2744>. Acesso em: 6 jun. 2021. 


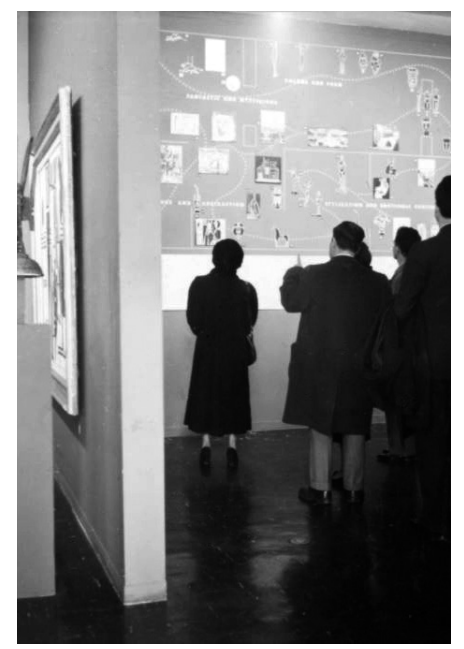

1.104 Visitantes diante da planta da montagem na exposição Timeless Aspects of Modern Art, MoMA, Nova York, 1948-49. Foto: Soichi Sunami. Fonte: https://www. moma.org/calendar/exhibitions/2845

1.105 Planta da montagem encartada no catálogo da exposição Timeless Aspects of Modern Art, MoMA, Nova York, 1948-49.

1.106 a 1.108 Vistas da exposição Modern Art in Your Life, MoMA, Nova York, 1949. Foto: Soichi Sunami. Fonte: https://www. moma.org/calendar/exhibitions/2744

1.109 Planta esquemática no catálogo da exposição Modern Art in Your Life, MoMA, Nova York, 1949.

1.110 René D'Harnoncourt, planta do projeto expográfico de Modern Art in Your Life, MoMA, Nova York, 1949. Fonte: STANISZEWSKI, p. 133.

168 A maior parte das exposições realizadas por esse programa do MOMA foram, no entanto, mostras realizadas pelo Departamento de Fotografia.

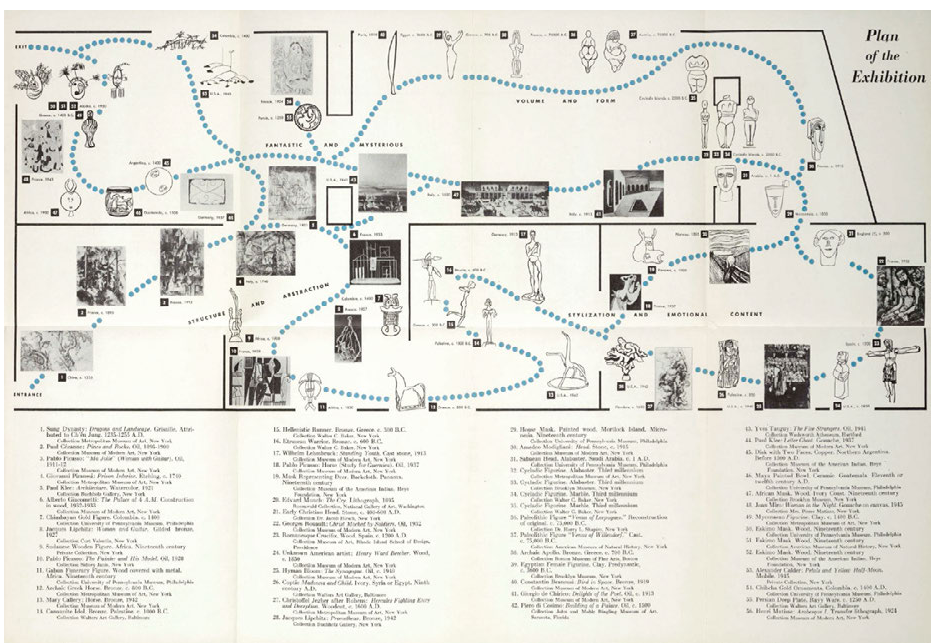

iniciar o percurso pelo centro do espaço, onde se distribuíam as pinturas e esculturas agrupadas nas cinwco vertentes. Junto a cada conjunto havia uma passagem que dava acesso às galerias periféricas, com os objetos das demais disciplinas. Tratava-se de uma solução expográfica engenhosa, que tornava mais evidentes as intenções curatoriais.

Com as múltiplas habilidades que vinha demonstrando como curador, designer de exposições e gestor do museu, aliado a seus vínculos internacionais, D'Harnoncourt mostrava-se credenciado para liderar os planos de difusão das exposições do MOMA para além dos EUA, com suporte governamental articulado por Nelson Rockefeller desde os anos de guerra. Contando com esse apoio, o diretor criou em $195^{2}$ um departamento dedicado exclusivamente à implantação de um programa de internacionalização de exposições, com a função de difundir a arte moderna em geral e a nova produção artística dos EUA em particular, organizando diversas exposições em instituições parceiras no exterior, bem como no próprio museu. ${ }^{168} \mathrm{O}$ programa acompanhou o crescimento da influência econômica e cultural do país no cenário global e impactou o modo como algumas tendências artísticas conquistaram aceitação e se estabeleceram na história da arte 

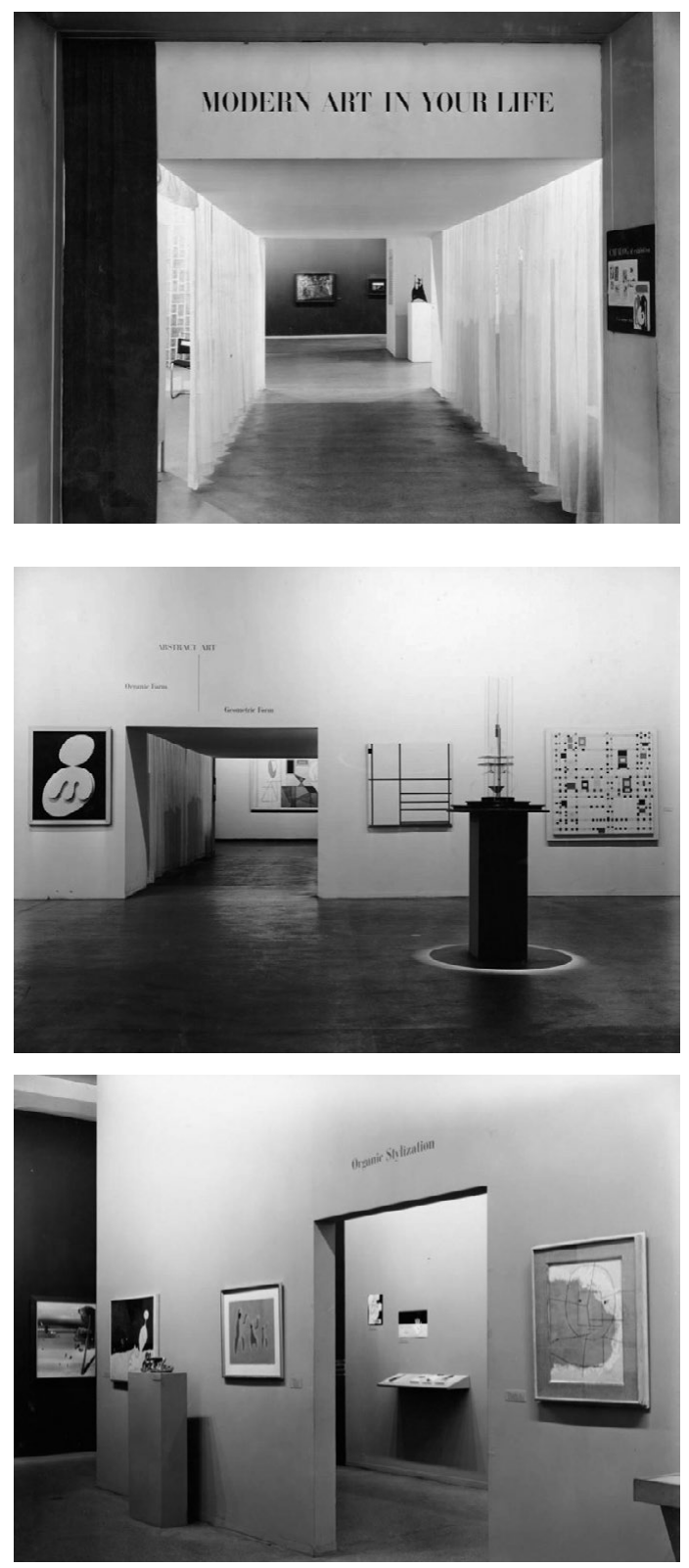

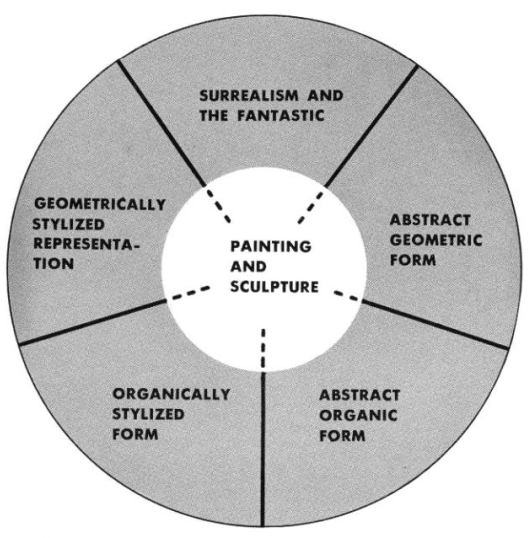

CENTRAL GaLLERY OF PAINTING AND SCULPTURE

GALLERIES OF APPLIED ART

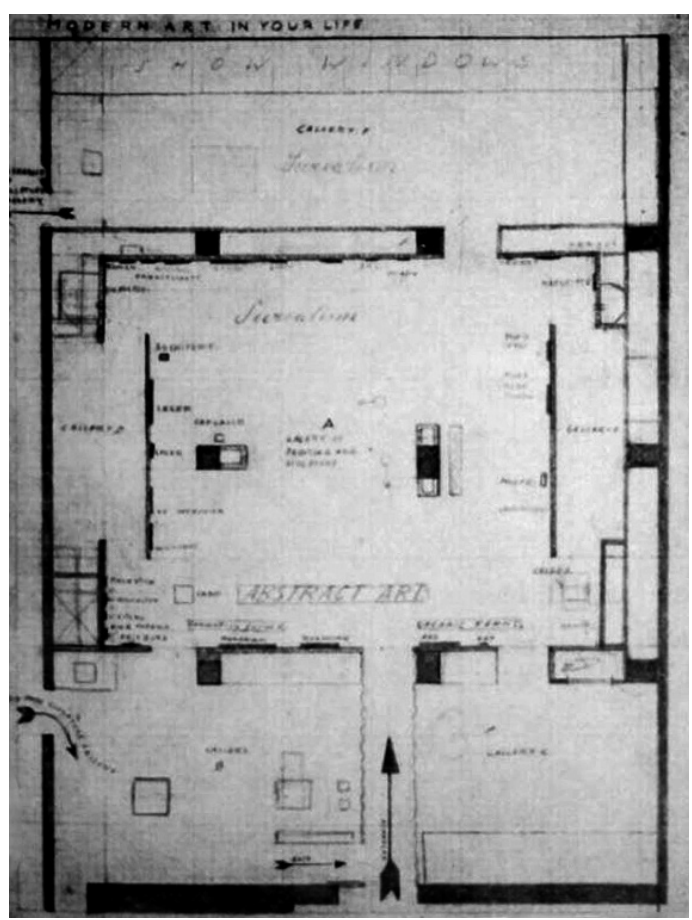




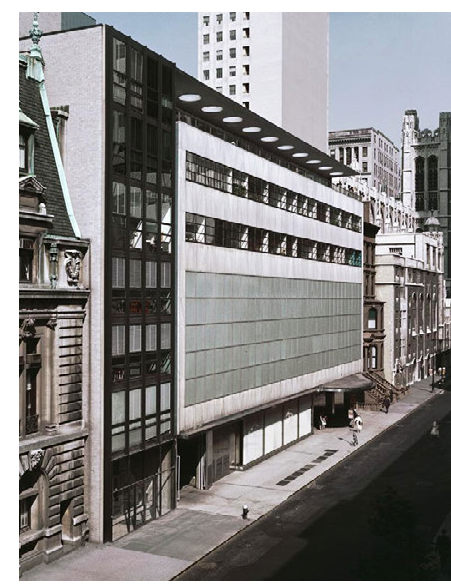

169 O programa de exposições itinerantes foi custeado por cinco anos com fundos doados por Rockefeller, uma vez que a internacionalização refletia seus interesses políticos e econômicos. Em 1956 o programa se converteu no International Council liderado pelo Moma que, entre outras atribuições de peso, dirigia a representação estadunidense na Bienal de Veneza, tendo o museu sido proprietário do pavilhão dos EUA entre 1954 e 1962. Embora o governo federal tivesse deixado de apoiar abertamente a difusão da arte moderna na década de 1950, foi revelado em 1960 que a CIA patrocinava secretamente o MомA e outras instituições culturais, como estratégia de defesa nacional durante os anos da guerra fria. Uma exceção de apoio governamental explícito foi o concedido à mostra organizada por Steichen, The Family of Man, inaugurada no MoмA em 1955, itinerando em seguida para outros países durante 8 anos e atingindo a marca de mais de nove milhões de visitantes. Cf. STANISZEWSKI, op. cit., p. 256. 170 Cf. HunTER, op. cit., p. 25-26.

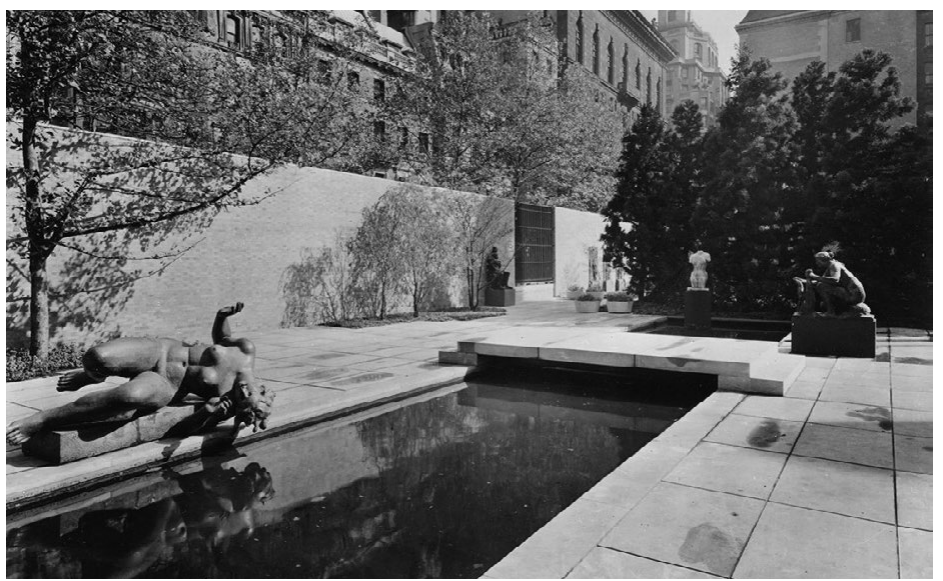

ocidental, conferindo ao MoMA status de centro internacional de arte moderna. ${ }^{169}$

Ao mesmo tempo, a gestão de D'Harnoncourt foi marcada pela ampliação da intensidade e escopo das ações realizadas localmente. Exercendo as funções de cinema, biblioteca, editora, escola, produtor de exposições para outras instituições e referência de gosto para qualquer objeto que envolvesse design, o MomA passava a atuar como um centro comunitário. Além de preservar e ampliar a sua coleção, o museu organizava aproximadamente 20 exposições anuais com curadoria e expografia originais - muitas delas com obras recentes, emprestadas de colecionadores, galeristas, artistas e outros museus -, frequentadas por um público cada vez mais numeroso e bem informado, o que gerou pressão por uma expansão de seu edifício. ${ }^{170}$

\subsubsection{UM NOVO JARDIM MODERNO COMO "CORAÇÃO" DO MUSEU}

Desde o início dos anos de 1950 já se discutia no Moma a necessidade de ampliação da sede de Goodwin e Stone, o que desencadearia uma série de intervenções no edifício realizadas por Phillip Johnson. O arquiteto já tinha adquirido então um considerável prestígio profissional, impulsionado pela sua volta 


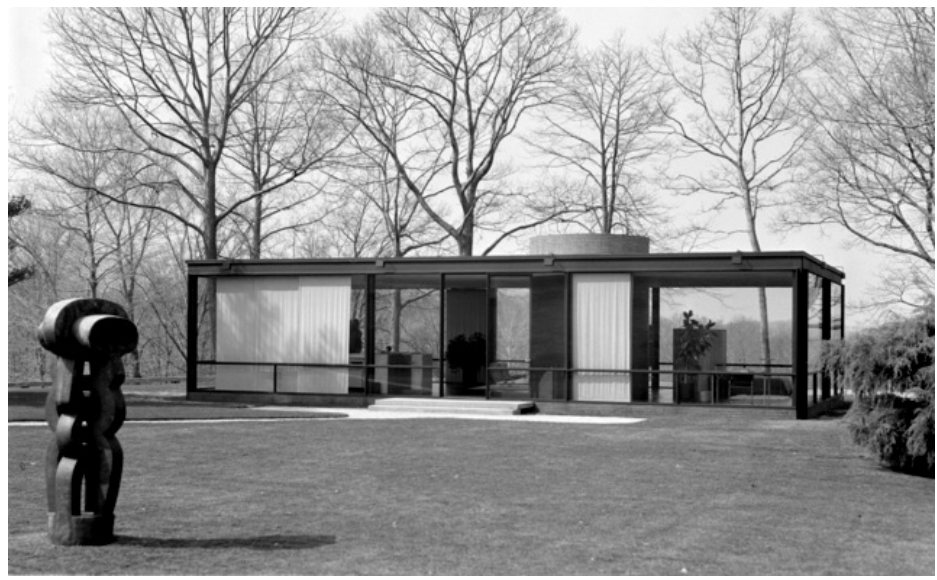

em 1946 ao cargo de Diretor do Departamento de Arquitetura e Design, no qual permaneceu até 1954. A primeira expansão, ainda tímida, foi a oeste, inaugurada em 1951, ocupando de lado a lado um estreito lote de menos de $6 \mathrm{~m}$ onde antes havia uma casa. A nova ala seguia o mesmo alinhamento e gabarito do museu, dando continuidade aos pavimentos internos e exibindo uma fachada com esquadrias de piso a teto regularmente reticuladas e de tonalidade escura - numa linguagem alinhada com o International Style de origem miesiana $-{ }^{171}$ mantendo em destaque o edifício original de $1939 .{ }^{172}$

Uma intervenção de maior impacto foi a reforma do jardim de esculturas realizada em 1953, que marcou de modo permanente a identidade do MoмA. Batizado nessa ocasião com o nome de uma das fundadoras que havia falecido recentemente, o Abby Aldrich Rockefeller Sculpture Garden logo passou a ser considerado "o coração do museu" ${ }^{173}$ tendo preservadas suas principais características nas diversas expansões que transformariam o edifício futuramente.

Johnson herdara da configuração anterior as bases de um jardim moderno, concebido por Alfred Barr e John McAndrew como uma galeria de arte a céu aberto, que, como vimos, favorecia a percepção individualizada das esculturas. A partir daí, o novo projeto acentuou as referências miesianas - tanto no rigor geométrico do desenho quanto no modo de insta-
1.111 Expansão a oeste do edifício do MoMA (Grace Rainey Rogers Annex), projeto de Philip Johnson de 1950, Nova York, 1953. Fonte: https://fluxusnine.wordpress.com/ about/

1.112 Jardim de esculturas do MoMA (Abby Aldrich Rockefeller Sculpture Garden), projeto de Philip Johnson, Nova York, 1953. Fonte: https:// www.archdaily.com/430903/ ad-classics-the-museum-of-modernart/523b20e9e8e44eef79000245-adclassics-the-museum-of-modern-artimage?next_project=no

1.113 The Glass House, projeto de Phillip Johnson de 1949, New Canaan, Connecticut, 1984. Foto: Pedro E.Guerrero. Fonte: https://www.artsy.net/artwork/ pedro-e-guerrero-the-glass-house-newcanaan-connecticut-phillip-johnsonarchitect

171 Johnson era um grande admirador de Mies van der Rohe, tendo promovido o arquiteto no museu desde a exposição coletiva Modern architecture: international exhibition, que lançara o International Style nos EUA em 1932, e ainda concedido a ele uma exposição individual, Mies van der Rohe, em 1947.

172 Não foram encontradas informações referentes ao programa dessa nova ala oeste projetada por Johnson (que seria demolida nos anos 1980). Plantas de projetos expográficos dos anos 1950 mostram que uma pequena área nos fundos do piso térreo, voltada para o jardim, abrigava exposições.

173 REED, Peter; SILVER-HOHN, Romy. Oasis in the City: The Abby Aldrich Rockefeller Sculpture Garden at The Museum of Modern Art. Nova York: The Museum of Modern Art, 2018, p. 10.

\section{2-143}


174 Johnson tinha profunda admiração por Mies van der Rohe, tendo, como curador do Departamento de Arquitetura e Design do мома, incluído diversas de suas obras em mostras do museu e organizado uma exposição exclusivamente dedicada ao arquiteto em 1947. Além disso, Johnson foi seu associado na elaboração do projeto do Seagram Building, construído em Nova York entre 1954 e 1958.

175 BENES, op. cit., p. 16. lar obras de arte em espaços arquitetônicos -, que já vinham sendo adotadas por Johnson em seus projetos de residências particulares. Sua própria casa estava entre elas - a chamada Glass House, construída num grande terreno em New Canaan em 1949, inspirada no projeto de 1945 de Mies van der Rohe para a Farnsworth House, ainda em construção nessa época, na cidade estadunidense de Plano, e concluída apenas em 1951. ${ }^{174}$

Como afirmou Benes, na época em que participou da curadoria da exposição International Style, o arquiteto compartilhava com Hitchcock a visão de jardins como "parte da arquitetura" e de paisagem como "natureza intocada". Ao iniciar sua própria carreira como arquiteto, no entanto, o interesse de Johnson teria se deslocado para os jardins pavimentados, bem como para o modelo da piazza italiana que povoava os debates da época sobre espaços cívicos e vida urbana moderna. ${ }^{175}$ Entre as múltiplas referências do novo projeto, compareciam ainda os jardins japoneses, evocados pelo ambiente abstrato e formalmente estilizado, integrando elementos naturais e construídos. O que ficou para trás na reestruturação do jardim foram as formas orgânicas que Barr e McAndrew haviam tomado emprestadas do Surrealismo e dos projetos de Aalto e Burle Marx, em favor de uma organização estritamente retilínea.

Johnson estruturou seu projeto a partir de uma grelha retangular marcada no piso pavimentado com placas de mármore, o mesmo material da fachada do edifício. O espaço externo foi organizado por uma grande área definida por um retângulo perfeito, instalada numa cota rebaixada com relação ao térreo do museu e limitada por uma estreita faixa em talude com vegetação rasteira nas bordas sul e oeste, além das quais um terraço em "L" fazia a transição com o edifício. A cota baixa do jardim, visualmente aberta, foi subdividida em quatro zonas para exposição de obras e circulação de público pela presença de dois espelhos d'água longilíneos, posicionados de modo paralelo e defasado e atravessados por uma placa de mármore, e por alguns agrupamentos de árvores, plantadas em canteiros definidos pela subtração de placas regulares do piso.

Apesar de configurado simultaneamente como um jardim modernista e um pátio urbano pavimentado, como apontou Benes, o espaço nunca foi propriamente público, não tendo 


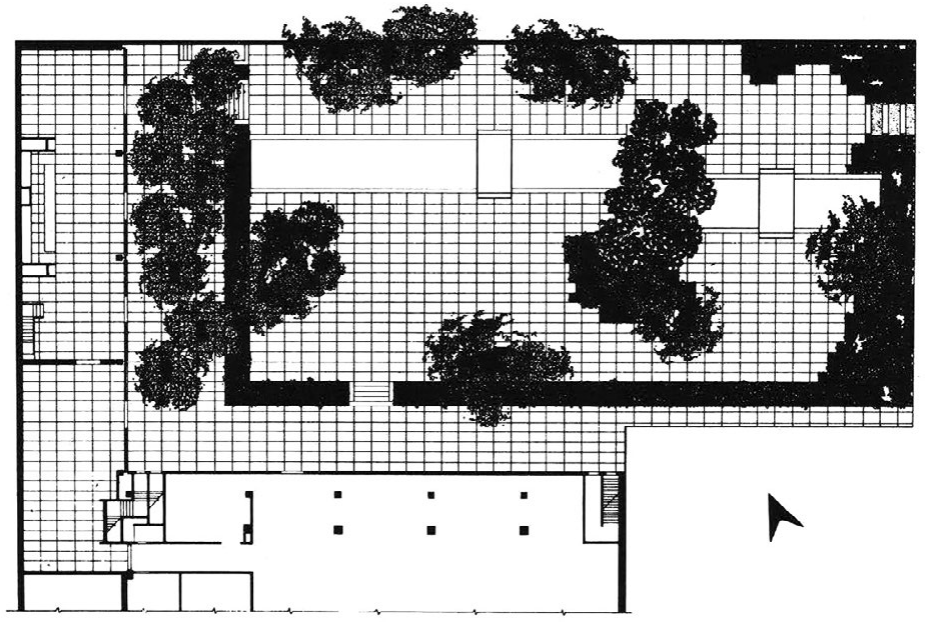

conexão nem mesmo visual com a calçada, dado o muro alto de tijolos na face da rua 54. Esse isolamento garantiu que o jardim permanecesse um refúgio no contexto agitado de Manhattan, como era o desejo dos conselheiros do MomA desde a construção da sede de 1939. Ainda que ao ar livre, a condição do jardim seguia preceitos similares aos das salas expositivas internas, os de uma galeria ambientada de modo discreto - com organização geométrica, pavimentação de mármore e vegetação mínima -, concebida para dar destaque principal às esculturas, dispostas de modo isolado para serem apreciadas individualmente.

O jardim foi reinaugurado em 1953 com a exposição Sculpture of the $x x$ th Century, com curadoria de Andrew Carnduff Ritchie (1907-1978), ocupando ainda as galerias adjacentes do térreo. Segundo divulgado no memorial à imprensa, a mostra tinha a ambição de "oferecer uma visão o mais abrangente possível da escultura do século xx em toda a sua riqueza e variedade de expressão", ${ }^{176}$ com 103 esculturas de artistas europeus e estadunidense, desde Rodin até a produção recente. As duas únicas fotos disponíveis do jardim nos arquivos da exposição mostram diversas esculturas posicionadas distantes umas das outras, algumas em locais estratégicos, como a de Aristides Maillol, The River (1938-39, completada em 1943) - posicionada na borda de um dos espelhos d 'água -, a de Gaston Lachaise,
1.114 Planta do jardim de esculturas do MoMA (Abby Aldrich Rockefeller Sculpture Garden), projeto de Philip Johnson, Nova York, 1953. Fonte: BENES, p. 17.
176 Press release in: THe Museum OF MODERn ART. Sculpture of the xxth Century (Apr 28-Sep 7, 1953). MOMA. Disponível em: <https:// www.moma.org/calendar/exhibitions $/ 2822$ ?locale $=p t>$. Acesso em: 21 mar. 2020, p.1. Tradução nossa. 

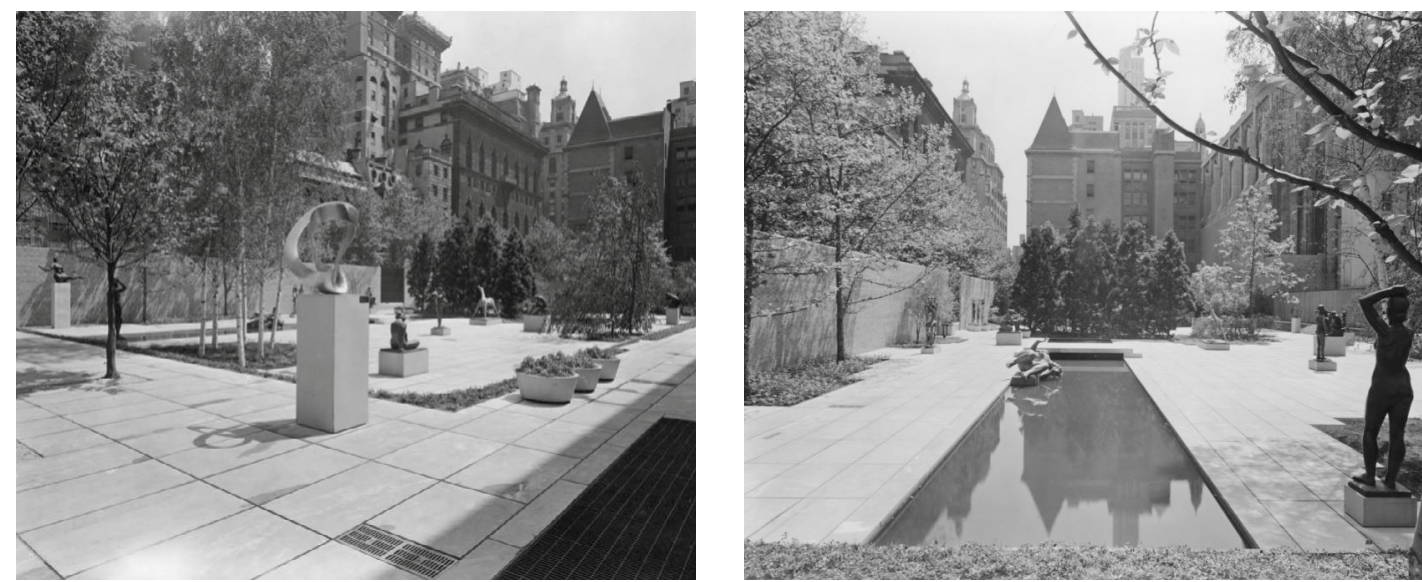

1.115 e 1.116 Vistas da exposição Sculpture of the XXth Century, MoMA, Nova York, 1953. Foto: Soichi Sunami. Fonte: https://www.moma.org/calendar/ exhibitions/2822

1.117 Plantas do projeto expográfico de Sculpture of the XXth Century, MoMA, Nova York, 1953. Desenho nosso. baseado em material de arquivo do MoMA.

177 Ibidem.

Floating Figure (1917) - com o muro de tijolos ao fundo - ou a de Max Bill, Tripartite Unity (1947-48) - isolada no meio do pátio.

No memorial à imprensa, consta ainda que "as cores usadas nas paredes da galeria foram escolhidas para refletir as cores do jardim - cinza, azul e verde suave - para que as seções interna e externa da exposição se tornem ainda mais estreitamente relacionadas". ${ }^{177}$ As plantas expositivas e as fotos da área interna confirmam a intenção de continuidade, mostrando que a galeria não foi tão subdividida quanto em outras montagens, mantendo certa fluidez entre as salas, sendo que apenas uma delas não tinha conexão visual com o exterior.

Observando as fotos, entretanto, chama a atenção um aspecto da arquitetura que gera uma sutil impressão de descontinuidade na exposição: a essa altura, cada setor do museu tinha um revestimento de piso distinto - o hall de entrada com placas cimentícias polidas de fundo preto pontilhado de branco (originais do projeto), as galerias expositivas a leste com placas vinílicas pretas rajadas de branco (possivelmente instalado sobre o piso cimentício monolítico original), a galeria mais recente a oeste com placas cimentícias de cor cinza claro pontilhado de branco e o jardim com mármore cinza rajado -, anunciando o aspecto de "colcha de retalhos" que o MOMA viria a adquirir com a somatória de ampliações e reformas subsequentes. 


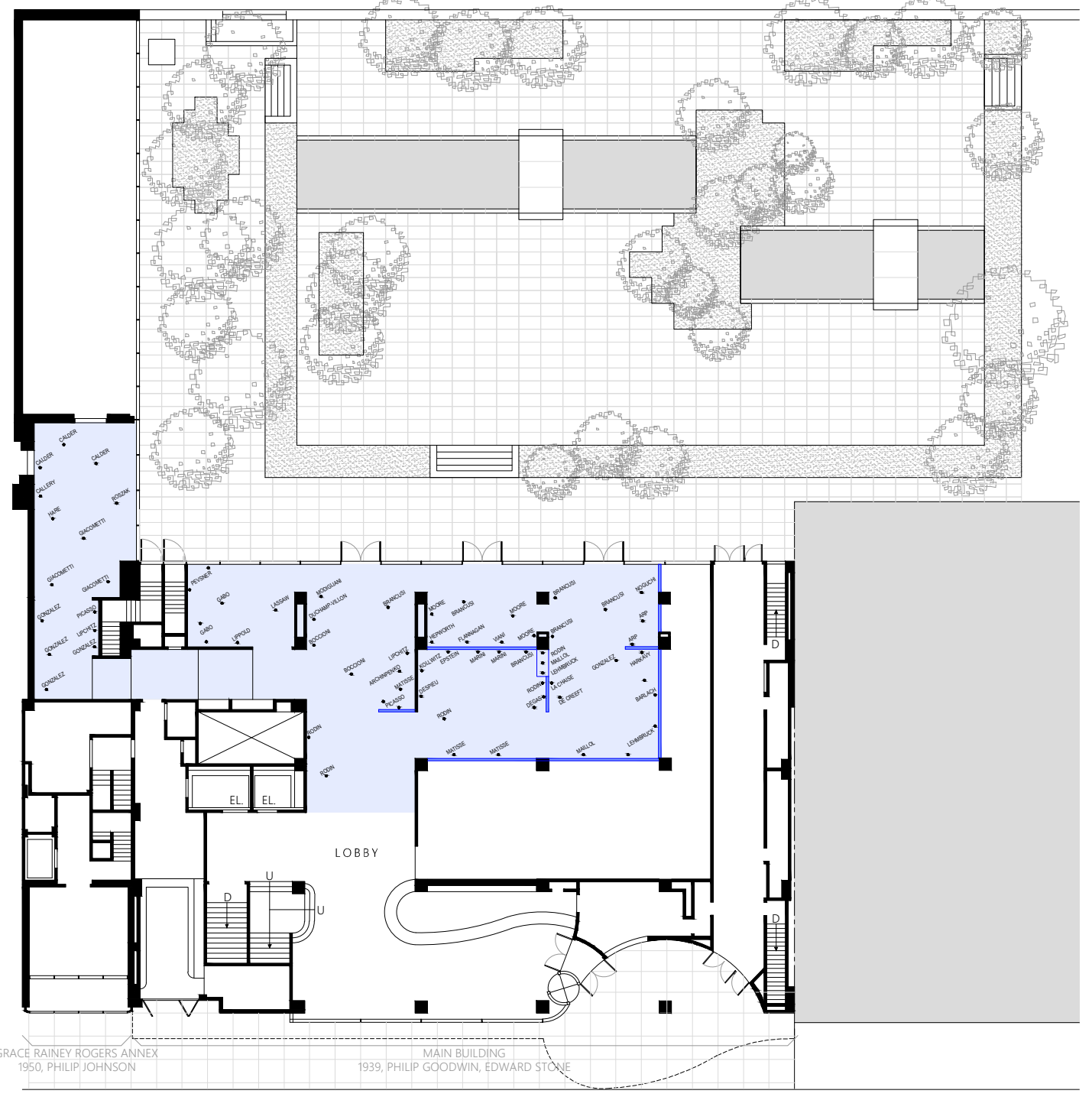

SCULPTURE OF THE XXTh CENTURY, MOMA NY, 1953

EXHIBITION LAYOUT - FIRST FLOOR

[LAYOUT EXPOSITIVO - TÉRREO] 

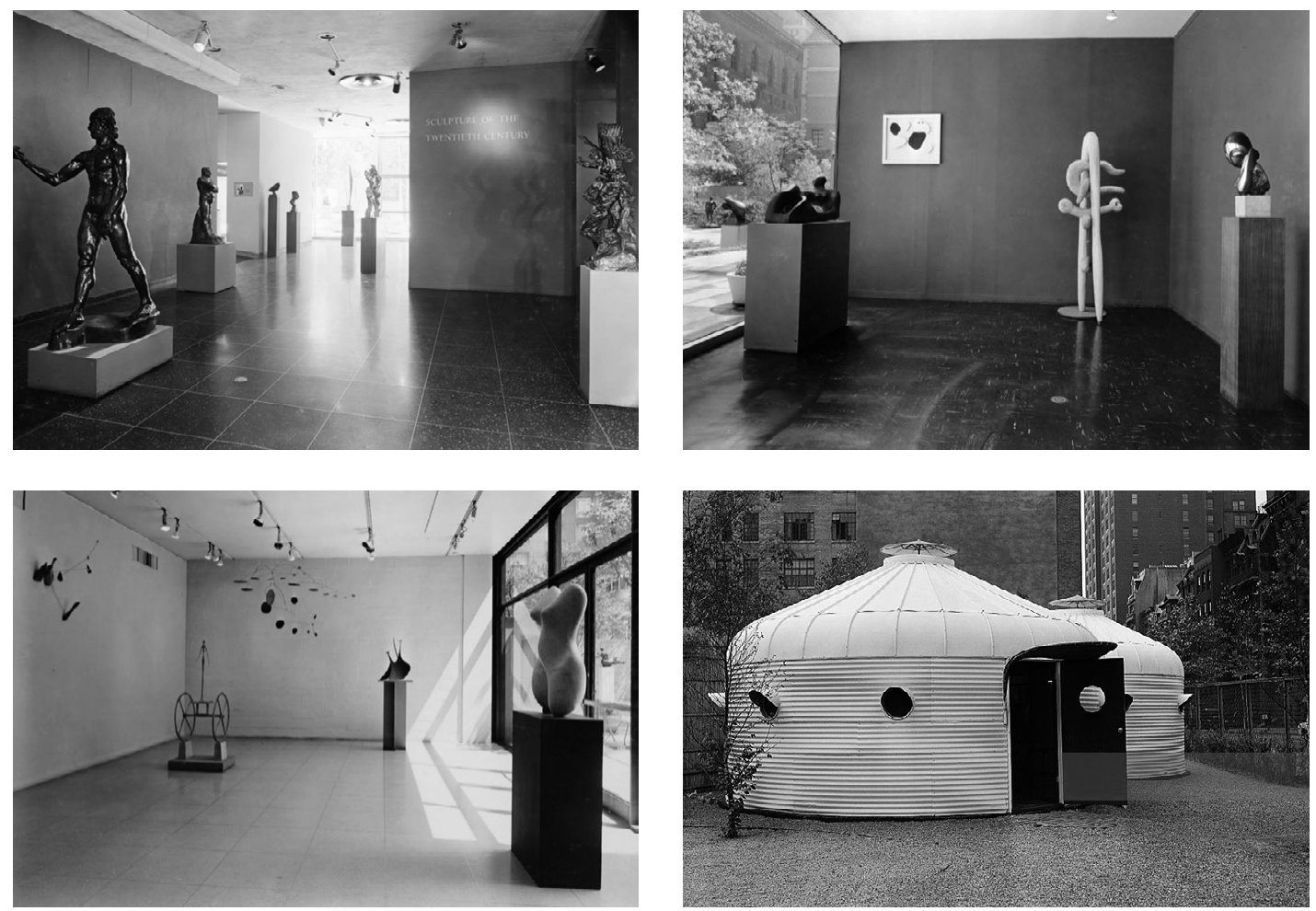

1.118 a 1.120 Vistas da exposição

Sculpture of the XXth Century, MoMA, Nova York, 1953. Foto: Soichi Sunami. Fonte: https://www.moma.org/calendar/ exhibitions/2822

1.121 Vista da exposição Buckminster Fuller's Dymaxion Deployment Unit, MoMA, Nova York, 1941-42. Foto: Bettmann. Fonte: https://www.gettyimages.com.br/ detail/foto-jornal\%C3\%ADstica/new-yorkny-view-of-the-dymaxion-deployment-unita-foto-jornal\%C3\%ADstica/517446346

1.122 Vista da exposição The House in the Museum Garden, MoMA, Nova York, 1949. Foto: Ezra Stoller. Fonte: https://www. moma.org/calendar/exhibitions/3251

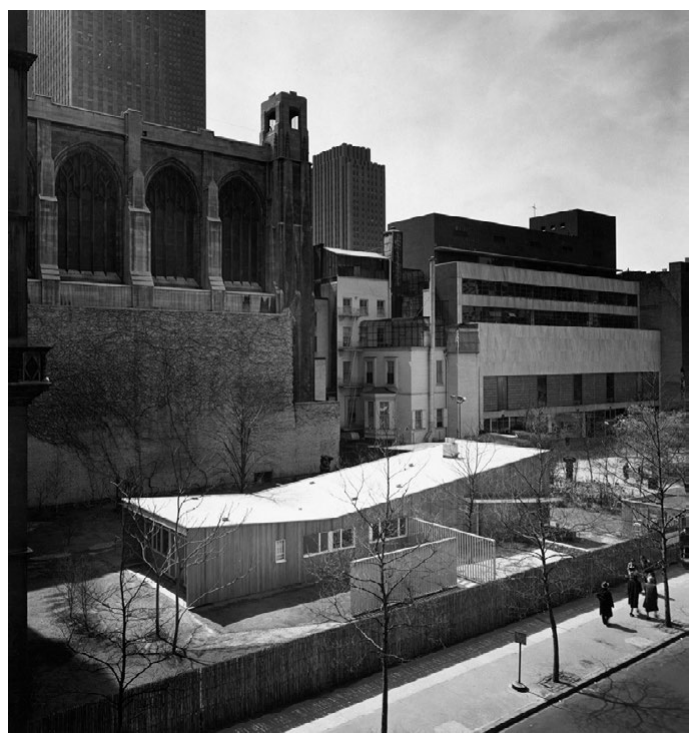




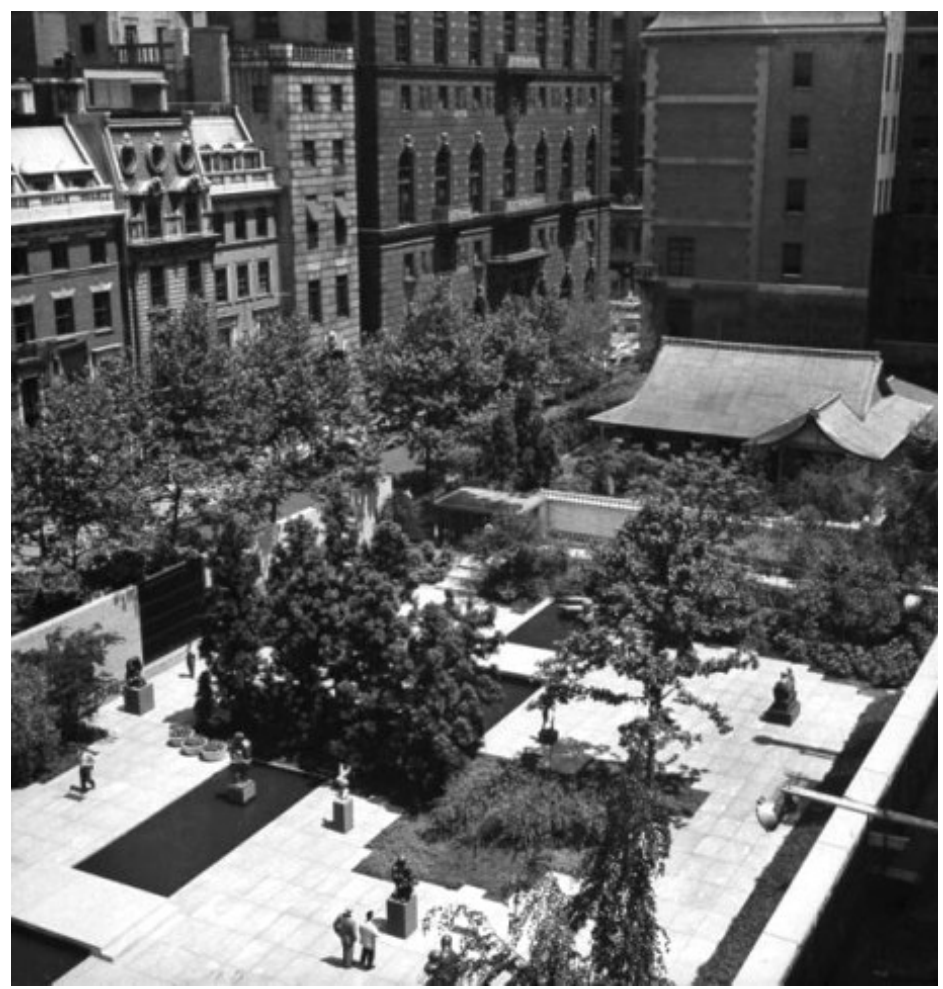

Mantendo-se praticamente intacto enquanto o edifício se transformava ao seu redor, o jardim continuaria abrigando não apenas exposições de esculturas, mas também de arquitetura em escala real, como já vinha acontecendo desde muito cedo com mostras como a de Buckminster Fuller, Dymaxion Deployment Unit, de 1941, contendo uma unidade de rápida, ${ }^{178}$ e a de Marcel Breuer, The House in the Museum Garden, de 1949, apresentando o protótipo de casa econômica. ${ }^{179} \mathrm{~A}$ primeira exposição dessa série realizada com grande sucesso no novo jardim foi Japanese Exhibition House, de 1954, que remontou um pavilhão construído no Japão, desenhado pelo arquiteto Junzo Yoshimura e baseado nos padrões de construção tradicionais daquele país dos séculos XVI e XVII. ${ }^{180}$
1.123 Vista da exposição Japanese Exhibition House, MoMA, Nova York, 1954. Foto: Michael Rougier/LIFE. Fonte: https:// www.architectmagazine.com/design/ how-moma-gets-it-right-with-a-japaneseconstellation_0

178 A mostra foi organizada pelo Departamento de Arquitetura e Desenho Industrial no contexto da II Guerra Mundial, mostrando um modelo de construção para ser usado como "local de defesa, abrigo de evacuação, barracas do exército, ou, em tempos de paz, como uma casa de praia para convidados. "Tradução nossa. Cf. Press release in: THE MusEuM OF MODERN ART. Buckminster Fuller's Dymaxion Deployment Unit (Oct 10, 1941-Apr 1, 1942). MOMA. Disponível em: < https:// www.moma.org/calendar/exhibitions/3015? locale $=$ pt $>$. Acesso em: 26 mar. 2020, n.p.. Tradução nossa.

179 Exposição organizada por Peter Blake, então curador de Arquitetura e Design do MoмA. Cf. The Museum of Modern ART. The House in the Museum Garden (Apr 12-Oct 30, 1949). MOMA. Disponível em: <https:// www.moma.org/calendar/exhibitions $/ 3251$ ? locale $=\mathrm{pt}>$. Acesso em: 26 mar. 2020.

180 Exposição organizada por Arthur Drexler, então curador de Arquitetura e Design do мома. Cf. The Museum of Modern ART. Japanese Exhibition House (Jun 16, 1954-Oct 15, 1955). МОмА. Disponível em: $<$ https://www. moma.org/calendar/exhibitions/2711? locale=pt $>$. Acesso em: 23 mar. 2020. 
1.124 Cerimônia de abertura das comemorações do 250 aniversário do MoMA, em conexão com a exposição XXVth Anniversary Exhibitions: Paintings from the Museum Collection, Nova York, 19 de outubro de 1954. Foto: Barry Kramer. Fonte: https://www.moma.org/calendar/ exhibitions $/ 2800$
181 A data de 1953 é apontada por STANISZEWSKI, op. cit, p. 292, enquanto no Press release da exposição xxvth Anniversary Exhibition: Paintings from the Museum Collection é mencionado que a decisão de constituir um acervo permanente foi tomada em 1952. Cf. Press Release in: THE Museum of MODERN ART. XXvth Anniversary Exhibition: Paintings from the Museum Collection (Oct 19, 1954-Feb 6, 1955). момA. Disponível em: <https://www. moma.org/calendar/exhibitions $/ 2800$ ?locale $=p t>$. Acesso em: 26 mar. 2020.

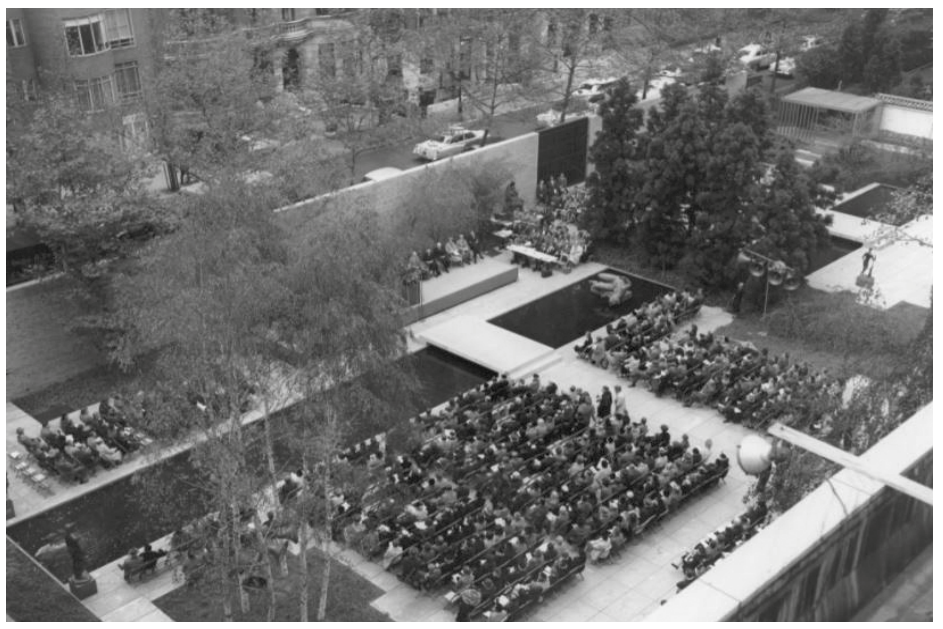

\subsubsection{A VALORIZAÇÃO DA COLEÇÃO}

O novo jardim havia sido inaugurado na época em que dois movimentos aconteciam simultaneamente no museu. De um lado fortalecia-se o programa de exposições temporárias, incluindo apresentações de diversificadas leituras da arte moderna e novas produções de artistas contemporâneos, e de outro intensificava-se a demanda por dar mais visibilidade ao seu acervo. Em 1953, o conselho tomou uma decisão que impactaria de modo profundo o perfil institucional do MOMA: o de conferir à sua coleção um caráter permanente, abandonando a prática de transferir obras mais antigas para outras instituições - como o Metropolitan -, e de fortalecer a política de aquisição, com vistas a constituir um panorama o mais completo possível da arte moderna, abrangendo desde mestres europeus do século XIX até artistas da contemporaneidade e de diversas nacionalidades. ${ }^{181}$

Prevalecia, afinal, a ideia de um museu de arte moderna atuando em ambas as direções, como defendido desde o início por Barr, que em 1954 organizou com Miller a maior exposição da coleção realizada até então no museu, xxvth Anniversary Exhibition: Paintings from the Museum Collection, ocupando as galerias dos três pavimentos com aproximada- 


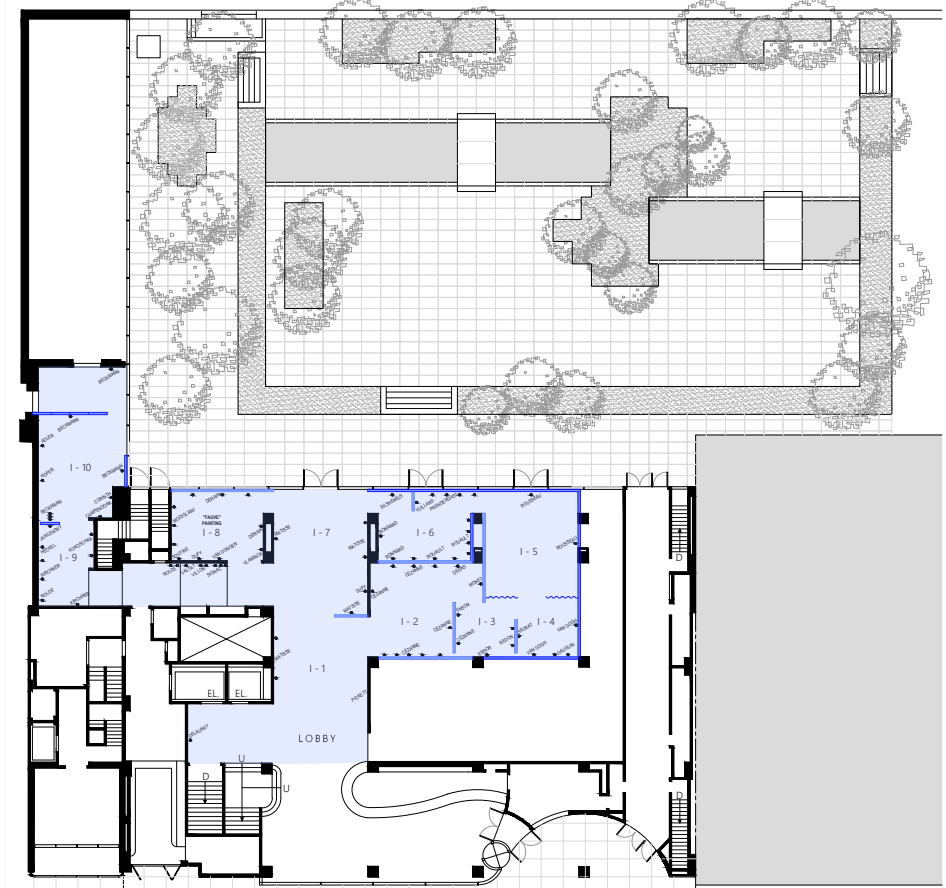

1.125 Plantas do projeto expográfico de XXVth Anniversary Exhibitions: Paintings from the Museum Collection, MoMA, Nova York, 1954-55. Desenhos nossos baseados em material de arquivo do MoMA.
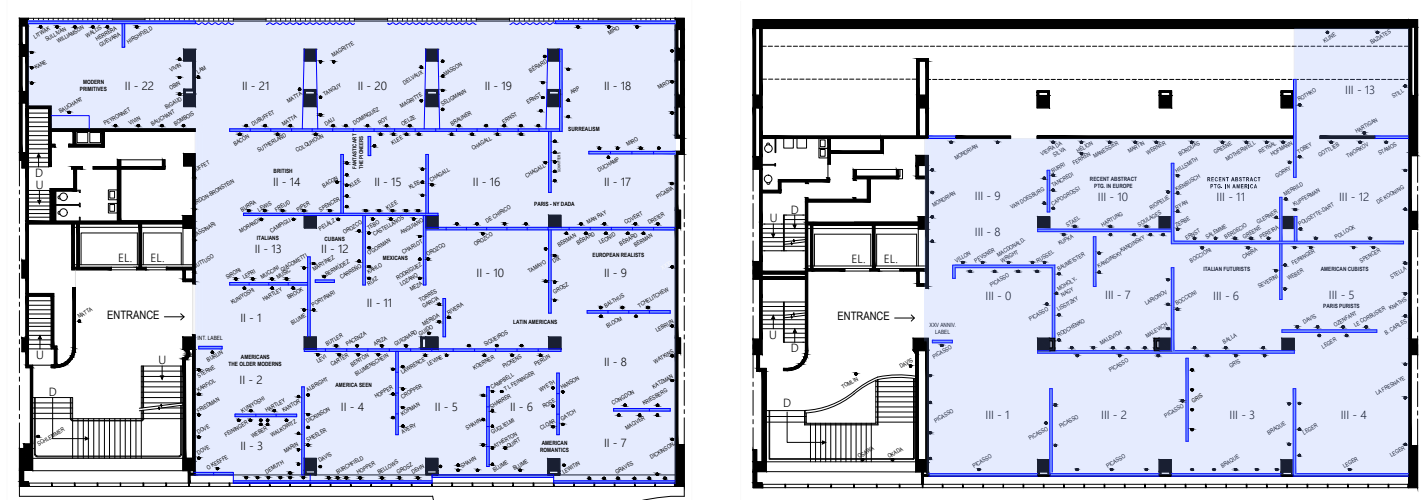

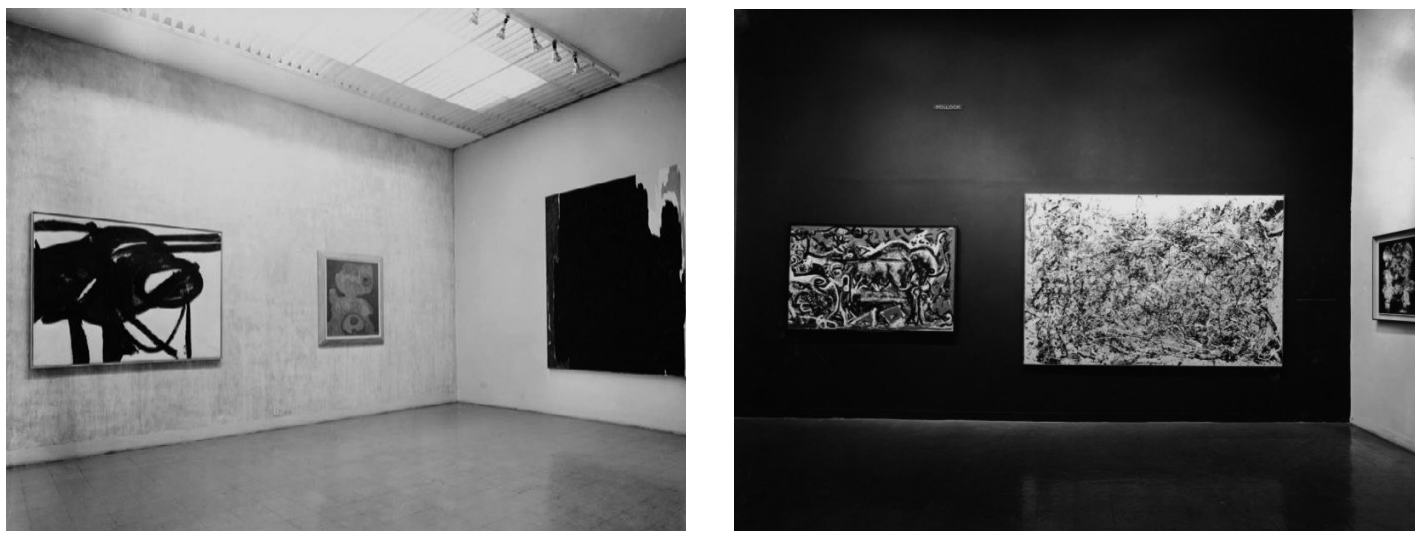

1.126 Franz Kline, Chief (1950), à esquerda e Clyfford Still, 1951-T No. 3 (1951), à direita, no 30 andar da exposição XXVth Anniversary Exhibitions: Paintings from the Museum Collection, MoMA, Nova York, 1954-55. Foto: Soichi Sunami. Fonte: https://www.moma.org/calendar/ exhibitions/2800

1.127 Jackson Pollock, The She-Wolf, 1943 (esquerda) e Number $1 A, 1948$ (direita) no 30 andar da exposição XXVth Anniversary Exhibitions: Paintings from the Museum Collection, MoMA, Nova York, 1954-55.Foto: Soichi Sunami. Fonte: https://www.moma.org/calendar/ exhibitions/2800

182 Ibidem.

183 Alguns desenhos indicam que os painéis eram modulares, provavelmente para serem relocados em diversas montagens, o que se verifica também em algumas fotografias que mostram sutis marcas verticais nas juntas entre eles. Cf. THE Museum OF MODERN ART ARCHIVEs, Planta do projeto expográfico de XXVth Anniversary Exhibition: Paintings from the Museum Collection, 1954. mente um terço da coleção de pinturas. Como informado no memorial à imprensa, que enaltecia a qualidade e a amplitude do acervo:

É a primeira vez em sua história que tantas galerias do museu são dedicadas a pinturas de sua própria coleção, que comumente é considerada a mais abrangente do mundo. A coleção inclui obras de arte dos Estados Unidos e Canadá, Europa, Ásia e América Latina que datam de 1875 até o presente. Na exposição atual, pinturas dos mestres do final do século xıx e alguns dos pintores pré-cubistas que ganharam fama no início do século xx estão apresentadas no primeiro andar. Pinturas expressionistas, realistas e fantásticas produzidas a partir de 1910 ocupam o segundo andar, e pinturas cubistas e abstratas, americanas e europeias do mesmo período, são expostas no terceiro andar. ${ }^{182}$

Observando as plantas expográficas da mostra, vemos uma subdivisão intensiva das galerias do segundo e terceiro pavimentos com painéis provisórios, criando salas com obras agrupadas por afinidade estética, cujo percurso sequencial relativamente cronológico culminava no núcleo Recent Abstract Paintings in America, o ápice da narrativa. ${ }^{183}$ Tal modo de dispor as obras viria a ser praticado à exaustão nas exposições do cada vez mais robusto e prestigioso acervo do MомA, 
permanentemente enriquecido com obras produzidas desde final do século XIX até as mais contemporâneas, ajudando a consolidar a visão "canônica" da arte moderna por mais algumas décadas.

Apesar da abrangência, xxvth Anniversary Exhibition era uma mostra temporária e, após a sua conclusão, a maior parte do acervo, incluindo as estrelas da coleção, voltaria aos depósitos até uma próxima exposição, a depender de recortes curatoriais específicos. A situação perdurou até 1958, quando a coleção permanente do MомA passou a contar com uma galeria do segundo pavimento exclusivamente reservada para sua exposição, ${ }^{184} \mathrm{o}$ que permitiu que essa se tornasse não apenas conhecida do público, mas que ocupasse definitivamente o lugar de principal referência entre os museus de arte moderna. Foi um passo sem volta que gerou nova pressão sobre a área do edifício de Goodwin e Stone, insuficiente para abrigar as atividades do museu naquele estágio de seu desenvolvimento.

\subsubsection{A LEGITIMAÇÃO DO MODERNISMO ESTADUNIDENSE}

A consolidação do MOMA como centro vital da vida cultural de Nova York nos anos 1950 ocorreu simultaneamente ao aprofundamento dos vínculos do museu com a produção de vanguarda dos artistas da cidade, que passaram a comparecer com peso progressivamente maior nas exposições do Departamento de Pintura e Escultura, dirigido entre 1949 e 1957 por Ritchie. A mostra Abstract Painting and Sculpture in America, organizada por ele em 1951, apresentava mais de 100 obras de 85 artistas dos EUA produzidas desde o momento imediatamente anterior à célebre exposição The Armory Show de 1913 até o período recente. ${ }^{185}$

A produção estadunidense contemporânea, por sua vez, continuava recebendo foco especial na série de curadorias de Dorothy Miller, que em 1952 organizou a exposição Fifteen Americans. Com 100 obras da primeira geração de 15 dos artistas ligados ao Expressionismo Abstrato, como Jackson Pollock, Mark Rothko, Clifford Still, William Baziotes e Brasley Walker Tomlin, ${ }^{186}$ a exposição conferiu, segundo Hunter, "um selo de
184 STANiszeWski, op. cit., p, 292. Curiosamente, a página dedicada a essa exposição no site do MomA não mostra fotos da montagem. Cf. THE Museum OF MODERN ART. Second Floor Permanent Collection (Oct 8, 1958). MoMA. Disponível em: $<$ https:// www.moma.org/calendar/exhibitions $/ 2858$ ? locale $=$ pt $>$. Acesso em: 26 mar. 2020.

185 Cf. The Museum of Modern ART. Abstract Painting and Sculpture in America (Jan 23-Mar 25, 1951). MOMA. Disponível em: $<$ https://www.moma.org/calendar/exhibitions/1989?locale $=\mathrm{pt}>$. Acesso em: 8 mar. 2020.

186 Os demais artistas eram Edward Corbet, Frederick Kiesler, Herbert Ferber, Richard Lippold, Thomas Wilfred, Joseph Glasco, Irving Kriesberg, Herbert Katzman, Herman Rose e Edwin Dickinson. Cf. The Museum of Modern ART. Fifteen Americans (Apr 9-Jul 27, 1952). МОМА. Disponível em: $<$ https://www.moma.org/calendar/exhibitions/3294?locale $=\mathrm{pt}>$. Acesso em: 8 mar. 2020. 

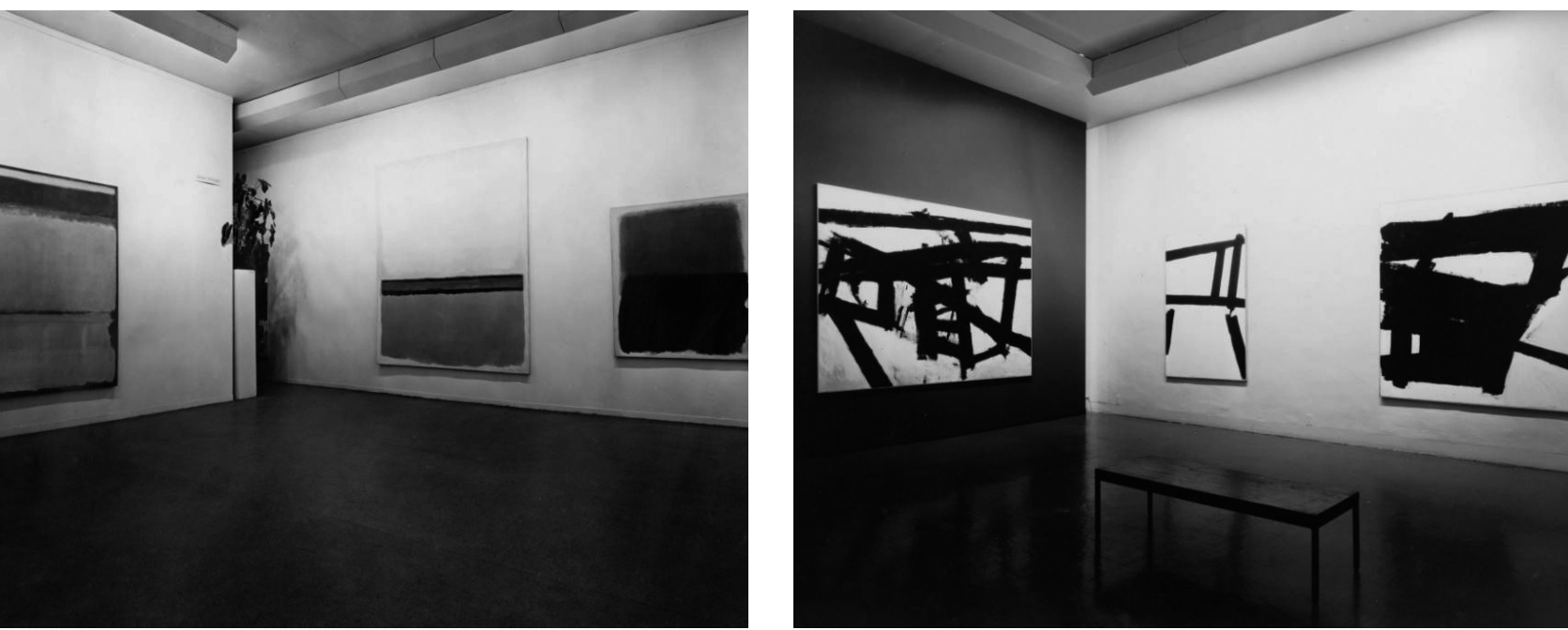

1.128 Vista da exposição Fifteen Americans, MoMA, Nova York, 1952. Foto: Soichi Sunami. Fonte: https://www.moma.org/ calendar/exhibitions/3294

1.129 Vista da exposição Twelve Americans, MoMA, Nova York, 1956. Foto: Soichi Sunami. Fonte: https://www.moma.org/ calendar/exhibitions/3331

187 HunTER, op. cit., p. 23.

Tradução nossa.

188 Entre os pintores estavam Smest Briggs, James Brooks, Sam Francis, Fritz Glarner, Philip Guston, Grace Hartigan, Franz Kline, e Larry Rivers e entre os escultores Hague, Ibram Lassaw, Seymour Lipton e Jose de Rivera. Cf. The Museum of Modern ArT. Twelve Americans (May 30-Sep 8, 1956). момА. Disponível em: <https:/www.moma.org/calendar/ exhibitions $/ 3331$ ?locale $=p t>$. Acesso em: 20 mar. 2020. aprovação" a essa produção. ${ }^{187}$ Em 1956, a série prosseguiu com Twelve Americans, mostrando go obras de oito pintores e quatro escultores. ${ }^{188}$

Para a discussão desta tese, é importante observar que, embora apresentassem obras que viriam a marcar um momento de fronteira da arte estadunidense, essas mostras organizadas por Miller não traziam novidades significativas na ambientação dos espaços expositivos e não ofereciam, nesse sentido, pistas sobre a radicalidade de parte dessa produção. Ao contrário, o padrão de montagem, que permaneceu constante ao longo da série, seguiu o ascetismo que Barr desenvolvera desde as primeiras mostras de arte no момА, pontualmente suavizado por variações de tonalidade das paredes de fundo das pinturas e por um maior distanciamento lateral entre as obras de grandes dimensões. O fato de pinturas de artistas agrupados sob o rótulo do Expressionismo Abstrato serem expostas no museu do modo convencionalmente empregado para pinturas modernas de cavalete - fixadas verticalmente nas paredes à altura dos olhos - reforçava ainda um dos lados da crítica a respeito dessas obras, o que valorizava sua condição de autonomia e seu lugar na linhagem da pintura modernista. Tal era o ponto de vista da crítica formalista, 
liderada por Clement Greenberg, segundo o qual o grande interesse dessas pinturas estaria em seu aspecto "planar", obtido com a aplicação "all over" de tinta sobre a tela e resultando na radical eliminação da ilusão de profundidade. ${ }^{189}$

De acordo com uma outra perspectiva, a da visão anti-formalista do crítico Harold Rosenberg (1906-1978), a principal contribuição das obras desse grupo de artistas estaria menos em suas qualidades enquanto pintura do que no fato de deslocarem a atenção para o gesto corporal que as produzia - em Pollock, o respingar da tinta sobre a tela disposta na horizontal sobre o piso -, daí que o autor tenha se referido a elas como "action painting" ${ }^{190} \mathrm{O}$ próprio Pollock assumia seu distanciamento com relação à pintura de cavalete, descrevendo seu envolvimento tanto corporal quanto mental com o fazer da obra como uma espécie de transe, essencial para a sua realização, como vemos em seu depoimento de 1947:

Minha pintura não vem do cavalete. Quase nunca estico minha tela antes de pintar. Eu prefiro pregar a tela não esticada na parede dura ou no chão. Preciso da resistência de uma superfície dura. No chão fico mais à vontade. Sinto-me mais perto, mais parte da pintura, pois assim consigo contorná-la, trabalhar pelos quatro lados e literalmente estar dentro da pintura. Isso é semelhante ao método dos pintores de areia indígenas do Oeste.

Continuo me afastando mais das ferramentas usuais do pintor, como cavalete, paleta, pincéis, etc. Prefiro bastões, espátulas, facas e tinta gotejante ou um empasto pesado com areia, vidros quebrados e outros materiais estranhos adicionados.

Quando estou dentro da minha pintura, não tenho consciência do que estou fazendo. Só depois de um período de familiarização é que vejo o que aconteceu. Não tenho medo de fazer mudanças, destruir a imagem etc, porque a pintura tem vida própria. Só quando perco o contato com a pintura é que o resultado é uma bagunça, senão há harmonia pura, um dar e receber fácil, e a pintura sai bem. ${ }^{191}$

O texto foi republicado nas páginas finais do catálogo produzido pelo момA na ocasião na mostra Jackson Pollock, orga-

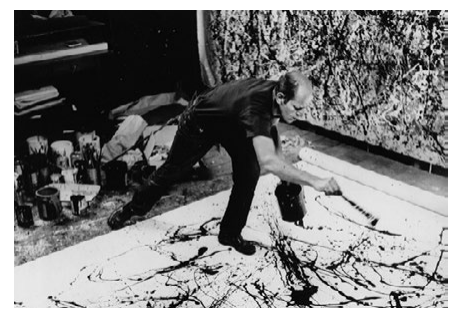

1.130 Foto do catálogo da exposição Jackson Pollock com a legenda "Jackson Pollock pintando Number 32 no verão de 1950, em seu estúdio em Springs, Long Island. Ao fundo está One, pintado no mesmo período". Tradução nossa. Foto: Hans Namuth. Fonte: HUNTER, 1956, pp. 1-2.
189 O ensaio “'American-Type' Painting”, de Clement Greenberg, foi publicado pela primeira vez em 1955, na Partisan Review, e foi incluído na coletânea de ensaios Art and Culture em 1955, tendo sido traduzido para o português como "Pintura 'de tipo americano". Cf. Greenberg, Clement. Arte e Cultura. São Paulo: Editora Ática, 1996, p. 214-233.

190 O ensaio "The American Action Painters", de Harold Rosenberg, foi publicado pela primeira vez em 1952 na revista Art News, tendo sido traduzido para o português como "Os Action Painters NorteAmericanos". Cf. RosenberG, Harold. A tradição do novo. São Paulo: Perspectiva, 1974, p. 11-22.

191 PoLlOCK, Jackson apud HUNTER, Samuel. Jackson Pollock. Nova York: The Museum of Modern Art, 1956, p. 33. Tradução nossa. 

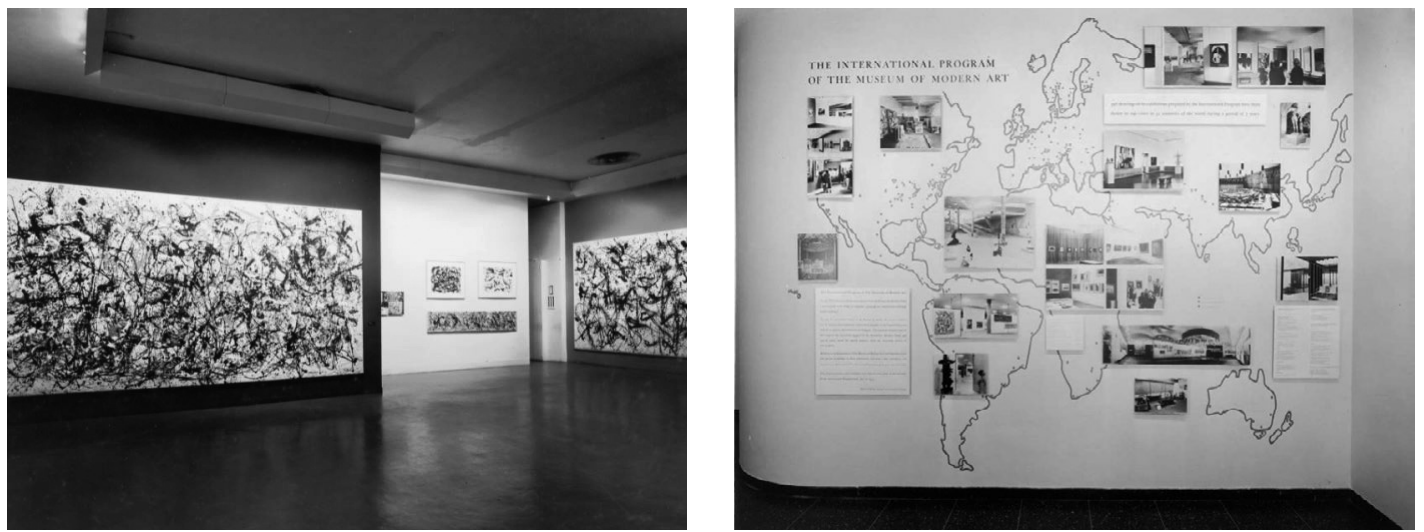

192 The Museum of Modern Art. Jackson Pollock (Dec 19, 1956-Feb 3, 1957). МОМА. Disponível em: $<$ https://www.moma.org/calendar/ exhibitions/1926?locale $=\mathrm{pt}>$. Acesso em: 8 mar. 2020.

193 A exposição Jackson Pollock deu início a uma série de mini-retrospectivas de artistas em meio de carreira realizadas pelo MOMA entre 1956 e 1957. Outras mostras da série foram dedicadas aos trabalhos de Balthus, Matta e David Smith. Cf. HunTER, op. cit., p. 26.

194 A legenda informa: "Jackson Pollock painting Number 32 in the summer of 1950 at his Springs, Long Island studio. In the background is One, painted during the same period. Photo Hans Namuth". HunTER, 1956, op. cit., pp. 1-2. nizada pelo próprio Hunter em 1956 - ${ }^{192}$ a primeira grande exposição realizada num museu com obras do artista, falecido havia poucos meses, e que, nos anos recentes, tinha passado de alvo de ridicularização pela imprensa a expoente máximo da arte estadunidense. ${ }^{193}$ A mostra contava com 35 pinturas e algumas aquarelas e desenhos produzidos entre 1938 e 1956, expostas comportadamente nas paredes das galerias consecutivas. Os registros fotográficos da montagem disponíveis no website do museu não permitem identificar se havia no espaço expositivo uma imagem que registrasse o processo de trabalho de Pollock - como a fotografia do artista "em ação" estampada no início do catálogo - ${ }^{194}$ que ofereceriam aos visitantes um entendimento do caráter performático dessas obras, produzidas de modo diverso de outras tantas pinturas expostas no museu. $\mathrm{O}$ que podemos identificar nas fotos em preto e branco são obras dispostas em paredes majoritariamente em tom claro, entre algumas de tonalidade escura. Como vimos anteriormente, tal expediente era usado também de modo pontual para ambientar obras do Surrealismo, uma das referências da arte associadas a Pollock, ao lado do Cubismo de Picasso e da arte muralista mexicana. Explícito nos textos do catálogo, esse vínculo com a tradição da pintura modernista europeia fazia-se presente, assim, de modo implícito na montagem expositiva. Para Hunter, no entanto, era importante enfatizar o descolamento dessas obras de certos aspectos do 
surrealismo, valorizando seu desenvolvimento em direção a uma pura abstração:

Pollock e vários de seus contemporâneos foram rápidos em adaptar as estratégias surrealistas às suas próprias necessidades artísticas. Eles expurgaram o estilo de mistificação e o conteúdo literário e aplicaram sua qualidade de liberdade para reabilitar valores puramente pictóricos. Em suas mãos, os meios expressivos de pintura, em vez de ideias associadas, tornaram-se o conteúdo essencial da obra de arte. ${ }^{195}$

Além de poder ser apresentado como a produção de ponta da linhagem modernista, o Expressionismo Abstrato servia ainda como um emblema dos valores de liberdade individual apregoados pelos Estados Unidos, uma confirmação da superioridade cultural do país em tempos de Guerra Fria. Daí que, além de difundir a nova arte estadunidense para o público interno, о мома incluiu em seu programa de internacionalização exposições dedicadas a essa produção, como Douze peintres et sculpteurs américains contemporains, realizada em 1953 no Museu Nacional de Arte Moderna de Paris (MNAM), com curadoria de Ritchie. Em 1955, o museu francês recebeu também a mostra Cinquante ans d'art aux Etats-Unis: Collections du Museum of Modern Art New York, uma antologia organizada por Miller contendo produção dos EUA das últimos 5 décadas, que foi apresentada em outras cidades da Europa. ${ }^{196}$

As obras ligadas ao Expressionismo Abstrato foram apresentadas numa das grandes exposições internacionais entre 1958 e 59: The The New American Painting as Shown in Eight European Countries 1958-1959, contendo 81 obras de 17 artistas selecionadas por Miller, que foi recebida com grande entusiasmo pelas oito cidades por onde passou - Basileia, Milão, Madri, Berlim, Amsterdã, Bruxelas, Paris e Londres. ${ }^{197}$ A mostra terminou sua turnê no próprio MoMA, que afixou, na antessala da galeria, um grande painel mostrando o escopo completo do ambicioso programa de intercâmbio internacional, que contabilizava 461 montagens de 60 exposições realizadas em 51 países, compreendendo as disciplinas dos diversos departamentos do museu - pintura e escultura, arquitetura e design,
1.131 Vista da exposição Jackson Pollock, MoMA, Nova York, 1956. Foto: Soichi Sunami. Fonte: https://www.moma.org/ calendar/exhibitions/1926

1.132 Vista da exposição The New American Painting as shown in 8 European Countries 1958-1959. MoMA, Nova York, 1959. Foto: Soichi Sunami. Fonte: https://www. moma.org/calendar/exhibitions/1990
195 HuNTER, 1956, op. cit., p. 9. Tradução nossa.

196 Cf. Douze peintres et sculpteurs américains contemporains - Exposition au Palais de Tokyo (24 avril - 7 juin 1953): inauguration de l'exposition"; Cinquante ans d'art aux Etats-Unis - Exposition au Palais de Tokyo, Musée national d'art moderne (avril - mai 1955). In: CENTRE POMPIDOU, Expositions du Centre Pompidou: reportages en argentique (1953-2003). Archives et Documentation du Centre Pompidou. Disponível em: $<$ https://archivesetdocumentation. centrepompidou.fr/ead.html?id=FRM5050=-0031Xooooo74_\&cFRM5050-Xoo31_0000074_ FRM5050-ХoO3189786\#! \{\%2 2content\%22:[\%22FRM505 o-Xo031_oooo074_FRM5050Xoo3189523\%22,false, $\% 22 \% 22]\}>$. Acesso em: 30 maio 2021.

197 No MNAM de Paris, a mostra foi acompanhada de uma outra dedicada exclusivamente a Jackson Pollock. Cf. Jackson Pollock et la Nouvelle Peinture Américaine Exposition au Palais de Tokyo (16 janvier - 15 février 1959), in: CENTRE POMPIDOU, op. cit. 


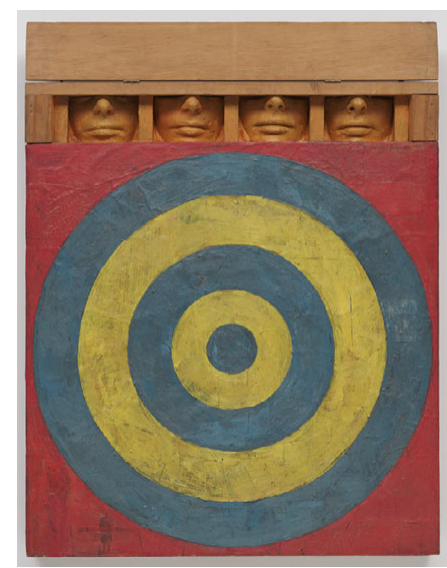

1.133 Jasper Johns, Target with Four Faces (1955). Fonte: https://www.moma.org/ collection/works/78393
198 Cf. The Museum of Modern ART. New American Painting as Shown in Eight European Countries 1958-1959 (May 28-Sep 8, 1959). МОмА. Disponível em: <https:/www.moma.org/calendar/ exhibitions/1990>. Acesso em: 20 mar. 2020.

199 Embora a promoção da produção do Expressionismo Abstrato tenha ficado muito associada a essas políticas, as exposições mais bem-sucedidas no exterior foram as de fotografia, filme e design, campos em que o EUA liderava. SANDLER, op. cit., p. 208.

200 Foster, Hal et al. Art Since 19oo: Modernism, Antimodernism, Postmodernism. Londres: Thames \& Hudson, 2004, p. 404. impressos, fotografias e filmes. ${ }^{198}$ The New American Painting expressava simultaneamente a influência do museu no cenário internacional e o prestígio adquirido pela arte estadunidense, marcando a posição central de Nova York no mundo das artes, que se sustentaria por mais algumas décadas. ${ }^{199}$

Estando na ordem do dia, o Expressionismo Abstrato tinha continuidade na obra de uma nova geração de artistas locais, que ficaram desapontados por não contaram com mesmo o apoio que Barr e Miller haviam dado à primeira geração da chamada Escola de Nova York. No final da década de 1950, um dos diversos caminhos experimentais da arte chamou especialmente a atenção de Barr, que foi rápido em adquirir para o museu quatro das seis pinturas expostas pelo então jovem artista Jasper Johns (1930-) em sua primeira exposição solo, realizada em 1958 na Galeria de Leo Castelli em Nova York. ${ }^{200}$

Ainda que museus e galerias continuassem expondo essas obras do modo convencional, artistas da nova geração a qual Johns pertencia estavam interessados em explorar a ideia da pintura como "arena de ação", seguindo a trilha aberta por Pollock. Exemplo disso são as assemblages de Johns e as combine-paintings de Robert Rauschenberg (1925-2008), que incorporavam em si objetos do cotidiano, expandindo os limites tradicionais entre pintura e escultura, num movimento que sinalizava um crescente interesse de aproximação entre arte e vida. Atuando em Nova York junto ao círculo do compositor John Cage e do coreógrafo Merce Cunningham, ambos se aproximaram também de Marcel Duchamp - cuja obra viria a se tornar uma referência central para o desenvolvimento da arte contemporânea - apropriando-se, cada um a seu modo, da noção de ready-made.

Em Target with Four Faces (1955), uma das pinturas adquiridas pelo момA, Johns pintou com círculos concêntricos de cores contrastantes a figura de um alvo, aplicando encáustica sobre folhas de jornal coladas. Misturando de modo ainda mais evidente pintura e escultura, o artista incrustou, em nichos individuais na parte superior da tela, quatros rostos moldados em gesso e cortados dos olhos, que podem ser ocultados por uma estreita folha de madeira presa no quadro com dobradiças. Em Bed (1955), que mais tarde também foi integrado ao 
acervo do момА, Rauschenberg criou um curto-circuito entre um objeto real - a cama - e um objeto artístico - a tela -, aplicando pinceladas abstratas sobre uma colcha e um travesseiro, dispostos na vertical. Johns e Rauschenberg viriam a ser apontados como precursores da Arte Pop, que, embora identificada inicialmente com obras produzidas na Inglaterra em meado dos anos 1950, viria a engrossar o rol da arte considerada tipicamente estadunidense, a partir do início dos anos 1960.

Obtendo reconhecimento institucional cedo em suas carreiras, Johns e Rauschenberg foram incluídos em mais uma exposição organizada por Dorothy Miller no момA, Sixteen Americans, em 1958, dessa vez com 100 obras de uma segunda geração de artistas da vanguarda estadunidense. ${ }^{201}$ Entre elas estavam pinturas da série Black Paintings realizadas a partir daquele mesmo ano por Frank Stella (1936-), um dos mais jovens artistas da mostra. Constituídas por faixas paralelas pintadas de preto sobre a tela deixada crua no intervalo entre elas, essas pinturas desprovidas de gestos expressivos ou alusão a símbolos apresentavam-se como objetos literais - apenas tinta sobre tela plana, numa outra abordagem a partir da objetualidade de Johns. O abandono radical de qualquer nível de representação nessas obras, deslocando a significação da arte do universo interior do artista para o mundo exterior, seria um dos aspectos centrais para o desenvolvimento da arte que viria a ser identificada como Minimalista, em meados dos anos 1960.

Muitas das obras da série Americans vinham sendo adquiridas para a coleção do museu e, embora apontassem para a ruptura com certos paradigmas da arte moderna - como a explosão dos suportes tradicionais -, continuavam, como vimos, sendo expostas de modo convencional e seguindo a trajetória histórica, sem que a expografia anunciasse a fratura nos paradigmas da arte que se agravaria ainda mais nos anos seguintes. O mesmo padrão era adotado em algumas exposições temporárias que incorporavam novos procedimentos artísticos, como The Art of Assemblage, organizada em 1961 pelo historiador da arte William Chapin Seitz (1914-1974). Contendo 250 obras de 130 artistas, a mostra apresentava a produção contemporânea - tanto estadunidense quanto europeia - na

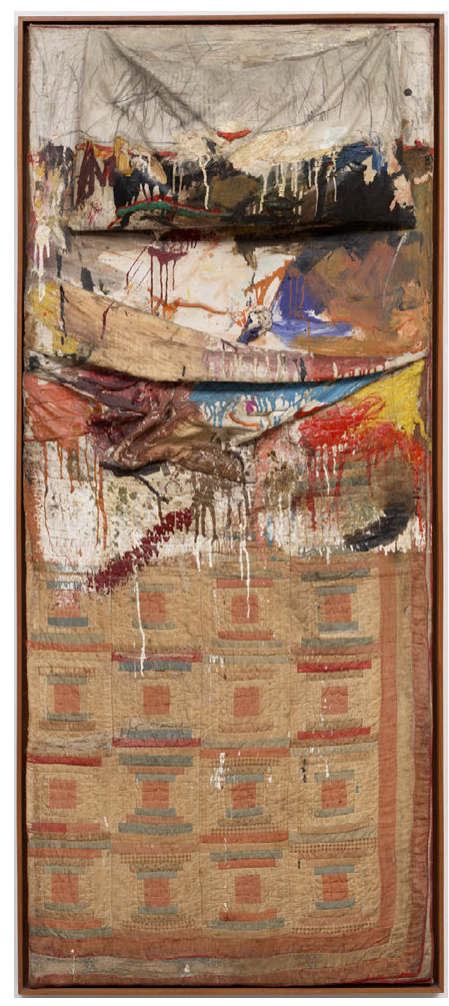

1.134 Robert Rauschenberg, Bed (1955). Fonte: https://www.moma.org/collection/ works/ 78712

201 Os outros artistas eram J. De Feo, Wally Hedrick, James Jarvaise, Ellsworth Kelly, Alfred Leslie, Landes Lewitin, Richard Lytle, Robert Mallary, Louise Nevelson, Julius Schmidt, Richard Stankiewicz, Albert Urban e Jack Youngerman. Cf. THE Museum OF MODERn ART. Sixteen Americans. MOMA. Disponível em: <https:// www.moma.org/calendar/exhibitions $/ 2877$ ? locale $=\mathrm{pt}>$. Acesso em: 8 mar. 2020. 

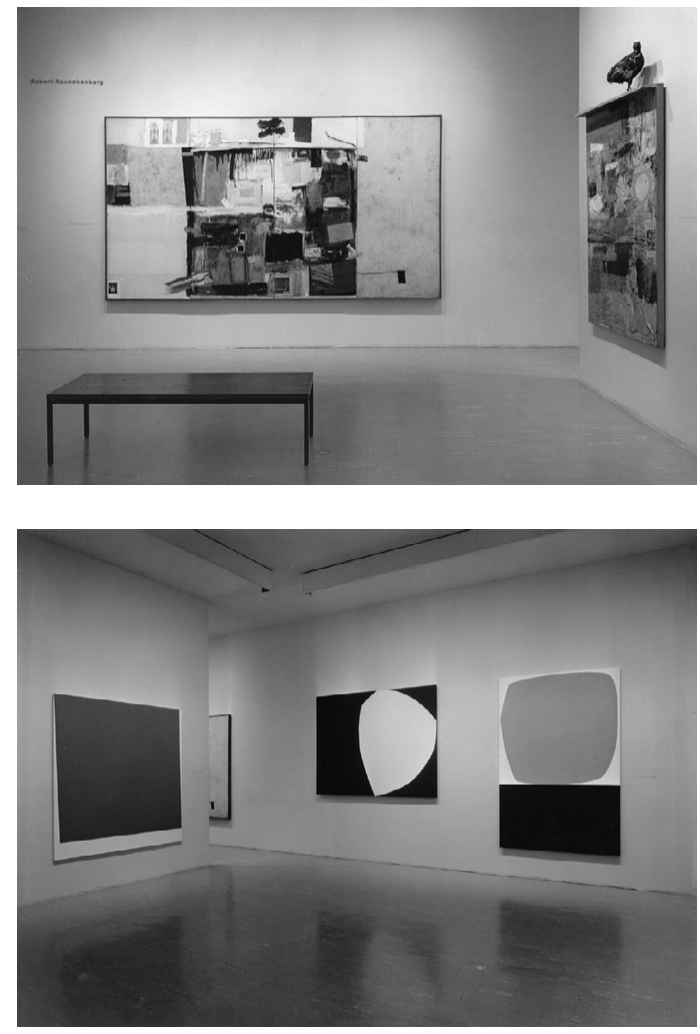

1.135 e 1.136 Vista da exposição

Sixteen Americans, MoMA, Nova York, 1959-60. Foto: Rudy Burckhardt. Fonte: https://www.moma.org/calendar/ exhibitions/2877

1.137 Vista da exposição Sixteen Americans, MoMA, Nova York, 1959-60. Foto: Soichi Sunami. Fonte: https://www. moma.org/calendar/exhibitions/2877

1.138 Vista da exposição The Art of Assemblage, MoMA, Nova York, 1961. Foto: Soichi Sunami. Fonte: https://www. moma.org/calendar/exhibitions/1880

1.139 Vista da exposição Jean Tinguely's Homage to New York, MoMA, Nova York, 1960. Quadro do filme de Robert Breer. Fonte: https://www.moma.org/audio/ playlist/40/649
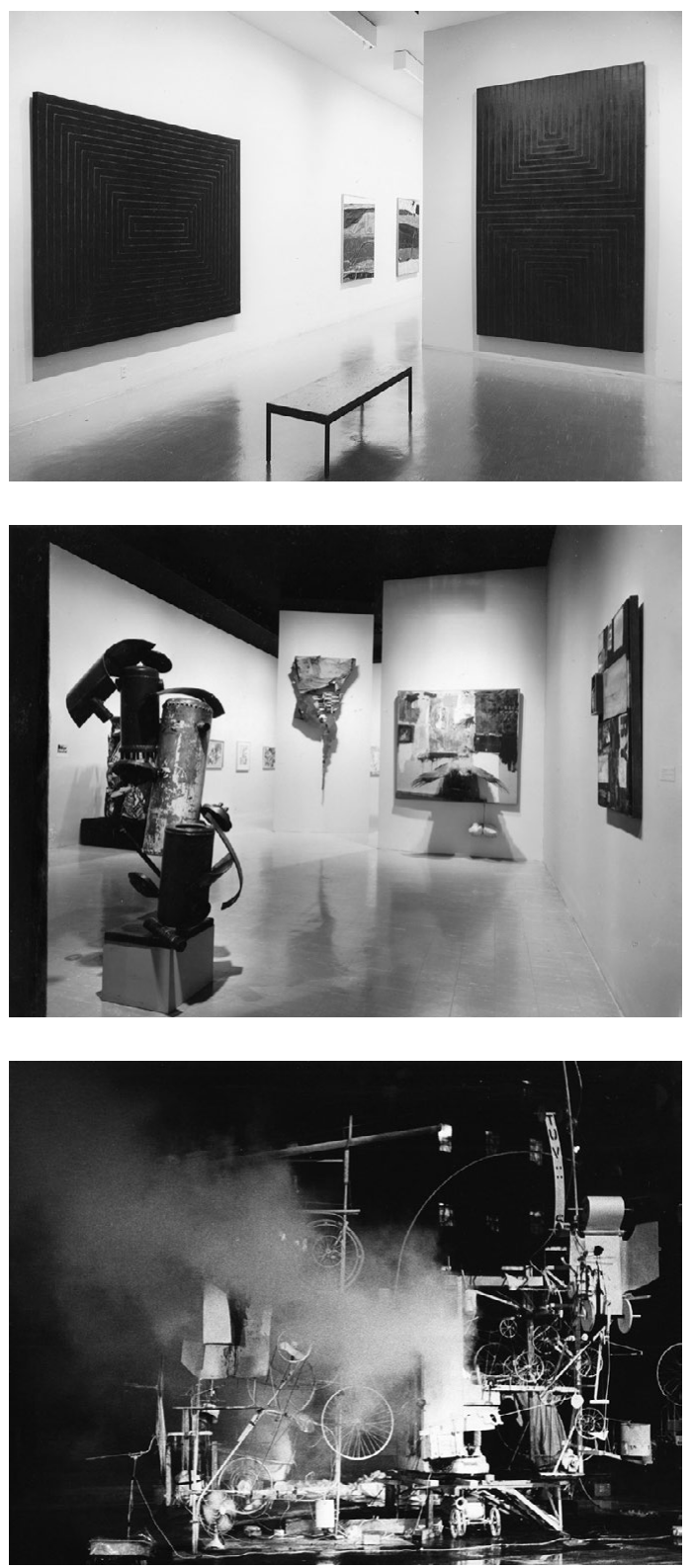
chegada de uma trilha histórica que tinha início com as colagens cubistas da década de $1910 .{ }^{202}$

Apresentando com agilidade artistas que viriam a desenvolver carreiras profícuas e abrir caminhos para novas explorações, as exposições de Miller e outras temporárias, além das aquisições, confirmavam a disposição do MOMA em integrar, ao menos em parte, a produção de vanguarda da arte contemporânea. Os experimentalismos daquele momento, no entanto, começavam a se expandir em direções variadas, muitas delas confrontando o modo mais convencional de operar e expor dos museus. Exemplo disso foi a obra do artista suíço Jean Tinguely (1925-1991), Homage to New York, apresentada no jardim do MoMA num evento noturno em 1960 para uma plateia de 250 convidados, incluindo autoridades, dirigentes do museu e membros da imprensa. ${ }^{203}$

A "escultura", como foi chamada, era uma máquina construída com peças abandonadas como rodas de bicicleta, pedaços de motores antigos, tambores de metal, um piano, um kart em miniatura e uma banheira, todas pintadas de branco e controladas por motores e temporizadores, que deveria se autodestruir após trinta minutos de funcionamento. O plano previa que, enquanto as peças fossem serradas, marteladas e derretidas, um balão meteorológico seria inflado até estourar, fumaça colorida seria lançada no ar, quadros seriam pintados e destruídos, garrafas seriam quebradas por um dispositivo que as derrubaria no chão, textos seriam desenrolados, o piano seria tocado por braços mecânicos, um rádio seria sintonizado nas estações de notícias e uma gravação com a voz do artista explicando a obra seria tocada ao mesmo tempo em que outra corrigiria sua explicação. A apresentação, porém, foi interrompida antes do momento previsto, quando uma peça de metal despencou sobre um operador de câmera, levando os bombeiros a entrar em ação e paralisar os motores ao apagar as chamas.

Ainda que o público não fosse incitado a atuar diretamente sobre sua realização, Homage to New York implicava numa certa divergência com relação à atitude contemplativa típica das galerias do museu, pois tratava-se de uma ação efêmera que demandava o encontro real com a obra e a vivência de seus desdobramentos, ao mesmo tempo calculados e imprevisíveis. Sua condição de dissidência relativa aos paradigmas da arte
202 Cf. The Museum of Modern ART. The Art of Assemblage (Oct 4-Nov 12, 1961). МОМА. Disponível em: <https://www.moma.org/calendar/exhibitions $/ 1880$ ?locale $=\mathrm{pt}>$. Acesso em: 21 mar. 2020.

203 Folheto de divulgação in: The Museum of Modern ART. Homage to New York: A SelfConstructing and Self-Destroying Work of Art Conceived and Built by Jean Tinguely (Mar 17, 1960). MOMA. Disponível em: <https:// www.moma.org/calendar/ exhibitions $/ 3369>$. Acesso em: 21 mar. 2021. 
moderna foi claramente apontada por Pontus Hultén (19242006) - diretor do Museu de Arte Moderna de Estocolmo, que tinha muita proximidade com Tinguely -, no texto que escreveu para o folheto de divulgação da obra:

As coisas de Tinguely são tão boas que talvez não sejam mais arte moderna. No lugar da regularidade, ele coloca a irregularidade. Suas máquinas não são máquinas, são antimáquinas. Elas são mecânicas e meta-mecânicas. Eles produzem anarquia. Essas coisas são mais livres do que um ser humano espera ser. Eles representam uma liberdade que sem elas não existiria. São pedaços de vida que escaparam dos sistemas: do bem e do mal, da beleza e da feiura, do certo e do errado. Tentar conservar a situação existente deixará o homem infeliz, porque não há esperança. Esse tipo de arte aceita mudanças, destruição, construção e acaso, isso impera de qualquer maneira. Essas máquinas são puro ritmo, máquinas de jazz. Mas atenção, porque não é um jogo inocente. ${ }^{204}$

No mesmo folheto, o texto de Barr, num tom informal e cheio de trocadilhos, também apontou para a condição disruptiva da obra, mas a inseriu numa longa tradição de inventores, sinalizando o entendimento elástico que tinha sobre a arte moderna:

Quarenta anos atrás, os avós de Tinguely zombaram de Mona Lisa e Cézanne. Recentemente, o próprio Tinguely inventou máquinas que quebram as conchas plácidas dos ovos imaculados de Arp, máquinas que, com a queda de uma moeda, rabiscam um bigode na musa automatista do expressionismo abstrato e (tire esse sorriso do seu rosto) um avanço apocalíptico no qual, como dizem, tinidos e batidas, formigamentos e emaranhados, sussurros e zumbidos, rangidos e chiados assobiam e explodem em um Crepúsculo dos Deuses catabólico de lixo e sucata. Ó, grande irmandade de Júlio Verne, Paul Klee, Sandy Calder, Leonardo da Vinci, Rube Goldberg, Marcel Duchamp, Piranesi, Man Ray, Picabia, Filippo Morghen, você está nessa? ${ }^{205}$

204 Ibidem. Tradução nossa. 205 Ibidem. Tradução nossa.
Pelo menos um dos mencionados da "irmandade" referida por Barr parecia "estar nessa" - o próprio Marcel Duchamp, que 
também contribuiu com um texto no folheto, impresso em francês com letra cursiva:

si la scie scie la scie

et si la scie qui scie la scie

est da scie que scie la scie

ily a suissscide métallique ${ }^{206}$

A obra de Tinguely representava um dos experimentalismos que ganharia força ao longo dos anos 1960, apontando para uma dissolução da condição de objeto, para uma expansão mais radical da arte para o espaço e para o engajamento com o público e o contexto. Homage to New York acabou, no entanto, sendo um evento sem maiores repercussões sobre a programação do MoмA naquela década, quando boa parte da arte de vanguarda passou a desenvolver seus trabalhos às margens do circuito mais institucionalizado ou em museus mais dispostos a assumir riscos, como será abordado no próximo capítulo desta tese.

Vemos, assim, que, mesmo que o museu tenha acolhido algumas obras que exploravam novas linguagens e relações espaciais - seja pela escala das pinturas, seja pela adição de objetos tridimensionais às telas -, as exposições de arte contemporânea continuavam nos anos 1960 sendo montadas com o objetivo de valorizar a percepção individual das obras, que seguiam sendo agrupadas por critérios estéticos e de autoria e dispostas em percursos sequenciais lineares. Em essência, nas exposições de arte contemporânea do Departamento de Pintura e Escultura realizadas nos anos de grande florescimento do MомA, continuava prevalecendo nas montagens a ambientação discreta que Barr estabelecera para as exposições de arte moderna.

\subsubsection{CONSERVADORISMO ARQUITETÔNICO}

É possível que a prevalência também nas mostras de arte contemporânea dessa época do padrão estetizado desenvolvido para a arte moderna tenha a ver, como apontou Staniszewski, com o peso que a exposição permanente do acervo havia conquistado no MomA na década de $1950,{ }^{207}$ o que certamente impactou a
206 Ibidem. Em tradução nossa: "se a serra serra a serra/ e se a serra que serra a serra/ é a serra que a serra serra/ há suissscídio metálico."

207 STANISZEWSKI, op. cit., p. 292. 


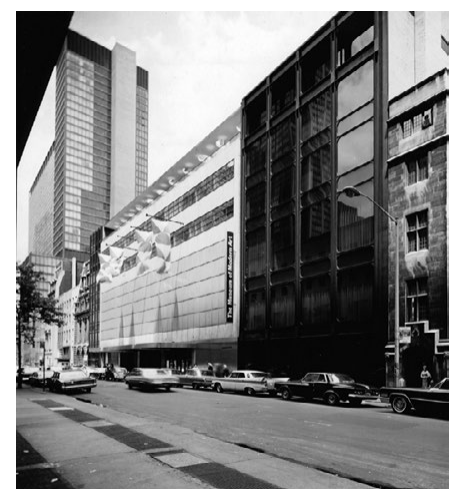

1.140 Fachada do MoMA voltada para a Rua 53 com expansões a leste e oeste, projetos de Philip Johnson nas décadas de 1950 e 60, Nova York, 1968. Fonte: http://www.ikuku.cn/article/ museumofmodernartniuyuexiandaiyishubow uguandelishihuigu

1.141 Fachada do MoMA voltada para a Rua 54 com expansão a leste, projeto de Philip Johnson de 1964, Nova York, s.d. Fonte: http://www.ikuku.cn/article/ museumofmodernartniuyuexiandaiyishubow uguandelishihuigu

$208 \mathrm{O}$ arquiteto tornara-se membro do Board of Trustees em 1957, permanecendo na posição até o ano de sua morte, em 2005.

209 No universo dos museus, no entanto, experiências modernas de natureza mais ousada estavam sendo realizadas na cidade, como o edifício projetado por Frank Loyd Wright para o Solomon Guggenheim Museum, que inaugurara em 1959 e o projeto de Marcel Breuer para a nova sede do Whitney Museum, que ficaria pronto em 1966.
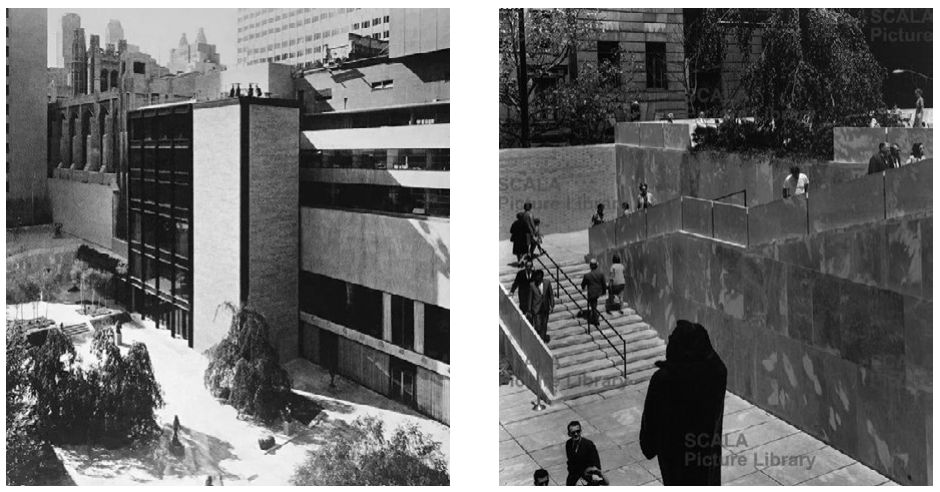

arquitetura do edifício. Em resposta à demanda por mais áreas para manter o programa de exposições temporárias e dar, ao mesmo, visibilidade à coleção permanente, mais uma expansão da sede do MомA foi encomendada a Philip Johnson, que assumiu em 1962 o projeto de uma nova ala inaugurada em 1964, nos lotes contíguos a Leste. ${ }^{208} \mathrm{O}$ edifício de 1939 ficou então emoldurado dos dois lados por fachadas filiadas ao International Style, que já era então a linguagem corrente nos edifícios corporativos em nível mundial. ${ }^{209}$ Sendo a única mantida nas reformas subsequentes, essa última ala é marcada por uma malha metálica estrutural bem mais robusta que a primeira e com o dobro da largura. Na mesma ocasião, o trecho a Leste do jardim também foi transformado, com a construção de um bloco opaco revestido em mármore, cujo teto funcionava como um terraço de esculturas acessado por uma escadaria em fita.

Conectando-se a cada um dos níveis preexistentes do edifício original, os pavimentos da nova ala Leste foram concebidos com planta retangular totalmente livre, desimpedidas de obstáculos, para que fossem utilizados como áreas expositivas "flexíveis". As duas faces visíveis, voltadas para a rua 53 e para o jardim, recebiam a mesma esquadria em grid metálico com vidro escuro, o que poderia minimizar o impacto externo causado pela sombra de painéis provisórios vedantes instalados de acordo com cada montagem - como acontecia com o painel translúcido Thermolux. Na face posterior, havia ainda um grande bloco opaco para abrigar uma nova escada servindo aos 


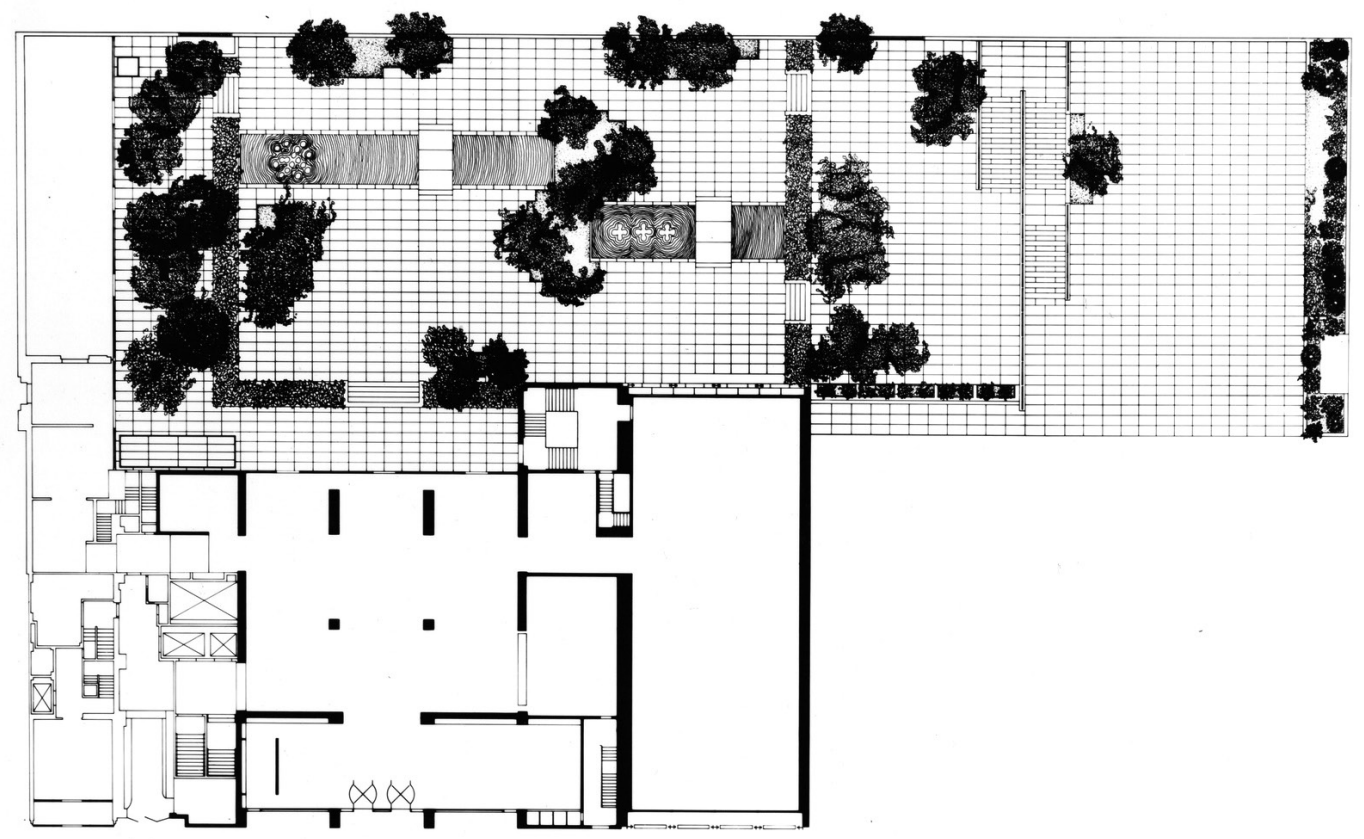

diversos andares. Revestido de tijolos e emoldurado por perfis metálicos, esse bloco sobrepunha-se a um trecho da fachada do jardim do edifício de Goodwin e Stone, representando a primeira de uma série de intervenções que levariam ao progressivo apagamento de sua face posterior.

Com a adição da ala Leste de Johnson, a área dedicada à exposição da coleção permanente de pintura e escultura passou de aproximadamente $1.000 \mathrm{~m}^{2}$ para $1.765 \mathrm{~m}^{2}$. Mais $622 \mathrm{~m}^{2}$ foram dedicados aos departamentos de Fotografia, Gravuras e Desenhos e Arquitetura e Design, que alternavam exposições do acervo e mostras temporárias diversas. ${ }^{210}$ Se a ampliação da visibilidade da coleção, que contava agora com mais que o dobro de área expositiva, podia contribuir para potencializar ainda mais o prestígio do MoмA como um dos mais influentes museus de arte moderna do mundo, podia em contrapartida representar um desequilíbrio no jogo de forças entre preservação da arte do passado e fomento da arte do presente. Ainda que a coleção continuasse a se atualizar, seu principal lastro vinculava-se a uma noção de modernidade que pertencia a
1.142 Ampliação do MoMAa leste do jardim, projeto de Philip Johnson, Nova York, 1964. Fonte: http://www.scalarchives. com/web/ricerca_risultati_adv. asp?nRisPag=36\&prmset $=0$ on $\&$ C PROV $=$ COLL\&IdCollection $=80303 \& S C$ Lang=eng\&Sort $=2$

1.143 Planta pavimento térreo do MoMA com com expansões a leste e oeste, projetos de Philip Johnson nas décadas de 1950 e 60. Fonte: https://www.moma. org/audio/playlist/294/3856

210 WALLACH, op. cit., p. 210. 

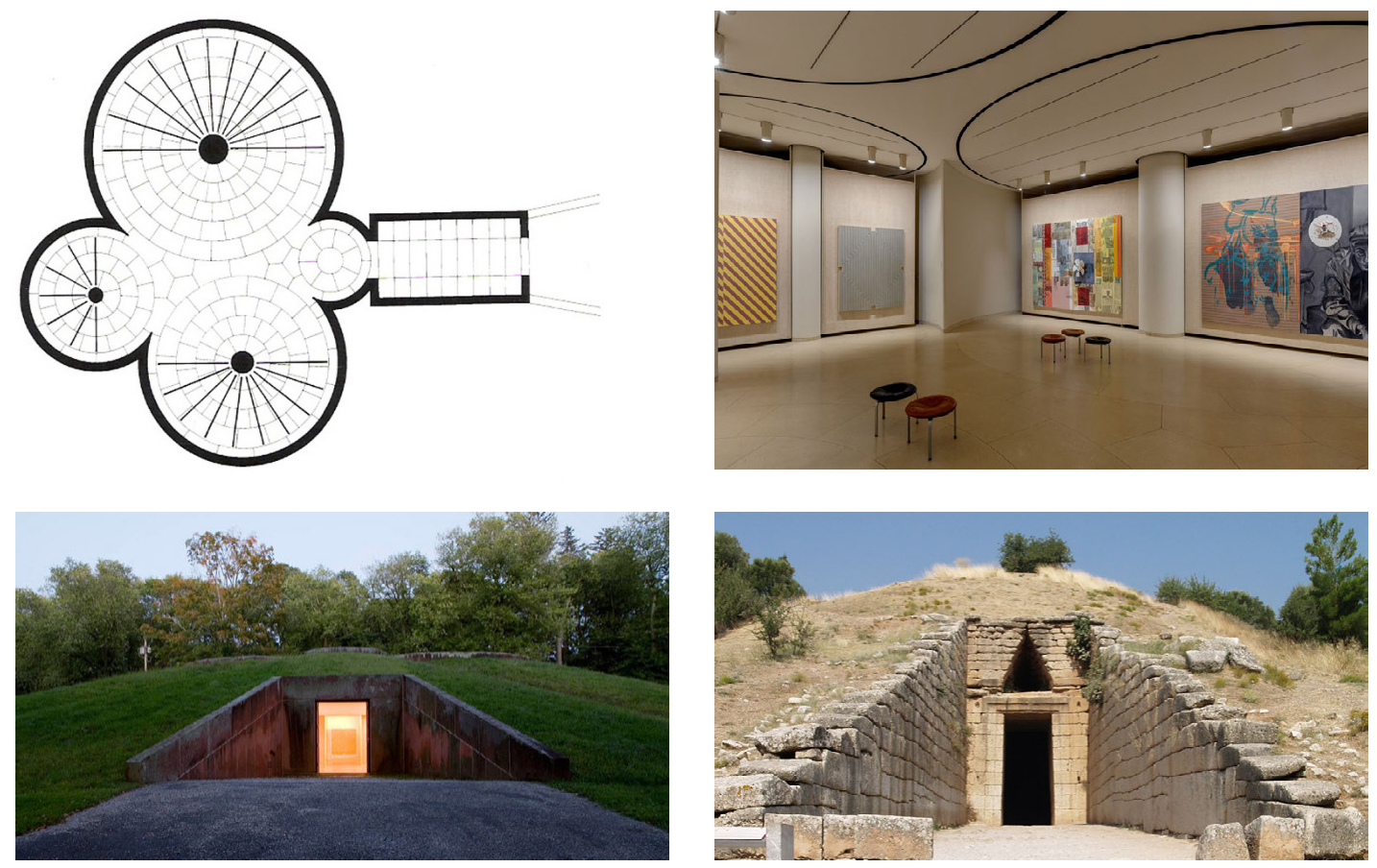

um ciclo histórico que começava a ser visto como encerrado, descolando-se cada vez mais das discussões que animavam o debate da produção contemporânea, que se fazia enquanto acontecimento no espaço em relação com o público, não como objetos colecionáveis.

$\mathrm{Na}$ análise de Wallach, as ideias de modernidade pelas quais o мома se empenhara em promover teriam prevalecido nos anos 1950, disseminando-se na arte, nos produtos industriais e na arquitetura e deixando, portanto, de serem percebidas como utópicas para se tornarem convencionais:

O futuro projetado pelo MомA durante os anos 1930 e 40 aconteceu - um futuro, como se viu, que coincidiu com uma expansão econômica sem precedentes e com o início do 'século americano'. Provou-se, porém, que esse futuro não era uma utopia. O modernismo da Bauhaus tornou-se a monotonia da Bauhaus, apoiando um racionalismo corporativo impessoal 
e a comodificação da forma arquitetônica. A 'nova pintura americana', como era frequentemente chamada, converteu-se num academicismo moderno. ${ }^{211}$

O autor argumentou que, não havendo no pós-guerra uma utopia convincente, o MoMA teria começado a olhar cada vez mais para si mesmo e para o passado, substituindo a "utopia" da fase anterior por uma "nostalgia" voltada a um período histórico em que um futuro utópico ainda era verossímil, afirmando ainda que "esse anseio pelo passado utópico veio a dominar as práticas do MOMA como instituição."

Nesse sentido, as ampliações de Johnson não colaboravam para atualizar a imagem inovadora que o museu tinha instaurado ao construir sua primeira sede, inaugurada como um exemplo pioneiro da arquitetura moderna nos EUA. Ao contrário, as duas novas alas laterais traziam um acento conservador tanto pela associação com a linguagem corporativa - disseminada em inúmeros edifícios do entorno -, quanto pelo novo status que, por contraste, conferiam ao edifício de Goodwin e Stone: o de testemunho de uma modernidade passada, a ser preservada enquanto patrimônio histórico. ${ }^{212}$ Segundo Wallach:

A fachada de 1939 significava agora o passado do MOMA - um passado tornado evidente por sua oposição à representação de Johnson do momento presente do museu. Tal contraste não deixou de ter suas ironias. O utopismo do момA parecia agora uma relíquia histórica, como tantas profecias fracassadas, diante dos projetos de aço e vidro sem sentido de Johnson e de dezenas de projetos semelhantes nas proximidades do museu: na verdade, esperanças futuristas dos anos 1930 oprimidas pela elegante e banal realidade do capitalismo corporativo do pós-guerra. O design tripartido de Johnson produziu assim um conjunto de significados sobre a situação histórica do момA e a importância de suas coleções, que anteciparam com muita precisão - ajudando também a determinar - tudo o que os espectadores encontrariam no próprio museu. ${ }^{213}$

Ao mesmo tempo em que seguia os dogmas miesianos na ampliação do MOMA, Johnson projetava nas proximidades de
1.144 Planta do pavilhão de pinturas, projeto de Philip Johnson de 1965, New Canaan, Connecticut. Fonte: https://www.archdaily. com/60259/ad-classics-the-glass-housephilip-johnson?ad_medium=gallery

1.145 Interior do pavilhão de pinturas, projeto de Philip Johnson de 1965, New Canaan, Connecticut, s.d. Foto: Michael Biondo. Fonte: https:// www.architecturaldigest.com/story/ glass-house-personal-effect-philip-johnson

1.146 Entrada do pavilhão de pinturas, projeto de Philip Johnson de 1965, New Canaan, Connecticut, s.d. Foto: Paul Warchol. Fonte: https://www.inexhibit. com/mymuseum/the-glass-house-philipjohnson-new-canaan-connecticut/

1.147 Entrada da Tumba de Atreu, século XIII a.C, Micenas, Grécia, 2006. Foto: Ken Russell Salvador. Fonte: https:// pt.m.wikipedia.org/wiki/Ficheiro:Treasury_ of_Atreus_Mycenae.jpg

211 Ibidem, p. 210. Tradução nossa.

212 Apesar de Johnson ter alterado algumas das características originais, reposicionando a entrada e eliminando alguns elementos curvos. Cf. WALLACH, op. cit. p. 211. 213 WALLACH, op. cit., p. 212. 


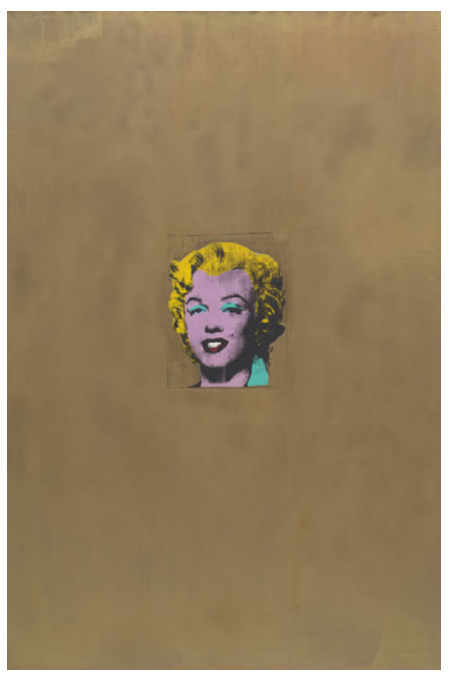

1.148 Andy Warhol, Gold Marilyn Monroe, 1962. Fonte: https://www.moma.org/ collection/works/ 79737

1.149 Andy Warhol, Untitled from Campbell's Soup I, 1968. Fonte: https://www.moma. org/collection/works/72312

1.150 Roy Lichtenstein, Girl with Ball,1961. Fonte: https://www.moma.org/collection/ works/ 79665

214 Philip Johnson em declaração de 1963 à revista Time apud LAMSTER, Mark. The Man in The Glass House. Boston: Little, Brown and Company, 2018, p. 299. Tradução nossa.

A coleção que Johnson vinha montando com seu companheiro, David Whitney, incluiria obras de Lee Bontecou, John Chamberlain, Jim Dine, Morris, Claes Oldenburg, Larry Poons, Bridget Riley, James Reconquist, Lucas Samaras, Frank Stella, Paul Thek, Wayne Thiebaud e Andy Warhol.
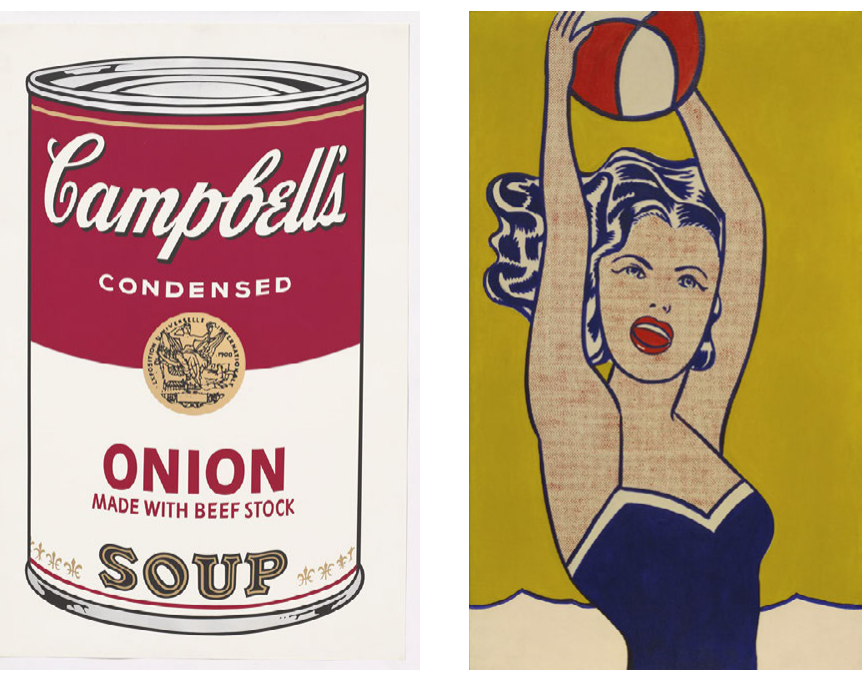

sua Glass House um pavilhão para pinturas com uma linguagem muito contrastante com o International Style modernista. Concluída em 1965, a construção semienterrada de sua galeria de arte era constituída por quatro espaços cilíndricos de diferentes diâmetros integrados entre si, três deles contendo divisórias móveis que giravam ao redor de colunas, comportando uma pintura de grandes dimensões em casa face. A entrada se dava por uma porta ao final de um corredor em rampa descendente, uma releitura de um monumento antigo - a Tumba de Atreu em Micenas, na Grécia -, o que indiciava a guinada que o arquiteto daria em sua carreira em direção à linguagem historicista do pós-modernismo.

Esse desvio da rota que escapava do alto modernismo estava presente também no perfil da coleção particular de arte que Johnson vinha montando recentemente e que viria a ocupar seu novo pavilhão, em que predominava a Arte Pop. Sobre essa produção, Johnson declarou: "É o movimento artístico mais importante do mundo hoje. [...] É uma reação muito forte contra o Expressionismo Abstrato e, como tal, é um grande alívio de se ver, porque reconhecemos as garotas bonitas e as garrafas de refrigerante". ${ }^{214}$ Podemos especular que seu tom provocativo visasse impulsionar o MOMA, muito associado ao Expres- 
sionismo Abstrato, a apoiar a Arte Pop como a nova "arte de seu tempo", que ainda contava com certa resistência de críticos que a consideravam excessivamente banal, tanto pelos conteúdos representados quanto pelos procedimentos artísticos. ${ }^{215}$ O próprio Johnson encarregou-se em doar para o museu obras recém produzidas por artistas centrais desse movimento, como as pinturas de Andy Warhol, Gold Marilyn Monroe (1962) e Campbell's Soup (1965), e de Roy Lichtenstein, Flatten - Sand Felás! (1962) e Girl with Ball (1961), contribuindo de forma expressiva para a atualização da coleção nos anos 1960. ${ }^{216}$

Algumas das vanguardas contemporâneas continuavam comparecendo em exposições do museu, como The Responsive Eye, de 1965, uma das mostras de maior sucesso de público da época, contendo trabalhos associados principalmente à $O p$ Art. Com mais de 125 pinturas e objetos de aproximadamente 75 artistas de dez países selecionados pelo curador William C. Seitz, a mostra é apresentada no memorial de imprensa como "uma ampla, poderosa e nova direção da arte contemporânea". ${ }^{217}$

A exposição foi montada na nova ala Leste de Johnson, cujas galerias tinham dimensões maiores, não interrompidas por colunas, e detalhes de acabamento mais sofisticados que no edifício antigo, como sulcos paralelos para trilhos de iluminação no forro. Observando-se os registros fotográficos da montagem nota-se, mais uma vez, que, a não ser pela maior amplitude dos espaços e pela presença de painéis angulados, não há uma novidade significativa no modo de expor, nem qualquer relação com a especificidade da arquitetura - tratada de modo genérico -, sendo a exposição fechada em si mesma, descontextualizada e altamente estetizada, o que é potencializado pela característica das próprias obras, que, como informa o museu, "empregavam geometria e teorias de cor e percepção para criar efeitos ópticos estimulantes". ${ }^{218}$

Também na nova ala projetada por Philip Johnson, foi organizada em 1968, pelo curador convidado E. C. Goossen, a exposição The Art of the Real: USA 1948-1968, que, segundo divulgação do museu, procurava explorar "uma mudança significativa identificável: o desenvolvimento da arte abstrata que é máxima na cor e mínima na forma e uma interação sem precedentes entre pintura e escultura." ${ }^{219}$ Boa parte dos 57
215 Foster et al., op. cit. p.445.

216 Entre as numerosas doações que o arquiteto viria a fazer ao museu estariam ainda obras de artistas associados ao Minimalismo, como Donald Judd, Dan Flavin e Frank Stella.

217 A mostra conteria "todas as tendências relevantes ao tema da exposição, incluindo aquelas categorizadas como Optical, Retinal ou Cool, Hard Edge Painting, Visual Research, The New Abstraction, La Nouvelle Tendance, Post Painterly Abstraction, Color Imagery e Programmatic Art.", incluindo entre os artistas Agam, Albers, Anuskiewicz, Brach, Qtellani, Gene Davis, Dorazio, Gerstner, Goodyear, Irwin, Kelly, Lohse, Louis, Mack, Martin, Mavignier, Molinari, Noland, Riley, Soto, Stanczak, Stella, Stroud,Tadasky, Tomasello, Vasarely, Wilding e Yvaral; o Groupe de Recherche d'Art Visuel (França), Gruppo " $T$ " e Gruppo " $N$ " (Itália), Equipo 57 (Espanha) e "Zero" (Alemanha)". Cf. Press-release in: THe Museum of ModerN ART. The Responsive Eye (Feb 23-Apr 25, 1965). момА. Disponível em: <https://www.moma.org/ calendar/exhibitions/2914?locale=pt $>$. Acesso em: 28 mar. 2020. Tradução nossa.

218 Ibidem.

219 Press release in: THe Museum OF MODERn ART. The Art of the Real (Jul 3-Sep 8, 1968). мОмA. Disponível em: $<$ https://www. moma.org/calendar/exhibitions/1911? locale $=\mathrm{pt}>$. Acesso em: 28 mar. 2020. Tradução nossa. 
1.151 Visitantena exposiçãoThe Responsive Eye, MoMA, Nova York, 1965. Foto: George Cserna. Fonte: https://www.moma.org/ calendar/exhibitions/2914

1.152 Vista da exposição The Responsive Eye, MoMA, Nova York, 1965. Foto: George Cserna. Fonte: https://www.moma.org/ calendar/exhibitions/2914

1.153 Vista da exposição Primary Structures, The Jewish Museum, 1966. Fonte: ALTSHULER, p. 57.

220 O termo Minimal Art surgiu pela primeira vez num ensaio crítico do filósofo britânico Richard Wollheim (1923-2003), publicado em 1965. Cf. BATCHELOR, David. Minimalismo. São Paulo: Cosac Naify Edições, 1999, p. 6.

221 Kynaston McShine começou a trabalhar no MoмA em 1959 e, seguindo uma recomendação de René D'Harnoncourt, assumiu o cargo de Curador do Departamento de Pintura e Escultura no Jewish Museum em 1965, para adquirir experiência, tendo atuado como diretor da instituição entre 1967 e 1968. McShine voltou ao Departamento de Pintura e Escultura do момА em 1968, primeiro como Curador Associado e pouco depois como Curador, tendo uma atuação destacada no museu até sua aposentadoria, em 2008. Cf. The Museum of Modern ART. Kynaston McShine Papers in The Museum of Modern Art Archives. MOMA. Disponível em: <https:// www.moma.org/research-and-learning/archives/finding-aids/ KynastonMcShinef $>$. Acesso em: 28 mar. 2021.

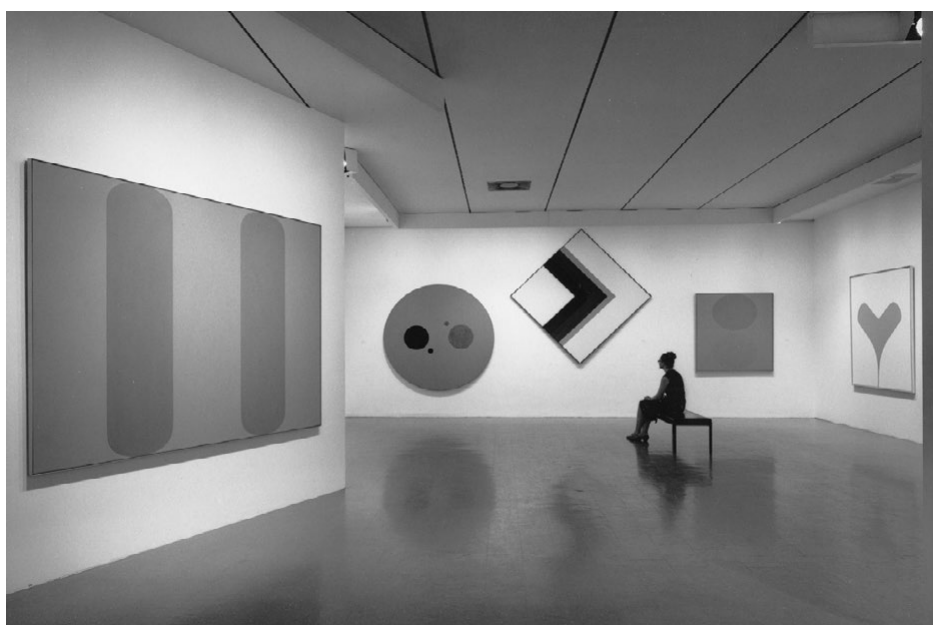

trabalhos produzidos por 33 artistas apresentados na mostra vinham sendo reconhecidos desde 1965 como representantes do Minimalismo, rótulo que viria a prevalecer a despeito de sua rejeição pelos autores das obras, que nunca se agruparam em torno de um movimento artístico propriamente dito. ${ }^{220}$ Entre os artistas de The Art of the Real estavam os estadunidenses Carl Andre, Donald Judd, Ellsworth Kelly, Lyman Kipp, Sol Lewitt, Robert Morris, Tony Smith e Robert Smithson, que haviam participado da mostra Primary Structures: Younger American and British Sculptors, organizada em 1966 pelo curador trindadense radicado nos EUA Kynaston McShine $\left(1935^{-2018}\right)^{221}$ no Jewish Museum de Nova York - o primeiro museu do país a expor essa produção e a conferir-lhe prestígio. Utilizando diferentes estratégias, seus trabalhos tinham em comum o uso de materiais e técnicas industriais em vez de meios artesanais e a disposição modular e serial dos elementos no lugar de organização compositiva, resultando em uma ordenação formal e expansão ambiental que deslocava o interesse da expressão individual do artista para a percepção do espectador de sua própria presença no espaço público compartilhado com a obra. Como explicou o curador no catálogo de The Art of the Real: 

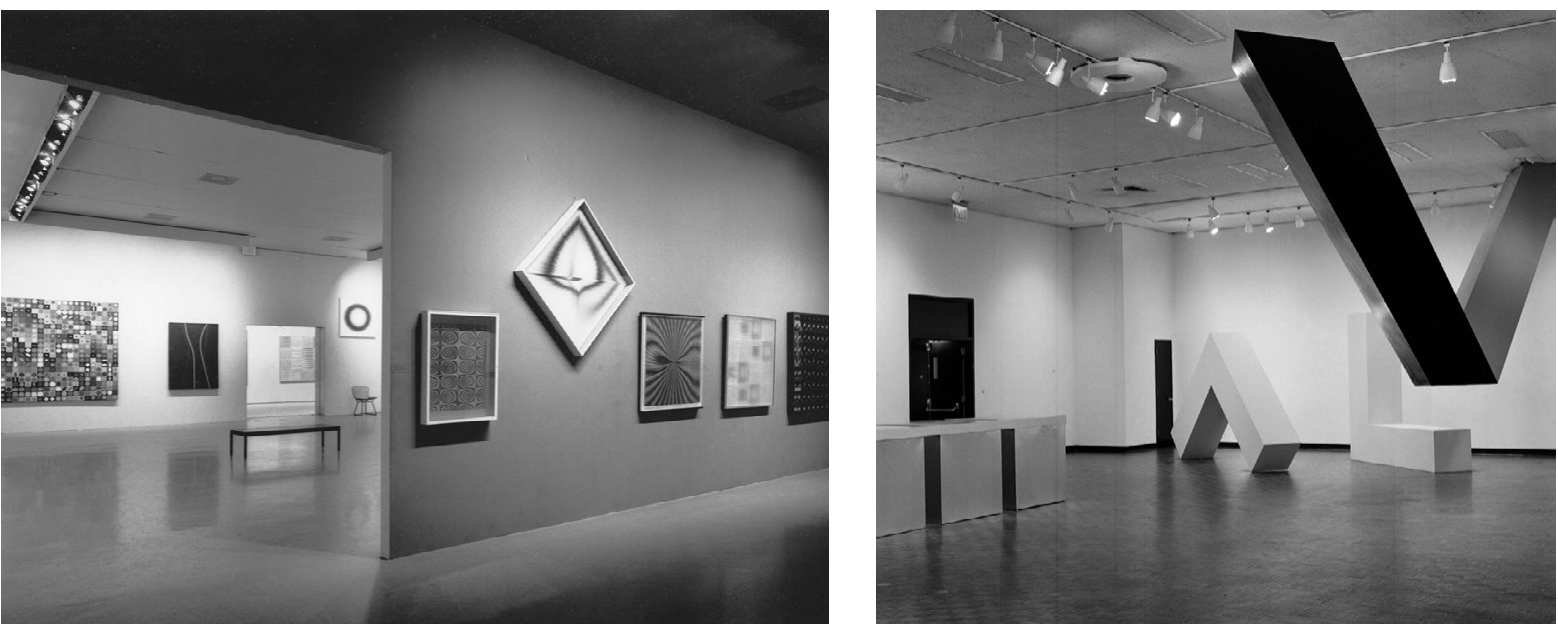

A nova atitude tem virado a arte do avesso: em vez de a experiência perceptiva ser tomada como meio para um fim, ela se tornou o fim em si mesma [...] Os próprios meios da arte foram isolados e expostos, obrigando o espectador a se perceber no processo de sua percepção. $O$ espectador não recebe símbolos, mas fatos, para fazer deles o que puder. Eles não direcionam sua mente, nem evocam núcleos confiáveis de experiência, mas o levam ao ponto em que ele deve avaliar suas próprias respostas particulares. Assim, o que antes estava oculto na arte - os dispositivos técnicos empregados pelo artista - agora é abertamente revelado; e o que estava antes do lado de fora - o significado de suas formas - foi voltado para o lado de dentro. ${ }^{22}$

Sobre os procedimentos da arte Minimalista, que levantam questões centrais para a discussão desta tese - a investigação das relações entre a arte e os espaços arquitetônicos das instituições destinados às exposições - vale destacar também alguns trechos de textos publicados por ocasião da exposição Primary Structures. Na introdução do catálogo da mostra, MsShine afirmou: "o trabalho é frequentemente arquitetônico, se não arquitetural. A maioria das esculturas não usam base ou pedestal, algumas são orientadas para as paredes, outras

222 GoOssen, E. C.. The art of the real USA, 1948-1968. Nova York: The Museum of Modern Art, 1968, p. 11. Tradução nossa. 

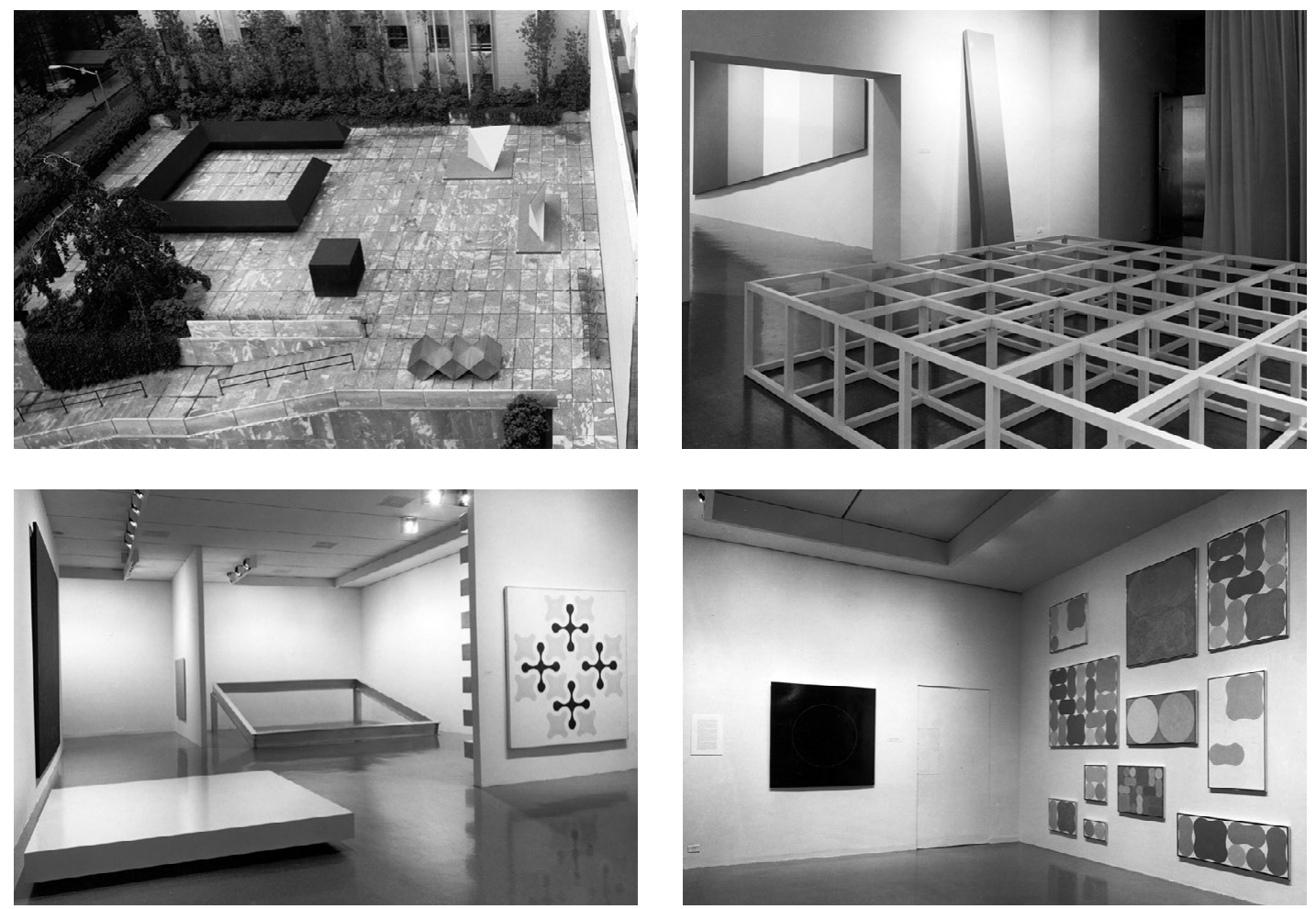

1.154 Vista da exposição Art of the Real, MoMA, Nova York, 1968. Foto: James Mathews. Fonte: https://www.moma.org/ calendar/exhibitions/1911

1.155 Sol Lewitt, Model for untitled scuplture (1966), na exposição Art of the Real, MoMA, Nova York, 1968. Foto: James Mathews. Fonte: https://www.moma.org/ calendar/exhibitions/1911

223 Apud Altshuler, op.cit., p. 59 .

224 Publicada em 1 de maio de 1966, apud ibidem, p. 61. Tradução nossa. até mesmo para o teto. O artista se sente livre para utilizar e o espaço de uma sala ou do exterior de acordo com as necessidades do trabalho". ${ }^{223}$ Escrevendo para o jornal The New York Times, o crítico Hilton Kramer (1928-2012) também posicionara esses trabalhos na fronteira entre os meios tradicionais da arte e na condição de expansão para o espaço: "Alguém pode dizer que a nova escultura é, de fato, uma espécie de pintura abstrata aspirando à condição de arquitetura: é escultura somente porque o meio escultura é o único meio pelo qual essa aspiração pode ser realizada". ${ }^{224}$

Em The Art of the Real, parte das obras estava exposta nas novas galerias isoladas do exterior a leste do jardim, em salas compartilhadas e não muito amplas. Por meio dos registros fotográficos, podemos observar que apenas algumas das esculturas de maior porte tinham uma presença mais arquitetônica, 


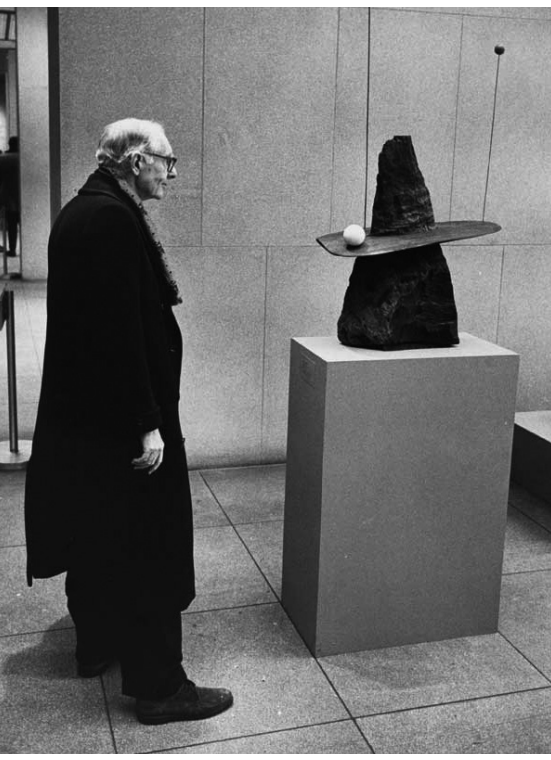

1.160 Alfred H. Barr Jr. diante da obra de Alexander Calder, Gibraltar (1936), MoMA, Nova York, 1967. Foto: Dan Budnik. Fonte: http://artpulsemagazine.com/ interview-with-mary-anne-staniszewski

225 The Museum of Modern ART, The Art of the Real (Jul 3-Sep 8, 1968), op. cit.. Tradução nossa. que algumas das galerias do museu, a peça tinha uma interrupção no contorno, por onde o espectador podia entrar e ficar contido em seus limites, constituindo uma das experiências mais acentuadamente arquitetônicas da exposição. A obra foi posicionada junto com outras cinco esculturas no novo terraço elevado criado com a expansão de Johnson, localizado na cobertura das galerias e integrado ao jardim por um jogo de escadas em ziguezague. No nível inferior do jardim, foi exposta a obra Fall (1968) de Carl Andre - um conjunto com 21 chapas de aço corten dobradas a 90 graus, cada uma com $70 \mathrm{~cm}$ de largura e 1,80m tanto de altura quanto de profundidade, justapostas lado a lado ocupando 14,7m de extensão. Além da posição e da escala, a qualidade arquitetônica da obra era evidenciada pela coincidência entre as dimensões das chapas e as das placas de mármore que revestiam o piso e a parede onde estava encostada.

No texto de parede na entrada da mostra, essa produção foi apresentada por Goossen como "uma tentativa de romper com a principal tradição europeia”, por deixar de lado elementos exteriores à realidade da obra para valorizar não a sua interpretação, mas um "confronto direto com o trabalho", no qual se intensificaria "sua realidade enquanto objeto". ${ }^{225}$ Ao mesmo tempo em que apontava para a ruptura com a linhagem da arte humanista europeia, o curador procurava afirmar que as características dessa nova produção seriam "tipicamente americanas”, daí que tenha incluído na exposição, "por seu significado histórico", obras mais antigas relacionadas ao Expressionismo Abstrato e à Pop Art, reiterando, assim, o discurso curatorial predominante no MoMA, tanto na coleção quanto em diversas exposições temporárias, como The Art of Assemblage, de 1961, como vimos anteriormente.

Enquanto parte da produção de vanguarda podia se enquadrar na narrativa que o MoMA construíra para a arte moderna, tendo sido integrada em suas exposições, muitas das experiências avançadas que se desenvolveram ao longo dos anos 1960 nos EUA, na Europa, no Japão e na América Latina - a serem abordadas no capítulo seguinte desta tese - não foram contempladas com o mesmo interesse pelo museu, seja porque divergiam dos paradigmas vigentes até então para a arte, seja 


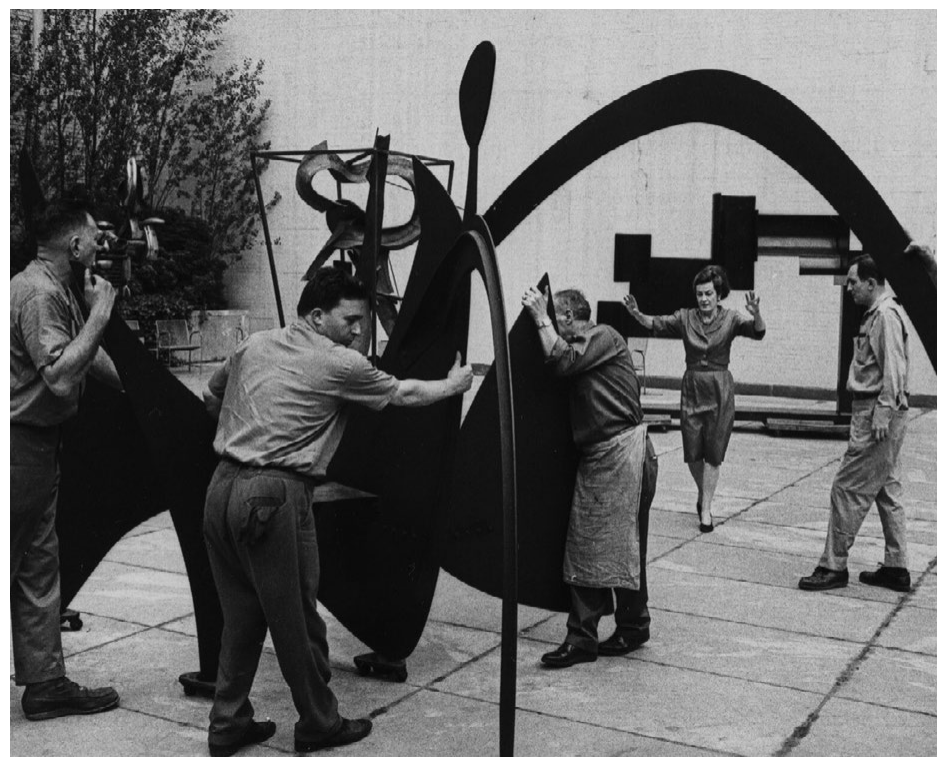

porque conflitavam com o modo de operar dessa e de outras instituições estabelecidas. A produção contemporânea deixava de ser constituída de objetos autônomos, produzidos fora do museu, para se voltar cada vez mais para a ativação do espaço.

O período de grande florescimento que o Moma vivera na década de 1950, conjugando a intensificação do programa de exposições, o estabelecimento da coleção permanente, o reconhecimento da arte produzida nos EUA e o prestígio que alcançara internacionalmente, representou um apogeu que deixaria de se sustentar conforme avançavam os anos $1960 .^{226}$ Fortemente vinculado à construção de uma tradição moderna, o момA teve parte de seu prestígio abalado quando uma parcela significativa da geração de artistas mais jovens passou a tomar distância do moderno para seguir novos caminhos. O momento coincidiu ainda com a despedida de figuras que haviam moldado sua estrutura e determinado seus rumos: aposentavam-se num curto intervalo de tempo o diretor fundador e então diretor das coleções, Alfred Barr (1967), o diretor do museu, René D'Harnoncourt (1968), e a curadora sênior ligada aos artistas locais de vanguarda, Dorothy Miller (1969). ${ }^{227}$

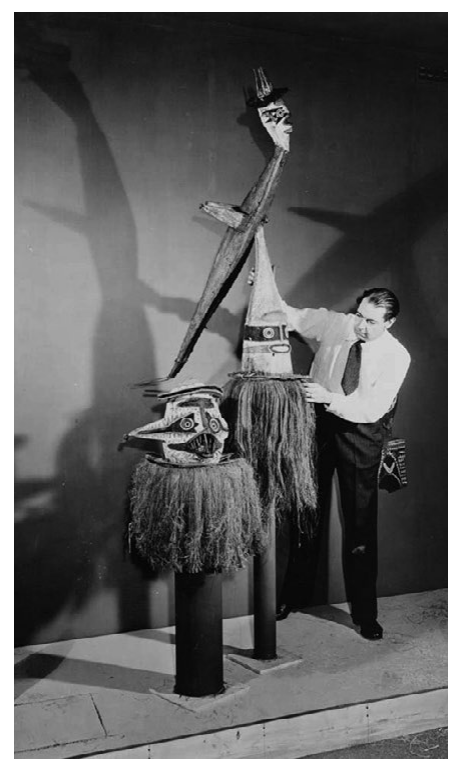

1.161 René d'Harnoncourt montando a exposição Arts of the South Seas, MoMA, Nova York, 1946. Foto: William Leftwich. Fonte: ELLIGOT, p. 11.

1.162 Dorothy Miller comendando a montagem da obra de Alexander Calder, Black Widow (1959), MoMA, Nova York, s.d. Fonte: https://www.moma.org/ magazine/articles/85

226 KraUss, Rosalind, A escultura no campo ampliado, Gávea, v. 1, p. 128-137, 1984.

227 D'Harnoncourt viria a falecer em 1968, vítima de um atropelamento, aos 87 anos de idade, Barr em 1981, aos 79 anos e debilitado por Alzheimer, e Miller em 2003, aos 99 anos. 
Às vésperas de completar quatro décadas de existência, marcadas por grandes realizações, o Museu de Arte Moderna de Nova York vivia o encerramento de um ciclo. A partir do final da década de 1960, a vinculação do MOMA com a "arte de seu tempo" se tornaria especialmente problemática e sua influência seria significativamente reduzida nos círculos de vanguarda da arte contemporânea, como veremos a seguir. 


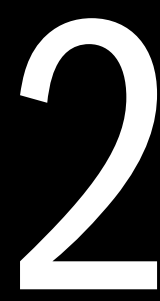

O MOMA ENTRE
ENCONTROS E

DESENCONTROS

COM A ARTE

CONTEMPORÂNEA 

Este capítulo é dedicado a analisar de que modo a ruptura com os paradigmas modernistas desencadeada pelos experimentalismos da arte nos anos 1960 impactaram a relação do Moma de Nova York com a produção contemporânea e com a configuração arquitetônica de seus espaços, até finais dos anos 1990. Como vimos no capítulo anterior, a conjugação do fomento da "arte de seu tempo" com uma estrutura de museu havia sido bem-sucedida na instituição desde sua fundação em 1929 até pelo menos finais da década de 1950. Até esse momento, ainda não havia uma divergência entre os termos "arte moderna" - conceito fundador do museu - e "arte contemporânea" - entendida até então como a produção da atualidade. A prosperidade que o момa viveu nos anos do pós-guerra articulava-se tanto a fatores políticos e econômicos - a consolidação dos EUA como uma nova potência mundial -, quanto culturais - o amadurecimento de uma arte moderna produzida no próprio país. Nos anos 1950, obras identificadas com o Expressionismo Abstrato estadunidense podiam ser apresentadas como a manifestação mais avançada do modernismo de linhagem europeia, afirmando o deslocamento do polo da arte moderna para o novo continente.

Os desdobramentos que se seguiram a partir de finais dessa década, no entanto, anunciavam o teor crítico que dominaria a produção de arte de ponta nos anos 196o. A partir de então, o emprego do termo "arte contemporânea" deixou de indicar a produção de qualquer momento presente e passou a nomear um novo ciclo histórico da arte, que perdura até hoje. Seu emprego veio a se referir a manifestações diversificadas que, a partir daquele momento, ampliaram os limites estabelecidos até então da própria definição de arte, concebendo novas formas de se relacionar com o contexto - incluindo público, instituições e espaços arquitetônicos, além de aspectos sociais mais amplos.

Artistas como Jasper Johns, Robert Rauschenberg e Frank Stella, que apontavam para novos paradigmas - como os identificados com a Arte Pop e com o Minimalismo - foram assimilados pelo мома com uma certa agilidade, tendo obras incluídas na exposição Sixteen Americans, organizada por Dorothy Miller em 1959. Nessa mesma época, contudo, artistas tanto locais 
quanto de partes diversas do mundo exploravam condições experimentais de criação e apresentação que colocavam em xeque a relação convencional da arte com os espaços institucionais dos museus. Daí o interesse para esta tese em observar, ainda que de modo parcial, algumas outras realizações representativas dos experimentalismos dos anos 1960 e 1970 na arte e em seus espaços de apresentação, entremeando-as aos eventos relacionados diretamente ao MoMA nas últimas décadas do século $\mathrm{xx}$.

\subsection{ARTE TOMA O ESPAÇO DOS MUSEUS NOS ANOS 1960}

Enquanto obras associadas ao Expressionismo Abstrato costumavam ser expostas nas paredes de museus e galerias como pinturas, os registros fotográficos de Jackson Pollock derramando tinta nas telas esticadas no chão chamavam a atenção para uma outra perspectiva - a ação que as produzia -, como abordado anteriormente. A noção de "action painting", porém, não se restringiu apenas a uma categoria empregada pela crítica de arte ${ }^{195}$ mas despertou o interesse de artistas que se atraíam pelas possibilidades de expansão da intervenção artística para o espaço além da tela, possibilitando uma atuação no chamado "mundo real". Exemplos disso foram as ações do grupo Gutai realizadas no Japão entre $1954 \mathrm{e}$ 1972, que organizou suas primeiras exposições coletivas em 1955, uma delas no Ohara Hall, em Tóquio, em que figurava Challenge to the Mud, de Kazuo Shiraga (1924-2008). Realizada com movimentos do corpo do artista sobre uma área circular coberta de lama sobre o piso de uma área a céu aberto, essa "pintura performática" deixava a condição de objeto para se configurar como uma ação efêmera, requisitando, assim, a presença simultânea do artista e do público para sua realização e apreciação.

Tal deslocamento do peso do "produto" para o do "acon-

195 Cf. "Os Action Painters NorteAmericanos”, in: RosENBERG, Harold. A tradição do novo. São Paulo: Perspectiva, 1974. tecimento" - contando com o engajamento do público - fazia parte de um movimento crescente em busca de uma aproximação entre arte e vida, o que norteou também a pesquisa 

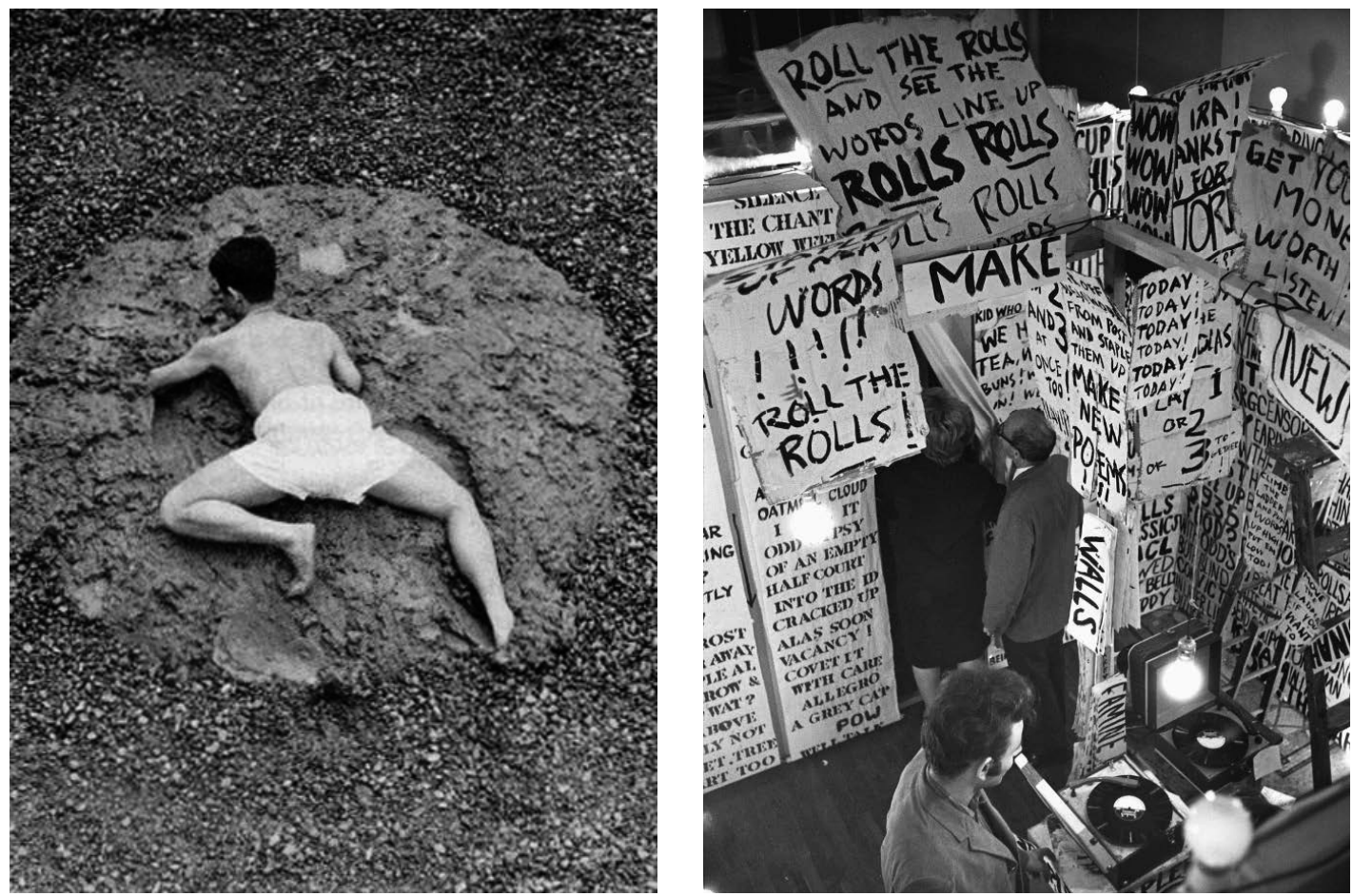

do estadunidense Allan Kaprow (1927-2006), um dos diversos artistas de Nova York que passou a desenvolver, a partir de 1957, obras constituídas não como objetos autônomos, mas como ambientes para serem penetrados e experimentados. Interessado pelo aspecto performático das pinturas de Pollock e de representantes do grupo Gutai, pelas noções de acaso e indeterminação das composições musicais de John Cage e ainda pela combinação de elementos do cotidiano das assemblages de Johns, Kaprow criou obras nomeadas de environments e happenings, que envolviam diversos modos de interação com o público, considerado, desse modo, não mais como espectador passivo, mas como participante ativo. Em Words, um environment realizado pela primeira vez em 1962 numa galeria de vanguarda (Smolin Gallery), o artista utilizou tecidos para subdividir o espaço em dois ambientes, recobrindo-os com uma profusão de cartazes grafados à mão
2.1 Kazuo Shiraga em sua performance Challenge to the Mud, Ohara Hall, Tóquio, 1955. Fonte: FOSTER, KRAUSS et al., p. 375.

2.2 Allan Kaprow, Words, Smolin Gallery, Nova York, 1962. Foto: Robert T. McElroy/ The Getty Research Institute. Fonte: REISS, p. 5 . 


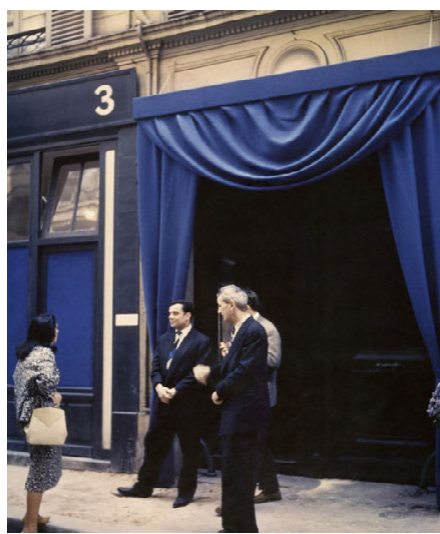

2.3 e 2.4 Entrada da Galeria Iris Clert na abertura da exposição Le Vide, de Yves Klein, Paris, 1958 e vista da exposição. Fonte: http://www.yvesklein. com/en/expositions/view/1158/ la-specialisation-de-la-sensibilite-a-l-e tat-matiere-premiere-en-sensibilitepicturale-stabilisee-le-vide-thespecialization-of-sensibility-in-the-rawmaterial-state-into-stabilized-pictorialsensibility-the-void/

2.5 Vitrine da Galeria Iris Clert durante a exposição Le Plein, de Arman, Paris, 1960. Foto: Shunk-Kender/Roy Lichtenstein Foundation. Fonte: https://www.inrap.fr/ magazine/II-etait-une-fois...-la-bandea-Niki/Decouvrir-le-Nouveau-Realisme/ La-bande-a-Niki\#undefined

196 Cf. Klein, Yves. La spécialisation de la sensibilité à l'état matière première en sensibilité picturale stabilisée, "Le Vide". Yves Klein. Disponível em: <http://www. yvesklein.com/en/expositions/ view/1158/la-specialisation-de-la-sensibilite-a-l-etat-matiere-premiere-en-sensibilite-picturale-stabilisee-le-vide-the-specialization-of-sensibility-in-the-raw-material-state-into-stabilized-pictorial-sensibility-the-void/>. Acesso em: 15 mar. 2021.
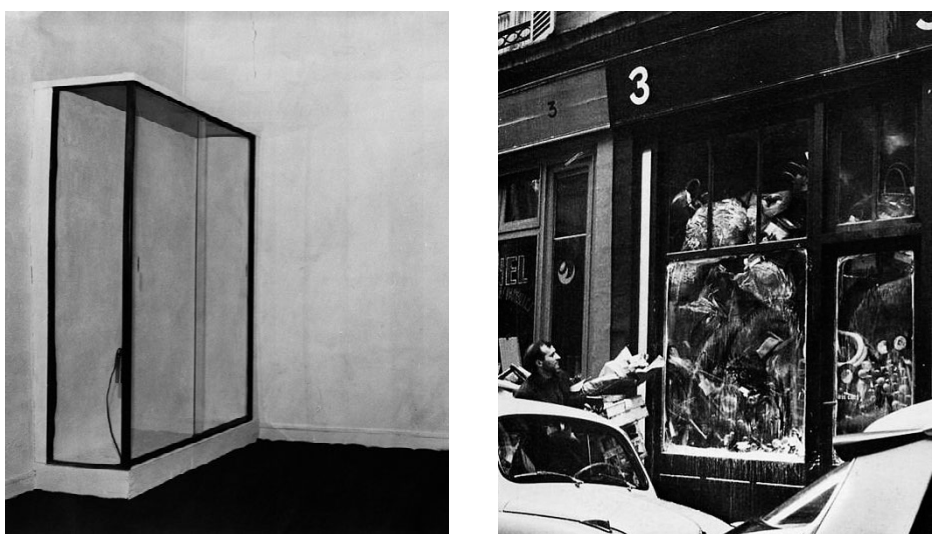

com frases e palavras soltas, evocando a ambiência urbana de outdoors, pichações e manchetes de jornal. O público era encorajado a realizar atividades variadas, como elaborar novos cartazes para afixá-los em locais à sua escolha ou tocar discos nas vitrolas dispostas sobre bancadas, completando a obra multissensorial com sua participação. Ao contrário de artistas associados à Arte Pop e ao Minimalismo, que criavam objetos que podiam - na maior parte dos casos - ser expostos como pinturas ou esculturas nos ambientes limpos e discretos de museus e galerias convencionais, Kaprow opunha-se à autoridade desses espaços institucionalizados, criando uma atmosfera efêmera e propositadamente conturbada pelo acúmulo de objetos corriqueiros e descartáveis em seus environments e happenings.

Mas não apenas espaços alternativos se prestavam a experimentalismos mais radicais, pois espaços convencionais também podiam servir como palco - e ainda como tema - para manifestações que desafiavam parâmetros estabelecidos da arte, como atestam duas exposições realizadas por volta dessa mesma época pelos artistas franceses Yves Klein (1928-1962) e Arman (1928-2005) na galeria de arte Iris Clert, em Paris. A primeira delas foi Le Vide [o Vazio], realizada por Klein em $1958,{ }^{196}$ na qual o artista pintou com o mesmo tom vibrante de azul - cor que patentearia pouco depois - tanto as bebidas oferecidas ao público convidado para a abertura da mostra, 

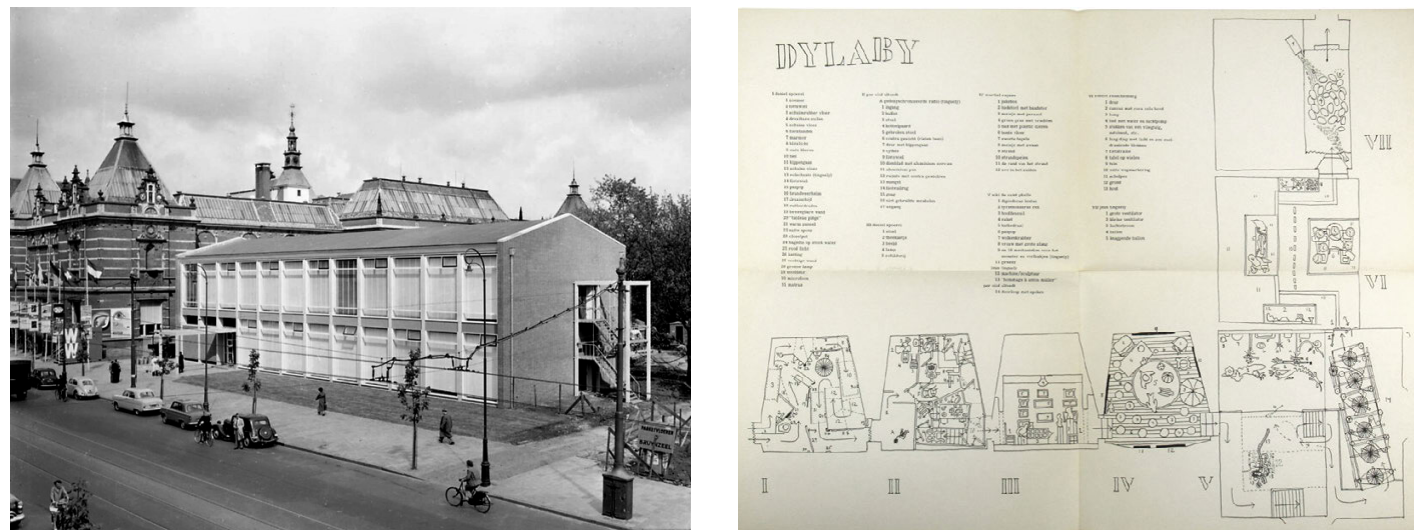

quanto a fachada da galeria e a cortina drapeada em frente à porta da rua, que, juntamente com os guardas convidados para "vigiar" a entrada, conferia um ar teatralmente cerimonioso ao evento, enfatizando os elementos da recepção para um evento sem nada a ser exposto. Em diálogo com a mostra de seu colega, Arman provocou questionamentos similares com recursos opostos na exposição Le Plein [o Cheio], de 1960. $\mathrm{O}$ artista tornou impossível a entrada na mesma galeria, preenchendo-a completamente com objetos sucateados, detritos e lixo, que, pressionados contra a vitrine transparente, ficavam em exposição para transeuntes da rua. ${ }^{197}$ Com essas exposições, Klein e Arman chamavam a atenção para o aparato de sustentação do sistema de arte, capaz de atribuir valor a qualquer coisa - até mesmo a algo inexistente ou a objetos de descarte.

Além de galerias comerciais, instituições mais estabelecidas - como museus de arte moderna e centros de arte dedicados à "arte de seu tempo" - também passaram a organizar exposições que integravam não apenas objetos, mas ainda intervenções artísticas que ocupavam o espaço com ações efêmeras, contando com a fundamental parceria intelectual e operacional conduzida por dirigentes de instituições, que apontavam para um novo tipo de prática curatorial. Esse foi o caso da exposição Dylaby (nome originado da contração da expressão Dynamic Laboratory), realizada em 1962 pelo Stedelijk Museum de Amsterdã - a última organizada ali por seu diretor, o holandês Willem

2.6 Edifício do Stedelijk Museum de Amsterdã, de 1895, com a nova ala inaugurada em 1954. Foto: Ben van Meerendonk/Coleção IISH. Fonte: https:// www.flickr.com/photos/iisg/4929852609/ in/album-72157625638168048/

2.7 Encarte do catálogo com mapa da exposição Dilaby, Stedelijk Museum, Amsterdã, 1962. Fonte: ALTSHULER, p. 29.

197 Yves Klein e Arman faziam parte de um grupo bastante politizado em torno de conscientização social que, nessa mesma época, lançou o manifesto do Novo Realismo, redigido por Pierre Restany e assinado ainda pelos artistas François Dufrêne, Raymond Hains, Martial Raysse, e Daniel Spoerri, Jean Tinguely e Jacques Villeglé, contendo uma única frase: "Os Novos Realistas tornaram-se conscientes da sua identidade coletiva; Nouveau Realisme = novas percepções do real". Apud Foster, Hal et al. Art Since 19oo: Modernism, Antimodernism, Postmodernism. Londres: Thames \& Hudson, 2004, p. 434.

O grupo expandiu-se em seguida, atraindo ainda artistas da França, dos EUA e do Brasil. 
2.8 Vista da Sala I da exposição Dylaby, ambientada por Daniel Spoerri, Stedelijk Museum, Amsterdã, 1962. Foto: Ed van der Elsken/Nederlands Fotomuseum. Fonte: ALTSHULER, p. 30.

2.9 Vista da Sala III da exposição Dylaby, ambientada por Daniel Spoerri, Stedelijk Museum, Amsterdã, 1962. Foto: Ed van der Elsken/Nederlands Fotomuseum. Fonte: ALTSHULER, p. 31.

2.10 Vista da Sala IV da exposição Dylaby, com a obra Raysse Beach de Martial Raysse, Stedelijk Museum, Amsterdã, 1962. Foto: Ed van der Elsken/Nederlands Fotomuseum. Fonte: ALTSHULER, p. 31.

2.11 Vista da Sala V da exposição Dylaby, com a obra de Niki de Saint Phalle, Shooting Gallery, Stedelijk Museum, Amsterdã, 1962. Foto: Ed van der Elsken/Nederlands Fotomuseum. Fonte: ALTSHULER, p. 32.

2.12 Niki de Saint Phalle (com um rifle) e Willem Sandberg (à sua esquerda), na obra Shooting Gallery da exposição Dylaby, Stedelijk Museum, Amsterdã, 1962. Foto: Ed van der Elsken/Nederlands Fotomuseum. Fonte: ALTSHULER, p. 32.

2.13 Instalação de Jean Tinguely na Sala VII da exposição Dylaby, Stedelijk Museum, Amsterdã, 1962. Foto: Ed van der Elsken/Nederlands Fotomuseum. Fonte: ALTSHULER, p. 33.

198 Willem Sandberg foi diretor do Stedelijk Museum de 1945 a 1963.

199 Altshuler, Bruce (Ed.). Biennials and Beyond. Exhibitions That Made Art History: 196-2002. Londres: Phaidon, 2013, p. 25-36.
Sandberg (1897-1984). ${ }^{198}$ A partir de um projeto para um espaço labiríntico não realizado que Jean Tinguely (1925-1991) concebera anteriormente, a exposição contava com obras comissionadas a esse e a outros cinco artistas - o também suíço Daniel Spoerri (1930-), os franceses Niki de Saint Phalle (1930-2002) e Martial Raysse (1936-), o finlandês Per Olof Ultvedt (1927-2006) e o estadunidense Robert Rauschenberg. ${ }^{199}$

Em Dylaby, sete das galerias tradicionais de uma das alas do edifício neorrenascentista holandês de 1895 foram transformadas em uma sequência de obras criadas individualmente ou em parceria entre os artistas. Na sala de entrada, ocupada por Daniel Spoerri, uma bifurcação permitia escolher entre dois percursos por corredores escuros cheios de objetos e em ziguezague, um mais longo e com planos escalonados e outro horizontal. Ambos convergiam para a sala seguinte, concebida por Per Olof Ultvedt, também subdividida em pequenos ambientes organizados numa sequência tortuosa com planos elevados e ocupados com mobília doméstica em posições inusitadas. Na terceira sala, Spoerri montou uma galeria expositiva com pinturas e esculturas tradicionais, porém dispostas de modo rotacionado, com uma das paredes laterais fazendo as vezes de piso e a oposta de teto. $\mathrm{Na}$ sequência, Martial Raysse instalou uma piscina circular no centro da sala, contendo um totem com o letreiro Raysse Beach em neon e cercada por itens praianos, como boias de vários e um guarda-sol, além de uma jukebox que podia ser operada pelo público, estimulado a dançar no interior do museu. Niki de Saint Phalle dispôs no ambiente seguinte esculturas de animais, acima das quais ficavam pendurados sacos cheios de tinta que podiam ser estourados com tiros de espingarda acionadas pelo público, que assim esparramava cores pelas peças e pela sala. Rauschenberg, por sua vez, apresentou a seguir diversas assemblages com objetos industriais - como relógios, pneus e tubos metálicos -, mas inseriu-as dentro de quatro "gaiolas" dispostas ao redor de um circuito demarcado no piso como uma pista de veículos. No fim do percurso, Tinguely estreitou a sala, inclinou o piso e espalhou balões de festa que se movimentavam constantemente pelo ar insuflado por ventiladores nas duas extremidades. 

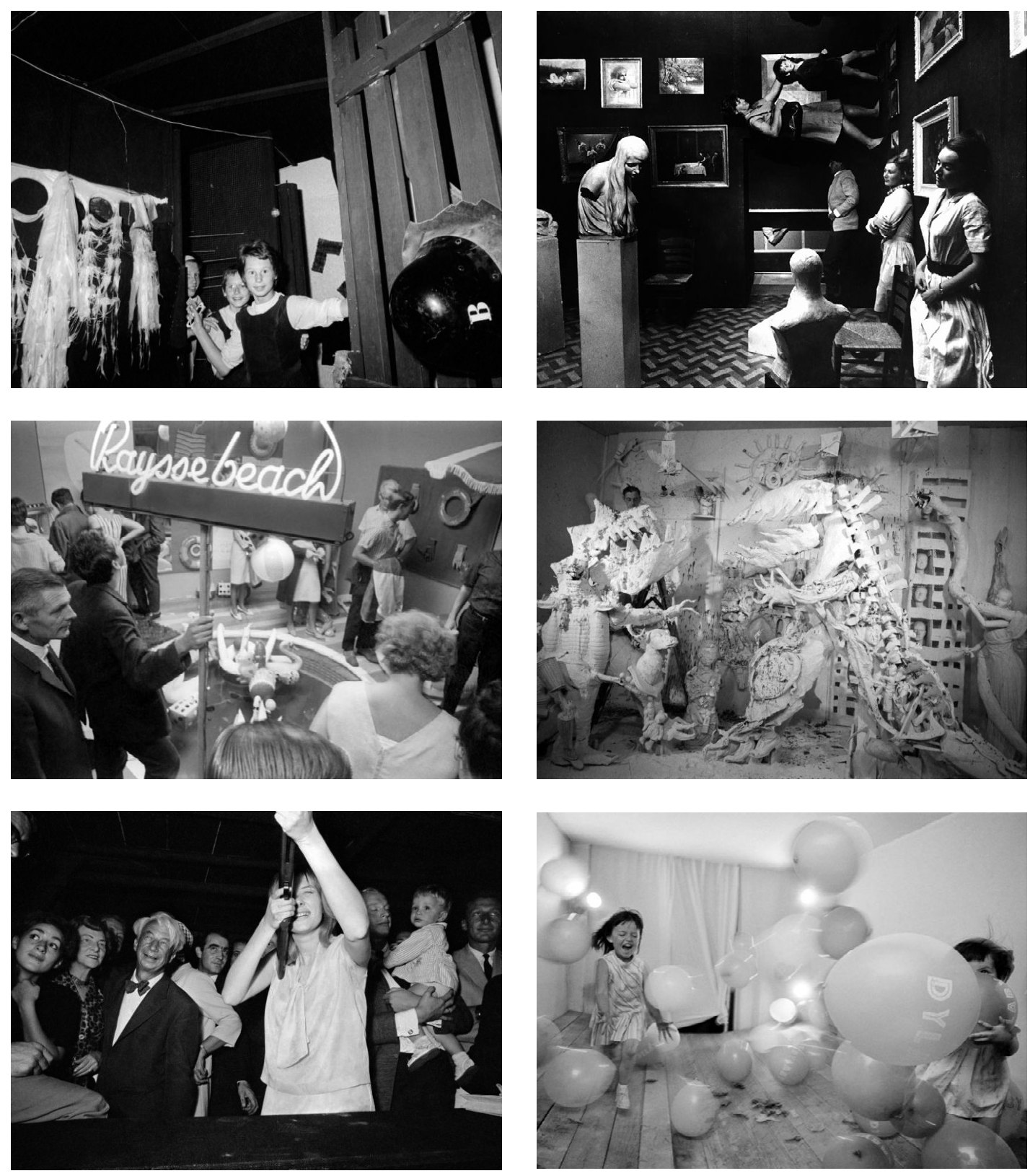


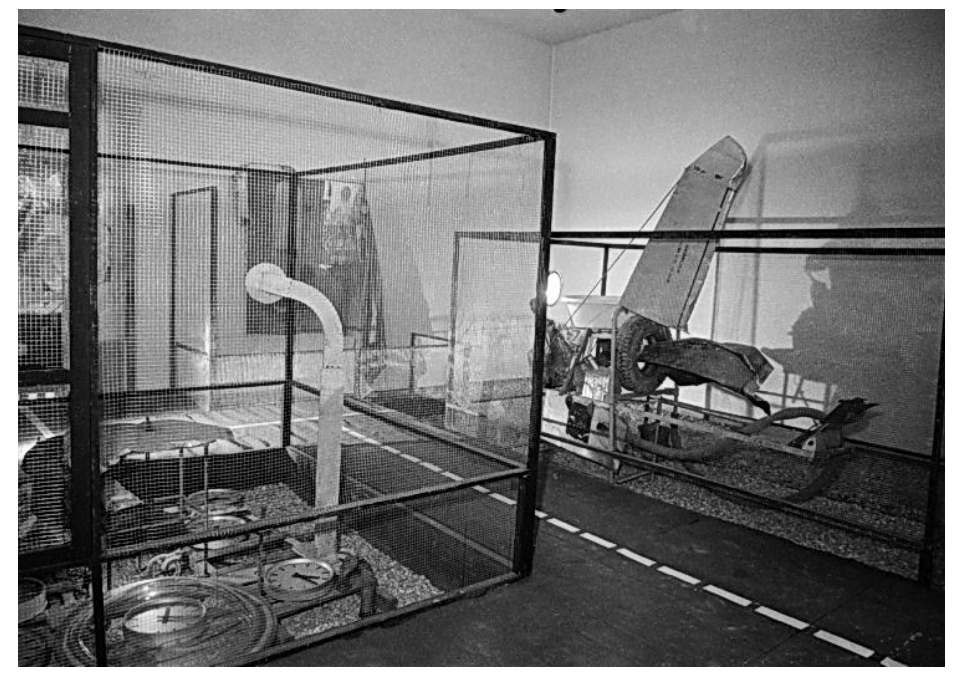

2.14 Instalação de Robert Rauschenberg na Sala VI da exposição Dylaby, Stedelijk Museum, Amsterdã, 1962. Fonte: ALTSHULER, p. 33.
Entre a atmosfera surrealista e/ou de entretenimento da mostra, pode-se observar nos registros fotográficos que a sala de Rauschenberg era a que menos se distanciava de um espaço museológico convencional, sugerindo uma atitude mais contemplativa do que interativa com as obras. Suas intervenções ambientais pareciam funcionar sobretudo como complemento para as assemblages, cujo caráter objetual colaborou para que estivessem entre as poucas peças remanescentes desse evento concebido como temporário. Ainda assim, a informalidade predominante nos ambientes expositivos indicava possibilidades mais abertas de interação do público com as obras, além de um grau mais intenso de colaboração entre artistas e instituições durante a concepção, produção e operação dos eventos.

Tal parceria entre artistas e museus passou a ser cada vez mais requisitada em exposições contendo obras que não eram objetos acabados, mas intervenções ambientais de caráter arquitetônico e/ou performático, que, não raro, criavam impasses embaraçosos ao forçar limites entre os compromissos das instituições e a liberdade de expressão dos artistas. Foi o que ocorreu com a primeira apresentação num museu da obra de Hélio Oiticica, Parangolé (1964), na inauguração da mostra coletiva Opinião 65, realizada em 1965 no Museu de Arte Moderna do 

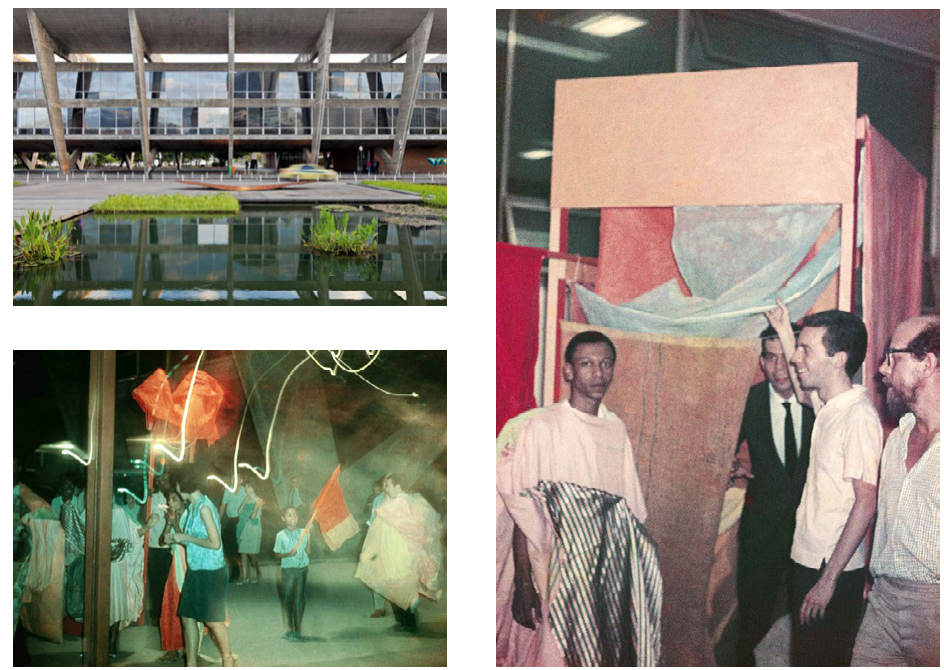

Rio de Janeiro, sediado num edifício modernista projetado em 1953 pelo arquiteto brasileiro Affonso Eduardo Reidy (1909-1964), com amplos espaços envidraçados, visualmente abertos para a paisagem. Organizada pelos galeristas Jean Boghici (1928-), romeno residente no Brasil, e Céres Franco (1926-), brasileira residente na França, a mostra reunia 29 artistas -13 de nacionalidade europeia e 16 de nacionalidade brasileira - em torno das pesquisas recentes afinadas com a tendência identificada como Nova Figuração, embora a diversidade de trabalhos apresentados extrapolasse esse rótulo. ${ }^{200}$ Diversos trabalhos apresentavam conteúdos que se contrapunham a valores e práticas do regime de ditadura militar instaurado recentemente no país (1964-1985) que, embora ainda não tivesse atingido o pico de repressão que marcaria os anos seguintes, já contaminava de tensão a atmosfera de qualquer evento cultural. Em contraste com a formalidade comum em vernissages da época no MAM carioca, Oiticica pretendia apresentar seu Parangolé numa performance de música e dança realizada no interior do museu com integrantes da escola de samba da Estação Primeira de Mangueira, vestidos com as capas criadas pelo artista. Seu plano, porém, não foi executado conforme previsto, pois logo que os sambistas começaram a tocar e dançar, dominando o

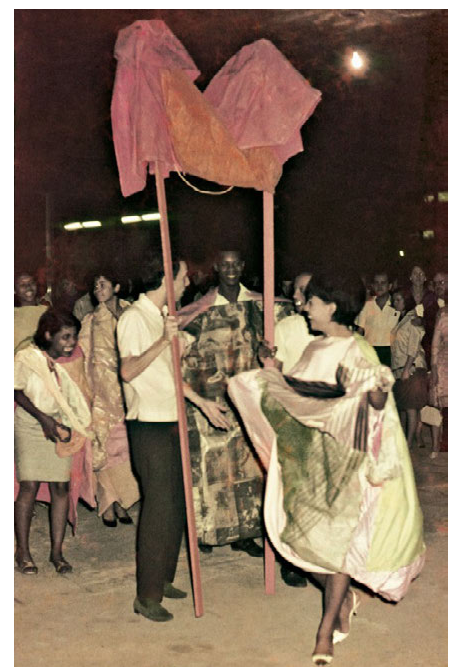

2.15 Fachada do Museu de Arte Moderna do Rio de Janeiro, projeto de Affonso Eduardo Reidy de 1953. Fonte: http://arqguia.com/obra/ museu-de-arte-moderna/?lang=ptbr

2.16 a 2.18 Hélio Oiticica e integrantes da escola de samba Estação Primeira de Mangueira em apresentação com seus Parangolés na inauguração da exposição Opinião 65, MAM, Rio de Janeiro, 1965. Foto: Desdémone Bardin. Fonte: https://mam.rio/historia/ parangole-em-opiniao-65/

200 ENCICLOPÉDIA ITAÚ Cultural. Opinião 65. Enciclopédia Itaú Cultural. Disponível em: <https://enciclopedia.itaucultural.org.br/evento81812/ opiniao-65-1965-rio-de-janeiro-rj>. Acesso em: 16 abr. 2021. 


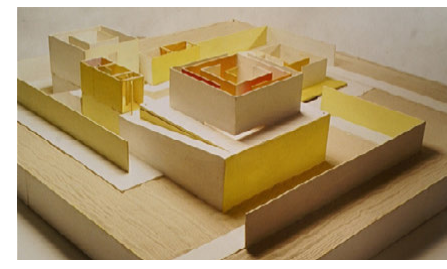

2.19 Hélio Oiticica, Projeto Cães de Caça, 1961. Fonte: https://doi.org/10.4000/ imagesrevues. 2262
201 Programa Helio Oiticica Itaú Cultural. Projeto Cães de Caça. Itaú Cultural. Disponível em: <https://legacy-ssl.icnetworks. org/extranet/enciclopedia/ho/ index.cfm?fuseaction=documentos $\& \operatorname{cod}=\mathbf{1 5 2} \&$ tipo $=2>$. Acesso em: 16 abr. 2021.

202 K.G. Pontus Hultén foi diretor do Moderna Museet de Estocolmo entre 1958 e 1973 .

203 Cf. Moderna Museet. Remembering She - A Cathedral (3.6 2018-10.3 2019). Moderna Museet. Disponível em: <https:// www.modernamuseet.se/stockholm/en/exhibitions/remembering-she-a-cathedral/>. Acesso em: 16 abr. 2021. espaço da exposição com sua música percussiva em alto volume, o grupo foi solicitado a se retirar do evento e a apresentação só pôde ser realizada no exterior, atraindo boa parte do público e dos artistas presentes para fora do museu, num exemplo emblemático das tensões que podiam surgir entre eventos de arte ambiental e os espaços institucionais, especialmente em conjunturas políticas desfavoráveis à liberdade de expressão.

Oiticica havia apresentado no mesmo museu uma de suas primeiras obras ambientais, o Projeto Cães de Caça, de 1961, integrando a mostra coletiva $3^{\underline{a}}$ Exposição de Arte Neoconcreta, realizada naquele mesmo ano. A obra propunha ao público uma vivência da cor por meio de um percurso labiríntico, composto por uma estrutura arquitetônica com planos coloridos que o artista chamou de "jardim", contendo cinco de seus Penetráveis, o poema Enterrado de Ferreira Gullar e o Teatro Integral de Reynaldo Jardim. ${ }^{201} \mathrm{O}$ projeto tinha um caráter inovador como experiência de arte ambiental, mas não chegou a ser concretizado e, tendo sido apresentado apenas em forma de maquete, não tinha potencial para causar o mesmo grau de constrangimento ao museu que a apresentação dos Parangolés.

Assim como o Stedelijk Museum de Amsterdã, outras instituições tinham mais disposição em assumir riscos com exposições experimentais ou transgressoras, como o Moderna Museet (Museu de Arte Moderna) de Estocolmo, dirigido pelo sueco K.G. Pontus Hultén (1924-2006). ${ }^{202}$ Em 1966, o diretor convidou três artistas que tinham trabalhado em Dylaby - Niki de Saint Phalle, Jean Tinguely e Per Olof Ultvedt - para, conjuntamente com ele, realizarem uma exposição interativa no museu, sediado desde 1958 num antigo ginásio de exercícios da marinha.$^{203} \mathrm{O}$ intenso trabalho colaborativo e improvisado dos artistas e do diretor transcorrido ao longo de cinco semanas resultou em Hon - en katedral (Ela - Uma Catedral), uma escultura de grandes dimensões $-28 \mathrm{~m}$ de comprimento por $6 \mathrm{~m}$ de altura - com a forma de uma mulher grávida deitada no chão, dentro da qual o público, penetrando pela região da vagina, encontrava uma série de ambientes com elementos como um aquário de peixes, um sofá, um bar, uma galeria expositiva, um pequeno cinema e um escorregador para crianças. Conforme relatou Hultén, "a obra parecia corresponder a algo no ar, à 

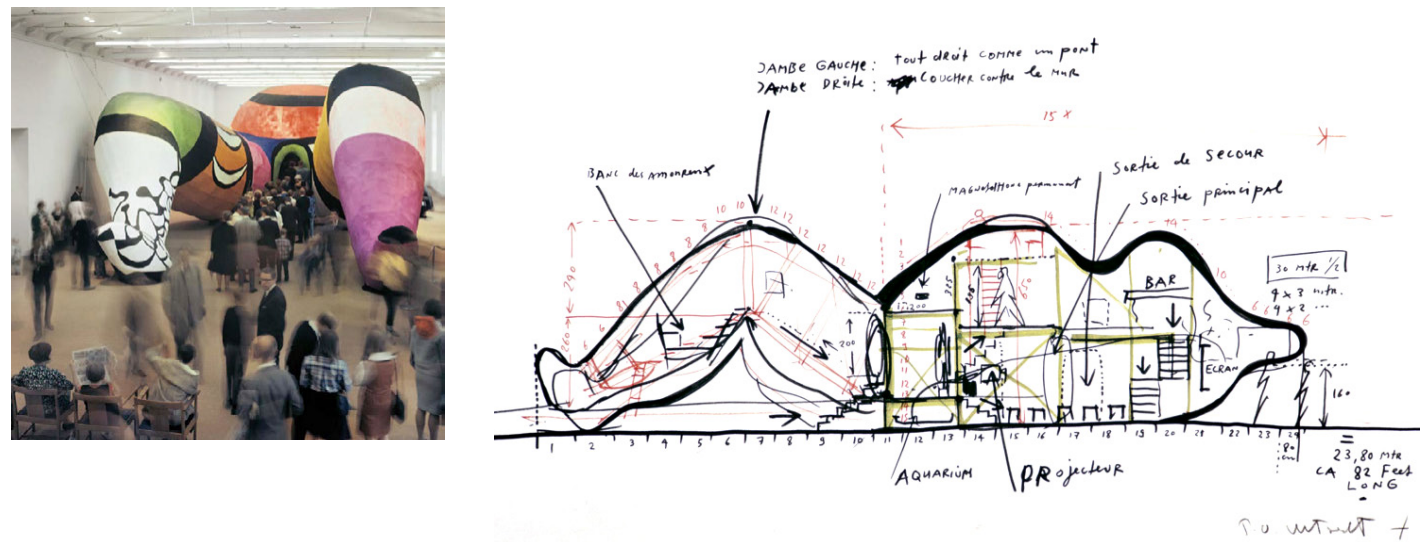

tão louvada 'liberação sexual' da época", ${ }^{204}$ o que teria colaborado para sua boa aceitação junto ao público e à crítica. A obra evidenciava que a interação com arte podia expandir-se para além do contato visual ou tátil, incluindo também o contexto sócio cultural em que estava inserida.

Em 1968, o diretor organizou ainda no Moderna Museet um evento que incitava de modo ainda mais intenso a participação do público - a mostra The Model - A Model for a Qualitative Society, concebida pelo artista dinamarquês Palle Nielsen (1942-), em colaboração com a jornalista sueca Gunilla Lundahl (1936), com autoria atribuída a um coletivo - The Working Group. ${ }^{205}$ Montado na principal galeria do museu, o projeto consistia num playground de grandes dimensões para crianças, dando sequência a um programa de implantação de parques infantis em Copenhage, que o artista vinha organizando clandestinamente com comunidades locais, estudantes de arquitetura e ativistas do grupo Action Dialogue. The Model era configurado por uma estrutura de madeira que podia ser escalada, tendo ao centro uma grande área coberta com blocos de espuma na qual se podia pular, rodeada por espécies de oficinas livres de pintura, marcenaria, figurinos e música. A ideia era que as atividades espontaneamente escolhidas pelas crianças pudessem oferecer um modelo de interação social para os adultos, encorajados não apenas a observar, mas a participar da brincadeira liderada por elas. Conforme expresso no catálogo, "A exposição é o trabalho das crianças./ Não há
2.20 Vista da instalação HON - en katedral, Moderna Museet, Estocolmo, 1966. Foto: Hans Hammarskiöld. Fonte: https:// www.afterall.org/article/hon-en-katedralbehind-pontus-hult-n-s-theatre-ofinclusiveness

2.21 Niki de Saint Phalle, Jean Tinguely, Per Olof Ultvedt, projeto para a instalação HON - en katedral, Moderna Museet, Estocolmo, 1966. Fonte: https://www. modernamuseet.se/stockholm/en/ exhibitions/remembering-she-a-cathedral/

204 Pontus Hultén apud OBRIST, Hans Ulrich. Uma breve história da curadoria. São Paulo: BEI, 2010, p. 59.

205 O grupo não existia, era apenas um nome criado por Nielsen. Cf. ARKEN MUSEUM OF MOderN ART. The Model: Palle Nielsen. Ishøj: ARKEN Museum of Modern Art, 2015, p. 30. Tradução nossa. 

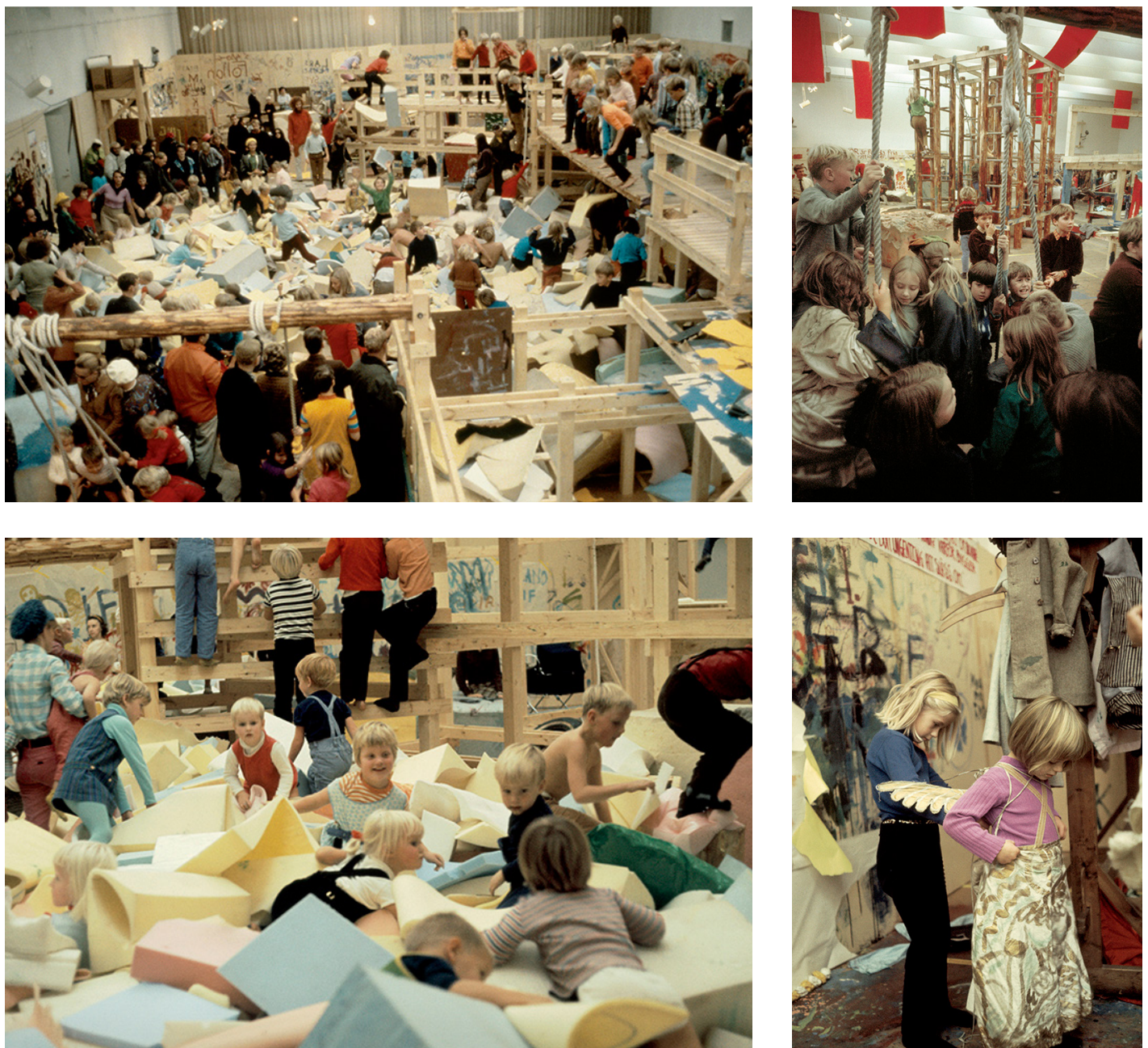

206 Palle Nielsen apud Ibidem, p. 31 .
exposição./Só é uma exposição porque as crianças estão brincando num museu de arte./Só é uma exposição para quem não está brincando. Por isso a chamamos de modelo." ${ }^{206}$ Exposição, de acordo com essa visão, seria algo que dependeria de um espaço destinado à arte - uma moldura institucional - e que pressuporia uma postura contemplativa, oposta à participativa - daí a rejeição da expressão para caracterizar o evento. Se a ideia de oferecer um modelo de interação para a sociedade 

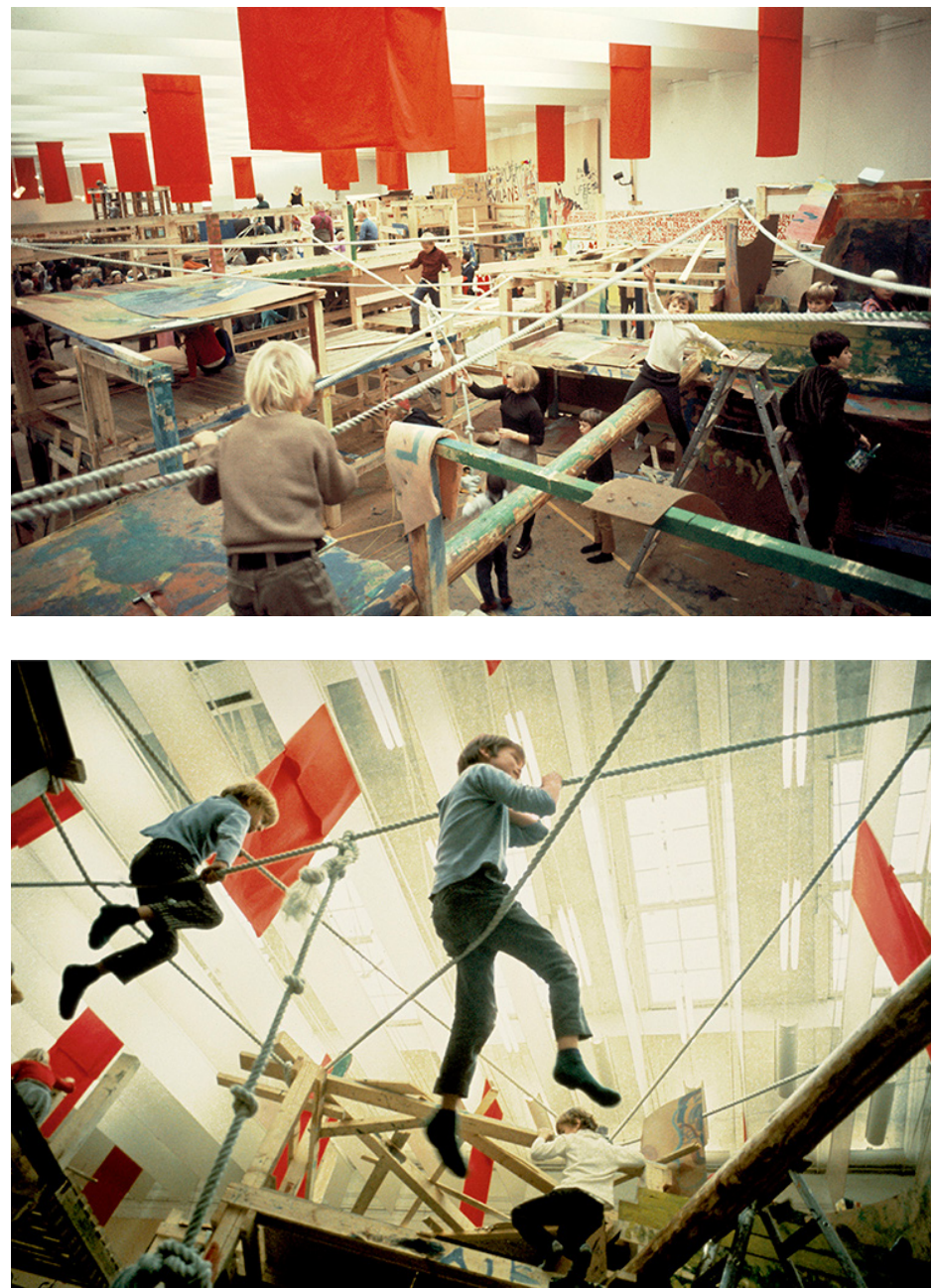

tinha um caráter utópico, a transformação que The Model operou no espaço expositivo foi concreta, pois a transferência do protagonismo da ação às crianças rompia efetivamente com o decoro e o elitismo frequentemente associados aos museus e apontava para novas possibilidades de engajamento do público com a arte e a instituição.

Por suas características ambientais, tomando todo o espaço expositivo e oferecendo uma experiência imersiva e participa-
2.22 a 2.27 Vistas de The Model - A Model for a Qualitative Society, de Palle Nielsen, Moderna Museet, Estocolmo, 1968.

Fonte: https://www.macba.cat/en/learnexplore/publications/palle-nielsen-modelmodel-qualitative-society 
tiva, The Model exemplifica o que chamamos hoje de "instalação" - embora o emprego do termo tenha se generalizado apenas mais tarde, podendo designar também o ato literal de montagem das obras numa exposição. Como registrou a historiadora da arte Claire Bishop, a origem da utilização do termo installation art estaria relacionada à expressão installation shot, que passou a ser empregada pela imprensa especializada para se referir ao registro fotográfico das montagens expositivas, a partir de meados dos anos 1960 - justamente quando o arranjo espacial das obras no espaço adquiria novo significado. ${ }^{207} \mathrm{~A}$ autora apontou ainda para o modo com que a linhagem desse tipo de obra tem sido comumente apresentada na história da arte:

A instalação já possui uma história cada vez mais canônica: de viés ocidental e se desenrolando ao longo do século $\mathrm{xx}$, essa história começa invariavelmente com El Lissitzky, Kurt Schwitters e Marcel Duchamp, passa a discutir Environments e Happenings no final dos anos 1950, acena em deferência à escultura Minimalista da década de 1960 e, finalmente, defende a ascensão da instalação nas décadas de 1970 e 1980. A história convencionalmente termina com sua apoteose como a forma de arte aprovada por excelência na década de 1990, como vista nas instalações espetaculares que ocupam grandes museus tais como o Guggenheim em Nova York e o Hall das Turbinas da Tate. ${ }^{208}$

A historiadora da arte Julie Reiss, por sua vez, descreveu o modo gradual com que o termo "instalação" viria a se tornar dominante. Nos anos 1960, seria comum empregar o termo environment - definido primeiramente por Kaprow - para designar uma variedade de obras que ocupassem todo o ambiente expositivo, envolvendo o público em seu interior e colocando-o, assim, na condição de participante. Sua utilização seria ainda frequente até meados dos anos 1970, ao lado de outras como Project art ou temporary art. Segundo a autora, o termo

207 BISHOP, Claire. Installation Art. Londres: Tate Publishing, 2005, p. 6. 208 Ibidem, p. 8. Tradução nossa. installation não teria substituído a expressão environment, mas teria passado, de modo lento, a ser empregado no lugar de "exposição", nos casos de trabalhos produzidos no próprio local 

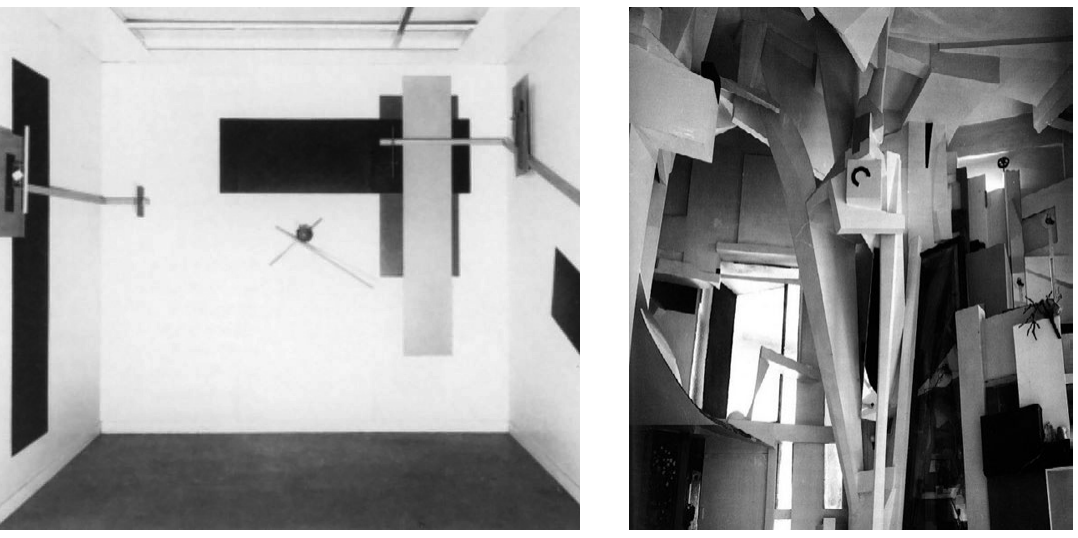

expositivo. Apenas no final dos anos 1980 é que a expressão installation art teria se generalizado para designar o gênero artístico que implicava ocupação do espaço e envolvimento do público. Desde sua consolidação a partir da década seguinte, a expressão "instalação" vem sendo utilizada inclusive para se referir a obras produzidas em momentos em que ainda não eram nomeadas como tal. ${ }^{209}$

Retomando o foco de discussão desta tese, importa atentar para o fato de esse tipo de obra ambiental, interativa e frequentemente efêmera - a instalação -, ter provocado uma ruptura com os paradigmas da arte estabelecidos no momento de seu surgimento, contrapondo-se ao modo convencional de operar dos museus e colocando novos problemas para a arquitetura dos espaços expositivos. Assim como outras manifestações experimentais que ocorriam simultaneamente na década de 1960, a instalação de arte não se enquadrava no modo estabelecido até aquele momento de comercializar, preservar e colecionar objetos, incluindo frequentemente o esvaziamento de qualidades formais tradicionalmente valorizadas e, por vezes, a efetiva desmaterialização das obras. Como observou Reiss, "em virtude de sua natureza efêmera, essas formas desafiavam o sistema de mercado do mundo da arte e, por extensão, tornaram-se um protesto contra a política das instituições." ${ }^{210}$

Mas não necessariamente obras que não se limitavam à condição de objeto e englobavam em si o espaço em que estavam

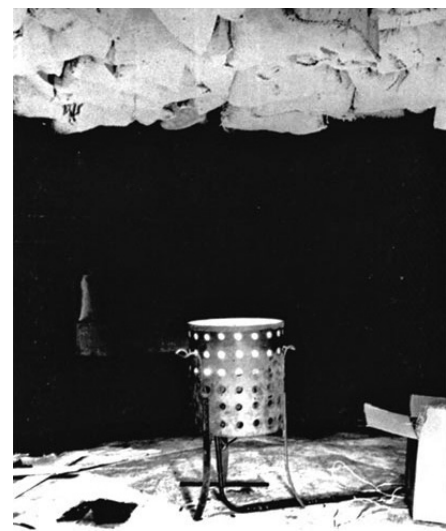

2.28 Reconstrução do Proun Space de El Lissitzky, Stedelijk Van Abbemuseum, Eindhoven, 1965. Fonte: https://doi. org/10.2307/1575865

2.29 Kurt Schwitters, Merzbau, Hannover, 1933. Foto: Wilhelm Redemann. Fonte: https://www.moma.org/explore/inside_ out/2012/07/09/in-search-of-lost-artkurt-schwitterss-merzbau/

2.30 Marcel Duchamp, Ciel de roussettes, Exposition Internationale du Surréalisme, Paris, 1938. Fonte: https://artplastoc. blogspot.com/2013/08/150-marcelduchamp-1887-1968-quatrieme.html

209 REISs, Julie H. From margin to center: the spaces of installation art. Cambridge, Massachussets: Massachusetts Institute of Technology, 1999. pp. XI-XII. 210 Ibidem, p. 77. Tradução nossa. 


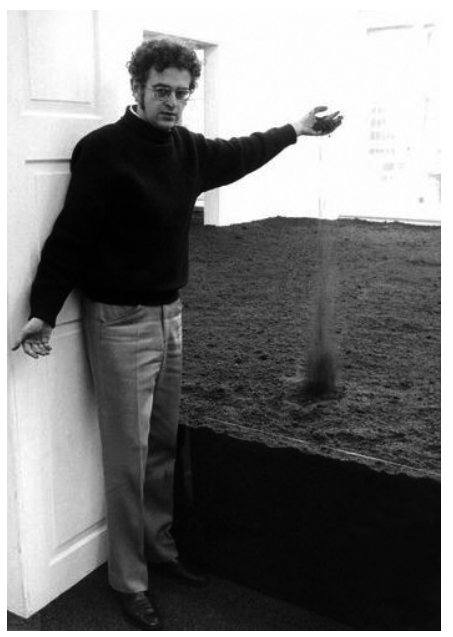

2.31 e 2.32 Artista e poster de sua exposição Walter de Maria The Land Show: Pure Dirt Pure Earth Pure Land, Galerie Heiner Friedrich, Munique, 1968. Fontes: https://www.cooperhewitt.org/ 2016/12/21/material-remains/ e https://i.pinimg.com/564x/06/76/65/ 0676656316aec11de46f8331e3b6 23cb.jpg
211 A obra foi doada pela galerista ao Museum of Contemporary Art de Los Angeles (MOCA) em 1984.

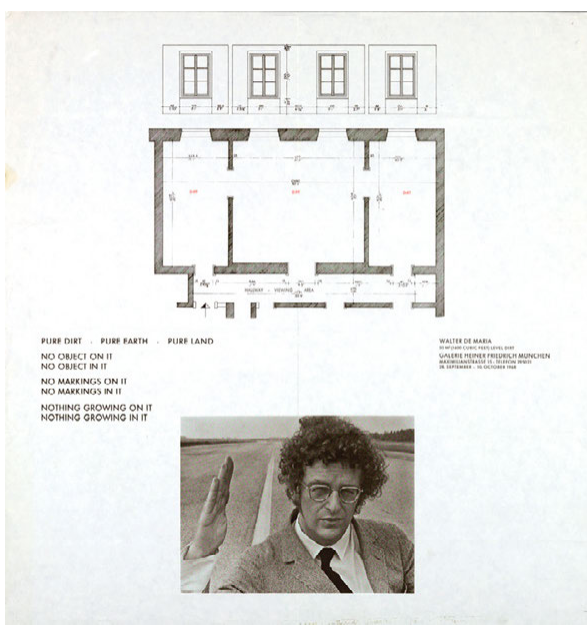

inseridas implicavam num modo de interação tão direta com o público, como no caso de The Model. Em 1968, o estadunidense Walter de Maria (1935-2013) realizou a exposição Walter de Maria The Land Show: Pure Dirt Pure Earth Pure Land, na qual preencheu a sala expositiva da Galeria Heiner Friedrich em Munique com 45 metros cúbicos de terra, incorporando todo o espaço arquitetônico à obra, mas permitindo ao público observá-la apenas pelo lado de fora, pelo vão da porta. Aquela seria uma das primeiras experiências identificadas como Earthwork, ou Land Art, que apontavam para o interesse de um grupo de artistas em incorporar a terra não apenas como matéria, mas sobretudo como espaço, tomando a paisagem intocada pelo ser humano como local de intervenção. Esse é o caso da obra Double Negative, realizada em 1969 pelo também estadunidense Michael Heizer (1944-), que consistia numa fenda de 9 metros de largura, 15 de profundidade e 457 de comprimento cavada no platô de uma região desértica no Estado de Nevada. A realização foi apoiada pela galerista Virginia Dwan, que comprou o terreno para a intervenção em troca da aquisição da obra, aceitando uma cláusula que a impedia de comercializá-la. ${ }^{211}$ Dada a dificuldade de acesso ao local remoto em que havia sido realizada, Double Negative era acessada sobretudo por registros fotográficos expostos na galeria, prescindindo, assim, do 


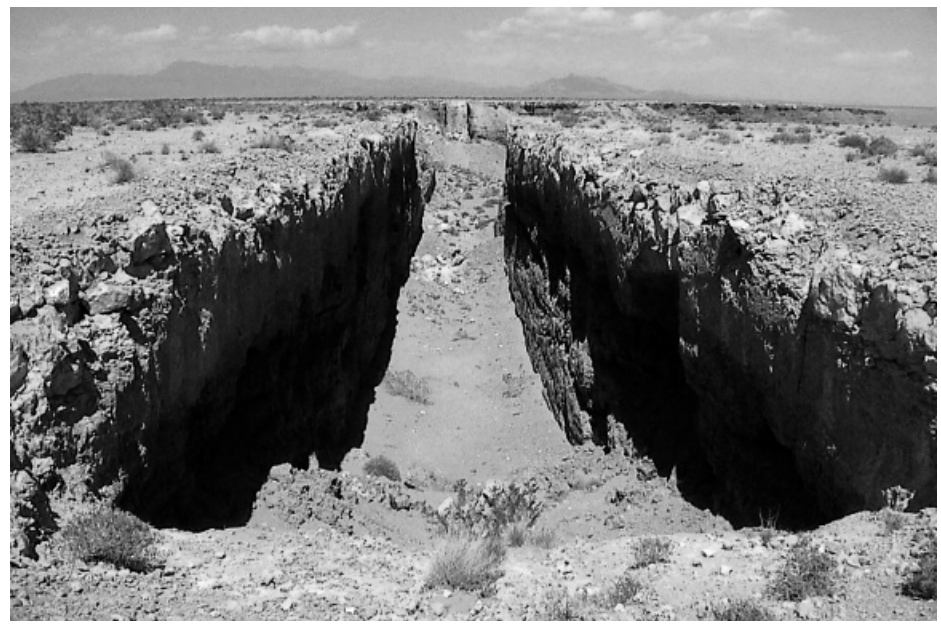

encontro físico com o público.

Foi com base na análise de obras de Heizer, de Maria e outros contemporâneos atuantes nos EUA a partir da segunda metade dos anos 1960 que a crítica estadunidense Rosalind Krauss (1941-) viria a desenvolver o conceito de "escultura no campo ampliado", englobando a intersecção entre arte e arquitetura, objeto da investigação desta tese. ${ }^{212} \mathrm{~A}$ autora identificou, nos procedimentos dessas obras, um rompimento tão profundo com as noções tradicionais de suporte, que teria implicado na transposição da fronteira histórica entre o modernismo e o pós-modernismo. Krauss apontou para a dificuldade de se continuar empregando o termo "escultura" para uma variedade de obras constituídas, por exemplo, de "corredores estreitos com monitores de TV ao fundo" - como em Performance Corridor, de Bruce Nauman (1969) -; "grandes fotografias documentando caminhadas campestres" - como em A line made by walking de Richard Long (1967) -; "espelhos dispostos em ângulos inusitados" - como em Mirrored Cubes de Robert Morris (1965); - ou "linhas provisórias traçadas no deserto" - como em Desert Cross, Walter De Maria (1969). ${ }^{213}$ E a dificuldade se agravaria ainda mais em certas obras dos anos seguintes, como as feitas de "pilhas de lixo enfileiradas no chão" - caso de Garbage Wall de Gordon Matta Clark (1971) -;
2.33 Michael Heizer, Double Negative, Deserto de Navada, 1969. Fonte: https:// news.artnet.com/art-world/harry-reidwants-to-save-michael-heizers-massiveland-art-installation-156543

212 Krauss, Rosalind. A escultura no campo ampliado. Gávea, v. 1, p. 128-137, 1984, p. 135 .

213 Ibidem, p. 129. 

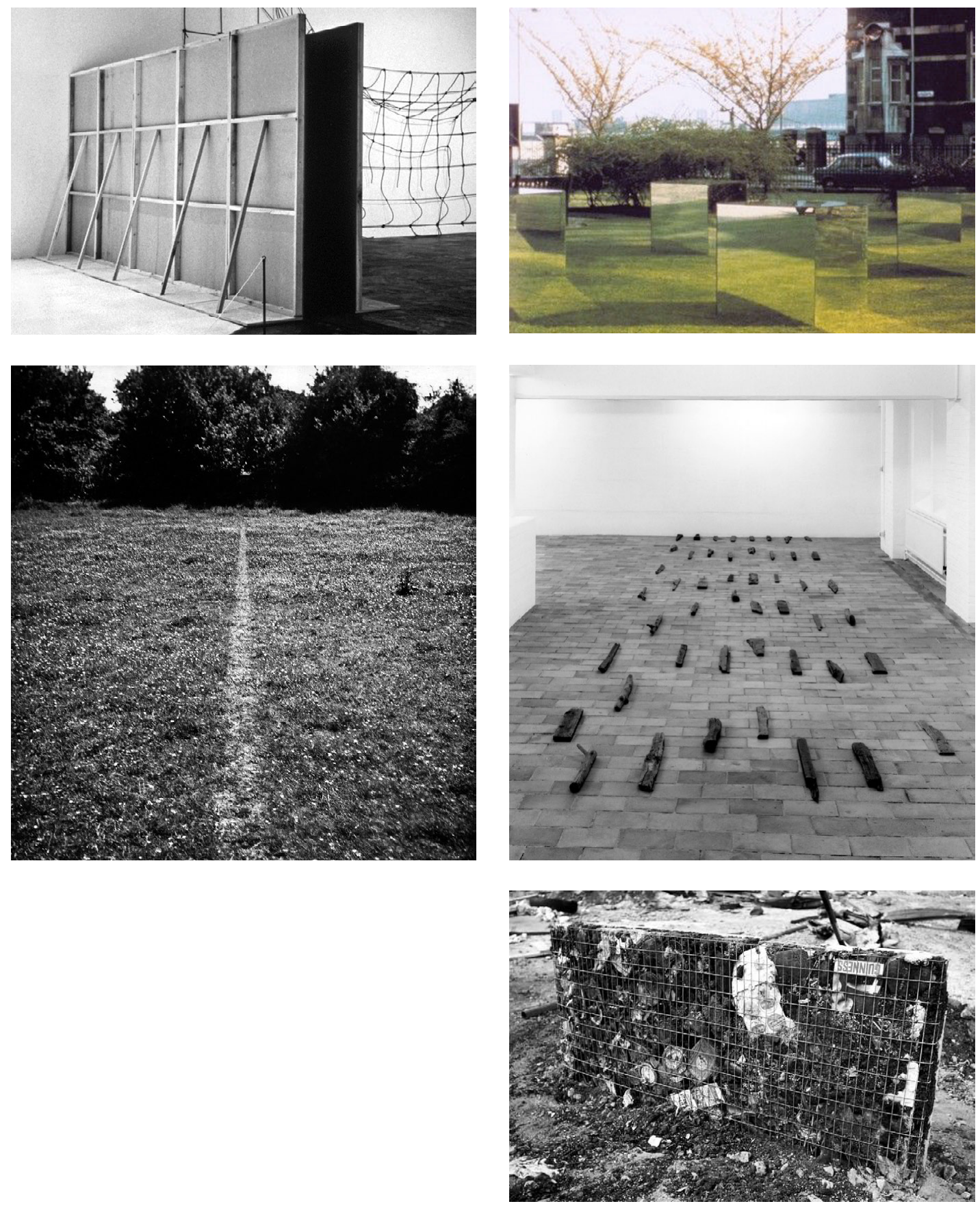
"sequóias serradas e jogadas na galeria" - como em Driftwood de Richard Long (1975) -; ou "toneladas de terra escavadas no deserto" - como em Double Negative de Michael Heizer (196970), já mencionada. ${ }^{214}$

A partir da constatação de que o termo escultura só faria sentido se compreendido no contexto do modernismo, cujo ciclo histórico estaria encerrado, Krauss defendeu que a nova relação espacial estabelecida por essas obras deveria ser pensada num campo ampliado que incluiria algumas combinações complexas dos conceitos positivos ou negativos de arquitetura e paisagem. Na intersecção entre esses dois termos estaria o campo que a autora chamou de local de construção, exemplificado pela obra de Robert Morris, Observatory (1971). ${ }^{215}$ Obras como Spiral Jetty, de Robert Smithson (1970) seriam, por sua vez, a combinação dos termos paisagem e não paisagem, categoria que a autora chamou de local demarcado. ${ }^{216}$ Por fim, a obra de Robert Irwin, Scrim veil-Black rectangle-Natural light (1977), exploraria o que seriam as possibilidades entre arquitetura e não arquitetura, o que denominaria de estrutura axiomática. ${ }^{217}$ Por estar justamente relacionada ao campo da arquitetura e englobar as relações entre os espaços expositivos das instituições e sua apropriação por artistas, essa última é, dentre as combinações levantadas pela autora, a que terá mais exemplos analisados ao longo desta tese.

O entendimento sobre o campo ampliado fora desenvolvido por Krauss a partir da escultura, observando sobretudo o aspecto formal da relação que certas obras estabeleciam com o espaço físico e a percepção fenomenológica a partir do Minimalismo, muitas das quais identificadas como site-specific, ou seja, concebidas e realizadas em estrita dependência de seus locais de inserção. Sobre as obras que deram origem a esse conceito - de implicação fundamental para as discussões desta tese -, a historiadora da arte sul-coreana Miwon Kwon (1961-) apontou:

Seja dentro do cubo branco ou no deserto de Nevada, seja arquitetônico ou orientado para a paisagem, a arte site-specific inicialmente considerou o local como um lugar existente, uma realidade tangível, cuja identidade era composta de uma com-
2.34 Bruce Nauman, Performance Corridor, 1969. Fonte: https://www.guggenheim. org/artwork/3148

2.35 Robert Morris, Mirror Cubes, 1965. Fonte: https://art.moderne.utl13. fr/2014/03/cours-du-24-mars-2014/2/

2.36 Richard Long, A line made by walking, 1967. Fonte: https:// www.tate.org.uk/art/artworks/ long-a-line-made-by-walking-ar00142

2.37 Richard Long, Driftwood, Herbert Foundation, Ghent, 1975. Fonte: https:// herbertfoundation.org/nl/collection/ richard-long

2.38 Gordon Matta-Clark, Garbage Wall, 1971. Fonte: https://www.muhka.be/ programme/detail/14-gordon-matta-clark
214 Ibidem, p. 130.

215 Ibidem, p. 135 .

216 Ibidem, p. 136.

217 Ibidem, p. 136. 

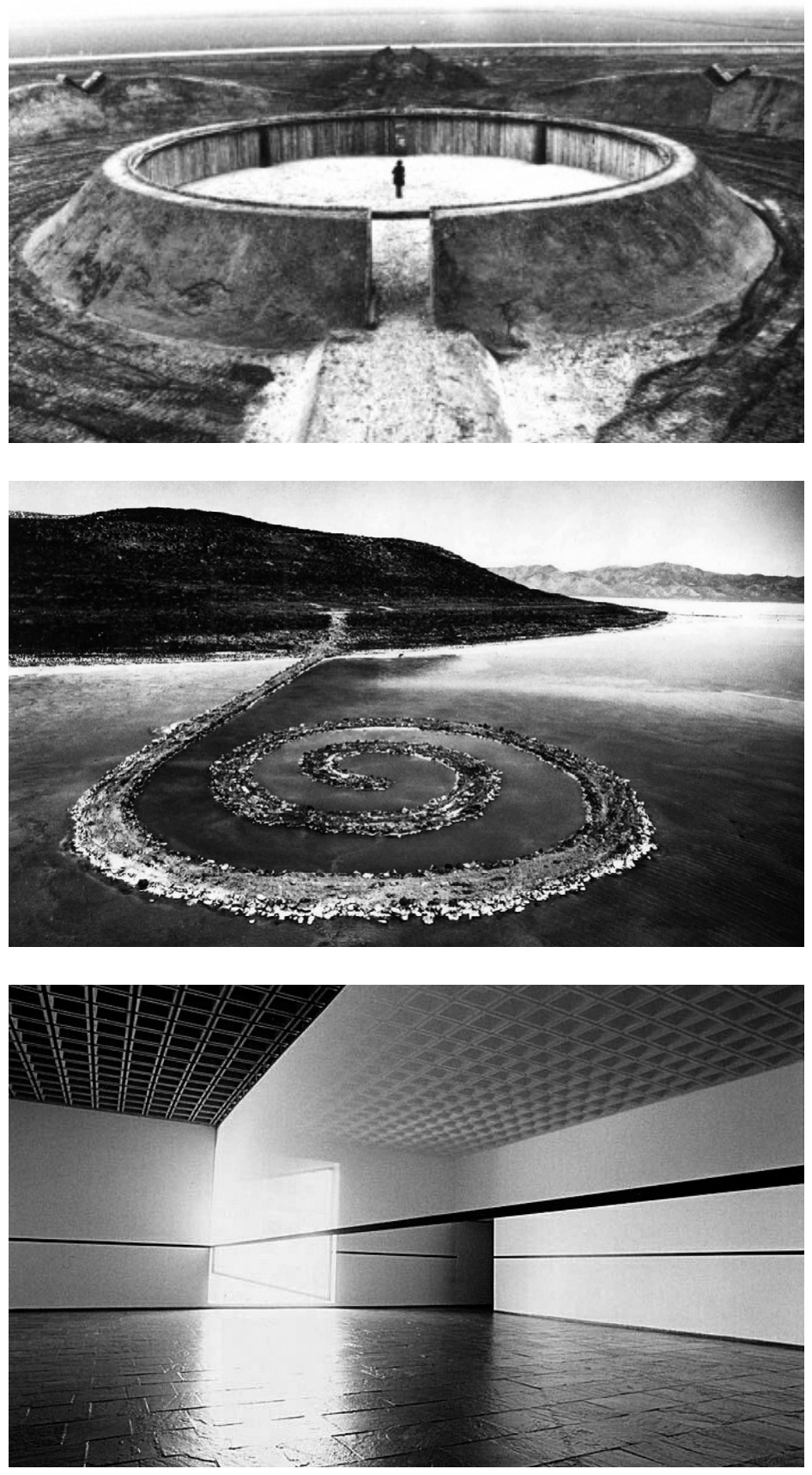
binação única de elementos físicos: comprimento, profundidade , altura, textura e forma de paredes e salas; escala e proporção de praças, edifícios ou parques; condições existentes de iluminação, ventilação, padrões de tráfego; características topográficas distintas e assim por diante..$^{218}$

Em finais dos anos 1960, no entanto, uma outra vertente da arte site-specific ganhava corpo, tendo como interesse abordar aspectos imateriais de seus locais de inserção, envolvendo não apenas o espaço físico, mas as esferas sociais, econômicas, políticas e culturais. Nesse sentido, as características dos espaços arquitetônicos designados à arte passaram a ser articuladas às condições ideológicas associadas aos mecanismos de produção, distribuição e recepção de obras, como explicou Kwon:

Enquanto o Minimalismo desafiou o hermetismo idealista do objeto de arte autônomo, desviando seu significado para o espaço de sua apresentação, a crítica institucional complicou ainda mais esse deslocamento ao destacar o hermetismo idealista do próprio espaço de apresentação. O espaço moderno de galeria/museu, por exemplo, com suas paredes totalmente brancas, iluminação artificial (sem janelas), clima controlado e arquitetura imaculada, foi percebido não apenas em termos de dimensões básicas e proporções, mas como um disfarce institucional, uma exposição normativa convenção servindo a uma função ideológica. As características arquitetônicas aparentemente benignas de uma galeria/museu, em outras palavras, foram consideradas como mecanismos codificados que desassociam ativamente o espaço da arte do mundo exterior, promovendo o imperativo idealista da instituição de tornar a si mesma e seus valores 'objetivos', 'desinteressados' e 'verdadeiros'. ${ }^{219}$

A vertente que passou a explorar essas articulações entre espaço e condições sociais ficou conhecida como "crítica institucional", tendo como expoentes artistas de diversas procedências, como o belga Marcel Broodthaers (1924-1976), o francês Daniel Buren (1938-), o alemão Hans Haacke (1936-) e o estadunidense Michael Asher (1943-2012). Como descreveu
2.39 Robert Morris, Observatory, Flevoland, 1971. Fonte: https://www.wikiart.org/en/ robert-morris/observatory-1997

2.40 Robert Smithson, Spiral Jetty, Salt Lake, 1970. Foto: Gianfranco Gorgoni. Fonte: https://www.artribune.com/ television/2015/09/land-art-oltre-ilsublime-in-un-film-la-grande-avventura-diun-gruppo-di-artisti-pionieri/attachment/ robert-smithson-spiral-jetty-1970/

2.41 Robert Irwin, Scrim veil - Black rectangle -Natural light, Whitney Museum of American Art, Nova York, 1977. Foto: Warren Silverman. Fonte: https://whitney. org/exhibitions/robert-irwin
218 Kwon, Miwon. One place after another: site-specific art and locational identity. Boston: Massachusetts Institute of Technology, 2002, p. 11. Tradução nossa.

219 Ibidem, p. 13. 
a artista estadunidense Andrea Fraser (1965-) - que, embora pertencente a uma geração bem mais jovem, situa sua própria atuação artística nessa linhagem, mostrando a longevidade dessa abordagem na arte contemporânea -, a expressão teria surgido como abreviação de "crítica às instituições", tendo como objeto referencial os lugares estabelecidos e organizados para apresentação da arte:

De 1969 em diante, começa a emergir uma concepção de 'instituição da arte' que não inclui só museu ou mesmo só os sites de produção, distribuição e recepção da arte, mas todo o campo da arte como universo social. Nos trabalhos de artistas associados à crítica institucional, a expressão começa a abarcar todos os sites nos quais a arte é apresentada - de museus e galerias a gabinetes corporativos e casas de colecionadores, e até mesmo espaços públicos quando neles há arte instalada. Também inclui os sites de produção da arte, ateliês, assim como escritórios, e os sites de produção do discurso artístico: revistas de arte, catálogos, colunas direcionadas à arte na imprensa popular, simpósios, conferências e aulas. E ainda os sites de produção de produtores da arte e do discurso artístico: programas de ateliês e residências, programas de história da arte e, agora, estudos curatoriais. ${ }^{220}$

Exemplo basilar da crítica institucional foi a série de eventos realizados por Broodthaers entre 1968 e $1972 \mathrm{em}$ torno de seu museu fictício - o Musée d'Art Moderne, Département des Aigles -, para o qual o artista se autonomeou o diretor. Sessenta personalidades do meio artístico atenderam ao convite para a cerimônia de abertura da "instituição" - fundada em setembro de 1968 na casa e ateliê de Broodthaers em Bruxelas, com a Section XIX ${ }^{\text {ème }}$ siècle -, que contou com um discurso inaugural proferido pelo curador alemão Johannes Cladders (1924-2009) - diretor de um museu real em seu país de origem, o Städtisches Museum de Mönchengladbach - e com os típicos comes e bebes de vernissages. Para a ocasião, o espaço foi assinalado com elementos

220 FrASER, Andrea. Da crítica às instituições a uma instituição da crítica. Concinnitas. v. 2, n. 13, p. 178-187, 2008, p. 182-3. que identificavam sua função, como a inscrição das "musée/ museum" nas janelas voltadas para fora e plaquetas de numeração das portas como em galerias expositivas, mas não tinha 

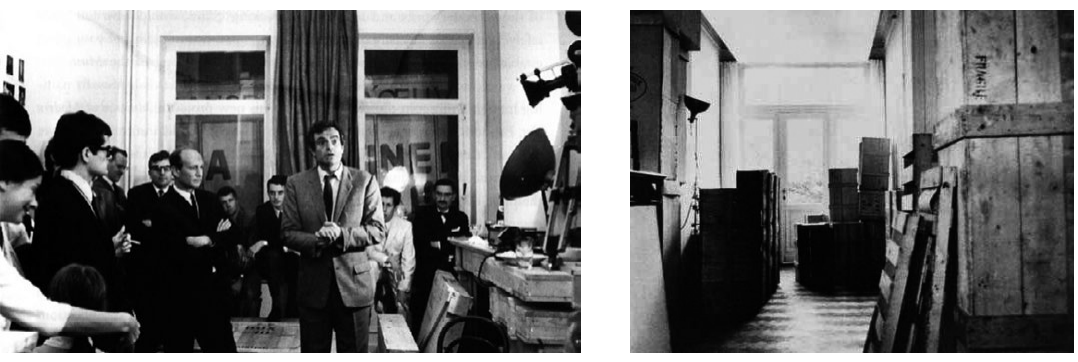

obras expostas. Ao invés disso, continha itens obtidos com a cooperação de uma transportadora e amigos, como informado em carta aberta publicada dois meses após o evento, impressa em papel timbrado e assinada por Broodthaers:

\section{1. embalagens;}

2. postais 'supervalorizados' [de pintores do século XIX como David, Ingres, Courbet, Meissonier e Puvis de Chavannes];

3. projeção permanente de imagens (a ser mantida) [slides de gravuras de Grandville];

4. uma equipe dedicada. ${ }^{21}$

A ausência de obras de arte "originais" cumpria a função de desnudar as condições institucionais da estrutura de produção artística, como havia ocorrido com a exposição Le Vide de Klein $\mathrm{e}$, antes, com os readymades de Duchamp - que apontavam para a função discursiva do artista e dos museus como centrais para a designação do que seria considerado "arte". Como destacou ainda o historiador da arte estadunidense Douglas Crimp (1944-2019), ao articular esse procedimento com referências à arte de um determinado passado "arcaico", Broodthaers teria exposto a ingenuidade de seus contemporâneos ligados à Arte Conceitual em sua crença de que estariam inaugurando possibilidades de escapar dos mecanismos dominantes de institucionalização, disseminação e comercialização da arte:

O dilema da arte contemporânea no final da década de 1960 - enquanto tentava escapar da asfixia imposta pelo museu e pelo mercado e se envolver nas lutas políticas de seu tempo -

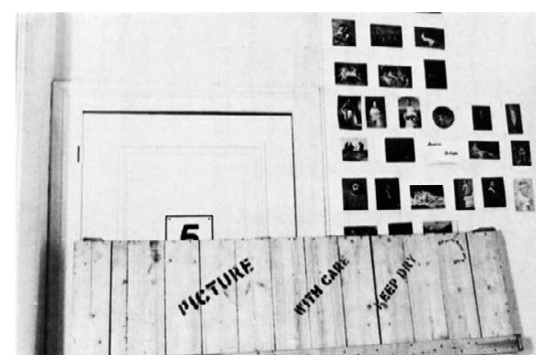

2.42 Marcel Broodthaers e convidados na inauguração de seu Musée d'Art Moderne, Département des Aigles, Bruxelas, 1968. Fonte: http://marcelbroodthaers.be/ departement-des-aigles/

2.43 e 2.44 Musée d'Art Moderne, Département des Aigles, Bruxelas, 1968. Foto: Maria Gilissen.

221 Marcel Broodthaers apud CRIMP, Douglas. Sobre as ruinas do museu. São Paulo: Martins Fontes, 2005, p. 186. 

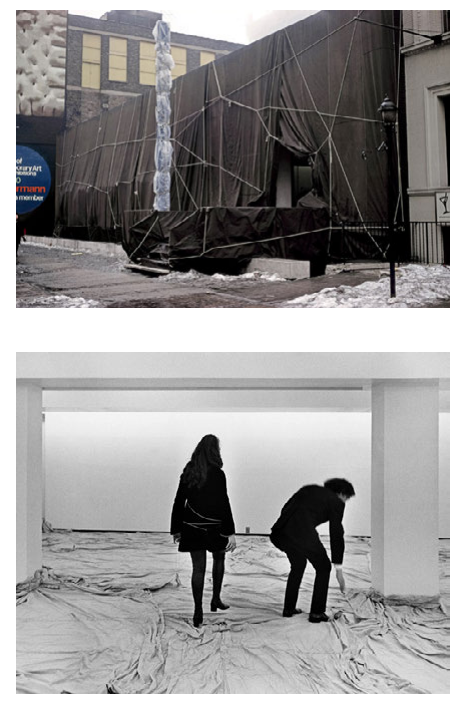

2.45 e 2.46 Christo e Jeanne-Claude, Wrapped Museum of Contemporary Art, Chicago, 1968-69. Foto: Shunk-Kender. Fonte: https://christojeanneclaude.net/ artworks/wrapped-mca/

222 CRIMP, op. cit., p. 188.

223 Cf. Christo; JEANNEClaude. Wrapped Museum of Contemporary Art (Chicago, 1968-69). Christo and Jeanne Claude. Disponível em: < https://christojeanneclaude.net/artworks/wrapped-mca/>. Acesso em: 16 abr. 2021.

224 Cf. Christo; JeAnNe-Claude. Wrapped Kunsthalle (Bern, Swittzerland, 1967-68). Christo and Jeanne-Claude, Disponível em: $<$ https://christojeanneclaude.net/ artworks/wrapped-kunsthalle/>. Acesso em: 16 abr. 2021. tinha raízes no século xix. Trabalhando como um arqueólogo do presente, Broodthaers revelaria o lugar de origem com a ficção que durou quatro anos, e cujo primeiro episódio foi a Section XIX ${ }^{\text {ème }}$ Siècle. ${ }^{222}$

Exposições que chamavam a atenção para a ausência de objetos ou mesmo de ações presenciais também podiam ser abrigadas em museus reais, como é o caso da intervenção realizada em 1969 pelo casal de artistas residentes nos EUA Christo (1935-2020) e Jeanne Claude (1935-), ele de origem búlgara e ela marroquina, no recém fundado Museum of Contemporary Art Chicago, dirigido então pelo holandês Jan van der Marck (1929-2010). A obra da dupla consistiu em empacotar a fachada insípida do museu com uma lona marrom e cordas - deixando desobstruídas apenas as entradas e a cobertura, por questões de segurança. No interior, o público não encontrava nada exposto nas paredes vazias, mas podia percorrer sem sapatos o piso e a escadaria recobertos por lona branca, que complementavam o empacotamento da instituição. A intervenção demandou uma estreita parceria com o diretor para o enfrentamento de inúmeros impasses de ordem prática e burocrática - do levantamento de fundos à aprovação nos órgãos competentes - desnudando os mecanismos de realização da arte e sua articulação com a instituição, no sentido material, operacional e simbólico. O impacto da obra, no entanto, estendia-se para além dos frequentadores regulares do museu, uma vez que sua estranha presença na cidade provocava o questionamento do público em geral sobre seu entendimento enquanto arte. ${ }^{223}$

Aquela não havia sido a primeira intervenção desse tipo realizada por Christo e Jeanne-Claude, pois a dupla havia realizado uma obra similar em 1968, empacotando com polietileno translúcido a Kunsthalle de Berna, sediada num edifício de 1918.224 Kunsthalle Bern Packed fazia parte de uma mostra com 12 obras ambientais - 12 Environments: 50 Years of the Kunsthalle Bern-, organizada pelo diretor suíço Harald Szeemann (1933-2005), que vinha, desde 1961, realizando na instituição exposições internacionais com artistas contemporâneos. A última de sua carreira na Kunsthalle foi Live in Your Head. When Attitudes Become Form. Works, Concepts, Processes, Situations, Information, realizada em 1969 com 69 artistas estadunidenses e europeus identificados 
com uma variedade de manifestações de vanguarda como o Minimalismo, a Op Art, a Arte Conceitual, Arte Povera, a Process Art e a Land Art, além da Crítica Institucional. ${ }^{225}$ Entre as obras incluídas estavam Splash Piece, de Richard Serra - uma massa de chumbo derretido despejada ao longo do rodapé da galeria -, 36" $\times 36$ " Removal to the Lathing or Support Wall of Plaster or Wallboard from a Wall, de Lawrence Weiner - um quadrado marcado na parede pela remoção da camada de revestimento -, Die Fettecke, de Joseph Beuys - um acúmulo de gordura no canto da galeria -, Acqua scivola (Igloo di vetro), de Mario Merz - um iglu de placas de vidro grosseiramente coladas com um galho de árvore no topo - e Art by Telephone, de Walter de Maria - um aparelho telefônico apoiado no piso com instruções para conversar com o artista do outro lado da linha. ${ }^{226}$ Alguns artistas participaram apenas com propostas que, mesmo sem terem chegado a se materializar, foram incluídas como obras no catálogo que acompanhou a exposição. A disposição dos trabalhos não foi pré-definida pelo diretor, que, ao invés de designar um ambiente individual a cada artista, encorajou-os a ocupar o edifício e transformá-lo em espaço de reunião, debate e ações experimentais, incluindo algumas intervenções destrutivas, no espírito anti-museu e antissistema. ${ }^{27}$

A exposição apontava para o papel central da organização curatorial para conferir sentido a obras que não correspondiam a valores intrínsecos da arte tradicionalmente estabelecidos e dependiam de uma certa mediação institucional para se comunicar com o público de então. Reconhecida no meio artístico como um panorama expressivo cobrindo a arte de vanguarda daquele momento, a mostra provocou, no entanto, grande polêmica no ambiente conservador de Berna. O mal-estar levou Szeemann a desvincular-se da instituição e a seguir sua carreira como curador independente, vindo a exercer grande influência no desenvolvimento de práticas curatoriais ligadas à arte contemporânea, que contavam com um intercâmbio mais fluido entre agentes, com curadores estabelecendo parcerias com artistas ou realizando exposições com status de obras de arte.

Outro exemplo da mistura de papéis no campo institucional da arte, antes nitidamente delimitados, foi o programa Raid the Icebox, lançado pelo no museu de arte da Rhode Island School
225 A exposição foi montada em seguida no Museum Haus Lange em Krefeld (Alemanha) e no ICA de Londres. Cf. Altshuler, op. cit., p. 94 .

226 Participaram da exposição Carl Andre, Giovanni Anselmo, Richard Artschwager, Thomas Bang, Jared Bark, Robert Barry, Joseph Beuys, Alighiero Boetti, Mel Bochner, Marinus Boezem, Bill Bollinger, Michael Buthe, Pier Paolo Calzolari, Paul Cotton, Hanne Darboven, Walter de Maria, Jan Dibbets, Ger van Elk, Rafael Ferrer, Barry Flanagan, Ted Glass, Hans Haacke, Michael Heizer, Eva Hesse, Douglas Huebler, Paolo Icaro, Alain Jacquet, Neil Jenney, Stephen Kaltenbach, Jo Ann Kaplan, Edward Kienholz, Yves Klein, Joseph Kosuth, Jannis Kounellis, Gary B. Kuehn, Sol LeWitt, Bernd Lohaus, Richard Long, Roelof Louw, Bruce McLean, David Medalla, Mario Merz, Robert Morris, Bruce Nauman, Claes Oldenburg, Dennis Oppenheim, Panamarenko, Pino Pascali, Paul Pechter, Michelangelo Pistoletto, Emilio Prini, Markus Raetz, Allen Ruppersberg, Reiner Ruthenbeck, Robert Ryman, Frederick Lane Sandback, Alan Saret, Sarkis, JeanFrédéric Schnyder, Richard Serra, Robert Smithson, Keith Sonnier, Richard Tuttle, Frank Lincoln Viner, Franz Erhard Walther, William G. Wegman, Lawrence Weiner, William T. Wiley, Gilberto Zorio e Daniel Buren (tendo o último participado sem ter sido convidado). Cf. Ibidem, p. 94.

227 Cf. Lorente, Jesùs Pedro. The Museums of Contemporary Art: Notion and Development. Surrey; Burlington: Ashgate Publishing, 2011, p. 224. 

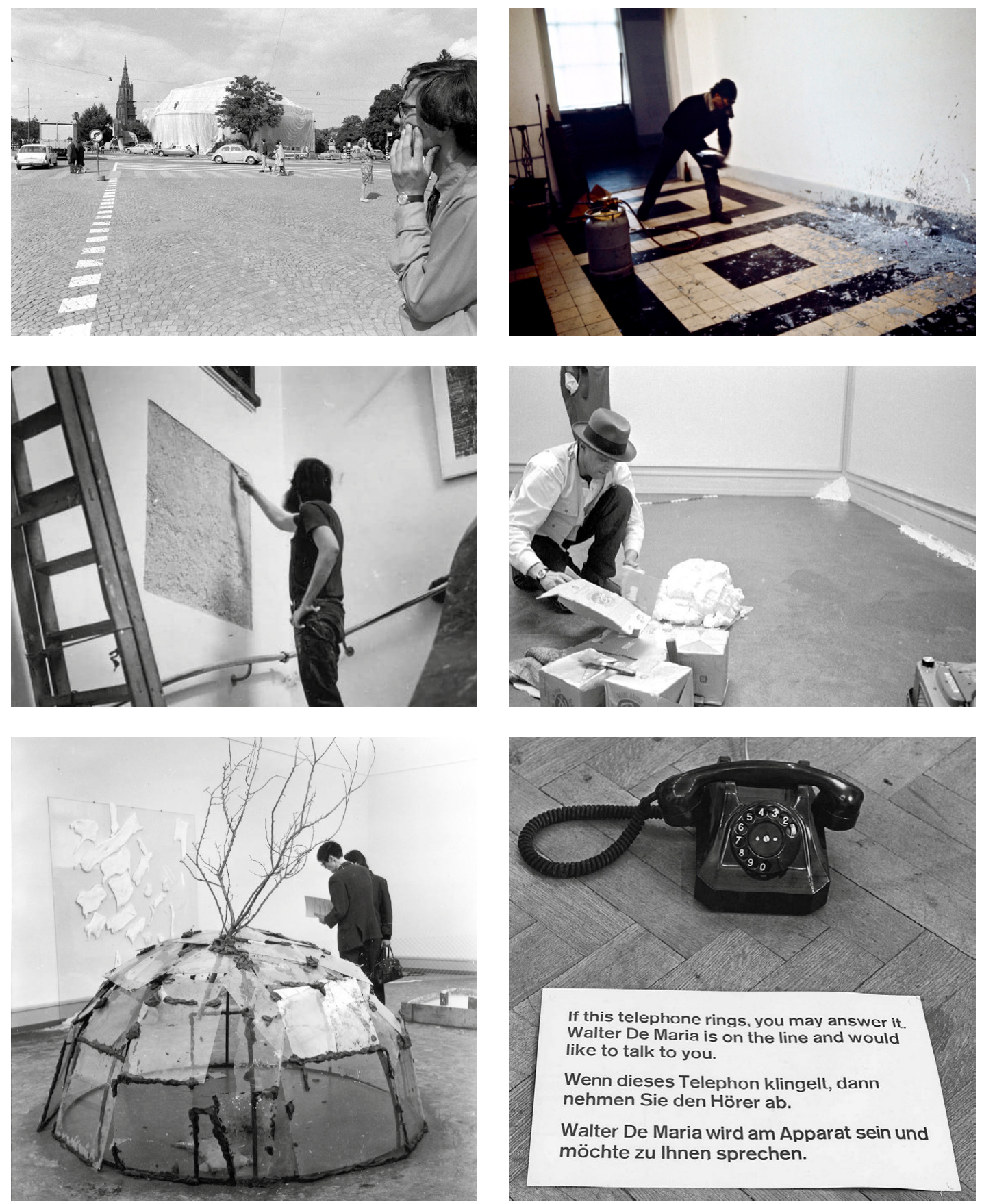
228 Apesar de organizada pelo RISD, a exposição foi montada antes no Institute for the Arts da Rice University de Houston e no Isaac Delgado Museum de Nova Orleans antes de ser inaugurada no RISD de Providence em 1970.

229 Musteata, Natalie. Defrosting the Icebox: A Contextual Analysis of Andy Warhol's Raid the Icebox 1. Journal of Curatorial Studies, v. 5, n. 2, p. 214-237, 2016. p. 229. Tradução nossa. of Design (RISD), que previa convidar artistas contemporâneos para realizar curadorias a partir do acervo permanente da instituição. Quando a exposição foi concebida, em 1969, o RISD estava, como tantas instituições à época, sob ataque de seus estudantes, que consideravam o museu elitista, ultrapassado e desconectado das necessidades do presente, com sua coleção de aproximadamente 45 mil itens abrangendo de artefatos utilitários a obras de arte desde a antiguidade. ${ }^{228}$ Diante da crise, o diretor Daniel Robbins, que já vinha realizando exposições de arte contemporânea no RISD, aceitou a sugestão do casal de colecionadores de Houston, Jean e Dominique de Menil, para criar um programa que conectasse a coleção às práticas contemporâneas, escolhendo um nome com o peso de Andy Warhol para inaugurar a série que demonstraria a vitalidade do museu, aproximando-o das demandas de sua comunidade.

$\mathrm{O}$ artista, no entanto, adotou uma abordagem inusitada tanto em sua curadoria quanto na montagem expositiva. Desprezando qualquer critério de "qualidade", Warhol selecionou 300 itens considerados de menor valor na coleção, dando preferência a objetos de arte aplicada em relação a obras catalogadas como de "belas-artes" - entre os quais alguns em mau estado de conservação -, apresentando-os na exposição do mesmo modo como ficavam guardados no depósito, ou seja, amontoados em grupos, sem qualquer preocupação de ordenação visual. Para a historiadora da arte Natalie Musteata, embora Warhol não fosse identificado com as demandas políticas de artistas conceituais, sua exposição pode ser entendida como um tipo de crítica institucional, ao desnudar, por contraste com as práticas convencionais, os mecanismos de seleção e apresentação empregadas na valorização dos objetos dos museus:

Ao rejeitar as convenções de exposição dos museus de arte, Warhol chamou a atenção para os próprios protocolos que conferem autoridade aos museus e definem a arte no capitalismo avançado. Em outras palavras, por meio de seus arranjos sem cerimônia e pouco ortodoxos, Warhol não estava apenas tornando públicas as terríveis práticas de armazenamento do Museu RISD, mas estava, sobretudo, desmistificando o museu ao despojá-lo de seu aparato artificial. ${ }^{29}$ 


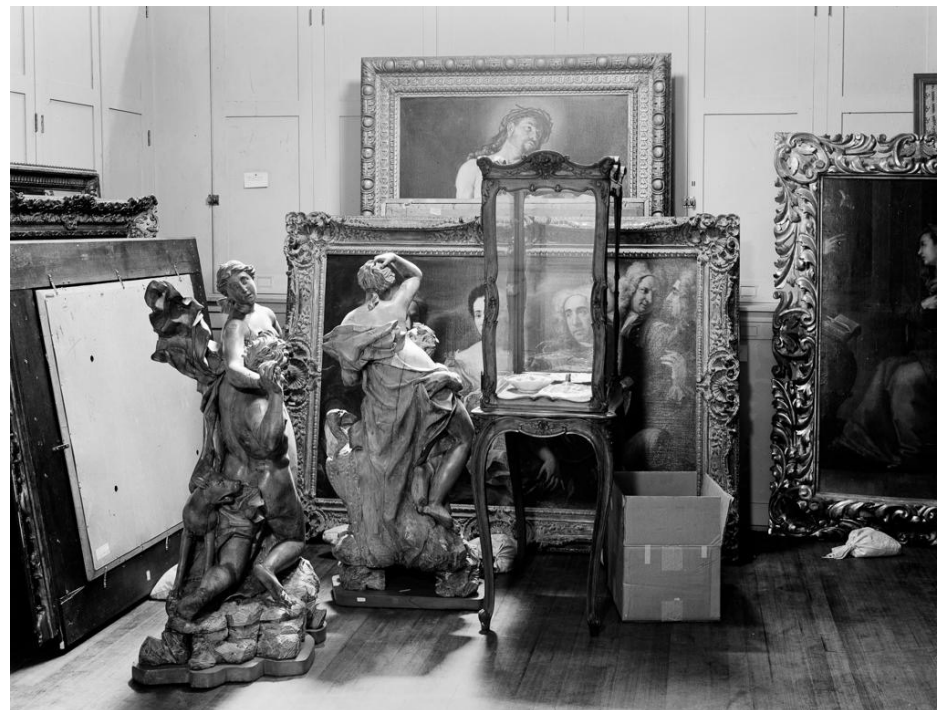

A autora chamou a atenção para similaridades entre a atitude de Warhol e a de Broodthaers, ao apontarem, cada um a seu modo, os mecanismos institucionais do museu, seguindo a trilha iconoclasta aberta por Duchamp. O teor crítico de Raid the Icebox I, inaugurada em 1970, teria, no entanto, passado despercebido pelo público e o efeito teria sido o oposto do esperado, enfurecendo ainda mais os opositores da política do RISD, o que teria causado a interrupção da série.

Nas exposições aqui elencadas, vemos que algumas instituições estabelecidas de arte - galerias, centros de exposição e museus - apoiavam a realização de manifestações experimentais da arte, enquanto outras estabeleciam limites mais restritos para sua realização. Havia ainda uma parcela significativa de artistas que atuavam em franca oposição à condição institucional, organizando-se de maneira independente em espaços alternativos, como veremos de modo mais detido ao longo deste capítulo. O movimento de contestação ao sistema de arte que crescia ao longo dos anos 1960 fazia parte da atmosfera difusa de rejeição à ordem vigente, dominada por estruturas consideradas autoritárias, obsoletas e incapazes de acompanhar a demanda das gerações mais jovens por transformações sociais
2.54 Vista da exposição Raid the Icebox 1, de Andy Warhol, Museum of Art, Rhode Island School, Providence, 1969. Foto: Erik Gould. Fonte: MUSTEATA, p. 226.

\section{6-207}


e culturais. A autoridade dos museus - guardiões de tradições, com seus modos convencionais de operar - deixava, assim, de ser respeitada, tornando-se alvo de rejeição por uma parcela significativa de artistas de vanguarda.

Mesmo se dedicados à arte moderna - compreendida até pouco tempo como contemporânea -, os museus tinham, por definição, compromisso com seus acervos, constituídos, afinal, por obras concretas, passíveis de serem comercializadas e colecionadas. Naquele momento, essas premissas apresentavam-se, por vezes, como entraves para experiências artísticas concebidas não como objetos físicos, mas como dispositivos realizados com recursos variados e miscigenados, muitas vezes efêmeros, que, agindo sobre o contexto - espacial, social, cultural - e no encontro com o público, despertassem novos modos de engajamento com o dito "mundo real", podendo mesmo ser substituídas por um projeto, ideia ou conceito artístico. Transformações tão profundas demandavam dos museus dedicados à "arte do seu tempo" uma revisão de postura: se o valor da arte deixava de se concentrar no objeto, como propiciar que obras efêmeras e desvinculadas de objetos concretos fossem compreendidas enquanto arte no espaço expositivo? E, ainda, qual o sentido de incluí-las numa coleção?

É com essas questões em mente que podemos retornar a um dos objetos de estudo desta tese, o Moma de Nova York, examinando de que modo os novos paradigmas da arte contemporânea que se disseminaram nos anos 1960 vieram a impactar a instituição, seus modos de conceber os espaços arquitetônicos destinados à arte e suas formas de apresentar as exposições nas décadas finais do século xx.

\subsection{O MoMA EM TURBULÊNCIA: 1969 E 70}

\subsubsection{SOB PROTESTOS}

O Moma tinha, ao longo da década de 1960, acompanhado parte das manifestações mais recentes da arte, realizando eventos como Homage to New York (1960), de Tinguely, e exposições coletivas como The Responsive Eye (1965), The Object 
Transformed, (1966) e Art of The Real (1968), como vimos no capítulo anterior. Essas exposições, contudo, não eram suficientemente amplas para demonstrar a variedade de novos caminhos trilhados pela produção recente, nem se apresentavam como uma nova forma de compreender a arte contemporânea. As montagens não se distinguiam daquelas realizadas para a arte moderna, pois seguiam o padrão praticado pelo museu de valorização individual dos trabalhos, articulados ainda por afinidades predominantemente formais e apresentados como obras autônomas.

O museu seguia sendo uma referência importante entre as instituições internacionais dedicadas à "arte do seu tempo" e, situada em Nova York, convivia de perto com boa parte da produção artística contemporânea em destaque. Enquanto ainda se mantinha como local de prestígio para uma parte da comunidade de artistas locais, outra parte via o museu como uma instituição conservadora em termos artísticos e, além disso, como um agente central no jogo do imperialismo americano, dada a proximidade de seus dirigentes com estruturas de poder, consideradas corrompidas e perniciosas. Daí que a instituição tenha chegado ao fim dos anos 1960 como um dos principais focos do descontentamento da geração de artistas mais jovens - seja pelos que desprezavam seu caráter elitista e posicionavam-se contra a própria ideia de museu, seja pelos que se sentiam desprestigiados por sua política seletiva de mostras e aquisições, como veremos a seguir.

O ano de 1969 inaugurou um período especialmente tenso no MOMA, envolvendo uma longa sequência de protestos liderados por diferentes grupos de artistas, deflagrados principalmente pela criação do Art Workers Coalition (AWC). O grupo teve origem numa ação organizada para remover a obra do artista Takis Vassilakis (1925-2019), Tele-Sculpture, de 1960, da exposição The Machine at the End of the Mechanical Age, em cartaz no MomA desde o fim de 1968 e organizada por Pontus Hultén. ${ }^{230}$ Embora a escultura pertencesse ao acervo do museu, o artista não concordava que tivesse sido exposta sem o seu consentimento. No dia 3 de janeiro, Takis e seus colegas desmontaram a obra e a levaram para o jardim, onde aguardaram até se reunirem com o recém-empossado diretor do MOMA, Bates Lowry (1923-2004),
230 Cf. The Museum of Modern ART. The Machine as Seen at the End of the Mechanical Age (Nov 27, 1968-Feb 9, 1969). МОМА. Disponível em: $<$ https://www. moma.org/calendar/exhibitions/2776? locale $=\mathrm{pt}>$. Acesso em: 22 abr. 2020. 


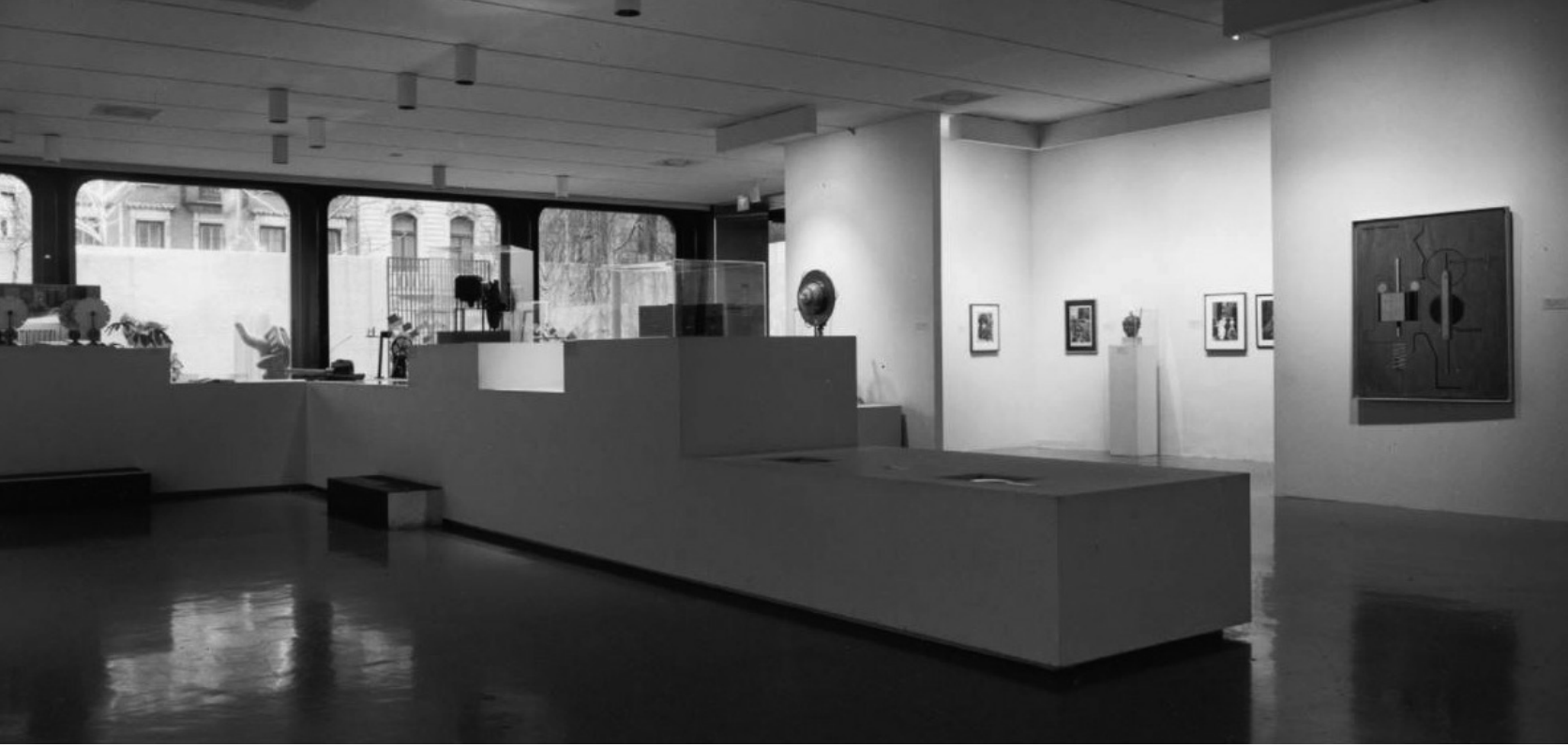

2.55 Vista da exposição The Machine as Seen at the End of the Mechanical Age, MoMA, Nova York, 1968-69. Foto: James Mathews.

231 LIPPARD, Lucy R. et al. 50 Years Later, a Conceptual Art Exhibition Still Courts Controversy. MOMA. Disponível em: <https://www. moma.org/magazine/articles/225>. Acesso em: 14 maio 2020, p. 9. Tradução nossa.

232 Cf. Elligot, Michelle. From the Archives: Faith Ringgold, the Art Workers Coalition, and the Fight for Inclusion at The Museum of Modern Art. момA. Disponível em: <https://www.moma.org/ explore/inside_out/2016/o7/29/ from-the-archives-faith-ringgold-the-art-workers-coalition-and-the-fight-for-inclusion-at-the-museum-of-modern-art/>. Acesso em: 22 abr. 2020. obtendo dele o compromisso de que Tele-Sculpture não seria devolvida à exposição e que o museu receberia os artistas numa reunião para ouvir suas demandas.

Preparando-se para um encontro oficial, o grupo atraiu diversos nomes ligados à arte de vanguarda e oficializou-se como AWC, fornecendo, como definiu a crítica e curadora estadunidense Lucy Lippard (1937-), "uma estrutura organizacional de relacionamento para artistas que misturavam arte e política”. ${ }^{231}$ Tendo o MomA como principal alvo dentre os museus estabelecidos, o grupo levou à Lowry no dia 28 de janeiro o documento 13 Demands, contendo reivindicações como: estabelecer um relacionamento mais aberto com artistas, ampliar direitos autorais e de controle sobre exposições de suas obras e promover curadorias experimentais e mais inclusivas - contendo artistas mais jovens, afrodescendentes, hispânicos e membros de outras comunidades marginalizadas -, além de oferecer entrada gratuita para o público. ${ }^{232} \mathrm{O}$ grupo demandava ainda que o MoMA realizasse uma sessão aberta de discussão sobre suas responsabilidades perante os artistas e o público. Diante da recusa do museu em abrigar tal encontro, o AWC organizou no dia 10 de abril uma Open Hearing na School of 
Visual Arts, reunindo aproximadamente 300 artistas, arquitetos, cineastas, críticos e funcionários de museus e galerias para manifestar "suas atitudes e reclamações sobre todas as instituições e condições da arte". ${ }^{233} \mathrm{Em}$ meio à crescente tensão, Lowry acabou abandonando a direção do Moma no dia 31 de maio, deixando o cargo aberto por 11 meses, até ser ocupado por John Hightower (1933-2013) em 1 de maio de 1970.

O AWC seguiu realizando ações e expandiu sua agenda para além das reivindicações diretamente ligadas ao sistema de arte, incluindo oposição à guerra do Vietnã, ao racismo e ao sexismo, e funcionando como matriz ou em cooperação com diversos outros grupos dedicados a causas mais específicas, como o Women Artists in Revolution (WAR), o Guerilla Art Action Group (GAAG) e o Black Emergency Cultural Coalition (BECC). O MOMA continuava na mira desses grupos, não apenas por conta das demandas de maior abertura para a participação de artistas, mas por ser o principal representante de um sistema de arte considerado corrompido pelas relações de poder, controlado por uma elite que sustentava as políticas mais condenáveis, incluindo a da guerra, e que alimentava um mercado de arte onde as obras eram comercializadas como bens de alto luxo.

Sintomático do descompasso que se evidenciava entre os novos rumos que a arte tomava naquele momento e o foco de interesse do museu foi a inauguração em 18 de junho de 1969 de The New American Painting and Sculpture: The First Generation, a maior exposição até então reunindo os pioneiros do Expressionismo Abstrato, contando com 157 pinturas e esculturas da própria coleção. ${ }^{234}$ Tal prestígio tinha essa produção no MOMA que a exposição permanente, que ocupava regularmente as galerias do segundo e terceiro pavimentos, ficou naquele momento reduzida ao terceiro andar, deixando todo o segundo para essa mostra temporária. O responsável pela curadoria foi o historiador da arte e colecionador William Rubin (1927-2006), que, tendo sido contratado pelo museu no ano anterior por indicação de Barr, tornou-se diretor do Departamento de Pintura e Escultura de 1973 a 1988, vindo a exercer grande influência nо мома. Em seu livro de memórias, Rubin deixou clara a direção de sua atuação naquele momento:
233 Manifestações de 69 participantes, entre os quais Carl Andre, Robert Barry, Gregory Battcock, Dan Graham, Hans Haacke, Joseph Kosuth, Sol LeWitt, Lucy Lippard e Seth Siegelaub foram compiladas no documento "What Should Be the Program of The Art Workers Regarding Museum Reform, and to Establish the Program of the Art Workers", enviado posteriormente a todos os museus de Nova York. Cf. AWC - ARTISTS WORKERS CoAtition. Open Hearing (1969). Primary Information. Disponível em: <http://www.primaryinformation.org/product/art-workers-coalition-open-hearing/>. Acesso em: 18 maio 2021.

234 Cf. The Museum of Modern ART. The New American Painting and Sculpture: The First Generation (Jun 18-Oct 5, 1969). MOMA. Disponível em: <https:// www.moma.org/calendar/exhibitions $/ 1927$ ?locale $=p t>$. Acesso em: 18 abr. 2020. 


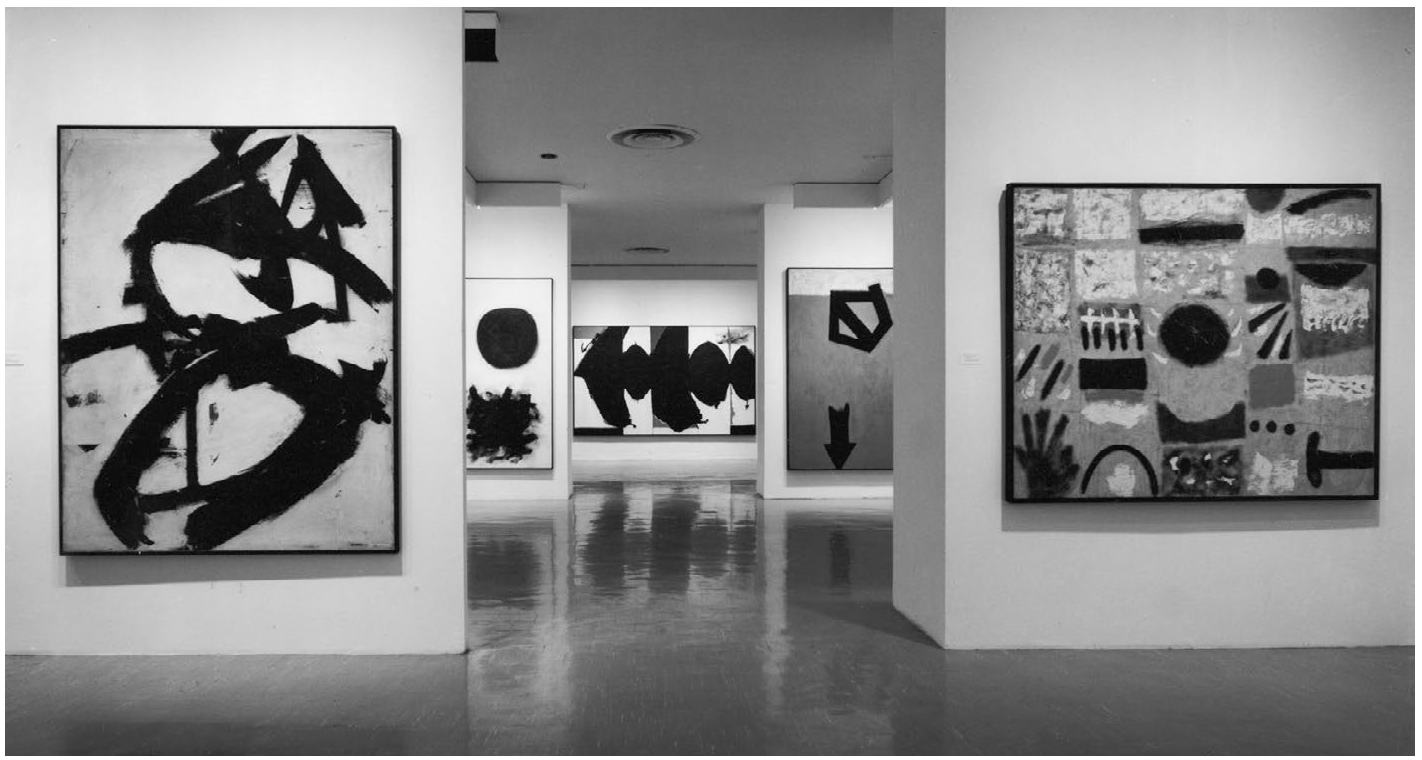

235 Rubin, William Stanley. A curator's quest : building the collection of painting and sculpture of the Museum of Modern Art, 1967-1988. Nova York: Harry N. Abrams, 2011. p. 123. Tradução nossa.

Rubin ainda afirma que "nenhuma exposição havia sido montada ainda nos EUA para mostrar a face do Expressionismo Abstrato", deixando de ressalvar que várias dessas obras já haviam participado, quando ainda eram recentes, de exposições da série sobre artistas contemporâneos estadunidenses organizada nas décadas anteriores por Dorothy Miller. Ibidem, p. 125. Tradução nossa.

236 Ibidem, p. 124.
Minha principal preocupação quando entrei para o museu era a expansão da coleção do Expressionismo Abstrato [...]. De modo geral, a coleção não dava conta de dimensionar a importância histórica do Expressionismo Abstrato, nem refletia seu vínculo ímpar com o museu, o principal mostruário de arte moderna da cidade (e do país) onde o movimento havia se desenvolvido. Eu tinha muita convicção de que o Expressionismo Abstrato tinha que ser representado com o seu status de fenômeno inovador, que merecia tanta importância quanto o Cubismo, Surrealismo ou qualquer outra passagem eletrizante do século $\mathrm{XX} .^{235}$

Rubin relatou ainda que, como diretor, recebeu todo o apoio do museu para dirigir os fundos de aquisição para a compra de obras desse período, embora extremamente valorizadas no mercado, pois ainda eram consideradas como "arte contemporânea" pelos membros do conselho. ${ }^{236} \mathrm{~A}$ figura de Rubin representava não apenas a identificação do MOMA com as obras do Expressionismo Abstrato, mas aprofundava a associação 
do Vista da exposição The New American Painting and Sculpture: The First Generation, MoMA, Nova York, 1969. museu com a visão predominantemente formalista da arte, acompanhada da mística do artista como gênio criador. Era a antítese do que procuravam os artistas das novas gerações que se rebelavam contra o sistema. Segundo Lippard,

o fervor anti-establishment na década de 1960 concentrou-se na desmistificação e descomoditização da arte e na premência de uma arte independente ou 'alternativa' que não pudesse ser comprada e vendida pelo setor ganancioso que possuía tudo o que estava sendo explorado pelo mundo e promovendo a guerra do Vietnã. ${ }^{237}$

Além de considerado o templo da arte estabelecida, diversos membros do conselho do MoMA tinham vínculos estreitos com as estruturas de poder, alguns beneficiando-se diretamente da guerra por meio de seus negócios. Se o ambiente de contestação política dominava a produção intelectual e cultural da época, sua associação com a arte nem sempre estava contida no conteúdo das obras, mas concentrava-se especialmente na forma de expressão, como identificou Lippard ao tratar da Arte Conceitual:

Com algumas exceções, a arte era apolítica, mas em um mundo artístico que ainda idolatrava Clement Greenberg (que por sua vez odiava publicamente a Arte Pop e a Minimalista), que negava até a presença de preocupações políticas e oferecia pouca ou nenhuma educação ou análise política, os artistas conceituais - a maioria dos quais tinha então entre vinte e trinta anos - pareciam e soavam como radicais. ${ }^{238}$

Exemplo disso é o happening não autorizado realizado no jardim do мома em 25 de agosto de 1969 pela artista Yayoi Kusama, Grand Orgy to Awaken the Dead, no qual seis moças e dois rapazes despidos passaram 20 minutos abraçando uns aos outros e também as esculturas, como a da figura feminina nua The River (1938-9), de Aristide Maillol, disposta no espelho d'água. Completando o ato, a artista leu seu manifesto Thou-
2.56 Vista da exposição The New American Painting and Sculpture: The First Generation, MoMA, Nova York, 1969. Foto: James Mathews. Fonte: https://www. moma.org/calendar/exhibitions/1927/ installation_images/19838
237 LIPPARD, op. cit., p. 14. Tradução nossa.

238 Ibidem, p. 13. Tradução nossa. 
2.57 Performance de Yayoi Kusama, Grand Orgy to Awaken the Dead, MoMA, Nova York, 1969. Foto: Mel Finkelstein. Fonte: https://www.moma.org/ interactives/exhibitions/2015/ messingwithmoma/

2.58 a 2.61 Performance de Guerrilla Art Action Group, A call for the immediate resignation of all the Rockefellers from the board of trustees of the Museum of Modern Art (Bloodbath), MoMA, Nova York, 1969. Fonte: http://artfcity. com/2012/03/30/reminder-arthandlers-protest-momas-ties-withsothebys-tonight-at-6-pm/
239 Yayoi Kusama apud THE NEW York Times. Naked Protesters Burlesque Bronze Nudes at Museum. The New York Times, 25/o8/1969. ed. p. 33, 1969. Tradução nossa.

240 O Guerilla Art Action Group (GAAG) foi criado em 1969 pelos artistas Jon Hendricks e Jean Toche e ficou ativo até 1976. Participavam ocasionalmente das ações Poppy Johnson, Joanne Stamerra e Virginia Toche. Cf. LEVy, Valentina G.. Revolutionary Instances and Activism in Art Practices at the turn of the 60 and 70 . Two cases compared: Hi Red Center and Guerilla Art Action Group. Luxflux, v. 54, 2014.

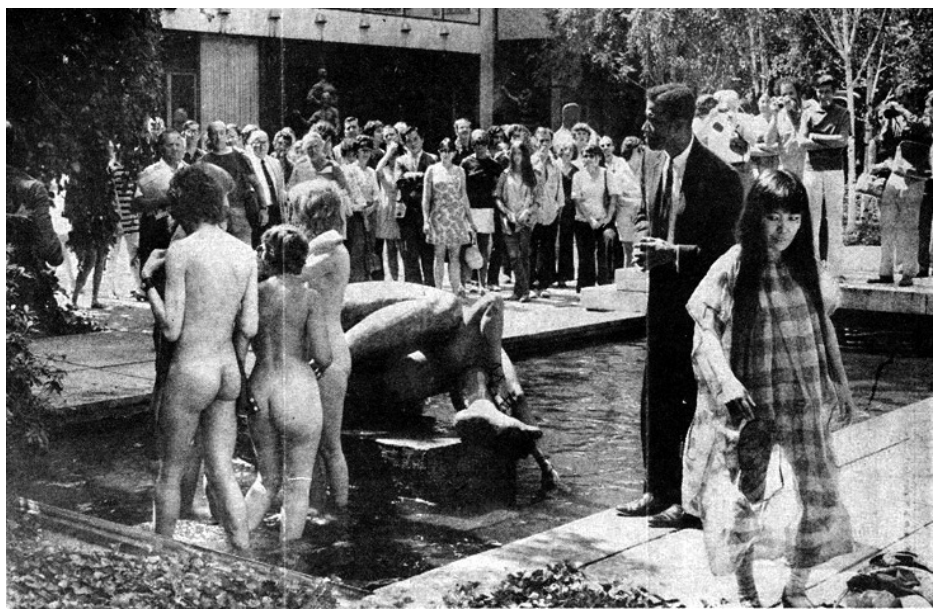

ghts on the Mausoleum of Modern Art, protestando abertamente contra a ausência de artistas mais jovens no museu: "O que é moderno aqui? Eu não vejo. Van Gogh, Cézanne, esses outros fantasmas, todos estão mortos ou morrendo. Enquanto os mortos expõem arte morta, os artistas vivos estão morrendo". ${ }^{239}$ A ação precisava ser acompanhada do título e do manifesto para evidenciar seu conteúdo contestatório, mas a forma de expressão podia ser compreendida de imediato como radical naquele contexto.

Entre os poucos grupos estadunidenses que tematizavam diretamente as reivindicações políticas em suas obras estava o Guerrilla Art Action Group (GAAG), ${ }^{240}$ que estreou suas ações contra o MомA no fim de outubro, removendo de uma exposição a obra de Kazimir Malevich, Suprematist Composition: White on White (1918). No lugar da tela, o grupo instalou um manifesto com três solicitações ao museu: a venda de obras de arte no valor de um milhão de dólares e a doação da soma a comunidades carentes do país; a eliminação de hierarquia e o acesso à gerência do museu a qualquer pessoa interessada e, por fim, o fechamento do museu até o término da Guerra do Vietnã. O grupo voltou ao MoMA em 10 de novembro para uma ação mais contundente, que, assim como a de Kusama, completava seu sentido acompanhada de seu título: A call for 

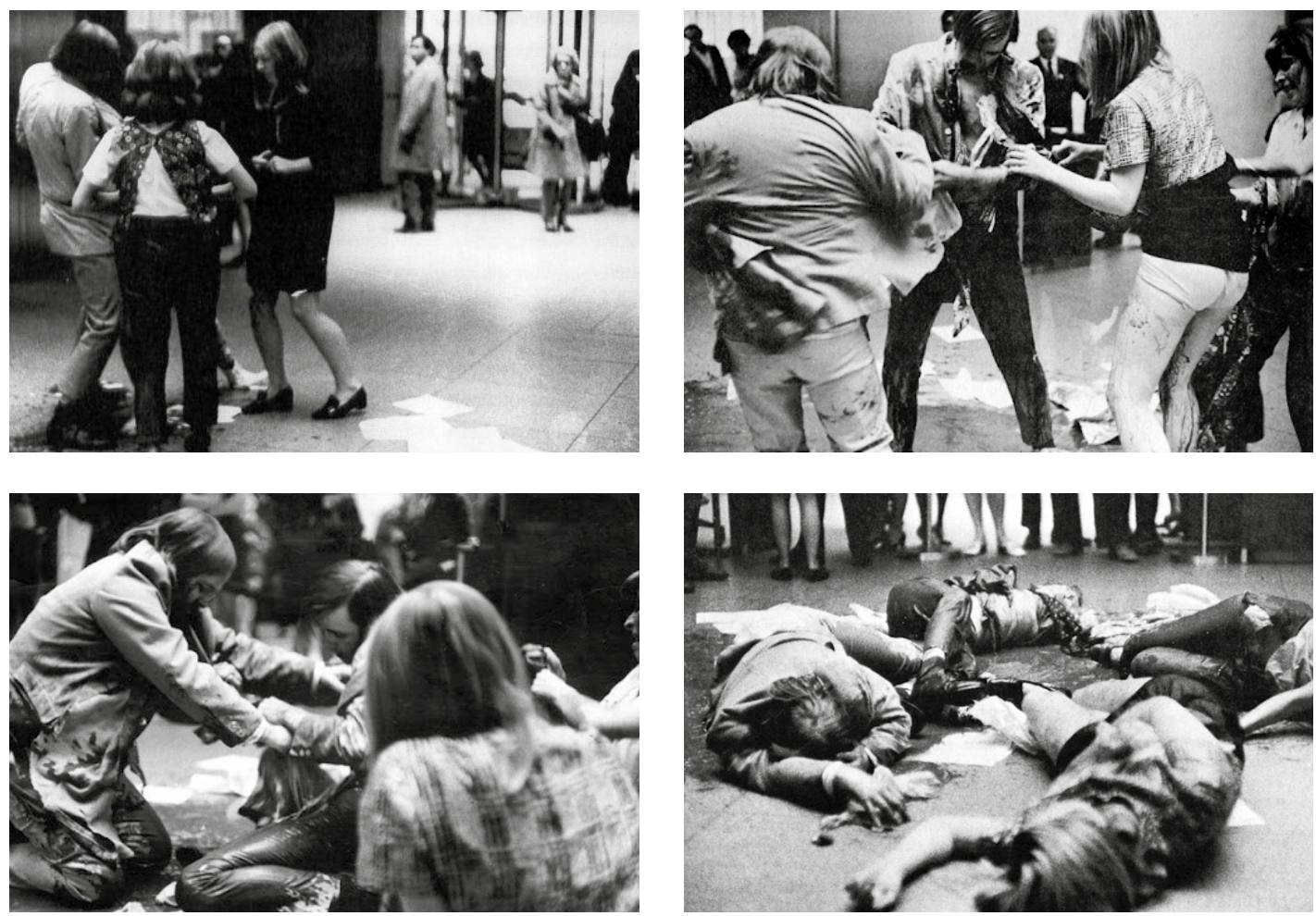

the immediate resignation of all the Rockefellers from the board of trustees of the Museum of Modern Art. Nessa performance, mais conhecida como Bloodbath, quatro artistas ligados ao GAAG, os fundadores Jon Hendricks e Jean Toche, acompanhados por Poppy Johnson e Silvianna (membros do grupo WAR), ${ }^{241}$ entraram no museu agindo como visitantes comuns e, após comprarem seus ingressos, simularam agressões entre eles diante do público no saguão de entrada, culminando com todos caídos no chão como mortos em meio a poças de sangue (real, mas de boi, trazido em bolsas escondido sob suas roupas). Dessa vez o alvo era bastante explícito, atingindo um ponto nevrálgico da instituição - a acusação se dirigia à incompatibilidade entre a missão do MOMA e os interesses da família mais influente entre os seus mantenedores, por serem esses ligados à indústria da guerra. ${ }^{242}$
241 O Women Artists in Revolution (WAR) foi criado sob o AWC, visando defender uma maior representatividade das mulheres artistas no universo da arte. Entre as participantes, estavam Nancy Spero, Poppy Johnson, Muriel Castanis, Sara Saporta, Dolores Holmes, Jacqueline Skiles, Juliette Gordon, Silvianna (Silvia Goldsmith) e Jan McDevitt. O grupo se dissolveu em 1971, mas deu origem a diversos outros esforços em prol da causa feminista em seguida. Cf. SwARTz, Anne K. Women Artists in Revolution. Oxford Art Online. Disponível em: < https:// doi.org/10.1093/gao/9781884446054. article.T2214396>. Acesso em: 26 abr. 2020.

242 Ibidem.

\section{4-215}




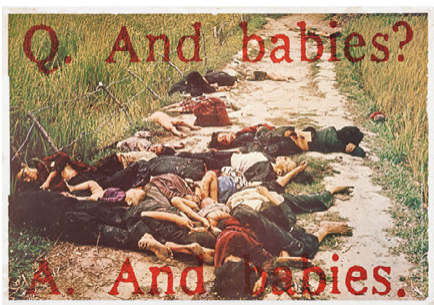

2.62 Art Workers' Coalition, And Babies, 1969. Fonte: https://en.wikipedia.org/ wiki/And_babies
243 O cartaz foi projetado por Irving Petlin, John Hendricks e Fraser Dougherty. Cf. Holsinger, M. Paul (Org.). War and American Popular Culture: A Historical Encyclopedia. Westport: Greenwood Press, 1999.
Em meio a escalada de ataques, o MomA vinha trabalhando ativamente para defender sua imagem junto ao público, divulgando dados sobre sua situação financeira e sua política de aquisição de obras e de gratuidade de ingressos para grupos específicos. Além disso, o museu tinha nomeado o curador Arthur Drexler para representar a instituição em reuniões com os membros do AWC para negociar as demandas do grupo, tendo aos poucos atendido algumas delas, como a criação de um subcomitê destinado a promover a produção de artistas ligados a variados grupos étnicos e a instituição da entrada livre num dos dias da semana. O MoMA chegou inclusive a acatar o pedido do AwC de fechar as portas em protesto à Guerra no Vietnam Moratorium Day, em 15 de outubro, assim como fizeram o Whitney e o Jewish Museum, nenhum deles interessado em estabelecer uma franca oposição aos artistas, preferindo cooperação, em distintos graus, dentro de seus respectivos limites institucionais.

O AWC ainda obteve o apoio do comitê do MомA para distribuir um cartaz intitulado And Babies, que mostrava uma fotografia de cadáveres caídos numa estrada em consequência do episódio que ficou conhecido como massacre de My Lai, ocorrido no Vietnã, em 1968. Sobre a imagem, foi impresso um trecho especialmente impactante da entrevista de um soldado a um jornalista de TV, que confirmava que o ataque estadunidense atingira não apenas homens, mulheres e crianças, mas também bebês. $\mathrm{O}$ apoio do museu, no entanto, foi cancelado na última hora por determinação conselho, que contava não apenas com Nelson Rockefeller, mas também com William S. Paley - diretor executivo da rede de televisão CBS, que havia transmitido a entrevista -, ambos apoiadores do governo Nixon. Diante da retirada do apoio do museu, o AWC articulou-se com o sindicato dos litógrafos da cidade e conseguiu imprimir cinquenta mil cópias dos cartazes, que foram amplamente distribuídos a partir de 26 de dezembro, sendo ainda divulgados pela imprensa, representando uma das peças gráficas mais bem-sucedidas de oposição à Guerra do Vietnã. ${ }^{243}$ 


\subsubsection{O LENTO ACOLHIMENTO A INSTALAÇÕES}

Fechando o ano, possivelmente o mais tumultuado da história do MомA até então, foi inaugurada em 30 de dezembro de 1969 a exposição Spaces, organizada pela jovem curadora assistente Jennifer Licht, a primeira mostra a convidar artistas para interagirem com os espaços do museu, criando intervenções concebidas especialmente para a ocasião. Licht havia apresentado a proposta para a exposição ao comitê de curadoria em maio de 1969, no momento em que o момa lidava com as pressões do AWC e outros grupos que reivindicavam mudanças institucionais em favor de maior participação de novas produções até então desprestigiadas pelo museu. A possibilidade de a mostra ser constituída por projetos criados para o local, na forma de intervenções ambientais, e não por objetos de arte pré-existentes, desafiava o museu em diferentes aspectos. Um deles era o deslocamento do controle do processo para as mãos dos artistas, uma vez que todo o trâmite de aprovação institucional seria feito sem que houvesse um domínio pleno do resultado do trabalho - a obra só seria conhecida ao final de sua montagem, pouco antes da abertura para o público. A natureza dos trabalhos ambientais também obrigava a equipe do museu a se envolver com sua execução, assumindo um novo tipo de interação com a classe artística. Por fim, o момA era um dos importantes agentes na consolidação de uma visão da arte moderna baseada no valor intrínseco das obras, associado às suas qualidades estéticas, que eram justamente os fatores mais condenados pela geração de artistas mais jovens, incluindo os que trabalhavam com obras ambientais.

Até finais dos anos 1960, muitas obras ambientais, chamadas hoje de instalações, vinham sendo realizadas fora dos espaços museus, em espaços alternativos, não apenas porque ainda não tinham conquistado a aceitação como arte em certas instituições consolidadas, mas também porque muitos dos artistas queriam se destacar do sistema que criticavam. O MомA havia exposto em 1968 a obra ambiental interativa de Robert Rauschenberg, Soundings - uma grande tela com imagens de cadeiras em silkscreen que se acendia em resposta aos sons produzidos pelo público -, mas os riscos eram reduzidos, uma

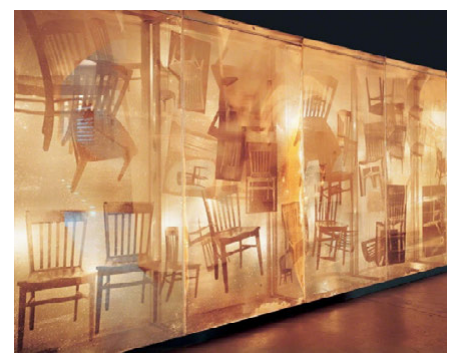

2.63 Robert Rauschenberg, Soundings, 1968. Fonte: https://www.artsy.net/ artwork/robert-rauschenberg-soundings 
vez que não eram desconhecidos da curadoria nem o artista, nem o trabalho - montado pouco antes no Stedelijk Museum em Amsterdã. ${ }^{244}$ Enquanto outros museus estavam mais dispostos a assumir riscos organizando grandes exposições com obras ambientais de artistas jovens, como vimos anteriormente, esse era um passo que o Moma ainda não ousara dar. Na opinião de Reiss, teria sido tardia a aceitação do museu nova-iorquino desse tipo de obra que envolvia abrir mão do controle sobre o espaço, como seria o caso da mostra Spaces:

Instalações de grande escala não foram expostas no museu até 1969 - onze anos após o primeiro Environment de Kaprow. De fato, instalações de qualquer tipo chegaram atrasadas a essa instituição e, quando chegaram, foi no contexto da Arte Conceitual e do Minimalismo. ${ }^{245}$

Buscando uma forma de acolher algumas das demandas dos artistas e ciente dos desafios que uma exposição de obras ambientais representava para o museu, Licht defendeu internamente sua proposta curatorial para Spaces argumentando que, ao se abrir para um tipo de arte que não se enquadrava nos moldes tradicionais e com menos condições de ser comercializada, o момА estaria assumindo sua responsabilidade de atuar como instituição a serviço do público e independente do mercado, cumprindo um papel no sistema de arte que as galerias não teriam interesse em fazer. Esse aspecto não fora, todavia, enfatizado nos materiais de apresentação da exposição para o público, que tinham um apelo mais populista, focando na condição do espectador como participante, e favorecendo, assim, a imagem democrática que o museu pretendia divulgar. ${ }^{246}$

244 Robert Rauschenberg já era então internacionalmente consagrado, tendo sido o primeiro estadunidense e o mais novo artista a receber o prêmio máximo da Bienal de Veneza - o Leão de Ouro -, em 1964.

245 ReISs, op.cit., p. 80-81. Tradução nossa.

246 Ibidem, p. 94. Tradução nossa.
A previsão inicial da exposição era convidar oito artistas para que cada um realizasse de forma livre um trabalho ambiental concebido para uma sala específica do museu, daí o título original ser Environments, alterado para Spaces, repercutindo a chegada dos astronautas estadunidenses à lua em julho daquele ano. A lista final de participantes foi composta por Michael Asher, Larry Bell, Dan Flavin, Robert Morris, Franz Erhard Walther e o grupo Pulsa, ocupando cada qual seu ambiente individual, não com conjuntos de objetos, mas com trabalhos únicos 


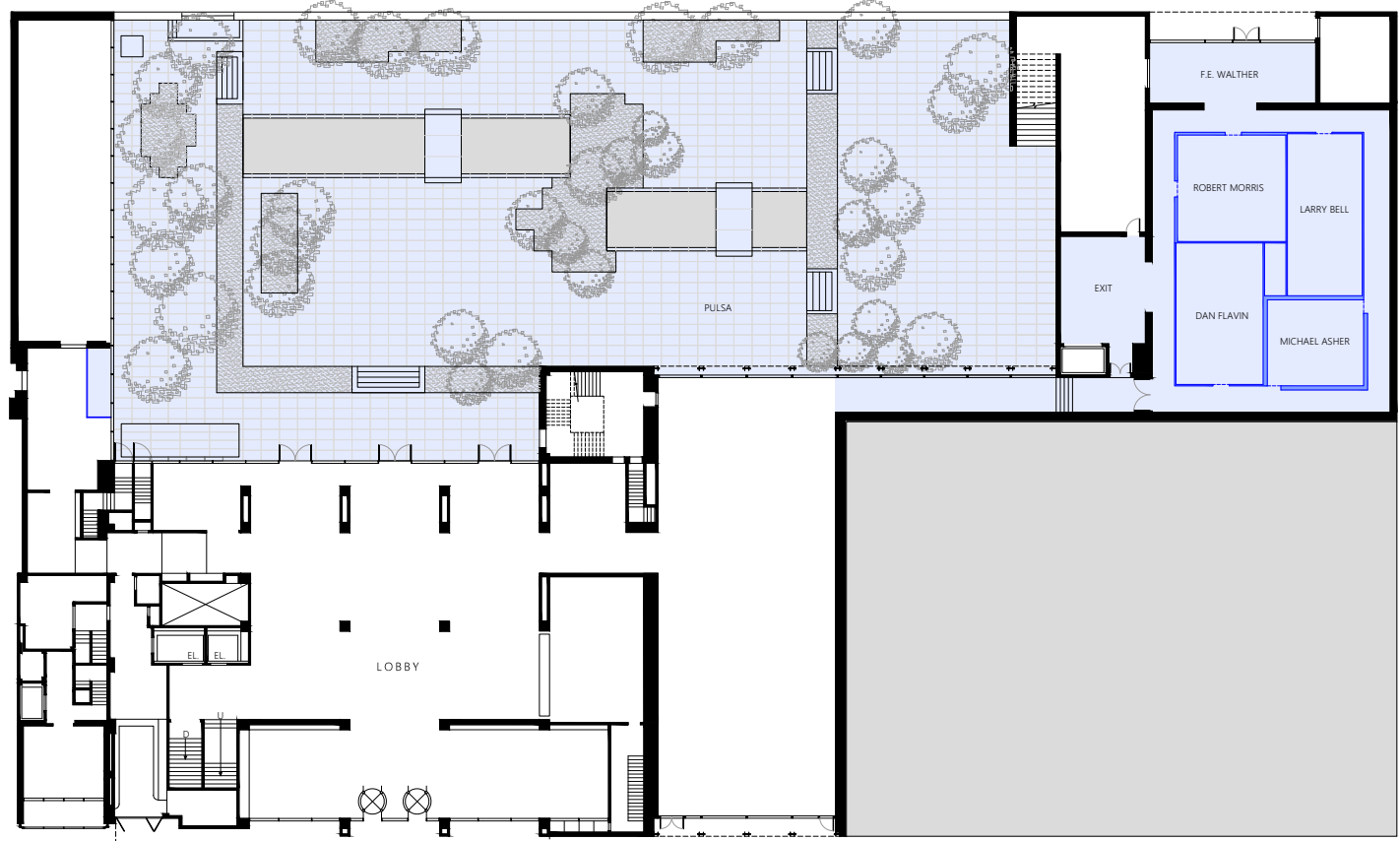

SPACES, MOMA NY, 1969

EXHIBITION LAYOUT - FIRST FLOOR

[LAYOUT EXPOSITIVO - TERREO]

concebido para as respectivas salas, instalados diretamente nas galerias e posteriormente desmontados, dando ênfase de diferentes maneiras à experiência do espectador no espaço. ${ }^{247}$

A exposição foi montada nas áreas recentemente projetadas por Philip Johnson: no jardim e no bloco térreo localizado em seu extremo leste, que era fechado em três lados e com uma face envidraçada voltada para a rua 54 . Na galeria interna, desimpedida de colunas e cega, um corredor de 1,80m em todo o perímetro permitia o acesso a quatro salas posicionadas no centro e isoladas entre si. Embora Licht tenha descrito cada ambiente individual como um "campo espacial independente e anônimo, desprovido de características arquitetônicas", ${ }^{248}$ nem todos as obras lidaram com o espaço de modo tão genérico e desvinculado da situação específica e do contexto real e,
2.64 Planta do projeto expográfico de Spaces, MoMA, Nova York, 1969. Desenhos nossos baseados em material de arquivo do MoMA.

247 REISS, op. cit., p. 88-89.

248 LICHT, Jennifer. Spaces. Nova York: The Museum of Modern Art, 1969. n.p. Tradução nossa. 

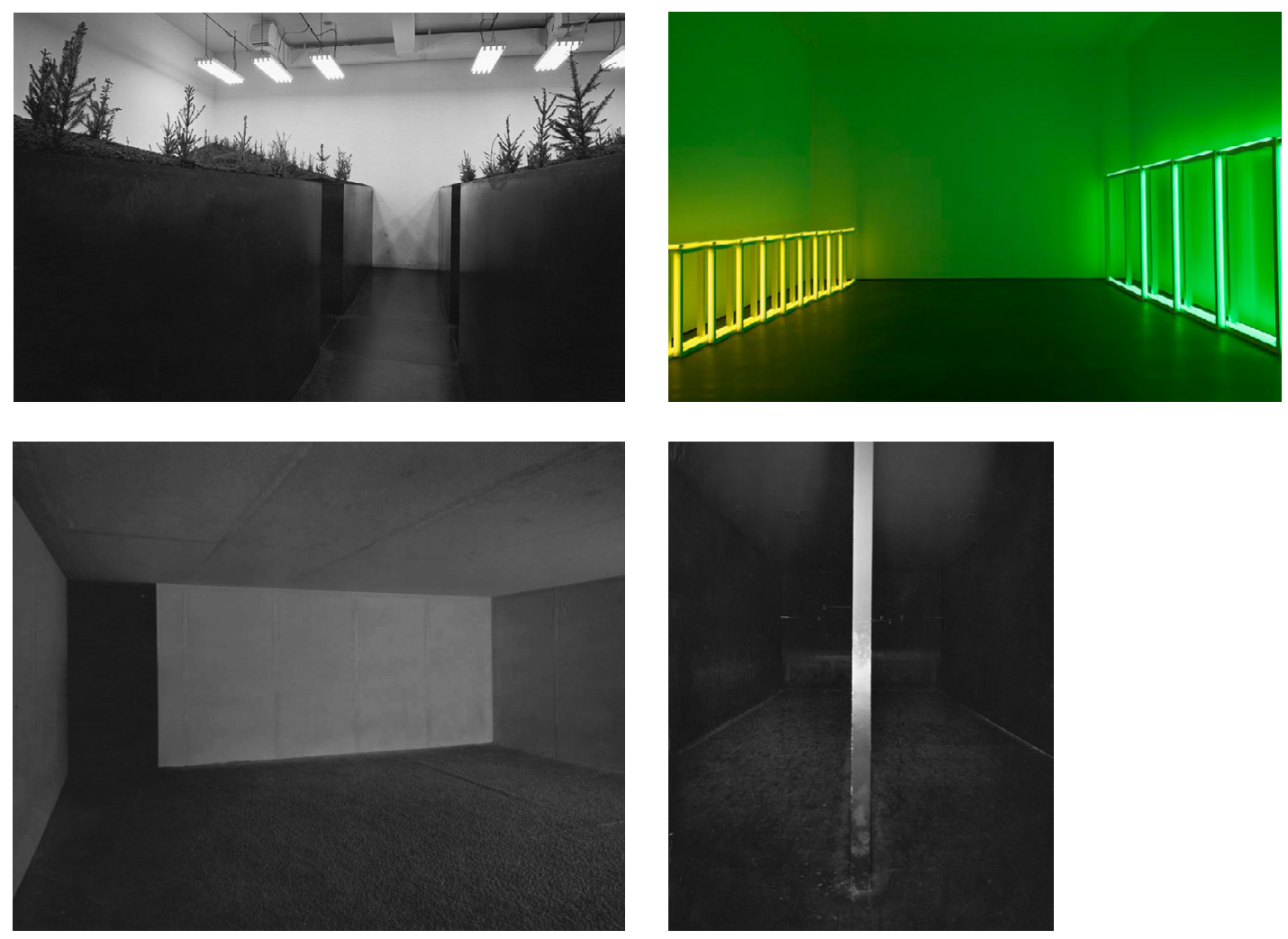

em alguns casos, as condições arquitetônicas e até mesmo as urbanas se fizeram presentes.

Os trabalhos mais isolados estavam nas quatro salas centrais, sem contato visual com o exterior. Numa delas estava o de Morris, que plantou árvores em quatro blocos de terra limitados por placas de aço Cor-ten, deixando livre uma estreita passagem em cruz, que permitia ao espectador entrar por um lado e sair por outro. Dotada ainda de equipamentos de refrigeração e iluminação para tornar o ambiente propício ao desenvolvimento das plantas, a sala de Morris era a que tinha menor grau de interação com o espaço externo, limitando a experiência ao seu interior, que fora configurado tendo como referência uma paisagem aberta. $\mathrm{O}$ trabalho de Flavin era composto de esculturas de lâmpadas fluorescentes, dialogando 

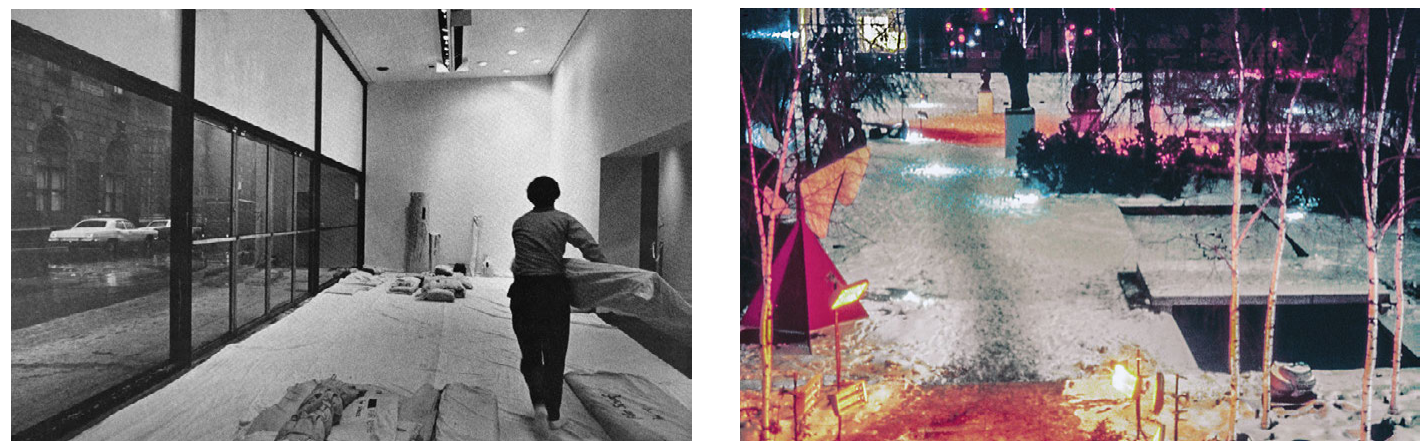

mais com as proporções retangulares do ambiente branco e homogêneo que com sua localização, embora a luz que emanasse de seu trabalho vazasse para o corredor, extrapolando os limites físicos do espaço que lhe fora designado. A obra de Bell consistia num ambiente escuro, todo pintado de preto, dividido ao meio no sentido longitudinal por um painel de vidro, trazendo para dentro da sala o reflexo da luz proveniente do corredor, num movimento inverso ao de Flavin. Também criando uma certa interação com o espaço exterior à sua sala, Asher cobriu todas as superfícies internas com material absorvente acústico, tornando o ambiente "surdo", exceto na região mais próxima às duas aberturas de entrada e saída do público situadas em quinas opostas, que, por contraste, evidenciavam os sons produzidos em outras áreas do museu.

A obra de Walter diferenciava-se das anteriores em vários aspectos, sendo a única da mostra que tinha um título Instruments for Processes - e que não era propriamente inédita - a data indicada no catálogo é 1962-69. Sua conexão com o contexto externo era visualmente direta, pois estava instalada na sala voltada para a rua 54, separada do passeio urbano apenas pela esquadria de vidro transparente. Sobre o piso recoberto por lona, estavam distribuídas peças de materiais diversos - como tela, tecido, feltro, couro, borracha e madeira - para serem manipuladas pelo público. Apesar de oferecer um grau de participação mais explícito, a experiência era limitada a um número reduzido de pessoas e aos horários pré-determinados em que o artista estaria presente, controlando pessoalmente
2.65 Robert Morris, Untitled, na exposição Spaces, MoMA, Nova York, 1969. Foto: James Mathews. Fonte: https://www. moma.org/calendar/exhibitions/2698

2.66 Dan Flavin, Untitled (for Sonja), 1969. Fonte: https://www. davidzwirner.com/exhibitions/2015/ corners-barriers-and-corridors

2.67 Larry Bell, Untitled, na exposição Spaces, MoMA, Nova York, 1969.

Foto: James Mathews. Fonte: https://www. moma.org/calendar/exhibitions/2698

2.68 Michael Asher, Untitled, na exposição Spaces, MoMA, Nova York, 1969.

Foto: James Mathews. Fonte: https://www. moma.org/calendar/exhibitions/2698

2.69 Franz Erhard Walther, Instruments for Processes, na exposição Spaces, MoMA, Nova York, 1969. Fonte: LICHT, n.p.

2.70 Pulsa, Untitled, na exposição Spaces, MoMA, Nova York, 1969. Fonte: http:// grahamfoundation.org/grantees/5947the-responsive-environment-designaesthetics-and-the-human-in-the-1970s 
2.71 Planta do projeto expográfico de Spaces com anotações manuscritas, MoMA, Nova York, 1969.

Fonte: https://www.moma.org/ interactives/moma_through_time/1960/ making-space-for-a-new-type-of-art/

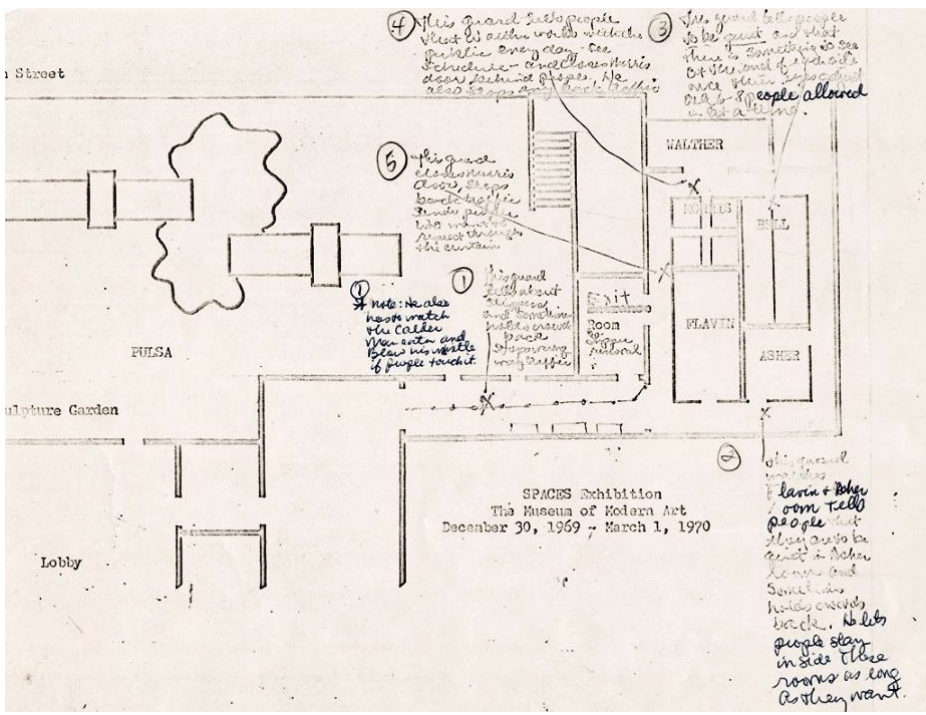

a ação, que podia ser observada ainda pelos transeuntes do lado de fora do museu. A instalação do grupo Pulsa também se relacionava mais abertamente com o contexto externo do museu, uma vez que, realizada no jardim de esculturas, era composta por um sistema de iluminação, som e calor controlado por computador, que reagia a estímulos do ambiente, como presença humana, fluxo de veículos e condição meteorológica. Nesse caso, a interação com o entorno arquitetônico e urbano - o "mundo real" - não era apenas de vizinhança ou proximidade visual, mas parte integrante do trabalho.

$O$ encontro dos trabalhos de instalação com o universo do museu provocava transformações em ambas as partes, impactando tanto a forma de atuar da instituição quanto no modo de instalar as obras pelos artistas, além de interferir a percepção desse tipo de arte pelo público. Somando-se aos desafios envolvidos na aprovação da mostra e na execução da montagem, o museu teve que aprender a lidar com um novo tipo de interação dos visitantes com as obras, que implicava um contato restrito não apenas ao visual, mas o engajamento do corpo todo, numa interação mais física e por vezes bastante informal, como tirar os sapatos e deitar-se no chão. $\mathrm{O}$ museu 
julgou necessário que os guardas oferecessem ao público orientações específicas antes de entrar em cada sala de Spaces, como mostram as anotações manuscritas sobre a planta da exposição. Como destacou Reiss, o impacto das instalações sobre os museus distinguia-se de outras manifestações contemporâneas da arte pelo tipo de envolvimento requerido do público:

A arte da instalação atendeu a algumas das mesmas condições que outras manifestações da arte transitórias e não passíveis à comoditização, mas oferecia ainda um potencial único para a participação do público. Devido ao envolvimento físico que muitas vezes exigia do espectador, a instalação de arte também podia transformar a atmosfera de um museu. [...] A arte de instalação tinha o potencial de mudar a relação entre o espectador e a obra de arte e romper com as regras de decoro adequadas ao museu. ${ }^{249}$

O impacto no modo de trabalhar dos artistas e nos resultados das obras podia ser também considerável. Os artistas incluídos em Spaces puderam contar com um tipo de suporte muito distinto daquele que encontravam nos espaços alternativos. Tendo à disposição espaços de maiores dimensões e financiamentos bem mais vultosos, viabilizados pelo apoio de 21 empresas parceiras do museu, os jovens artistas puderam empregar materiais e tecnologias mais sofisticadas do que estavam habituados até então. ${ }^{250}$ Para o público do MoMA, que tendia a ser significativamente mais numeroso e diversificado que o dos frequentadores de espaços alternativos, a experiência de interagir com as instalações podia evocar a sensação de contravenção, mas, ao mesmo tempo, o perceptível nível elevado de recursos investidos na realização da mostra podia reforçar a sensação oposta, chamando a atenção para a condição de museu bem estabelecido. Para alguns artistas que vinham protestando contra o vínculo umbilical do мома com certas estruturas de poder, dentro e fora do universo da arte, não havia conciliação possível com a instituição. É o caso de James Turrell, que, sustentando sua crítica ao museu, rejeitou o convite para participar de Spaces, ${ }^{251}$ dando uma amostra de que a exposição não havia apaziguado totalmente os ânimos dos artistas contemporâneos com o MOMA.
249 REISS, op. cit., p. 78.

Tradução nossa.

250 Era comum que empresas parceiras patrocinassem exposições do Moma e de outros museus. A Coca-Cola havia patrocinado a exposição The Family of Man no момA (1955) e a Philip Morris, além de ter sido uma das patrocinadoras da exposição do museu The Responsive Eye (1965), bancara inteiramente a controversa exposição When Attitudes Become Form (1969). A prática viria a se generalizar nas exposições de arte na década de 1980.

251 Ibidem, p. 97. 


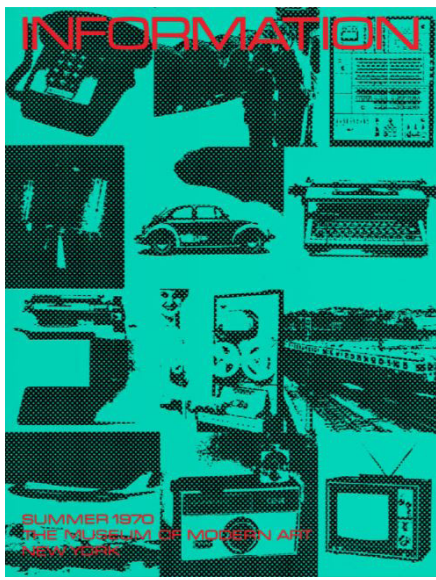

2.72 Capa do catálogo da exposição Information, MoMA, Nova York, 1970.
Ainda que Spaces tenha aberto algumas portas para a realização de outras exposições que incluíam instalações, a completa assimilação desse tipo de arte pelo MoMA não foi imediata, tornando-se um gênero aceito pelos principais museus apenas duas décadas mais tarde. No interior da instituição, figuras de peso como William Rubin preferiam estabelecer limites mais claros para o conceito de um museu dedicado à arte moderna, excluindo certos modos de produção que passavam a dominar as práticas contemporâneas. Usando a mostra Spaces como demonstração de seu argumento, Reiss ressaltou o fato de que, embora o mercado de arte tenha sido mais receptivo às novidades, a lentidão dos principais museus em acolher instalações teria levado esse tipo de expressão a permanecer à margem do sistema estabelecido por mais duas décadas. ${ }^{252}$ Se pode ser válido para o MoMA, a tese da autora não leva em conta exemplos de acolhida de manifestações experimentais por outros museus de prestígio - de dentro e de fora dos EUA - já na década de 1960, como exemplificam as exposições apresentadas no início deste capítulo.

Apesar das especificidades da história do момА, as dificuldades de conciliação nesse período entre a posição da instituição e os caminhos da arte contemporânea jogam luz sobre as complexas questões que a arquitetura dos museus passaria a enfrentar daí em diante. Se mostras temporárias sempre tiveram o potencial de, por meio de recursos cenográficos, transformar os espaços expositivos em maior o menor grau, tais transformações mantinham-se até então sob o controle dos museus, representados por seus curadores. No momento em as obras passaram a ser concebidas especialmente para os locais de exposição, o domínio do espaço foi transferido para as mãos do artista, resultando, como apontou o historiador da arte e curador Nicholas Serota (1946-), num novo tipo de interação entre os agentes da arte:

A galeria ou museu se converteu em ateliê, incitando uma mudança significativa na relação convencional entre o artista, a obra e o curador. Deixando de ser apenas um imparcial perito em qualidade, que visita o ateliê ou a coleção particular para selecionar obras e reunir material a ser apresentado ao público 
no museu, o curador passa a ser um colaborador, chegando muitas vezes a se engajar com o artista na realização do trabalho. ${ }^{253}$

Tal dissolução de fronteiras entre papéis, vinculada ao questionamento das convenções dos museus e à tomada do espaço pelas obras e resultando na intersecção entre os campos da arte e da arquitetura, levanta questões centrais para a investigação desta tese, que serão aprofundadas em seguida. Em que medida certos padrões arquitetônicos e expográficos adotados até então pelos museus, em especial pelo MOMA, puderam ser tomados como campo fértil para as novas práticas? Na mão inversa, viria o museu a adotar novos parâmetros arquitetônicos para se acomodar a essa arte em diálogo aberto com o contexto real - social, político e cultural - que se desenrolava em seu entorno?

\subsubsection{ARTE CONCEITUAL E OS LIMITES INSTITUCIONAIS}

Em meio aos protestos do AWC, o MOMA designara o curador Kynaston McShine para organizar, com bastante liberdade, uma outra mostra dedicada à nova geração de artistas, desta vez mostrando um panorama internacional. ${ }^{254}$ Inaugurada em junho de 1970, Information foi não apenas a exposição mais emblemática desse momento tumultuado, como também um dos marcos da história da arte contemporânea. Enquanto Spaces contava com apenas seis obras de artistas residentes nos EUA, tendo como foco a instalação -, Information tinha um caráter panorâmico e diversificado da Arte Conceitual, cobrindo um amplo espectro de manifestações. Ao invés de selecionar obras conhecidas, o curador convidou 150 artistas - majoritariamente jovens e de 15 países, entre os quais Argentina, Brasil, Canadá e Iugoslávia ${ }^{-255}$ para apresentarem propostas artísticas especificamente para a mostra.

Com trabalhos expostos nas galerias do museu, nas ruas da cidade ou apenas constando como indicações no catálogo, Information tinha afinidades com outras exposições coletivas realizadas previamente na Europa, como When Attitudes Become Form, mostrando a expansão da noção de arte para além da produção de objetos e incitando o público a uma interação
253 SEROTA, Nicholas. Experience or Interpretation: The Dilemma of Museums of Modern Art. Londres: Thames \& Hudson, 200o. p. 36. Tradução nossa.

254 McShine, afrodescendente e nascido em Trinidad e Tobago, trabalhava no Moma desde 1959 e havia passado dois anos no Jewish Museum, onde organizara a exposição Primary Structures (1967), evento fundamental para conferir respaldo ao Minimalismo no universo dos museus.

255 A lista completa de artistas incluiu: Vito Acconci, Carl Andre, Siah Armajani, Keith Arnatt, Art \& Language Press, Art \& Project, Richard Artschwager, David Askevold, Terry Atkinson, David Bainbridge, John Baldessari, Michael Baldwin, Barrio, Robert Barry, Frederick Barthelme, Bernhard and Hilla Becher, Joseph Beuys, Mel Bochner, Bill Bollinger, George Brecht, Stig Broegger, Stanley Brouwn, Daniel Buren,ictor Burgin, Donald Burgy, Ian Burn and Mel Ramsden, James Lee Byars, Jorge Luis Carballa, Christopher Cook, Roger Cutforth, Carlos D’Alessio, Hanne Darboven, Walter de Maria, Jan Dibbets, Gerald Ferguson, Rafael Ferrer, Barry Flanagan, Group Frontera, Hamish Fulton, Gilbert and George, Giorno Poetry Systems, Dan Graham, Hans Haacke, Ira Joel Haber, Randy Hardy, Michael Heizer, Hans Hollein, Douglas Huebler, Robert Huot, Peter Hutchinson, Richards Jarden, Stephen Kaltenbach, On Kawara, Joseph Kosuth, Christine Kozlov, John Latham, Barry Le Va, Sol LeWitt, Lucy R. Lippard, Richard Long, Bruce McLean, 
Cildo Campos Meirelles, Marta Minujin, Robert Morris, N. E. Thing Co. Ltd., Bruce Nauman, New York Graphic Workshop, Newspaper, Group Oho, Helio Oiticica, Yoko Ono, Dennis Oppenheim, Panamarenko, Giulio Paolini, Paul Pechter, Giuseppe Penone, Adrian Piper, Michelangelo Pistoletto, Emilio Prini, Alejandro Puente, Markus Raetz, Yvonne Rainer, Klaus Rinke, Edward Ruscha, J. M. Sanejouand, Richard Sladden, Robert Smithson, Keith Sonnier, Ettore Sottsass jr., Erik Thygesen, John Van Saun, Guilherme Magalhaes Vaz, Bernar Venet, Jeffrey Wall, Lawrence Weiner e Ian Wilson. Cf. Master checklist in: THe Museum of MODERn ART. Information (Jul 2-Sep 20, 1970). MOMA. Disponível em: <https:// www.moma.org/calendar/exhibitions $/ 2686$ ? locale $=\mathrm{pt}>$. Acesso em: 15 maio 2020.

256 LIPPARD, Lucy R. Six years: the dematerialization of the art object from 1966 to 1972. Berkeley e Los Angeles: University of California Press, 2001.

257 Lawrence Weiner in: MCsHINe, Kynaston L.. Information. Nova York: The Museum of Modern Art, 1970. p. 134. Tradução nossa.

258 Ibidem, p. 138. Tradução nossa. que levasse à tomada de consciência do mundo ao seu redor. Além da dissolução dos limites entre as categorias tradicionais - pintura, escultura, desenho, gravura, fotografia, cinema, teatro, música, dança e poesia -, essa nova arte buscava afirmar a primazia do projeto ou da ideia sobre a concretização da obra, contrapondo-se ao modo como os museus classificavam, expunham e colecionavam arte. Sintetizando o deslocamento do foco do objeto para a participação do espectador, numa atitude que Lippard classificara como "desmaterialização da arte", ${ }^{256}$ o artista norte americano Lawrence Weiner ocupou sua página no catálogo da exposição com a declaração:

1. $\mathrm{O}$ artista pode construir a peça

2. A peça pode ser fabricada

3. A peça não precisa ser construída

4. Sendo cada uma das condições equivalente e consistente com a intenção do artista,a decisão sobre a condição cabe ao receptor na ocasião da recepção. ${ }^{257}$

No ensaio do mesmo catálogo, McShine identificou o espírito atrevido e rebelde dos artistas como reação esperada às crises sociais, políticas e econômicas que se generalizavam na época. Depois de mencionar situações sociais ao mesmo tempo corriqueiras e dramáticas que ocorriam do Brasil, Argentina e Estados Unidos, o curador refletiu sobre o impacto desses contextos na motivação dos artistas: "Pode parecer descabido, se não absurdo, levantar-se de manhã, entrar numa sala e aplicar pinceladas de tinta de um pequeno tubo num quadrado de tela. Sendo um jovem artista, o que se pode fazer que pareça relevante e significativo?". ${ }^{258}$ As respostas se voltariam principalmente à crítica aos sistemas estabelecidos, dentro e fora do universo da arte, utilizando recursos os mais variados.

A obra Service Area, do estadunidense Vito Acconti, consistia no redirecionamento de sua correspondência pessoal para o endereço do MOMA. Com a designação de um funcionário para vigiar o conteúdo depositado numa caixa de acrílico transparente localizada numa das salas da exposição, a obra trazia para a cena a participação geralmente oculta da instituição nos processos artísticos. O brasileiro Hélio Oiticica, um dos poucos 

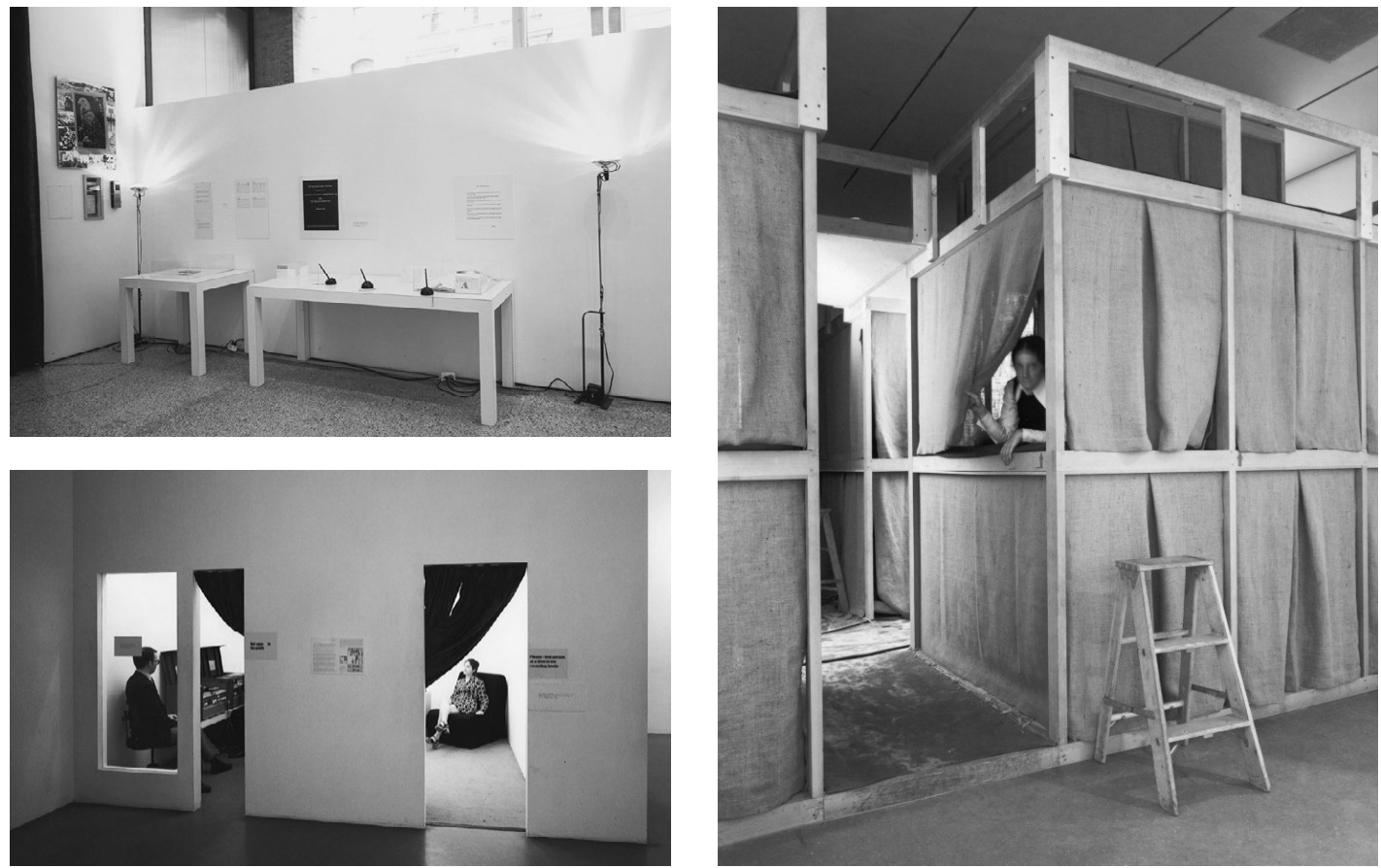

2.73 Vito Acconti, Service Area, na exposição Information, MoMA, Nova York, 1970. Foto: James Mathews.

sarrafos de madeira formando conjuntos de camas sobrepostas e dispostas lado a lado, separadas por tecidos. Os visitantes podiam deitar-se e aconchegar-se no interior das células, numa atitude estranha à formalidade habitual dos museus da época, tornando ambíguos os limites entre as esferas pública e privada. Os argentinos do Grupo Frontera ${ }^{259}$ realizaram a obra Especta, composta por uma pequena sala usada como estúdio de gravação para filmar depoimentos dos visitantes, que eram transmitidos do lado de fora da sala em dois monitores de TV, ao lado de outros dois contendo depoimentos anteriores e mais dois mostrando imagens do público assistindo às entrevistas. Exibindo pelas telas de TV as diferentes perspectivas dos visitantes, a obra buscava destacar o papel central dos meios de comunicação de massa na construção da identidade cultural contemporânea. ${ }^{260}$

2.74 Hélio Oiticica, Barracão Experiment 2, na exposição Information, MoMA, Nova York, 1970. Foto: James Mathews.

2.75 Grupo Frontera, Especta, na exposição Information, MoMA, Nova York, 1970. Foto: James Mathews.

259 Composto pelos artistas Adolfo Bronowski, Carlos Espartaco, Mercedes Esteves e Ines Gross.

260 ANDRADE, Marco Pasqualini de. Latin American artists in MOMA's 1970 exhibition "Information", in: Chicago: [s.n.], 2014.

\section{6-227}



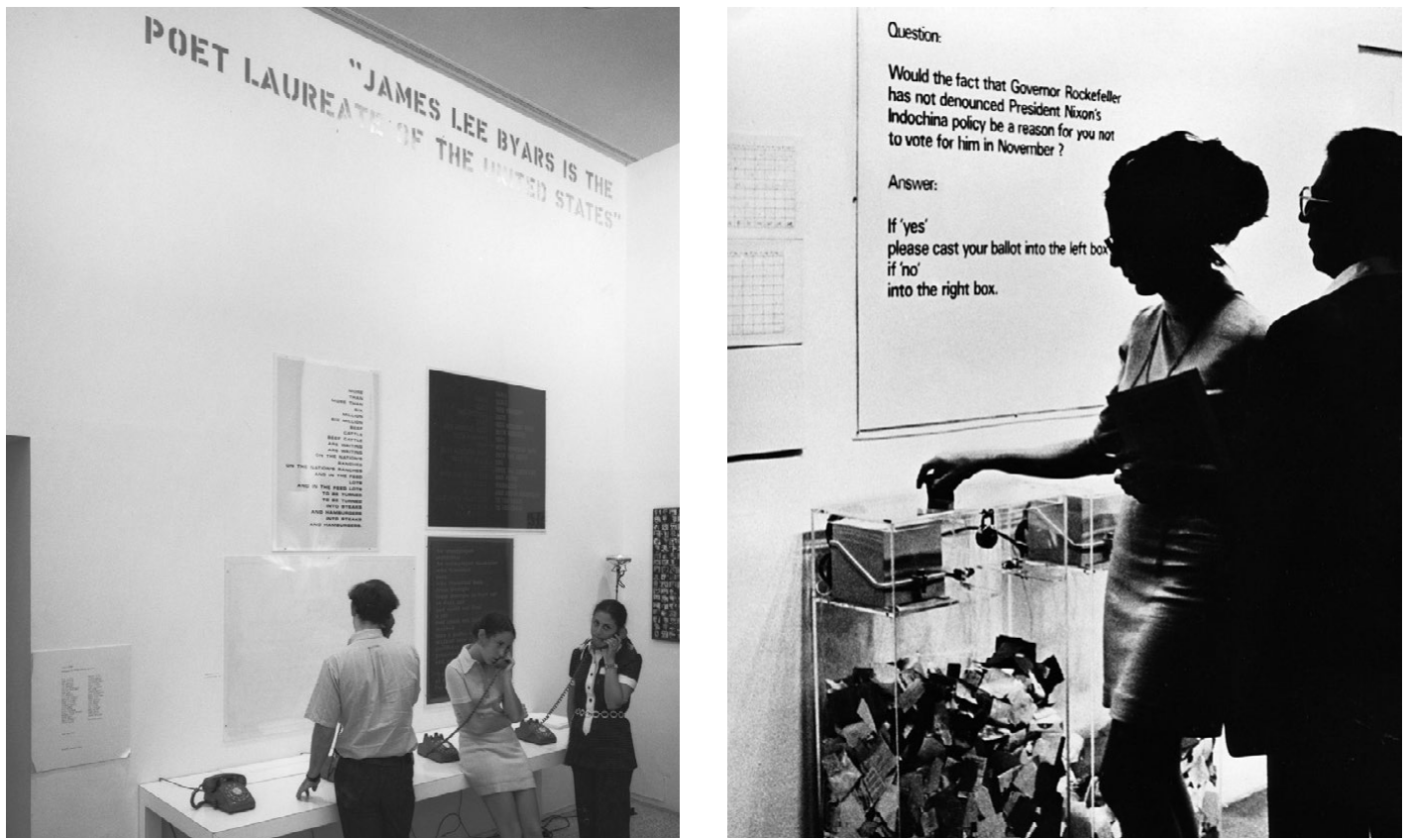

2.76 John Giorno, Dial-A-Poem, na exposição Information, MoMA, Nova York, 1970. Foto: James Mathews.

2.77 Hans Haacke, MoMA Pool, na exposição Information, MoMA, Nova York, 1970. Fonte: https://www.wikiart.org/en/ hans-haacke/moma-poll-1970

261 Cf. Giorno, John. The Dial-APoem Poets, 1972. Ubuweb: Sounds. Disponível em: <http:/www.ubu. com/sound/dial.html>. Acesso em: 16 maio 2020.
Em meio ao tom geral de crítica ao sistema, a exposição continha trabalhos que causavam conflitos mais diretos com o museu, como a obra Dial-A-Poem, do estadunidense John Giorno, que consistia em quatro aparelhos de telefone que permitiam ao visitante escutar a um dos 12 poemas selecionados por dia, entre os 700 gravados por 55 poetas vivos. ${ }^{261}$ Os poemas podiam ser acessados também de fora do museu, por meio de uma ligação telefônica comum. Usando o sistema de comunicação amplamente disseminado, Giorno procurava estender o alcance da poesia contemporânea a um público mais amplo, mas o conteúdo subversivo dos poemas, boa parte politicamente radical, chamou a atenção da imprensa e do FBI, trazendo uma publicidade considerada negativa para os mantenedores do museu.

Um incômodo ainda maior para o MOMA foi a obra do alemão Hans Haacke, MomA Pool - exemplo emblemático da "crítica institucional" - que denunciava abertamente os vínculos dos museus com as estruturas de poder. Haacke dispôs 
na entrada da exposição duas urnas de votação transparentes, cada qual destinada às respostas "sim" ou "não" dos visitantes à questão - revelada apenas na véspera da abertura -: "o fato de o governador Rockfeller não ter denunciado a política do presidente Nixon sobre a Indochina seria um motivo para você não votar nele em novembro?". ${ }^{262}$ Embora a obra tenha atingido diretamente os dirigentes do museu - presidido à época por David Rockefeller, irmão do candidato à reeleição a governador do estado de Nova York, Nelson Rockefeller -, o conselho preferiu não a censurar, evitando assim criar uma polêmica que amplificasse $o$ alcance da provocação e prejudicasse a imagem de instituição democrática que o museu procurava sustentar.

McShine não se furtara a usar de toda a liberdade curatorial que lhe havia sido confiada, não apenas estendendo-a em boa medida aos artistas, mas apimentando a mostra com a inclusão de documentos de eventos recentes dos embates com o museu, como a performance Grand Orgy in the Garden de Yayoi Kusama e o cartaz And Babies do Awc. Ocupando a direção do MoMA, um cargo de confiança definido diretamente pelo conselho, John Hightower enfrentou maiores dificuldades com a instituição por seu alinhamento com as demandas dos artistas e o apoio à realização de uma exposição com tal conteúdo. Durante aquele período de grandes tensões, seu perfil mais progressista não contribuiu para que permanecesse no posto por muito tempo, tendo sua demissão ocorrido em dezembro de $1972 .{ }^{263}$

Para Lippard, que colaborara com a concepção de Information e participou com uma proposta artística no catálogo, a exposição "foi um marco não por ter sido a primeira do gênero (não foi), mas porque ocorreu no MoMA, sendo um desvio especialmente drástico da rotina usual do museu". ${ }^{264}$ Seguindo o raciocínio da autora, é plausível supor que a recepção do conteúdo teria sido mais rarefeita se a mesma mostra tivesse sido realizada num espaço de arte alternativo ou num museu de menor escala. Tendo ocorrido na instituição que representava o poder tanto no campo das artes, quanto no da política e da economia, a exposição provocava um curto-circuito que intensificava a percepção do teor crítico das obras.

Information foi montada no pavimento térreo do museu, ocupando as duas galerias leste da ampliação projetada por
262 Conforme tradução de Amanda Ruggiero in: RUgGiero. Amanda Saba, Hélio Oiticica no Moma de Nova York. Arquitextos, v. ano 17, n. 193.01, 2016.

263 Poucos dias antes da abertura da mostra, John Hightower enviara um memorando aos membros do conselho prevenindo-os sobre possíveis incômodos que algumas obras de Information podiam causar devido às vinculações com questões políticas, especialmente as que denunciavam abusos da Guerra do Vietnã ou injustiças sociais. Mesmo sabendo que esses conteúdos podiam contrariar a intenção expressa por dirigentes de não se envolver em ações políticas, o diretor defendeu que ainda assim a obrigação do museu seria apresentar ao público essa produção contemporânea. Cf. HigHTOWER, John B., Memorandum to the Trustees, 26/o6/1970, apud ALTSHULER, op. cit., p.138. Além de indispor-se com o conselho, Hightower ainda enfrentou a sindicalização dos funcionários do museu, que organizaram uma greve em 1971 contra demissões, protestando ao lado de artistas dissidentes. Cf. Vitello, Paul, John Hightower. Besieged Art Museum Director, Dies at 8o. The New York Times, 14/07/2013. ed. p. 22, 2013.

264 LiPPARD et al., op. cit., p.14. Tradução nossa. 

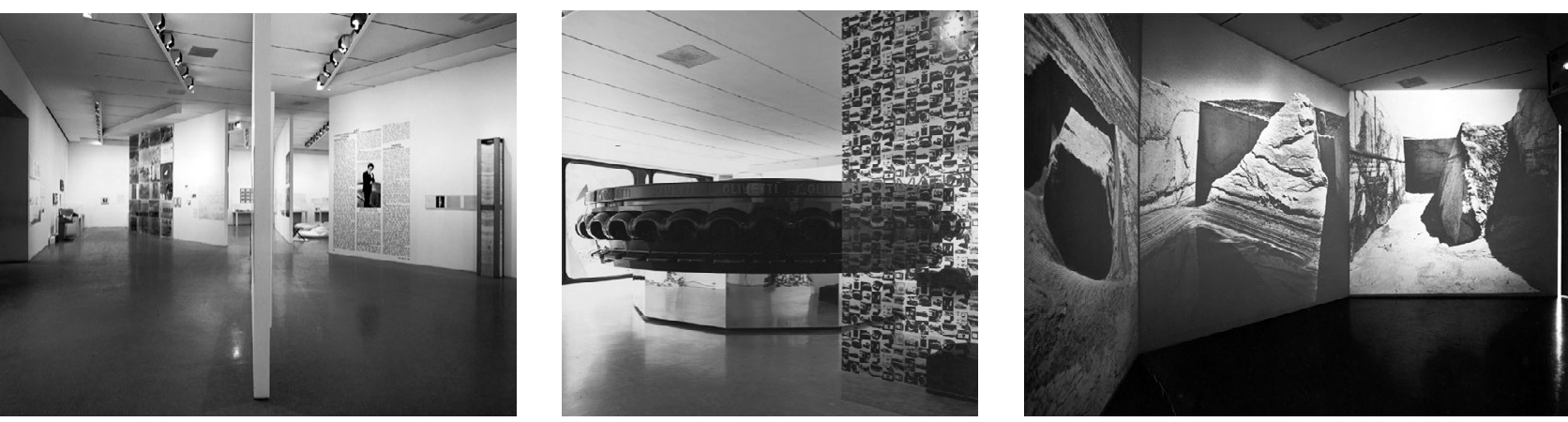

2.78 Vista da exposição Information, MoMA, Nova York, 1970. Foto: James Mathews. Fonte: https://www.moma.org/ calendar/exhibitions/2686

2.79 e 2.80 Ettore Sottsass Jr., Visual Jukebox e vista dos painéis com projeções de slides de Michael Heizer na na exposição Information, MoMA, Nova York, 1970. Foto: James Mathews. Fonte: https://www.moma.org/calendar/ exhibitions/2686

265 Por não ter tido acesso aos desenhos do projeto expográfico desta galeria e por haver poucas fotos desta área disponíveis na página de Information no web-site do момА, não foi possível ter uma compreensão mais aprofundada sobre a configuração expográfica dessa parte da exposição. É possível deduzir apenas que a estrutura de Visual Jukebox e a obra MOMA Pool estavam instaladas na região próxima à esquadria voltada para o jardim e ao corredor de acesso à galeria seguinte, localizada mais a leste. Cf. THE MusEuM OF MODERN ART, Information (Jul 2-Sep 20, 1970).

266 Cf. AsHER, Michael. Writings 1973-1983 on Works 196-1979. Halifax e Los Angeles: The Press of the Nova Scotia College of Art and Design e The Museum of Contemporary Art Los Angeles, 1983, p. 25.
Philip Johnson. A entrada se dava pela galeria envidraçada para a rua 53 e para o jardim, na qual foi instalada, ao lado da obra de Haacke e outras, uma grande estrutura circular - Visual Jukebox -, projetada pelo austro-italiano Ettore Sottsass Jr., responsável pelo design dos produtos Olivetti. ${ }^{265} \mathrm{O}$ equipamento transmitia simultaneamente 40 filmes em telas individuais e, embora os mesmos tivessem sido exibidos também no auditório do museu, sua presença no espaço expositivo eliminava a segregação habitual das peças audiovisuais e conferia-lhe status similar ao de outras manifestações das artes mais afeitas ao universo dos museus. Por outro lado, a estrutura de Sottsass, montada anteriormente numa feira comercial, trazia em todo o perímetro letreiros com a marca do fabricante, o que poderia causar estranheza pelo modo explícito de indicar o patrocínio empresarial junto às obras de arte, especialmente numa mostra onde predominava a crítica aos sistemas estabelecidos.

A maior parte das obras estavam instaladas na galeria cega mais a leste, na mesma área onde estavam as instalações de Spaces, porém com uma ambiência oposta à dessa mostra anterior, por ser um espaço mais aberto, fluido e luminoso, como mostram as fotos da montagem e a planta do projeto expográfico, com poucos elementos utilizados para setorizar o espaço. ${ }^{266}$ Ao centro da principal sala, quatro painéis soltos em diagonais simétricas, formando um " $\mathrm{x}$ " aberto, abrigavam trabalhos predominantemente documentais, incluindo fotos e textos, expostos também nas paredes perimetrais e na pequena sala contígua voltada para a rua 54 , cuja esquadria de vidro foi 


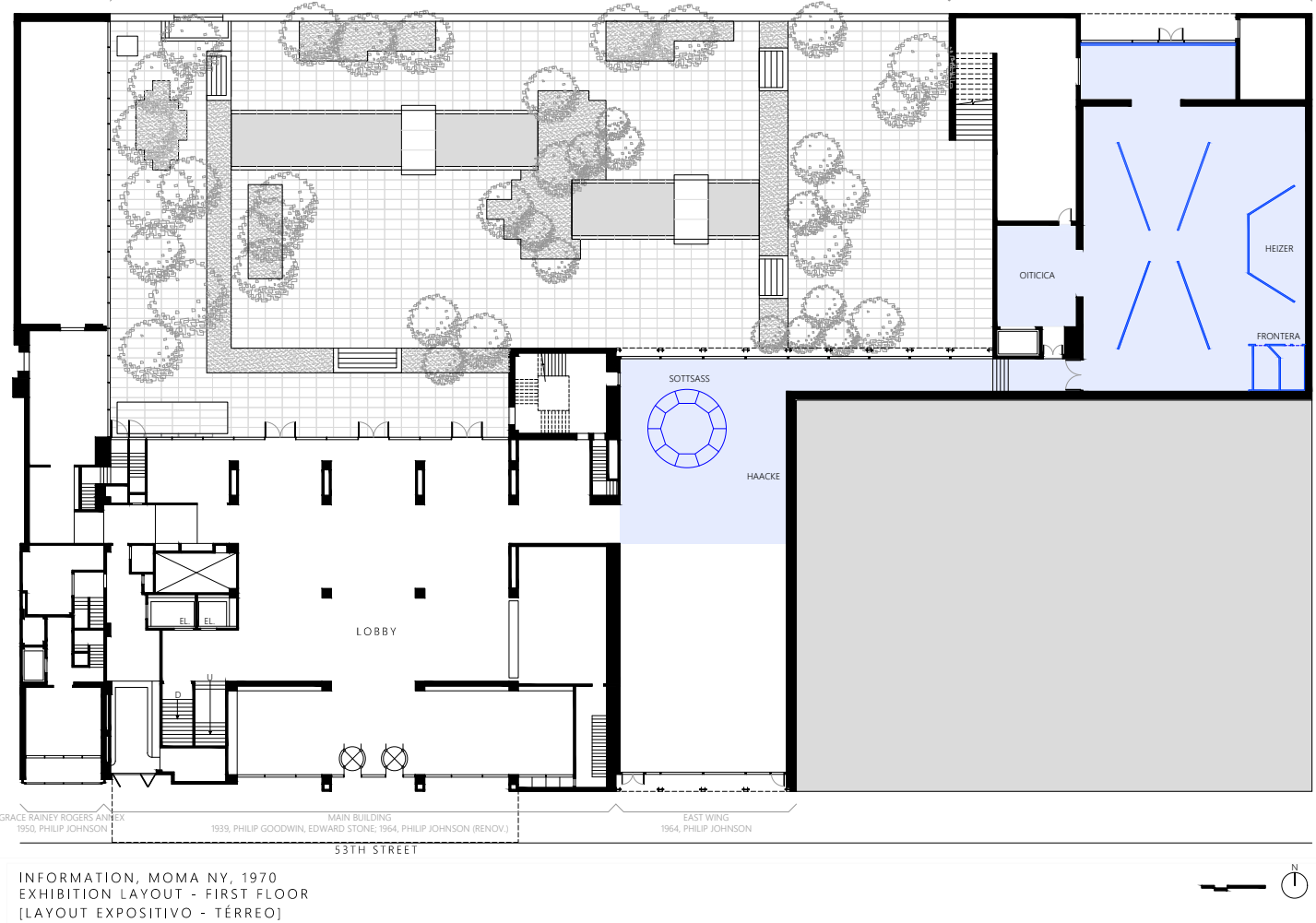

fechada até meia altura por um painel opaco. Alinhada com o eixo central dos painéis diagonais, uma pequena área fechada em formato trapezoidal abrigava nas três superfícies internas projeções de slides de Michael Heizer. Mais uma pequena área foi fechada num dos cantos da galeria para instalar as cabines de gravação do Grupo Frontera. Uma segunda sala contígua à principal e sem aberturas para o exterior foi designada para a obra ambiental de Helio Oiticica.

Possivelmente contribuía para a sensação de confrontação o fato de a ambiência expográfica de Information não ter recebido um tratamento distinto do padrão tradicional que o MOMA depurara ao longo dos anos nas montagens dedicadas à arte moderna, nas quais "distrações" visuais eram evitadas para não prejudicar a percepção das obras, valorizadas indi-

2.81 Planta do projeto expográfico de Information, MoMA, Nova York, 1970. Desenhos nossos baseados em material de arquivo do MoMA. 
vidualmente. As salas de Information tinham também uma configuração "discreta”, dada pela ordenação geométrica dos painéis e pela tonalidade branca das superfícies. Porém, ao invés de conter objetos esteticamente elaborados e visualmente atraentes para serem contemplados, a mostra exibia painéis preenchidos por grandes quantidades de fotografias, cartazes e textos, ao lado de equipamentos de tecnologia recente e de uso cotidiano, como aparelhos telefônicos, monitores de TV e fotocopiadoras, os quais teriam seu sentido artístico não devido à sua qualidade estética e fatura material, mas vinculado ao engajamento dos espectadores nas reflexões e ações propostas.

Analisando a relação entre os procedimentos da Arte Conceitual e o padrão expográfico de Information, Staniszewski apontou para a exposição como um marco da virada que o MOMA vinha dando desde os anos 196o. Ao contrário do que tinha feito nos chamados "anos de laboratório", o museu viria deixando de explorar recursos variados de expografia para atribuir sentido às narrativas curatoriais. Muitas das estratégias de cunho didático, documental, informativo ou político que o museu adotara nas exposições do passado teriam sido incorporadas por artistas, transformando-se na própria substância de seus trabalhos. As exposições recentes vinham sendo apresentadas de modo cada vez mais isolado no universo do museu, tendo deixado de incluir elementos que estabelecessem conexões com o mundo exterior, na contramão do que vinha fazendo a nova geração de artistas contemporâneos. Para a autora, o abandono da exploração expográfica representava uma transferência radical da atribuição de sentido do museu para os artistas, que permitiria que о мома adotasse uma postura de "neutralidade" diante dos impasses ideológicos, que vinham incomodamente expondo seus limites institucionais:

Bem quando os curadores e designers de exposições do MoMA pararam de tratar as expografias como representações dominadas não apenas por considerações estéticas, mas também ideológicas, históricas, econômicas, bem como políticas, os artistas conceituais estavam assiduamente desafiando a premissa que uma exposição de arte fosse apolítica e esteticamente autônoma. Em outras palavras, as práticas artísticas tornaram-se 
mais politicamente autoconscientes com relação à atuação das instituições de arte no momento em que o MOMA, em particular, e os museus de arte moderna em geral, estavam desautorizando essas realidades em suas práticas expográficas. Ironicamente, a análise das dimensões ideológicas de uma exposição pelos artistas conceituais simultaneamente circunscreveram a política ao domínio individual do artista, liberando assim a instituição de qualquer responsabilidade e alimentando o mito de uma instituição de arte como um local neutro. ${ }^{267}$

Para a percepção do público, entretanto, essa estratégia do museu de evitar adotar uma posição ideológica mais explícita no espaço expositivo pode ter sido demasiadamente sutil, tendendo a passar despercebida. Parece difícil, afinal, estabelecer uma fronteira tão perceptível entre a posição do museu e a de artistas, considerando que essa exposição de natureza panorâmica e antissistema foi organizada por membros da instituição e montada em sua própria sede. Essa talvez tenha sido a razão de ter sido Information a primeira e última grande exposição coletiva de arte contemporânea realizada da década de 1970 pelo museu, ${ }^{268}$ que preferiu adotar em seguida alternativas menos arriscados de acolher a produção de jovens artistas, como veremos mais adiante.

\section{3 À MARGEM DAS CONVENÇÕES: ANOS $1960 \mathrm{E} 1970$}

\subsubsection{ESPAÇOS ALTERNATIVOS COMO LABORATÓRIOS DA ARTE CONTEMPORÂNEA}

Ao invés de representar uma convergência de interesses com o universo institucionalizado dos museus, a presença de um número grande de artistas de vanguarda numa exposição realizada pelo момА acabou explicitando a profunda cisão que havia se instalado entre eles e o museu desde os anos 1960. Enquanto artistas buscavam formas de expressão fora dos limites convencionais, contestando o sistema estabelecido, muitos museus ainda resistiam a acolher abertamente esse tipo de produção e a reconhecê-la como arte. A cidade de Nova York
267 STANISZEWSKI, Mary Anne. The Power of Display: a history of exhibition at the Museum of Modern Art, Londres: The MIT Press, 1998, p.281. Tradução nossa.

268 Ibidem, p. 276. 

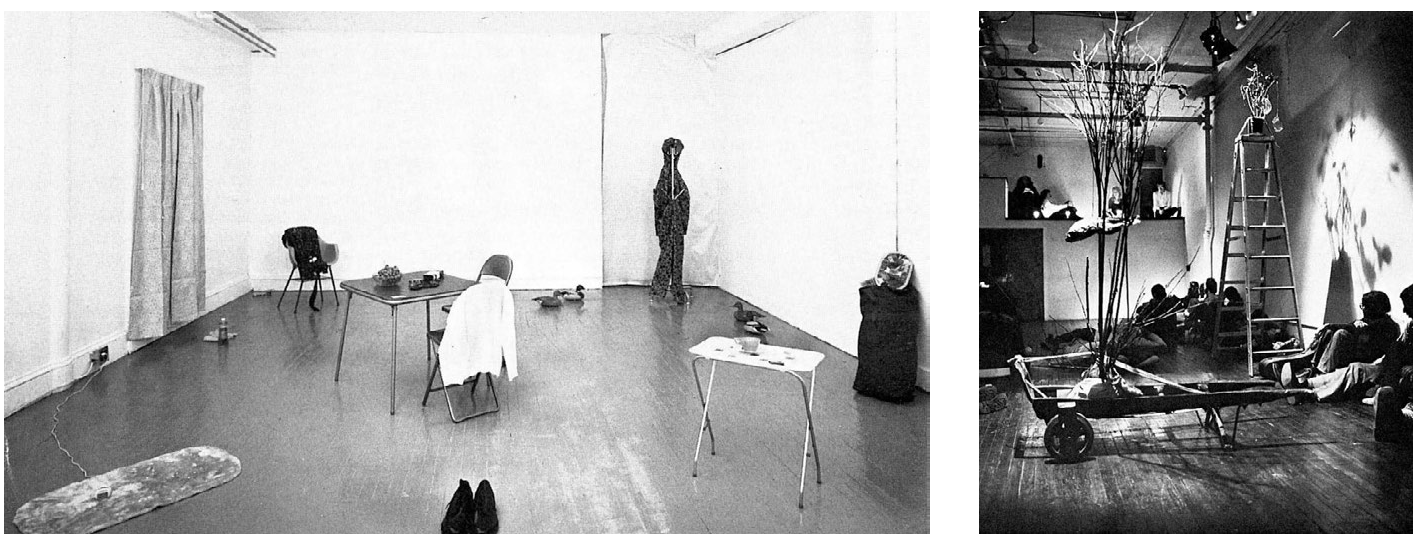

2.82 Vista da exposição de Eleanor Antin, California Lives, Gain Ground, Nova York, 1970. Foto: Peter Moore. Fonte: APPLE, p. 21.

2.83 Performance de Gordon Matta-Clark, Christmas Piece, 98 Greene Street, Nova York, 1969. Fonte: APPLE, p. 28. continuava atraindo parte significativa de jovens artistas contemporâneos de diversas partes do mundo, que, dedicados a variadas manifestações experimentais, desvencilhavam-se não apenas da obrigação de produzir objetos, mas das fronteiras territoriais, uma vez que a arte imaterial, em forma de ideia ou proposta, podia circular com ampla liberdade e rapidez pelo globo, promovendo um intercâmbio internacional de velocidade e proporções inéditas. Simultaneamente, havia artistas que, embora também não se dedicassem a produzir objetos em conformidade com as categorias tradicionais, tinham sua produção muito ligada a intervenções físicas em espaços reais, criando instalações identificadas como site-specific, cuja circulação era limitada ou até impossível, em função do grau de dependência do local em que eram realizadas.

Atuando às margens do sistema estabelecido, jovens artistas vinham se articulando em torno de espaços alternativos para realizar seus trabalhos, os chamados artist-run spaces. Com vasta quantidade de imóveis desocupados e desvalorizados pelo estado de deterioração, a região em torno do bairro nova-iorquino do SoHo tornara-se um polo de atração para a nova geração em busca de locais amplos e de baixo custo para viver e trabalhar em ateliês individuais e coletivos e para realizar eventos artísticos incluindo instalações, performances, apresentações musicais e teatrais, saraus de poesia, debates, festas etc. Diversos desses espaços instalaram-se no SoHo em 1969 
- ano em que se constituía o AWC -, como o Gain Ground e o 98 Greene Street, e diversos outros surgiram seguida. ${ }^{269}$

Atuar nos locais alternativos possibilitava a artistas uma experiência muito distinta da que proporcionavam os museus. Em primeiro lugar, a gestão predominantemente coletiva e sem hierarquias permitia grande agilidade na realização das ações e maior abertura para participação de artistas iniciantes. Em segundo, o estado precarizado das construções oferecia um cenário dessacralizado para a realização de intervenções, contrastando com a ambiência pristina dos museus, especialmente a que havia se desenvolvido no MoмA. Moldados pela arquitetura eclética de finais do século XIX e utilizando a técnica industrial do ferro fundido, antigos armazéns comerciais e indústrias leves do SoHo eram dotados de amplos salões, podendo receber obras de grande escala, que por vezes acrescentavam novas cicatrizes aos edifícios. Os limites não eram mais de caráter institucional, mas da ordem do mundo real, concreto, que se tornara o foco do interesse de muitos artistas. Ao contrário das salas brancas, abstratas e isoladas em si mesmas dos museus modernos, ou da ambiência doméstica e elegante das galerias comerciais de arte, tais espaços alternativos eram cheios de ruídos que desnudavam sua história pregressa de apogeu e decadência. Impregnada dessas marcas, sua arquitetura tornava-se, assim, parte obrigatória da apreensão das obras, ou mesmo integrante da proposta artística.

Como aponta a artista e escritora Jacki Apple (1941-), os benefícios de contar com locais tão precários para atuação eram superiores ao grande esforço envolvido para torná-los minimamente habitáveis e à insegurança sobre a possibilidade de sustentar seu funcionamento. Espaços alternativos desempenharam papel aglutinador de uma comunidade de artistas com produções diversificadas, mas que compartilhavam ideias e propósitos comuns, dispostos a somar forças para identificar, limpar e reformar os edifícios deteriorados, planejar os programas e levantar fundos privados para mantê-los. ${ }^{270}$

É preciso pontuar que espaços alternativos de exposição e artistas ao seu redor nos EUA puderam contar com um suporte oficial, vindo do Programa de Artes Visuais do NEA - National Endowment for the Arts -, dirigido desde 1969 por Brian
269 Cf. APPLE, Jacki. Alternatives in Retrospect: An Historical Overview, 1969-1975. Nova York: The New Museum, 1981.

270 Ibidem, p. 9. 

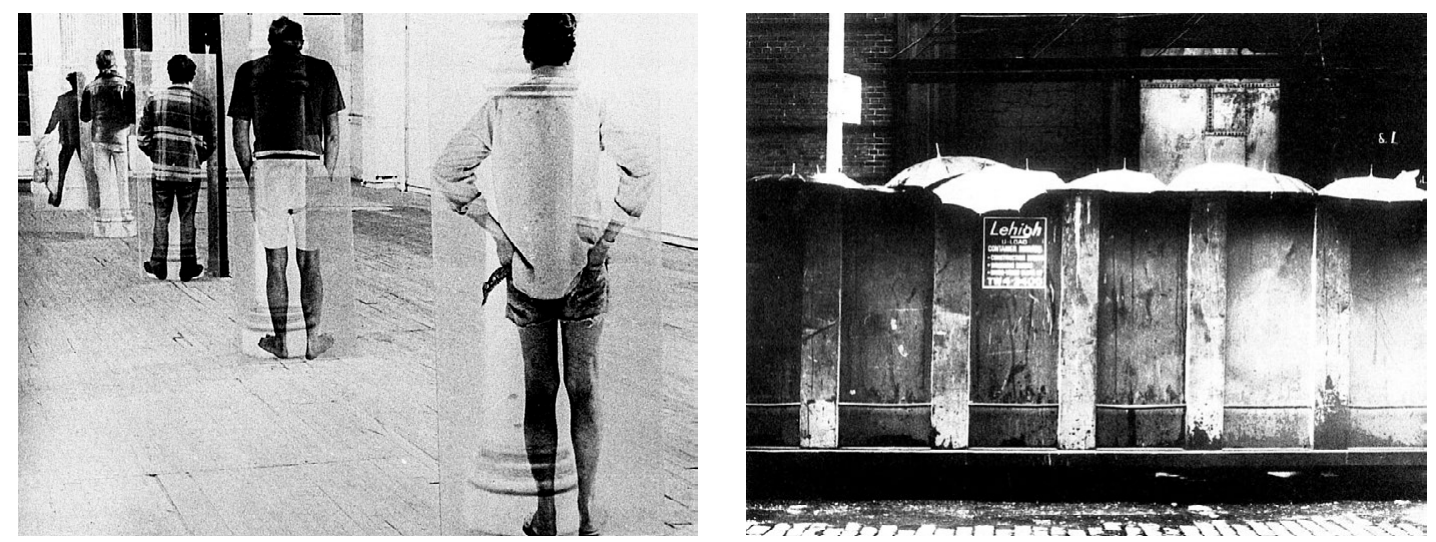

2.84 Instalação de Jeffrey Lewis na 112 Greene Street, Nova York, 1974. Fonte: APPLE, p. 42.

2.85 Instalação de Gordon Matta-Clark, Open House, entre 98 e 112 Greene Street, Nova York, 1972Fonte: APPLE, p. 39.

271 Ibidem, p. 14.

272 O grupo incluía os artistas Laurie Anderson, Tina Girouard, Suzanne Harris, Jene Highstein , Bernard Kirschenbaum, Richard Landry e Richard Nonas. Cf. APPLE, op. cit., p. 15.

273 Segundo Reiss, "a maioria dos trabalhos ambientais de MattaClark não foi realizada no local, no 112 Greene Street ou em qualquer outro espaço alternativo. Sua forma única de instalação, que envolvia cortar partes de edifícios, teve início no próprio espaço em que morava e logo migrou para edifícios abandonados em Nova York. Ele expôs ruínas fragmentadas de edifícios no 112 Greene Street e fez outros projetos por lá, mas cada vez mais se distanciava até mesmo da margem do mundo da arte." ReIss, op. cit. p. 114-115. Tradução nossa.
O’Doherty, que, além de crítico de arte, atuava também como artista sob vários pseudônimos, entre eles Patrick Ireland. O programa direcionou recursos para o fomento dessa categoria de atividade, que floresceu por todo o país. Foi com o apoio financeiro concedido pelo NEA que o artista Jeffrey Lew criou em 1970, num imóvel de sua propriedade, a galeria 112 Greene Street, um dos mais ativos dentre os espaços alternativos dessa época, promovendo simultaneamente ações de artistas conhecidos e desconhecidos. O local funcionou até o fim de 1975 como um laboratório para o desenvolvimento de obras de instalação, muitas das quais de grande porte e concebidas em estreita relação com os elementos físicos do espaço, incluindo paredes e pisos desgastados, além de detritos do ambiente urbano. Artistas trabalhavam em cooperação na realização dos trabalhos, que eram ainda incorporados como cenários - ou "coadjuvantes" - de outras performances de música e dança. ${ }^{271}$

Uma das figuras centrais atuando no 112 Greene Street foi o artista Gordon Matta-Clark, em torno do qual se reunia o grupo Anarchitecture, interessado em explorar "vazios, lacunas, interrupções e movimentos do ambiente físico". ${ }^{272}$ Os trabalhos de Matta-Clark envolvendo intervenções diretas em edifícios abandonados da cidade, incluindo remoção de paredes e pisos para criar aberturas de proporções arquitetônicas, exemplificam o tipo de instalação site-specific em relação absoluta com o local e avessa às condições de trabalho e aos espaços imaculados dos museus. ${ }^{273}$ 
A via aberta com os espaços alternativos de Nova York deixaria marcas profundas nos modos de produção e exposição da arte contemporânea, impactando o entendimento sobre a relação entre arte e arquitetura e, consequentemente, sobre a arquitetura de museus, foco de interesse desta tese. Nessa articulação entre artistas e lugares, vale destacar a atuação de Alanna Heiss (1943-), que se incorporou à cena nova-iorquina em 1970, quando passou a desenvolver uma série de ações que viriam, décadas à frente, resultar numa surpreendente convergência com o MомA, como veremos mais adiante. Tendo tido formação como instrumentista de música clássica e uma passagem pelo curso universitário de filosofia e artes, Heiss não era artista, nem historiadora ou crítica da arte, mas participava ativamente do círculo de amizade de artistas alternativos, sendo casada com um deles, Jene Highstein (1942-2013). Atraído pela efervescência da cena artística de Nova York, o casal voltara de uma temporada de cinco anos em Londres, onde Heiss havia se dedicado a variadas atividades, incluindo trabalhos em museus, galerias e numa organização chamada Space, voltada a converter galpões desocupados em ateliês de artistas. ${ }^{274}$ Recém-chegada aos EUA, Heiss dirigiu-se aos museus que considerava amigáveis para artistas, como o мома е o Whitney, para propor um projeto de exposições de obras do acervo nos galpões onde ficavam armazenadas, sempre em regiões afastadas da cidade, com o intuito de ampliar o acesso à arte às populações de bairros periféricos, como o Bronx e o Queens. O desinteresse dos museus por esse tipo de ação, devido, na opinião de Heiss, ao fato de essas exposições não terem compromisso com uma "experiência visual coerente" - como as organizadas de acordo com projetos curatoriais tradicionais -, levou ao seu desencantamento com a possibilidade de aproximação com as instituições estabelecidas da cidade, cujas atividades se mostravam muito distantes do que se passava no ambiente artístico fora de seus limites. $^{275}$

Mirando em oportunidades de promover eventos artísticos independentes do circuito convencional, Heiss tirou partido da familiaridade que vinha adquirindo com a burocracia administrativa de Nova York em seu posto de diretora de progra-
274 O projeto Space foi fundado em 1968 pelos artistas Bridget Riley, Peter Sedgley e Peter Townsend, que haviam se inspirado nos espaços alternativos de Nova York. Com o apoio do Greater London Council e do Arts Council of Great Britain, eles fundaram o primeiro de muitos estúdios para artistas instalados em galpões industriais desocupados de Londres, criando um tipo de parceria entre o poder público, proprietários de imóveis e artistas que seria replicada em diversas cidades do mundo. Cf. Space. The Space Story. Space Studios. Disponível em: $<$ https://spacestudios.org.uk/space-story/>. Acesso em: 25 maio 2020.

275 Em entrevista concedida em 2014, Heiss afirmou que considerava o MOMA em 1970 bastante atualizado com os acontecimentos da arte e especialmente receptivo aos artistas, destacando nesse sentido as atuações de John Hightower (diretor do museu de 1970 a 1972), Jeniffer Licht (curadora assistente que realizara a mostra Spaces) e Pierre Apraxine (curador assistente). O Whitney seria também amigável, mas não o Guggenheim, que ainda não tinha exposto obras do Minimalismo e que seria desinteressante para os artistas por conta das paredes curvas de seu edifício. Cf.: HEIss, Alanna. Alanna Heiss with David Carrier and Joachim Pissarro, with the assistance of Gaby CollinsFernandez. The Brooklyn Rail. Disponível em: $<$ https://brooklynrail.org/2014/12/art/alanna-heiss>. Acesso em: 16 abr. 2021. 
276 Fundado em 1893, The Municipal Art Society of New York (MAS) é apresentado como "uma organização sem fins lucrativos que protege o patrimônio espacial de Nova York, incentiva o planejamento cuidadoso e o design urbano e advoga por bairros inclusivos nos cinco distritos. " Cf. THE MUNICIPAL ART SOCIETY OF NEW YORK. History: Celebrating more than 125 years of advocacy on behalf of New York and New Yorkers. The Municipal Art Society of New York. Disponível em: $<$ https://www.mas.org/about-us/ history/>. Acesso em: 26 jul. 2020. Tradução nossa.

277 A exposição ocorreu no denominado Scupltor Pier, localizado junto à cabeceira da ponte, e no Performance Pier (Pier 14). Cf. BIESENBACH, Klaus; FUNCKE, Bettina (Orgs.). MOMA PS1: A History. Nova York: The Museum of Modern Art, 2019. p. 29. Conforme depoimento de Heiss em 2010, pouca coisa foi realizada do lado do Brooklyn, considerado então um lugar de difícil acesso e desinteressante para a atuação dos artistas. HEIss, Alanna. Oral history interview with Alanna Heiss. Smithsonian Archives of American Art. Disponível em: <https://www.aaa.si.edu/collections/interviews/oral-history-interview-alanna-heiss-15902\#transcript>. Acesso em: 25 maio 2020.
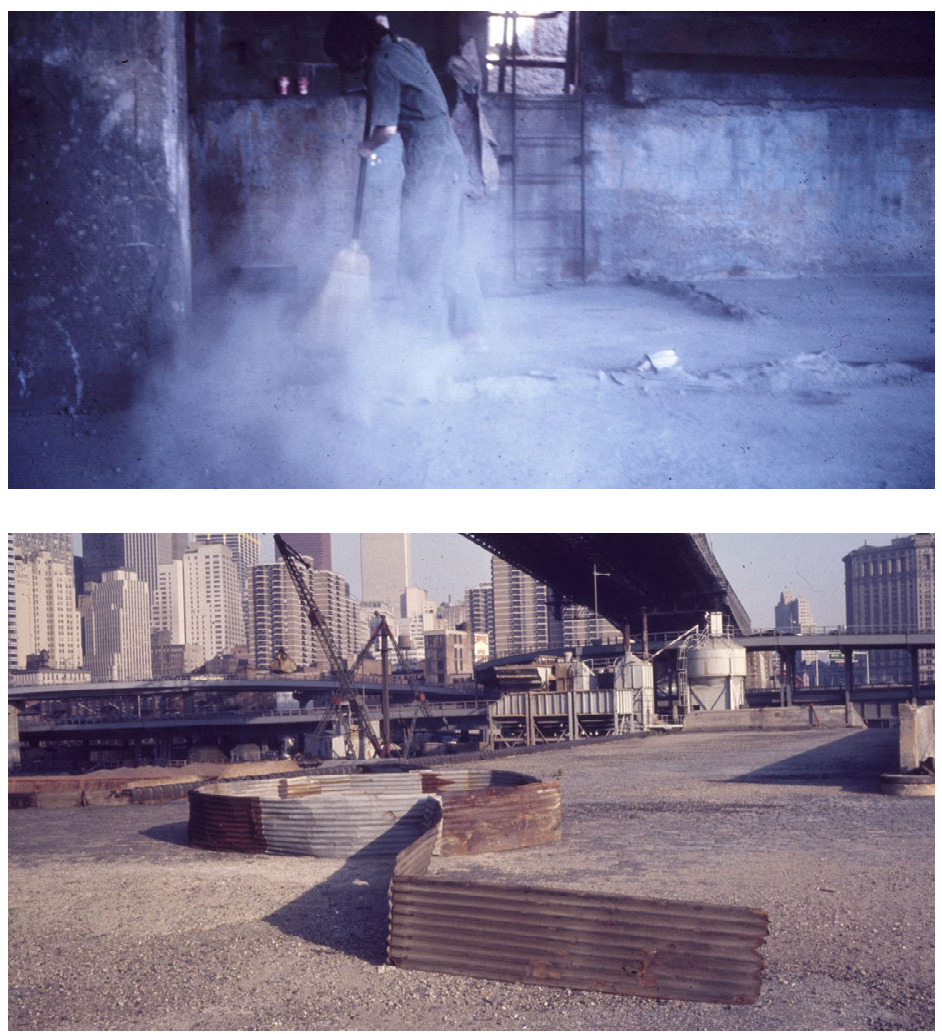

mação num órgão chamado Municipal Art Society. ${ }^{276}$ Aproveitando a ocasião da comemoração do $88^{\circ}$ aniversário da ponte do Brooklyn, ela organizou, em maio de 1970, o "festival" The Brooklyn Bridge Event, que reuniu por quatro dias ações de mais de 20 artistas em píeres desocupados do East River.

Junto à cabeceira da ponte do lado de Manhattan, ficavam as obras apresentadas como "escultóricas", realizadas em interação com os elementos arquitetônicos, paisagísticos e até com detritos encontrados no local, ocupando salas abandonadas e o próprio píer. ${ }^{277}$ Tina Girouard realizou a obra Swept House, varrendo o piso de forma a delimitar ambientes com "paredes" de poeira, onde objetos descartados faziam as vezes de mobília. Richard Nonas construiu uma escultura com restos de painéis metálicos ondulados. Bill Beckley pen- 

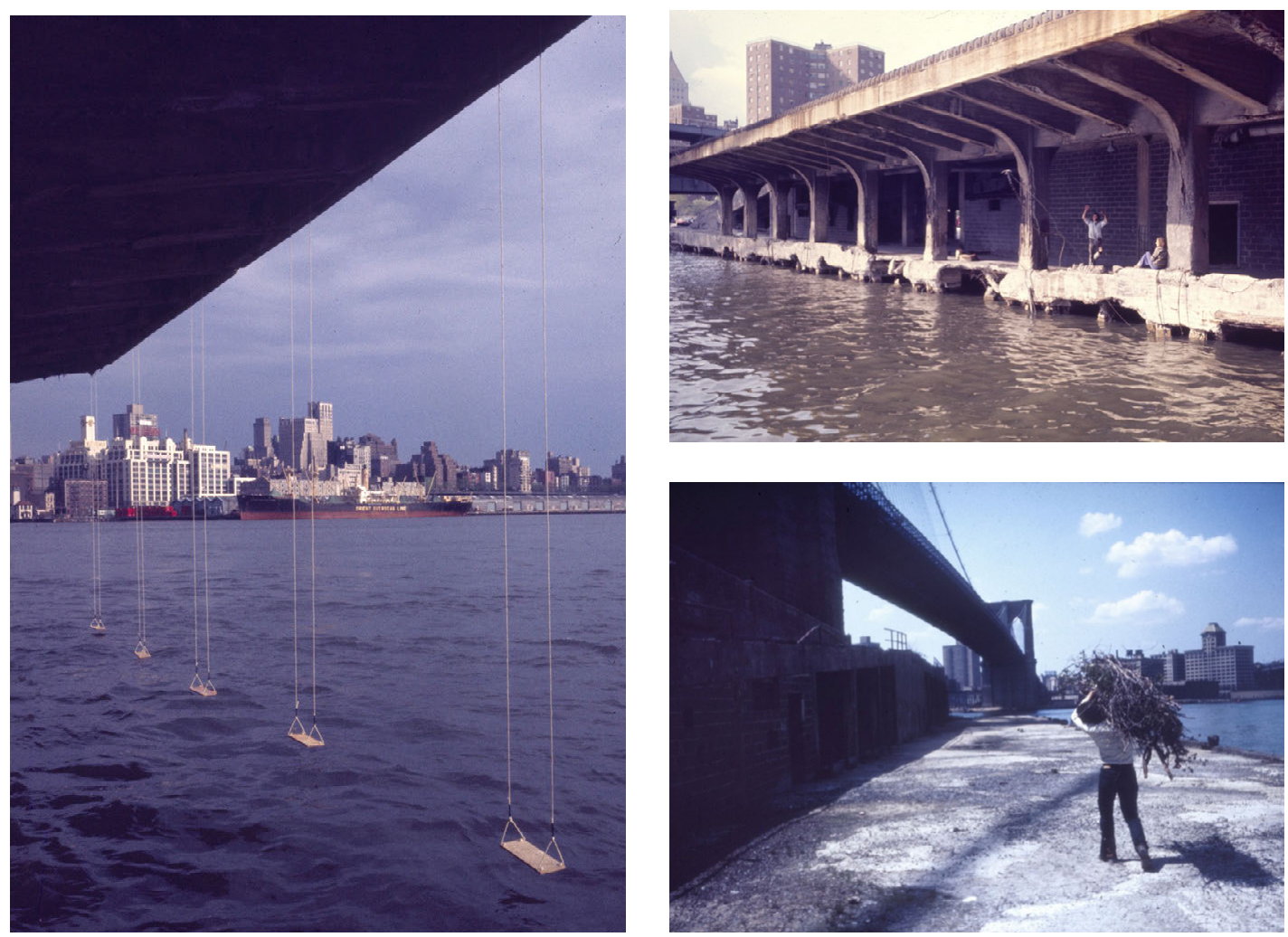

2.86 Tina Girouard, Swept House, na exposição The Brooklyn Bridge Event, Nova York, 1970. Fonte: https://www.moma. org/calendar/exhibitions/3936

2.87 Instalação de Richard Nonas na exposição The Brooklyn Bridge Event, Nova York, 1970. Fonte: https://www.moma. org/calendar/exhibitions/3936

2.88 Instalação de Bill Beckeley na exposição The Brooklyn Bridge Event, Nova York, 1970. Foto: Carol Goodden. Fonte: https://www.moma.org/calendar/ exhibitions/3936
2.89 Jed Bark, Fishing and Salvage Project, na exposição The Brooklyn Bridge Event, Nova York, 1970. Foto: Carol Goodden. Fonte: https://www.moma.org/calendar/ exhibitions/3936

2.90 Gordon Matta-Clarck trabalhando na exposição The Brooklyn Bridge Event, Nova York, 1970. Fonte: https://www.moma.org/ calendar/exhibitions/3936

\section{8-239}


278 A ação esteve na origem do restaurante Food, criado no SoHo pouco depois pelo então casal Goodden e Matta-Clark, responsáveis por seu funcionamento de 1971 a 1973. GoldsteIn, Bethsheba. Guest Post Series: Bethsheba Goldstein Interviews Carol Goodden about the Origins of FoOD. SoHo Memory Project. Disponível em: $<$ https://sohomemory.wordpress. com/2012/o6/3o/guest-post-series-bethsheba-goldstein-interviews-carol-goodden-about-food/>.

279 Alana Heiss in: BIEsenbaCH; FunCKE, op. cit., p. 29. Tradução nossa. Áreas deterioradas da região sul de Manhattan ocupadas informalmente por artistas acabaram de fato sendo valorizadas nos anos seguintes, atraindo galerias de arte e outros estabelecimentos comerciais e tornanto-se economicamente inviável para a permanência de artistas. Cf. HALlE, David; Tiso, Elisabeth, Lessons from Chelsea. International Journal of he Humanities. v. 3, n. 11, p. 45-66, 2006.

280 Com vários livros publicados, Brendan Gill também escrevia artigos para a revista New Yorker, com a qual colaborou por mais de 60 anos produzindo crítica de teatro, cinema, literatura, artes visuais e arquitetura. Além disso, liderou diversos órgãos ligados à arte e arquitetura, tendo sido presidente do I.A.U.R, do Municipal Art Society, da New York Landmarks Conservancy e da Andy Warhol Foundation for the Visual Arts e vice-presidente da American Academy of Arts and Letters.

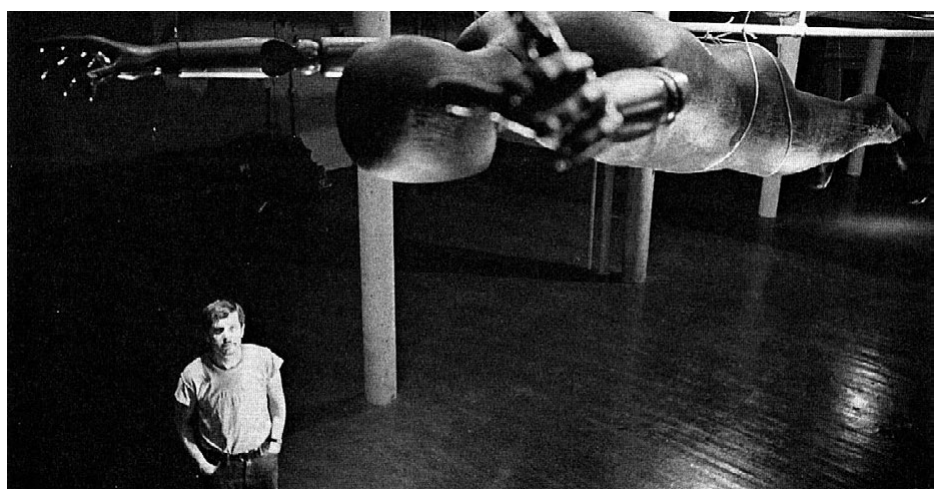

durou longos balanços na borda da ponte, que em movimento avançavam sobre a água. Jed Bark realizou a ação Fishing and Salvage Project, pescando objetos despejados no rio. Com Carol Goodden, Matta-Clarck cobriu carros abandonados com galhos de árvore coletados ao redor, usados também para alimentar o fogo em que assou por longas horas um porco inteiro, servido em sanduíches a todos os participantes no encerramento do evento. ${ }^{278}$

O breve texto de apresentação impresso no folheto de divulgação assinado por Heiss aponta para um valor positivo das ações artísticas para a cidade, em forma de ressignificação de espaços abandonados:

Espera-se que esta oportunidade demonstre a habilidade da cidade de Nova York para aproveitar os recursos de sua comunidade artística. Permitindo seu envolvimento com a paisagem urbana, áreas desocupadas e abandonadas podem se transformar em espaços significativos. ${ }^{279}$

Eventos efêmeros, porém, não eram o principal foco de Heiss, seu interesse voltava-se principalmente para a conversão de edifícios abandonados em espaços artísticos, que pudessem ter algum tipo de programação continuada, como o que fundou um ano depois, o 10 Bleecker Street, com intenso intercâmbio com o 112 Greene Street. Dando sequência ao seu projeto, uniu-se ao escritor Brendan Gill (1914-1997), ${ }^{280}$ para criar em 1972 

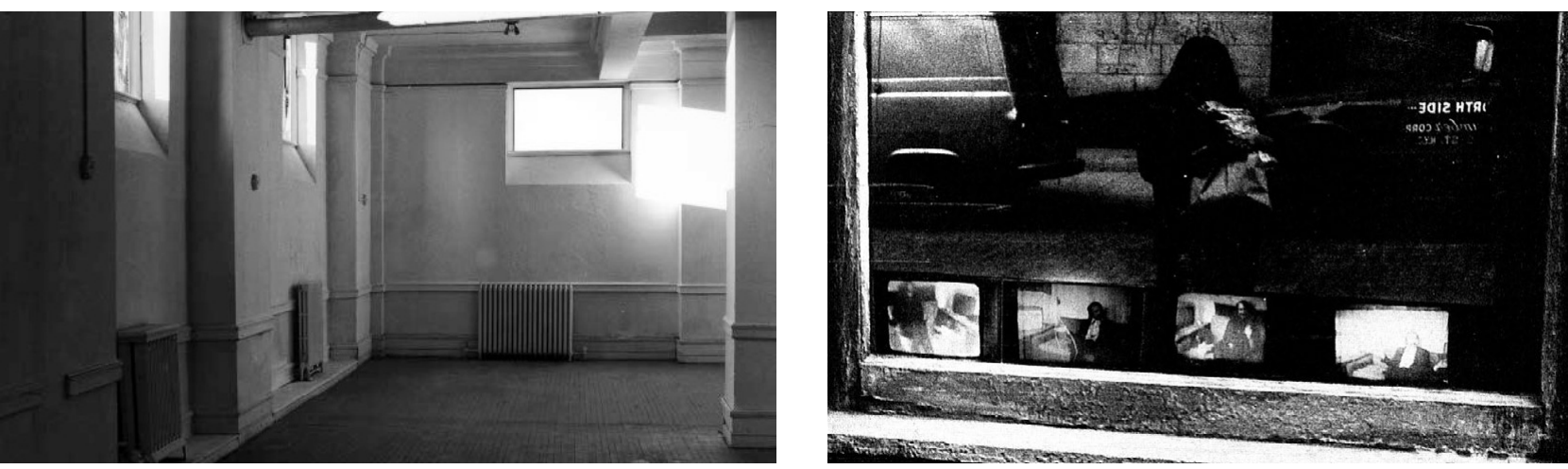

o Institute for Art and Urban Resources - I.A.U.R., uma entidade sem fins lucrativos e com estrutura de associados, com a qual obtinha permissão de proprietários de imóveis em desuso para instaurar espaços para atividades artísticas, replicando em parte estratégias utilizadas pelo Space de Londres. Dedicados primordialmente à realização de exposições de arte, sem interesse em formar coleções, esses espaços podiam funcionar simultaneamente como ateliês, teatros e centros comunitários. Sob o I.A.U.R., foram criados inicialmente o Clocktower, o 3 Mercer e o Coney Island Sculpture Factory, em 1973, e o Idea Warehouse, em 1974, cada um deles com um perfil específico de atuação, ${ }^{281}$ tendo a entidade chegado a ocupar simultaneamente 11 edifícios de propriedade municipal, federal ou particular em Nova York. ${ }^{282}$

O caráter "alternativo" desses espaços não se devia apenas ao fato de atuarem às margens do circuito de museus e galerias, mas também por contar com uma programação curatorial e um modo de gestão mais informal, aberta à participação de artistas, eles mesmos responsáveis por patrocinar, produzir e instalar as obras. Localizados em regiões abandonadas onde prosperavam atividades ilegais, alguns espaços eram suscetíveis a invasão por gangsteres, que acabavam por vezes sendo contratados para manter em certa segurança os imóveis e as obras instaladas. O caráter industrial desses lugares contrastava com o ambiente refinado das principais galerias de arte, localizadas em regiões valorizadas da cidade. Pouco depois, no
2.91 Douglas Davis, The Flying Man (Images from the Present Tense II), Idea Warehouse, Nova York, 1975. Fonte: APPLE, p. 47.

2.92 Michael Asher, Clocktower, Nova York, 1976. Foto: Helen Winkler. Fonte: REISS, p. 120.

2.93 Dieter Froese, Toenis Loop Re-Stage, 3 Mercer, Nova York, 1975. Fonte: APPLE, p. 51.

281 Segundo Alana Heiss, "o Clocktower era para arte que pudesse ser vista em uma situação utópica: Jim Bishop, Joel Shapiro, Richard Tuttle. As exposições que organizei na 10 Bleecker Street foram de esculturas: Nancy Holt, Richard Nonas. The Coney Island Sculpture Factory era diferente: era um espaço de produção onde se podia fazer suas próprias esculturas de grandes dimensões. Teve John Chamberlain, teria tido Richard Serra. E a galeria do Idea Warehouse era especificamente sobre arte performática." HEIss, 2014, op. cit. Tradução nossa 282 HeISS, 2010, op. cit. 
entanto, diversas galerias vieram a se instalar no SoHo, tirando partido da efervescência artística do bairro e incorporando elementos da estética dos espaços alternativos nos imóveis que ocupavam. ${ }^{283}$

\subsubsection{PS1 COMO ANTI-MUSEU: A INSTITUCIONALIZAÇÃO DO ALTERNATIVO}

O potencial das atividades artísticas para promover a valorização de imóveis e áreas degradadas atraiu o interesse da prefeitura de Nova York, que em 1975 convidou o I.A.U.R. para implantar um centro de artes de maior porte num dos bairros periféricos da cidade - regiões costumeiramente negligenciadas pelos museus. Aquela era uma oportunidade de, ao invés de continuar dispersando investimentos em vários pequenos espaços por períodos incertos, concentrar esforços num projeto mais efetivo, ao compreender uma área maior que comportasse uma programação mais variada e ambiciosa em escala. Dentre os diversos edifícios disponíveis do município, o escolhido foi o da antiga Public School no. 1-PS1 - no bairro do Queens, bem servido por transporte público e conectado visualmente à ilha de Manhattan. Construído em 1892, o edifício de tijolos terracota em estilo neorromânico estava desocupado desde 1963 e corria o risco de ser demolido, pois, embora razoavelmente preservado no exterior, tinha os interiores bastante deteriorados em consequência de vandalismo e de intempéries, com tábuas de piso empenadas, trechos de forros despencados, paredes com camadas de tinta descascada de diversas cores e mofo por toda parte. ${ }^{284}$

O edifício tinha uma organização tipicamente escolar, com planta em "U" ao redor de um pátio, corredor lateral na haste central e corredor central nas alas laterais, contendo a parte mais antiga (Old Wing) salas mais largas e a mais recente (New Wing) salas mais estreitas. Os três andares eram conectados

283 HeISs, 2010, op. cit.

284 Cf. Foote, Nancy. The Apotheosis of the Crummy Space. Artforum, p. 28-37, 1976. por seis núcleos de escadas duplas para permitir a circulação simultânea de um grande número de estudantes. Heiss já tinha adquirido uma boa experiência organizando exposições em espaços antigos e desocupados, que julgava mais apropriados 


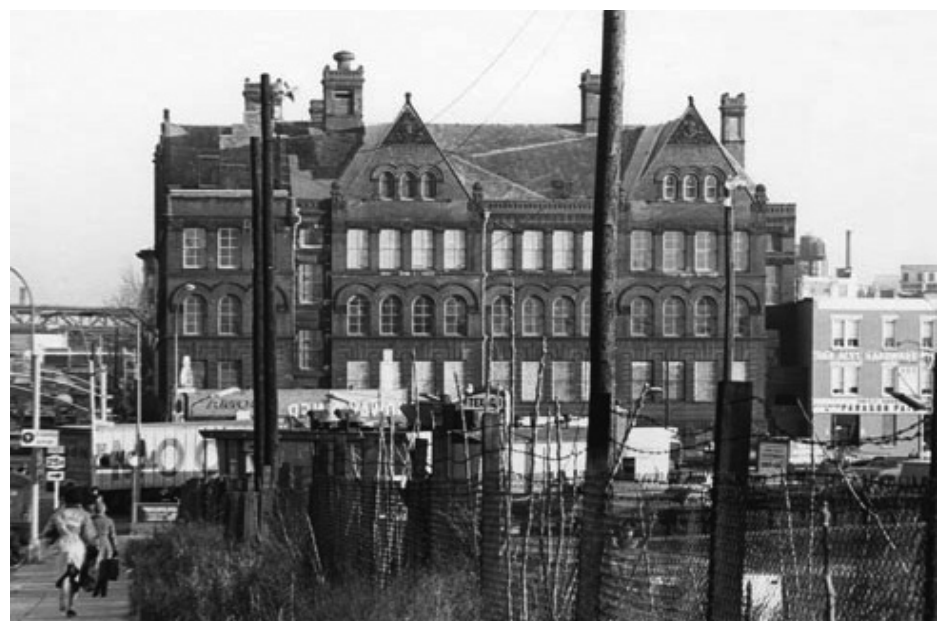

como espaços de arte que as galerias dos museus, e viu naquele edifício condições ainda mais interessantes:

Eu era muito favorável a edifícios vazios - edifícios antigos sendo usados para arte em vez de edifícios novos -, porque, em primeiro lugar, estavam disponíveis, em segundo, eram baratos e em terceiro lugar, certos tipos de edifício institucional - como escolas -, tinham uma divisão de espaço muito humana. No caso do PS1, são salas de aula prototípicas, com aproximadamente 6 por 7 metros. Não é um quadrado e tem janelas de um dos lados, é maravilhoso para arte. ${ }^{285}$

Heiss, no entanto, não se fiou apenas em sua própria experiência para avaliar o potencial do edifício em abrigar um centro de arte contemporânea, mas contou com o aconselhamento e o entusiasmo de seu amplo círculo de amigos curadores nacionais e internacionais, galeristas, colecionadores e sobretudo artistas, um modo de operar que entendia como distinto do dos museus, como relatou mais recentemente: "As lideranças dos museus nunca aproveitaram os conselhos dos artistas. Os museus queriam expor as obras, mas nunca perguntavam aos artistas como poderiam fazer um trabalho melhor. Isso era, e ainda é, chocante para mim." ${ }^{286}$ Essa afirmação aponta para
2.94 Vista externa do edifício da escola abandonada P.S. 1 em 1976. Foto: Jonathan Dent. Fonte: https://www. moma.org/interactives/exhibitions/2012/ artistinplace/
285 HEISS, 2010, op. cit. Tradução nossa.

286 Alana Heiss in: BIESENBACH; FUNCKE, op. cit., p. 40. Tradução nossa. 


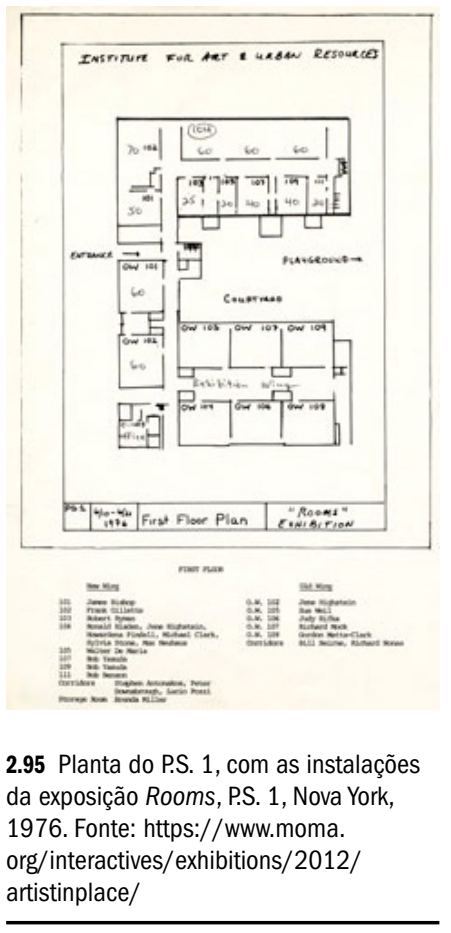

287 Shael Shapiro apud GLUEcK, Grace. Abandoned School in Queens Lives Again as Arts Complex. The New York Times, 10/o6/1976, ed. p. 38, 1976.

288 Cf. SMITH, Roberta. ART REVIEW; More Spacious and Gracious, Yet Still Funky at Heart. The New York Times. 31/10/1997. ed. 1997. um ponto de especial interesse desta tese: o modo como se dá a negociação entre instituição e artistas, indispensável no contexto dos museus dispostos a fomentar a arte contemporânea.

Para Heiss, cuja atuação até então implicava uma crítica aos museus, que por sua vez não se interessavam por seus projetos, o passo rumo a institucionalização deveria apontar para outra direção. O novo centro de arte contemporânea deveria ser concebido, assim, como um "anti-museu". Isso significava eliminar do horizonte a constituição de uma coleção, bem como evitar os longos processo de planejamento e aprovação de exposições, garantindo uma agenda flexível e variada, aberta à colaboração de artistas e curadores convidados. Esse modelo de centro de arte sem coleção associado à produção contemporânea vinha, nos anos 1970, se difundindo em diversos locais da Europa, especialmente na Alemanha, que contava com uma profusão de kunsthalles de diversas escalas espalhadas por todo o país.

A partir de um contrato de uso do imóvel da antiga escola do Queens por 20 anos, criou-se então o Project Studio One, mantendo a sigla PS1 e prevendo espaços para exposições, auditório para seminários, performances e saraus de poesia e ainda 35 estúdios de artistas a preços acessíveis. Ao invés de recuperar todo o edifício, o que demandaria um alto investimento, foram realizados apenas reparos que permitissem condições mínimas de funcionamento, como eliminação de vazamentos da cobertura, substituição dos pisos do auditório para realização de performances e instalações elétricas e hidráulicas. Mantendo o estado geral de decrepitude, as intervenções praticamente imperceptíveis contaram com a consultoria do arquiteto Shael Shapiro, que, envolvido desde finais dos anos 1960 com a conversão de edifício industriais em espaços de artistas no SoHo, deixou claro o espírito dessa obra: "Estamos na verdade apenas limpando o prédio. [...] Sempre que possível, estamos fazendo nada." ${ }^{287}$ Ainda que o orçamento tenha sido equivalente a $10 \%$ do que a prefeitura estimara para a recuperação total do edifício, foi necessário recorrer a um empréstimo bancário para complementar os financiamentos concedidos pelo New York State Council on the Arts e pelo NEA.

Com $7.800 \mathrm{~m}^{2}{ }^{288}$ área três vezes superior à da maioria das escolas públicas, o edifício era maior que muitos museus, 
incluindo os nova-iorquinos момA e Guggenheim, o que, para Heiss, permitia que o modelo de anti-museu fizesse frente a eles, oferecendo mais oportunidade de experimentação para artistas contemporâneos: "Eu estava farta de espaços temporários e queria fazer a primeira ameaça realmente séria aos museus. Eu queria me comprometer totalmente com algo tão enorme que seria o maior espaço de arte contemporânea do mundo." ${ }^{899}$ Dispondo desse grande edifício para realizar suas atividades, o I.A.U.R. manteve em funcionamento apenas o PS1 e o Clocktower, desvencilhando-se dos demais espaços sob sua gerência.

A exposição que inaugurou o PS1 foi Rooms, aberta ao público de 10 a 26 de junho de 1976, com trabalhos de 75 artistas de Nova York, da Costa Oeste e da Europa, tendo como princípio norteador a interação com o espaço, com a maioria das obras sendo instalações site-specific. ${ }^{290} \mathrm{~A}$ escala do edifício permitia que a mostra apresentasse de uma só vez a diversidade de possibilidades dessas formas de manifestação, conferindo-lhes legitimidade como arte, independentemente dos museus e galerias. Como relatou Heiss:

Rooms não foi o início das instalações de arte, foi um reflexo de uma mudança no modo de fazer arte que tinha acontecido na década anterior: artistas queriam controlar cada detalhe do espaço onde expunham. Era um gênero estranho para as galerias exporem e para os museus armazenarem, por isso foi deixado de lado pela maioria dos museus e apenas algumas galerias o exibiam, relutantemente. ${ }^{291}$

Em seu ensaio para a revista Artforum, Nancy Foote procurou elencar os diversos modos pelos quais os artistas da exposição direcionaram sua estética pessoal às condições do lugar. ${ }^{292}$ Uma das abordagens teria sido tematizar o passado escolar do edifício, como Marcia Hafif, cuja obra Schoolroom consistiu no preenchimento das lousas de toda uma sala - antes destinada ao ensino de caligrafia - com poemas eróticos, grafados com giz em letra cursiva, recuperando a prática anterior da artista como professora. Jeff Lew realizou a obra Library, instalando uma estante com livros de metal na sala onde no passado fun-
289 Alana Heiss apud Ibidem.

290 Participaram da exposição Rooms os artistas: Vito Acconci, Carl Andre, Antonakos, Michael Asher, Evriah Bader, John Baldessari, Jared Bark, Jennifer Bartlett, Bill Beirne, Robert Benson, James Bishop, Ronald Bladen, Power Boothe, Daniel Buren, Scott Burton, Michael Clark, Colette, David's Wrath, Douglas Davis, Walter de Maria, Peter Downsbrough, Stefan Eins, Joel Fisher, Dieter Froese, Steve Gianakos, Frank Gillette, Tina Girouard, Michael Goldberg, Ron Gorchov, Robert Grosvenor, Ira Joel Haber, Marcia Hafif, Suzanne Harris, Dale Henry, Lynn Hershman, Jene Highstein, Patrick Ireland, Bill Jenson, Alain Kirili, Bernard Kirschenbaum, Joseph Kosuth, Shigeko Kubota, Garry B. Kuehn, Jeffrey Lew, Gordon Matta-Clark, Brenda Miller, Antoni Miralda, Mary Miss, Richard Mock, Bruce Nauman, Max Neuhaus, Richard Nonas, Patsy Norvell, Doug Ohlson, Dennis Oppenheim Nam June, Paik, Howardena Pindell, Lucio Pozzi, David Rabinowitch, Judy Rifka, Robert Ryman, Fred Sandback, Alan Saret, Richard Serra, Judith Shea, Charles Simmonds, Ned Smyth, Eve Sonneman, Sylvia Stone, Marjorie Strider, Michelle Stuart, Susanna Tanger, Hap Tivey, Richard Tuttle, Susan Weil, Lawrence Weiner, Doug Wheeler, Robert Yasuda.

291 Alana Heiss in: BIESENBACH; FUNCKE, op. cit., p. 98.

Tradução nossa.

292 FoOTe, op. cit., p. 30. Tradução nossa. 

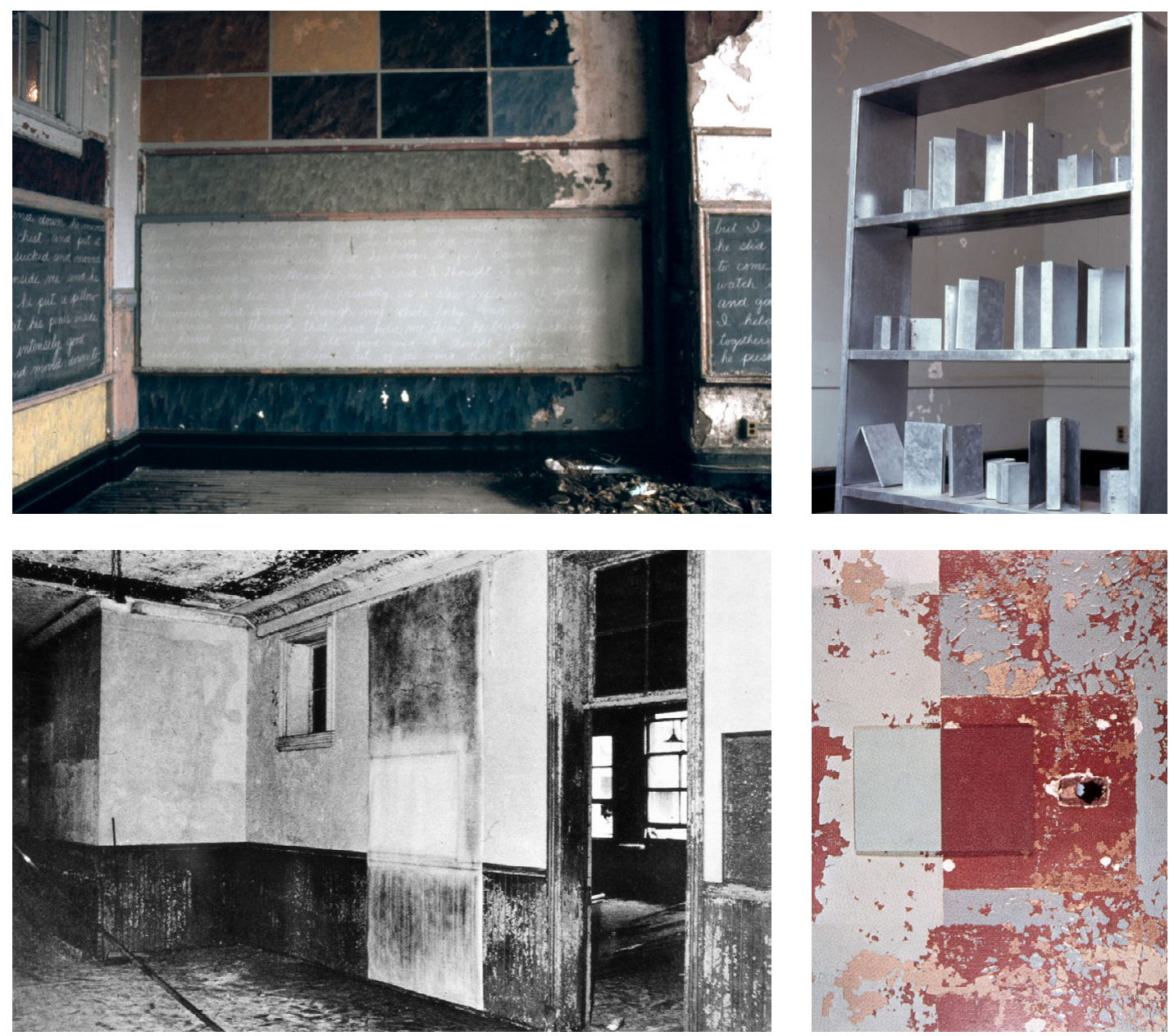

2.96 Marcia Hafif, Schoolroom, na exposição Rooms, P.S. 1, Nova York, 1976. Fonte: https://www.moma.org/calendar/ exhibitions/3991

2.97 Jeff Lew, Library, na exposição Rooms, P.S. 1, Nova York, 1976. Foto: A. West. Fonte: https://www.moma.org/calendar/ exhibitions/3991
2.98 Michelle Stuart, East, West Wall Memory Relocated, na exposição Rooms, P.S. 1, Nova York, 1976. Fonte: https://www.moma.org/ calendar/exhibitions/3991

2.99 Lucio Pozzi, P.S. 1 Paint, na exposição Rooms, P.S. 1, Nova York, 1976. Fonte: https://www.moma.org/calendar/ exhibitions/3991 
cionara a biblioteca, enquanto Bill Beirne reproduziu num dos corredores o som do burburinho de crianças saindo da aula. Outro modo de se relacionar com o local teria sido explorar o próprio edifício em seu estado arruinado, revelando as camadas sucessivas do tempo, como fez Michelle Stuart com East, West Wall Memory Relocated, que, usando a técnica de frottage, decalcou duas faixas de paredes opostas de um corredor, expondo os painéis com as marcas um em frente ao outro, mas invertendo suas posições. Mais um exemplo disso seria o trabalho de Lucio Pozzi, P.S.1 Paint, que inseriu pequenos retângulos preenchidos regularmente com duas cores de pinturas antigas na fronteira entre uma cor e outra, em contraste com a irregularidade da superfície descascada ao redor. O estado precário do edifício teria permitido ainda que alguns artistas realizassem obras site-specific envolvendo a destruição de algumas partes, como Gordon Matta-Clark, que realizou a obra Doors, Floors, Doors, criando aberturas retangulares com cortes no assoalho de três salas aprumadas, reproduzindo no piso as dimensões das portas adjacentes. Alan Saret, por sua vez, desbastou um trecho oblongo de uma parede voltada para a fachada, deixando tijolos expostos e um pequeno buraco por onde um raio de luz penetrava o interior, nomeando sua obra de The Hole at P.S.1, Fifth Solar Chthonic Wall Temple.

Conforme descreveu Foote, a maioria dos artistas procurou articular suas linguagens pessoais ao cenário que se apresentava, tirando partido da ambientação peculiar do edifício escolar abandonado. Participando com a obra Between \& Through Space \& Light, Daniel Buren aplicou suas listras verticais às janelas do auditório, um dos poucos espaços que haviam sido recuperados naquele momento. Richard Serra instalou seu trabalho Untitled no sótão do edifício, encrustando uma viga metálica no piso de concreto e uma outra junto ao plano inclinado da cobertura, na mesma projeção, fundindo-as literalmente e perceptivelmente ao edifício. Patrick Ireland deu continuidade a uma de suas séries com a obra Rope Drawing\#19, instalando 25 cordas de varal de diferentes comprimentos fixadas com fios de nylon no piso e no teto e formado uma malha quadrada de $5 \times 5$, que instigavam o público a se deslocar pela sala procurando pontos de vista em que linhas de mesma altura 

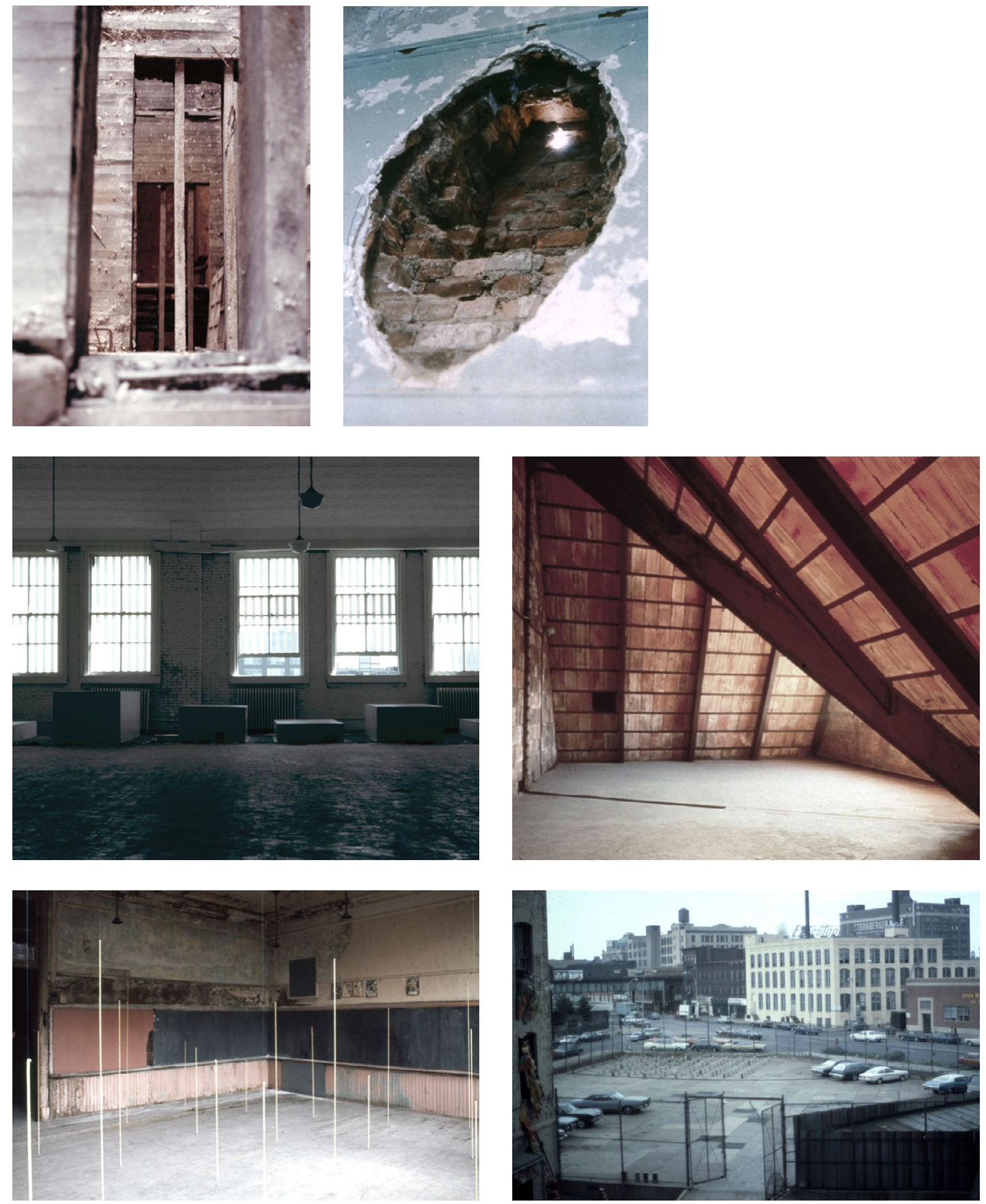
se alinhassem. No pátio externo, Carl André instalou Lament for the Children, posicionando 100 paralelepípedos verticais de concreto nas quinas de placas da pavimentação existente, formando também um quadrado, acrescido por elementos anti-formais, como as rachaduras das placas e a vegetação crescendo no intervalo entre elas. $\mathrm{O}$ resultado, nas palavras de Foote, "poderia ser melhor descrito como uma espécie de cemitério pós-minimalista”. ${ }^{293}$

Segundo a autora, "um espaço como o P.s.1, devastado pelo tempo e pelo uso, oferece um filão muito mais rico para extrair ideias do que qualquer lugar limpo e bem iluminado". ${ }^{294}$ Essa opinião estava em sintonia com o ânimo de artistas que não se identificavam com as condições convencionais dos museus, como vemos no depoimento dado por Marcia Hafif à época da exposição:

Para mim, a oportunidade de trabalhar num espaço que era tão diferente das galerias ou dos estúdios com paredes brancas era uma experiência libertadora e fértil. Se alguém pensasse em termos de limpeza, o projeto pareceria impossível, mas depois de um breve tempo o edifício fazia emergir uma percepção de que essa estrutura devastada pelo tempo e pelas intempéries oferecia um elemento para se relacionar para além do vazio. Ao invés de um espaço neutro, era carregado de associações fantasma. ${ }^{295}$

As condições do PS1, tão precárias quanto a dos espaços alternativos, foram tomadas pelos artistas como oportunidade de apropriar-se do espaço de um modo que não seria possível nos ambientes convencionais dos museus, como expressou Tina Girouard, refletindo sobre o tema poucos anos depois: "Ao invés de oferecer paredes brancas, um espaço alternativo oferece paredes cinzas. Isso lhe dá um controle maior sobre o que você quer expor. Muitos projetos jamais teriam sido feitos se não fossem os espaços alternativos." ${ }^{296}$

Se abriam novas possibilidades para artistas, as características do espaço do PS1 teriam ainda, segundo Foote, um impacto positivo na fruição das obras pelo público, na medida em que contribuiriam para uma aproximação entre as partes:
2.100 Gordon Matta-Clark, Doors, Floors, Doors, na exposição Rooms, P.S. 1, Nova York, 1976. Foto: A. West. Fonte: https:// www.moma.org/calendar/exhibitions/3991

2.101 Alan Saret, The Hole at P.S.1, Fifth Solar Chthonic Wall Temple, na exposição Rooms, P.S. 1, Nova York, 1976. Fonte: https://www.moma.org/calendar/ exhibitions/3991

2.102 Daniel Buren, Between \& Through Space \& Light, na exposição Rooms, P.S. 1, Nova York, 1976. Foto: A. West. Fonte: https://www.moma.org/calendar/ exhibitions/3991

2.103 Richard Serra, Untitled, na exposição Rooms, P.S. 1, Nova York, 1976. Foto: Michael Moran. Fonte: https://www.moma. org/calendar/exhibitions/3991

2.104 Patrick Ireland, Rope Drawing\#19, na exposição Rooms, P.S. 1, Nova York, 1976. Fonte: https://www.moma.org/calendar/ exhibitions/3991

2.105 Marjorie Strider, Rescue \#1 (esquerda) e Carl André, Lament for the Children (fundo), na exposição Rooms, P.S. 1, Nova York, 1976. Fonte: https://www. moma.org/calendar/exhibitions/3991

293 Ibidem, p. 34. Tradução nossa. 294 Ibidem, p. 3o. Tradução nossa. 295 Marcia Hafif in: BiesenbaCH; FUNCKE, op. cit., p. 61.

Tradução nossa.

296 Tina Girouard in: Ibidem, p. 45. Tradução nossa. 
Paradoxalmente, o ambiente de destruição do P.s.1 tornou boa parte de uma arte difícil mais acessível. Trabalhos que numa galeria tenderiam a parecer valiosos ou acadêmicos, adquiriram aqui um outro aspecto. Quando seus impulsos geradores se tornaram visíveis, perderam em parte seu ar distante. Alinhando-se a circunstâncias fora de um contexto artístico 'puro', conseguiram, em muitos casos, tornar-se muito mais interessantes. ${ }^{297}$

O interesse de Heiss, no entanto, não visava atrair para o PS1 um público numeroso, mas voltava-se, sobretudo, para ampliar as oportunidades de expressão para os artistas e de interação das obras com o espaço. Conforme declarou, seu objetivo era:

Trabalhar diretamente com artistas, identificar na arte que estavam fazendo qual teriam eles mais interesse em expor naquele momento - não necessariamente a mais recente - e colocar esse trabalho num espaço físico onde houvesse uma conexão mágica entre o observador e a obra. O número de visitantes nunca era importante. $\mathrm{O}$ visitante individual era importante. ${ }^{298}$

Sobre a condição arquitetônica do PS1, Heiss apontou ainda para um aspecto nevrálgico que o diferenciaria dos museus concebidos a partir de um projeto convencional:

O espaço é tão grande quanto o de um museu, mas o problema dos museus é que suas instalações são construídas antes de a arte ser feita. Estamos interessados em um espaço que possa deliberadamente ser flexível às demandas da nova arte. ${ }^{299}$

297 FoOTE, op. cit., p. 35. Tradução nossa.

298 Alana Heiss in: BiesenbaCH; FUNCKE, op. cit., p. 42.

Tradução nossa.

299 Alana Heiss in Glueck, op. cit. Tradução nossa.
A flexibilidade a qual Heiss se referia representava a negação de qualquer arquitetura impositiva, acabada e intocável como espaço propício para a arte. As condições dos lugares não deveriam impedir que artistas os transformassem, no limite de sua destruição, o que não significa um desinteresse por suas qualidades arquitetônicas. Ao contrário, Heiss deixou evidente em diversas de suas declarações o papel central que a espacia- 
lidade desempenhava para a arte contemporânea, ressaltando sua incompatibilidade com espaços convencionais de exposição. No catálogo da mostra inaugural, ela indicou a intenção de oferecer um modo de expor compatível com a produção de arte que se distanciara dos museus:

Rooms (PS1) representa uma tentativa de lidar com um problema. A maioria dos museus e galerias são projetados para mostrar obras-primas; objetos executados e concebidos em outros lugares para serem expostos em espaços relativamente neutros. No entanto, muitos artistas hoje em dia não fazem obras de arte autônomas; não querem, nem tentam. Tampouco estão, na maioria dos casos, interessados em espaços neutros. Ao invés disso, seus trabalhos incluem os espaços em que se localizam, abraçando-os, usando-os. O campo visual deixa de ser a moldura para se tornar o material. $\mathrm{E}$ isso dificulta o modo de expor... A arte se transforma. Os modos de expor devem se transformar também. ${ }^{300}$

Podemos entender que essa transformação pressupõe mais do que um novo modo de expor, mas a construção de um diálogo aberto com a arquitetura e o público na produção e apresentação da arte. A criação do PS1, institucionalizando em grande escala a prática de espaços de arte alternativos, representou, em síntese, um modo particular de oposição ao universo dos museus estabelecidos, tendo como ênfase, além da flexibilidade da programação, uma concepção espacial que opunha às condições ideias de espaços modernos o contexto real de um edifício marcado por sua história de usos e principalmente de desusos. Sustentando a condição de "anti-museu", Heiss rejeitou o convite para inscrever o PS1 na American Museum Association, deixando não apenas de se beneficiar com fundos públicos destinados aos museus, mas de receber o mesmo tipo de atenção pela imprensa, por não constar da lista oficial de instituições de arte.

Outras iniciativas em prol da arte contemporânea que se opunham a museus convencionais procuravam fazê-lo dentro do sistema, com foco sobretudo na diversificação de recortes curatoriais. É o caso do New Museum de Nova York, criado em
300 Alana Heiss apud Reiss, op. cit., p. 126. Tradução nossa. 
301 Marcia Tucker deixara o cargo de curadora do Whitney Museum of American Art, que ocupara de 1967 a 1976, por considerar que a instituição não se dispunha a assimilar a diversidade da produção contemporânea, privilegiando artistas estadunidenses, brancos e heterossexuais, perfil dominante na história da arte tradicional. Cf. The New Museum. History. New Museum. Disponível em: <https:// www.newmuseum.org/history $>$. acesso em: 26 jul. 2020.
1977 pela historiadora e crítica de arte Marcia Tucker (19402006), com uma atuação politicamente mais ativa e radical, colocando em destaque produções contemporâneas pouco valorizadas pelos museus de arte moderna, como as de artistas mulheres, e mantendo, no entanto, a estrutura de museu, incluindo a prática de formar uma coleção. ${ }^{301}$

Não sendo catalogado como museu e livre de certas amarras institucionais, o PS1 podia operar de modo informal, prescindindo até mesmo de certos compromissos com o público, como a determinação de horários fixos de funcionamento. Seguindo a agenda pessoal de Heiss, o centro abria apenas após o almoço - ocasião em que a equipe se reunia para trabalhar num restaurante próximo ao edifício - e permanecia aberto até o período da noite. Se o regime destoava do praticado até então pelos centros de arte, era condizente com o ritmo cotidiano de boa parte dos artistas que gravitam ao seu redor, o que evidencia o lado para o qual estava orientado.

Depois de Rooms, o edifício passou a abrigar diversas atividades simultâneas. Curadores eram convidados a fazer exposições que eles não poderiam fazer num museu e, ao invés de buscar conferir uma coerência aos eventos de uma mesma temporada, a programação do PS1 visava propositadamente apresentar ao mesmo tempo diferentes pontos de vista de igual interesse, valorizando a diversidade de manifestações da arte contemporânea. Se o lugar levou muito tempo para atrair o público menos especializado - seja pela localização periférica, seja pelo funcionamento informal ou pela própria dificuldade de assimilação do tipo de arte que abrigava - logo tornou-se um polo de atuação para curadores e artistas estadunidenses e estrangeiros, especialmente os europeus, contribuindo para o intercâmbio internacional da arte contemporânea fora do circuito oficial dos museus. O sucesso, nos EUA, de um modelo baseado na rejeição ao espaço convencional dos museus, como difundido nas kunsthalles europeias, colocou em cheque não apenas o padrão expositivo dominante desenvolvido pelo MомA, como o próprio papel da arquitetura destinada a abrigar a arte. 


\subsubsection{O CONCEITO DE CUBO BRANCO COMO CRÍTICA AO MUSEU MODERNISTA}

A criação de um centro de arte contemporânea de grande porte como o PS1 representava a consagração de certas qualidades dos espaços alternativos geridos por comunidades locais de artistas em várias regiões dos EUA, especialmente em Nova York. Entre os fatores que impulsionaram pouco a pouco a legitimação desse tipo de espaço para arte contemporânea, vale destacar a atuação de Brian O'Doherty, que não apenas dirigia a distribuição de recursos do NEA para essas iniciativas, mas exercia uma especial influência no meio artístico por atuar também como crítico - publicando ensaios para veículos especializados desde o início dos anos 1960 - e artista - tendo realizado uma de suas primeiras instalações no 112 Greene Street (sob o pseudônimo de Patrick Ireland, conforme mencionado anteriormente). ${ }^{302}$ Segundo relato de Heiss, O'Doherty teria sido o responsável por conferir o nome de "espaço alternativo" a essa categoria de lugar - conhecido antes como workshop - ${ }^{303}$ e ainda que ele teria tido a iniciativa de procurar o I.A.U.R. para oferecer-lhe financiamento, contribuído com orientações para a instalação do PS1 no antigo edifício e tornando-se por fim, membro do conselho do centro de arte, ${ }^{304}$ além de ter realizado uma instalação em Rooms. Enquanto seu trabalho como artista era guiado pela interação com o espaço, sua atuação como crítico desempenhou um papel importante na identificação de uma crise relacionada à estética convencional dos museu e galerias de arte, de matriz modernista, apontando para seu impacto nas condições de produção e recepção das obras, com implicações econômicas e sociais.

Em março de 1976, enquanto estavam em andamento os preparativos para a conversão da antiga escola no centro de arte contemporânea PS1, a revista Artforum publicou o primeiro de uma série de três artigos de O'Doherty ${ }^{305}$ reunidos no livro publicado 10 anos mais tarde: No interior do cubo branco: $A$ ideologia do espaço da arte. ${ }^{306}$ Cunhada nessa ocasião, a expressão "cubo branco" veio a se consolidar como uma das imagens mais sintéticas e influentes para se referir, de modo crítico, ao modo de expor caracterizado por espaços de geometria sim-
302 Cf. REISs, op. cit., p. 123.

303 Cf. Heiss, 2010, op. cit.

304 Cf. BIESENBACH; FunCKE, op. cit., p. 45 .

305 O'DOHERTy, Brian. Inside The White Cube, Part I: Notes on the Gallery Space. Artforum, v. 14, n. 7, 1976; Idem. Inside the White Cube, Part II: The Eye and the Spectator. Artforum. v. 14, n. 8, 1976 e Idem, Inside The White Cube. Part III: Context as Content. Artforum. v. 15, n. 3, 1976.

306 O'DOHERTY, Brian. No Interior do Cubo Branco: a ideologia do espaço da arte. São Paulo: Martins Fontes, 2002. 
$307 \mathrm{O}$ autor se refere à linhagem da arte moderna ligada aos experimentos de Marcel Duchamp.

308 O'DOHERTY, 2002, op. cit., pp.2-3. ples, com paredes brancas e isolados do exterior, que havia se consolidado como hegemônico para a arte moderna, tanto em museus e galerias comerciais, quanto em grandes exposições de arte, como bienais.

A reflexão do autor se deu no momento em que, como vimos, havia frutificado na arte contemporânea uma série de acontecimentos que vinham, desde os anos 1960, questionando de diversas maneiras o sistema institucional da arte e tensionando o espaço dos museus e galerias. Manifestações variadas como performances e happenings, environments e instalações, land art $\mathrm{e}$ body art, tinham em comum a busca por dissolver as fronteiras entre arte e vida. Segundo o argumento de O'Doherty, o padrão "cubo branco" privilegiaria uma outra apreensão, enfatizando a condição das obras de arte como entidades autônomas, separadas da vida - do mundo externo e da passagem do tempo -, favorecendo sua aparência de eternidade, de beleza imortal própria aos objetos sagrados. A neutralidade do espaço expositivo seria, portanto, não apenas uma ilusão, mas uma ideologia em favor de uma determinada sensibilidade ligada à arte abstrata e supostamente autônoma, em detrimento de outras manifestações da arte moderna, que teriam sido relegadas a um segundo plano pela historiografia ${ }^{307}$ Para o autor, "a história do modernismo é enquadrada por esse espaço intimamente; ou melhor, a história da arte moderna pode ser correlacionada com as mudanças nesse espaço e na maneira como o vemos". ${ }^{308}$

No encerramento da série de artigos sobre o "cubo branco", escrito em 1986, e, portanto, com algum recuo temporal, O'Doherty viria a concluir que o espírito artístico de contestação que teria se encorpado a partir de 1964, inaugurando o pós-modernismo, teria, no entanto, sido refreado após 1976 justamente o ano de abertura do PS1 - levando ao fracasso um quadro potencialmente revolucionário de contestação geral contra o status-quo:

Sem dúvida grande parte da arte do final dos anos 60 e 70 tinha esse tema: Como o artista encontra outro público ou um contexto em que sua visão minoritária não seja cooptada? As soluções apresentadas - local específico, temporária, sem comercialização, fora do museu, dirigida a um público que 
não o de arte, passando do objeto para o corpo e para a ideia, até para a invisibilidade - não se mostraram inacessíveis ao apetite assimilador da galeria. $\mathrm{O}$ que aconteceu foi um debate internacional sobre percepção e sistemas de valores - liberal, ousado, às vezes pragmático, às vezes grosseiro, sempre contra o sistema político e sempre padecendo de um orgulho que exige a definição de limites. ${ }^{309}$

Na perspectiva do artista e escritor, o afastamento ou a negação do objeto não teriam impedido que a arte continuasse a circular como produto, integrada ao circuito capitalista de valores, no sistema composto por galerias que expõe as obras, colecionadores e instituições públicas que as adquirem, revistas que as divulgam, acadêmicos que produzem a história da arte, que, por fim, atestam as coleções dos museus. Para O'Doherty, o esforço dessa geração de artistas em questionar de diversas maneiras o contexto de sua própria atividade teria esmorecido diante da evidência da impossibilidade de se descolar do sistema de valores culturais e econômicos em que era produzida e, afinal, consumida. Para o autor, o ímpeto contestatório teria se arrefecido na década de 1980, cedendo lugar à ânsia pelo consumo. Ainda que de maneiras veladas, boa parte da arte acompanharia essa tendência, tendo a galeria como palco, ao mesmo tempo em que perderiam energia os espaços alternativos.

$\mathrm{Se}$, ao longo de seus artigos, O'Doherty tenha poucas vezes se referido diretamente aо момА, mencionado entre inúmeros outros espaços de arte, outros autores que levaram adiante a investigação do conceito de "cubro branco" localizaram o museu nova-iorquino como um dos principais núcleos a partir do qual o modelo se desenvolveu e se difundiu - desde os tempos de Alfred Barr -, como vimos no primeiro capítulo desta tese. ${ }^{310}$ Além disso, como tem sido reiterado, o padrão idealizado e de valorização da autonomia das obras seguiu sendo adotado e aprimorado pelo MомA, constituindo-se como a marca registrada da maioria de suas exposições, especialmente nas coleções, até as reformulações mais recentes, que serão abordadas do capítulo seguinte. Por enquanto, seguiremos esse percurso com a análise de exposições e projetos arquitetônicos do museu nas últimas décadas do século $\mathrm{xx}$.
309 Ibidem, p. 113.

310 Cf. GRASSKAMP, Walter. The white wall - on the prehistory of the 'white cube'. Oncurating: Curating critique, p. 78-90, 2011. 


\section{$2.4 \quad 0$ MOMA E AS INICIATIVAS PONTUAIS DE ATUALIZAÇÃO: ANOS 1970 A 90}

\subsubsection{ARTE CONTEMPORÂNEA EM DOSES CONTROLADAS}

Logo depois da virada da década de 1960 para 1970, quando os artistas inundavam o MomA de protestos e ao mesmo tempo se voltavam para ações vinculadas aos espaços alternativos, um grupo contendo representantes de vários departamentos do museu envolvidos com a arte mais experimental se organizou para estabelecer o programa Projects, anunciado como "uma série de pequenas exposições apresentadas para informar o público sobre as pesquisas e explorações atuais nas artes visuais". ${ }^{311}$ Tendo como um dos modelos a mostra Information e também liderado inicialmente pelo curador Kynaston McShine, ${ }^{312}$ o programa, que incluía o comissionamento de obras especialmente para cada exposição, foi o primeiro do tipo criado por um

311 Em 2006 a série foi rebatizada como The Elaine Dannheisser Projects Series, em referência ao nome da colecionadora de arte contemporânea que legou sua coleção ao MoMA após sua morte, em 2001. Cf. THE MUSEUM of MODERn ART. The Elaine Dannheisser Projects Series. MOMA. Disponível em: <https:// www.moma.org/calendar/ groups/4>. Acesso em: 14 jun. 2020.

312 Outras figuras apontadas como ativas no programa são Jennifer Licht, Bernice Rose, Cora Rosevear, Howardena Pindell e Jane Necol e Barbara London. Cf. STORR, Robert. History of Projects. MOMA. Disponível em: <https:// assets.moma.org/momaorg/shared/pdfs/docs/calendar/projects/ HistoryofProjects.pdf $>$. Acesso em: 13 jun. 2020.

313 Após a reforma inaugurada em 2004, o programa deixou de ter um local especialmente designado a ele no museu, como veremos no capítulo seguinte desta tese. museu nos EUA, contando inicialmente com fundos do NEA $\mathrm{e}$ no New York State Council on the Arts. Com a realização de três a sete exposições por ano, cada uma delas organizada em geral por curadores jovens e dedicada a um único artista - muitas vezes pouco conhecido -, e ocupando inteiramente uma sala localizada por muitos anos no pavimento térreo, a série Projects acabou se consolidando como um programa permanente do MомA. ${ }^{313} \mathrm{Na}$ época de sua criação, tratava-se de manter uma aproximação com a produção ainda não assimilada da arte contemporânea de um modo menos arriscado, circunscrevendo-a à condição de "experimento", pois, embora os trabalhos pudessem se tornar plenamente conhecidos apenas às vésperas da abertura, a chance de produzirem um impacto negativo para a imagem do museu eram de antemão minimizados devido a escala reduzida das exposições, muitas vezes de curta duração.

Sob a perspectiva dos artistas ligados aos questionamentos ao sistema, expor numa instituição como o MOMA significaria um esvaziamento de sua crítica e da razão de ser de seu trabalho? Certamente muitos enfrentaram essa questão como um dilema. No entanto, a criação do AWC, que liderou em 1969 a série de protestos contra o museu, não tinha como objetivo destruir o museu, mas, conforme verificamos em suas demandas, aproximar-se dele, tornando-o mais aberto à produção 
de artistas jovens ou pertencentes a grupos não devidamente representados pela instituição. Por um lado, museus estabelecidos e ambientes configurados segundo o modelo "cubo branco" não se prestavam a certos tipos de instalação que envolviam ações mais contundentes ou ameaçadoras da integridade de seu espaço ou que interagissem mais radicalmente com o contexto real, em contraste com as possibilidades mais abertas oferecidas por espaços alternativos. Por outro, instituições consolidadas ofereciam suporte à concretização de projetos que dificilmente seriam viabilizados de outra forma, além de atrair um público potencialmente mais numeroso e diversificado.

Se dificuldades de viabilização podiam ser contornadas de outras formas, havia uma condição impossível de ser oferecida por espaços alternativos: o diálogo próximo com a história da arte. Tratando em 2011 do longo panorama de trabalhos realizados pelo programa Projects, que incorporou as críticas dirigidas ao museu, a curadora do Moma Kathy Halbreich (1949-) observou que "essas instalações revelavam com frequência uma relação edipiana com os mestres consagrados [...] expostos em outras partes do edifício, uma relação que demandava revolver ideias sobre as quais se baseavam a pintura e a escultura modernistas". ${ }^{314}$ Sua afirmação reforçava a opinião emitida em 1996 por Robert Storr (1949-), também curador do museu, de que, em relação aos artistas de Projects, "há muito poucos locais onde o que eles produzem pode ser entendido adequadamente no contexto da história da arte, que informa seu trabalho seja por influência ou oposição". O curador defendeu ainda a condição privilegiada e inigualável do MомA para proporcionar esse diálogo:

Somente onde existem coleções abrangentes de arte moderna - e para o período das décadas de 1860 a 1960 nenhuma se equipara à do MOMA - é possível ver como a última novidade da arte recente, e às vezes a mais irreverente ou desconcertante, se relaciona com tradições como as do Cubismo, Dadaísmo, Surrealismo, Construtivismo e Expressionismo. ${ }^{315}$

Se as opiniões de Halbreich e Storr não podem ser dissociadas do fato de favorecerem o museu em que trabalhavam, vale
314 HalbReicht, Kathy. Forty Years of Projects. MOMA. Disponível em: $<$ https://assets. moma.org/momaorg/shared/ pdfs/docs/calendar/projects/ FortyYearsofProjects.pdf $>$. Acesso em: 13 jun. 2020.

315 STORR, Robert. History of Projects. Op. cit, p. 2. Tradução nossa. 

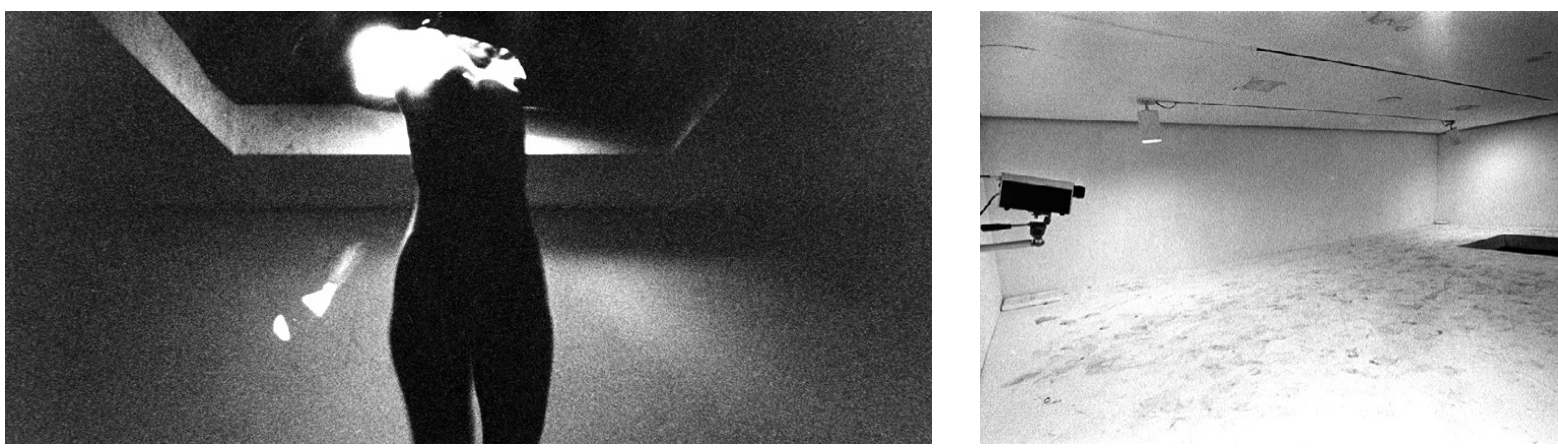

2.106 Visitante na exposição Projects: Keith Sonnier, MoMA, Nova York, 1971.

2.107 Vista da área sobre a plataforma da galeria menor na exposição Projects: Keith Sonnier, MoMA, Nova York, 1971. Foto: Richard "Dickie" Landry. Fonte: https://www.moma.org/calendar/ exhibitions/2667
316 Pontus Hultén in: OBRIST, op. cit., 66.

317 Ibidem, p. 67. observar que não eram os únicos a defender as vantagens de uma instituição que se dedicava a exposições temporárias ser lastreada numa coleção. Para o sueco Pontus Hultén - cuja fecunda carreira internacional como curador incluiu dirigir por quinze anos o museu de arte moderna de Estocolmo, dirigir a fundação do Centro Georges Pompidou em 1973 e ajudar a criar o museu de arte contemporânea de Los Angeles em 1980 - uma coleção seria, como declarou em 1996, "absolutamente fundamental”, "a espinha dorsal de uma instituição; ela permite sobreviver num momento difícil, como, por exemplo, quando um diretor é demitido". ${ }^{316}$ Sua posição teria sido decisiva para resistir às pressões de configurar o Pompidou como uma kunsthalle, desvinculada de um acervo. Sua defesa da articulação entre coleção e exposições temporárias não dizia respeito apenas à sustentação institucional, mas à qualidade da experiência que essa proximidade podia proporcionar:

Eu acho o encontro entre a coleção e a exposição temporária uma experiência enriquecedora. Ver uma exposição de On Kawara e, então, visitar a coleção produz uma experiência que é mais que a soma das partes. Há uma espécie de curiosa energia que começa a circular, e esta é a razão verdadeira para uma coleção. A coleção não é um abrigo no qual se refugiar, é uma fonte de energia tanto para o curador, quanto para o visitante. ${ }^{317}$

A promoção desse tipo de diálogo produtivo com a história da arte não interessava, no entanto, a boa parte de artistas de 
vanguarda atuantes na virada dos anos 1960 e 1970, que preferiam não se render aos compromissos inerentes a atuação submetida ao sistema instituído da arte. Os que trabalhavam no âmbito da crítica institucional, por sua vez, viam benefícios em instalar seus trabalhos provocativos no museu - o objeto palpável de sua crítica. A exposição Information continha diversas obras dessa categoria, entre as quais o paradigmático MOMA Poll de Hans Haacke, cujo intencional desconforto não poderia ser tão efetivo se exposto em outro lugar.

Diante da consciência mais aguçada de que a situação em que a arte era exposta interferiria em sua percepção, ou chegaria mesmo a constituir sua própria substância, o MoMA podia ser entendido como um lugar com grande potencial para interação, especialmente no contexto crítico. Mas, vale observar também que, apesar de alvo do descontentamento por parte de boa parte de artistas - seja por seu envolvimento com estruturas de poder, seja por ser o principal representante de uma arte considerada elitista e ultrapassada - o MoMA não deixara de ser um destino desejável para muitos deles, consagrados ou jovens. A série Projects acabou por contribuir para construir a aceitação como arte de manifestações que rompiam de diversas maneiras com os paradigmas modernistas, abrindo espaço para a incorporação de obras de arte contemporânea mais disruptivas na coleção do museu e impulsionando a carreira de diversos jovens artistas.

A primeira exposição do programa foi realizada em maio de 1971 com a instalação Sem Título de Keith Sonnier. O artista cortou a sala em duas partes na vertical, fazendo com que o público tivesse que percorrer agachado o ambiente de 1,20m de altura até chegar a um recorte no teto, onde era possível ficar em pé e visualizar a parte superior da galeria. No nível de cima, banhado por uma luz vermelha, uma câmera filmava a imagem segmentada da pessoa e a transmitia em tempo real a um monitor de vídeo na parte de baixo, de modo que nunca era possível ver a própria imagem. Sobre essa obra, Halbreich observou que Sonnier, "fazendo ruir o senso do espectador sobre o que constitui o espaço público e o privado, evidencia ainda mais a sensação de estar participando de uma alucinação que se instalou no tempo e no espaço". ${ }^{318} \mathrm{~A}$ autora indicou ainda
318 HALbReicht, op. cit., p. 2. Tradução nossa. 
2.108 Vista da exposição Projects: Pier 18, MoMA, Nova York, 1971. Foto: Ken Probst. Fonte: https://www.moma.org/calendar/ exhibitions/3524
319 Participaram do evento os artistas Vito Acconci, David Askevold, John Baldessari, Robert Barry, Bill Beckley, Mel Bochner, Daniel Buren, Jan Dibbets, Terry Fox, Dan Graham, Douglas Huebler, Lee Jaffe, Richards Jarden, Gordon Matta-Clark, Mario Merz, Robert Morris, Dennis Oppenheim, Allen Ruppersberg, Italo Scanga, Richard Serra, Michael Snow, Keith Sonnier, Wolfgang Stoerchle, John Van Saun, George Trakas, William Wegman, and Lawrence Weiner. Cf. The Museum of Modern ART. Projects: Pier 18 (Jun 18-Aug 2, 1971). MOMA. Disponível em: $<$ https://www.moma.org/calendar/exhibitions/3524?locale $=p t>$. Acesso em: 14 jun. 2020.

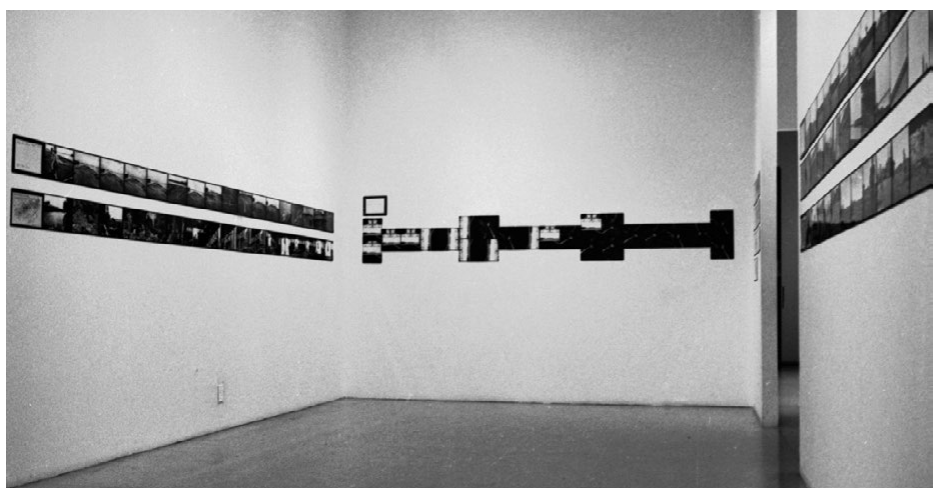

que a inclusão do espectador no espaço pictórico, desvinculado do diálogo com as convenções da pintura modernista, foi uma trajetória seguida por muitos artistas desde então.

Mostrando outro tipo de produção contemporânea, a segunda exposição da série, Projects: Pier 18, contou não com instalações, mas com a documentação fotográfica de ações de 27 artistas, convidados pelo curador independente Willoughby Sharp (1936-2008) a usar de variadas formas um espaço abandonado às margens rio Hudson ${ }^{319}$ Realizadas entre junho e agosto de 1971, um mês depois do Brooklyn Bridge Event organizado por Alanna Heiss, as ações de natureza variada foram registradas pela dupla de fotógrafos Shunk-Kender, seguindo as instruções dos próprios artistas. Dan Graham foi registrado fotografando seu próprio corpo, Bill Beckley tocando trumpete e George Trakas desenhando o píer a partir de seu barco. Michael Snow e Jan Dibbets, por sua vez, realizaram seus trabalhos apenas dando orientações à dupla de fotógrafos, $o$ primeiro com duas fotos simultâneas de diferentes ângulos sobre a mesma cena e o segundo com uma série mostrando a variação da luminosidade de acordo com o sol. A montagem no MOMA, organizada por Jennifer Licht, mostrava sequências das fotos relativas a cada artista, posicionadas lado a lado e fixadas diretamente nas paredes brancas das salas, enfatizando não seu valor plástico, mas seu caráter documental.

Instalações e documentação de ações podiam aparecer conjugadas na série, como exemplificou a mostra de Eleanor Antin, 
Projects: 100 Boots, organizada pela curadora assistente Jane Necol e inaugurada em maio de 1973. Num trabalho típico da arte conceitual, a mostra reuniu 50 cartões postais com fotos de ações realizadas durante 2 anos e meio, nas quais a artista registrou 100 botas de borracha como personagens em situações variadas pelo país - descendo escadas, enfileiradas diante de pontos de ônibus ou carrinhos de sorvete e finalmente na calçada em frente ao MOMA, onde a peregrinação completa foi exposta. A ação incluía o envio dos postais a 1000 pessoas e instituições em intervalos irregulares e era complementada no museu por uma instalação contendo materiais de apoio como colchões, sacos de dormir e radio, posicionados atrás de uma porta com olho mágico, semifechada com uma corrente de segurança.

A série Projects configurou-se também como a principal porta de entrada para a inserção no момA de trabalhos em vídeo. O museu já havia exposto obras do pioneiro da videoarte Nam June Park, na mostra de 1968, The Machine as Seen at the End of the Mechanical Age - da qual tinha sido removida a obra de Takis pelo grupo que formaria $\mathrm{o} \mathrm{AWC}-$, mas foi a partir da participação na série de Barbara London (1946-) que essa mídia passou a ter uma presença mais significativa e constante na instituição. Realizada em 1974, a primeira exposição da então curadora assistente foi Projects: Video II ${ }^{320}$ que exibia em sessões diárias registros de performances dos artistas Gilbert \& George, Joseph Beuys, Ulrike Rosenbach e Rebecca Horn. ${ }^{321}$ No ano seguinte, London foi responsável por inaugurar no museu a prática de aquisição de vídeos, a primeira nova mídia a entrar para a coleção depois de 40 anos. ${ }^{322}$ Em 1977, a curadora organizou a mostra Projects: Nam June Paik, com uma seleção de trabalhos realizados pelo artista entre 1963 e 1977.

Além da série Projects, o MoMA realizou poucas exposições de maior porte com artistas contemporâneos nos anos 1970. ${ }^{323}$ A maior coletiva desde Information foi Eight contemporary artists, organizada por Jennifer Licht em 1974, incluindo oito artistas da Europa, Estados Unidos e Austrália. Repetindo uma solução recorrente nas mostras dos estadunidenses organizadas por Dorothy Miller nas décadas anteriores, já adotada por Licht na mostra Spaces, os artistas contavam
320 A mostra foi precedida por Projects: Video I, organizada dois meses antes por Jennifer Licht, com vídeos de Vito Acconti, Lynda Benglis, Robert Morris, Richard Serra, Keith Sonnier e William Wegman. The Museum OF Modern ART. Projects: Video I (Aug 26-Oct 31, 1974). МOMA. Disponível em: <https://www. moma.org/calendar/exhibitions/2516? locale=pt $>$. Acesso em: 19 jun. 2020.

321 Cf. The Museum of Modern ART. Projects: Video II (Nov 1, 1974Jan 31, 1975). МОмА. Disponível em: <https://www.moma.org/calendar/ exhibitions/2508>. Acesso em: 18 jun. 2020.

322 Cf. The Museum of Modern ART. A New Video Frontier. MOMA. Disponível em: <https://www. moma.org/interactives/moma through_time/197o/a-new-video-frontier/>. Acesso em: 18 jun. 2010.

323 Uma exposição de maior porte dedicada à arte contemporânea na década foi a retrospectiva de Sol Lewitt - que já era então um artista bastante consagrado - realizada na galeria à leste do jardim em 1978, com curadoria de Alicia Legg (1915-2002). Cf. THE MusEuM OF Modern ART. Sol LeWitt (Feb 3Apr 4, 1978). MOMA. Disponível em: <https://www.moma.org/calendar/ exhibitions $/ 1971$ ? locale $=p t>$. Acesso em: 26 jul. 2020. 

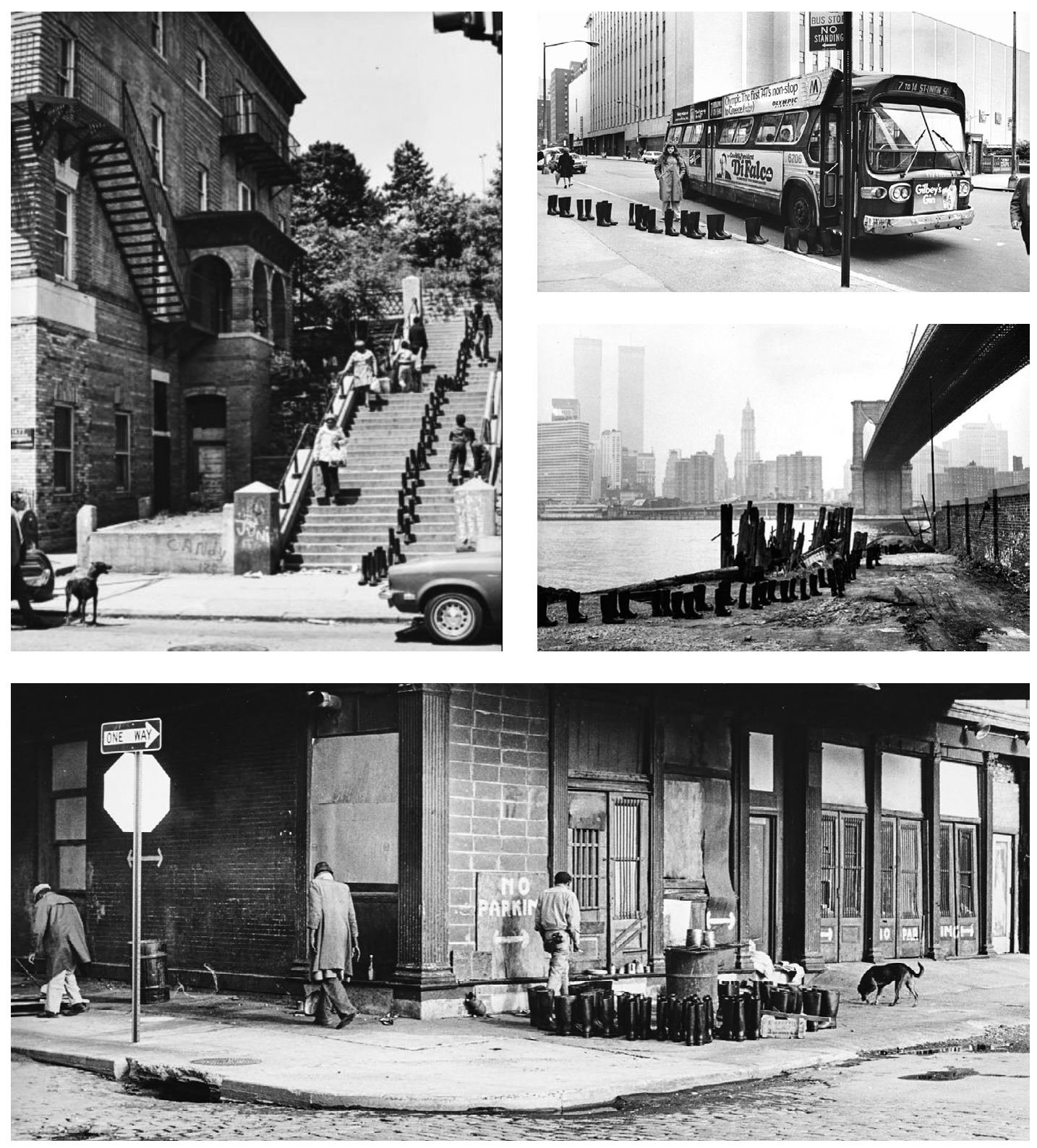

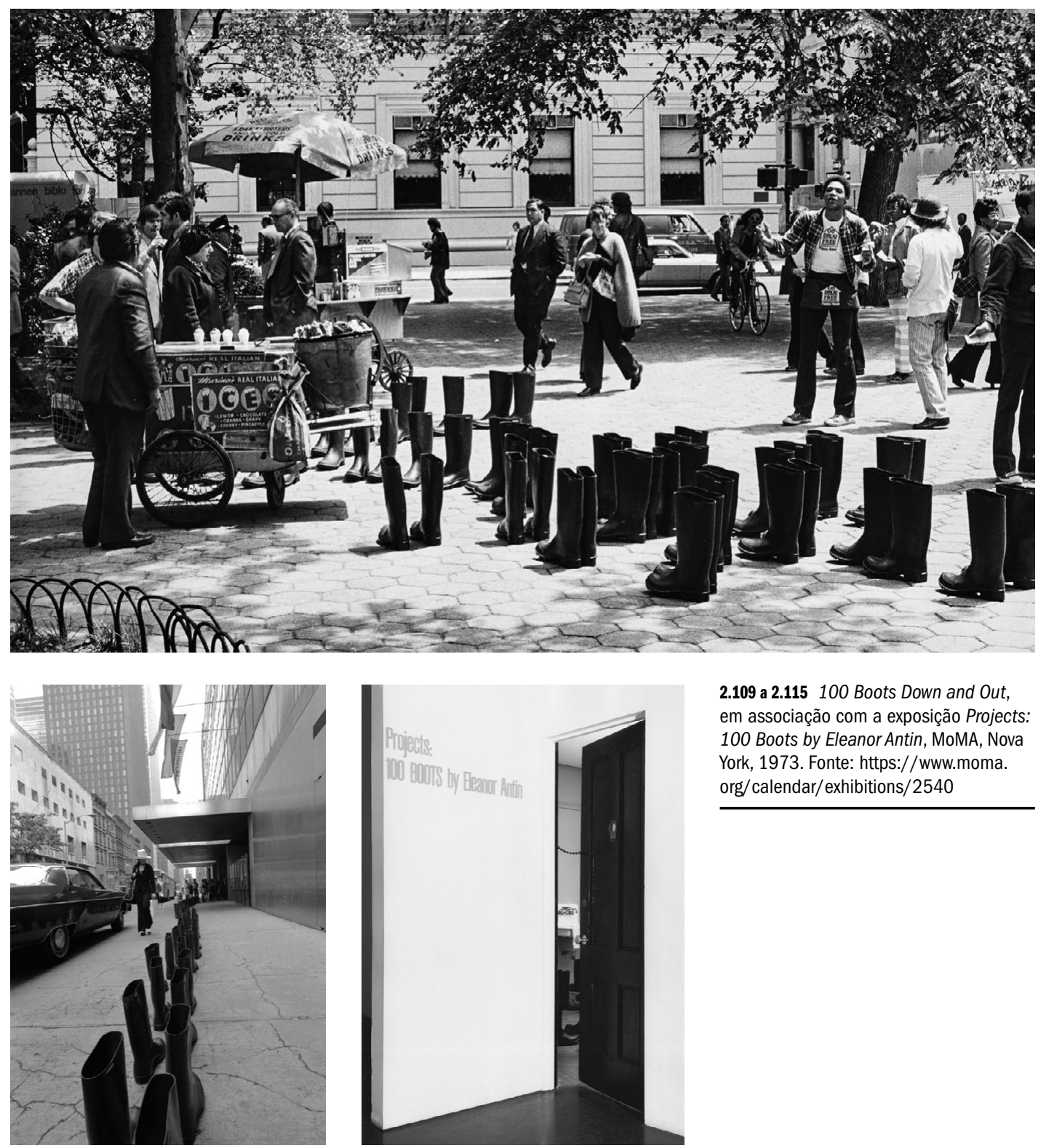

2.109 a 2.115 100 Boots Down and Out, em associação com a exposição Projects: 100 Boots by Eleanor Antin, MoMA, Nova York, 1973. Fonte: https://www.moma. org/calendar/exhibitions/2540 

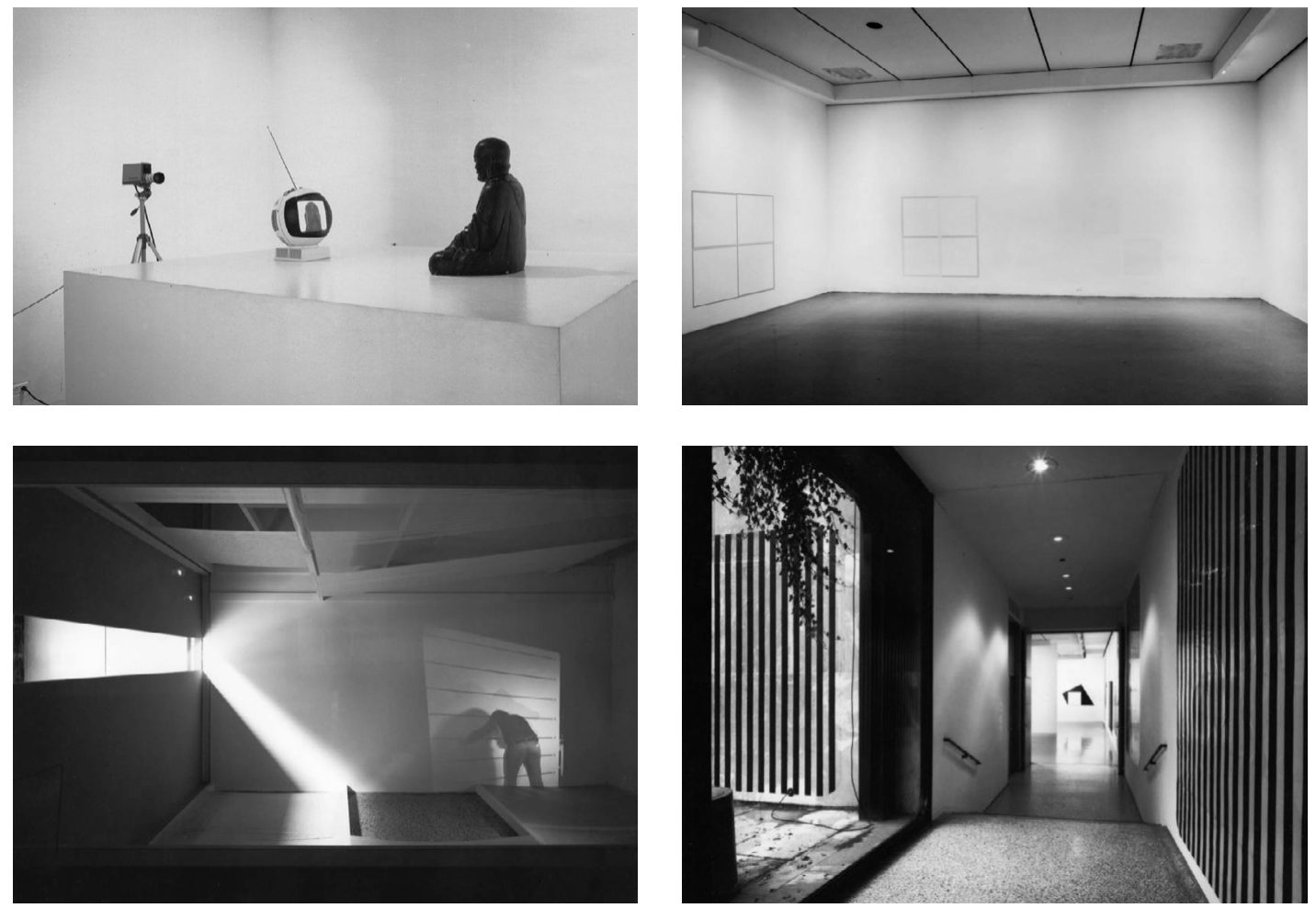

com ambientes individuais, ocupados de variadas maneiras de acordo com sua abordagem particular. Robert Hunter aplicou figuras geométricas diretamente na parede com estêncil (Untitled) e Vito Acconci realizou a instalação Sounds for a Second Sight, ocupando três ambientes usando som e projeção de slides. Daniel Buren realizou a obra Corridor-Passage, colando grandes folhas de papel listrado nas paredes junto à circulação envidraçada da galeria e no jardim de esculturas, além de instalar o mesmo padrão num painel de anúncios na região baixa de Manhattan, relacionando interior e exterior no âmbito do museu e da cidade. Alighiero Boetti, Hanne Darboven, Jan Dibbets, Brice Marden e Dorothea Rockburne, por sua vez, expuseram trabalhos que não se relacionavam tão diretamente com os espaços do museu. 


\subsubsection{O FLERTE COM O PÓS MODERNO NA EXPANSÃO DOS ANOS 80}

Passado o auge das contestações da virada dos anos 1960 para os 70, o arrefecimento das tensões permitiu que o MомA retomasse uma certa estabilidade no transcorrer da década, mantendo o foco na arte moderna, incluindo de maneira lateral a produção mais recente com a série Projects. Richard Oldenburg. (1933-2018) foi nomeado para a direção em 1972, permanecendo no cargo até 1995, e William Rubin consolidou sua influência na instituição em $1973^{324}$, ao assumir o posto de Diretor do Departamento de Pintura e Escultura - que havia sido de seu mentor Alfred Barr -, passando a controlar as novas aquisições e exposições da coleção permanente e atuando no sentido de sustentar e expandir a condição "canônica" do acervo do MoMA. Tendo servido de paradigma para diversas novas instituições de arte moderna criados nos anos 1950 e 60 nos EUA e em países da América Latina e Europa, o modelo de coleção e padrão expositivo do museu continuava a conquistar novas fronteiras, atingindo agora a Ásia. Como apontou Lorente,

o novo emblema da civilização ocidental era um tipo de museu que deveria ser similar em qualquer lugar, com obras idênticas dispostas numa sequência onipresente de artistas venerados e mundialmente famosos, projetados em massa por arquitetos internacionais, exibindo sua inconfundível assinatura. No interior, prevalecia a museografia tipo cubo branco, imitando o aspecto pálido e higienizado dos hospitais onde o visitante quieto transitava por templos-bunkers contemplando em êxtase uma montagem inspirada no MOMA. ${ }^{325}$

Apesar de paradigma global entre os museus de arte moderna, o MOMA perdia espaço como referência para a arte contemporânea. Espaços alternativos tinham descortinado uma série de possibilidades não convencionais para abrigar a produção mais recente, como vimos, enquanto surgiam simultaneamente soluções que procuravam responder às novas demandas da arte dentro do campo institucional. Em 1977, foi inaugurado em Paris o Centro Georges Pompidou, integrando o Museu Nacional de
2.116 Vista da exposição Projects: Nam June Paik, MoMA, Nova York, 1977. Foto: Katherine Keller. Fonte: https://www. moma.org/calendar/exhibitions/2377

2.117 Robert Hunter, Untitled, na exposição Eight Contemporary Artists, MoMA, Nova York, 1974. Foto: Katherine Keller. Fonte: https://www.moma.org/calendar/ exhibitions/2510

2.118 Vito Acconci, Sounds for a Second Sight, na exposição Eight Contemporary Artists, MoMA, Nova York, 1974. Foto: Katherine Keller. Fonte: https://www. moma.org/calendar/exhibitions/2510

2.119 Daniel Buren, Corridor-Passage, na exposição Eight Contemporary Artists, MoMA, Nova York, 1974. Foto: Katherine Keller. Fonte: https://www.moma.org/ calendar/exhibitions/2510
324 Cf. The Museum of Modern ART. Projects: 100 Boots by Eleanor Antin (May 30-Jul 8, 1973). MOMA. Disponível em: <https:// www.moma.org/calendar/exhibitions/2540>. Acesso em: 14 jun. 2020.

325 LORENTE, op. cit., p. 221. Tradução nossa. 
326 DUNCAN, Carol; WALLACH, Alan. Museum Of Modern Art As Late Capitalist Ritual: An Iconographic Analysis, Marxist Perspectives, v. 4, p. $28-51,1978$.

327 Ibidem, nota 22, p. 50. Tradução nossa.
Arte Moderna da França (MNAM) e o Centro de Criação Industrial (CCI) dedicado à produção contemporânea num grande equipamento cultural de atividades múltiplas, oferecendo possibilidades arquitetônicas e expográficas que se distanciavam inicialmente do paradigma modernista do cubo branco, rivalizando com o MoмA também em termos de coleção, possuindo a segunda mais importante do mundo.

Enquanto os artigos publicados em 1976 por O'Doherty sobre a "ideologia do cubo branco" tinham um caráter abrangente - ao realizar uma crítica ao tratamento da arte moderna pelo MoмA de modo implícito -, uma crítica mais direta e contundente ao museu foi lançada pelos historiadores da arte Carol Duncan e Alan Wallach, no artigo "Museum Of Modern Art As Late Capitalist Ritual: An Iconographic Analysis”, publicado em 1978 na revista Marxist Perspectives. ${ }^{326}$ Tendo como objeto de análise a exposição da coleção permanente arranjada por Willliam Rubin em 1973, os autores caracterizaram o museu como um espaço de natureza mística, cujo percurso labiríntico, com sequência de salas isoladas do exterior, livres de distrações e pontuado por objetos icônicos, ofereceria ao visitante um ritual de sacralização da arte moderna, tratada como canônica, reiterando a condição do indivíduo conforme os valores do capitalismo ocidental liderado pela cultura estadunidense. Em nota ao texto, os autores apontaram de modo mais específico para o tratamento secundário das práticas contemporâneas pelo museu:

Embora o MomA tenha colecionado arte posterior ao Expressionismo Abstrato, não a integrou ao programa iconográfico permanente do museu. A arte das décadas de 1960 e 1970 aparecem em instalações temporárias, geralmente no primeiro andar. Como a ortodoxia do MOMA está profundamente enraizada na ideologia dos anos 1950, o museu perdeu, durante a última década, muito da influência que tinha antes no mundo da arte. ${ }^{327}$

A observação de Duncan e Wallach pode ser cotejada com diversos depoimentos de William Rubin, repletos de sinais de que as energias do museu continuavam concentradas numa arte que não podia mais ser considerada "do seu tempo", enfatizando esforços direcionados primordialmente para completar o que o 


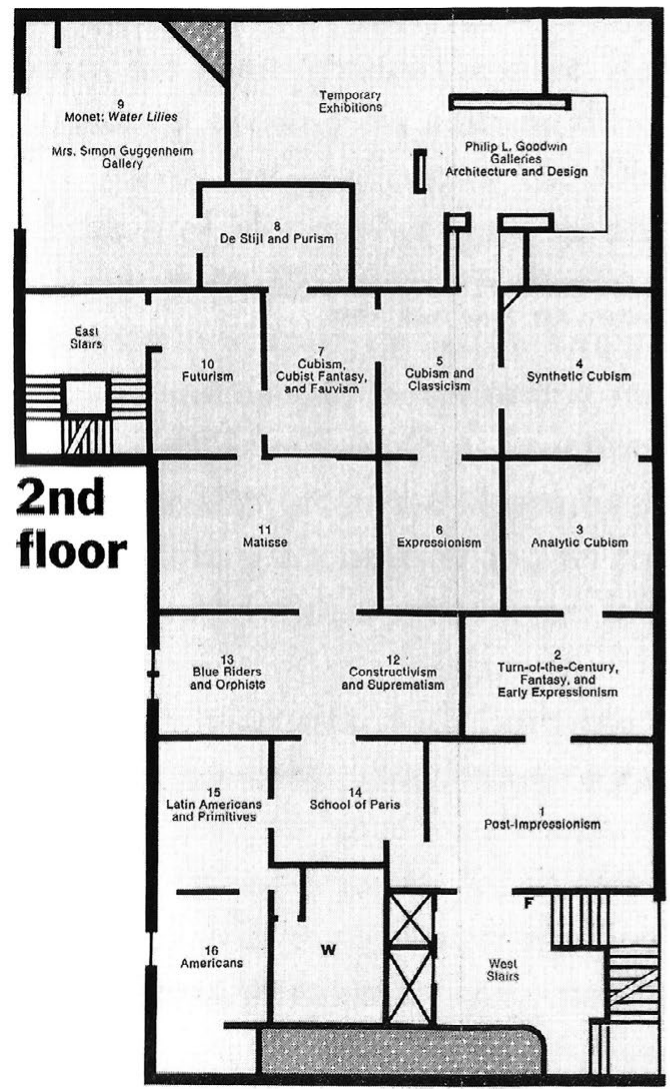

curador julgava serem "lacunas" na coleção dos expoentes do modernismo. No final da década de 1970, Rubin e Oldenburg chegaram a elaborar com o diretor do Guggenheim, Thomas Messer, um acordo de fusão do museu com o MомA, considerando a complementariedade das coleções. O plano, que não se concretizou, previa que o edifício de Frank Lloyd Wright, com seus ambientes expositivos ao redor das rampas helicoidais e considerado por Rubin "uma obra de arte arquitetônica, mas um museu desajeitado", ${ }^{328}$ não fosse usado para expor obras de arte, mas apenas para mostras de arquitetura.

Diante da expansão da coleção e do público, discussões sobre a necessidade de ampliar o edifício do museu já tinham voltado à tona nessa época. O MOMA, no entanto, enfrentava
2.120 Mapas da exposição da coleção do MoMA, Nova York, nos pavimentos 2 e 3 em 1973. Fonte: ELDERFIELD, p. 89.

328 Rubin, William. op. cit., p. 122. Tradução nossa. 


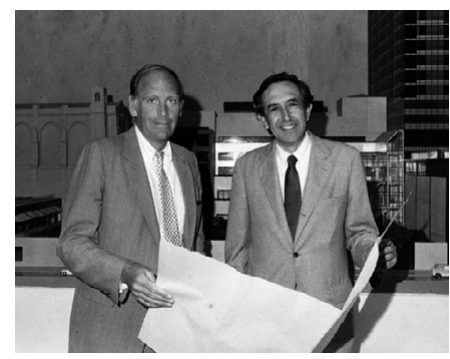

2.121 0 director do MoMA de Nova York, Richard Oldenburg, e o arquiteto César Pelli, com a maquete do novo edifício do museu ao fundo, 1983. Fonte: https:// www.moma.org/magazine/articles/125

2.122 Estudo de César Pelli para a Museum Tower do MoMA, Nova York, 1983? Fonte: PELLI, p. 99.

2.123 Museum Tower do MoMA, projeto de César Pelli, Nova York, 1984. Foto Brian Rose. Fonte: http://www.brianrose.com/ portfolio/overview.htm

2.124 Vista da Rua 53 com Museum Tower do MoMA, projeto de César Pelli, Nova York, 1984. Foto Brian Rose. Fonte: http://www. brianrose.com/portfolio/overview.htm

2.125 e 2.126 Elevações do Museum Tower do MoMA, projeto de César Pelli, nas ruas 53 e 54, Nova York, 1983? Fonte: PELLI, p. 100.

329 MAZUREK, Lily R. MOMA and the Museum Tower: Breaking Ground for the Eighties. Nova York: The Museum of Modern Art, 1982.

330 Richard Oldenburg apud THE MUSEUM OF MODERN ART. MOMA Through Time. MOMA. Disponível em: <https://www.moma.org/ interactives/moma_through_ time>. Acesso em: 2 jan. 2020. Tradução nossa. sérios problemas financeiros com um déficit crescente, originado com o alto custo da expansão anterior do edifício, realizada em 1964. A solução veio com a articulação de um intrincado pacote de suporte financeiro a instituições de finalidade pública de Nova York, The Trust for Cultural Resources, criado em 1976 para possibilitar isenção de impostos, empréstimo de valores e aquisição de propriedades por meio de equivalência de taxas imobiliárias, em associação com empreendedores privados. ${ }^{329}$ Abrindo precedente para outras instituições, o MoMA inscreveu-se no programa e vendeu o espaço aéreo para empreendedores imobiliários construírem um condomínio residencial de alto padrão de $5^{2}$ andares sobre os 6 pavimentos do museu, usando o valor arrecadado com a transação e as taxas imobiliárias para sanar suas dívidas e auxiliar o financiamento de uma nova expansão e renovação de seu edifício. Diante da controvérsia gerada pelo envolvimento incomum de um museu de arte - sem fins lucrativos por definição - com um empreendimento imobiliário, Oldenburg justificou deste modo as razões da operação:

O verdadeiro objetivo de todo esse projeto nunca foi tornar a instituição lucrativa, mas garantir espaço adequado para o museu. O problema era como fazer tudo isso, como obter mais espaço, quando mal podíamos bancar o espaço que tínhamos antes. ${ }^{330}$

Sinal do peso que o empreendimento teve na operação foi a designação em 1979 do arquiteto argentino radicado nos EUA César Pelli (1926-2019) - autor de diversas torres comerciais no país -, para projetar não apenas a fachada do condomínio residencial Museum Tower, mas também a expansão do edifício do мома nos lotes a oeste da sede original. Com as obras que transcorreram entre 1980 e 1984, o museu duplicou a área das salas expositiva e da biblioteca, ganhou um novo auditório e ampliou as áreas de estudos, armazenamento do acervo, restaurante e livraria.

Para além das questões programáticas, o projeto deveria enfrentar a questão de como expandir tão significativamente a área, preservando ao mesmo tempo a identidade moderna 

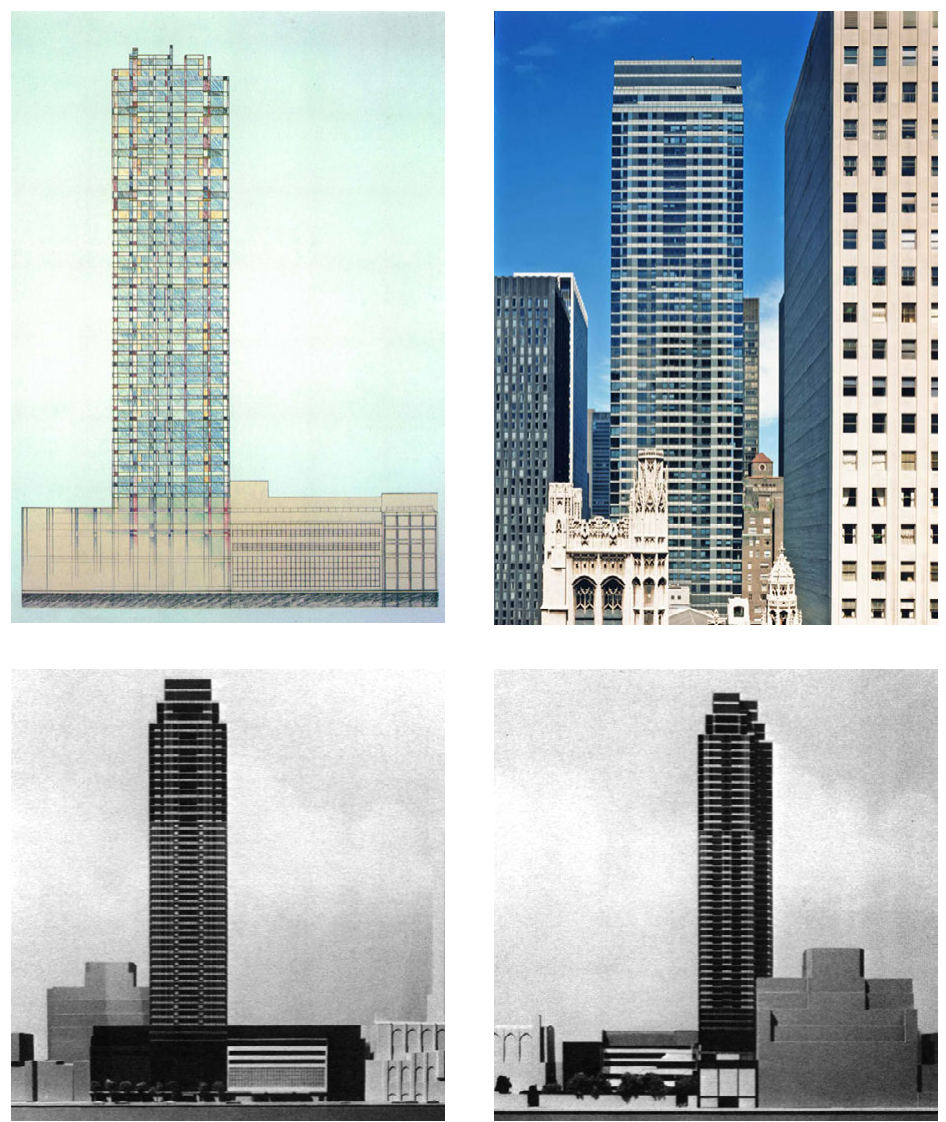

do museu - fortemente vinculada ao projeto de Goodwin e Stone. Para Pelli, o edifício de 1939 não seria nem tão grande para atender às atuais necessidades em seu interior, nem tão pequeno para ser absorvido por uma nova construção: "esta não é uma composição, mas uma agregação, uma nova entidade, respeitosa com seu próprio passado, com todos os estágios intermediários permanecendo aparentes.”331

Alinhados com o limite do lote na rua 53, os andares superiores dedicados aos apartamentos tiveram as fachadas elaboradas, segundo o arquiteto, sob inspiração das composições sincopadas de Mondrian, como a tela Broadway Boobie-Woogie (1943-43), com uma pele de vidro reticulada com
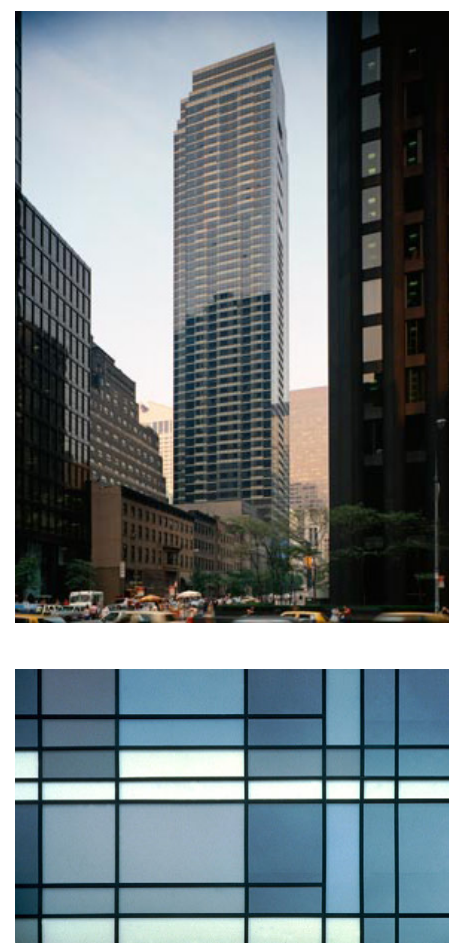

2.127 Fachada do Museum Tower do MoMA, projeto de César Pelli, Nova York, 1984. Foto: Pelli Clarke Pelli Architects. Fonte: https:// pcparch.com/project/museum-of-modernart-gallery-expansion-and-residential-tower/

331 Pelli, Cesar. The Museum of Modern Art Project. Perspecta. v. 16, p. 97-107, 1980. P. 107. Tradução nossa. 
2.128 Vista do Museum Tower e Garden Hall para o jardim de esculturas na Rua 54, com projeto de César Pelli, Rua 53, Nova York, 1984 a 1987. Foto: Brian Rose. Fonte: http://www.brianrose.com/ portfolio/overview.htm

2.129 Vista do Museum Tower e Garden Hall para 0 jardim de esculturas na Rua 54, com projeto de César Pelli, Rua 53, Nova York, 1984 a 1987. Foto: Pelli Clarke Pelli Architects. Fonte: https://pcparch.com/ project/museum-of-modern-art-galleryexpansion-and-residential-tower/
332 Destoando da sobriedade geral do embasamento com um certo ar de opulência, o acesso ao condomínio é feito por portas giratórias com esquadrias douradas, cobertas por uma marquise revestida de material espelhado, demarcando muito claramente um outro território. Não ficaram esclarecidos com precisão nesta pesquisa os limites de atuação do projeto de Pelli no edifício do condomínio. É possível que o desenho da entrada do Museum Tower tenha sido realizado pelo mesmo arquiteto designado pelos empreendedores para projetar os andares dos apartamentos.

333 PELli, op. cit., p. 101. Tradução nossa.
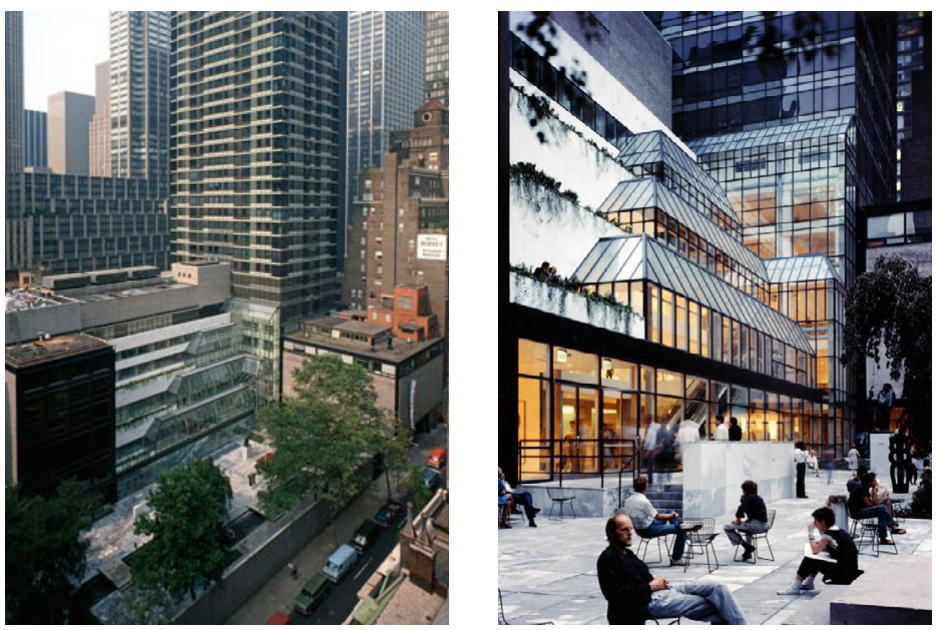

variações sutis de cor. Sua presença, no entanto, não resultou significativamente perceptível para o transeunte, uma vez que a largura exígua da rua dificultava a visada das cotas mais altas. Destacando o bloco antigo, os andares inferiores foram tratados de modo rebaixado, construídos em continuidade ao seu alinhamento e gabarito e revestidos nos pavimentos das novas galerias por uma esquadria de vidro escuro sobre paredes opacas e por placas de granito preto no nível térreo. ${ }^{332}$ Pelli assumiu ter mantido a estratégia adotada na expansão anterior, afirmando que

a leitura básica da nova ala oeste será uma parede escura e brilhante, com a mesma relação de contraste com a fachada de Goodwin-Stone que a ala leste de Johnson. O edifício Goodwin-Stone continuará sendo o símbolo e a entrada do Museu de Arte Moderna e manterá sua relação histórica com o resto do quarteirão como um medalhão branco sobre fundo escuro. Os diferentes estágios de expansão do museu serão claramente identificáveis. $^{333}$

No interior do edifício, as salas expositivas também não receberam destaque nessa expansão, projetadas, a pedido do museu, como extensões das galerias existentes, em continuidade com os 


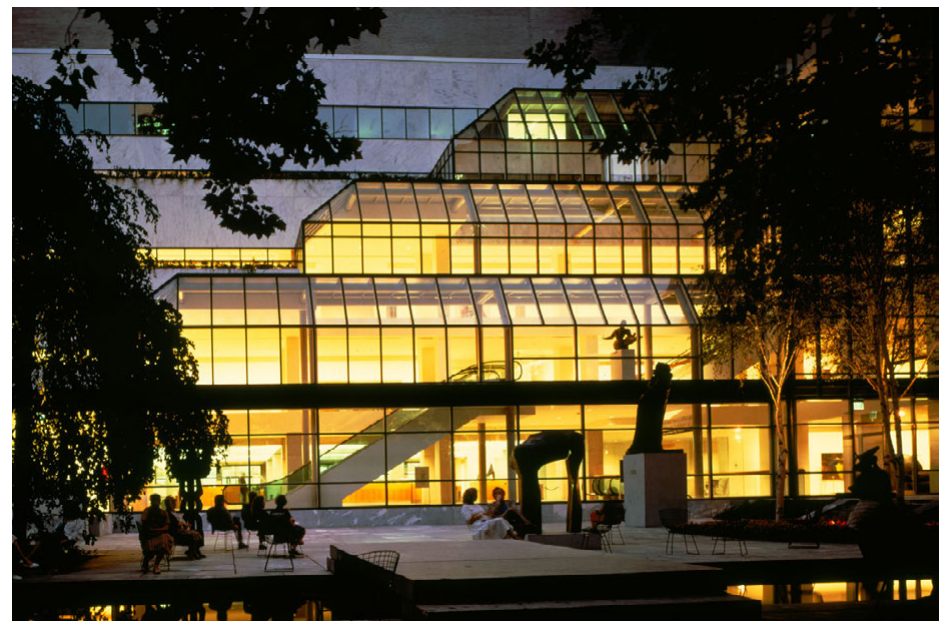

níveis de piso e com o mesmo padrão de acabamento. A marca do projeto de Pelli ficou concentrada num novo átrio envidraçado justaposto à fachada do jardim, abrigando um conjunto de escadas rolantes em continuidade, que reorganizava a circulação vertical do público no museu, abrigando também esculturas.

Com um volume escalonado acompanhando as diagonais do percurso e estruturado com perfis cilíndricos robustos, o átrio tinha uma linguagem movimentada que destoava da sobriedade dominante das arquiteturas do edifício e do jardim existentes. Enquanto esquema, a solução tinha como precedente o conjunto de escadas rolantes externas do recém-inaugurado Centro Georges Pompidou, apontado como o precursor de uma tendência crescente no final do século xx: a da espetacularização de museus, projetados por arquitetos que viriam constituir o chamado star system, no bojo da inclusão dos equipamentos culturais ao circuito turístico internacional de massa. No edifício de Piano \& Rogers, as escadas articulavam-se ao contexto da cidade, sendo inicialmente franqueadas ao público, que desfrutava delas como um mirante urbano. $\mathrm{O}$ átrio de Pelli, anexo a um edifício existente e voltado para o interior do lote, era mais tímido quanto ao alcance público e à escala, mas também transmitia uma sensação de grandiosidade que contrastava com a ausência de hierarquia e com a

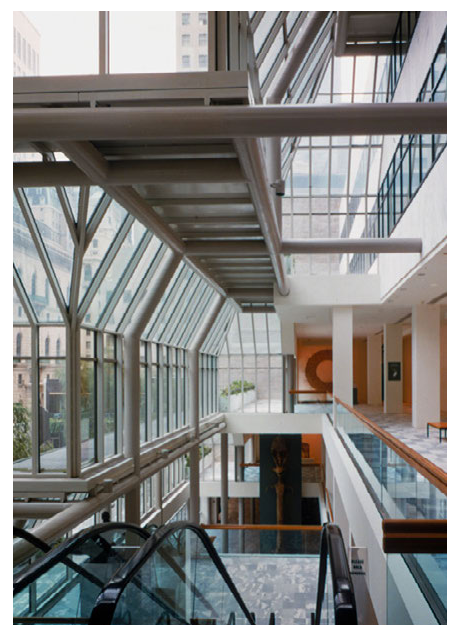

2.130 Vista do Museum Tower e Garden Hall para 0 jardim de esculturas na Rua 54, com projeto de César Pelli, Rua 53, Nova York, 1984 a 1987. Foto: Scott Frances. Fonte: https://www.moma.org/magazine/ articles/ 125

2.131 Interior do Garden Hall do MoMA, projeto de César Pelli, Nova York, 1984. Fonte: https://www.moma.org/magazine/ articles/125 
austeridade dos espaços modernistas do edifício de 1939, concebidos a partir de uma perspectiva específica sobre como a arte deveria ser exposta. Como apontou Allan Wallach,

Críticos reclamaram que o átrio do MOMA - dotado de elevadores, piso de mármore polido e iluminação intensa - não é adequado para a exposição de obras de arte. [...] Mas não é exatamente essa a função de um espaço assim - um espaço que foi deliberadamente espetacularizado (mais ou menos como mil shopping centers 'pós-modernos'), um espaço que irradia uma espécie de intensidade flutuante destinada a sobrecarregar qualquer objeto colocado dentro dela? ${ }^{334}$

Para o autor, que buscou analisar as implicações ideológicas das mutações arquitetônicas do MoMA, ao levar o visitante a entrar duas vezes no museu - primeiro pelo edifício antigo, preservado na fachada, depois pelo novo átrio que dava acesso às galerias -, a intervenção de Pelli enaltecia a experiência contrastante entre a utopia modernista congelada no passado e o presente dominado pela euforia do capitalismo tardio. Wallach observou que, embora o arquiteto defendesse a impossibilidade de transformar a herança de Goodwin e Stone e de Johnson, por considerar que ainda estariam presentes "as funções, as ideias, as crenças que moldaram esses edifícios", ${ }^{335}$ seu projeto teria provocado uma transformação inevitável:

o design de Pelli distancia ainda mais o passado do момА - um passado que adquire uma aura de irrealidade, uma sensação de ser selado como uma cápsula do tempo, já que agora é experimentado pela mediação do presente do átrio. ${ }^{336}$

334 Wallach, Alan. The Museum of Modern Art: The Past's Future. Journal of Design History. v. 5 , n. 3, p. 207-215, 1992. p. 212. Tradução nossa.

335 Pelli, César. op. cit., p. 107. Tradução nossa.

336 WALlach, op. cit., p. 212. Tradução nossa.
Enquanto se atualizava como equipamento cultural capaz de acolher o público cada vez mais numeroso que passou a frequentar museus no mundo todo, flertando com a linguagem pós-moderna em seu novo átrio, o MoMA continuava ancorando sua identidade na arte moderna. Além de manter preservada e em destaque a fachada modernista voltada para a rua 53 e o padrão das galerias do edifício de 1939, o museu confirmava a fidelidade ao mesmo padrão expográfico e modelo 
narrativo da história da arte na montagem do acervo dirigida por William Rubin para a reinauguração do edifício em 1984. O curador depurou ainda mais o ambiente expositivo com a eliminação de potenciais "distrações" no espaço, tornando mais rígido o itinerário pré-estabelecido e contínuo rumo à abstração - da Escola de Paris à de Nova York. Na opinião de Serota sobre essa montagem,

Nada do caráter ecumênico da abordagem de Barr permaneceu. Reforçada por uma prática de enquadrar todos as obras num estilo único de moldura, dourada ou de madeira, e apesar de grupos exemplares de obras de Matisse, Picasso, de Chirico e dos Expressionistas Abstratos, a apresentação de alguns dos mais importantes trabalhos e movimentos do século $\mathrm{xx}$ foram reduzidas à forma de uma sequência de slides. ${ }^{337}$

Pouco depois, o curador envolveu-se numa grande polêmica em torno da exposição "Primitivism" in 2oth Century Art: Affinity of the Tribal and the Modern, organizada com a colaboração do historiador da arte Kirk Varnedoe (1946-2003), em 1984. ${ }^{338}$ Ocupando dois andares do museu, a mostra apresentava aproximadamente 150 obras de artistas modernos produzidas desde finais do século xIX até aquele momento - incluindo Picasso, Gauguin, Brancusi, Modigliani, Klee e representantes do Expressionismo e do Surrealismo - lado a lado com 150 objetos de culturas indígenas da África, Oceania e América do Norte, além de máscaras e esculturas das coleções particulares de artistas. Dispostos teatralmente no interior de vitrines iluminadas em salas relativamente escuras ou em paredes e pedestais similares aos das obras modernas a que estavam relacionados, os objetos "primitivos" não eram acompanhados de informações básicas como data, função e conexões com crenças religiosas e mitológicas de suas culturas de origem. O que se buscava valorizar eram apenas as qualidades formais dos objetos, em função do interesse que pudessem ter no desenvolvimento da arte moderna.

A mostra foi duramente criticada pelo historiador da arte Thomas McEvilly (1939-2013), em ensaio publicado na revista Artforum, que procurou evidenciar como tal forma de apre-
337 Serota, op. cit., p. 13. Tradução nossa.

338 Cf. The Museum of Modern ART. "Primitivism" in 2oth Century Art: Affinity of the Tribal and the Modern (Sep 27, 1984-Jan 15, 1985). МОМА. Disponível em: $<$ https://www.moma.org/calendar/ exhibitions $/ 1907>$. Acesso em: 11 abr. 2021. 


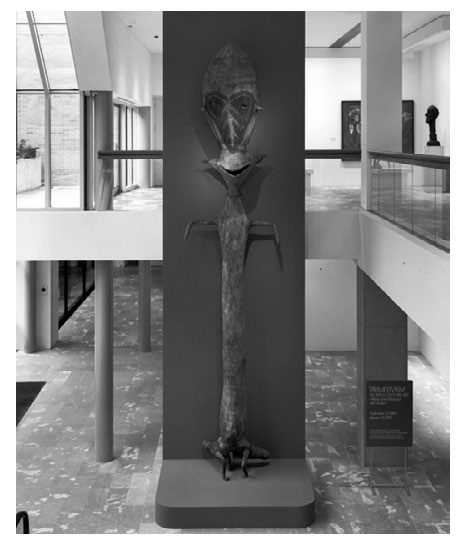

2.132 a 2.134 Vistas da exposição "Primitivism" in 20th Century Art: Affinity of the Tribal and the Modern, MoMA, Nova York, 1984. Foto: Katherine Keller. Fonte: https://www.moma.org/calendar/ exhibitions/1907

2.135 Vista da exposição Magiciens de la Terre, Centro Georges Pompidou e Grande Halle de la Villete, Paris, 1989. Fonte: https://www.magiciensdelaterre.fr/
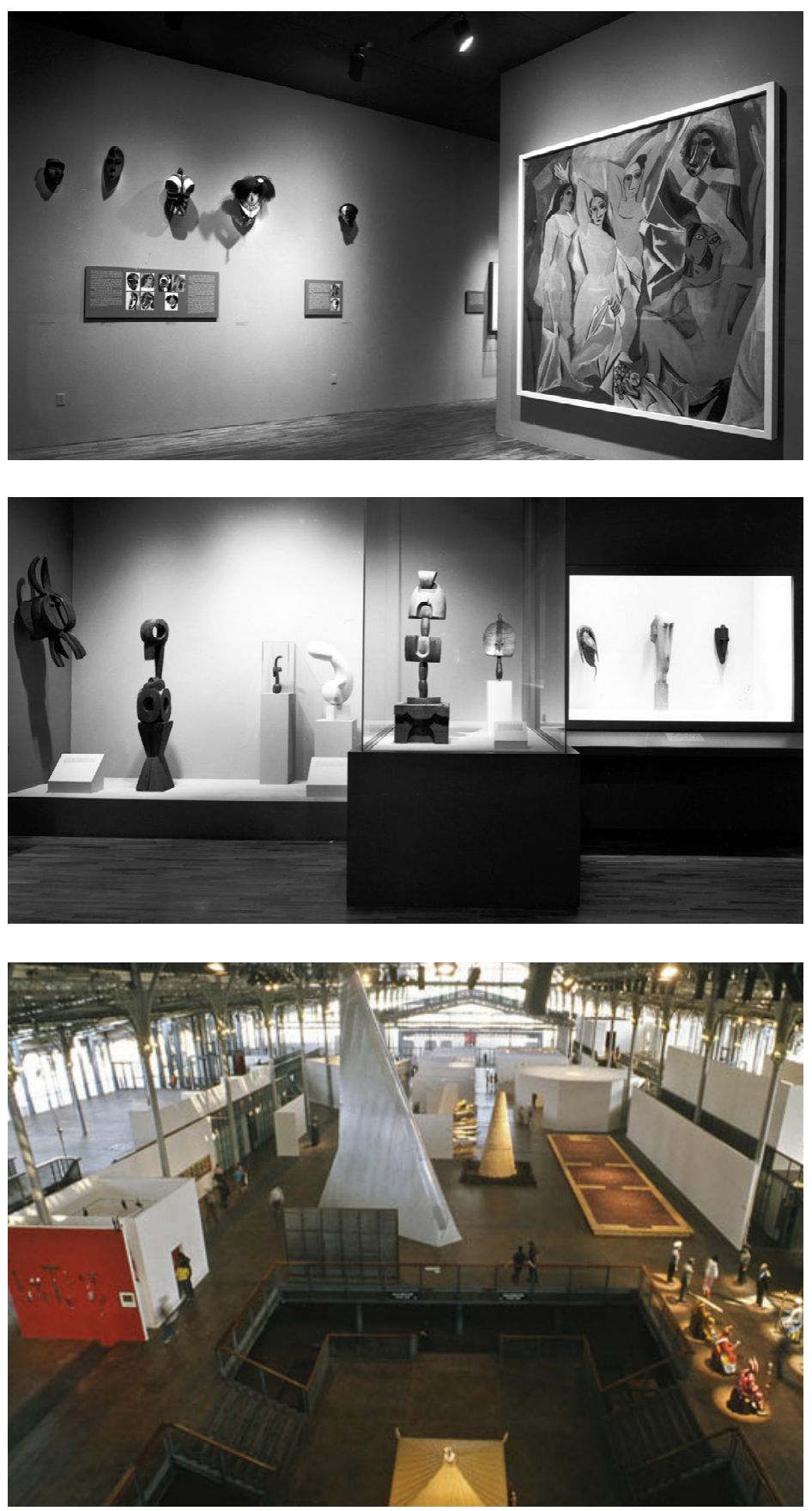
sentação distanciava o público da compreensão do contexto, significado, conteúdo e intenção primordiais das obras indígenas. Segundo o autor, a exposição exemplificaria uma prática amplamente disseminada no universo dos museus, que reforçava a ideologia colonialista da superioridade da arte ocidental sobre a produção cultural de outras regiões do planeta. ${ }^{339}$ Rubin e Varnedoe lançaram sua defesa em números seguintes da mesma revista, argumentando que a "recontextualização" da arte "primitiva" na exposição teria como objetivo contar uma "história particular" dentro da história da arte ocidental, o que não funcionou para esfriar a controvérsia. ${ }^{340}$ O debate ganharia novo fôlego com a exposição Magiciens de la Terre, que viria a ser realizada como contraponto à mostra do MoмA em 1989, no Centro Georges Pompidou e no Grande Halle de la Villete, em Paris, com curadoria de Jean-Hubert Martin, contendo a produção de 50 artistas, provenientes em igual proporção dos EUA e da Europa e de outros continentes comumente menos prestigiados em mostras panorâmicas de arte contemporânea. ${ }^{341}$

É plausível supor que a alta repercussão que o debate em torno de "Primitivism" in 2oth Century Art alcançou estivesse vinculada, mais uma vez, ao fato de a exposição ter sido organizada numa instituição tão visada quanto o MOMA. Associado ao poderio estadunidense e a uma visão seletiva e excludente da arte, o museu vinha aprofundando a estetização de suas mostras, expandindo ainda mais a influência internacional de seu modelo curatorial e expográfico e ainda se aproximando de uma tendência à espetacularização da arquitetura de museus, coroada pela nova expansão de Pelli. Depois da acomodação das tensões com jovens artistas no final dos anos 1960, o museu, tendo Rubin como figura emblemática, passava nos anos 1980 a alvo de críticas dos que defendiam uma abordagem multiculturalista de valorização de tradições até então excluídas da narrativa eurocêntrica da arte. Tendo permanecido na direção do departamento até 1988, o curador, no entanto, manteve firme o foco em mostrar a coleção como uma grandiosa trajetória evolutiva da história da arte moderna de matriz europeia, como evidencia seu relato:
339 Thomas McEvelly viria a escrever em 1986 o texto de Introdução ao livro de O'Doherty, No Interior do Cubo Branco: a ideologia do espaço da arte, op. cit., pp. Xv-XxvII.

340 Cf. The Museum of MODERn ART. The Controversial "Primitivism" Exhibition. MOMA. Disponível em: $<$ https://www. moma.org/interactives/moma through_time/1980/>. Acesso em: 3 jul. 2020.

341 A exposição não foi menos controversa, sendo criticada tanto por direitistas por desprezar critérios supostamente universais de qualidade estética e por esquerdistas por impor a visão do Ocidente sobre produções provenientes de outros contextos. O próprio McEvelly voltaria se envolver no debate no artigo "The Global Issue", publicado na Artforum de março de 1990, ratificando as inconsistências da mostra, mas apontando, em defesa do evento: "esta foi a primeira grande exposição conscientemente disposta a descobrir um modo pós-colonialista de apresentar objetos juntos. Foi o maior evento da história social da arte, não da história estética. 'Magiciens' abriu a porta do mundo longamente insular e hermético da arte ocidental para os artistas." Thomas McEvelly apud ALTSHULER, op.cit. p. 294. Tradução nossa. 
342 Rubin, op. cit., p. 35-38. Tradução nossa.

343 Cf. Press release in: THE Museum of Modern ART. Artist's Choice: Burton on Brancusi (Apr 7-Jul 4, 1989). MOMA. Disponível em: <https://www.moma.org/ calendar/exhibitions/2133?locale $=\mathrm{pt}>$. Acesso em: 4 jul. 2020. Press release de março de 1989, p. 3 . Tradução nossa.

344 A série Artist's Choice teve 14 edições entre 1989 e 2019 (aproximadamente uma a cada 2 anos), enquanto Projetcs teve 110 entre 1971 e 2019 (mais de duas por ano).
O museu tem as obras necessárias para apresentar cronologicamente e passo a passo o princípio do Cubismo a partir da multifacetada Demoiselles d'Avignon de Picasso, partindo das chamadas obras 'africanas' em direção às linguagens complexas ao Cubismo Analítico e sintético - e ao mesmo tempo ilustrar como Georges Braque se uniu a Picasso em muitos aspectos para fazer do Cubismo um diálogo único nos anais da história da arte. Isso não pode ser visto em nenhum outro museu do mundo, um fato que para mim constitui uma obrigação. Não mostrá-lo, ou interrompê-lo a não ser ocasionalmente, seria uma violação da responsabilidade museológica, seja qual for a narrativa que a substitua. ${ }^{342}$

\subsubsection{ARTISTAS NO PAPEL DE CURADORES}

Apontado por Rubin para sucedê-lo no MoMA, Kirk Varnedoe assumiu em 1988 o cargo de Curador Chefe no Departamento de Pintura e Escultura, enquanto Rubin, apesar de não pertencer mais ao quadro ativo, manteve sua influência sobre o museu, tendo sido nomeado Diretor Emérito do departamento. Mantendo no geral o curso de seu antecessor, Varnedoe foi responsável por uma nova iniciativa pontual para aproximar o museu dos artistas contemporâneos, convidando-os para "selecionar, justapor e comentar obras da coleção de pinturas e esculturas do museu". ${ }^{343}$ A série foi chamada Artist's Choice e se tornou, assim como Projets, um programa permanente no museu, embora tenha realizado um número significativamente menor de mostras. ${ }^{344}$

A primeira exposição da série foi Artist's Choice: Burton on Brancusi, realizada em 1989, na qual o escultor Scott Burton (1939-1989) selecionou peças a partir do entendimento já consolidado de que o tratamento escultórico das bases de Brancusi fazia com que o espaço ao seu redor estivesse implicado em sua obra. Burton estabeleceu seu recorte vinculando uma análise histórica ao seu próprio interesse em explorar como artista, objetos escultóricos que funcionavam como móveis em espaços públicos, numa abordagem de matriz minimalista. Sua interpretação buscava demonstrar como "algumas das 


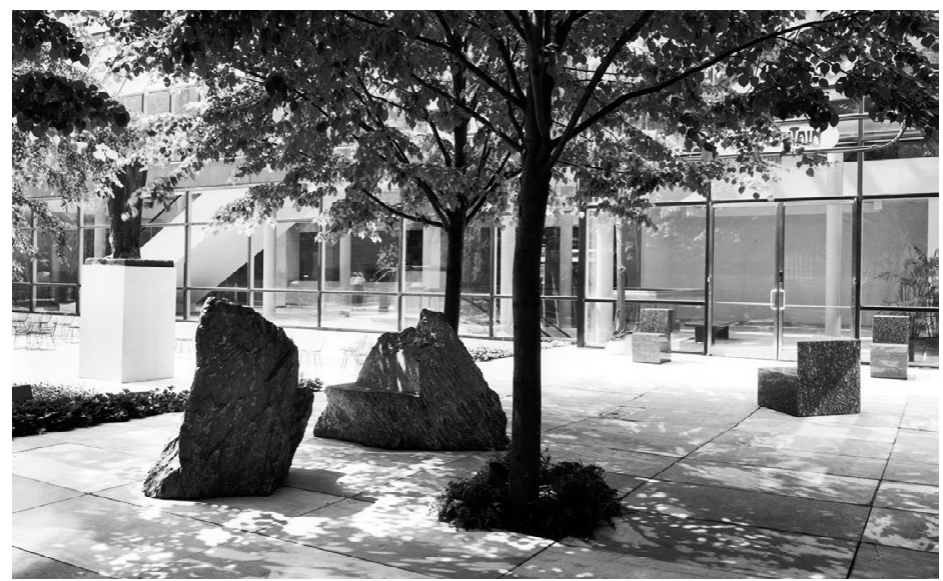

mesas-pedestais de Brancusi são da mesma ordem conceitual de quaisquer de seus bustos e torsos". ${ }^{345}$

Enfatizando o elo entre os dois artistas, peças de Burton também foram expostas no museu, embora, localizadas no jardim de esculturas, estivessem distantes das peças de Brancusi, instaladas na entrada das galerias do terceiro andar, seguindo o mesmo padrão de apresentação das exposições de arte do MOMA. O modo de seleção e apresentação dessa exposição dava força à argumentação do museu sobre a pertinência de sua coleção de arte moderna para os artistas da atualidade, como vemos na declaração de Varnedoe:

Temos que reconhecer que uma parte crucial da tradição moderna é a resposta criativa dos artistas às obras de seus pares e antecessores. Essa instalação nos ajuda a entender mais claramente não apenas as raízes do próprio trabalho de Burton, mas um aspecto do diálogo mais amplo entre tradição e inovação com arte contemporânea. ${ }^{346}$

A estratégia do мома não era inédita, tendo similaridades, por exemplo, com o programa Raid the Icebox, abordado anteriormente. Apesar da má recepção da exposição organizada em 1969 por Andy Warhol para a série - que levou à sua descontinuidade pelo museu de Rhode Island -, diversas instituições

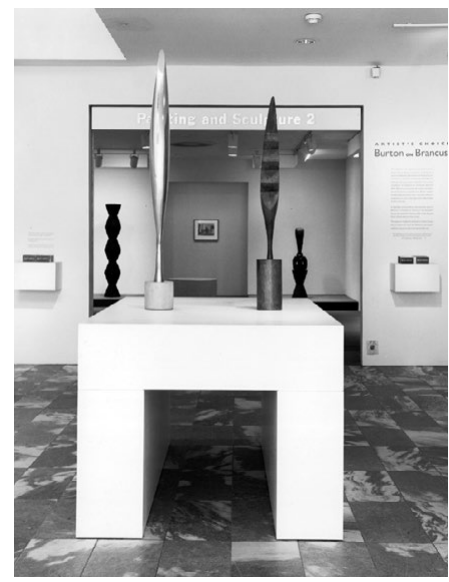

2.136 e 2.137 Vistas da exposição Artist's Choice - Burton on Brancusi, MoMA, Nova York, 1989. Foto: Mali Olatunji. Fonte: https://www.moma.org/calendar/ exhibitions/2133
345 Burton. Scott. Artist's Choice: Burton on Brancusi. Nova York: The Museum of Modern Art, 1989. n.p. Tradução nossa.

346 Kirk Varnedoe in Press release de março de 1989, op. cit., p. 3. Tradução nossa. 
dos EUA e de outros países implantaram programas similares nos anos seguintes, buscando do mesmo modo aproximar acervos históricos das práticas contemporâneas, atraindo um público mais jovem e diversificado, como foi o caso dos programas The Artist's Eye, da National Gallery de Londres (1977-90), e Connections, do Museum of Fine Arts de Boston (1989-93).

A julgar pela longevidade, o Artist's Choice teve um saldo positivo para o MOMA, embora algumas das edições tenham se desviado mais do padrão curatorial e expográfico convencional do museu, como foi o caso da terceira exposição da série, Artist's Choice: Chuck Close, Head-On/The Modern Portrait, inaugurada em 1991. Para a mostra, o artista Chuck Close (1940-) selecionou 170 retratos do acervo do museu produzidos por artistas consagrados e pouco conhecidos em diferentes mídias - desenhos, pinturas, gravuras, fotografias e esculturas - e os expôs de modo acumulado, porém ordenado, ocupando inteiramente as superfícies expositivas de uma única galeria no terceiro andar. As obras bidimensionais foram arranjadas nas paredes em forma de "mosaico", como nos salões pré-modernos, ou sobrepostas umas às outras e apoiadas em fileiras de prateleiras, enquanto oitos bustos foram dispostos em suportes suspensos nas paredes, variando de altura para que os olhos ficassem alinhados.

Assim como em Raid the Icebox I, o artista não selecionou as obras segundo um critério de qualidade, tampouco de preferência pessoal, mas, ao contrário de Warhol, definiu um recorte bastante claro, escolhendo apenas retratos de cabeça e ombro, o que representava uma limitação severa considerando que esse não era um gênero abundante na arte moderna, a especialidade do museu. Tanto os parâmetros de seleção quanto o modo de apresentação refletiam o processo criativo do próprio artista, o de preencher o campo visual com pequenas unidades de cor ou tons de cinza, criando estruturas complexas que resultavam também em retratos. Outro critério para a seleção foi que as figuras retratadas tivessem uma importância para os autores das obras, do mesmo modo como tinham para o seu próprio trabalho. $\mathrm{O}$ acúmulo de retratos permitia estabelecer novas relações entre as obras, que podiam de outro modo passar despercebidas. Como explicou Varnedoe, 


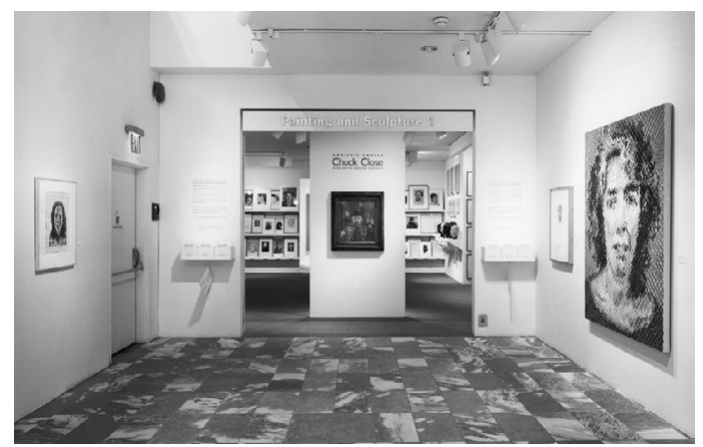

justapondo tantas imagens semelhantes de cabeça e ombro, a montagem nos encoraja a ver o que o artista chama de 'sintaxe' - os dispositivos abstratos, sistemas de marcas ou opções de enquadramento, ponto de vista etc - dentro dos quais se percebem semelhanças nos diferentes retratos. ${ }^{347}$

Para Close, desviar-se do modo convencional de expor no MомA era o que possibilitava desmontar uma postura contemplativa, permitindo um novo tipo de aproximação com as obras e conferindo-lhes nova vitalidade:

Para os propósitos desta exposição em particular, contrário a característica pela qual o Museu de Arte Moderna é conhecido, que é a de dar lugar e espaço a essas obras de arte, fazendo de cada uma delas um objeto contemplativo em frente ao qual se pode ficar e prestar homenagem com reverência, sem mais nada em sua visão periférica. De um jeito engraçado, tento subverter o que eu gosto no museu. E tenho certeza de que muitas pessoas pensam que há algo quase sacrílego em empilhar a arte desse modo e que sentem que não se está mostrando o devido respeito pelo trabalho. Mas é outro aspecto que estou procurando.

Estou tratando esses trabalhos de maneira semelhante à maneira como trato minha própria coleção em casa. Apoio muitas fotos em paredes ou prateleiras e sempre as reorganizo. Quando algo vai para a parede e fica lá, torna-se esperado e se calcifica. Detesto quando a arte se torna invisível dessa
2.138 e 2.139 Vistas da exposição Artist's Choice - Chuck Close, MoMA, Nova York, 1991. Foto: Mali Olatunji. Fonte: https:// www.moma.org/calendar/exhibitions/324
347 VARnedoe, Kirk. in: Close, Chuck. Artist's Choice: Chuck Close, Head-On/The Modern Portrait. Nova York: The Museum of Modern Art, 1991. p.1. Tradução nossa. 
maneira; torna-se apenas um fundo sem sentido para um coquetel casual - é apenas decorativo. Por isso, estou sempre mexendo em minhas fotos, colocando algo ao lado de outra coisa para tentar obter um novo impulso - para fazer com que não seja uma experiência fraca, que é o que tende a ser. ${ }^{348}$

O assumido desvio de Close das convenções parece não ter causado desconforto para o момA. Ao contrário, podia servir, mais uma vez, para demonstrar a abertura do museu às práticas contemporâneas e à autocrítica, tanto quanto a importância de sua coleção, como evidenciava a apresentação de Varnedoe no catálogo da mostra:

atravessando fronteiras de meios, tamanhos e níveis de valor convencionalmente aceitos, o programa de Close incorpora uma ideia desconhecida (e, como ele sustenta, um pouco subversiva) do que é o museu.

Esta instalação enfatiza o papel do museu não como um árbitro seletivo de valor, mas como um banco de dados de unidades de informação acumuladas - cada uma das quais pode informar, de maneiras diferentes e imprevisíveis, a imaginação dos artistas que vêm para cá.

Ao abandonar as convenções normais de montagem seletiva e bem espaçada, pelas quais os museus dão atenção especial a obras específicas, esse programa libera - e desafia - os espectadores a formarem suas próprias hierarquias de escolha e padrões de atenção. ${ }^{349}$

Assim como Projects, as mostras de Artist's Choice eram de pequena escala, mas tinham um resultado ainda mais possível de ser controlado, por terem como matéria as próprias obras do museu. Em ambas as séries, a autoria passava para as mãos dos artistas, no primeiro caso principalmente na forma de instalações e no segundo explicitamente como curadoria, sendo uma fusão das duas formas no caso da exposição de Close, uma vez que sua abordagem tinha um forte caráter ambiental. Com

348 Close, Chuck. op. cit., p.3. Tradução nossa.

349 Ibidem, p.3. Tradução nossa. esses programas, o museu podia manter-se numa confortável posição de assimilar certo grau de subversão, sem se comprometer demais no nível institucional. 


\subsubsection{A ASSIMILAÇÃO DAS INSTALAÇÕES}

Quando o programa Artist's Choice foi lançado, a instalação de arte - que havia florescido num ambiente de contraposição às instituições estabelecidas no final da década de 1960 -, vinha se tornando uma modalidade aceita desde meados dos anos 1980, chegando ao final da década a ser procurada pelos principais museus, que passaram a comissioná-la. O contexto cultural estadunidense, entretanto, havia se transformado bastante, tendo o espírito da contracultura cedido lugar ao seu oposto, à propensão ao conformismo consumista da era Reagan, alimentada por um período de crescimento econômico expressivo no país. O mercado de arte se aquecera com a retomada de um certo protagonismo pela pintura e passou também a comercializar instalações, seguindo uma tendência de comoditização da cultura, que avançou inclusive sobre as manifestações que na origem contestavam a associação da arte com mercadoria.

Como apontou Reiss, a institucionalização da instalação já podia ser percebida em Nova York nas edições da Bienal do Whitney Museum desde 1981 e ainda no Dia Center for the Arts, que, fundado em 1974, instalara-se num galpão industrial do bairro Chelsea em 1987, trazendo a público a coleção do casal de Menil, contendo um conjunto significativo de obras minimalistas e pós minimalistas. ${ }^{350}$ Entrando no espaço "sacro" dos museus, as instalações teriam cruzado a última fronteira, migrando, na opinião da autora, das margens para o centro, e transformando-se no processo, embora guardando sua dimensão essencialmente pública:

A institucionalização teve um impacto significativo na arte da instalação. Não é de surpreender que, uma vez tornadas atribuição dos principais museus, as instalações tenham perdido parte de seu caráter de ponta. Isso não impediu que os artistas desejassem expor suas instalações em museus. A arte da instalação é uma forma de vitrine que precisa de um espaço público para existir e os museus são os espaços públicos mais validadores. ${ }^{351}$

A argumentação de Reiss deixou de lado, todavia, o fato de que os museus seguiram não sendo os únicos ou mesmo princi-
350 A coleção, que contava com espaços para instalações individuais de artistas em imóveis do SoHo, viria instalar-se em 2003 num outro edifício fabril de grande escala no município de Beacon.

351 REISs, op. cit., p. 137.

Tradução nossa. 
pais locais de interesse dos artistas contemporâneos para a realização ou validação de suas intervenções, que com frequência ocorrem em lugares inusitados, não especificamente destinados a exposições. No cenário da arte contemporânea, grandes mostras periódicas - bienais, Manifesta, Documenta - ou centros culturais sem vínculo com coleções - kunsthalles conquistaram prestígio no mínimo equiparável ou de museus estabelecidos. Ainda assim, o MомA, sendo um local de grande atração de público, continuava tendo o potencial de validar trabalhos de vanguarda e impulsionar artistas desconhecidos. Depois da exposição coletiva Spaces, porém, o museu passara mais de duas décadas limitando instalações principalmente à série Projects, com mostras individuais numa pequena sala, como vimos. O hiato foi interrompido em 1991, com a exposição Dislocations, a primeira curadoria organizada por Robert Storr (1949-) no museu, que convidou para realizar obras com a participação de sete artistas consagrados que utilizavam uma variada gama de linguagens, além de representarem um boa diversidade de nacionalidade, raça, gênero e idade, sendo eles os estadunidenses Chris Burden (1946-2015), Bruce Nauman (1971-), Adrian Piper (1948-) e David Hammons (1943), as francesas Louise Bourgeois (1911-2010) e Sophie Calle (1953-) e o russo Ilya Kabakov (1933-).

No texto de apresentação, o curador introduziu seu conceito para a exposição tratando de pontos que vinham sendo apontados pela crítica dos anos 1970 como fatores de distanciamento do MomA das práticas contemporâneas. Como que se referindo ao argumento usado por Carol Duncan e Allan Wallach no ácido artigo publicado em 1978, Storr discorreu sobre o caráter transcendental que a experiência de contemplação da arte propiciaria nos museus de arte de modo geral e de seu afastamento do mundo real:

Ser movido pela arte é retirar-se das circunstâncias habituais e afastar-se de si mesmo, para melhor olhar para o lugar de onde se partiu e para a identidade limitada deixada para trás. Com ou sem metafísica, e por mais breve que seja o momento, esse estado pode ser chamado de transcendência. Mas onde estamos? O museu é o paradigma moderno desses mundos à parte. 
Para alguns, seus espaços compreendem uma esfera espiritual mais alta, o que pode levar as reivindicações de transcendência a assumir conotações explicitamente religiosas. Esses recintos especiais e disponíveis constituem um modelo para uma ordem humana inatingível por outros meios, assim como um local para rituais de meditação e adoração. Abrigando altares dedicados à intenção pura e à certa 'qualidade', são santuários ordenados para a contemplação da arte. Para esse modo de pensar, a arte é tanto veículo quanto destino, sendo o museu um domínio protegido e protetor no qual a transposição ocorre. Mesmo quando concebido de modo inteiramente secular ou materialista, o museu como santuário existe como desafio ao fluxo exterior a suas paredes. ${ }^{352}$

Mencionando em seguida a expressão de Brian O’Doherty, o curador explicou como o espaço expositivo denominado "cubo branco", que abarcaria diversas das variações nos modos de expor em museus e galerias, seria o cenário apropriado para a experiência transcendental e isolada do exterior:

Essa caixa austera é a arquitetura essencial para a pintura e a escultura essencialistas. Uma versão pop-up tridimensional dos mais puros exemplos bidimensionais da pintura não objetiva, o Cubo Branco é um recipiente perfeitamente moldado a partir dos quadrados brancos (ou com pintura lisa) que se destinava a conter. Nesse lugar, um espectador idealmente desinteressado se defronta com objetos autônomos cuja função é focar a mente perturbada. Não é permitido que contingências remotas ou preocupações mundanas atravessem a entrada desse reino rarefeito, interrompendo assim a troca muda. ${ }^{353}$

Storr tratou então de apontar para os impactos da reação da arte à falência das utopias da modernidade racionalista nesse modelo "purista" de espaço expositivo: "Frequentemente os termos preferidos nessa oposição eram intencionalmente ininteligíveis, estridentes, desdenhosos ou corrosivos. Uma força contrária entra então em cena e sua expressão material ocupa um lugar incerto e desestabilizador no Cubo Branco." ${ }^{354}$ Até esse ponto, sua argumentação parecia apontar para a fra-
352 STORR, Robert. Dislocations. Nova York: The Museum of Modern Art, 1991, p. 18-19.

Tradução nossa

353 Ibidem, p. 19.

354 Ibidem. 
tura que muitos críticos reconheceram como o fim do ciclo modernista. O curador, no entanto, preparara o terreno para defender um outro ponto de vista, o de que transgressões e descontinuidades não seriam contraditórias ao modernismo, mas inerentes a ele, contendo em sua essência o mesmo ímpeto de excluir da arte as imperfeições do mundo:

Qualquer relato da arte moderna que deixe de fora tal multiplicidade de tendências é incompleto, assim como é falsificado qualquer outro que em benefício da polêmica a denuncie como precursora estranha, acontecimento lateral e incômodo ou consequência decadente do alto modernismo. A antiarte é imanente à arte pela arte, assim como a dúvida obscurece a crença e o protesto responde à doutrina. O modernismo, em sua plenitude fraturada, é a história das pequenas perturbações e dos grandes transtornos que essa dialética ocasionou.

Não era incomum que curadores do MoMA defendessem a contemporaneidade da arte moderna, seja rejeitando certos tipos de expressão, como fizera Rubin, seja promovendo o diálogo entre tradição e inovação, como fizera Varnedoe. Ao contextualizar no âmbito da arte moderna uma mostra com sete instalações que se contrapunham ao modo convencional de exposição nas galerias do мома, pode-se imaginar que o texto de Storr transmitisse dois tipos de mensagem. Em primeiro lugar, a de que o museu, ao comissionar instalações especialmente para a exposição, estaria se aproximando tanto dos artistas - com quem teriam que trabalhar em cooperação para a montagem das obras -, quanto do público - estimulado a interagir com elas. Essa impressão era reforçada pelo conteúdo do catálogo que, assim como na mostra Spaces, descortinava o processo de projeto e execução das obras, mostrando mais que apenas imagens acabadas. Por outro lado, o texto podia assegurar os membros mais conservadores da instituição de que, apesar de propositadamente anticonvencional, a mostra não representava um desvio dos propósitos tradicionais do MoмA. Ao afirmar que "o desejo de deslocar ou desorientar responde a um desejo ainda mais profundo de reposicionar e reorientar", ${ }^{355} \mathrm{O}$ curador procurou articular os princípios da exposição à dialé- 
tica dos opostos, que, conforme argumentara, seria inerente ao modernismo.

Amplificando o conteúdo potencialmente transgressor de cada uma das instalações, a distribuição dos trabalhos no museu fugia dos moldes convencionais, ao dispersá-los em vários pontos do edifício. Um grupo com três instalações preencheu toda a galeria do subsolo, que era destinada, segundo o projeto de Pelli, a mostras temporárias. A primeira sala do percurso foi inteiramente escurecida para abrigar a obra de Bruce Nauman, Anthro/Socio, composta por monitores de TV empilhados e três projeções em vídeo sobre grandes áreas de parede, mostrando apenas a cabeça de um homem careca, ora em pé, ora de cabeça para baixo, entoando em diferentes sequências os versos feed me/eat me/help me/hurt me. Ecoando por toda a sala, os sons se sobrepunham e não estavam sincronizados com os movimentos dos lábios do cantor, criando uma experiência inquietante.

A sala seguinte continha a instalação The Bridge, de Ilya Kabakov, que construiu uma estreita passarela elevada cruzando a sala, ocupada por dezenas de pequeninas figuras humanas rodeadas por um amontoado caótico de móveis de tamanho natural e pinturas encostadas nas paredes, que representavam uma cena de destruição de um centro comunitário soviético, conforme descrito num texto afixado na parede. Ao longo da passagem, o público podia observar os personagens por meio de um binóculo, o que criava uma aproximação com a escala real.

A última sala desse grupo continha a obra Twosome de Louise Bourgeois, constituída por dois grandes cilindros de aço - tanques de gasolina em desuso -, o de menor diâmetro escorregando na horizontal para dentro do outro. O movimento evocava o ato sexual - tema dominante na obra da artista -, o que era reforçado pela luz vermelha no interior da peça. Embora a obra tivesse um aspecto escultórico, a relação das peças com a sala e com o público fazia com que adquirisse uma condição de instalação, como defendeu Bourgeois: "É muito importante para mim que as pessoas possam dar a volta na peça. Então elas se tornam parte do ambiente - embora, de certa forma, não seja um ambiente, mas a relação de duas células. A instalação é realmente uma forma entre escultura e teatro." ${ }^{356}$
356 Louise Bougeois in: Ibidem, p.37. 
2.140 Mapa da exposição Dislocations, MoMA, Nova York, 1994. Fonte: https:// www.moma.org/calendar/exhibitions/350

2.141 Bruce Nauman, Anthro/Socio, na exposição Dislocations, MoMA, Nova York, 1994. Foto: Scott Frances. Fonte: https:// www.moma.org/calendar/exhibitions/350

2.142 llya Kabakov, The Bridge, na exposição Dislocations, MoMA, Nova York, 1994. Foto: Scott Frances. Fonte: https:// www.moma.org/calendar/exhibitions/350

2.143 Louise Bourgeois, Twosome, na exposição Dislocations, MoMA, Nova York, 1994. Foto: Scott Frances. Fonte: https:// www.moma.org/calendar/exhibitions/350

2.144 Sophie Calle, Ghost, na exposição Dislocations, MoMA, Nova York, 1994. Foto: Scott Frances. Fonte: https://www. moma.org/calendar/exhibitions/350

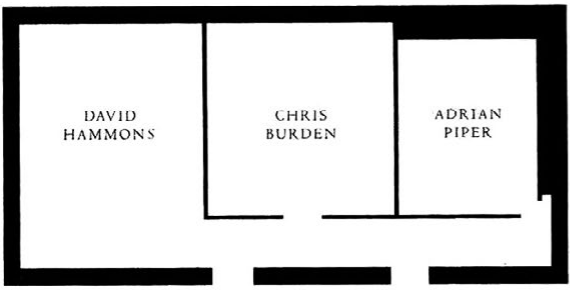

THIRD FLOOR
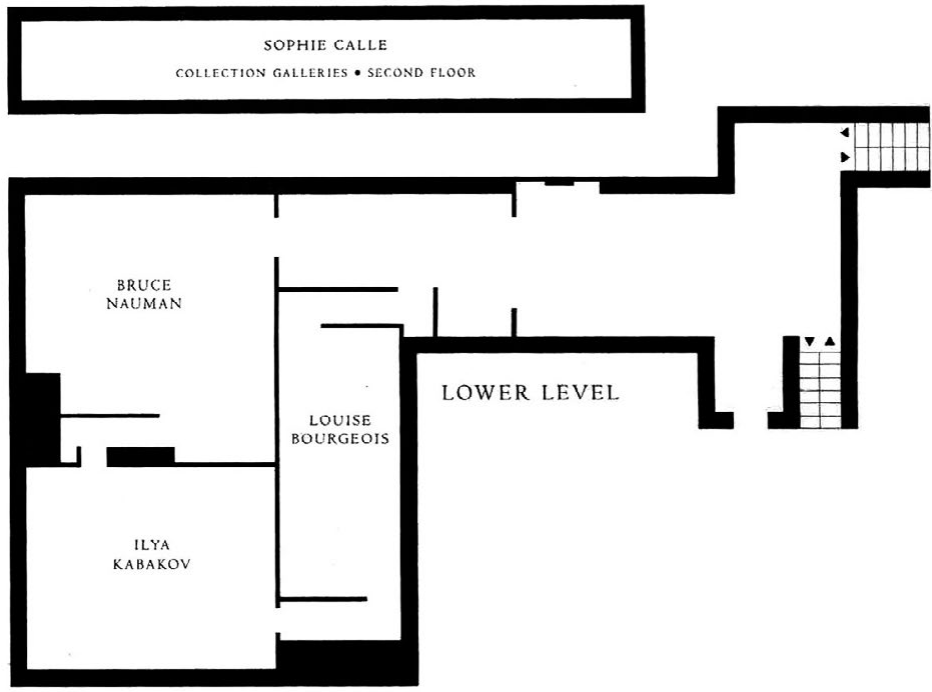

A intervenção de Sophie Calle, denominada Ghost, ocorreu em meio às obras da coleção permanente de arte europeia, localizadas no segundo andar do edifício. Utilizando um expediente associado à arte conceitual, a artista removeu cinco pinturas das paredes, colocando em seu lugar relatos dos funcionários do museu sobre as obras, impressos nas mesmas dimensões dos quadros ausentes.

Outras três obras foram montadas em salas enfileiradas na galeria do terceiro andar, ocupando todo o bloco leste desenhado por Johnson, reservado à coleção permanente de arte contemporânea. Com a instalação What It's Like,What It Is, \#3, a artista Adrian Piper transformou uma das salas numa arena com arquibancadas em todo o perímetro e uma faixa de espe- 

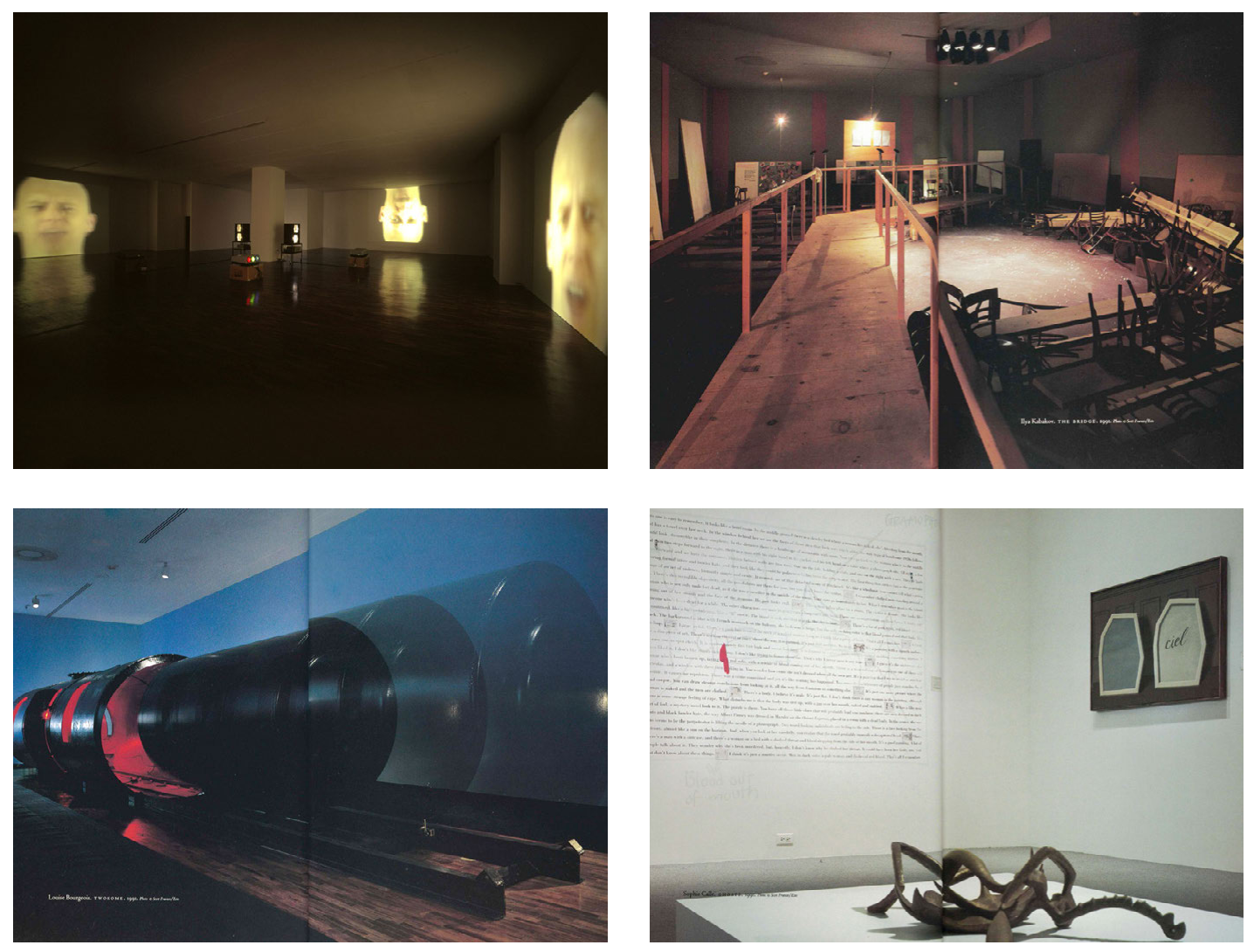

lhos acima, voltadas para um prisma central com monitores de vídeo nas quatro faces. O espectador sentava-se no ambiente todo branco e, enquanto via-se refletido no espelho, assistia à imagem do rosto de um homem afro-americano repetindo dizeres que se contrapunham a estereótipos racistas: "I'm not stupid.... I'm not lazy."

Na sala ao lado, Chris Burden dispôs a obra The Other Vietnam Memorial, contendo uma série de placas de cobre que pivotavam em torno de um cilindro vertical, com a inscrição de nomes de três milhões de vietnamitas mortos durante a guerra do Vietnam. A peça fazia um contraponto ao memorial de Maya Lin, instalado em Washington em 1982, que continha nomes de aproximadamente 58 mil estadunidenses mortos 

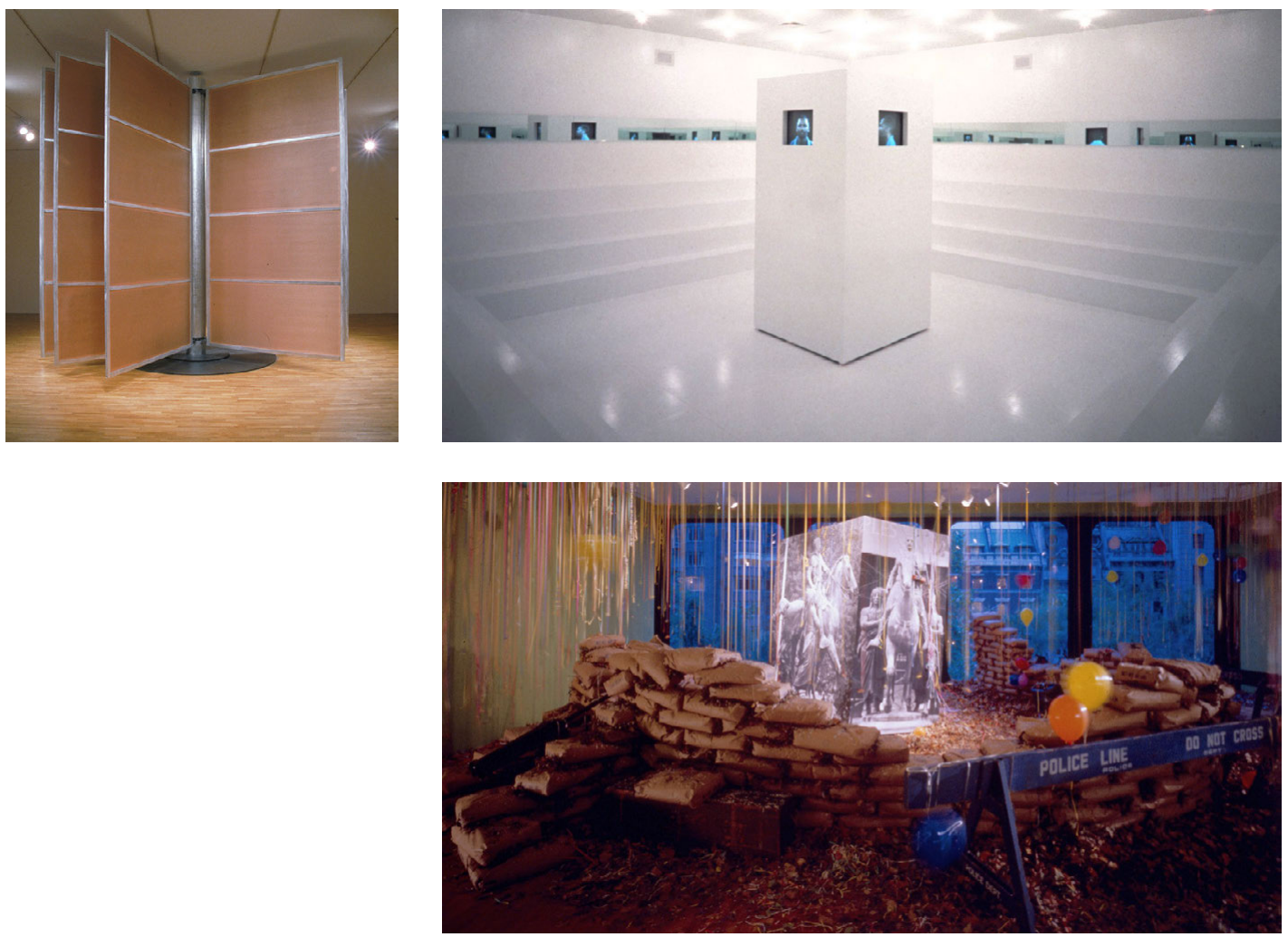

2.145 David Hammons, Public Enemy, na exposição Dislocations, MoMA, Nova York, 1994. Foto: Scott Frances. Fonte: https:// www.moma.org/calendar/exhibitions/350

2.146 Adrian Piper, What It's Like, What It Is, \#3, na exposição Dislocations, MoMA, Nova York, 1994. Foto: Scott Frances. Fonte: https://www.moma.org/calendar/ exhibitions $/ 350$

2.147 Chris Burden, The Other Vietnam Memorial, na exposição Dislocations, MoMA, Nova York, 1994. Foto: Scott Frances. Fonte: https://www.moma.org/ calendar/exhibitions/350 no mesmo conflito. A participação do público se dava com a movimentação das placas, que se abriam como páginas de um livro de grandes proporções, revelando seu conteúdo escrito.

Na terceira sala do conjuto, David Hammons instalou sua obra Public Enemy, a única da exposição a explorar a condição arquitetônica do edifício, mantendo desimpedida a abertura para o jardim pela fachada envidraçada, estabelecendo assim uma relação visual com o contexto urbano. O artista, afrodescendente que vivia no Harlem e trabalhava em parques e terrenos vazios de Nova York, deixou perceptível o quão estranho podia parecer o espaço convencional dos museus para alguém que se identificava com outro ambiente cultural, articulando sua obra a partir dele: 
É difícil lidar com esse cubo branco. Não vejo a importância de interagir com ele. [...] As paredes brancas são muito difíceis porque tudo está fora de contexto. Elas não me dão nenhuma informação. Não é assim que minha cultura percebe o mundo. Nós nunca construiríamos uma forma como essa ou salas desse modo. Para nós, isso é para pessoas loucas - você é colocado nelas no hospital. Nunca tinha visto um lugar com esse tipo de sala até entrar no mundo da arte..$^{357}$

A estratégia de Hammons para confrontar esse espaço, que lhe pareceu de uma estranha pureza, foi saturá-lo com elementos variados provenientes do "mundo real". Sacos de areia formando uma barricada foram empilhados ao redor de grandes reproduções fotográficas, mostrando ângulos de uma escultura posicionada em frente ao American Museum of Natural History. A imagem representava o presidente dos EUA Theodore Roosevelt (1858-1919) montado num cavalo, acompanhado de um lado por uma figura de um indígena estadunidense e de outro por um afro-americano, ambos a pé. Apontando sua mira para a foto, metralhadoras apoiavam-se sobre a barricada, por sua vez cercada por barreiras policiais. Carregando ainda mais o ambiente, um papel de parede estampado de coloração verde revestia as paredes e folhas secas cobriam o chão, balões de festa flutuavam no ar e fitas coloridas pendiam do teto, enquanto ressoavam ruídos de helicópteros. Com sua instalação alegórica, Hammons subvertia a assepsia do cubo branco, acirrando a sensação de incômodo e deslocamento proposta por Storr.

Para o curador, o estranhamento provocado tanto por cada um dos trabalhos individuais - que abrangiam diferentes linguagens -, quanto por sua distribuição inusual no museu, tinha o potencial de incitar a participação do público, levando-o a tomar consciência de suas sensações e perspectivas:

Dislocations, portanto, implica mudanças calculadas de localização e ponto de vista e a colaboração indireta do artista e do público no mapeamento de espaços anteriormente não imaginados, ou no remapeamento dos que são dados como óbvios. Esse envolvimento do público é exigido na exposição,
357 David Hammons in: Ibidem, p. 55 . 
358 Ibidem, p. 20.

359 É o caso das críticas de Adam Gopnik ("Empty Frames," The New Yorker, 25/11/1991) de Roberta Smith ("In Installation Art: A Bit of the Spoiled Brat", The New York Times, 18/10/1991) e de Hilton Kramer (“мома Mia,You Call This Art?", New York Observer, 4/11/1991). Cf. REISS, op. cit., pp.146-148.

360 Adam Gopnik (op.cit.) e Arthur C. Danto ("Dislocationary Art", The Nation, 6/1/1992). Cf. REISS, op. cit., pp.148-149.

361 Mais uma vez Adam Gopnik (op.cit.) e também Holland Cotter ("Dislocating the Modern", Art in America 80, no.1, 3/1/1992). Cf. REISs, op. cit., p.149. uma vez que os artistas [...] prepararam com cuidado o cenário para o nosso estranhamento inicial. Todos testam nossa visão quanto a hábitos impacientes de observação e o reflexo da necessidade de segurança quando confrontados com circunstâncias desconhecidas ou causas familiares - mas difíceis de suportar - de ansiedade. Cada um exige que o observador individual reconsidere sua identidade à luz de uma determinada situação e a liberdade ou restrição de movimento - portanto, perspectivas - impostas a ele dentro dela. ${ }^{358}$

Dislocations desempenhou um papel importante na história do MомA, mas também impactou o modo como as obras foram recebidas. Como já havia ocorrido com Spaces, os artistas puderam contar com recursos financeiros em geral bem maiores do que o habitual, fato que impactou em suas decisões. Hammons, por exemplo, que construía suas obras fora do universo dos museus a partir de dejetos, havia cogitado deixar o ambiente vazio exceto por uma fatia de pão colocada no centro da sala, mas acabou preferindo empregar todo o orçamento à sua disposição na instalação, despendendo um valor bem mais alto do que de costume. Para diversos críticos, o resultado foi inconsistente com sua obra anterior, o que não seria exclusividade de seu trabalho, uma vez que o volume de recursos empregados nas instalações realizadas nos museus, em geral muito maior do que em espaços alternativos, chamava a atenção do espectador e dificilmente deixaria de afetar sua percepção.

Boa parte das reações à exposição não questionaram o fato de o MoмA estar abrigando instalações, mas acusaram as obras de privilegiar conteúdos abertamente políticos em detrimento das qualidades estéticas que o museu sempre valorizara. ${ }^{359}$ Houve também críticas que apontaram para o fato de que, ao ocupar grandes áreas de um museu com a autoridade do MOMA, as instalações adquiriam um prestígio que tendia a abafar o conteúdo crítico que tais artistas desejavam expressar. ${ }^{360}$ Outros, por fim, questionavam se alguns dos trabalhos efetivamente se enquadravam na categoria instalação, que dependeria tanto de sua condição de site-specific quanto do fato de integrar a participação do espectador. ${ }^{361}$ 
A soma das variadas repercussões aponta para o fato de que quanto mais relacionada estivesse a arte ao seu contexto - englobando dimensões arquitetônicas, políticas, sociais, culturais etc -, maior seria o peso da instituição que a abrigava no modo como seria percebida. O sentido de uma exposição como Dislocations, como mostrou o próprio Storr, dependia do fato de ter sido realizada no MомA:

Espalhados por todo o museu, incluindo a sutil intervenção na coleção 'permanente', as obras da exposição estão, enquanto durarem, ligadas às muitas constelações comparáveis do passado recente e não tão recente que ocupam os salões separados no interior do amplo edifício do modernismo. Espera-se que, com sua presença, esses trabalhos venham a destacar algumas das conexões entre essa estrutura e o mundo ao seu redor. ${ }^{362}$

O modo como Storr explorou o espaço do museu na exposição Dislocations pode ser lido como uma solução engenhosa para reaproximar o museu das práticas contemporâneas, entendendo a necessidade de dessacralizar a arte, aproximá-la de seu contexto mundano e ampliar a diversidade de artistas. A dificuldade de fazer isso no interior do MOMA, considerado um "templo" da arte moderna, pode explicar tanto a ousadia empregada por Storr na configuração de sua exposição de estreia no museu, quanto a cautela de sua argumentação em favor da continuidade do modernismo, validando a atualidade da missão do museu.

\subsection{MOMA E PS1: 0 ENCONTRO DE DOIS PARADIGMAS OPOSTOS NO FIM DO SÉCULO XX}

\subsubsection{A CONSOLIDAÇÃO DO PS1 COMO MODELO PARA A ARTE CONTEMPORÂNEA}

Enquanto a aproximação entre instalações de arte e museus estabelecidos se deu mediante uma acomodação de ambas as partes, espaços de arte associados à arte contemporânea também se transformavam, movimentando-se rumo à institu- 
363 Entre as mostras de artistas estadunidenses realizadas na década de 1980 no PS1 destacam-se as individuais de Barbara Kruger - 1980, Robert Grosvenor - 1984, John McCracken - 1986, Richard Tuttle - 1988, Jackie Winsor - 1988 e David Hammons - 1990 e as coletivas Afro-American Abstraction - 1980, New York/New Wave - 1981, Timeline: The Chronicle of US Intervention in Central and Latin America - $1984 \mathrm{e}$ Forced Out: The Agony of the Refugees in Our Time - 1990. Entre as internacionais, destacam-se as mostras de Anette Messager - 1981, as coletivas Expressions: New Art from Germany - 1983, The Knot: Arte Povera at P.S.1 - 1985, Brazil Projects - 1988 e China-1989. Cf. Johnatan Lill in: BIESENBACH; FUNCKE (Orgs.), MOMA PS1: A History, p. 78-79. cionalização. A trajetória do PS1 exemplifica esse processo, que vinha se intensificando desde a sua criação em 1976. A gestão da imensa área disponível de seu edifício envolvia uma agenda complexa, com artistas ocupando de 10 a 20 salas com mostras individuais, ao mesmo tempo em que exposições coletivas de variadas escalas eram organizadas por curadores, algumas focadas em mídias específicas, como poesia, moda, arquitetura, vídeo, filme e fotografia.

Formalizado no National and International Studio Program, o programa idealizado por Alanna Heiss para o PS1 costumava expor numa mesma temporada de 50 a 100 artistas provenientes de todas as regiões dos EUA e de outros países, especialmente da Europa, muitas vezes financiados por seus locais de origem. Além disso, a cada ano eram selecionados para o programa de residência 40 artistas para montar seus estúdios no edifício, onde por vezes chegavam a morar. Diversos artistas estadunidenses que viriam a se tornar importantes realizaram suas primeiras individuais no PS1, quando ainda não eram conhecidos, enquanto a programação tornou-se altamente internacionalizada, incluindo mostras de regiões consideradas mais periféricas e exposições de caráter acentuadamente político, vinculadas a questões da atualidade. ${ }^{363}$ As curadorias continuavam enfatizando, ao invés de objetos acabados, obras site-specific que exploravam as características do edifício escolar.

Mantendo uma abertura incomum para a arte pouco estabelecida e mesmo sem contar com uma fonte estável de financiamento, o centro se firmava como uma referência na cena da arte contemporânea. Embora fosse visto como um espaço alternativo em comparação com instituições tradicionais, sua atuação mirava no universo dos museus, ainda que com a intenção de confrontá-lo, mantendo uma intensa participação de artistas na definição de sua programação, baseada em concepções curatoriais variadas, mas consistentemente comprometidas com inovações. Daí que, mesmo operando apenas com mostras temporárias e sem constituir uma coleção - nos moldes de uma kusthalle -, o centro tenha mudado seu nome para PS1 Museum em 1988. Embora suas diversas iniciativas para promover a arte contemporânea tivessem girado em torno da noção de "alternativo", Alanna Heiss fazia uma distinção 
muito clara entre o projeto do centro e o dos espaços que havia organizado no início dos anos 1970:

Eu deixei o espaço alternativo, do qual a Clocktower é um excelente exemplo, para construir de um museu alternativo, que consistia em assumir uma responsabilidade de longo prazo em pagar as contas do aquecimento, da energia elétrica, do telhado - as próprias coisas sobre as quais, como organizadores de guerrilhas, não se assume a responsabilidade. Tudo o que você faz com a guerrilha é ocupar o espaço, fazer exposições, divulgá-las e jogar tomates nos grandes. E quando você ocupa um espaço como o PS1, está dizendo, ok, eu também sou grande $\mathrm{e}-$ mas eu irei operar de maneira diferente. E esse era o meu lema. ${ }^{364}$

O PS1 teria um compromisso de outra ordem, daí que o museu fosse uma referência, ainda que fosse para ser subvertida:

O PS1 é o único museu radical de sucesso no mundo nesses termos - nunca foi pensado como um espaço alternativo. Era uma perspectiva completamente diferente. Tudo o que fiz foi com ou contra o mundo dos museus. Espaços alternativos eram outra coisa. Era como brincar, era como se divertir com artistas fazendo festivais. O PS1 era muito sério. ${ }^{365}$

O processo de institucionalização para o qual se dirigia o PS1 não era visto como uma ameaça à sua razão de ser, como no caso de espaços alternativos, mas, ao contrário, como uma consequência desejável de seu sucesso, um reconhecimento de que era possível operar um "museu" de arte contemporânea independente de certas amarras das instituições convencionais. Como afirmou Johnatan Lill, "Ao final da década, o PS1 não era mais um arrivista no mundo da arte, mas uma instituição de Nova York, o 'lugar normal' que Heiss tinha vislumbrado.”366

Apesar da vitalidade da programação e da boa receptividade dos artistas, o PS1 ainda não atraia um número significativo de visitantes no início dos anos 1990, a não ser em eventos agendados, como inauguração de exposições. O bairro do Queens vinha recebendo outros centros de arte instalados
364 HeIss, 2010, op. cit., p. 21. Tradução nossa.

365 HeIss, 2014, op. cit., p. 14. Tradução nossa.

366 Ibidem, p. 79. Tradução nossa. 


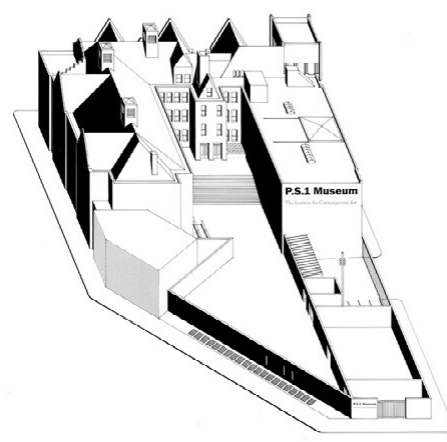

2.148 Isométrica do projeto de reforma do PS1 Contemporary Art Center, de Frederick Fisher and Partners Architects, Nova York, 1997. Fonte: https://fisherpartners.net/ projects/moma-ps1-renovation/
367 Cf. Truppin, Andrea. P.s.1 Contemporary Art Center, Long Island City, New York. Architectural Record, n. agosto de 1998, 1998.

368 Ibidem, p. 119.

369 Ibidem, p. 119. Tradução nossa.

370 Frederick Fisher, in:

BIESENBACH; FUNCKE, op. cit., p. 182 .

371 Pelo projeto, Frederick Fisher recebeu em 1998 do New York Municipal Arts Society o Prêmio Brendan Gill (criado em homenagem ao escritor e crítico de arquitetura que dirigira o órgão até sua morte, no ano anterior). em edifícios industriais, mas, embora facilmente acessível por metrô a partir de Manhattan, era tido como afastado do circuito artístico da cidade. Apesar das grandes dimensões, o edifício não podia ser completamente aproveitado devido ao seu estado ainda precário e por conter muitos espaços sem requisitos adequados de acessibilidade. ${ }^{367}$ Se a deterioração da antiga escola havia sido um trunfo quando o centro foi aberto, permitindo que artistas tomassem seus espaços como terreno aberto a intervenções variadas, incluindo algumas destrutivas, os dispendiosos esforços na execução de reparos e manutenção para que tivesse condições funcionais mínimas desviavam a atenção que se desejava empregar na realização da intensa programação artística.

Aprofundando o movimento de institucionalização desencadeado com a própria instalação em 1976 do centro de arte contemporânea num grande imóvel público, iniciou-se em 1994 um processo de reforma do edifício do PS1, viabilizado na maior parte por fundos da prefeitura de Nova York. Liderado pelo escritório de Frederick Fisher, arquiteto sediado na Califórnia com experiência em espaços de arte, o projeto contou com a intensa colaboração de um comitê de artistas composto por James Turrell, Richard Nonas, Richard Deacon e Robert Ryman. ${ }^{368}$ Mantendo-se à frente do processo, Alana Heiss acreditava que o envolvimento de escultores nas decisões era especialmente valioso, "porque eles frequentemente se deparam com problemas de espaço". ${ }^{369}$ Fisher, por sua vez, reconheceu que sua abordagem veio da proximidade com artistas como Eric Orr, James Turrell e Robert Irwin, que ensinaram sua equipe a "abraçar sem preconceitos a materialidade e a experiência dos espaços. ${ }^{370}$ A participação decisiva de artistas nas definições da reforma pode ser entendida como uma intenção de assegurar que o espírito de abertura à criação que caracterizava o PS1 fosse mantido nas diretrizes da renovação. Se o processo teve um resultado arquitetônico inovador para um espaço de arte, este não era visível nas características de cada ambiente expositivo, mas na combinação de espaços muito bem-acabados com outros deixados no estado bruto do edifício original, considerados site-specific. ${ }^{371}$ 

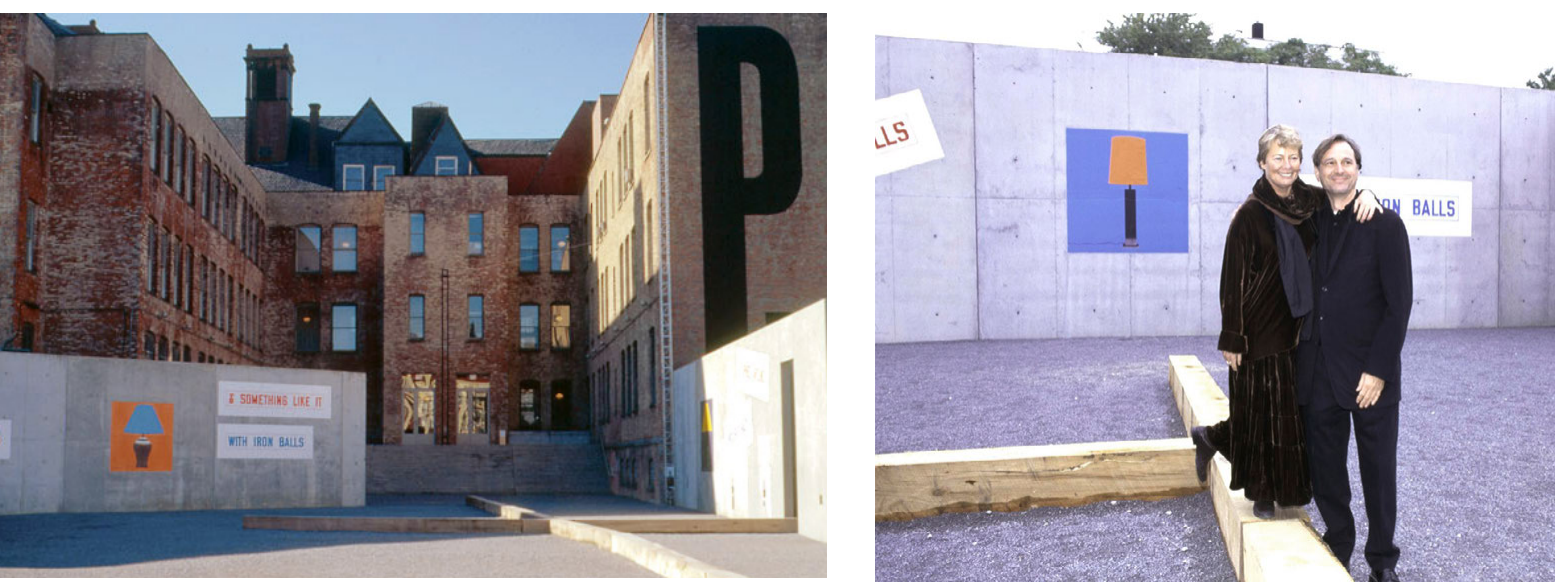

A intervenção mais marcante do projeto foi a inversão da posição da entrada, incorporando as áreas livres de um estacionamento adjacente e do pátio, que abrigava as atividades de recreação nos fundos da antiga escola, e aproximando a área de acolhimento do público à estação de metrô, mais recente que o edifício. A área externa foi subdividida em espécies de salas expositivas ao ar livre, delimitadas por muros de concreto aparente que, conforme afirmou Fisher, isolariam o pátio do "caos visual da vizinhança", criando um "ambiente neutro disponível para todo tipo de instalação, performance e socialização." ${ }^{372}$ Mesmo que o PS1 tenha se notabilizado por espaços que instigavam a interação com o contexto real, o arquiteto advogava pela necessidade de oferecer à atuação de artistas ambientes isolados, sem interferências externas, que pudesse ser totalmente controlados pela obra: "Boa parte da arte precisa ser hermeticamente isolada para estabelecer seu próprio território. Quando contido, o artista constrói o ambiente e cria o mundo." 373

As afirmações de Fisher evidenciam que a reforma do PS1 não tinha como objetivo apenas de dar condições funcionais e de acessibilidade ao antigo prédio, mas de dotá-lo de espaços nos moldes convencionais associadas a galerias e museus de arte. No interior, enquanto alguns ambientes mantiveram visíveis o aspecto desgastado, as marcas da história e os materiais da
2.149 Pátio do PS1 Contemporary Art Center, projeto de reforma de Frederick Fisher and Partners Architects, Nova York, 1997. Fonte: http://www.markorange. com/projects/int-fred-fisher/images.html

2.150 Alanna Heiss, diretora do PS1 Contemporary Art Center, e o arquiteto Frederick Fisher, na reabertura do centro, Nova York, 1997. Fonte: https://press. moma.org/news/moma-announcedpublication-on-the-history-of-moma-ps1/
372 Ibidem. Grifo nosso.

373 Frederick Fisher apud TRUPPIN, op. cit., p. 119. Tradução nossa. 


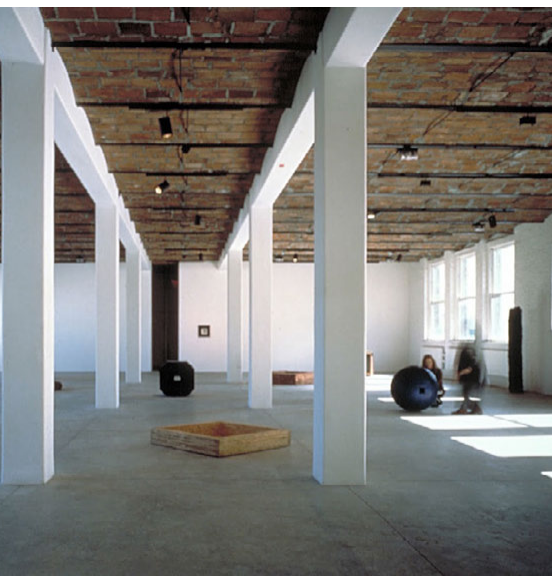

2.151 Vistas de salas renovadas do PS1 Contemporary Art Center, projeto de Frederick Fisher and Partners Architects, Nova York, 1997. Fonte: https://fisherpartners.net/projects/ moma-ps1-renovation/

2.152 James Turrel, Meeting, PS1 Contemporary Art Center, Nova York, 1980. Fonte: https://jamesturrell.com/work/ meeting/
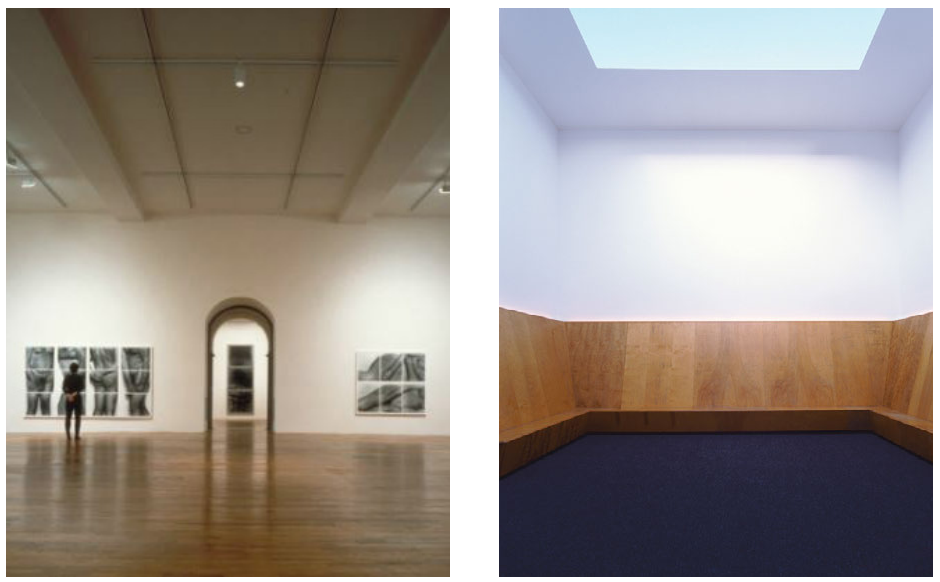

construção original - como paredes de tijolos, vigamentos de madeira e lajes abobadas -, outros foram renovados segundo o padrão "cubo branco", num tratamento propositadamente não homogêneo do edifício, definido de acordo com as características e condições variadas de cada espaço. Algumas intervenções artísticas realizadas anteriormente foram mantidas, como a obra de James Turrell Meeting, de 1980, que consistia numa abertura no teto de uma sala do pavimento superior, enquadrando a vista do céu em permanente mutação.

A estrutura de circulação permaneceu a mesma, com seis prumadas de escada conectando os corredores que acessavam as salas de aula convertidas em galerias, algumas delas ampliadas pela remoção de subdivisões. Desse modo, não se tentou organizar um percurso único de visitação, como em museus tradicionais, mas, segundo Fisher, preservar "a liberdade do visitante de perambular à vontade, construindo uma experiência pessoal parcialmente mediada". ${ }^{374}$ Não havia, porém, uma intenção de fazer uma distinção clara entre espaços de circulação e de exposição, pois intervenções de arte podiam ocorrer em qualquer parte do edifício, incluindo corredores e escadas, convivendo com vestígios de mostras anteriores.

Durante os três anos em que transcorreu a reforma, o PS1 ficou fechado apenas por um ano, com pequenas mostras ocorrendo simultaneamente às obras no tempo restante. Passando 

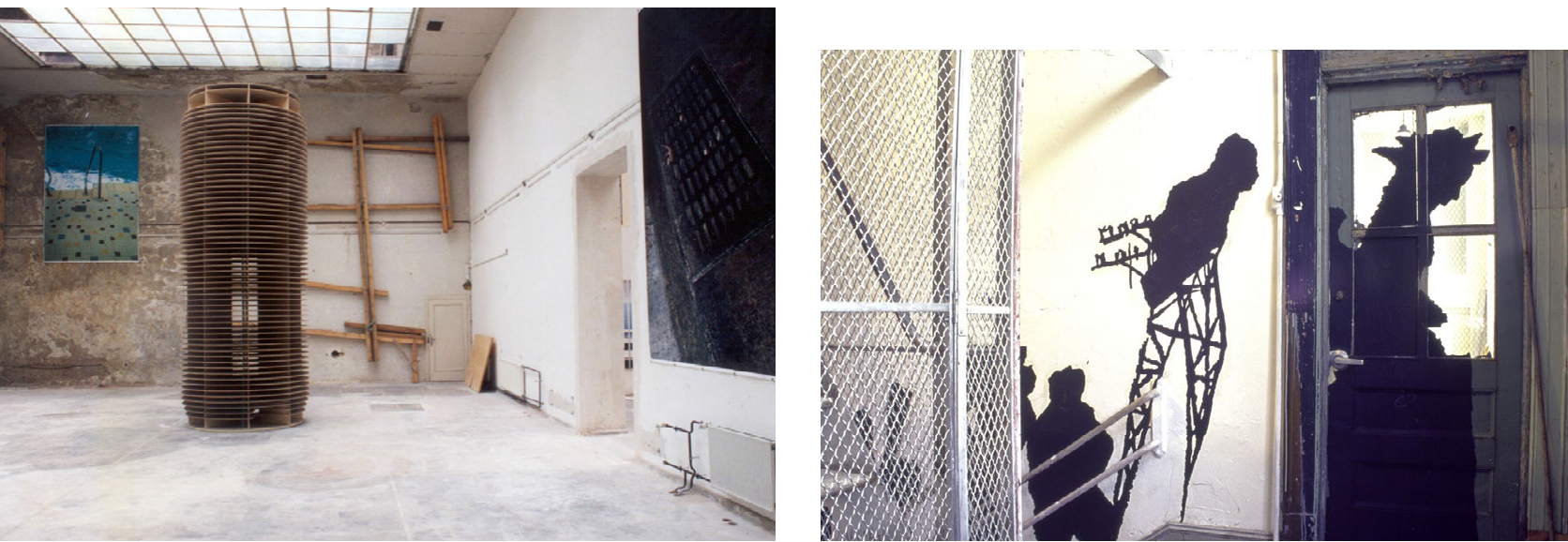

de uma área de aproximadamente $7.800 \mathrm{~m}^{2}$ para $11.600 \mathrm{~m}^{2}$, o edifício continuava sendo um dos maiores espaços de arte contemporânea do mundo. Na reinauguração ocorrida em outubro de 1997 - sob o novo nome de P.s.1 Contemporary Art Center -, o edifício foi inteiramente ocupado por exposições organizadas por um time de curadores, entre os quais Klaus Biesenbach, que passou a colaborar com o PS1 em 1996, trazendo sua experiência como um dos fundadores e diretor do Kunst-Werke Institute for Contemporary Art (KW) de Berlim. Causando impacto no meio de arte de Nova York, o evento contou com instalações de mais de 100 artistas, com retrospectivas de Jack Simth e Jackie Winsor e com a inauguração da série Vertical Painting, dedicada a intervenções site-specific nas escadas. ${ }^{375}$

Em 1998, o pátio passou a abrigar a cada verão eventos interdisciplinares integrando música e arquitetura. Nas tardes de fim de semana acontecia o Warm-up, um programa curatorial dançante, incluindo música eletrônica, house, hip hop, rock e sons experimentais que atraiu milhares de pessoas para ao PS1. Para o primeiro evento, foi realizada a série de instalações Percutaneous Delights, do grupo austríaco Gelatin, contendo piscinas, chuveiros, solários, saunas e ambiente refrigerados, estabelecendo as bases de um programa de intervenções arquitetônicas que, assim como o Warm-up, tornariam-se permanentes no centro. ${ }^{376}$
2.153 Vista da 1a Bienal de Berlim, KunstWerke Institute for Contemporary Art (KW), 1996. Fonte: https://news.artnet.com/ art-world/klaus-biesenbach-making-berlinbiennale-506594

2.154 William Kentridge, Stair Procession, da série Vertical Painting, PS1

Contemporary Art Center, Nova York, 1997. Foto: Eileen Costa. Fonte: https://www. moma.org/calendar/exhibitions/4692

375 A série Vertical Painting ocorreu de outubro de 1997 a junho de 1998 e contou com intervenções de 14 artistas, entre os quais Cecily Brown, R.H. Quaytman, William Kentridge e Mary Heilman, algumas ainda visíveis no local.

376 Cf. MoMA PS1. Young Architects Program 1998: Percutaneous Delights by Gelatin (Jun 30-Aug 30, 1998). МОМА. Disponível em: $<$ https://www.moma.org/calendar/ exhibitions/3702>. Acesso em: 26 jul. 2020. 


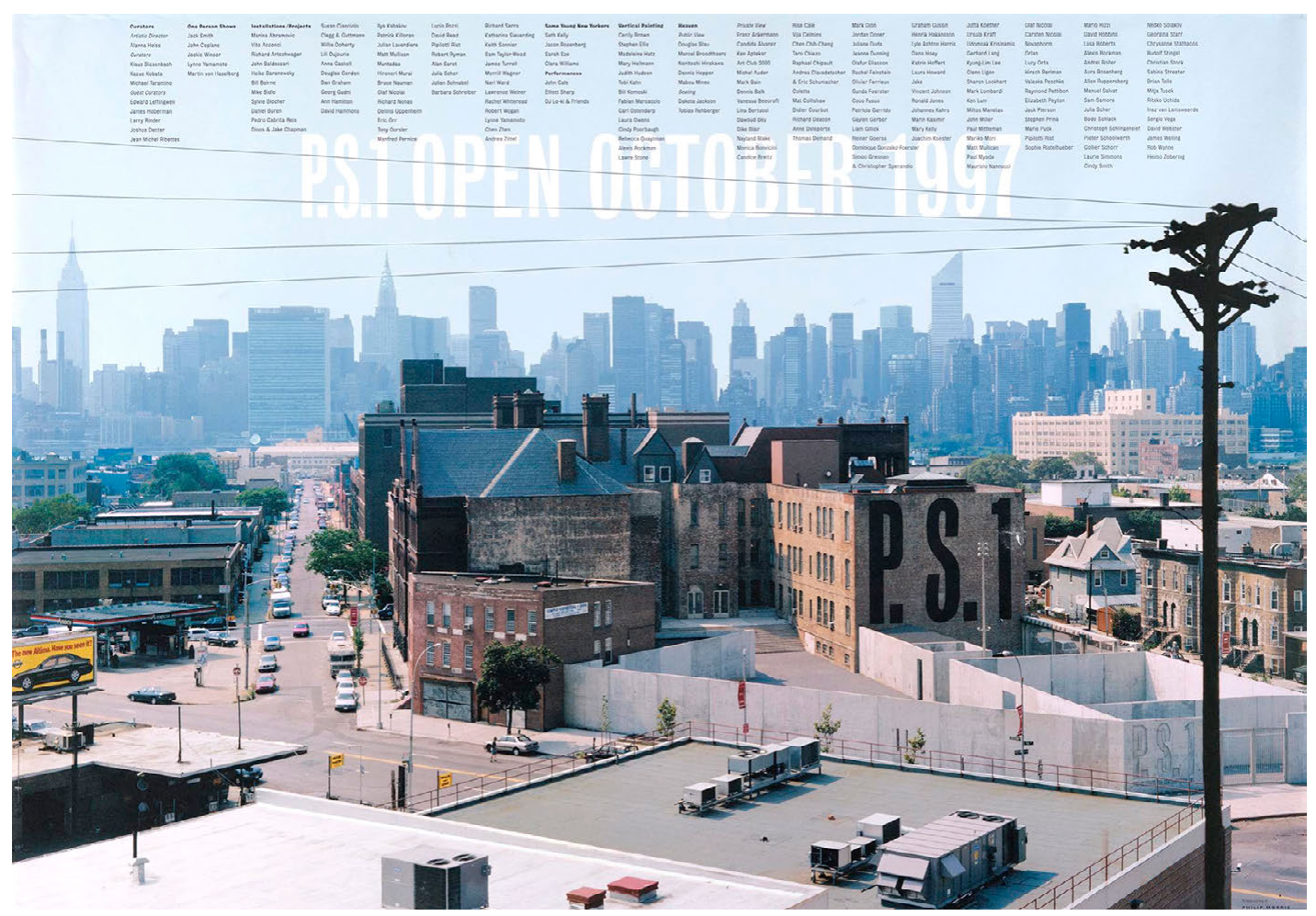

2.155 Cartaz da reabertura do PS1 Contemporary Art Center, Nova York, 1997. Fonte: https://press.moma.org/news/ moma-announced-publication-on-thehistory-of-moma-ps1/

377 HeISs, 2014, op. cit., p. 16. Tradução nossa.
Tendo solucionado muitos dos problemas do edifício, permitindo a ampliação do espaço e da programação, a reforma teve também como consequência um novo grau de compromisso com o público, uma vez que as obras tinham sido custeadas com recursos do município, que também bancava parte dos custos anuais de operação do centro. Como contou Heiss, "antes disso, era um museu noturno. Era um museu clube. Entrar lá já era o museu. Sortudo de quem conseguisse entrar. Nunca tivemos que divulgar nossas aberturas. Dane-se. Tente entrar. Era assim mesmo.” ${ }^{377}$ Mudando seu perfil, o PS1 via-se agora diante de novas obrigações: cumprir horários fixos de funcionamento, permanecer aberto por muitos dias da semana, administrar um número maior de funcionários e assegurar o bom estado de funcionamento do edifício, além de continuar gerenciando a complexa programação numa área 


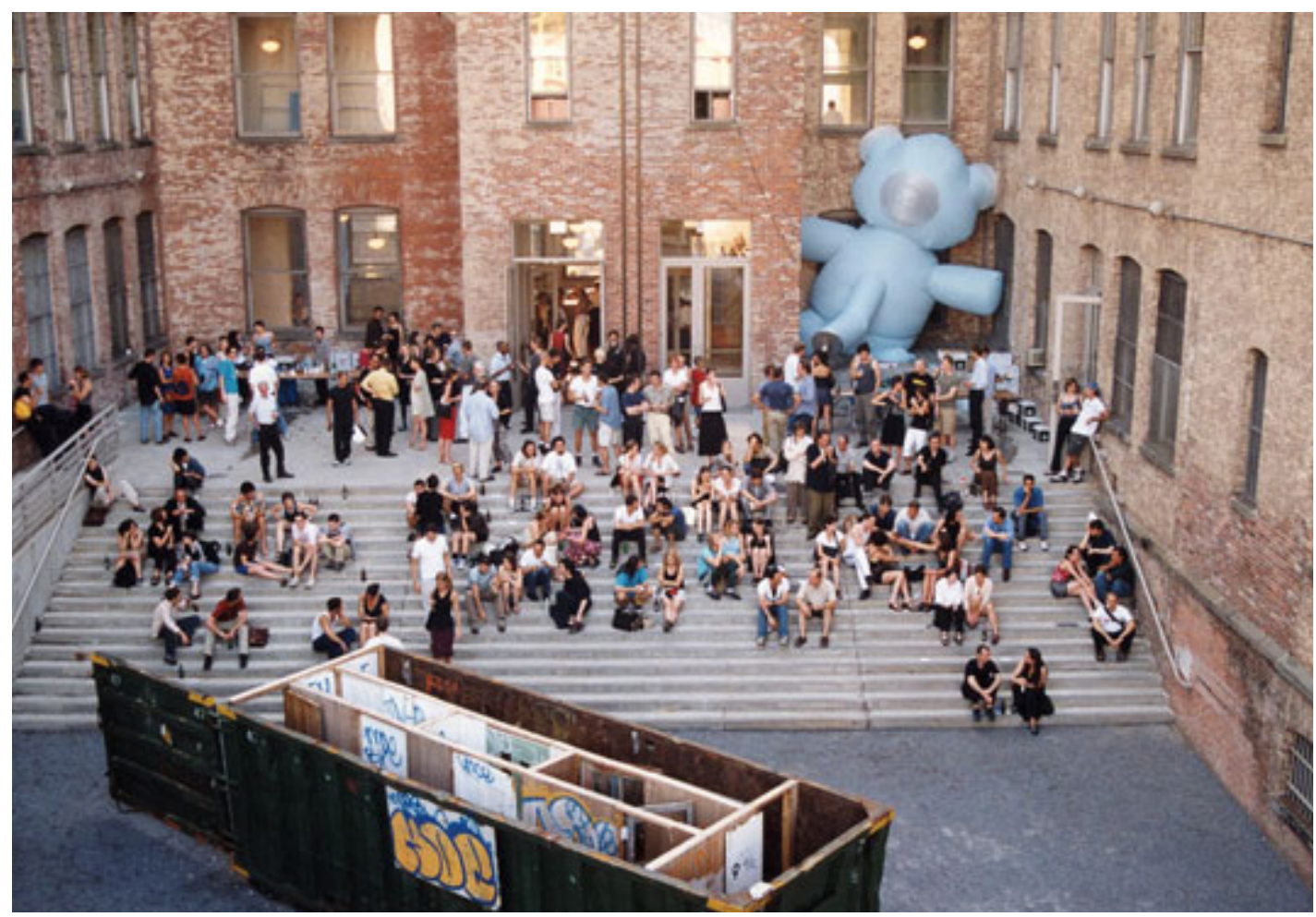

expandida, envolvendo uma equipe renovada de curadores conectados a uma rede de artistas nacionais e estrangeiros. Tendo conquistado inclusive uma certa organização financeira, o centro atingia um novo estágio de maturidade, tornando-se uma referência de espaço dedicado à arte contemporânea, não apenas no âmbito local, mas também no cenário internacional, inspirando novas iniciativas pelo mundo. ${ }^{378}$

\subsubsection{UMA FUSÃO INESPERADA}

A reinauguração do PS1 coincidiu com o momento em que o MOMA promovia um concurso de arquitetura para projetar uma de suas mais ambiciosas ampliações de sua sede, que culminou em dezembro de 1997 com a seleção do escritório de
2.156 Vista do pátio do PS1 Contemporary Art Center com a instalação de Gelatin, Percutaneous Delights, e de Gordon MattaClark's, Open House (dumpster), Nova York, 1998. Fonte: https://www.moma.org/ interactives/moma_through_time/1990/ urban-beach-hamptons-for-hipsters/
378 Cf. HEISs, 2010, op. cit., p. 23. 


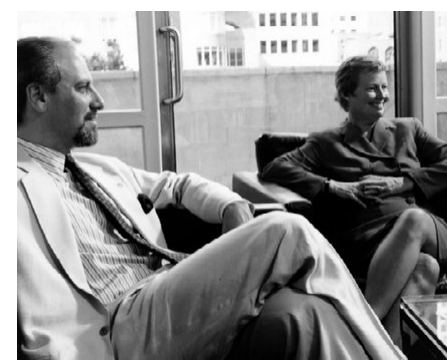

2.157 Glenn Lowry, diretor do MoMA de Nova York, e Alanna Heiss, diretora do PS1 Contemporary Art Center, durante uma entrevista, Nova York, 1999. Foto: Mark Morosse. Fonte: https://www.moma.org/ interactives/moma_through_time/1990/ the-avant-garde-and-the-old-guard/
379 Como relatou Glenn Lowry, a resposta inesperada de Alanna Heiss sobre a parceria foi "I'm not really interested in dating. I'm interested in marriage." In: BIESENBACH; FunCKE, op. cit., p. 4.
Yoshio Taniguchi para a tarefa, como veremos em detalhe no próximo capítulo. Desde 1995, o museu vinha sendo dirigido pelo historiador da arte Glenn Lowry (1954-), que conduzia sua gestão em prol da valorização da arte contemporânea e dos artistas atuantes. No final de 1998, o diretor entrou em contato com Alanna Heiss, a fim de estudar uma parceria para realizar algumas atividades do MoмA durante o período de fechamento parcial da sede de Manhattan a partir de 1999, para viabilizar a realização das obras. Heiss, no entanto, manifestou seu interesse não por um acordo efêmero, mas por uma parceria de longa duração do PS1 com o MOMA, desencadeando uma rápida negociação que, causando surpresa geral no meio artístico ao ser anunciada oficialmente em fevereiro de 1999, resultou num plano de fusão das duas instituições, previsto para desenvolver-se ao longo de uma década. ${ }^{379}$

Para uma instituição com o peso do MOMA - que ao completar 70 anos atraía mais de 1,6 milhões de visitantes por ano, dispunha de uma alocação de verbas da ordem de 300 milhões de dólares e possuía a principal coleção de arte moderna e contemporânea do mundo -, não parecia haver grandes desvantagens em se associar ao PS1, ainda que este se identificasse como um anti-museu. Ao contrário, o MOMA poderia contar não apenas com a grande área do edifício renovado do PS1 - o que era especialmente auspicioso no momento da reforma de sua própria sede -, mas também com a experiência de uma gestão mais arejada e próxima aos artistas, que tinha o potencial de promover uma reaproximação do museu com a arte contemporânea, o que vinha há tempos mostrando-se uma dificuldade da instituição. Para muitos dos que valorizavam o espírito irreverente do PS1, a parceria foi tida como problemática. $\mathrm{O}$ receio era de que o centro, desproporcionalmente menos poderoso, estivesse cedendo ao modo tradicional de operar do MOMA, tornando-se uma entidade tão engessada quanto as que sempre criticara, e deixando de oferecer oportunidades de desenvolvimento de expressões de arte divergentes das valorizadas pelos museus.

Como observara Reiss, no entanto, mesmo manifestações nascidas num contexto alheio ao dos museus, como a instalação, já haviam sido nos anos 1990 amplamente incorporadas 
pelas principais instituições de arte do mundo, indicando uma atenuação das diferenças entre os espaços alternativos e os mais estabelecidos, como evidenciava a nova parceria:

"O anúncio da fusão é chocante, dada a história das duas instituições e do papel do PS1 na promoção de arte radical, como instalações. Sem dúvida, esta nova união contribuirá com a autoridade do MOMA para a arte mostrada no PS1, conferindo ainda mais legitimidade à instalação em todo o mundo da arte. A fusão é uma evidência tangível do arco evolutivo da instalação artística em direção ao convencional, o movimento final para o centro." ${ }^{380}$

Alana Heiss, por sua vez, estava interessada em "dar continuidade ao grande museu alternativo de um modo que pudesse continuar sendo uma alternativa a um museu." ${ }^{381}$ Em sua perspectiva, a fusão apresentava-se como uma possibilidade de garantir a longevidade do projeto do PS1 independentemente de seu envolvimento pessoal, que havia sido decisivo para as conquistas alcançadas ao longo de duas décadas de funcionamento: "uma das principais razões pelas quais eu estava interessada em me fundir com o MoмA foi perceber que haveria novas ideias e sustentação para esse lugar querido, para além da minha capacidade." ${ }^{382}$ Entre seus receios, estava o de que o PS1 se transformasse futuramente num centro de arte sofisticado ou numa instituição voltada a coleções. Para Heiss, a formação de um acervo de arte contemporânea seria incompatível com o conceito de anti-museu, pois acreditava que a realização de exposições valorizando obras consolidadas da coleção seria uma tendência dominante nos museus de arte, que acabaria inevitavelmente desviando o foco das novas produções. Daí que tenha propositadamente evitado dotar os espaços do PS1 de condições museológicas convencionais, como controle de temperatura e umidade para preservação de obras de arte. ${ }^{383}$

Embora a fusão pudesse trazer uma estabilidade financeira sem precedentes para o PS1, a sustentação ambicionada por Heiss não era apenas dessa ordem. Em sua opinião, associar-se ao MOMA não era uma rendição ao status quo ou uma demons-
380 REISS, op. cit., p. 157.

Tradução nossa.

381 HeIss, 2010, op. cit., p. 22. Tradução nossa.

382 Heiss, 2104, op. cit., p. 17. Tradução nossa.

383 Ibidem, p. 16-17. 
tração de fragilidade, mas uma vantajosa oportunidade de levar um centro de arte contemporânea que se desenvolvera de modo singular, à margem das instituições convencionais, a se confrontar com o principal museu de arte moderna, tendo acesso à sua coleção, expertise curatorial e estrutura de divulgação - incluindo publicações e ações educativas - e podendo, em troca, promover uma renovação na atitude do museu perante a produção de vanguarda:

No final, em 2000, eu pensei: somos muito fortes. Não temos dívidas reais. Temos uma dívida de 100 mil dólares - isso não é nada. Temos um conselho fabuloso, um conselho muito poderoso. Temos artistas alinhados em todo o mundo. O que restou? O que parecia interessante, então, era confrontar o Museu de Arte Moderna - o adversário definitivo desde o início! O que somos hoje? Podemos trabalhar juntos? O maior museu de arte moderna do mundo - na minha opinião - e o PS1, que não tinha que ser o melhor - o melhor é uma palavra comum -, mas certamente era o maior e certamente o mais forte anti-museu. O que tudo aquilo significava? O que esse confronto poderia significar - com que possíveis resultados? Eu pensei, vamos falar sobre isso! E, desde o início, Glenn e eu logo compreendemos que, em 10 anos, essas duas organizações poderiam estar combinadas de modo interessante. ${ }^{384}$

Para Alanna Heiss, o entendimento baseou-se muito mais na convergência das visões pessoais de cada um dos dois diretores do que nos interesses de suas respectivas instituições. Além de mirar nas oportunidades de experimentar novas formas de promover a arte contemporânea, muito mais ágeis no PS1 que no MOMA, Lowry via como outra vantagem da associação a localização do centro no bairro do Queens. Apesar de situado na margem oposta do East River com relação a Manhattan, o PS1 encontrava-se a apenas 15 minutos de metrô a partir da sede do museu e ficava próximo ao galpão que seria adquirido para armazenar e expor parte da coleção durante sua reforma - o MOMA QNS. A possibilidade de criar o que o diretor vislum384 Heiss, 2014, op. cit., p. 14. Tradução nossa. brava como um "corredor cultural via metrô" era fortalecida pela presença de outras instituições culturais na região, como 
o Isamu Noguchi Garden Museum e o American Museum of the Moving Image. ${ }^{385}$

O plano de fusão previa que Heiss continuasse por mais alguns anos na direção do centro, ao mesmo tempo em que assumiria nо момА a posição de vice-diretora, reportando-se em ambos os cargos à Lowry. Os conselheiros do PS1 seriam mantidos durante os dez primeiros anos, mas trabalhariam em conjunto com novos membros apontados pelo museu. O MOMA teria o direito de escolher o nome de todos os conselheiros apenas após completado o processo de fusão, o que acabou ocorrendo em 2008. Como defendia Lowry, o PS1 estaria para o MOMA como uma faculdade para sua universidade, ${ }^{386}$ sendo tratado como mais um de seus departamentos, com relativa independência: "não temos nenhuma intenção de alterar o programa vibrante que tem sido desenvolvido por Alanna Heiss ao longo dos últimos 30 anos." ${ }^{387}$

Apesar desse discurso, a fusão podia ser vista como um ato de capitulação do projeto do PS1, que levaria inevitavelmente ao enfraquecimento de seus laços com correntes mais radicais da arte. Heiss, no entanto, enfatizou em diversas de suas declarações que seu propósito nunca teria sido o de criar mais um espaço alternativo, mas o de fazer frente aos museus estabelecidos, como podemos perceber nas características arquitetônicas da reforma de 1997. Em seu entendimento, o PS1, após duas décadas de funcionamento, havia amadurecido e precisava de uma perspectiva de continuidade lastreada não na energia de um grupo específico de pessoas, mas numa organização de caráter institucional. Vale observar que são raros os projetos que conseguem se sustentar em moldes mais radicais por tanto tempo, pois o sucesso frequentemente traz consigo um certo grau de acomodação a estruturas mais estabelecidas. Além disso, a própria produção contemporânea já não se contrapunha do mesmo modo aos museus - ao contrário, encontrava cada vez mais acolhida nos espaços institucionalizados da arte. Naquele momento, a possibilidade de convergência entre um museu do prestígio do мома e um espaço experimental como o PS1 mostrava-se vantajosa para ambas as partes.

O primeiro evento conjunto das duas instituições, realizado no verão de 1999 para celebrar a fusão anunciada pou-
385 Glenn Lowry apud Vogel, Carol. A Museum Merger: The Modern Meets The Ultramodern, p. 1, 1999. Tradução nossa.

386 Cf. Vogel, op. cit.

387 Glenn Lowry apud KAUFMAN, Jason Edward. MOMA completes merger with PS1. The Art Newspaper. 1/12/2020. ed. 2020. 


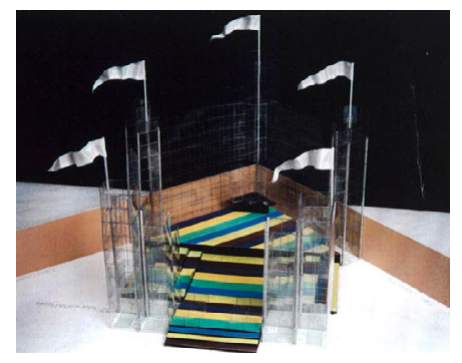

2.158 Maquete para o Dance Pavilion para o Warm Up 1999, projeto de Philip Johnson, em conjunção com a exposição Young Architects Program 1999 realizada em colaboração com o MoMA, PS1 Contemporary Art Center, Nova York, 1999. Fonte: https://www.moma.org/ interactives/moma_through_time/1990/ an-architect-dj-saved-my-life/
388 Philip Johnson apud THE Museum of Modern ART. A Virtuoso Pavilion. MOMA. Disponível em: <https://www. moma.org/interactives/moma_ through_time/1990/an-architect-dj-saved-my-life/>. Acesso em: 22 jun. 2021. cos meses antes, foi a construção de uma estrutura projetada para o segundo Warm-up do PS1, pelo então nonagenário Philip Johnson, numa reunião simbólica do arquiteto mais influente de Nova York - vinculado ao MoMA desde os primórdios da instituição - com a plateia de milhares de jovens que enchia os pátios no centro nas tardes dançantes. Abrigando o tablado do DJ, uma arquibancada e a pista de dança, a estrutura temporária do chamado Dance Pavillion foi construída com andaimes revestidos por telas, formando cinco torres coroadas por bandeiras, imaginada por Johnson como um "anfiteatro medieval com um ar de ficção científica", ${ }^{388}$ tendo o arquiteto feito uma participação especial como DJ no dia da abertura.

O MOMA carecia de um espaço em sua sede para a realização de exposições de arquitetura envolvendo construções temporárias em escala real, desde que a área externa do jardim de sua sede foi reduzida pela ampliação projetada pelo próprio Johnson nos anos 1960. O pátio do PS1 foi logo visto como um espaço propício para recuperar essa prática, que deveria explorar, ao espírito do centro, instalações experimentais de arquitetura. Com esse objetivo, foi inaugurado no verão de 2000 o Young Architects Program (YAP), que, sob coordenação de Terence Riley, curador chefe do Departamento de Arquitetura e Design do MOMA, passou a promover concursos anuais de arquitetura aberto a jovens profissionais para a realização de intervenções temporárias, simultâneas aos eventos dançantes do Warm-up.

Para além desses eventos pontuais, era preciso desenvolver um modo de colaboração que conjugasse experiências, expertises e estrutura de cada uma das instituições. Havia uma grande incerteza sobre qual seria o resultado do embate entre dois modos antagônicos de operar, especialmente porque, na época da fusão, segundo Heiss, apenas quatro ou cinco entre os 50 trustees do MomA tinha vínculos com a arte contemporânea:

O PS1 tinha uma sólida missão como um anti-museu: expor a maior parte da arte da nossa cultura e do nosso tempo de um modo que eu acreditava ser o melhor, mas também demonstrar como fazer isso sem as restrições e os demorados prazos de um museu. Mas então, como poderia um anti-museu trazer sua bem-sucedida missão, suas árduas batalhas e conquistas, 

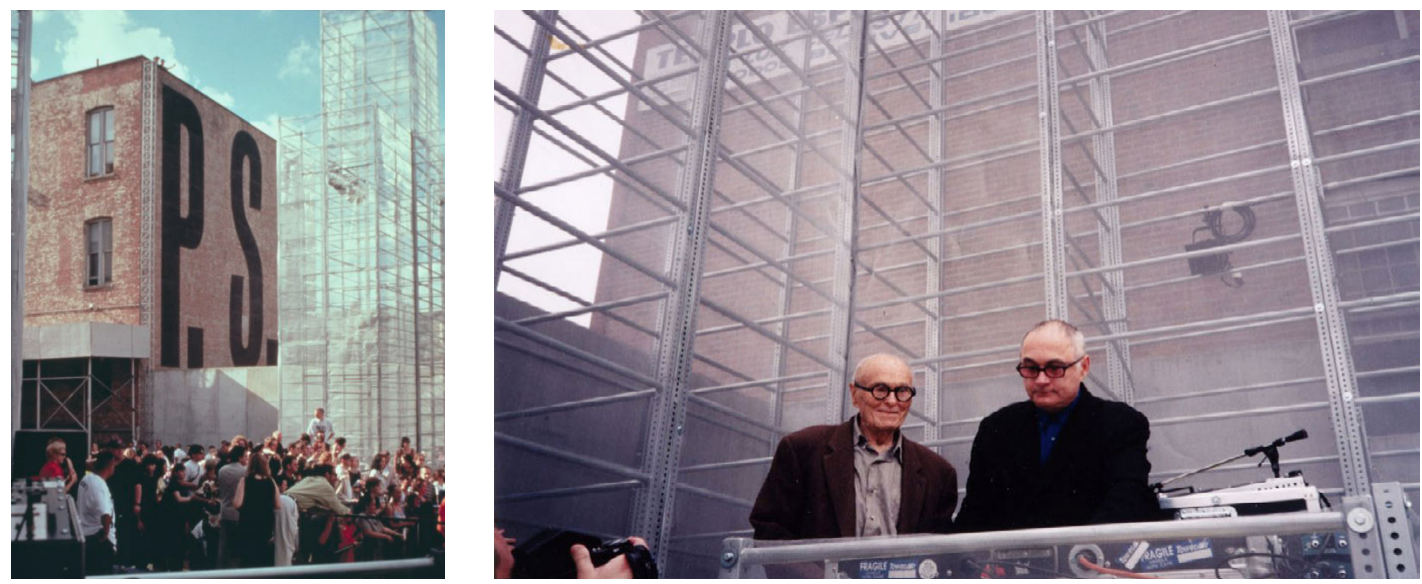

para um museu-museu? E como poderia o museu trazer para o anti-museu, o radical posto avançado, um conhecimento sobre como melhorar seu funcionamento? Teriam os doadores, colecionadores e trustees interesse e animação com a oportunidade de se tornar mais bem informados sobre a arte contemporânea do modo como está sendo exposta hoje e sobre os artistas que a produzem? A resposta foi um retumbante sim. E foi um ainda mais apaixonado sim com o passar dos anos. ${ }^{389}$

Inaugurada um ano após o anúncio público da fusão, em fevereiro do ano 200o, Greater New York foi a primeira exposição realizada conjuntamente entre as duas instituições, colocando a parceria à prova. Segundo Heiss, o projeto inspirou-se na exposição que inaugurou a Bienal de Berlim em 1996, organizada por Klauss Biesenbach, como desdobramento de sua atuação à frente do instituto de arte contemporânea Kw. Com o nome Berlin/Berlin, o evento ajudou a consolidar a cidade como um polo importante da arte contemporânea, reunindo jovens artistas atraídos para lá após a queda do muro. ${ }^{390}$ O plano para Greater New York previa levantar o que estava sendo produzido por artistas atuantes na região metropolitana de Nova York, a partir de visitas aos ateliês locais - uma prática corriqueira para os curadores do PS1, mas que destoava do modo como vinha trabalhando a maior parte da equipe do
2.159 Cabine de som no Dance Pavilion na abertura do Warm Up 1999, realizado em colaboração com o MoMA, PS1 Contemporary Art Center, Nova York, 1999. Foto: Eileen Costa. Fonte: https://www.moma.org/ interactives/moma_through_time/1990/ an-architect-dj-saved-my-life/

2.160 Philip Johnson atuando como DJ no Warm Up 1999, PS1 Contemporary Art Center, Nova York, 1999. Fonte: https://www.moma.org/interactives/ moma_through_time/1990/ an-architect-dj-saved-my-life/
389 Alanna Heiss in: BIESENBACH; FUNCKE, op. cit., p. 208. Tradução nossa. 390 Ibidem, p. 205. 


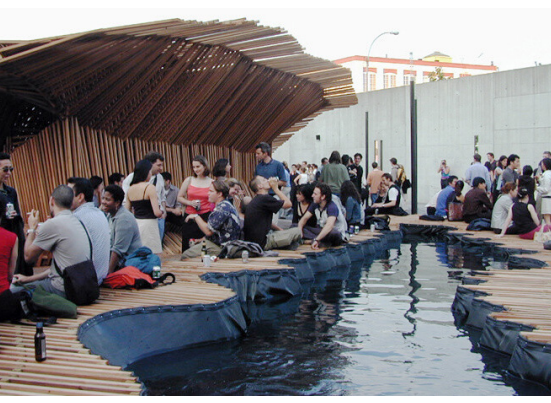

2.161 SHoP, Dunescape, Young Architects Program, realizado em colaboração com o MoMA, e PS1 Contemporary Art Center, Nova York, 2000. Fonte: https://www. moma.org/calendar/exhibitions/3700

2.162 ROY, subWave, Young Architects Program, realizado em colaboração com 0 MoMA, PS1 Contemporary Art Center, Nova York, 2001. Fonte: https://www.moma. org/calendar/exhibitions/3698

2.163 EMERGENT Architecture, Light-Wing, Young Architects Program, realizado em colaboração com o MoMA, PS1 Contemporary Art Center, Nova York, 2003. Fonte: https://www.moma.org/calendar/ exhibitions/3696

391 A exploração de novos artistas locais tinha sido a missão da curadora Dorothy Miller durante os 35 anos em que trabalhara como curadora do MомA ao lado de Alfred Barr, resultando numa notória série de exposições de arte contemporânea estadunidense entre 1942 e 1966.

392 No capítulo seguinte desta tese, serão apresentados alguns dos projetos curatoriais desenvolvidos por Biesenbach no MомA, após a fusão com o PS1.

393 Biesenbach permaneceu como diretor do MOMA PS1 até 2018, sendo sucedido por Kate Fowle.
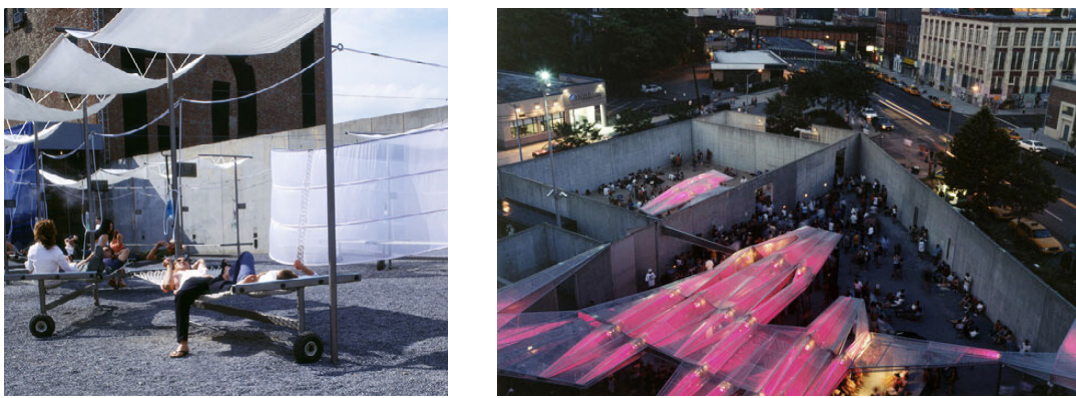

MомA. ${ }^{391}$ Enquanto os curadores do centro estavam acostumados a trabalhar com diversos artistas e projetos simultaneamente, os do museu dedicavam-se habitualmente a um único projeto ou artista por longos períodos na preparação de cada exposição, sendo a maior parte delas de caráter retrospectivo e deixando em segundo plano a exploração sobre a cena atual. A exposição desafiou o MOMA a movimentar-se num ritmo mais acelerado e mais próximo a artistas atuantes. Envolvendo 30 pessoas das equipes curatoriais, lideradas por pares de curadores compostos por um nome de cada instituição, Greater New York ocupou grande parte do edifício do PS1 com obras de 147 artistas locais jovens e emergentes e veio a se tornar mais um dos programas permanentes do centro, com edições de frequência quinquenal.

A parceria viria a resultar num fortalecimento da presença de arte contemporânea também no MOMA, com a participação ativa de Biesenbach, que, à frente do Departamento de Mídia e Performance nos anos de transição da fusão, desenvolveu ações pioneiras no museu, como a criação de séries dedicadas a performances e workshops para artistas e curadores e a implantação de uma política de aquisição dessas modalidades de arte para a coleção. ${ }^{392}$ Em 2009, o curador foi nomeado diretor do PS1, sucedendo Alanna Heiss, que ocupara o cargo de 1976 a $2008 .^{393}$ Completada a fusão, o centro passou a se chamar MOMA PS1 e incorporou-se definitivamente à estrutura do museu, embora mantendo uma certa independência na programação.

O depoimento dado por nessa época James Turrell - que em 1969 havia se recusado a participar da mostra Spaces para 

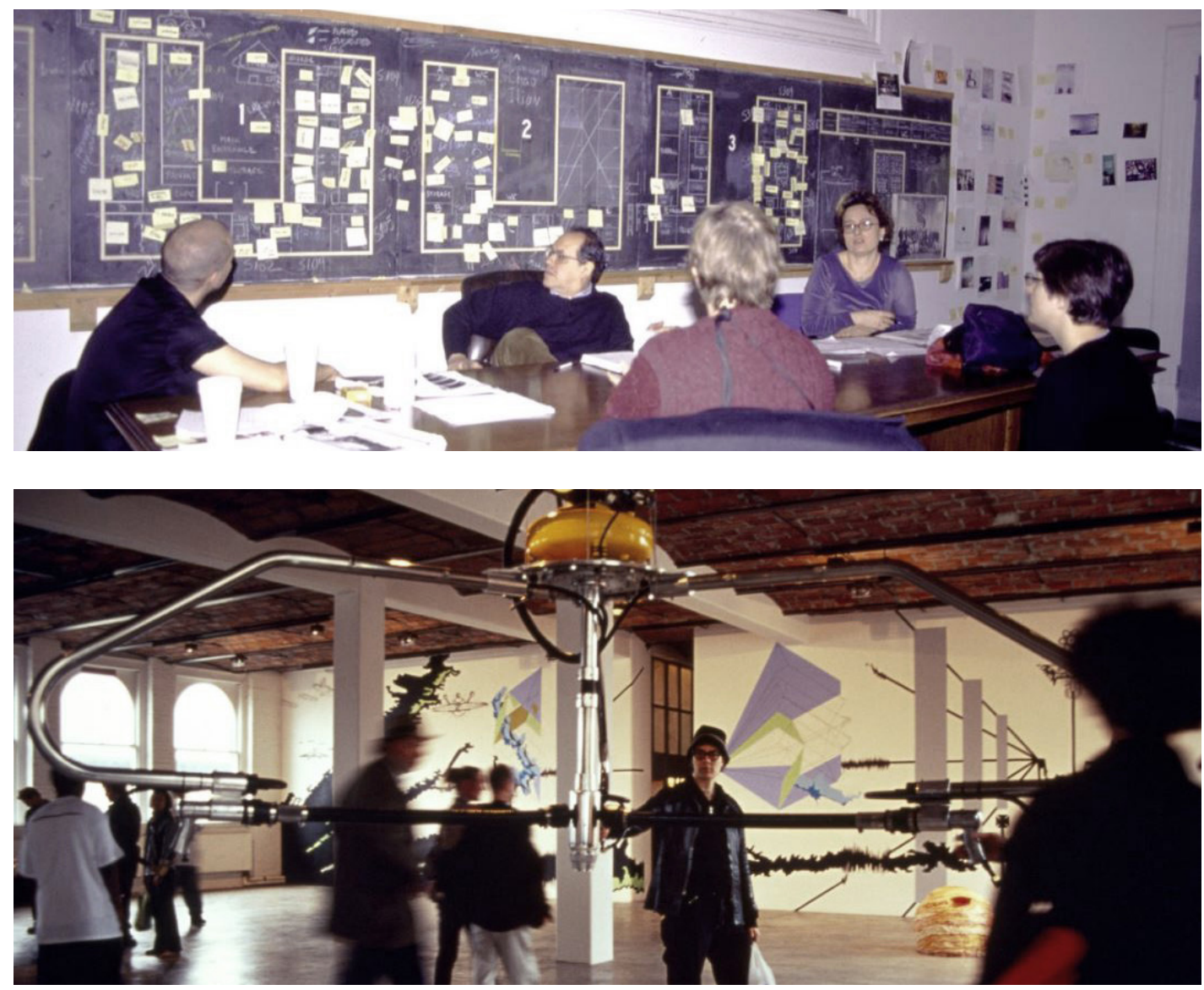

sustentar sua crítica ао момА - é um indício de que o museu teria sido bem-sucedido ao promover uma difícil conciliação: "Funciona bem para o MOMA agora, com o PS1 eles podem participar da arte contemporânea e dos acontecimentos atuais e ao mesmo tempo manter os clássicos modernos na ilha. É como uma válvula de segurança." ${ }^{394}$

O MомA, no entanto, não segregou completamente a arte contemporânea aos espaços do PS1, mas passou a dar mais destaque à produção recente também em sua sede de Manhattan, tanto em mostras temporárias de grande porte quanto nas amplas galerias dedicadas à coleção contemporânea, conquista-
2.166 e 2.167 Reunião de planejamento e vista da exposição Greater New York realizada em colaboração com o MoMA, PS1 Contemporary Art Center, Nova York, 2000. Fonte: https://www.moma.org/ interactives/moma_through_time/2000/ greater-new-york/

394 James Turrell in: BIESENBACH; FUNCKE, op. cit., p. 119.

Tradução nossa. 


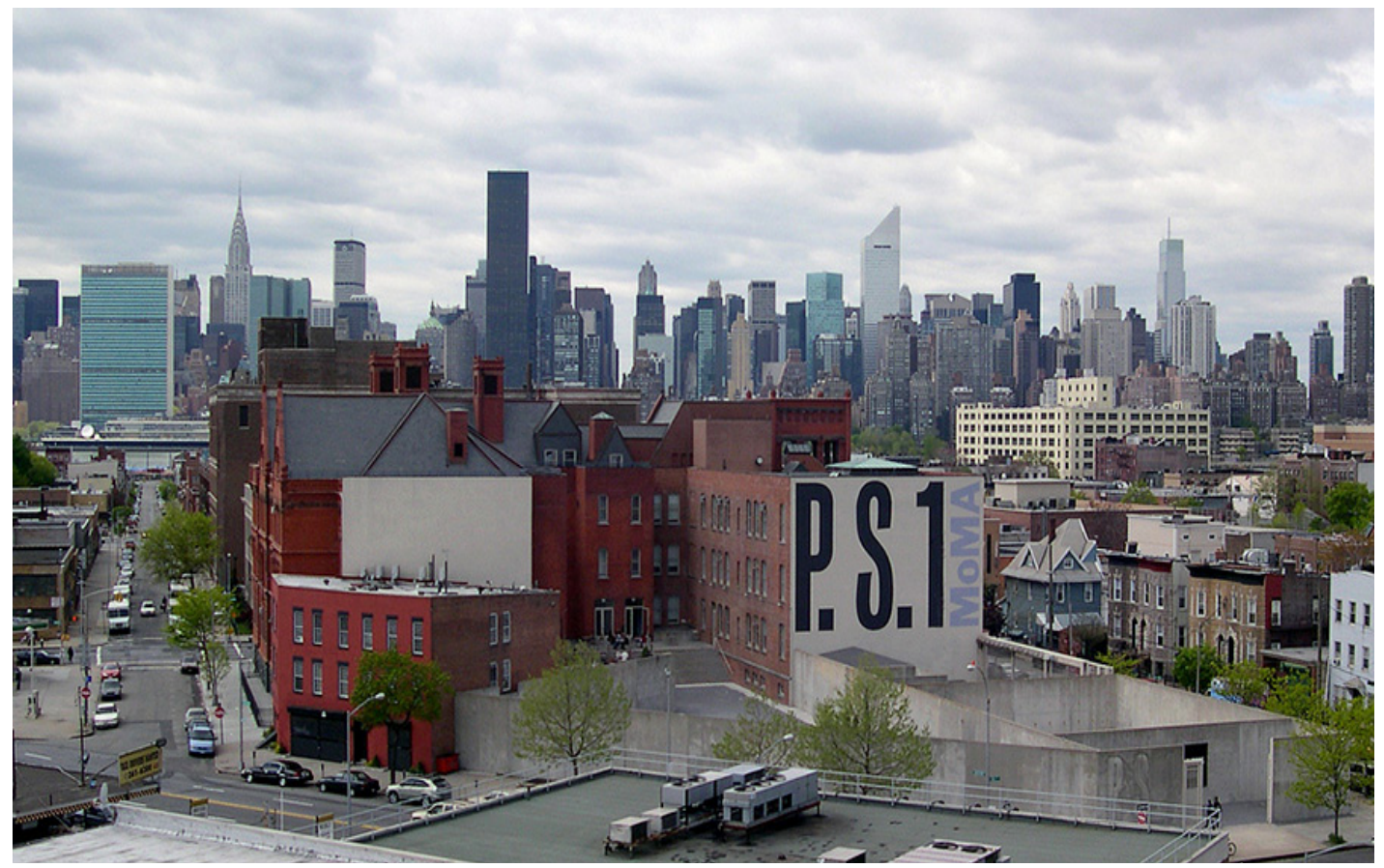

2.168 Edifício do PS1 com o skyline de Nova York, 2005. Foto: Timothy Vogel. Fonte: https://www.frieze.com/article/ moma-ps1-retracted-job-offer-afterfinding-out-curator-had-baby-now-shesfiling-metoo

395 Glenn Lowry in: Ibidem, p. 4. Tradução nossa. das a partir da ampliação do edifício. Em termos arquitetônicos, o museu passaria a contar com dois contextos arquitetônicos muito diferentes para expor a arte contemporânea. Se o PS1 seria, na opinião de Glenn Lowry, "um espaço ideal para a arte de seu tempo", ${ }^{395}$ que tipo de oportunidades as novas arquiteturas do момА poderiam oferecer a artistas? Esse será o tema investigado no próximo capítulo, que abordará os acontecimentos do museu transformados pelos projetos contemporâneos de Yoshio Taniguchi, concluído em 2004, e de Diller Scofidio + Renfro, inaugurado em 2019. 


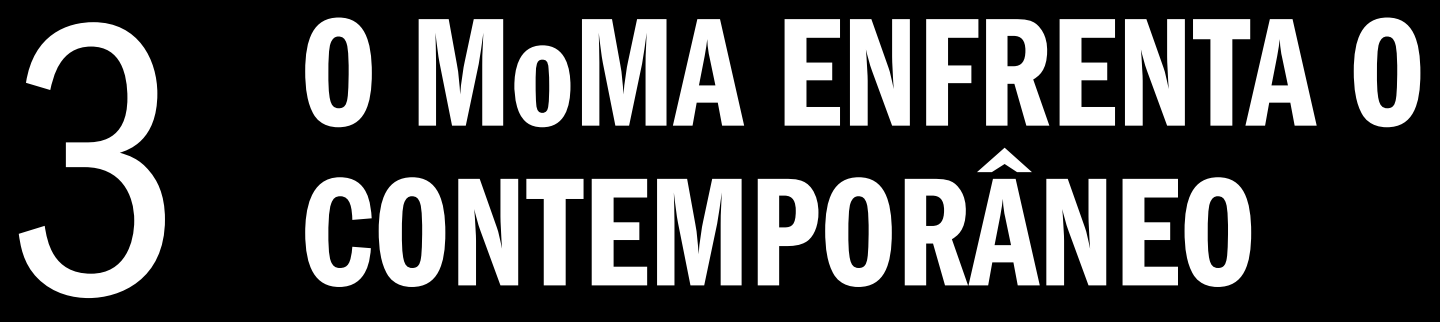



A arquitetura é um catalisador para o museu. Penso que, em parte, é porque, ao contrário de muitos outros museus, a arquitetura não é apenas um objeto para nós - um invólucro, um ambiente no qual articulamos um programa - é também um tema. Colecionamos arquitetura e design: é um campo de estudo, e tudo o que construímos, por definição, torna-se um dos principais proponentes de nossa ampla coleção. ${ }^{396}$

A aproximação da virada do milênio foi acompanhada no mundo todo por intensas especulações sobre as perspectivas que se abririam no século xxi e sobre o que seria estar "atualizado" para enfrentá-las. Essa era uma questão especialmente sensível para о момA - uma instituição profundamente identificada com a tradição moderna que marcara o século xx e que ainda não tinha encontrado um modo consistente de integrar a produção contemporânea em sua programação artística e na expressão arquitetônica de sua própria sede. Os anos 1990 viam crescer o prestígio dos museus enquanto programa privilegiado da arquitetura, transformados em vetores de renovação urbana e polos de atração turística e disputados por arquitetas e arquitetos do chamado star-system. Exemplo mais icônico desse movimento de protagonismo da arquitetura no circuito internacional dos museus é o Guggenheim Bilbao projetado pelo canadense radicado nos EUA Frank Gehry (1929-), que, construído entre 1994 e 1997, viria a se tornar uma referência da arquitetura contemporânea na passagem do milênio, especialmente por conta da volumetria espetacular de suas fachadas de titânio, marcando fortemente sua presença na cidade e contribuindo assim para projetá-la em escala global.

Foi nesse contexto que, em meados da década de 1990, o museu decidiu empreender mais uma expansão de grande porte, que viria a ser inaugurada em 2004 com projeto do arquiteto japonês Yoshio Taniguchi (1937-). Apesar de a expansão ter sido concebida com uma perspectiva de longa duração, o museu contrataria, menos de 10 anos depois, o escritório Diller Scofidio + Renfro (DS+R) para projetar, em colaboração com a firma Gensler, mais uma ampliação, inaugurada em etapas, de 2017 a 2019. Além de confirmar a voracidade expansiva do момA, essa última reforma seria acompanhada por um novo processo

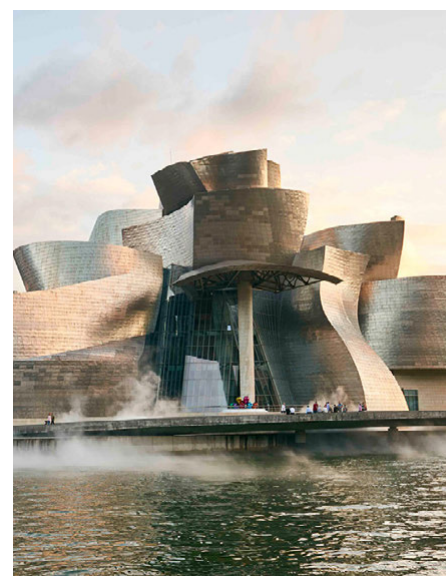

3.1 Guggenheim Bilbao, projeto de Frank Gehry de 1997, s.d. Fonte: https:// www.guggenheim-bilbao.eus/pt-pt/ horarios-e-tarifas

396 Glenn Lowry. Building the Future: Museums of Modern Art in the Twenty-First Century. In: ELDERFIELD, John (ed.). Imagining the Future of The Museum of Modern Art. Nova York: The Museum of Modern Art, 1998. p. 30. Tradução nossa. 
de revisão institucional, visando favorecer perspectivas da história da arte mais inclusivas e com maior integração entre as diversas mídias nas exposições da coleção, bem como ampliar ainda mais a presença da arte contemporânea no museu.

Com o objetivo de compreender de que modo o мома procurou afirmar sua identidade moderna, revisar seu cânone e manter-se, ao mesmo tempo, significativo no cenário contemporâneo, este capítulo será dedicado a confrontar as expectativas do museu com as soluções dessas duas etapas de expansão e com as variadas formas pelas quais curadores e artistas contemporâneos se engajaram nos espaços arquitetônicos renovados.

\subsection{A EXPANSÃO DA VIRADA DO MILÊNIO: 1996 A 2004}

\subsubsection{A CONCEITUAÇÃO DE UM MUSEU CONTEMPORÂNEO}

As discussões sobre a necessidade de uma expansão de grande escala da sede do MOMA vinham mobilizando seus curadores sêniores, staff e membros do conselho desde o início dos anos 1990, conforme indicado no volume Imagining the Future of the Museum of Modern Art. ${ }^{397}$ Organizado por John Elderfield (1943-), um dos curadores chefes do museu à época, a publicação documentou o passo a passo do longo processo que culminou com a escolha do arquiteto Yoshio Taniguchi para liderar o projeto arquitetônico, sendo, portanto, fonte central de informação para a primeira parte deste capítulo da tese. Segundo Glenn Lowry, que assumira a direção da instituição em 1995, justamente na época em que se estruturavam as ações para a renovação do museu, a motivação inicial para a expansão teria sido a necessidade de acomodar a crescente coleção de arte contemporânea. A última reforma que o museu sofrera, a partir de projeto de César Pelli de 1984, teria levado em conta mais as carências daquele momento - em que o crescimento do acervo era muito desproporcional às dimensões do edifício, gerando sérias limitações às exposições - do que um plano para o futuro. A ideia agora era não apenas ampliar a área, mas transformar o MомA em um novo museu. Nas palavras de Lowry, 
o projeto rapidamente transformou-se numa ampla iniciativa institucional para explorar as possibilidades intelectuais, programáticas e físicas que garantissem que o Museu de Arte Moderna continuasse a ser um lugar de debate e descoberta e de entretenimento e engajamento no próximo século. ${ }^{398}$

Diante da dificuldade de se antecipar ao futuro, os dirigentes se comprometeram a reavaliar periodicamente as aspirações e metas do museu para evitar que se tornasse uma instituição estagnada. Logo no início das discussões, foi estabelecido que as definições que orientariam a expansão deveriam mirar nos próximos 25 a 30 anos, uma duração finita, mas tida como longa o suficiente para que a intervenção não estivesse obsoleta na ocasião da reinauguração. Na conceituação do perfil do museu, o ponto mais importante consolidado então, e reiterado a todo momento, foi o compromisso do MoMA tanto com a arte contemporânea quanto com a arte moderna, considerada uma tradição vital e dinâmica, que merecia continuar a ser explorada, mantendo-se como a marca da instituição.

Entre os primeiros pontos em discussão estava o endereço da expansão. Cogitou-se adquirir um segundo terreno em outra região da cidade, construir sobre a biblioteca pública em frente ao edifício, escavar sob o jardim de esculturas e até mesmo transferir todo o museu para um outro local em Manhattan. Embora mais custosa que as demais, a opção que prevaleceu foi a de adquirir lotes na mesma quadra - o maior deles contendo o Hotel Dorset e alguns outros com construções menores contíguas. O мома ficaria, assim, concentrado no mesmo local onde a instituição moldara sua identidade como um "museu de rua", incrustado no denso tecido urbano de Midtown, entre as ruas 53 e 54. Além disso, era importante manter a coesão da coleção para reafirmar a conexão entre a arte moderna e a contemporânea. A decisão envolveu o compromisso de membros do conselho em levantar os vultosos fundos necessários para viabilizar o projeto e desencadeou o processo de planejamento envolvendo várias frentes de ação.

A primeira delas foi a criação, em setembro de 1995, de um comitê denominado Imagining the Future, formado por alguns membros do conselho, pelo diretor e por sete curadores chefe,
398 Glenn Lowry. The New Museum of Modern Art Expansion: A Process of Discovery. In: ELDERFIELD, 1998, op. cit., p. 11. Tradução nossa. 


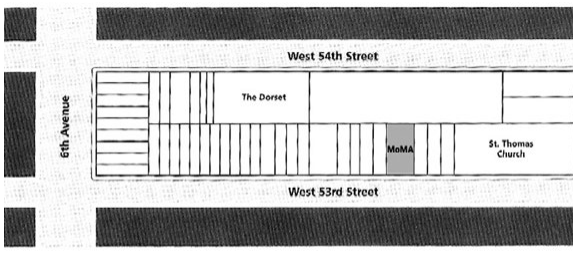

Site of the original Goodwin-Stone building, 1939

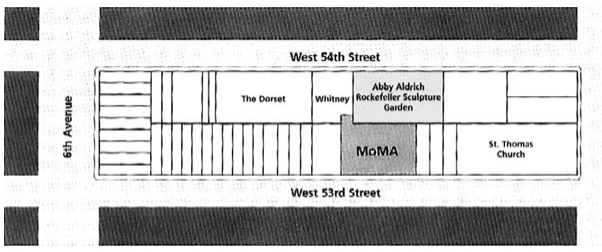

Museum site, including The Abby Aldrich Rockefeller Sculpture Garden, 1954

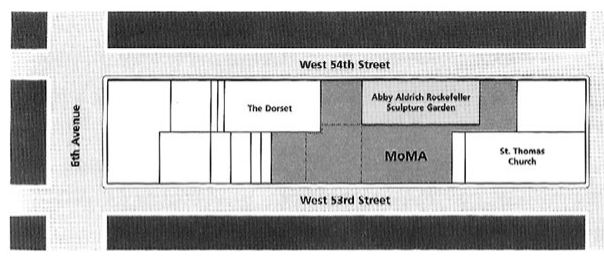

Museum site, 1984

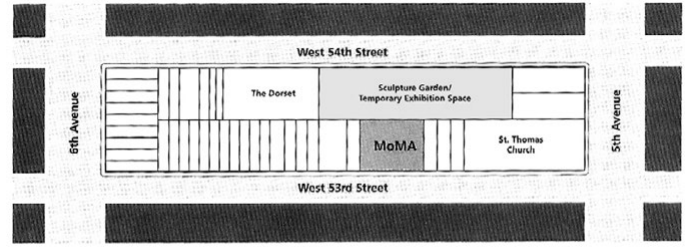

Site of the original Goodwin-Stone building, 1939
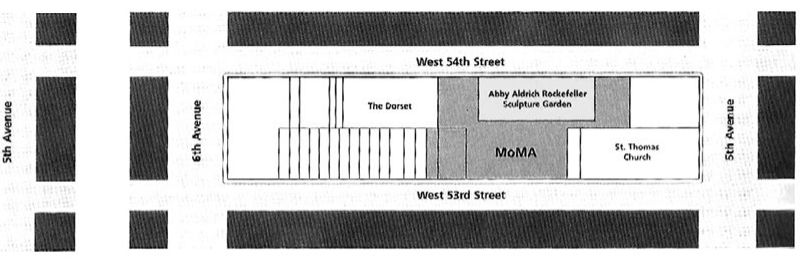

Museum site and adjacent properties, 1968
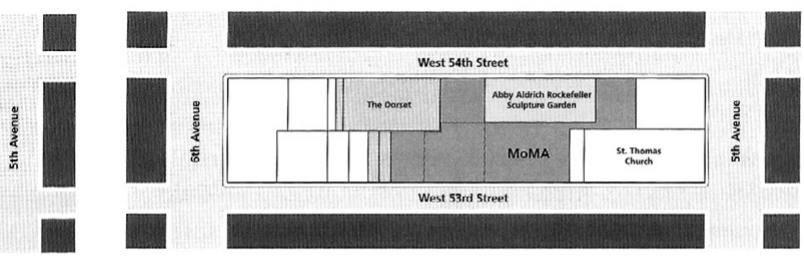

Museum site and adjacent properties, 1996
3.2 e 3.3 Ocupação do MoMA de 1939 a 1996. Fonte: ELDERFIELD, pp. 96-97. visando levantar as aspirações institucionais para o futuro, com base nas qualidades admiradas em outros museus. Entre as principais questões conceituais em discussão estavam: Como equilibrar a dívida com a tradição e a história com seus compromissos com o futuro? Qual o significado do museu no século XXI enquanto fonte de pesquisa sobre a arte do século $\mathrm{xx}$ ? Qual o escopo e forma da missão educativa do museu, considerando a importância de sua influência intelectual e artística mundial? Como encarar o desafio de fazer o melhor uso das novas tecnologias? E, sobre o papel da arquitetura na expansão: Qual seria a melhor organização das galerias pra contar a(s) história(s) da arte moderna e contemporânea? Como os 


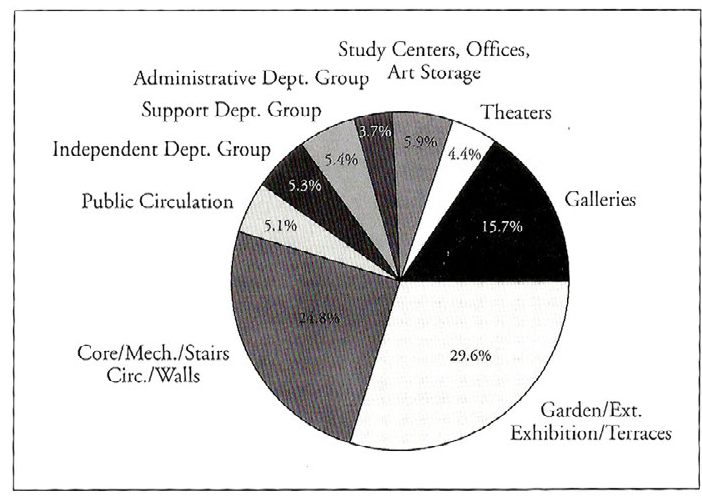

Allocation of floor space by area, 1939

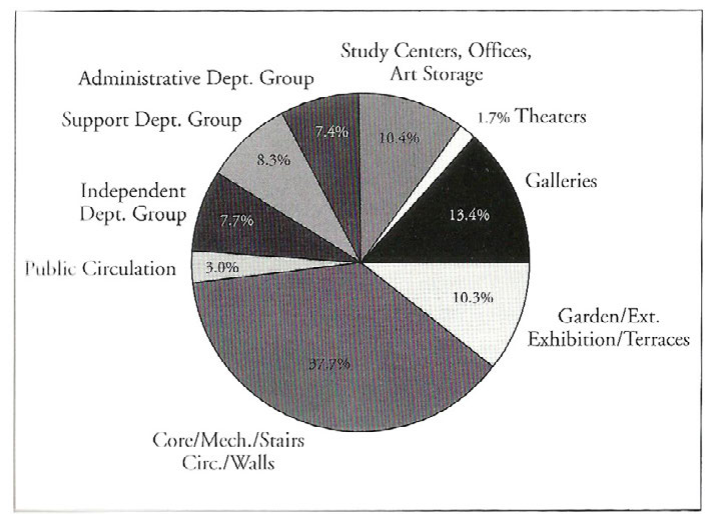

Allocation of floor space by area, pre-1894 Muscum expansion

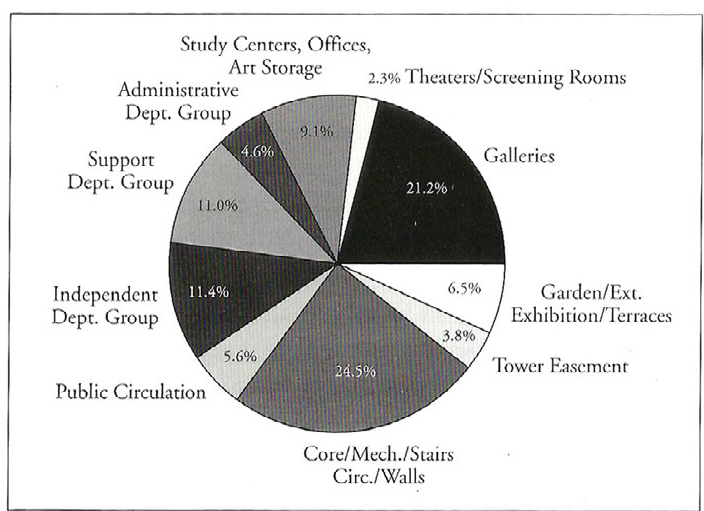

Allocation of floor space by area, 1996 


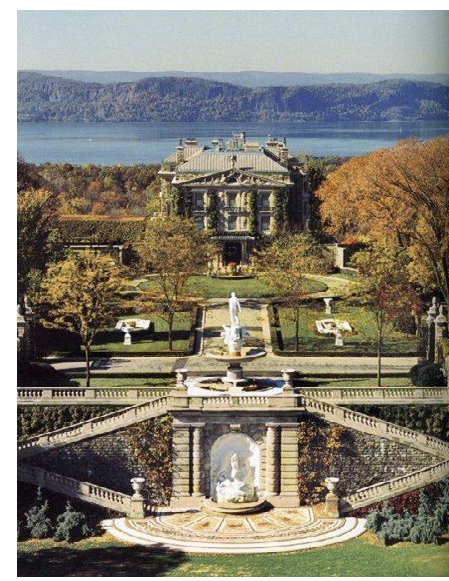

3.4 Propriedade da Família Rockefeller no Hudson Valley, local do espaço de convenções Pocantico Center, Sleepy Hollow, s.d. Fonte: https://www.cbsnews. com/news/rockefeller-home-sweet-home/

399 Ibidem, p. 13.

400 Mission Statement. In:

Elderfield, 1998, op. cit., p.20.

Tradução nossa.

401 Cf. Executive Statement. In: EldERFIELD, 1998, op. cit., pp. 21-26.

402 Glenn Lowry. The New Museum of Modern Art Expansion: A Process of Discovery.

In: ELDERFIELD, 1998, op. cit., p. 13-14. Tradução nossa.

403 Ibidem, pp 14-15.

404 Cf. Ibidem, p.14. espaços do museu poderiam encorajar o público a se engajar e dialogar com a coleção? Como manter a sensação de intimidade a partir de um crescimento tão expressivo? ${ }^{399}$

Incorporando em seguida a participação dos setores de aquisição, conservação e educação, a discussão culminou com a atualização da missão do museu, que logo na primeira frase dava a medida do lugar que о мома pretendia ocupar no cenário das artes: "Fundado em 1929 como uma instituição educacional, o Museu de Arte Moderna se dedica a ser o principal museu de arte moderna do mundo." ${ }^{000}$ Além dos propósitos mais amplos que definiam o perfil institucional, foi criado também um documento que estabelecia uma base lógica para orientar a nova ampliação. ${ }^{401}$ Conforme resumiu Lowry, os documentos resultantes - aprovados pelo conselho em 2 de outubro de 1996 - partiam do seguinte pressuposto: "o museu deve se comprometer com as consequências de suas crenças de que a arte moderna permanece uma tradição vital e dinâmica, baseada numa contínua série de argumentos e contra-argumentos que precisam ser explorados por meio de exposições, instalações e publicações." ${ }^{402}$

Na próxima etapa, o museu promoveu discussões mais abertas, para, segundo Lowry, "aguçar e desafiar as opiniões do próprio museu sobre seus requisitos para o futuro" e explorar "ideias pertinentes à sua expansão", ${ }^{403}$ possibilitando, assim, afinar o rol comum de aspirações que conceituassem o papel do museu e preparassem-no para o concurso de arquitetura que redesenharia sua sede. De 4 a 6 de outubro de 1996, foi organizado um encontro mais restrito que ficou conhecido como Pocantico Conference, por ter sido sediado no Pocantico Center, um centro de convenções localizado numa propriedade da família Rockefeller a norte de Nova York. Para discutir o tema "Construindo o Futuro: Museus de Arte Moderna no Século XXI", foram selecionados 32 participantes dos EUA e do exterior, entre os quais diretores de museus, críticos, intelectuais, artistas, arquitetos, além de sete curadores chefes do момА e os membros do conselho do comitê do museu dedicado ao processo de seleção do projeto de arquitetura. ${ }^{404}$

Boa parte das discussões, organizadas em quatro sessões, girou em torno de especulações sobre como a organização 
espacial da coleção poderia contribuir para expor visões mais diversificadas da arte moderna, partindo do pressuposto de que o modelo criado, praticado e difundido pelo próprio MомA precisava ser repensado numa perspectiva mais atual e menos dogmática. Ainda que demandasse uma revisão significativa da postura institucional, a necessidade de alterar o modo de apresentação da coleção produzia um certo consenso dentro e fora do museu - o de que o projeto arquitetônico da nova sede não deveria induzir à repetição do mesmo modelo de narrativa por salas enfileiradas em sequência linear, e sim oferecer flexibilidade suficiente para acomodar novas e variadas possibilidades de arranjo no futuro, incluindo maior integração entre as diferentes mídias e a incorporação de novas tecnologias na interação com o público.

Mais interessante para a investigação desta tese do que os debates envolvendo as formas de apresentação da coleção foram, no entanto, as discussões em torno dos impasses da arquitetura de espaços dedicados à arte contemporânea - tanto a produzida naquele momento, quanto a que viria a ser produzida no futuro -, que acabaram por levantar mais dúvidas e questionamentos do que parâmetros concretos para orientar o futuro projeto arquitetônico para o MOMA.

Alguns dos participantes externos deixaram claro que os desdobramentos da arte a partir dos anos 1960 haviam resultado numa crise no estabelecimento de limites entre arte e arquitetura, particularmente impactante no caso de museus. Conforme apontou o arquiteto japonês Arata Isozaki (1931-), desde que artistas começaram a criar não apenas objetos, mas o ambiente ou o próprio espaço, a relação entre conteúdo e contêiner teria se tornado muito problemática, trazendo dificuldades para os edifícios dedicados a esse novo tipo de arte. Ele relatou que, ao projetar o Museu de Arte Contemporânea de Los Angeles (MOCA), concluído em 1986, tentou não prejudicar ou perturbar a arte, criando salas de exposição de características "discretas" e com diferentes proporções e graus de luminosidade, visando desse modo acomodar diversos tipos de manifestação. Ainda assim, numa grande retrospectiva de Robert Irwin realizada naquele museu em 1993, o artista teria preferido criar uma abertura na parede conectando salas origi- 


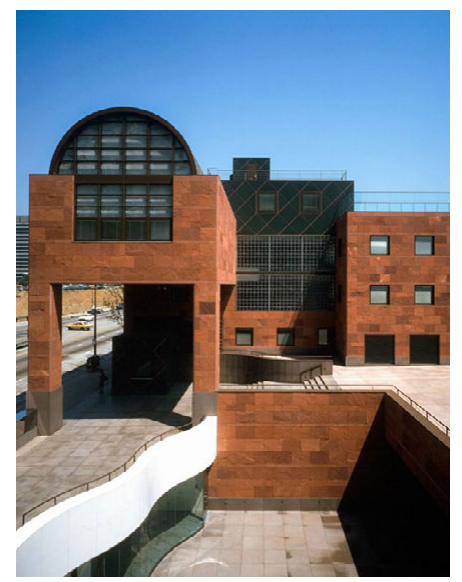

3.5 Museu de Arte Contemporânea de Los Angeles (MOCA), projeto de Arata Isozaki, 1986. Fonte: https://i. pinimg.com/originals/be/19/6a/ be196acbac79fcd95445fedf81c85c7f.jpg

3.6 Museu de Arte Contemporânea de Nagi, projeto de Arata Isozaki, 1994. Fonte: https://upload.wikimedia.org/ wikipedia/commons/c/ca/Nagi_MOCA.jpg

3.7 Museu de Arte Moderna Louisana, projeto de Jørgen Bo e Wilhelm Wohlert, Humlebæk, 1958. Fonte: https://www. reddit.com/r/CozyPlaces/comments/ j4eowo/art_museum_in_denmark_ with_a_gorgeous_view/

405 Arata Isozaki. Conversation III. In: ELDERFIELD, 1998, op. cit., p. 53. Tradução nossa.

406 Ibidem, p. 54. Tradução nossa. nalmente separadas, para, segundo Isozaki, "quebrar o contêiner do interior para o exterior", o que o levou a especular: "se Gordon Matta-Clark ainda estivesse vivo, ele certamente abriria um buraco no piso ou no teto". ${ }^{405} \mathrm{Na}$ opinião do arquiteto, os projetos para uma nova geração de museus demandariam uma reorientação profissional:

Temos que focar nessa relação entre os arquitetos que projetam museus e os artistas que trabalham dentro dele. A maioria dos artistas - muitas vezes tenho essa impressão quando trabalho com eles - querem ser arquitetos, ... e algumas vezes os arquitetos querem ser artistas, para eliminar qualquer trabalho de arte no interior [...]. Se nos mantivermos na profissão, como arquitetos, podem ocorrer conflitos constantes com os artistas... O papel do arquiteto deve ser um pouco diferente do construtor de hoje, deve ser de construtor e ao mesmo tempo de mediador intelectual junto ao artista. ${ }^{406}$

Isozaki mencionou, então, seu projeto para o pequeno Museu de Arte Contemporânea de Nagi, inaugurado em 1994, como um exemplo de um novo conceito de espaço para arte, por envolver artistas em todo o processo de concepção arquitetônica. O museu é constituído por apenas três espaços, projetados cada qual com um artista diferente - gerando espécies de instalações artístico-arquitetônicas semipermanentes. Pode-se dizer que, embora o modo de projetação colaborativa apresentado pelo arquiteto possa servir como referência para outras situações, não funciona como parâmetro para museus destinados a abrigar exposições de coleções de obras já existentes, tampouco para exposições temporárias de arte contemporânea. Há uma incompatibilidade evidente entre a efemeridade programada de eventos artísticos por museus que, como о момА, pretendiam abrigar a produção de arte constantemente atualizada, e a tendência à longa duração dos edifícios, que em geral precisam mobilizar somas muito maiores de recursos e de tempo para serem materializados.

A ideia de que os artistas deveriam participar mais ativamente da concepção arquitetônica dos museus foi expressa por vários outros participantes do encontro, entre eles o curador e 

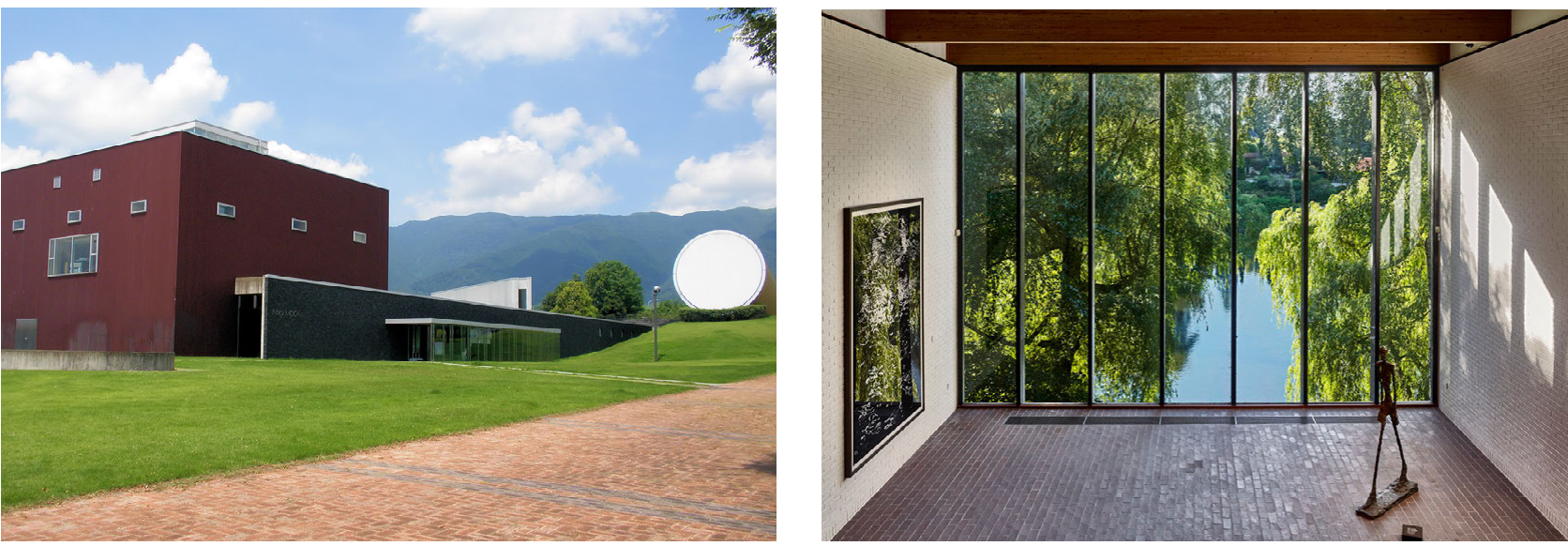

crítico de arte sueco Lars Nittve (1953-), então diretor do Museu de Arte Moderna de Louisiana, na Dinamarca, que afirmou:

Para mim o ponto de partida deve ser os artistas. A partir daí, é preciso pensar sobre o encontro entre o artista, a obra de arte e o público. O museu existe para criar uma espécie de ponto de encontro ideal entre a obra de arte e o público. Isso significa que devemos de fato nos envolver com artistas em discussões sobre que espaço eles preferem, que situação eles gostariam, o que eles têm em mente quando trabalham produzindo suas obras. ${ }^{407}$

O tipo de colaboração a que Nittve se referia era de natureza muito distinta da relatada por Isozaki. O exemplo apontado como bem-sucedido pelo curador foi o que envolveu a decisão tomada em 1994, após consulta a centenas de artistas, em vez de construir um novo edifício para a Tate Modern de Londres, a instalasse numa usina elétrica desativada, convertendo-a num grande espaço, que seria inaugurado em 2000, com projeto do escritório suíço Herzog \& de Meuron. ${ }^{408}$ Uma das razões apontadas por Nittve para essa preferência entre artistas seria a experiência relatadas pelas pessoas consultadas de que, ao converter um edifício existente em espaço de arte, mais energia poderia ser investida no interior - entendido como ponto focal - ao invés de despendida com a forma e a fachada. O raciocínio

407 Lars Nittve. Conversation I. In: ELDERFIELD, 1998, op. cit., p. 35. Tradução nossa.

408 Lars Nittve seria apontado em 1998 o primeiro diretor da Tate Modern, quando essa ainda estava em construção, com inauguração prevista para 2000. Nittve permaneceu no cargo apenas até 2001, um ano após a inauguração, quando assumiu o cargo de diretor do Museu de Arte Moderna de Estocolmo. Cf. TATE Modern. Director appointed for new Tate Gallery of Modern Art. Tate. Disponível em: $<$ https://www.tate. org.uk/press/press-releases/director-appointed-new-tate-gallery-modern-art>. Acesso em: 28 set. 2020 e REINOLDS, Nigel, Tate Modern chief quits for job in Sweden. The Telegraph, 21/06/2001. ed. 2001. 
intervenções em comparação com espaços imaculados das galerias tipo "cubo branco", que haviam sido, por sua vez, vistos como mais neutros para expor a arte moderna, pelo menos até a primeira metade do século $\mathrm{xx}$.

O estadunidense Bill Viola (1951-), um dos representantes da categoria artística no encontro, endossou a opinião de que os artistas deveriam participar da concepção arquitetônica, manifestando ainda sua convicção sobre o papel essencial do espaço para a experiência da arte e do museu como lugar de encontro com objetos, tanto modernos (históricos) quanto contemporâneos, independentemente de desdobramentos futuros internos ou externos ao universo da arte: "não importa o que aconteça, não importa o que a tecnologia nos dê, não importa o quanto mude a sociedade, o museu continuará sempre um lugar de comunhão com os objetos. ${ }^{{ }^{410} \text { Considerando }}$ o potencial do MомA para liderar a vanguarda da discussão nacional sobre o lugar da arte, afetando toda a comunidade, o artista sugeriu que, se quisesse ser de fato contemporâneo em termos da arquitetura de seu edifício, o museu deveria: "envolver artistas também no próximo estágio, quando descer realmente à minúcia da discussão com os arquitetos sobre espaços, mantendo os artistas como parte do processo." ${ }^{\text {111 }}$ Viola fez então um pedido aos arquitetos:

Por favor, deem-nos espaços simples, apenas simples, espaços maravilhosos, belos, elegantes. Eles podem ter um caráter não há nada como um bom diálogo entre uma obra de arte e um espaço; não existe tal coisa como um espaço neutro - mas deem-nos espaços agradáveis, simples, maravilhosos, belos, e deixem lugar para paixão nesses espaços, que é o que mantém tudo junto. ${ }^{412}$

Embora a fala do artista seja bastante vaga e não forneça elementos suficientes para identificar o tipo de espaço a que se referia, sua ênfase em qualidades como "simples" - associadas a outras qualidades como "belos" e a com "caráter" - nos permite imaginar que sua preferência fosse por uma arquitetura mais discreta para os espaços de arte, uma opinião recorrente no meio artístico, particularmente no próprio момА.
410 Bill Viola. Conversation IV. In: ELDERFIELD, 1998, op. cit., p. 64. Tradução nossa.

411 Ibidem, p. 65. 412 Ibidem, p. 65. 


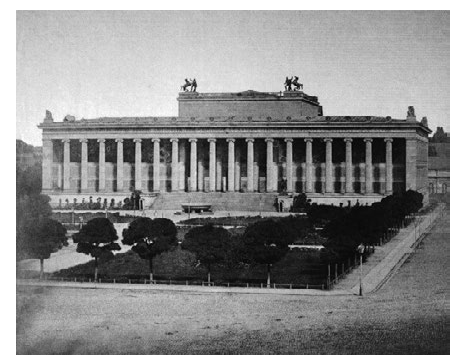

3.10 Altes Museum, projeto de Karl Friedrich Schinkel de 1825-30, Berlim, antes de 1854. Fonte: https:// en.wikipedia.org/wiki/Altes_Museum

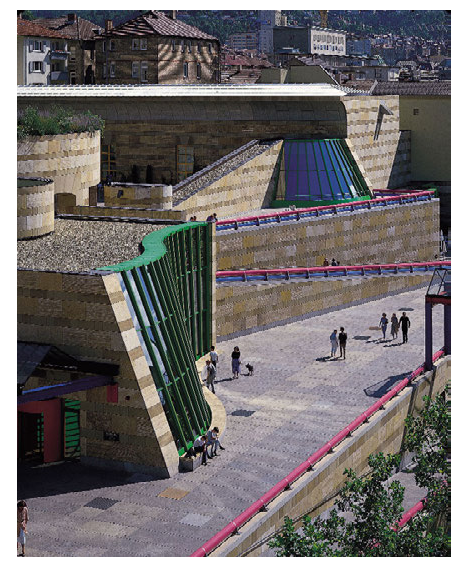

3.11 Neue Staatsgalerie, projeto de James Stirling e Michael Wilford, Stuttgart, 1984. Foto: Richard Bryant/ARCAID. Fonte: https://www.britannica.com/biography/ James-Stirling

413 Richard Serra. Conversation I. In: ELDERFIELD, 1998, op. cit., p. 37. Tradução nossa.

414 Ibidem.
O estadunidense Richard Serra (1938-) também fez suas recomendações, mas expressou maior assertividade indicando o que não deveria ser feito, sem apontar caminhos possíveis para a arquitetura da nova expansão. Em primeiro lugar, o artista condenou a tipologia de museus "caixa-forte" mencionada antes na conversa - que incluiria a longa linhagem do setecentista Schinkel ao contemporâneo Stirling. Tal modo linear de apresentação da arte seria enciclopédico e enfadonho, pois, em sua opinião, "não lida com o modo pelo qual a arte transformou o contexto onde foi feita, mas a deixa num novo contexto que a pacifica e a reduz a uma leitura histórica que nada tem a ver com suas relações com o contexto na qual foi primeiramente vista ou produzida." ${ }^{413}$

Em seguida, Serra também criticou a tendência de instalar instituições de arte em espaços industriais, uma prática surgida da ocupação de lofts por artistas de sua geração, que teria, em seguida, se convertido em produto. A "caixa industrial” teria se transformado numa espécie de "instalação transportável de consumo" -, o que, em sua avaliação, estaria "roubando o ímpeto inicial de desafiar o lugar”. Na visão do artista, o engajamento com a arte implicaria em "lidar com a tensão da função em relação aos espaços e lugares onde ela é exposta”, pois "as pessoas que entram em contato com a arte devem ter consciência de que a tensão com a função é um dos conteúdos da obra de arte.” Seria, portanto, preciso "criar uma condição na qual a relação dos trabalhos de arte com o contêiner seja de algum modo surpreendente". ${ }^{414}$

Referindo-se especificamente aos espaços do MomA, Serra sugeriu uma remodelação completa, aproveitando a oportunidade de utilizar desta vez a quadra toda e abandonando inclusive o jardim de esculturas desenhado por Philip Johnson - considerado por ele muito convencional e destoante do modo como imaginava que a escultura seria vista no século seguinte. Para além dessas indicações mais concretas, também não é possível extrair das reflexões do artista um parâmetro claro para balizar que tipo de espaço de arte deveria ser previsto pelo novo projeto arquitetônico, já que a tônica de sua fala foi a ruptura com uma tipologia convencional e a defesa de uma configuração aberta e indefinida para o museu: 
Acredito que a situação deve ser mantida muito aberta e muito fluida, e acredito também que deve ser reservado espaço para um crescimento, porque, se este museu for continuar no próximo século, não o completem agora. Construam-no e deixem-no aberto, como uma espécie de estrutura centopédica mutável, porque os espaços que vocês precisarão em 2050 não são espaços que possam prever em 2010. Creio que é preciso ter um certo tipo de definição aberta para esses lugares e espaços que estão sendo designados... Penso que deve haver uma fratura. Essa situação deve ser desmontada. A noção dessas grandes caixas para um museu deve ser superada. Esqueçam de Schinkel e esqueçam de Stirling: isso acabou, não pode continuar no próximo século. ${ }^{415}$

Quem havia evocado durante a conversa essa ideia de uma tipologia e de uma certa linhagem de museus havia sido o arquiteto estadunidense Peter Eisenmann (1932-), que contestara sua validade, argumentando que os melhores museus que conhecia não ocupavam espaços concebidos como museus. Considerando que a tipologia de um museu seria tão maleável quanto a de uma casa, Eisenmann afirmou, dialogando com Serra:

Museus deveriam começar não pelo projeto de um museu, mas por criar uma obra de arquitetura que lide com o mundo de hoje... Talvez o programa deva ser um programa de ideias e conceitos que conduzam a espaços nos quais a surpresa e as relações cheias de tensão entre a arte, os espaços e o público possam ser criadas [...]. Não podemos pensar num modo específico de arte, porque estamos falando de uma mistura heterogênea, não apenas com relação às pessoas que veem essa arte, mas também com relação aos próprios artistas. Então, talvez o único programa que se possa fazer, porque não se deseja um espaço indefinidamente flexível, seja... afirmar como se faz arquitetura hoje ao invés de afirmar como se faz um museu. ${ }^{416}$

O arquiteto holandês Rem Koolhaas (1944-), por sua vez, expressou seu ceticismo com relação à aposta na arquitetura como solução para o problema do MOMA, declarando que
415 Ibidem.

416 Peter Eisenman. Conversation I. In: EldERfIELD, 1998, op. cit., p. 39. Tradução nossa. 
417 Rem Koolhaas. Conversation IV. In: EldeRfIELD, 1998, op. cit., p. 62. Tradução nossa.

418 Ibidem, p. 63.

419 Ibidem, p. 63. "se o Museu provou alguma coisa, é que é possível ser uma instituição de arte muito bem-sucedida em uma arquitetura medíocre". ${ }^{417}$ Em sua opinião, o aspecto mais marcante do museu seria sua capacidade de produzir "aura", por meio de operações de seleção e exclusão, de propaganda e de manipulação de mídias, praticadas desde os primórdios da instituição. A principal questão para o MoMA seria, então, como manipular e modernizar sua aura, o que, em grande medida, independeria da arquitetura. Questionando-se sobre como manter a experiência do encontro íntimo com a arte "autêntica" em face do grande volume de visitantes do MoмA, Koolhaas apresentou como solução que o museu investisse também na disseminação das obras de arte por outros meios, criando sistemas paralelos, um deles baseado em mídias artificiais e outro na experiência com a autenticidade das obras, que só assim poderia ser preservada.

$\mathrm{O}$ arquiteto manifestou ainda sua opinião de que a perseguição de uma perfeita continuidade entre o passado e o futuro seria "um fardo" para a instituição, apontando para o que entendia como um paradoxo daquele momento: "о MомA sabe tudo sobre o século xx e nada sobre o século XXI". ${ }^{418} \mathrm{Em}$ sua perspectiva:

Talvez seja libertador para todos os envolvidos aceitar a divisão arbitrária do novo milênio como um corte entre conhecer e não conhecer, entre produto e processo; no qual, no século xx, o MomA seria uma máquina de produzir aura (o que lhe garante uma vida eterna), e no século XxI apoiaria a experimentação, a pesquisa, que viriam efetivamente a resultar numa nova visão da arte..$^{419}$

Koolhaas declarou ainda considerar que, se baseada na ideia de exclusão ou de uma solução fechada, a arquitetura seria um campo limitado para enfrentar a complexidade das questões que se apresentavam então para o MoMA:

A divergência de interesses, a necessidade de novos componentes, a diferenciação dos públicos, combinados com a enormidade do lugar, fazem deste problema urgente uma questão mais 


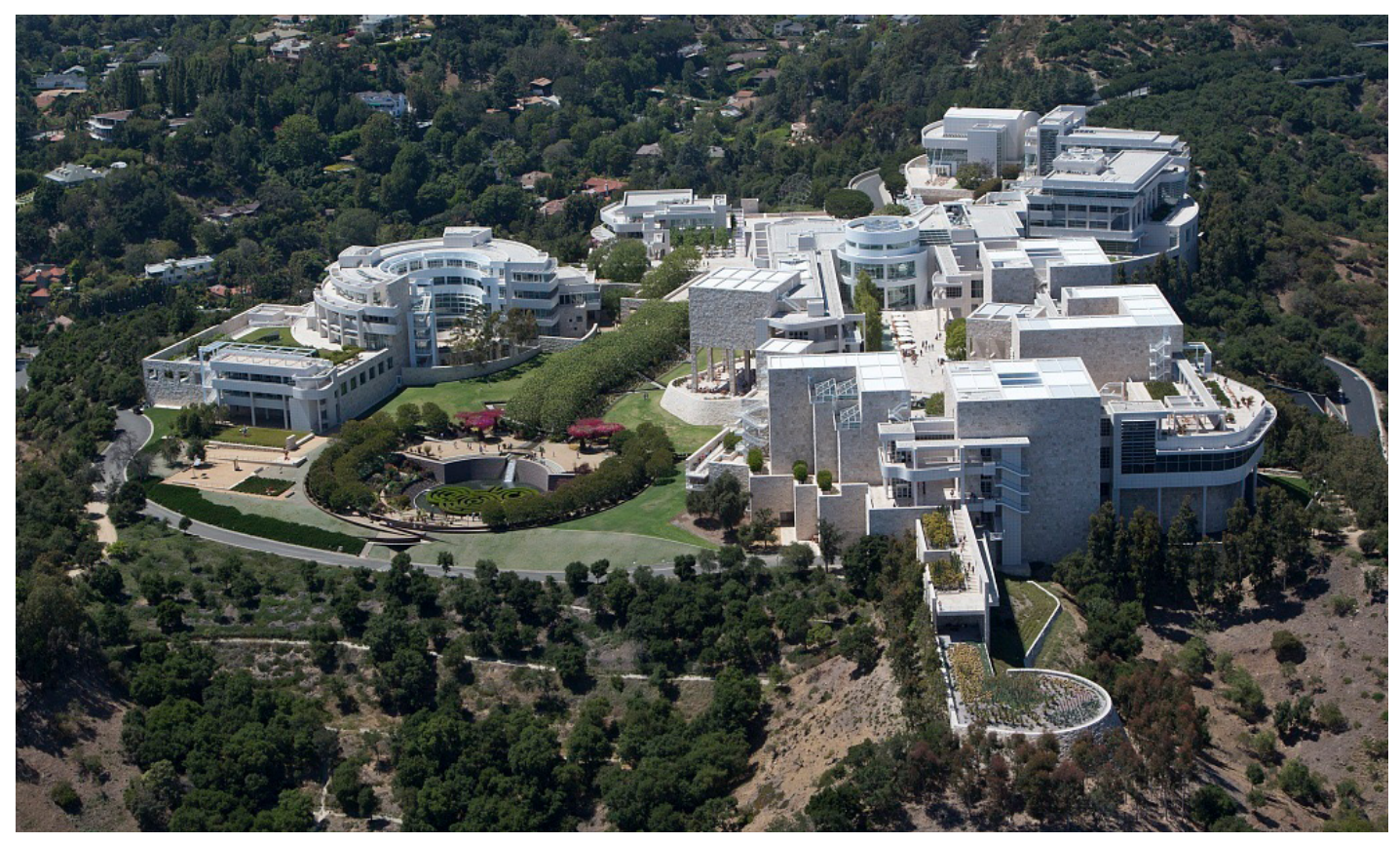

de urbanidade do que de arquitetura [...]. O urbano é o meio ideal, combinando o imprevisível com algum grau de organização, pois uma cidade nunca prevê o que vai acontecer; ao invés disso, oferece os potenciais latentes para as coisas acontecerem, acontecerem de uma maneira relacionada. ${ }^{420}$

Como sugestão para enfrentar o desafio do момА, o arquiteto vislumbrou um ponto de partida radical: o desmantelamento de todo o programa do museu visando interesses programáticos, a exemplo da solução adotada para o J. Paul Getty Museum em Los Angeles, ${ }^{421}$ que teria dispersado o centro em vários volumes em função de interesses arquitetônicos e de uma diversificação.

Concluindo o encontro, o arquiteto e curador chefe do Departamento de Arquitetura e Design, Terence Riley (1954-), ${ }^{422}$ ressaltou que as falas anteriores apontaram para o fato de que "não há fórmula para um ótimo museu", ${ }^{423}$ havendo, entre as instituições bem sucedidas, aquelas em que a arquitetura não
3.12 J. Paul Getty Museum, projeto de Richard Meier \& Partners de 1997, Los Angeles, 2012. Foto: Carol M. Highsmith. Fonte: https://picryl.com/ media/aerial-view-of-the-j-paul-gettymuseum-of-art-in-los-angles-california-1

420 Ibidem, p. 63.

421 Projeto do escritório Richard Meier \& Partners, concluído em 1997.

422 Terence Riley ingressara no MoMA em 1991 e ocuparia o cargo de diretor do Departamento de Arquitetura e Design do museu entre 1992 e 2005 .

423 Terence Riley. Summary Session. In: ELDERFIELD, 1998, op. cit., p. 72. Tradução nossa. 

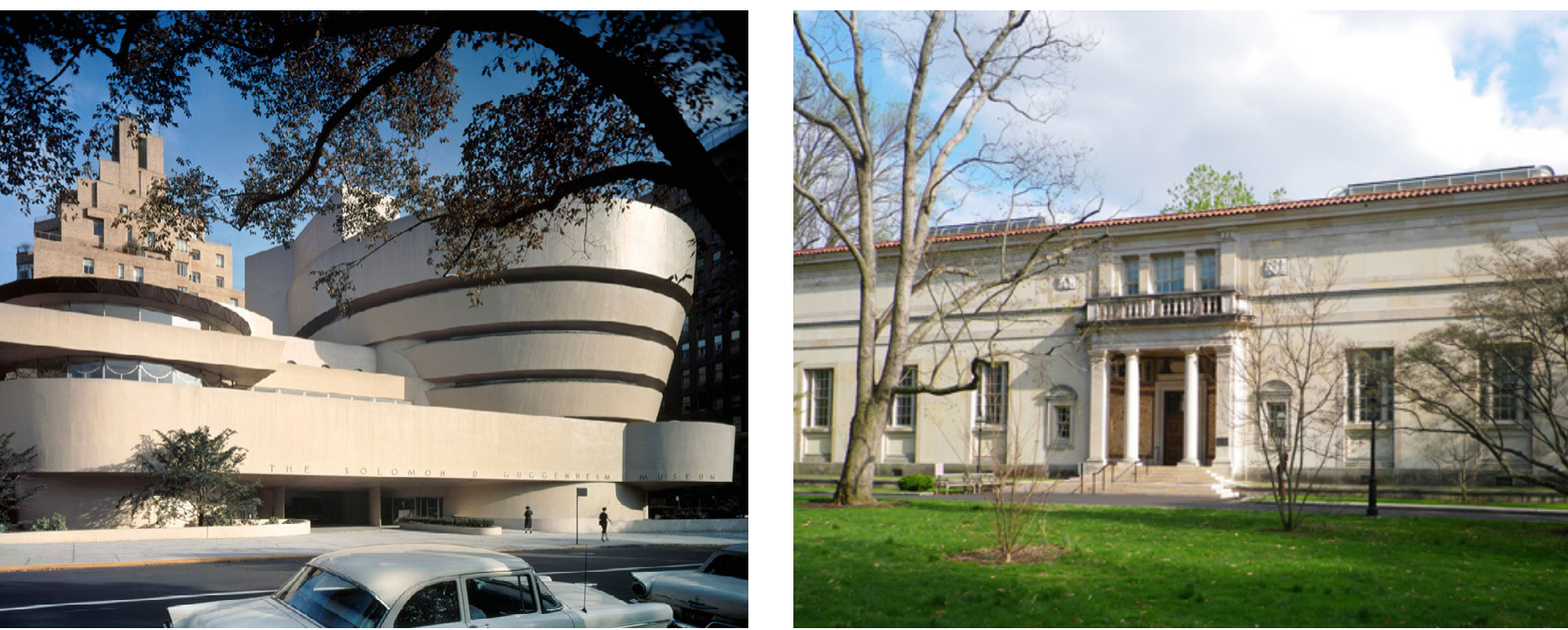

3.13 The Solomon R. Guggenheim Museum, projeto de Frank Lloyd Wright, Nova York, 1959. Foto: Robert E. Mates. Fonte: https://www.archdaily.com.br/ br/877911/58-anos-de-evolucao-nomuseu-guggenheim-de-frank-lloyd-wright

3.14 Sede da Barnes Collection de 1922 a 2012, Merion, s.d. Foto: Dmadeo. Fonte: https://www.philanthropyroundtable. org/home/resources/donor-intent/ donor-intent-resource-library/ outsmarting-albert-barnes assumiria um papel central - como o caso do próprio MOMA, conforme mencionou Koolhaas -, outras em que, ao contrário, a arquitetura seria tão impactante que poderia deixar a arte em segundo plano - como o Guggenheim de Frank Lloyd Wright em Nova York - e ainda aquelas em que o valor da coleção tornaria quase desnecessária a atividade curatorial, como no caso da Barnes Foundation na Filadélfia. Riley destacou o que Eisenmann identificara como uma ironia na procura do момА daquele momento: o fato de que, para se projetar um museu, melhor seria evitar projetar um museu, ou seja, não se deveria perseguir um paradigma - um "monumento a uma ideia do passado", mas procurar criar um modelo novo. O curador apontou ainda para um aspecto que não fora mencionado pelos demais participantes: o fato de que, estando o MoмA situado não num lugar remoto, mas no centro de Manhattan, isso o tornaria necessariamente parte de um organismo maior, de natureza complexa, transgressiva e disruptiva. Identificando o momento como de risco e oportunidade, Riley fez um balanço entre as expectativas e o resultado do encontro:

Uma das questões, e uma muito sensata, que se esperava que pudéssemos responder, é com o que o novo Museu se 
parecerá, e eu devo informar que não há uma conclusão. O encontro foi bastante inconclusivo a esse respeito, mas penso que foi também importante para perceber que não há pressa para discutir estilo e que as metáforas, significados e estratégias são muito mais importantes [...]. Não passamos tanto tempo falando sobre com o que se pareceria o Museu - não a princípio, de todo modo -, mas refletindo sobre como ele seria em diversos outros aspectos antes de pensar sobre com o que ele se pareceria. ${ }^{424}$

A expectativa mencionada por Riley de que a discussão pudesse ter explorado de modo mais direto qual "estilo" arquitetônico corresponderia às demandas de atualização do museu para o século xxi ecoa, de certa forma, o modo de abordar a arte moderna que predominara nо мома ao longo de toda sua história. Denota, portanto, o descompasso da instituição com relação aos caminhos trilhados por boa parte da arte contemporânea a partir dos anos 1960, que deslocara o foco do objeto para o contexto e, conforme apontou Isozaki, tornara problemática a relação entre conteúdo e contêiner. Enquanto representantes do museu seguiam enfatizando a possibilidade de sustentar uma continuidade entre moderno e contemporâneo - identificada por Koolhaas como um fardo -, vozes externas apontavam para uma situação de crise e para a necessidade de uma abordagem mais aberta e indefinida não apenas para a arquitetura, que deveria levar mais em conta a perspectiva da arte, mas também para a postura institucional. O caráter "inconclusivo" evidencia, afinal, a natureza problemática da premissa colocada para o encontro, o de elencar um "rol comum de aspirações", ou seja, de atender a uma expectativa de "convergência" de visões, que talvez só pudesse ser de fato alcançada pela identificação de um "estilo" de arquitetura para o museu no presente e no futuro. O paradoxo estava no fato de que essa busca, se havia sido condizente com o espírito do modernismo no século $\mathrm{xx}$, era incompatível com o ambiente contemporâneo, no qual a noção de "caminho único" cedera lugar à aceitação de que múltiplas e divergentes manifestações podiam simultaneamente representar expressões "de seu tempo".

424 Ibidem, p. 72. 


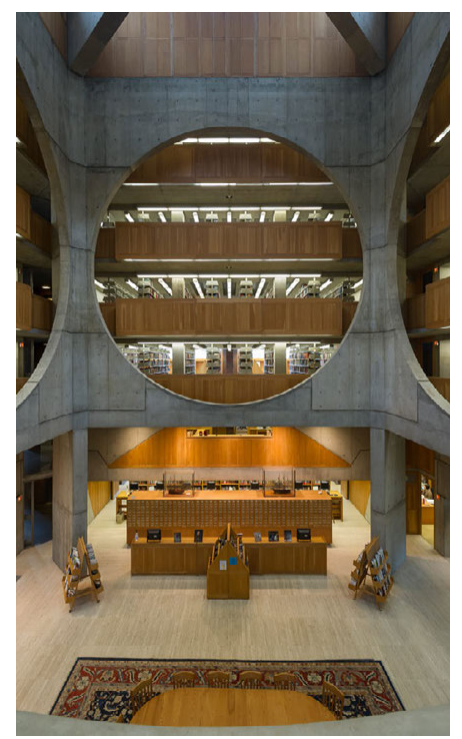

3.15 Biblioteca da Phillips Exeter Academy, projeto de Louis Kahn de 1971, Exeter, 2011. Foto: Xavier de Jauréguiberry. Fonte: https://divisare. com/projects/304785-louis-kahn-xavierde-jaureguiberry-library-at-phillips-exeteracademy

425 Em 22 de outubro de 1996, Glenn Lowry apresentou a palestra Building the Future: Some Observations on Art, Architecture, and the Museum of Modern Art. Cf. ELDERFIELD, 1998, op. cit.

426 Terence Riley. Rethinking the Modern. In: ELDERFIELD, 1998, op. cit., p. 122. Tradução nossa.

427 Ibidem, p. 122.

428 Ibidem, p. 123.

429 Ibidem, p. 124.

\subsubsection{ESPAÇO CRÍTICO E CELEBRATÓRIO}

A segunda rodada de discussões, organizada de outubro a dezembro de 1996 e integrada ao programa do мома Studies in Modern Art, foi aberta ao público e dedicada ao tema "Imaginando o Futuro do Museu de Arte Moderna no Século XxI", sendo mais focada nos aspectos arquitetônicos do museu do que nos conceituais do encontro anterior. Das quatro sessões - duas palestras (proferidas por Lowry e por Riley) ${ }^{425}$ e duas mesas de debate -, vale destacar os pontos de interesse para esta tese, os que dizem respeito aos espaços arquitetônicos destinados à arte.

Ao procurar "descrever as qualidades das galerias, bem como de outros espaços em que a arte é exposta", ${ }^{426}$ Terence Riley explorou o conceito que chamou de "espaço crítico". Tal espaço estaria em contraste com o espaço monumental, uma vez que permitiria uma postura cética do espectador, sendo, nas palavras do curador, "um espaço onde indivíduos sentem-se livres para exercitar seu próprio julgamento sobre como irão participar no contexto do museu." ${ }^{427}$ Além da experiência individual, vinculada a uma ideia de espaço crítico, seria preciso, segundo Riley, considerar a natureza celebratória da experiência coletiva com a arte: "museus deveriam celebrar esse evento cada vez mais raro, a experiência compartilhada, na qual um grande número de estranhos faz momentaneamente parte de um evento comum." ${ }^{428}$

Um dos exemplos da conjugação desses dois tipos de espaço levantados pelo curador seria não um museu, mas a biblioteca da Phillips Exeter Academy em New Hampshire - projeto de Louis Kahn de 1967-71 -, na qual o espaço central grandioso do átrio estaria associado à experiência coletiva e celebratória, enquanto espaços de menores proporções ao seu redor favoreceriam atividades individuais. Riley então esclareceu: "o que estou chamando de espaço crítico se distancia do centro, criando espaços de atividade mais autônoma, espaços nos quais o indivíduo pode escolher participar ou não, ser ou não parte de um grupo, espaços nos quais se é livre para ser cético." ${ }^{229} \mathrm{~A}$ experiência de intimidade com a arte, frequentemente apontada como uma das principais qualidades do MOMA, teria como 
origem os ambientes das residências burguesas nas quais a arte moderna era exposta por colecionadores pioneiros. Segundo o curador, a ideia de intimidade era muito associada à escala reduzida e não grandiosa, mas, em sua opinião, poderia ser entendida como oportunidades dentro de um edifício e, nesse sentido, ser vinculada à sua própria definição de espaço crítico: "se um grande edifício almeja proporcionar algum sentimento de intimidade, ele deve, em primeiro lugar, dar ao visitante a sensação de estar participando da criação de sua própria experiência intelectual e social.” ${ }^{430}$

Terminada a explanação de Riley, o diretor Glenn Lowry instigou seu colega a relacionar as noções de "caixa branca" e "caixa preta" com a suposta necessidade de configurar galerias como "espaços neutros" e a abordar as implicações disso para a experiência de olhar para a arte na atualidade..$^{431} \mathrm{O}$ curador mencionou então ao aspecto ideológico contido na associação entre o espaço tipo "caixa branca" e a ideia de "neutralidade" - o de que, quanto mais discreto o espaço, mais acentuadas seriam as características das obras de arte. Conforme defendeu, esse tipo de ambiente acabaria fazendo com que as obras fossem vistas como nunca teriam sido antes, pois nem os ateliês de artistas, nem as casas dos colecionadores se assemelhariam à "caixa branca".

Por outro lado, segundo Riley, parte da evolução da "caixa branca" teria se dado no MoMA não por razões ideológicas, mas por motivos "puramente pragmáticos". O museu teria adotado continuamente esse padrão expositivo em função especialmente da insuficiência crônica de áreas expositivas, o que o teria levado, ao longo de sua história, a apresentar o acervo de modo rotativo, intercalado com exposições temporárias, tendo para isso que demolir e reconstruir paredes constantemente. A solução "caixa branca" estaria, portanto, associada sobretudo a uma necessidade de reprogramação permanente dos espaços expositivos, que também caracterizaria a mais atual "caixa preta", usada para instalações audiovisuais imersivas. Associando a prática da reprogramação a uma ideia de "arquitetura descartável", o curador comentou que, "se a arte não fosse tão fabulosa e maravilhosa, ninguém ia querer vir a este museu" e lembrou ainda que Philip Johnson, seu antecessor no
430 Ibidem, p. 124.

431 Nessa discussão, tanto Lowry quanto Riley referem-se ao tipo de espaço expositivo supostamente neutro como white box, ao invés do equivalente white cube, expressão que se popularizara desde que fora cunhada por Brian O'Doherty nos anos 1970 . 
432 RILEy, ibidem, p. 124.

Tradução nossa.

433 Ibidem, p. $134-5$. departamento, se desculpava por "não haver arquitetura" em seu projeto dos anos 1960 para as galerias a leste do jardim. O arquiteto teria afirmado: "flexibilidade significa a negação da arquitetura, é uma pura equação econômica". ${ }^{432}$

Na opinião de Riley, a "caixa branca descartável" não seria considerada pelo Mома o melhor tipo de espaço para os artistas exporem suas obras, pois, "se esses trabalhos serão sempre vistos num contexto definido pelo curador, haverá, no limite do possível, o momento em que a obra de arte poderá ser vista do modo como foi inventada pelo artista. Creio que isso é algo que queremos continuar." ${ }^{" 33}$ Essa última colocação acabava, no entanto, apontando para um paradoxo: para mostrar obras de arte do modo com que cada artista a teria inventado, seria possível evitar a prática da reprogramação constante dos espaços expositivos e da necessidade de uma "arquitetura descartável", pelo menos para as áreas reservadas para as galerias? Tal questão, inescapável para qualquer museu de arte contemporânea, seria um especial desafio para о момА, cujo projeto arquitetônico teria que considerar ainda o peso de sua tradição como museu de arte moderna.

Neste ponto, é preciso observar que todo o processo de discussão sobre a arquitetura em relação aos espaços da arte que tivera início ao final de 1996 foi feito sem que qualquer um dos participantes considerasse a hipótese de que o MомA viesse, apenas dois anos depois, a iniciar as negociações com o centro de arte contemporânea PS1 para fundir as duas instituições. Como vimos no capítulo anterior, a fusão nasceria, num primeiro momento, da necessidade do museu de encontrar parceiros para continuar sua programação enquanto a sede de Manhattan estivesse em obras e do interesse de Alanna Heiss, que liderava o PS1, em associar-se de modo permanente a uma instituição que garantisse a longevidade de seu projeto. A proposta do PS1 baseava-se numa ampla participação dos artistas nas decisões e ações, bem como numa condição na qual o edifício era entendido não como um contêiner pronto para receber a arte, tampouco como uma arquitetura destituída de expressão ou com um tipo de flexibilidade ligada ao "descartável”, mas como uma matéria passível de ser transformada pela incorporação de seus elementos pelos artistas. 
A parceria com uma instituição de arte fundada em outras bases e com espaços radicalmente diversos do MoMA não estava de fato no horizonte de possibilidades enquanto as discussões sobre a ampliação da sede estavam em curso, tendo o anúncio da fusão, em 1999, surpreendido toda a comunidade artística. É digno de nota, porém, que o PS1, atendendo a muitos das qualidades apontadas nos debates e palestras como positivas para espaços de arte contemporânea, tenha ainda assim passado longe das discussões daquele momento. Podemos especular que uma das razões para que um espaço como o PS1 estivesse fora do campo de referências discutidas para a ampliação do MOMA tenha sido, além de sua evidente condição marginal na cidade e no circuito das instituições estabelecidas, o fato de que sua arquitetura não respondesse a uma das demandas caras ao museu, por não representar propriamente um "estilo" - moderno ou contemporâneo -, nem uma expressão autoral, mesmo após a recente reforma projetada por Frederick Fisher. Fato é que, mesmo tendo conduzido o processo de ampliação visando cobrir diversas frentes para se preparar para um futuro desconhecido, um elemento inesperado cruzou o caminho do момA e a fusão foi colocada em prática enquanto as decisões acerca do novo projeto arquitetônico já estavam tomadas, apesar de a obra mal ter sido iniciada.

\subsubsection{O PROCESSO DE ESCOLHA DE UMA PROPOSTA ARQUITETONNICA}

Dado o interesse desta tesa na investigação dos espaços arquitetônicos destinado à arte contemporânea, vale se deter mais minuciosamente no exame das etapas seguintes do processo conduzido pelo мома para escolha de uma proposta de projeto, visando compreender os fatores que viriam a determinar o resultado entendido então pela instituição como a expressão arquitetônica mais sintonizada com suas expectativas naquele momento, a de, segundo Lowry, "construir um edifício inteligente, eficiente e vital para o seu futuro." ${ }^{434}$

Ainda em 1996, ao mesmo tempo em que promovia debates em torno de conceitos e propostas para ampliar e renovar sua
434 Glenn Lowry. The New Museum of Modern Art Expansion: A Process of Discovery. In: ELDERFIELD, 1998, op. cit., p. 19. Tradução nossa. 
435 O comitê de seleção de arquitetura era composto por Sid R. Bass (presidente), David Rockefeller, Ronald Lauder, Agnes Gund, Marshall Cogan e Jerry Speyer, contando com a participação do diretor do MoмA, Glenn D. Lowry, e do curador chefe do Departamento de Arquitetura e Design, Terence Riley, e a assessoria de Edward Larrabee Barnes, Barbara Jakobsen, Philip Johnson e do vice-diretor de assuntos curatoriais, John Elderfield. Cf. Foster, Hal et al. The MoMA Expansion: A Conversation with Terence Riley. October, v. 84, p. 3-30, 1998.

$436 \mathrm{O}$ termo charrete tem origem na expressão charrette da língua francesa e é utilizado com sentido similar na língua inglesa: designa um período de trabalho intenso voltado à solução de um projeto, comumente associado aos dias que antecedem o prazo final de apresentação de um concurso de arquitetura. sede, o museu dedicava-se a frentes de ação mais práticas na preparação das bases para o desenvolvimento do projeto e a seleção de equipe de arquitetura. A empresa de arquitetura Cooper, Robertson and Partners foi contratada para realizar, junto aos diversos departamentos do museu, uma análise detalhada das necessidades programáticas, definindo cenários válidos tanto para o ano de 2005 - quando a obra deveria estar concluída - quanto para 2025, para quando estava prevista a próxima reavaliação institucional. Em paralelo, foi formado um comitê que definiria o processo e o critério de escolha da equipe que lideraria o projeto de arquitetura. ${ }^{435}$ Diante da complexidade da missão, que envolvia as restrições de zoneamento de Nova York e a presença de edifícios de outras épocas a preservar, o comitê estabeleceu que o processo não deveria começar direto por propostas projetuais para a ampliação do edifício, mas pela exploração, por um grupo restrito de dez arquitetos convidados, das possibilidades de ocupação do lote, considerando as necessidades e condições específicas do museu e as questões conceituais e funcionais previamente levantadas. Denominado no processo de Charrete ${ }^{436}$ essa primeira etapa de seleção seria um esforço concentrado de reflexão mais aberta que permitiria ao comitê definir as três equipes que tivessem apresentado as abordagens mais interessantes sobre o museu sob a ótica da arquitetura e do urbanismo, que participariam em seguida de um concurso de projeto nos moldes mais convencionais.

Conforme explicou Terence Riley, que, estando no papel de curador chefe do Departamento de Arquitetura e Design, exerceu grande influência na condução do processo de seleção, era importante garantir que a reflexão arquitetônica participasse não apenas da elaboração de uma solução para problemas pré-estabelecidos pelo museu, mas que contribuísse para a definição do próprio diagnóstico dos problemas que envolviam a expansão:

A ideia era que, antes de o programa ser concluído como um documento, um grupo de arquitetos reagisse a ele na etapa inicial do processo de seleção e fornecesse, pela primeira vez, imagens arquitetônicas, pensamento arquitetônico. Em 
seguida, o museu revisaria o programa à luz disso, e então avançaria para um concurso mais tradicional. A diferença entre uma Charette e uma concurso, na minha opinião, é que um concurso normalmente busca uma solução única otimizada para um problema arquitetônico. ${ }^{437}$

Para o curador, o processo deveria ser elaborado de forma a equilibrar o jogo de forças na relação entre arquiteto e instituição. Nos EUA, seria mais comum que o cliente ou empreendedor - individual, corporativo ou institucional - escolhesse livremente um arquiteto, fazendo com que esse atuasse mais como um prestador de serviços e tivesse menos condição de oferecer uma contribuição intelectual. Na Europa, ao contrário, haveria uma longa tradição de realização de concursos de projeto, o que conferiria ao arquiteto selecionado "uma vantagem terrivelmente grande no relacionamento." ${ }^{438} \mathrm{O}$ peso do contratante também seria reduzido em processos nos quais o critério de escolha visasse a produção de uma obra "assinada" por um grande nome da arquitetura. Por esses motivos, Riley entendia que o modelo bastante específico de seleção adotado naquele momento seria o mais adequado para possibilitar o sucesso do projeto:

Primeiro, a instituição precisa entender o que quer ser e deve ser capaz de expressar isso claramente. Em segundo, o arquiteto deve compreender o que está sendo comunicado [...]. No caso do MOMA, você tem uma instituição de quase setenta anos. Portanto, ela tem uma história, mas não quer simplesmente fazer as coisas como já fez antes. O processo deve ser capaz de comunicar isso ao arquiteto. Isso significa que deve haver diálogos e trocas de ideias que normalmente não estão presentes em muitos modelos de seleção. ${ }^{439}$

A definição das dez equipes convidadas para a Charette se deu em janeiro de 1997, quando o comitê de seleção se reuniu para analisar portfolios de uma ampla gama de equipes de arquitetura atuantes no cenário internacional, entre relativamente jovens e mais estabelecidos, chegando aos nomes de Wiel Arets, Jacques Herzog \& Pierre De Meuron, Steven Holl, Toyo Ito, Rem
437 Terence Riley in: Foster, Hal et al, op. cit., p. 4. Tradução nossa. 438 Ibidem, p. 5 . 439 Ibidem, pp. 5-6. 


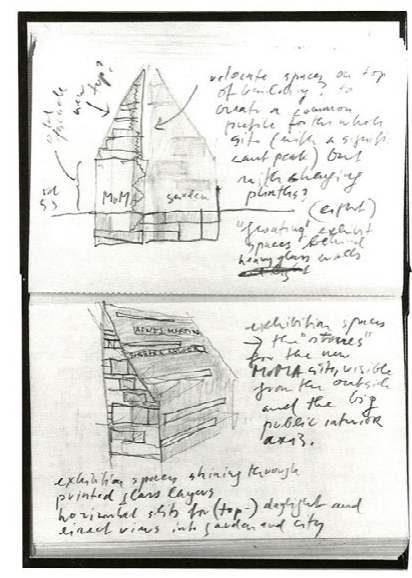

3.16 Sketchbook Art and People in the 21st Century apresentado por Herzog \& De Meuron para a charrete do MoMA, Nova York, 1997. Fonte: ELDERFIELD, p. 232.

3.17 Croquis apresentado por Yoshio Taniguchi para a charrete do MoMA, Nova York, 1997. Fonte: ELDERFIELD, p. 251.

440 Glenn Lowry. The New Museum of Modern Art Expansion: A Process of Discovery. In: ELDERFIELD, 1998, op. cit., p. 16. Tradução nossa.

441 Ibidem, pp.10-26.

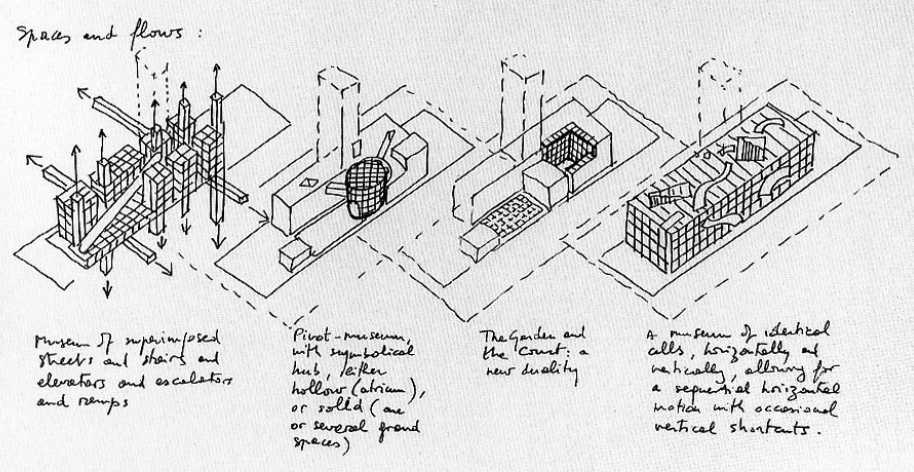

Koolhaas, Dominique Perrault, Yoshio Taniguchi, Bernard Tschumi, Rafael Vigñoli e Tod Williams \& Billie Tsien. Conforme afirmou Glenn Lowry, que cada uma dessas equipes fora escolhida pelo comitê por ter "explorado as possibilidades da arquitetura moderna de novas e interessantes maneiras que expandiram e desafiaram os parâmetros da arquitetura moderna." ${ }^{40}$

Os selecionados participaram de um workshop realizado no MOMA de 17 a 19 de fevereiro de 1997, para que se familiarizassem com membros chave do pessoal e do conselho do museu, com o próprio edifício, com o programa de necessidades, com as questões conceituais e com as leis de zoneamento. Ao final, cada equipe recebeu uma caixa-estojo na qual deveriam ser depositados croquis, desenhos, plantas e textos que elucidassem suas propostas, a serem entregues ao museu em pouco mais de um mês. Os critérios para definir, a partir da Charrete, de duas a quatro equipes que passariam para a etapa seguinte de concurso de projeto foram: demonstração de clara liderança no projeto, capacidade de desafiar o museu - valorizando ao mesmo tempo sua missão -, habilidade de pensar simultaneamente a grande e a pequena escala e sensibilidade à arte - especialmente relativa às produções modernas e contemporâneas. ${ }^{441}$

Os finalistas foram apontados pelo comitê de seleção e pelo conselho do museu em 9 de abril de 1997, segundo as razões expostas por Riley: os suíços Jacques Herzog e Pierre De Meuron 


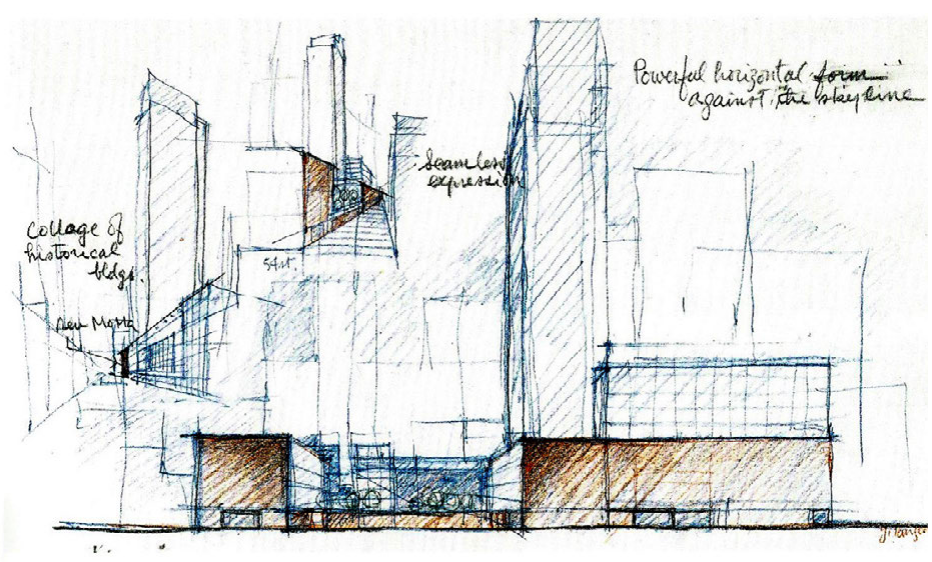

(ambos 1950-) teriam apresentado ideias engenhosas e provocativas que refletiriam uma aguçada consciência sobre o desenvolvimento do papel da arquitetura em moldar a apreciação da arte; o também suíço Bernard Tschumi (1944-)teria demonstrado profunda compreensão das questões curatoriais e da missão do museu e uma excitante reconceituação do lote; o japonês Yoshio Taniguchi (1937-), por sua vez, teria revelado elegância e clareza nos conceitos de projeto e sensibilidade à luz e ao espaço. ${ }^{442}$

No intuito de tornar pública a discussão e divulgar os esforços do museu na renovação, o MoMA organizou em seguida uma exposição com o material da Charette, denominada Toward the New Museum of Modern Art: Sketchbooks by Ten Architects, remetendo tanto ao título de uma exposição realizada para preparar a expansão de 1964 - Toward the New Museum of Modern Art: A Bid for Space - quanto ao título do manifesto de Le Corbusier traduzido para o inglês como Toward a New Architecture (Vers une Architecture, no original em francês). ${ }^{43}$ Segundo Lowry,

Por meio dessas alusões, a exposição buscava não apenas apresentar as charettes no contexto das aspirações do museu para o futuro, mas também situá-las na sua extensa história arquitetônica do museu e afirmar seu compromisso com a tradição do modernismo. ${ }^{444}$
3.18 Diagramas spaces and flows apresentados por Bernard Tchumi para a charrete do MoMA, Nova York, 1997. Fonte: ELDERFIELD, p. 258.
442 RiLEY, Terence. The Charette. In: EDERFIELD, op. cit., pp.142-159. Tradução nossa.

443 Cf. The Museum of Modern ART. Toward the New Museum of Modern Art: Sketchbooks by Ten Architects (May 1-Oct 7, 1997). MOMA. Disponível em: <https://www.moma.org/calendar/ exhibitions/3071?>. Acesso em: 30 maio 2021.

444 Glenn Lowry. The New Museum of Modern Art Expansion: A Process of Discovery. In: EDERFIELD, op. cit., p.17 Tradução nossa. 
445 Cf. The Museum of Modern ART. Rethinking the Modern: Three Proposals for The Museum of Modern Art (Mar 5-Apr 28, 1998), мОмA. Disponível em: <https:// www.moma.org/calendar/exhibitions/204>. Acesso em: 28 set. 2020.

446 John Elderfield apud LESSARD, Suzannah. Quietly, He Grew on Them. The New York Times Magazine, 12/o4/1998. ed. p. 30, 1998.
As três equipes selecionadas passaram então para a etapa de concurso de projetos, retornando ao museu de 4 a 6 de junho de 1997 para mais uma rodada de discussões e reuniões, que incluíram a análise de todas as ideias apresentadas na Charette. Entre final de julho e início de agosto de 1997, Lowry, Riley e o diretor do projeto de expansão, William Maloney, viajaram para a Europa e o Japão para reunir-se com cada equipe de arquitetura em seus respectivos escritórios e esclarecer dúvidas ainda durante o desenvolvimento dos projetos, que seriam entregues em 26 de setembro de 1997.

Um extenso trabalho de análise dos projetos foi empreendido pelas equipes designadas pelo museu, que anunciou, em dezembro de 1997, a proposta de Yoshio Taniguchi como a vencedora do concurso. Entre os três finalistas do concurso, o projeto escolhido era o mais discreto, sem elementos de destaque como a torre multifacetada de vidro e aço que Herzog \& de Meuron propuseram para o setor curatorial, ou o bloco em balanço para as galerias de arte contemporânea do projeto de Tschumi. Todo o material das propostas - pranchas com desenhos, esquemas, fotomontagens e textos, além de maquetes - foi exposto ao público na mostra Rethinking the Modern: Three Proposals for The Museum of Modern Art, que ficou em cartaz no museu de 5 de março a 28 de abril de $1998 .^{445}$

Em matéria publicada nessa ocasião no The New York Times Magazine, a escritora Suzanna Lessard relatou que os representantes do MoMA demonstraram grande satisfação com o resultado, tendo John Elderfield afirmado que "uma onda de euforia percorreu o staff quando a seleção se tornou conhecida. Todo mundo estava animado com o quão interessante isso seria”. ${ }^{446}$ Segundo a autora, a decisão teria sido apoiada por boa parte da imprensa, mas teria causado decepção nos círculos de vanguarda e entre os arquitetos excluídos do concurso, que esperavam que o MomA pudesse ter feito uma escolha mais ousada naquele momento, quando acabavam de ser inaugurados museus de arquitetura impactante, como Guggenheim Bilbao, de Frank Gehry, e o Getty Center em Los Angeles, de Richard Meier. Para os descontentes, o museu teria desperdiçado a oportunidade de realizar o mais importante edifício 
contemporâneo do mundo ao fazer uma escolha considerada cautelosa e desinteressante. ${ }^{447}$ Sinal de quanto o resultado fora inesperado foi a avaliação publicada pela New York Magazine durante a Charette, que havia conferido nenhuma chance a Taniguchi e o favoritismo a Rem Koolhaas, que acabou nem passando para a segunda etapa da concorrência.

Apreende-se daí que poucos levaram à sério a intenção expressa pelo MомA de tratar o contemporâneo em continuidade com o moderno, o que o próprio Koolhaas tinha apontado como um fardo para a instituição nos debates de Pocantico. Embora pudesse ser vista por artistas e arquitetos contemporâneos como equivocada, incômoda ou mesmo retrógrada, a ideia de continuidade estava entranhada na instituição, constituindo-se, naquele momento, como uma convicção, uma baliza para enfrentar os tempos futuros sem perder sua identidade. O que levou à aprovação consensual pelo comitê da proposta vencedora foi terem considerado sua atitude respeitosa - mas não subserviente - com relação às demandas apresentadas pelo MомA, tanto em termos programáticos e funcionais quanto simbólicos. Taniguchi baseou seu projeto não numa ideia preconcebida sobre arte e arquitetura no cenário atual, mas na compreensão dos interesses específicos daquele museu, tendo estudado a fundo tanto sua história quanto suas necessidades, por meio de investigações nos arquivos e na biblioteca, e também de conversas com visitantes e funcionários. ${ }^{448}$ Sem contestar o que muitos viam como uma incongruência, Taniguchi compreendeu melhor que seus concorrentes as expectativas do museu de preparar-se para o século XxI mantendo em evidência seus vínculos intrínsecos com o século xx.

\subsubsection{O PROJETO VENCEDOR DE TANIGUCHI}

Com a equipe menos internacional entre as participantes, Taniguchi nunca havia realizado um projeto fora do Japão, nem participado de um concurso antes e tampouco tinha feito um edifício institucional de tamanho porte. Não que fosse um profissional inexperiente, na época em que venceu o concurso tinha 60 anos recém-completados, a idade mais avançada entre
447 Cf. Ibidem.

448 Taniguchi permanecera por 10 dias em Nova York depois do anúncio da Charette para empreender pessoalmente essa pesquisa. 

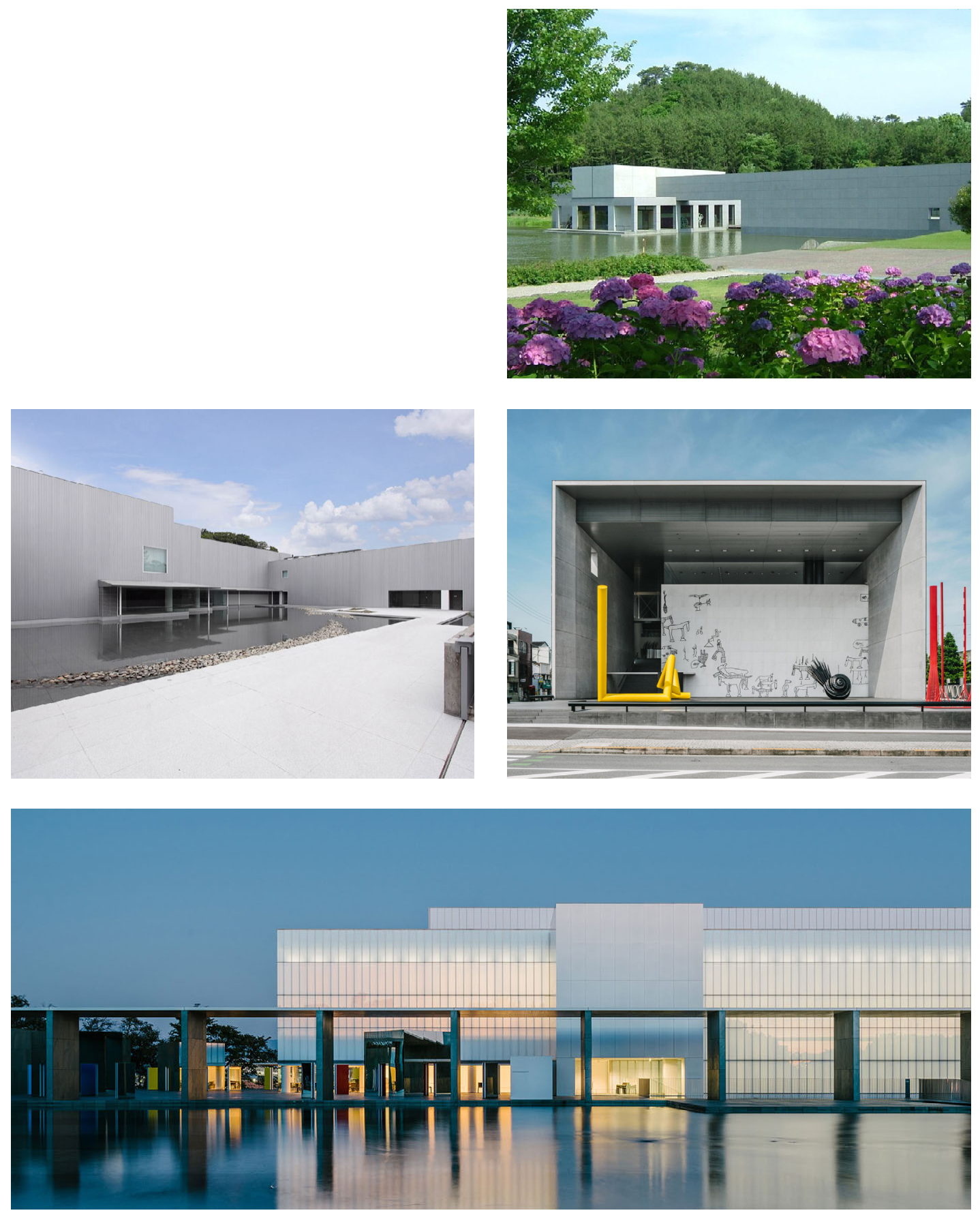
os concorrentes, e uma carreira sólida. Filho de Yoshiro Taniguchi (1904-1979), um arquiteto renomado em seu país, Yoshio Taniguchi se diplomara na Escola de Design de Harvard e, de volta ao Japão em 1964, integrou a equipe do arquiteto veterano Kenzo Tange (1913-2005). Com a morte do pai, assumiu o escritório que ele havia fundado - o Taniguchi \& Associates - e, na época em que recebeu o convite do Moma, já tinha um respeitável currículo de obras. Entre os edifícios institucionais e museus que havia projetado e construído nos anos recentes estavam o Museu da Fotografia Ken Domom (Sakata, 1983), a Galeria Higashiyama Kaii (Nagano, 1990) o MIMOCA - Museu de Arte Contemporânea Marugame Genichiro-Inokuma (Marugame, 1991) e o Museu Municipal de Arte de Toyota (Toyota, 1995). Pouco conhecidas no exterior, suas obras haviam chamado especialmente a atenção de Glenn Lowry e Terence Riley em suas viagens para selecionar as dez equipes que participariam da Charette. Comentando anos mais tarde a experiência de visitar o MIMOCA em Inokuma, Lowry enunciou os aspectos que ele e Riley tinham visualizado com possibilidades para o MOMA:

O edifício abraça a praça urbana com um grande pórtico que se projeta para fora, o que capturou nossa imaginação como um modo de responder ao espaço. Nós podíamos imaginar soluções análogas em termos de como nosso jardim poderia ser posicionado como um espaço urbano principal. ${ }^{449}$

Um dos aspectos-chave do projeto de Taniguchi foi, de fato, a revalorização do jardim de esculturas, que foi emoldurado por dois volumes construídos, simbolizando a dupla missão do museu: o das exposições a oeste e o do setor educativo a leste. Voltados visualmente um para o outro, os dois volumes foram tratados de modo similar, com geometria simples e revestidos na fachada faceada à rua 54 por placas de ardósia preta polida, conferindo sobriedade e unidade ao conjunto. A pertinência da manutenção do jardim havia sido intensamente discutida, tanto no encontro de Pocantico quanto nas propostas apresentadas na Charrete. Na etapa seguinte do concurso, foi enfatizada a importância que o museu conferia não apenas a um jardim,
3.19 Museu da Fotografia Ken Domom, projeto de Yoshio Taniguchi, Sakata, 1983. Fonte: https://sakatacity.com/todo/ ken-domon-museum-of-photography/

3.20 Galeria Higashiyama Kaii, projeto de Yoshio Taniguchi, Nagano, 1990. Fonte: https://www.culture.nagano.jp/en/ facilities/373/

3.21 Museu de Arte Contemporânea Marugame Genichiro-Inokuma (MIMOCA), projeto de Yoshio Taniguchi, Marugame, 1991. Fonte: https://www.mimoca.org/en/

3.22 Museu Municipal de Arte de Toyota, projeto de Yoshio Taniguchi, Toyota, 1995. Fonte: https://www. ana-cooljapan.com/destinations/aichi/ toyotamunicipalmuseumofart

449 Entrevista com Glenn Lowry e Yoshio Taniguchi ao programa televisivo de Charlie Rose em 25/5/2001. LOWRY, Glenn; TANIGUCHI, Yoshio. MoMA Expansion. In: Charlie Rose, Nova York: PBS Bloomberg Television, 2001. (transcrição e tradução livre da autora). 


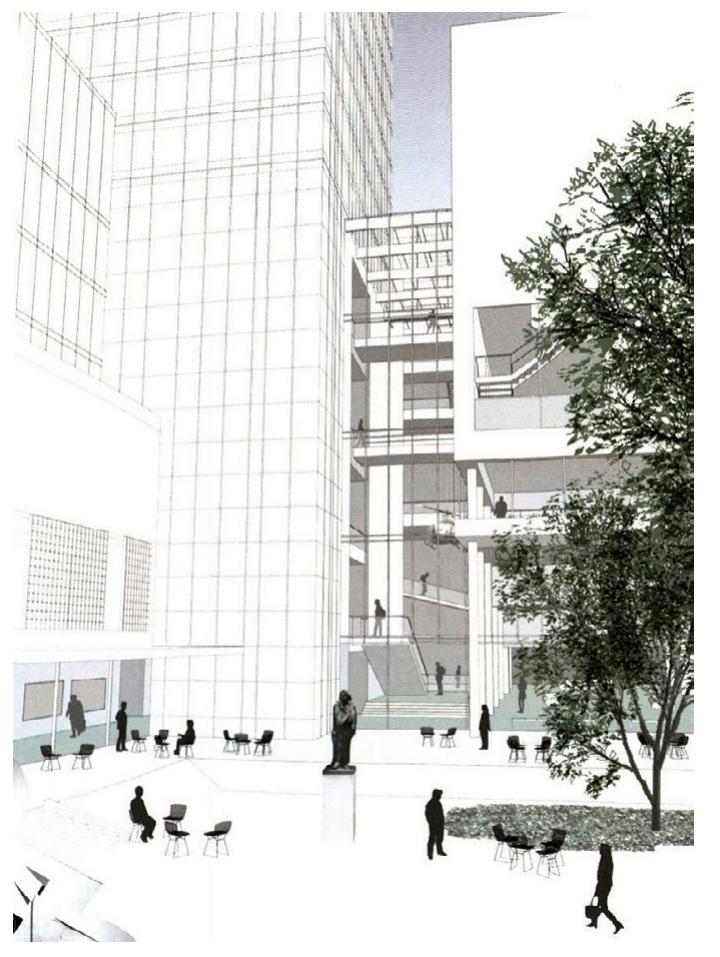

gem de arquiteturas de diversas épocas do MOмA, tratadas desse modo como parte do acervo do museu.

Numa abordagem original, a base do Museum Tower de Pelli, que desde sempre fora envelopada por outros volumes, teve na proposta vencedora uma das quinas exposta para o jardim. Também era possível ver a torre a partir dos espaços ao redor de um átrio assimétrico banhado por luz natural. ${ }^{454}$ Conforme defendeu o arquiteto, "esta exposição seletiva é um reconhecimento e uma expressão dos fortes laços do museu com Manhattan, uma cidade de arranha-céus." ${ }^{455}$

Outro elemento do projeto que buscava valorizar os vínculos do museu com a cidade era uma espécie de avenida interna criada para conectar no térreo do edifício as ruas 53 e 54 . A nova passagem seria integrada visualmente ao jardim na horizontal e ao átrio na vertical e concentraria as áreas de acolhimento balcões de bilheteria, informações, guarda-volumes e loja - e o
3.25 Perspectiva do jardim do MoMA em direção às galerias expositivas no projeto de Yoshio Taniguchi, 1997. Imagem: Taniguchi Associates. Fonte: TANIGUCHI, 1999, p. 262.

3.26 Perspectiva do átrio do MoMA com iluminação natural no projeto de Yoshio Taniguchi, 1997. Imagem: Taniguchi Associates. TANIGUCHI, 1999, p. 269.

454 Cf. TANiguchi, Yoshio. The Architecture of Yoshio Taniguchi. Nova York: Harry N. Abrams, 1999.

455 Terence Riley. The Architectural Competition: Introduction. In: EDERFIELD, 1998, op. cit., p. 276 Tradução nossa. 


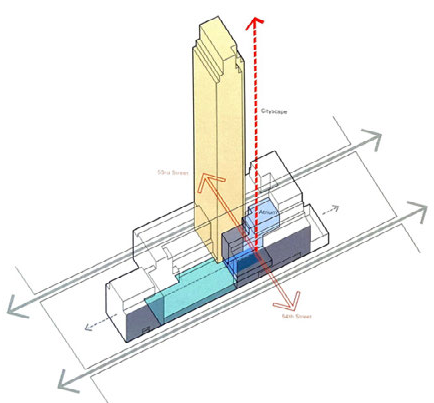

3.27 Isométrica mostrando a interface do MoMA com a cidade no projeto de Yoshio Taniguchi, 1997. Imagem: Taniguchi Associates. Fonte: TANIGUCHI, 1999, p. 262.

3.28 Plantas dos pavimentos térreo e 1 do MoMA no projeto de Yoshio Taniguchi, 1997. Imagem: Taniguchi Associates. Fonte: TANIGUCHI, 1999, p. 265.
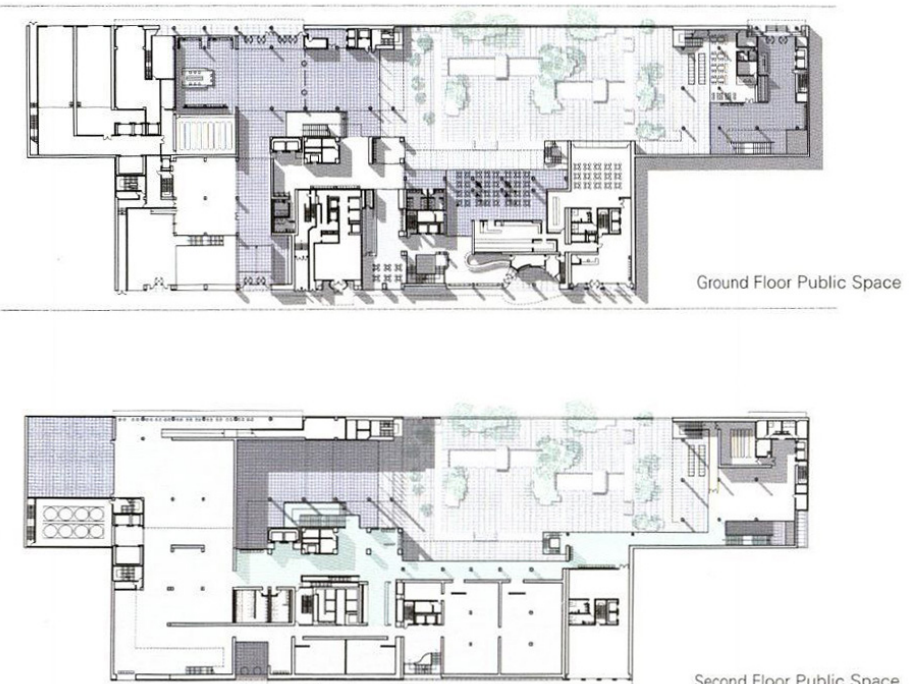

Second Floor Public Space
3.29 Plantas do pavimento térreo do MoMA no projeto de Yoshio Taniguchi, 1997. Imagem: Taniguchi Associates.

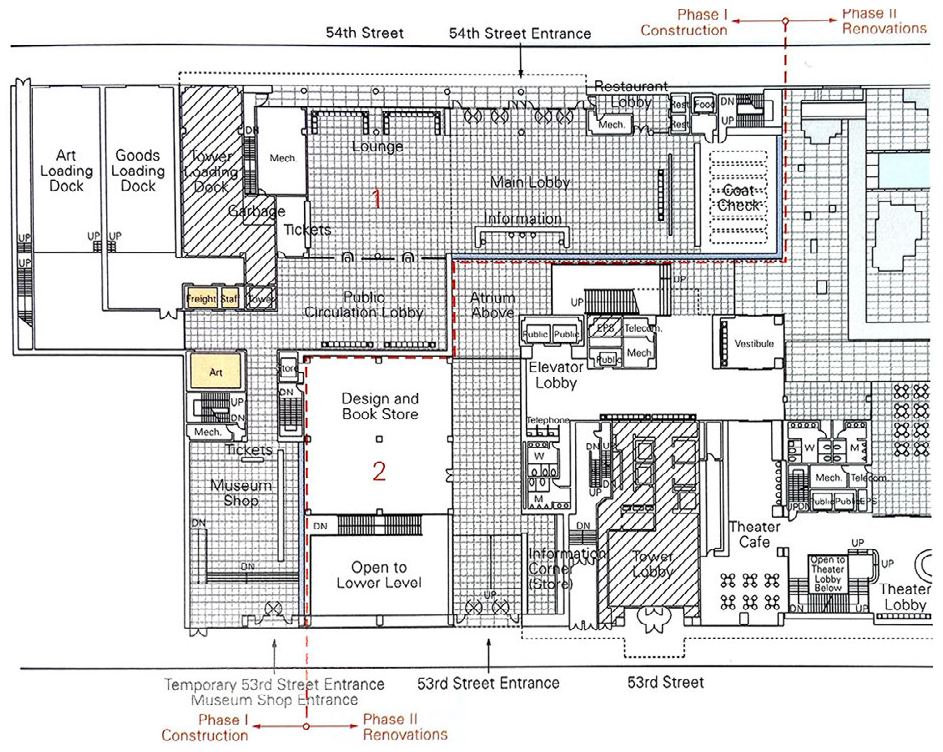


acesso às galerias por escadas e elevadores. $\mathrm{O}$ arquiteto propôs que a entrada principal de público fosse feita por esse novo eixo, privilegiando a rua 54, por onde também acessariam os grupos, no bloco a Leste do setor educativo. Na face do bloco de Goodwin e Stone voltada para a rua 53, seria localizado o acesso aos auditórios de filmes e vídeo e ao restaurante, que poderiam funcionar independentemente, em horários não coincidentes com os do museu.

Além das soluções de circulação, recepção e fachadas, era central para o sucesso do projeto o modo de organizar no conjunto as galerias expositivas, que eram, afinal, o principal programa do museu, e sua carência crônica. Assim como nas demais expansões, o projeto de Pelli ampliara as áreas de exposição, mas posicionara a galeria dedicada a mostras temporárias - nomeada de René d'Harnoncourt em homenagem ao antigo diretor - numa área localizada no subsolo do museu, contribuindo para evidenciar a condição rebaixada que a arte recente ali exposta tinha no museu. Conforme registrado nos documentos produzidos ainda em 1996 para orientar a expansão, o museu entendia esse como um problema importante a ser abordado pelo projeto:

Para garantir que o acervo permaneça permanentemente montado, o museu precisa de galerias de exposições temporárias com flexibilidade e dignidade adequadas à importância de seus programas. Embora as Galerias René d'Harnoncourt tenham sediado uma série de exposições temporárias de destaque ao longo dos doze anos de sua existência, a qualidade das mostras não tem sido suficiente para superar a antipatia que artistas, críticos, o público e muitos dos curadores têm por este espaço. Para otimizar a experiência do visitante no Museu, todas as galerias, tanto de exposições temporárias como de coleções, devem ter uma presença dentro do museu que seja visível, acessível e digna. ${ }^{456}$

Taniguchi adotou em seu projeto diversas estratégias para atender a essa expectativa do museu. Em primeiro lugar, concentrou as galerias expositivas em oito pavimentos localizados na área da expansão a oeste, dispondo-as ao redor do átrio e

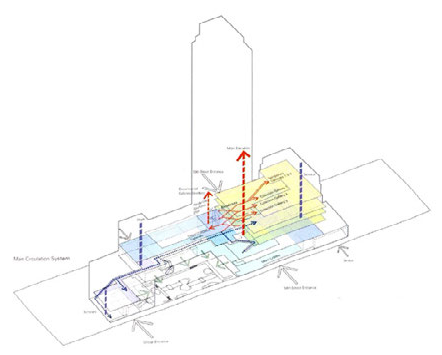

3.30 Isométrica mostrando o sistema de circulação do MoMA em relação com a cidade no projeto de Yoshio Taniguchi, 1997. Imagem: Taniguchi Associates. Fonte: TANIGUCHI, 1999, p. 263.
456 Glenn Lowry. The New Museum of Modern Art Expansion: A Process of Discovery. In: EDERFIELD, op. cit., p.25 Tradução nossa. 


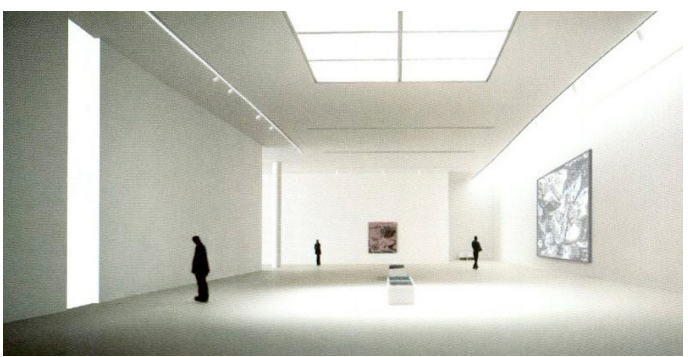

3.31 Perspectiva da galeria de exposições temporárias do MoMA com iluminação natural no projeto de Yoshio Taniguchi, 1997. Imagem: Taniguchi Associates. Fonte: TANIGUCHI, 1999, p. 263. entremeando-as por espaços abertos para as vistas internas e externas. $\mathrm{O}$ arquiteto considerou que as galerias dedicadas ao acervo de arte contemporânea deveriam ter pé direito mais alto, dado que boa parte das obras recentes teriam escala maior que a de épocas mais remotas. No entanto, ao invés de iniciar a ordem cronológica de baixo para cima, conforme arranjos tradicionalmente praticados no MoMA, ele propôs uma inversão: posicionou as galerias de maior pé direito no segundo pavimento, com acesso pelo piso inferior do átrio logo acima do térreo, tornando-as mais próximas da chegada do público e procurando, assim, valorizar a presença da arte contemporânea no museu. As galerias dedicadas à coleção de arte moderna seriam, de acordo com seu esquema, posicionadas nos andares logo acima, permitindo escapes visuais e de percurso ao longo da visitação, mas preservando, com um pé direito reduzido, uma escala mais "íntima" - aspecto sempre muito valorizado pela instituição.

O projeto previa ainda que o volume das exposições fosse escalonado nos três últimos andares nas faces norte e leste, não apenas para atender os requisitos do zoneamento, mas principalmente para que recebessem luz natural, por meio de claraboias posicionadas em faixas laterais ou no centro das salas. As galerias dedicadas a mostras temporárias, por sua vez, seriam localizadas nos dois pavimentos superiores. $\mathrm{O}$ átrio também seria apto a receber trabalhos temporários, especialmente os de grande escala, que poderiam ser vistos a partir dos diversos níveis das galerias e áreas de circulação ao seu redor.

Quando o projeto chegava, em 2001, à etapa final de desenvolvimento, Glenn Lowry recordou o que havia cativado os 


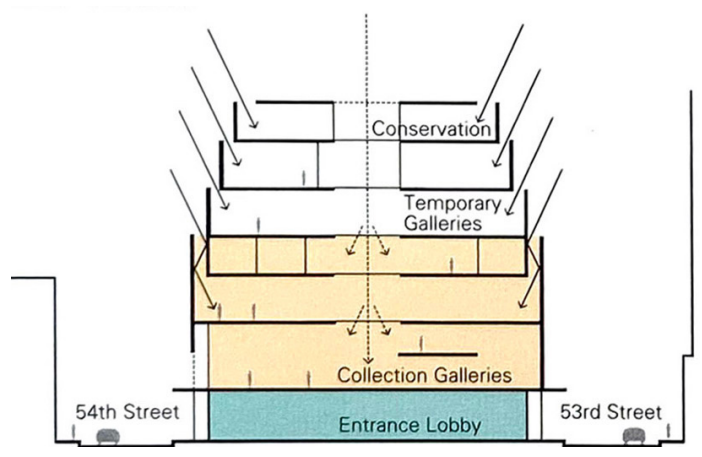

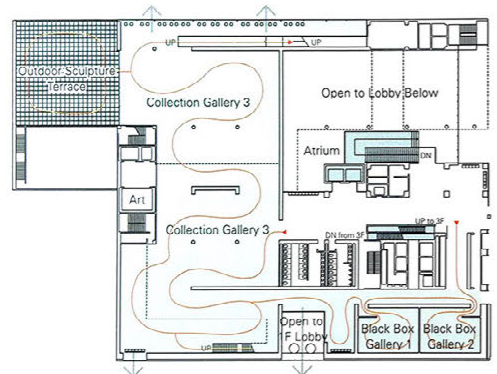

Second Floor . Collection Gallery 3

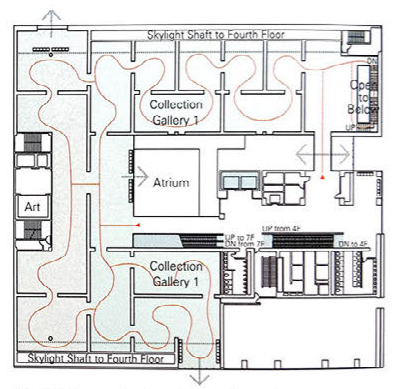

Sixth Floor - Collection Gallery 1

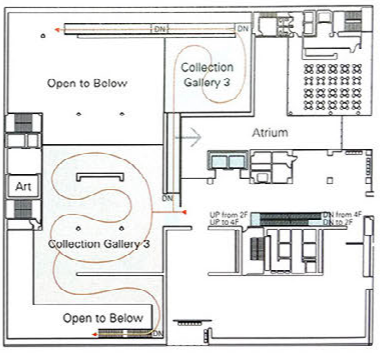

Third Floor · Collection Gallery 3

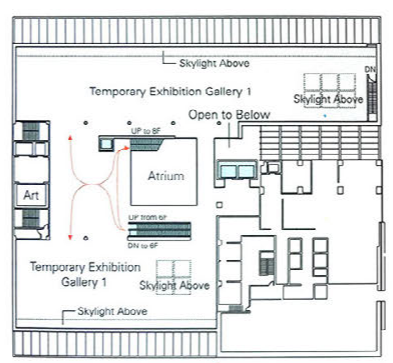

Seventh Floor - Temporary Gallery 1

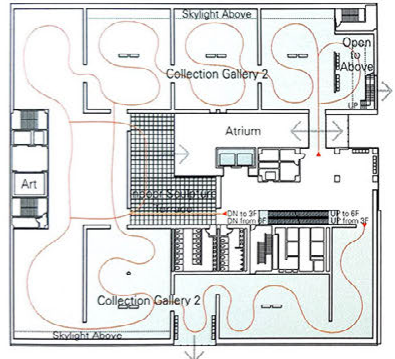

Fourth Floor - Collection Gallery 2

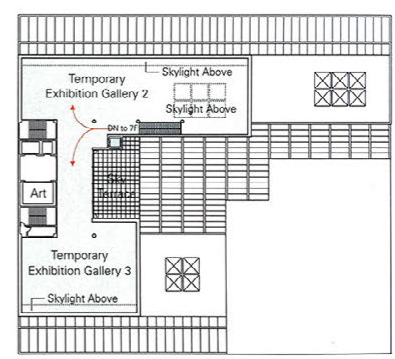

Eighth Floor - Temporary Galleries 2 and 3

3.32 Corte do esquema de de iluminação natural das galerias expositivas do MoMA no projeto de Yoshio Taniguchi, 1997. Imagem: Taniguchi Associates. Fonte: TANIGUCHI, 1999, p. 262.

3.33 Plantas das galerias expositivas do MoMA no projeto de Yoshio Taniguchi, 1997. Imagem: Taniguchi Associates. Fonte: TANIGUCHI, 1999, p. 268-69. 
representantes do мома е os levara a escolher o projeto de Taniguchi no concurso:

Clareza e senso de elegância do design e reconhecimento de como usar os detalhes mais simples e sutis para criar um espaço amplificado e poderoso. Ele também compreendeu que a arquitetura, no nosso caso, precisava, de um lado, respeitar o passado, mas não ser escravo dele, e de outro lado, demonstrar que a linguagem do modernismo era maleável e flexível, que teria ainda vitalidade e poderia ser adotada de um modo absolutamente contemporâneo. E então o que ele fez foi inverter completamente nossas próprias ideias. Nós tínhamos uma ideia de que a arquitetura contemporânea deveria ser importante para o museu e que a arte contemporânea deveria ser privilegiada, mas nós também contamos a história da arte moderna do final do século XIX até o presente e gostaríamos de nos assegurar que essa história pudesse ser contada de modo ainda melhor em nossas novas galerias. Basicamente todos os arquitetos lidaram com isso e apresentaram histórias - galerias que começavam com o final do século xIX e continuavam de um jeito ou de outro até o presente. Yoshio virou isso de cabeça para baixo e disse: 'você vai entrar neste museu e a primeira arte que vai encontrar é a contemporânea, e a história será contada de trás para frente. Se estão realmente comprometidos com a arte contemporânea, coloquem-na à frente.' Bem, isso nos arrebatou! É claro que significava também que as galerias mais novas e poderosas seriam as primeiras a serem vistas. ${ }^{457}$

Além das qualidades do partido geral mais visíveis, o projeto de Taniguchi teria minuciosamente solucionado os diversos problemas práticos e funcionais levantados pelo staff do museu, conforme relatou o curador Kirk Varnedoe:

Havia uma piada de que as restrições no local não deixavam espaço para a arquitetura [...]. Taniguchi respondeu a todas as restrições e ainda assim produziu o edifício mais poético. É o velho sonho do modernismo, de que se você realmente enfrenta a função com clareza, não existe uma barreira entre a função e 
a poesia. Pela primeira vez, agora teremos espaços físicos reais que terão uma força condizente com o nosso museu. A lacuna entre o que somos e o que parecemos será completada. ${ }^{458}$

\subsubsection{UM PROCESSO “EXTRAORDINÁRIO" PARA 0 DESENVOLVIMENTO DO PROJETO}

Para o desenvolvimento do projeto, foi adotado um modo de trabalho diferente do praticado até então pelo museu, conforme descrito pelo arquiteto Shiro Matsushima, que levantou dados e realizou entrevistas com diversos arquitetos e representantes do museu envolvidos na empreitada. ${ }^{459}$ Riley teria afirmado: "o projeto que deseje alcançar resultados extraordinários deve aceitar condições extraordinárias para o seu sucesso." ${ }^{\prime 60}$

Taniguchi costumava manter seu escritório relativamente pequeno, desenvolvendo poucos projetos ao mesmo tempo, para manter o controle sobre os trabalhos. Por esse motivo, tinha previsto instalar um escritório em Nova York dedicado especialmente ao projeto do мома. O museu, no entanto, preferiu que o desenvolvimento do projeto fosse apoiado por um escritório local, familiarizado com as condições específicas de construção e de zoneamento de Nova York e com as regras de licitação vigentes nos EUA - muito distintas das do Japão. Diante da determinação do cliente, Taniguchi julgou essencial que o escritório local não tivesse apenas um perfil de desenvolvedor, mas pudesse efetivamente colaborar na concepção, para estabelecer uma parceria criativa e mais afinada com seu próprio modo de trabalhar. O MOMA indicou então o escritório Kohn Pedersen Fox Associates (KPF), que nunca tinha desenvolvido um projeto para outro arquiteto, mas tinha interesse na parceria por conta da importância do cliente e pela oportunidade de aproximar-se da área de museus, com a qual tinha menos experiência.

As responsabilidades do escritório KPF incluíam o desenvolvimento da concepção, a elaboração de todos os desenhos construtivos e o acompanhamento de obra. Todos concordavam, no entanto, que seria importante contar com a participação de Taniguchi não apenas durante a fase inicial de concepção,
458 Kirk Varnedoe apud LeSSARD, op. cit., n.p. Tradução nossa.

459 Ver Matsushima, Shiro. мома, The Museum of Modern Art. New York, Cambridge: Center for Design Informatics - Harvard Design School, 2003.

460 Terence Riley apud Ibidem, p. 3. Tradução nossa.

A expressão usada pelo museu e pelos arquitetos para qualificar o modelo de desenvolvimento do projeto era more-than-ordinary arrangement. 
como ocorria tradicionalmente na divisão de atribuições entre escritório autor e desenvolvedor, mas ao longo de todos as etapas do projeto, inclusive a de executivo, embora de modo mais reduzido.

No momento em que o processo se iniciava, acelerava-se a incorporação pelos escritórios de arquitetura de recursos digitais de desenho e comunicação, cuja eficiência ainda pouco desenvolvida se apresentava como um desafio no estabelecimento de uma parceria internacional entre equipes não previamente entrosadas, situadas em países tão distantes e culturalmente distintas quanto os EUA e o Japão. Taniguchi, cujo escritório ainda não tinha uma longa experiência com desenhos computadorizados, teria preferido desenvolver o projeto do MOMA à mão, mas o museu não lhe deu essa opção. A diversidade de recursos analógicos e digitais usados simultaneamente retratam a transição tecnológica que coincidia com a virada do milênio: croquis à mão e desenhos em CAD, modelos eletrônicos e físicos e envio de arquivos pela internet, por fax e até pelo correio, em papel ou CD-ROM. Apesar da relativa agilidade no compartilhamento de documentos e da possibilidade de realização de reuniões virtuais por teleconferências (realizadas semanalmente, em salas especialmente preparadas para isso), os encontros presenciais eram considerados indispensáveis para que as intenções de projeto fossem desenvolvidas de acordo com a concepção de Taniguchi após a fase de concepção, quando o KPF assumiria maior responsabilidade e a sede do projeto se deslocaria de Tóquio para Nova York. Membros das duas equipes viajavam com frequência de uma cidade a outra para trabalhar no escritório parceiro, por temporadas de duração variada, dependendo da etapa do projeto. Na avaliação de Matsushima, embora desproporcionalmente mais próximo do cliente e recebendo suas demandas diretamente, o escritório estadunidense manteve o respeito à condição de autor de Taniguchi, colaborando em todo processo para que o projeto fosse desenvolvido segundo sua orientação: "a chave para este arranjo foi que as distintas funções de responsabilidade foram estabelecidas desde o início, o que criou uma relação colaborativa entre arquiteto de concepção e arquiteto executivo, um modelo diferente do modelo hierárquico convencional.”461 
No final dos anos 1990, a qualidade da construção em Nova York, muito orientada para o setor comercial e corporativo, não era considerada de alto padrão, sendo muito inferior à da construção japonesa. O primeiro edifício público e importante daquela época a atingir um alto nível construtivo na cidade viria a ser o planetário do Museu Americano de História Natural, projeto liderado pelo estadunidense James Polshek (1930-) do Ennead, que, inaugurado em 2000, tornara-se referência entre os arquitetos pela execução precisa de sua fachada. Para o projeto do мома, Taniguchi esperava que as cortinas de vidro - que envelopavam diversos blocos e eram consideradas essenciais para dar unidade ao conjunto -, atingissem o mesmo grau de excelência com o qual estava habituado e o detalhamento desse elemento concentrou grande parte dos esforços dos arquitetos na etapa do executivo.
3.34 American Museum of Natural History, Rose Center for Earth and Space, projeto de James Polshek (Ennead), Nova York, 2000. Fonte: http://www.ennead.com/ work/rose

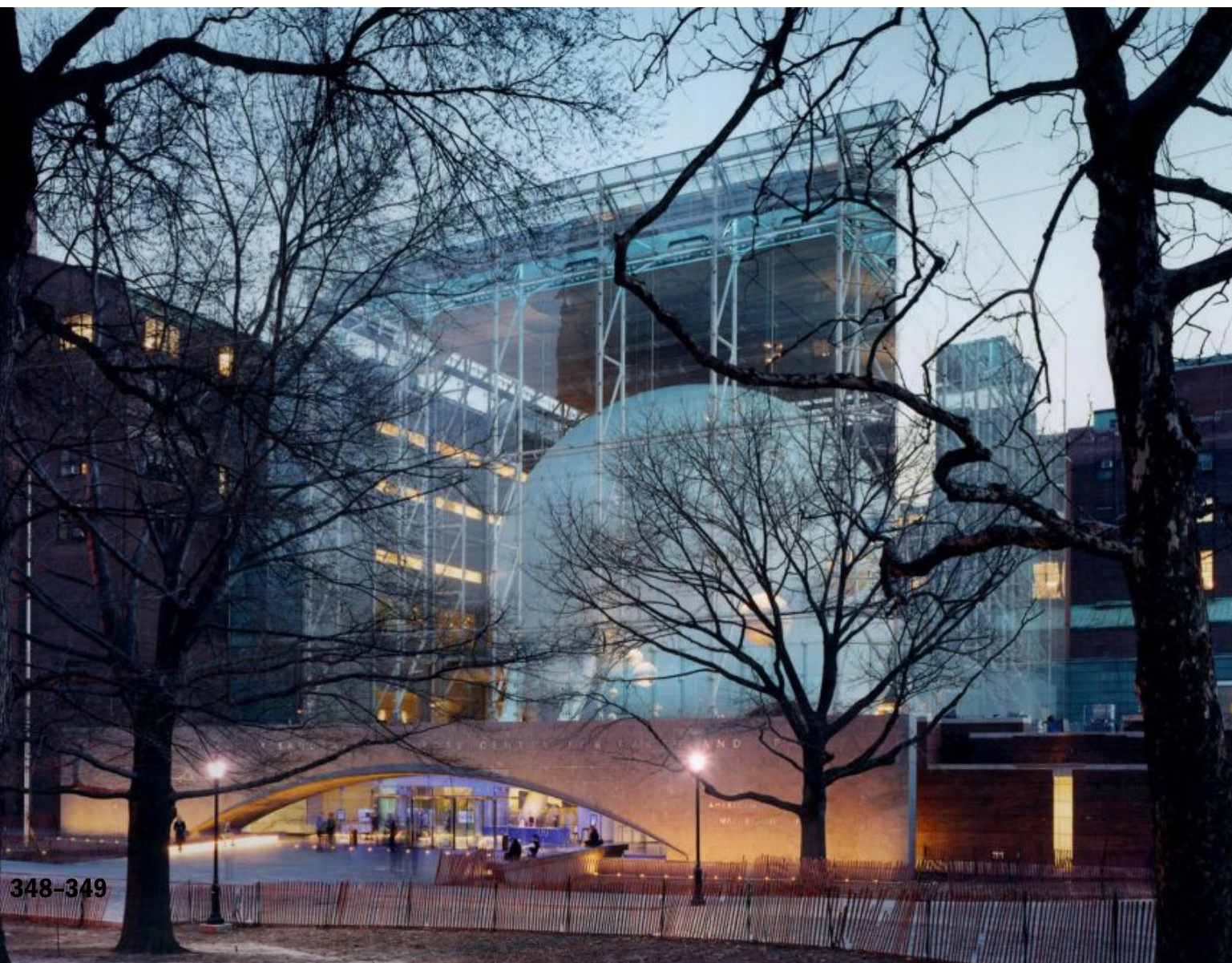


O desenvolvimento do projeto sofreu alguns contratempos, como uma grande alteração de programa iniciada no fim de 2000, coincidindo com a data prevista para a conclusão do projeto por Taniguchi, que ocorreu em janeiro de 2001. As alterações foram entregues pelo escritório KPF em agosto, pouco antes dos atentados de 11 de setembro de 2001, que, de acordo com os registros de Matsushima, agravaram ainda mais as dificuldades que o museu já vinha apresentando para levantar toda a verba necessária para a realização da obra, que já havia começado. Como consequência, os arquitetos foram requisitados a fazer revisões severas no projeto para adequar-se ao orçamento disponível, deixando de intervir em algumas partes e revisando outras, optando por soluções construtivas menos sofisticadas.

\subsubsection{ESPAÇOS DA ARTE NO NOVO PROJETO}

Dentre as alterações ao longo do processo - corriqueiras em projetos de arquitetura da complexidade dessa expansão do MOMA - as mais relevantes para a discussão desta tese são as que envolvem a configuração dos espaços destinados à arte, sendo uma delas a que diminuiu a presença de luz natural nas galerias expositivas. Ocupando o posto de presidente do conselho do museu à época do concurso que escolhera o projeto de Taniguchi, Agnes Gund (1938-) comentou que "sua sensibilidade à luz teve um grande peso em nossa decisão." ${ }^{462}$ Dada a susceptibilidade a variações externas, esse tipo de solução, no entanto, dificulta que a intensidade de iluminação no interior das salas permaneça constante e pode eventualmente trazer riscos para a conservação de objetos mais sensíveis. A presença de iluminação natural nas salas expositivas - um importante elemento de contato com o mundo exterior - conflitava, afinal, com o grau mais rígido de controle sobre esses espaços praticado pelo мома, o que só poderia ser obtido por meio de iluminação artificial. Possivelmente por esses motivos, o museu chegou a solicitar, segundo apurou Matsushima, a eliminação das claraboias dos últimos andares expositivos. Os arquitetos

462 Agnes Gund apud Lessard, op. cit., p. 4o. Tradução nossa. da KPF, entendendo a importância desse elemento para o pro- 
jeto de Taniguchi, teriam levado seis meses trabalhando para reverter a decisão do seu cliente, restabelecendo por fim as claraboias, ainda que em quantidade e dimensão reduzidas.

Esse caso ilustra a dificuldade do museu em aceitar soluções mais expressivas do ponto de vista da arquitetura - ainda que admirassem suas qualidades - para espaços especificamente destinados à arte. A intenção foi, mais uma vez, manter nas galerias a máxima flexibilidade para que esses espaços pudessem se adaptar às imprevisíveis necessidades futuras, permitindo a subdivisão com paredes em dry wall para a criação de variados circuitos e de ambientes para instalações diversas dos artistas. Ou seja, a tendência no MoMA era manter nas galerias a qualidade inexpressiva que Riley havia identificado como "arquitetura descartável", permitindo sua constante reprogramação e o controle ambiental por meios artificiais e além disso, evitando causar "distrações" que pudessem alterar o modo convencionado pelo museu de expor as obras. No novo projeto do museu, tanto as galerias dedicadas à exposição de arte moderna quanto as reservadas à produção mais recente do acervo e às mostras temporárias mantiveram-se como espaços discretos, com salas com geometria regular e paredes brancas, sem romper com o modo tradicional de expor arte no museu. Uma certa cisão se confirmava então, com as galerias tendendo a ser "reservadas" para o domínio da arte, enquanto a arquitetura poderia se manifestar de modo mais expressivo apenas nos espaços internos intersticiais e secundários e na fachada do edifício.

Um desses espaços que adquiriu maior expressão arquitetônica foi o átrio, que, no desenvolvimento do projeto, deixou de ter uma configuração assimétrica, com cortes de dimensões variadas em cada piso, para ganhar proporções maiores e mais quadradas em pavimentos seguidos, tendo sua verticalidade acentuada. Com altura livre de $30 \mathrm{~m}$ e paredes suspensas do piso, o chamado Marron Atrium ${ }^{463}$ adquiriu em sua versão final um caráter monumental, aproximando-se, assim, do que Riley chamara de "espaço celebratório", dando ao museu um ambiente interno em que a experiência coletiva com a arte pudesse ser valorizada. Esse papel vinha até então sendo cumprido apenas pelo jardim externo de esculturas, apesar de seu

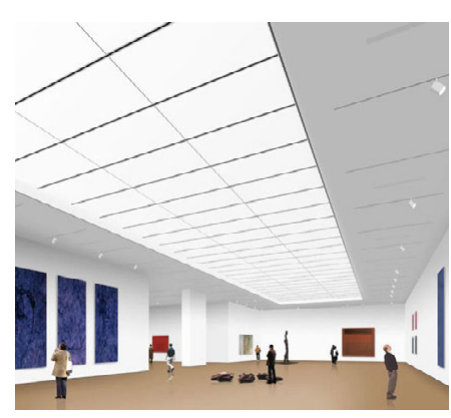

3.35 Perspectiva mostrando grande clarabóia numa das galerias de exposições temporárias do MoMA elaborada durante o desenvolvimento do projeto de Yoshio Taniguchi, 2001. Fonte: MATSUSHIMA, p. 14.
463 O nome completo desse espaço é The Donald B. and Catherine C. Marron Atrium, casal que vinha contribuindo financeiramente para as expansões do MoмA desde a década de 1980. Donald B. Marron (1934-2019) tornara-se membro do board of trustees do MOMA em 1975. 


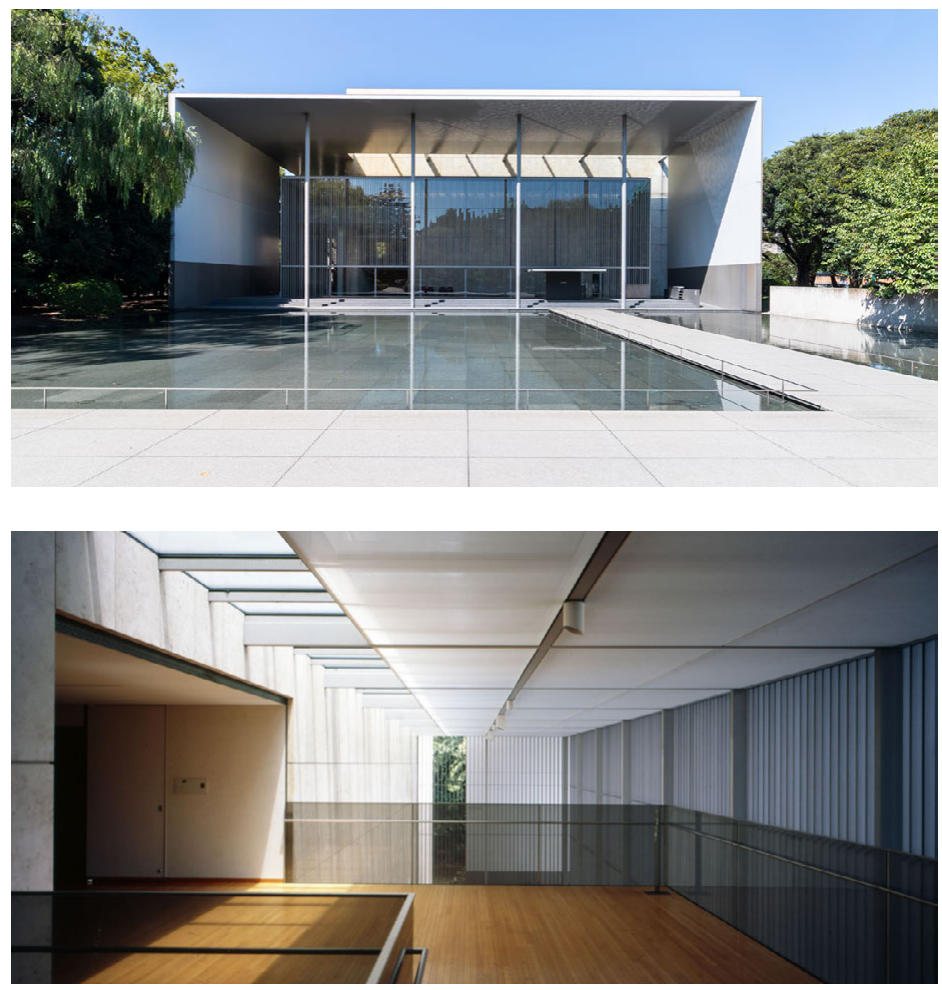

vimos, de modo bastante convencional, numa configuração arquitetônica que, de tão habitual no universo da arte, acabava por se tornar "invisível".

Relembrando suas impressões sobre a visita à Galeria dos Tesouros de Horyuji em Tóquio, projetada por Taniguchi e inaugurada em 1999, Glenn Lowry afirmou que esse seria

possivelmente o museu mais bonito construído neste século. É como uma caixa bentô: cheio de surpresas, inacreditável e lindamente solucionado e muito bem detalhado. Parece tão simples - apenas dois cubos interseccionados -, mas entrar e assistir ao modo como a arquitetura explode em espaços e se dissolve em arte é umas das experiências mais mágicas que alguém pode ter. ${ }^{465}$
3.37 e 3.38 Galeria dos Tesouros de Horyuji, projeto de Yoshio Taniguchi de 1999, Tóquio, 2018. Foto 1: Kakidai. Fontes: https://en.m.wikipedia.org/ wiki/File:2018_The_Gallery_of_Horyuji_ Treasures_01.jpg e http://www.ddarcart. com/2013/08/yoshio-taniguchi-galleriadi-horyuji.html

465 LOWRY; TANIGUCHI, op. cit. Tradução nossa. 
466 LANGE, Alexandra. This New House. New York Magazine, 8/10/2004. ed. 2004, p. 11. Tradução nossa.
No projeto do мома, podemos identificar esse efeito de "dissolução da arquitetura em arte" no trajeto que parte dos espaços de acolhimento e circulação, que tem no átrio seu ponto mais expressivo, e chega ao interior das galerias, onde o espaço, repetindo com poucas variações o padrão depurado pelo próprio museu para expor arte moderna, anula de certa forma a arquitetura para enfatizar o protagonismo da arte. Essa cisão entre o domínio do espaço pela arte e o da arquitetura se apresentava até mesmo em museus como o Guggenheim Bilbao de Frank Gehry, que abrigava uma série de galerias expositivas que seguiam o paradigma convencional de suposta neutralidade.

Os esforços do момА para obter uma arquitetura que respondesse aos seus anseios de atualização eram, no entanto, de outra ordem, pois, como vimos, o respeito a uma identidade consolidada ligada ao moderno era uma premissa da renovação. Trabalhando dentro de uma estrita margem, o projeto de Taniguchi manteve uma expressão rebaixada não apenas nas galerias expositivas, mas também nas fachadas, criando apenas alguns pontos de interesse na articulação dos vários elementos do conjunto. Isso era o que bastava para atender às expectativas do момА, e para, segundo Riley, apontar para uma conciliação que parecia perdida numa espécie de disputa entre a arquitetura e arte num museu:

Colecionadores de arte que acreditavam na arte não como um empreendimento voltado ao entretenimento, nem como um negócio, mas como algo realmente importante, começaram a se sentir como dinossauros depois de Bilbao [...]. O que as pessoas verão aqui é algo inesperado: que um museu pode ser um ótimo lugar para a arte e também ser incrivelmente dinâmico e espetacular. Isso contraria a sabedoria aceita no mundo da arte, que era a de que ou você tinha um edifício que era uma obra de arte em si ou coisa nenhuma, uma obra de arquitetura neutra. Acho que o que o edifício de Taniguchi faz é explodir um pouco isso, afirmando 'Desculpe, essas não são as únicas duas opções. ${ }^{466}$

Esse "ótimo lugar para arte" mantinha em grande medida a prática tradicional do момA não apenas ao rebaixar o protago- 


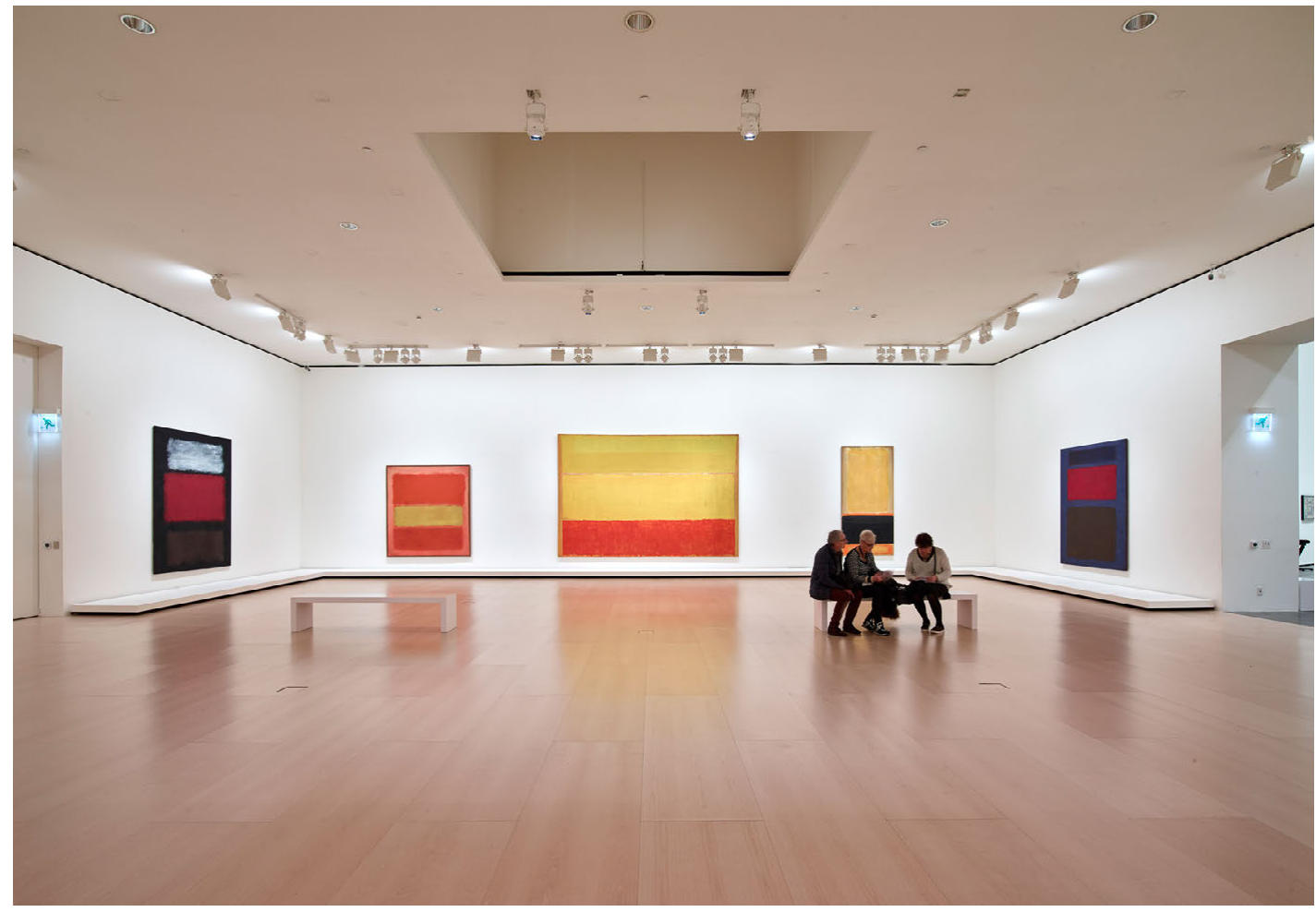

nismo arquitetônico nas galerias, como também no modo de ocupar esses espaços com exposições do acervo permanente ligado ao Departamento de Pintura e Escultura - o mais prestigiado nо момА -, disposto do segundo ao quinto andar do novo bloco de galerias. Enquanto no concurso o setor expositivo contava com oito andares, a versão final ficou apenas com seis, sendo o último dedicado às mostras temporárias e o único que permaneceu escalonado com relação ao imediatamente inferior e com claraboias. Logo abaixo, no quinto pavimento, começava o circuito cronológico da coleção organizado em 14 galerias, com obras dos pós-impressionistas dos anos 1880 ao Surrealismo do início da década de 1940, passando pelos diversos movimentos de vanguarda formativos da arte moderna, como Fauvismo, Cubismo, Futurismo, Expressionismo, Dadaísmo e Abstracionismo. A narrativa continuava em 11 salas do
3.39 Sala expositiva do museu Guggenheim Bilbao, projeto de Frank Gehry de 1997, s.d. Fonte: https://cms.guggenheim-bilbao.eus/ uploads/2019/03/sin-titulo-markrothko-8.jpg 
467 мома Press Release 387070 , de 15/11/2004, p.1. In: THE MuseuM OF MODERn ART. Painting \& Sculpture II. MOMA. Disponível em: <https:/www.moma.org/calendar/ exhibitions/1220 $>$. Acesso em: 22 set. 2020.

468 Colaboraram com Elderfield nesta montagem a equipe de curadores formada por Ann Temkin, Joachim Pissarro e Anne Umland.

469 John Elderfield apud LANGE, 2004, op. cit., p. 8 Tradução nossa. quarto andar, partindo das conexões entre o Surrealismo tardio e o Expressionismo Abstrato, passando por obras europeias e sul-americanas dos anos 1950 e 1960 e pela Pop Art e chegando até o Minimalismo e o Pós-Minimalismo, até 1970.

Na tentativa de aliviar a sequência linear excessivamente impositiva que tradicionalmente orientava as montagens do acervo do момА, foram inseridas algumas possibilidades de ramificação no percurso, permitindo ao público certo grau de escolha, conforme indicava a apresentação no material de divulgação da exposição inaugural de 2004:

Embora as obras da coleção sejam expostas em uma sequência essencialmente cronológica, o design distinto das galerias permite que a progressão não seja linear, enfatizando assim como artistas, movimentos e estilos coincidiram, competiram um com outro, e abriram novos caminhos na evolução da arte moderna. Cada galeria é uma apresentação coesa que relata um episódio da história da arte moderna; embora cada galeria individual constitua uma parte integrante da narrativa mais ampla, ela também pode ser autônoma como um capítulo independente dessa história. ${ }^{467}$

Para o então curador-chefe do departamento e responsável pela montagem, John Elderfield, ${ }^{468}$

A vantagem disso não é apenas que as pessoas se sentem mais confortáveis se tiverem escolha, mas acho que é realmente mais verdadeiro para o que a arte moderna é [...]. Não é um desenvolvimento. É uma sequência. É um debate entre diferentes opiniões sobre o que é arte moderna, conforme representada por esses movimentos. ${ }^{469}$

O mapa da exposição do acervo organizada por William Rubin em 1984 após a reforma de Pelli mostra de fato uma longa sequência de salas que atravessa de modo contínuo edifícios de três épocas distintas -1939, 1964 e $1984^{-}$, começando e terminando no hall das escadas rolantes e sem possibilidades de desvios no meio do caminho. O mapa da montagem de Elderfield, por sua vez, indica algumas alternativas de percurso por 


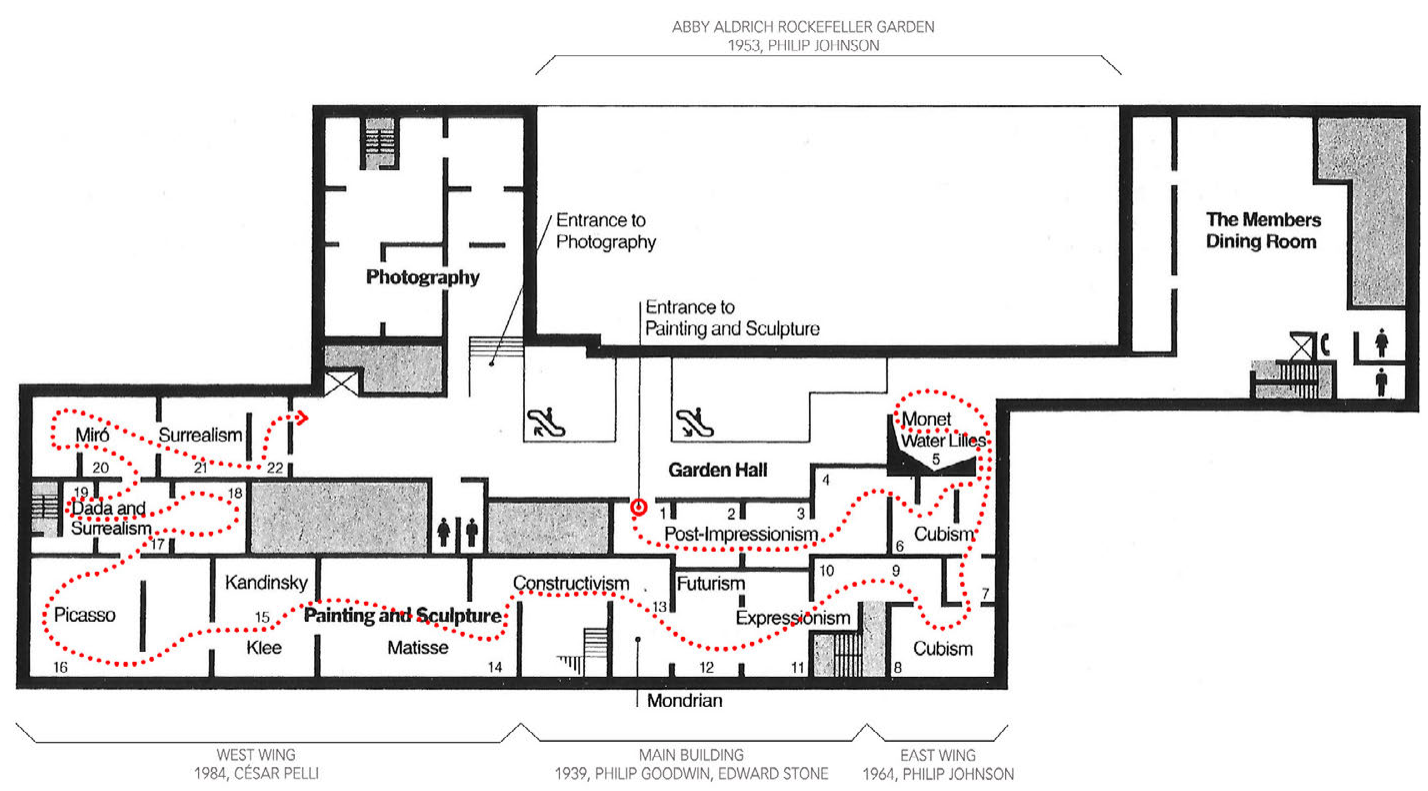

passagens entre as salas, mas retomando sempre a sequência predominante, a não ser que se decidisse deixar de percorrer alguns setores, cortando caminho, por exemplo, pela escada que conectava o quinto andar ao quarto no meio do circuito, com vista para o átrio. Possibilidades mais efetivas de oferecer ao público variedades de percurso ou relações visuais entre os diversos núcleos expositivos poderiam ter sido obtidas com uma montagem que utilizasse divisórias leves conectando os espaços de modo mais fluido e transparente, ao invés da solução um tanto inócua de abrir algumas poucas passagens adicionais entre salas fechadas.

Mais importante para arejar o longo percurso e ajudar o visitante a se localizar no edifício eram algumas aberturas pontuais nas fachadas que permitiam vistas para a cidade e para o jardim e os rasgos voltados para o átrio que possibilitavam perspectivas variadas do interior desse espaço. De todo modo, a manutenção da organização expográfica por salas individualizadas tornava difícil escapar da sequência narrativa estruturada que era a marca do MOMA, uma tradição iniciada por

3.40 Mapa da rota de visitação da coleção permanente do MoMA, Nova York, em 1984. Desenho nosso sobre mapa do MoMA in: ELDERFIELD, p. 90. 
3.41 e 3.42 Mapa da rota de visitação da coleção permanente do MoMA, Nova York, em 2004. Desenho nosso sobre panfleto do MoMA.

3.43 e 3.44 Foto: Timothy Hursley. Fonte: http://www.timothyhursley.com/moma/ s2nlbpxztjtsky29z9skvpa0jvt5zp

470 LESSARD, 1998, op. cit., p. 35.
Alfred H. Barr, acentuada por William Rubin, mantida por Kirk Varnedoe e não essencialmente rompida por John Elderfield. O museu havia, afinal, rejeitado a possibilidade de construir um outro edifício num local distante para expor obras mais recentes do acervo justamente para não criar uma interrupção na "coerência sequencial da evolução moderna". ${ }^{470}$

A sequência narrativa acabou, no entanto, tendo uma pausa dentro do próprio edifício, uma vez que o andar seguinte, o terceiro - que se expandia em direção a leste englobando as áreas dos blocos de Goodwin e Stone e Philip Johnson -, foi destinado a espécies de museus dentro do museu, cada um deles dedicado a um departamento - Fotografia, Desenhos e Arquitetura e Design -, contando também com uma

\section{5}

\section{Painting and} Sculpture I 1880s-1940s

Paul Cézanne

Frida Kahlo

Henri Matisse

Piet Mondrian

Claude Monet

Pablo Picasso

Vincent van Gogh

and others*

\section{Café}

* CERTAIN WORKS OF ART MAY NOT BE ON VIEW AT ALL TIMES.

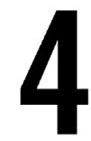

\section{Painting and} Sculpture II 1940s-1980

Jasper Johns

Yayoi Kusama

Roy Lichtenstein

Jackson Pollock

Robert Rauschenberg

Mark Rothko

Andy Warhol

and others*

* CERTAIN WORKS OF ART MAY NOT BE ON VIEW AT ALL TIMES.
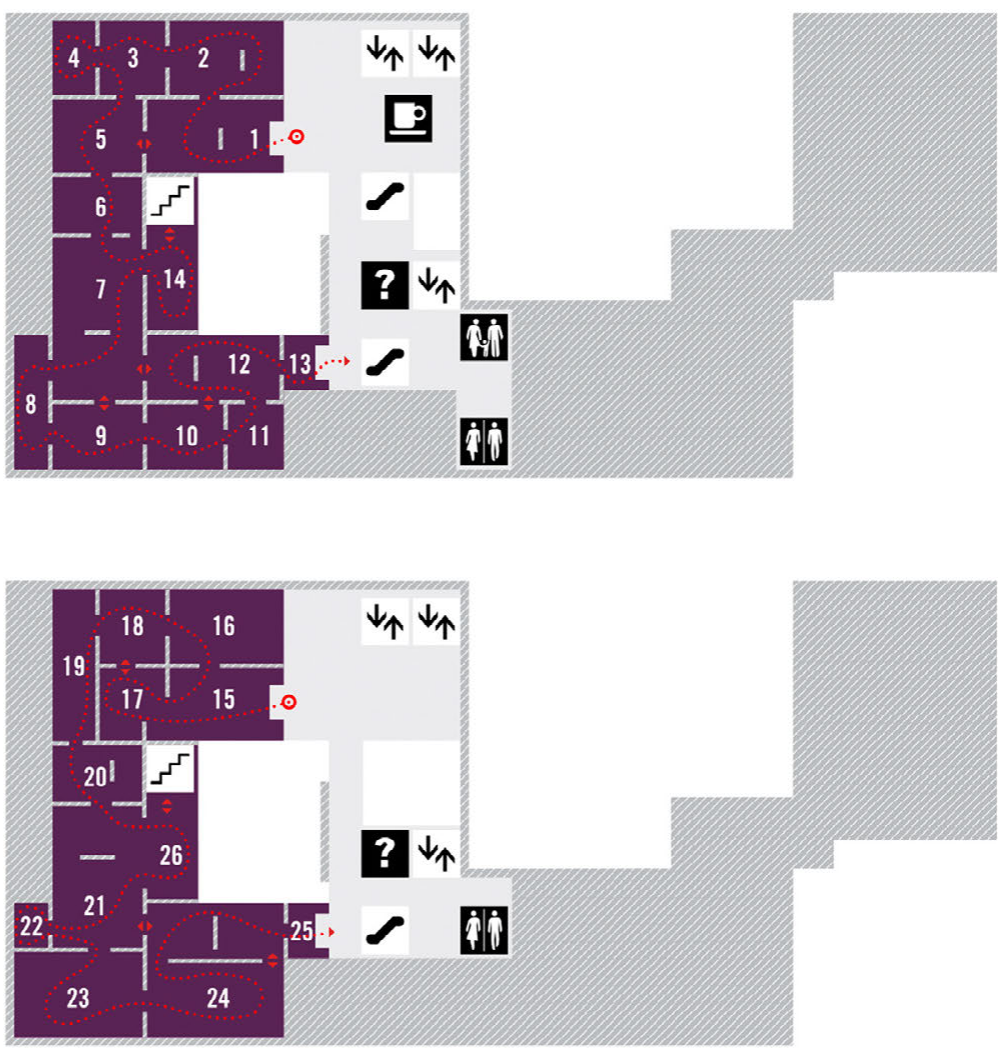

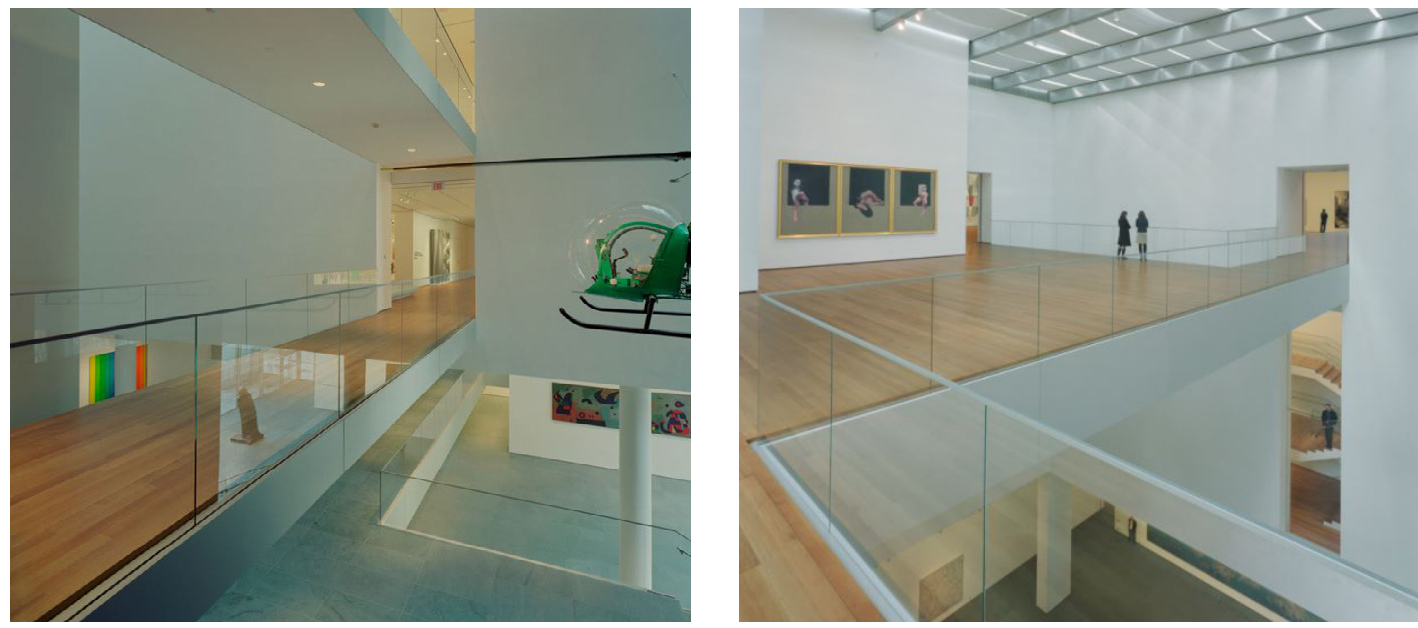

3

Architecture and Design (A\&D)

Drawings (DR)

Photography (PH) Special

Exhibitions (SE)
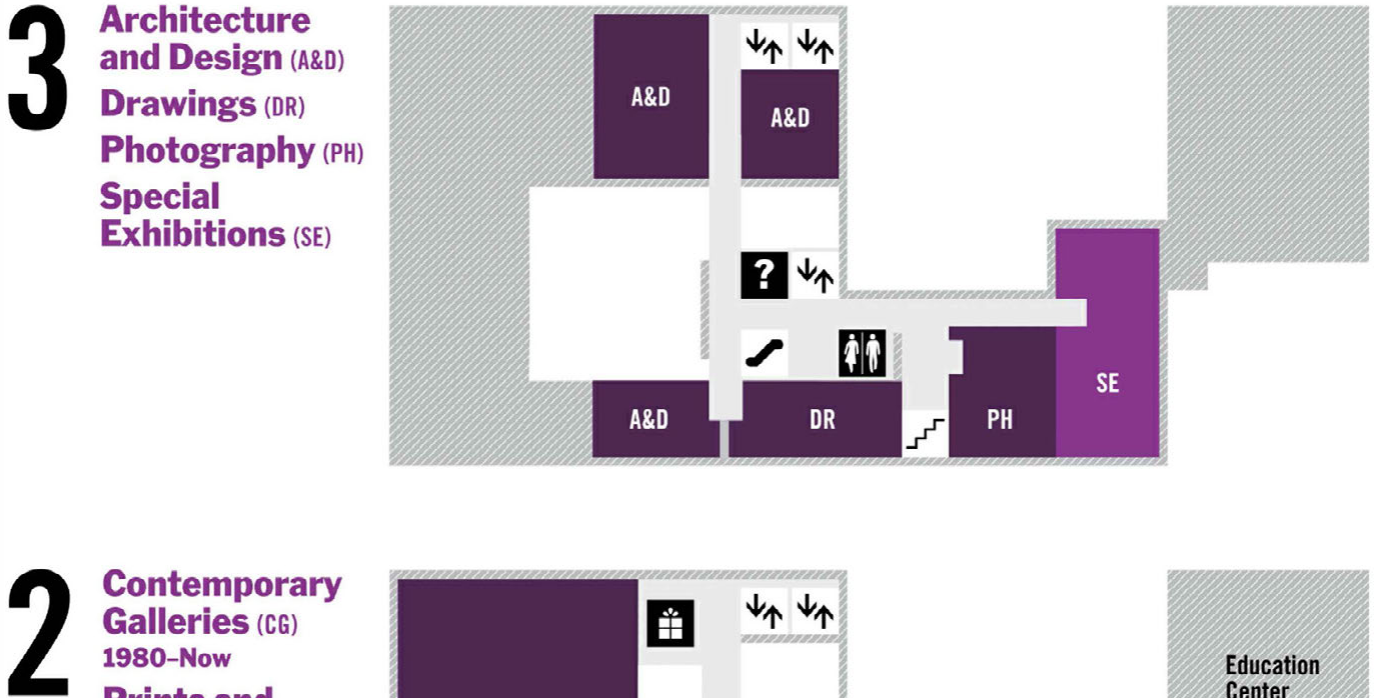

Contemporary Galleries (CG) 1980-Now

Prints and Illustrated Books (P\&|B)

Media (ME)

Marron Atrium

Special

Exhibitions (SE)

Café

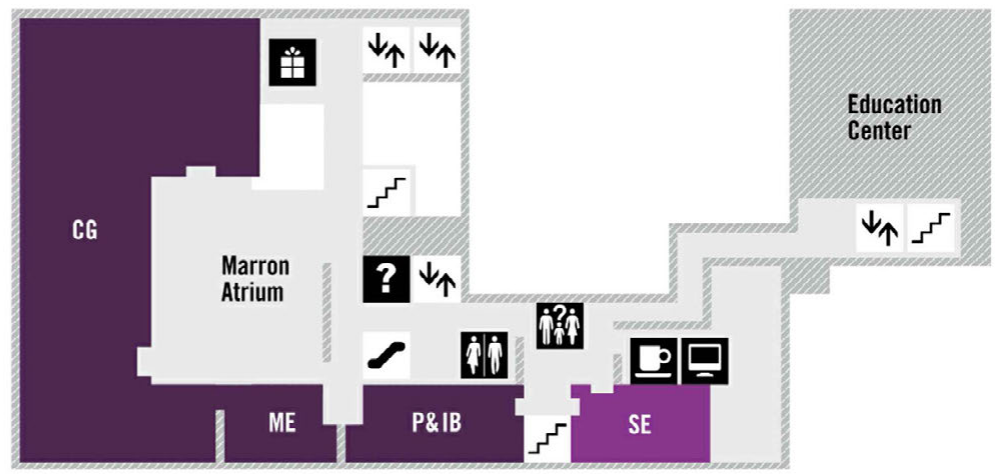

Store 

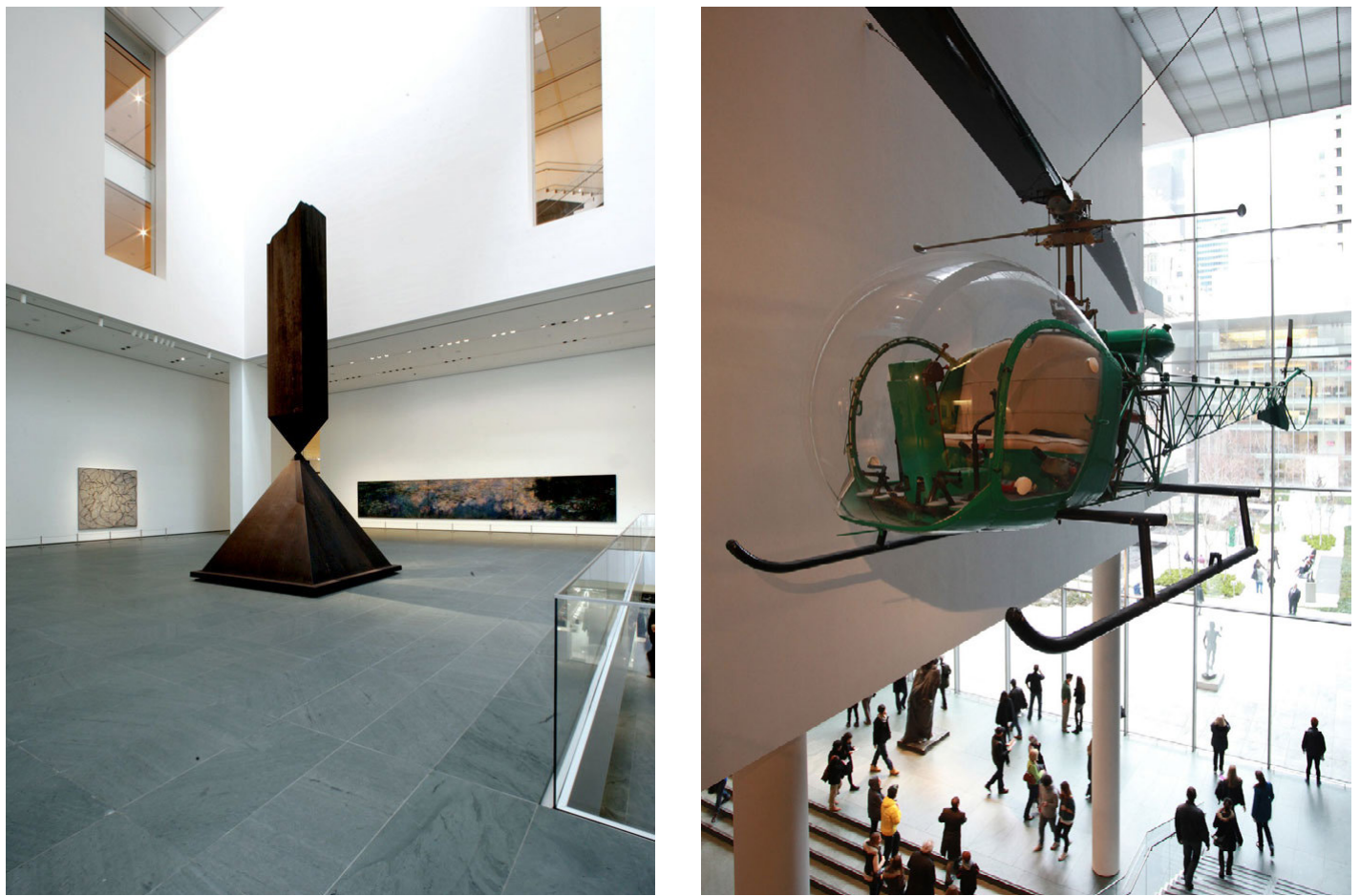

3.45 Marron Atrium com Escultura de Barnett Newman, Broken Obelisk (1963-69), e pintura tríptica de Claude Monet, Water Lilies (1914-26), MoMA, Nova York, 2004. Foto: Fred Conrad/ The New York Times. Fonte: https:// www.nytimes.com/2011/01/02/arts/ design/02moma.html

3.46 Helicóptero Bell-47D1, projeto de Arthur Young de 1945, MoMA, Nova York, 2004. Foto: Hiroko Masuike/The New York Times. Fonte: https://www. nytimes.com/2012/09/26/arts/design/ museum-of-modern-art-plans-to-be-openevery-day.html galeria para exposições especiais. Na área leste do segundo pavimento - nos blocos de Pelli e Goodwin e Stone - foram posicionadas as áreas dos departamentos de Gravuras e Livros Ilustrados e mais uma galeria para exposições especiais, enquanto a oeste foi retomada a exposição do acervo, dedicado à arte contemporânea a partir de 1970, incluindo um setor dedicado a mídias como filme e vídeo e prevendo uma rotatividade maior das obras. Essa era a estratégia do projeto para que, como vimos, a arte mais recente ficasse valorizada por estar mais perto da chegada do público e com acesso pelo piso do átrio.

O museu foi reaberto ao público em 20 de novembro de 2004, comemorando os 75 anos de sua fundação. Nessa ocasião, foram expostos no átrio um conjunto de obras díspares, de diversas épocas da coleção, mas que tinham em comum o diálogo com a grande escala do ambiente, entre as quais a 
escultura de 7,5m de Barnett Newman, Broken Obelisk (1963-69), e a pintura tríptica de Claude Monet, Water Lilies (1914-26), de $2 \mathrm{~m}$ de altura por $12,76 \mathrm{~m}$ de largura. Suspenso sobre a escada de acesso a esse espaço, no vão entre o bloco das galerias e o do Museum Tower, estava ainda o helicóptero Bell-47D1 projetado por Arthur Young em 1945, da coleção de Arquitetura e Design, que já havia sido exposto sobre as escadas rolantes do antigo Garden Hall de Pelli.

\subsubsection{RECEPÇÃO CRÍTICA EM 2004}

As críticas publicadas à época na imprensa foram em geral elogiosas à arquitetura de Taniguchi, sem deixar de observar que a escolha do мома por esse projeto afirmava a face conservadora da instituição e sua intenção de não deixar a arquitetura se sobrepor à arte. Na revista The New Yorker, Paul Goldberger (1950-) escreveu que "as geometrias rígidas de pedra e vidro de Taniguchi soam tão convencionais quanto uma colunata dórica", mas, por outro lado, reconheceu que a linguagem "elegantemente contida" da fachada "prova que é possível abrigar um edifício dentro de uma espécie de tradição moderna clássica e ainda impregná-lo de frescor. " O crítico apontou como a maior virtude do projeto a conexão do museu com a cidade e destacou também as qualidades do grande espaço central: "o átrio contém aberturas, projeções, varandas e mirantes precisamente posicionados; é um exercício pristino em proporção, escala e luz, não o tipo de arquitetura agitada de hotel que a palavra 'átrio' evoca." ${ }^{471}$

Em artigo publicado no The New York Times, Nicolai Ouroussoff (1962-) escreveu: "o museu ampliado é uma composição serena que mistura arte, arquitetura e a cidade em uma experiência estética transcendente. Suas superfícies nítidas e formas bem proporcionadas limpam a bagunça na qual o edifício havia se transformado ao longo de três expansões." ${ }^{472} \mathrm{O}$ crítico sustentou o tom laudatório ainda que reconhecesse que a nova expansão do edifício indicasse que a instituição estaria mais voltada para o século passado que para o atual:
471 Goldberger, Paul. Outside the Box. The New Yorker, 2004, n.p. Tradução nossa.

472 Ouroussoff, Nicolai. Art Fuses With Urbanity in a Redesign of the Modern. The New York Times, 2004, n.p. Tradução nossa. 
O museu basicamente abandonou sua pretensão sobre o futuro décadas atrás. Esse papel terá que ser assumido por outra geração e outro museu. Por enquanto, devemos aplaudir o MoмA pelo que ele é: um monumento aos valores do século $\mathrm{xx}$, uma estrutura arquitetônica precisamente calibrada cuja energia emocional brota da arte que abriga. É uma das obras de arquitetura mais requintadas que surgiram nesta cidade em pelo menos uma geração. ${ }^{473}$

Depois de descrever as qualidades espaciais do átrio, Ouroussoff indicou que o ponto alto do projeto de Taniguchi teria sido manter a arte como protagonista: "por mais assertivo que seja seu design, todo o poder emocional flui da arte. É um exemplo quase perfeito de como a arquitetura pode ser forte sem competir com a arte que abriga." ${ }^{" 74} \mathrm{O}$ crítico apontou para um aspecto anacrônico das qualidades dessa arquitetura, mas reconheceu o seu poder persuasivo:

É uma noção de pureza estética que parece difícil de digerir hoje. Há décadas, os arquitetos mais revolucionários têm procurado sondar os cantos mais sombrios da imaginação - os conflitos psicológicos e sociais que os modernistas tendiam a ignorar. Eles entendem que verdades universais podem ser evasivas. No entanto, é difícil não sentir nostalgia por um idealismo tão puro. Agora temos uma expressão impressionante desse mito no coração de Manhattan. ${ }^{475}$

Em crítica publicada no site da $C N N$, o jornalista Porter Anderson afirmou que as características do átrio - com superfícies duras e ângulos rígidos - instigariam as pessoas não a permanecer ali, mas a subir para os andares acima e explorar a arte. Reiterando de certa forma qualidades defendidas por Riley, o crítico identificou como o aspecto mais interessante do projeto de Taniguchi a variedade de escalas e ambiências oferecida no percurso entre os andares - com espaços mais agitados e expansivos - e as galerias - com proporções mais familiares e uma ambiência mais acolhedora e tranquila para o encontro com a arte: 

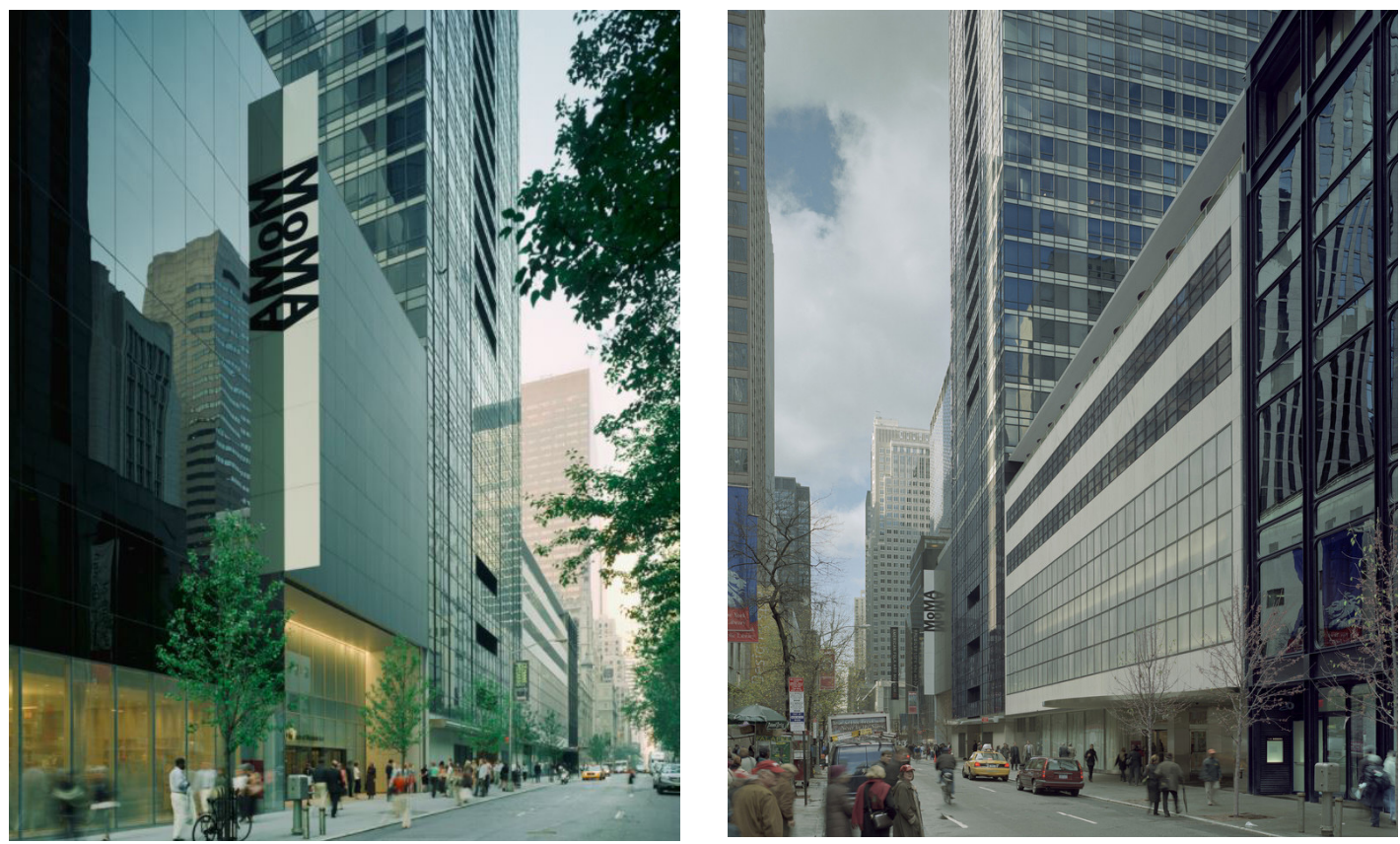

Taniguchi precisa de apenas alguns passos para levar-nos da grandeza espacial festiva do centro de seu edifício para a presença mais amena e branda das obras da coleção. E conforme nos deslocamos de andar em andar, trocando de mídia e de ênfase, ele nos revigora com alguns minutos 'do lado de fora' na área aberta com vista para o átrio, na companhia de nossos pares, antes de entrar no silêncio das salas do próximo andar. $^{476}$

A conclusão de Anderson é que a arquitetura do museu teria correspondência com os procedimentos da arte contida ali: "Taniguchi está fazendo, de uma forma ou de outra, exatamente o que cada artista representado no MoMA fez: ele está estabelecendo tensões e resolvendo-as - ou não - de espaço em espaço e de material em material. Aqui a forma corresponde ao conteúdo." 477

O artigo publicado por Hal Foster na London Review of Books logo após a inauguração traz no título o questionamento do difí-

3.47 e 3.48 Fachada do MoMA na Rua 53 com expansão de Yoshio Taniguchi, Nova York, 2004. Foto: Timothy Hursley. Fonte: http://www.timothyhursley.com/moma/ a6xj4wdgh3xhcs9ynjem224m0l1bna
476 ANDERson, Porter.

Commentary: Inside moma, art within art. CNN. Disponível em: $<$ http://edition.cnn.com/2004/ TRAVEL/11/23/inside.moma/index. html>, n.p. Tradução nossa.

477 Ibidem. 
478 Cf. Foster, Hal. It's Modern but is it contemporary? London Review of Books, v. 26, n. 24, 2004.

479 Cf. Foster, Hal. Museum Tales of Twentieth-Century Art. In: Dialogues in Art History, from Mesopotamian to Modern: Readings for a New Century. Washington: National Gallery of Art, 2009, v. 74, p. 352-375 e Foster, Hal. Museus Minimalistas. In: O complexo ArteArquitetura. São Paulo: Cosac Naify Edições, 2015. (publicado originalmente em 2011).

480 Foster, 2004, op. cit., n.p. Tradução nossa. cil equilíbrio almejado pelo museu: It's Modern but is it contemporary? ${ }^{478} \mathrm{O}$ autor desenvolveu o mesmo argumento em duas publicações posteriores, em 2009 e 2011 - que também serão examinadas aqui - iniciando sempre com uma análise dos aspectos curatoriais da exposição permanente da coleção, entrelaçando-a em seguida com a arquitetura do edifício. ${ }^{479}$ Para Foster, a fronteira cronológica localizada nos anos 1940 seria cruzada espacialmente de forma excessivamente suave entre o quinto e o quarto pavimentos do museu, reforçando a omissão dos impactos sobre a arte da ruptura causada pela II Guerra Mundial. Já o intervalo entre a arte moderna e a contemporânea aconteceria de forma abrupta demais no edifício, dado que a sequência da exposição se daria apenas dois pavimentos abaixo, nos espaços de escala muito maior do segundo pavimento. $\mathrm{O}$ corte no ano de 1970 criaria ainda uma separação arbitrária entre certos grupos de obras e artistas, o que o MoMA identificou como mais problemático diante da insistência do museu em afirmar a continuidade entre o moderno e o contemporâneo:

O novo MoMA insiste na conexão, mas não a demonstra: na verdade, ele expressa a desconexão na lacuna entre pisos e espaços. Antes de o novo design ser escolhido, cogitou-se manter em Midtown um museu de época dedicado à arte modernista, com uma nova estrutura de arte contemporânea em outro lugar. Essencialmente, é isso que temos, mas no mesmo edifício. É um casamento forçado que parece um baile da Cinderela. ${ }^{480}$

Foster examinou os problemas da configuração espacial das galerias de arte contemporânea - ponto de especial interesse para esta tese -, considerando que a premissa da grande escala como recurso de flexibilidade não deveria ser tão generalizada:

Tal é a difícil situação do MoMA diante do campo expandido da arte contemporânea: como conter, ou ainda apresentar, trabalhos que são imensos, site-specific e/ou comissionados? Aqui, como em qualquer lugar, a resposta é que é melhor ser grande que lamentar depois - grande como 1.400 metros quadrados com paredes de 6,4 metros de altura. Mas nem todos os artistas contemporâneos requerem tanto espaço quanto Serra 


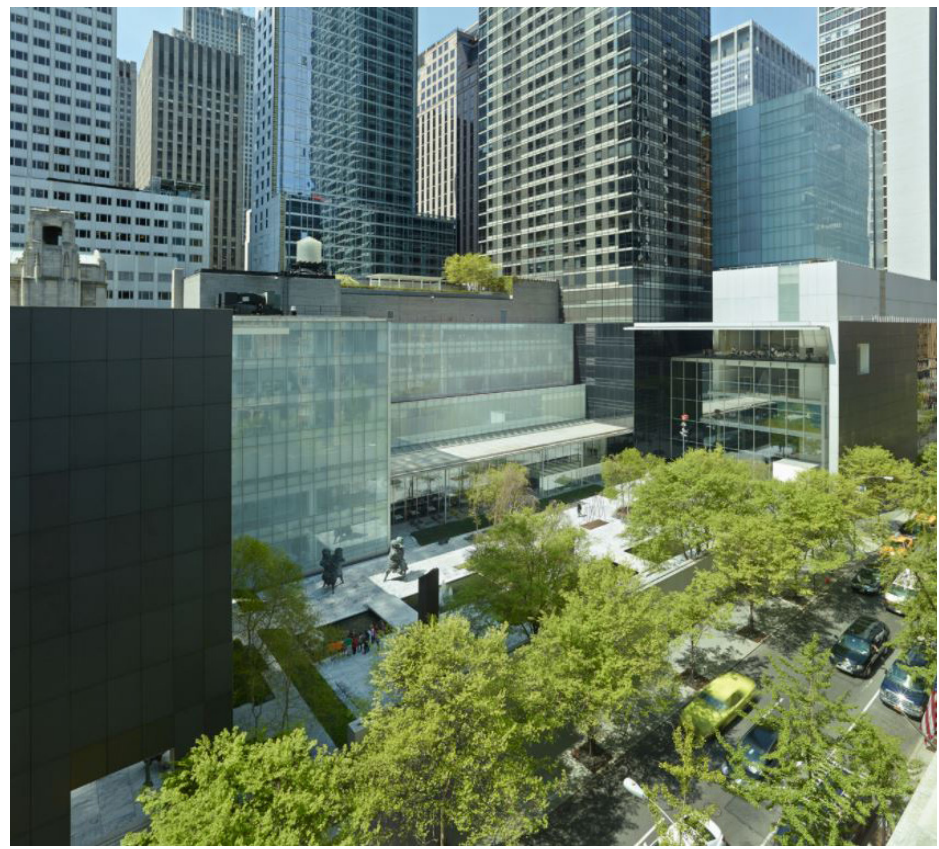

3.49 Blocos do MoMA voltados para a Rua 54 com expansão de Yoshio Taniguchi, Nova York, 2004. Foto: Timothy Hursley. Fonte: http:// www.timothyhursley.com/moma/ a6xj4wdgh3xhcs9ynjem224m011bna

3.50 Jardim de esculturas do MoMA olhando para o bloco de exposiçoes a oeste com expansão de Yoshio Taniguchi, Nova York, 2004. Foto: Timothy Hursley. Fonte: http:// www.timothyhursley.com/moma/ a6xj4wdgh3xhcs9ynjem224m0l1bna

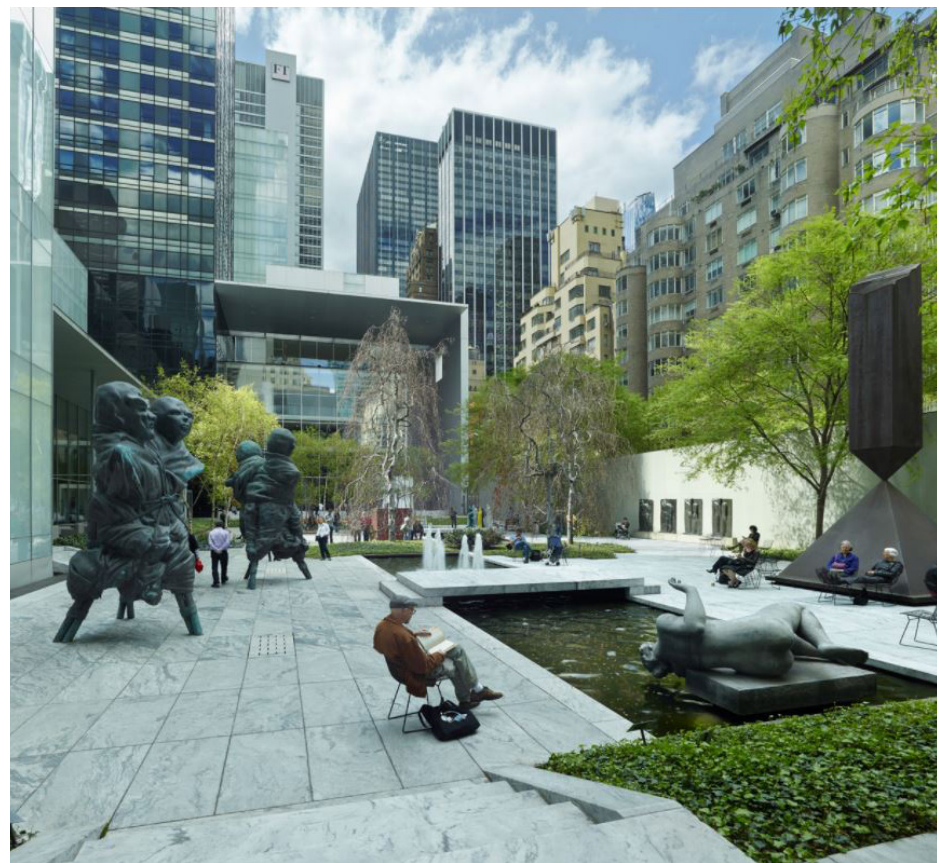


3.51 e 3.52 Saguão do MoMA voltado para 0 jardim de esculturas após projeto de expansão de Yoshio Taniguchi, Nova York, 2004. Foto: Timothy Hursley. Fonte: http://www.timothyhursley.com/moma/ a6xj4wdgh3xhcs9ynjem224m0l1bna
481 Ibidem.

482 Cf. The Museum of Modern ART. Light Construction (Sep 21, 1995-Jan 2, 1996). МОМА. Disponível em: <https://www.moma.org/calendar/exhibitions/469>. Acesso em: 30 maio 2021.
[...]; sua escala não deveria ser a norma. Enorme não significa necessariamente flexível; na verdade pode ser bem rígido. Flexível pode significar uma mistura de grandes e pequenos espaços, e sem dúvida é o que veremos no futuro. As paredes altas, porém, vão continuar difíceis: poucas obras podem se sustentar em tamanha superfície branca além do extremo Minimalismo ou de pinturas bombásticas. ${ }^{481}$

De fato, grandes espaços vazios, quando "cenários" para objetos artísticos, mesmo se configurados por volumes geometricamente simples, podem adquirir um caráter monumental tão interferente quanto as espetaculares rampas do Guggenheim de Frank Lloyd Wright. À escala ampliada das galerias contemporâneas, se somava a amplitude ainda maior do Marron Atrium, contra o qual poucas obras conseguiam se impor. Apesar de ter criado espaços grandiosos e de ter realizado transformações significativas no edifício, a intervenção de Taniguchi tinha uma presença discreta, dada a ambiência limpa e sofisticada de sua arquitetura, orientada para a "invisibilidade" e a leveza.

Discutindo se a qualidade de leveza do novo edifício seria tão capaz de fazer a conexão entre o moderno e o contemporâneo quanto veiculavam os representantes do MoMA, Foster evocou a exposição Light Construction, organizada por Terence Riley em 1995, pouco antes de o museu colocar em andamento as ações que resultaram na expansão. ${ }^{482}$ Haveria, para o autor, uma contradição na associação das qualidades ambíguas de transparência e translucidez de certas arquiteturas recentes presentes na mostra com a suposta conjugação entre os preceitos estéticos modernistas e a virtualidade do mundo digital contemporâneo:

[...] a transparência literal da arquitetura moderna estava mais ligada à clareza estrutural do que aos efeitos fenomênicos. Logo, ainda que o novo MomA seja apresentado como fiel à tradição modernista, em importantes aspectos não o é; ou, antes, se é leal, o que conta como modernista é que mudou, e de fato 'modernista' aqui passou a significar 'minimalista', e ambos a implicar a leveza: uma sublimação do material e da técnica, não sua exposição; uma fetichização da substância e da 

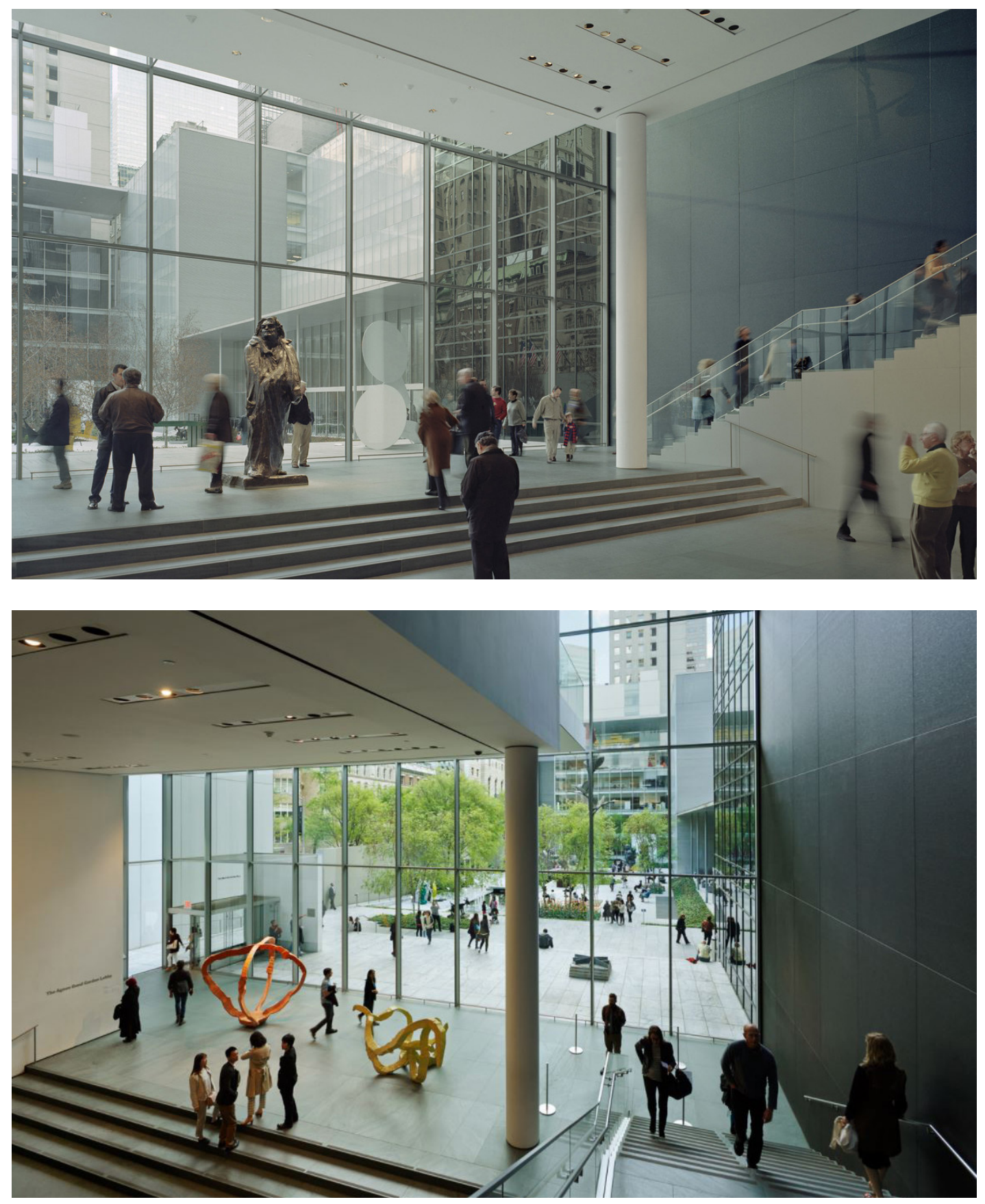


\section{The Modern's Mutations}

A look back on the Museum of Modern Art's history of renovations as it plans to reopen its 53rd Street location.

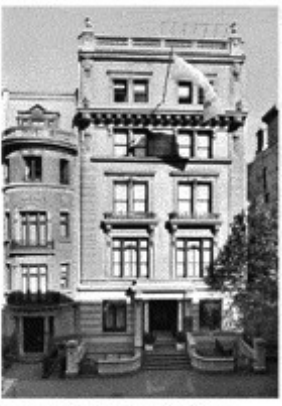

May 3, 1932 The Modern moves from its original location on Fifth Avenue to a town house at 11 West 53rd Street.

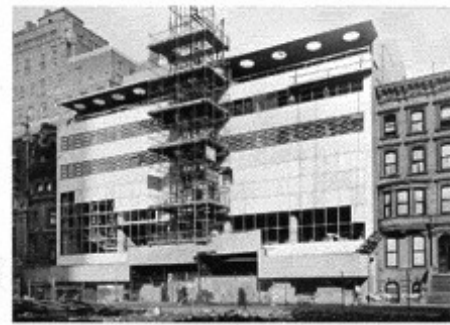

January 1938 - May 1939 The construction of an International Style building, designed by Philip L. Goodwin and Edward Durell Stone.

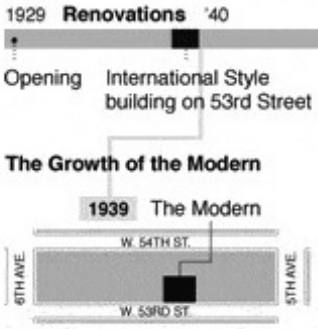

50

60

$\begin{array}{llll}\begin{array}{l}\text { North } \\ \text { wing }\end{array} & \text { Sculpture } & \text { Fire } & \text { Philip Johnson, } \\ \text { closure } & \text { renovations }\end{array}$

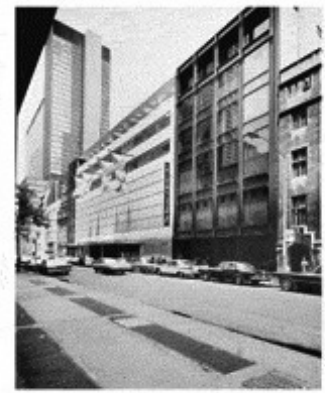

1963 - 1967 The Modern undergoes major renovations and expansions under designer Philip Johnson.

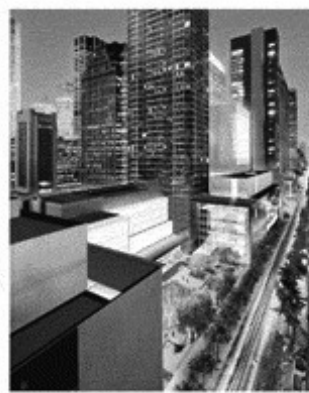

November 2004 After closing in spring 2001, and moving temporarily to Queens, the Modern plans to reopen at 11 West 53rd Street.

90

' 80

Cesar Pelli, construction of west wing and museum tower
Move to Queens. construction of new museum

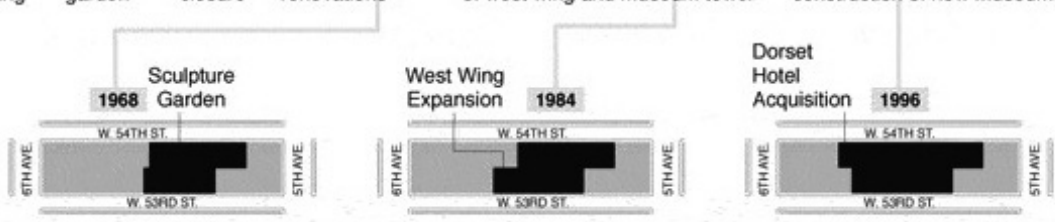

para sua efetivação - para deixar a arte em primeiro plano acabaria por reforçar, afinal, a crença modernista na suposta autonomia da obra de arte que o museu ajudara a moldar, como defendeu Foster:

Como sabemos, a autonomia da obra de arte desliza facilmente para o culto da mercadoria e o faz no MomA renovado a um nível de sublimação requintada como nunca visto antes: esse belo espaço de contemplação desinteressada é também um grande santuário de fetiches financeiros (as obras-primas de valor inestimável) e de capital refinado (a elegante remodelação do edifício). ${ }^{485}$

A sublimação ao mesmo tempo estética, financeira e arquitetônica seria a qualidade definitiva do novo MomA na opinião de Foster, que concluiu de forma irônica seu artigo de 2004:
3.55 Transformações do MoMA de 1939 a 1996.
485 Foster, 2009, op. cit., p. 361. Tradução nossa. 
3.56 Yoshio Taniguchi e Glenn Lowry em depoimento sobre o projeto do MoMA, Nova York, 2004. Fonte: https://www. youtube.com/watch?v=lyVJ2QAnd0o
486 Foster, 2004, op. cit., n.p. Tradução nossa.

487 Yoshio Taniguchi apud NAKAMOTO, Michiyo. Yoshio Taniguchi unveils the new Moma. The Financial Times, 15/10/2004. ed. 2004, p. 3. Tradução nossa.

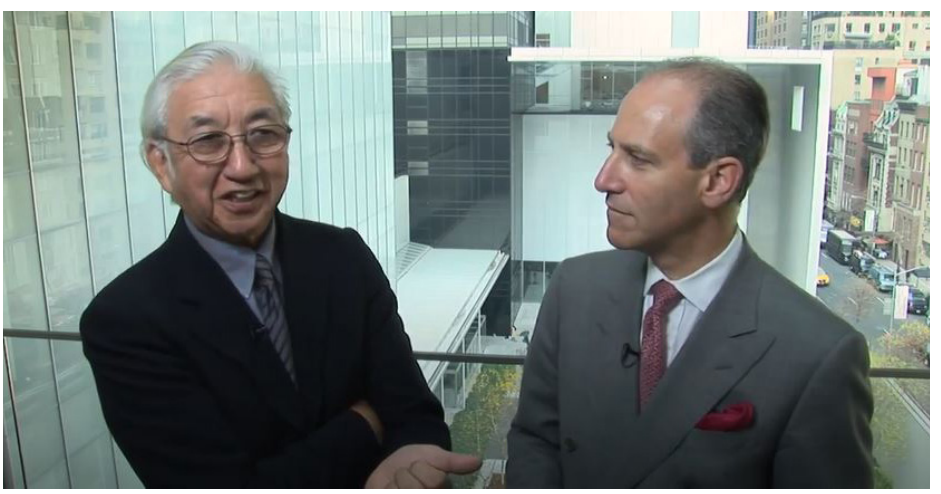

"É um ar inebriante e quase todos parecem contentes só em respirá-lo." 486

Vale mencionar ainda o artigo publicado no The Financial Times pela jornalista baseada em Tóquio, Michiyo Nakamoto, que obteve uma das raras entrevistas com Taniguchi, avesso a declarações à imprensa por acreditar que "a arquitetura fala por si mesma." Entre suas afirmações, destaca-se a que diz respeito ao modo como o arquiteto via a relação entre a arte e a arquitetura no caso do MoMA:

O papel do museu é evidenciar a estética dos artefatos que são expostos em seu interior. Portanto, a arquitetura não deve ser concluída antes que a arte e as pessoas estejam dentro dela. Sendo esse o caso, a própria arquitetura torna-se dominadora. O MомA tem arte e é um recipiente para essa arte, então, se você desenhar muito a caixa, o conteúdo ficará ofuscado. O que pensei em fazer foi, principalmente, criar um espaço confortável que fosse um pano de fundo adequado para o encontro entre a maravilhosa arte do MoмA e as pessoas que o visitam. ${ }^{487}$

Vemos, portanto, que havia uma grande convergência entre a visão de Taniguchi e os anseios do Moma no entendimento de que, para que a arte mantivesse o protagonismo que sempre teve na instituição, a arquitetura deveria manter um tom relativamente rebaixado. Considerando a ideia de que a arquitetura seria concluída apenas com a arte e com as pessoas, 
como declarou o arquiteto, torna-se ainda mais importante para o interesse desta pesquisa verificar o modo como os artistas contemporâneos viriam a dialogar com os novos espaços, revelando suas potencialidades e deficiências, participando da interação com a instituição e a arquitetura.

\subsubsection{ARTE CONTEMPORÂNEA NO NOVO MoMA}

A ideia de fazer desaparecer o contêiner para valorizar a arte já vinha sendo contestada desde os anos 1960 e era, como vimos no Capítulo 2 desta tese, um dos componentes que marcaram a fronteira que surge então entre a arte moderna e a contemporânea. As novas galerias expositivas do MoMA não apresentavam novidades significativas em sua configuração, a não ser pela escala ampliada das áreas dedicadas à coleção do período mais recente, mantendo-se fiel à tradição do "cubo branco", moldada e difundida pela própria instituição nas diversas expansões de sua sede, incluindo a de Taniguchi. As galerias dedicadas à mídia, por sua vez, seguiam também uma configuração espacial padrão, o da "caixa preta". Sendo assim, os espaços das novas galerias não são os que oferecem grande interesse para investigar o modo de interação entre obras de arte contemporânea e a arquitetura do edifício reformado e ampliado, mas outras áreas não exclusivamente dedicadas à arte, como o átrio, os espaços de circulação e a própria fachada, nas quais a arquitetura pode se desenvolver com uma expressão menos presa a padrões convencionais. As exposições selecionadas para análise focaram, além dos espaços arquitetônicos menos convencionais, trabalhos realizados por artistas vivos, que se envolveram pessoalmente na elaboração das montagens.

Um projeto que explorou de modo intenso a relação com a arquitetura no novo мома foi a vídeo instalação Sleepwalkers, do artista estadunidense Doug Aitken (1968-), exposta de 16 de janeiro a 12 de fevereiro de 2007 não no interior do edifício, mas do seu lado de fora ${ }^{488} \mathrm{O}$ trabalho consistia em oito projeções de grande formato sobre partes da fachada do museu: uma sobre as portas de entrada da rua 53 , duas em empenas cegas voltadas para uma área livre a oeste do edifício - a do vizinho Folk
488 THe Museum of MOderN ART, Sleepwalkers: Doug Aitken (Jan 16-Feb 12, 2007). MOMA. Disponível em: <https://www. moma.org/calendar/exhibitions/10>. Acesso em: 3 out. 2020. 


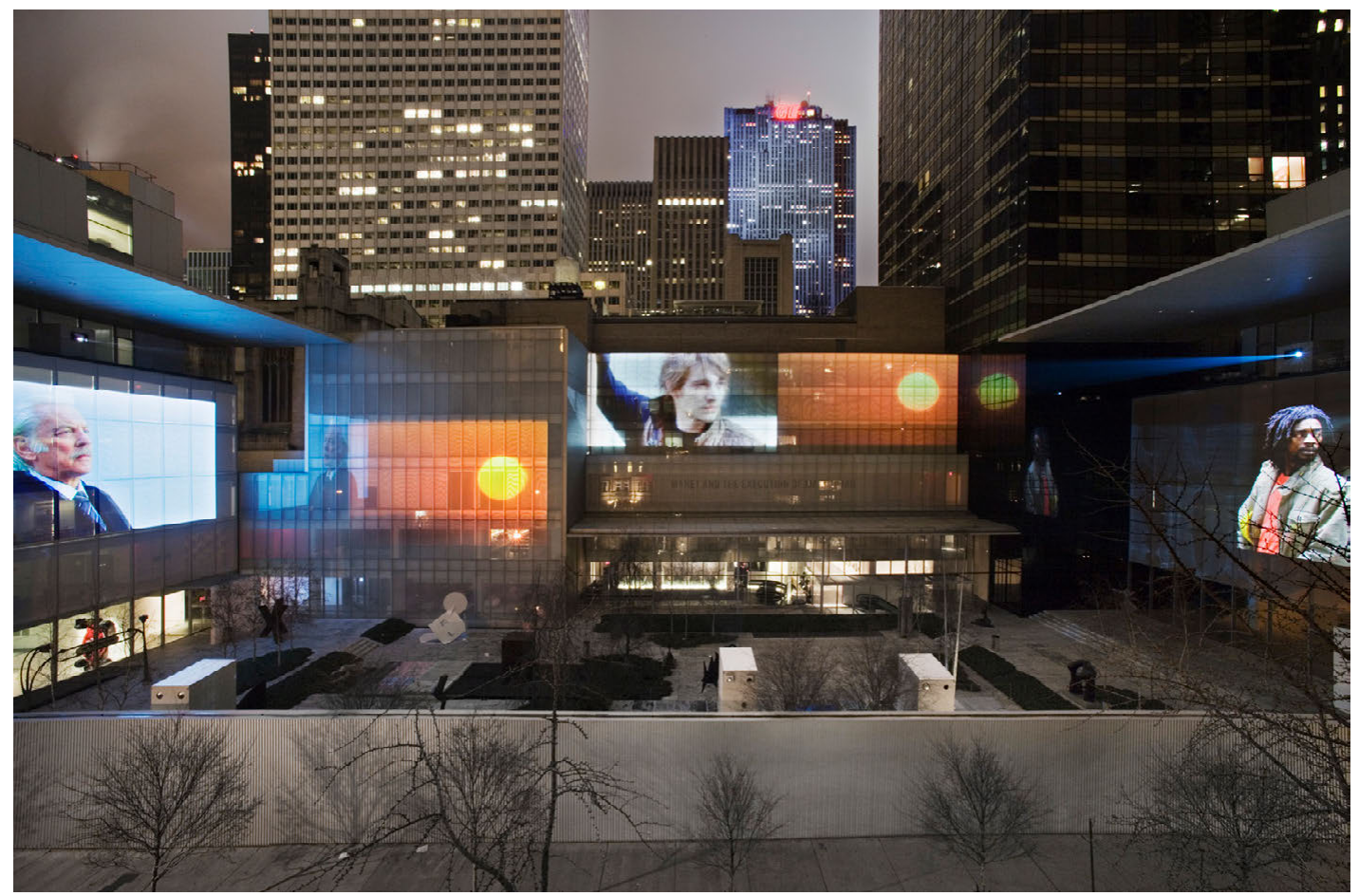

3.57 Vista da exposição Doug Aitken: sleepwalkers, MoMA, Nova York, 2007. Fonte: https://www.moma.org/calendar/ exhibitions $/ 10$
Art Museum e a do bloco de galerias do próprio museu - e as demais sobre os panos de vidro leitoso das faces do MomA voltadas para o jardim de esculturas. As projeções tinham início ao anoitecer e retratavam cinco personagens arquetípicos de Nova York acordando e seguindo sua rotina entre casa e trabalho, passando cada um deles por um dos cinco distritos da cidade. Os personagens - um mensageiro de bicicleta, um eletricista, um executivo, uma funcionária do correio e outra de um escritório - apareciam ora em ações similares, ora em cenas individuais, alternando sua posição nas telas a cada recomeço do ciclo, que durava 13 minutos. A experiência dessa espécie de cinema urbano site-specific requeria um deslocamento do visitante em torno do edifício, sendo impossível apreender a obra de uma só vez. Conforme afirmou Glenn Lowry, Aitken explorou a arquitetura de um modo que não tinha sido previsto nem pelos curadores, nem pelo arquiteto: 
O papel de lugares como museus, onde as paredes se tornam barreiras, é o de enquadrar algo em seu interior. Esse projeto remove essa parede, expondo-a do outro lado, e cria um tipo muito diferente de diálogo com o público, porque o público geralmente vem ver o interior do museu e precisa fazer uma escolha consciente para entrar. O público que vê esse trabalho pode ser totalmente fortuito e casual, mas é atraído, mesmo assim, a refletir sobre a obra em relação com um edifício, uma rua, uma parte da cidade, uma experiência urbana mais ampla. Nesse sentido, portanto, está sendo pedido às pessoas que repensem sua relação com a estrutura física da cidade..$^{489}$

Enquanto na visão de Taniguchi e dos dirigentes do мома a esperada dissolução da arquitetura se daria por sua leveza e invisibilidade, Doug Aitken, usando as fachadas como telas, apostava no potencial de transformação das imagens projetadas como meio de conferir fluidez aos edifícios:

Nada é permanente. Mudança é uma das coisas que temos que assumir. Isso tem a ver com o modo como esse trabalho procura se fundir com a arquitetura e a cidade, afirmando que talvez um edifício possa ser algo diferente de uma estrutura sólida. Talvez possa ser também mutante, esteticamente e emocionalmente fluido. Talvez um arranha-céu possa ser uma cascata de imagens e ideias em movimento. ${ }^{490}$

O projeto tinha começado a ser concebido sete anos antes pela organização Creative Time - fundada em 1974 e dedicada a realizar projetos de arte contemporânea em espaços públicos de Nova York, atuando inicialmente fora do circuito de museus e galerias. Sua realização, de grande complexidade, só se viabilizou a partir da parceria com o момA e com o apoio da prefeitura. A curadoria foi compartilhada entre Peter Eleey, do Creative Time, e Klaus Biesenbach, que, vindo do PS1, integrara-se ao corpo de curadoria do MOMA em 2004, como desdobramento da fusão das duas instituições, tornando-se o primeiro curador chefe do sétimo departamento curatorial criado pelo museu em 2006, dedicado a Mídia. ${ }^{491}$ Biesenbach havia trabalhado em parceria com Aitken na organização da exposição coletiva
489 Glenn Lowry em conversa com Doug Aitken e Anne Pasternak in: Ibidem, n.p. Tradução nossa.

490 Doug Aitken in: Ibidem.

491 Cf. The Museum of Modern ART. The Museum of Modern Art Creates New Curatorial Department. мOмA. Disponível em: $<$ http://press.moma.org/ wp-content/press-archives/PRESS_ RELEASE_ARCHIVE/Media.pdf $>$. Acesso em: 3 out. 2020. 


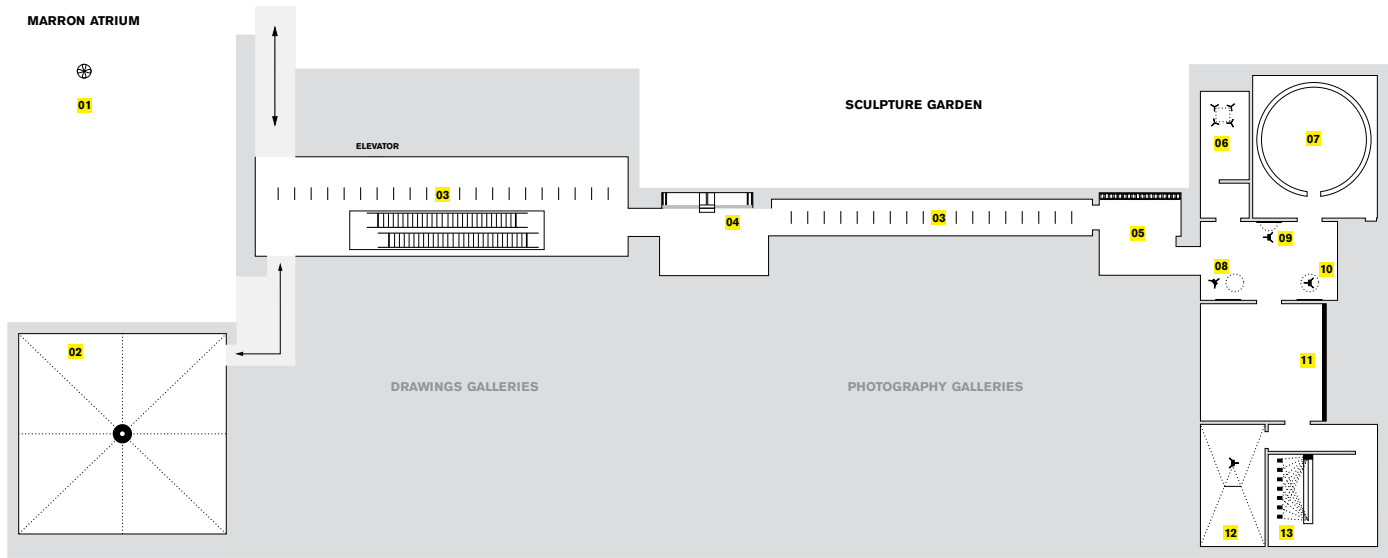

THIRD FLOOR

01 Ventilator, 1997. Altered fan, wire, and cable. Collections of Peter Norton and Eileen Harris Norton, Santa Monica, California. Suspended in the Museum's Marron Atrium, an electric fan swings above head level in everchanging arcs.

02 I only see things when they move, 2004. Wood, color-effect filter glass, stainless steel, aluminum, HMI lamp, tripod, glass cylinder, motors, and control unit. Courtesy Tanya Bonakdar Gallery, New York. Bright light shines through rotating color-effect filter glass panels, creating shifting prismatic bands of colors on the surrounding walls.

03 Room for one colour, 1997. Monofrequency lights. Courtesy the artist Tanya Bonakdar Gallery, New York; and neugerriemschneider, Berlin. Monochromatic bulbs emit light at such a narrow frequency that they affect your normal color perception, making the contents of the room appear in yellow or shades of black.

04 Space reversal, 2007. Mirror foil, mirror, aluminum, wood, steel, and drywall. Courtesy the artist; Tanya Bonakdar Gallery, New York; and neugerriemschneider, Berlin. An opening in this corridor provides a portal into an enclosed space where you and the outside surroundings are reflected into infinity.

05 Negative quasi brick wall, 2003. Stainless steel. Boros Collection, Berlin. Stainless steel "quasi bricks" with mirrored interiors are stacked in six different positions to create a reflective and kaleidoscopic wall.

$061 \mathbf{m}^{3}$ light, 1999. Halogen lamps, steel stands, and fog machine. Private collection. In a dark room filled with fog, the beams of twenty-four spotlights articulate one cubic meter of space. $07360^{\circ}$ room for all colours, 2002. Stainless steel, projection foil, fluorescent lights, wood, and control unit. Private collection, courtesy Tanya Bonakdar Gallery, New York. Since the nineteenth century, painted panoramas have given viewers a sense of what it feels like to stand in faraway landscapes or participate in historic events. Rather than illustrating a particular scene, Eliasson's installation immerses you in the color spectrum itself.

08 Mirror door (user)

09 Mirror door (spectator)

10 Mirror door (visitor), 2008. Spotlights, tripods, and mirrors, Courtesy the artist; Tanya Bonakdar Gallery, New York; and neugerriemschneider, Berlin. Spotlights are aimed at rectangular mirror doors, creating pools of light on the gallery floor as well as in the artificial dimension within the mirrors. The related work, Mirror door (observer), is on view at P.S.1.

11 Moss wall, 1994. Wood, moss, and wire, Courtesy the artist; Tanya Bonakda Gallery, New York; and neugerriemschneider, Berlin. A hidden wood-andwire structure anchors live reindeer moss to the gallery wall. Throughout the duration of the exhibition, the curtain of soft moss alters in shape and color, giving off a natural fragrance.

12 Wall eclipse, 2004. Mirror, motor, HMI lamp, tripod, and transformer. Private collection. A spotlight shines on a mirror that hangs from the ceiling and rotates on its axis at a speed of one revolution per minute. Once in every rotation, the mirror's shadow fully eclipses the wall behind it while the mirror's reflection illuminates the opposite wall.

13 Your strange certainty still kept, 1996. Water, strobe lights, acrylic, foil, wood, pump, and hose. The Dakis Joannou Collection, Athens. A curtain of water droplets, illuminated by strobe lights, appears frozen in midair.

3.58 Mapa da exposição Take your time: Olafur Eliasson, MoMa, Nova York, 2008. Fonte: https://www.moma. org/interactives/exhibitions/2008/ olafureliasson/\#/intro/ 
realizada no PS1 em 2004, Hard Light, que tinha o trabalho do artista como âncora. ${ }^{492} \mathrm{Com}$ a experiência acumulada ao longo dos anos atuando com a cena de vanguarda - tendo fundado o Kunst-Werke Institute for Contemporary Art (KW) em 1991 e a Bienal de Berlim em 1996 e nesse mesmo ano integrado à equipe do PS1 - o curador representava para o MOMA uma das possibilidades de o museu fortalecer os vínculos com a produção internacional de uma nova geração de artistas.

Algumas das curadorias das quais Biesenbach participou em seguida envolveram artistas que também exploraram novas formas de interação com a arquitetura do edifício. Uma delas foi uma grande exposição retrospectiva do dinamarquês-islandês Olafur Eliasson (1967-), Take Your Time, organizada em 2008 em parceria com a curadora Roxana Marcoci, do Departamento de Fotografia, e com Madeleine Grynsztejn, curadora do Museu de Arte Moderna de São Francisco - SFMOMA -, onde fora montada antes uma versão menor da mostra. Incluindo 38 trabalhos - environments e instalações imersivas de escalas variadas, fotografias, gravuras e modelos -, a exposição apoiava-se no modo específico de produção do artista para expandir a noção convencional de museu, como explicaram Biesenbach e Marcoci:

Durante os últimos dois anos, trabalhamos diretamente com o artista e o Studio Olafur Eliasson para conceber uma exposição em dois locais - MOMA e PS1 - catalisando as metodologias curatoriais e as perspectivas espaciais do Kunsthaus e do Kunsthalle e, assim, realizar uma exposição sobre o processo do artista, sendo ao mesmo tempo um estudo retrospectivo, um lugar experimental e um laboratório. ${ }^{493}$

As 13 obras expostas no момA em parte das galerias dedicadas aos departamentos de Arquitetura e Design e ao de Fotografia, na área de exposições especiais do terceiro pavimento e também no átrio. A primeira obra que o público encontrava no museu era Ventilator, de 1997, que consistia em um ventilador suspenso a 2,40m do piso por um longo cabo preso no teto do átrio, que balançava impulsionado pela hélice. Ao invés de enfrentar a grande escala do espaço com uma obra monumental - como
492 Cf. The Museum of Modern ART. Hard Light (Jun 27-Sep 20, 2004). МОМА. Disponível em: <https://www.moma.org/calendar/ exhibitions/4809>. Acesso em: 3 out. 2020.

493 Press release de 15 de abril de 2008, p. 1, in: The Museum OF MODERn ART. Take your Time: Olafur Eliasson (Apr 20Jun 30, 2008). МОМА. Disponível em: <https://www.moma.org/ calendar/exhibitions/31 e https:// www.moma.org/interactives/ exhibitions/2008/olafureliasson/\#/ intro/>. Acesso em: 3 out. 2020. Tradução nossa. 


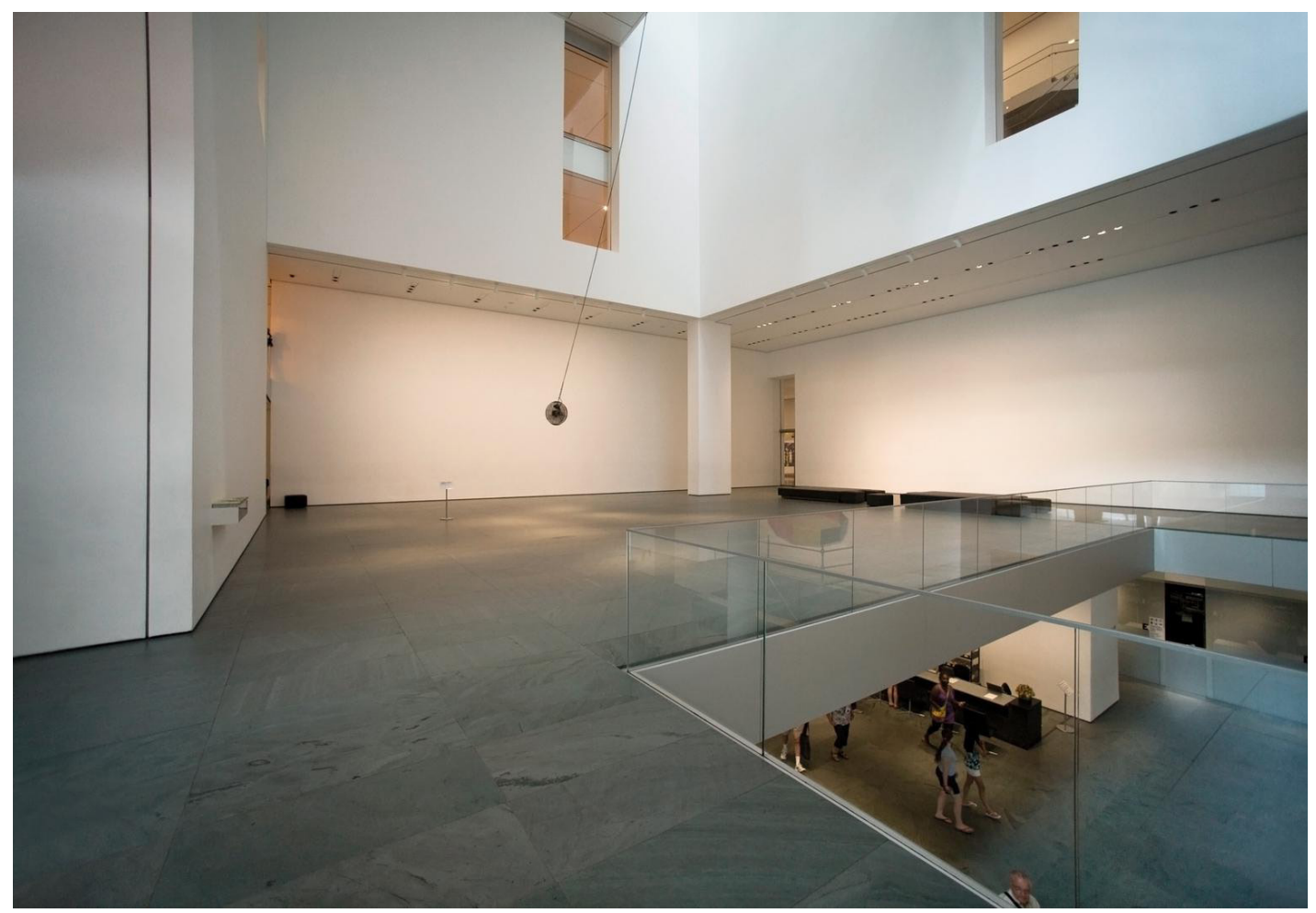

494 A obra consistia num plano espelhado fixado no teto, duplicando um meio círculo de luminosidade intensa que produzia a imagem de um imenso sol no interior ampliado do museu. Cf. TATE MOdERN. Olafur Eliasson the Weather Project: about the installation. Tate. Disponível em: $<$ https://www.tate.org.uk/whats-on/ tate-modern/exhibition/unilever-series/unilever-series-olafur-eliasson-weather-project-o $>$. Acesso em: 6 nov. 2020. havia feito em 2004 ao instalar The Weather Project no enorme Hall das Turbinas da Tate Modern de Londres -, ${ }^{494}$ Eliasson ocupou o átrio apenas com o movimento desorganizadamente pendular de uma pequena peça, que, embora diminuta, levava o espectador a percorrer todo o volume do espaço com o olhar que acompanhava o deslocamento da peça. Esse é um exemplo de como o artista buscava integrar o fator temporal na experiência das obras num museu, conforme explicou num dos dewpoimentos registrados no site da exposição:

Creio que haja um paradoxo, olhando a história dos museus e sobre o que tratavam no início - preservando a história, voltados essencialmente para colecionar objetos da realidade, preservando-os num contêiner de algum modo fora da realidade - e o fato de que museus hoje, pelo menos na minha 


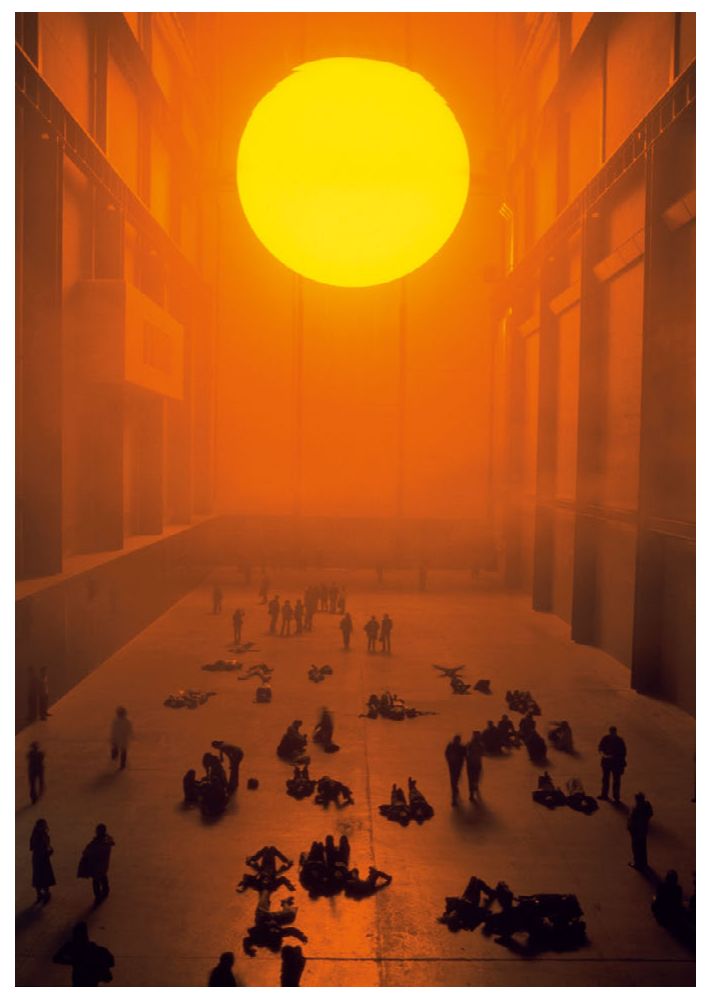

visão, deveriam ser uma parte do mundo, uma parte dos tempos em que vivemos. Mesmo que tenham coleções históricas, ainda precisam enfatizar o fato de que se está olhando para elas a partir de onde estamos hoje. A crença mais básica que está por trás do meu trabalho é que a ótica em si não tem um lugar no mundo se não houver uma pessoa fazendo algum uso individual desse objeto. Isso vale desde ouro e diamantes até a arte. $\mathrm{E}$ ainda mais mistificador e ainda mais alienante que o universo dos objetos é o dinheiro no banco, independente do lugar onde as pessoas olham para isso, se iludem com isso, são rodeadas ou não por isso. Se o objeto se torna uma imposição do indivíduo, do sujeito, não integramos o transcorrer do tempo. Aqui estou com uma exposição num museu e eu gostaria muito de tirar o museu do seu próprio estigma de ser de certo modo atemporal, acrescentando tempo a ele, como

3.59 Olafur Eliasson, Ventilator (1997), em exposição no MoMA, Nova York, 2008. Foto: Christopher Burke. Fonte: https://olafureliasson. net/archive/exhibition/EXH101100/ take-your-time-olafur-eliasson\#slideshow

3.60 Olafur Eliasson, The weather project (2003), em exposição na Tate Modern, Londres, 2003. Foto: Andrew Dunkley \& Marcus Leith/Tate Photography. Fonte: https://olafureliasson.net/ archive/exhibition/EXH101100/ take-your-time-olafur-eliasson\#slideshow 
495 Depoimento de Olafur Eliasson em vídeo Time in Museums. In: THE MUSEUM OF MODERn ART, Take your Time: Olafur Eliasson, op. cit. Transcrição e tradução nossas. uma dimensão que seja produtiva para a qualidade do trabalho. Não é, portanto, sobre o museu, mas sobre o espectador. Tem aqui, portanto, algo um tanto generoso, na minha opinião: vamos sugerir que, ao menos nesta exposição, o museu devolva o tempo para o espectador, para as pessoas, para o uso que quiserem dar. Então acredito que o princípio fundamental de 'tomar seu tempo' é o da generosidade. ${ }^{495}$

Nas galerias de configuração convencionais, protegidas de interferências externas, foram montadas diversas instalações luminosas e/ou com superfícies espelhadas concebidas anteriormente. Nesses casos, a arquitetura original das salas era de fato rebaixada ou mesmo anulada, para dar lugar às diferentes experiências imersivas e arquitetônicas propostas pelo artista.

Além desses espaços especificamente destinados a exposições, Eliasson ocupou também áreas de circulação entre as galerias para instalar a obra, Room for One Colour, de 1997. Com a substituição das lâmpadas comuns por outras especiais que emitiam uma luz amarelada, a percepção do espectro de cores era anulada, fazendo com o que o público fosse surpreendido, num espaço em que não se esperava encontrar uma obra, com a experiência de enxergar a si mesmo e aos visitantes em preto e branco. Vemos, portanto, que espaços de configuração ambígua - interiores expandidos como átrios, ou locais transitórios como circulações - tornaram-se também locais de interesse de intervenção dos artistas, de modos por vezes surpreendentes, o que revela a dificuldade de prever em projeto como a arquitetura será ocupada.

No PS1, ao invés de escolher um dos espaços em que a presença do antigo uso escolar era mais visível, o artista preferiu uma antiga sala de aula, transformada em "cubo branco" na reforma de 1997, para a instalação que dava nome à exposição, Take your Time. Composta por um plano espelhado circular inclinado, suspenso à altura do teto e em rotação pelo eixo central, a obra instigava o engajamento dos espectadores, que costumavam se deitar no chão para contemplar sua imagem e a do edifício refletida acima. Nesse caso, porém não havia uma interação da obra com aspectos específicos da arquitetura do edifício, como aconteceria em montagens posteriores, como a 


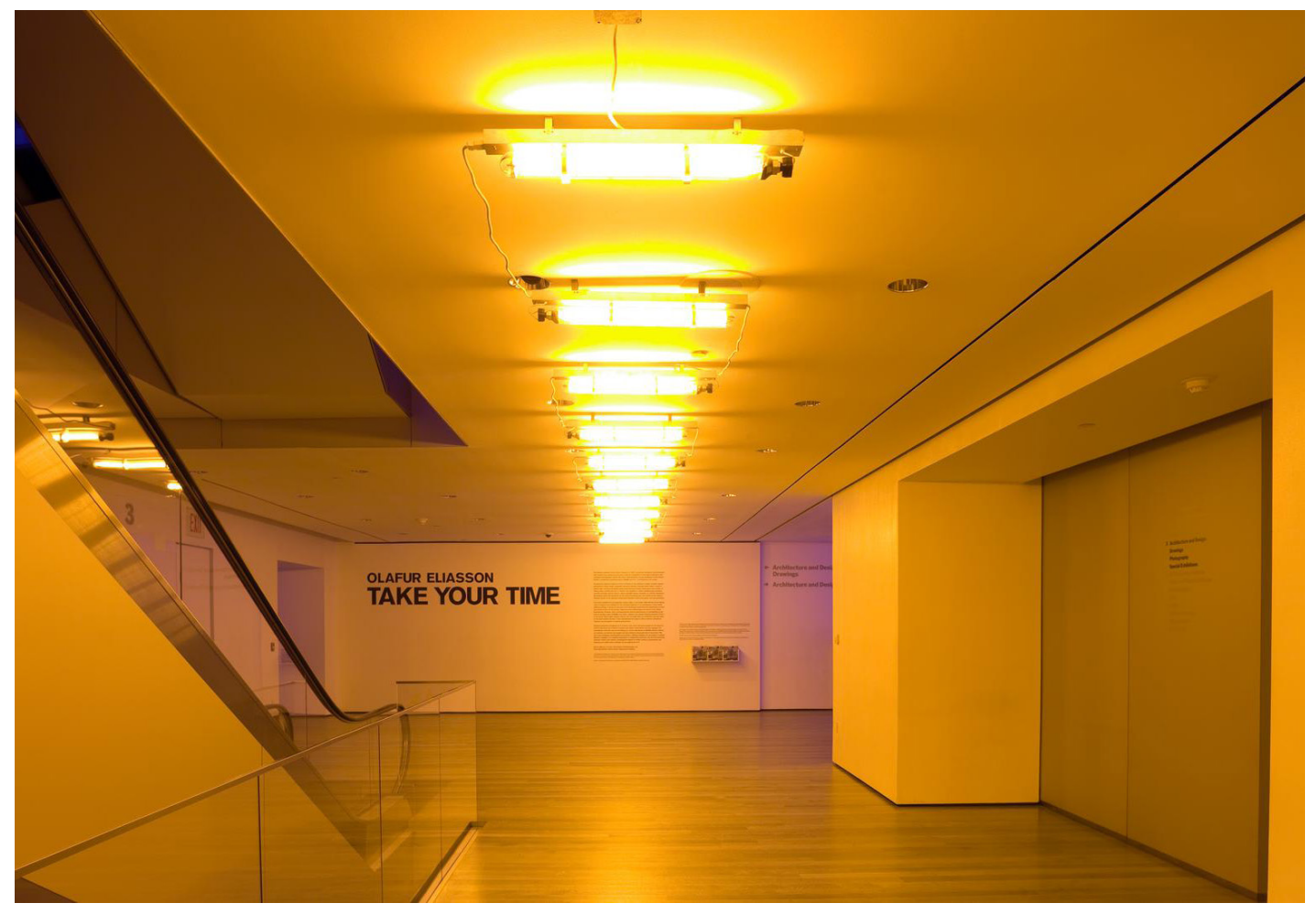

realizada em 2011 na Pinacoteca do Estado em São Paulo, que tinha a instalação exposta no espaço nada convencional do pátio central do edifício, conhecido como Octógono. ${ }^{496}$

Ao final do mesmo ano de 2008, foi inaugurada no момА uma outra exposição que explorou a nova arquitetura do edifício, a da suiça Pipilotti Rist (1962-), Pour Your Body Out (7354 Cubic Meters). A artista foi convidada pelo curador Biesenbach para elaborar um trabalho especialmente para o átrio, um espaço que vinha se mostrando difícil de ser dominado devido à sua grande escala. Rist realizou então uma videoinstalação site-specific de enormes proporções, convertendo as superfícies do ambiente em telas de 7,6 metros de altura por uma largura total de $6 \mathrm{om}$. Acompanhadas por uma trilha sonora, imagens em movimento lento incluíam uma plantação de tulipas, uma mulher e um porco mordendo maçãs numa relva viçosa,

3.61 Olafur Eliasson, Room for One Colour (1997), MoMA, Nova York, 2008. Foto: Christopher Burke. Fonte: https://olafureliasson.net/ archive/exhibition/EXH101100/ take-your-time-olafur-eliasson\#slideshow

496 A exposição realizada em 2011 por Olafur Eliasson em São Paulo, Corpo da Obra, foi montada simultaneamente na Pinacoteca do Estado e no SESC Belenzinho. 

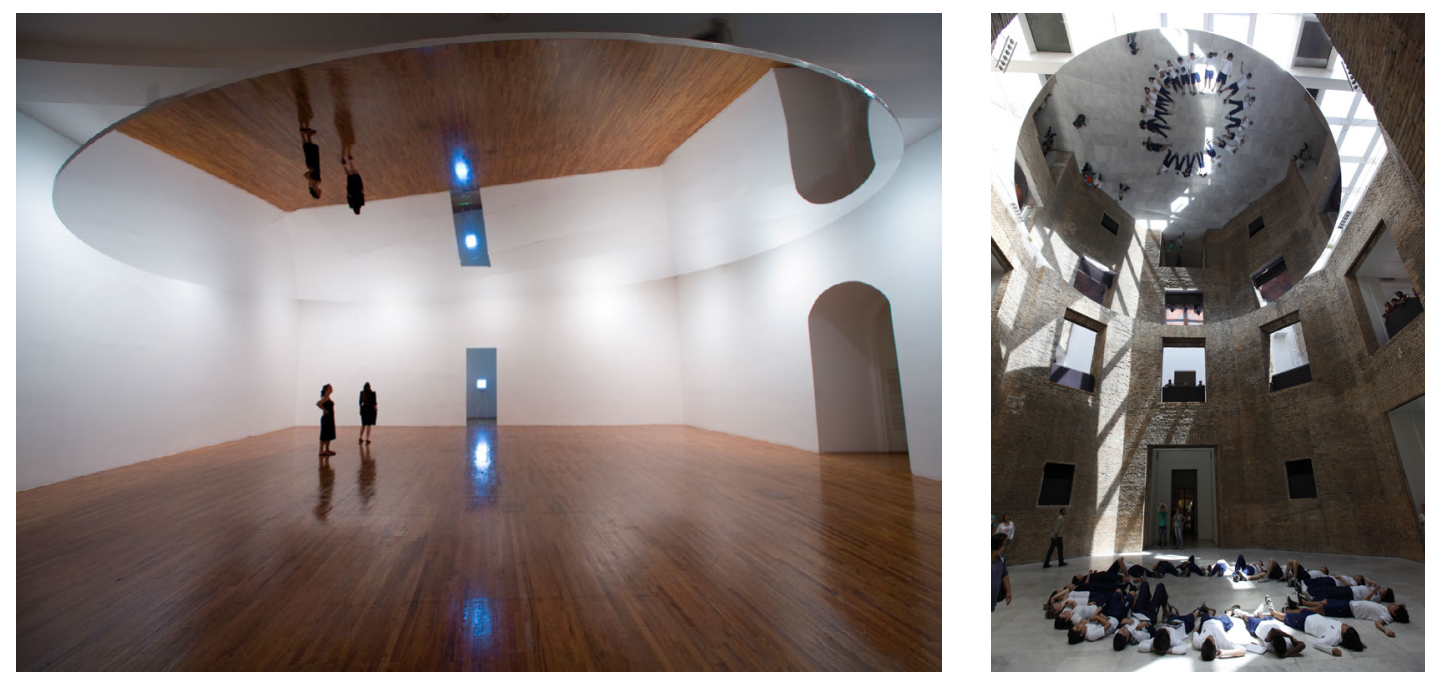

3.62 Olafur Eliasson, Take Your Time (2008), em exposição no MoMA PS1, Nova York, 2008. Foto: Christopher Burke. Fonte: https://olafureliasson. net/archive/exhibition/EXH101100/ take-your-time-olafur-eliasson\#slideshow

3.63 Olafur Eliasson, Take Your Time (2008), em exposição na Pinacoteca do Estado, São Paulo, 2011. Foto: Olafur Eliasson. https://olafureliasson.net/ archive/exhibition/EXH102015/olafureliasson-seu-corpo-da-obra-your-body-ofwork\#slideshow
497 Press release, in: THE Museum OF MODERN ART. Pipilotti Rist: Pour Your Body Out (7354 Cubic Meters) (Nov 19, 2008-Feb 2, 2009). MOMA. Disponível em: <https:// www.moma.org/calendar/exhibitions/307>. Acesso em: 4 out. 2020, p. 1. Tradução nossa. dedos desenterrando minhocas e sequências mais abstratas que tingiam o espaço todo com cores vibrantes. No memorial divulgado à imprensa pelo museu, a intenção do trabalho é assim descrita:

Pour Your Body Out expressa o desejo da artista de reconciliar os espectadores com a percepção de seus próprios corpos e do ambiente circundante, por meio da aceitação da incrível variedade de formas bonitas e feias que constituem os seres humanos e o mundo. Neste trabalho, a intenção de Rist é visualizar o processo de pensamento interior de um indivíduo nas paredes do átrio. Ao mesmo tempo, o título alude ao impressionante volume do átrio central como estrutura arquitetônica. ${ }^{497}$

Algumas adaptações foram feitas no espaço para valorizar a experiência imersiva, como a instalação de cortinas drapeadas de cor magenta, que impediam a entrada de luz natural pelas frestas do átrio voltadas para o exterior. Para tornar o ambiente mais convidativo para a permanência, o piso foi coberto por carpete, atenuando a reverberação do som, e um sofá circular foi instalado no centro, ocultando as caixas de som e convidando as pessoas a se sentar ou deitar conforta- 


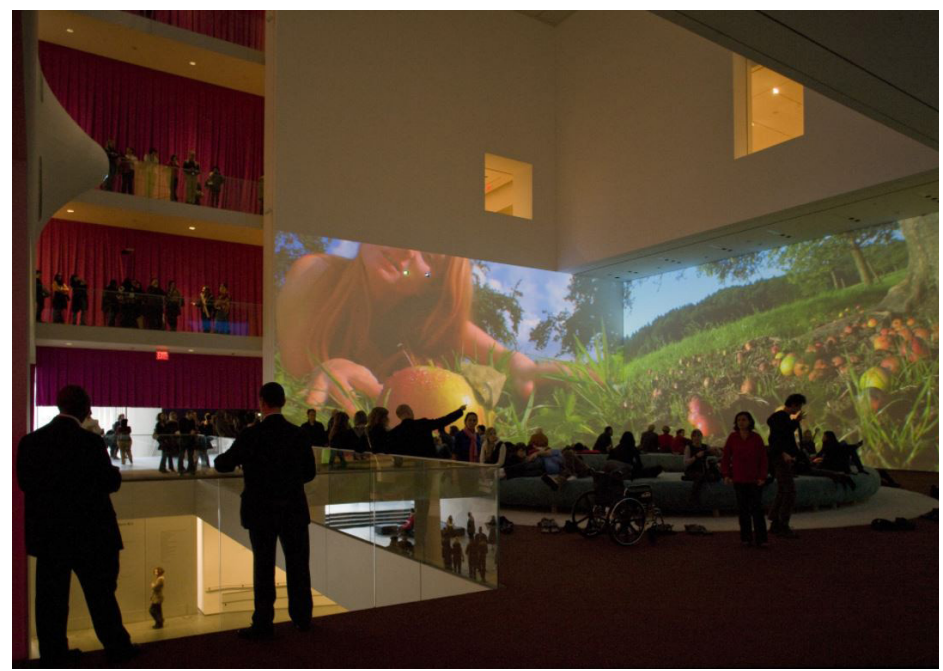

velmente, deixando os sapatos ao redor. A instalação de luz e som podia ser vista e ouvida, ainda que parcialmente, a partir de espaços adjacentes ao átrio, como o saguão de entrada, as salas de exposição dos pavimentos acima e as passarelas entre as salas, dando conta, assim, de ocupar não apenas esse grande espaço, mas de expandir sua presença para outras áreas do museu. Assim como fizera Aitken com as fachadas, Rist converteu as superfícies construídas, desta vez no coração do edifício, em imagens em movimento, integrando a arquitetura ao seu trabalho. Em suas palavras, "o conceito básico não foi tentar destruir ou provocar a arquitetura, mas se fundir nela, como se eu fosse beijar Taniguchi". ${ }^{498}$

Outro tipo de manifestação artística que o museu pretendia valorizar naquele momento era o que envolvia performances, o que levou o recém-criado Departamento de Mídia a ter seu nome alterado, em 2009, para Departamento de Mídia e Arte Performática - o primeiro desse tipo, segundo o website da instituição. Seu objetivo seria "colecionar, expor e preservar arte baseada no tempo", mas, distinguindo-se do Departamento de Filme, voltado mais especificamente a obras cinematográficas, seu foco seria em trabalhos incluindo “imagens em movimento, instalações de filmes, vídeo, per-
3.64 Vista da exposição Pipilotti Rist. Pour Your Body Out (7354 Cubic Meters), MoMA, Nova York, 2008. Foto: Thomas Griesel. Fonte: https://www.moma.org/ collection/works/121312
498 THe Museum OF MOderN ART. Behind the Scenes with Pipilotti Rist, Pour Your Body Out (7354 Cubic Meters). Youtube. Disponível em: <https://www.youtube.com/watch?v=89vgdELbVyQ $>$. Acesso em: 4 out. 2020, p. o-20 s. Transcrição e tradução nossas. 


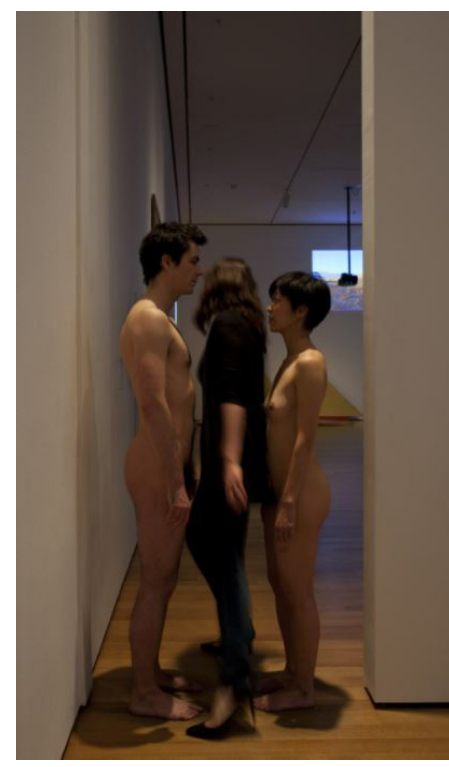

3.65 Performers em Imponderabilia (1977/2010), na exposição Marina Abramović: The Artist Is Present, MoMA, Nova York, 2010. Foto: Jonathan Muzikar. Fonte: https://www.moma.org/calendar/ exhibitions/964

499 The Museum of Modern ART. Media and Performance. MOMA. Disponível em: <https:// www.moma.org/collection/about/ curatorial-departments/media-performance>. Acesso em: 24 jul. 2020. Tradução nossa.

500 The Museum of Modern ART. Press release: MoMA deepens commitment to collecting, preserving, and exhibiting performance art through a range of pioneering initiatives. MOMA. Disponível em: <http://press. moma.org/wp-content/press-archives/PRESS_RELEASE_ARCHIVE/ PerformanceRelease.FINAL.pdf $>$. Acesso em: 4 out. 2020. formance, obras baseadas em movimento e som e outras obras que representem o tempo ou a duração e são feitas e apresentadas em um ambiente de galeria." ${ }^{499}$ Ainda tendo Biesenbach como curador chefe, o departamento lançou novos programas específicos voltados a performances. Um deles seria a série de dois anos de exposições, o Performance Exhibition Series, que ocuparia diversos espaços do museu com instalações documentando performances passadas, reencenações ao vivo de performances históricas e peças de performance originais. O museu continuaria também fomentando o programa Performance Workshops, reunindo grupos de artistas e curadores internacionalmente conhecidos para debater a relação entre instituições de arte e produções baseadas em performance.

Apesar de anunciados pelo museu como "iniciativas pioneiras", ${ }^{500}$ programas dedicados a performances promovidos por instituições de arte não eram inéditos. Quando fundado por Alanna Heiss mais de três décadas antes, em 1976, o PS1 já contava com um espaço especialmente dedicado a performances, o auditório da antiga escola. A importância desse tipo de programa para o PS1 pode ser medida pelo fato de o auditório ter sido a única área do edifício a ser renovada naquela ocasião, quando todo o resto da construção permanecera com as condições precárias em que se encontrava pelos anos de abandono. Mesmo antes de integrar-se ao PS1 e depois ao MoMA, Biesenbach também já havia incorporado performances à programação artística do centro de arte contemporânea KW de Berlim no início da década de 1990. O pioneirismo do programa de performances restringia-se, portanto, ao universo do próprio момА. A valorização pelo museu da arte de performance, tardia num contexto mais amplo, é um dos aspectos mais evidentes do impacto da experiência que o PS1 agregara ao MoMA no movimento de aproximação da instituição com a produção da arte contemporânea.

Para o interesse desta tese, é importante observar que esse impacto não se restringiu à natureza da programação do museu, mas repercutiu de modo decisivo no modo como o edifício passou a ser usado a partir de então. Exemplo disso foi a performance da artista iugoslava Marina Abramović (1946-), 
The Artist is Present, nome da grande exposição realizada no museu sobre sua obra em 2010. ${ }^{501} \mathrm{~A}$ curadoria foi realizada também por Biesenbach, que assumira no ano anterior o lugar ocupado por mais de três décadas por Alanna Heiss na diretoria do MOMA PS1, novo nome que o centro de arte contemporânea recebeu com a conclusão do processo de fusão das duas instituições, iniciado em 1999.

Os núcleos dedicados à retrospectiva da carreira de Abramović foram expostos nas galerias temporárias do sexto pavimento do момА, mostrando aproximadamente 50 trabalhos realizados em quatro décadas, incluindo peças sonoras, vídeos, instalações, fotos e performances individuais e coletivas. Além do vasto material documental, a mostra contava com cinco performances reencenadas pela primeira vez não pela própria artista, mas por um grupo de 39 artistas selecionados e treinados por ela especialmente para a atuar nas obras, revezando-se em turnos. Entre essas estava a performance Imponderabilia (1977/2010), na qual um casal de artistas nus posicionados frente a frente ficava imóvel no vão da porta de uma das galerias, fazendo com que os visitantes que desejassem entrar tivessem que passar no exíguo espaço entre os dois corpos, encarando um ou outro. Tratava-se, sem dúvida, de um modo novo de ocupar as galerias do museu, mas a novidade mais significativa que a exposição trouxe de relacionar a arte com a arquitetura se deu no átrio.

Durante a elaboração da exposição, o átrio havia sido reservado para a única performance a ser realizada pela própria artista. Conforme relatou Biesenbach, ${ }^{502}$ o plano inicial de Abramović era construir junto a uma das imensas paredes uma escada com sete estágios, ${ }^{503}$ cada um deles representando uma das décadas de sua vida e obra. A artista iniciaria a performance no alto, utilizando figurinos e adereços, que iam sendo substituídos à medida em que ela fosse descendo até chegar ao nível mais baixo onde estaria o público, acomodado, por sua vez, em espreguiçadeiras de lona. Com palco frontal de um lado e plateia do outro, o espaço teria uma estrutura de certa forma convencional para um teatro, embora inusual para um museu. A ideia, no entanto, foi substituída por outra, originada, segundo o curador, da experiência da artista diante do
501 Cf. The Museum OF Modern ART. Marina Abramovi: The Artist Is Present (Mar 14-May 31, 2010). МОМА. Disponível em: $<$ https://www.moma.org/calendar/exhibitions/964>. Acesso em: 30 maio 2021.

502 Klaus Biesenbach. Marina Abramović: The Artist Is Present. The Artist Was Present. The Artist Will Be Present. In: THE Museum of Modern ART. Marina Abramovic: The Artist Is Present, Nova York: The Museum of Modern Art, 2010, p. 12-21.

503 MARINA Abramović: The Artist is Present. Direção: Matthew Akers. Produção: Jeff Dupre. [S.l.]: HBO Documentary Films, MusicBox Films, 2012. 1 DVD (106 min), color. 


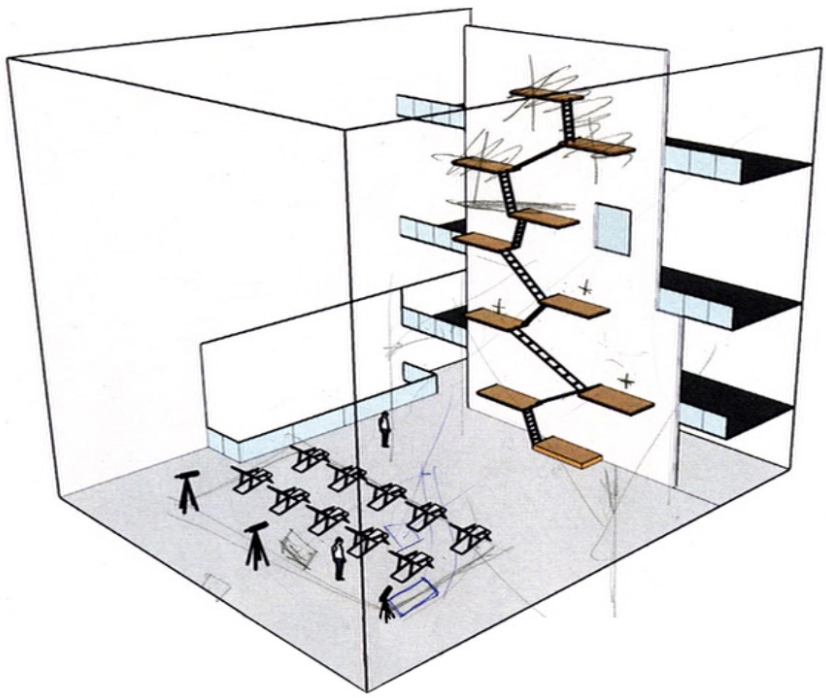

3.66 Versão inicial do projeto de performance no átrio para a exposição Marina Abramović: The Artist Is Present, MoMA, Nova York, 2010. Fonte: Marina at MoMA in: MARINA. espaço negativo da obra de Michael Heizer North, East, South, West (1967/2002), instalada no centro de arte Dia Beacon. Marina Abramović já havia realizado no Japão uma performance com seu parceiro Ulay num espaço negativo escavado na terra. $\mathrm{O}$ trabalho fazia parte da série Nightsea Crossing, feita de 22 performances em diferentes países e continentes entre 1981 e 1987, nas quais cada um dos artistas sentava-se imóvel numa das pontas de uma mesa retangular, encarando um ao outro por horas seguidas. Assim como a obra de Heizer e o buraco na terra da performance no Japão, o átrio do MOMA também podia ser considerado um espaço negativo. A partir dessa ideia, a performance The Artist is Present foi reconceituada, deixando para trás uma ocupação do espaço nos moldes teatrais para converter-se numa experiência concentrada num pequeno ponto do imenso espaço vazio.

Esse ponto consistia numa mesa quadrada com duas cadeiras posicionadas frente a frente, numa das quais a artista ficaria sentada ao longo das horas em que o museu estivesse aberto, durante os três meses de duração da exposição, encarando não um outro artista performático, mas qualquer pessoa que se sentasse à sua frente, pelo tempo que essa desejasse. Enfatizando 


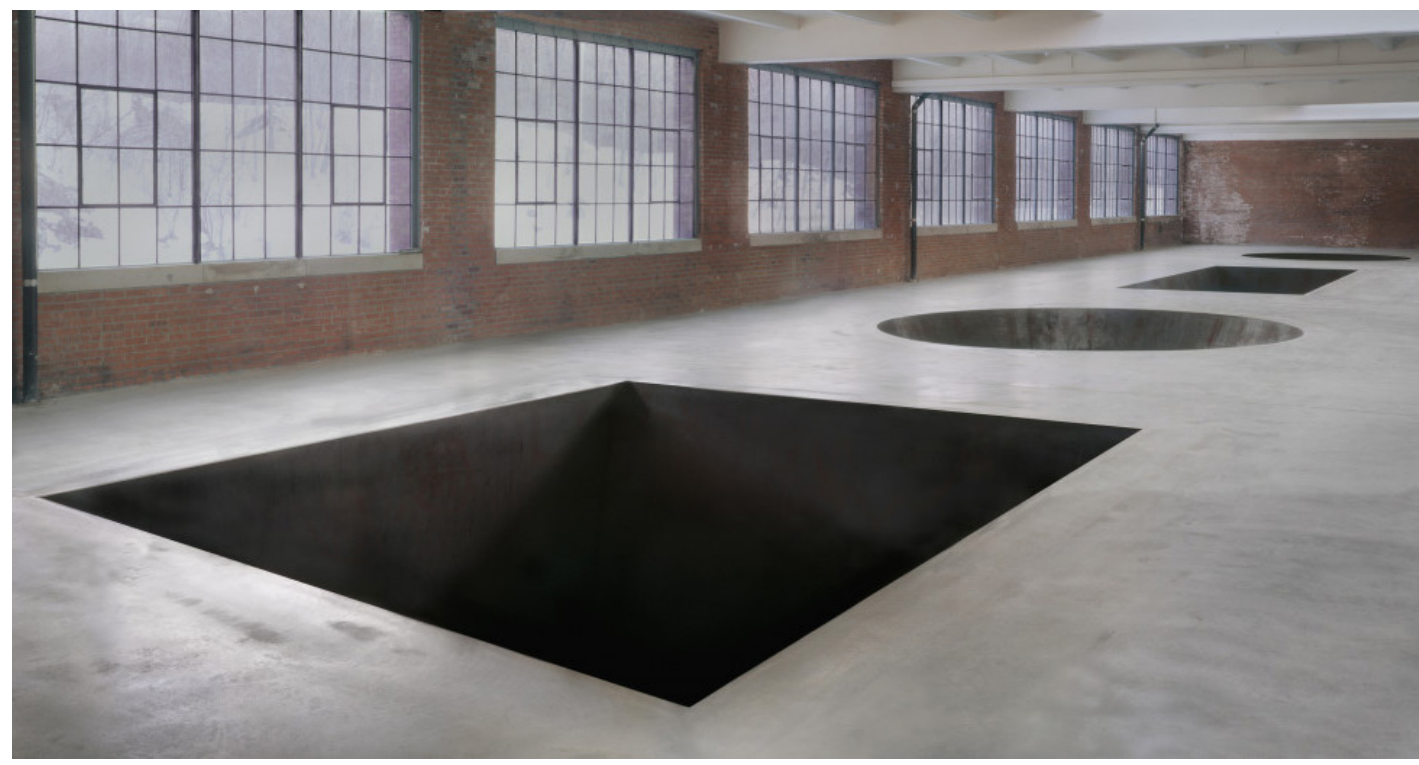

3.67 Michael Heizer, North, East, South, West $(1967 / 2002)$, instalada no centro de arte Dia:Beacon. Foto: Tom Vinetz. Fonte: https://www.diaart.org/collection/ collection/heizer-michael-north-eastsouth-west-19672002-2003-174-1-4

3.68 Marina Abramović e Ulay, Nightsea Crossing (1981-1987), First International Biennial Exhibition, Ushimado, 1985. Fonte: THE MUSEUM OF MODERN ART, 2010, p. 14.

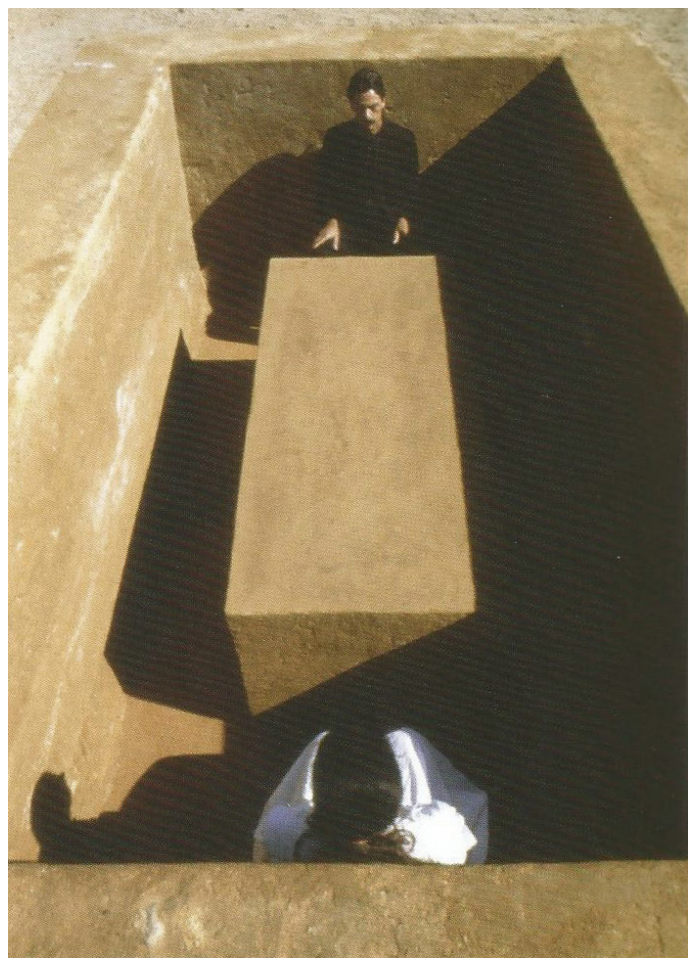

\section{4-385}


3.69 e 3.70 Vista da exposição Marina Abramović: The Artist Is Present, MoMA, Nova York, 2010. Foto 3.68: Jonathan Muzikar. Fonte: https://www.moma.org/ audio/playlist/243/3133

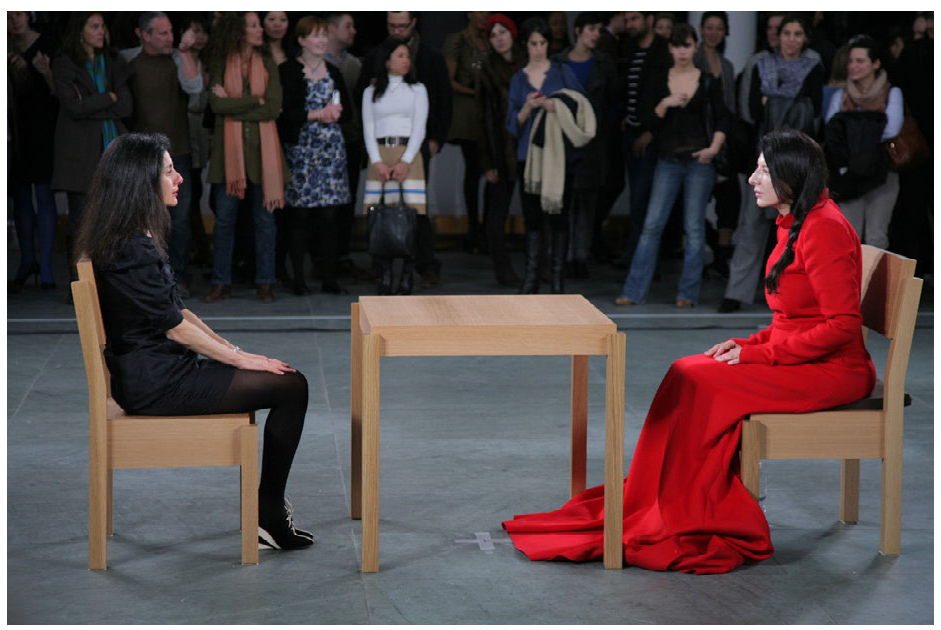

o vazio - o espaço negativo - o conjunto ficava no centro de um quadrado marcado com uma linha branca no piso verde de ardósia e iluminado nos quatro cantos por refletores de cinema, limitando a presença dos demais espectadores ao lado de fora. Ao contrário da expectativa da artista e do curador, que imaginavam que a cadeira oferecida ao público ficaria vazia a maior parte do tempo, a exposição acabou se tornando um polo de imensa atração em Nova York, levando mais de mil visitantes entre os 750 mil que frequentaram o museu no período a enfrentar longas filas para participar da obra, sentando-se na cadeira para ficar com seus olhos nos olhos de Marina Abramović.

Além dos espectadores acumulados do espaço entre o perímetro do quadrado e as paredes do átrio, outros visitantes podiam observar a performance mais à distância a partir dos espaços das passarelas e das aberturas para o átrio nas salas expositivas ao redor, como em balcões de um teatro. Nos registros em filme da performance, vemos que o magnetismo que conectava a artista e os visitantes não parecia ser abalado nem mesmo pelo fato de o ambiente ser consideravelmente ruidoso, dada a presença de um grande número de pessoas emitindo sons, que se amplificavam pela reverberação produzida pelas superfícies duras do interior edifício. É possível que o interesse do público em participar da obra tivesse a ver com 


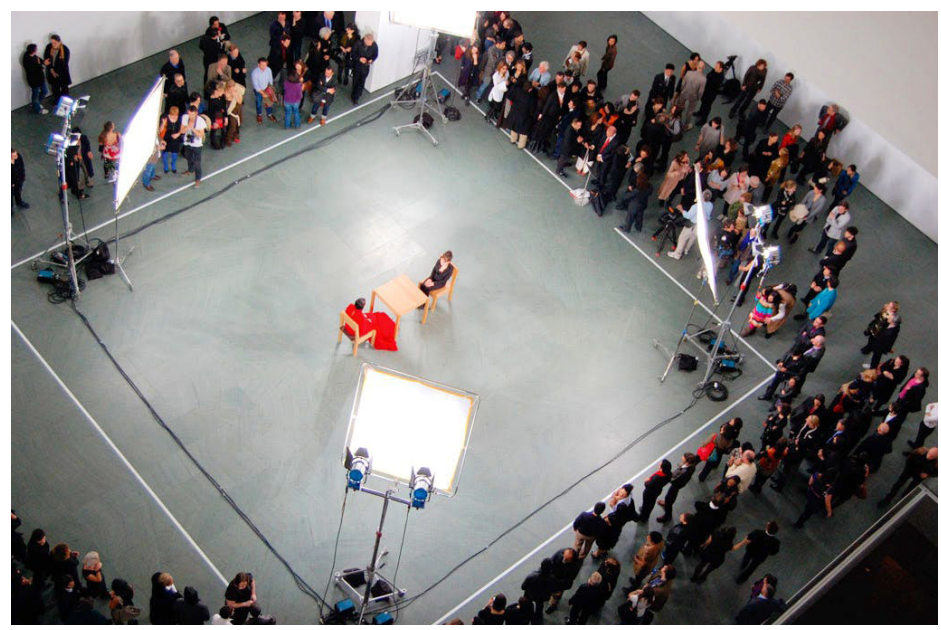

a oportunidade de ficar cara a cara com uma artista já então considerada uma celebridade, uma "lenda urbana", como definiu Biesenbach. ${ }^{504}$ Independente disso, o fato de a obra estar "em cena" durante todo o tempo em que o público tinha acesso ao museu, somado à atração que exercia, conferia ao espaço átrio uma ambiência de templo - destino de peregrinação para realização de um ritual transformador de purificação.

A associação dos museus a templos não era, no entanto, uma novidade. Ao contrário, essa ideia vinha sendo usada desde os anos 1970 para criticar os museus de arte moderna, por autores como Brian O'Doherty, Carol Duncan e Alan Wallach, como vimos no Capítulo 2 desta tese. A estrutura ritualística dos museus de arte moderna viria, em linhas gerais, pela organização narrativa das coleções baseada numa noção evolutiva das obras - expostas como criações de indivíduos geniais - rumo à abstração formal. A apreciação incluiria apenas o olho, mas não o corpo do espectador. $\mathrm{O}$ ambiente ideal dessa experiência, tida como alienante, seria o espaço imaculado do museu, que não se deixaria contaminar pelas imperfeições do mundo real, promovendo, assim, o ambiente sacralizado e a experiência de suspensão temporal propícios aos rituais.

O interesse para a discussão desta tese do tipo de ocupação espacial promovida pela performance The Artist is Present 
está no fato de apontar para a possibilidade de convivência no museu entre elementos tidos como opostos, ou mesmo excludentes, pela crítica da linhagem de $\mathrm{O}^{\prime}$ Doherty à chamada "ideologia do cubo branco". Em primeiro lugar, há a configuração arquitetônica do átrio, que embora fosse um espaço praticamente cúbico, de grandes proporções e completamente branco, não estava de modo algum isolado do exterior, mas, ao contrário, conectado visualmente não apenas aos espaços internos ao seu redor, como também aos espaços externos do jardim e da cidade, deixando-se "contaminar" por luz e som produzidos fora de seus limites. Os espaços expositivos conhecidos como "cubo branco" tinham origem nos espaços ascéticos dos projetos da Bauhaus, cuja linguagem modernista opunha-se à ambiência da monumentalidade clássica. $O$ grande vazio central do átrio parecia de algum modo sintetizar esses dois fatores. Em segundo lugar, devemos observar a natureza da ação requerida pela performance que, apesar de essencialmente baseada no olhar, envolvia o corpo todo do espectador, que se fundia com a obra na relação de reciprocidade estabelecida com a artista. Por fim, vale notar que a experiência de suspensão do tempo relatada por diversos participantes envolvia uma noção ligada não às qualidades estéticas supostamente atemporais de um objeto de arte, mas à intensidade da vivência da presença, a partir da disponibilidade total da artista a entregar-se à relação humana com cada indivíduo. Se aquela ação ritualística contida no museu parecia deixar de fora o mundo real, não se pode negar que promovia uma experiência concreta e bastante verdadeira, tanto para os participantes, quanto para a artista.

A performance de Marina Abramović mostrou que era possível criar um diálogo intenso entre a experiência artística e arquitetura apesar da desproporcionalidade entre os elementos físicos do trabalho e as dimensões do espaço. O grande átrio foi ocupado apenas com elementos mínimos, essenciais: dois corpos, o da artista e o do espectador, e a ação, imóvel e introspectiva, do olhar de um para o outro. Por outro lado, esse espaço mostrou-se propício a acomodar mais que a ação propriamente dita, permitindo a participação do numeroso público que a acompanhava a ação à distância. $\mathrm{O}$ fato de o evento poder ter sido "assistido ao vivo" por um grande número de pessoas cer- 
tamente contribuiu para o sucesso que alcançou, o que ressalta o aspecto funcional do átrio: sua aptidão para ser ocupado de diferentes maneiras.

No fim daquele ano, um artigo da crítica de arte Roberta Smith (1948-) publicado no The New York Times dava a medida da transformação da percepção sobre o espaço do átrio, a partir das diferentes formas como a arte contemporânea passou a ser ali apresentada, ganhando assim maior protagonismo na programação do museu. Para a autora, o átrio evoluíra de uma zona morta a um capítulo especial da história do museu:

No início, era o principal símbolo da visão fracassada do novo prédio, e seu efeito na arte exposta nele era sombrio. Hoje em dia, o átrio tornou-se um símbolo de algo que poderia ser chamado de Novo Moma. É o sinal mais proeminente da vertiginosa, até desesperada, aceitação do museu do novo e do próximo, de instalações em grande escala e videoarte, como bem como a arte performática e, geralmente, a arte como entretenimento e espetáculo. Como tal, o átrio é tanto uma medida da nova vitalidade do мома quanto um sintoma de algo um tanto assustador sobre a direção que a arte contemporânea vem tomando, ou para onde o MoMA a está levando. Como muitos visitantes de museus, posso me sentir profundamente ambivalente sobre o que se passa no átrio - variando entre vexada, seduzida, favorecida, alienada e comovida. Ainda assim, penso que sua transformação conta como um progresso. Pelo menos agora, em vez de nos preocuparmos com os sinais vitais do MомA, podemos nos preocupar mais uma vez com o que ele está e o que não está fazendo, com a nova vida que assumiu..$^{505}$

Além de se mostrar propício para exposições de mídia e performance, o átrio também podia ser ocupado de formas interessantes por outros tipos de instalação, mais escultóricas ou pictóricas, com obras especialmente comissionadas para o espaço ou adaptadas para ele. Uma delas foi a obra do artista brasileiro Carlito Carvalhosa (1961-2021), Sum of Days, exposta no átrio em $2011 .{ }^{506} \mathrm{~A}$ obra consistia em imensas cortinas de tecido TNT muito leve, branco e translúcido pendendo
505 SMITH, Roberta; Hold That Obit; MoMA's Not Dead. The New York Times, 02/o1/2011. ed. 2011. Tradução nossa.

506 Cf. The Museum of Modern ArT. Carlito Carvalhosa: Sum of Days (Aug 24-Nov 14, 2011). MOMA. Disponível em: <https:// www.moma.org/calendar/ exhibitions/1151>. Acesso em: 11 out. 2020. 


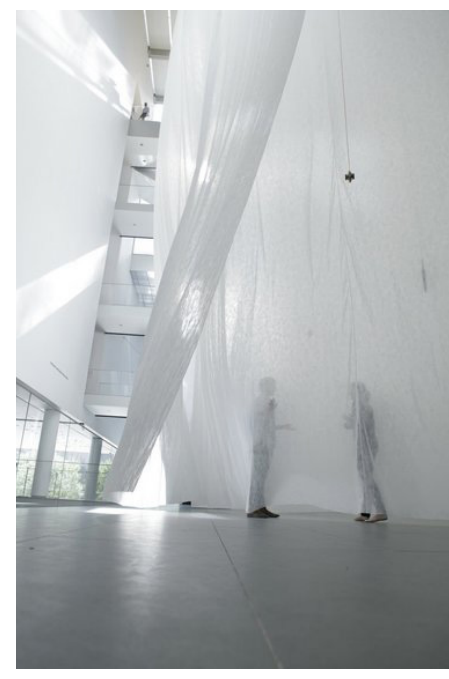

3.71 Vista da exposição Carlito Carvalhosa: Sum of Days, MoMA, Nova York, 2011. Foto: Clara Cavour. Fonte: https://www.nj.com/entertainment/ arts/2011/08/carlito_carvalhosa_ combining_s.html

3.72 Vista da exposição Carlito Carvalhosa: A Soma dos Dias, Pinacoteca do Estado, São Paulo, 2010. Foto: Tatiana Marques. Fonte: https://vitruvius. com.br/index.php/revistas/read/ arquiteturismo/05.058/4205

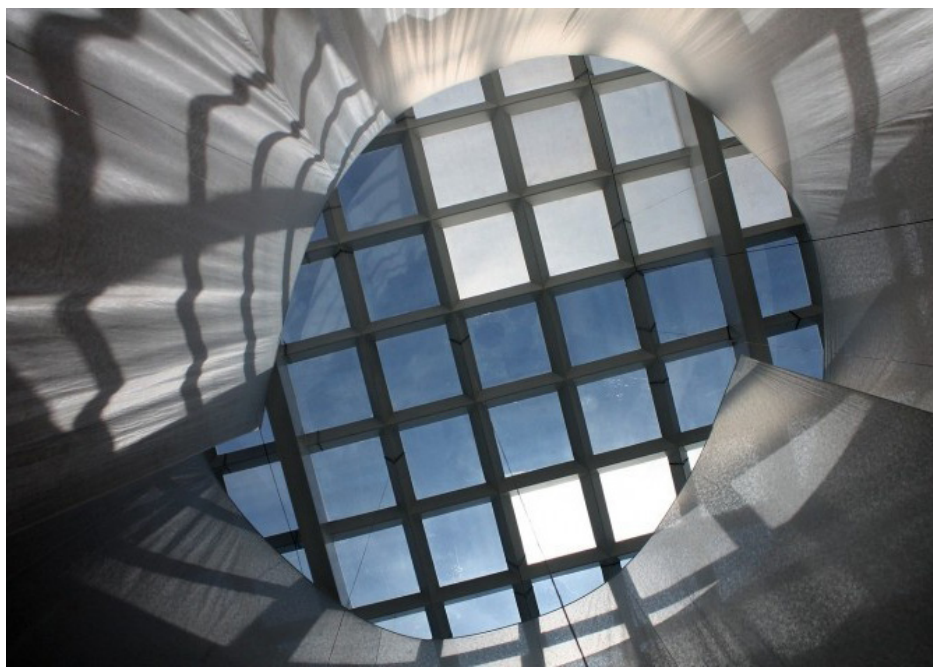

do teto de duas linhas espirais intercaladas, formando uma espécie de labirinto, e entr emeadas por pequenas caixas de som e microfones, que gravavam e transmitiam a soma dos sons captados no ambiente nos dias anteriores. No interior do espaço definido pelo tecido eram realizadas performances com músicas de Philip Glass, tocadas por ele mesmo ou por outros artistas convidados. Na apresentação da obra pelo artista, em vídeo publicado pelo museu, vemos o modo como ele procurou relacionar a obra àquele espaço arquitetônico, ocultando seus contornos:

A ideia dessa peça é que você pode realmente mudar um espaço muito grande usando uma pequena quantidade de material. Então há um grande volume feito com uma espécie de pele que pesa quase nada. Aqui você tem uma atitude de vaguear. Você não vai para dentro ou para fora, você fica vagando pela peça [...]. Ela preenche todo o espaço do átrio, que é bastante grande e é visto de vários pontos diferentes [...]. De certa forma você não pode vê-lo, você não vê as linhas, não vê mais as bordas das paredes ou do piso. Então o que você vê quando entra no museu parece uma grande cachoeira que está caindo sobre você e fica se movendo o tempo todo, nunca 
se apresentando como um objeto. Não é que o espaço esteja definindo a escultura, é mais ou menos como se a escultura contivesse o espaço. Essa é exatamente a ideia da obra. Você sabe como ele é, mas você não o vê mais por inteiro. ${ }^{507}$

Instalada do Octógono da Pinacoteca do Estado de São Paulo no ano anterior, a obra chamara a atenção de representantes do Mома, como a colecionadora e membro do conselho Patricia Cisneros e o diretor Glenn Lowry, que, segundo relatou o artista em entrevista à autora, visitavam exposições da cidade durante a Bienal, interessados em explorar a arte contemporânea no Brasil. ${ }^{508}$ Era possível imaginar que o trabalho tivesse uma presença interessante se transposto para o átrio do мома, que, assim como o Octógono, tinha grandes dimensões e proporções verticais, daí o convite para que o artista montasse a exposição no museu, sob a organização do curador de arte latino-americana, Luis Pérez-Oramas (1960-) e da assistente de curadoria Geaninne Gutiérrez-Guimarães, do departamento de fotografia. O depoimento do artista sobre a adaptação do trabalho para ser montado num outro lugar revela o seu entendimento sobre os fatores determinantes na relação entre arte e arquitetura e as particularidades do espaço do átrio:

Para a exposição no MOMA, fiz várias adaptações em relação à Pinacoteca - no desenho da forma, na maneira como se adaptava com o espaço, que lá era quadrado e na Pinacoteca octogonal. O MомA é maior e tem a questão da visitação, que é um problema complicado. A exposição foi das mais visitadas em Nova York naquele ano, acho que teve 500 mil pessoas, algo assim. Eles já tinham me dito que isso era um problema sério, porque é muita gente, então é uma experiência totalmente diferente da Pinacoteca, que tem visitação menor. No caso do момA, a luz vem de cima, mas na diagonal, a obra foi montada de uma forma que luz entrasse de lado. Fiz umas linhas de luz na parede que aumentaram muito a luminosidade do lugar, $o$ que é muito importante para o trabalho. Eu pensava que, como o museu tem muita visitação, eu poderia criar um espaço de silêncio no meio dele, essa era a ideia. Para isso controlamos
507 Carlito Carvalhosa in: THE Museum of Modern Art. Behind the Scenes: Carlito Carvalhosa: Sum of Days. Youtube. Disponível em: <https:/www.youtube.com/ watch?v=F5jYq10_L14 $>$. Acesso em: 11 out. 2020. Transcrição e tradução nossas.

508 Carvalhosa, Carlito. Entrevista concedida a Ana Paula Pontes, São Paulo, 11 de janeiro de 2019. Apêndice D desta tese. 
509 Ibidem.

510 Carvalhosa, Carlito. Sum of Days. MOMA. Disponível em: $<$ https://www.moma.org/explore/ inside_out/2011/11/o1/sum-of-days/>. Acesso em: 11 out. 2020. 511 Carvalhosa, 2019, op. cit. o público, porque o trabalho ficava logo na frente da escada de acesso ao museu. Fizemos a saída por aquele lado, assim as pessoas tinham que dar a volta, e o público se espalhava. Isso foi bom, porque dava um tempo maior, era uma experiência mais coletiva - sempre tinha gente dentro, entrando, saindo, no meio do caminho, nos descaminhos que tinha dentro do trabalho. No MoмA o comportamento do ar também era diferente, era muito mais selvagem. Tinha uma coisa bonita, tinha uma presença mais escultórica do que na Pinacoteca - às vezes o trabalho subia, descia, parecia um pulmão. Você via de longe e tinha uma coisa escultórica. Ele se erguia, aconteciam umas coisas estranhíssimas, que eram muito interessantes - essa coisa de revelar o que não está lá. Ficou lindo lá, eu também fiquei surpreso ao ver que o trabalho também funcionava de um outro jeito. ${ }^{509}$

Complementando sua declaração publicada no site do MoMA de que o convite para transpor a obra da Pinacoteca para o museu nova-iorquino teria sido "uma oportunidade para refletir sobre o modo como o trabalho existe independentemente do seu contexto, observando o que permaneceria igual e o que se transformaria no novo lugar", ${ }^{510}$ o artista comentou:

Eu não me interesso muito pela ideia de site-specific. Eu acho que os trabalhos devem sempre ser confrontados com sua condição. Eles podem e devem viajar. Eu não acho que o trabalho precisa formar uma unidade indissolúvel com o lugar, acho que o trabalho atua muito contra o lugar, em atrito com o lugar ou em tensão com o lugar. O que me interessa é justamente essa transformação de um espaço com a instalação do trabalho. O trabalho do MomA podia ser visto de longe, na Pinacoteca não. Isso era uma novidade para mim. Era uma relação diferente do que na Pinacoteca - o ruído era diferente, a luz era diferente, a luz lateral era totalmente diferente. Teve um monte de coisas que mudaram por conta da mudança de lugar. $\mathrm{O}$ interesse era esse, claro [...]. Os espaços eram diferentes, mas eles eram suficientemente semelhantes para que você pudesse tentar tensionar uma coisa com a outra. ${ }^{511}$ 
O átrio era, como já vimos, o espaço arquitetônico mais complexo do projeto de Taniguchi: estruturado por uma geometria regular, mas conectado aos espaços adjacentes e ao exterior por aberturas visuais e luminosas dispostas irregularmente. Seu potencial como lugar a ser confrontado pela arte era, portanto, muito distinto das anódinas galerias expositivas ao seu redor. Carvalhosa esclareceu as razões pelas quais, em sua opinião, os demais espaços do Mома careceriam dessa qualidade:

O prédio do MoмA traz algumas questões sobre o lugar da arte. Você nunca sabe em que andar você está, porque os andares são muito iguais. É uma consequência da ideia do 'cubo branco': não há um lugar. Não é um labirinto em que você se perde, é um não-lugar: sem lugar não há como a arte confrontar o mundo. Numa igreja italiana, você vê os quadros do Caravaggio, na igreja dos franceses em Roma, eles estão em um lugar escuro, com um altar, uma confusão -, essa é a condição da arte. Você vai em San Rocco, ou no Palácio dos Dodges, e as pinturas estão no mundo. O 'cubo branco' cria uma situação de um lugar indiferente, onde você no fundo não está confrontando coisa alguma. O MoMA talvez tenha sido ampliado com esse desejo de ser um espaço que desaparecesse. [...] O que eu sinto é que os museus têm que ser um lugar! Tem que ser um lugar e esse é um problema da arquitetura de museus. A ideia de que se vai transformar um edifício num lugar que não existe... Curiosamente, de certa forma meu trabalho é isso, criar um espaço 'apagado', mas preciso de um lugar para fazer isso, se não, não há confrontação, não há problema. Nos museus tradicionais, aquelas marcas todas da história do prédio, como as janelas, frisos etc, são importantes. É importante ter janela no museu. ${ }^{512}$

Carvalhosa mencionou que os visitantes relatavam diversas sensações e imagens evocadas no interior do trabalho, como estar no fundo do mar, numa igreja ou em meio a nuvens e recordar memórias da infância: "Acho isso interessante porque mostra que criamos conteúdo olhando para algo. Até quando não há nada lá. Isso é uma coisa sobre a obra, você vê coisas, é possível ver coisas, e criar conteúdo por meio da experiência." ${ }^{13}$
512 Ibidem.

513 The Museum of Modern ART, Behind the Scenes: Carlito Carvalhosa: Sum of Days, op. cit. Transcrição e tradução nossas. 


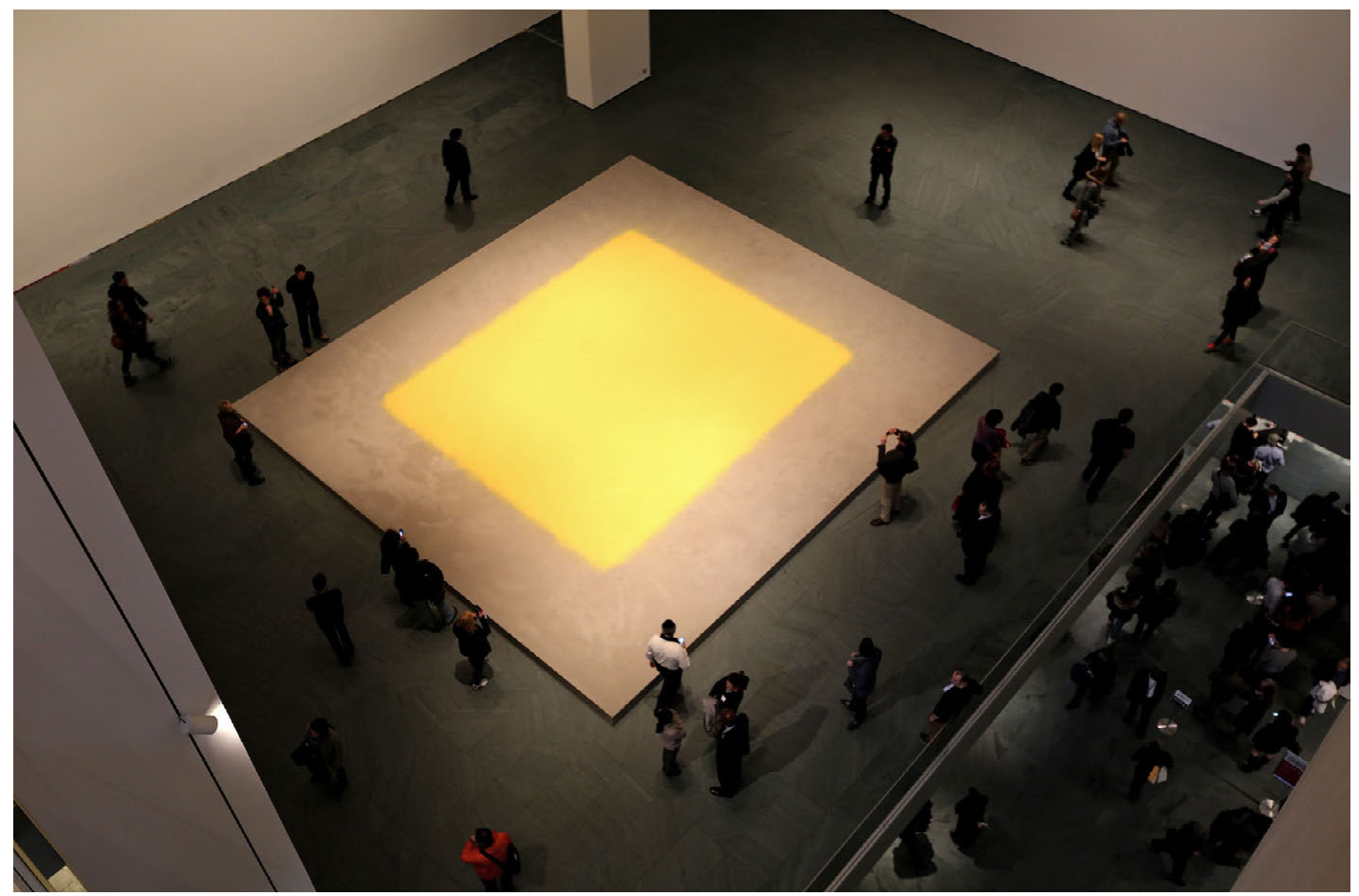

3.73 Vista da instalação de Wolfgang Laib, Pollen from Hazelnut, MoMA, Nova York, 2013. Foto: Thomas Griesel. Fonte: https://www.moma.org/calendar/ exhibitions/1140
514 Cf. The Museum of Modern ART. Wolfgang Laib (Jan 23-Mar 11, 2013). MOMA. Disponível em: <https:/www.moma.org/calendar/ exhibitions/1315 $>$. Acesso em: 11 out. 2020.
Mais uma vez, a vivência do trabalho adquiriu um caráter de suspensão, de certa forma ritualístico, para o qual a configuração arquitetônica da obra e do edifício desempenhava um papel importante.

A última exposição selecionada aqui para analisar as variadas formas de exploração do espaço arquitetônico do átrio do MOMA pelos artistas contemporâneos é a realizada em 2013 pelo alemão Wolfgang Laib (1950-), organizada pelas curadoras Lilian Tone e Ann Temkin, do Departamento de Pintura e Escultura. ${ }^{514}$ A mostra continha uma única obra, Pollen from Hazelnut, que consistia num campo de cor amarela de $5,5 \times 6,40 \mathrm{~m}$ produzido por pólen depositado pacientemente pelo artista sobre um tablado cinza posicionado no centro do piso. Desta vez, a natureza ritualística do trabalho não estava centrada na relação do espectador com a obra, como nas obras que vimos anteriormente, mas no processo de vida e obra do artista, que vinha 
por décadas se dedicando a coletar pólen manualmente de plantas ao redor de sua residência e ateliê, num vilarejo no sul da Alemanha. Ainda que a presença do campo de cor pudesse ser visualmente intensa e intrigante - pelo brilho luminoso do amarelo e pela manualidade visível nas sutis irregularidades da superfície granulada -, o espectador precisaria ter informações para além do que estava presenciando para ter acesso a um nível maior de engajamento com a obra. Contribuíam para isso um texto de parede e um vídeo mostrando as etapas de produção do trabalho de Laib - da coleta manual do pólen e seu armazenamento em jarras de vidro à sua instalação no piso do museu com o impacto ritmado de uma colher sobre uma peneira cheia do material. Ainda assim, os registros fotográficos da montagem nо мома mostram que os elementos mínimos da instalação de Laib, resultado de uma imensa concentração de trabalho, conseguiam preencher o enorme espaço do átrio, especialmente pelo interesse de ser apreciado a partir de diversos pontos, da perspectiva de quem estava no piso, que via um campo de pólen estendendo-se horizontalmente, ou de quem estava nos andares mais acima, que via pelo ângulo vertical um retângulo de luz amarela tingindo o piso.

A soma das variadas experiências de ocupação do espaço do átrio nos mostra que, mesmo sendo esse espaço interno o mais elaborado no projeto de ampliação de Taniguchi, sua real significação não pode ser apreendida exclusivamente do ponto de vista arquitetônico, ou seja, independentemente de seu uso como espaço de arte. Fraquezas e potenciais desse espaço foram sendo desveladas por cada uma das exposições que abrigou mais bem-sucedidas ou menos -, alimentando tanto para a instituição quanto para os artistas um repertório de possibilidades a ser indefinidamente explorado por futuras ocupações.

Recuperando o binômio ideal apresentado por Terence Riley para a arquitetura do novo museu - o da conjugação de um tipo de espaço "crítico" para a experiência individual e íntima com a arte com outro de caráter "celebratório" para a experiência coletiva - podemos dizer que, no novo edifício do момА, o primeiro correspondeu às galerias da coleção, principalmente às de arte moderna - embora sem acrescentar novidades significativas na configuração arquitetônica. O segundo tipo de 
espaço corresponderia com mais sucesso ao átrio, quando confrontado por certas obras de arte contemporânea. É preciso sublinhar que a forma de ocupação delineada para esse grande espaço central pela instituição e pelo arquiteto no momento da concepção do edifício só ganhou nitidez com as seguidas experiências artísticas ali realizadas.

\subsection{A MAIS RECENTE EXPANSÃ0: 2014 A 2019}

\subsubsection{RENOVAÇÃO CURATORIAL}

No período que se seguiu à inauguração da expansão de Taniguchi, ao mesmo tempo em que o мома e os artistas convidados experimentavam maneiras de ocupar o novo edifício, tornava-se mais premente a necessidade de flexibilizar os modos de expor e narrar a história - ou "as histórias" - da arte moderna e contemporânea a partir da coleção do museu. Essa tendência, que vinha sendo discutida em meios acadêmicos e noutras instituições desde os anos 1960 e no moma desde a década de 1990, acentuou-se ainda mais com a substituição de antigos curadores por uma nova geração que passou progressivamente a assumir a liderança dos diversos departamentos entre 2007 e 2014, pressionando o museu em direção a uma atualização mais significativa da abordagem curatorial. Ainda que envolvesse uma autocrítica de peso, a renovação mostrava-se indispensável diante da intenção do museu em sustentar uma posição relevante no cenário contemporâneo da arte. O movimento ganhou impulso concreto no MoMA com a criação em 2009 do programa curatorial interno Contemporary and Modern Art Perspective (C-MAP), que trazia estudiosos e artistas de todo o mundo para a realização de seminários no museu e promovia viagens de pesquisa curatorial a cidades na América do Sul,

515 Cf. THE MUSEUM OF MODERN ART. Global research: C-MAP. MOMA. Disponível em: <https:// www.moma.org/research-and-learning/international-program/ global-research>. Acesso em: 2 nov. 2020. Ásia, Índia e Europa Central e Oriental. ${ }^{515}$ Isso resultou no fortalecimento do caráter internacional e diversificado das aquisições do acervo, que continuou se ampliando, com a inclusão de obras da produção contemporânea a partir dos anos 1960, bem como de obras do período moderno antes consideradas "menores", preenchendo lacunas que permitiriam, como mani- 
festara o diretor Glenn Lowry em 2014, "contar a história de modo mais completo". ${ }^{516}$

Ficava mais premente nesse momento a intenção do museu de distanciar-se da narrativa canônica ditada pela própria instituição, que começara a se moldar desde a época do primeiro diretor, Alfred Barr. Um dos legados mais duradouros de sua gestão havia sido a organização do MoMA de acordo com departamentos específicos para cada disciplina, com a intenção de desenvolver a arte moderna compreendida em sua dimensão mais ampla, valorizando simultaneamente a pintura e a escultura outras áreas como design, arquitetura, fotografia e cinema. Essa estrutura multi-departamental nunca deixou de ser a espinha dorsal do museu, que compreendia então seis áreas curatoriais: Pintura e Escultura, Arquitetura e Design, Fotografia, Desenhos e Gravuras, Mídia e Artes Performáticas e Filmes. Se por um lado isso ajudou a desenvolver especialidades entre os curadores e uma relação próxima com colecionadores de cada área, o que constituíra um suporte importante para o museu, acabou, ao longo do tempo, mostrando-se uma condição contraditória com relação aos rumos da arte contemporânea. Enquanto a visão sobre a arte moderna que predominara no museu por muito tempo valorizava as obras de acordo com a especificidade de cada meio, a produção da arte já vinha há muito assumindo um caráter multidisciplinar, tornando sem sentido tentar enquadrar certas obras de acordo com os critérios de especialização departamental. Diante disso, como relatou Lowry, o ambiente do museu transformou-se:

Temos agora uma geração de curadores-chefes na faixa dos 40 e 50 anos de idade, cuja forma de pensar foi moldada por um tipo de história da arte muito diferente. Onde havia grande tensão entre curadores praticando aqui e noutros lugares nos anos 1980 e 9o, entre especialidades e teoria crítica, para a geração atual essa quase não é uma questão. É muito mais fluido agora. ${ }^{517}$

Mesmo sem haver no horizonte um plano de dissolução dos departamentos, o Moma vinha se orientando para uma atuação colaborativa entre eles, promovendo uma visão mais mul-
516 Glenn Lowry apud SHEETS, Hilarie, MOMA's New Curatorial Guard. ARTnews, 1/10/2014. ed. p. 104, 2014.

517 Glenn Lowry apud ibidem. Tradução nossa. 

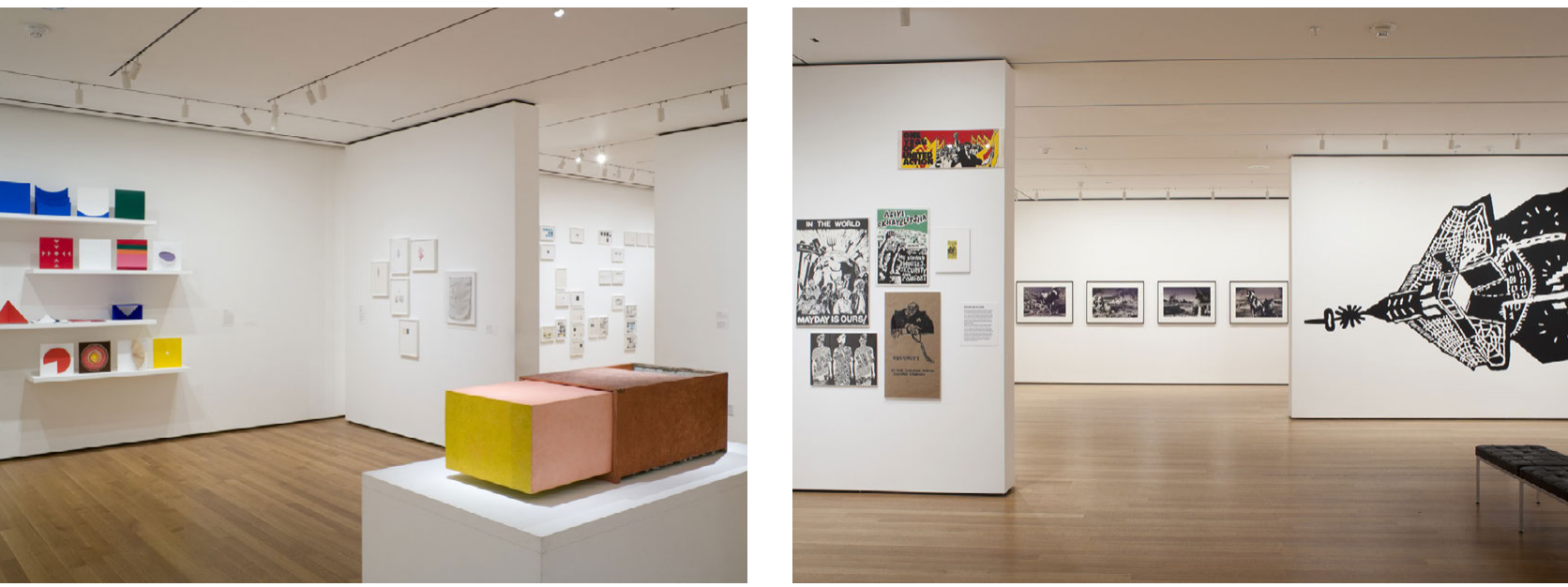

3.74 Vista da exposição New Perspectives in Latin American Art, 1930-2006:

Selections from a Decade of Acquisitions, MoMA, Nova York, 2008. Foto: Jonathan Muzikar. Fonte: https://www.moma.org/ calendar/exhibitions/55

3.75 Vista da exposição Impressions from South Africa, 1965 to Now, MoMA, Nova York, 2011. Foto: Thomas Griesel. Fonte: https://www.moma.org/calendar/ exhibitions/1140

518 Anne Tempkin apud ibidem. Tradução nossa. ticultural e interdisciplinar da arte, incluindo a do período moderno. Ao invés da tradicional história linear baseada em obras canônicas e segmentada por disciplinas, pretendia-se organizar a exposição permanente do acervo relacionando diversos meios e técnicas, visando criar uma narrativa mais nuançada e inclusiva, com espaço para abordar, por exemplo, questões de gênero, raça e ativismos e produções de regiões mais diversificadas do globo. À frente do departamento de maior peso no museu, o de Pintura e Escultura, a curadora Ann Temkin expressou o tom da autocrítica que vinha impactando a instituição:

O centro da discussão tem sido realmente a substituição de um sistema que é de certa maneira obsoleto - fotografia, mídia - para um no qual estamos pensando em toda a apresentação de modo integral. Hoje estamos afirmando: é claro que há muitas histórias; a coleção representa muitas histórias. Que não se repita o dogmatismo do passado. ${ }^{518}$

Essa intensa revisão curatorial era apontada como a principal razão para a decisão que viera a público em janeiro de 2014 de empreender uma nova expansão do edifício. Apesar de ter quase dobrado a área expositiva e criados galerias de ampla escala 


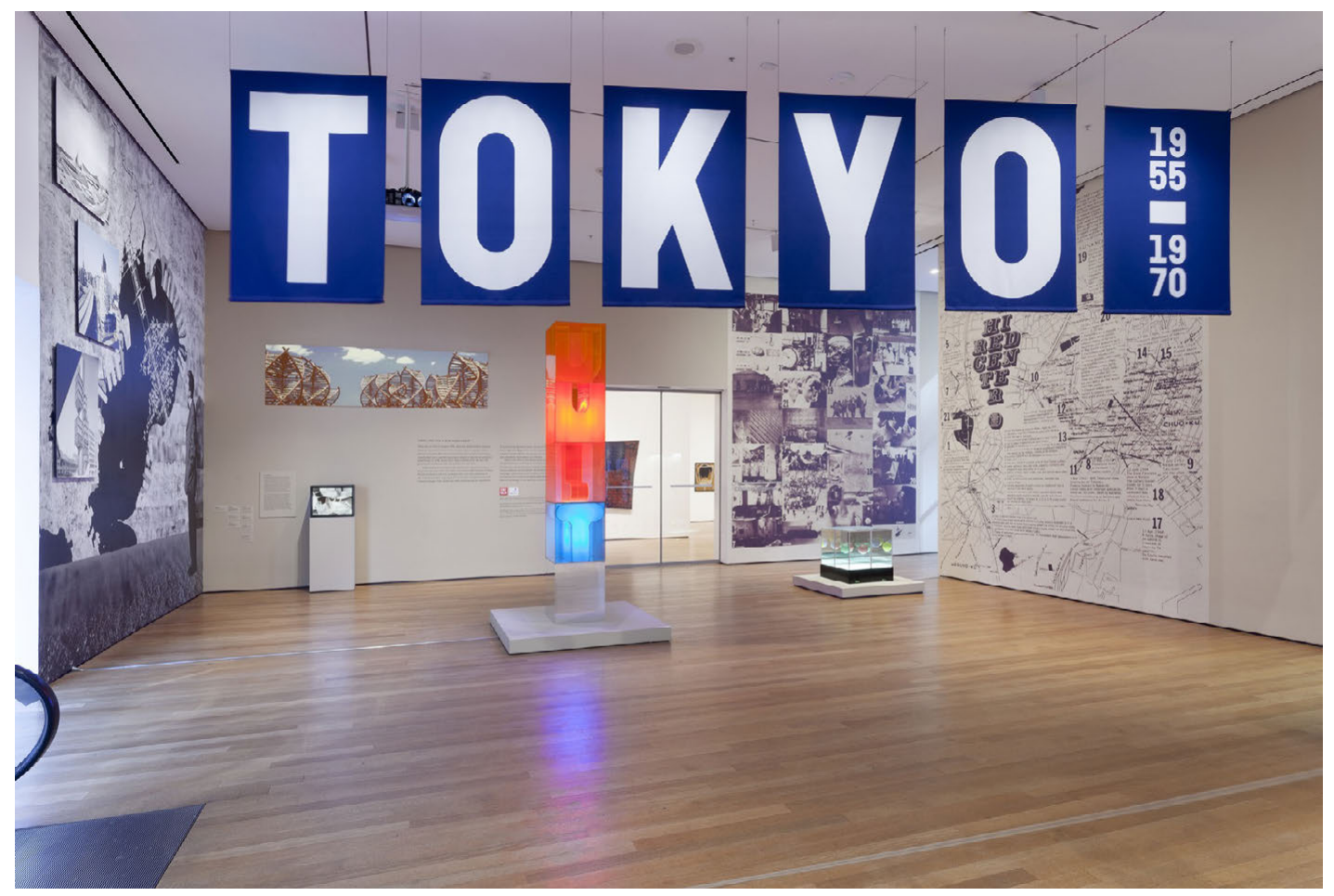

para arte contemporânea, o projeto de Taniguchi havia seguido a orientação vigente antes dessa nova perspectiva tomar corpo, mantendo a setorização espacial dos diversos departamentos curatoriais nas áreas expositivas, configuradas, como vimos, em ambientes isolados como espécies de "museus dentro do museu". Ainda que fosse possível reorganizar a disposição das coleções nos espaços existentes, atendendo à nova demanda por mesclar peças de vários departamentos num mesmo ambiente, a disposição das galerias continuava, na visão dos curadores, a privilegiar o circuito linear sequencial de salas enfileiradas, sem a flexibilidade para ser adaptada de acordo com a nova intenção de criar alternativas à uma narrativa evolutiva e única da história da arte moderna e contemporânea.

Por um tempo, a solução visualizada por Temkin, responsável pela maior área à mostra da coleção, foi tornar a exposição permanente mais rotativa, trocando peças com mais frequên-
3.76 Vista da exposição Tokyo 1955-1970: A New Avant-Garde, MoMA, Nova York, 2013. Foto: Thomas Griesel. Fonte: https:// www.moma.org/calendar/exhibitions/1225

\section{8-399}




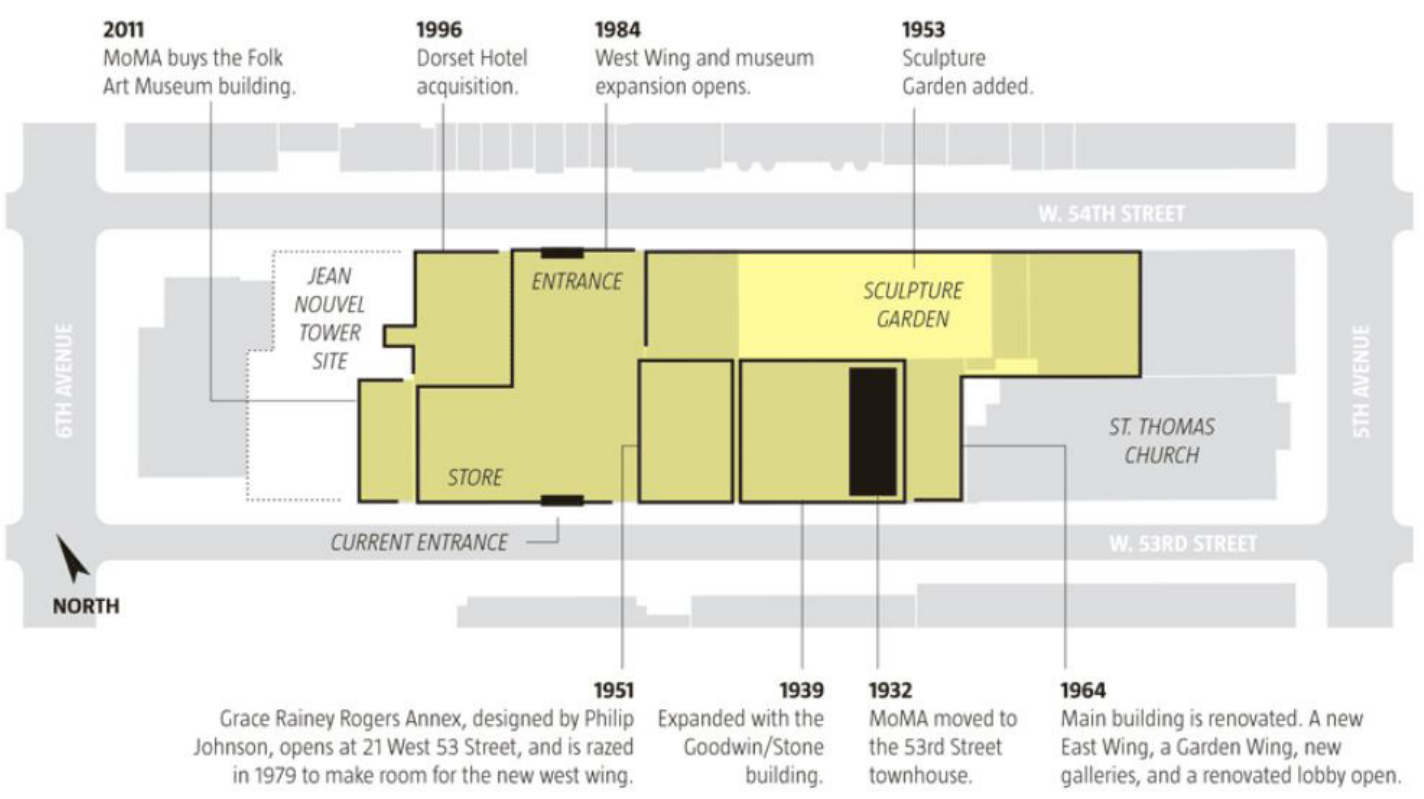

3.77 Diagrama das expansões do MoMA de 1932 a 2011. Imagem: Nicolas Rapp Studio. Fonte: https:// nicolasrapp.com/studio/portfolio/ architectural-rendering-isometric-map/

3.78 Diagrama do campus do MoMA com a expansão de 2019. Imagem: Nicolas Rapp Studio. Fonte: https:// nicolasrapp.com/studio/portfolio/ architectural-rendering-isometric-map/ cia, de modo a possibilitar que o público tivesse contato com o maior número possível de obras do acervo e com variados arranjos entre elas, ainda que para isso fosse preciso visitar o museu diversas vezes, com um certo intervalo de tempo. O problema incontornável, porém, era uma vez mais a desproporção entre o tamanho da coleção, em permanente crescimento, e as dimensões finitas do edifício projetado por Taniguchi, que passou a ser considerado, novamente, insuficiente para as ambições da instituição.

Mais uma nova expansão foi então possibilitada a partir de um acordo com empreendedores imobiliários viabilizado por vultosos aportes financeiros de seus mantenedores, que permitiu aо мома ocupar os andares inferiores de um edifício de apartamentos num lote contíguo a oeste, em troca de aumentar o potencial construtivo de um edifício projetado pelo arquiteto francês Jean Nouvel, destinado a abrigar 145 apartamentos de alto padrão e respectivos serviços, numa enorme torre de 82 andares. O MOMA aproveitou ainda a falência do Folk Art Museum, situado num lote adjacente também a oeste, 


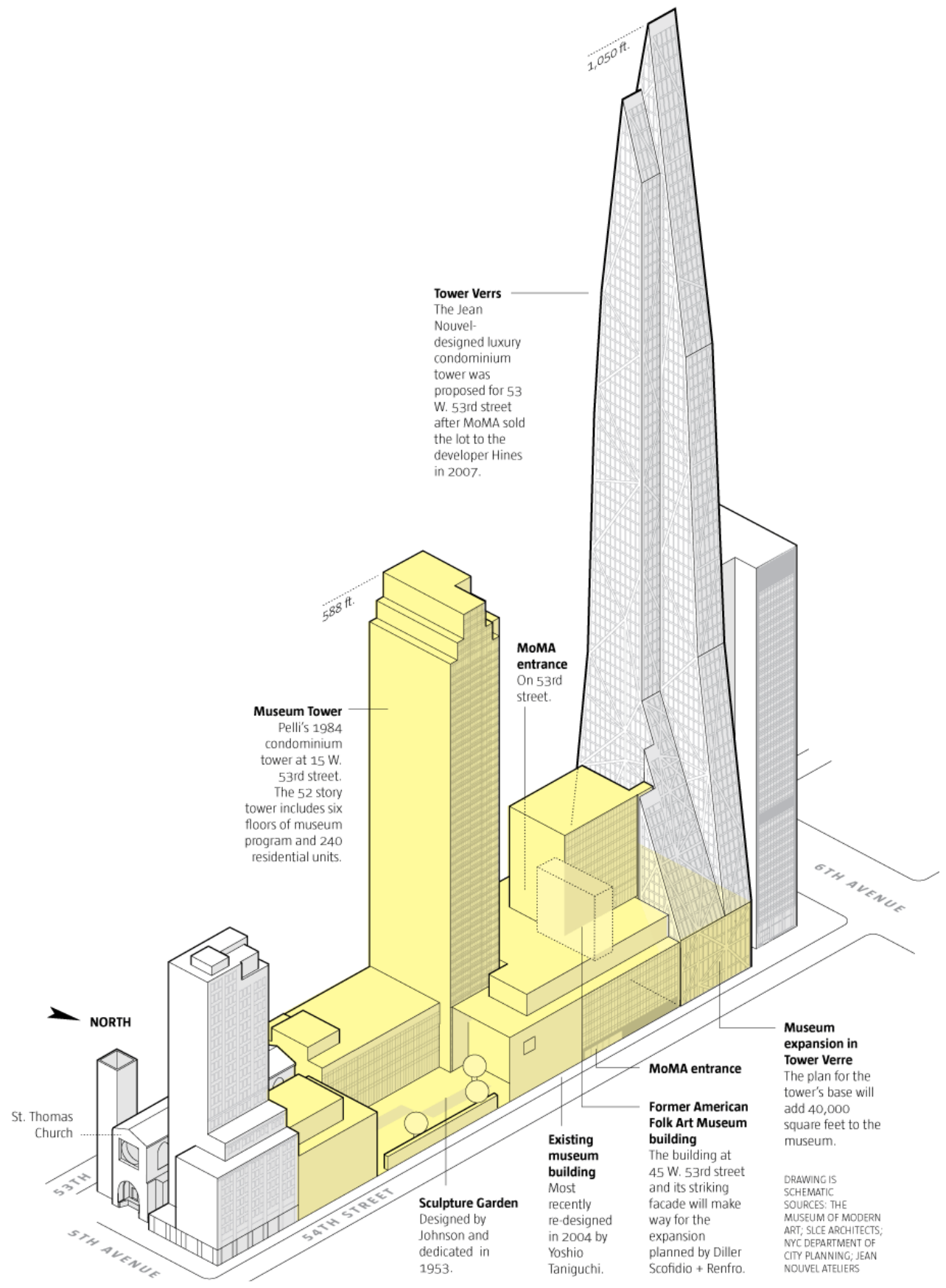




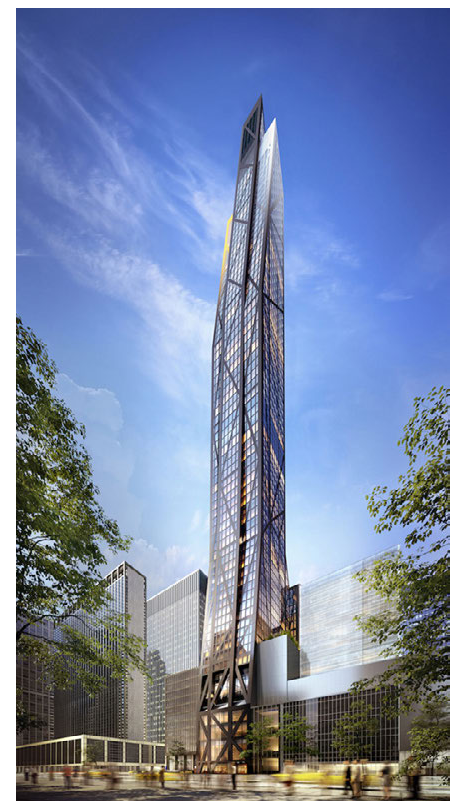

3.79 Perspectiva do edifício 53W53, projeto de Jean Nouvel, Nova York, 2019. Imagem: VUW Studio. Fonte: https:// www.dezeen.com/2017/09/08/jeannouvel-53w53-moma-tower-progressconstruction-photographs-new-yorkarchitecture/

3.80 American Folk Art Museum, projeto de Tod Williams + Billie Tsien, Nova York, 2001. Foto: Ozier Muhammad/The New York Times. Fonte: https://www.nytimes. com/2013/04/11/arts/design/momato-raze-ex-american-folk-art-museumbuilding.html

3.81 Intitute of Contemporary Art (ICA), projeto de Diller Scofidio + Renfro, Boston, 2006. Foto: Iwan Baan. Fonte: https://dsrny.com/project/institute-ofcontemporary-art?index $=$ false $\&$ section $=p r$ ojects\&search=ica

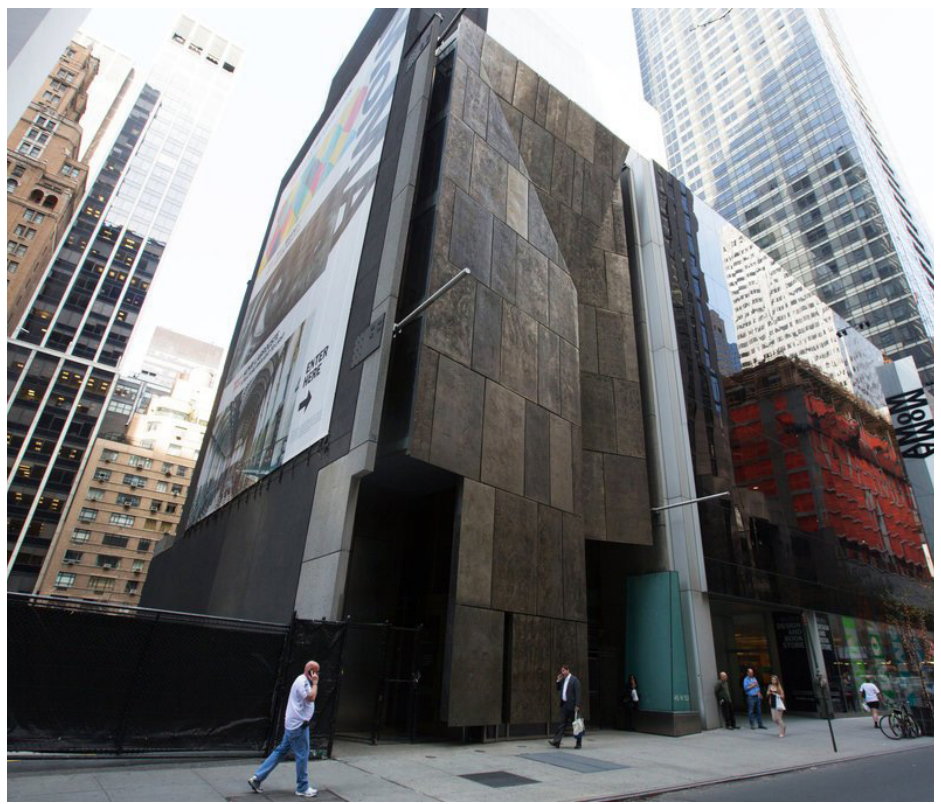

para incorporar aos seus planos de expansão a área ocupada pelo pequeno edifício construído apenas 12 anos antes com projeto dos arquitetos Tod Williams \& Billie Tsien, que viria a ser demolido.

\subsubsection{AS RAZÕES DA ESCOLHA DO ESTÚDIO DILLER SCOFIDIO + RENFRO}

No planejamento da mais recente expansão do MoMA, não houve um processo extenso de debates com a comunidade artística, nem um concurso de arquitetura como o que culminara com a escolha de Taniguchi. Num debate público sobre o projeto promovido pela liga de arquitetura de Nova York em 2014, Glenn Lowry explicou a seleção e suas razões:

Nós escolhemos o estúdio Diller Scofidio + Renfro, depois de entrevistar diversos escritórios de arquitetura, porque eles compreendem as potências e deficiências do museu; porque 

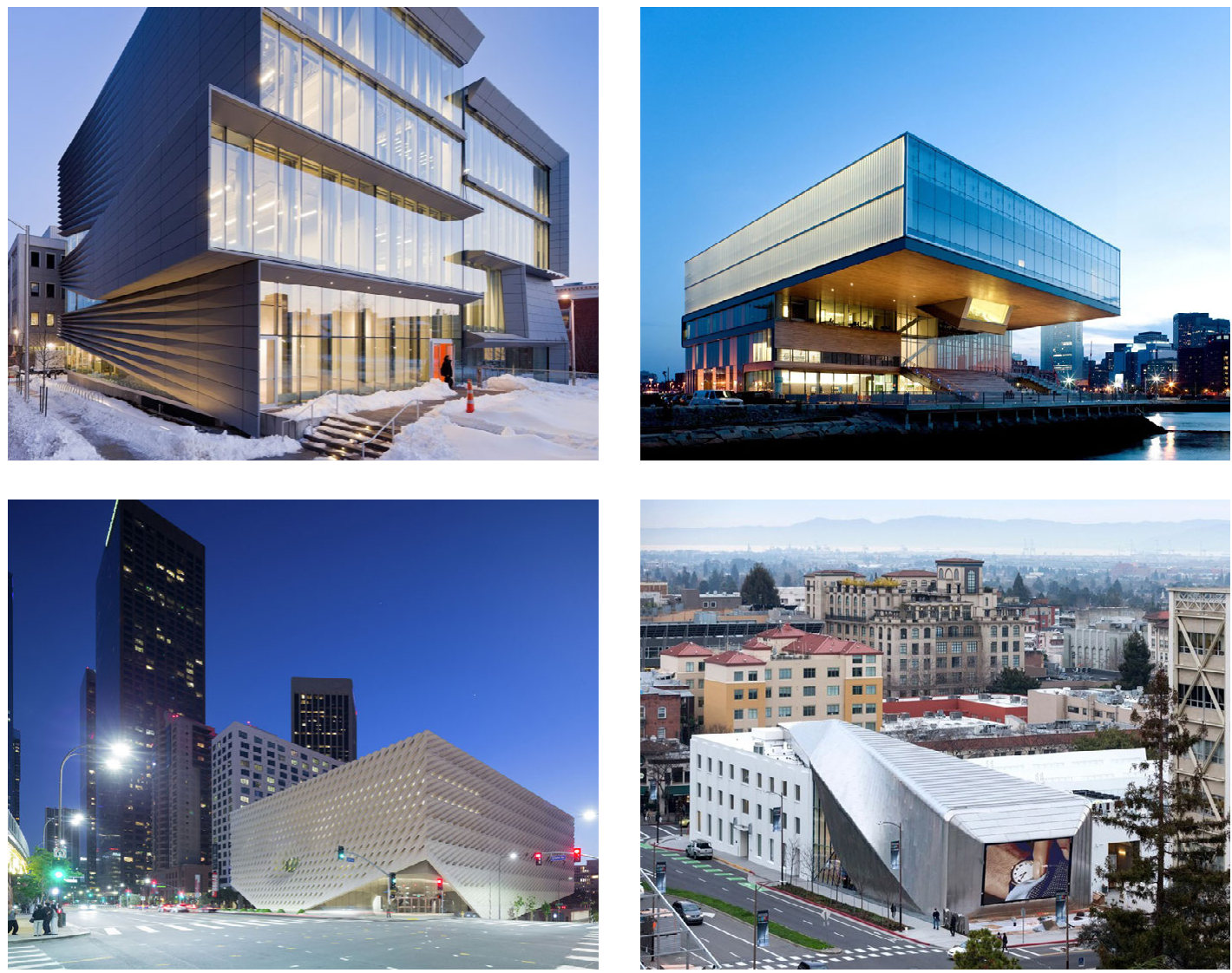

3.82 Perry and Marty Granoff Center for the Creative Arts, Brown University, projeto de Diller Scofidio + Renfro, Providence, 2011. Foto: Iwan Baan. Fonte: https:// www.archdaily.com.br/br/796464/centropara-as-artes-criativas-perry-and-martygranoff-diller-scofidio-plus-renfro?ad_ medium=gallery

3.83 The Broad Museum, projeto de Diller Scofidio + Renfro, Los Angeles, 2015. Foto: Iwan Baan. Fonte: https://www. archdaily.com.br/br/773021/museuthe-broad-diller-scofidio-plus-renfro?ad_ medium=gallery
3.84 Berkeley Art Museum and Pacific Film Archive (BAMPFA), projeto de Diller Scofidio + Renfro, Berkeley, 2016. Foto: Iwan Baan. Fonte: https://dsrny.com/project/ berkeley-art-museum-and-pacific-filmarchive? index $=$ false $\&$ search $=$ Berkeley $\% 20$ Art\%20Museum\&section=projects 

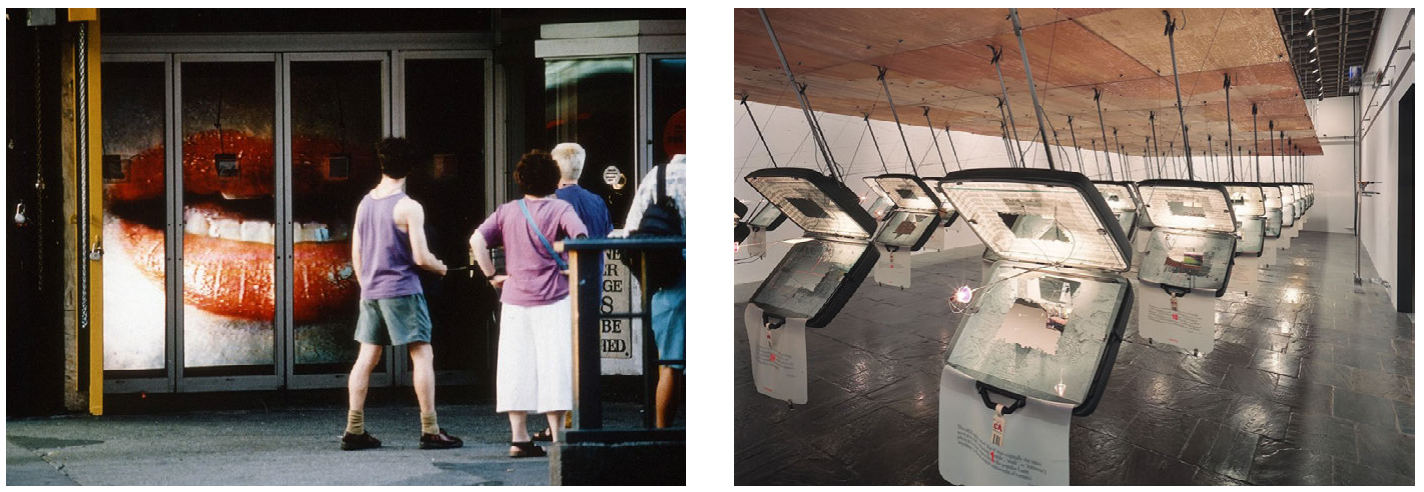

3.85 Elizabeth Diller e Ricardo Scofidio, Soft Sell, Rialto Theater, Nova York, 2003. Fonte: https://dsrny.com/project/soft-sel I? index =false \&section=projects $\&$ search $=$ soft $\% 20$ cell

3.86 Elizabeth Diller e Ricardo Scofidio, Tourism: Suitcases Sudies, na exposição Scanning: The Aberrant Architectures of Diller Scofidio, Whitney Museum of American Art, Nova York, 2003. Fonte: https:// dsrny.com/project/tourisms-suitcasestudies? index $=$ false \&search $=$ Tourism $\% 20$ Suitcases $\% 20$ Studies\&section=projects

519 Glenn Lowry in: THE

Architectural League. A

Conversation on the Museum of Modern Art's Plan for Expansion (28/01/2014). Youtube. Disponível em: <https://www.youtube.com/ watch?v=55EEkVA276I $>$. Acesso em: 14 out. 2020 . 19'45" a 20'15". Transcrição e tradução nossas. estiveram, ao longo de muitos anos, engajados numa crítica institucional profunda e interessante sobre museus, e especificamente sobre o Museu de Arte Moderna; por sua habilidade comprovada em dar vida nova a edifícios existentes, assim como por seu profundo entendimento das necessidades dos museus no século XXI. ${ }^{519}$

O engajamento crítico do estúdio DS $+\mathrm{R}$ com museus envolvia a prática com projetos de edifícios para esse fim, muitos deles realizados recentemente nos Estados Unidos, entre os quais o ICA - Intitute of Contemporary Art em Boston (2006) e o Center for the Creative Arts da Brown University, em Providence (2011), além de outros então prestes a serem inaugurados, como o The Broad Museum em Los Angeles (2015) e o Berkeley Art Museum and Pacific Film Archive (BAMPFA) da Universidade da Califórnia, Berkeley (2016).

$\mathrm{O}$ DS $+\mathrm{R}$ tinha também um outro tipo de familiaridade com instituições culturais, por acumular uma larga experiência com projetos multidisciplinares, em que a arquitetura se fundia às artes visuais e cênicas. Elizabeth Diller (1954-) e Ricardo Scofidio (1935-) haviam fundado o estúdio em 1981 e direcionaram sua prática aos projetos de edifícios apenas tardiamente, tendo dedicado longos anos do início de sua parceria a projetos incluindo peças multimídia (em parceria com companhias de teatro e dança), instalações site-specific, imagens e objetos que abordavam questões como consumo, desejo e gênero e 


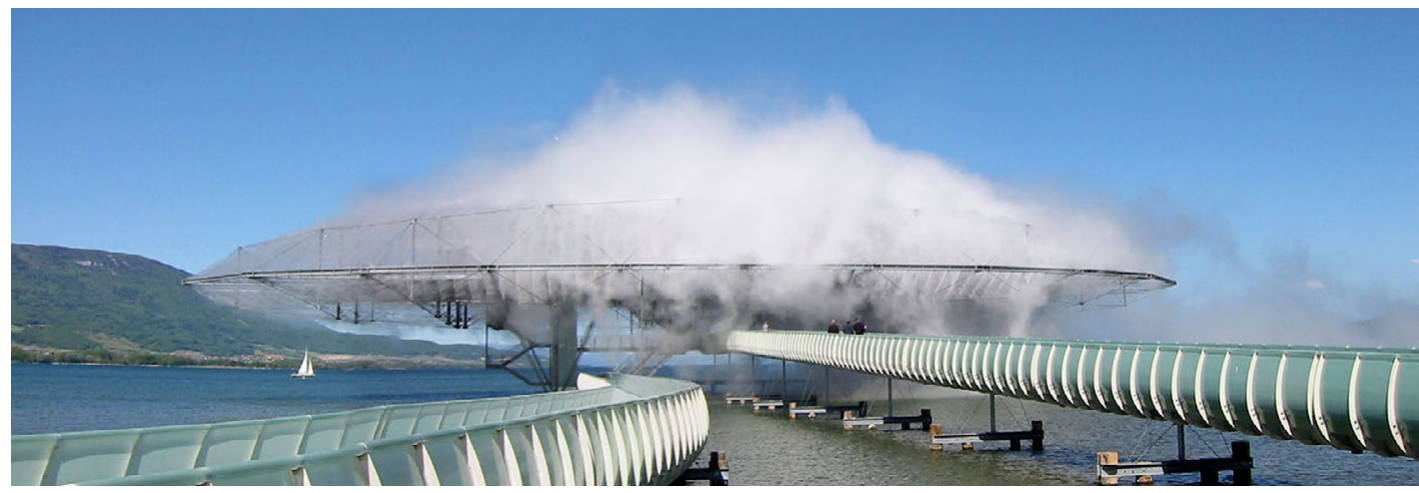

intervenções eletrônicas mesclando arquitetura e mídia. ${ }^{520}$ Esse trânsito por diversas disciplinas, mais raro entre os arquitetos, é intrínseco à produção da arte contemporânea e, como vimos, contextualizava a intenção atual do MOMA em romper as barreiras departamentais ligadas a mídias específicas para a exposição de sua coleção. Todavia, devido às complexidades do processo - incluindo inserção num conjunto heterogêneo de construções, compatibilização técnica com diversas disciplinas, aprovação junto a órgãos competentes em diversas instâncias, execução com prazos justos e mobilização e controle de grande orçamento -, o museu exigiu que o DS+R se associasse a um escritório de maior porte para o desenvolvimento executivo do projeto. Daí a colaboração com Gensler, com quem o DS+R já vinha estabelecendo uma boa parceria, como no projeto para o centro médico da Columbia University (Roy and Diana Vagelos Education Center), que viria a ser concluído em 2016.521

$\mathrm{Na}$ expansão anterior, o longo processo de debates que precederam a escolha do arquiteto e do projeto revelavam as incertezas que o MOMA enfrentava para a transformação de grande porte de sua sede. As demandas apresentadas agora pelo museu eram bem mais específicas:

Os objetivos do projeto são três: aumentar o espaço da galeria e permitir que o Museu exponha significativamente mais de sua diversificada coleção de maneiras mais profundas e interdisciplinares, proporcionar aos visitantes uma experiência
3.87 Elizabeth Diller e Ricardo Scofidio, The Blur Building, Swiss Expo, Yverdon-lesBains, 2002. Foto: Beat Widmer. Fonte: https://dsrny.com/project/blur-building

520 Charles Renfro (1964-) entrou no estúdio em 1997 e tornou-se sócio em 2004. Desde 2015, também passou a integrar o quadro de sócios o arquiteto Benjamin Gilmartin, que entrou no estúdio em 2004.

521 Gensler é uma empresa multidisciplinar que abarca as áreas de arquitetura, interiores, comunicação visual, design digital, urbanismo, consultoria imobiliária e sustentabilidade. É uma das maiores empresas de projeto dos EUA e atua globalmente, tendo 50 escritórios distribuídos em 16 países. Cf. GENSLER. Services. Gensler. Disponível em: <https:// www.gensler.com/about/services $>$. Acesso em: 20 jun. 2021. 
mais acolhedora e confortável e conectar melhor o Museu ao tecido urbano do centro de Manhattan. ${ }^{522}$

Em lugar do protagonismo que tivera a arquitetura na expansão anterior, a expectativa principal para este projeto seria, conforme mencionara Lowry, a de "dar vida nova aos edifícios existentes", como noutros projetos que o DS+R realizara em Nova York - o High Line Park e o complexo cultural do Lincoln Center. Esse último envolvera uma série de projetos encadeados, realizados entre 2003 e 2010, e resultara sobretudo numa potencialização do conjunto, mantendo sua identidade original a partir da valorização das construções modernas existentes, costuradas com intervenções pontuais contemporâneas. Nesses dois projetos, a fusão disciplinar se dava entre os campos que relacionam mais obviamente a arquitetura à sua dimensão cívica, como o urbanismo e o paisagismo. Na opinião do crítico Hal Foster, que em seu livro O Complexo Arte e Arquitetura (publicado originalmente em 2011) dedicara o capítulo "Máquinas pós-modernas” à análise da obra do DS+R,

a reconexão do Lincoln Center com a cidade é claramente a tônica do projeto como um todo. [...] A proposta era interconectar a atividade urbana com a cultural - e ao mesmo tempo desenvolver um projeto que também fosse uma alternativa à arquitetura imagética de muitas instituições recentes. ${ }^{523}$

522 The Museum of Modern ART. Press release: The Museum of Modern Art completes first phase of major renovation and reveals final design for multi-year expansion and renovation project, designed by Diller Scofidio + Renfro in collaboration with Gensler. MOMA. Disponível em: <https:// press.moma.org/wp-content/uploads/2017/08/6_MOMA_June2017_ PressRelease.pdf $>$. Acesso em: 17 out. 2020. Tradução nossa. 523 FOSTER, 2015, op. cit., p. 125.
Foster afirmou ainda que o modo como o DS+R vinha tomando como premissa em seus projetos as condições preexistentes à sua implantação implicaria numa dimensão interdisciplinar mais abrangente:

Assim como o ICA, a High Line é uma plataforma para olhar e para passear; seu projeto sugere uma inteligência atenta à vista e o lugar. Também sugere uma intervenção no campo ampliado da arquitetura por meio do qual os projetistas fazem avaliações a partir das condições mistas do solo (ou, nesse caso, ligeiramente acima dele). Isso está em sintonia com uma forte tendência na arte recente para um modelo de trabalho de campo, de projetos produzidos a partir de pesquisas de determinado local, 
3.90 Fases do projeto de revovação e expansão do MoMA por Diller Scofidio + Renfro, Nova York, 2017-2019. Imagem: $\mathrm{DS}+\mathrm{R}$.

3.91 Fachada do MoMA voltada para a Rua 53 com projeto de revovação e expansão por Diller Scofidio + Renfro, Nova York, 2017-2019. Imagem: DS+R.
526 Ibidem, p. 124.

527 Elizabeth Diller apud THE Museum OF MODERN ART, 2017, op. cit. Tradução nossa. certamente transformá-lo. Mais adiante em seu raciocínio sobre os projetos para o Lincoln Center, Foster afirmou que "o DS+R desenvolve aqui sua própria linguagem, mas o faz a serviço do programa". ${ }^{226} \mathrm{~A}$ afirmação do autor parece desconsiderar que $\mathrm{o}$ programa seja um dado inerente à arquitetura, definindo-a para além de suas qualidades sensório-espaciais. Nesse sentido, o tipo de "adaptação" às "condições mistas" e preexistentes que o DS+R vinha demonstrando pode estar relacionado simplesmente ao fato de que seus trabalhos mais recentes tenham se orientado para a realização de obras claramente arquitetônicas - dependentes do dado programático -, ainda que incluíssem recursos mais facilmente reconhecíveis em outras disciplinas com maior independência de compromissos externos.

No projeto para o момA, estava claro que a abordagem dos arquitetos teria que levar em conta a noção de adaptabilidade, considerando tanto a abertura dos espaços a utilizações futuras quanto a atenção às construções pré-existentes. Sua concepção e desenvolvimento dependeu de pesquisas aprofundadas para decifrar as intenções arquitetônicas que originaram as diversas camadas construídas ou demolidas do conjunto, para a partir de então definir pontos nevrálgicos sobre os quais intervir com firmeza e delicadeza, possibilitando que o museu crescesse expandindo proporcionalmente sua capacidade vital e mantendo-se como um organismo íntegro, como explicou Elizabeth Diller:

Este projeto nos incitou a trabalhar com a rica história arquitetônica do MомA, incorporando os edifícios existentes do museu em um todo compreensível por meio de intervenções cuidadosas e calculadas sobre lógicas anteriores, bem como a construção de novas lógicas decorrentes das aspirações atuais do момА. Este trabalho exigiu a curiosidade de um arqueólogo e a habilidade de um cirurgião. ${ }^{527}$

Jerry Saltz, um dos críticos de arte mais assíduos a respeito do museu, relatou surpresa quanto ao modo como a arquiteta se referira ao projeto no tour de apresentação da primeira etapa da obra em 2017: "agora que o estúdio mergulhou nas profundezas dos problemas, até mesmo esses arquitetos dos mais impetuosos pararam de falar em 'interconectividade' e 

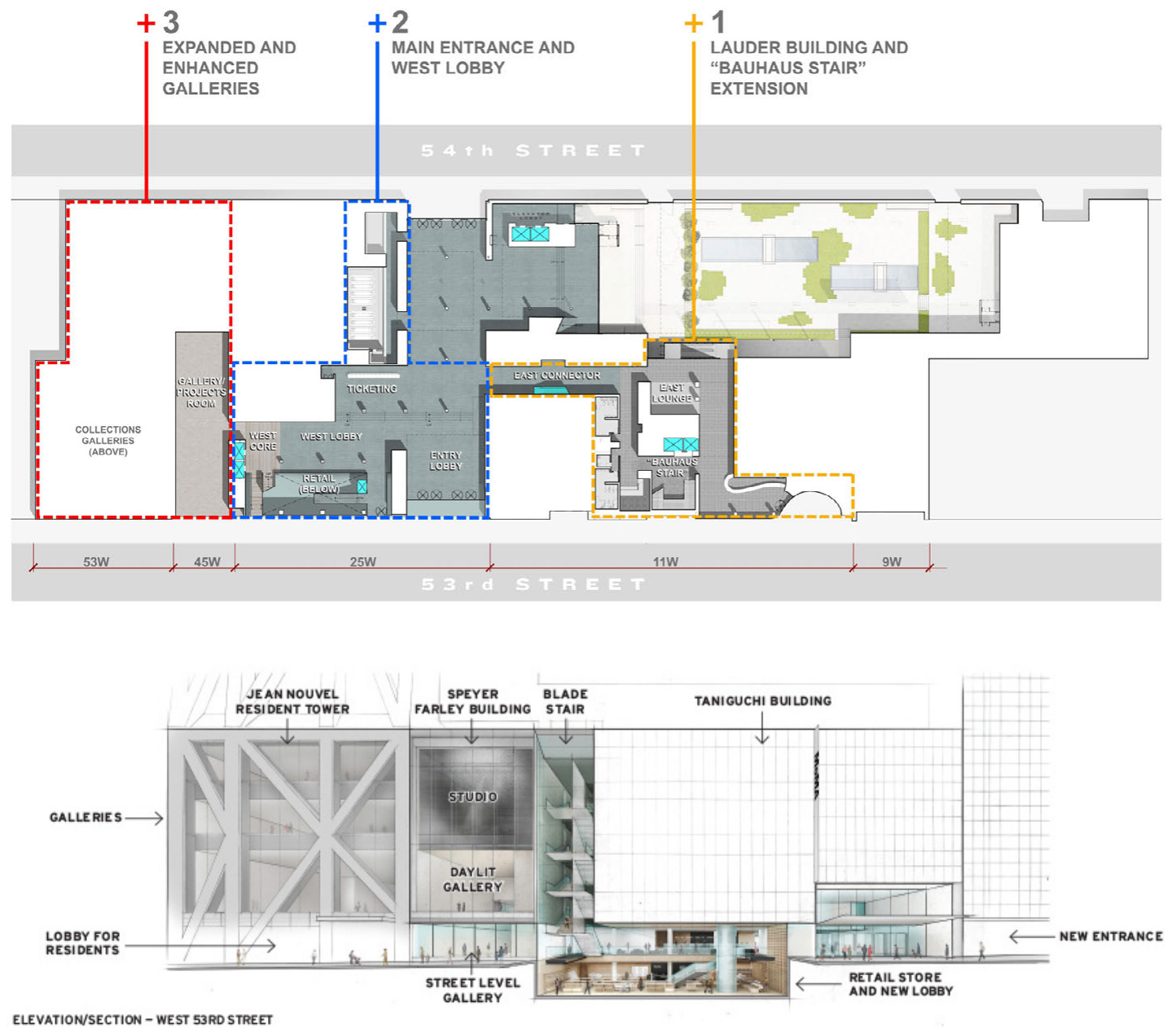

ELEVATION/SECTION - WEST 53RD STREET

$\begin{array}{ll}1 & \text { ENTRANCE LOBBY } \\ 2 & \text { TICKETING/LOUNGE } \\ 3 & \text { RETAIL STORE } \\ 4 & \text { COLLECTIONS } \\ 5 & \text { BLADE STAIR }\end{array}$

1 ENTRANCE LOBBY

5 BLADE STAIR

$\begin{array}{ll}6 & \text { STREET-LEVEL GALLERY } \\ 7 & \text { PROJECTS GALLERY } \\ 8 & \text { DAYLIT GALLERY } \\ 9 & \text { GALLERY NOUVEL } \\ & \text { BUILDING }\end{array}$

10 GOODWIN STONE BUILDING

11 JOHNSON BUILDING

12 TANIGUCHI EDUCATION

13 STUDIO 
3.92 Bauhaus Stair no MoMA, renovação de Diller Scofidio + Renfro, Nova York, 2017. Foto: Iwan Baan. Cortesia de Diller Scofidio + Renfro.

3.93 Bauhaus Stair no MoMA antes da reforma, interrompida no 20.

Pavimento, Nova York, s.d. Fonte: https:// ap.hunterdouglas.asia/cb/project/ museum-of-modern-art-moma

3.94 Escadaria do edifício da Bauhaus, projeto de Walter Gropius de 1926 , Dessau, 2009. Foto: Oliver Lins. Fonte: https://oliverlins.com/stories/ bauhaus-dessau/
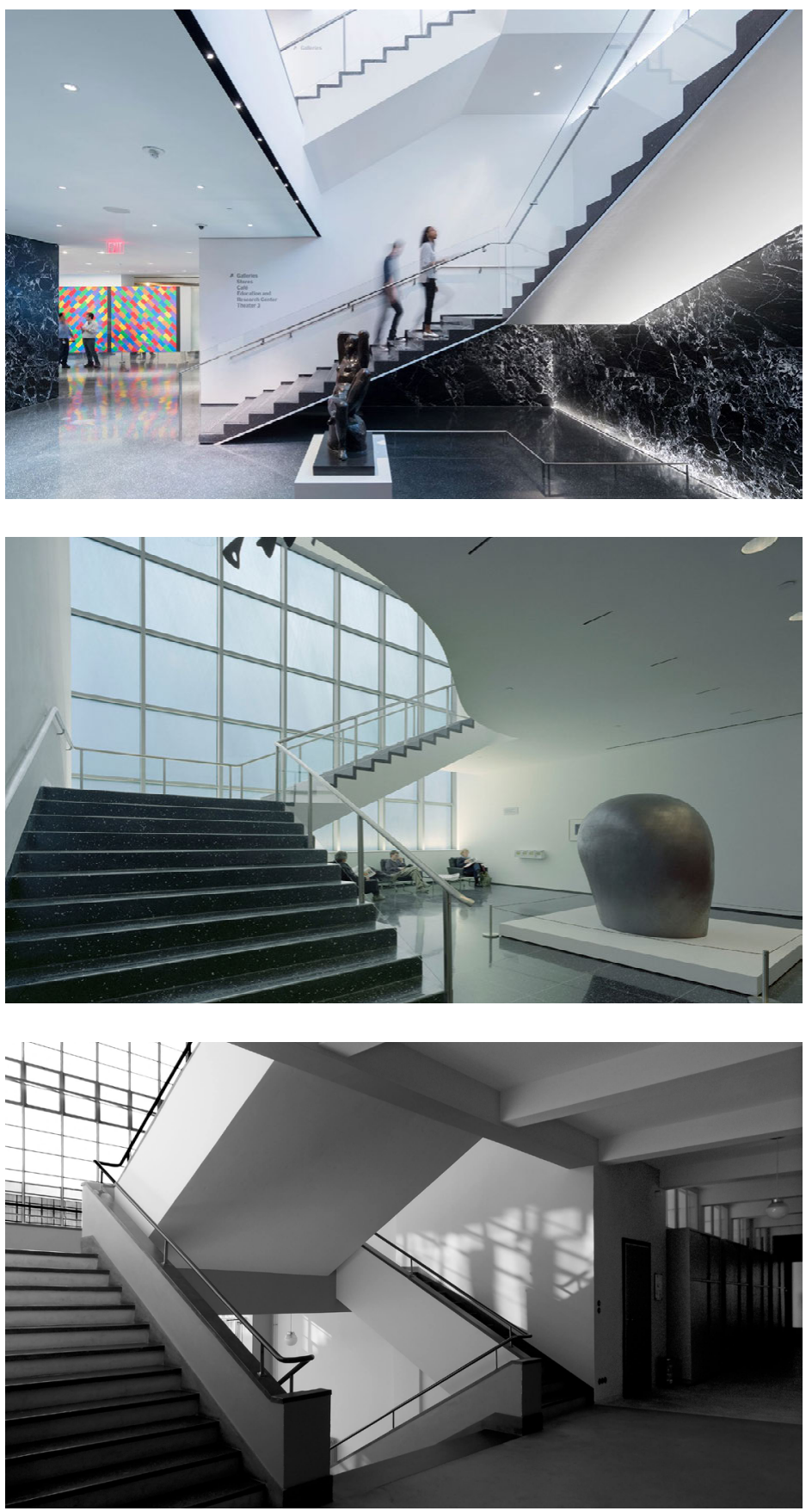

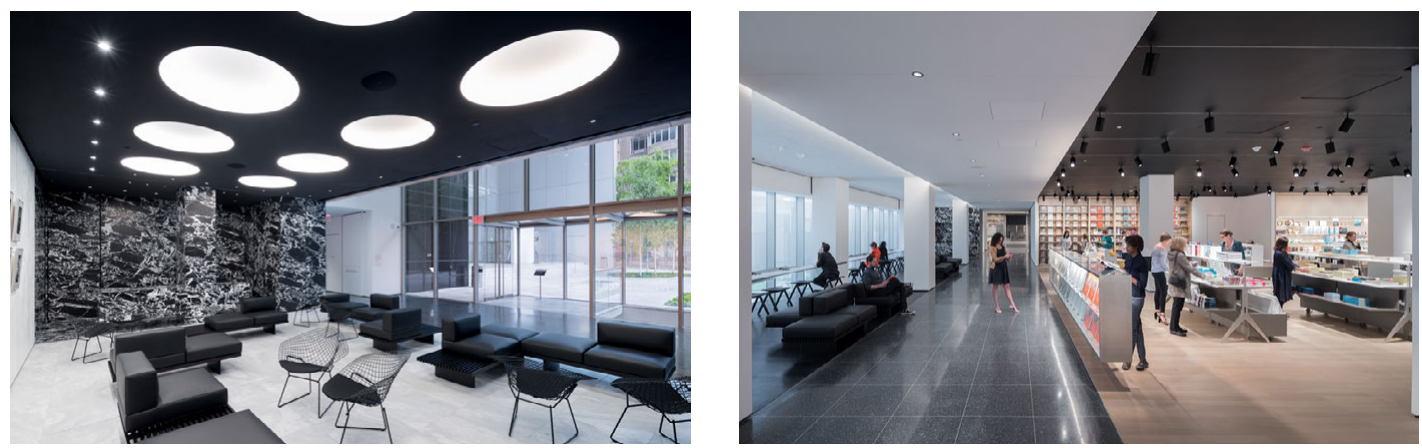

'autocrítica'. Em vez disso, estão atuando e soando muito mais como solucionadores de problemas práticos". ${ }^{528}$ Ainda que essa necessidade de lidar com pequenas contingências cause desencanto em quem prefere olhar para a arquitetura sob a ótica de grandes questões conceituais, é preciso reconhecer que essa é uma das habilidades essenciais para quem, como afirmara Foster, "busca criar estruturas apropriadas" na realização de projetos arquitetônicos.

\subsubsection{RECEPÇÃO E CIRCULAÇÃO NA AMPLIAÇÃO DE DILLER SCOFIDIO + RENFRO E GENSLER}

Em junho de 2017, as únicas partes da reforma abertas ao público foram as que envolveram blocos remanescentes mais antigos do museu - o de Goodwin e Stone de 1939 e o de Philip Johnson de 1964 a leste. Alguns elementos do primeiro edifício moderno do MомA foram recuperados, como a escadaria conhecida como Bauhaus Stair, que havia sido removida na reforma de 1984 e parcialmente reconstruída em 2004. Reconectando o térreo aos pavimentos acima, os primeiros lances foram reinstalados, mas utilizando, ao invés da pesada estrutura de concreto da versão original, placas de aço extremamente delgadas que, fixadas nas paredes e avançando em balanço, fazem a escada parecer flutuar. Para os materiais de acabamento, foi adotada a mesma palheta de cores para as áreas de circulação desse bloco, com preto nas placas de granilite

528 SALTZ, Jerry. I Give In, Moma. You've Won Me Over. Halfway, Anyway., New York Magazine, 27/07/2017. ed. 2017. Tradução nossa.
3.95 Ambiente de descanso voltado para o jardim no pavimento térreo do MoMA, renovação de Diller Scofidio + Renfro, Nova York, 2017. Foto: Iwan Baan. Cortesia de Diller Scofidio + Renfro.

3.96 Descanso (esquerda), café (fundo) e loja (direita) na área do edifício do MoMA de 1939, com renovação de Diller Scofidio + Renfro, Nova York, 2019. Foto: Iwan Baan. Cortesia de Diller Scofidio + Renfro. 

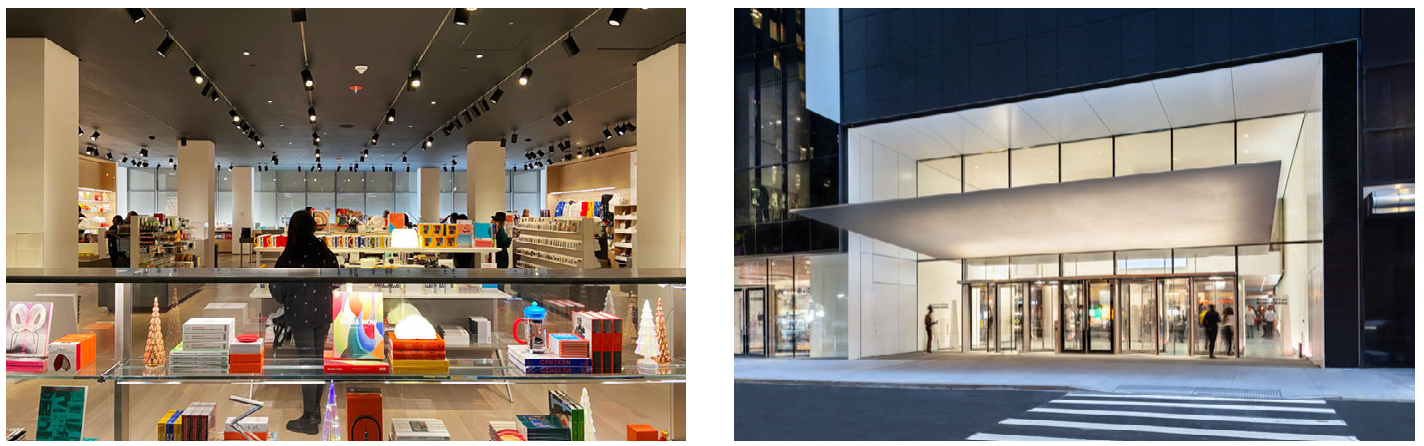

3.97 Loja na área do edifício do MoMA de 1939, com renovação de Diller Scofidio + Renfro, Nova York, 2019. Foto: nossa.

3.98 Nova marquise de entrada do MoMA na Rua 53, renovação de Diller Scofidio + Renfro, Nova York, 2019. Foto: Brett Beyer. Cortesia de Diller Scofidio + Renfro. polido do piso e branco predominando nas paredes e forros. Conferindo maior expressividade aos ambientes, algumas superfícies foram revestidas com mármore preto marcado com veios brancos - Grand Antique d'Aubert, proveniente da França -, realçando o contraste com os acabamentos mais austeros adotados na expansão de Taniguchi, que adotara placas de ardósia verde acinzentado para os pisos das áreas de circulação.

Alguns serviços foram acrescentados na fronteira entre $o$ bloco de 1939 e o de 2004, como sanitários públicos e um guarda-volumes reservado a membros do museu. Ainda no térreo, foi criado um novo ambiente de descanso numa área ocupada antes por equipamentos de serviço, cuja vista para o jardim foi possibilitada pela remoção de uma parede na lateral das escadas rolantes que dão acesso aos dois auditórios do subsolo. Foi mantido inalterado o sofisticado restaurante The Modern, também voltado para o jardim e com entrada independente pelo bloco de Philip Johnson, voltado para a rua 53. Um novo café foi localizado no pavimento acima, com acesso pela área onde ficava uma das galerias expositivas do bloco de Goodwin e Stone, ocupada agora por mais uma área de descanso com vista para o jardim e por uma loja - que mantinha visível pelo interior a fachada de vidro translúcida do projeto original. No terceiro pavimento, as áreas expositivas dos dois blocos foram reconfiguradas, removendo divisórias não estruturais para permitir maior flexibilidade de uso em diferentes montagens. Essas intervenções, apresentadas como "cirúrgicas", tiveram como resultado a valorização da arquitetura do bloco de Goodwin e 

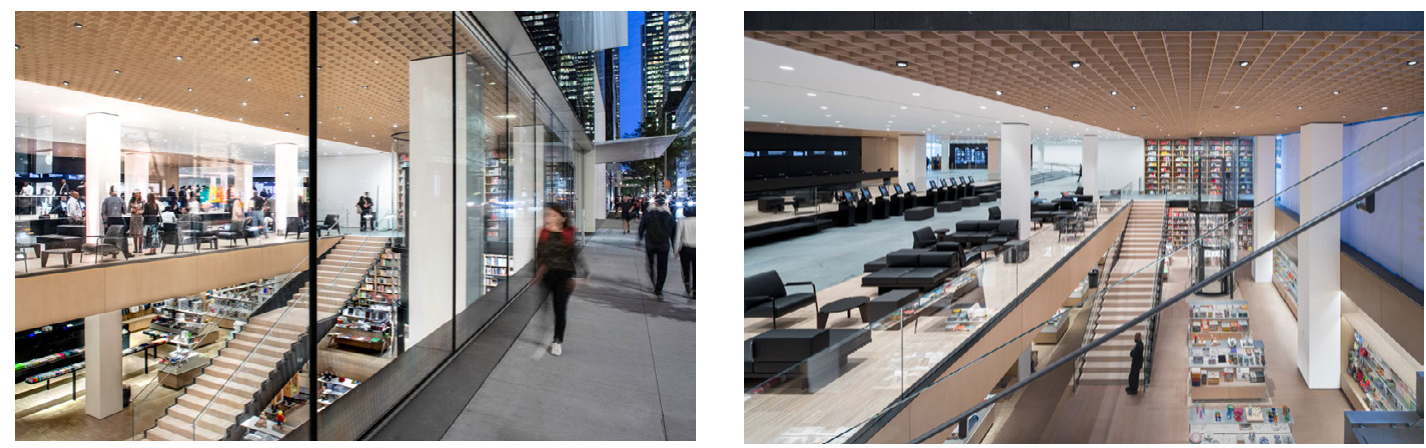

Stone, bastante modificado nas reformas anteriores. Tornou-se, desse modo, mais perceptível a diferença entre os edifícios de cada época, um tanto embaralhados pelo tratamento mais homogêneo de antes.

Depois de fechado por 4 meses para a finalização da obra, o museu foi reinaugurado em outubro de 2019, revelando a versão completa do projeto. Com investimento de 450 milhões de dólares, o museu foi ampliado em $4.33 \mathrm{om}^{2}$, chegando a uma área total de $65.77 \mathrm{Om}^{2}$. Uma das questões importantes para o MомA era criar melhores condições de receber o público, que havia crescido vertiginosamente na década anterior. Ao invés de aliviar a superlotação, o efeito da ampliação de 2004 havia sido o de agravá-la, com aglomerações e filas típicas de aeroportos em época de férias. $\mathrm{O}$ museu vinha recebendo uma média de 18 a 25 mil visitantes ao dia, chegando a mais de 3 milhões ao ano e com expectativa de atingir 3,5 milhões depois da reinauguração.

Na segunda etapa da obra, foram realizadas intervenções significativas no saguão de acesso principal de público, como a elevação do pé direito sobre a entrada da rua 53, onde foi instalada uma marquise de aço em balanço, dando maior destaque à entrada do museu. A loja a oeste dessa entrada foi transferida para o subsolo, mas, com a remoção da laje do térreo, ficou com pé direito duplo, mantendo-se visível para o transeunte, sem, no entanto, obstruir a visão de outras áreas no interior do museu. A faixa conectando as ruas 53 e 54 ficou mais liberada da concentração de público com a transferência de balcões de
3.99 Loja do MoMA em subsolo e voltada para a Rua 53, com renovação de Diller Scofidio + Renfro, Nova York, 2019. Foto: Brett Beyer. Cortesia de Diller Scofidio + Renfro.

3.100 Bilheteria (esquerda) e loja (direita) do MoMA, com renovação de Diller Scofidio + Renfro, Nova York, 2019. Foto: Brett Beyer. Cortesia de Diller Scofidio + Renfro.

\section{$412-413$}




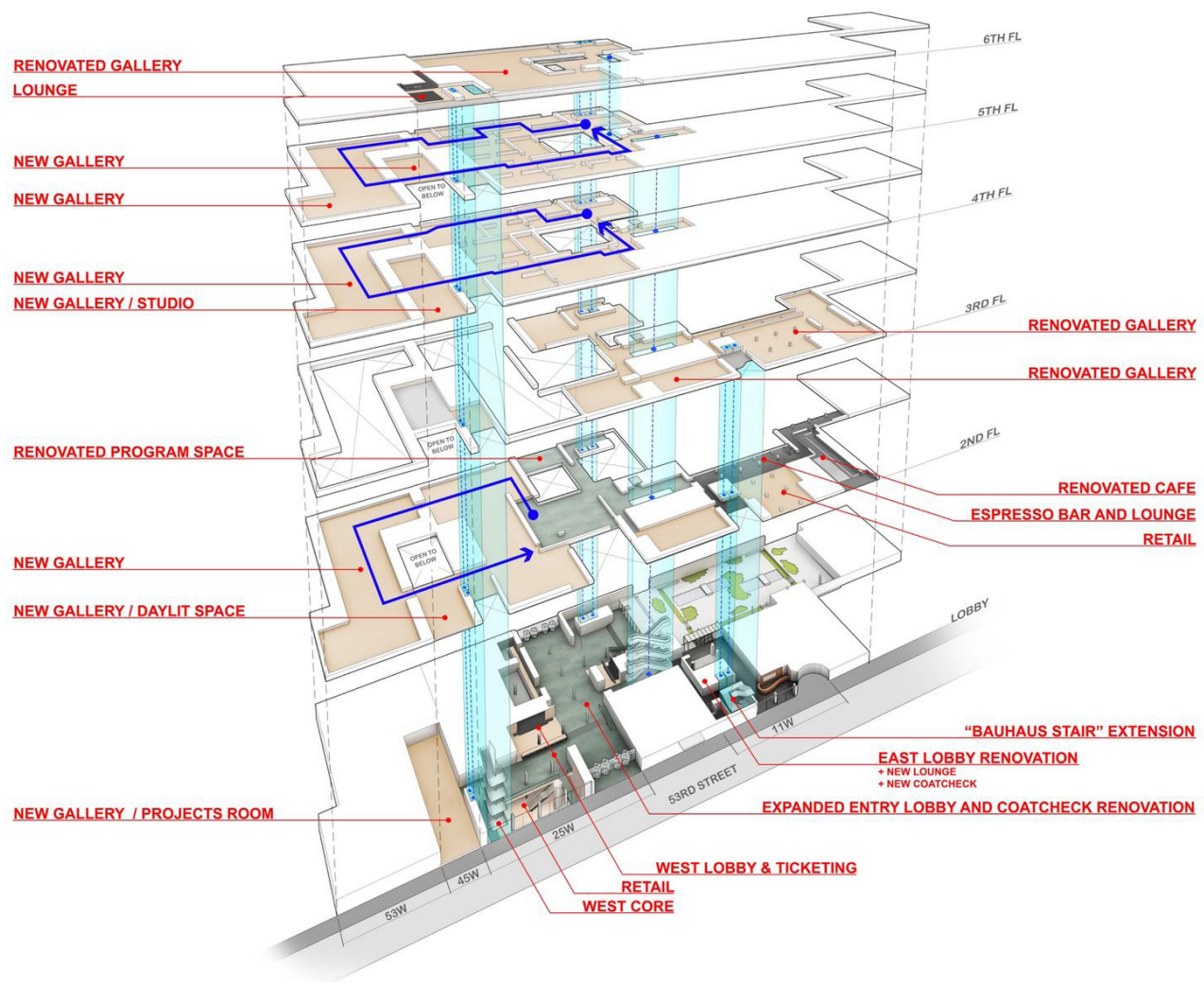

3.101 Diagrama do projeto de renovação do MoMA por Diller Scofidio + Renfro com indicação em azul das prumadas de circulação, Nova York, 2019. Imagem: DS+R. informação, bilheteria e mais uma área de descanso para áreas nas laterais. Esses ambientes de maior permanência foram tratados de modo distinto das zonas de passagem, recebendo nos pisos, paredes e forros superfícies de madeira com absorção acústica, criando uma atmosfera mais acolhedora e menos ruidosa na recepção dos visitantes.

Visando evitar congestionamentos excessivos, houve um aumento de $25 \%$ das áreas públicas do museu e foram criadas novas prumadas de circulação vertical, permitindo que o acesso dos visitantes às exposições, fosse distribuído em vários pontos. O público podia agora optar por dois caminhos principais para acessar as galerias expositivas. Um deles seria à leste, tomando as conhecidas escadas rolantes e elevadores ou a escada fixa 

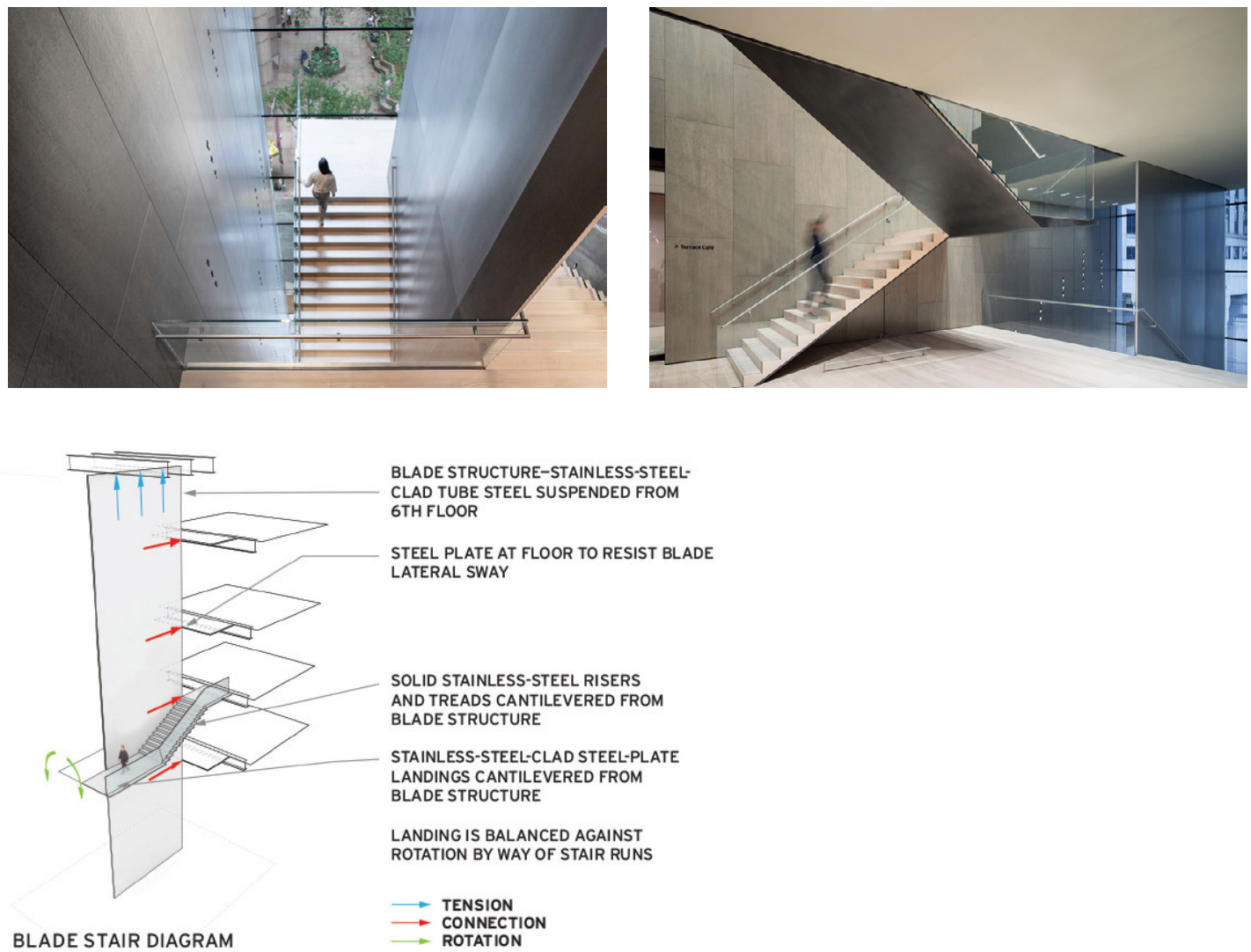

em frente ao jardim, que levava ao piso do átrio. O outro seria à oeste, tendo acesso gratuito a duas novas galerias no térreo ou subindo por uma nova prumada de elevadores acompanhado de uma escada fixa junto à fachada envidraçada para a rua 53. Construída ao redor de uma fina placa de aço suspensa no teto, a chamada Blade Stair percorre todos os pavimentos sem tocar as paredes, que por sua vez foram revestidas de painéis de madeira micro perfurados para ampliar a absorção acústica.

A mais nova expansão a oeste ampliou em $30 \%$ as áreas expositivas, que chegavam agora ao total de $15.33 \mathrm{om}^{2}$, comportando 60 galerias. Para que fosse possível ao visitante completar a volta nos pavimentos 2,4 e 5 , dedicados à coleção, foi preciso demolir o edifício do Folk Art Museum. O DS+R havia imposto

3.102 e 3.104 Vistas e Diagrama da Blade Stair, projeto de renovação do MoMA por Diller Scofidio + Renfro, Nova York, 2019. Foto 3.102: Brett Beyer. Foto 3.103: Iwan Baan. Imagem: DS+R. Cortesia de Diller Scofidio + Renfro. 
529 A demolição do edifício movimentou uma enorme polêmica no meio das artes e da arquitetura de Nova York. Cf. THE ARChitectural LeAGUe, op. cit.

530 SMITH, Roberta. MomA's Art Treasure, No Longer Buried. The New York Times, 18/10/2019. ed. 2019. Tradução nossa.

531 LANGE, Alexandra. Navigating the new MoMA. New York Magazine, 21/10/2019. ed. 2019. Tradução nossa. como condição para sua contratação a oportunidade de avaliar alternativas de incorporá-lo, ao invés de dar como certa a sua demolição, como havia sido decidido a priori pela instituição. Ao final dos seis primeiros meses de estudo, no entanto, concluiu-se que a manutenção do edifício seria incompatível com as demandas do момА de criar um percurso fluido de visitação, completando uma volta pelas exposições. ${ }^{529}$

Apesar de não ter havido intervenção no átrio, a expansão do edifício a oeste e o acréscimo de uma nova prumada de circulação fez com esse grande espaço adquirisse outro peso no edifício, como observou a crítica de arte Roberta Smith: "Um benefício psicológico é que o grande (e desprezado) átrio de Taniguchi perde ênfase. Ele não parece tão grande quando é possível se afastar dele". ${ }^{530}$ Opinião coincidente foi manifestada pela crítica de arquitetura Alexandra Lange, que apontou para a perda de protagonismo desse espaço por ter deixado de ser um ponto nodal de circulação:

O grande átrio do segundo andar é essencialmente emudecido por esse arranjo, que privilegia a circulação. Em um museu neoclássico como o Metropolitan, o átrio é o motor da circulação. Na versão do MomA dos anos 1980, César Pelli tentou combinar circulação e grandiosidade por meio de um conjunto de escadas rolantes sob um teto semelhante a um jardim de inverno. Agora temos uma circulação com muito pouco charme e um grande espaço que é residual, sem propósito. Você poderia dar voltas e mais voltas no museu e nunca mais precisar ir lá. O que você precisa é de um mapa, um elevador e uma planta. ${ }^{531}$

As novas galerias da coleção, ocupando os andares inferiores da torre de apartamentos projetada por Jean Nouvel - The David Geffen Wing - foram projetadas em continuidade com as áreas expositivas de Taniguchi, como espaços sem expressão arquitetônica - tipo "genéricos" ou "descartáveis" - para permitir, mais uma vez, uma grande flexibilidade para que pudessem ser facilmente reconfigurados conforme a nova orientação curatorial, que demandava rotatividade periódica da exposição e a quebra da linearidade dos percursos, por meio de passagens 


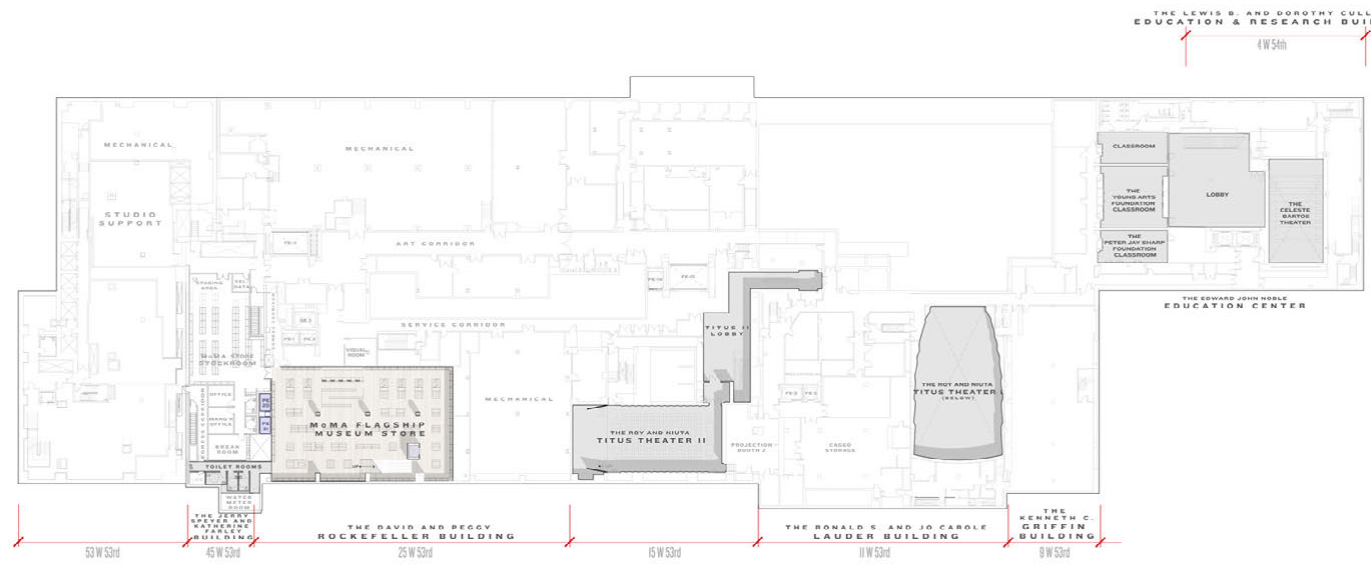

L E V E L - 1
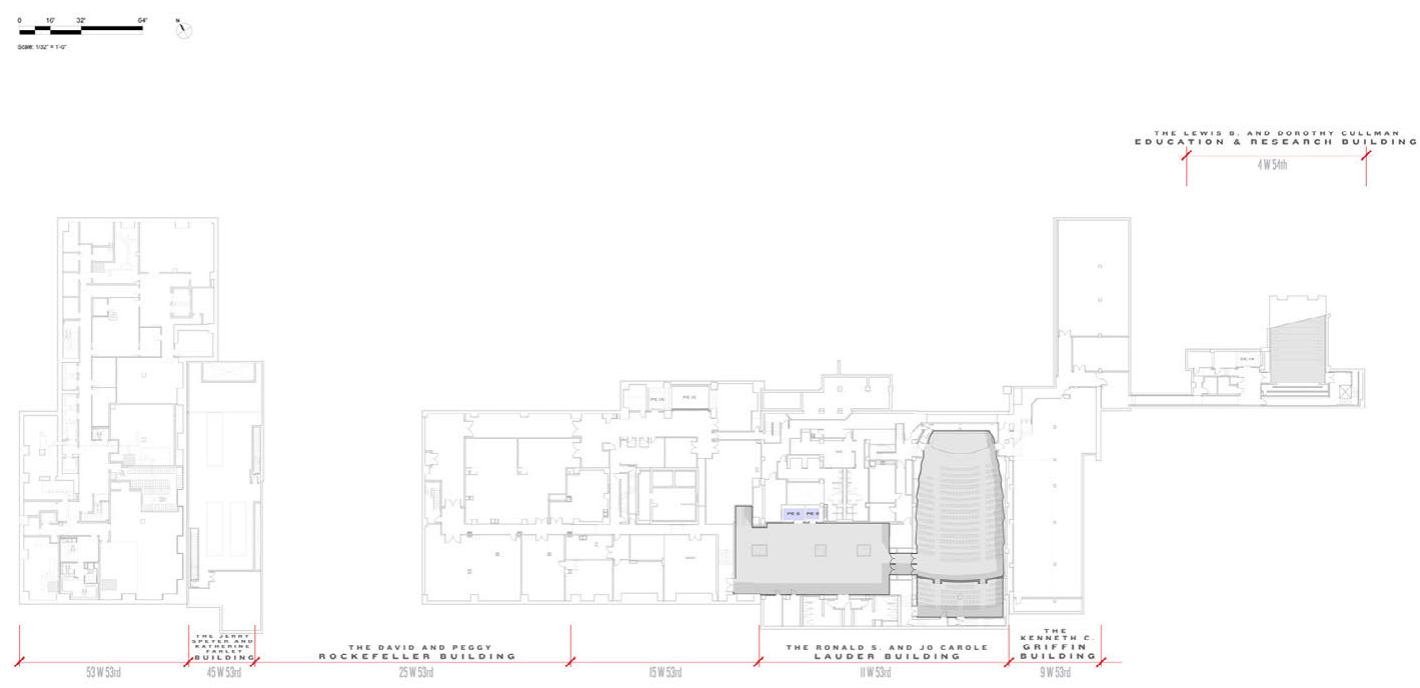

L E V E L - 2

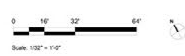

3.105 e 3.106 Projeto de renovação e expansão de Diller Scofidio + Renfro para o MoMA, Nova York, 2019. Plantas Pavimento -1 e Pavimento -2 - Subsolo. Desenhos: DS+R. Cortesia de Diller Scofidio + Renfro. 


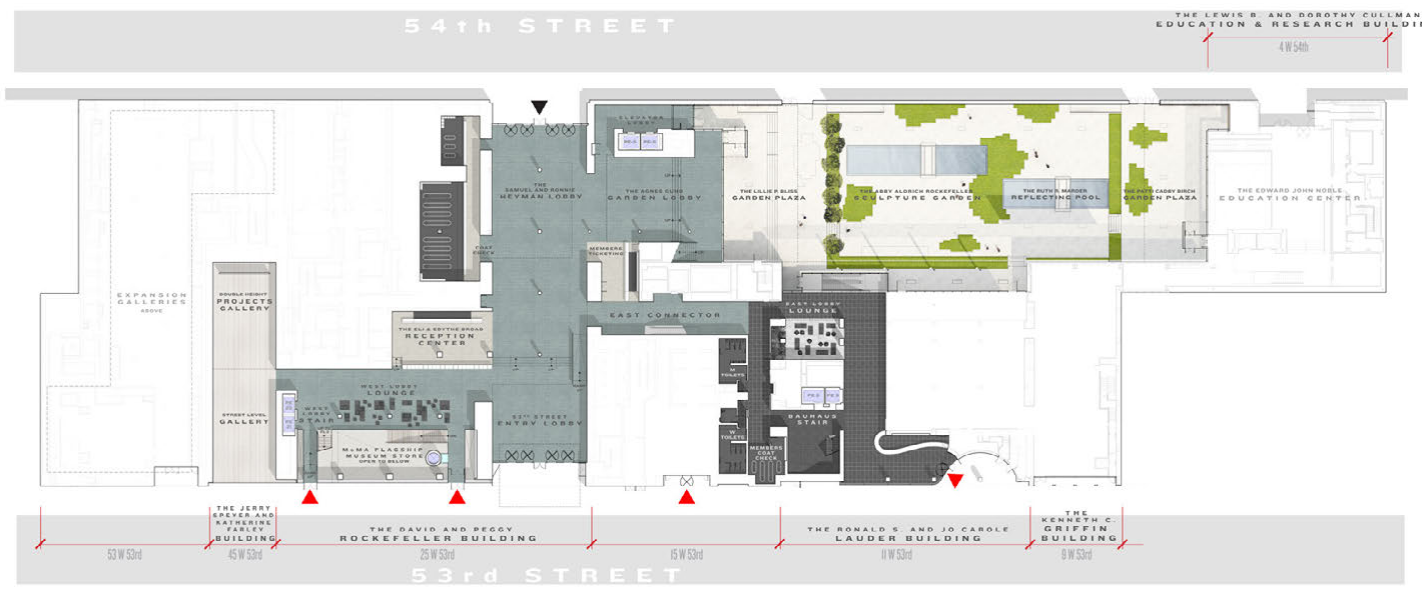

L E V E L 1

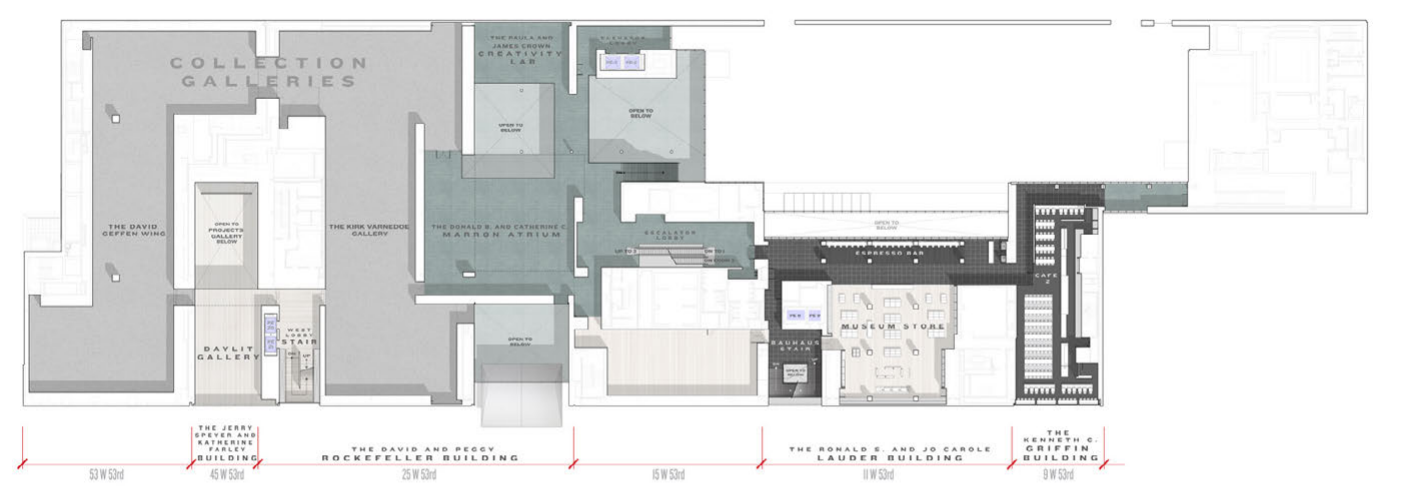

LEVE L 2

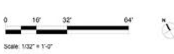

3.107 e 3.108 Projeto de renovação e expansão de Diller Scofidio + Renfro para o MoMA, Nova York, 2019. Plantas

Pavimento 1 - Térreo e Pavimento 2. Desenhos: DS+R. Cortesia de Diller Scofidio + Renfro. 


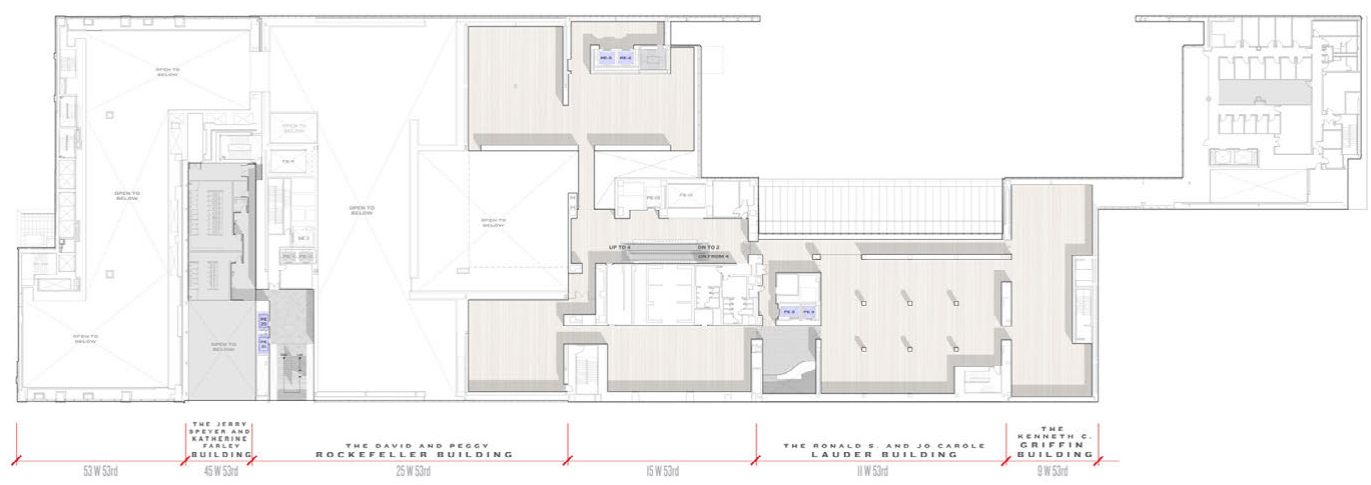

LE V E L 3
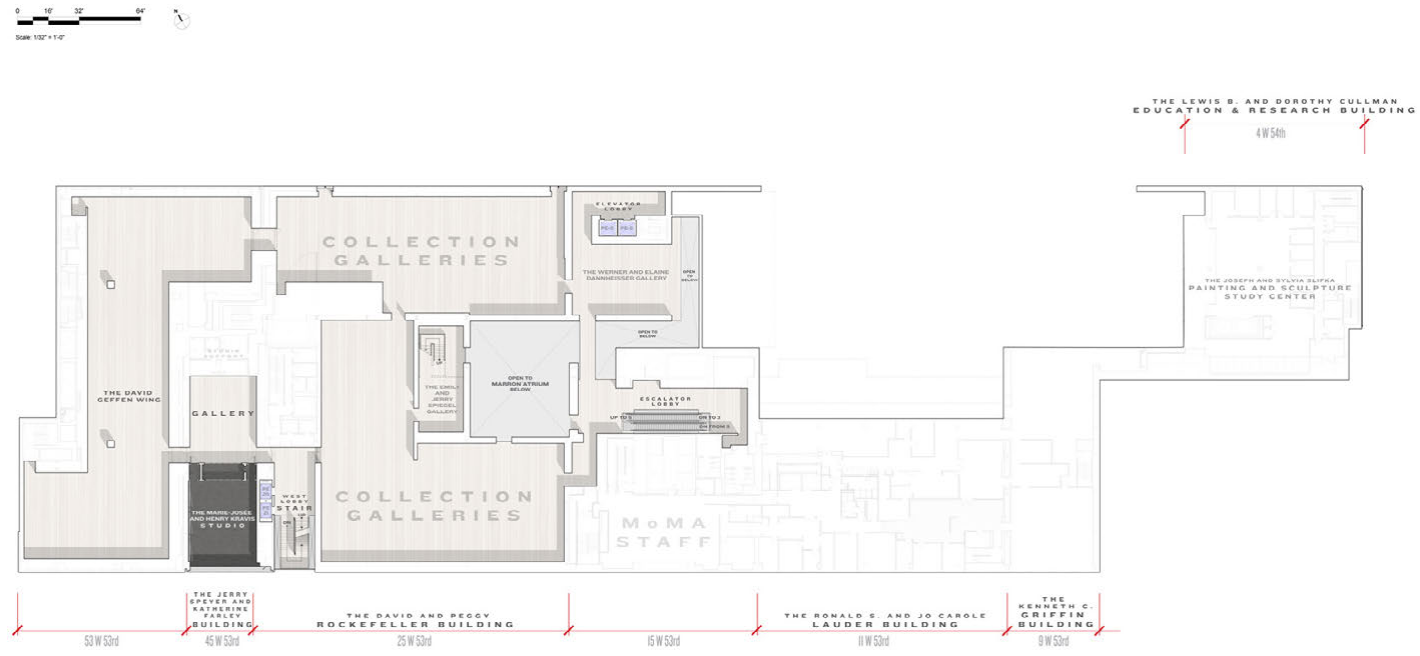

LE V E L 4

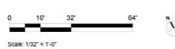

3.109 e 3.110 Projeto de renovação e expansão de Diller Scofidio + Renfro para o MoMA, Nova York, 2019. Plantas Pavimento 3 e Pavimento 4. Desenhos: DS+R. Cortesia de Diller Scofidio + Renfro. 


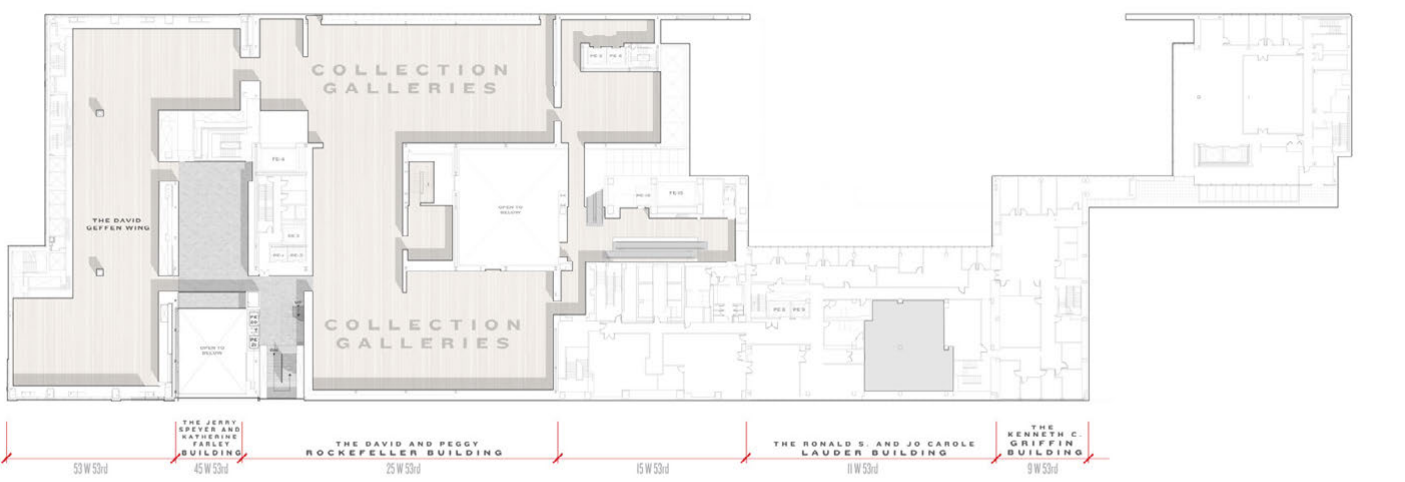

\section{LE V E L 5}
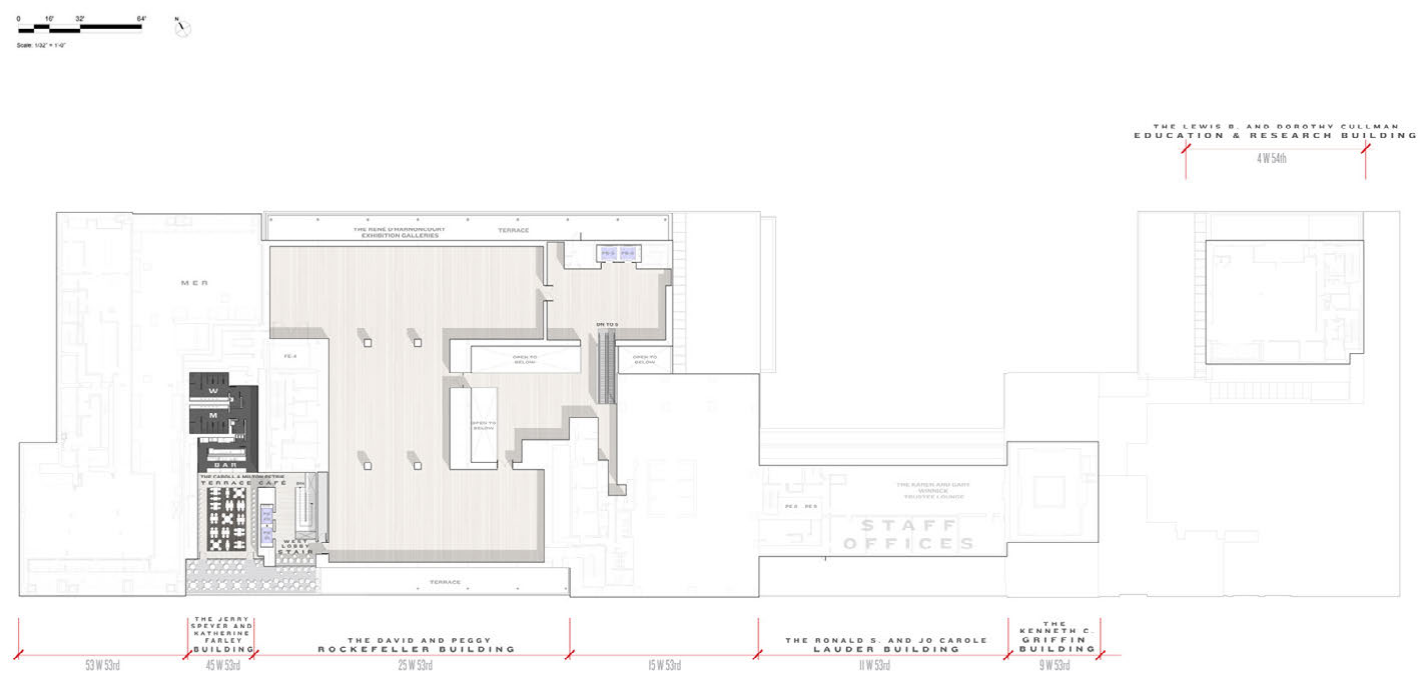

L E V E L 6

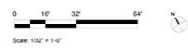

3.111 e 3.112 Projeto de renovação e expansão de Diller Scofidio + Renfro para o MoMA, Nova York, 2019. Plantas Pavimento 5 e Pavimento 6. Desenhos: DS+R. Cortesia de Diller Scofidio + Renfro. 


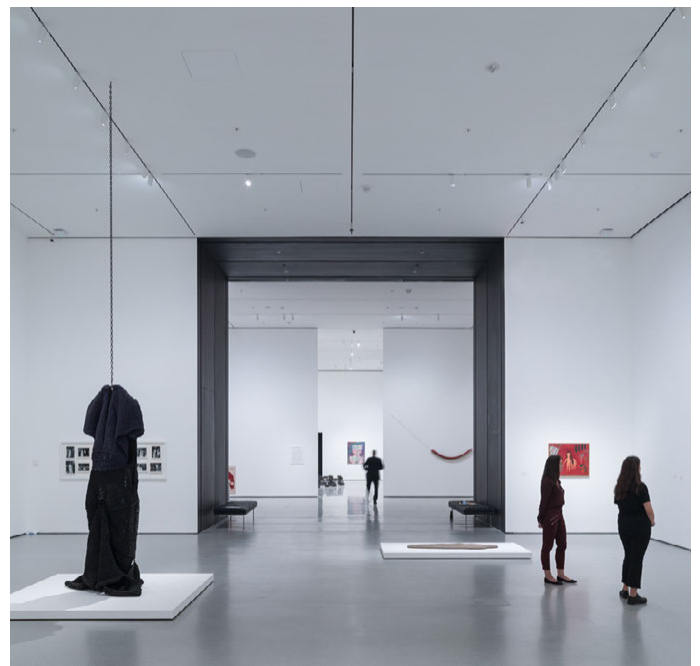

alternativas entre as salas. Além de paredes e tetos brancos (uma base que poderia ser alterada pelo projeto expográfico), foram adotados pisos de madeira com tonalidade menos saturada e lâmpadas com temperatura de cor mais fria, além de soluções que permitiram ocultar ainda mais os diversos tipos de equipamento necessários para segurança e controle ambiental. Um sutil contraponto a essa atmosfera anódina foi dado pelo acabamento dos portais de transição entre os blocos, feitos por placas de aço de tonalidade escura, com presença mais marcante que o aço inox empregado na versão anterior. Embora a distribuição em planta das galerias permitisse perfazer uma volta completa e contínua nos andares da coleção, o acréscimo da nova prumada de circulação e de passagens entre as salas cumpria a função desejada pelos curadores de oferecer alternativas ao percurso principal.

\subsubsection{GALERIAS DE EXCEÇÃO PARA A ARTE}

Para o interesse desta tese, o ponto mais relevante do projeto da última reforma do MOMA não está na reconfiguração
3.113 Portal entre as galerias existentes e as novas a oeste do MoMA, projeto de expansão e renovação de Diller Scofidio + Renfro, Nova York, 2019. Foto: Iwan Baan.

3.114 Diagrama do projeto de expansão e renovação do MoMA de Diller Scofidio + Renfro, Nova York, 2019. Imagem: DS+R. Cortesia de Diller Scofidio + Renfro. 

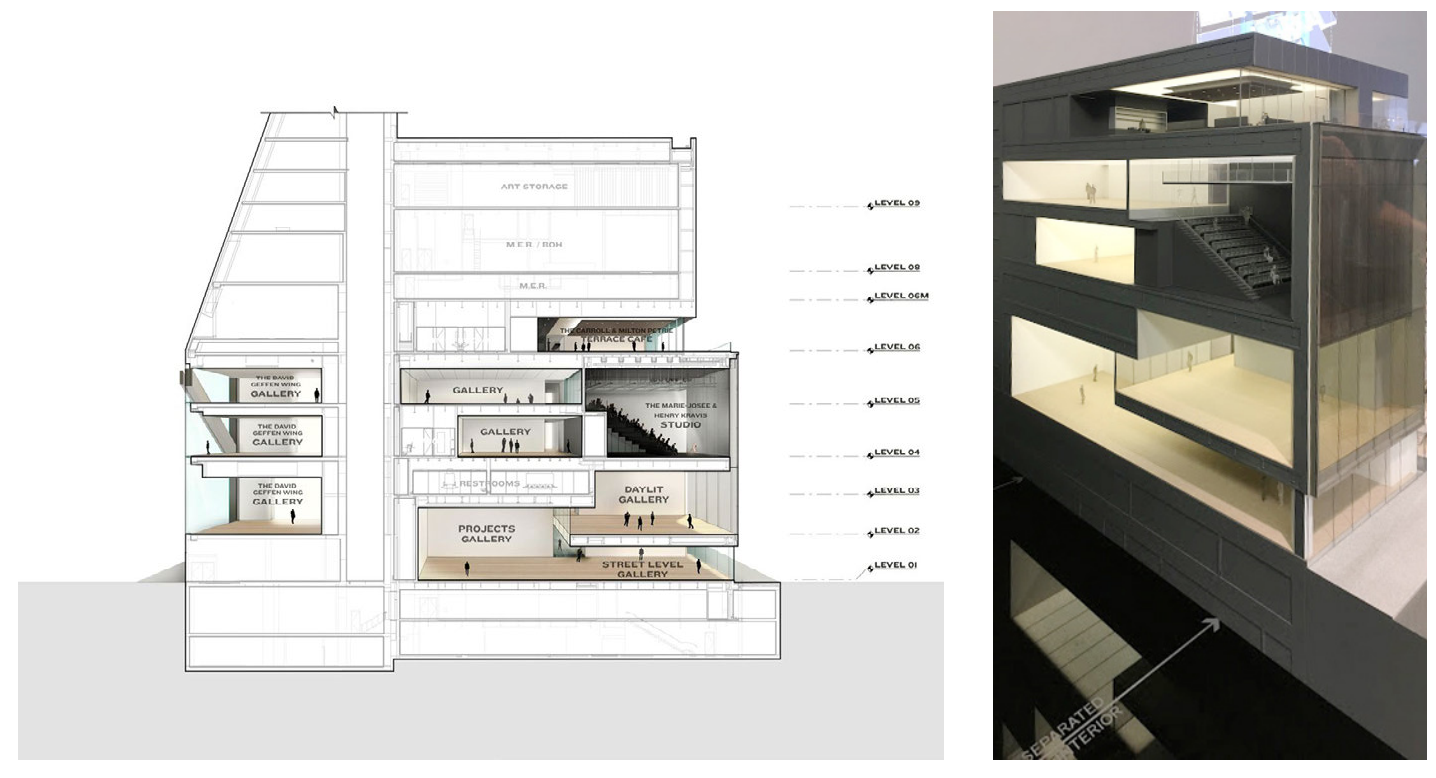

3.115 Corte das novas galerias empilhadas do MoMA, projeto de Diller Scofidio + Renfro, Nova York, 2019. Imagem: DS+R. Cortesia de Diller Scofidio + Renfro.

3.116 Maquete das novas galerias empilhadas do MoMA, projeto de Diller Scofidio + Renfro, Nova York, 2019. Foto: nossa

532 Este parque pertence ao Deutsche Bank e faz parte de uma rede de espaços públicos de propriedade privada de Nova York, Privately Owned Public Space - POPS, e foi projetada por Kevin Roche John Dinkeloo and Associates. Cf. ADvocates FOR Privately OWNed Public Space. The Municipal Art Society of New York, 31 West 52nd Street. APOPSMAS. Disponível em: <https:// apops.mas.org/pops/mo50o88/>. Acesso em: 6 nov. 2020. arquitetônica geral dos espaços públicos, nas fachadas, nem nas galerias convencionais da coleção, mas nos novos tipos de espaços de arte propostos pelos arquitetos, organizados no conjunto de galerias dispostas verticalmente na expansão a oeste, e nas possibilidades oferecidas por eles à arte contemporânea. O lote ocupado antes pelo Folk Art Museum tinha localização nodal para o projeto, não apenas porque permitia completar a volta do percurso de visitação, como vimos, mas também porque voltava-se para a rua 53 , bem em frente a um pocket park que dava passagem até a rua 53 , criando uma perspectiva visual aberta no denso tecido dessa região de Manhattan. ${ }^{532}$ Tais condições foram tomadas no projeto como oportunidades para inserir, em meio ao circuito de galerias dedicadas ao acervo e no pavimento térreo, esse conjunto de salas expositivas com características divergentes do padrão do museu. Variando em proporção, iluminação, infraestrutura e conexões visuais e, na maior parte delas, com franca abertura visual para a cidade -, as novas galerias dessa prumada ofereciam condições arquitetônicas especiais para expor arte no interior do MOMA. 

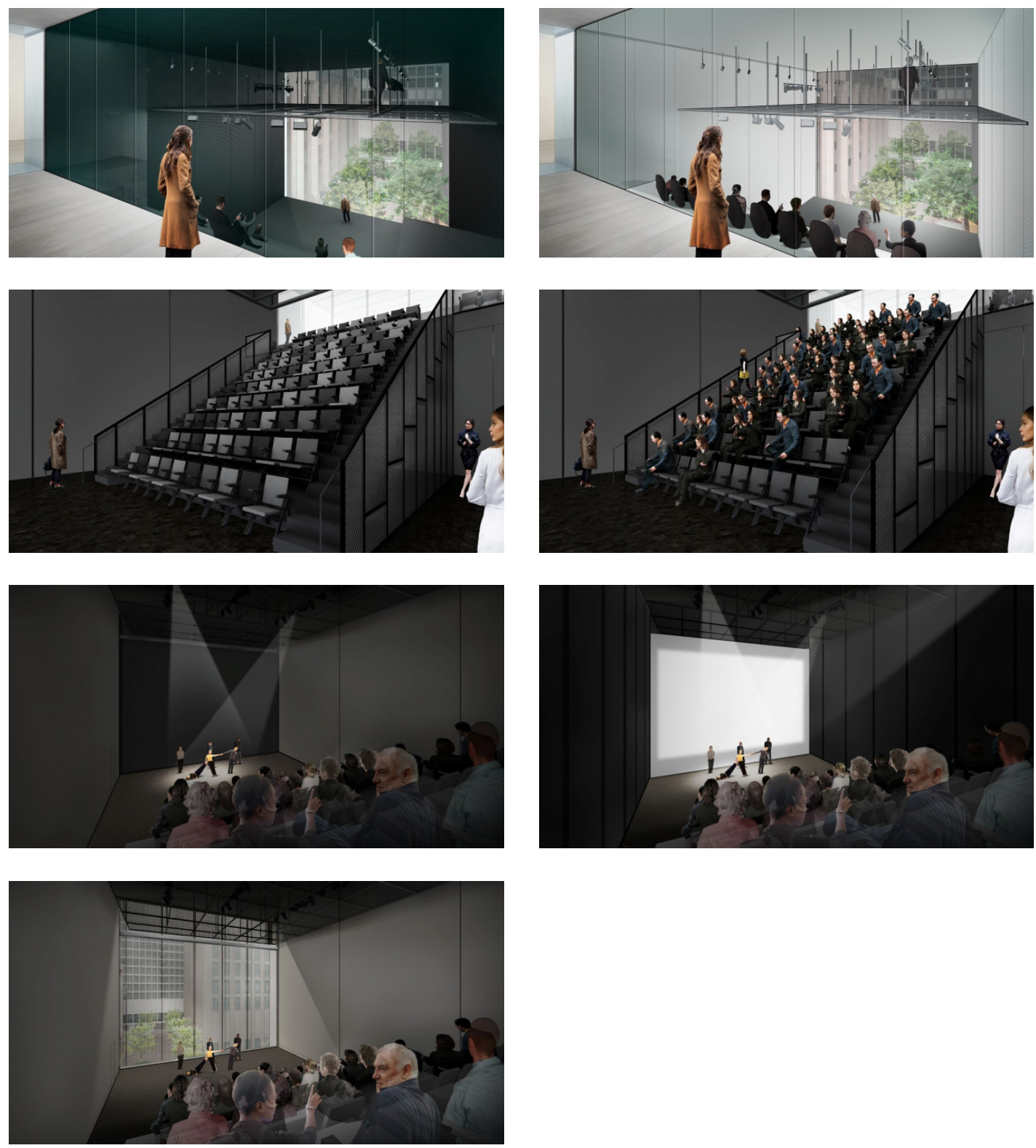

3.117 a 3.123 Perspectivas do Studio Gallery do MoMA, projeto de Diller Scofidio + Renfro, 2019. Imagem: DS+R. 


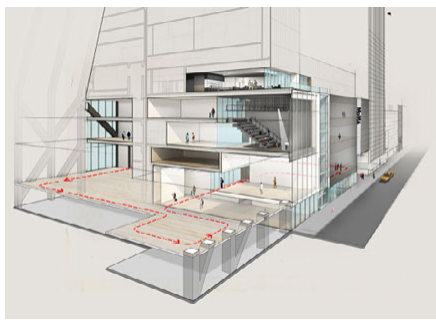

3.124 Corte das novas galerias empilhadas do projeto de expansão e renovação do MoMA de Diller Scofidio + Renfro, Nova York, 2019. Imagem: DS+R. Cortesia de Diller Scofidio + Renfro.
533 Renfro, Charles. The New moma. Youtube. Disponível em: $<$ https://www.youtube.com/watch?$\mathrm{v}=\mathrm{aPC} 4 \mathrm{PkiPfiM} \& \mathrm{t}=303 \mathrm{~s}>$. Acesso em: 18 out. 2020.12 " 36 ' a 12 "50'. Transcrição e tradução nossas.
Uma dessas novas "galerias empilhadas" foi chamada de Studio Gallery - uma sala multiuso de pé direito duplo voltada para a fachada, totalmente transformável para acolher performances de música, dança e teatro, instalações experimentais multimídia, ou mesmo palestras, seminários e conferências, com 100 assentos em arquibancada retrátil. Com superfícies escuras - entre cinza e preto - essa sala foi originalmente chamada pelos arquitetos de Grey Box, com a intenção de conceituá-la entre o "cubo branco" das galerias destinadas a pinturas, esculturas e instalações e o teatro tipo "caixa preta" voltada para peças audiovisuais. $\mathrm{O}$ ambiente recebeu tratamento acústico de alta performance, com possibilidade de completo isolamento do exterior e dos ambientes do museu, paredes laterais pivotantes até 15 graus para quebrar o eco e painéis retráteis para ampliar o nível de absorção sonora. No teto, foi instalada uma estrutura em grelha que permite suportar peças pesadas, equipamentos de iluminação e acesso para técnicos e artistas. Os grandes panos de vidro voltados para o exterior receberam uma malha metálica entre as camadas e aplicação de serigrafia no exterior, para proteger o ambiente interno dos raios de sol e do ofuscamento, mantendo ao mesmo tempo a transparência e a vista para a cidade. Foi previsto ainda que o plano da fachada pudesse ser configurado de maneiras variadas por meio de painéis retráteis, que permitem convertê-la em tela de projeção, plano translúcido ou blecaute. Na face oposta à fachada, foram instalados painéis removíveis para possibilitar a integração com a galeria da coleção no quarto pavimento e um plano fixo envidraçado na faixa superior, oferecendo a vista dessa sala pela cota de cima para o visitante percorrendo o circuito expositivo do quinto pavimento.

Logo abaixo desta sala, no segundo pavimento, foi proposta uma outra variação de espaço para arte, a Daylite Gallery, também com pé direito duplo e permanentemente envidraçada. Como explicou Charles Renfro num programa televisivo, a ideia dessa galeria era permitir que a arte pudesse ser vista a partir da rua, fundindo-se com a cidade: "estamos no meio de Nova York, na parte mais densa da cidade, e queríamos que o novo MOMA refletisse essa condição." ${ }^{533}$ Enquanto a prática nas demais galerias do museu vinha sendo a de construir painéis 
opacos em frente às fachadas de vidro, transformando-as em paredes, nesta sala curadores e artistas deveriam submeter-se à condição de transparência oferecida pela arquitetura para definir os trabalhos a serem ali expostos.

No nível térreo da mesma prumada, foi criada a Street Level Gallery, localizada, como o nome diz, ao nível da rua, separada da calçada apenas pela esquadria de vidro. A proposta veio do diagnóstico de que, com a expansão de 2004, o caminho que o público precisava percorrer no edifício até o primeiro contato com a arte tornara-se muito penoso e distante, sendo importante reinstaurar agora galerias de arte mais próximas à entrada e com acesso gratuito, livre de ingresso. Denominado inicialmente de Art Bay, esse espaço expositivo contava nas primeiras versões com uma grande porta de vidro que permitiria acesso direto pela rua, numa configuração que remetia, de certa forma, às habituais vitrines das galerias comerciais de arte. A abertura direta para a calçada foi, no entanto, abandonada por ter sido considerada inviável do ponto de vista logístico, mas o conceito principal foi mantido - o de oferecer ao público em geral um contato mais franco com a arte do museu, com visibilidade a partir da rua e acesso franqueado.

Em continuidade com nova Street Level Gallery foi desenhado um outro espaço expositivo mais ao fundo, a Projects Room, dedicada ao programa de instalações experimentais de arte contemporânea. Com pé direito de 7,9om - o mais alto das galerias do MомА - e conectada visualmente à Daylite Gallery acima por um plano envidraçado, esse espaço foi concebido para comportar uma gama variada de trabalhos. Antes da reforma de 2004, a série Projects, contando com uma sala permanente, era frequentemente organizada pela equipe de curadores mais jovens, trazendo trabalhos mais arriscados e de artistas em início de carreira. No projeto de Taniguchi, a Projects Room havia sido suprimida e a função acabara sendo absorvida em parte pelo grande átrio. No entanto, como vimos, esse espaço não apresentava condições propícias para expor trabalhos de médio e pequeno porte, que acabavam apequenados diante da sua monumentalidade. Por sua proeminência no edifício, o átrio não era um substituto adequado para essa finalidade, e passou, afinal, a ser controlado por curadores sêniores, que 

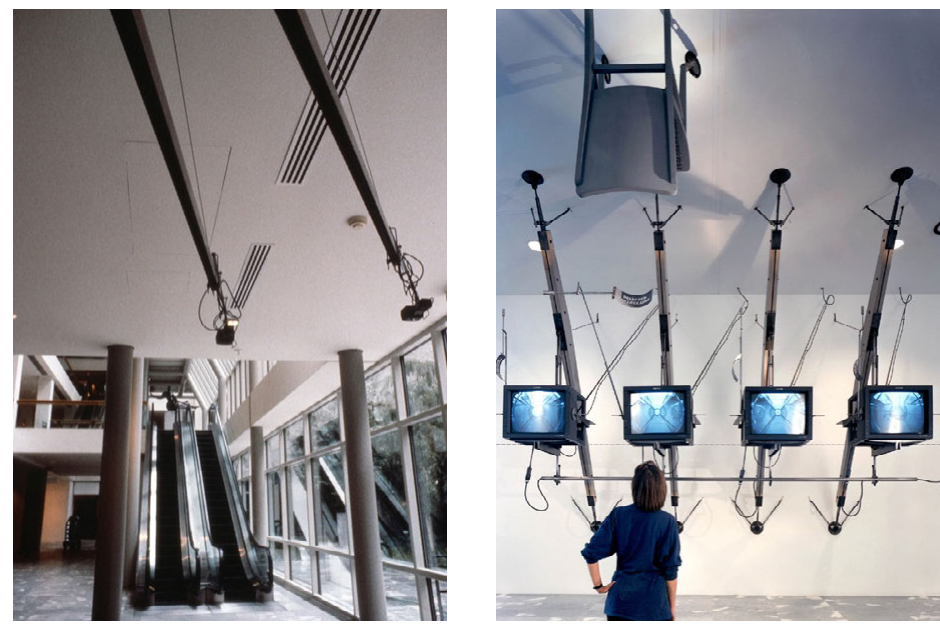

dizer sim ou não até que [a montagem] chegasse ao final, pois o que se fazia era realmente novidade". ${ }^{537} \mathrm{~A}$ instalação realizada por Diller e Scofidio para o museu em 1989 levou o nome de Para-site, um de seus projetos que procuravam abordar de modo crítico os sistemas de vigilância e controle que vinham se tornando mais e mais corriqueiros nos espaços públicos, incluindo os museus. $\mathrm{O}$ trabalho incluía câmeras de vídeo instaladas em pontos estratégicos de circulação do MOMA, como diante das portas giratórias de entrada e na chegada das escadas rolantes, e transmitiam ao vivo as imagens dos visitantes para monitores instalados na sala expositiva. A intenção expressa pelos autores era a de desvelar os códigos implícitos num ambiente dedicado a expor a arte, com um procedimento claramente metalinguístico: "a instalação conecta eletronicamente a Projects Room com três locais remotos de circulação do museu, vinculando espectadores autoconscientes e desavisados numa reflexão sobre o olhar - a atividade primária do museu". ${ }^{538}$ Uma linha tracejada desenhada nas paredes sugeria limites que dividiam virtualmente a sala, apontando também para o fato de a percepção do espaço estar vinculada sobretudo a uma construção mental abstrata e subjetiva, não a um dado a priori da realidade.

A galeria continha ainda elementos que criavam estranhamentos à percepção habitual de objetos familiares, como um
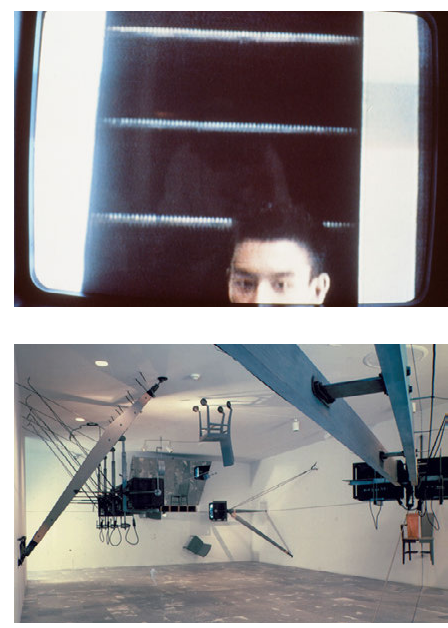

537 Ibidem.

538 Diller SCOFIDIO + RENFRO. Para-site. DSR-NY. Disponível em: $<$ https://dsrny.com/project/para-site>. Acesso em: 6 nov. 2020. 
539 Ibidem.

540 Ver segundo capítulo desta tese.

541 RENFRO, 2019, op. cit., 6'56" a 7’21”. Transcrição e tradução nossas. espelho instalado junto ao teto num ângulo de 45 graus, invertendo a visão de piso e teto, e cadeiras suspensas ou instaladas de cabeça para baixo diretamente no teto ou com rodízios e algumas cortadas ao meio, mostrando a estrutura interna como vértebras de uma espinha dorsal. Além dessa referência direta ao corpo humano, as estruturas de sustentação das câmeras e monitores de vídeo eram mais que apenas funcionais, mas desenhadas de modo a tornar bastante expressivas as articulações das peças de madeira e aço, artefatos de aspecto tecnológico que lembravam ao mesmo tempo patas de insetos de escala ampliada. O nome da obra, Para-site, chamava a atenção para o vínculo intrínseco com o seu site-specific - aquela determinada galeria inserida numa instituição em particular - e também remete à natureza "parasita" de uma instalação dentro de um museu. Conforme apresentação dos autores, "assim como o parasita tecnológico provoca interferência numa rede de informações, a instalação interrompe os sistemas do museu para interrogá-lo". ${ }^{539}$

Inserida no contexto da produção artística pós-moderna, a obra Para-site, assim como outros projetos de Diller e Scofidio, não se limitava a um meio específico, mas mesclava diversas disciplinas. As referências à história da arte eram múltiplas, indo das produções de Marcel Duchamp no contexto dadaísta aos corredores de vídeo realizados por Bruce Nauman no fim dos anos 1960 e podiam ainda ser relacionadas à primeira obra da série Projects, realizada em 1971 por Keith Sonnier. ${ }^{540}$ Tendo realizado diversos projetos a partir de cruzamentos entre as fronteiras da arquitetura e outras disciplinas, provocando curtos-circuitos e estranhamentos nos modos convencionais de percepção usuais, o estúdio DS+R estava agora do "do outro lado do balcão", elaborando projetos para os espaços "vazios" que seriam ocupados por outros artistas no MOMA, das maneiras mais inesperadas.

Segundo Renfro, essas novas galerias seriam os espaços do projeto que mais se aproximariam do novo conceito de curadoria do мома de dissolver fronteiras entre mídias e apresentar trabalhos de diferentes naturezas num único espaço - "a representação arquitetônica dessa ambição". ${ }^{541}$ Ao invés de uma arquitetura rebaixada, oferecendo apenas mais área para reprogramação como na maior parte das áreas expositivas, foi 
possível inserir, nessa pequena porção do museu, uma experiência arquitetônica mais qualificada. Trata-se de uma nota de exceção na sequência ainda mais longa de galerias da coleção, como observou o crítico de arquitetura do jornal The New York Times, Michael Kimmelmann:

Tive minhas dúvidas sobre essas galerias quando foram anunciadas pela primeira vez. Pareciam uma vaga desculpa para cavar uma passagem para o edifício de Nouvel. Mas acabaram sendo uma das melhores partes da expansão, possibilitando uma nova programação no museu e assinalando, de uma forma que grande parte do resto do museu não consegue, em direção à cidade como um todo. ${ }^{542}$

Assim como Para-site inseria-se na série Projects com referências a instalações anteriores, o projeto arquitetônico para as novas galerias sobrepostas se referenciava nos modos de expor nо момА, propondo discussões sobre modos de inserir a arte no museu. Ainda que tenham certa continuidade com os padrões de acabamento adotados nas galerias convencionais, as salas especiais criadas por DS+R não se configuram como espaço genéricos ou supostamente "neutros", pois foram desenhados em função das condições particulares de seu contexto específico - institucional e físico, do museu e da cidade - tanto quanto uma obra site-specific, destinando-se a abrigar variadas expressões artísticas contemporâneas.

Exceto por esse conjunto relativamente pequeno no edifício do MомA, vemos que, de modo geral, o DS+R não procurou agregar mais uma marca arquitetônica ao edifício, mas trabalhar a partir de um contexto dado, ainda que com mais discrição que em projetos anteriores, como observou a crítica da revista Architectural Record, Suzanne Stephens:

Ao contrário do Lincoln Center, onde o DS+R retrabalhou de modo brilhante um complexo modernista dos anos 1960, os esforços dos arquitetos aqui são mais sutis e exibem menos brio. No entanto, eles mostraram sofisticação e habilidade em ultrapassar os limites das técnicas e materiais atuais para melhorar o que encontraram. ${ }^{543}$
542 Kimmelman, Michael. With a \$450 Million Expansion, MoMA Is Bigger. Is That Better? The New York Times, 10/10/2019. ed. p. 1, 2019. Tradução nossa.

543 Stephens, Suzanne. Museum of Modern Art Addition by Diller Scofidio + Renfro in collaboration with Gensler. Architectural Record, 2/12/2019. ed. 2019. 
544 DAvidson, Justin. The New MomA Tries to Get Out of Its Own Way. We'll See If It Can. New York Magazine, 9/10/2019. ed. 2019. Tradução nossa.

545 Ibidem.
Se nas discussões de 1996 o museu manifestava uma preocupação sobre o que seria a expressão arquitetônica contemporânea adequada à sua nova sede, o momento atual e a natureza da encomenda demandavam uma outra postura, como apontou o crítico de arquitetura Justin Davidson: "hoje, os arquitetos afirmam com orgulho não oferecer uma assinatura, adaptando seus gostos às necessidades do trabalho. Ter um estilo saiu de moda." ${ }^{544}$

O crítico registrou ainda a abordagem de Diller sobre o modernismo, tema dominante nas discussões sobre expansão anterior: "O modernismo ainda não acabou [...]. Ainda o vivemos e o repensamos constantemente. Somos mais sábios e mais cínicos sobre algumas de suas aspirações utópicas, mas existem alguns grandes objetivos com os quais ainda trabalhamos." Um deles seria técnico: o de levar os materiais ao limite, como nas peças de aço extremamente delgadas empregadas em vários dos novos elementos do MомA, especialmente nas escadas (Blade Stair e Bauhaus Stair) e na marquise da rua 53. $\mathrm{O}$ outro objetivo seria social: encontrar um equilíbrio entre a democratização do museu e a superlotação típica dos aeroportos. "Décadas atrás, detratores diziam que o museu era muito elitista [...]. Agora dizem que tem público demais e é muito difícil comungar com uma obra de arte. É um dilema, e não tenho certeza se solucionamos bem." ${ }^{545}$

Como um museu não é um edifício para um fim utilitário - como um terminal de transportes, no qual os fluxos são mais dirigidos -, mas um local destinado a promover uma experiência sensível - que visa criar atmosferas favoráveis ao engajamento do público com a arte -, um projeto pode apenas apostar numa direção, sem ter garantias de que os objetivos serão atingidos. Em conversa com o crítico Jerry Saltz, publicada uma semana após a abertura do museu, Davidson comentou justamente esse aspecto difícil de antecipar e equilibrar:

a parte prazerosa da experiência é que o museu parece uma cidade grande, com toda a empolgação e desorientação que isso sugere. Você fica fazendo descobertas [...]. A parte frustrante é quando você quer desacelerar, sair do fluxo e apenas 
passar alguns momentos de silêncio com uma obra de arte que você adora. Achei isso virtualmente impossível. ${ }^{546}$

A avaliação dos resultados não pode, no entanto, ser imediata, mas depende de uma acomodação da parte da instituição - por meio da atuação dos curadores que organizam as exposições -, de artistas atuantes que propõe formas inesperadas de ocupação dos espaços e do público que irá se comportar de maneira imprevisível. Nesse sentido, esta tese assume um certo risco ao tratar de uma condição tão nova quanto a reinauguração recente do момА, mas procura apontar para os focos de atenção na observação do desenvolvimento de dinâmicas futuras no museu.

\subsubsection{NEUTRALIDADE, FLEXIBILIDADE E A EXPRESSÃO ARQUITETÔNICA NOS ESPAÇOS DE ARTE}

Mesmo lidando com as limitações dadas pelos edifícios pré-existentes, pelas intenções curatoriais e o pelo padrão expositivo do MомА, as duas últimas intervenções arquitetônicas conseguiram criar alguns espaços excepcionais no museu - o átrio de Taniguchi e o conjunto de galerias sobrepostas da equipe liderada pelo estúdio DS+R. Como temos visto no decorrer desta tese, o padrão desenvolvido pela instituição ao longo de suas nove décadas de existência envolvia a noção de neutralidade para os ambientes expositivos associado a uma demanda por flexibilidade para reprogramação das galerias, o que reduzia, de saída, o campo da arquitetura para a maior parte dos espaços dedicados à arte na sede do museu. Esse era o caso das galerias da coleção, ampliadas nas últimas reformas seguindo determinados paradigmas enraizados na cultura do museu, conforme relatou Elizabeth Diller:

Os curadores não gostam de fazer espaços altos além de seis metros de altura e há certos tipos de parâmetros dentro dos quais eles trabalham. É diferente de outras instituições com as quais trabalhamos. É também como se uma determinada arte se encaixasse em galerias assim, enquanto há obras que parecem não pertencer a esse tipo de espaço. A relação entre
546 DAvidson, Justin; SALTZ, Jerry, Two Critics - Art and Architecture - Compare Their MoMA Experiences. New York Magazine, 19/11/2019. ed. 2019. Tradução nossa. 


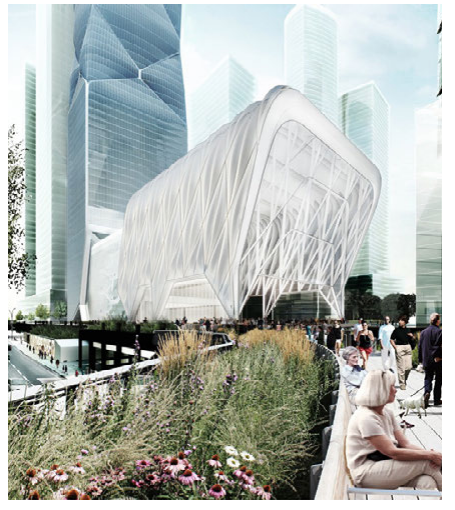

3.132 Perspectiva para The Shed, projeto de Diller Scofidio + Renfro e Rockwell Group, Nova York, 2019. Imagem: DS+R e Rockwell Group. Fonte: https://www. archdaily.com.br/br/01-105260/dillerscofidio-plus-renfro-projetou-um-galpaocultural-telescopico-para-nova-york?ad_ medium=gallery

547 Diller, 2017, op. cit.

Tradução nossa.

548 Ibidem. a arte e as galerias é muito estreita no final, então os artistas continuam fazendo obras numa dada escala porque são do tamanho das galerias, eu acho. Se houvesse galerias maiores ou mais altas, os artistas fariam coisas maiores ou mais altas - ou orçamentos maiores. ${ }^{547}$

Considerando que as características dos ambientes expositivos poderiam impactar a produção dos artistas, Diller afirmou ainda acreditar, a partir de sua experiência atuando como artista e arquiteta, que ao projetar espaços de arte, "a voz do arquiteto precisa ser reduzida para dar aos outros autores a chance de se expressar, pois não é possível 'apagar' a arquitetura e o espaço". ${ }^{448}$ No MoMA, essa redução estava dada a priori pelos padrões da instituição, que haviam sido mesclados com as características especiais das novas galerias. A mais divergente delas era, como vimos, a Studio Gallery, que, além da grande fachada envidraçada e dos acabamentos escuros, era toda transformável, configurada como um teatro black box para receber uma variada gama de produções artísticas. A ideia de espaços amplamente reconfiguráveis para arte contemporânea seria também o mote de um outro projeto do estúdio DS+R, The Shed, desenvolvido paralelamente ao do MoMA, mas sem as limitações de uma instituição pré-existente. Vale, portanto, examinar brevemente como um mesmo escritório abordou a questão dos espaços de arte contemporânea em condições radicalmente distintas.

The Shed era um complexo cultural totalmente novo, localizado numa das pontas do High Line Park, parte do projeto de desenvolvimento imobiliário da região de Hudson Yards, a oeste de Manhattan. Sua realização envolveu a aquisição por uma grande incorporadora do potencial construtivo do espaço aéreo sobre o terreno pertencente ao município e usado como pátio de manobras de trens da companhia metropolitana de transporte público de Nova York, a MTA. O município instituira um concurso em 2008 para eleger uma proposta para o centro cultural e o DS+R, em parceria com estúdio de design Rockwell Group, venceu apresentando um conceito de operação vinculado a um projeto arquitetônico, que acabou moldando a concepção da instituição. 

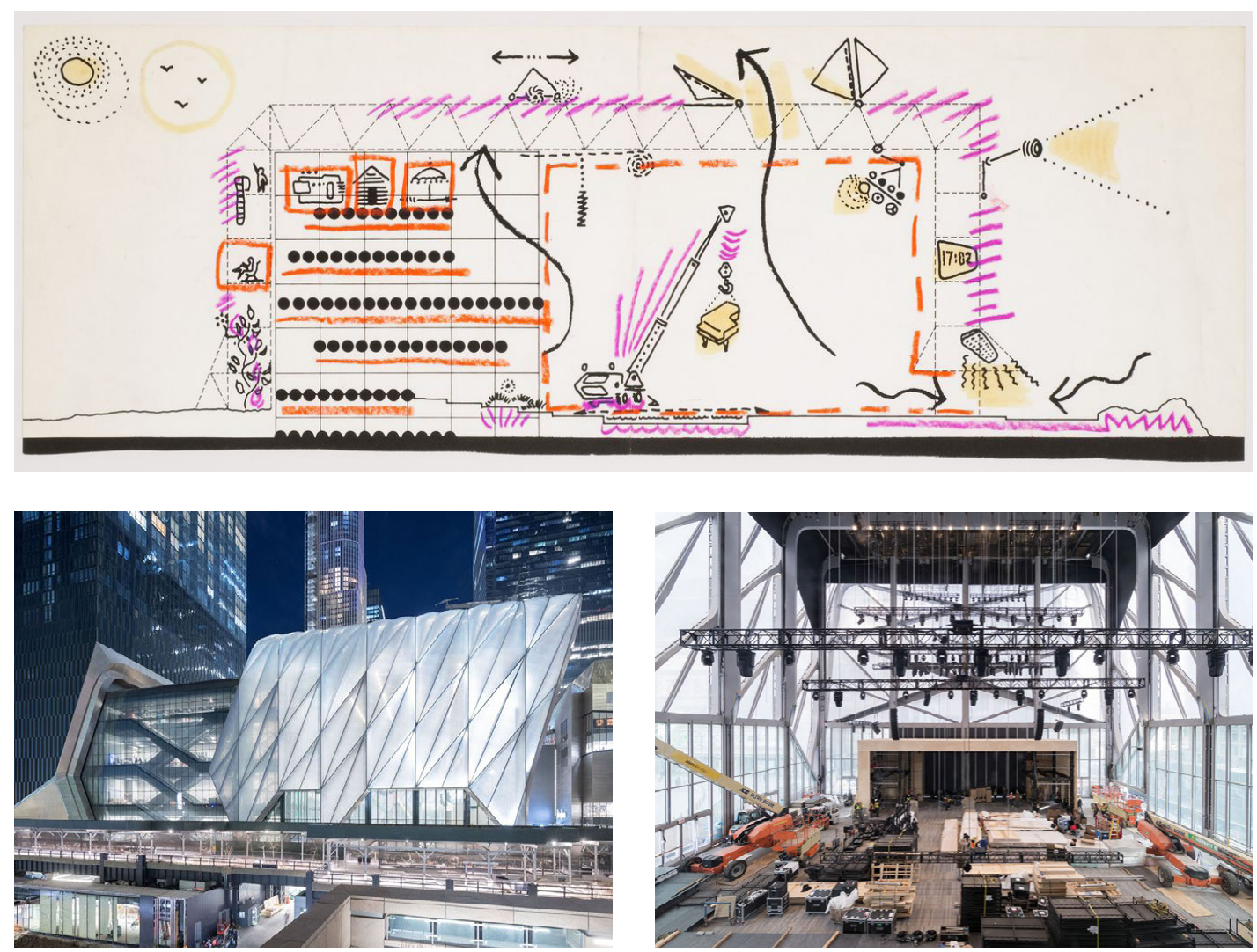

Com a pretensão de criar um edifício capaz de abrigar as mais variadas manifestações culturais possíveis de imaginar, a referência indicada pelos arquitetos para The Shed foi o projeto para o Fun Palace, o célebre centro multifuncional concebido entre 1959 e 1961 por Cedric Price (1934-2003). Embora não tenha sido realizado, o projeto do arquiteto britânico havia inspirado a concepção de projetos culturais contemporâneos tão diversos quanto os parisienses Centro Georges Pompidou - projeto de Piano e Rogers aberto em 1977 - e o Local de Criação Contemporânea do Palais de Tokyo - projeto de Lacaton e Vassal inaugurado de 2002 e 2012 - a serem abordados no próximo capítulo desta tese.

Inaugurado em abril de 2019 - seis meses antes do novo MOMA - o The Shed consiste num edifício de oito andares para
3.133 Corte do Fun Palace mostrando uso potencial do interior, projeto de Cedric Price, Londres, 1963.Fonte: Cedric Price fonds. Collection Centre Canadien d'Architecture/ Canadian Centre for Architecture, Montréal Copyright: (C) CCA. Fonte: https://www.cca.qc.ca/en/ search? page $=13 \&$ query $=$ fun + palace \&_= 1624483228275

3.134 e 3.135 Fachada e espaço interno do The Shed, projeto de Diller Scofidio + Renfro e Rockwell Group, Nova York, 2019. Foto: Iwan Baan. Fonte: https://iwan.com/portfolio/ the-shed-diller-scofidio-renro/\#22195 
549 Elizabeth Diller apud KinSELLA, Eileen. What Will the \$50o Million Shed Arts Center Actually Do? No One Seems toKnow. Artnet, 25/05/2017. ed. 2017. Tradução nossa.

550 DILLER, 2017, op.cit. Transcrição e tradução nossas. programas culturais e serviços, incluindo dois andares de galerias expositivas, um teatro versátil, salas de ensaio, ateliê para artistas e um espaço para eventos. Sobre esse bloco fixo desliza uma casca formada por uma estrutura metálica com fechamento translúcido e apoiada sobre quatro rodas, prolongando a área coberta à frente ou deixando-a aberta como praça. Uma série de outros dispositivos integrados às estruturas possibilitam expandir a versatilidade de uso ao conjunto, para abrigar e promover variadas atividades ligadas às artes visuais e performáticas e à cultura popular. No evento de divulgação da obra, Diller defendeu sua visão para a ampla flexibilidade de configurações espaciais previstas nesse projeto:

A oportunidade de projetarmos do zero um edifício para as artes nos obrigou a questionar: 'Como será a arte daqui a 10 anos? 20 anos? 30 anos?' E a resposta é que não podíamos saber. Os artistas de hoje estão trabalhando para além das disciplinas, em todas as mídias e escalas. Isso continuará mudando. A única coisa sobre a qual poderemos sempre ter certeza é que sempre haverá necessidade de espaço, necessidade de capacidade estrutural para carga e necessidade de energia elétrica. ${ }^{549}$

Considerando as condições mais desimpedidas de concepção desse projeto, podemos considerar que ele representa a visão ideal de seus autores sobre o que arquitetura poderia oferecer, em essência, para abrigar a multifacetada arte contemporânea, considerando toda a indefinição futura. Segundo Diller, o projeto "é realmente uma máquina de criar espaço para a arte - trata-se apenas de estrutura e infraestrutura [...]. Tendo isso, é possível fazer qualquer coisa." ${ }^{550} \mathrm{~A}$ concepção manifestada pela arquiteta aponta para uma radical flexibilidade vinculada à transformação como aposta para um edifício destinado a propostas culturais tão abertas quanto essa, relegando a configuração espacial para os usuários, nesse caso programadores e artistas. O Culture Shed, no entanto, não deixa de produzir uma imagem icônica com sua impressionante casca deslizante.

No caso do MомA, a flexibilidade também era uma demanda de projeto, uma pré-condição para que os curadores pudessem 
ter liberdade de montar as exposições, especialmente no caso das galerias da coleção. A transformação não significava poder alterar radicalmente os espaços, mas ter liberdade para estruturar percursos variados, escapando da linearidade excessiva, dispondo de mais área para apresentar, além da grande quantidade de obras canônicas incontornáveis, obras menos conhecidas que pudessem oferecer interpretações alternativas da história da arte moderna e contemporânea. Sobre as novas galerias convencionais sob a torre de Jean Nouvel, Diller comentou:

Eles apenas acrescentaram mais espaço, porque o que é novo para o MOMA não é necessariamente novo para outras instituições. Então, você olha para as galerias Taniguchi, elas são todas paredes fixas, portais, aberturas, todas têm cerca de 12 por 15 metros, são galerias realmente grandes e a circulação é difícil. Eles realmente precisavam de flexibilidade no sentido literal, eles querem poder fazer espaços pequenos e grandes, mas querem fazê-lo sob demanda e não querem ter que dizer: aquele pequeno trabalho sempre vai estar sempre naquele canto. Eles querem simplesmente poder reorganizar o espaço o tempo todo. Talvez seja uma maneira mais comum de pensar sobre flexibilidade..$^{551}$

Já nas galerias sobrepostas junto à fachada da rua 53, a flexibilidade está principalmente na oferta de espaços com caráter singular, com diferentes proporções e perspectivas visuais. Desse modo, a arquitetura e suas relações com a cidade tornam-se uma pré-condição para a curadoria e os artistas, o que, se por um lado coloca limites à reconfiguração dos espaços, abre possibilidades que um ambiente "genérico" não pode oferecer. Vemos, portanto, que há várias alternativas de dotar a arquitetura destinada a espaços de arte da necessária qualidade de flexibilidade, para além do tipo de mutabilidade ostentada no projeto para o Culture Shed. Entre elas estão tanto o rebaixamento da expressão da arquitetura e a oferta de grandes áreas - como nas galerias da coleção do MOMA -, quanto o seu oposto, a configuração arquitetônica vinculada ao seu lugar de implantação, físico e cultural - como nas novas galerias sobrepostas do museu. 


\subsubsection{ARTE NAS ÁREAS INTERSTICIAIS DO MUSEU}

Uma das premissas adotadas por esta tese é a de que, em qualquer espaço destinado à arte, a avaliação das virtudes e limitações da arquitetura fica incompleta se feita de modo descolado de sua ocupação posterior por outros atores, curadores e artistas, que podem interagir com ela de maneiras variadas, enriquecendo-a ou abafando-a em diferentes graus. Enquanto o projeto de Taniguchi já acumulou mais de 15 anos de experiências que exploraram e revelaram seu potencial de ocupação, a reforma e expansão liderada por DS+R é ainda muito recente, tendo completado pouco mais de um ano no momento da redação deste capítulo da tese. A análise possível da interação da arte com a atual configuração arquitetônica do MOMA deve assumir, portanto, as limitações do fato de só poder abordar, por enquanto, uma pequena amostra da ocupação do edifício renovado, baseando-se em visita ao edifício e às exposições de inauguração em novembro de 2019 - um mês após a reabertura do museu -, em diversas publicações a esse respeito pela crítica especializada e em material publicado no site do museu sobre algumas das exposições seguintes. ${ }^{552}$

Se antes da última reforma era preciso percorrer uma série

552 A redação deste capítulo da tese transcorreu no segundo semestre de 2020 e primeiro de 2021. A primeira troca de exposições do Moma ocorreu abril de 2020, o que coincidiu com o início do período de fechamento do museu por conta da pandemia de Covid-19. O museu foi reaberto em 27 de agosto de 2020 , mas passou a operar em condições excepcionais, com horário reduzido e número muito limitado de visitantes para evitar aglomerações.

553 Cf. The Museum of Modern ART. Public Space Artist Commissions. MOMA. Disponível em: <https://www.moma.org/calendar/exhibitions $/ 5170^{>}$. Acesso em: 20 jun. 2021. de espaços até ter o primeiro contato com a arte no MoMA, agora havia uma obra disposta no primeiro espaço de chegada, o saguão estendendo-se da rua 53 à 54. Tratava-se de Echo, um environment do artista francês Philipe Parreno (1964-), um dos seis trabalhos site-specific comissionados na ocasião de sua reabertura para os espaços intersticiais - chamados pelo museu de públicos, embora nem todos de livre acesso -, sob supervisão da curadora Yasmil Raymond, do Departamento de Pintura e Escultura. ${ }^{553}$ Echo é um conjunto autômato composto por vários elementos dispostos nas paredes e no teto: dois alto-falantes móveis, uma veneziana, uma tela de vídeo e algumas luminárias móveis e a marquise da entrada. Coordenados por um equipamento denominado de "cérebro", as peças captam dados relativos a condições atmosféricas no interior do edifício e no seu entorno - como dados climáticos e a presença de pessoas no saguão -, respondendo a elas aleatoriamente com movimento, acendimento de lâmpadas, acionamento de vídeos e emissão de 

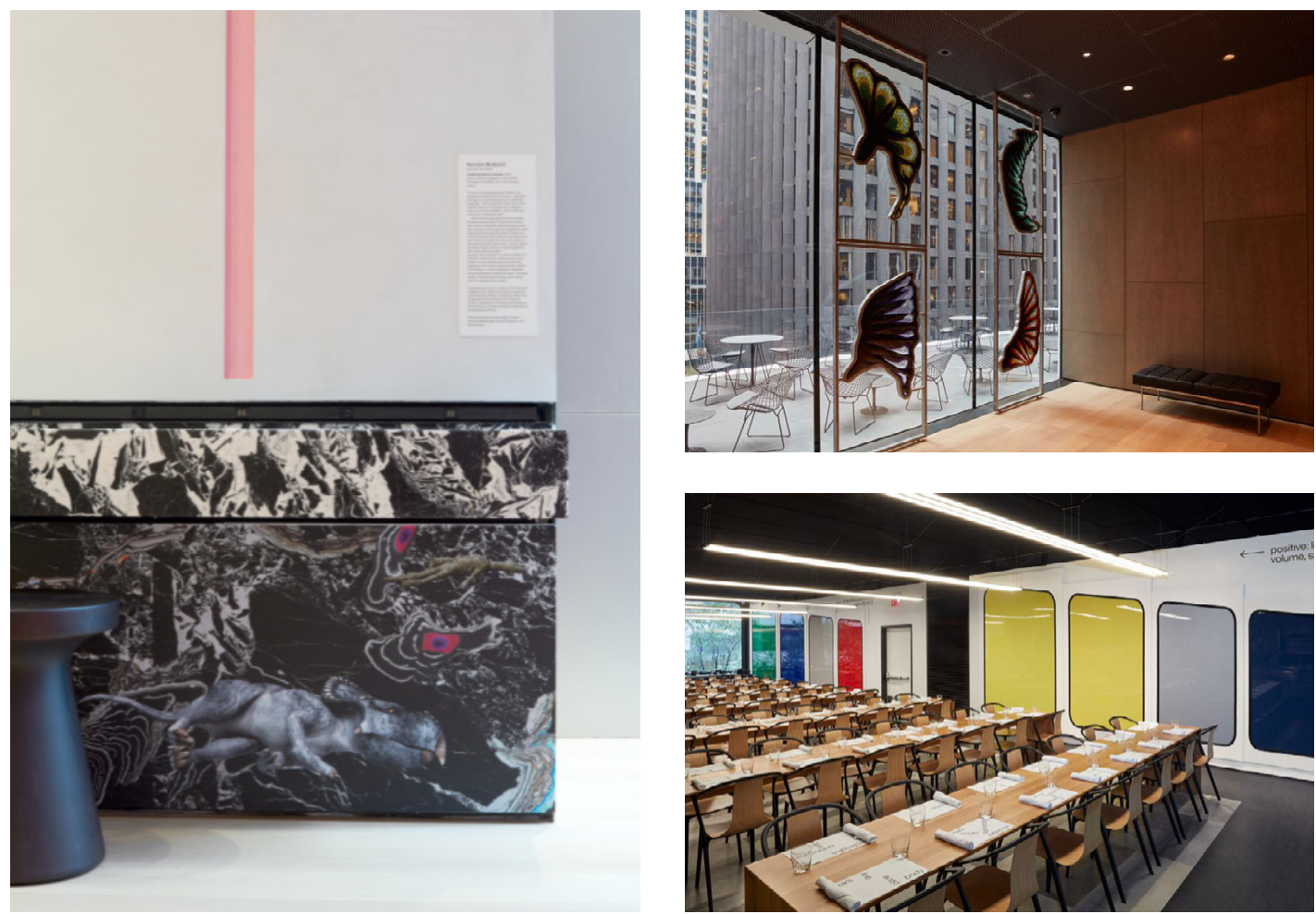

existente a obra Towards an Alphabet Dino Runes, uma espécie de papel de parede com motivos de dinossauros, dialogando diretamente com os elementos arquitetônicos. Na fachada de vidro do saguão de chegada da escada, foi instalada ainda a obra Single Brushstrokes in Lead (Embryo, Rat, Elephant, Fin), composta por quatro vitrais descritos pela artista como "fósseis de uma pincelada", destoantes da ambiência impessoal do espaço e do detalhamento ultrassofisticado da esquadria. ${ }^{555}$ Por complementação ou contraste, o conjunto de intervenções de Kerstin colocava sua linguagem particular em diálogo com as características plásticas da arquitetura.

O café do segundo pavimento, no bloco de Phillip Johnson, recebeu a obra Full Scale False Scale, do coletivo de design gráfico Experimental Jetset, composto pelos holandeses Danny van den Dungen, Marieke Stolk e Erwin Brinkers. Os designers
3.142 Experimental Jetset, Full Scale False Scale (2009), em exposição na cafeteria do MoMA, Nova York, 2019. Foto: Heidi Bohnenkamp. Fonte: https://www.moma. org/slideshows/525

555 Cf. The Museum of Modern ART. Kerstin Brätsch: Fossil Psychics for Christa (2019). MOMA. Disponível em: <https:// www.moma.org/calendar/exhibitions $/ 5170$ ?slideshow $=523 \&$ slide $=0>$. Acesso em: 3 nov. 2020 . 


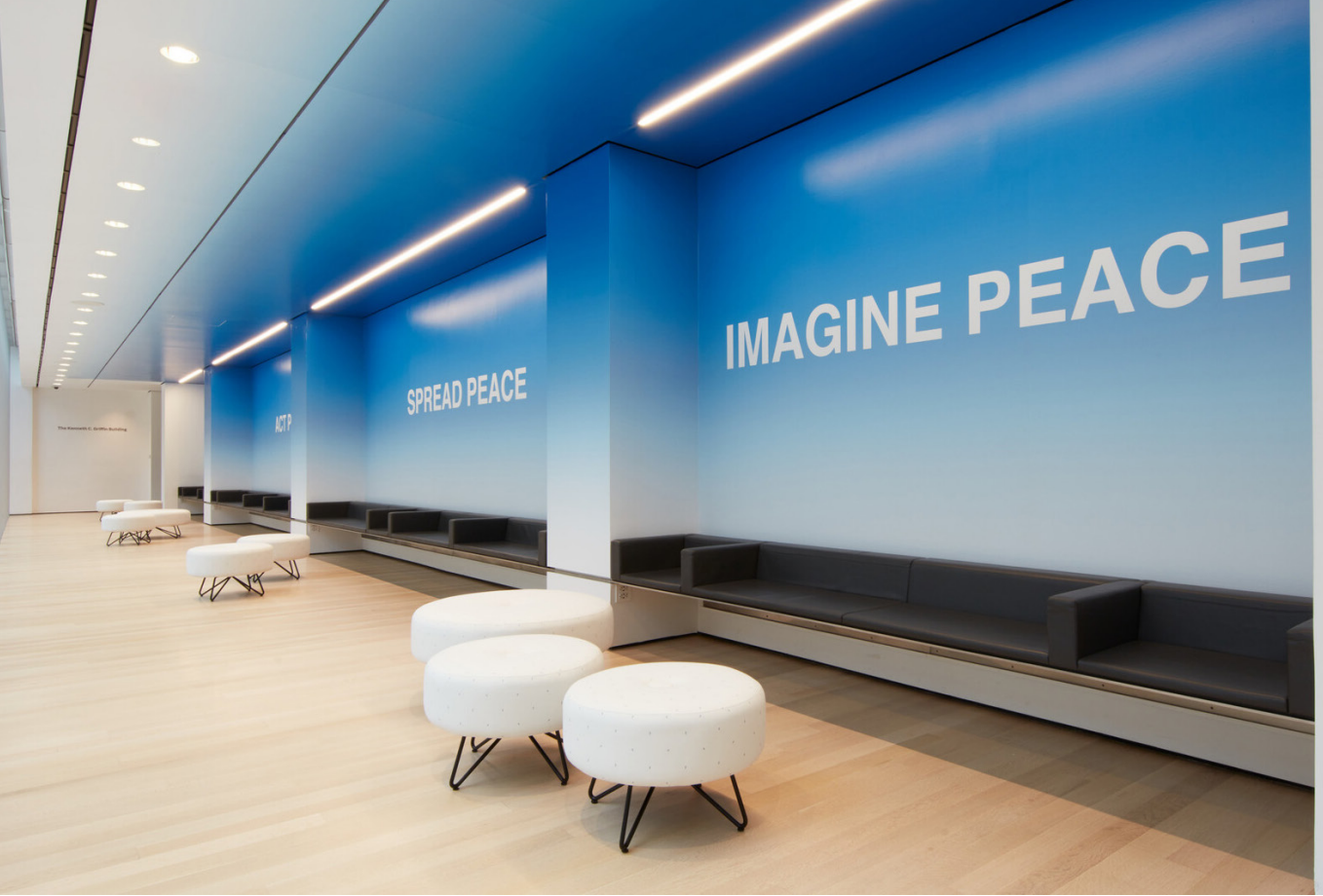

3.143 Yoko Ono, PEACE is POWER (2019), em exposição numa área de circulação do MoMA, Nova York, 2019. Foto: Heidi Bohnenkamp. Fonte: https://www.moma. org/slideshows/527
556 Cf. THe Museum of MOdern ART. Yoko Ono: PEACE is POWER (2019). MOMA. Disponível em: $<$ https:/www.moma.org/calendar/ exhibitions $/ 5170$ ?slideshow $=527 \&$ slide_index $=0>$. Acesso em: 3 nov. 2020. instalaram nas paredes painéis de alumínio recortados com os mesmos contornos de cantos arredondados das esquadrias do próprio edifício de 1964, pintados com as cores usadas em 1928 por Theo van Doesburg, Sophie Taeuber-Arp e Jean Arp no interior de um café na Áustria, unindo referências de duas pontas da arquitetura modernista. Ampliando o caráter imersivo da intervenção, expressões relacionadas a teorias modernistas de cor e espaço foram aplicadas junto aos painéis das paredes e ainda nos jogos americanos sobre as mesas.

Por fim, a obra PEACE is POWER, da japonesa sediada nos EUA Yoko Ono (1933-), foi instalada num estreito corredor envidraçado no terceiro pavimento do bloco de Goodwin e Stone, voltado para o jardim de esculturas. ${ }^{556}$ Dando continuidade à série "Imagine Peace", iniciada em 2000, a artista inscreveu na longa parede pintada de azul celeste as frases "THINK PEACE", "ACT PEACE", "SPREAD PEACE” e "IMAGINE PEACE”, aplicou o título da obra em 24 idiomas na fachada de vidro e a palavra "yes" escrita à mão no estofado do comprido sofá, transformando integralmente um espaço de passagem numa obra imersiva. 

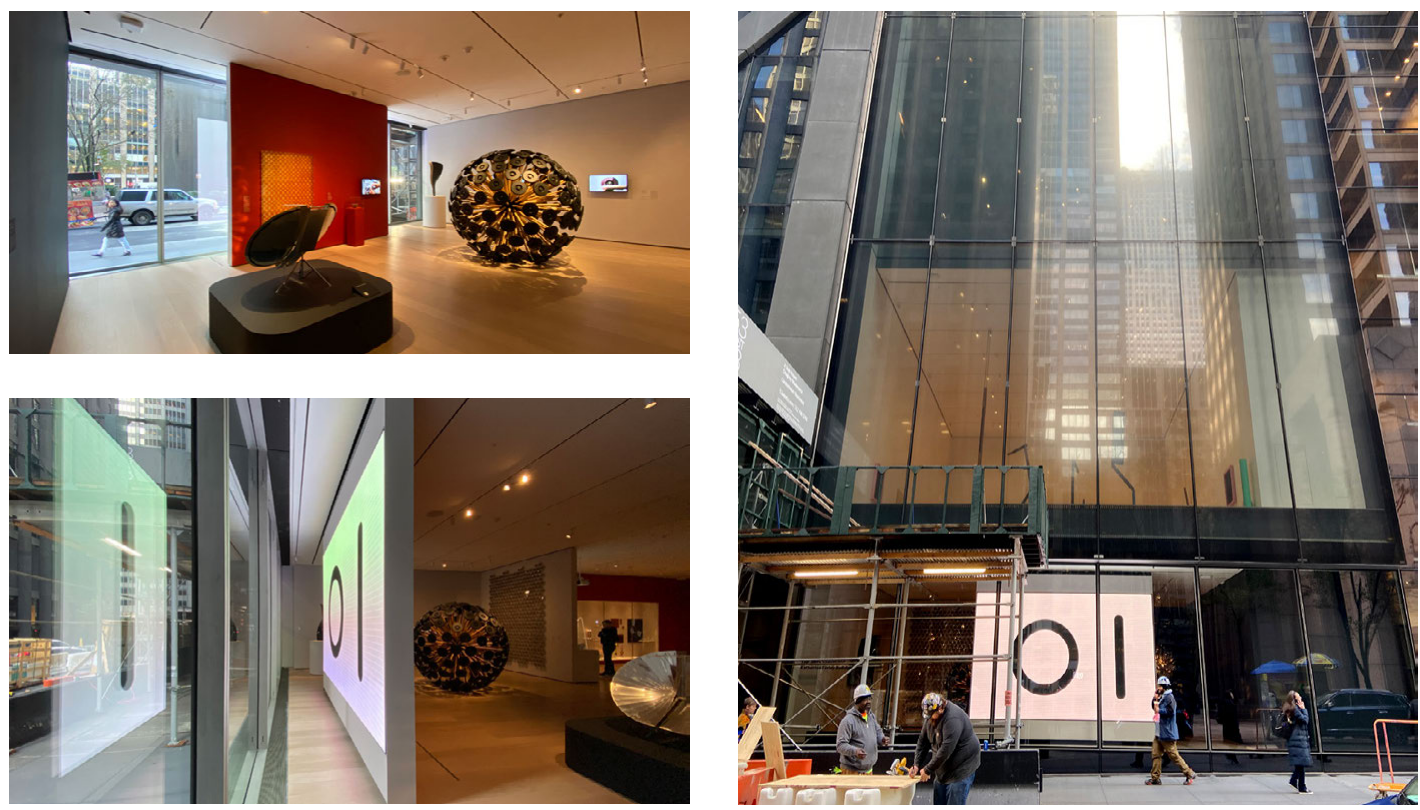

Cada uma a seu modo, as obras comissionadas para o MOMA tiravam partido de ambientes não originalmente destinados a exposições, transformando variados espaços arquitetônicos em arte. No entanto, apenas as obras localizadas no térreo tinham acesso franqueado, como também era o caso das duas novas galerias ao lado da Blade Stair, a oeste da entrada. Nas exposições de abertura, essas salas não receberam exposições que exploraram suas características arquitetônicas especiais, privilegiando o conteúdo artístico e perspectivas curatoriais relativamente independentes de seus locais de instalação. A Street Level Gallery, voltada para a fachada, foi ocupada com a exposição coletiva Energy, organizada pela curadora Paola Antonelli e a assistente Anna Burckhardt, do Departamento de Arquitetura e Design. ${ }^{557}$ A mostra reunia peças de design produzidas nas últimas décadas que interagiam de diferentes maneiras com energia - térmica, cinética, elétrica ou reprodutiva -, propondo alternativas para um cenário futuro com menos recursos disponíveis. Para criar mais superfícies expositivas, a pequena sala foi subdividida em dois ambientes com painéis provisó-
3.144 a 3.146 Vista da exposição Energy na Sala 1 South (Street Level Gallery), MoMA, Nova York, 2019. Foto: nossa.
557 Cf. The Museum of Modern ART. Energy (Oct 21, 2019-Jan 26, 2020). MOMA. Disponível em: $<$ https://www.moma.org/calendar/ exhibitions/5100 $>$. Acesso em: 6 nov. 2020. 
558 Cf. The Museum of Modern AR. Projects 110: Michael Armitage (Oct 21, 2019-Jan 20, 2020). МОМА. Disponível em: <https:// www.moma.org/calendar/ exhibitions/5099>. Acesso em: 25 out. 2020.

559 Cf. The Museum of ModerN ART. Neri Oxman: Material Ecology (May 14-Oct 18, 2020). MOMA. Disponível em: <https:// www.moma.org/calendar/ exhibitions/5090 $>$. Acesso em: 25 out. 2020. rios apoiando objetos de parede, textos, projeção de vídeos e vitrines e o no centro do espaço foram dispostas peças maiores, apoiadas diretamente no piso ou sobre bases. Além do branco acinzentado adotado como cor padrão das paredes das galerias do museu, foram utilizadas em algumas superfícies cores mais marcantes, como o vermelho, o azul e o preto. No terço central da fachada voltada para a rua, foi construída uma parede opaca afastada cerca de $80 \mathrm{~cm}$ da esquadria de vidro, utilizada como superfície expositiva na face interna e do lado oposto com um painel de vídeo embutido, exibindo para o exterior uma imagem em movimento dos componentes gráficos que formam o símbolo de ligado e desligado, onipresente em equipamentos eletrônicos. Vista da rua, com o painel de vídeo destacado em primeiro plano, a sala expositiva podia facilmente ser confundida com uma loja. Além disso, com a profundidade visual interrompida pelas subdivisões e a dimensão reduzida de boa parte dos objetos, a exposição não era especialmente convidativa para os transeuntes, possivelmente anestesiados pelas vitrines chamativas daquela região da cidade.

Localizada mais ao fundo, estava a mostra Projects 110: Michael Armitage, organizada pelas curadoras Thelma Golden e Legacy Russel, do The Studio Museum in Harlem, com o qual o MoMA estabelecera uma parceria para organização conjunta de exposições. ${ }^{558}$ Embora de grandes dimensões, as oito pinturas realizadas pelo artista nascido em 1984 no Quênia e sediado em Londres - incorporando elementos tanto da arte europeia quanto da produzida no leste da África - ocupavam apenas uma pequena faixa do pé direito duplo da nova Projects Room. Vemos que nas duas exposições inaugurais apresentadas nessas salas do térreo, a espacialidade dos novos espaços não foi um dado significativo para as escolhas curatoriais, pois ambas as exposições não exploraram as qualidades arquitetônicas que as diferenciavam das salas convencionais das demais galerias do museu.

Mais bem-sucedida nesse sentido foi exposição seguinte, Neri Oxman: Material Ecology, inaugurada em maio de 2020, também com curadoria de Antonelli e Burckhardt. ${ }^{559}$ A mostra expunha trabalhos desenvolvidos pela designer e arquiteta de origem israelense Neri Oxman (1976-) e seu grupo de pesqui- 

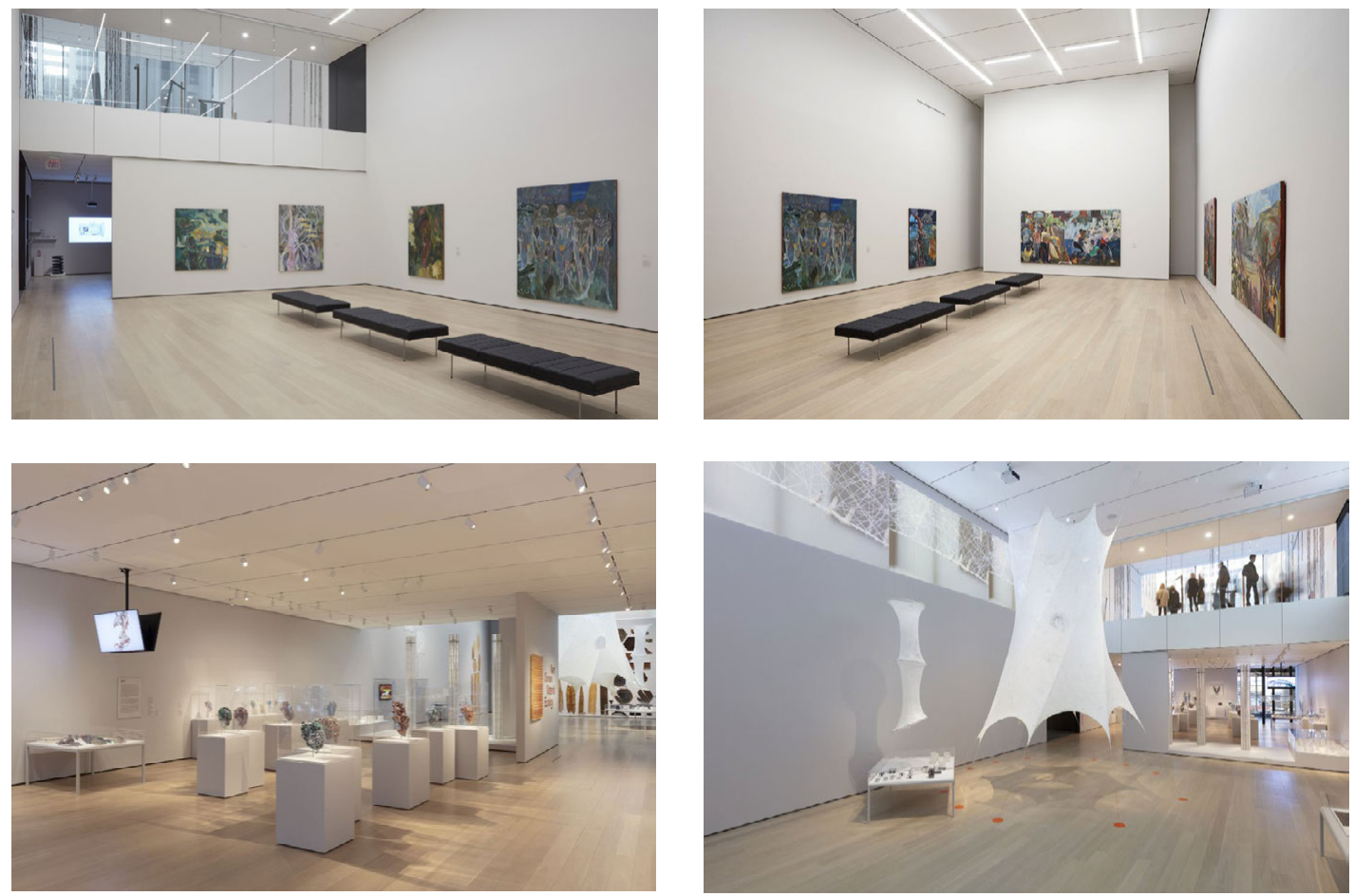

sadores do grupo Mediated Matter, sediado no MIT Media Lab, envolvendo ciência dos materiais, tecnologias de fabricação digital e design orgânico. Além de utilizar as duas salas ao mesmo tempo, tirando partido da profundidade visual, a montagem explorou também a altura da Projects Room ao fundo, com uma grande peça chamada Silk Pavilion, uma estrutura de tecido produzida por bichos da seda sobre uma malha espacial construída em laboratório, apontando para as possibilidades de parceria e coabitação entre animais e humanos. Outros tipos de material produzidos dessa forma foram dispostos suspensos no teto, em paredes, bases ou vitrines e toda a faixa superior da Projects Room foi ocupada por projeções de vídeo mostrando os processos de fabricação das peças. Na fachada para a rua da Street Level Gallery, manteve-se o painel opaco no terço central, mas a conexão visual entre as salas e a forma ocupação dos espaços criava mais interesse tanto para quem estava do lado
3.147 e 3.150 Vista da Sala 1 North (Projects Gallery) na exposição Projects 110: Michael Armitage, MoMA, Nova York, 2019. Foto: Heidi Bohnenkamp. Fonte: https://www.moma.org/calendar/ exhibitions/5099

145 e 146 Vista das Sala 1 North (Projects Gallery) e 1 South (Street Level Gallery) na exposição Neri Oxman: Material Ecology, MoMA, Nova York, 2020. Foto: Denis Doorly. Fonte: 


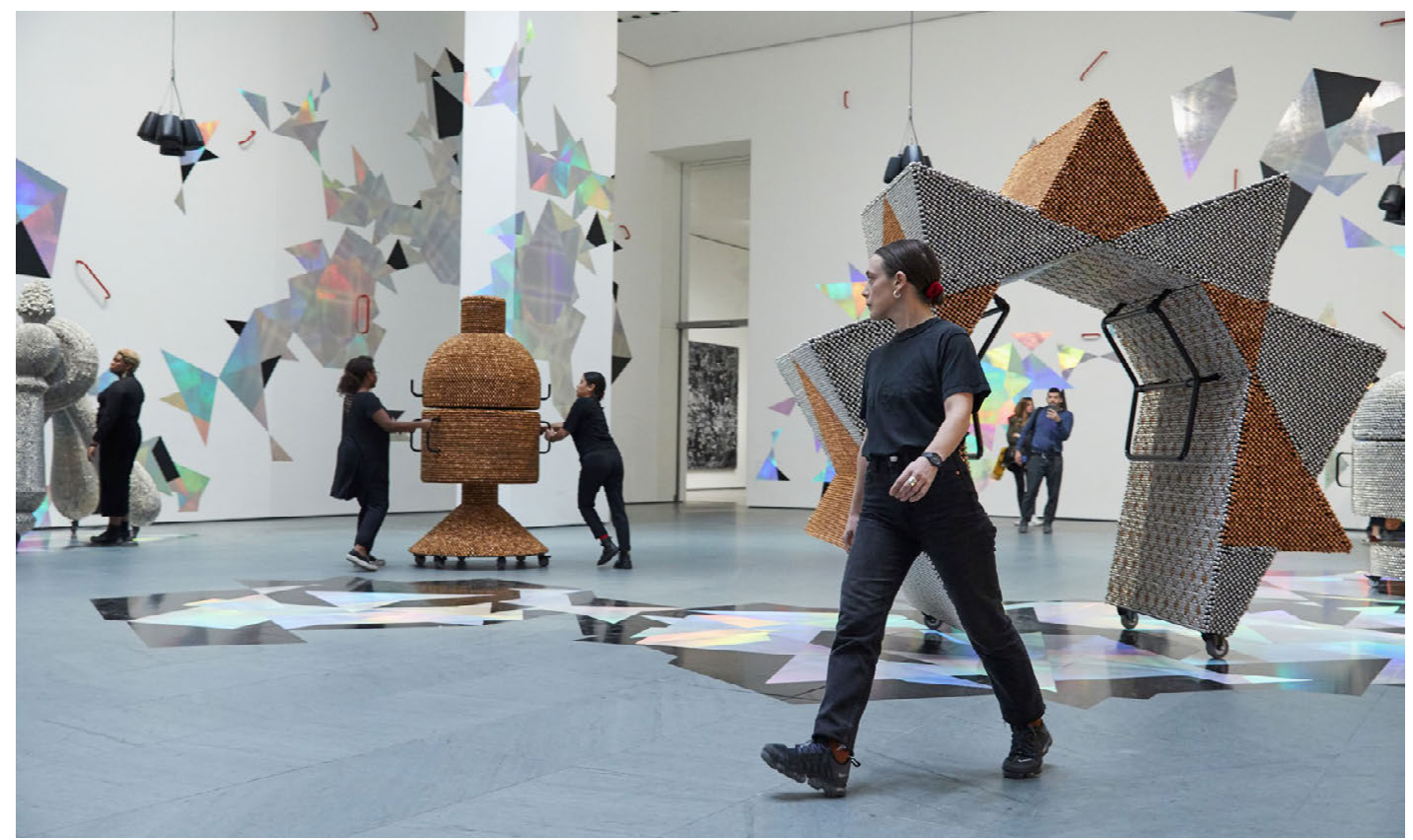

3.151 Vista da exposição Haegue Yang: Handles, MoMA, Nova York, 2019. Foto: Denis Doorly. Font e: https://www.moma. org/calendar/exhibitions/5080 de fora do museu quanto para quem observava a exposição a partir do andar de cima.

Embora não fosse franqueado, o átrio continuava sendo o espaço focal do museu, destinado à circulação e ao mesmo tempo à arte. Na reabertura do MOMA em 2019, esse grande espaço recebeu, mais uma vez, uma instalação performática: Handles, comissionada à artista coreana Haegue Yang (1971-), com curadoria de Stuart Comer, do Departamento de Mídia e Performance e Taylor Walsh do Departmento de Desenhos e Gravuras. Seis esculturas com formas que remetiam a grandes maçanetas em escala ampliada e a outras referências tinham apoios sobre rodízios e alças para serem deslocadas numa coreografia pré-definida, ativando o som de pequenos sinos que envelopavam as formas. A ocupação do espaço se completava por grupos de triângulos pretos e furta-cor aplicados no piso e nas paredes - que também recebiam alças - e alto-falantes que pendiam do teto, reproduzindo sons de pássaros. Conforme apresentação do museu, a intenção era "criar um ambiente 
ritualizado e complexo com ressonância pessoal e política", ${ }^{560}$ mas a condição do átrio - ruidoso e tendendo à dispersão - dificultava o acesso do público aos conteúdos cifrados do trabalho, que não eram apreendidos apenas na vivência da obra, mas dependiam de informações textuais complementares.

\subsubsection{A NOVA APRESENTAÇÃO DA COLEÇÃO}

O foco da renovação do Moma estava, como já vimos, na nova forma de conceber a apresentação da coleção. Antes de entrar na análise da interação entre arte e arquitetura nas galerias ampliadas que receberam as exposições reconfiguradas, vamos retomar ponto a ponto as novas demandas curatoriais que impulsionaram o museu a empreender mais uma expansão e reforma.

Segundo Ann Temkin, o MoMA passava por uma alteração sem precedentes nos modos de abordar a arte, refletindo uma conjuntura mais ampla: "Os últimos cinco a dez anos são os de maior mudança e de revisão radical para a história da arte e, por extensão, para a curadoria do museu nesse meio século [...]. Coisas assumidas nos últimos quarenta, vinte, dez ou até cinco anos foram desmanteladas. ${ }^{\text {"61 }}$ Se o museu sempre declarara que a autocrítica era parte constituinte do entendimento da arte moderna e contemporânea, essa postura ainda não tinha produzido uma reformulação tão profunda na apresentação da coleção. No volume MOMA Now, lançado na ocasião da reabertura em 2019, o texto "Reimagining the Modern", assinado pelos curadores chefes dos seis departamentos, ${ }^{562}$ explicitou com grande ênfase essa autocrítica:

As galerias que os visitantes agora encontram representam as convicções de uma nova geração de curadores-chefes, que passaram os últimos anos trabalhando juntos para conceber um modo de apresentação que consideramos fiel ao nosso próprio tempo. Nossa abordagem do acervo do museu reflete muito mais que opiniões individuais; indica uma reconsideração intensiva da prática curatorial atualmente em curso em museus de todo o mundo. Com base em desenvolvimentos
560 Cf. The Museum of Modern ART. Haegue Yang: Handles (Oct 21, 2019-Feb 28, 2021). МOMA. Disponível em: <https://www. moma.org/calendar/exhibitions/5080>.

561 Ann Temkin apud SALTz, Jerry, What the Hell Was Modernism? The Museum of Modern Art tries to open itself up. New York Magazine, 2/10/2019. ed. 2019. Tradução nossa. apud ibidem. Tradução nossa.

562 Quentin Bajac (Fotografia), Christophe Cherix (Desenhos e Gravuras), Stuart Comer (Media e Performance), Rajendra Roy (Filme), Martino Stierli (Arquitetura e Design) e Ann Temkin (Pintura e Escultura). 
563 THe Museum OF MOderN ART. MoMA Now. Nova York: The Museum of Modern Art, 2019, p. 19-20. Tradução nossa.

564 Cf. CoHen, Alina, The 5 Biggest Changes to Look for at the New MoмA. Artsy, 11/10/2020. ed. 2020 .

565 SALTz, What the Hell Was Modernism? The Museum of Modern Art tries to open itself up, op. cit. Tradução nossa.

566 The Museum of Modern ART, MoMA Now, 2019, op. cit, p.26. Tradução nossa. acadêmicos que datam de muitas décadas, o pensamento curatorial foi além do modelo familiar de uma história linear da arte, na qual o trabalho de um artista, um movimento, inexoravelmente leva ao próximo em uma evolução progressiva. O princípio de organização de um cânone, com sua ênfase na definição de mestres singulares, parece fora de sintonia com o interesse atual em elucidar um tecido complexo de múltiplas histórias, muitas das quais estão totalmente ausentes das narrativas baseadas em cânones. Aqui no MomA, nossa insatisfação com uma abordagem canônica no século xxı tem particular pungência, pois a própria história institucional do Museu está fortemente ligada à tal narrativa da arte moderna. ${ }^{563}$

Um dos aspectos básicos dessa desconstrução do cânone envolvia selecionar as obras de modo a equilibrar a representatividade dos artistas, expondo uma diversidade maior de atores, como já vinha acontecendo no museu, mas de modo limitado pela desproporção entre volume de acervo e espaço disponível nas galerias. A montagem inaugurada em 2019 contou com aproximadamente 2.400 itens da coleção - 1000 a mais do que antes $-{ }^{564}$ dos quais, segundo estimativa do museu, $28 \%$ eram produzidos por mulheres - contra 5\% em 2004 - e $21 \%$ por artistas de fora da Europa Ocidental, dos EuA e do Canadá. Na opinião do crítico Jerry Saltz, essa nova proporção seria "enorme para o MOMA, para o modernismo e para a arte". ${ }^{565}$ Mas a renovação pretendia não apenas substituir uma narrativa por outra - mais inclusiva -, mas abrir-se a possibilidades variadas de interpretação da história da arte moderna e contemporânea:

Nosso objetivo não é simplesmente melhorar um cânone aceito há muito tempo, adicionando um conjunto de artistas que não foram incluídos antes. Em vez disso, estamos fazendo perguntas sobre como artistas e obras de arte recentemente reconhecidos, do passado e do presente, transformam nossos pontos de vista sobre esse chamado cânone e como eles nos convidam a reconfigurar narrativas da história da arte que haviam sido pensadas como firmemente estabelecidas. ${ }^{566}$ 


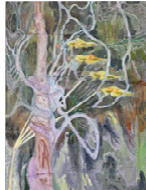

Fall 2019

1 North

Mrojects 110:

Oct 21, 2019-Jan 20, 202

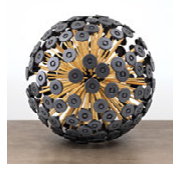

Fall 2019 1 South
Energy Energy
Oct 21, 2019-Jan 26, 2020

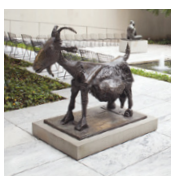

Fall 2019-Spring 2020 Sculpture Garden A Century of Sculpture Oct 21, 2019-May 2020
Pablo Picasso. She-Goat. 1950 (cast 1952)

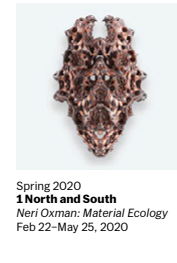

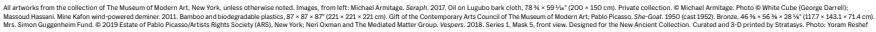
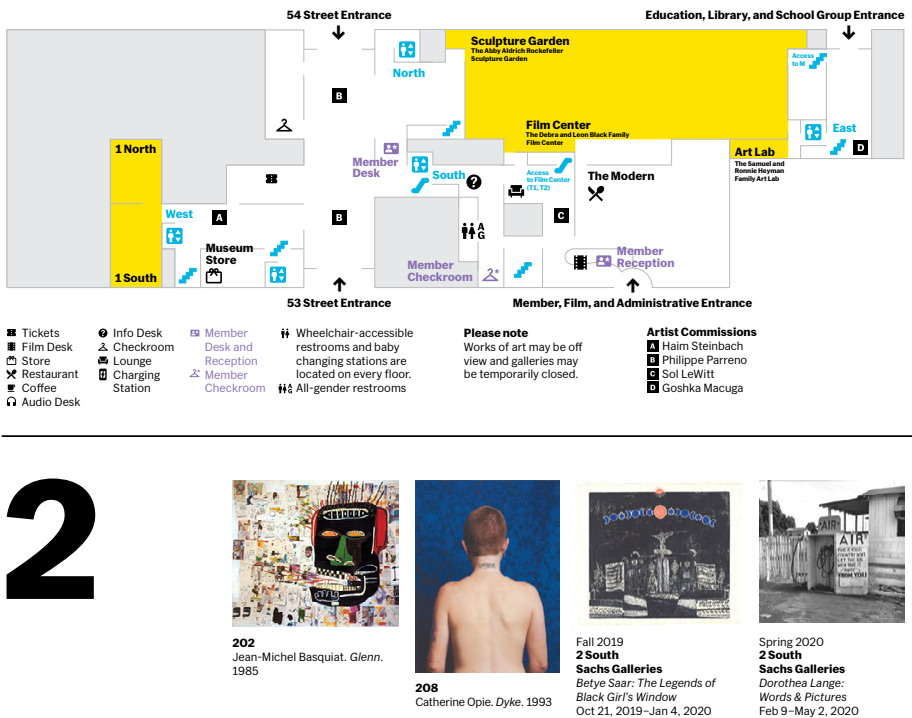

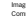

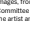

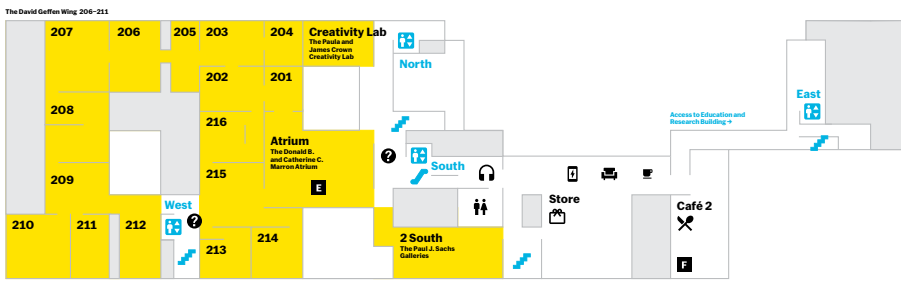

Collection

201 Public Images

202 Downtown New York

204 Gretchen Bender's Dumping Core O05 Print, Fold, Send 206 Transfigurations 208 True Stories
209 Inner and Outer Space 210 Richard Serra's Equal 211 JoDI's My\%Desktop 213 All People 214 Surface Tension
215 Worlds to Come
216
Building Citizens Artist Commissions Artist Commissions
E Haegue Yang 213 Wu Tsang's We hold
where study
3.152 a 3.157 Mapa de visitação dos pavimentos 1 a 6 do MoMA, Nova York, Outono de 2019 a Primavera de 2020. Fonte: https://www.moma.org/ momaorg/shared/pdfs/docs/visit/ Visitor_Guide_10_10_19.pdf 

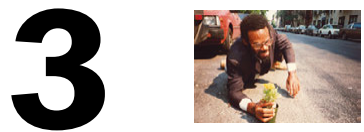

Fall 2019
3 South

3 South

member: Pope.L, 1978-2001

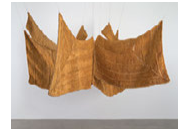

Fall 2019-Spring 2020

3 North

Johnson Galleries oct 21, 2019-Apr 2020
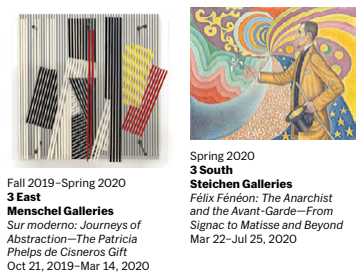

Spring 2020 3 South Steichen Galleries
Félix Fénéon: The Anarchtst Elix Feneon: The Anarchist Signac to Matisse and Beyon Mar 22-Jul 25, 2020
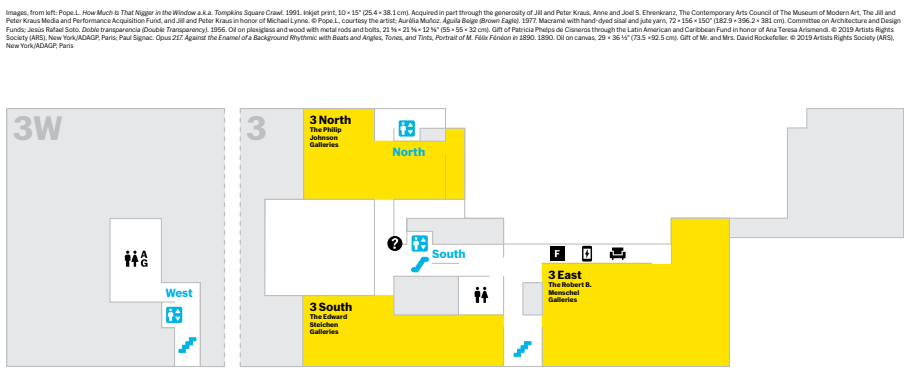

Artist Commission
E Yoko Ono

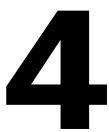

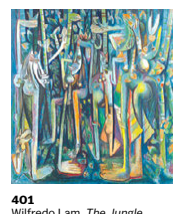

Wilfredo Lam. The Jungle.

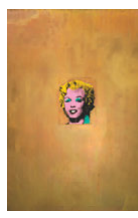

412

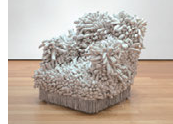
$\mathbf{4 1 2}$
Yayoi Kusama. Accumulation
No. 1.1962

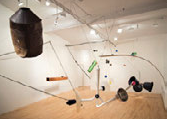

Fall 2019

Kravis Studio

David Tudor and Composers

Rainforest V(variation 1)
Oct 21, 2019-Jan 5, 2020 Andy Warhol. Gold
Marilyn Monroe. 1962

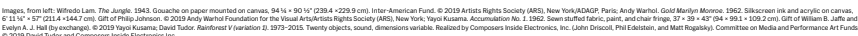

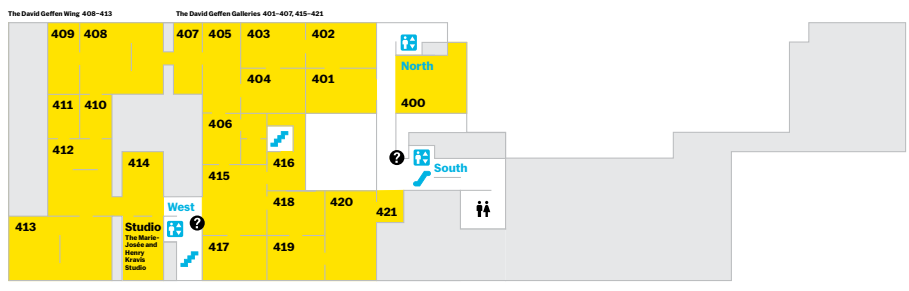

Collection
1940s-1970s

400 New Monuments

401 Out of War

402 In and Around $\mathrm{H}$

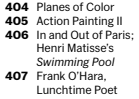

405 Action Painting II

406 In and Out of Paris:

Frank O'Hara,
Lunchtime Poet

408 Stamp, Scavenge, Cr

409 Abstract Lens
410 At the Border of Art

and Life

and Life
411 Andy Warhol's Kiss,
Blow Job, and Sleep

412 From Soup Cans to

Flying Saucers

413 Breaking the Mold

414 City as Sta
415 Idea Art

416 The Art of the Multiple

417 Architecture Systems
418 Joan Jonas's Mirage

420 War Within, War Withou

Rosemarie Trockel's 


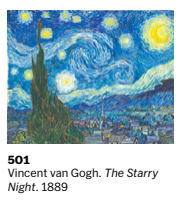

500 Pogany. 1913
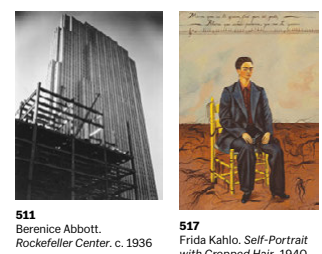

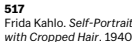

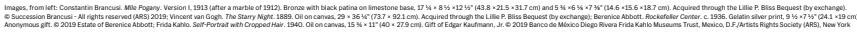

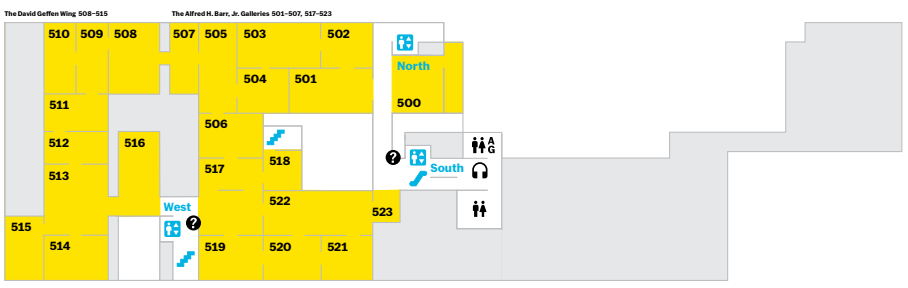

Collection
1880s-1940s

500 Constantin Brancusi

501 19th-Century Innovato

$\mathbf{5 0 2}$ Early Photography
503 Around Les Demoiselles
d'Avignon 504 New Expression in

505 Circa 1913

$\mathbf{5 0 6}$ Herni Matisse
$\mathbf{5 0 7}$ Artists' Books and Prints
508 Readymade in Paris and 509 Flow York 513 Design for Modern Life Company 510 Machines, Man 511 The Vertical Cit
512 Abstraction and Utopia $\quad \mathbf{5 1 9}$ Architecture for Modern Art 514 Pasign for Moderntio 520 Picturing America

5214 Paris 19205 sers of Popular Painting 516 Artist's Choice: Amy Sillman $\mathbf{5 2 3}$ British Prints from the 517 Surrealist Objects
Machine Age

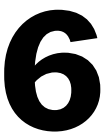

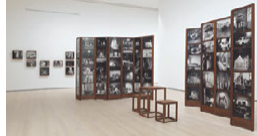

Fall 2019

Surrounds: 11 installations

Oct 21, 2019-Jan 4,2020

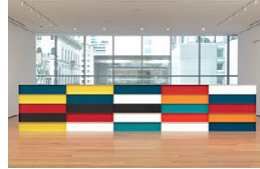

Spring 2020

Judd
Mar 1-Jul 11, 2020
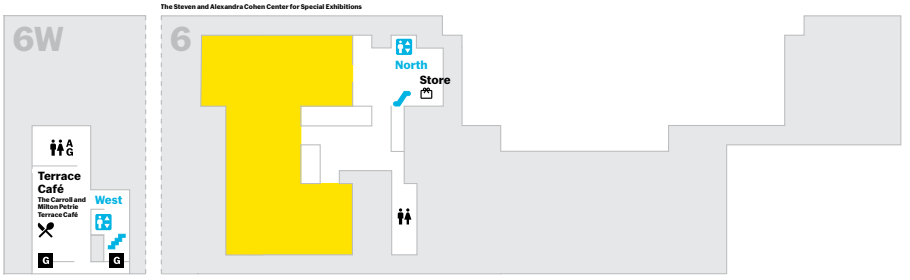

Artist Commissions
Gerstin Brätsch

Access to 6 W using west

Access to 6 W using w
elevator and stair 
A variedade de narrativas envolvia a convivência de obras de diversos departamentos - numa mesma sala, ou em espaços adjacentes -, rompendo com a segregação que orientara modos anteriores de apresentação da coleção:

Agora aplicamos às galerias de coleções o mesmo espírito interdisciplinar que trouxemos para nossas exposições especiais. A maioria das cerca de sessenta galerias de coleção do MOMA combinam obras de dois ou mais departamentos curatoriais do museu, todas ocorrendo ao longo de uma espinha cronológica ampla pelos três andares do edifício. Ao mesmo tempo, várias galerias apresentam histórias específicas de cada um dos meios representados em nossa coleção, mas elas se encontram no contexto de um ambiente totalmente pluralista. ${ }^{567}$

Conforme apresentado pelo museu, cada uma das galerias podia explorar um tópico individual, um único artista, um meio ou disciplina, um lugar particular num dado momento histórico, ou uma ideia criativa compartilhada. Para garantir a oportunidade de apresentar variadas narrativas e enfrentar a carência crônica de área expositiva no edifício - mesmo ampliadas, as galerias comportam apenas $10 \%$ do acervo total do museu,$-{ }^{568} \mathrm{O}$ esquema de rotatividade previa renovação de um terço das galerias a cada seis meses, resultando numa alteração completa da exposição da coleção a cada um ano e meio. Claro que os trabalhos mais consagrados não sairão de cartaz, mas podem ser confrontados por obras diversas, de acordo com novas interpretações ou com discussões relativas a assuntos da atualidade. Toda essa fluidez demandou à arquitetura, como vimos, tornar os espaços mais flexíveis e facilmente reprogramáveis, e, portanto, com um desenho discreto, o que, afinal, dava o tom do projeto como um todo, como afirmou Renfro:

567 Ibidem, p. 24.

568 Cf. STEPHens, Museum of Modern Art Addition by Diller Scofidio + Renfro in collaboration with Gensler.
Para tornar possível a visão curatorial do MOMA, nossa intervenção arquitetônica teve que ser bastante furtiva de várias maneiras [...]. Sabíamos que não poderíamos sobrecarregar os diferentes edifícios projetados nos últimos quase 100 anos, então buscamos trabalhar por dentro do DNA do MOMA para 
promover um novo conceito de detalhamento que reflete o século XXI. ${ }^{569}$

Nas galerias, esse detalhamento implicava soluções de design que ocultassem ainda mais a parafernália de dispositivos técnicos obrigatórios num museu, como grelhas de ar condicionado, detectores de fumaça, câmeras de segurança, trilhos de iluminação etc. Como observou Davidson, em conversa com Jerry Saltz:

A mudança da missão curatorial, se de fato está acontecendo, colocou os arquitetos em uma posição estranha. Eles tiveram que criar um edifício que expressasse a visão atual do museu, mas também pudesse resistir a uma futura reversão de tendência. Se a atual administração sai ou muda de atitude, e em poucos anos a noção de descendência entre os artistas se reafirma, a arquitetura deve se adaptar sem suar a camisa. Tenho certeza que pode fazer isso. Este edifício funciona tão bem para um museu do tipo 'O que é Arte Moderna?' quanto para um do tipo 'Isto é Arte Moderna!'. Mas isso cria uma tensão entre uma estética de design de alta precisão e um museu que deliberadamente obscurece sua própria marca. ${ }^{570}$

As galerias da coleção foram concebidas, sobretudo, como território livre dos curadores, como afirmou Lowry, "o verdadeiro valor deste projeto não é mais espaço, nem um espaço melhor, mas sim a nova plataforma que cria para a curadoria do MOMA repensar a experiência do museu." ${ }^{571}$ Diante dessas premissas, parece válida a observação de Davidson de que "a principal tarefa da arquitetura é simplesmente sair da frente." ${ }^{572}$

Se, no entanto, a dimensão da arquitetura ficou rebaixada, o tratamento expográfico se encarregou de pontuar a longa sequência de galerias com situações mais carregadas de expressão e personalidade. Em alguns poucos casos, isso esteve articulado com espaços com características arquitetônicos mais marcantes, como as salas de chegada às galerias pelas prumadas do projeto de Taniguchi, com amplas superfícies envidraçadas voltadas para o jardim de esculturas. No quinto pavimento, dedicado à coleção de das décadas de 1880 a 1940, esse espaço (sala 50o), antes um café, foi inteiramente ocupado por nove
569 Charles Renfro apud: FRANKLIN, Sydney, MOMA reopens with a $\$ 450$ million megaexpansion and slick renovation. The Architects Newspaper, 16/10/2019. ed. 2019.

570 DaVIDSON; SALTZ, Two Critics - Art and Architecture Compare Their Moma Experiences. Tradução nossa.

571 Glenn Lowry, Introduction. In: The Museum of MODERn ART, MoMA Now, p. 9. Tradução nossa.

572 Davidson, The New Moma Tries to Get Out of Its Own Way,. We'll See If It Can, op. cit. Tradução nossa. 

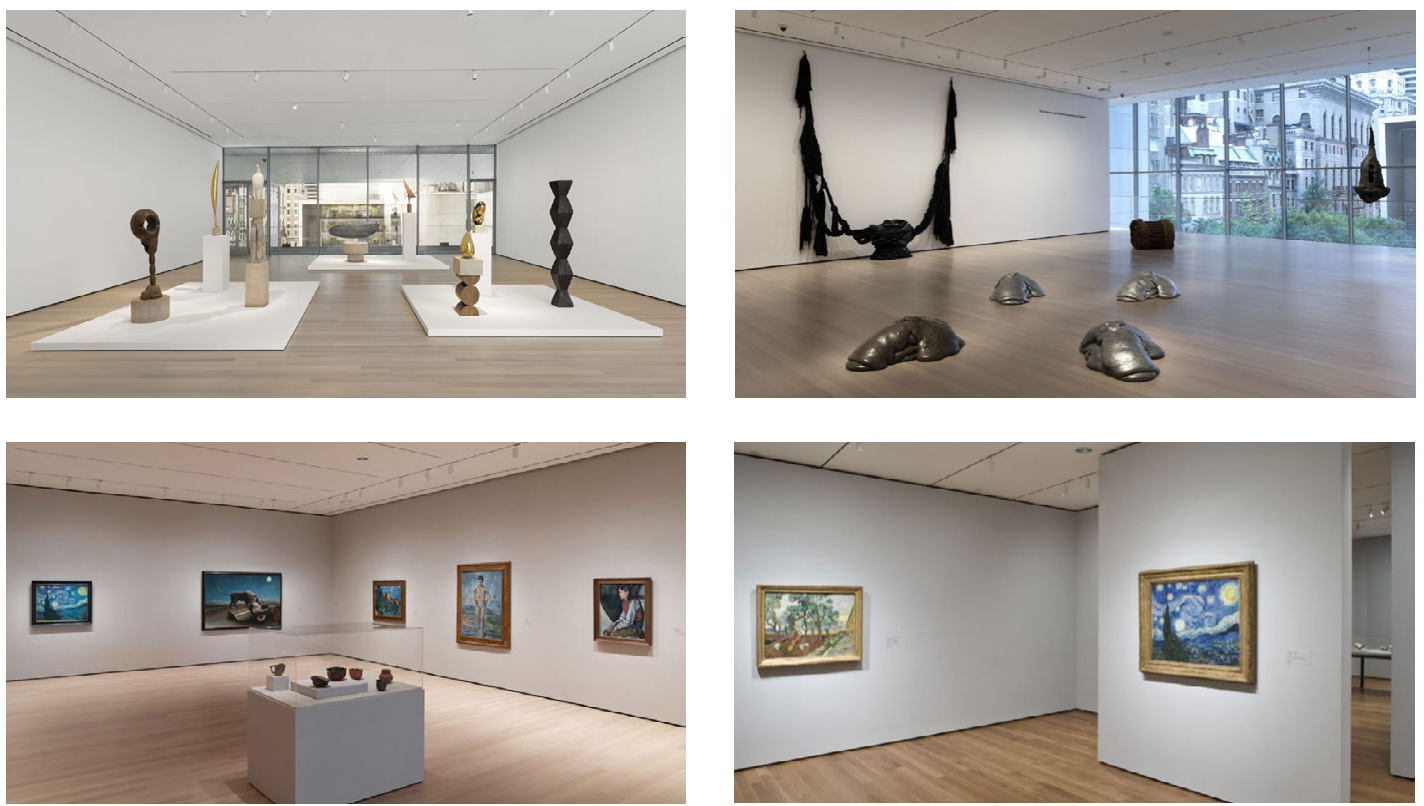

3.152 Vista da Sala 500: Constantin Brancusi na exposição Collection 1880s-1940s, MoMA, Nova York, 2019. Foto: Martin Seck. Fonte: https://www. moma.org/calendar/galleries/5133

3.153 Vista da Sala 400: New Monuments na exposição Collection 1940s-1970s, MoMA, Nova York, 2019. Foto: Robert Gerhardt. Fonte: https://www.moma.org/ calendar/galleries/5145

3.154 Vista da Sala 501: 19th-Century Innovators na exposição Collection 1880s-1940s, MoMA, Nova York, 2019. Foto: Jonathan Muzikar. Fonte: https:// www.moma.org/calendar/galleries/5134

3.155 Exemplo de "parede dos heróis" na exposição Van Gogh and the Colors of the Night, MoMA, Nova York, 2009. Foto: John Wronn. Fonte: https://www.moma.org/ collection/works/ 79802 esculturas de Constantin Brancusi produzidas entre as décadas de 1910 e 1930, distribuídas em três tablados baixos. No quarto pavimento, cobrindo o período dos anos de 1940 a 1970, o espaço equivalente (sala 400) recebeu um conjunto de nove esculturas produzidas nos anos 1960 e 1970 por Lynda Benglis, Louise Bourgeois, Barbara Chase-Riboud, Melvin Edwards e Jackie Winsor, agrupadas sob o título New Monuments e apoiadas nas paredes, no teto, ou diretamente no piso. Introduzindo o percurso de cada pavimento com trabalhos que estariam mais adiante na linha do tempo, vemos que, em ambos os casos, a seleção de obras privilegiou sua articulação com o contexto espacial posicionando-as em locais com características arquitetônicas especiais - a vista para o exterior e a condição de antessala -, em detrimento de uma sequência cronológica mais estrita.

Abrindo o percurso interno da coleção do quinto andar - The Alfred H. Barr Jr. Galleries - a primeira galeria recebeu o título de 19th-Century Innovators (sala 501) e continuava expondo algumas das obras célebres da coleção, como The Bather (c. 1885), de Paul Cézanne, The Starry Night (1889), de Vincent van 

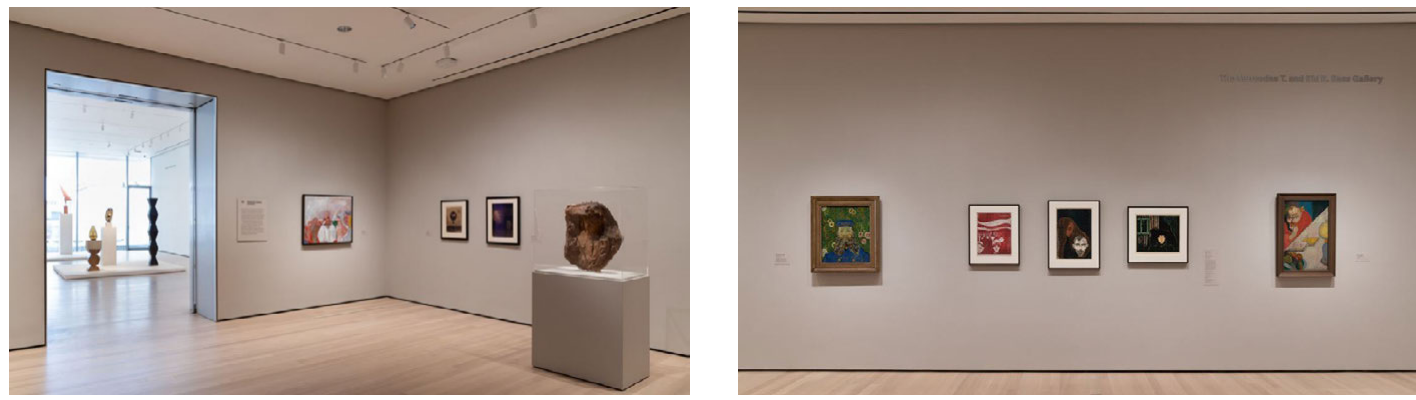

Gogh e The Sleeping Gypsy (1897), de Henri Rousseau, mas num contexto distinto. A parede que ficara durante quinze anos em frente à entrada com a pintura de Cézanne - situação apelidada no museu de "paredes dos heróis" - foi removida, segundo a curadora Jodi Hauptman, "para sugerir a pluralidade de histórias que você encontraria à medida que avançasse." ${ }^{573}$ Indicando a participação feminina na produção da época, duas gravuras de Mary Cassat - que não haviam sido expostas no museu por duas décadas - foram dispostas ao lado de uma pintura de Édouard Vuillard, anunciando ainda a nova intenção curatorial de integrar distintos suportes, o que era ainda mais acentuado pela presença de cerâmicas de George Ohr numa vitrine no centro da sala. Como explicou Ann Temkin, "percebemos que seria importante indicar para nós e para os nossos visitantes, que, desde esse ponto de partida, todos os departamentos do museu estariam representados. Esta galeria é um microcosmo do que vai acontecer com o resto desses milhares de metros quadrados de espaços expositivos. ${ }^{\text {574 }}$

Outro aspecto que a curadoria queria explorar era o olhar contemporâneo sobre obras produzidas em tempos distantes, como exemplifica a parede que continha três gravuras de Edvard Munch, entre uma pintura de van Gogh e outra de Gauguin, todas mostrando rostos angustiados. Para Hauptman, a sensação de ansiedade transmitida por esses trabalhos relacionava a atmosfera do século XIX a um sentimento comum nos dias de hoje: "para salas que lidam com material histórico, é muito importante descobrir maneiras de se conectar com o presente." 575
3.156 Vista da Sala 501: 19th-Century Innovators na exposição Collection 1880s-1940s, MoMA, Nova York, 2019. Foto: Jonathan Muzikar. Fonte: https:// www.moma.org/calendar/galleries/5134

3.157 Da esquerda para direita: Vincent van Gogh, Portrait of Joseph Roulin (1889); Edvard Munch, Angst (1896, assinado 1897), Man's Head in Woman's Hair (Mannshode i Kvinnehår) (1896) e Moonlight I (Måneskinn I) (1896) e Paul Gauguin, Portrait of Meijer de Haan (1889), em exposição na Sala 501, MoMA, Nova York, 2019. Foto: Jonathan Muzikar. Fonte: https://www.moma.org/ calendar/galleries/5134

573 TEMKIN, Ann; HaUptMan, Jodi. Gallery 501: 19th-Century Innovators. MOMA. Disponível em: <https://www.moma.org/ magazine/articles/198>. Acesso em: 31 out. 2020. Tradução nossa.

574 Ibidem.

575 Ibidem. 
Vale notar uma diferença básica no método de trabalho dos curadores que, diferentemente de antecipar as definições em projeto como os arquitetos, costumam definir a exata posição de cada obra no espaço de uma galeria durante a própria montagem, a partir da observação da interação entre os trabalhos e destes com o espaço real, como relatou Temkin:

É importante enfatizar que, à medida que instalamos [as obras], independente de quantas coisas tenhamos definido no papel, ou mesmo em pequenos modelos tridimensionais, as decisões são realmente tomadas no espaço. Não há absolutamente nenhuma maneira de planejar uma galeria no papel ou num modelo [...] porque muito do nosso trabalho consiste em olhar. ${ }^{576}$

Um outro tipo de interação importante a considerar são as que ocorrem entre salas adjacentes. O conteúdo da segunda sala do percurso (502), intitulada Early Photography and Film, valorizava a relação das pinturas da sala anterior com os novos meios tecnológicos de produção de imagens que surgiam na mesma época, como descreveu Hauptman:

Assim que você entrar [na primeira galeria], você verá filmes com o canto do olho. Você verá imediatamente imagens em movimento, e aquele lampejo de luz é um lembrete de que muitos desses artistas viveram em um momento onde eles não puderam deixar de ser impactados ou ter algum tipo de diálogo com essas novas formas de mídia. ${ }^{577}$

A nova abordagem curatorial impactou ainda o tratamento expográfico das salas, que deveria enfatizar o caráter específico de cada uma, dentro da arquitetura "genérica" do bloco de galerias. Em matéria de Casey Lesser, a diretora de projeto expográfico e produção do MoMA, Lana Hum, revelou os critérios que orientaram a nova ambientação das galerias:

Estávamos pensando e questionando esse tipo de caixa branca anônima, que é realmente a linguagem das exposições de arte 576 Ibidem. moderna e contemporânea [...]. Todas as obras na época em 577 Ibidem. que foram feitas eram reveladoras e radicais e queríamos cap- 


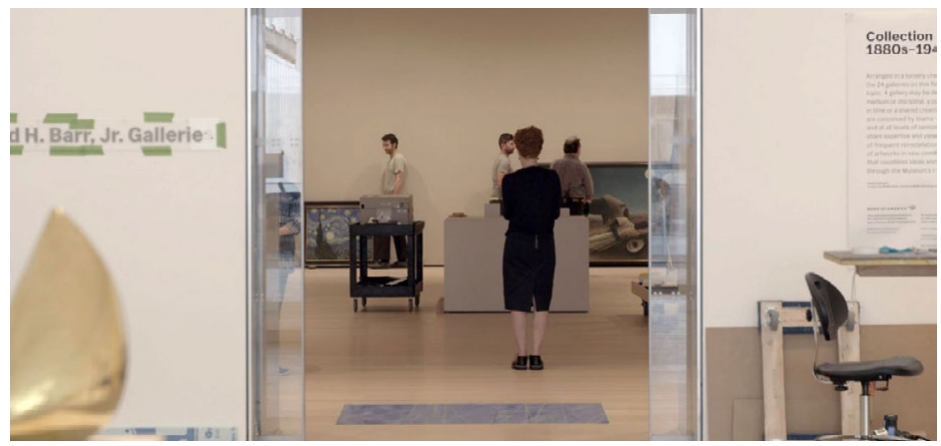

turar isso... mas descobrimos que a caixa branca fica aquém. É muito anônima. Não oferece contexto suficiente. ${ }^{578}$

De fato, o princípio norteador da "caixa branca" baseava-se, como vimos, na anulação do contexto, envolvendo a arte numa atmosfera de pureza e suposta neutralidade, evitando criar interferências na apreciação individual de cada obra. Agora, no entanto, a intenção da curadoria era outra, a de estabelecer diálogos entre as obras a partir de interpretações contemporâneas. Diante disso, como afirmou a curadora Sarah Suzuki, responsável por supervisionar o planejamento e a implantação da renovação do museu, era necessário adotar uma nova abordagem para os espaços físicos das galerias e "afastar-se dos modos tradicionais de exposição". ${ }^{579}$

Um dos recursos empregados então pelo projeto expográfico foi a utilização de uma variada palheta de cores para as paredes, definidas em conjunto por curadores e designers, com a consultoria da fornecedora britânica de tintas Farrow \& Ball's. Além de auxiliar no controle de luminosidade, variável de acordo com o suporte - mais alta para pinturas, menos intensa para papéis e fotografias e reduzida ao máximo para filmes -, as cores podiam destacar as tonalidades dos trabalhos, criar uma atmosfera correspondente aos seus conteúdos e quebrar a monotonia do longo percurso das galerias.

Para a primeira sala, a cor pastel escolhida para as paredes foi um cinza quente alaranjado (Elephant's Breath), que, segundo a curadora Ann Tempkin, "parecia deixar os pigmen-
3.158 Ann Temkin (de costas) liderando a montagem da Sala 501, MoMA, Nova York, 2019.Fonte: https://www. moma.org/magazine/articles/198

3.159 Cor Elephant's Breath, da Farrow \& Ball. Fonte: https://www.artsy.net/article/ artsy-editorial-new-moma-fresh-palettepaint-colors-challenges-white-cube
578 Lana Hum apud LESSER, Casey. At the New MomA, a Fresh Palette of Paint Colors Challenges the White Cube. Artsy, 23/12/2019. ed. 2019. Tradução nossa.

579 Sarah Suzuki apud ibidem. 

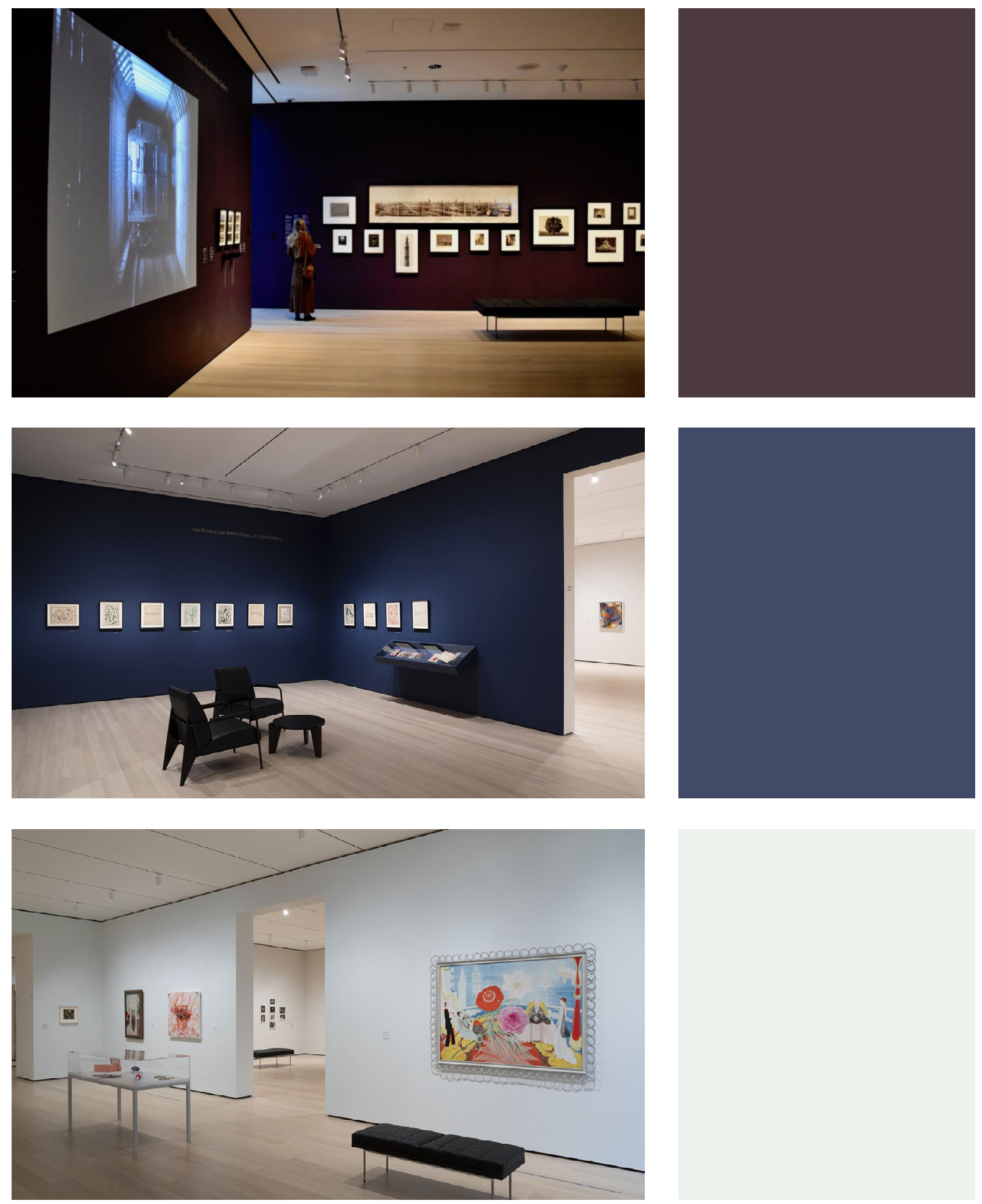
tos dessas pinturas da década de 1890 realmente brilharem na tela e se definirem de um modo muito vibrante". ${ }^{580}$ Para Hum, "é intimista, mas é uma cor que se sustenta por si mesma como um contraponto tanto aos tipos de cores turbulentas e rodopiantes de van Gogh, quanto às mais calmas, domésticas e aquareladas de Mary Cassat." ${ }^{581}$ A galeria seguinte foi escurecida, mas, contrapondo-se à atmosfera anódina da típica "caixa preta" para projeções imersivas, foi pintada com uma cor arroxeada (Pelt), destacando a presença dos filmes nas paredes e dialogando com as tonalidades amarronzadas das fotografias.

Além de cores fortes, algumas salas convidavam a uma pausa para descanso, como a galeria Artists Books and Prints in Russia (sala 507), pintada com um azul escuro (Serge) e mobiliada com duas poltronas estofadas e uma mesinha de apoio no centro. Em alguns casos, a definição de cores partiu da leitura particular dos curadores sobre as obras, como a galeria Florine Stettheimer and Company (sala 509), pintada com um azul muito pálido (Cabbage White), extraído de uma das pinturas da artista. Para a galeria dedicada exclusivamente a uma das grandes atrações do museu, Claude Monet's Waterlillies (sala 515), a cor escolhida foi baseada na que $\mathrm{o}$ artista adotara para ambientar a obra da mesma série no museu L' Orangerie de Paris (Wevet) - uma "quase uma não cor", como definiu Hum, um tom luminoso que seria "a melhor expressão daquela luz marcada de sol de Giverny". ${ }^{582}$ Na galeria Surrealistic Objects (sala 517), por sua vez, a cor escolhida foi um rosa antigo (Sulking Room Pink), como fundo para pinturas tão formalmente distintas quanto as de Frida Kahlo, Salvador Dali, Joan Miró e Pablo Picasso, mostrando que a escolha podia descolar-se da palheta cromática dos trabalhos para ressaltar uma ambiência geral ligada aos seus conteúdos. De todo modo, as cores cumpriam a função de ressaltar interpretações dos curadores e enriquecer a experiência da visitação pelo extenso conjunto de galerias, como observou a crítica de arquitetura Alexandra Lange,

Quando você está vagando, é mais fácil perceber como as galerias ficam agradáveis quando pintadas de outra cor que não o branco [...]. Mais interrupções desse tipo tornariam o museu como um todo mais legível. O contraste na cor ou na densi-
3.160 Vista da Sala 502: Early Photography and Film na exposição Collection 1880s-1940s, MoMA, Nova York, 2019. Fonte: https://news.artnet. com/app/news-upload/2019/10/momaphoto-gallery-1024x683.jpeg

3.161 Vista da Sala 507: Artists Books and Prints in Russia na exposição Collection 1880s-1940s, MoMA, Nova York, 2019. Foto: Jonathan Muzikar. Fonte: https://www.moma.org/calendar/ galleries/5103

3.162 Vista da Sala 509: Florine Stettheimer and Company na exposição Collection 1880s-1940s, MoMA, Nova York, 2019. Fonte: https://www. moma.org/calendar/galleries/5105

3.163 a $1.165 \mathrm{Na}$ coluna da direita as cores Pelt, Serge e Cabbage White, da Farrow \& Ball. Fonte: https://www.artsy.net/article/ artsy-editorial-new-moma-fresh-palettepaint-colors-challenges-white-cube

580 Temkin, Hauptman, op. cit. Tradução nossa.

581 Lana Hum apud LeSSER, op. cit. Tradução nossa.

582 Ibidem. 

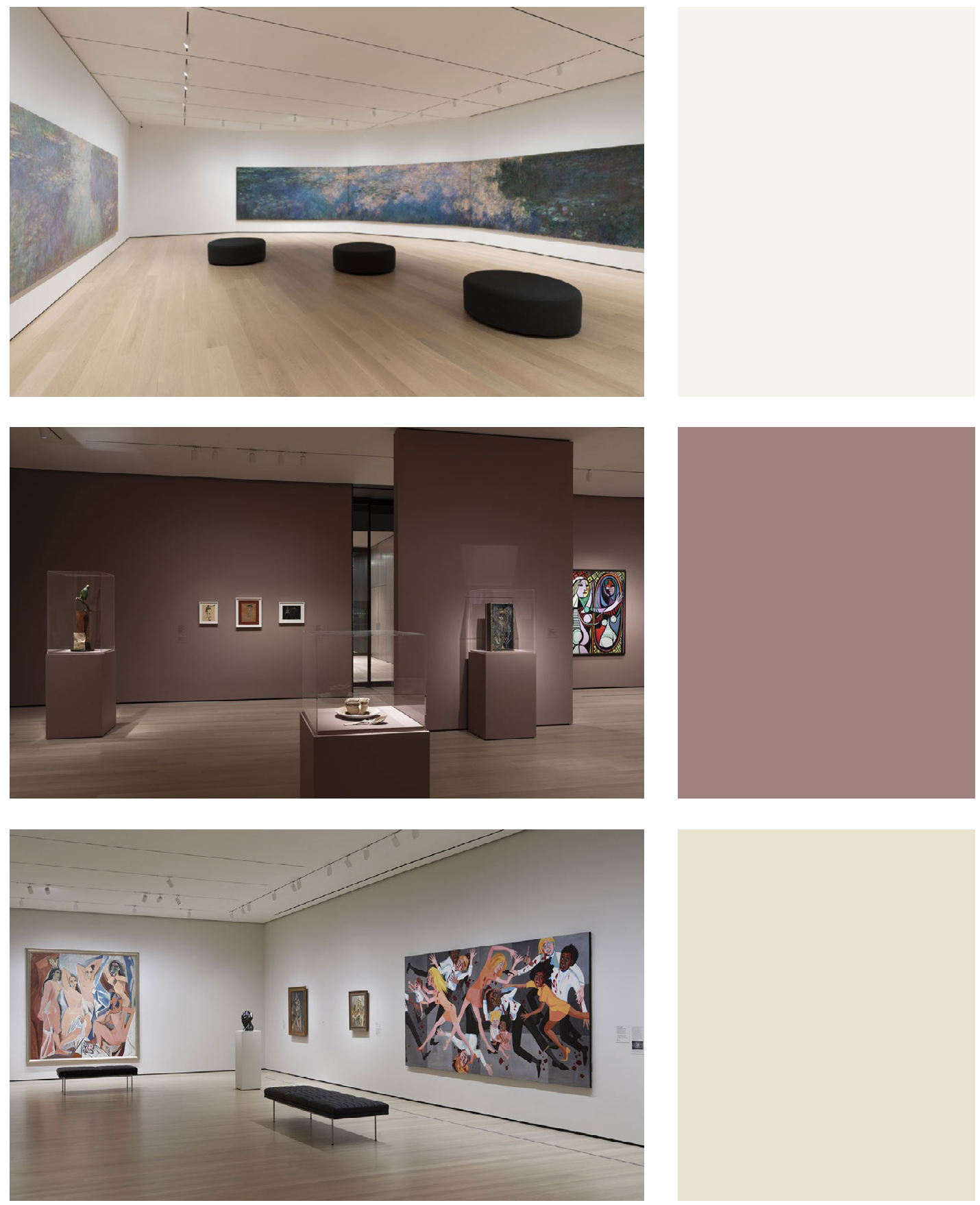
dade da apresentação adiciona um pequeno redemoinho ao mapa mental das pessoas, de modo que o corredor das salas não parece infinito. ${ }^{583}$

Entremeadas a essas galerias coloridas, a maior parte das salas do мома continuou, como explicou Hum, empregando uma palheta básica com sutis variações de branco (Wimborne White) e cinzas claros (Skimming Stone), especialmente as dedicadas a confrontar obras de períodos muito díspares. Esse era o caso da terceira galeria da coleção (sala 503), que expôs, ao lado do ícone do museu, Demoiselles d'Avignon (1907), de Picasso, a pintura American People Series \#20: Die (1967), da afro-estadunidense Faith Ringgold (1930).

Considerando exposição do acervo do MoMA como um todo, observamos que a maioria das salas pintadas com cores especiais ficou concentrada no quinto pavimento, que reúne as peças mais antigas da coleção. No quarto pavimento - The David Geffen Galleries -, as poucas galerias que fogem de modo mais evidente da palheta básica são Frank $O$ 'Hara, Lunchtime Poet (sala 407) - cinza médio -, At the border of Art and Life (sala 410) - vermelho vivo -, Joan Jonas's Mirage (sala 418) - preta com iluminação dramática sobre os objetos -, além da pequena galeria com uma tela de projeção e sofás, Andy Warhol's Kiss, Blow Job, and Sleep (sala 411) - também preta, mas como pano de fundo para os filmes. No segundo pavimento, dedicado à produção a partir dos anos 1970, não foram utilizadas cores especiais, apenas um branco básico, alternado com o preto ou cinza escuro para as projeções imersivas. Alguns artistas, como Richard Serra, foram pessoalmente responsáveis pela instalação dos trabalhos no espaço. Sua obra Equal (sala 210) consiste de oito grandes blocos de aço maciço sobrepostos em quatro pares, em posições sutilmente distintas, e, dado o peso das peças, exigiu um reforço especial na laje e teve que ser entrar no edifício pela lateral, antes da execução da esquadria e, portanto, dificilmente entrará no rodízio previsto para as exposições.

Vemos, portanto, que, quanto mais distantes no tempo são as obras e menos vinculadas em sua concepção original ao espaço ao redor - limitadas a seus suportes específicos -, mais
3.166 Vista da Sala 515: Claude Monet's Water Lilies na exposição Collection 1880s-1940s, MoMA, Nova York, 2019. Foto: Jonathan Muzikar. Fonte: https:// www.moma.org/calendar/galleries/5110

3.167 Vista da Sala 517: Surrealist Objects na exposição Collection 1880s-1940s, MoMA, Nova York, 2019. Foto: Jonathan Muzikar. Fonte: https:// www.moma.org/calendar/galleries/5140

3.168 Vista da Sala 503: Around Les Demoiselles d'Avignon na exposição Collection 1880s-1940s, MoMA, Nova York, 2019. Foto: Heidi Bohnenkamp. Fonte: https://www.moma.org/calendar/ galleries/5135

3.169 a 3.171 Na coluna da direita cores Wevet, Sulking Room Pink e Skimming Stone da Farrow \& Ball. Fonte: https:// www.artsy.net/article/artsy-editorialnew-moma-fresh-palette-paint-colorschallenges-white-cube
583 LANGE. Navigating the new MoMA, op. cit., n.p. Tradução nossa. 

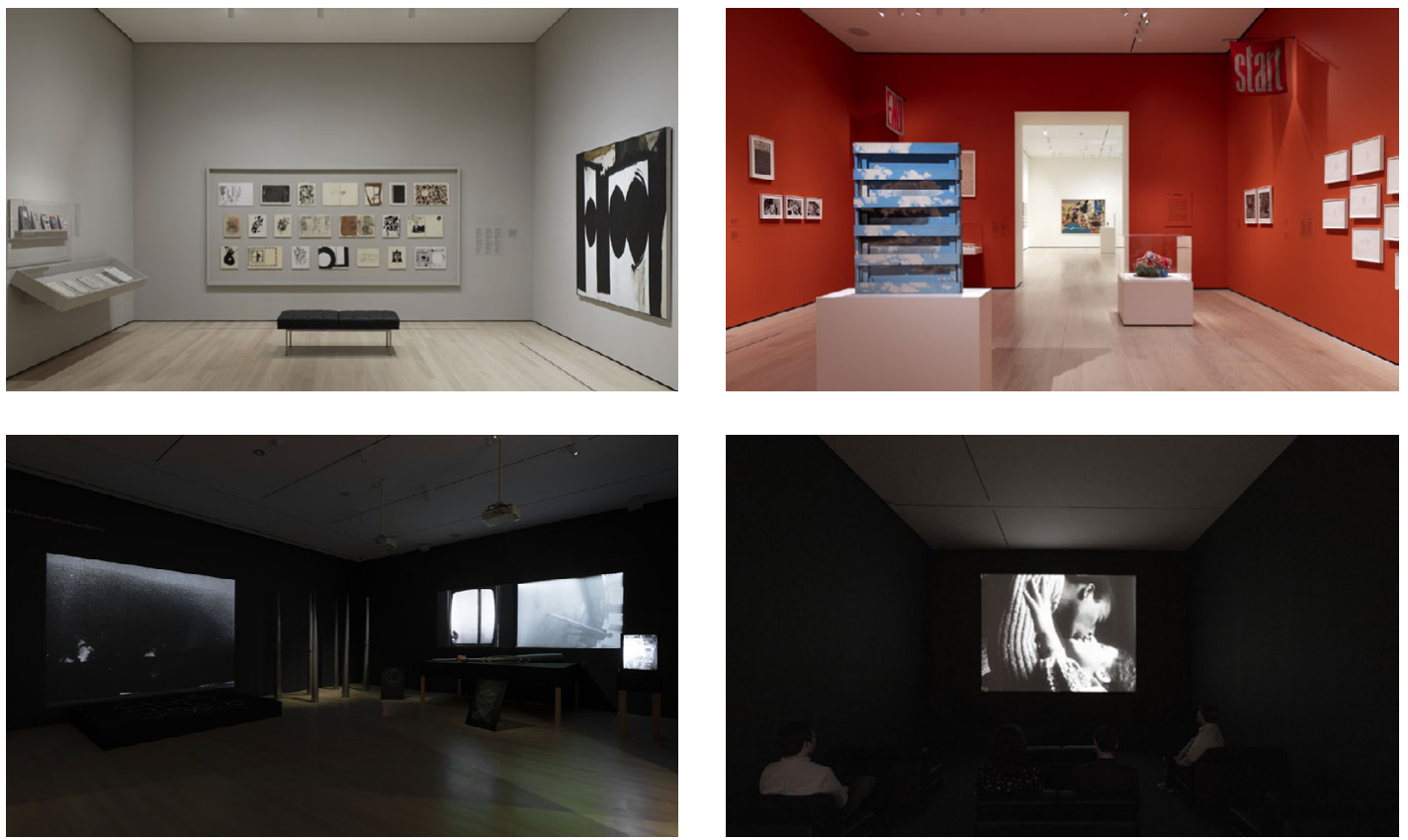

3.172 Vista da Sala 407: Frank O'Hara, Lunchtime Poet na exposição Collection 1940s-1970s, MoMA, Nova York, 2019. Foto: Heidi Bohnenkamp. Fonte: https:// www.moma.org/calendar/galleries/5147

3.173 a 3.175 Vista da Sala 410: At the Border of Art and Life, Sala 418: Joan Jonas's Mirage e Sala 411: Andy Warhol's Kiss, Blow Job, and Sleep na exposição Collection 1940s-1970s, MoMA, Nova York, 2019. Foto: Robert Gerhardt. Fontes: https://www.moma.org/calendar/ galleries/5121, https://www.moma.org/ calendar/galleries/5149 e https://www. moma.org/calendar/galleries/5122 liberdade de ambientação expográfica se permitiram os curadores. As galerias da coleção do MoMA tornam-se, no conjunto, progressivamente mais anódinas do ponto de vista expográfico quando nos aproximamos do período atual, considerando que o espaço expositivo é território exclusivo do artista.

Ainda nas galerias da coleção, outras situações podiam criar rupturas à ambientação convencional, pela variedade dos objetos expostos, como algumas das salas focadas em arquitetura e design. A galeria Design for Modern Life (sala 513) reunia projetos arquitetônicos, peças gráficas, utensílios, móveis, pinturas e um modelo em escala real da cozinha de Frankfurt (1926-27), projetada pela arquiteta austríaca Margarete Schütte-Lihotzky (1897-2000). A galeria Architecture Systems (sala 417) continha desenhos e modelos arquitetônicos, diversas peças da série Superfície Modulada (1957-58) de Lygia Clark e, em frente à entrada, um fragmento da fachada envidraçada do edifício sede das Nações Unidas (1952), do comitê de arquitetos formado por Wallace K. Harrison, Max Abramovitz, Oscar 

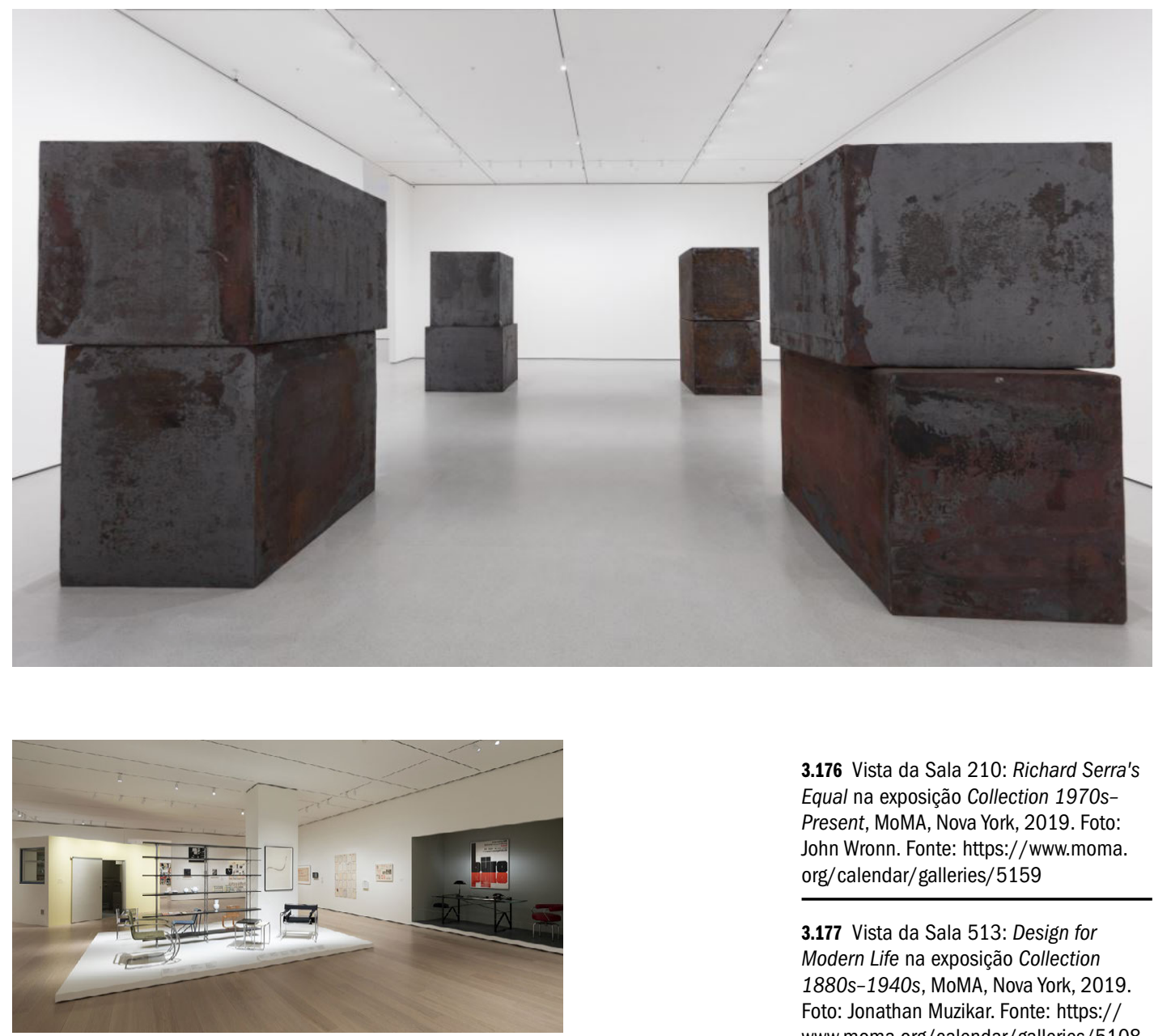

3.176 Vista da Sala 210: Richard Serra's Equal na exposição Collection 1970sPresent, MoMA, Nova York, 2019. Foto: John Wronn. Fonte: https://www.moma. org/calendar/galleries/5159

3.177 Vista da Sala 513: Design for Modern Life na exposição Collection 1880s-1940s, MoMA, Nova York, 2019. Foto: Jonathan Muzikar. Fonte: https:// www.moma.org/calendar/galleries/5108

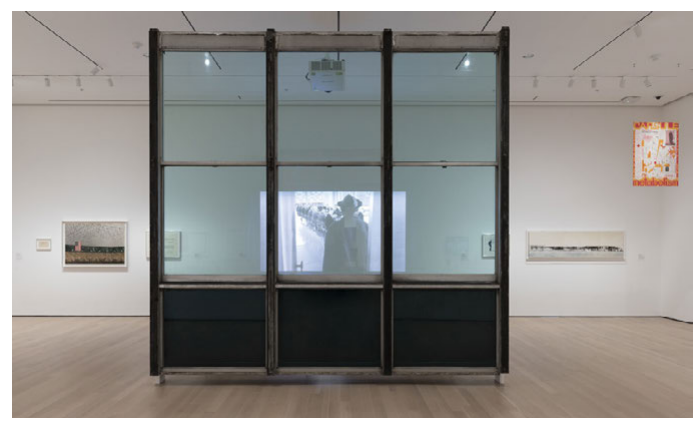

3.178 Vista da Sala 417: Architecture Systems na exposição Collection 1940s-1970s, MoMA, Nova York, 2019. Foto: Robert Gerhardt. Fonte: https:// www.moma.org/calendar/galleries/5148 
instalação expográfica. $\mathrm{O}$ denso conjunto de obras foi disposto nas paredes e também em tablados escalonados no perímetro da sala como um estádio, o que, segundo a artista, provocava uma inversão de papéis, sendo as obras as figuras e o espectador o objeto observado por elas. ${ }^{585}$ The Shape of Shape foi uma das exposições que mais chamou a atenção da crítica, que valorizou o olhar livre da artista sobre a coleção, como enfatizou Jerry Saltz "é de longe a melhor exposição individual do museu - porque ela pensa como uma artista!" ${ }^{586}$ Roberta Smith foi no mesmo caminho:

A série do moma Artist's Choice raramente decepciona e essa interação é uma das melhores - e está entre as mais valiosas das mostras inaugurais (...). Seu esforço é paralelo às abordagens em curso nas galerias de coleção permanente, mas reflete um apetite visual relativamente robusto - o olho desimpedido do artista - de que o museu precisa mais. A densa instalação da exposição incentiva surpreendentes conexões.

Logo abaixo, no quarto pavimento, a Studio Gallery - The Marie-Josée and Henry Kravis Studio - foi inaugurada com a instalação sonora Rainforest v (variation 1) (1973-2015), concebida por David Tudor (1926-1996) e realizada pelo grupo Composers Inside Eletronics Inc. ${ }^{587} \mathrm{~A}$ obra é composta por uma série de objetos do cotidiano suspensos no espaço - como um barril de metal, um disco rígido de computador antigo e tubos de plástico - que emitem sons variados produzidos por transdutores neles embutidos (nas primeiras mais antigas, a obra era ativada por performers). Nesse novo espaço expositivo, foi mantida aberta não apenas a fachada com vista para a cidade, como também os painéis que limitavam a sala ao norte, fazendo com que o ambiente ficasse integrado tanto com o exterior, quanto com o interior do museu, estabelecendo uma interessante continuidade visual com galeria seguinte, denominada justamente de City as Stage (sala 414).

A obra apresentada no mesmo espaço em agosto de 2020 foi a instalação imersiva audiovisual Cinematic Illumination (1969), do japonês Shuzo Azuchi Gulliver (1947-), ${ }^{588}$ constituída por um painel circular suspenso no teto que recebia na face
585 Em depoimento disponível no vídeo Introducing Virtual Views: Amy Sillman-The Shape of Shape, in ibidem.

586 DAVIDSON; SALTZ, 2019, op. cit. Tradução nossa.

587 The Museum of Modern ART. David Tudor and Composers Inside Electronics Inc.: Rainforest V (variation 1) (Oct 21, 2019-Jan 5, 2020). МОМA. Disponível em: $<$ https://www.moma.org/calendar/ exhibitions/5077>. Acesso em: 1 nov. 2020.

588 Cf. The Museum of Modern ART ARCHIVES, Shuzo Azuchi Gulliver's Cinematic Illumination (Aug 27, 2020-Apr 18, 2021). MOMA. Disponível em: <https:// www.moma.org/calendar/exhibitions/5205>. Acesso em: 1 nov. 2020. 

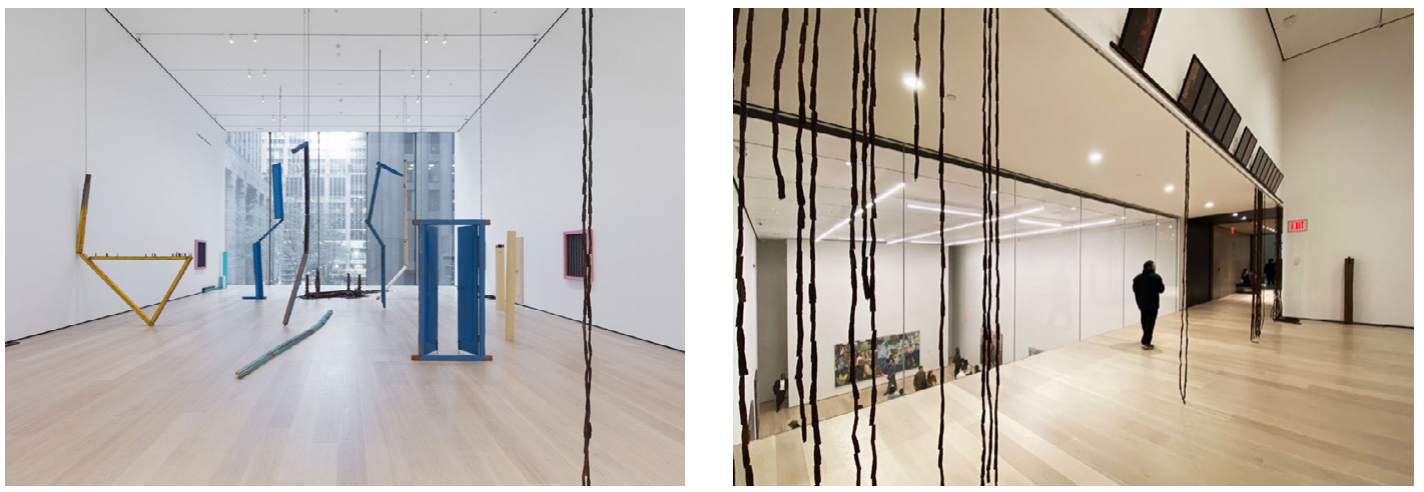

3.185 Vista da Sala 212 (Daylite Gallery): Sheela Gowda's Of All People na exposição Collection 1970s-Present, MoMA, Nova York, 2019. Foto: John Wronn. Fonte: https://www.moma.org/calendar/ galleries/5171

3.186 Conexão visual entre as Salas 212 (Daylite Gallery) e 1 North (Projects Gallery), MoMA, Nova York, 2019. Foto: nossa.
589 Cf. The Museum of Modern ART ARCHIVEs. Sheela Gowda's Of All People (Fall 2019-Fall 2020). MOMA. Disponível em: <https:// www.moma.org/calendar/galleries/5171>. Acesso em: 1 nov. 2020. interior imagens em movimento giratório transmitidas por 18 projetores de slides e acompanhadas por música de discoteca, como no ambiente para o qual havia sido originalmente concebida. Dessa vez a sala foi totalmente isolada do exterior, com a fachada envidraçada para a rua oculta por um dispositivo blecaute e os painéis da face oposta fechados, impedindo que o som vazasse para as galerias adjacentes e tornando a experiência mais imersiva. Diversas outras salas do museu receberam instalações audiovisuais em configurações tipo "caixa preta" como essa, mas sem contar com as mesmas condições técnicas de instalação, que era o que distinguia a Studio Gallery para esse tipo de utilização. As duas únicas montagens já realizadas no espaço mostram a condição versátil oferecida pela arquitetura e seu potencial para ser explorada nas mostras seguintes.

Localizada imediatamente abaixo, a Daylite Gallery (sala 212) - permanentemente envidraçada e com pé direito alto como as demais galerias contemporâneas do segundo pavimento - recebeu na reinauguração a instalação escultórica $O f$ All People (2011), da indiana Sheela Gowda (1957-). ${ }^{589}$ A obra é composta por fragmentos arquitetônicos - batentes de portas, molduras de janelas e uma mesa de madeira - coletados de casas demolidas em consequência da modernização da cidade natal da artista, Bangalore, e pintados com as cores vivas das construções da região. Apoiados nas paredes, no teto e no piso, esses elementos são acompanhados de milhares de pequenas estatuetas de madeira usadas em certos rituais sociais comu- 
nitários, algumas suspensas em cordões formando uma espécie de cortina no ponto de conexão entre a prumada da Blade Stair e as galerias na expansão a oeste, de onde se vê a galeria da Projects Room abaixo. Nesse caso, vemos como as relações visuais estabelecidas com a cidade de Nova York e as pinturas de Michael Armitage pelas superfícies transparentes da arquitetura se apresentam como contrapontos ao ambiente isolado das galerias convencionais, quebrando a monotonia do percurso, bem como oferecendo possibilidades de acrescentar novas camadas de interpretação às obras.

\subsubsection{EXPOSIÇÕES TEMPORÁRIAS}

As galerias dedicadas a exposições temporárias ficam agora espalhadas em diversos pontos do edifício do MomA. A maior área delas é a do sexto pavimento, o mais alto, criada pela ampliação de Taniguchi, que permaneceu inalterada, a não ser pelo nome - chamada antes de Renée d'Harnoncourt Exhibition Galleries passou a se chamar The Steven and Alexandra Cohen Center for Special Exhibitions, refletindo o deslocamento do peso dos nomes que moldaram conceitualmente o museu para os de seus atuais financiadores. O espaço recebeu na reabertura a mostra coletiva Surrounds: 11 Installations, organizada por oito curadores de quatro departamentos diferentes, com peças de arte contemporânea do acervo adquiridas nos 15 anos anteriores e nunca antes expostas no museu. ${ }^{590}$ A seleção dos trabalhos foi assim apresentada pelo museu:

Cada obra incluída na exposição foi concebida a partir de diferentes circunstâncias individuais - como uma contribuição para uma bienal, como um elemento de um corpo maior de um trabalho em andamento, como uma resposta a uma obra clássica de história da arte ou como uma obra autônoma não relacionada a outras, mas as instalações estão unidas em sua ambição e escopo, marcando mudanças decisivas nas carreiras de seus criadores e no campo mais amplo da arte contemporânea. ${ }^{51}$
590 Com trabalhos dos artistas Allora \& Calzadilla, Sadie Benning, Janet Cardiff e George Bures Miller, Sou Fujimoto, Sheila Hicks, Arthur Jafa, Mark Manders, Rivane Neuenschwander, Dayanita Singh, Hito Steyerl e Sarah Sze.

591 Press release, in: THE Museum OF MODERN ART, Surrounds: 11 Installations (Oct 21, 2019-Jan 4, 2020). МОМА. Disponível em: <https://www.moma.org/calendar/ exhibitions/5073 $>$. Acesso em: 28 out. 2020. 
3.187 Vista da performance Allora \& Calzadilla's Fault Lines, de Jennifer Allora e Guillermo Calzadilla, na exposição Surrounds: 11 Installations, MoMA, Nova York, 2019. Foto: Heidi Bohnenkamp. Fonte: https://www.moma.org/calendar/ exhibitions $/ 5073$

3.188 a 3.191 Vista das instalações The Killing Machine (2007), de Janet Cardiff e George Bures Miller, Liquidity Inc. (2014), de Hito Steyerl, da videoinstalação Apex (2013), de Arthur Jafa e da instalação Work of Days (1998), de Rivane Neuenschwander, na exposição Surrounds: 11 Installations MoMA, Nova York, 2019. Fotos: Denis Doorly. Fonte: https://www.moma.org/calendar/ exhibitions $/ 5073$
Para reunir trabalhos de naturezas distintas e não concebidos especialmente para um espaço específico, a solução de apresentação foi a subdivisão da ampla área da galeria em salas menores, criando um ambiente individualizado para cada obra, na maior parte dos casos isolada das demais e dos espaços ao redor. Algumas das obras que mais precisavam de isolamento eram a instalação performática Fault Lines (2013) da estadunidense Jennifer Allora (1974-) e do cubano Guillermo Calzadilla (1971-) - com espécies de pódios de pedra espalhados pela sala, sobre os quais dois meninos sopranos interagiam em diálogos cantados -, o environment imersivo The Killing Machine (2007), dos canadenses Janet Cardiff (1957-) e George Bures Miller (1960-) - um balé robótico com adereços, luz e som acionado pelos visitantes -, a vídeo instalação Liquidity Inc. (2014), do alemão Hito Steyerl (1966-) - com um tatame montado sobre uma estrutura de andaimes em frente à tela de projeção, sob uma claraboia que recebeu um filtro azul, alterando toda a coloração da sala -, o vídeo imersivo Apex (2013), do estadunidense Arthur Jafa (1960-) - instalado num ambiente escuro, tipo black box e a instalação Work of Days (1998), da brasileira Rivane Neuenschwander (1967-) - uma pequena sala com piso e paredes recobertos com pedaços quadrados de adesivo transparente com sujeira coletada em seu ateliê, uma espécie de "cubo branco" subvertido.

Outras obras constituídas por grupos de peças estáticas também se beneficiaram pelo isolamento em salas individuais que permitiam uma leitura dos objetos um a um e também em conjunto, como a instalação Museum of Chance (2013), da indiana Dayanita Singh (1961-) - 160 fotografias emolduras individualmente ou em espécies de biombos articulados variando de posição a cada montagem -, a instalação escultórica composta por Room with Chairs and Factory (2002-08) e Fox/Mouse/ Belt (1992, moldado em 2007), do Holandês Mark Manders (1968-) - com grupos de peças articuladas no espaço rarefeito da sala -, a instalação arquitetônica do japonês Sou Fujimoto (1971), Architecture Is Everywhere (2015) - pequenos modelos arquitetônicos abstratos feitos com objetos comuns apoiados em pedestais regularmente dispostos por toda a sala - e o conjunto Shared Eye (2016), do estadunidense Sadie Benning (1973-) 

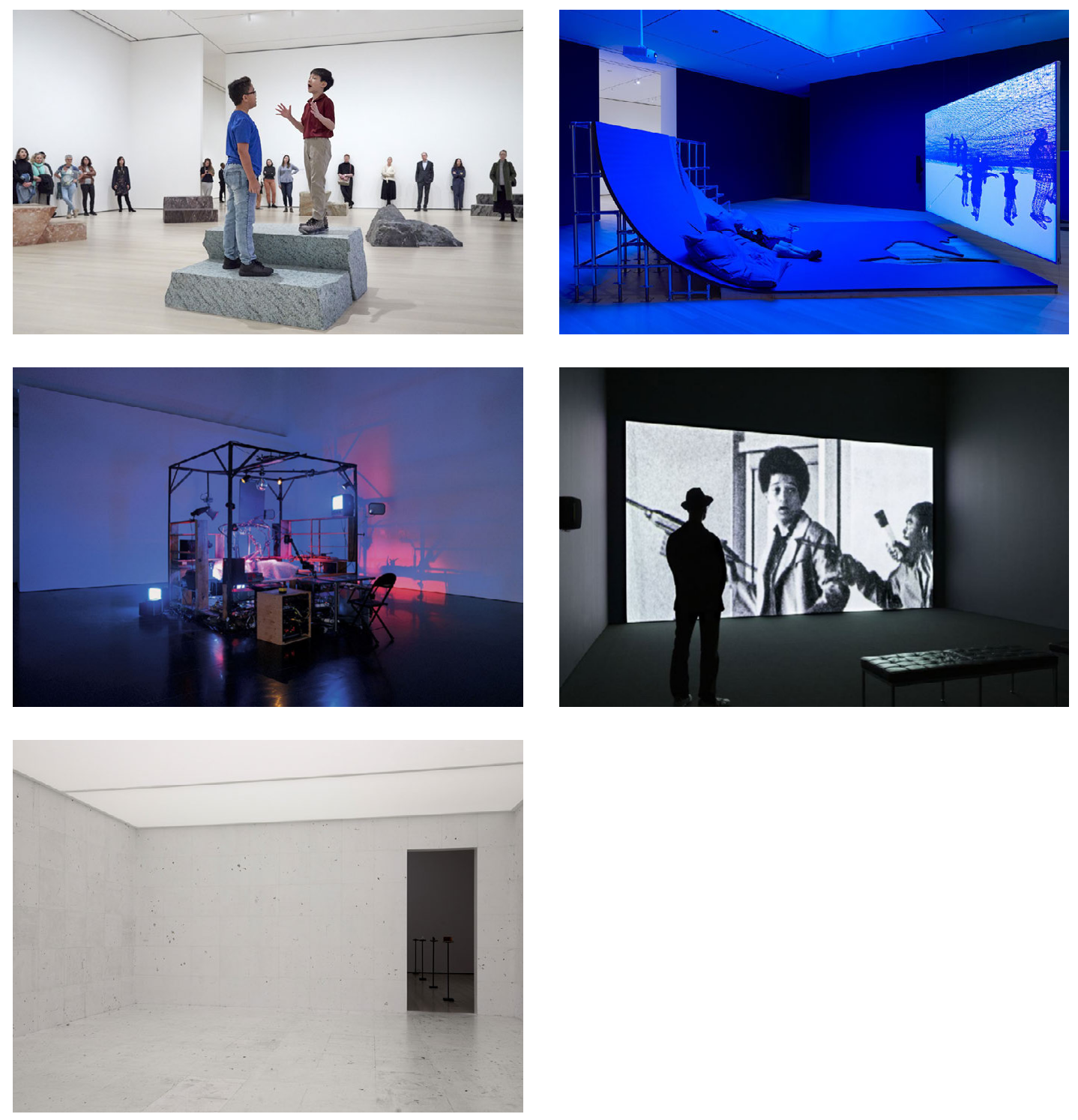

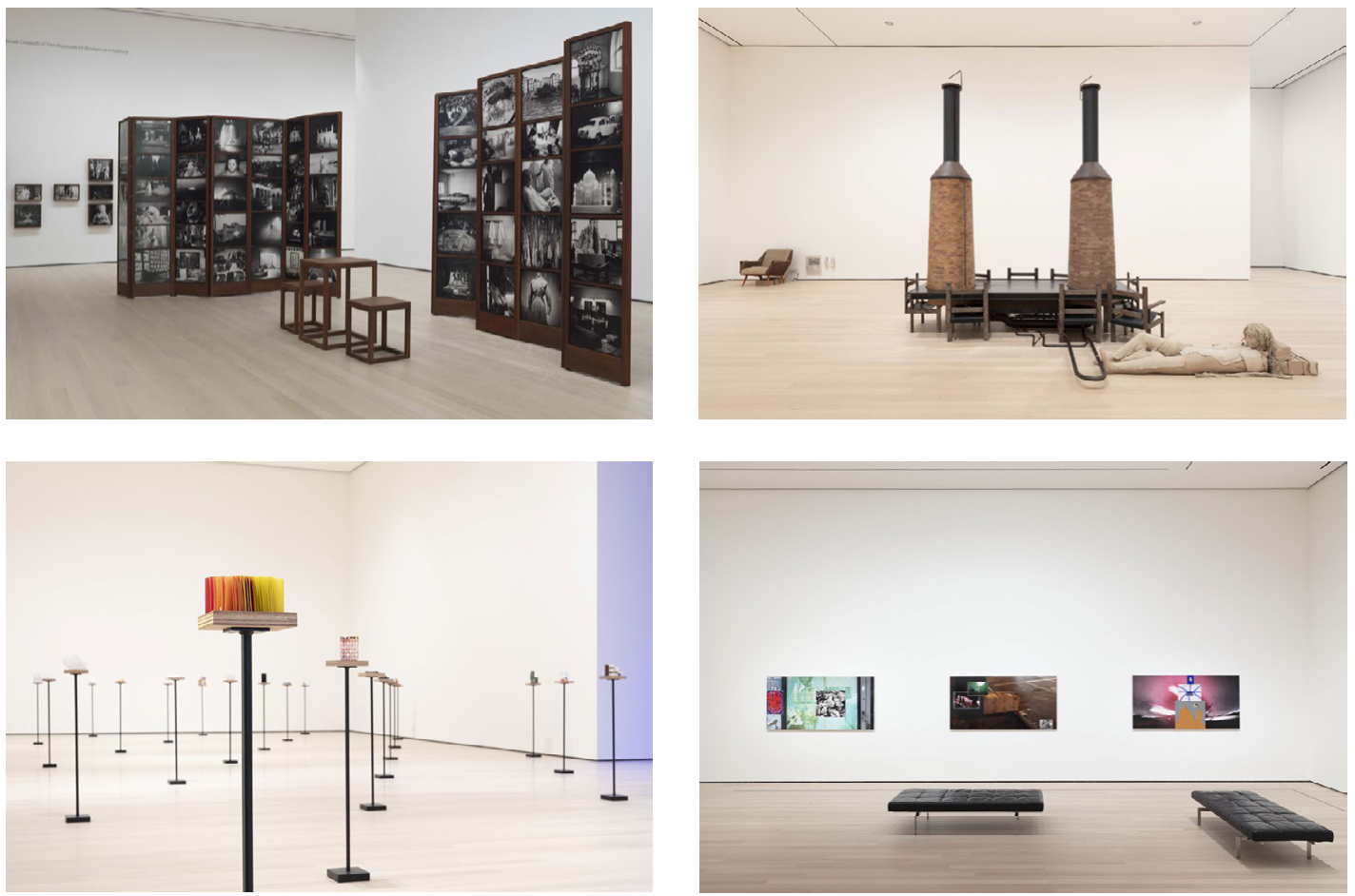

3.192 a 3.195 Vista das instalações Museum of Chance (2013), de Dayanita Singh, Room with Chairs and Factory (2002-08), de Mark Manders, Architecture Is Everywhere (2015), de Sou Fujimoto e do conjunto Shared Eye (2016), de Sadie Benning na exposição Surrounds: 11 Installations, MoMA, Nova York, 2019. Fotos: Denis Doorly. Fonte: https://www.moma.org/calendar/ exhibitions $/ 5073$
- 40 painéis retangulares fixados nas paredes combinando objetos tridimensionais com imagens análogas encontradas em fotografias existentes ou produzidas digitalmente pelo artista.

Apenas duas das onze obras foram dispostas em espaços abertos, como a escultura Pillar of Inquiry/Supple Column (20132014), da estadunidense Sheila Hicks (1934-) - vários feixes de cordões de tecido multicoloridos pendendo até o chão a partir de um recorte quadrado no teto, instalado na área da chegada dos elevadores e escadas rolantes - e a instalação Triple Point (Pendulum) (2013), da estadunidense Sarah Sze (1969-) - um conjunto escultórico feito com objetos do cotidiano distribuídos no piso em torno de um pêndulo móvel, posicionado numa área integrada aos demais espaços do museu e do exterior por passarelas, escadas rolantes, claraboia e esquadria.

A predominância de ambientes individualizados para cada trabalho, como vemos nessa mostra, havia se tornado uma 

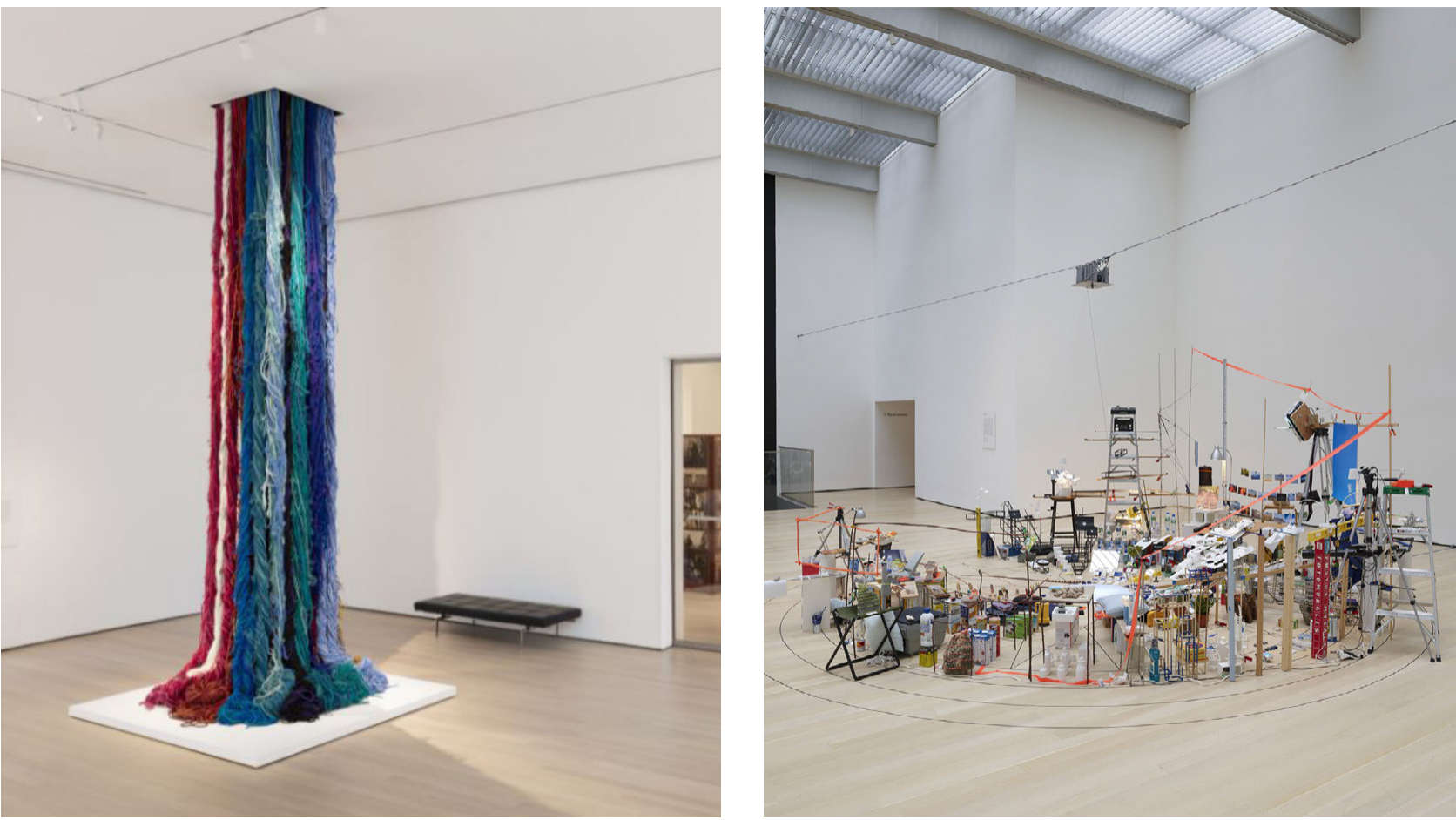

solução corriqueira de organizar mostras coletivas de arte contemporânea. Podemos encontrar raízes de tal modo de organização no tipo de arranjo instaurado pela curadora Dorothy Miller em sua série de exposições Americans - realizadas no MOMA entre 1942 e 1963-, revelando artistas atuantes nos EUA, contemporâneos à sua época. ${ }^{592}$ Fora Miller quem desenvolvera no museu a prática de agrupar obras de um único artista numa sala individualizada, conferindo uma coerência estética a cada ambiente, ainda que as peças expostas fossem então pinturas e esculturas, cada qual supostamente contida nos limites de seu próprio suporte material, sem as atuais interações com o contexto ao redor.

Com a tomada do espaço pela arte contemporânea e com a ampla utilização de elementos provenientes do universo cotidiano, a criação de contornos espaciais para delimitar o universo de cada obra tornou-se, em muitos dos casos, uma
3.196 e 3.197 Vista das instalações Pillar of Inquiry/Supple Column (2013-2014), de Sheila Hicks e Triple Point (Pendulum) (2013), de Sarah Sze (1969-), na exposição Surrounds: 11 Installations, MoMA, Nova York, 2019. Fotos: Denis Doorly. Fonte: https://www.moma.org/ calendar/exhibitions/5073

592 Cf. Capítulo 1 desta Tese. 


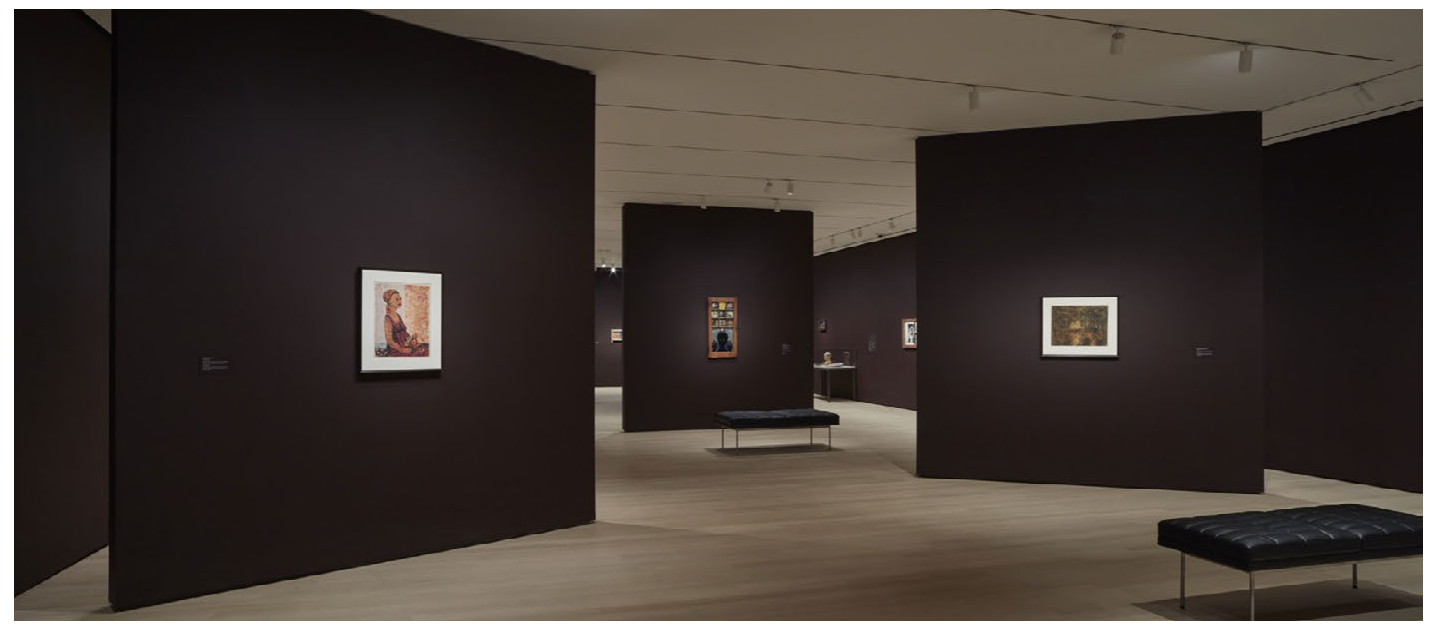

3.198 Vista da exposição Betye Saar: The Legends of Black Girl's Window, MoMA, Nova York, 2019. Foto: Heidi Bohnenkamp. Fonte: https://www.moma.org/calendar/ exhibitions $/ 5060$ necessidade. Surrounds é um exemplo claro disso, pois continha obras que abarcavam o espaço ao redor em diferentes graus, cada uma a seu modo, tornando complicada a convivência entre elas num mesmo ambiente. Nesse caso, além do tom rebaixado da arquitetura, também a expografia evitou criar supostas "distrações” à percepção das obras, mantendo o padrão asséptico convencional, limitando-se a estruturar o percurso de uma sala à outra. Podemos compreender esse modo de apresentação como uma espécie de atualização do "cubo branco" modernista, mas que, ao invés de valorizar a autonomia de cada obra com a suposta neutralidade do espaço, cumpre a função de relegar o completo domínio do espaço à arte, oferecendo a ela um contêiner o menos interferente possível, que vem a ser justamente o ambiente convencional disseminado como habitat "natural" da arte nos museus modernos, e que, portanto, tornara-se "transparente" à percepção.

Uma outra mostra de arte contemporânea foi localizada na única galeria de exposições temporárias que já havia no segundo pavimento, sob o bloco de Pelli e com acesso pelo átrio e pelo bloco de Goodwin e Stone - The Paul J. Sachs Galleries. A exposição montada ali para a reinauguração foi a individual The Legends of Black Girl 's Window, dedicada à obra da afro-estadunidense Betye Saar (1926-) e organizada pelos curadores Chris- 

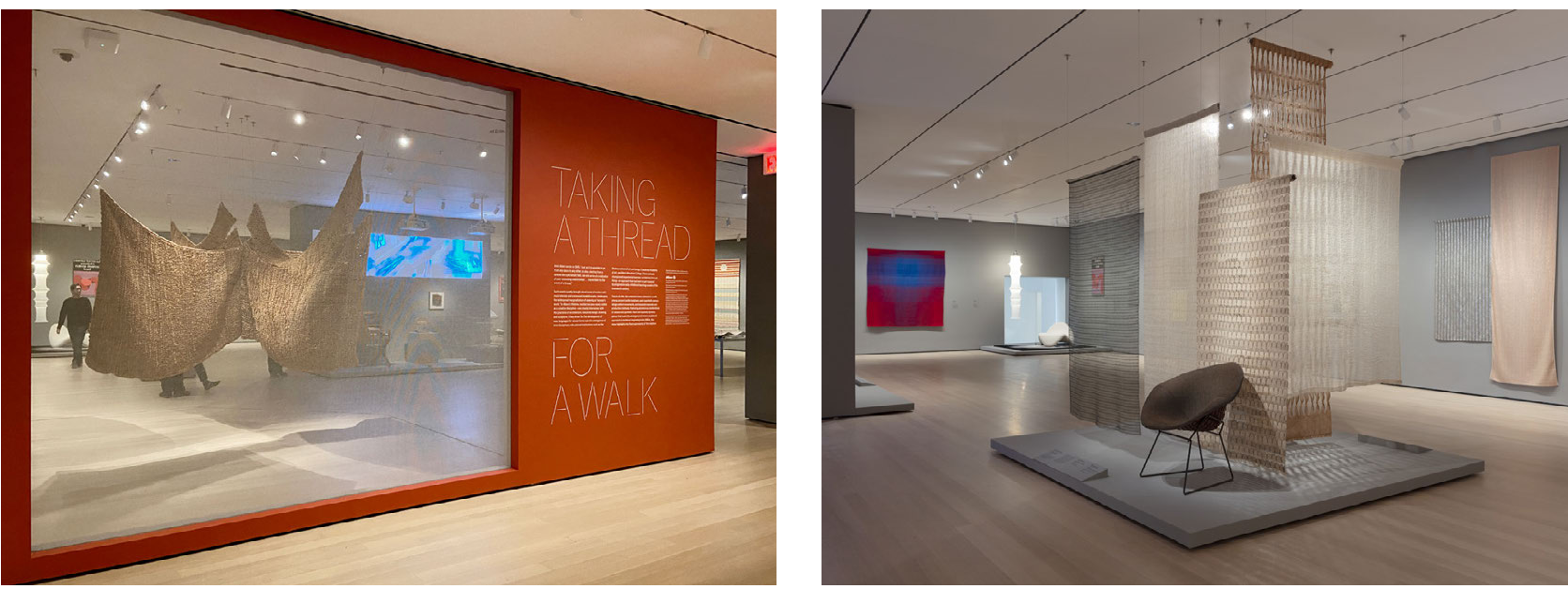

tophe Cherix e Esther Adler e as assistentes Ana Torok e Nectar Knuckles, do Departamento de Desenhos e Gravuras. Para expor as mais de 40 gravuras e colagens produzidas pela artista nos anos de 1960, a ambientação se aproximou mais de algumas salas da coleção do que da montagem de Surrounds. Ao invés de subdividido em salas, o espaço manteve-se contínuo, pontuado no centro por pequenos painéis posicionados em ângulos variados, e com as paredes pintadas de marrom café. ${ }^{593} \mathrm{O}$ conjunto das obras, de dimensões medianas e contidas em seus suportes bidimensionais, foi valorizado por essa solução expográfica ao mesmo tempo sutil e expressiva. Essa espécie de "ousadia" considerando o contexto do MomA era mais frequente, como vimos, em salas dedicadas a obras históricas ou às artes aplicadas, e mais rara nas exposições de arte contemporânea. Na mostra de Saar, os trabalhos não tinham uma dimensão espacial, mas os curadores puderam contar com o aval da artista para apoiar suas decisões sobre a montagem.

Outras três galerias dedicadas a exposições temporárias ficaram concentradas no terceiro pavimento, nas áreas antes reservadas a departamentos específicos. As salas a norte (voltada para a rua 54) - The Philip Johnson Galleries - receberam em 2019 a mostra Taking a Thread for a Walk, organizada pela curadora Juliet Kinchin e o assistente Andrew Gardner, do
3.199 e 3.200 Vista da exposição Taking a Thread for a Walk, MoMA, Nova York, 2019. Foto 3.199: nossa. Foto 3.200: Denis Doorly. Fonte: https://www.moma. org/calendar/exhibitions/5101

593 Cf. The Museum of Modern ART. Betye Saar: The Legends of Black Girl's Window (Oct 21, 2019Jan 4, 2020). MOMA. Disponível em: <https://www.moma.org/calendar/ exhibitions/506o>. Acesso em: 1 nov. 2020. 
594 Cf. The Museum of Modern ART. Taking a Thread for a Walk (Oct 21, 2019-Jan 10, 2021). MOMA. Disponível em: <https://www. moma.org/calendar/exhibitions $/$ 5101 ?locale $=p t>$. Acesso em: 1 nov. 2020.

595 Cf. The Museum of Modern ART. Sur Moderno: Journeys of Abstraction - The Patricia Phelps de Cisneros Gift (Oct 21, 2019-Sep 12, 2020). MOMA. Disponível em: $<$ https:/www.moma.org/calendar/ exhibitions/5061>. Acesso em: 1 nov. 2020.

596 Inés Katzenstein é curadora do Departamento de Arte Latinoamericana e diretora do Patricia Phelps de Cisneros Research Institute for the Study of Art from Latin America, sediado no MoMA; María Amalia García é curadora e consultora do Consejo Nacional de Investigaciones Científicas y Técnicas (CONICET) - Universidad Nacional de San Martín, na Argentina, e Karen Grimson é assistente de curadoria do Departamento de Desenhos e Gravuras do MoMA.

597 Segundo informações do museu, a coleção do MoMA conta com mais de 5 mil obras de arte moderna e contemporânea de artistas latino-americanos, distribuídas em seus seis departamentos curatoriais. Cf. THE Museum OF MODERn ART. Press release: The Museum of Modern Art anuncia Sur moderno: Journeys of Abstraction - The Patricia Phelps de Cisneros Gift. MOMA. Disponível em: <https://press.moma.org/ wp-content/uploads/2020/o6/ MOMA_CisnerosSurmoderno_ FINAL_PressRelease-PR_8.17.20. pdf $>$. Acesso em: 1 nov. 2020, p. 2.
Departamento de Arquitetura e Design. ${ }^{594}$ A exposição coletiva apresentava obras que conectam antigas tradições têxteis, movimentos de reforma de design do início do século 20 e materiais e métodos industriais de produção, destacando o surgimento de uma abordagem mais escultórica da arte têxtil a partir dos anos 1960. A galeria era introduzida por uma parede vermelha com um recorte coberto por um véu, revelando no interior pintado de cinza médio uma grande peça escultórica suspensa no teto, acompanhada de uma variedade de objetos - tapeçarias, cortinas, toalhas de mesa, painéis decorativos, amostras de tecido, poltronas, brinquedos educativos, esculturas, pintura, luminária, tear, revistas, livro, cartazes, peças publicitárias, estudos e fotografias e vídeos documentais. A sala contava num dos cantos com uma abertura de onde se podia avistar o átrio, que, mesmo pequena, ajudava o visitante a se localizar no edifício.

$\mathrm{Na}$ área dos blocos de Goodwin e Stone e Johnson a leste The Robert B. Menchel Galleries - foi montada a exposição Sur Moderno:Journeys of Abstraction - The Patricia Phelps de Cisneros Gift, ${ }^{595}$ com curadoria de Inés Katzenstein, María Amalia García e Karen Grimson, ${ }^{596}$ dando especial destaque na reabertura do museu à arte latino-americana do acervo. ${ }^{597}$ A mostra contava com mais de 100 pinturas, esculturas e obras sobre papel produzidos por artistas do Brasil, Venezuela, Argentina e Uruguai, entre os quais Lygia Clark, Gego, Raúl Lozza, Hélio Oiticica, Jesús Rafael Soto e Rhod Rothfuss, selecionados entre os 200 trabalhos doados entre 1997 e 2016 ao MomA por Cisneros, que, além de colecionadora, era membro do conselho do museu. Como anunciado pelo museu, a mostra reunia obras focadas no conceito de transformação da sociedade e da vida por meio da reinvenção da arte pela abstração, incluindo material documental para situar as produções em seus contextos. A exposição contava ainda com a presença de obras de outras procedências, como a escultura Spatial Construction $n^{\circ} 12$ (c. 1920), do russo Aleksandr Rodchenko (1891-1956), e a pintura Broadway Boogie Woogie (1942-1943), do holandês Piet Mondrian (1872-1944), destacando a influência do construtivismo russo e do neoplasticismo no desenvolvimento da arte moderna latino-americana. Essas relações apontavam para outras pos- 


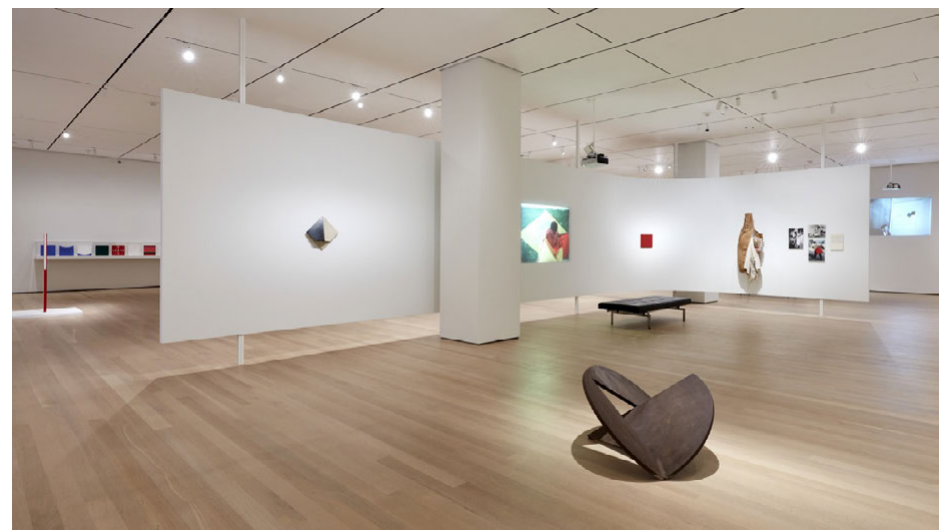

sibilidades de conexão com o acervo e com a história da arte moderna, como observou Roberta Smith,

Sur moderno é ao mesmo tempo um déjà vu e uma mirada para o futuro. Assim como em partes do antigo мома, tem foco único na abstração - geralmente pura -, mas filtrada por uma sensibilidade totalmente diferente, cuja contenção e racionalismo refletem muitas vezes a influência da arte geométrica europeia. É emocionante imaginar essas obras de Cisneros integradas à coleção do MOMA, minando a assertividade e a escala de boa parte da arte americana do pós-guerra, de Jackson Pollock a Richard Serra. Como pode ser visto aqui, a doação de Cisneros tem um alcance de tirar o fôlego. ${ }^{598}$

A qualidade da coleção e da mostra eram especialmente valorizadas pelo projeto expográfico, um dos que tinham mais personalidade entre as mostras da reabertura de 2019, ainda que não empregasse cores fortes ou estabelecesse uma articulação especial com a arquitetura, pois a cor predominante era o branco e a galeria expositiva sem uma expressão especial. Ao invés de subdividido em pequenas salas, o espaço foi estruturado com leveza e fluidez por painéis elevados do chão apoiados em suportes delgados que se dobravam em curvas ao redor dos espessos pilares da estrutura do edifício de 1939, em referência a um modo de expor muito frequente em exposições
3.201 Vista da exposição Sur Moderno: Journeys of Abstraction - The Patricia Phelps de Cisneros Gift, MoMA, Nova York, 2019. Foto: Heidi Bohnenkamp. Fonte: https://www.moma.org/calendar/ exhibitions/5061
598 Sмiтн, MomA's Art Treasure, No Longer Buried. Tradução nossa. 


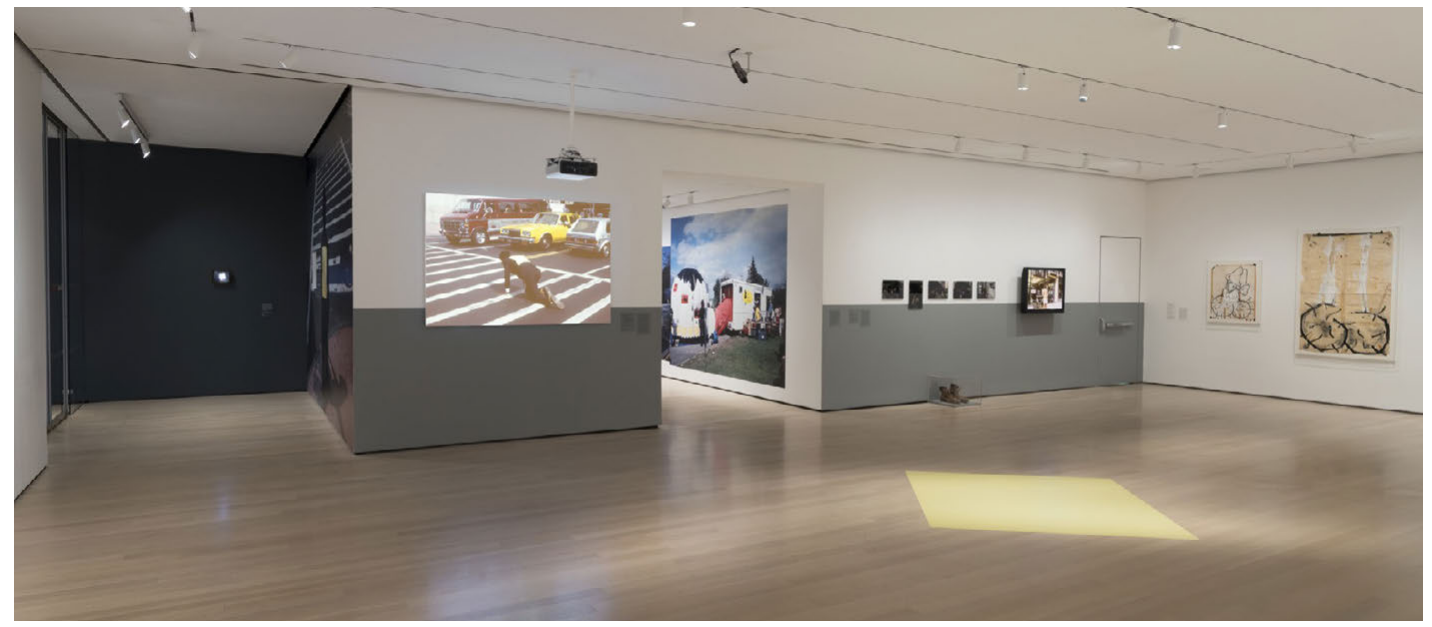

3.202 Vista da exposição member: Pope. L, 1978-2001, MoMA, Nova York, 2019. Foto: Martin Seck. Fonte: https://www. moma.org/calendar/exhibitions/5059
599 Cf. The Museum of Modern ART. member: Pope. L, 1978-2001 (Oct 21, 2019-Feb 1, 2020). МОМA. Disponível em: <https://www. moma.org/calendar/exhibitions/5059>. Acesso em: 1 nov. 2020. 600 Ibidem. de arte moderna dos anos 1950. Esses, por sua vez, remetiam à arquitetura produzida na época, especialmente a do brasileiro Oscar Niemeyer, cujas obras de Brasília figuravam em fotografias da mostra.

Ainda no terceiro pavimento, na área ao sul (voltada para a rua 53, sob o bloco de Pelli) - The Edward Steichen Galleries - foi apresentada a exposição member: Pope. L, 1978-2001, organizada pelos curadores Stuart Comer e Danielle A. Jackson, do Departamento de Mídia e Performance. ${ }^{599}$ A mostra apresentava o caráter provocador e subversivo da obra do afro-estadunidense William Pope.L (1955-) - que chamava a si mesmo de "pescador do absurdo social" - abrangendo registros de performances teatrais e ações de rua, pintura, vídeo, desenho, instalação e escultura. A tensão contida nos trabalhos - entre a cultura do consumo e do sucesso e a sociedade fraturada por conflitos sociais, raciais e econômicos - não foi explicitamente refletida na ambientação da exposição, tratada como tantas das outras galerias "genéricas" de arte contemporânea no edifício. Conforme expresso no texto de introdução da mostra, essa tensão seria "intensificada pela apresentação dessas obras de arte subversivas em um importante museu de arte".${ }^{600}$ Nesse aspecto, podemos fazer um paralelo com o conflito entre o conteúdo apresentado e o contexto institucional na exposição Information, 
apresentada no MomA em 1971, que, como vimos no Capítulo 2 desta tese, continha diversas obras que revelavam ao público valores e condutas que o museu preferia ocultar, deixando cicatrizes duradouras no museu, que evitou repetir esse tipo de mostra por muitos anos. Se o MomA continuava em muitos aspectos representando uma elite social - especialmente por sua dependência de financiadores ligados às altas rodas do poder econômico do país -, a nova postura autocrítica das curadorias do museu como um todo, manifestamente mais abertas a desmontar parâmetros estabelecidos, provocava ela mesma uma certa neutralização do teor subversivo dessas obras, arrefecendo a possibilidade de tensão que havia noutros tempos.

\subsubsection{RECEPÇÃO CRÍTICA EM 2019}

Bastante comentada mesmo antes da sua concretização, o momento de reinauguração do MoMA movimentou ainda mais a imprensa especializada dos EUA que, bastante familiarizada com o museu, buscou apontar os prós e contras das mudanças, focando especialmente nas implicações da nova apresentação da coleção. Um dos questionamentos era se o museu conseguiria equilibrar as variadas interpretações curatoriais com a função didática de ensinar a história da arte, como observou o crítico de arte e arquitetura do jornal The Washington Post, Philip Kennicott:

Há uma diferença entre complicar as narrativas e abandoná-las. O MoMA parece querer fazer o último, mas não consegue se deixar. O grosso da narrativa nas galerias permanece amplamente cronológica, com as estrelas de suas coleções praticamente ainda onde se espera encontrá-las. O perigo é que o museu venha a ter um sistema de dois níveis, dependente ainda das peças icônicas que os visitantes exigem ver, complementadas por convidados ocasionais trazidos temporariamente para complicar as coisas. Ainda mais preocupante é o objetivo declarado de abandonar a função didática. Ninguém quer uma organização cultural que intimide, mas se quer aprender. É uma questão de tom. ${ }^{601}$
601 Kennicott, Philip. The new MOMA is a lot bigger. But you may not learn as much about the art. The Washington Post, 10/10/2019. ed. 2019. Tradução nossa. 
Outra questão era o quanto a nova abordagem curatorial do MомA teria de fato mudado e o que isso poderia representar para a história da arte no futuro. Ao fim de um longo texto sobre a difusão de uma visão do modernismo pelo museu, Jerry Saltz concluiu:

Não sou um radical, então estou feliz que o museu não esteja mudando tanto. Não quero destruir o MOMA ou outros museus do modernismo (apesar de suas falhas). Eu ainda preciso frequentá-lo regularmente para me comunicar com os ancestrais. Outros vão defender reformar e substituir todo o sistema. Se o мома tem um amor radical pela arte em vez de um amor pelo sistema subjacente, ele terá um papel nas próximas gerações - e pode ser que os futuros historiadores da arte apontem para esta apresentação como um ponto de inflexão -, a instituição central do modernismo comprometida com um novo conjunto de ideias sobre o que ela foi, o que ela representa e o que nos oferece hoje. Digo ao момa: traga os mortos de sua reserva - artistas considerados 'errados' não fazem parte da velha história - coloque-os todos à vista, deixe-nos decidir. Todos nós amamos a arte. Mas, como escreveu James Baldwin, 'O amor é uma batalha... O amor é crescimento.' Depois de um século, estamos finalmente começando a superar o modernismo. ${ }^{602}$

Algumas das observações apontaram para a imbricada relação entre a arquitetura e as formas de apresentação da arte na renovação, como as de Alexandra Lange:

Normalmente, quando um novo museu é aberto, os críticos de arquitetura tratam do edifício e os críticos de arte das exposições. Isso funciona para edifícios com limites. Mas o novo MOMA não é um objeto estático ou sólido; é uma hidra, traçando seu caminho por trás do desfile permanente de cortinas

602 SALTZ, 2019, op. cit. Tradução nossa.

603 LANGE, 2019, op. cit. Tradução nossa. de vidro prateadas e pretas na Rua 53, serpenteando em três direções - oeste, norte e sul -, atrás de superfícies grandiosas e suavemente finas [...]. O poder do novo MOMA - o flex - vem da arte, não da arquitetura. ${ }^{603}$ 
Justin Davidson descreveu várias situações de ruptura na "antiga linha do tempo de ismos, influências e grandes homens" em que os curadores teriam reorganizado a coleção "de acordo com temas deliberadamente enigmáticos, períodos embaralhados e mídias desordenadamente díspares", concluindo: "se esta nova organização encanta, ilumina ou apenas irrita você, dependerá em parte de sua fidelidade à versão dos livros de história da arte, mas tem um efeito poderoso na arquitetura." ${ }^{604}$ Jerry Saltz, por sua vez, comemorou explicitamente a quebra do percurso linear:

Eu adoro que, pela primeira vez, você pode se perder no MoмA. Tal como acontece com o Metropolitan, podemos começar a construir nossas próprias histórias, em vez de nos submetermos ao velho bullying 'Cézanne gerou Picasso, que gerou Duchamp, que gerou tudo pós-1979'. ${ }^{605}$

Hal Foster procurou articular os aspectos da arte e da arquitetura ao discurso e ao modo de funcionamento da instituição de maneira mais abrangente. Para o crítico, as mudanças nas formas de apresentação poderiam atrair o interesse de novos públicos: "essa apresentação é, a um só tempo, mais acurada e atraente, especialmente para os jovens, de backgrounds e habilidades midiáticas diversas, possivelmente neófitos diante de grande parte dos trabalhos expostos." ${ }^{606}$ Embora tenha considerado o novo момA "basicamente um sucesso", o crítico não deixou de apontar o que considerava alguns erros: "A atual apresentação mobiliza duas grandes maldições da história da arte tradicional: anacronismo - a confusão de trabalhos de diferentes períodos - e pseudomorfismo - a presunção de que coisas parecidas umas às outras também se assemelham de outras maneiras," afirmou Foster, avaliando que os curadores, ao desvincularem as obras de seus contextos estritos de produção, estariam se comportando como artistas e produzindo resultados incertos: "as conexões variam do inspirado ao caprichoso". ${ }^{607}$ Em sua opinião, a falta do amparo mais consistente da história da arte em alguns pontos da coleção indicaria uma atitude populista, próxima a uma condescendência elitista.

Quando analisara o projeto de Taniguchi em 2004, Foster centrara sua crítica, como vimos anteriormente, na sublimação
604 DAVIDSON, 2019, op. cit. Tradução nossa.

605 Davidson; Saltz, Two Critics - Art and Architecture Compare Their Moma Experiences, op. cit. Tradução nossa.

606 Foster, Hal, Mudança no MOMA, ARS, v. 315, n. 18 (38), p. 315327,2020, p. 320 .

607 Ibidem, p. 322 . 
estética e ao mesmo tempo financeira dos recursos investidos naquela expansão, que supostamente fariam a arquitetura "desaparecer", replicando o modo com que o capital financeiro apagaria seus rastros. Naquele momento, no entanto, o museu não havia amadurecido a postura autocrítica que provocara a atual renovação curatorial, apresentada agora pela instituição como um movimento democratizante. Para o autor, no entanto, o novo momento traria à tona uma incompatibilidade inerente entre a intenção que orientara a organização do edifício e das exposições e os vínculos profundos do museu com representantes da mais alta elite financeira:

Daí se chega ao tema mais perturbador no que concerne ao novo MомA e muitos outros museus hoje: a contradição entre missão pública e interesse privado ou, mais cruamente, entre democracia e plutocracia. Um éthos democrático percorre o discurso do novo MoмA, tanto em suas operações internas colaboração entre departamentos, diversidade de modos de apresentação, dissolução de velhas hierarquias entre grande arte e arte ordinária [high and low art] e mídia - quanto em sua visada externa: 'A límpida fachada de vidro, novas galerias no nível da rua, um piso térreo de acesso livre e aberto a todos oferecem mais transparência e trazem a arte mais próxima das pessoas nas ruas do centro de Manhattan', diz um press release. Tal associação entre transparência arquitetônica e sociedade igualitária foi uma senha para os designers progressistas no período do entre guerras, mas não se sustentou nas décadas subsequentes. Afinal, uma vez que adentramos a coleção permanente, é num espaço à parte que nos encontramos; absorvidos em arte, talvez não notemos que passamos aos pisos inferiores da torre do edifício corporativo 53 W53, desenhado por Jean Nouvel para a Hines, uma incorporadora global a qual o момA havia vendido o terreno muitos anos antes. Finalmente, nos deparamos com os nomes de todos os fundadores afixados aos espaços, novos e antigos: David Geffen, Jerry Speyer, Ronald Lauder, Kenneth Griffin, Donald Marron etc. Aventuras ambiciosas por certo exigem suporte colossal, dizem os realistas; para que então questionar? Preferiríamos que o dinheiro fosse gasto em iates maiores ou ilhas melhores? E não teria sido sempre 
assim? Por que fingir que a fortuna em combustível fóssil de Rockefeller é mais limpa do que essas, financeiras? É só o mais velho dinheiro novo. De todo modo, qual é a alternativa, com o fim do suporte federal e a ninharia do que provém do governo local? Há que se considerar, igualmente, a competição, na qual eles [os museus] estão, também, integralmente envolvidos. ${ }^{608}$

O momento atual estaria, segundo Foster, pressionando a "trégua tácita" estabelecida com os museus contemporâneos, que envolveria evitar questionar suas fontes de financiamento enquanto eles continuassem a nos oferecer "exposições impactantes em belas galerias". ${ }^{609}$ Assim como outros museus de peso, o Moma esteve recentemente na mira de protestos contra a "filantropia tóxica" ou a favor de uma decolonização mais profunda nas instituições culturais. Em março de 2019, o Whitney Museum fora alvo do grupo Decolonize This Place, que organizou uma série de protestos pedindo o afastamento do vice-presidente Warren B. Kanders - dono de uma empresa fabricante de gás lacrimogênio usada contra manifestantes e imigrantes do mundo todo -, que acabou renunciando ao cargo em julho do mesmo ano.

Na noite de 18 de outubro de 2019, quando o Moma promovia uma festa fechada para celebrar a renovação, 150 ativistas ligados aos grupos Art Space Sanctuary e New Sanctuary Coalition organizaram um protesto na entrada do evento solicitando o desvinculamento do museu de pessoas e negócios associados a prisões privadas - locais de encarceramento massivo de imigrantes recém-chegados aos EUA. As solicitações eram especialmente dirigidas ao membro do conselho e empresário Larry Fink, colecionador de peso e dono da empresa financeira Black Rock, investidor em grupos prisionais. O objetivo dos protestos não era afastar Fink do MомA, mas pressioná-lo a remover seus investimentos desse tipo de negócio e ainda direcioná-los a organizações comprometidas com causas sociais, num movimento conhecido por divest-reinvest. ${ }^{610}$

Num contexto em que o descontentamento social voltara à tona com mais frequência, era de se esperar que as mudanças anunciadas pelo мома como uma profunda autocrítica fossem recebidas com desconfiança por parte da sociedade, dados os
608 Ibidem, pp. 324-25.

609 Ibidem, p. 325 .

610 Cf. Greenberger, Alex, Activists Interrupt MOMA Opening Party, Urging Museum, Trustee to Cut Alleged Ties to Private Prisons. ARTnews, 18/10/2020. ed. 2020. 


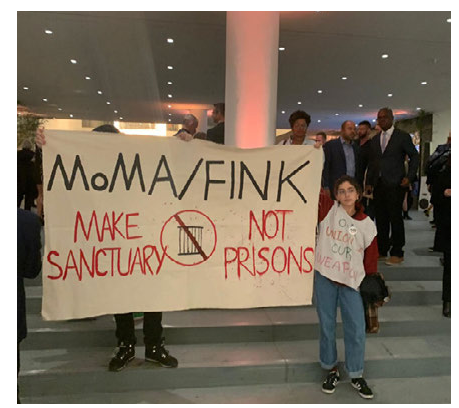

3.203 Protesto na festa de abertura do MoMA, Nova York, 18 de outubro de 2019.FonteL https://www.artnews.com/ art-news/news/moma-opening-party-larryfink-protest-13420/
611 Durbin, Andrew. What Does the New Moma Mean for Contemporary Art? Frieze Magazine, 16/10/2020. ed. 2020.

612 Foster, 2020, op.cit., p. 326. No idioma original, o autor utiliza o termo decolonize. A tradução para o Português é de Sônia Salzstein. alicerces de sustentação do museu, responsáveis pela viabilização da própria renovação. Na avaliação do escritor e editor da revista Frieze, Andrew Durbin,

Há pouco desconforto, pouco reconhecimento da ruína econômica e social que assola o mundo fora do museu - pelo menos pela própria instituição. Poucas lágrimas. Isso pode ser adequado (ou talvez inevitável) para um museu tão grande como о мома, que se move lentamente, deliberadamente, enquanto muitos do lado de fora protestam contra a desigualdade crescente e a extinção iminente, escrevem cartas abertas desafiando os negócios habituais do museu ou tuitam suas frustrações com o ritmo glacial de mudanças significativas, na arte e em outros lugares. Um novo MOMA, com um novo ethos em torno de sua coleção, nunca poderia ter mudado totalmente. A mudança real é um jogo melhor jogado do lado de fora. ${ }^{611}$

Mesmo com todos os esforços empreendidos para renovar sua apresentação, tornando-a mais alinhada com as demandas atuais por diversificação e inclusão, as fontes de recursos que continuam a suprir o MOMA - e que permitem que a instituição ainda se sustente como a maior detentora de arte moderna e contemporânea do mundo - não podem ser consideradas "limpas", como apontou também Foster:

O MOMA merece aplausos por internacionalizar sua coleção modernista e globalizar sua apresentação contemporânea, por incluir artistas mulheres à primeira e artistas negros à ultima. Em certa medida, o museu também diversificou o seu estafe, ainda que não o seu Conselho. Mas o que seria, verdadeiramente, descolonizar o MoMA? Por certo, significaria maior escrutínio de seus patronos e mais estudos sobre a formação da coleção e o desenvolvimento da instituição. Parte desse trabalho começou nas décadas de 1960 e 1970, mas prosseguir com a tarefa requer artistas mobilizados, ativistas e acadêmicos - mais 'pescadores do absurdo social'. ${ }^{612}$

Ao referir-se à expressão de William Pope.L, Foster apontou para o potencial da arte em transformar realidades, trazendo 
à tona verdades ocultas, muitas vezes desconcertantes, sobre os sistemas de opressão subjacentes ao sistema social na qual está inserida. Por outro lado, a renovação curatorial anunciada pelo MoмA só pôde mostrar-se de modo mais completo em 2019 meio século depois do ano 1969, marcado por intensos protestos de artistas e ativistas que vinham reivindicando uma maior aproximação do museu com as novas realidades da arte e da sociedade, como vimos no Capítulo 2 desta tese. Ou seja, por mais dinâmico que pretendesse ser, o peso do MoмA dificultara que tivesse se movido com mais agilidade em direção a práticas efetivamente contemporâneas e socialmente sustentáveis, seja pelo tamanho de sua coleção, pelo antigo apego à narrativa canônica da história da arte, pela origem de suas fontes de financiamento, ou por sua estrutura cada vez mais hierarquizada.

Em meio a tantas galerias encapsuladas em espaços suspensos do mundo, intercaladas por alguns relances de conexão com o exterior, as curadorias anunciaram sua disposição para rever a linearidade e seletividade da narrativa anterior e trabalhar em prol de aproximar obras históricas ou atuais a questões que tocam o universo sensível de um número mais diversificado de pessoas. De todo modo, a realidade não deixará de bater à porta mais cedo ou mais tarde, seja pela pressão de grupos excluídos, seja pela atuação de artistas contemporâneos, de quem a instituição também depende para manter-se viva.

\subsubsection{UM TERRITÓRIO ABERTO}

Os caminhos seguidos pelo moмa nas duas últimas décadas para realinhar-se como uma instituição de arte "do nosso tempo" ofereceram um vasto material para refletir sobre a complexidade dos espaços destinados à arte contemporânea - o foco desta tese. A partir do que foi analisado até aqui, podemos sintetizar de que modo as características particulares do projeto de $\mathrm{DS}+\mathrm{R}$ podem contribuir para oferecer possibilidades espaciais mais interessantes para abrigar arte contemporânea no museu.

Para além da perene obstinação em manter seu posto como um baluarte no universo da arte, vemos que a preocupação 
marcante do Moma na virada do século em sustentar uma identidade moderna - inclusive enquanto um estilo arquitetônico -, foi atenuada pela aposta em assumir de modo mais desimpedido uma multiplicidade de perspectivas, tanto no âmbito da concepção e apresentação das exposições, quanto no de seu edifício.

Nas sucessivas reformas e ampliações anteriores do museu, dois dos blocos mais antigos - o de Goodwin Stone e o de Philip Johnson - vinham se mantendo como índice daquela marca, que, no entanto, foi mais valorizada na fachada que no interior do edifício, tratado em geral de modo homogêneo, para que eventuais descontinuidades arquitetônicas não trouxessem sobressaltos à experiência da arte. Na última reforma, no entanto, houve uma intenção de valorizar a singularidade das várias camadas construídas, acentuando algumas das características arquitetônicas das áreas públicas de cada bloco, como os acabamentos em branco e preto do edifício de Goodwin e Stone e as placas de ardósia da ampliação de Taniguchi, em contraste com os novos revestimentos em madeira, as estruturas em aço delgado e os planos transparentes da intervenção atual. $\mathrm{O}$ tratamento descontínuo não foi adotado apenas nos espaços públicos, mas também nas novas galerias sobrepostas, que, embora inseridas no meio do percurso das galerias homogêneas, oferecem outras perspectivas visuais, integrando espaços internos e externos do museu. $\mathrm{O}$ enorme edifício do MOMA ganha, assim, mais condições de ser lido como um lugar, marcado por diversas intervenções ao longo da história e situado num contexto urbano específico, articulado ao mundo real.

Era justamente essa demanda por uma interação com o mundo real que estava na origem da produção que passou a ser chamada de arte contemporânea, marcando a fronteira com a arte moderna a partir dos anos 1960. Como vimos no capítulo 2, os espaços de arte que surgiram naquele momento explicitavam essa relação com a atuação em locais não originalmente destinados à arte e muitas vezes bastante inóspitos, como os edifícios e espaços urbanos abandonados. Surgido nesse contexto e instalado em 1976 no prédio deteriorado de uma escola desativada, a proposta do PS1 era a de se contrapor ao padrão das instituições convencionais como um "anti-mu- 
seu", e sua surpreendente fusão com o MOMA em 1999 não fez com que as duas instituições ficassem mais parecidas uma com a outra em termos arquitetônicos. Enquanto o PS1 não sofreu transformações significativas em seu espaço desde então, o MOMA passou por duas expansões e renovações com projetos arquitetônicos ambiciosos, sofisticados e custosos. Por outro lado, é possível identificar na renovação da abordagem curatorial do момА - mais multidepartamental, internacionalizada e diversificada e com maior integração com artistas contemporâneos - e na maneira de espalhar a arte por todo o edifício - como no programa atual de arte comissionada para os espaços ditos públicos do museu e nas formas de ocupar o átrio -, um movimento de aproximação com o tipo de prática que animara o PS1 nas duas décadas em que funcionou de modo independente, antes da fusão.

Interessante observar como o MoMA se refere a realizações do PS1 em sua página na internet Exhibition history, que disponibiliza atualmente informações sobre mais de 5.0oo exposições desde a fundação da instituição em 1929, contendo fotografias das montagens e das obras, listas de obras, press releases e catálogos. ${ }^{613}$ Estão indicadas como realizações do MOMA PS1 - nome atual da instituição - não apenas as exposições que aconteceram no PS1 desde a sua fundação em 1976 até a fusão com o MOMA em 1999, como ainda as ações realizadas pelo I.A.U.R. liderado por Alanna Heiss desde 1971. Na página lançada no site do museu em 2019, MOMA through Time, apresentada como "uma história incompleta do MомA e do MOMA PS1, contada por meio dos objetos do arquivo," ${ }^{14}$ foram selecionadas entre as exposições em destaque entre as décadas de 1970 e 1990 apenas 6 do MOMA contra 17 do I.A.U.R. e do PS1, a maioria delas relacionadas à arte contemporânea. O modo com que foram fundidos numa mesma história os eventos realizados pelas duas instituições enquanto ainda eram independentes e a desproporção numérica entre eles indica um reconhecimento do distanciamento do MOMA com relação à arte contemporânea nas décadas finais do século xx.

Com relação à arquitetura, também não é celebrada a intervenção desse período, pois foram praticamente apagadas do interior do edifício as marcas da reforma de César Pelli de 1984.
613 Cf. The Museum OF Modern ART. moma Through Time. MOMA. Disponível em: < https:// www.moma.org/interactives/ moma_through_time $>$. Acesso em: 2 jan. 2020.

614 The Museum of MOderN ART. Exhibition History. MoMA. Disponível em: < https://www. moma.org/calendar/exhibitions/ history>. Acesso em: 27 mar. 2021. 


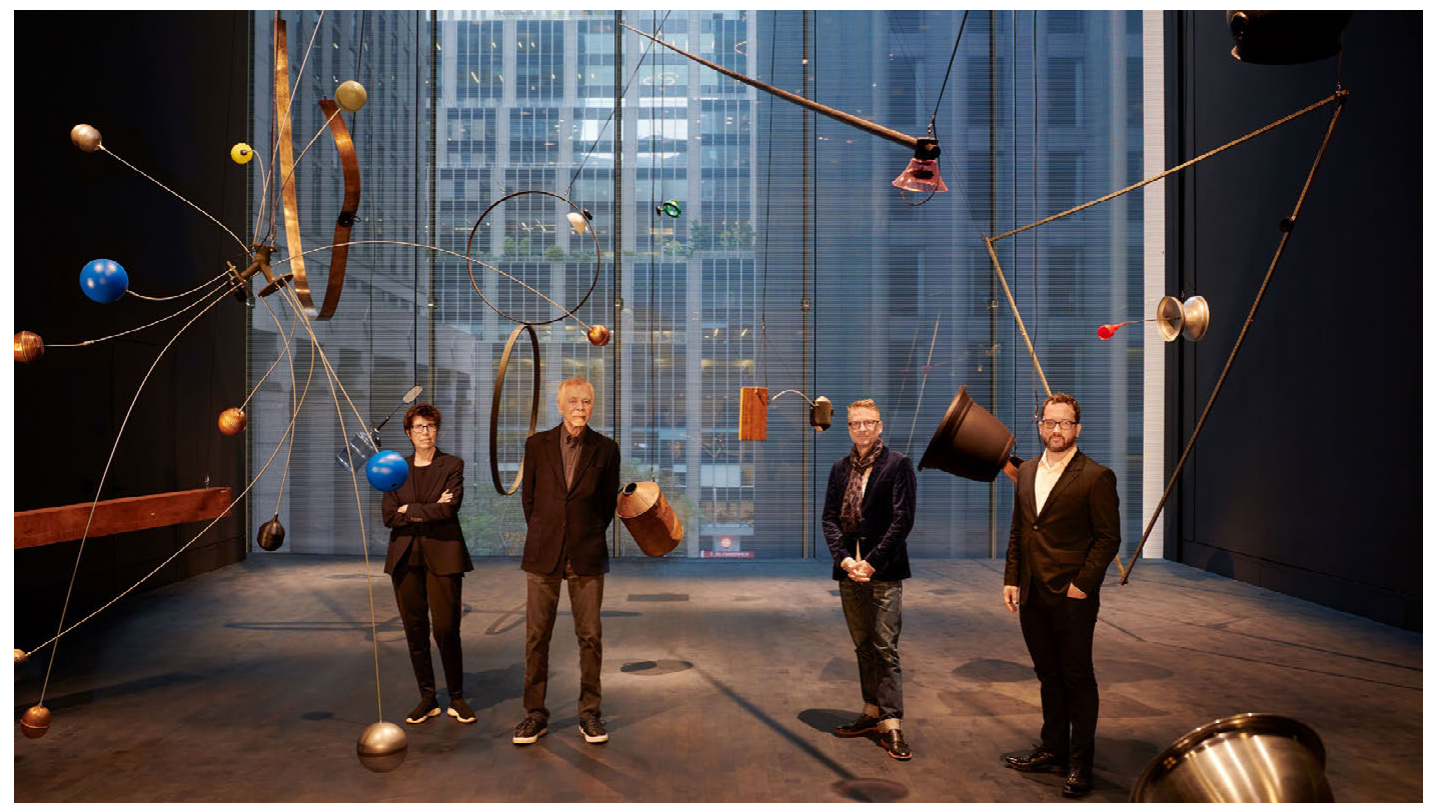

3.204 Elizabeth Diller, Ricardo Scofidio, Charles Renfro e Benjamin Gilmartin (sócios do DS+R) na Studio Gallery do MoMA, Nova York, 2019.

615 Glenn Lowry in: THE MusEuM OF MODERN ART. MOMA Now, op. cit., p. 27 .Tradução nossa.
Ao contrário dessa, as duas últimas expansões foram concebidas de modo mais articulado com as aspirações da instituição e com a intenção de retomar um vínculo com as práticas contemporâneas. Embora aparentemente mais limitada, a intervenção de DS+R e Gensler beneficia-se de ter sido concebida numa época em que a instituição não parece depender tanto da arquitetura para ditar esses rumos quanto na época do projeto de Taniguchi. O museu deixou de buscar um objeto arquitetônico acabado, para abrir-se a possibilidades desconhecidas, como vemos na declaração de Lowry: "É nosso objetivo que as galerias do Museu não apenas promovam novas formas de ver e pensar sobre os artistas e as obras de arte, mas também sinalizar que sempre haverá mais possibilidades além daquelas atualmente concebidas ou articuladas.” ${ }^{615}$ Os espaços arquitetônicos do museu são um território aberto que passará agora a ser explorado por curadores e artistas, para só então revelar seus potenciais. Assim como a curadoria, o edifício do MOMA passou também a contar várias histórias de suas arquiteturas. 


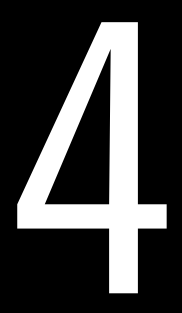

o PALAIS DE TOKYO EA ARQUITETURA DO MUNDANO 

O museu ordena os saberes e estados do conhecimento, enquanto que o papel do Palais de Tokyo é o de criar desordem. É por isso que é muito perigoso e, portanto, gerador. Ele refecunda porque instaura a desordem no coração da ordem. o Palais de Tokyo deve estar do lado de Dionisio, enquanto os museus estão do lado de Apolo. ${ }^{616}$

Na mesma época em que o MomA se preparava para a chegada do século XXI procurando uma forma de realinhar-se com as práticas contemporâneas, como vimos no capítulo anterior, a França também se organizava para atualizar sua rede de espaços de arte. Visando reconquistar para o país uma condição há muito tempo perdida como propulsora da "arte de seu tempo", decidiu-se, no final dos anos 1990, implantar um "local de criação contemporânea" numa das alas do Palais de Tokyo de Paris, então em desuso. O projeto arquitetônico de adaptação do edifício - construído em 1937 para abrigar a primeira sede do Museu Nacional de Arte Moderna (MNAM) - foi realizado pela dupla francesa Anne Lacaton (1957-) e Jean-Philippe Vassal (1954-) e concluído em duas etapas, em 2002 e 2012. Enquanto o projeto de Taniguchi inaugurado em 2004 ampliara o edifício do момА, promovendo uma renovação integral que homogeneizara ao máximo seus espaços internos, o partido adotado para reabilitar o Palais de Tokyo foi o de intervir o mínimo no edifício, deixando à vista as marcas de sua história e seu estado deteriorado. Na concepção de Lacaton \& Vassal, essa seria a condição mais propícia para abrigar manifestações contemporâneas, pois legava a artistas e curadores a tarefa de completar o edifício com suas variadas intervenções sobre o espaço. Daí que, se o Palais de Tokyo pode ser colocado do lado de Dionísio - na metáfora de seu diretor, Jean de Loisy,$-{ }^{617}$ o MOMA pode facilmente ser entendido no espectro de Apolo.

Desde a fusão com o centro de arte contemporânea PS1, em 1999, о мома passou a conter em si mesmo esses dois polos, ainda que mantidos de forma razoavelmente independente. No entanto, como vimos no segundo capítulo desta tese, a condição espacial do PS1 - que se instalara como um "anti-museu" em 1976 num edifício deteriorado de uma antiga escola abandonada - não havia sido uma proposta arquite-
616 Jean de Loisy (presidente e curador chefe do Palais de Tokyo de 2012 a 2018). Explorer l'Intégralité de l'humain. In: PALAIS DE TOKYo. Palais 15: Histoire du Palais de Tokyo depuis 1937. Paris: Palais de Tokyo, 2012, p. 276. Tradução nossa. 617 Ibidem. 
tônica, mas partira de uma concepção curatorial bastante vinculada ao modo como artistas vinham atuando, à margem das instituições estabelecidas e de espaços convencionais de arte. Se o PS1 era uma referência para a concepção do "local de criação contemporânea", no Palais de Tokyo esse modo de intervenção mínima sobre o espaço havia sido adotado como um partido arquitetônico por Lacaton \& Vassal, tornando-se um dos projetos referenciais da dupla, que viria a ser laureada com o Pritzker Architecture Prize em 2021. O estudo desse projeto oferece um contraponto importante ao caso do MомA, ampliando a reflexão sobre a arquitetura de espaços destinados à arte contemporânea.

Considerando que o espaço arquitetônico emoldura a experiência com a arte, a principal questão que se coloca é compreender quais possibilidades de exploração são ampliadas ou
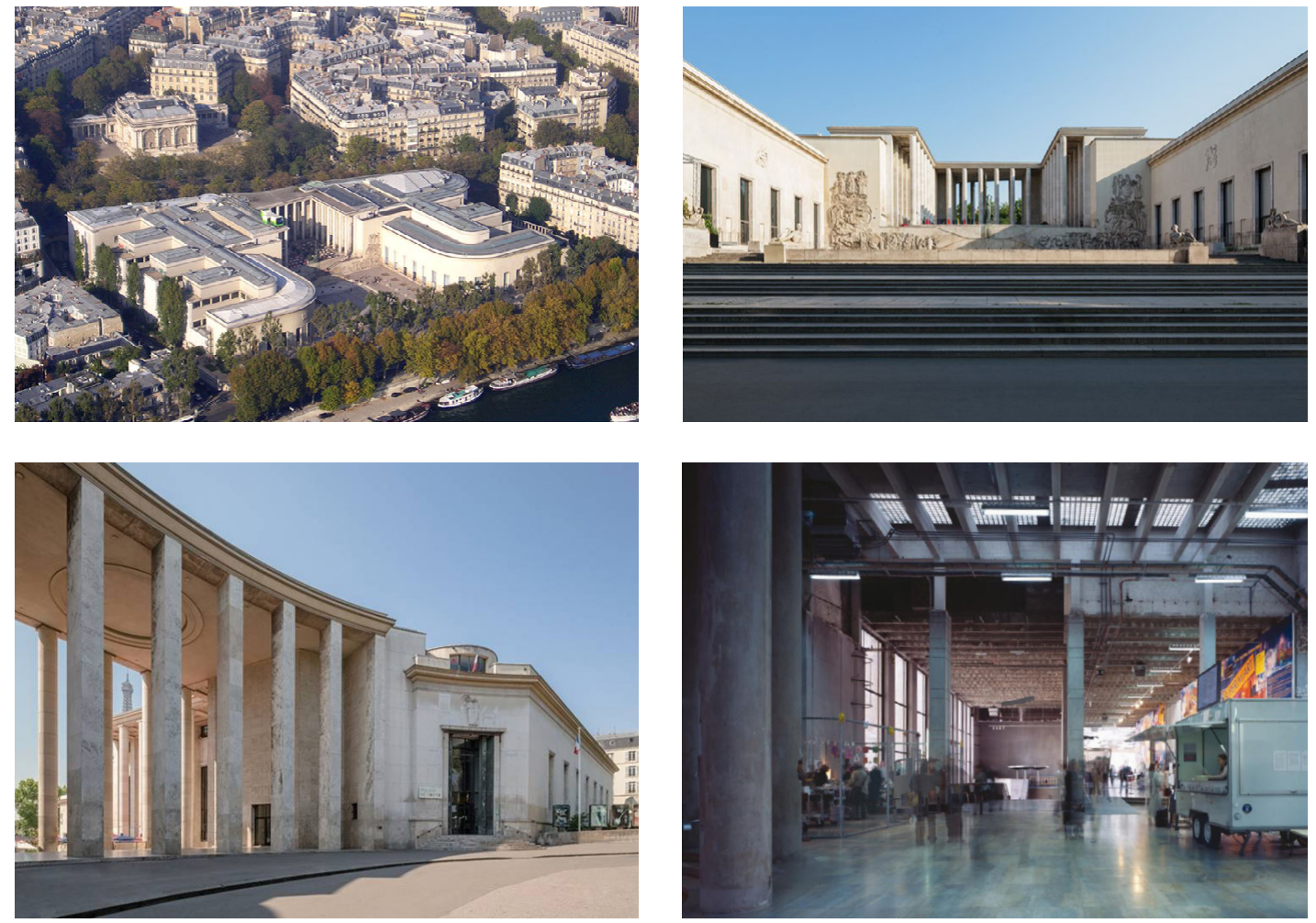
limitadas pelo edifício do Palais de Tokyo, a partir da leitura de obras de artistas que vêm interagindo com esse espaço. Ao mesmo tempo, será investigado como o partido arquitetônico foi concebido de modo compartilhado com a orientação curatorial dos franceses Nicolas Bourriaud (1965-) e Jérôme Sans (1960-) na fundação do centro e como o espaço desse edifício vem sendo apropriado desde então por outros projetos de curadoria.

\subsection{UM PALÁCIO PARA A ARTE MODERNA NA FRANÇA: ANOS 1930 A 1970}

O encontro com o Palais de Tokyo é frequentemente descrito como uma experiência de estranhamento. Visto do exterior, o edifício fornece poucas pistas de que se trata de um espaço destinado à arte moderna ou contemporânea. Em primeiro lugar, por sua localização no circuito urbanístico monumental da região do Trocadéro, um bairro que mistura uma intensa presença do turismo de massa - dada a proximidade com a Torre Eiffel -, com a frieza dos edifícios Haussmanianos de ostensiva elegância, habitados por uma alta burguesia. $\mathrm{O}$ ar de formalidade, impregnado na fachada tardiamente clássica do museu - construído em 1937 na ocasião da Exposição Internacional de Paris - já era anacrônico quando o edifício se destinava à arte moderna e, mesmo que seja muito frequente a instalação de museus em edifícios históricos, sua tradicional monumentalidade não deixa de ser inesperada como imagem atual para um centro de arte contemporânea. Ao adentrar o edifício, porém, o tom cerimonioso presente no exterior se desmancha brutalmente provocando uma nova surpresa com o impacto da visão dos imensos salões, que fazem lembrar uma ocupação irregular de um monumento abandonado, ou de uma obra interrompida. Tal deslocamento das referências museais convencionais é capaz de embaralhar os códigos de conduta dos visitantes, fazendo-os vacilar indecisos entre o decoro e a transgressão.

$\mathrm{O}$ aspecto deteriorado no interior do Palais de Tokyo convoca a memória de suas diferentes ocupações durante as seis décadas que antecederam sua conversão em "local de criação
4.1 Vista aérea das alas oeste e leste do Palais de Tokyo no 160 distrito de Paris a partir da Torre Eiffel, Paris, 2008. Foto: Strobilomyces. Fonte: https://commons. wikimedia.org/wiki/File:Palais_de_ Tokyo_20030101w.JPG

4.2 Fachada do Palais de Tokyo para a Av. de New York, antiga Av. de Tokyo, Paris, 2017. Fonte: https://www. connaissancedesarts.com/musees/ palais-tokyo/reouverture-des-musees-unepetition-du-palais-de-tokyo-interpelle-laministre-de-la-culture-11152539/

4.3 Fachada do Palais de Tokyo para a Av. Président Wilson, Paris, 2017. Foto: Florent Michel. Fonte: https://www.eventail.be/ component/k2/2840-le-palais-de-tokyo\#

4.4 Espaço de entrada do Palais de Tokyo, projeto de Lacaton \& Vassal, Paris, 2002. Foto: Philippe Ruault. Fonte: https://www. lacatonvassal.com/index.php?idp=20 


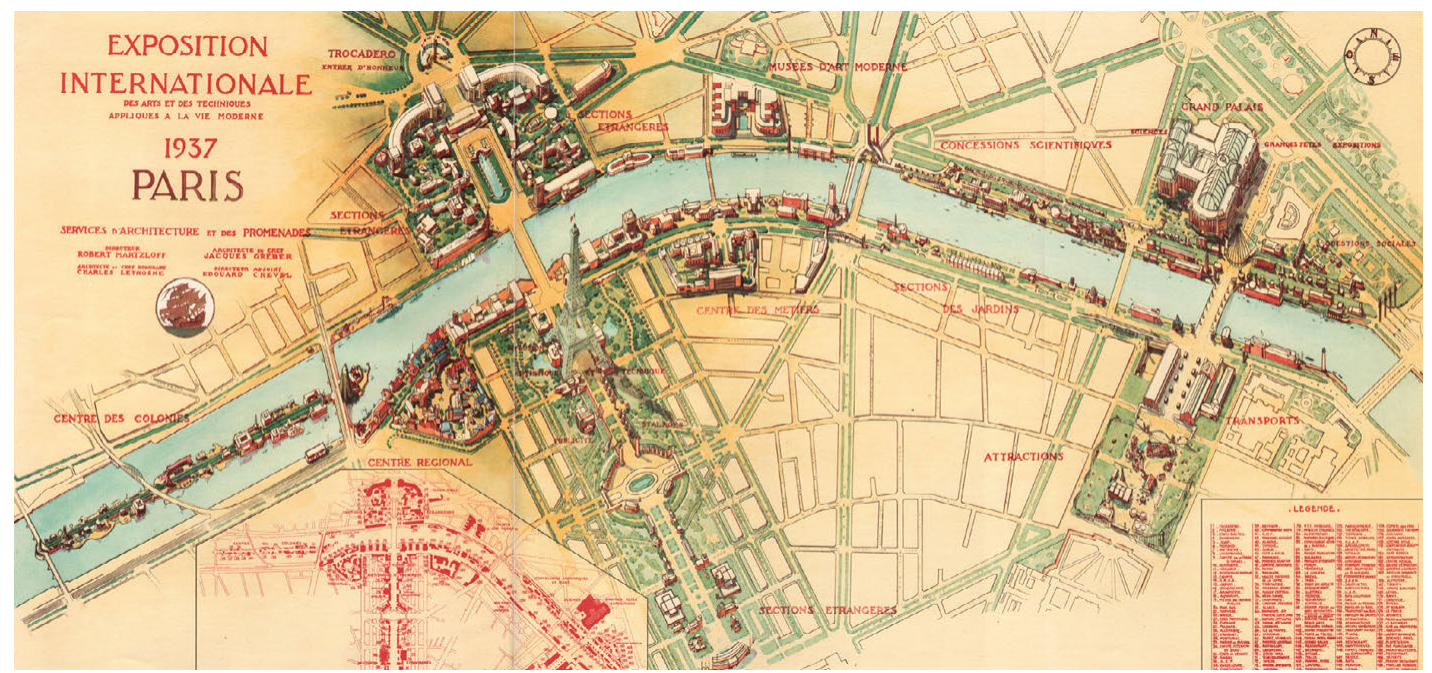

4.5 Mapa da Exposição Internacional de Paris de 1937. Desenho: Services d'architecture et des promenades de la Ville de Paris. Fonte: https://doi. org/10.4000/chrhc. 6017
618 A via foi rebatizada de Avenue [ou Quai] de New York, devido às posições opostas da França e do Japão durante a II Guerra Mundial. Como o registro do antigo endereço foi apagado, é comum que a origem do nome do edifício ou seu uso atual sejam até hoje erroneamente associados à cidade de Tóquio, no Japão. contemporânea”, em 2002. São muitos os exemplos de centros de arte instalados em edifícios históricos destinados originalmente a outros usos, como palácios, escolas e indústrias. $\mathrm{O}$ Palais de Tokyo, por sua vez, tinha na arte sua razão de origem, estando desde sempre inscrito na rede de museus na França. Cheia de acontecimentos grandiosos e descaminhos, a história do Palais de Tokyo precisa ser contada para contextualizar a condição presente de sua arquitetura e o modo como a exibição eloquente das camadas sobrepostas do tempo impacta a experiência com a arte contemporânea em seu interior.

\subsubsection{UM EDIFÍCIO ANACRÔNICO}

Tendo seu nome associado ao endereço, no então denominado Quai de Tokyo, na borda do Rio Sena, ${ }^{618}$ o edifício do Palais de Tokyo foi inaugurado na ocasião da Exposição Internacional de Artes e Técnicas Aplicadas à Vida Moderna de Paris, de 1937. Um plano elaborado em 1933 pelo arquiteto Auguste Perret (1874-1954) previa o agrupamento na região do Trocadéro de um conjunto de 12 museus dispersos noutras áreas da cidade e, pela primeira vez em Paris, seriam construí- 

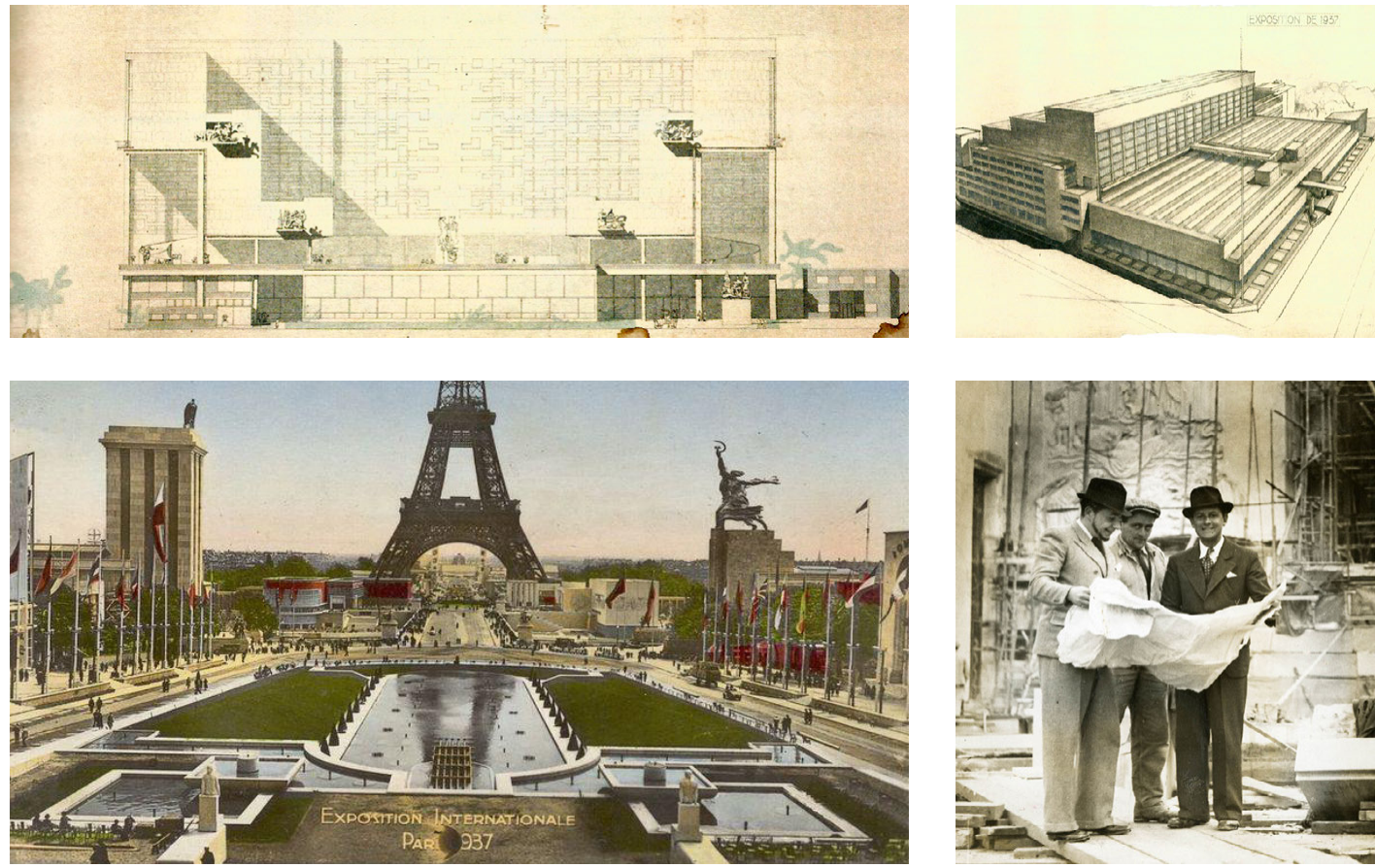

dos edifícios destinados especificamente para abrigar museus, que até então vinham ocupando antigos palácios ou mansões adaptadas. O Palais de Tokyo deveria acomodar, num mesmo terreno, uma instituição municipal e outra nacional, ambas dedicadas à arte moderna, que até então não tinha um museu específico na cidade.

Apesar de contar com a participação de alguns expoentes da arquitetura moderna, como Le Corbusier (1887-1965) e Robert Mallet-Stevens (1886-1945), o concurso de arquitetura realizado em 1934 acabou por eleger um projeto mais conservador, elaborado pelos jovens arquitetos franceses Jean-Claude Dondel (1904-1989) e André Aubert (1905-1987), associados na ocasião aos colegas Paul Viard (1880-1943) e Marcel Dastugue (1881-1970). Ao invés de buscar uma linguagem moderna condizente com sua destinação, o projeto vencedor estava mais afeito ao espírito de monumentalidade impregnado na Exposição, cujos pavilhões buscavam, cada um a seu

4.6 Fachada do projeto apresentado por Le Corbusier para os dois museus de arte moderna de Paris no concurso de 1934. Fonte: PALAIS DE TOKYO, 2012, p. 27.

4.7 Perspectiva do projeto apresentado por Robert Mallet-Stevens para os dois museus de arte moderna de Paris no concurso de 1934. PALAIS DE TOKYO, 2012, p. 27.

4.8 Pavilhões da Alemanha (esquerda) e URSS (direita) para a Exposição Internacional de Paris de 1937. Fonte: http://www.arthurchandler.com/ paris-1937-exposition

4.9 Jean-Claude Dondel, pessoa não identificada e André Aubert no canteiro de obras do MNAM, Paris, ca. 1935-1937. Fonte: https://expositions-virtuelles. citedelarchitecture.fr/portraits_architectes/ donje.php 


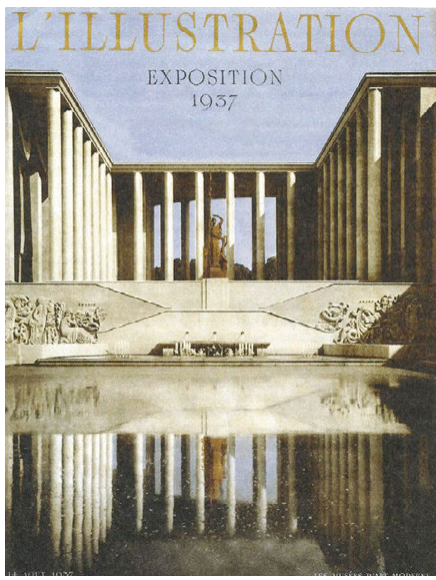

4.10 Fachada do Palais de Tokyo na Capa do número 4928 da revista L'lllustration de 14 de agosto de 1937. Fonte: PALAIS DE TOKYO, 2012, p. 31.

4.11 e 4.12 Plantas do térreo inferior dos museus de arte moderna do Estado e da cidade de Paris, projeto dos arquitetos Dondel, Aubert, Viard e Dastugue, 1934 e 1935. Fonte: PALAIS DE TOKYO, 2012, p. 28.

4.13 e 4.14 Perspectivas do projeto dos museus de arte moderna de Paris, projeto dos arquitetos Dondel, Aubert, Viard e Dastugue, 1935. Fonte: http://artair.canalblog.com/ archives/2012/12/26/25998171.html

4.15 Perspectiva do projeto dos museus de arte moderna de Paris, projeto dos arquitetos Dondel, Aubert, Viard e Dastugue, 1937. Desenho: Decaris. Fonte: PALAIS DE TOKYO, 2012, p. 22.

619 O pavilhão da Alemanha foi projetado por Albert Speer e o da União Soviética por Boris Iofan. modo, a expressão da superioridade de seus países, como exemplificam claramente os edifícios da Alemanha e da União Soviética, localizados face a face, enquadrando a perspectiva da Torre Eiffel. ${ }^{619}$

A reflexão sobre como a arte moderna seria exposta não estava em primeiro plano no partido do projeto, definido principalmente em função de sua inserção como monumento na paisagem urbana. Cada um dos museus foi implantado numa ala do edifício: o Museu de Arte Moderna da Cidade de Paris a leste e o Museu Nacional de Arte Moderna (MNAM) a oeste. Entre eles, um pátio aberto e escalonado conectava visualmente o palácio Galliera acima ao Rio Sena, configurando um eixo central de simetria arrematado na face superior por uma colunata aberta e no nível inferior por um espelho d'água, emoldurado por volumes que se curvavam em ambos os lados. No projeto apresentado para o concurso, um auditório posicionado nessa faixa central unia as duas alas pelo andar abaixo do nível da entrada superior, mas a solução foi modificada ao longo do desenvolvimento e os edifícios tornaram-se independentes na versão construída.

Com a fachada revestida de pedras e ornada com esculturas, a imagem do conjunto associava-se diretamente à solidez dos palácios franceses, num emprego desenvolto da linguagem acadêmica, cujo anacronismo rendeu ao edifício críticas severas desde o início. Nos interiores, entretanto, técnicas avançadas de concreto armado foram empregadas para a obtenção dos grandes vãos dos salões, concebidos como amplos espaços nus, cujos acabamentos ficariam a cargo da museografia, a ser instalada posteriormente.

Os arquitetos preocuparam-se especialmente em dotar as salas expositivas de abundante luz natural e para isso organizaram na ala oeste uma sequência de salas expositivas numa planta dentada, permitindo entrada de luz natural por aberturas laterais altas e claraboias, filtrando-a com um forro translúcido leitoso. Segundo os padrões museográficos tradicionais, a distribuição homogênea de luz proporcionada por essa solução seria adequada para a exposição de pinturas, enquanto as esculturas deveriam receber iluminação por aberturas mais baixas nas laterais, ressaltando assim os volumes, como foi 

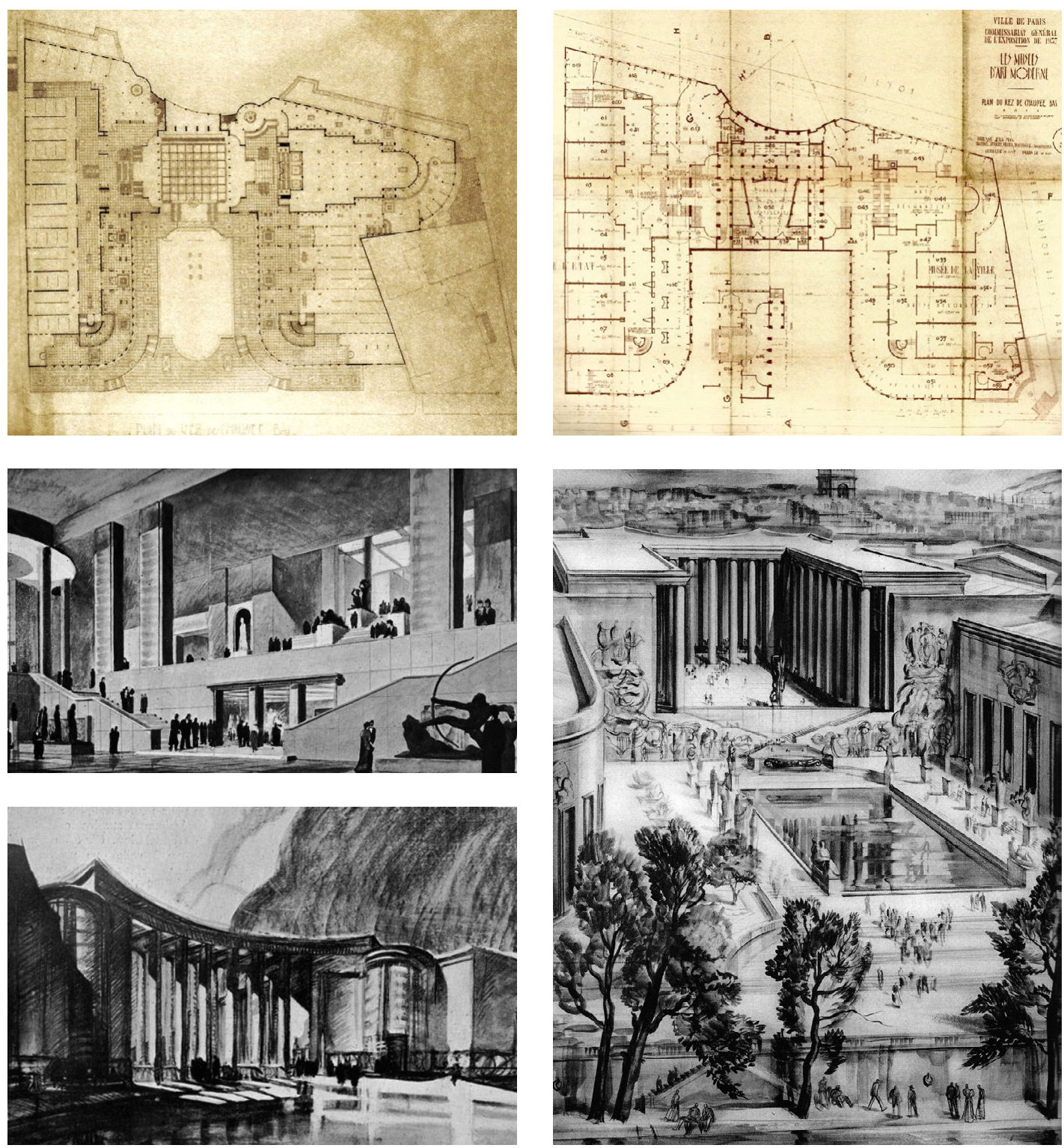

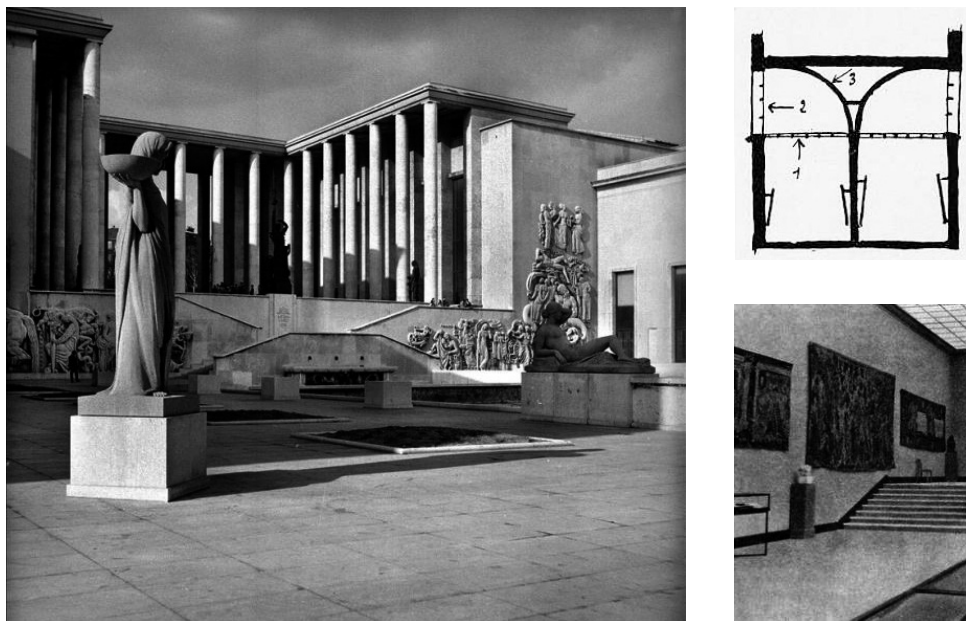

1. VERRE OPALIN

2. VERRE PRISMatique

3. PAROI RÉFLÉ-

CHISSANTE

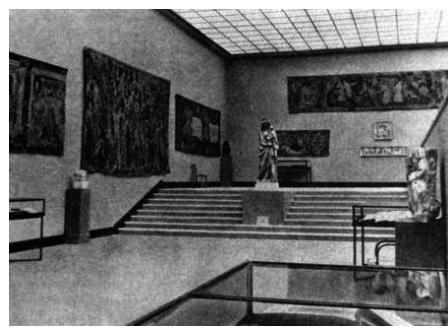

4.16 Fachada do Palais de Tokyo para a Av. de New York, antiga Av. de Tokyo, Paris, s.d. Fonte: https://www.luxsure. $\mathrm{fr} / 2013 / 06 / 12 /$ nouvel-accrochage-descollections-permanentes-au-mam/

4.17 Esquema de iluminação zenital pelas janelas laterais das salas de pintura do térreo do Palais de Tokyo. Fonte: http://paris-projet-vandalisme.blogspot. com/2013/09/les-musees-d-artmoderne-au-palais-de.html

4.18 Vista da exposição retrospectiva Chef-d'œuvre de l'art Français, MNAM, Pairis, 1937. Fonte: PALAIS DE TOKYO, 2012, p. 31. adotado nos salões contínuos com aberturas voltadas para as fachadas. Foi previsto ainda um sistema de persianas acionadas eletricamente para regular a intensidade luminosa, mas o dispositivo acabou não funcionando por muito tempo devido à dificuldade de manutenção. A circulação entre os pavimentos era organizada por um conjunto de saguões conectados por escadas e voltados para a esplanada central, solução espelhada na ala leste.

Ao término da Exposição Internacional, o conjunto foi fechado até completar as obras, sendo a ala oeste reaberta em 1938, com a inauguração do MNAM. A nova instituição agrupou as coleções de arte naquele momento "contemporâneas", divididas até então entre o Museu de Luxemburgo (artistas franceses) e o Museu Jeu de Paume (escolas estrangeiras). O recém-inaugurado Museu Nacional de Arte Moderna mal completava o primeiro aniversário quando a II Guerra Mundial foi deflagrada e, diante da ameaça de confisco de obras pelos nazistas - que usavam a arte moderna como anti-exemplo de produção cultural, denominando-a de "arte degenerada" -, parte da coleção foi escondida fora de Paris. Ao final de 1941, com a França sob jugo do governo alemão, os subsolos de ambos os museus foram transformados em depósito de bens pertencentes a famílias judaicas perseguidas e espoliadas. 


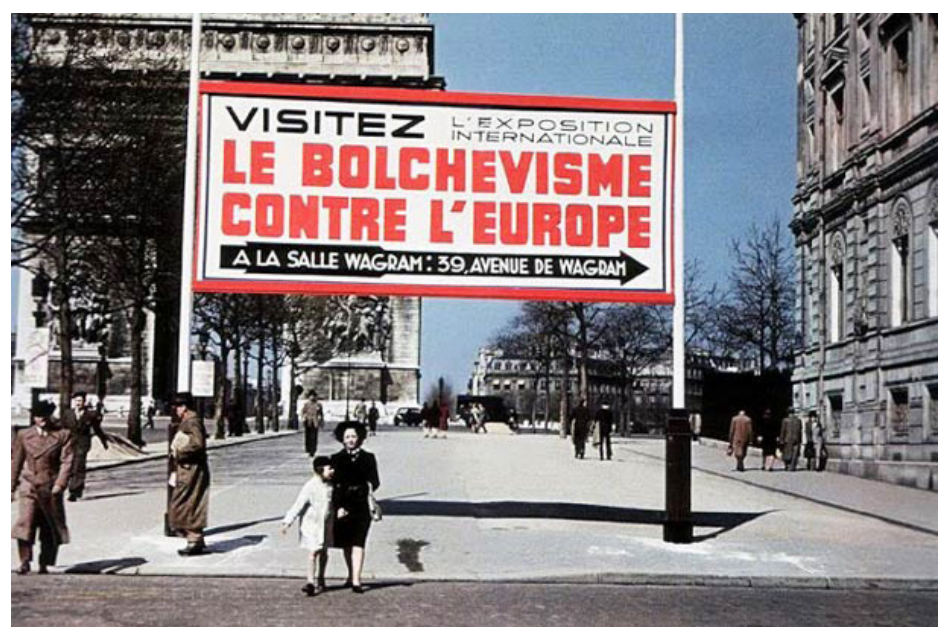

Com o fim da guerra em 1945, o MNAM foi reaberto em 1947, enquanto o Museu de Arte Moderna da Cidade de Paris só foi inaugurado na ala leste bem mais tarde, em 1961.

Após superado o trauma da ocupação alemã, o MNAM teve que se haver com as dificuldades de sua adaptação ao edifício do Palais de Tokyo. Segundo o historiador de arquitetura francês Jean Baptiste Minnaert (1964-), a gestão da disposição museográfica mostrou-se então complicada, dada a excessiva distinção arquitetônica entre as salas - configuradas de acordo com a especialização dos suportes -, a dificuldade de estabelecer um percurso compreensível para o público, a recorrência de paredes curvas e a ausência de climatização controlada. ${ }^{620}$

Além disso, o edifício demandava um esforço penoso de conservação, o que o levou, já em 1956, a ser novamente fechado para vultosas obras de recuperação. Os crescentes questionamentos sobre a pertinência de manter a sede do MNAM no Palais de Tokyo apontavam não apenas para as características do edifício que teriam levado ao seu estado precário de conservação - o que seria solucionável -, mas sobretudo para o anacronismo de sua arquitetura, uma irremediável "falha de origem". O modelo palaciano e monumental sob o qual o edifício fora moldado mostrava-se obsoleto diante da arqui-
4.19 Cena urbana de Paris durante a ocupação alemã durante a II Guerra Mundial, entre 1940 e 1944. Foto: André Zucca. Fonte: https://www.pariszigzag.fr/ secret/histoire-insolite-paris/en-imagesparis-sous-loccupation-allemande

620 Cf. Jean Baptiste Minnaert. Un Palais Pour Deux Musées d'Art Moderne. In: PALAIS DE TOKYO, 2012, op. cit., pp. 23-35. 
4.20 Sala de esculturas do MNAM no térreo inferior do Palais de Tokyo, Paris, 1942. Fonte: PALAIS DE TOKYO, 2012, p. 42.

4.21 Artigo sobre o fechamento do MNAM para obras de manutenção publicado no Le Figaro Litteraire em 17 de março de 1956. Fonte: PALAIS DE TOKYO, 2012, p. 35.

4.22 e 4.23 Inauguração da exposição Douze peintres et sculpteurs américains contemporains, MNAM Paris, 1953.

Fonte: https://archivesetdocumentation. centrepompidou.fr/ead.

html? id=FRM5050-X0031_0000074\&c=F RM5050-X0031_0000074_FRM5050-X0 03189786\#! \{\%22content\%22:[\%22F RM5050-

\subsection{4 e 4.25 Vista da exposição}

Cinquante ans d'art aux Etats-Unis, MNAM, Pairis, 1955. Fonte: https:// archivesetdocumentation.centrepompidou. fr/ead.html?id=FRM5050-X0031_000 0074\&c=FRM5050-X0031_0000074_ FRM5050-X003189786\#! \{\%22content\%2 2:[\%22FRM5050-
621 Ibidem.

622 Cf. Press release. In: THE Museum OF MODERN ART. American Painting and Scuplture Show to Inaugurate Museum's International Program in Paris Opening on April 24. MOMA. Disponível em: <https://www. moma.org/momaorg/shared/pdfs/ docs/press_archives/1704/releases/ MOMA_1953_oo34_33.pdf $>$. Acesso em: 30 maio 2021.

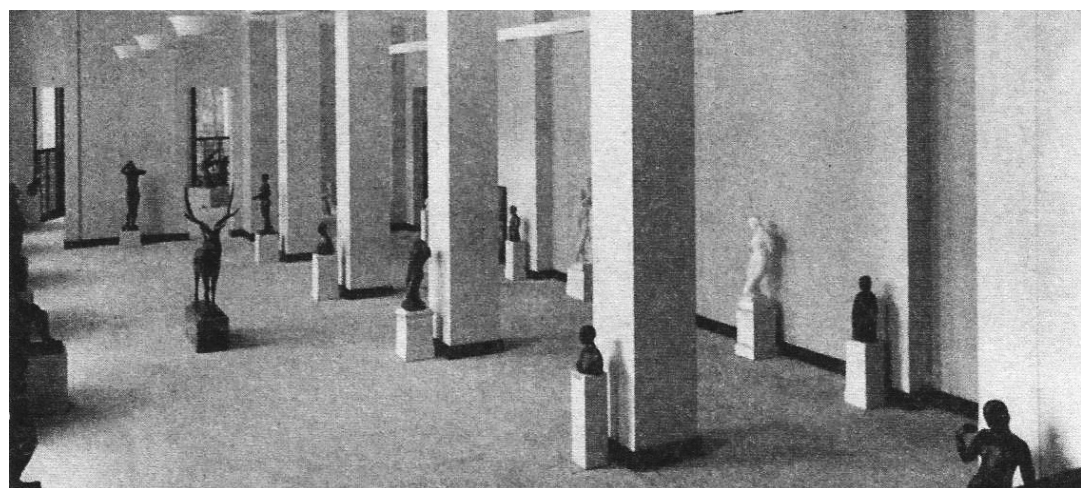

tetura moderna, já então bastante madura tanto na França quanto no exterior. Com linguagem arquitetônica francamente moderna e dotada de espaços contínuos e flexíveis, o Museu de Arte Moderna do Rio de Janeiro, inaugurado em 1948 com projeto de Affonso Eduardo Reidy, era apontado pela imprensa francesa como um modelo mais bem-sucedido de museu de arte moderna. ${ }^{621}$

\subsubsection{MUSEUS EM CONFLITOS DE IDENTIDADE}

O mal-estar diante do atraso do MNAM com relação à produção mais atual não se limitava à sua arquitetura, pois também seu acervo se mostrava defasado com relação aos rumos que a arte vinha tomando no cenário internacional. Se a França tinha sido o celeiro da arte moderna da metade do século XIX ao início do XX, depois da II Guerra as atenções haviam se deslocado para a produção estadunidense, amparada por influentes críticos e instituições como o MoMA de Nova York, que a tratavam como a legítima herdeira da "Escola de Paris". O MNAM vinha dialogando intensamente com essa produção nos anos 1950, realizando diversas exposições temporárias como Douze peintres et sculpteurs américains contemporains (1953), Cinquante ans d'art aux Etats-Unis (1955) e Jackson Pollock et la Nouvelle Peinture Américaine (1959) - integrados ao programa internacional de exposições do MOMA nova-iorquino - ${ }^{622}$ 
ET DEJAA EN RUINE LE MUSEE D'ART MODERNE DOIT ETRE REMPLACE
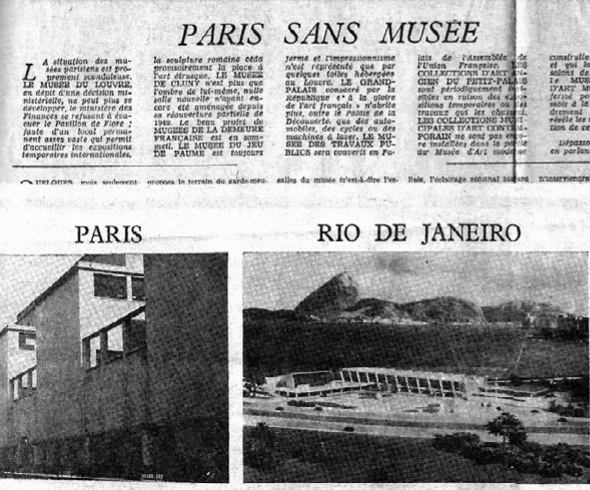

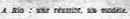

BEAUX-ARTS

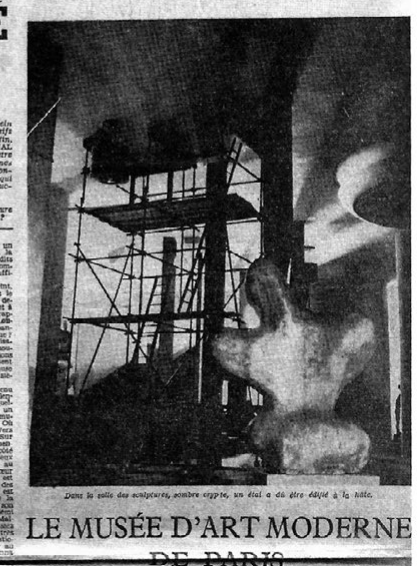

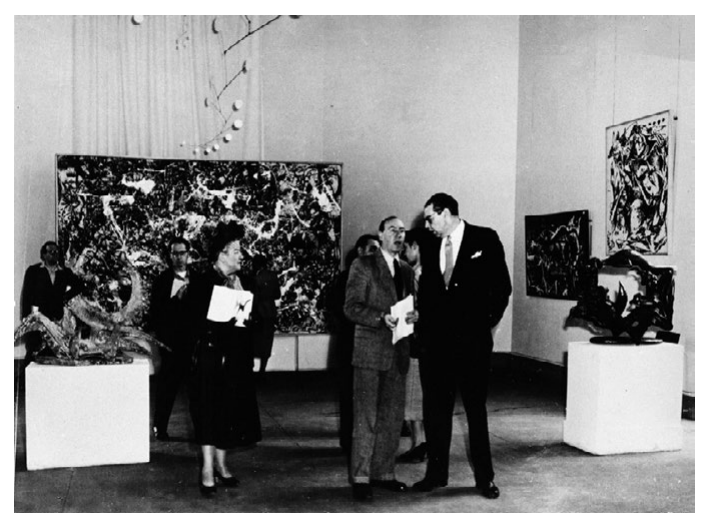
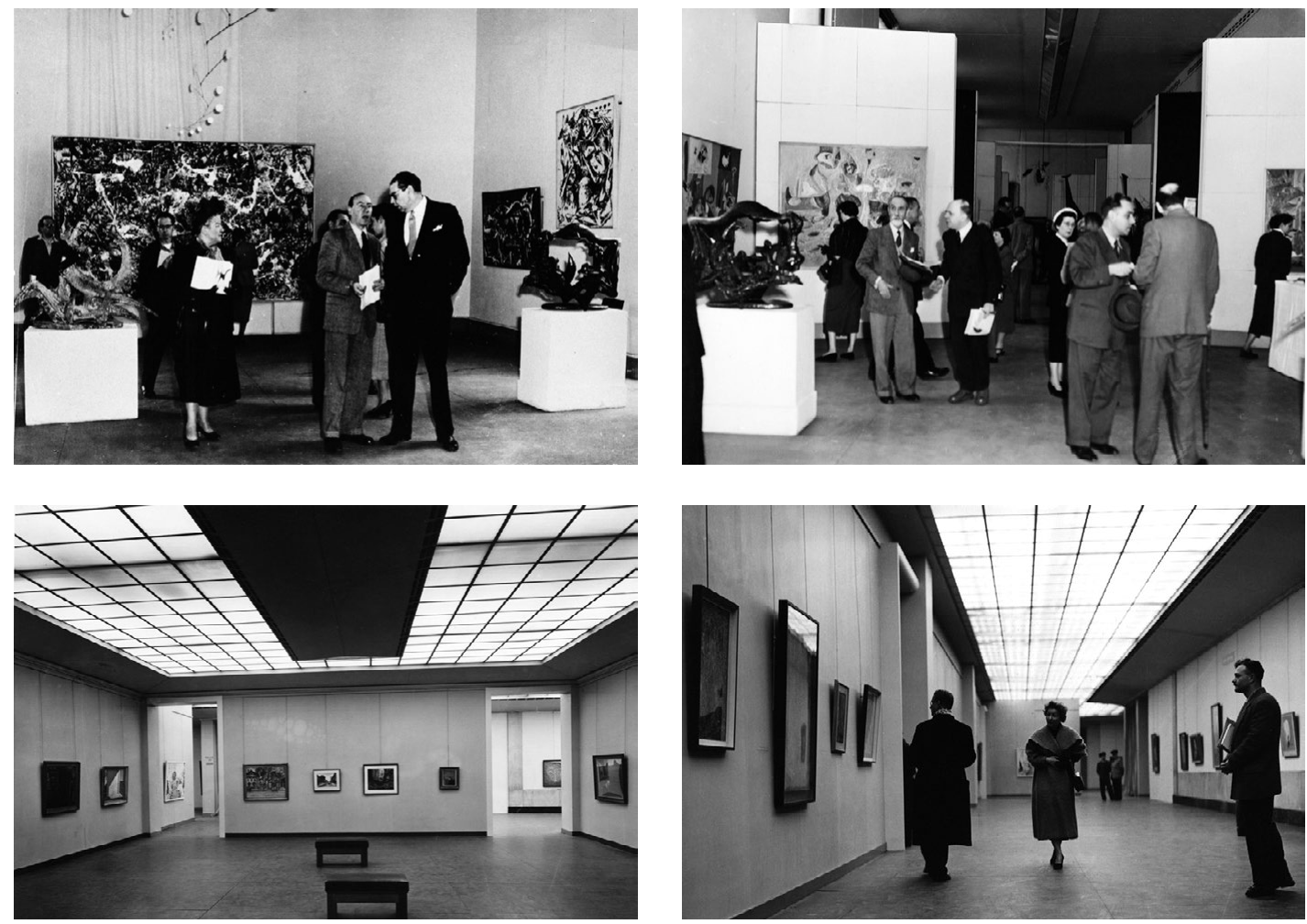


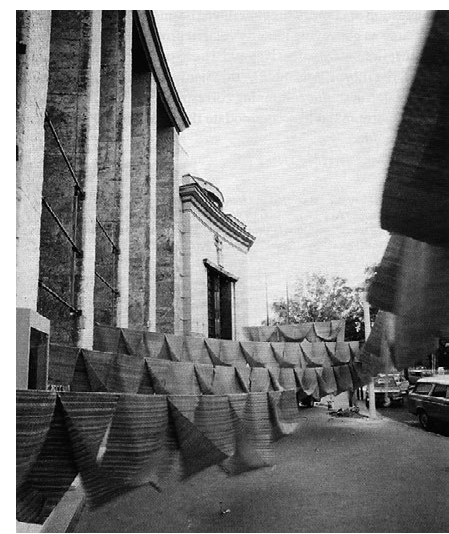

4.26 Vista da instalação de Ana Lupas, Tapis Volants pout la Paix (1973), 8a Bienal de Paris, esplanada do Palais de Tokyo, 1973. Foto: André Morain. Fonte: PALAIS DE TOKYO, 2012, p. 61.

4.27 Vista de uma das salas do MNAM na 10a Bienal de Paris, 1977. Foto: André Morain. Fonte: PALAIS DE TOKYO, 2012, p. 61.

623 Cf. CEnTre PoMpidou. Expositions du Centre Pompidou: reportages en argentique (19532003). Archives et Documentation du Centre Pompidou. Disponível em: $<$ https://archivesetdocumentation. centrepompidou.fr/ead.html?id=FRM5050=-0031Xooooo74_\&cFRM5050-Xo031_0000074_ FRM5050-ХoO3189786\#! $\{\% 2$ 2content\%22:[\%22FRM505 o-Xoo31_oooo074_FRM5050Xoo3189523\%22,false, $\% 22 \% 22]\}>$. Acesso em: 30 maio 2021.

624 Durante a gestão de Jean Leymarie, que assumiu o cargo de curador do Museu Nacional de Arte Moderna, de 1968 a 1973.

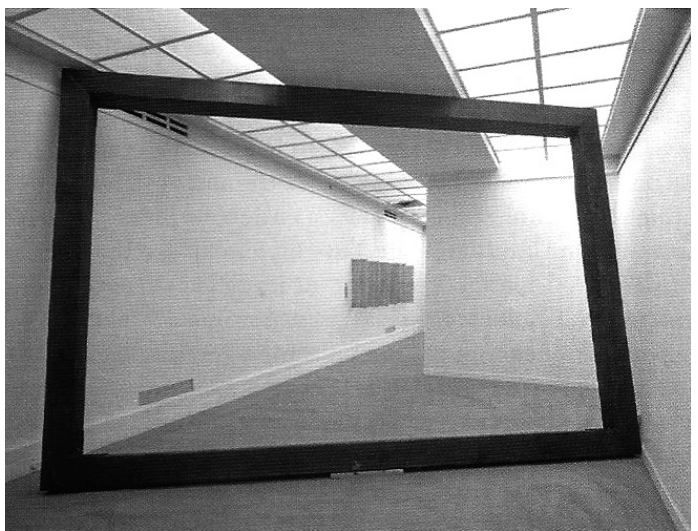

e Le dessin contemporain aux Etats-Unis (1954). ${ }^{623}$ Foi apenas mais tarde, sob impacto dos movimentos progressistas de maio de 1968, que o MNAM se reorganizou de modo mais consistente em direção a uma maior aproximação das questões atuais da arte, considerando suas múltiplas facetas e complementando seu acervo com obras internacionais, muitas das quais produzidas por artistas estadunidenses. ${ }^{624}$

Os espaços do museu chegaram a receber eventos pontuais ligados à arte contemporânea, como a Bienal de Paris - que se distribuía em várias instituições da cidade -, nas edições de 1969, 1973, 1975 e 1977. Além dos salões internos do Palais de Tokyo, a esplanada também foi ocupada com intervenções monumentais e performances durante as Bienais. Ao mesmo tempo, a arte atual havia deixado nesse período de ser o escopo do museu, que ficou limitado às obras consideradas históricas a partir a criação, em 1967, do Centro Nacional de Arte Contemporânea (CNAC) - responsável por obras de artistas ativos na atualidade. Embora estivesse instalado noutra sede, o CNAC usava partes do edifício do Palais de Tokyo para armazenar obras e realizar exposições temporárias, o que ocasionava uma convivência tensa com o MNAM.

Essa cisão institucional entre artistas falecidos e vivos, e ainda entre franceses e estrangeiros, era praticada desde muito cedo na história nos museus na França. O primeiro museu aberto ao público no país em 1750, antes mesmo da inauguração 

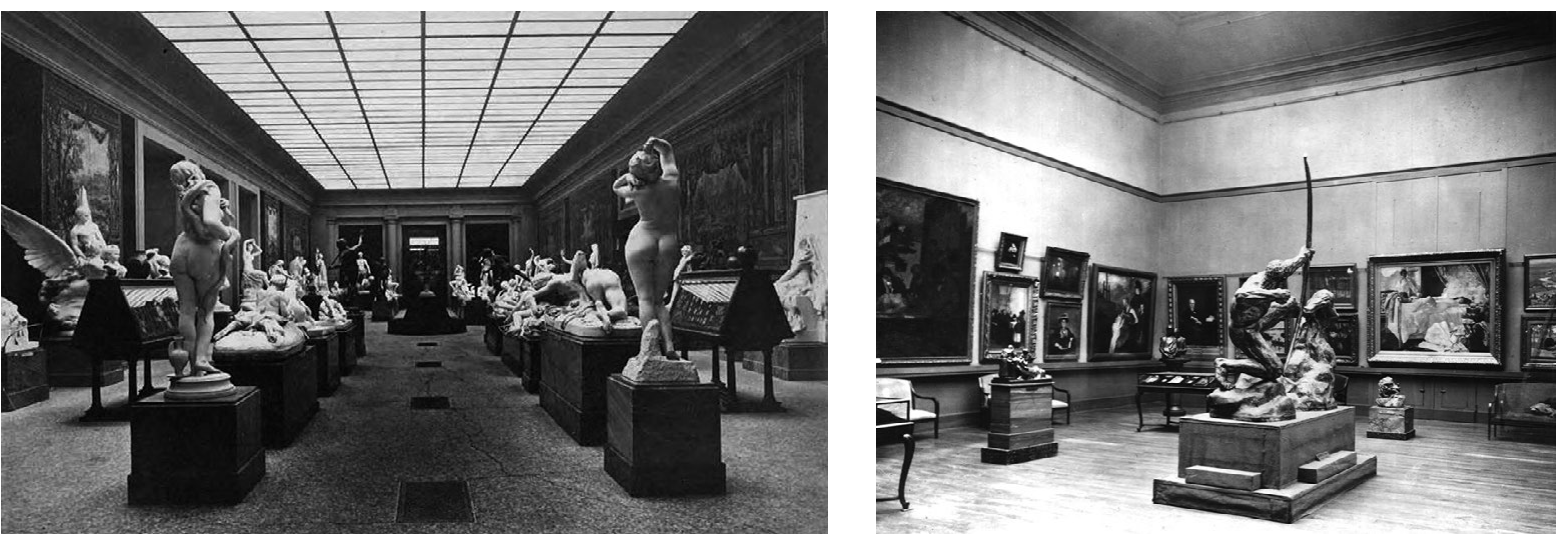

do Museu do Louvre em 1793, foi o Museu de Luxemburgo. Passando a abarcar em 1818 o Museu dos Artistas Vivos, a instituição se tornara a primeira da história voltada à "arte contemporânea", dedicando-se a colecionar obras de artistas de nacionalidade francesa que haviam sido selecionadas nos Salões da Academia de Belas Artes, que ocorriam anualmente no Museu do Louvre. A regra de gestão das coleções determinava que, passados dez anos da morte de cada artista, suas obras deveriam ser transferidas definitivamente para o Louvre se fossem consagradas pela "opinião universal" e, caso contrário, seriam doadas a outras instituições. Apenas a partir do final do século XIX, o Museu de Luxemburgo passou a aceitar obras de artistas de nacionalidade estrangeira, que permaneceram ali até 1922, quando foram transferidas para o Jeu de Paume. ${ }^{625}$

A trajetória que percorreu a coleção de obras impressionistas exemplifica o processo movimentado de construção da missão dos diversos museus de arte franceses, especialmente no que se refere a artistas a seu tempo "contemporâneos". Obras que haviam sido expostas pela primeira vez nos salões do Louvre passavam ao Museu dos Artistas Vivos no Luxemburgo. Tendo algumas seguido esse caminho, as obras impressionistas voltaram para o Louvre em 1929 - quando já consagradas -, seguindo em 1947 para o Jeu de Paume, até que se estabilizaram no Museu d'Orsay, inaugurado em 1986 especificamente para este fim.

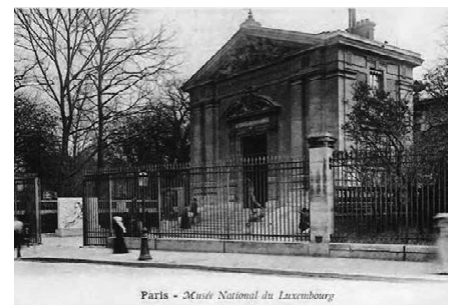

4.28 a 4.30 Salas e Fachada do Musée Nationale du Luxembourg, Paris, s.d. Fonte: http://icamt.mini.icom.museum/ wp-content/uploads/sites/13/2019/01/ PALESTRA_12_Virginia_Fienga.pdf

625 Cf. PALAIS DE TOKYo. Le lieu \& son histoire. Palais de Tokyo. Disponível em: <https://www. palaisdetokyo.com/fr/content/lieu-histoire-palais-de-tokyo $>$. Acesso em: 27 maio 2021. 

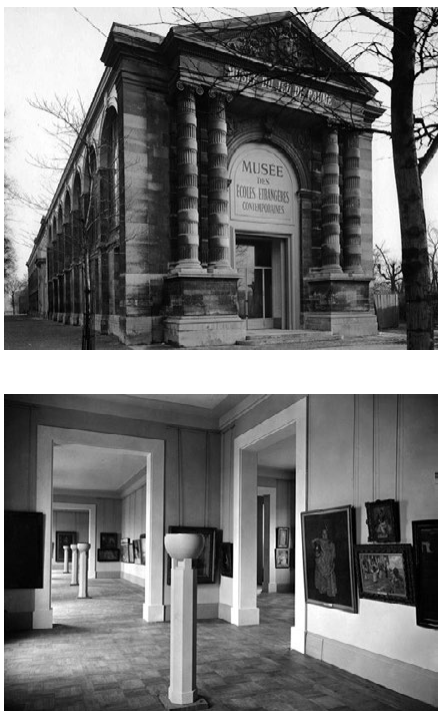

3.31 e 4.32 Fachada e vista de uma das salas do Musée du Jeu de Paume - Musée des Écoles Étrangères Contemporaines, Paris, s.d. Fonte: http://icamt.mini. icom.museum/wp-content/uploads/ sites/13/2019/01/PALESTRA_12 Virginia_Fienga.pdf

4.33 Vista de uma das salas do Musée du Jeu de Paume - Musée des Écoles Étrangères Contemporaines, Paris, entre 1947 e 1977. Fonte: http://icamt.mini. icom.museum/wp-content/uploads/ sites/13/2019/01/PALESTRA_12_ Virginia_Fienga.pdf

4.34 Vista do interior do Musée d'Orsay, Paris, s.d. Fonte: https://m.musee-orsay. $\mathrm{fr} / \mathrm{fr} /$ soutenez-le-musee.html

4.35 Planta da exposição do acervo do MNAM de Paris na ala oeste do Palais de Tokyo em 1976. Fonte: PALAIS DE TOKYO, 2012, p. 52.
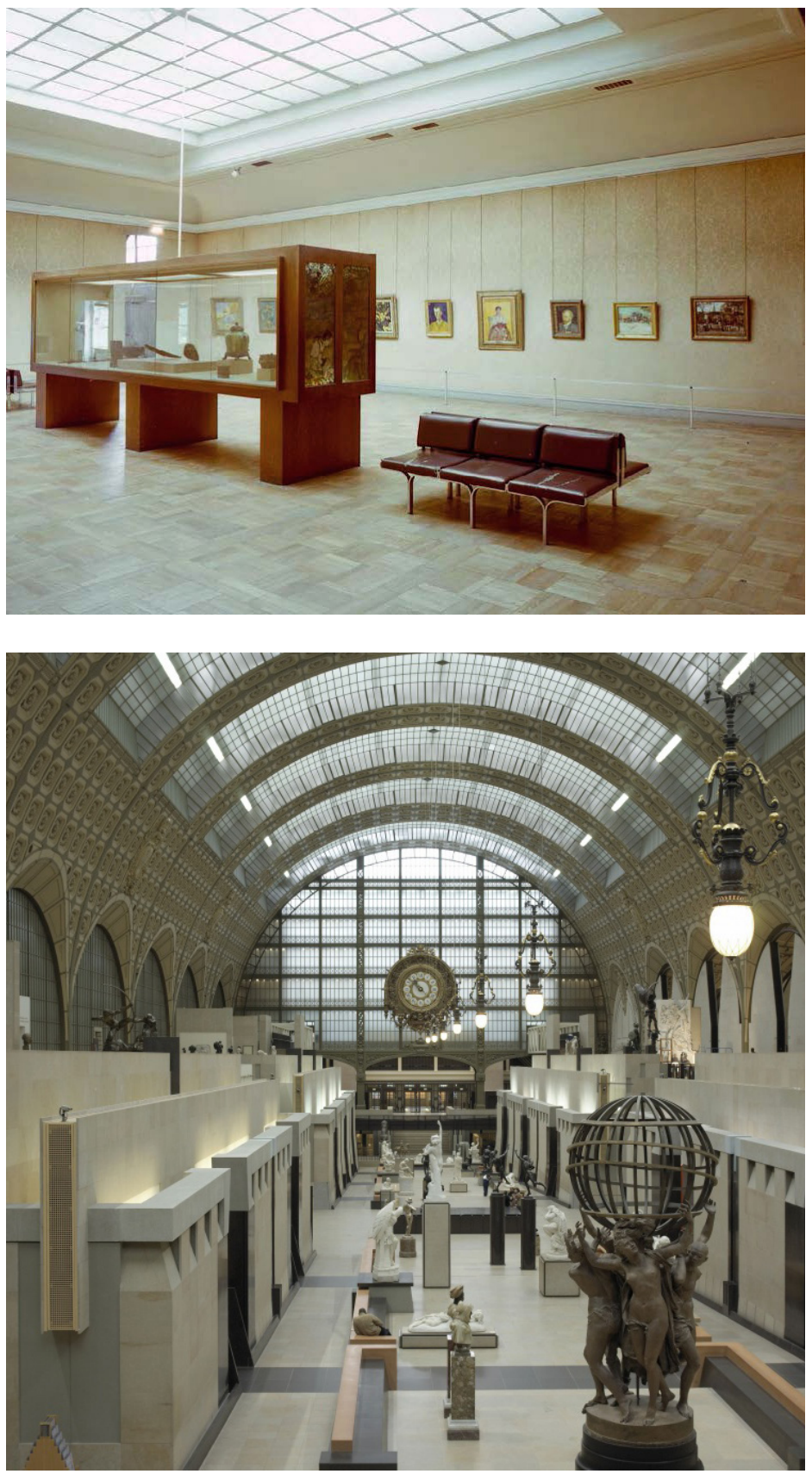


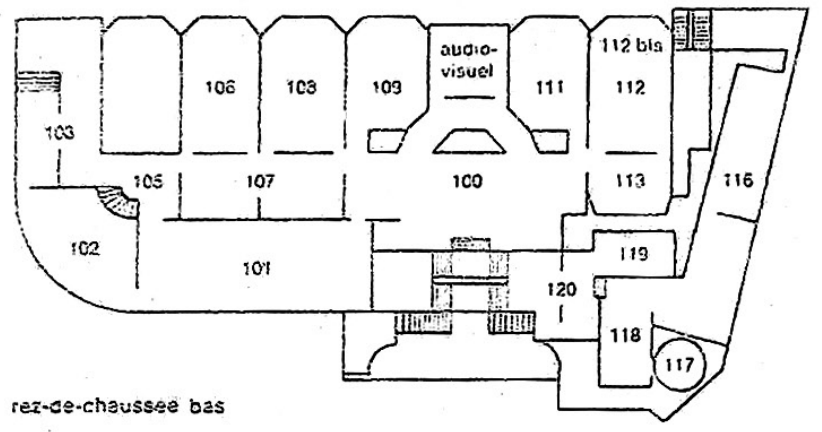

100 Peintures al sculpitures contemporaines Donation Gaudier-8rezska.

Presenlation de dessins

101 Sculplures contemporaines

102-103 Donation Laurens

105 Dessins de Caldes

106 Sculptures 1950-1960.

Germaine Aichier

107 Sculplures cubisles

108 Donation Gonzalez

109 Alelier Erancusi

111 Donalion Pevsner

112 Donation Dunoyer de Segonzac

1 i2 bis Donalion Kemeny

113 Prtsentations lemporaires

116-119 Exposition Mantai

120 Abstraction americaine
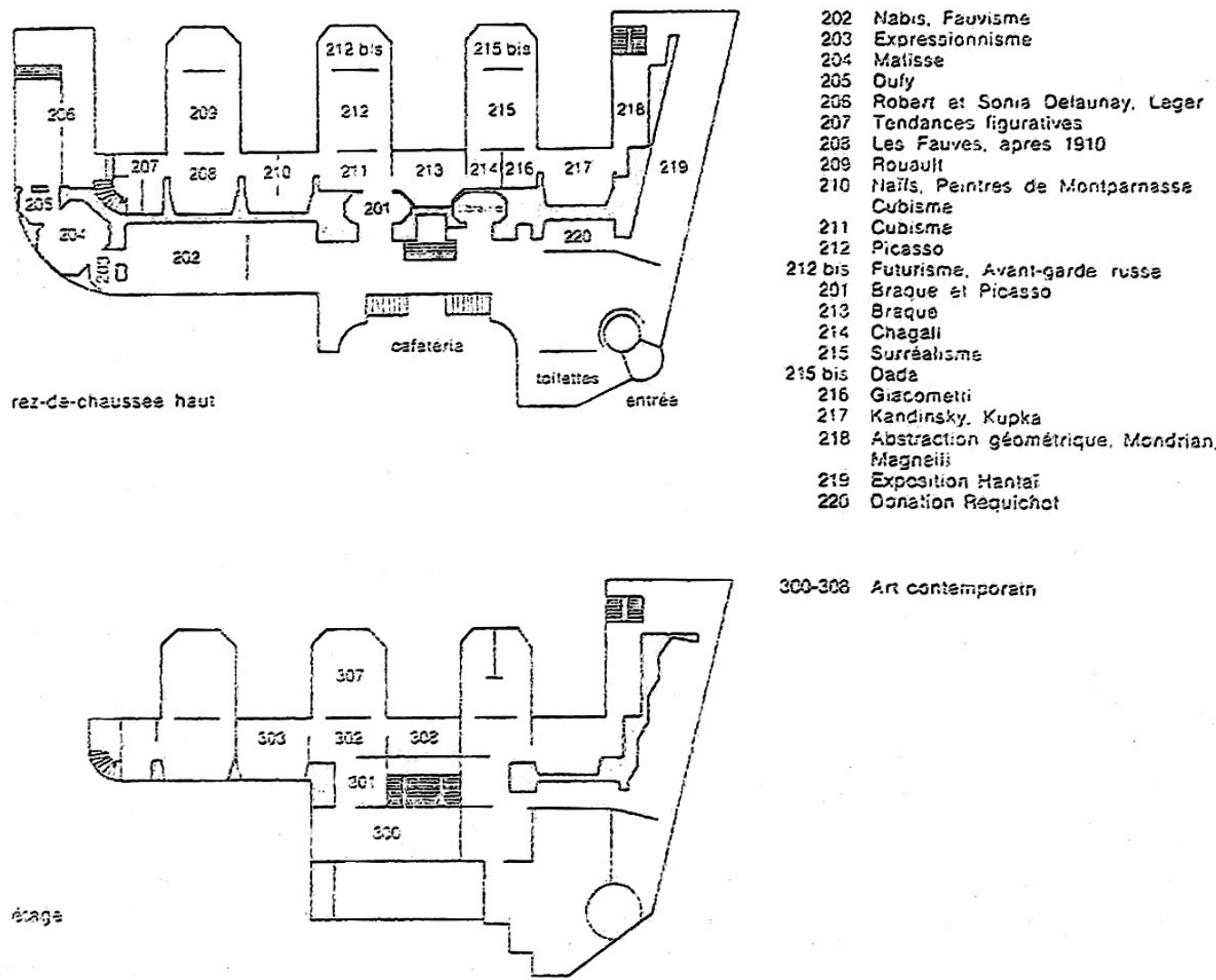

300-308 A.r contemporatn 

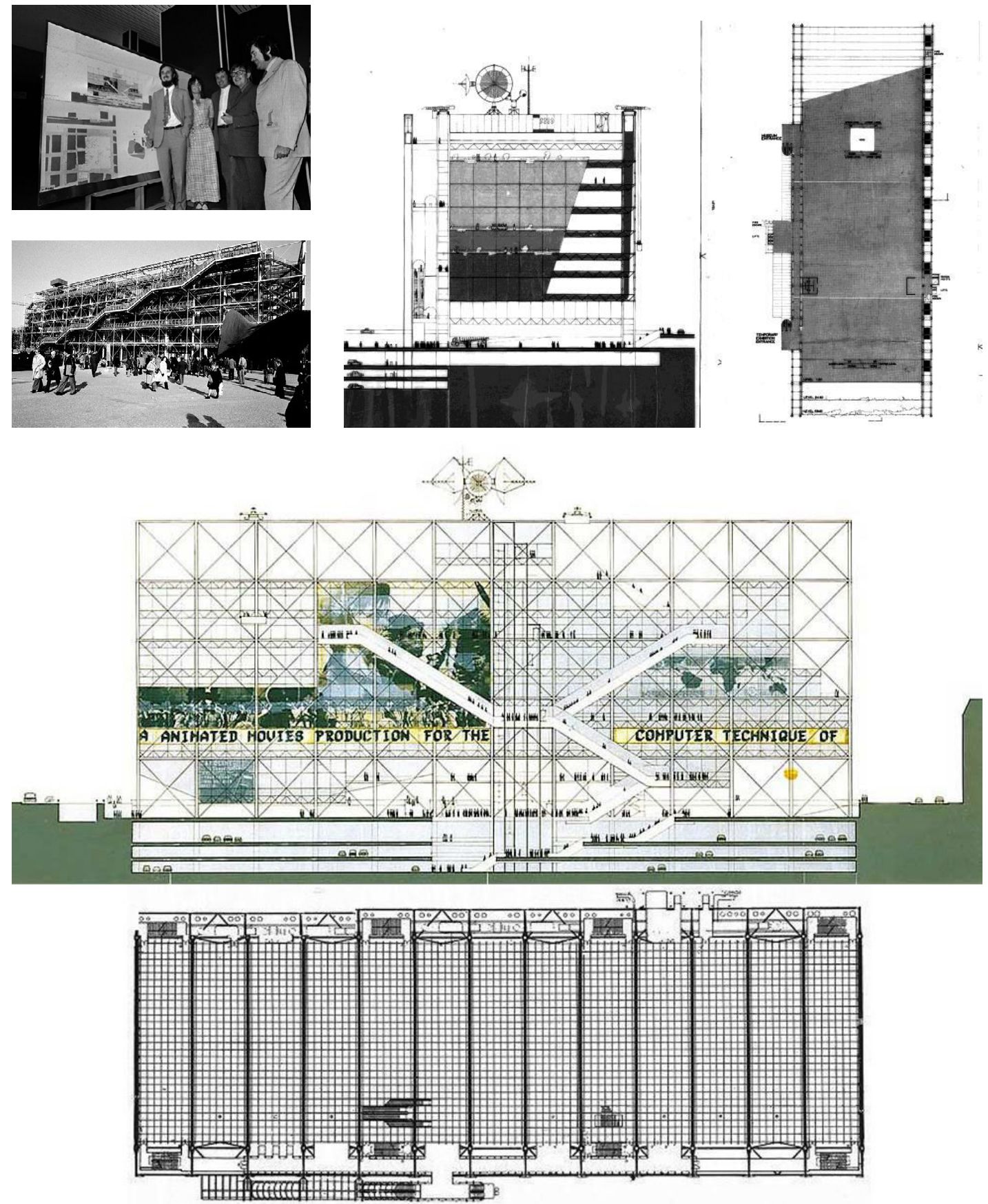
O contínuo esforço da França em manter uma posição de destaque no cenário da arte - seja mantendo a tradição de fomentar a produção "contemporânea", seja reorganizando as coleções históricas em antigas e novas instituições museais - perpassa toda a história do Palais de Tokyo e a entrelaça à do Centro Georges Pompidou, para onde foi transferido o MNAM em 1977. A criação de um novo e ambicioso equipamento cultural no bairro do Marais em Paris havia sido proposta pelo presidente da República e amante das artes Georges Pompidou (1911-1974), desde que assumira o cargo em $1969 .{ }^{626}$ Embora houvesse um desejo de que o edifício contasse com uma assinatura francesa, o concurso internacional de arquitetura instaurado em 1971 escolheu o projeto da dupla inglesa Su (Susan Jane) Rogers (1939-) e Richard Rogers (1939-; 1933-, respectivamente) e do italiano Renzo Piano (1937-). Contando com grande orçamento para sua realização, o novo edifício foi concebido como o oposto do Palais de Tokyo, exibindo em sua fachada toda a técnica de sua construção e liberando o interior para a máxima flexibilidade. Seu programa polivalente não se restringia apenas ao museu - destinado às coleções de arte moderna, contemporânea e de design, e à realização de exposições temporárias - mas incluía também uma grande biblioteca pública - a Biblioteca Kandinsky (вK) -, o Centro de Criação Industrial (CCI), salas polivalentes para espetáculos e posteriormente o IRCAM - Instituto de Pesquisa e Coordenação Acústica.

Considerando a condição estatal desses centros de arte na França, os projetos tanto do Palais de Tokyo quanto do Centro Georges Pompidou representaram, em suas respectivas conjunturas políticas, os anseios de afirmação da superioridade cultural do país no cenário internacional. Na década de 1930, a França se encontrava há muito tempo numa posição cultural hegemônica, o que possivelmente dificultou o entendimento mais amplo de que a opção por uma linguagem clássica para a sede do museu de arte moderna fosse vista como problemática enquanto símbolo para a arte "contemporânea" de então. Já na década de 1970, o aspecto conservador das instituições culturais era o principal alvo de ataques de parte expressiva de intelectuais, artistas e da juventude em geral, que, embalados pelos protestos de 1968, clamavam por renovação das estrutu-
4.36 Renzo Piano, Su Rogers, Richard Rogers, Ted Huppold e Peter Rice diante de seu projeto vencedor do concurso para o futuro Centro Beaubourg, Paris, 1971. Fonte: https://www.georges-pompidou. fr/georges-pompidou/portail-archives/ renzo-piano-richard-rogers-1971

4.37 Inauguração do Centro Georges Pompidou (Beaubourg), Paris, 1977. Fonte: https://www.archimag.com/ bibliotheque-edition/2017/02/06/ bpi-fete-40-ans-lance-nouveau-projetscientifique

4.38 e 4.39 Desenhos apresentados pela equipe Piano + Rogers para o concurso do Centro Beaubourg em 1971 (corte transversal, planta e fachada). Fonte: https://www.researchgate.net/profile/ Boris-Hamzeian/publication/324389654_ The_Evolution_of_the_Pompidou_ Centre\%27s_Air_Conditioning_System_ Toward_a_new_figure_of_architecture/ links/5b450f4a0f7e9b1c722341fb/ The-Evolution-of-the-Pompidou-CentresAir-Conditioning-System-Toward-a-newfigure-of-architecture.pdf

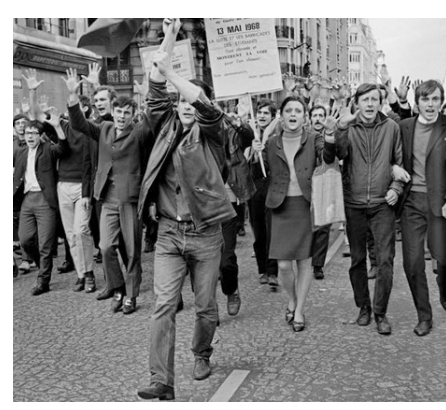

4.38 Protestos de Maio de 1968 em Paris. Foto: Philippe Gras. Fonte: https://revistacult.uol.com.br/home/ quarenta-anos-depois/

626 O presidente Georges Pompidou faleceu antes da inauguração do centro, que acabou sendo batizado com seu nome.

\section{4-505}


4.41 Vista da exposição Visages de l'Homme para os não videntes, Musée d'Arts et d'Essai (ala Oeste do Palais de Tokyo), Paris, 1978. Fonte: PALAIS DE TOKYO, 2012, p. 67.

4.42 Vista da exposição William Klein: Le Commun des Mortels, Centre Nacionale de la Fotographie (ala oeste do Palais de Tokyo), Paris, 1986-87. Foto: Bernard Boudin/Le Bar Floréal. Fonte: PALAIS DE TOKYO, 2012, p. 78.
627 Em 1993, houve uma fusão das instituições que compartilhavam o edifício do Centro Pompidou, e o novo MNAM-CCI passou a integrar as coleções de arte moderna e contemporânea, bem como as de arquitetura e design. Cf. CEnTRE PoMpidou. L'Histoire des Collections. Centre Pompidou. Disponível em: < https://www.centrepompidou.fr/fr/Collections/Lhistoire-des-collections $>$. Acesso em: 27 maio 2021.

628 Cf. Un Musée d'Art \& d'Essai. In: PALAIS DE TOKYO, 2012, op. cit., pp. 64-71.

629 Cf. Les Nouvelles Images. In: PALAIS DE TOKYO, 2012, op. cit., pp. 72-81.

630 Projeto do arquiteto canadense radicado nos EUA Frank Gehry (1929-), inaugurado em 2005. ras convencionais. Uma resposta arquitetônica conservadora ou tímida nesse contexto dificilmente seria considerada apta a ajudar a França a se posicionar novamente num lugar de proeminência do debate cultural para além de suas fronteiras.

Numa perspectiva histórica, o projeto desenvolvido pela equipe de Dondel e Aubert foi desde cedo visto como uma expressão inadequada para o seu propósito, uma espécie de canto do cisne da tradição, enquanto que o de Piano \& Rogers, apontando na direção oposta, acerta em cheio seu alvo e torna-se de imediato um paradigma da arquitetura internacional, uma referência para edifícios culturais no mundo todo. Com sua transferência para os espaços amplamente flexíveis do novo Centro Pompidou, o MNAM encontrou uma arquitetura mais sintonizada com sua atividade essencial, voltada à promoção da arte moderna e contemporânea. ${ }^{627}$

Com o início da transferência das obras do MNAM para o Pompidou em 1976, a ala oeste do Palais de Tokyo - inaugurada quarenta anos antes e tendo funcionado como museu por apenas trinta anos - ficou esvaziada de sua função original e deixou de ter uma destinação consistente, passando a ser ocupada por mais três décadas de modo descontínuo por diversas instituições culturais do Estado. Alguns de seus espaços foram utilizados até 1986 pelo Musée d'Art \& d'Essai, dedicado a exposições temporárias variadas de caráter didático, com acervos de diversos museus nacionais, especialmente do Louvre. No mesmo período, passou a abrigar simultaneamente a coleção de obras pós-impressionistas que seriam destinadas ao futuro Museu d' Orsay, bem como doações de obras modernas que ainda não haviam sido transferidas para o Pompidou ${ }^{628} \mathrm{Em}$ 1984, instalou-se também no edifício o Centre National de la Photographie, que organizava exposições com a intenção de criar uma instituição dedicada à fotografia e ao cinema, a Maison de l'Image ${ }^{629} \mathrm{Em} 1986$, salas de cinema foram instaladas no prédio, antecedendo o plano de instalação definitiva no local de um Palais du Cinéma, cujas obras tiveram início em 1995, mas foram abandonadas em 1998, com a decisão da Instalação da Cinemateca Francesa no bairro de Bercy. ${ }^{630}$

O Centro Georges Pompidou, por sua vez, já completava então duas décadas de funcionamento e tinha visto sua cole- 

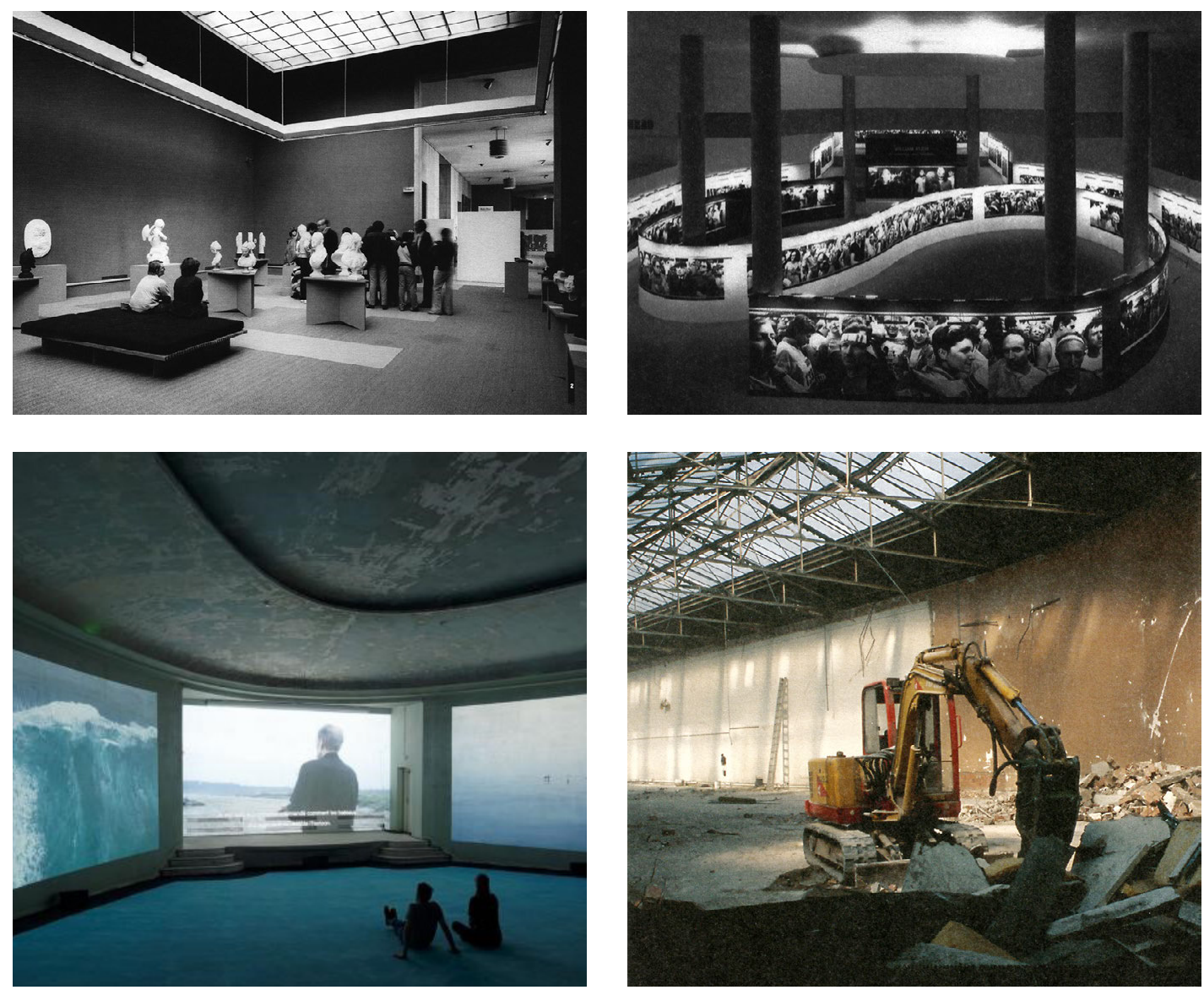

4.43 Vista de uma sala de projeção na Maison de l'Image (ala Oeste do Palais de Tokyo), entre 1986 e 1995. Fonte: https:// www.palaisdetokyo.com/fr/content/ lieu-histoire-palais-de-tokyo

4.44 Obras interrompidas do Palais du Cinéma - Museu do Cinema e Cinemateca Francesa (ala Oeste do Palais de Tokyo), Paris, 1995. Foto: Jacques Lebar. Fonte: PALAIS DE TOKYO, 2012, p. 96.

4.45 La Cinémathèque Française, projeto de Frank Gehry, Paris, 2005. Fonte: https://myarchitecturalguide. wordpress.com/2018/10/15/ la-cinematheque-francaise-frank-gehry/

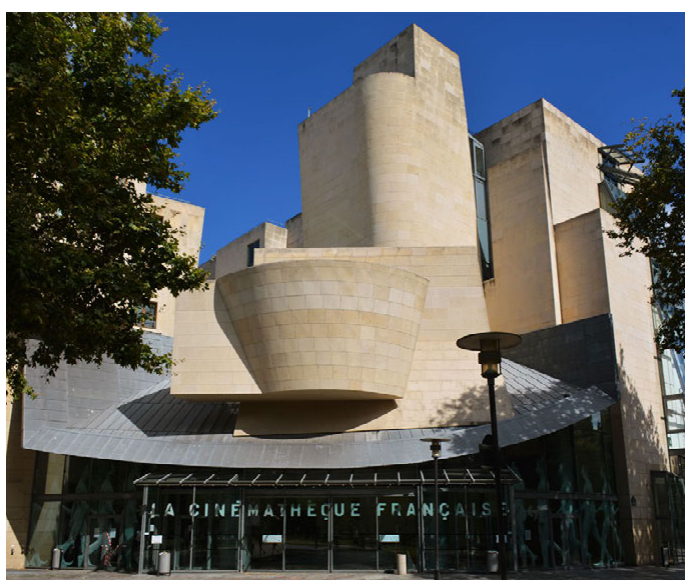

\section{6-507}



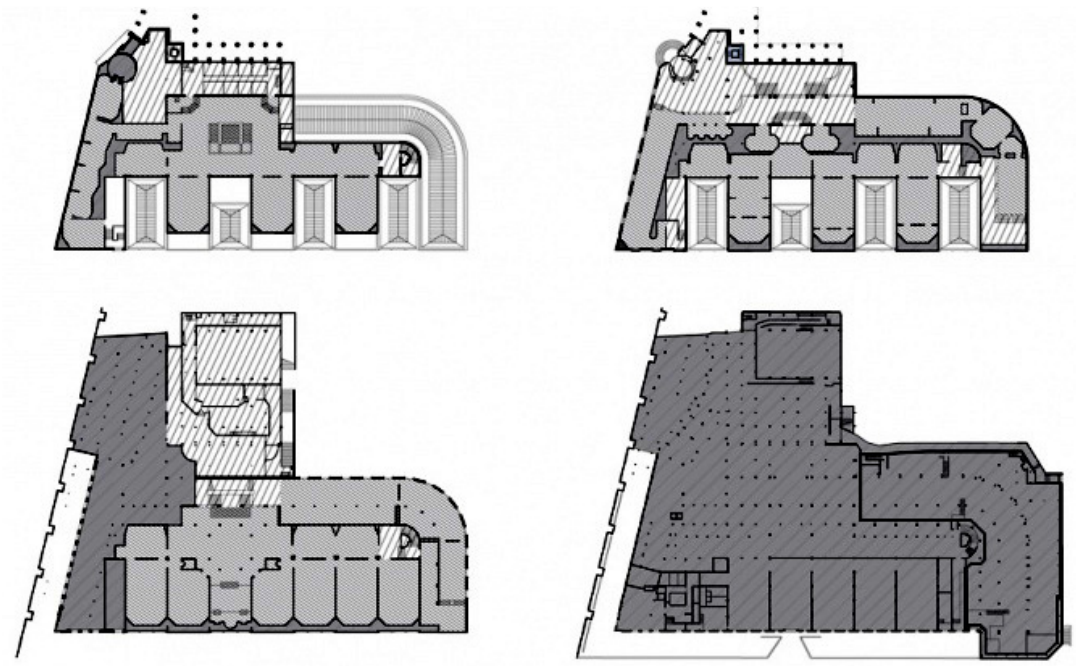

Musée Nationale d'Art Moderne 1947-77
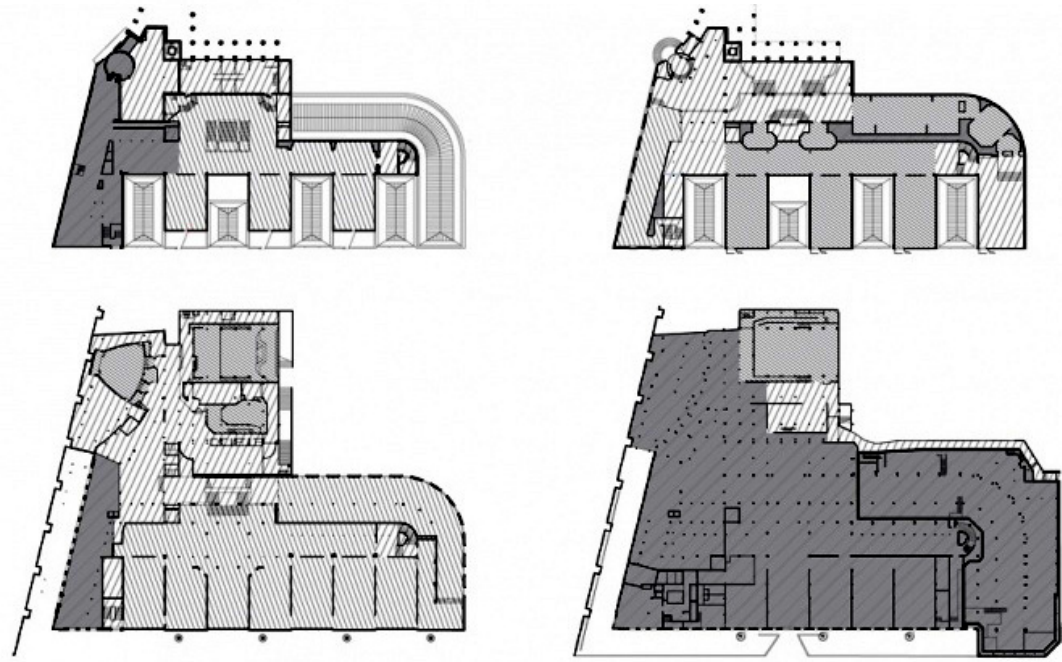

Musée d'Art et d'Essay

Centre National de la Photographie

Palais du Cinéma

disuse

infrastructure, administration

permanent use

temporary use 

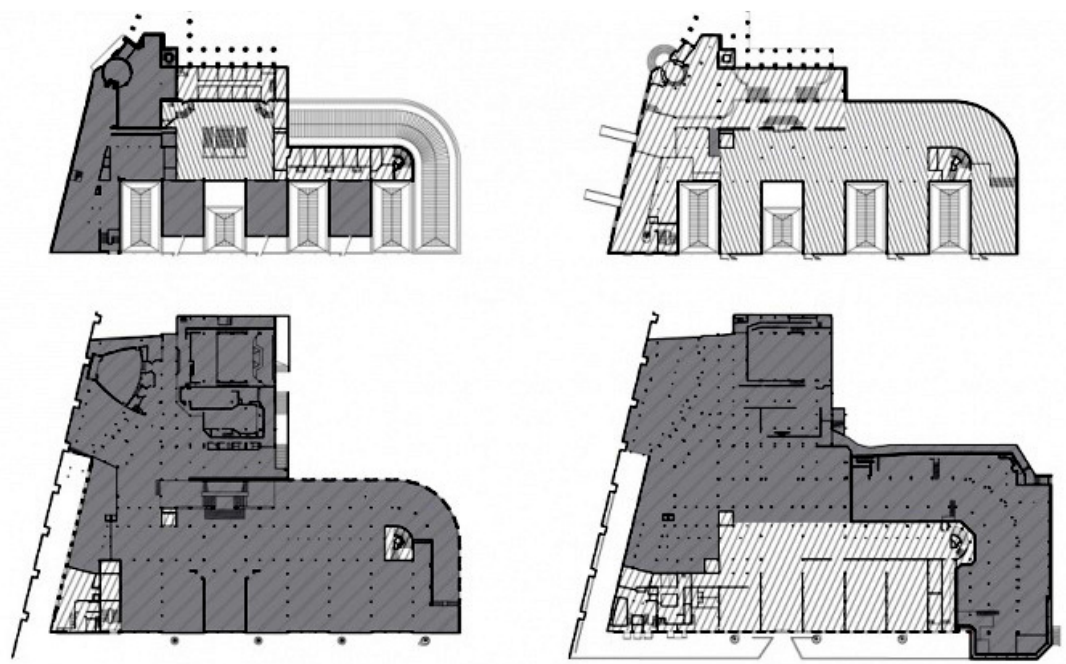

Palais de Tokyo.

Site de Création Contemporaine.

First Phase of Construction.

2002
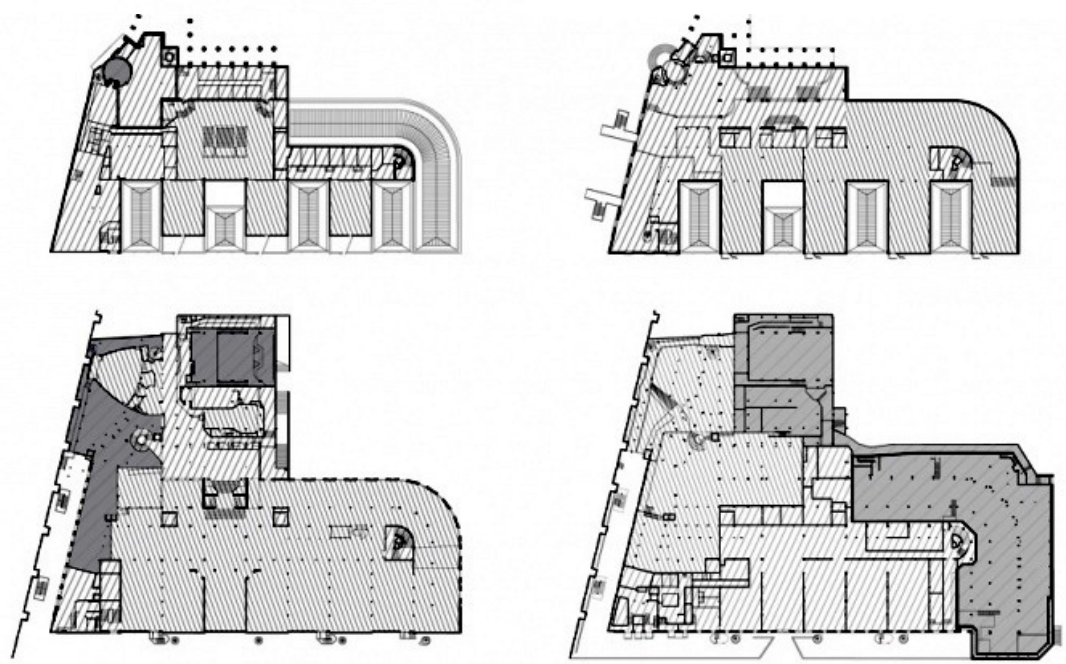

Palais de Tokyo

Site de Création Contemporaine

Second Phase of Construction

2012

\section{disuse}

infrastructure, administration

permanent use

temporary use
4.46 a 4.49 Plantas da ocupação da ala oeste do Palais de Tokyo entre 1974 e 2012. Fonte: https://www.archaic-mag. com/classics-palais-de-tokyo-jeanclaude-dondel-andre-aubert-paul-viardmarcel-dastugue-lacaton-vassal/ 


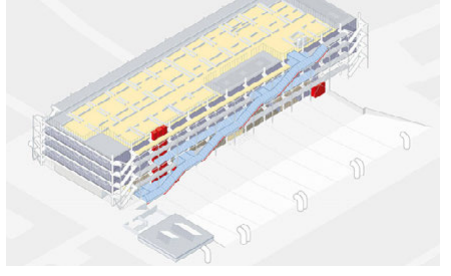

4.50 Mapa interativo do Pavimento 4 do Centro Georges Pompidou, dedicado à coleção de arte moderna de 1905 até meados dos anos 1960, Paris, 2021. Fonte: https://www.centrepompidou.fr/fr/ visite/plan-interactif?floor $=5$

631 Embora o Centro Pompidou disponha de aproximadamente $5.000 m^{2}$ para exposição de arte contemporânea e tenha galerias no andar térreo dedicadas a isso, essa atividade tem menos visibilidade que as outras, segundo o curador de arquitetura do centro, Olivier Cinqualbre. Cf. CINQUALBRE, Olivier. Entrevista concedida a Ana Paula Pontes no escritório do Centro Georges Pompidou. Paris, 19 de julho de 2018. Apêndice C desta tese.

632 A década de 1990 foi marcada pela grande visibilidade do grupo Young British Artists (YBA), promovido pela Saatchi Gallery. As obras pertencentes à galeria integraram a exposição Sensation, que estreou na Royal Academy de Londres em 1997 e itinerou em 1999 para o museu Hamburger Bahnhof de Berlim e para o Brooklyn Museum de Nova York. ção de arte moderna e contemporânea se transformar numa das mais importantes do mundo, rivalizando com a do MOMA e tendo que enfrentar os mesmos problemas de insuficiência de área que o museu de Nova York, podendo expor ao público uma parcela muito reduzida de seu acervo. A necessidade de os programas permanentes como o museu e a biblioteca ampliarem suas áreas de ocupação no edifício acabou fazendo com que a flexibilidade prevista originalmente para o Pompidou ficasse comprometida, tanto em termos da programação quanto da gestão de espaços. Exemplo perceptível desse processo é a subdivisão da planta livre do edifício em pequenas salas convencionais nas áreas dedicadas à coleção, conforme projeto da arquiteta italiana Gae Aulenti (1927-2012), que, inaugurado em 1985 - apenas 8 anos após a inauguração do centro -, visou aumentar as superfícies de apoio para expor o enorme acervo, em progressiva expansão. Desde então, as qualidades flexíveis do edifício deixaram de ser exploradas nas exposições de longa duração do MNAM, que mantém até hoje as linhas gerais da compartimentação espacial definida por Aulenti. A complexidade do modelo e o peso institucional que o Pompidou adquiriu acabou por desviar o foco do centro do aspecto vital de sua missão original: a de fomentar a produção das novas gerações ligadas à criação contemporânea. ${ }^{631}$

Paradoxalmente, o próprio esforço institucional empregado para esse fim levou a França, mais uma vez, a uma situação institucional um tanto defasada com relação à agilidade da cena da arte contemporânea no final dos anos 1990. ${ }^{632}$ Dando continuidade à política do Estado de sustentar uma posição de proeminência do país no mundo da arte, o Ministério da Cultura e da Comunicação lançou, no início de 1999, um concurso para definição de um programa dedicado à jovem criação francesa, visando instaurar um novo centro para este fim. O Palais de Tokyo, com sua imensa área construída e vaga, foi então escolhido para acolher esse programa, que deveria guardar uma posição de independência com relação às instituições museais existentes, contando com poucos recursos para a sua implantação. A proposta que venceu o concurso foi a apresentada pelos críticos de arte Nicolas Bourriaud e Jérôme Sans, ambos com experiência de cura- 
doria no circuito internacional. Ao final do mesmo ano, um outro concurso foi lançado para a escolha de um projeto de reabilitação do edifício para a implantação do novo centro, elegendo como vencedores os arquitetos Anne Lacaton e Jean-Philippe Vassal.

Desde que foi inaugurado como "local de criação contemporânea" em 2002 e ampliado em 2012, o Palais de Tokyo vem conquistando cada vez mais prestígio no cenário da arte contemporânea, deixando para trás a má fortuna que assombrou o edifício por longos anos. Conforme afirmou Minnaert,

Para a crítica progressista, o classicismo refinado do Palais de Tokyo era menos atemporal que anacrônico, menos sereno que anódino. Certamente a duração da obra ficou indiferente às críticas que recebeu. Mas podemos ler hoje em dia o Palais de Tokyo como um caso de micro história particularmente rico, como amostra de uma disputa de forças entre a técnica museográfica e a celebração da paisagem urbana, entre os homens das artes e as equipes político-administrativas, entre a identidade nacional e a modernidade internacional, entre o tempo curto da programação e o tempo longo dos sucessivos e contraditórios usos. É um dos edifícios públicos que demoram a receber um regime de funcionamento que lhes permitirá envelhecer bem. Com a reabertura do Museu de Arte Moderna da Cidade de Paris em 2006, e em 2012 de um novo Palais de Tokyo na ala ocupada pelo antigo museu do Estado, aposta-se que o século xxi terá mais apreço pela obra prima de Jean-Claude Dondel e André Aubert do que o século $\mathrm{xx} .^{633}$

Sem nunca ter sido reconhecido como digno representante da modernidade e tendo sobrevivido a décadas de desvios e maus tratos, o edifício do Palais de Tokyo, dedicado exclusivamente a projetos temporários e desvinculado das funções museais de preservação de coleções, parecia ter finalmente encontrado um programa propício a aproveitar plenamente seu potencial com sua destinação de espaço de arte contemporânea, como veremos a seguir.
633 Jean Baptiste Minnaert in: PALAIS DE TOKYO, 2012, op. cit., p. 33 . 


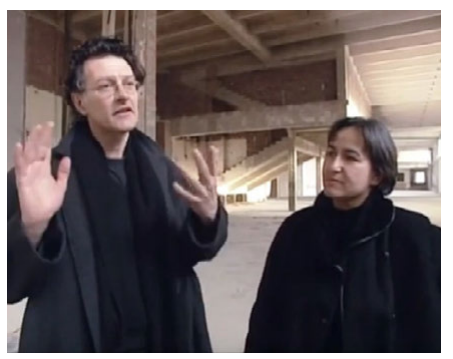

4.51 Jean-Philippe Vassal e Anne Lacaton nas obras do Palais de Tokyo, Paris, 2000. Filme: Paris - Forum des images. Fonte: https://www.youtube.com/ watch?app=desktop\&v=E111 XXML56Y

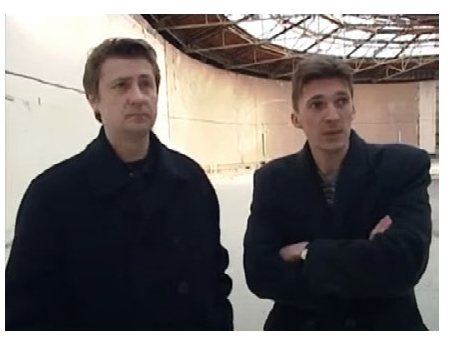

4.52 Jérôme Sans e Nicolas Bourriaud nas obras do Palais de Tokyo, Paris, 2000. Filme: Paris - Forum des images. Fonte: https://www.youtube.com/ watch?app=desktop\&v=E111XXML56Y

634 Anne Lacaton e Jean-Philippe Vassal. Conversation with Mathieu Wellner. In: PeTZET, Muck; HeIlMEyer, Florian; Verlag, Hatje Cantz (Ed.). Surplus - Reduce Reuse Recycle-Architecture as Resource. Ostfildern, Berlim: German Pavilion at the 13th Venice Architecture Biennale, 2012, p. 14.

\subsection{O PALAIS DE TOKYO COMO "LOCAL DE CRIAÇÃO CONTEMPORÂNEA": ANOS 2000 A 2010}

\subsubsection{UM PROJETO COMPARTILHADO}

Para a realização da obra da primeira fase da instalação do "local de criação contemporânea" no Palais de Tokyo em Paris, entre 2000 e 2002, a dupla Anne Lacaton e Jean-Philippe Vassal deixaram seu escritório de arquitetura na cidade de Bordeaux para instalar-se no canteiro de obras juntamente com os curadores Jérôme Sans e Nicolas Bourriaud, que, além de terem sido os responsáveis pela concepção inicial do centro, permaneceram na direção até 2006. A grande sintonia entre as propostas das equipes de curadoria e de arquitetura torna difícil distinguir de qual das partes vieram as referências e as soluções que se converteram no projeto de reabilitação do edifício, o que, como veremos, é coerente com o caráter assumido por ambas as partes de incompletude e autoria coletiva.

Essa não havia sido a primeira vez que Lacaton \& Vassal vencera um concurso de projetos com uma proposta de intervenção mínima, tendendo a zero, sobre uma realidade pré-existente. Em 1996, o escritório fora escolhido para liderar o projeto de "embelezamento" da pequena Praça Léon Aucoc em Bordeaux, tendo apresentado a recomendação de não realizar alterações, uma vez que, segundo eles, o espaço já funcionaria muito bem no estado em que estava. Na visão da dupla, o ato de construir não se limitaria à dimensão material, concreta, mas seria, primordialmente, o ato de pensar, de tomar uma posição, de "construir uma situação", considerando não apenas os aspectos físicos, mas também as demais sensações que compõe uma "ambiência". ${ }^{634}$

O plano para a implantação do local de criação contemporânea no Palais de Tokyo previa uma duração relativamente curta, de 5 anos, aguardando o momento em que o governo pudesse investir uma soma mais significativa de recursos no empreendimento. Às equipes concorrentes do concurso foi apresentado um programa bastante vago e oferecida apenas uma semana para a apresentação de propostas. Quando se depararam com os amplos salões vazios do Palais de Tokyo, ainda mais monumentais dada a remoção das divisórias inter- 

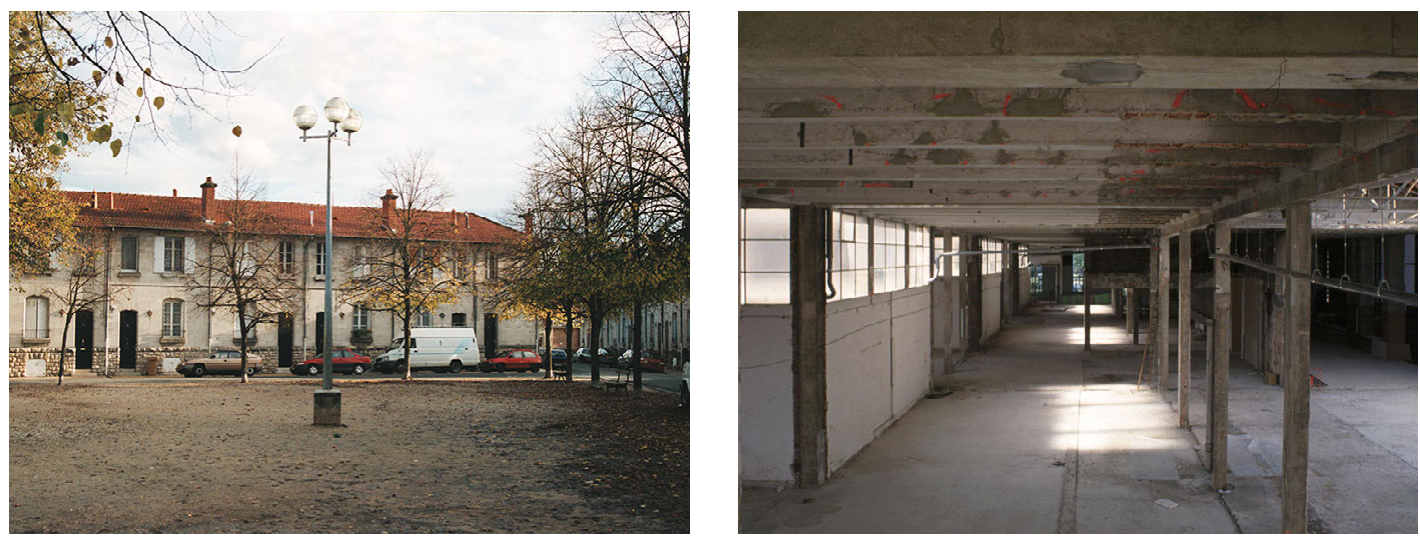

nas durante as obras anteriores, Lacaton e Vassal consideraram o edifício um verdadeiro achado. Ainda que estivesse num estado bastante deteriorado, as qualidades da construção original de amplitude, iluminação natural, esbelteza das estruturas de concreto e mesmo as cicatrizes dos diversos usos bastariam, em sua opinião, para configurar uma condição apropriada para a implantação de um centro dedicado a exposições temporárias de arte contemporânea, atividade que já havia ocorrido ocasionalmente no local, em Bienais e mostras avulsas realizadas por outras instituições culturais. Não haveria, portanto, necessidade de adicionar um "desenho" ao edifício existente, mas de criar condições mínimas de utilização pública. Ao invés de um projeto apresentado de modo convencional, a dupla submeteu ao concurso um pequeno texto relatando suas impressões sobre o lugar, explicando como colocariam em prática suas intenções de reabilitá-lo ao uso, além de fotomontagens.

Contrariando a premissa do concurso de atuar sobre apenas $5.000 \mathrm{~m}^{2}$ do total de $24.300 \mathrm{~m}^{2}$ do edifício, Lacaton e Vassal propuseram ampliar a reabilitação para $7.800 \mathrm{~m}^{2}$, tomando como partido restringir as intervenções a obras de infraestrutura, acessibilidade e manutenção, e com isso oferecer o máximo de área possível ao uso dentro do orçamento designado, de somente 3 milhões de Euros. Na opinião da dupla, a restrição orçamentária não foi uma limitação, mas, ao contrário, uma "sorte" para o projeto: o que teria permitido que tivessem liber-

4.53 Praça Léon Aucoc, Bordeaux, 1996. Foto: Lacaton \& Vassal. Fonte: https:// www.lacatonvassal.com/index.php?idp $=37$

4.54 Vista do interior do Palais de Tokyo (ala Oeste) antes da implantação do Local de Criação Contemporânea, Paris, s.d. Foto: Lacaton \& Vassal. Fonte: https:// www.lacatonvassal.com/index.php?idp $=20$ 
635 Anne Lacaton in: Columbia GSAPP. Lacaton \& Vassal. Youtube, [s.l.: s.n., s.d.]. Disponível em <https://www.youtube.com/ watch?app $=$ desktop $\& v=$ Twiz-dw9-e4\&feature=youtu.be $>$. Acesso em: 30 maio 2021.

636 Anne Lacaton e Jean-Philippe Vassal in: PETzET et al., op. cit., p. 13 .

637 Anne Lacaton e Jean-Philippe Vassal. Comme une p.aysage sans limites. In: PALAIS DE TOKYO, 2012, op. cit., p. 105. dade para fazer qualquer proposta, e ainda para que todas as decisões sobre as intervenções fossem extremamente criteriosas, nada além do estritamente necessário. ${ }^{635}$ Conforme defendeu Anne Lacaton, a proposta “não é uma recusa - é um projeto envolvendo uma decisão consciente de não fazer nada”, enquanto Jean-Philippe Vassal afirmou que a postura pressupõe "questionar a própria profissão - e com isso, o modo como a arquitetura é praticada". ${ }^{636}$

No projeto para a reabilitação do Palais de Tokyo, ambos consideraram mais importante restituir as condições de uso do local e mantê-lo sem acabamentos, não apenas para dar liberdade aos futuros ocupantes, que poderiam reconfigurá-lo a cada ocasião, mas também para oferecer uma ambiência mais informal e descontraída, aproximando a relação entre o público e a arte. Na visão de Lacaton:

Um centro de arte é um lugar social. No Palais de Tokyo, me parece que a arquitetura e as obras são mais descomplicadas. O centro de artes é também um lugar de experimentação, enquanto que um estado de perfeição, frequentemente almejado nos museus, impõe uma distância entre as obras e o espectador. Por fim, a imperfeição que pode haver no Palais de Tokyo torna mais familiar a aproximação com a arte. Isso não significa que seja vulgar, impreciso ou de qualidade inferior. É simplesmente uma forma mais humana. Hoje em dia as pessoas desejam estar à vontade em qualquer lugar. E estar um pouco mais relaxado não representa uma ameaça à compreensão de uma obra de arte. O que conseguimos no Palais de Tokyo foi justamente um equilíbrio delicado entre um lugar de vida e um lugar de apresentação da arte. ${ }^{637}$

O espírito de informalidade e aproximação com a arte desse relato poderia muito bem servir para descrever as intenções que animaram a criação do Centro Pompidou no contexto das demandas de renovação cultural pós 1968. Embora tenha sido instalado num edifício extremamente arrojado e também considerado anticonvencional à época de sua inauguração, o Pompidou, como vimos, tornara-se em pouco tempo um equipamento sobrecarregado pelo crescimento de partes do 

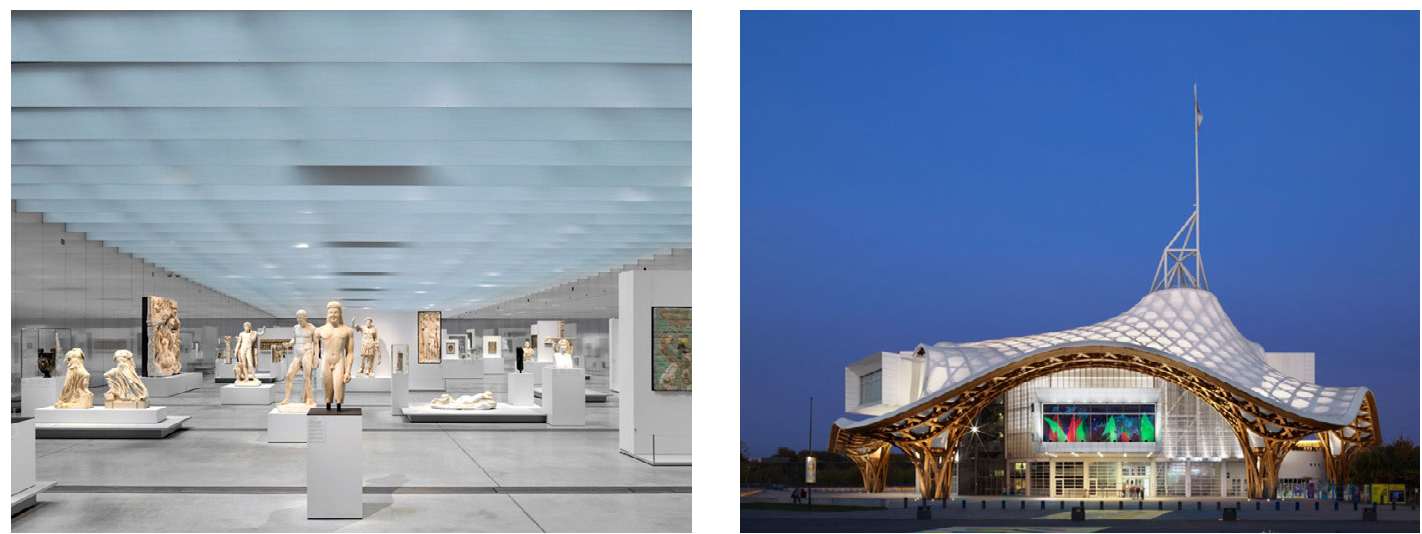

programa permanente, como a biblioteca e o museu. Para Lacaton, o resultado do projeto do Palais de Tokyo estava diretamente vinculado a condições opostas às do Pompidou, pois sua criação não contou com grandes recursos nem com o compromisso de zelar por uma coleção, o que caracterizaria o modelo institucional tradicional:

O Centro Pompidou se transformou numa instituição pesada de gerir, como o Louvre. Não surpreende ver que ambos procuram uma renovação por meio de dois museus fora de seus limites, em Lens (Louvre) e em Metz (o Centro Pompidou). Em contraste com essas instituições, muito dependentes das restrições de proteção e conservação de obras, a sorte do Palais de Tokyo foi justamente a de ser um projeto um pouco precário, não previsto para durar e sem muitos recursos. Nós tínhamos plena consciência de que três milhões de Euros para intervir seria suficiente apenas para algo inacabado. Foi sobretudo estimulante. ${ }^{638}$

Os curadores Bourriaud e Sans já haviam explicitado nas diretrizes de funcionamento do Palais de Tokyo a contraposição ao modelo das instituições museais convencionais, que consideravam excessivamente rígidas e burocráticas para acompanhar as dinâmicas da produção atual. A partir de experiências prévias de atuação no circuito internacional de arte contemporânea,
4.55 Vista do interior da Galerie du Temps no Musée du Louvre - Lens, projeto arquitetônico de SANAA e museográfico de Studio Adrien Gardère,2012. Fonte: https://www.goppion.com/projects/ louvre-lens

4.56 Centre Pompidou - Metz, projeto de Shigeru Ban Architects, Metz, 2010. Foto: Jacqueline Trichard. Fonte: https:// magazine.bellesdemeures.com/en/luxury/ lifestyle/pompidou-metz-centre-10-yearsexhibitions-and-strong-local-anchoringarticle-35539.html

\section{4-515}

638 CASCARO, David. Le musée décontracté. Une installation des Lacaton Vassal au Palais de Tokyo. Lacaton \& Vassal. Disponível em: $<$ https://www.lacatonvassal.com/ publications.php?fka=95>. Acesso em: 1 out. 2018 , p. 27. 
639 Nicolas Bourriaud apud CASCARO, op. cit., p. 44.

640 Nicolas Bourriaud e Jérôme Sans. Un Site à Habiter. In: PALAIS DE TOKYO, 2012, op. cit., p. 126. rejeitavam o caráter reverencial associado aos museus, afirmando um interesse em se aproximar da dinâmica mais flexível e informal dos espaços da vida cotidiana, como as praças públicas, ou as startups.

Um dos centros de arte apontados por eles como referência era o PS1 de Nova York. Como vimos no segundo capítulo desta tese, o centro havia sido fundado em 1976 como um "anti-museu" e sua idealizadora, Alanna Heiss, procurava explorar possibilidades alternativas de apresentar arte contemporânea sem as amarras institucionais, opondo-se à ideia de formar uma coleção e dedicando-se exclusivamente a projetos de exposições temporárias, nos moldes de uma kunsthalle. A manutenção do aspecto deteriorado dos interiores desta antiga escola pública era afirmada por Heiss como negação do modelo elitista do museu-templo e como propulsora da ampliação das possibilidades de exploração espacial pelos artistas. No Palais de Tokyo, no entanto, a mesma solução foi defendida primeiramente pela equipe de arquitetura, e não pela curadoria, como relatou Bourriaud: "Tínhamos imaginado no início as paredes brancas. Eles [Lacaton e Vassal] nos convenceram a tentar mostrar a arte de outro modo. Tentamos fazer dessa necessidade uma virtude." ${ }^{339}$

Embora a "necessidade" fosse também da ordem do pragmático - pois deixar de tratar as superfícies permitiu distribuir os recursos limitados e estender a intervenção a uma área maior -, a decisão de não ocultar as marcas de usos prévios e deixar à mostra a precariedade do edifício tinha implicações conceituais, uma vez que reforçava a contraposição ao modelo de espaço expositivo mais disseminado por museus de arte moderna e contemporânea, concebidos como ambientes "puros" e isolados das interferências do mundo exterior. A solução arquitetônica não encontrou grandes dificuldades de ser acatada, por mostrar-se, afinal, bastante propícia para corroborar a proposta dos curadores. Como afirmou Bourriaud:

Defendíamos a ideia de uma alternativa que permitisse sair da posição dominante para adotar um ponto de vista profano [...]. Queríamos inserir o cotidiano no espaço sagrado do 'cubo branco'. Considerávamos as paredes como um 'ruído de fundo', como o equivalente ao rumor da cidade. ${ }^{640}$ 


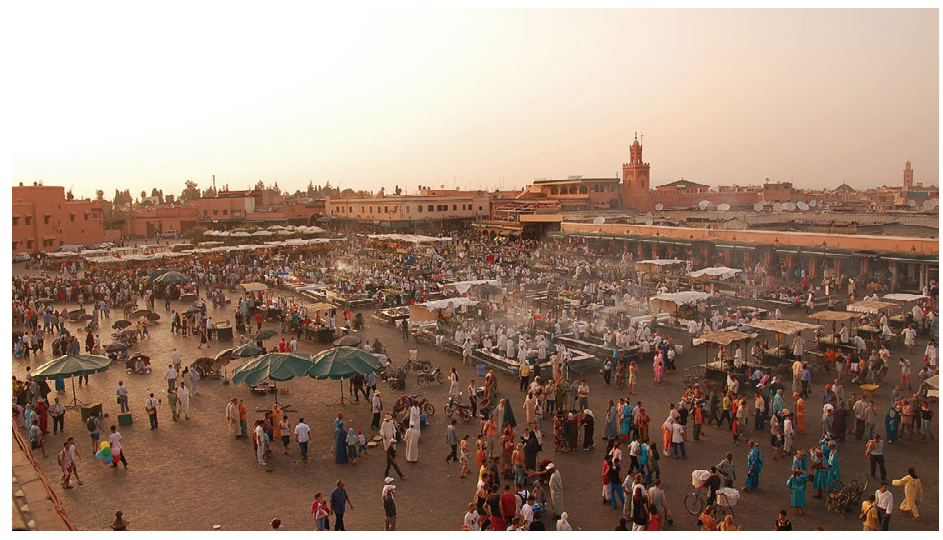

Os espaços urbanos eram de fato apontados como referências para o projeto, como era o caso da praça Jemaa el-Fna em Marrakech, por sua vastidão horizontal e variedade de usos espontâneos, frequentemente citada tanto pelos arquitetos quanto pelos curadores. Outra imagem associada ao Palais de Tokyo era a da "ocupação", pela forma como o centro se instalou no edifício que mantinha ainda as marcas dos anos de abandono, o que Lacaton e Vassal preferiam considerar não como um objetivo estético, mas uma consequência da abordagem conceitual, que os levou a optar pela manutenção do estado precário do edifício. De todo modo, o resultado era o oposto do espaço "purificado" de interferências externas, cujos "ruídos" prejudicariam a experiência com a obra de arte.

A rejeição do modelo "cubo branco", no entanto, não implicava para a dupla abandonar uma certa ideia de neutralidade, mas até reafirmá-la, a partir da inexistência das próprias paredes ou da impermanência da configuração dos espaços, como observamos na fala de Jean-Philippe Vassal:

A partir do momento em que imaginamos fazer com que as paredes desapareçam, não há mais necessidade de pintá-las de branco. A mais forte neutralidade que poderíamos propor aos artistas é a das paredes que não existem, ou seja, em perpétua transformação. ${ }^{641}$
4.57 Praça Jemaa-el-Fna, Marrocos, s.d. Fonte: https://pt.wikipedia.org/wiki/ Jemaa_el-Fna 


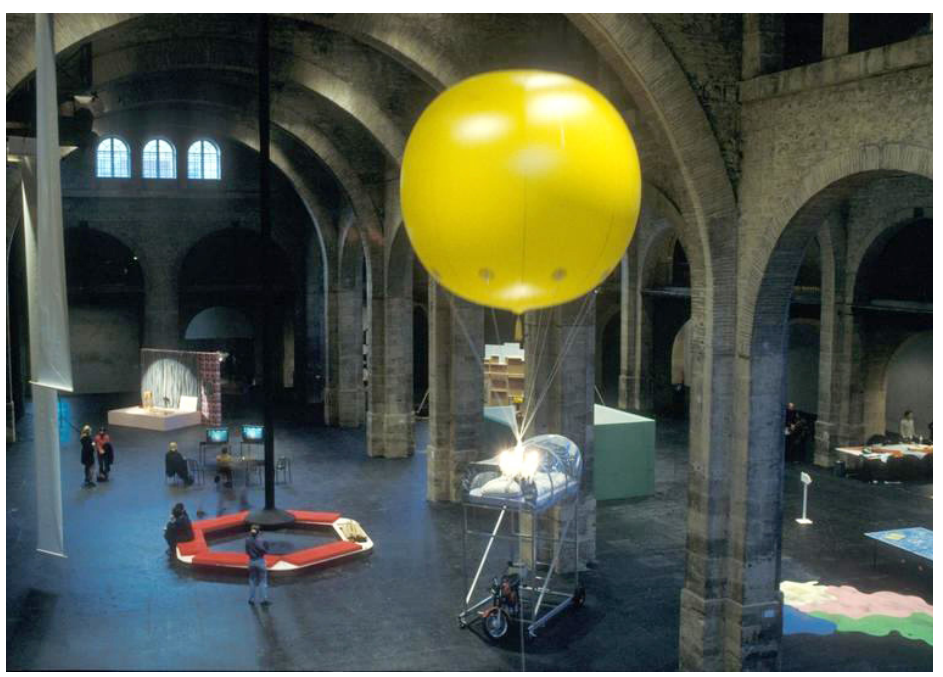

4.58 Vista da exposição Traffic, CAPC, Bordeaux, 1996. Foto: Frédéric Delpech. Fonte: http://www.capc-bordeaux.fr/ category/menu/le-musee/histoire-du-capc

642 Bourriaud, Nicolas. Estética relacional. São Paulo: Martins Fontes, 1998.

643 Todos os artistas mencionados por Nicolas Bourriaud em seu livro Estética relacional participaram, junto a outros, da exposição Traffic no CAPC Bordeux, sendo: Henry Bond, Vanessa Beecroft, Maurizio Cattelan, Dominique GonzalezFoerster, Liam Gillick, Christine Hill, Carsten Höller, Pierre Huyghe, Miltos Manetas, Jorge Pardo, Philippe Parreno e Rirkrit Tiravanija.
Enquanto o espaço convencional e sacralizado do "cubo branco" correspondia à noção de obra de arte autônoma, de acordo com a narrativa dominante do modernismo, o tipo de espaço "profano" que Nicolas Bourriaud imaginava para o Palais de Tokyo ecoava certas qualidades opostas às da autonomia, conforme havia explicitado em seu livro Estética Relacional, publicado em 1998. ${ }^{642}$ Bourriaud exemplificou seu conceito a partir de obras diversas de artistas com quem vinha trabalhando na década de 1990, especialmente os que participaram da exposição Traffic, montada em 1996 no Museu de Arte Contemporânea de Bordeaux (CAPC), que, instalado num antigo entreposto de mercadorias coloniais construído em 1820, também se configurava como um espaço expositivo não convencional. ${ }^{643} \mathrm{O}$ autor defendeu então que os trabalhos que vinculou à “estética relacional” se caracterizariam não por uma ênfase nos aspectos formais, mas no tipo de relação que estabeleceriam com o público, mais convivial e interativa, numa sensibilidade desenvolvida a partir dos relacionamentos em rede advindos da internet e da nova economia baseada menos na produção de mercadorias e mais na prestação de serviços.

Seu livro seguinte, Pós-Produção, de 2004, deu continuidade ao raciocínio, apontando como as novas formas de criação se 

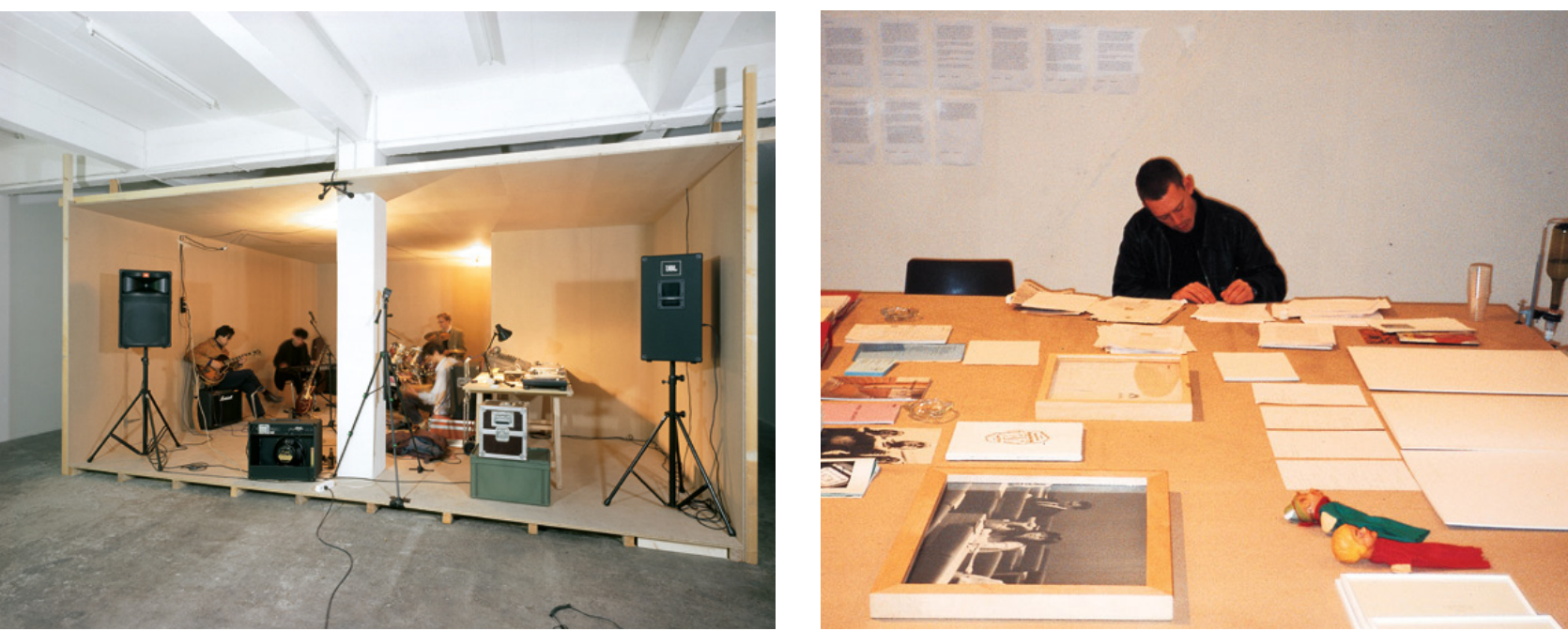

baseariam mais na seleção e recombinação de objetos culturais pré-existentes do que na produção de novos objetos. Publicado enquanto Bourriaud já atuava como curador do Palais de Tokyo, é possível ler na descrição dos processos criação da diversidade de artistas que compuseram a exposição a estratégia arquitetônica empregada também no projeto de Lacaton \& Vassal:

Todas essas práticas artísticas, embora muito heterogêneas em termos formais, compartilham o fato de recorrer a formas já produzidas. Elas mostram uma vontade de inscrever a obra de arte numa rede de signos e significações, em vez de considerá-la como forma autônoma ou original. Não se trata mais de fazer tábula rasa ou de criar a partir de um material virgem, e sim de encontrar um modo de inserção nos inúmeros fluxos da produção [...]. Os artistas atuais não compõem, mas programam formas, em vez de transfigurar um elemento bruto (a tela branca, a argila), eles utilizam o dado. Evoluindo num universo de produtos à venda, de formas preexistentes, de sinais já emitidos, de prédios já construídos, de itinerários balizados por seus desbravadores, eles não consideram mais o campo artístico (e poderíamos acrescentar a televisão, o cinema e a literatura) como um museu com obras que devem ser citadas
4.59 Rirkrit Tiravanija, Rehearsal Studio No. 6, exposição no Kunst Halle Sankt Gallen, 1996. Fonte: https://www. kunsthallesanktgallen.ch/en/exhibition/ id-20011996.html

4.60 Liam Gillick, Prototype Erasmus Table \#2, exposição no S.M.A.K Gent, 1994. Fonte: https://www.lespressesdureel.com/ EN/ouvrage. .php?id=4199\&menu $=0$ 


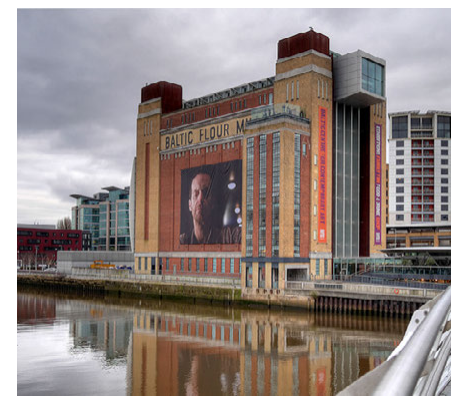

4.61 Baltic Flour Mill | BALTIC Centre for Contemporary Art, projeto de Ellis Williams Architects, Gateshead, 2002. Fonte: https://generatorstudios.co.uk/location/

644 Bourriaud, Nicolas. Pósprodução: Como a arte reprograma o mundo contemporâneo. São Paulo: Martins Fontes, 2010, p. 12-13.

645 BISHOP, Claire. Antagonism and Relational Aesthetics. October, v. 110, p. 51-79, 2004, p. $5^{2}$. Tradução nossa.

646 Ibidem, p. 51. ou "superadas", como pretendia a ideologia modernista do novo, mas sim como uma loja cheia de ferramentas para usar, estoques de dados para manipular, reordenar e lançar. ${ }^{644}$

O edifício que abrigara primeiramente o MNAM e depois outros usos esporádicos não passaria por uma renovação propriamente dita, mas seria mantido no estado em que se encontrava, exibindo suas "formas preexistentes", não para ser "citado" como um antigo museu, mas para ser recontextualizado como um centro de arte contemporânea, sendo inscrito numa outra "rede de signos e significações”. Enquanto a conexão do projeto do Palais de Tokyo à "estética relacional” é difícil de ser verificada para além do campo discursivo - tomando a afirmação de Anne Lacaton de que a "imperfeição" possibilitaria uma maior aproximação do espectador com a arte - é mais evidente a consonância do procedimento arquitetônico que orienta a reabilitação do edifício com os processos artísticos descritos sob o conceito de “pós-produção”. De todo modo, características observadas por Bourriaud no tipo de arte produzida dos anos 1990 - como o fato de se apresentarem mais como trabalhos em andamento do que como obras acabadas - são claramente assumidas no projeto de Lacaton \& Vassal.

Essa convergência conceitual entre a arquitetura do espaço expositivo e o conteúdo a ser exposto seguiria, conforme apontou a crítica de arte britânica Claire Bishop (1971-), uma tradição que remontaria às mostras dadaístas dos anos 1920, ambientadas no sentido de "reforçar ou sintetizar as ideias contidas no trabalho". ${ }^{645}$ Associando o projeto do Palais de Tokyo diretamente ao conceito de "estética relacional", a autora reconheceu que sua arquitetura "logo se tornou paradigmática de uma tendência visível entre os locais europeus de arte para redefinir o modelo 'cubo branco' de exposição arte contemporânea”. ${ }^{646}$ Bishop, no entanto, do mesmo modo como indicou descrença no potencial emancipador de certas obras valorizadas no contexto da "estética relacional" - pelo fato de Bourriaud não levar em conta a qualidade das relações das propostas artísticas -, demonstrou desconfiar também do aspecto retórico da associação desses novos centros de arte contemporânea a algumas imagens fortes, que os vincularia 


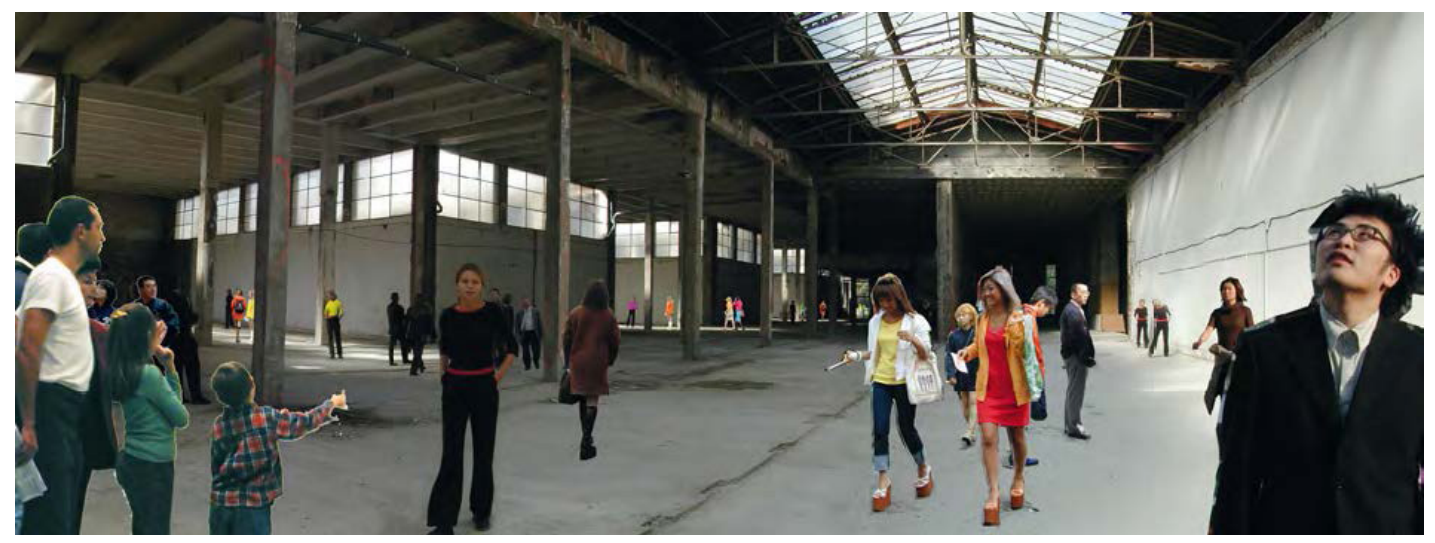

4.65 a 4.67 Fotomontagens elaboradas em 2000 por Lacaton \& Vassal para 0 projeto de implantação do Centro de Criação contemporânea no Palais de Tokyo. Imagens: Lacaton \& Vassal. Fonte: https://www.lacatonvassal.com/index. php?idp $=20$
649 Anne Lacaton in: CASCARO, op. cit., p. 13 . e acrescentamos apenas o que faltava para devolver ao uso este lugar por si só impressionante, prevendo que as partes existentes, tal como se mostravam, faziam parte de um todo, que elas não perturbariam a percepção dos espaços extraordinários e, portanto, não havia necessidade de escondê-las. O que importa é o incrível potencial do lugar que o projeto permitiu recuperar. ${ }^{649}$

Ainda que para Lacaton \& Vassal o que contava era uma "ética", a "estética" material do edifício atuava de modo impactante na experiência da arquitetura. Como apontou a crítica Sandra Karina Löschke, nas próprias fotomontagens elaboradas para ilustrar as possibilidades de ocupação do edifício, a estética material da arquitetura estaria evidentemente valorizada, ao invés de colocada num plano rebaixado, e dela dependeria a ambiência informal pretendida:

As imagens mostram o Palais de Tokyo funcionando num duplo registro: o encontro físico com o edifício (a sensorialidade das paredes cruas, a pátina da estrutura exposta da cobertura etc) se torna o tema da experiência estética (pessoas estão olhando para isso), e sua estética informal parece promover as atividades igualmente informais acontecendo. As imagens demonstram, portanto, a conjunção da estética material e do tipo de comportamento que a experiência pro- 


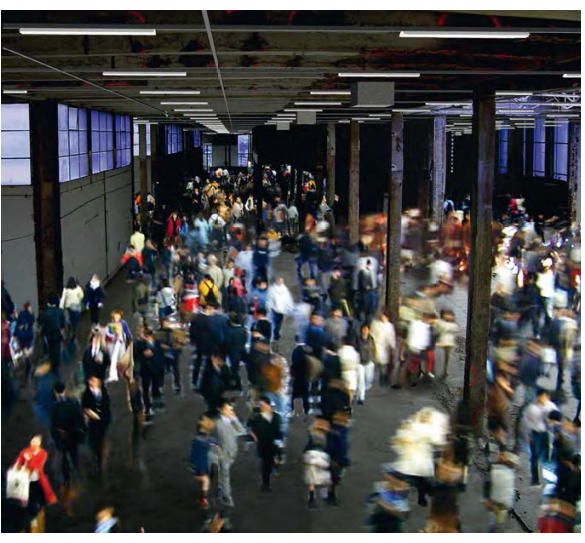

move. O resultado é uma estética do uso - se concordarmos que as atividades dos usuários equivalem a uma estética. ${ }^{650}$

Lacaton defendia que, para um local de exposição como esse, "o arquiteto não deve atuar demais para deixar espaço para os artistas e as obras". ${ }^{651} \mathrm{E}$ se de fato não se possa dizer que a equipe de arquitetura tenha "atuado demais" nesse caso pois, ao contrário, a intervenção visível no edifício existente foi mínima - isso não evitou que a ambiência fosse percebida desde o início como impactante. Segundo Löschke, no Palais de Tokyo a experiência estética da arquitetura não seria rebaixada, mas teria, no mínimo, presença equivalente à própria arte.

Embora equipes de arquitetura e curadoria tenham sempre defendido o protagonismo de artistas no Palais de Tokyo, ambas as duplas sofreram críticas por terem supostamente dado destaque excessivo a suas áreas de atuação. Claire Bishop, observando os programas tipo Le Salon, em que artistas atuam como designers, "redecorando" a cada seis meses um espaço de descanso do centro, atacou:

Um efeito da insistente promoção dessas ideias do artista como designer, função acima da contemplação, e do inacabado acima da resolução estética é, no fim das contas, para elevar o status do curador, que ganha o crédito pelo gerenciamento espacial da experiência geral do tipo laboratório. ${ }^{652}$
650 LÖsCHKE, Sandra Karina. Materials-in-fact: Material aesthetics and ethics in Lacaton \& Vassal's Palais de Tokyo. In: Materiality and Architecture. Nova York: Routledge, 2016, p. 48. Tradução nossa.

651 Anne Lacaton in: PALAIS DE TOKYO, 2012, op. cit., p. 104. 652 BISHOP, op. cit., p. 53. 
4.68 Abertura do Centro de Criação Contemporânea no Palais de Tokyo, projeto de Lacaton \& Vassal, Paris, 2002. Foto: Philippe Rouault. Fonte: https://www. lacatonvassal.com/index.php?idp $=20$

4.69 a 4.71 Centro de Criação Contemporânea no Palais de Tokyo, projeto de Lacaton \& Vassal, Paris, 2002. Foto: Philippe Rouault. Fonte: https://www.lacatonvassal.com/index. php?idp=20
A colocação de Bishop, no entanto, parece não levar em conta o fato de que a experiência geral de um espaço de arte, se sua ocupação integral não for concebida por um ou uma artista, será sempre de responsabilidade da curadoria. Ao contrário do que argumentou a autora, isso não depende do caráter experimental das exposições, sendo até mais acentuado no caso de mostras convencionais, especialmente naquelas em que a curadoria é responsável por determinar a reunião de obras de caráter autônomo, concebidas independentemente da interação com o espaço.

É o que explicitou o filósofo e crítico de arte alemão Boris Groys (1947-), ao diferenciar os papéis de artistas e da curadoria no contexto da arte contemporânea, cuja natureza seria
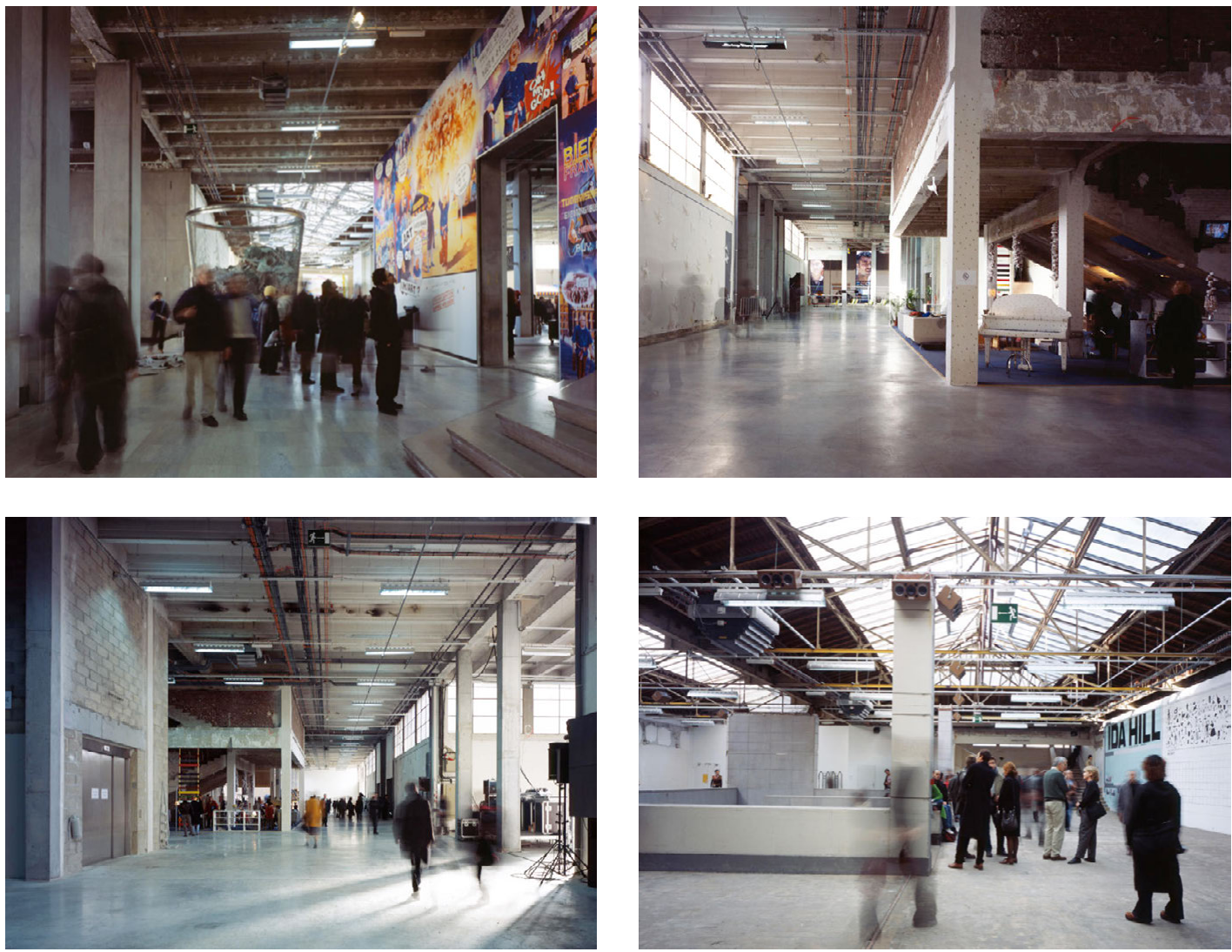
dependente da prática da exposição. Ao contrário de artistas que, ao criarem uma instalação, teriam liberdade para ditar as regras simbólicas de ocupação do espaço, sem a necessidade de se submeter a nada além de sua lógica particular, curadores, ao realizarem uma exposição convencional a partir da seleção de obras, teriam a liberdade limitada pela obrigação de justificar suas escolhas perante o público, mesmo no caso de projetos experimentais:

O artista e o curador encarnam, muito claramente, essas duas formas de liberdade: a soberana e incondicional liberdade de fazer arte sem ter responsabilidade com o público e a institucional e condicional liberdade da curadoria que tem responsabilidade com o público. $\mathrm{E}$ mais, isso significa que a instalação de arte - na qual o ato de produção coincide com o ato de apresentação - torna-se o terreno experimental perfeito para revelar e explorar a ambiguidade que reside no centro da noção ocidental de liberdade. Portanto, nas últimas décadas nós vimos a emergência de projetos curatoriais inovadores que parecem conferir ao curador poder para agir de modo autoral e soberano. E vimos também a emergência de práticas artísticas procurando ser colaborativas, democráticas, descentralizadas e sem autoria. ${ }^{653}$

Enquanto uma proposta curatorial poderia ser criticada de modo parcial, por ter ou não incluído determinada obra numa exposição, ou tê-las disposto desta ou daquela maneira no espaço, a instalação artística só poderia ser avaliada como um todo, nunca a partir de elementos isolados do trabalho. Embora possa vir a agir de modo mais "autoral e soberano", o curador, na argumentação de Groys, teria a liberdade restrita, por ser necessariamente condicionada à instituição e ao público.

É nesse sentido que podemos ver na ênfase na liberdade conferida a artistas declarada por Bourriaud e Sans a contraposição ao modelo institucional tradicional, que continuou a ser sustentada por seus sucessores no Palais de Tokyo. Cada artista, porém, atuava apenas num momento pontual, cabendo à curadoria estabelecer um nexo entre a sequência de eventos, como explicou Marc-Olivier Wahler (1964-), ao descrever sua
653 Groys, Boris. Politics of Installation. E-flux, n. Journal \#02, p. 1-8, 2009, p. 3-4. Tradução nossa. 
4.72 e 4.73 Plantas Níveis 0 e $1 \mathrm{~A}$ do Centro de Criação Contemporânea no Palais de Tokyo, projeto de Lacaton \& Vassal, Paris, 2002-12. Fonte: https://www.lacatonvassal.com/index. php?idp $=20$
654 Marc-Olivier Wahler. De l'Exposition au programme. In: PALAIS DE TOKYO, 2012, op. cit., p. 183. Tradução nossa.

655 O programa Le Pavillon Ozenfant foi criado e dirigido pelo artista Ange Leccia e funcionou no Palais de Tokyo desde antes da sua abertura, em 2001, até 2017. atuação como diretor e curador chefe do centro de 2006 a 2012. O ambiente das décadas de 1980 e 90 teria sido, segundo ele, marcado pela passagem de uma arte voltada a exposições a uma arte orientada para eventos descontínuos como feiras e bienais - embaralhando os papéis antes mais distintos da trilogia composta por museus, centros culturais e galerias. Wahler defendeu que, embora a programação do Palais de Tokyo fosse baseada em eventos temporários, seria necessário construir um sentido de continuidade para que pudesse contribuir de modo relevante com o debate contemporâneo: "o centro de arte pode ainda assumir um papel principal a partir do momento em que deixa de se definir como um receptáculo de exposições e passa a se pensar como um laboratório voltado para a reflexão sobre a exposição como um meio de conhecimento". ${ }^{654}$

Muita relevância é dada à ambiência crua da arquitetura do Palais de Tokyo, que se mostraria assim um espaço mais receptivo a intervenções de artistas. No entanto, talvez tenha contribuído com o mesmo peso para as possibilidades experimentais a imensidão e variedade de espaços disponíveis no edifício para a atuação de artistas e curadores, tanto para a realização de cada exposição quanto para a elaboração da programação como um todo. Durante sua gestão, Wahler estruturou o funcionamento do centro a partir de três temporadas de três meses cada por ano, nas quais conviviam exposições com ritmos diferentes: as que preenchiam toda a temporada, as que duravam seis semanas, as de um mês e as conferências e performances de apenas uma noite. A programação não seguiria um plano pré-estabelecido, mas seria construída de modo aberto, em colaboração com artistas, podendo ainda se mesclar a outros eventos "satélites", como instalações e ações específicas, a produção da Revista Palais e outras publicações e os programas dedicados a artistas emergentes, como o Les Modules - com duas ou três exposições mensais - e o Le Pavillon - residência artística anual contemplando atividades no centro e noutras cidades da França e no exterior. ${ }^{655}$

Se admitimos que uma exposição se define por uma composição de obras, então o que seria uma composição de exposições? Uma programação, evidentemente. E se constatamos que a 


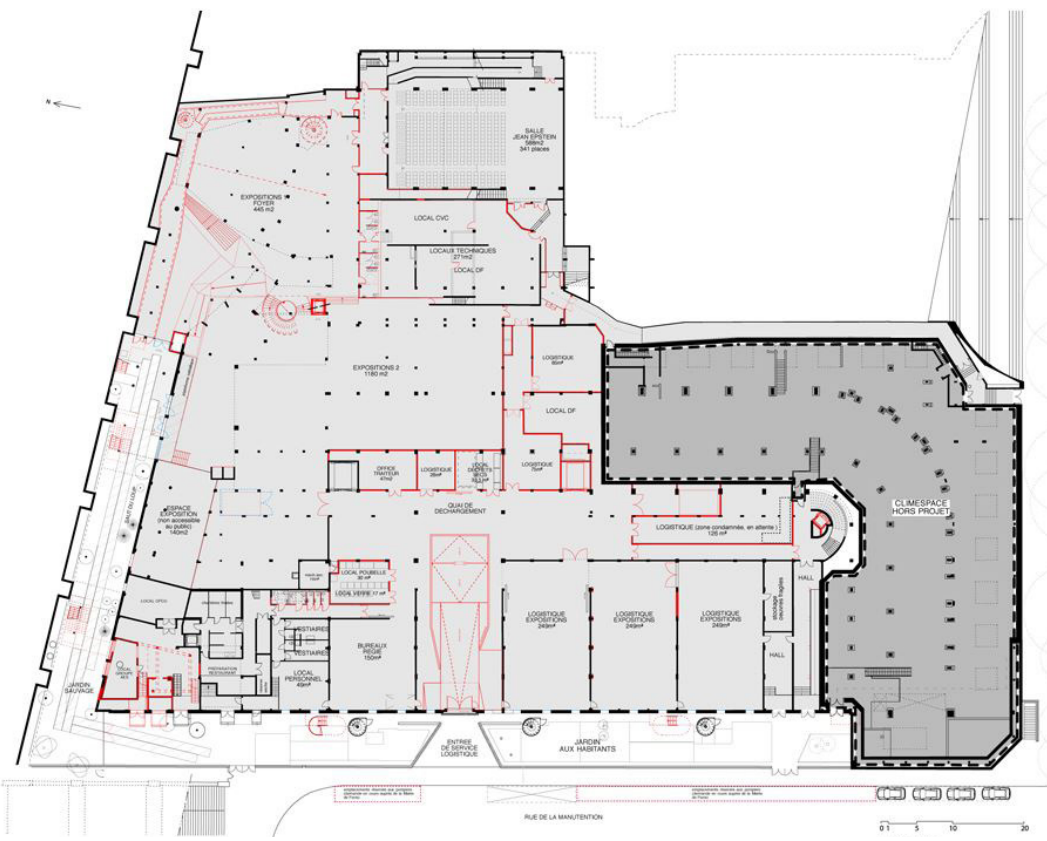

Nível 0

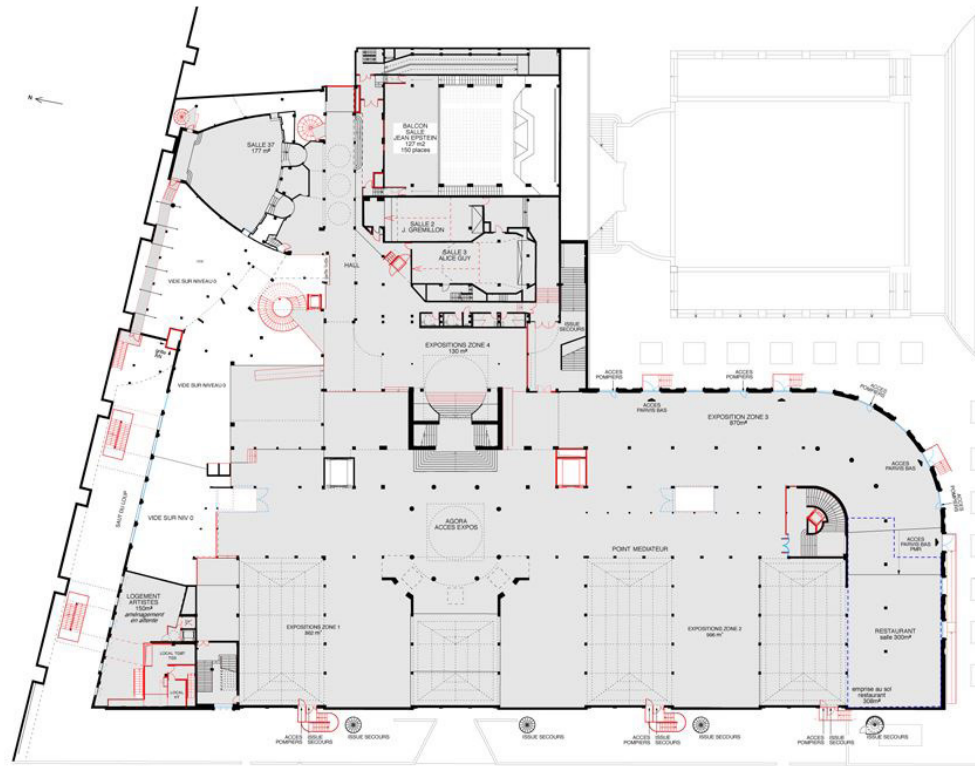

Nível $1 \mathrm{~A}$ 
4.74 a 4.77 Plantas Níveis 1B, 1C, N2 e $3 A$ do Centro de Criação Contemporânea no Palais de Tokyo, projeto de Lacaton \& Vassal, Paris, 2002-12. Fonte: https://www.lacatonvassal.com/index. php?idp $=20$

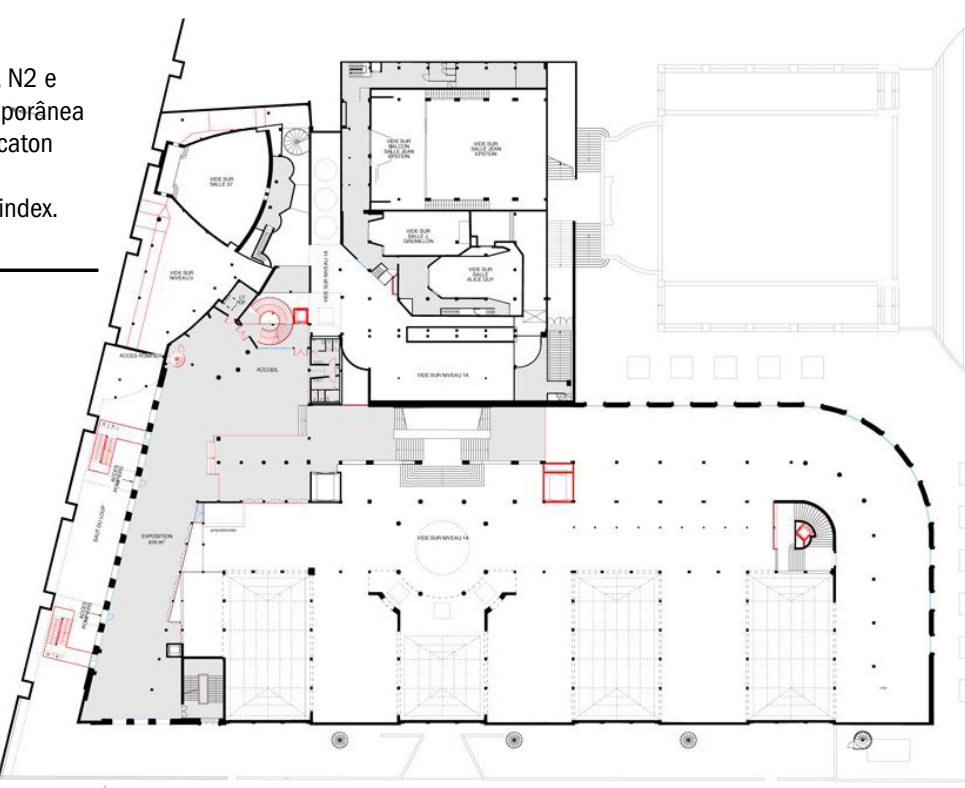

Nível 1B

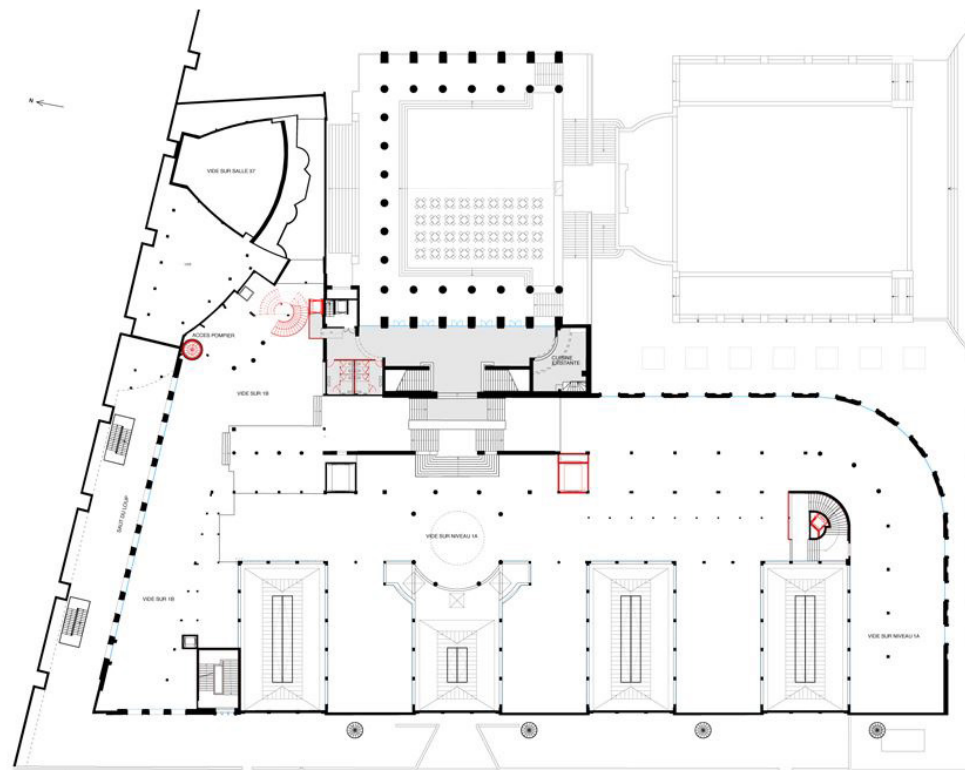

Nível $1 \mathrm{C}$ 


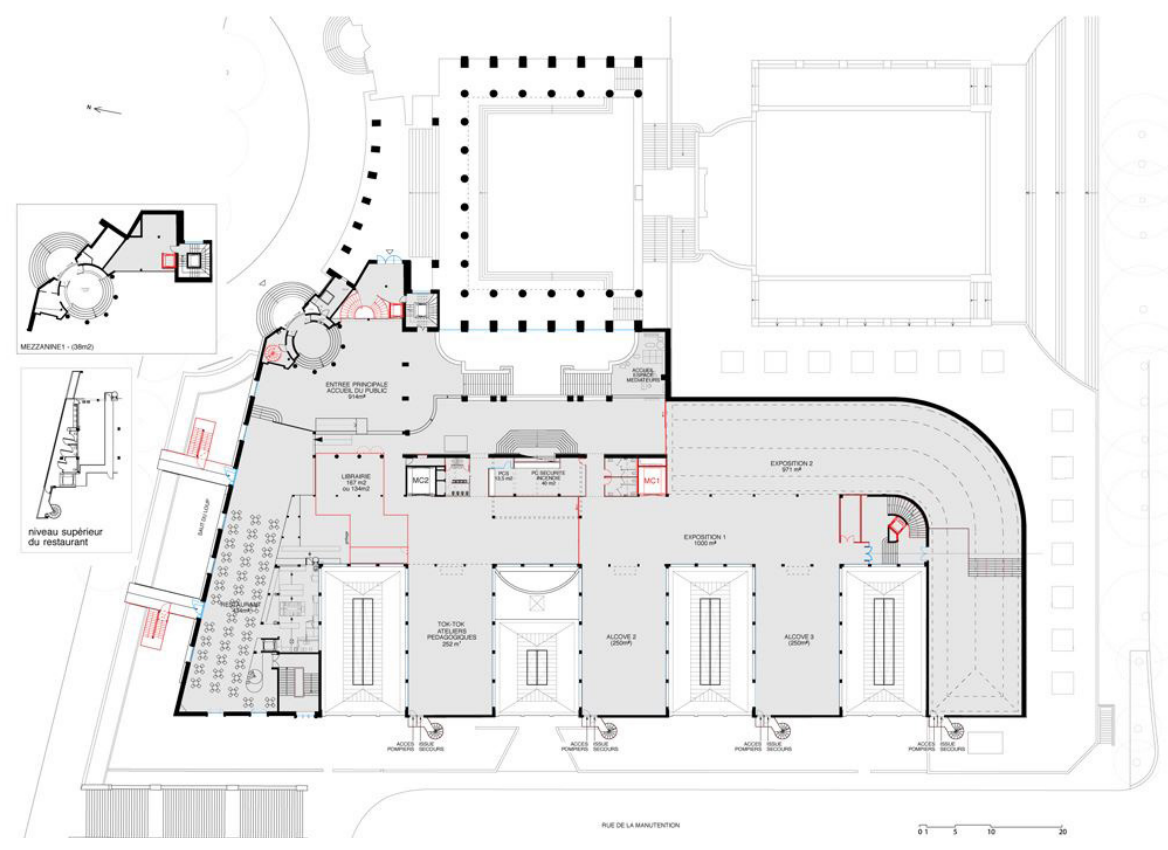

Nível 2

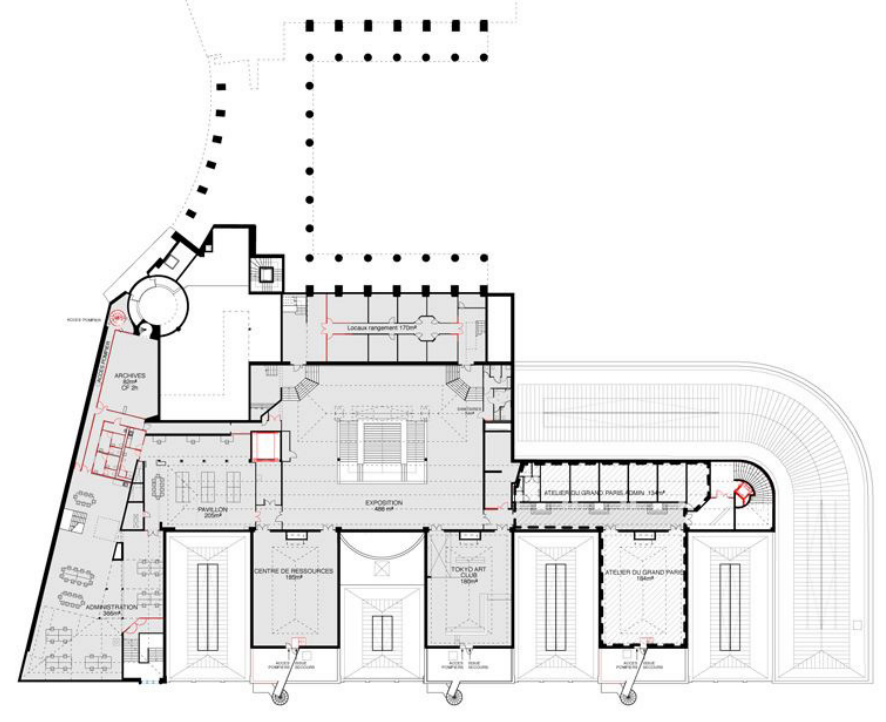

Nível 3A 
4.78 e 4.79 Plantas Níveis 3B e da Cobertura do Centro de Criação Contemporânea no Palais de Tokyo, projeto de Lacaton \& Vassal, Paris, 200212. Fonte: https://www.lacatonvassal. com/index.php?idp $=20$

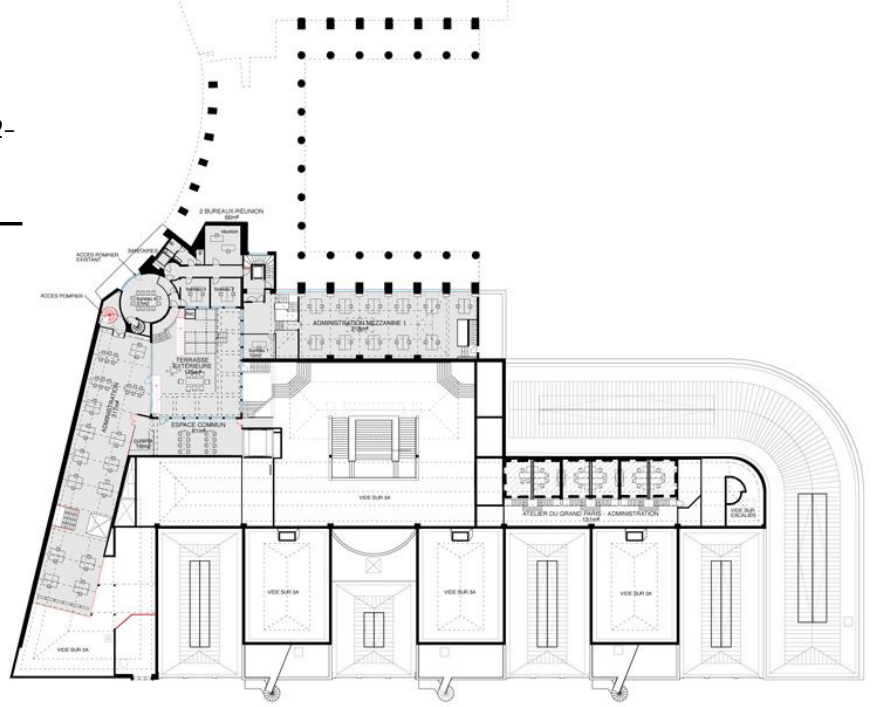

Nível 3B

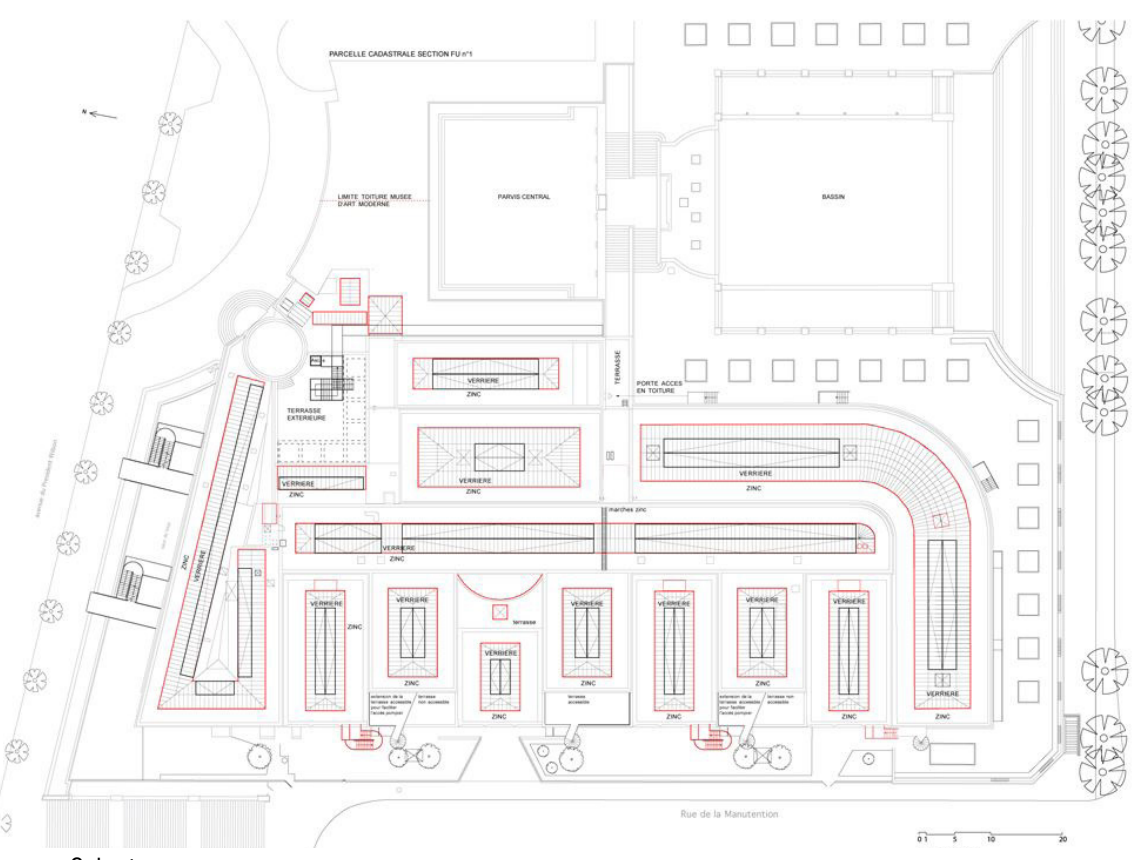

Cobertura 
exposição se tornou desde há algumas décadas um verdadeiro meio, é preciso também considerar a programação como um meio de modo integral. Para ir além da exposição como ponto fixo ou evento, é preciso, portanto, integrá-la num conjunto que a exceda. O Palais de Tokyo tornou-se desse modo um laboratório para a definição e elaboração do "meio programa", compreendido como uma ferramenta de reflexão, de conhecimento e de perspectiva, não somente das obras e das exposições, mas também do programa em si mesmo. ${ }^{656}$

Wahler deixava claro, assim, que, mesmo oferecendo a artistas o protagonismo na criação de suas exposições, no longo prazo a consistência das atividades do centro ficaria a cargo da curadoria, considerando a programação como "meio" de reflexão sobre a arte. $\mathrm{O}$ curador afirmou a prática de conceber as exposições especialmente para o local, que vinha desde o início sendo sustentada no Palais de Tokyo:

Para mim, as obras e o espaço que lhes recebe ditam suas leis. No início, duas ou três obras se impõe no espaço e funcionam como espécies de entroncamentos ao redor dos quais a exposição vai se articular. A conexão entre cada obra é primordial: determina a cor, a energia, a dinâmica da exposição. Nunca devemos deixar que se desenvolva a impressão de que uma exposição esteja a serviço de uma história precisa ou, pior, de uma teoria qualquer. Procuro construir exposições que não possam ser reduzidas a um catálogo. Na medida em que a exposição é a emanação de um lugar, eu nunca penso em itinerância de exposições [...]. É impossível para mim saber o resultado de uma exposição antes de ver quais são as relações que cada obra vai estabelecer com seu entorno. ${ }^{657}$

Se o PS1 tinha sido uma referência - não apenas pela programação, mas também pelo tratamento ao edifício existente e ao tipo de informalidade que poderia promover -, o exemplo estadunidense carecia das qualidades de amplitude e variedade dos espaços internos, o que necessariamente limitava certas experiências. No Palais de Tokyo, apenas poucos programas ocupam áreas de modo permanente - como os setores administrativo e
656 Marc-Olivier Wahler in: PALAIS DE TOKYO, 2012, op. cit., p. 187.

657 Ibidem, p. 188. 

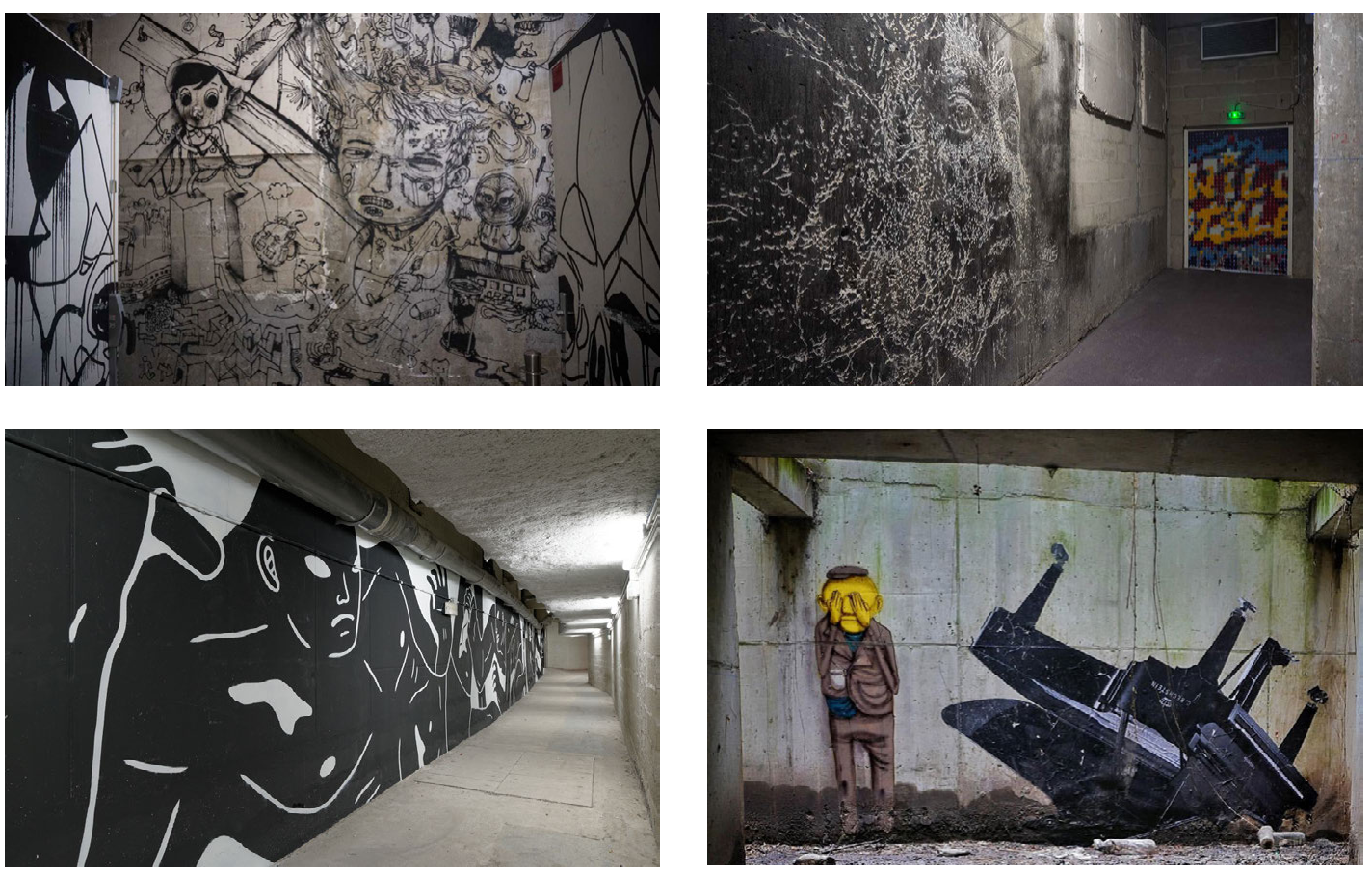

4.80 Interveção mural de Dran, série Lasco, Palais de Tokyo, Paris, 2014. Fonte: https://kandmv.com/portfolio/lascoproject-palais-de-tokyo-paris-france-2014/

4.81 Interveção mural de kan-Vhils, série Lasco, Palais de Tokyo, Paris, 2014. Fonte: https://kandmv.com/portfolio/lascoproject-palais-de-tokyo-paris-france-2014/

4.82 Interveção mural de Cleon Peterson, série Lasco, Palais de Tokyo, Paris, 2014. Fonte: https://www.palaisdetokyo.com/ en/event/lasco-project-visit

4.83 Interveção mural de Os Gemeos e JR5, série Lasco, Palais de Tokyo, Paris, 2016. Fonte: https://ilgorgo.com/ os-gemeos-jr-new-pieces-paris/ educativo - e as instalações dos concessionários - como livraria, restaurantes e boate. A área disponível para exposições é tão abundante que muitas vezes não chega a ser inteiramente ocupada, permanecendo simplesmente vazia até que algum projeto de arte tenha interesse em explorá-la. Foi o que aconteceu com a série Lasco, iniciada em 2012, em que artistas atuantes em espaços murais urbanos foram convidados para criar trabalhos para as áreas pouco acessíveis do edifício, localizadas nos cavernosos subsolos, cuja finalidade original era apenas a de destacar a construção do terreno úmido à margem do rio Sena. Após dez edições do projeto, ainda restavam em 2018 muitas áreas livres no subsolo para possíveis novas intervenções e, embora não haja um esforço de conservação das obras já realizadas - que não são consideradas como parte de um "acervo" -, elas permanecem nos locais em que foram realizadas até que as próximas gestões do centro decidam removê-las. A área que ocupam não é facilmente acessível ao público, que 
só pode percorrê-las em determinados horários, acompanhado pelos mediadores, não sendo, portanto, local apropriado para as demais exposições.

Quando têm como missão constituir e manter um acervo - como museus -, é inevitável que centros de arte reservem espaços permanentemente dedicados a, no mínimo, guardar as obras numa reserva e expor ao público as principais peças, que frequentemente se tornam desproporcionalmente numerosas em relação à dimensão dos respectivos edifícios. Liberado desta missão por operar como uma kunsthalle e com área superior a muitos museus que detém coleções, o Palais de Tokyo dispõe de uma imensa superfície disponível para a criação de exposições. Isso representa uma ferramenta de especial valor para a experimentação com a arte contemporânea, tanto para conceber uma instalação ou uma exposição particular, quanto para gerir o centro como um todo.

\subsubsection{O IDEAL DE LIBERDADE: A PRAÇA E O FUN PALACE}

A utilização por Lacaton \& Vassal da Praça Jemaa el-Fna como referência para sua intervenção no Palais de Tokyo estava calcada não apenas na intenção do projeto em de promover usos espontâneos, diversificados e cambiantes, mas também na vastidão da área de $7.800 \mathrm{~m}^{2}$ reabilitada na primeira fase de obras, concentrada num único pavimento. Para a dupla, essa disponibilidade horizontal funcionaria como um espaço urbano, "uma paisagem sem limites". ${ }^{658}$ Com a inclusão de $16.500 \mathrm{~m}^{2}$ distribuídos nos demais pavimentos do edifício na segunda fase de intervenção, realizada entre 2010 e 2012, a referência passou a ser o projeto para o Fun Palace, do arquiteto britânico Cedric Price e da diretora teatral Joan Littlewood, ${ }^{659}$ entendido por Lacaton \& Vassal como "um contêiner aberto e inteligente, que fabrica a liberdade de uso, a flexibilidade, a renovação dos projetos sem conformismo". ${ }^{660}$ Nunca construído, esse projeto era constituído basicamente por um conjunto de torres e patamares articulados como um sistema infraestrutural para dispor diversos usos a partir de um planejamento coletivo, constantemente transformável e nunca delimitado por uma forma pré-
658 Cf. Anne Lacaton e JeanPhilippe Vassal in: PALAIS DE TOKYO, 2012, op. cit., pp. 97-105.

659 O projeto para o Fun Palace também foi abordado no terceiro capítulo desta tese.

660 Cedric Price apud LaCATON, Anne; VASSAL, Jean-Philippe. Palais de Tokyo. Lacaton \& Vassal. Disponível em: <https:// www.lacatonvassal.com/index. php?idp=2o\#>. Acesso em: 27 maio 2021. Tradução nossa. 


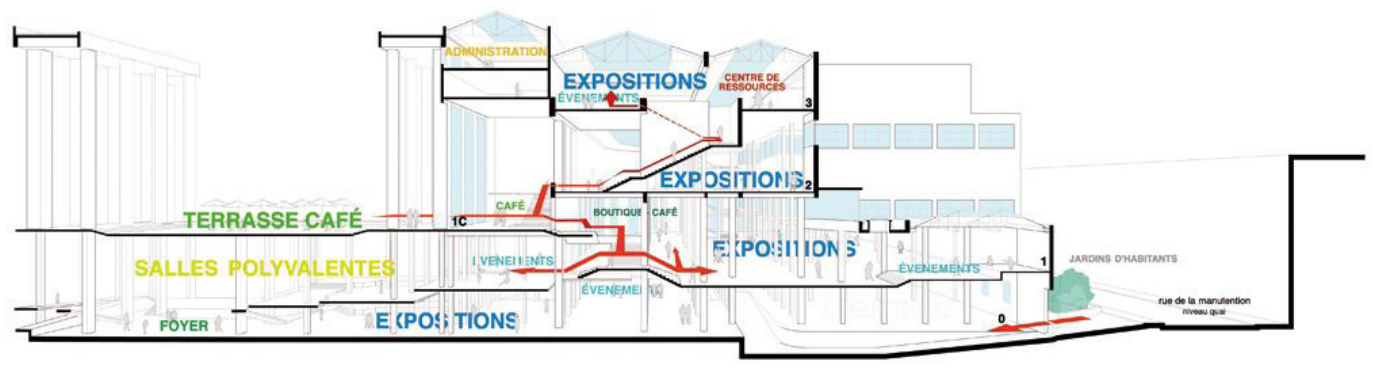

4.84 Corte do Centro de Criação Contemporânea no Palais de Tokyo, projeto de Lacaton \& Vassal, Paris, 2002-12. Fonte: https://www.lacatonvassal.com/ index.php?idp $=20$
661 Ibidem.

662 Avenue du Président Wilson. -concebida. A possibilidade que ofereceria de exploração espacial na vertical tinha sido conquistada também no Palais de Tokyo, agora que se previa a ocupação integral de seus quatro andares. Especialmente interessados na relação descontraída do público com o local, Lacaton e Vassal escolheram as seguintes palavras de Price sobre o Fun Palace para ilustrar suas ideias para o Palais de Tokyo:

Entrar e sair... ou apenas dar uma espiada de passagem.

Não há necessidade de procurar a entrada - pode-se entrar por todo lado. Nem portas, nem hall, nem filas, nem guichê: tudo é aberto.

Observar, tomar um elevador, uma rampa, uma escada rolante, para ir a qualquer lugar que pareça interessante...

Escolher o que fazer, ou observar alguém fazendo algo.

A qualquer hora do dia ou da noite, inverno ou verão, dá no mesmo. Se chover, a cobertura contém a chuva, mas não a luz. ${ }^{661}$

Para conferir a máxima permeabilidade ao Palais de Tokyo, Lacaton e Vassal apostaram na possibilidade de manter abertas as diversas portas existentes de acesso dos terraços ao interior, além de acrescentar novas entradas por meio da construção de passarelas na fachada da avenida superior. ${ }^{662}$ Mesmo preservando a entrada pela porta principal do edifício histórico, voltada para a colunata central, a exclusividade de acesso seria assim diluída.

Durante a primeira fase de funcionamento, não havia cobrança de ingresso no centro, o que permitia de fato uma grande liberdade de entrar e sair por diversos pontos do edifí- 

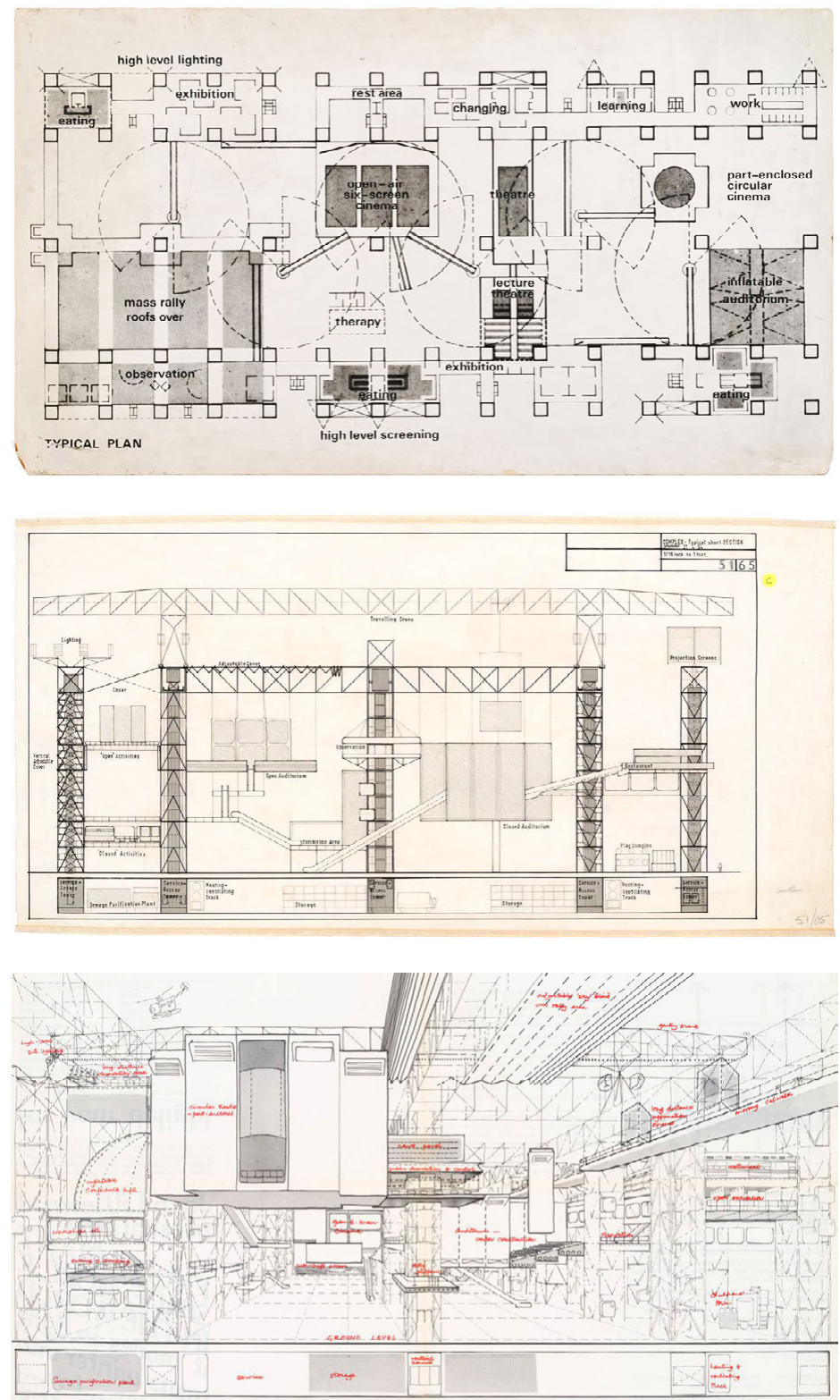

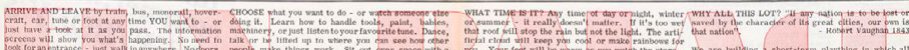

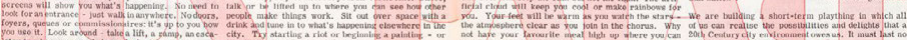

4.85 e 4.86 Planta e corte de Cedric Price para o projeto do Fun Palace, Londres, ca. 1964. Fonte: https://www.cca.qc.ca/en/ search? page $=5 \&$ query $=$ fun + palace $\& \_=$ 1624483228259

4.87 Perspectiva de Cedric Price em brochura de divulgação do Fun Palace, 1964. Fonte: https://www.cca.qc.ca/en/ search? page $=5 \&$ query $=$ fun + palace $\&$ = 1624483228259 

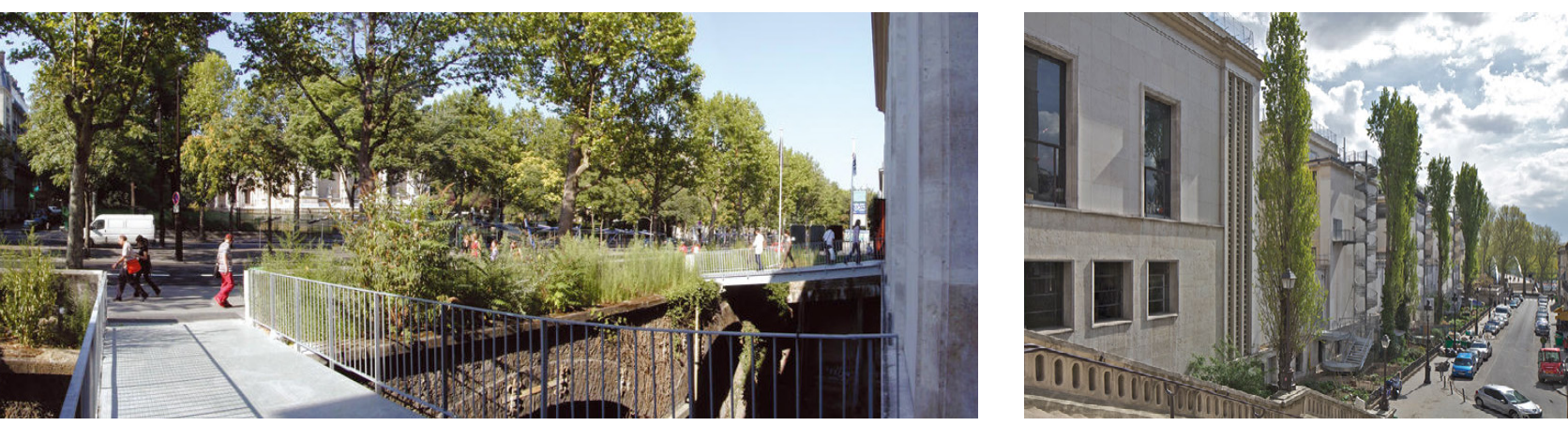

4.88 Passarelas de acesso ao Palais de Tokyo pela Av. Président Wilson, projeto de Lacaton \& Vassal, Paris, 2002-12.

Foto: Philippe Rouault. Fonte: https:// www.lacatonvassal.com/index.php? idp $=20$

4.89 Fachada do Palais de Tokyo para a Rue de la Manutention, Paris, s.d. Foto: Philippe Rouault. Fonte: https:// www.lacatonvassal.com/index.php?idp $=20$

663 CASCARO, op. cit., p. 55. Tradução nossa. cio. Somada a essa permeabilidade, a crueza do interior, lembrando um território sem dono, colaborava para que os códigos de conduta não fossem evidentes para o público, que explorava de múltiplas formas a suposta permissividade do novo equipamento cultural. Segundo relato do francês David Cascaro (1950-), que atuou como diretor de público do Palais de Tokyo de 2000 a 2006, eram frequentes os mal-entendidos durante os dois primeiros anos de funcionamento do centro, até mesmo entre artistas, que acreditavam que poderiam simplesmente "ocupar" o edifício com suas obras, independentemente de qualquer intermediação institucional. Parte do público visitante também se comportava como se o centro fosse um lugar onde tudo era permitido. Podendo entrar gratuitamente no edifício, muitas pessoas sentiam-se à vontade para se apropriar do espaço com atividades que os museus geralmente proíbem - tais como fumar e comer - ou são apenas inabituais - como ler um livro, descansar e fazer uma reunião de trabalho. Para Cascaro, "toda a dificuldade para o público reside nessa ambivalência entre o museu que permanece o templo da arte e o lugar de vida que permeia a cidade na escala de um espaço cultural" ${ }^{663} \mathrm{O}$ estabelecimento de alguns limites demandou um trabalho constante do centro junto ao público e as normas foram sendo ajustadas conforme as experiências com os diferentes eventos.

Ao longo dos anos, a necessidade de fronteiras mais rígidas se impôs, em função da ameaça concreta de atentados a locais públicos na França, o que obrigou o Palais de Tokyo a 

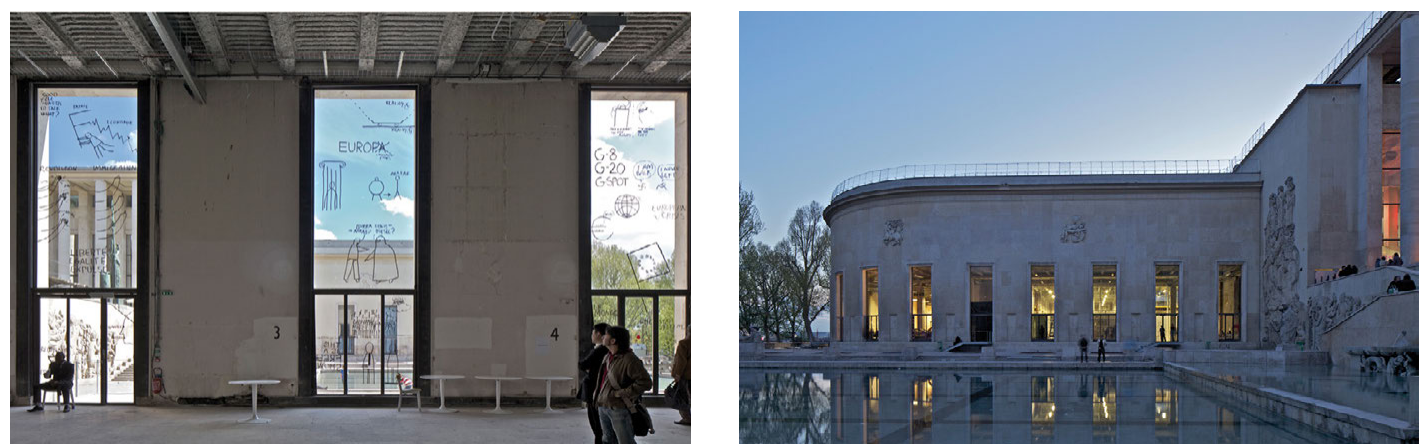

implantar no edifício um controle de entrada, interrompendo uma relação mais franca entre interior e exterior. Somada à cobrança de ingressos, a entrada exclusiva pela porta principal representou um corte brutal da permeabilidade da concepção arquitetônica original, impactando diretamente tanto a realização de determinados tipos de obras quanto a organização dos circuitos expográfico, bem como a informalidade da visitação. $\mathrm{O}$ acesso único fortemente guardado pela equipe de segurança, que também vigia de perto o comportamento do público no espaço interno, evidencia que a relação desse centro de arte com o seu entorno não está livre das tensões do contexto social e político em que se insere. Como afirmou Cascaro: "se a arte pode por vezes fazer pensar que ela escapa às regras do mundo real, a arquitetura e a programação do Palais de Tokyo revelam incessantemente um jogo de vai e vem com a realidade, entre o exterior e o interior.”664

Embora essas restrições possam ter sido originadas por questões externas à gestão do centro, são o que há de mais corriqueiro em locais dedicados a exposições, mesmo nos menos tradicionais. Portas, saguões, filas e guichês fazem parte do habitual ritual de entrada de espaços expositivos, compondo uma etapa de preparação do espírito de visitantes, que, ao atravessarem essas barreiras, poderiam deixar para trás o universo real e passar para uma experiência com a arte supostamente menos "contaminada" pelo mundo exterior. No Palais de Tokyo, essa impressão de "pureza", com frequência acentuada pela arquitetura dos museus, é fortemente contraposta pelo
4.90 Interior do Palais de Tokyo, projeto de Lacaton \& Vassal, Paris, 2002-12. Foto: Philippe Rouault. Fonte: https:// www.lacatonvassal.com/index.php?idp $=20$

4.91 Fachada do Palais de Tokyo voltada para o pátio interno, Paris, s.d. Foto: Philippe Rouault. Fonte: https://www.lacatonvassal.com/index. php?idp $=20$

664 Ibidem, p. 56 

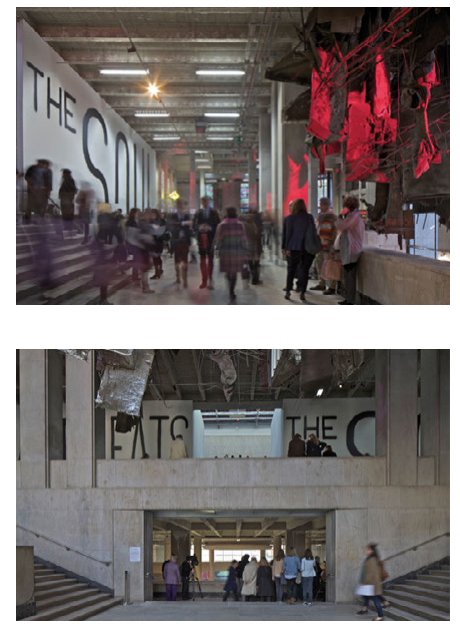

4.92 a 4,94 Interior do Palais de Tokyo, projeto de Lacaton \& Vassal, Paris, 2002-12. Foto: Philippe Rouault. Fonte: https://www.lacatonvassal.com/index. php?idp $=20$

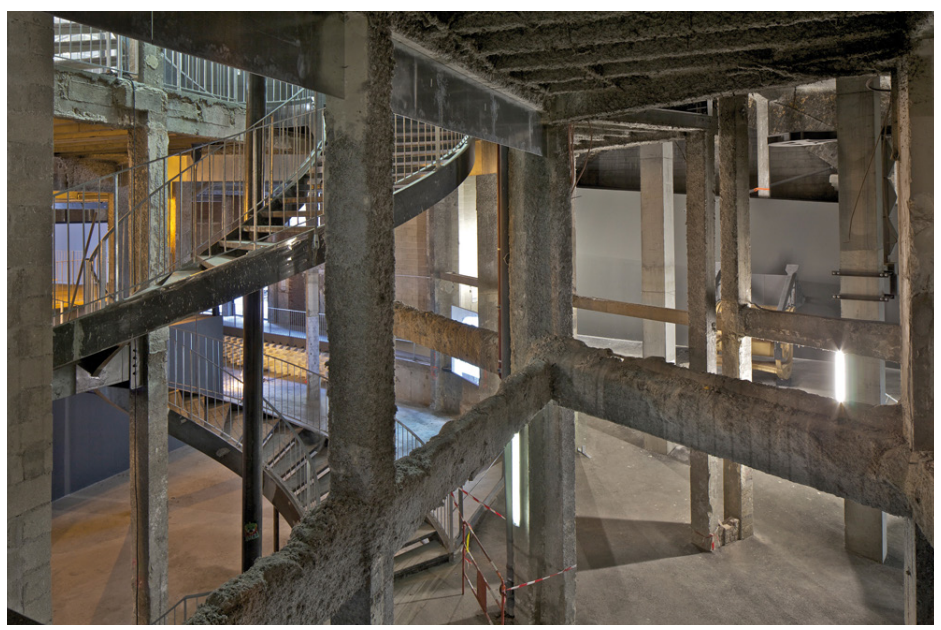

aspecto bruto e visualmente poluído do interior, funcionando, como afirmou Bourriaud, como um "ruído de fundo" que remeteria, ao menos no âmbito simbólico, ao espaço aberto à livre circulação da cidade. Sendo assim, no Palais de Tokyo, o contraste entre interior e exterior acaba ocorrendo de modo invertido: dada a sofisticação dos edifícios do entorno e da própria fachada, o interior é mais "ruidoso" que o exterior imediato. Embora contradiga a intenção expressa pela proposta arquitetônica por uma maior permeabilidade, a limitação do acesso e a impossibilidade de entrar e sair livremente acabou intensificando a condição de moldura anti-institucional que a arquitetura normalmente oferece para a experiência com a arte contemporânea.

É possivelmente o fato de a lógica de ocupação do edifício estar vinculada de modo tão íntimo à arte contemporânea especialmente à sua manifestação em eventos temporários que permite que o projeto de Lacaton \& Vassal venha resistindo a certas contingências e limitações imprevistas na concepção inicial. Embora o centro tenha sido implantado com o objetivo de promover múltiplas formas de criação contemporânea, esteve sempre bem ancorado no campo das artes visuais, e mais especificamente na forma de "exposição", como vem afirmando seus sucessivos diretores. Ao assumir o cargo de 

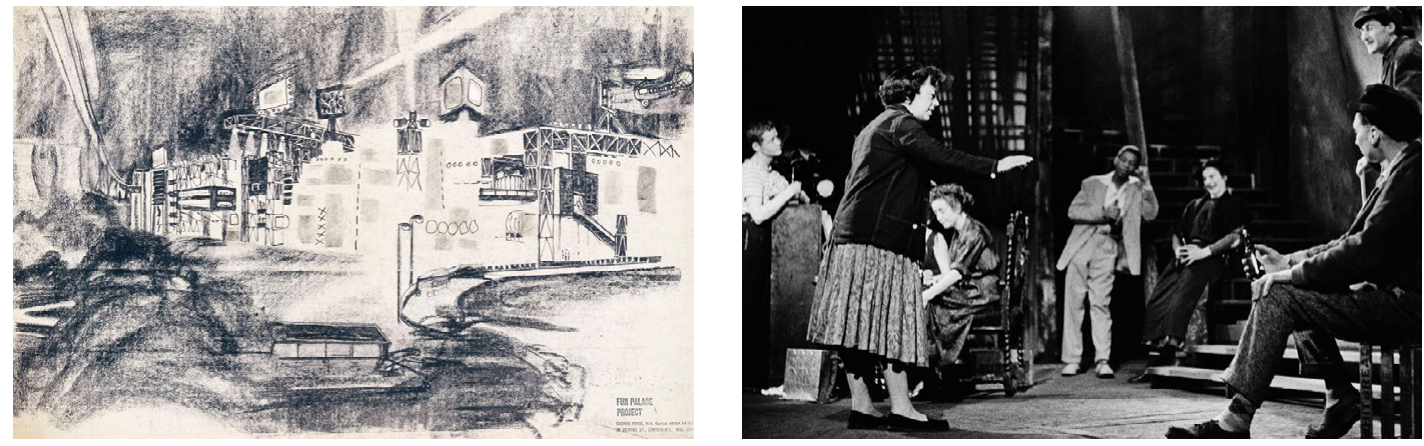

presidente e curador chefe do centro logo após a sua ampliação em 2012, Jean de Loisy esclareceu sua filiação a esse universo, ainda que meios de expressão originados noutras áreas pudessem ser incorporados: "Não vou apresentar nem teatro, nem dança, nem design de modo particular. Vou apresenta-los na porosidade que eles têm com as artes plásticas e com o meio da exposição." ${ }^{\prime 65}$ Mesmo constituindo um único programa arquitetônico, as exposições, de duração limitada, concretizam por si só a dinâmica de transformação constante do espaço prevista para o Palais de Tokyo.

O Fun Palace, por sua vez, apesar de ser uma referência que alimenta o ideário de diversos espaços de arte contemporânea, não nascera do universo das artes visuais, nem especificamente de exposições, e sim do campo do teatro, a partir das ideias de sua criadora, a diretora britânica Joan Littlewood, que as apresentou a Price. Mesclando diversos meios de expressão e atividades educativas e de lazer, o programa do complexo teria possivelmente mais semelhança com o que reconhecemos hoje nos centros culturais multidisciplinares. Apresentados de modo mais literal no projeto Fun Palace, os ideais de liberdade do usuário, multiplicidade de experiências e permeabilidade com o universo exterior só podem ser compreendidos no Palais de Tokyo no âmbito mais específico das exposições
4.95 Perspectiva do projeto de Cedric Price para o Fun Palace em Meads site, Londres, 1963-64. Fonte: https://www.cca.qc.ca/ en $/$ search?page $=5 \&$ query $=$ fun + palace\&_=1624483228259

4.96 Joan Littlewood em seu People's Theater. Fonte: https://www.bl.uk/20thcentury-literature/articles/an-introductionto-joan-littlewoods-theatre-practice

665 Jean de Loisy in: Palais DE TOKYO, 2012, op. cit., p. 270. Tradução nossa. 


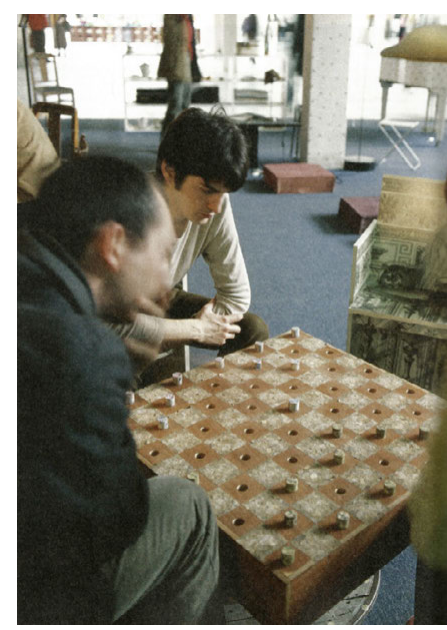

4.97 Meshac Gaba, Musée d'Art Contemporain Africain, projeto Le Salon do Palais de Tokyo, Paris, 2002. Fonte: PALAIS DE TOKYO, 2012, p. 136.

de arte contemporânea, que compõe seu programa primordial. Sem poder evitar por completo a referência institucional dos museus, apesar da retórica em contrário, o centro permanece num movimento constante de afastamento e aproximação com a tradição expositiva das artes visuais, o que se intensifica à medida em que se consolida entre os mais prestigiados centros europeus de arte contemporânea.

Enquanto no Palais de Tokyo a transformação espacial se dá a partir das exposições, com o protagonismo assumido por artistas, em colaboração de intensidade variável com a curadoria, no Fun Palace o público seria o principal responsável pelo agenciamento da programação das atividades e da consequente configuração dos espaços, com o auxílio não de uma instância humana hierarquicamente superior, mas por meio de recursos cibernéticos. A arquitetura, apoiada por diversas disciplinas, assim como no Palais de Tokyo, não era concebida enquanto objeto acabado, mas como um abrigo extremamente flexível. Sua transformação permanente, no entanto, seria operada "de baixo para cima". O objetivo do projeto de Price e Littlewood era promover uma determinada ideia de desenvolvimento humano voltado para as massas, apoiado num projeto político de democratização vinculado à conjuntura do pós-guerra na Inglaterra, tomando a ascensão do Partido Trabalhista como oportunidade de romper com a tradicional hegemonia aristocrática. Desvinculado de qualquer instituição preexistente, o cunho transgressor do Fun Palace estaria na firme insistência na falta de controle sobre o espaço, gerando uma imprevisibilidade programada de suas configurações, cuja gestão ficaria a cargo de pessoas comuns.

Se o Palais de Tokyo fora concebido também como impermanente e a ser completado por usuários, seu edifício não dispõe, por sua vez, de nenhum recurso tecnológico avançado de construção e operação, pois, ao contrário, permanece com as precariedades de uma construção antiga e propositadamente não atualizada. Embora os representantes do centro manifestem uma afinidade com a relação mais participativa do que contemplativa do público com a arte e com uma grande abertura para acolher variadas propostas artísticas, não há como no Fun Palace a possibilidade de que visitantes atuem na 
transformação dos espaços, que são concebidos a priori, como em qualquer instituição museal tradicional.

Poderiam artistas, atuando sobre o espaço expositivo em última instância institucional, criar situações potencialmente transformadoras no âmbito social? Defendendo ser esse o enfoque do Palais de Tokyo, Jean de Loisy defendeu que sim:

as crises de hoje em dia justificam mais que nunca os que acreditam que o artista, por sua habilidade de pensar o real de outro modo, é provavelmente o único capaz de imaginar outros sistemas e de nos permitir reconstruir de modo totalmente diferente a nossa organização social. ${ }^{666}$

Para Bourriaud, seria justamente a qualidade emancipadora que ele identificara na arte dos anos 1990 a que procurava valorizar em seus projetos de curadoria no Palais de Tokyo. Os trabalhos que identificou com o conceito de "estética relacional" seriam aqueles que produziriam "uma arte que toma como horizonte teórico a esfera das relações humanas e seu contexto social mais do que a afirmação de um espaço simbólico autônomo e privado". ${ }^{667}$ Segundo a argumentação de Bourriaud, a promoção de uma relação mais convivial e interativa com o público teria, por si só, implicações políticas - por sua capacidade de estimular relações humanas mais positivas, baseadas em laços de comunidade.

Já vimos antes as críticas feitas por Claire Bishop sobre a associação entre o caráter participativo da arte e seu potencial liberador feita por Borriaud, independente da qualidade das relações promovidas e, por outro lado, a argumentação de Boris Groys sobre a natureza soberana da atuação de artistas ao realizarem instalações de arte contemporânea. Desimpedido do compromisso de defender uma instituição em particular ou um grupo específico de trabalhos, o autor trouxe um ponto de vista mais complexo sobre o papel político da arte. Artistas, para Groys, determinariam a configuração espacial seguindo apenas sua lógica privada, agindo como legisladores absolutos na criação de regras, cujo cumprimento caberia à instituição controlar. O público, convivendo no espaço da instalação enquanto "comunidade", teria sua participação submetida a
666 Ibidem, p. 274.

667 Bourriaud, 1998, op. cit. 
essas regras pré-determinadas. Agindo de modo soberano e fora de parâmetros estritamente racionais, artistas trariam à tona o fato de que o funcionamento das democracias atuais não seria exclusivamente da ordem do impessoal e, portanto, inquestionável, mas dependeria também de poderes exercidos de modo individual e autoritário. Como defendeu o crítico, operando entre a liberdade incondicional de artistas e a liberdade institucional de curadores, a arte não cumpriria um papel de agente de transformação direta da realidade social, mas tornaria mais evidentes seus mecanismos ocultos:

O objetivo da arte, afinal, não é mudar as coisas - as coisas estão mudando por si só o tempo todo, de qualquer maneira. A função da arte é principalmente a de revelar, tornar visíveis as realidades geralmente negligenciadas. Ao assumir a responsabilidade estética de um modo muito explícito pelo design do espaço expositivo, o artista revela a dimensão soberana oculta da ordem democrática contemporânea, que a política, na maioria das vezes, tenta esconder. O espaço da instalação é onde somos imediatamente confrontados com o caráter ambíguo da noção contemporânea de liberdade que funciona nas nossas democracias como tensão entre liberdade soberana e institucional. ${ }^{668}$

Groys tomou a liberdade artística como um dispositivo para revelar a dependência da ordem democrática de poderes soberanos ocultos que a controlam. Seu raciocínio também independe da qualidade das relações que uma obra poderia propor, apoiando-se sobretudo na condição de domínio da arte sobre o espaço, enquanto instalação. $\mathrm{O}$ modo como a liberdade de artistas costumava ser apresentada pelas duplas de arquitetura e curadoria do Palais de Tokyo podia dar a impressão de que fosse um fim em si mesma. Ainda assim, a concepção de uma arquitetura na qual cabe a artistas a tarefa de completá-la, ou seja, de dominar o espaço, ilustra o argumento de Groys a respeito do papel soberano de artistas na arte contemporânea, com suas implicações na explicitação de mecanismos sociais velados. No Palais de Tokyo, como em qualquer outro contexto 668 GROYs, op. cit., p.7. curatorial estruturado, a instalação, apesar de definida por 

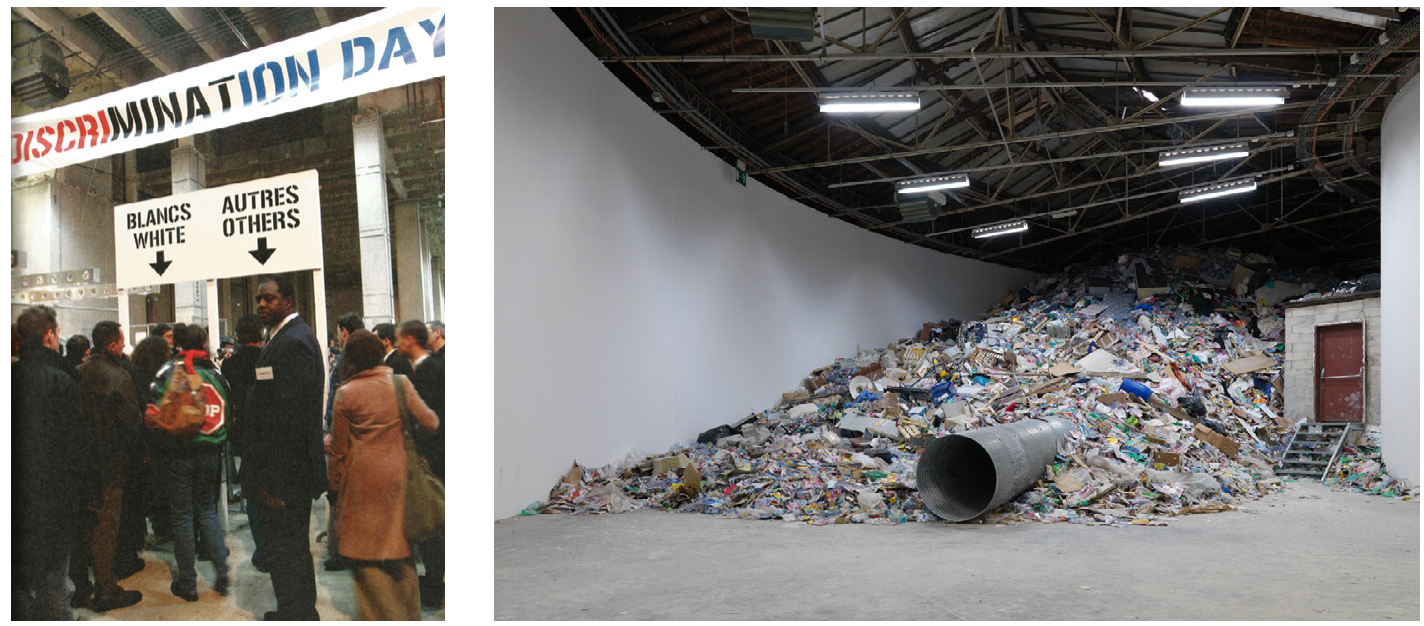

artistas, não estaria totalmente desimpedida dos condicionantes institucionais. Como observou Groys, "não devemos nos iludir que possa haver qualquer coisa como um espaço completamente caótico de instalação, como os Dadaístas ou do tipo Fluxus, livres de qualquer controle." ${ }^{669} \mathrm{~A}$ arte contemporânea, como a sociedade em que se insere, se faria, afinal, no atrito entre a liberdade individual e o domínio público.

No Palais de Tokyo, como vimos, a liberdade do visitante não tem o mesmo impacto sobre o espaço que no projeto do Fun Palace, pois não ultrapassa a possibilidade de fruição descontraída ou o engajamento num trabalho de arte pré-concebido. Apresentada como radicalmente aberta, a proposta de Price não chegou a ser testada concretamente para permitir uma avaliação de sua dinâmica, o que, no entanto, não nos impede de duvidar que ficasse isenta dos conflitos entre indivíduos e grupos sociais impregnados em seu contexto. Nesse sentido, continua tendo força para pensar o projeto de Lacaton \& Vassal a imagem mais assimilada da praça, por se tratar de um espaço público de convívio não necessariamente harmônico, mas frequentemente conflituoso, que implica o exercício de propor e ceder às propostas do outro, da maneira como observou David Cascaro:
4.98 Jota Castro, Exposition Universelle 1, Palais de Tokyo, Paris, 2005. Fonte: PALAIS DE TOKYO, 2012, p. 173.

4.99 Christophe Buchel, Dump, Palais de Tokyo, Paris, 2008. Fonte: PALAIS DE TOKYO, 2012, p. 216.

669 bidem, p.4. 
Metáfora de seu projeto de adaptação do Palais de Tokyo, a praça pública exprime plenamente sua maneira de pensar a arquitetura como um espaço de negociação. Espaço de negociação entre a arquitetura e o edifício, entre a arquitetura e o programador; espaço de negociação, invariavelmente, entre o curador da exposição e o artista, entre o artista e o edifício, entre os próprios artistas; espaço de negociação, enfim, entre os artistas, as obras e os visitantes. ${ }^{670}$

Entre essas múltiplas interações entre os ocupantes do Palais de Tokyo, interessa investigar a seguir a negociação entre arte e arquitetura, observando de que maneiras o espaço do edifício vem sendo explorado pelos artistas.

\subsubsection{NO DOMÍNIO DA ARTE}

Como tem sido afirmado ao longo desta tese, qualquer arquitetura concebida para abrigar arte tem um componente obrigatório de incompletude, uma vez que, mesmo em museus convencionais, as mostras que ali se instalarão têm o potencial de transformar em diferentes graus o espaço, tornando-o em alguns casos irreconhecível. A maneira com que essa incompletude se manifesta varia imensamente em cada projeto, podendo ser entendida como um território vazio e anódino que busca desaparecer como expressão, deixando que os trabalhos de arte se relacionem com o espaço de uma maneira mais abstrata, ou, de modo oposto, como a ausência literal de acabamentos, uma forma de afirmar a condição concreta do espaço como ponto de partida e interlocução para a instalação da arte. Se um espaço concebido segundo as convenções para ser percebido como "neutro" pode favorecer a experiência da obra de modo destacado de seu contexto, as características muito particulares da arquitetura do Palais de Tokyo, deixando à mostra as marcas que o edifício acumulou ao longo de sua história de imbricadas relações com as instituições culturais da França, configuram, como vimos, um cenário de acentuada presença tanto na concepção dos trabalhos por artistas quanto 670 CASCARO, op. cit., p. 36-37. na recepção das obras pelo público, independente das inten- 
ções afirmadas por Lacaton e Vassal de criar um espaço aberto a ser complementado pelos futuros ocupantes.

Sendo a incompletude um dado essencial do projeto do Palais de Tokyo, ficaria igualmente inconclusa a reflexão sobre sua arquitetura sem considerar também os modos como ela tem sido "completada" pelos diversos eventos que abrigou desde que a dupla de arquitetos cedeu a cena a curadores e artistas. Nesse sentido, foi valioso como material para esta pesquisa o número 15 da revista Palais, ${ }^{671}$ dedicado à história do local desde 1937 e lançado na ocasião em que o centro foi reinaugurado com área ampliada, em 2012, reunindo diversas entrevistas com artistas e curadores que atuaram no Palais de Tokyo a partir de sua abertura em 2002. Também foi esclarecedor o depoimento colhido em 2018 diretamente com uma das curadoras do centro, Rebecca Lamarche-Vadel, que expôs a visão atual do centro sobre as formas com que a arquitetura do edifício se faz presente na programação geral das atividades e no trabalho de artistas. ${ }^{672}$

Observando a atuação de diversos artistas no Palais de Tokyo, ficou claro que, embora o edifício tenha um forte protagonismo, cada qual explora o espaço à sua maneira, evidenciando-o em maior ou menor grau de acordo com sua poética particular, eventualmente anulando sua presença com a construção de ambientes à maneira do "cubo branco" ou da "caixa preta". Embora haja trabalhos com características mais independentes do contexto arquitetônico, interessa inicialmente focar em alguns casos em que as obras se relacionam mais fortemente com as características específicas do Palais de Tokyo, como veremos a seguir.

Quando a artista brasileira Rivane Neuenschwander (1967-) foi convidada ao local para preparar a exposição Superficial Ressemblance de 2003, uma falha no edifício lhe chamou a atenção - no conjunto de esquadrias de vidros translúcidos na faixa superior de uma sala, um único módulo de vidro transparente entre outros foscos permitia visualizar a ponta da Torre Eiffel, localizada na margem oposta do Rio Senna. Esse foi o ponto de partida para criar sua obra Ici-là-bas/Aqui acolá, que, em termos de intervenção no espaço, consistiu simplesmente em colocar uma escada metálica junto à parede, dando acesso

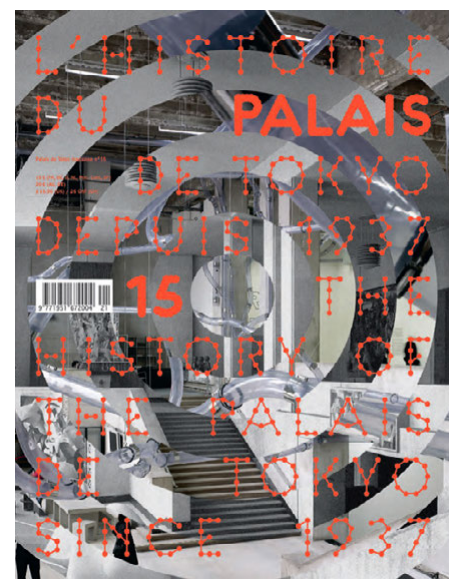

4.100 Capa da revista Palais no. 15: L'Histoite du Palais de Tokyo, 2012.

671 Cf. Palais DE ToKyo. Palais 15: Histoire du Palais de Tokyo depuis 1937.

A revista Palais é publicada semestralmente pelo Palais de Tokyo.

672 Cf. LAMARCHE-VADEL, Rebecca. Entrevista concedida a Ana Paula Pontes no Palais de Tokyo. Paris, 23 de julho de 2018. Apêndice B desta tese. 

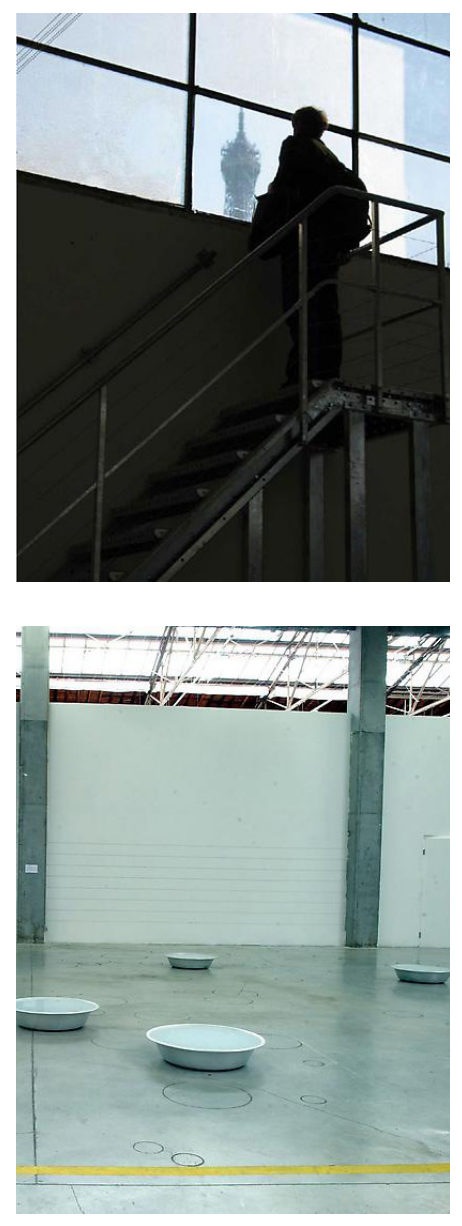

4.101 a 4.104 Vistas da exposição de Rivane Neuenschwander,

Superficial Resemblance, Palais de Tokyo, Paris, 2003. Fonte: https:// www.tanyabonakdargallery.com/ exhibitions/105/
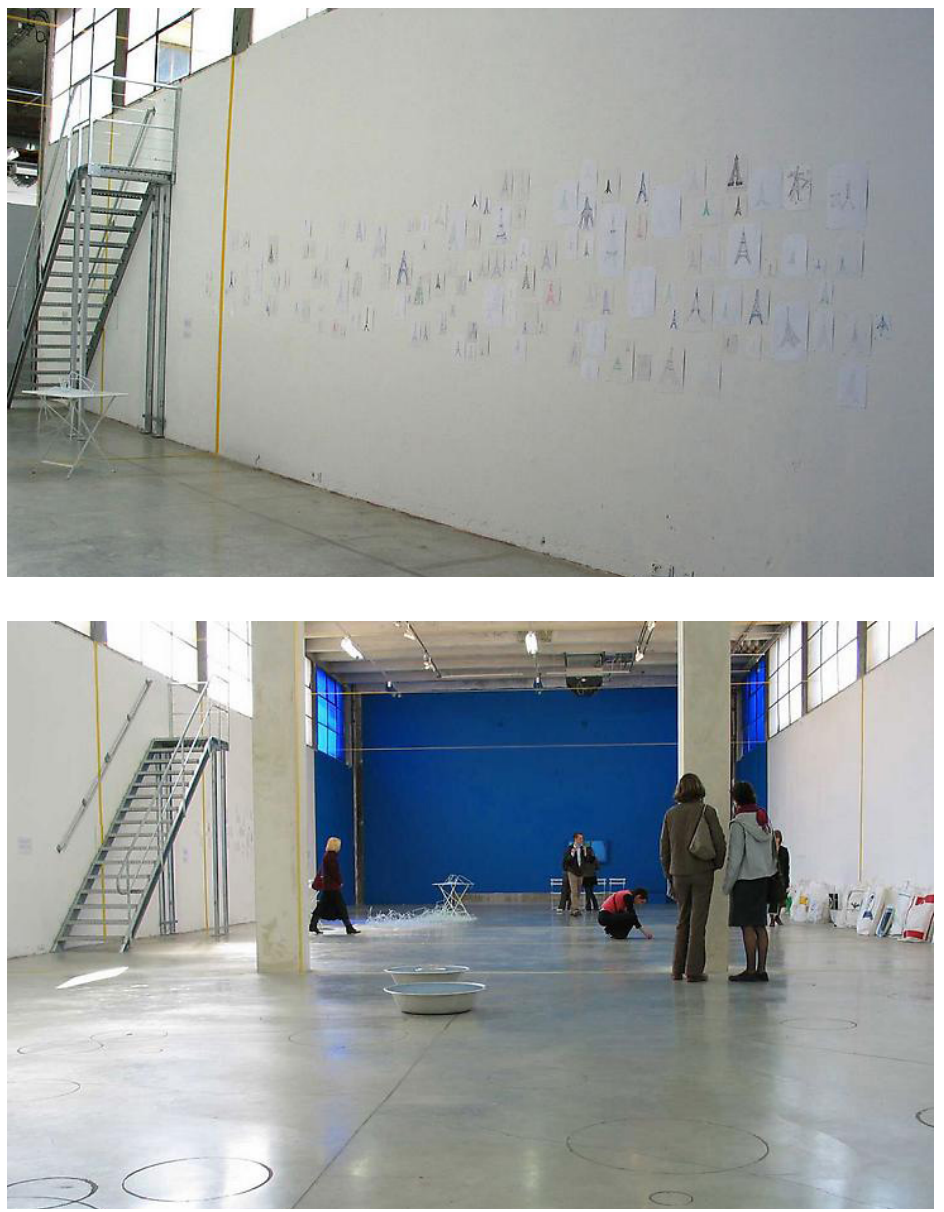

à vista parcial do monumento - o signo mais forte da cidade de Paris, identificado pela maioria das pessoas no mundo todo. Depois de descer a escada, o público era convidado a produzir de memória um desenho da torre e fixá-lo na parede, formando um painel feito por outros visitantes que passaram por ali. Esse é um caso de dependência absoluta de uma situação muito particular - o que configura a obra como site-specific -, pois seria impossível conceber o trabalho em qualquer outro local que não naquela pequena área junto à esquadria defeituosa, localizada numa sala específica de um determinado edi- 
fício, situado por sua vez na cidade cujo ícone é aquele monumento singular. Como relatou a artista:

Essa negligência arquitetônica, essa falha no acabamento, esse acidente histórico, enquadrava nada menos que o monumento mais importante da cidade e um dos maiores sucessos da engenharia. Evidentemente, a janela fazia também a ligação entre o espaço interior e o espaço exterior, mas não com qualquer exterior, já que ao vermos a Torre Eiffel tomamos a consciência do fato de estarmos em Paris. A exposição partia então dessa particularidade arquitetônica para abordar em seguida temas como o discurso, a semiótica, as relações virtuais e a ação dos visitantes. ${ }^{673}$

Ao lado desta obra, um dos outros trabalhos, Continente/ Andando em círculos, propunha uma forma distinta e bem mais sutil de relação com o espaço e com o público, produzindo-se lenta e involuntariamente com a fixação da sujeira trazida do exterior por visitantes sobre linhas circulares feitas com cola no piso da sala. Embora esse trabalho relacione-se de modo mais abstrato com o espaço, encontra-se no mesmo ambiente que Ici là-bas/Aqui acolá, que "contamina" a leitura dos que o rodeiam, assim como tudo o que acontece no espaço expositivo, que compõe uma experiência totalizante.

Em 2013, outro artista brasileiro, Henrique Oliveira (1973-), também partiu da arquitetura do edifício para realizar sua instalação site-specific, Baitogogo, assim apresentada no site do Palais de Tokyo:

O próprio edifício parece ser a matriz que origina este volume em madeira de 'tapumes', um material usado nas cidades brasileiras para construir os muros dos canteiros de obra. [...] A partir de um tipo de antropomorfismo arquitetônico, Henrique Oliveira revela a estrutura do edifício. No Palais de Tokyo, ele interage com as características existentes e estruturantes do espaço, prolongando e multiplicando pilares e vigas para lhes conferir uma dimensão vegetal e orgânica, como se o edifício adquirisse vida. ${ }^{674}$
673 Rivane Neuenschwander. Fenêtre sur la tour. In: PALAIS DE TOKYO, 2012, op. cit., p. 145. Tradução nossa.

674 Cf. PALAIS DE TOKYO.

Henrique Oliveira: Baitogogo (Du 30/11/2013 au18/12/2016). Palais de Tokyo. Disponível em: <https:// www.palaisdetokyo.com/fr/evenement/henrique-oliveira $>$. Acesso em: 27 maio 2021. Tradução nossa. 


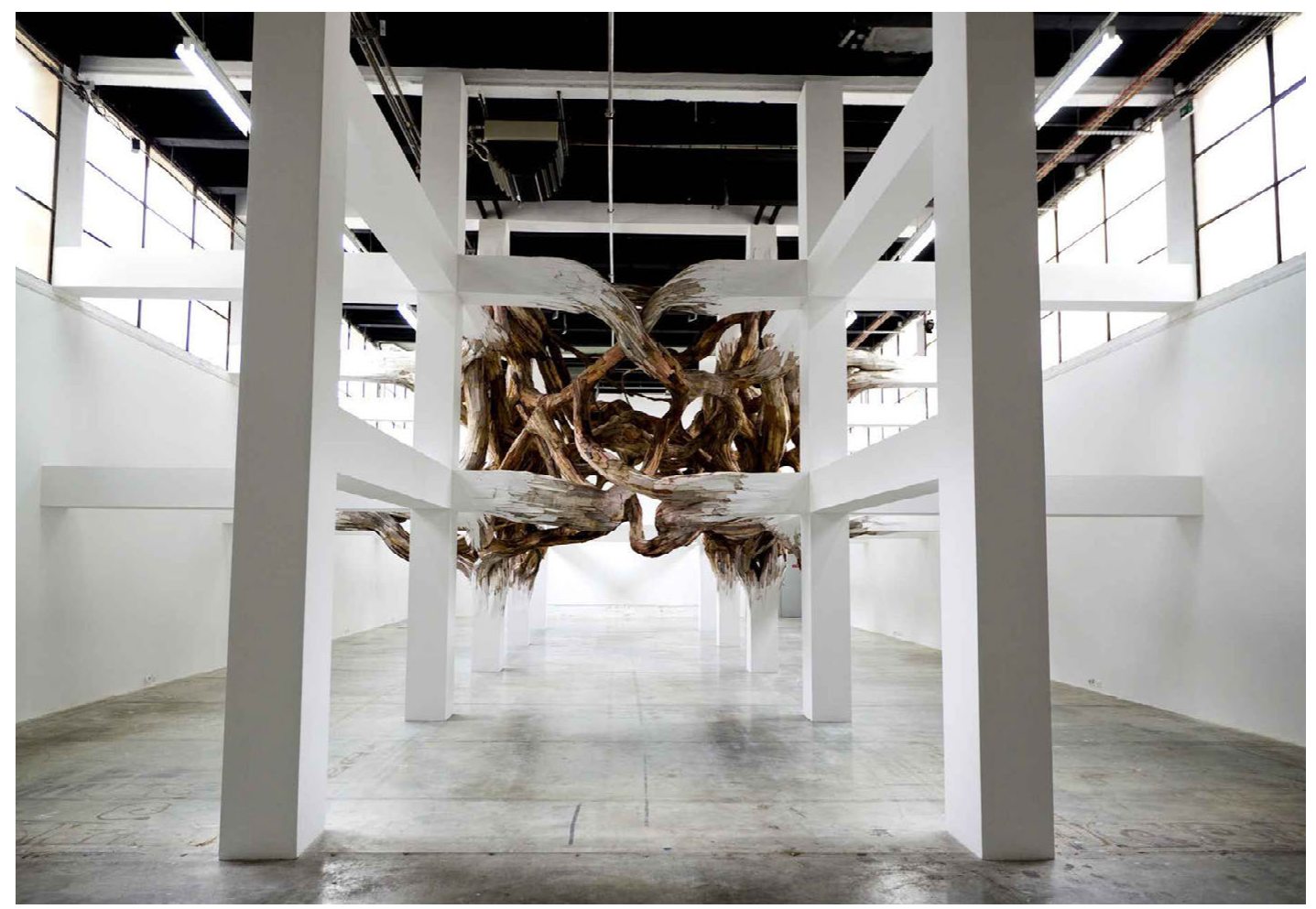

4.105 Vista da instalação de Henrique Oliveira, Baitogogo, Palais de Tokyo, Paris, 2013. Foto: André Morin? Fonte: https://slash-paris.com/en/evenements/ henrique-oliveira-fissure/sous
A relação com a arquitetura que o trabalho estabelecia tinha um forte componente formal: as novas barras foram instaladas seguindo a modulação da estrutura existente e confundindo-se com ela, enfatizando os elementos construtivos concretos identificados visualmente. Embora estática, a obra convocava a sensação temporal quando as peças brancas de geometria perfeita se transfiguravam em troncos irregulares de madeira exposta, nervosamente entrelaçados como tumores crescendo desregradamente. $\mathrm{O}$ artista continuou realizando obras a partir dessa poética em outros centros de arte, mas o fato de Baitogogo ter sido instalada no espaço do Palais de Tokyo permite lembrar os percalços que o próprio edifício sofreu entre sua criação como museu de arte moderna - uma monumental realização arquitetônica sobre a qual se perdeu o controle - até se tornar o atual centro de arte contemporânea, onde a condição 

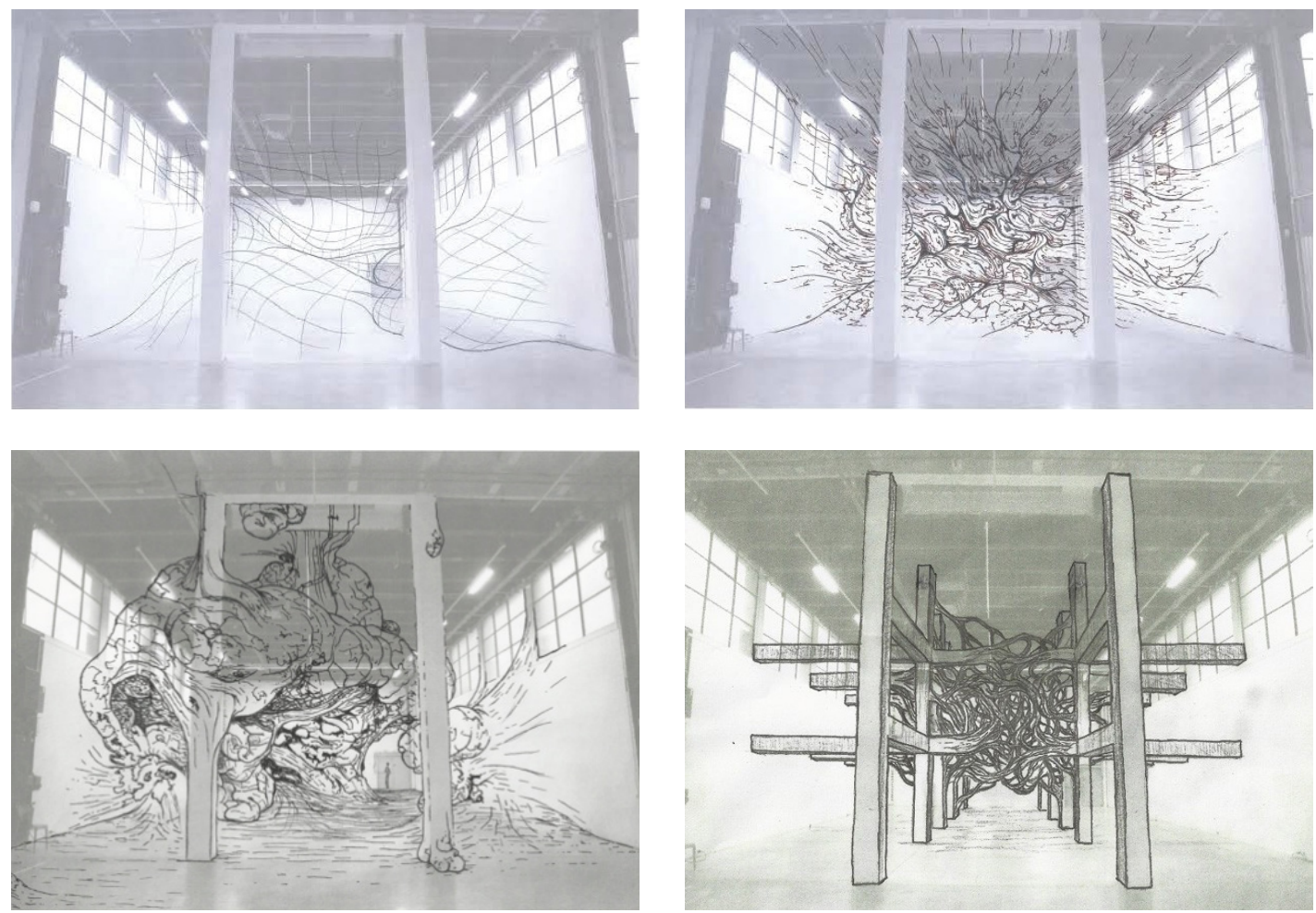

visível de inacabamento e a relativa improvisação é assumida com franqueza.

A exposição realizada pelo artista alemão Tobias Rehberger (1966-) em 2002, Night Shift, tensionava de outro modo a arquitetura do Palais de Tokyo, considerando a abundante iluminação natural dos espaços internos, concebidos segundo padrões considerados "ideais" na década de 1930 para apreciação de pintura e escultura. Desejando trabalhar com a ausência desta fonte luminosa, o artista não usou do expediente corriqueiro de bloquear fisicamente as aberturas para o exterior, mas preferiu determinar que a visitação de sua exposição tivesse início apenas no horário correspondente ao pôr do sol de cada dia, aproveitando o fato de o centro ficar aberto regularmente até meia noite. Uma das instalações, Reus, era feita por várias lâmpadas que se acendiam individualmente em função do

4.106 a 4.107 Henrique Oliveira, Studies for space intervention at Palais de Tokyo, 2013. Fonte: https://www.mutualart.com/ Artwork/Studies-for-space-intervention-atPalais/404ED57840298BBD

4.108 Henrique Oliveira, Studies for space intervention at Palais de Tokyo, 2013. Fonte: https://www.claudinecolin.com/ fr/891-henrique-oliveira

4.109 Henrique Oliveira, Studies for space intervention at Palais de Tokyo, 2013. Fonte: https://www. interiordesign.net/slideshows/ detail/7828-paris-on-the-amazon/ 

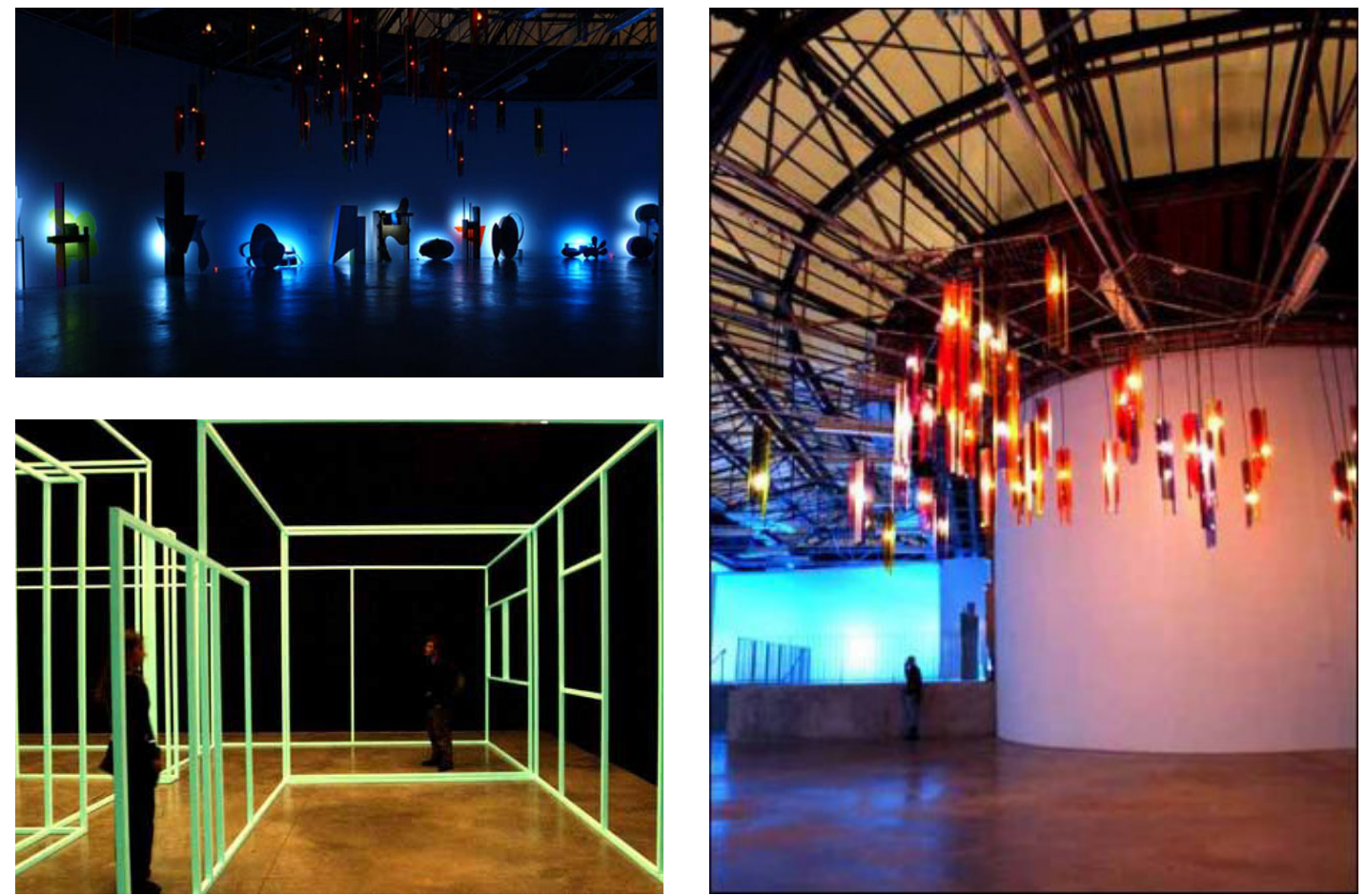

4.110 a 4.112 Vistas da exposição de Tobias Rehberger, Night Shift, Palais de Tokyo, Paris, 2002. Fonte: https://www. paris-art.com/night-shift/ número de pessoas na sala, estando permanentemente ativadas de modo parcial, chamando a atenção para a escuridão inusitada do ambiente, projetado originalmente em função de sua qualidade luminosa. Uma outra obra, o filme 81 Years, tinha a duração correspondente ao título, referência ao tempo de vida médio de uma pessoa e, portanto, assistido apenas parcialmente pelo público. A instalação Paris Light Bungalow Dreaming, por sua vez, era uma estrutura geométrica de tubos metálicos revestida com tinta luminescente, que armazenava a energia luminosa que recebe durante o dia e permanecia acesa durante a noite. A impossibilidade da apreensão completa dos trabalhos pelo público, questão que permeava a exposição, repercutia e era amplificada pela interdição do acesso às obras nos momentos em que estavam expostas à luz solar que penetrava o edifício. Sem usar um mascaramento de tipo cenográfico para ocultar as condições arquitetônicas, mas tornando-as 
visualmente inapreensíveis, o procedimento do artista anulava e ao mesmo tempo revelava a identidade do Palais de Tokyo, vinculada tanto às soluções espaciais definidas na sua origem histórica quanto ao seu modo de funcionamento contemporâneo que lhe dava acesso no período noturno.

Os horários de funcionamento do Palais de Tokyo permitiam abrir uma exposição no momento em que todas as outras fecham. Eu estava interessado em ilustrar a noção de que a estrutura de uma exposição pode ser capaz de modificar o funcionamento de um espaço de exposição. Naquela época eu acreditava que o Palais de Tokyo era um lugar onde se podia testar a estrutura e a significação de um lugar onde a arte é exposta. ${ }^{675}$

No trabalho 24 Heures Foucault, de 2004, o suíço Thomas Hirschhorn (1957-) explorou novamente o horário de abertura do centro, assim como a duração do evento, que teve início ao meio dia de um sábado e terminou no dia seguinte na mesma hora, no contexto do programa Nuit Blanche (Noite em Claro), organizado anualmente pela prefeitura de Paris para promover ações envolvendo arte contemporânea e espaços públicos. Embora não tenha conseguido viabilizar que a exposição se estendesse por sete semanas, como previsto no projeto original, Hirschhorn considerou que a duração reduzida do evento atuou a favor do seu trabalho, ao reforçar o aspecto "precário" que vinha lhe interessando há tempos. Ocupando uma área de $1.300 \mathrm{~m}^{2} \mathrm{com}$ materiais frágeis, o artista construiu um percurso recriando os locais emblemáticos de um museu convencional, tais como salas expositivas, biblioteca, arquivos, auditório e até mesmo loja e bar. Abrigando palestras, debates e encontros informais em torno da obra do filósofo francês Michel Foucault, ${ }^{676}$ esses ambientes foram concebidos, segundo Hirschhorn com a intenção de "criar um 'momento público' e um 'espaço público'” com o qual pudesse "dar forma”, enquanto artista, a seu "amor pela filosofia e à amizade entre Arte e Filosofia" ${ }^{677}$ Para ele, a transformação do espaço com a recriação de ambientes a partir de sua própria lógica de precariedade e informalidade não implicaria que o contexto de instalação das
675 Tobias Rehberger. Tester la Structure. In: PALAIS DE TOKYO, 2012, op. cit., p. 149. Tradução nossa.

676 O falecimento de Michel Foucault completava 20 anos na ocasião, dando origem a comemorações em torno da obra do filósofo francês.

677 Thomas Hirschhorn. Comme un Cerveau en Action. In: PALAIS DE TOKYO, 2012, op. cit., pp. 162164. Tradução nossa. 

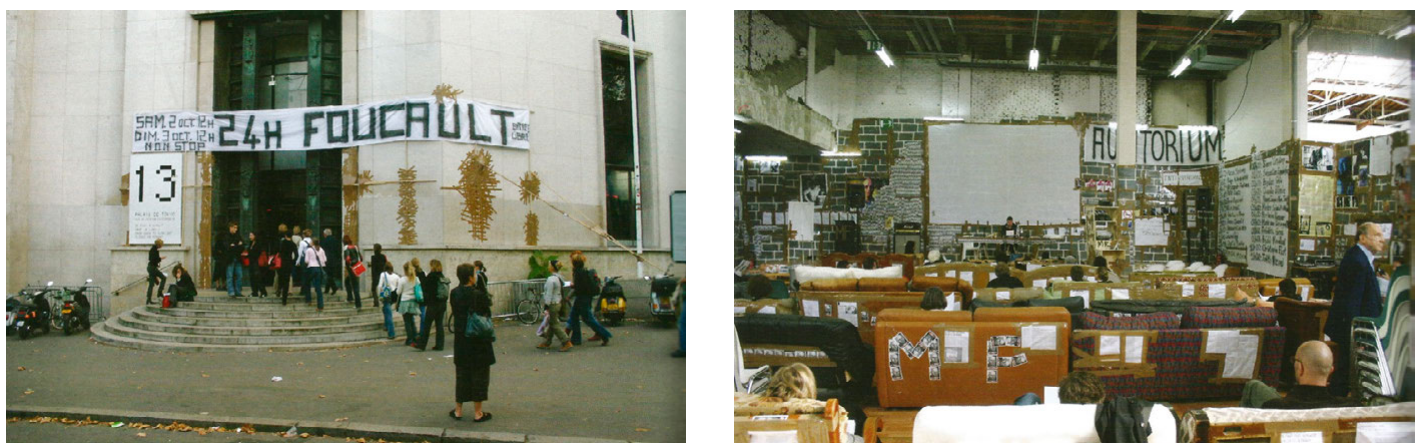

4.113 e 4.114 Vistas da exposição de Thomas Hirshhorn, 24 Heures Foulcaut, Palais de Tokyo, Paris, 2004. Foto: Romain Lopez. Fonte: PALAIS DE TOKYO, 2012, p. 160. obras fosse indiferente para o seu trabalho. Ao contrário, ele via como ativa a interação entre sua arte e a arquitetura do edifício:

O Palais de Tokyo é um espaço que cria as condições para que a obra de arte se torne uma confrontação, um diálogo direto e à altura dos olhos. Eu 'vesti' esse espaço - com paredes de papelão, um piso em linóleo e neons adicionais - justamente para reforçar o 'corpo crítico' do meu trabalho e para enfatizar sua 'forma precária'. 24 h Foulcault deveria ser uma bateria, uma bateria carregada. Ao 'vestir' esse espaço, eu quis criar um recipiente, um balde ou uma caixa, uma caixa craniana. Eu quis que o público - que eu vejo como 'público não exclusivo' - se encontre no interior de um cérebro em ação. A instituição Palais de Tokyo não desapareceu, mas durante vinte e quatro horas, a instituição - que eu não renego - se tornou um recipiente real. Um recipiente ativo que abriga uma obra de arte. ${ }^{678}$

Thomas Hirschhorn é um dos artistas que declarou abertamente a identificação de sua forma de expressão com a arquitetura do Palais de Tokyo, por sua ambiência crua e informal, como um território de ocupação. A precariedade que lhe interessava, também assumida no edifício, ofereceria, segundo o artista, condições favoráveis ao acolhimento das obras, colocando o público num estado de espírito propício a uma interação ativa com a arte: 
Anne Lacaton e Jean-Philippe Vassal criaram um espaço aberto que é um sonho para a arte, um sonho para uma obra de arte individual e um sonho para um artista. Meu trabalho 24 h Foulcault deu forma a um desses sonhos. A arquitetura do Palais de Tokyo encoraja o visitante a se deslocar, prestar atenção e manter-se engajado. ${ }^{679}$

Se Hirschhorn via as características do Palais de Tokyo como receptivas à livre atuação de artistas e propulsoras do engajamento do público com a arte, esse entendimento não é evidente para os que não tem a mesma inserção no circuito artístico, nem a mesma familiaridade com as regras de funcionamento dos centros de arte. Como vimos, o estranhamento provocado pelo desnudamento do interior, especialmente nos anos iniciais, podia encorajar em visitantes e artistas comportamentos informais bem-vindos, mas também certas atitudes que ultrapassavam os limites que o centro pretendia tolerar. Por outro lado, havia também uma leitura de que a ação de Lacaton \& Vassal seria como uma cenografia - uma estetização do canteiro de obras e da indigência - e que a negação do tratamento habitual dado a espaços expositivos seria incongruente com sua destinação como centro de arte. ${ }^{680}$

Ao longo dos anos, a utilização do espaço interno acabou sofrendo modificações pela incorporação de intervenções realizadas por sucessivas exposições que trataram as superfícies do edifício, atenuando o aspecto bruto do interior. Corriqueiras em ambientes museais, paredes brancas, demasiadamente associadas a uma institucionalização que se pretendia negar, eram inexistentes no momento em que o centro foi inaugurado. Sua primeira ocorrência se deu pouco depois da inauguração, na ocasião da exposição Vue d'en Haut, realizada em 2002 pelo alemão Wolfgang Tillmans (1968-), "simplesmente porque sua obra exigia", como justificou Bourriaud. Vale destacar que o fato foi relembrado como um evento memorável tanto pelo curador como por Lacaton e Vassal, que, apesar de advogarem pelas transformações posteriores, prefeririam que fosse preservada a distinção entre o estado original e deteriorado do edifício e as posteriores intervenções. A utilização de paredes brancas sempre esteve
679 Ibidem, p. 162.

680 Cf. CASCARo, op. cit. 

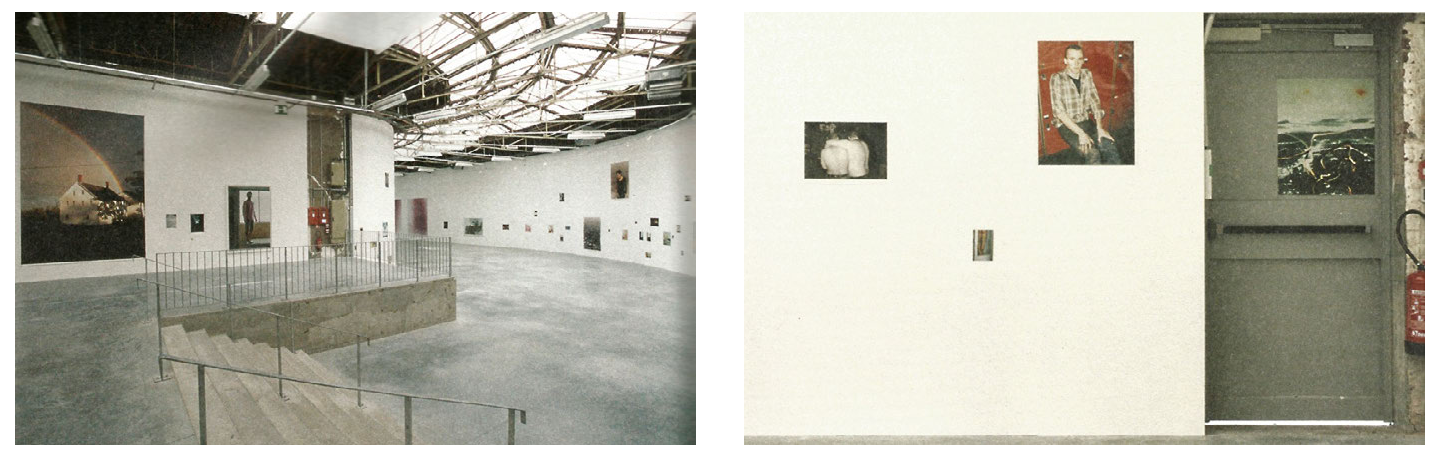

4.115 e 4.116 Vistas da exposição de Wolfgang Tillmans, Vues d'en Haut, Palais de Tokyo, Paris, 2002.

Foto: Marc Domage. Fonte: PALAIS DE TOKYO, 2012, p. 138.
681 bidem, p. 31 .

682 Tatiana Trouvé.

Redimensionner l'Espace. In:

PALAIS DE TOKYO, 2012, op. cit., p. 168. Tradução nossa. em pauta na elaboração do projeto para o Palais de Tokyo, como relatou Lacaton:

A discussão já existia antes da abertura. Os próprios diretores se questionavam, se perguntavam até que ponto os artistas aceitariam trabalhar num lugar naquele estado. De todo modo, tínhamos realizado vários meses antes da abertura imagens virtuais dos efeitos das paredes brancas no pavimento das exposições. Num lugar vazio, as paredes brancas adquirem muito mais importância em relação à beleza do lugar tal como ele estava. Mas para nós isso não era um verdadeiro problema, pois as paredes em si não tinham grande importância e sabíamos que o lugar mudaria rapidamente em função das exposições a pedido dos artistas. Pensamos, entretanto, que seria preferível adicionar painéis a pintar diretamente as paredes, pois a dificuldade é saber onde parar. Seria preciso consertar as imperfeições da parede antes de pintá-la? Nossa intenção era que tudo de novo que fosse feito fosse normalmente bem feito, para que não houvesse confusão entre o existente com suas imperfeições e o que fosse acrescentado. ${ }^{681}$

Comentando a primeira exposição que realizou em 2002 no Palais de Tokyo, Polders, a artista italiana baseada na França Tatiana Trouvé (1968-) relatou acreditar que "naquele momento a arquitetura do Palais de Tokyo era considerada em si um espetáculo: o lugar se apresentava como tal". ${ }^{682}$ Havia então 

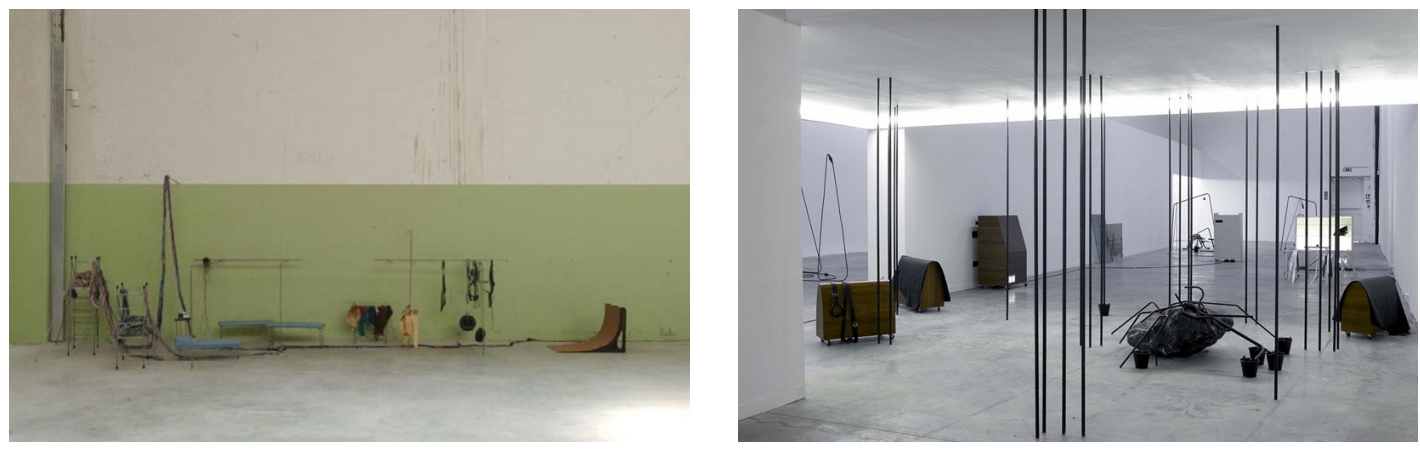

a imposição de manter certas marcas de usos anteriores do edifício, como uma faixa de pintura verde, que a artista acabou incorporando ao seu trabalho. Posteriormente, essas imposições foram desaparecendo, permitindo intervenções diretas sobre o edifício, o que resultou numa maior homogeneização dos espaços, com paredes progressivamente sendo pintadas de branco. Para a exposição de 2007, Double-mind, a artista já não encontrou a mesma resistência para transformar o espaço e pôde inverter a condição de antes, reconfigurando o espaço em função de sua obra.

Vemos então que a ambiência crua do edifício foi encarada de diversas maneiras por criadores e usuários: arquitetos e curadores responsáveis pela concepção inicial acreditavam que essa condição reforçava a identidade anti-institucional do Palais de Tokyo, favorecendo a liberdade de uso e uma relação mais engajada com a arte, o que foi endossado por artistas como Hirschhorn e também por boa parte dos visitantes, que se sentiram desobrigados a seguir certos padrões de comportamento habituais nos museus tradicionais. Artistas como Rivane Neuenschwander e Tatiana Trouvé incorporaram certas marcas "defeituosas" do edifício aos seus trabalhos, sendo para a primeira um ponto de partida de sua obra e para a segunda um dado de certa forma imposto, incorporado num trabalho concebido de modo mais independente das características do espaço. Wolfgang Tillmans, por sua vez, exigindo a instauração de paredes brancas para ambientar sua obra, inaugurou a prática seguida por outros de anular os "ruídos"
4.117 Vistas da exposição de Tatiana Trouvé, Poulders, Palais de Tokyo, Paris, 2002. Fonte: https://www. artnews.com/art-in-america/features/ tatiana-trouv-62835/

4.118 Vistas da exposição de Tatiana Trouvé, Double Mind, Palais de Tokyo, Paris, 2007. Fonte: http://le-beau-vice.blogspot. com/2007/02/suivre-tatiana-trouvelisabeth-ballet.html 
do edifício histórico e reinstaurar o ambiente dos espaços de arte mais limpos e homogêneos, identificados com o repertório convencionalmente adotado em museus. Observando as exposições ao longo do tempo, podemos questionar a seguir se seria possível ao Palais de Tokyo sustentar a postura anti-institucional que animou sua criação, enquanto amadurece e se consolida como um dos equipamentos culturais mais bem estabelecidos no cenário internacional da arte contemporânea.

\subsubsection{MATURIDADE OU INSTITUCIONALIZAÇÃO?}

683 O primeiro restaurante a funcionar no hall a partir da inauguração do Palais de Tokyo em 2002 foi o Tokyo Idem, cuja ambientação era marcada pela aplicação de imagens de retratos nas esquadrias da fachada principal da intervenção Portraits, do artista suíço Beat Streuli. O restaurante foi substituído pouco depois pelo Tokyo Eat, com projeto realizado em colaboração por artistas e arquitetos Stéphane Maupin (arquitetura e iluminação), Ivan Fayard (mesas), André, Marcus Kreiss, Olivier Babin, Kolkoz Zevs (cadeiras) e Bernard Brunon (pintura mural). Em 2017, foi instalado o novo restaurante e bar de drinks Les Grands Verres, projetado pela arquiteta Lina Ghotmeh. No Palais de Tokyo funciona ainda o ultrassofisticado restaurante Monsieur Bleu, localizado no final do grande saguão curvo, ligado ao terraço voltado para o Rio Senna e com entrada independente.

O espaço da livraria foi triplicado e transferido a área utilizada anteriormente pelo setor educativo, de atendimento às crianças. A gestão passou a ser realizada pela Cahier d'Art, associada à Walther König, com projeto realizado por Office Kersten Geers David Van Severen.
Depois de quase duas décadas de sua inauguração, o Palais de Tokyo já não causa o mesmo estranhamento que antes, mas o abrandamento de sua aparência radical não foi consequência apenas das intervenções das exposições. A experiência de entrar no edifício se alterou também por conta das já mencionadas restrições por razões de segurança, e ainda pelo tratamento das áreas de recepção, que perderam progressivamente o aspecto precário dos anos iniciais, especialmente depois da entrada de novos concessionários a partir de 2017. O balcão de bilheteria e informações, que quando o centro abriu funcionava num trailer adaptado, foi posteriormente alojado num móvel sobre rodízios e finalmente se instalou em bancadas especialmente desenhadas para esse fim, mais integradas ao edifício. A primeira livraria, cujo espaço se delimitava por um alambrado no meio do saguão de entrada, foi transferida para um dos amplos salões antes expositivos, ambientada agora por estantes bem organizadas e distribuídas em todo o perímetro. $O$ restaurante do saguão, que inicialmente tinha o ar informal de uma cantina universitária, cedeu lugar primeiro a um mais bem estruturado, mas ainda com aspecto despojado, e posteriormente a um outro de padrão superior, com decoração sofisticada e preços mais elevados. ${ }^{683}$ Se antes o visitante entrava no Palais de Tokyo por um ambiente que lembrava o de um grêmio estudantil, onde se imagina encontrar a juventude inquieta, agora é recebido num saguão que, apesar de ainda ter trechos sem acabamentos aqui e ali, não espanta quem espera dirigir-se a um estabelecido museu. 

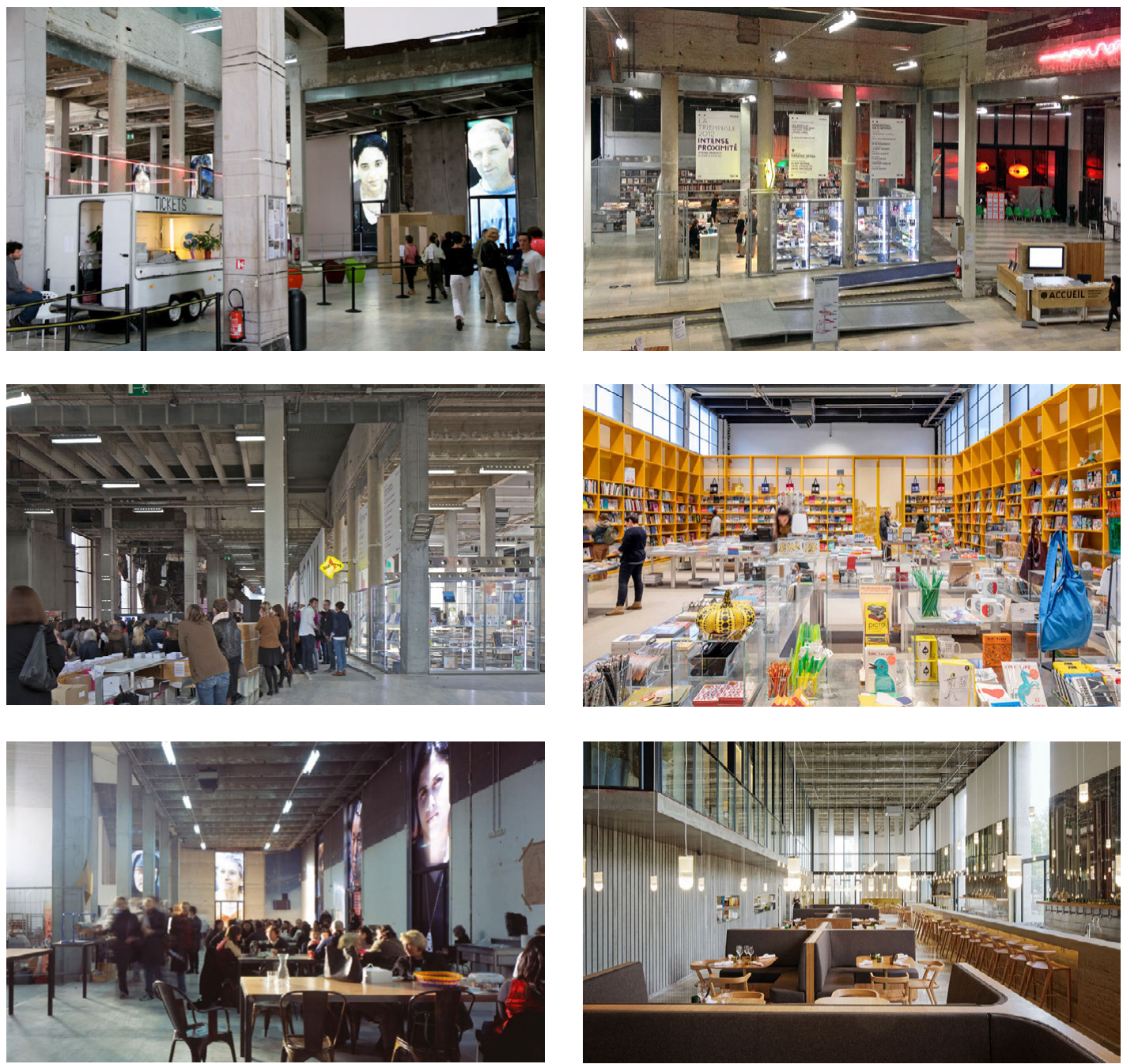

4.119 Trailer adaptado para bilheteria no Palais de Tokyo, Paris, 2002? Foto: Ivar Hagendoorn. Fonte: https://www. ivarhagendoorn.com/photos/series/ palais-de-tokyo-9/

4.120 e 4.121 Livraria do Palais de Tokyo, Paris, 2002? Foto 4.121: Philippe Rouault. Fonte: https://www.lacatonvassal.com/ index.php?idp $=20$
4.122 Livraria do Palais de Tokyo, Paris 2019. Foto: Florent Michel. Fonte: https:// www.vogue.fr/fashion-culture/article/ paris-10-most-beautiful-bookstores

4.123 Lanchonete Tokyo Idem do Palais de Tokyo, Paris, 2002? Foto: Philippe Rouault. Fonte: https://www.lacatonvassal.com/ index.php?idp=20
4.124 Restaurante Le Grands Verres, Palais de Tokyo, Paris, 2017. Foto: Takuji Shimmura. Fonte: https://www. linaghotmeh.com/en/ouverture-au-palaisde-tokyo.html

\section{6-557}




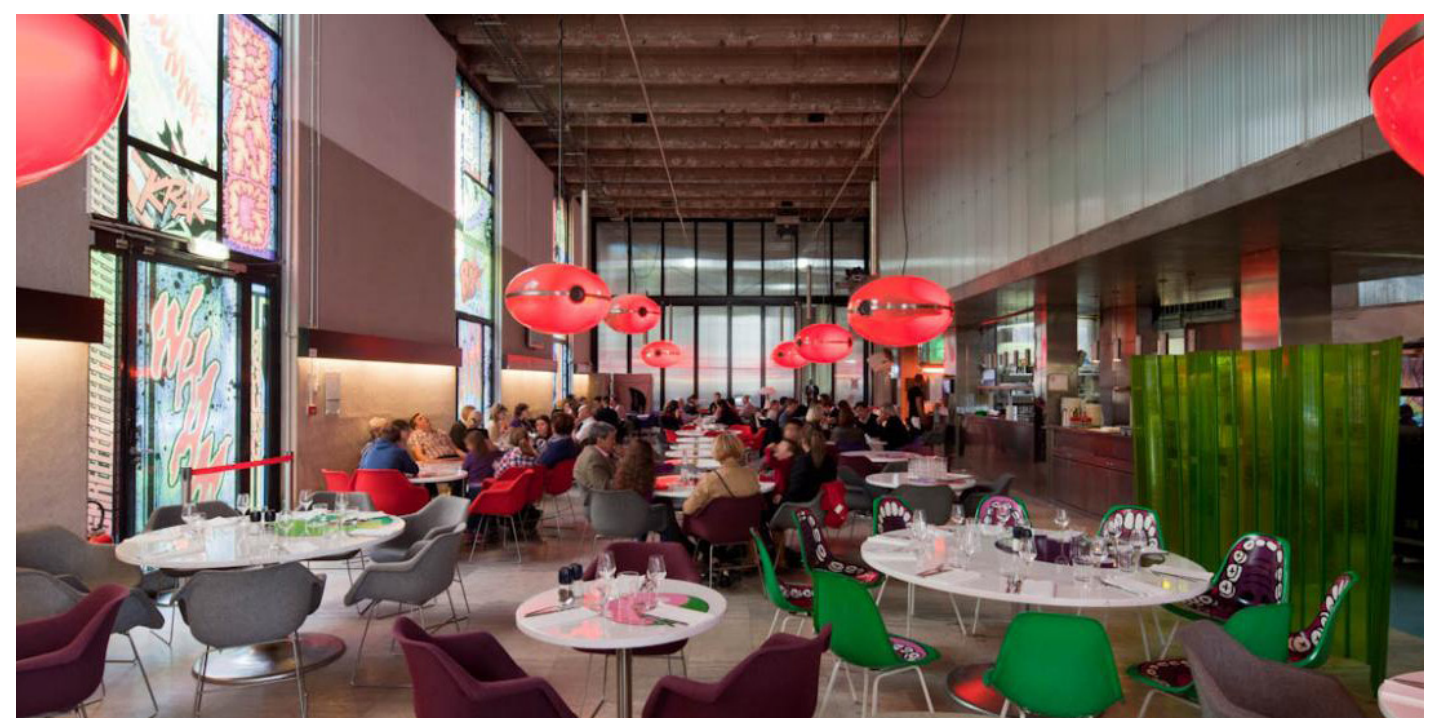

4.124 Restaurante Tokyo Eat, Palais de Tokyo, Paris, s.d. Fonte: https://www.soulby. com.br/palais-de-tokyo-by-lacaton-vassal/

684 A exposição Encore um jour banane pour um poisson-rêve esteve em cartaz no Palais de Tokyo de 22 de junho a 9 de setembro de 2018. A curadoria foi realizada por Sandra Adam-Couralet e Yoann Gourmel associados a Kodama Kanazawa, com roteiro do artista francês Clément Cogitore (1983-) e expografia de Laure Pichat. Cf. PALAIS DE TOKYO. ENFANCE: Encore un jour banane pour le poisson-rêve (Du 22/o6/2018 au 09/og/2018). Palais de Tokyo. Disponível em: $<$ https://www.palaisdetokyo.com/ fr/evenement/enfance>. Acesso em: 27 maio 2021.

685 Pseudônimo de Tatsu Nishi.
Em visita ao Palais de Tokyo em julho de 2018, a principal exposição em cartaz, Encore um jour banane pour um poisson-rêve ${ }^{684}$ surpreendia pelo aspecto majoritariamente convencional de sua montagem. A principal exceção era a obra do artista japonês Amabouz Taturo (1960-), ${ }^{685}$ que instalou na porta principal a obra A doll's house, levando o público a passar obrigatoriamente pelo interior de uma casa de bonecas em escala humana para entrar no centro. Composta por obras de diversos artistas, a exposição organizava-se numa sequência de salas visualmente segregadas por paredes brancas, a partir de um percurso de visitação unidirecional pré-determinado, que de modo geral tirava partido mais da grande disponibilidade de amplos espaços vazios do que de características específicas da arquitetura do edifício.

Em que medida essas transformações seriam índice de uma limitação da liberdade de criação a qual o Palais de Tokyo procurou associar-se desde a inauguração como "local de criação contemporânea", contrapondo-se ao peso das instituições museais tradicionais? Comentando seus planos ao assumir o cargo de diretor-presidente a partir da reabertura e ampliação do centro em 2012, Jean de Loisy buscou reforçar a concepção original de Nicolas Bourriaud e Jérôme Sans: 


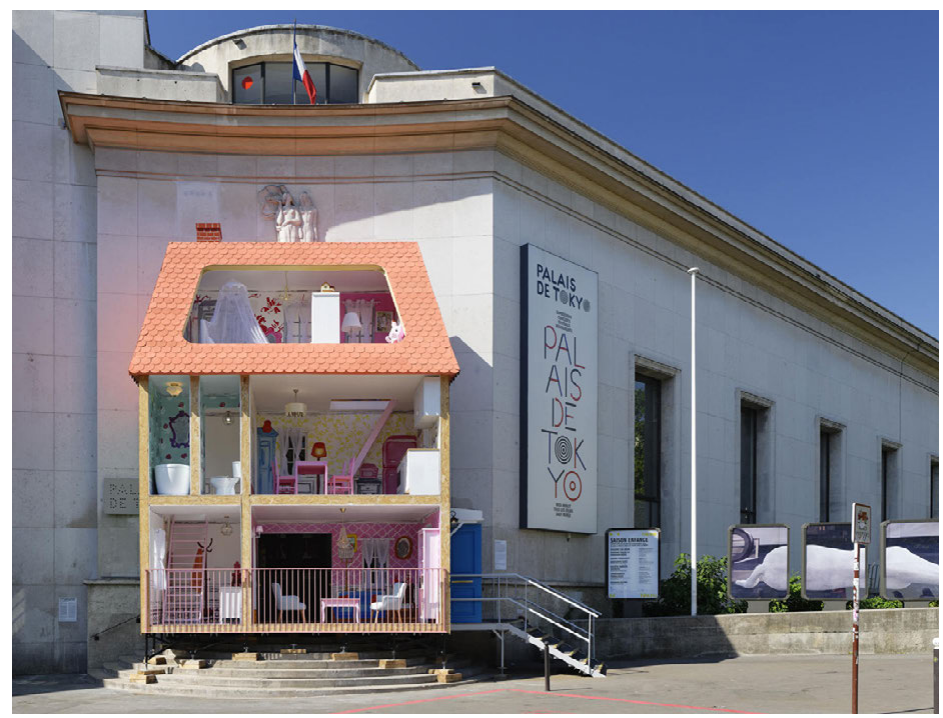

O Palais de Tokyo deve introduzir novas situações e garantir que elas sejam provisórias. Se não for capaz desse deslocamento permanente, ele se tornará uma instituição. O paradoxo do Palais de Tokyo é que ele é indubitavelmente a maior instituição francesa para arte contemporânea, e talvez mesmo europeia, atualmente. Sendo assim, se ela se institucionaliza, está morta. O Palais de Tokyo deve ser preservado de qualquer tentativa de institucionalização. Se deixar de ser livre e insolente, se vier a se tornar estável e rigoroso, se for sério, ele se tornará tedioso e desaparecerá enquanto aventura. ${ }^{686}$

Qual seria, portanto, a estratégia imaginada para garantir o "deslocamento permanente" ou o "caráter provisório" das situações para que o Palais de Tokyo, sendo de fato uma grande instituição de arte europeia, não ficasse refém das amarras da dita "institucionalização"? Segundo Loisy, como vimos, o caminho seria acompanhar o ritmo de renovação constante intrínseco à própria arte, atuando de maneira muito próxima a cada artista, compreendido como "um agente de transformação, de contestação e reinvenção da realidade e do mundo que ecoa na sua obra”. Desse modo, “o Palais de Tokyo deve
4.125 Vista da instalação de Amabouz Taturo, A Doll's House, Palais de Tokyo, Paris, 2018. Fonte: https://twitter.com/palaisdetokyo/ status/1129308073108168706

686 LOISY in: PALAIS DE TOKYO, 2012, op. cit., p. 276.

\section{8-559}


687 Ibidem, p. 273.

688 Jean de Loisy apud RÉGNIER, Philippe. Jean de Loisy présente les nouveaux espaces du Palais de Tokyo et ses activités hors les murs. Le Quotidian de l'Art, 1261-30 mars 2017. ed. 2017. $\{\backslash \backslash \mathrm{b}\{\}$ Le Quotidian de $1 \backslash$ uco $\|$ u18o \{\} Art $\}$, 1261|uco||u8211\{\}30 mars 2017. .| ucollu16o\{\}ed. 2017.","plainCitation":"RÉGNIER, Philippe, Jean de Loisy présente les nouveaux espaces du Palais de Tokyo et ses activités hors les murs, Le Quotidian de 1'Art, 1261-30 mars 2017. ed. 2017.","dontUpdate":true,"noteIndex":73\},"citationItems":[\{“id”:732,"uris”:[“http:// zotero.org/users/local/PPMoZcPG/ items/HAFJIHNT"],"uri”:[“http:// zotero.org/users/local/PPMoZcPG/ items/HAFJIHNT"],"itemDa ta”:\{“id":732,"type”:"articlenewspaper","container-title":"Le Quotidian de 1'Art","edition":"1261 - 30 mars 2017","title":"Jean de Loisy présente les nouveaux espaces du Palais de Tokyo et ses activités hors les murs","URL":"https://www.lequotidiendelart. com/articles/1058o-jean-de-loisy-presente-les-nouveaux-espaces-du-palais-de-tokyo-et-ses-activites-hors-les-murs. html","author":[\{ “family”:"RÉGNIER","given":"Philippe"\}],"accessed":\{“date-parts":[[“2019”,1,4]]\},"issued”:\{“date-parts":[[“2017”,3,30]]\}\}\}],"schema":"https://github.com/ citation-style-language/schema/ raw/master/csl-citation.json"\}

689 LAMARCHE-VADEL, op. cit. Transcrição e tradução de Celina Olga e Caroline Fretin. se tornar o eco, e mais que isso, o porta voz de artistas que querem transformar nossa consciência do real, ou mesmo da própria realidade". ${ }^{687}$

Em depoimento oferecido em 2018, Rebecca Lamarche-Vadel, que integrava então a equipe de curadoria liderada por Loisy desde 2012, relativizou a impressão de que o modo como o espaço do Palais de Tokyo vinha sendo utilizado indicasse um movimento generalizado rumo à institucionalização. Segundo argumentou a curadora, se as relações que o centro tem que estabelecer com seus financiadores para o seu sustento teriam levado a uma estetização de espaços explorados pelos concessionários, esse comprometimento não indicaria um impacto direto no trabalho de artistas e curadores na elaboração das exposições.

O centro tem tido de fato que lidar com certas consequências de seu sucesso, devido a um crescimento expressivo em poucos anos, com aumento tanto do número de visitantes quanto da captação de recursos. Enquanto inicialmente as verbas destinadas ao funcionamento eram repartidas de maneira equivalente entre o setor público - Ministério da Cultura - e parcerias com agentes privados - patrocínio e mecenato -, cada qual com 50\%, o aporte de recursos privados aumentou, diminuindo proporcionalmente a parcela estatal para $37 \%$ do total, conforme apurado em $2017 .{ }^{688}$ Lamarche-Vadel relatou que esse crescimento veio acompanhado de uma pressão econômica e que, de fato, o espírito mais "leve" e "informal" que se destacava dez anos antes, especialmente notável nos espaços de entrada, cedeu lugar à atmosfera mais estabelecida dos dias de hoje: "talvez a estética da instituição seja mais tranquilizadora nesses casos do que movimentos um pouco mais frágeis e mais informais”. Em sua opinião, o trabalho dos curadores seria o de equilibrar isso nas exposições, tentando ser "o máximo possível, surpreendentes e inventivos". ${ }^{689}$

Com relação à exposição Encore un jour banane pour le poisson-rêve, parte da temporada Enfance, Lamarche-Vadel (que não teve envolvimento direto com o trabalho) afirmou que o caráter supostamente mais convencional da montagem estaria relacionado sobretudo à natureza coletiva da mostra, com as complexidades inerentes à arte contemporânea. Definir como 

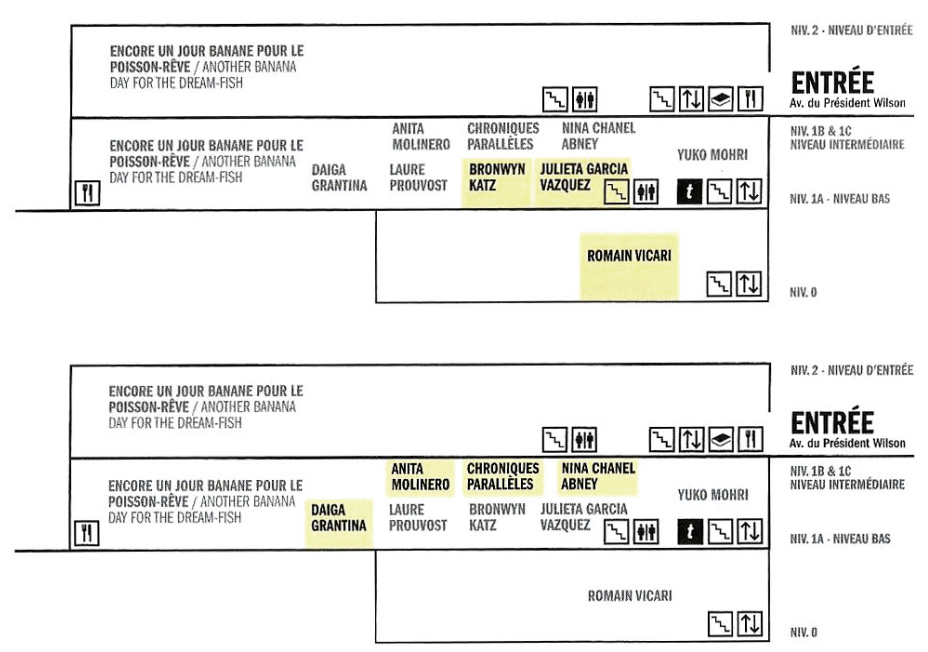

serão dispostas obras distintas reunidas sob um mesmo tema sem criar diálogos indesejáveis entre elas seria o trabalho do curador, que atuaria nesses casos como "curador-autor", a partir de um ponto de vista mais objetivo e destacado da exposição. Nessa exposição, contudo, a opção pela "separação dos mundos" não teria sido apenas em decorrência da individuação de cada trabalho, mas responderia à intenção do projeto de construir um espaço labiríntico a partir de passagens. Como imaginado pelo artista francês Clément Cogitore (1983-), o público transitaria de obra em obra como um herói percorrendo etapas de um jogo ou vivenciando um ritual, tendo que se guiar por um caminho determinado pelo espaço, sem referências prévias de orientação.

Embora a exposição tivesse sido organizada claramente como uma narrativa linear, com começo, meio e fim bem definidos, não havia uma clara sinalização indicando seu início e era possível entrar erroneamente no percurso labiríntico no sentido inverso, o que podia indicar uma hesitação do centro em assumir de modo franco a intenção de guiar a visitação que orientou a montagem. A curadora relatou que,

no começo, em 2012, jogávamos muito mais com a perda de referências, com a desorientação. E fomos muito criticados
4.126 Mapa das exposições da temporada Enfance no Palais de Tokyo, Paris, 2018. Fonte: Brochura distribuída no Palais de Tokyo. 

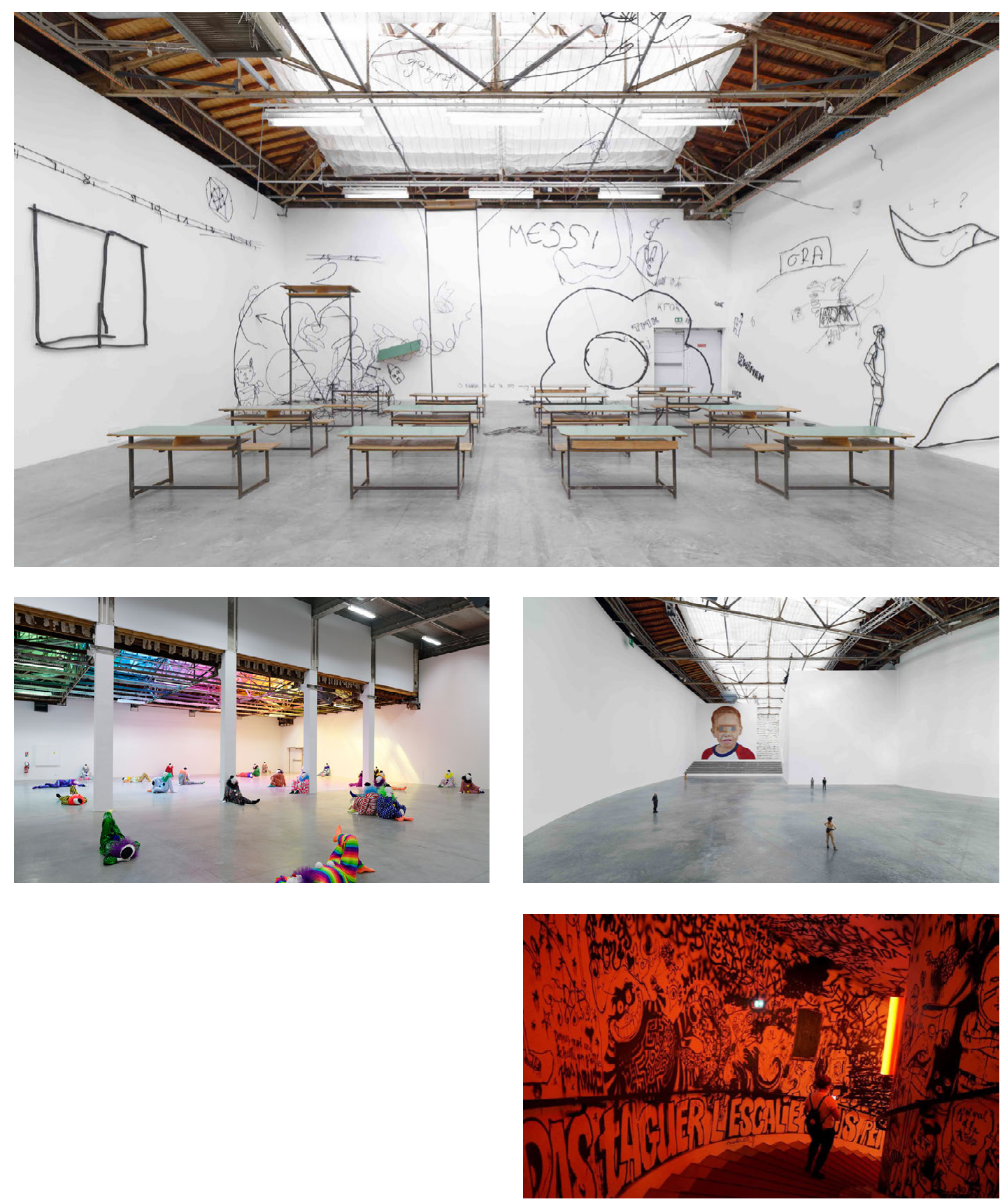
por isso. Diziam: 'A gente se perde o tempo todo', 'É incompreensível', 'A gente não consegue', e, de fato, vimos nisso um medo real, por parte do visitante, de se perder, de perder referências e perder sinais de orientação claros e distintos. Assim, é verdade que as exposições que guiam os visitantes tendem a tranquilizá-los e a ter mais sucesso. [...] O que é interessante é que as pessoas esperam que a instituição as guie ao invés de fazer com que se percam. E, embora não nos definamos aqui como instituição, somos percebidos como tal e as pessoas esperam ser guiadas. ${ }^{690}$

De todo modo, a curadora reafirmou que não haveria um modo pré-estabelecido de ocupar o espaço, e sim um planejamento baseado na natureza de cada projeto. Na temporada de Enfance, de 2018, havia diversas exposições coabitando o edifício, ${ }^{691}$ mas várias outras temporadas contam com mostras individuais, como as da série Carte Blanche, em que um ou uma artista ocupa uma grande área do edifício ou partes que lhe interessem, o que geralmente resulta numa relação mais ativa com a arquitetura. ${ }^{62}$ Lamarche-Vadel afirmou que todas as exposições são novas produções que partem das propostas de artistas e de pesquisas que envolvem não apenas as obras que serão apresentadas, mas também os modos de expor, e que, nos projetos em que tem trabalhado, procura conferir à questão arquitetônica a mesma importância que a das obras, uma vez que as exposições de arte contemporânea implicariam sempre uma "experiência física”. Ela relatou que, mesmo no Palais de Tokyo, houveram artistas que preferiram expor em espaços mais convencionais, mas também houve quem optou pelo contrário:

Se há uma consolidação em favor da institucionalização, da museificação, talvez seja porque as pessoas se sentem mais seguras com essa estética, que, antes de tudo, é desejada por artistas. [...] E se há paredes brancas que lembram esses códigos, não é verdade que todos os projetos vão nesse sentido. Aqui, a cada temporada temos uma renovação. Estou pensando em Korakrit Arunanondchai ou Thomas Hirschhorn, ou no que fizemos com Tino [Sehgal]. Havia o desejo de não recorrer ao white cube de modo algum. Além disso, acho que o fato de integrar
4.127 Vista da instalação de Petrit Halilaj, Abetare (Wallpaper)(2015-2018), Palais de Tokyo, Paris, 2018. Fonte: http://www. laurepichat.com/encore-un-jour-banane

4.128 Vista da instalação de Ugo Rondinone, Vocabulary of Solitude (2014-2016), Palais de Tokyo, Paris, 2018. Fonte: https://www.palaisdetokyo. com/fr/evenement/enfance

4.129 Vista da instalação de Tomoaki Suzuki, La porte de la désolation, Palais de Tokyo, Paris, 2018. Foto: Aurélien Mole. Fonte: https://www.palaisdetokyo.com/fr/ evenement/enfance

4.130 Vista da instalação de Dran, La chambre de la melancolie, Palais de Tokyo, Paris, 2018. Fonte: https://www. palaisdetokyo.com/fr/evenement/enfance

690 Ibidem.

691 Exposições individuais de Laure Pouvost, Julieta García Vazquez, Bronwyn Katz e Romain Vicari, exposição coletiva Chroniques Parallèles, com obras de Anne Horel, Emmanuel Lagarrigue, Hugo Láhelec e Eric Minh Cuong Castaing, e instalações da série Anémochories, oevres in situ, com obras de Anita Molinero, Daida Grantina e Nina Chanel Abney.

692 A série Carte Blanche, que permite que artistas utilizem até $13.000 \mathrm{~m}^{2}$ do total de $24.300 \mathrm{~m}^{2}$ do edifício, teve início em 2013 com o artista francês Philippe Parreno. 

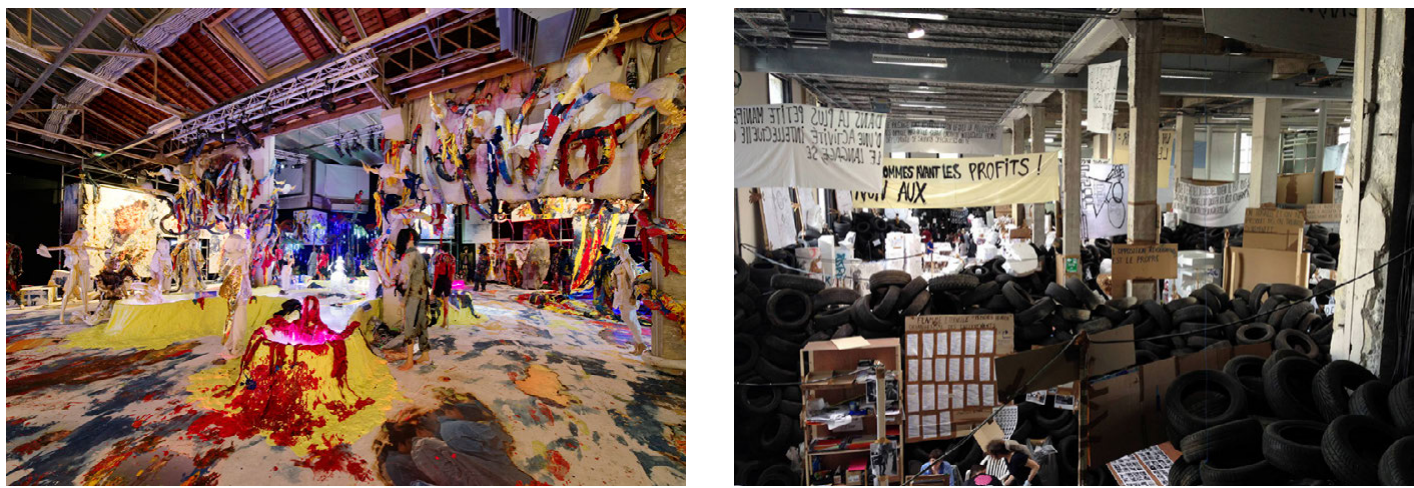

4.131 Vista da instalação de Korakrit Arunanondchai, Painting with history in a room filled with people with funny names 3 , Palais de Tokyo, Paris, 2015. Fonte: https:// www.contemporaryartdaily.com/project/ korakrit-arunanondchai-at-palais-de-tokyoparis-9206

4.132 Vista da exposição de Thomas Hirschhorn, Flamme Éternelle, Palais de Tokyo, Paris, 2014. Foto: Monsieur Harold. Fonte: http://www.summilux.net/forums/ viewtopic.php?f=24\&t=65434
693 Ibidem. ou não esses espaços como espaços de reflexão também é uma questão de sensibilidade e de escola artística. Para mim, mais uma vez, isso é absolutamente fundamental, constitutivo. ${ }^{693}$

Tanto na exposição do artista tailandês Korakrit Arunanondchai (1986-), Painting with history in a room filled with people with funny names 3 , de 2015, quanto na do suíço Thomas Hirschhorn, Flamme Éternelle, de 2014, o ambiente era carregado e caótico, cada um contrapondo-se à sobriedade do "cubo branco" à sua maneira: o primeiro com uma explosão de cores atiradas em várias direções e o segundo com paredes de pneus empilhados e outros materiais precários dispostos de uma maneira aparentemente improvisada.

Na Carte Blanche do germano-britânico Tino Sehgal (1976-), de 2016, a contraposição ao espaço convencional dos museus se deu de outra forma: foram retiradas todas as paredes internas do Palais de Tokyo, deixando-o vazio e sem subdivisões, tal como imaginado no projeto de Lacaton \& Vassal. De natureza imaterial, sua obra não adicionava qualquer objeto ao espaço, contando apenas com a presença de pessoas: 400 "participantes”, dispersos pelo edifício e vestidos da mesma forma que o público comum, realizavam ações coordenadas envolvendo visitantes que perambulavam por conta própria pelos amplos salões. Lembrando da forte emoção que lhe causara a visita ao monumental ao edifício ainda em obras em 2012, Lamarche-Vadel, relatou que, como curadora dessa mostra, sugeriu a Sehgal 

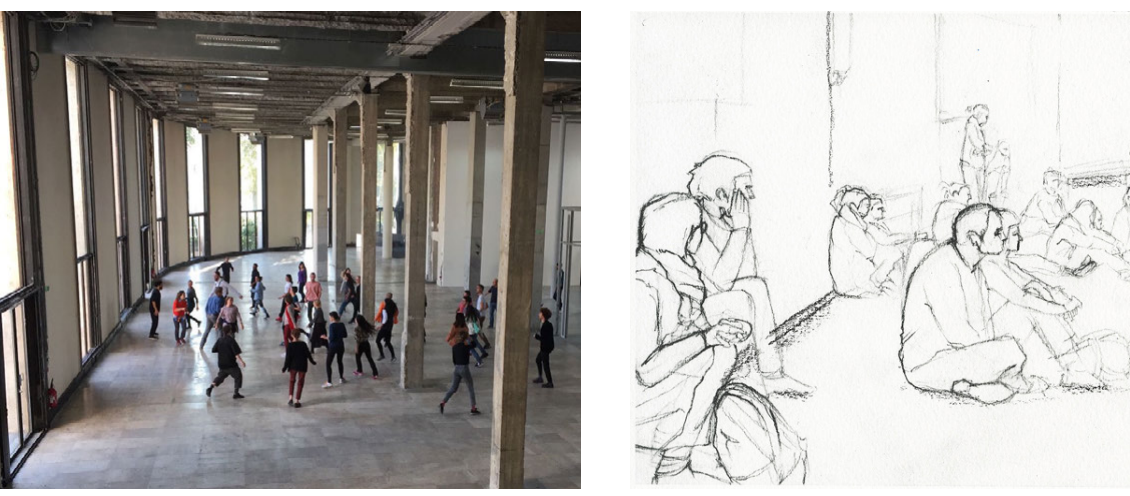

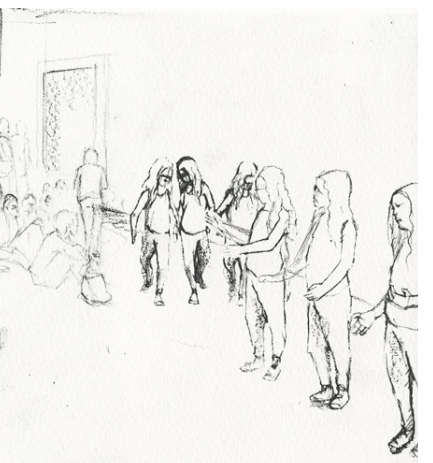

a ideia de esvaziar radicalmente o espaço por acreditar que seria ele o único a artista que lhe permitiria "mostrar ao público o Palais de Tokyo em sua nudez mais extrema". Enquanto o edifício tinha sido construído num contexto de exaltação da performance do Estado e da indústria de produção de objetos da década de 1930, Sehgal estaria, segundo ela, "numa perspectiva de recusa de extração dos recursos naturais do planeta", realizando sua exposição não apenas sem acrescentar objetos ao espaço, mas vetando inclusive a produção de quaisquer acessórios, como convites, folhetos ou textos de parede:

O importante para mim era justamente confrontar esse templo com o pensamento de Tino Sehgal, que era o da ociosidade material, para repensar nossos encontros imateriais e como opera a intersubjetividade. Sendo assim, em termos de arquitetura, não éramos nem institucionais nem não institucionais. Deixamos a instituição se fazer como um espaço que encarna uma ideia, um símbolo. E, efetivamente, o simples fato de as pessoas passarem pela porta era para nós o cenário, o mindset, no qual a pessoa se coloca quando entra nesse espaço. E isso nos bastava para ativar a exposição e deixar viver o espaço arquitetônico pelo que ele é em termos de referência estética e simbólica para o visitante. ${ }^{694}$

Implícita em qualquer espaço expositivo, a função ritualística apontada nesse relato foi enfatizada na Carte Blanche de
4.133 Vista da exposição Carte Blanche à Tino Sehgal, Palais de Tokyo, Paris, 2016. Fonte: https://www.exibart.com/libri-ededitoria/le-ragioni-dell-ecoincivilta-per-ilfilosofo-stefano-righetti/

4.134 Philippe Parreno, Tino Sehgal's Annlee, desenho realizado no Palais de Tokyo, Paris, 2016. https://www. palaisdetokyo.com/en/event/tino-sehgal

\section{$564-565$}

694 Ibidem. 

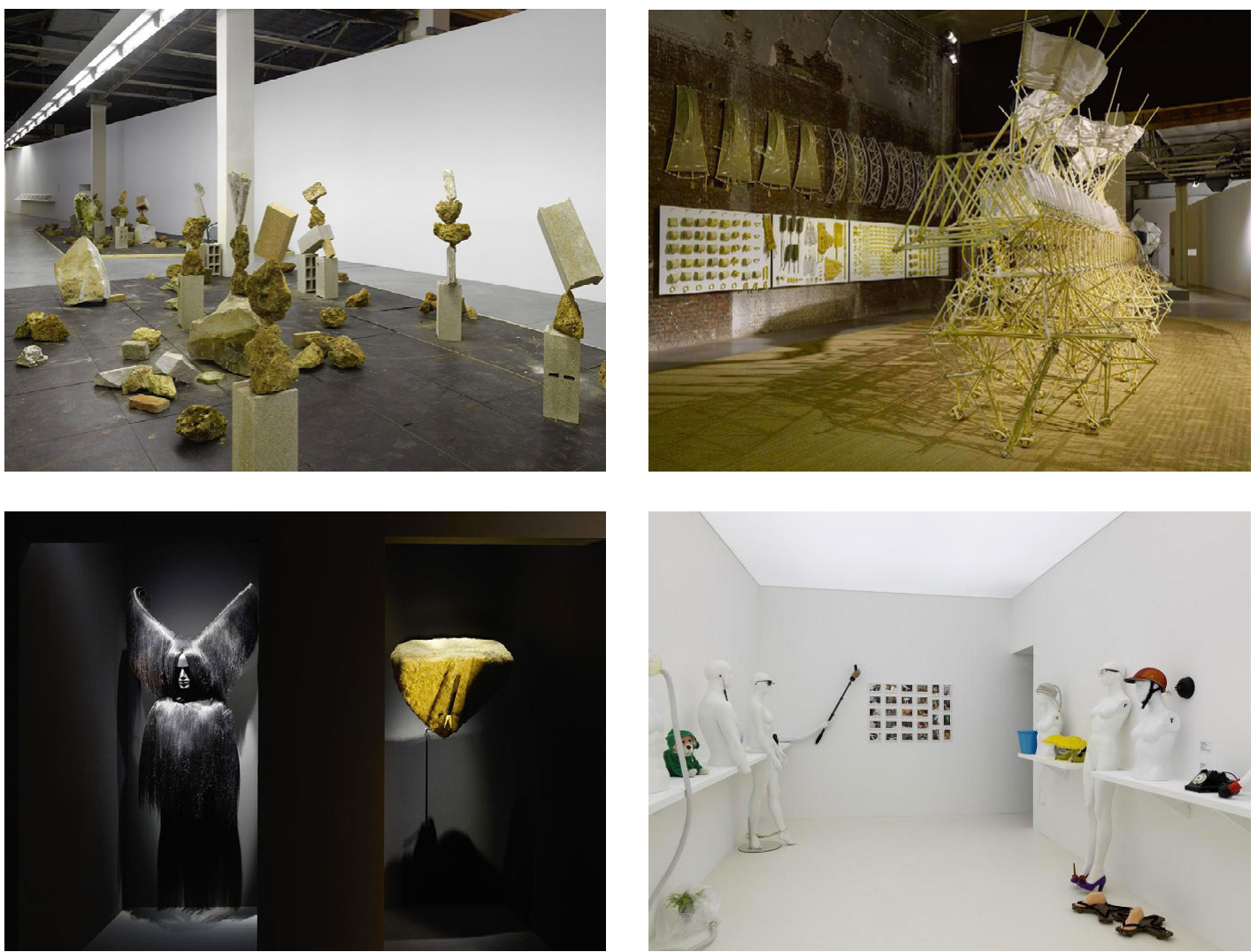

4.135 a 4.138 Vistas das instalações de Bridget Polk, Balancing rocks, de Theo Jansen, Animaris Umerus (2010-2015), de Charlie Le Mingu e de Kenji Kawakami na exposição Le Bord des Mondes, Palais de Tokyo, Paris, 2015. Fotos: André Morin. Fonte: https://www.artsy.net/show/ palais-de-tokyo-le-bord-des-mondes-atthe-edge-of-the-worlds?sort=partner show_position
Tino Sehgal pela exacerbação da ociosidade do edifício e pela ausência completa da estetização convencional. Lamarche-Vadel defendeu que a exploração dos códigos museais não se resumiria à simples adesão ou rejeição das convenções, mas poderia funcionar como um jogo complexo com a ideia de "instituição". Um contraexemplo que apresentou foi o da exposição Le Bord des Mondes, de 2015, em que a relação com a arquitetura foi novamente fundamental, mas com ambientação concebida de forma oposta, aproximando-se do modelo convencional dos museus. A mostra reunia criações produzidas por 25 pessoas independentes consideradas outsiders no mundo da arte, como a estadunidense Bridget Polk (1960-), que empilhou pedras em frágil equilíbrio, ou o engenheiro 
holandês Theo Jansen (1948-), que criou esqueletos de "animais" que se movimentam utilizando algoritmos genéticos e a energia do vento. A curadora relatou que estiveram em discussão duas possibilidades de montar a exposição: uma mais desordenada, do tipo "faça você mesmo", e outra elegante e precisa, que foi a que acabou prevalecendo. Para garantir a precisão, o projeto expográfico foi realizado em parceria com um arquiteto ${ }^{695}$ usando paredes brancas, legendas e demais códigos museais que resultaram num espaço descrito por ela como "extremamente elegante", visando "reproduzir uma arquitetura de exposição institucional", para "enganar o olhar" e investigar: "quando apresentamos algo como uma obra, olhamos isso como uma obra ou não?"

Para Lamarche-Vadel, essa ambientação "institucional" colaborou para que a recepção da exposição fosse muito positiva junto ao público e à imprensa, que nunca caracterizou os criadores como outsiders, mas como "legítimos" artistas, e reconheceu: "a instituição tem códigos arquitetônicos incríveis para instaurar um poder". Vemos que as convenções museais estão no horizonte de percepção de espaços de arte contemporânea seja como presença - em Le Bord des Mondes, seja como ausência - na Carte Blanche de Tino Sehgal. Sua utilização, no entanto, pode ser feita de modo crítico, como defendeu a curadora: "o que procurei fazer para muitas exposições foi usar a arquitetura como meio simbólico e como ferramenta para conceber o espaço".

Nem sempre as montagens do Palais de Tokyo contam com um profissional dedicado a conceber o projeto expográfico, pois muitas vezes artistas organizam o espaço por conta própria, estabelecendo uma relação mais direta entre sua obra e o edifício. Embora não lhes seja imposto que tirem partido explícito da arquitetura do Palais de Tokyo, Lamarche-Vadel afirmou acreditar que as exposições que melhor funcionam no centro são aquelas em que se leva em consideração a experiência física no conjunto espacial maior do edifício.

A curadora lembrou do modo como o artista francês Pierre Huyghe (1962-) integrou a dinâmica da arquitetura em seu trabalho realizado na sala Music Temple, localizada no labiríntico e escuro pavimento inferior, a convite de Tino Sehgal. ${ }^{696} \mathrm{~A}$
695 O projeto expográfico de $L e$ Bord des Mondes foi desenvolvido pelo arquiteto Stéphane Maupin, que realizou outros projetos no Palais de Tokyo, para o restaurante e a livraria. Cf. MAUPIN, Stéphane, SMAC. Stéphane Maupin. Disponível em: <https://www.stephanemaupin.com/>. Acesso em: 27 maio 2021.

696 Integrando a sua Carte Blanche no Palais de Tokyo, Tino Sehgal convidou ainda os artistas Daniel Buren, James Coleman, Felix Gonzalez-Torres, Isabel Lewis e Philippe Parreno. 

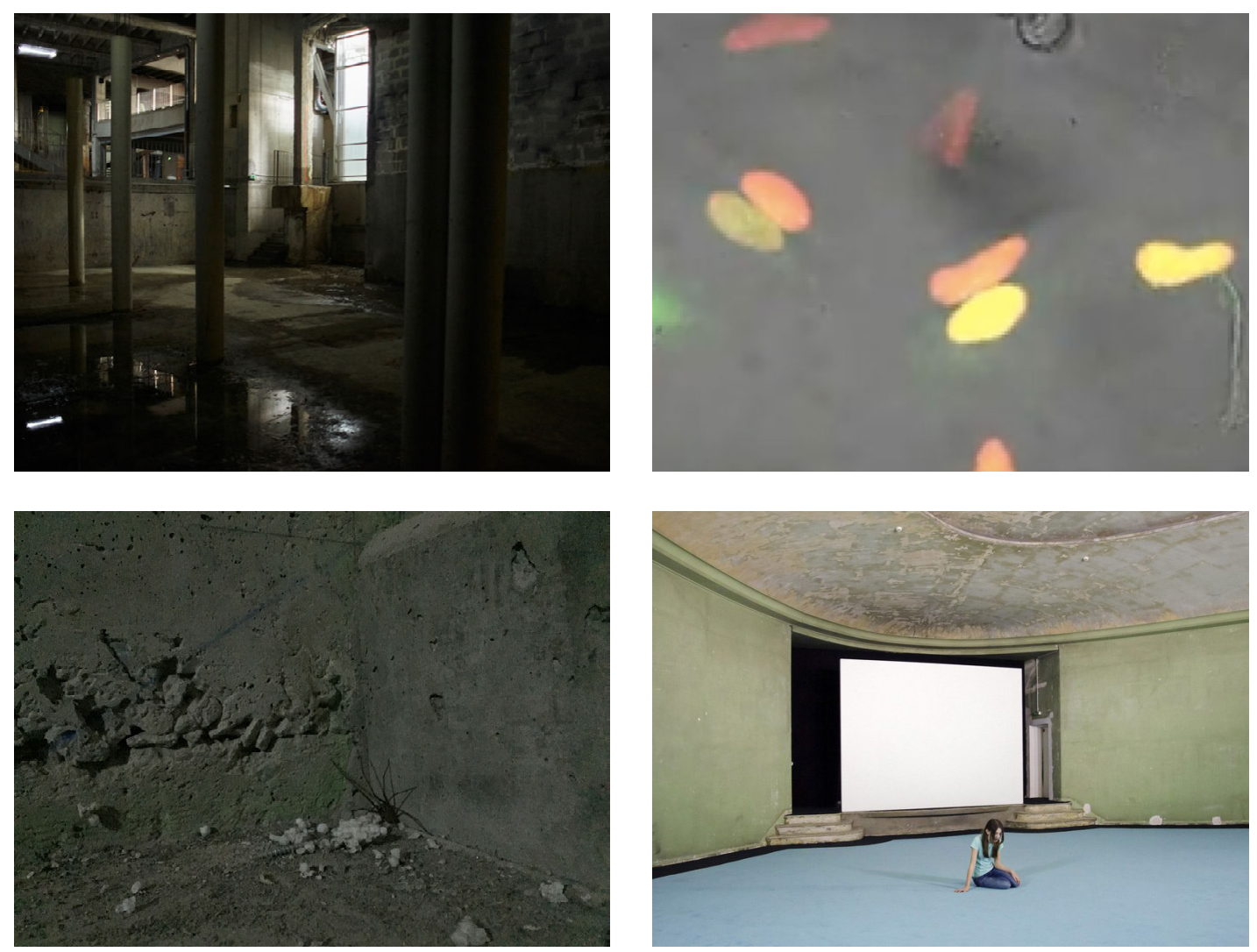

4.139 a 4.142 Vista da instalação de Pierre Huyghe, Living Cancer Variator, exposição Carte blanche à Tino Sehgal, Palais de Tokyo, Paris, 2016. Foto: Ola Rindal. Fontes: https://www.estherschipper.com/ exhibitions/521-carte-blanche-to-tinosehgal-with-pierre-huyghe-and-philippeparreno/ e http://www.zerodeux.fr/essais/ obra consistia no desenvolvimento de uma célula cancerígena humana que, posicionada a uma estrutura conectada a diversos acontecimentos do edifício, crescia com maior ou menor rapidez de acordo com o que se passava noutros locais. Funcionavam como "combustível" para alimentar a célula elementos como movimentos de moscas e camundongos soltos pelo edifí-

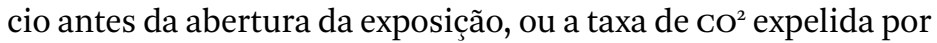
dançarinos e os batimentos cardíacos de uma menina, ambos realizando a obra de Tino Sehgal noutras salas. O crescimento da célula, por sua vez, devolvia energia ao edifício provocando o deslocamento dos elevadores, a alteração da intensidade de iluminação e o aumento ou diminuição de um grande vazamento de água existente. Para Lamarche-Vadel, a instalação 

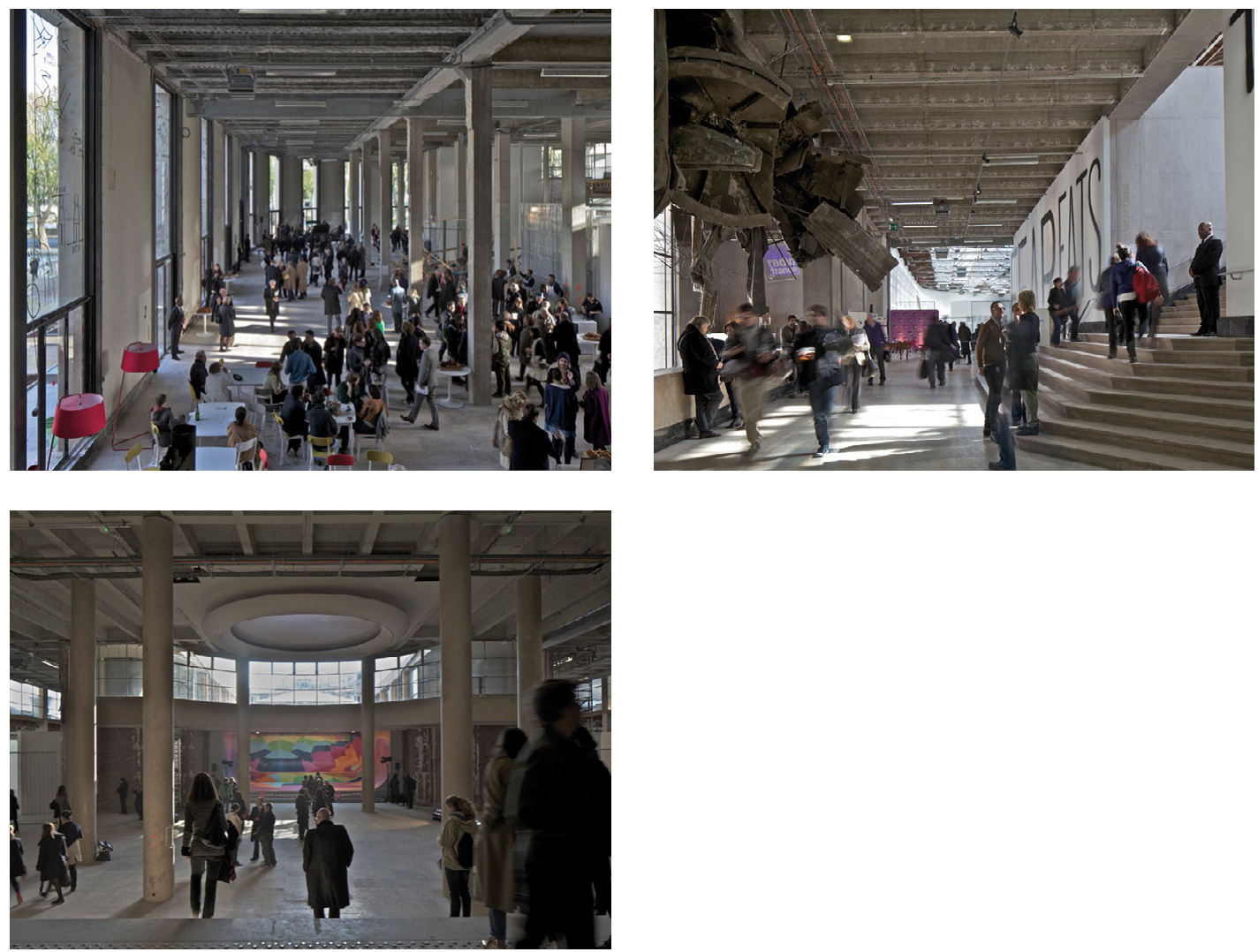

de Pierre Huyghe, ao integrar os elementos construídos aos acontecimentos vitais no Palais de Tokyo, foi "uma reflexão em torno de toda a arquitetura enquanto fluido em movimento, enquanto matéria movediça." ${ }^{697}$

A curadora relatou que nem sempre é simples para artistas vencer o desafio de dominar esse espaço, tal sua "autoridade" e "poder", especialmente no caso dos mais jovens, que ainda não amadureceram suficientemente seu trabalho, havendo o risco de certas obras ficarem empobrecidas diante da monumentalidade do contexto. A definição sobre os modos de expor partiria então da própria natureza do trabalho artístico, no confronto com o edifício:

4.143 a 4.145 Interior do Palais de Tokyo, projeto de Lacaton \& Vassal, Paris, 2002-12. Foto: Philippe Rouault. Fonte: https://www.lacatonvassal.com/index. php?idp $=20$ 
$\mathrm{O}$ espaço se adapta às obras e não o contrário. Esse gigantismo do Palais nos permite desenhar o espaço arquitetônico para que ele esteja à altura das obras [...]. Redesenhamos a cada ocasião o espaço de modo que a arquitetura responda aos diálogos e não sufoque as obras. ${ }^{698}$

De todo modo, a curadora afirmou considerar que as exposições que são concebidas junto a uma reflexão arquitetônica são mais completas, pela possibilidade de constituírem um universo de "ficção", no sentido da definição registrada por Coleridge de suspension of disbelief ${ }^{699}$ ou seja, por seu potencial de engajar o espectador no universo ficcional criado pelo artista, como endossa o depoimento de Jean de Loisy,

A crença na possibilidade da obra é uma convenção necessária e frequentemente uma consequência do impacto que ela nos transmite. A outra necessidade é a confiança. Se entramos sem confiança, se não aceitamos a proposta do artista, que vai além da materialidade da obra, não temos acesso à exposição. Não há acesso possível à arte contemporânea sem confiança no artista. $^{700}$

O acesso à obra, portanto, implicaria uma submissão total às regras simbólicas criadas de antemão por cada artista de modo soberano e privado, como apontado por Boris Groys, exigindo do espectador uma postura que Loisy denominou de "confiança". Nesse sentido, é coerente que um domínio maior das propostas artísticas sobre o espaço, que Lamarche-Vadel chamou de "reflexão arquitetônica", leve ao que a curadora considera ser uma exposição "mais completa".

698 Ibidem.

699 Expressão registrada em 1817 pelo poeta, crítico e ensaísta inglês Samuel Taylor Coleridge (1772-1834).

700 Jean de Loisy in: PaLAIS DE TOKYO, 2012, op. cit., p. 273. Tradução nossa.

\subsubsection{QUE HÁ DE ESPECÍFICO PARA A ARTE CONTEMPORÂNEA NO PALAIS DE TOKYO}

Observando o modo variado com que propostas artísticas e curatoriais vêm se relacionando com o edifício, voltamos à questão: de que forma a arquitetura do Palais de Tokyo proporcionaria oportunidades específicas para a arte contemporânea, 
ou seja, favoreceria experiências impossíveis de realizar em outros espaços?

Para Lamarche-Vadel, o fato de o interior do edifício não ser protegido por lei ${ }^{701}$ permitiria que artistas tenham liberdade de intervir no espaço sem prejudicar sua integridade, favorecendo um "diálogo entre o contemporâneo e a história". ${ }^{72}$ Ela contou que muitos episódios relacionados ao Palais de Tokyo, alguns reais e outros nunca comprovados, "continuam a assombrá-lo", sendo "uma inspiração permanente" para artistas, permitindo interações não restritas a "comentários literais", mas reflexões sobre seu caráter simbólico. Assim, muitos artistas "lidam com essa história, interagem com esses códigos, mesmo que não seja necessariamente o objetivo principal das obras". ${ }^{703}$

Entre tantos casos de centros de arte contemporânea instalados em edifícios antigos adaptados, o Palais de Tokyo, cuja arquitetura foi projetada para abrigar o Museu Nacional de Arte Moderna, tem a especificidade de conter em si um vasto panorama da construção da rede de museus da França e do contexto cultural e político mais amplo do país, expresso nos modos como se concebeu a apresentação da arte desde os tempos modernos. Marcas dos nomes dos antigos espaços do museu, como a Galerie du Capricorne, nomeada em função de uma exposição do alemão Max Ernst (1891-1976), ou letreiros de sinalização da época da cinemateca e ainda traços de exposições recentes deixados por toda parte são preservados porque, segundo Lamarche-Vadel, sempre se fez questão no centro de "fazer conviver o passado e o presente". A presença visível desses vestígios faz com que qualquer proposta artística a ser instalada no edifício torne explícita a tomada de posição diante de sua arquitetura, seja com a incorporação pelas obras de suas características materiais ou de sua carga simbólica, seja construindo um certo isolamento com recursos cenográficos. Embora a área dedicada a exposições seja muito vasta e o edifício contenha ambientes de características muito variadas, a liberdade de criação fica, de certo modo, condicionada ao confronto direto com a história, o que não é tão explícito em espaços museais tratados de modo mais convencional e pretensamente "neutro".

Por outro lado, o edifício vem de fato sendo utilizado com grande liberdade, conforme preconizado pelo projeto de
701 Segundo Lamarche-Vadel, o interior do Palais de Tokyo não está classificado na lista do Ministério da Cultura da França como monumento histórico a ser preservado. Cf. LAMARCHE-VADEL, op. cit.

702 Ibidem. Grifo nosso. 703 Ibidem. 

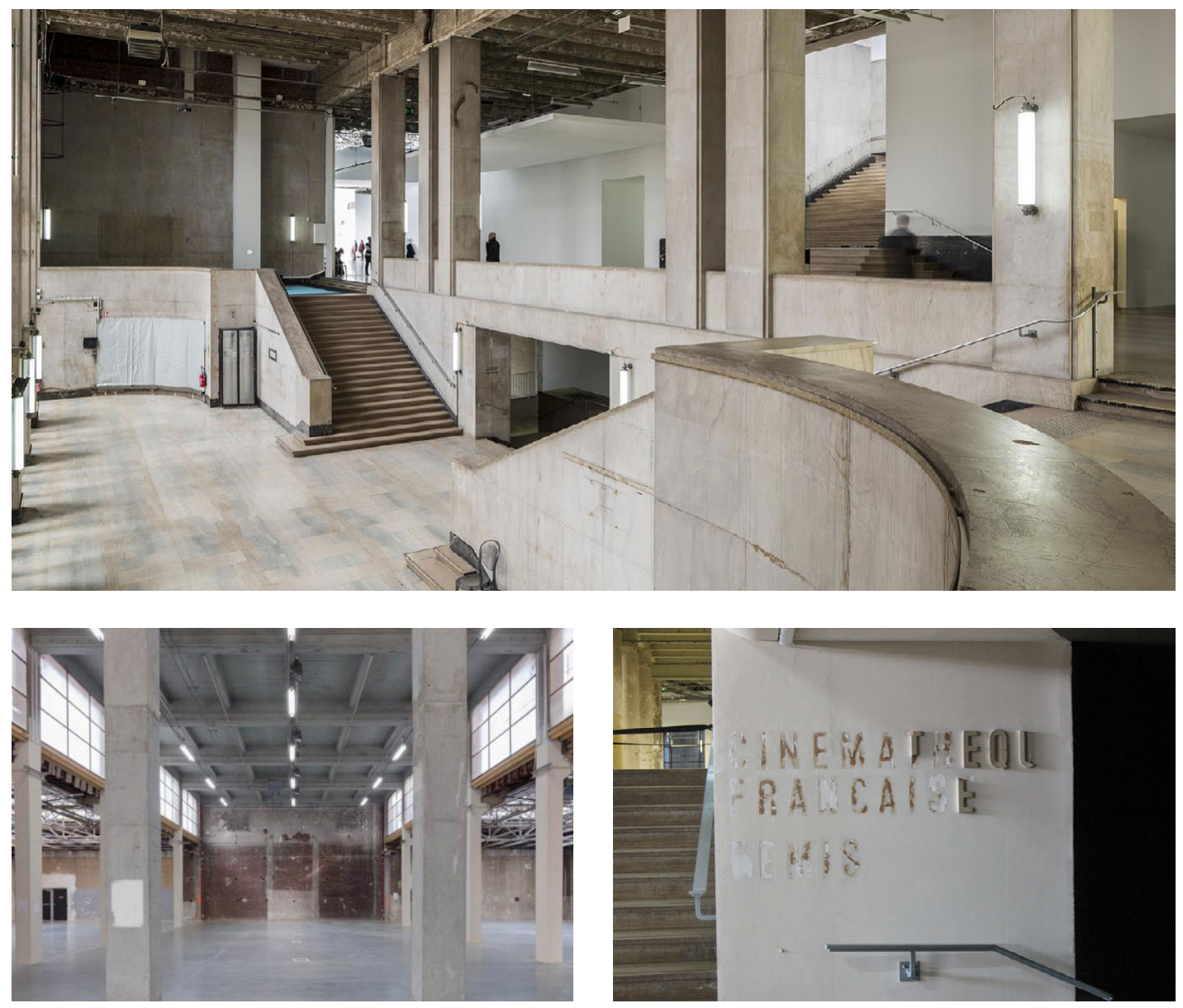

4.146 a 4.148 Interior do Palais de Tokyo, projeto de Lacaton \& Vassal, Paris, 2002-12. Foto 4.146: Gareth Gardner. Fontes: https://garethgardner.com/ portfolio/palais-de-tokyo, https:// decoyslettersfromparis.blogspot. com/2014/12/paris-disparu.html e http://www.palaisdetokyo.com/fr/ content/lieu-histoire-palais-de-tokyo e
Lacaton \& Vassal, cujo "imenso talento", segundo Lamarche-Vadel, consistiria em "aceitar que o gesto arquitetônico não está terminado no momento da entrega", deixando "um lugar que vai ser escrito por todos aqueles que vão habitá-lo depois". A dupla de arquitetura teria ido "o mais longe possível em seu campo de atividade" e caberia a artistas e curadores a responsabilidade de "dar vida ao lugar":

É um revezamento. Eles intervieram muito pouco e, de algum modo, essa atitude nos encoraja a encontrar soluções por nós 

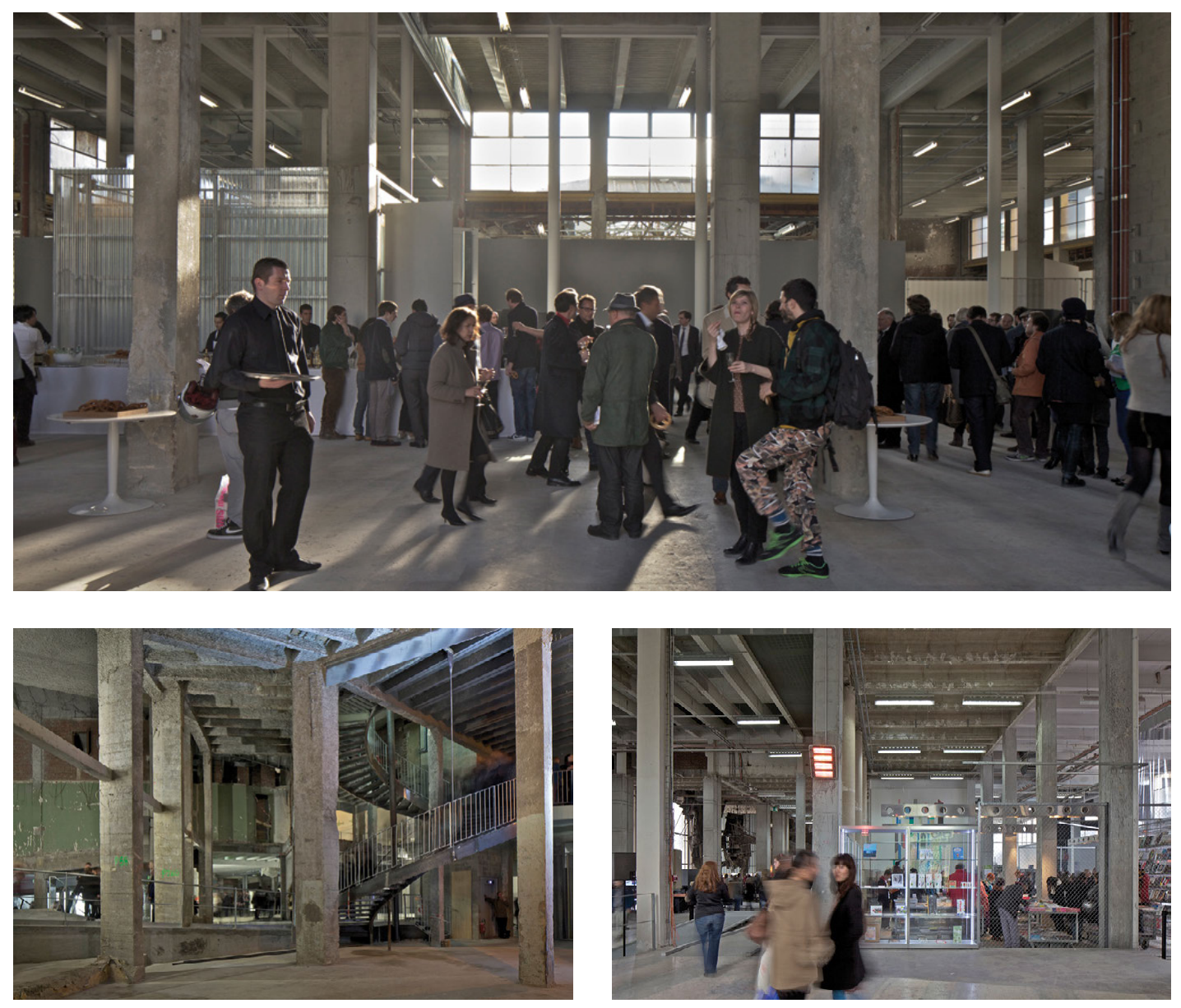

mesmos, ou seja, não há mais essa ideia de que a arquitetura se torna o principal mestre de obras para todo o sempre. ${ }^{704}$

E de fato novas soluções para o edifício tem sido buscadas sem a participação de Lacaton \& Vassal, seja para a implantação de novas atividades exercidas por concessionários - restaurante, livraria - como já previa o projeto, seja para as que são geridas pelo próprio centro - administração, setor educativo. O mesmo vale para as questões relacionadas a aspectos construtivos do edifício, que apresenta dificuldades constantes de manuten-
4.149 a 4.151 Interior do Palais de Tokyo, projeto de Lacaton \& Vassal, Paris, 2002-12. Foto: Philippe Rouault. Fonte: https://www.lacatonvassal.com/ index. php?idp $=20$

704 Ibidem. 

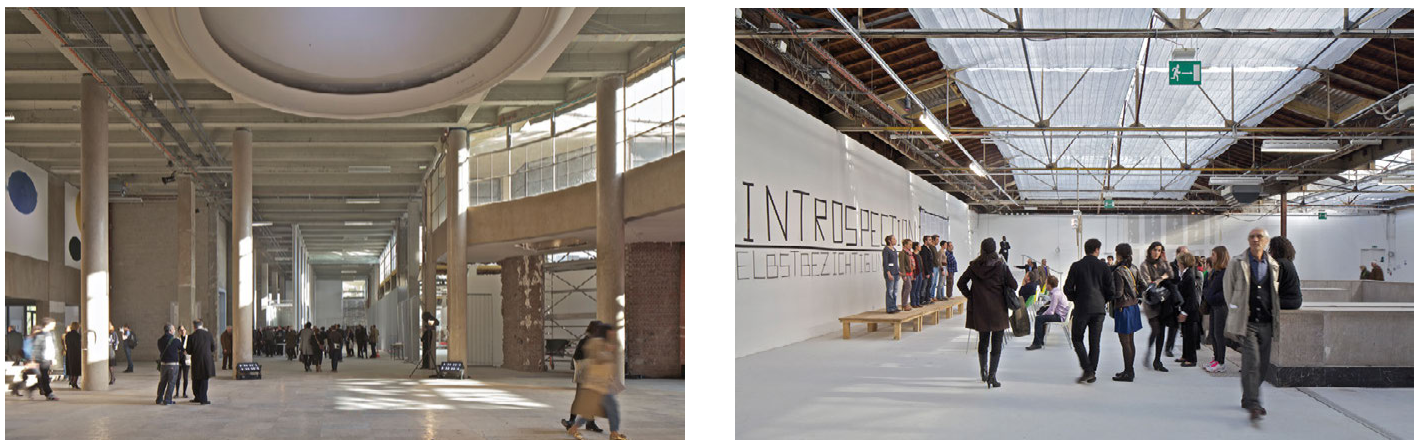

4.152 a 4.154 Interior do Palais de Tokyo, projeto de Lacaton \& Vassal, Paris, 2002-12. Foto: Philippe Rouault. Fonte: https://www.lacatonvassal.com/ index.php?idp $=20$
705 Ibidem.

706 Ibidem. ção, por sua dimensão gigantesca e a persistência de aspectos precários. Com sua grande área de cobertura envidraçada, o interior do edifício é extremamente exposto às condições externas, podendo atingir de 40 graus no verão a 10 graus negativos no inverno, além de apresentar frequentes vazamentos. O edifício só pode resistir nesse estado a partir da aceitação de suas limitações, que levam à impossibilidade de domínio sobre o espaço e, portanto, à incompatibilidade com as exigências de uma instituição museal tradicional.

"É sempre o mesmo jogo com as leis, com as regras", afirmou Lamarche-Vadel, "é preciso criar com a vantagem dos inconvenientes desse espaço. Isso nos dá uma enorme liberdade na criação de exposições, na criação de espaços, na transformação etc. e, ao mesmo tempo, restrições enormes, dentro dos limites do controle que se pode ter sobre o espaço." ${ }^{705}$ Conforme relatou a curadora, a necessidade de lidar com os constantes imprevistos decorrentes desta precariedade levou as pessoas que trabalham no centro, em geral muito apegadas ao lugar, a desenvolver um repertório próprio de improvisações que acabou estreitando as relações entre colegas. Em sua opinião, o edifício, imenso e "impossível de dominar", funcionaria como uma "zona de ocupação temporária", inspirando os membros da equipe a agir como "piratas". ${ }^{706}$

Pela forma como o edifício vem sendo utilizado por artistas e curadores, podemos observar que a sintonia entre a visão curatorial original de Bourriaud e Sans e a concepção arquitetônica de Lacaton \& Vassal, vem, afinal, sendo mantida por 
Se mesmo assim é possível considerar o Palais de Tokyo como um "lugar" favorável à experiência com a arte contemporânea, podemos supor, ainda que provisoriamente, que mais frutífero que "baixar a voz" da arquitetura, seria conceber espaços efetivamente abertos ao contexto cultural, criando assim condições que tornem mais evidentes a negociação inevitável entre arte e arquitetura no contexto contemporâneo. 
CONCLUSÃO 

Tendo em vista a hipótese de que, ao invés de uma disputa pelo protagonismo entre arte e arquitetura, tais campos possam estabelecer relações dialéticas e simbióticas nos espaços de instituições destinadas a exposições de arte contemporânea, foram eleitos como objetos de estudo desta tese duas instituições identificadas como paradigmas tomados como antagônicos enquanto abordagem arquitetônica e expográfica para arte contemporânea.

De um lado, o moma de Nova York representando o museu de arte moderna que considerou, desde as origens até os dias de hoje, que a arquitetura dos espaços expositivos deveria evitar "distrações" à experiência da arte, privilegiando uma ambientação "limpa" tendendo à "invisibilidade", como vimos especialmente em certas análises relativas ao projeto de Yoshio Taniguchi, concluído em 2004. Também extremamente custosa, a expansão mais recente empreendida pelo museu, inaugurada em 2019, manteve-se em grande medida nessa linhagem, tendo sido a principal demanda para o escritório Diller Scofidio + Renfro (DS+R) e seus colaboradores da Gensler a de ampliar ainda mais as galerias expositivas, oferendo às equipes de curadoria um território desimpedido - homogêneo, bem-acabado e livre de predeterminações -, para permitir montagens variadas de exposições da coleção ou temporárias.

Do outro lado do espectro, o Palais de Tokyo de Paris apresenta uma ambiência "ruidosa" que não passa despercebida pelo público visitante, devido às marcas de descontínuos usos pregressos que "contaminam" os espaços heterogêneos de sua arquitetura, mantidas visíveis a partir das intervenções mínimas, implementadas em 2002 e 2012, conforme projeto de Lacaton \& Vassal para reabilitação do edifício histórico, visando converte-lo num "local de criação contemporânea".

Se a resolução formal permite situar em polos opostos a abordagem da arquitetura e dos modos de apresentação da arte nessas duas instituições - contrapondo o "pristino" ao "mundano" -, o exame mais atento das condições de encomenda dos projetos, bem como das apropriações de seus espaços por intervenções artísticas e exposições, revelou algumas convergências que relativizam o simples antagonismo estabelecido inicialmente, ampliando as perspectivas para balizar futuros 
projetos de edifícios destinados à arte contemporânea, um dos objetivos desta tese.

\section{O CUBO BRANCO COMO REFERÊNCIA CULTURAL}

Vimos como os modos de apresentação da arte desenvolvidos pelo MомA desde os seus primórdios privilegiaram a apreensão de obras enquanto objetos autônomos, removendo progressivamente do espaço expositivo elementos que se interpusessem à relação de "intimidade" pretendida na sua contemplação. Esse tipo de espaço de arte "limpo" e encapsulado em si mesmo que Brian O'Doherty nomeara de “cubo branco", identificando em sua suposta neutralidade uma ideologia -, foi adotado como o habitat "natural" da arte moderna em museus e galerias do mundo todo. Tal forma de apresentação continua sendo empregada em mostras de arte contemporânea, apesar dos clamores dessa produção pela substituição da postura contemplativa pela participativa; e da noção de obra de arte autônoma pelo diálogo mais direto não apenas com o contexto físico, mas ainda com o sócio cultural e econômico.

Se não surpreende que o Moma siga adotando o mesmo padrão expositivo desenvolvido para a arte moderna em grande parte das mostras de arte contemporânea, causa maior estranheza que algumas das exposições realizadas no Palais de Tokyo recebam tratamento similar. Vemos que, no caso do Palais de Tokyo, montagens ao modo "cubo branco" produzem, inevitavelmente, um contraste com a arquitetura do edifício, gerando espécies de ilhas museológicas em meio à ambiência acidentada de sua arquitetura, trazendo uma camada adicional de significados para a exposição, integrando-se de modo mais evidente à proposta artística e curatorial. No MOMA, ao contrário, tal ambientação não produz esse efeito. Para provocar ali uma condição contrastante é necessário adotar um procedimento oposto ao da "limpeza" do espaço e da individuação das obras, uma vez que a maior parte da coleção e das exposições temporárias são apresentadas em espaços tratados homogeneamente desse modo convencionalmente estabelecido, privilegiando a apreciação individual de cada obra. Vimos 
com as mostras estudadas que o impacto da ambientação de uma exposição - e seu potencial para agregar significado a ela - não é dado apenas por sua configuração expográfica específica, mas depende de seu contexto de implantação numa determinada arquitetura e instituição, num determinando momento histórico.

Se é fato que o paradigma do "cubo branco" ainda predomina no MoмA - mesmo nas exposições de arte contemporânea -, isso por si só não implica numa insistência na suposta neutralidade do espaço expositivo. Trata-se, sobretudo, da afirmação da marca distintiva do museu, que o ancora na tradição da arte moderna, a partir da qual a instituição projeta a promoção e aquisição da produção recente. Abrir mão da prevalência desse modo de expor seria, possivelmente, disruptivo demais para a identidade do museu. Ou seja, assim como no Palais de Tokyo, a ambientação ao modo "cubo branco" em exposições de arte contemporânea no MoMA de hoje funciona como associação a uma referência cultural, não necessariamente como repetição de um padrão normativo de apresentação de obras, vinculado à ideologia da neutralidade, como argumentara O'Doherty em 1976. Desde então, tanto o contexto de produção da arte quanto a postura dessa instituição sofreram mutações. Passados trinta anos, o próprio autor apontou para a alteração do significado desse modelo, mediante a tomada definitiva do espaço pela arte, considerando especialmente a disseminação de novas mídias, que acabam por converter o "cubo branco" na "caixa preta":

Com a intrusão de instalações, vídeo e tudo o mais, o cubo branco tornou-se cada vez mais irrelevante; a galeria torna-se um site - 'o lugar', diz o dicionário, 'onde algo está, esteve ou deve estar.' A ligação dessa arte midiática com a cultura popular trouxe para a galeria energias indisciplinadas que não têm mais empenho na preservação do espaço branco clássico. Enquanto a galeria transformava outrora tudo o que estava nela em arte (e ainda o faz ocasionalmente), com essas mídias o processo se inverte: agora, essas mídias transformam a galeria, insistentemente, em seus termos. ${ }^{707}$
707 O'DOHERTY, Brian. Studio and Cube: On The Relationship Between Where Art is Made and Where Art is Displayed. Nova York: The Temple Hoyne Buell Center for the Study of American Architecture, 2009, p. 40. Tradução nossa. 
708 Cf. Diller, Elizabeth.

Entrevista concedida a Ana Paula Pontes no escritório da DS+R, Nova York, 18 de julho de 2017. Apêndice A desta tese.

709 Foster, Hal. O que vem depois da Farsa?, São Paulo: Ubu Editora, 2021, p. 90.
Foi pensando nas possibilidades literais de transformação da galeria por variadas formas de expressão contemporânea que o DS+R propôs para o MoMA um terceiro modelo de galeria, a “caixa cinza" - nomeada de Studio Gallery -: uma proposta de espaço arquitetônico cambiável, entre o "cubo branco" e a "caixa preta”, equipado para acomodar, além dos suportes convencionais de arte, eventos de natureza teatral, como performances e dança. ${ }^{708}$ Como observou Hal Foster, "qualquer museu que pretenda mostrar um conjunto representativo da arte moderna e contemporânea precisa, de alguma maneira, levar em consideração todos esses ambientes - num só edifício ou conjunto de edifícios." ${ }^{709}$ Assim como as exposições que abrigam, quaisquer desses modelos serão inevitavelmente percebidos não de modo isolado, mas em relação a seus contextos de implantação. Todavia, isso é especialmente mais efetivo no caso do "cubo branco", pelo fato desse padrão ter se tornado uma forte referência cultural - uma imagem que funciona como sinônimo de "espaço expositivo" -, o que pode ser explorado em termos de reiteração - como na maior parte das galerias do MoMA -, ou de contraste - quando inserido nos salões do Palais de Tokyo. Nesse sentido, o emprego atual desse paradigma por instituições de arte contemporânea pode ser lido na chave do conceito de "pós-produção" desenvolvido por Nicolas Bourriaud, ou seja, como um recurso estético e simbólico para inscrever uma exposição ou obra individual numa rede de significações culturais reconhecíveis. O "cubo branco" pode, assim, tornar-se um dado propositadamente perceptível de uma exposição, descolando-se de sua condição de invisibilidade, ou de suposta neutralidade.

É preciso, todavia, diferenciar o emprego da ambientação ao modo "cubo branco" em intervenções expográficas e instalações artísticas - de natureza temporária - de sua adoção em configurações arquitetônicas de salas expositivas - de cunho permanente. Vimos que é perfeitamente possível adotar temporariamente esse modelo no interior de um edifício cheio de cicatrizes e irregularidades como o Palais de Tokyo, mas as possibilidades de romper seus limites para estabelecer diálogos visuais com o contexto específico ficam de antemão limitadas se a própria arquitetura é definida como tal, como ocorre em grande parte das galerias expositivas do момА. 
Dado o reconhecimento do potencial de diálogo com a arquitetura para intensificar a experiência com a arte, já experimentado em exposições realizadas no átrio do MOMA, fez parte das demandas para o projeto de DS+R e Gensler não apenas a ampliação das salas especificamente destinadas à exposição, a maioria delas desenhadas de modo convencional, mas a criação de intervalos entre as galerias fechadas - ambientes de circulação e descanso -, que também foram usados como espaços expositivos para obras site-specific comissionadas para a ocasião da reabertura do museu, em 2019. Como vimos, o projeto procurou dotar o museu de mais espaços expositivos que instigassem a interação da produção contemporânea com a arquitetura, inserindo, em meio ao percurso ampliado de galerias convencionais, o conjunto de galerias sobrepostas desenhadas com características excepcionais - visualmente conectadas entre si e com a cidade ao redor.

As exposições examinadas nesta tese permitiram observar que ambos os edifícios estudados oferecem oportunidades de interlocução para propostas artísticas, apesar da evidente distinção entre a ambiência arquitetônica em cada um deles - assumidamente "precária" do Palais de Tokyo e ostensivamente bem-acabada no MOMA -, razão para terem sido tomados como paradigmas antagônicos. Se toda percepção da arte e de sua condição expográfica afeta e é ao mesmo tempo afetada pela arquitetura e pela instituição que o contém, qual seria o lugar da autoria em projetos arquitetônicos para espaços de arte contemporânea?

\section{O LUGAR DA AUTORIA NA ARQUITETURA DESTINADA À ARTE}

Enquanto artistas revelam possibilidades inusitadas de ativação dos espaços, transformando-os com suas intervenções, instituições cumprem um papel central na definição das bases para a arquitetura de suas sedes, estabelecendo o programa de necessidades, o orçamento a ser investido, o perfil das atividades e a própria escolha de escritórios de arquitetura que julgam mais apropriados para seus objetivos. Por razões distintas, eram estreitas as margens de atuação oferecidas à arquitetura tanto 
710 Cedric Price apud LACATON, Anne; VASSAL, Jean-Philippe. Palais de Tokyo. Lacaton \& Vassal. Disponível em: <https:// www.lacatonvassal.com/index. php?idp $=20 \#>$. Acesso em: 27 maio 2021. na expansão mais recente do MomA liderada por Diller Scofidio + Renfro quanto na intervenção inicial no Palais de Tokyo concebida por Lacaton \& Vassal. Todavia, a contenção expressiva de ambas as intervenções - cada qual ao seu modo - não se deve apenas às especificidades das demandas das respectivas instituições, mas coincidem com a própria visão de seus autores sobre até onde deveriam atuar mediante as condicionantes que se apresentavam em cada umas das situações.

Como vimos ao longo desta tese, os dois escritórios têm um denominador comum como referência para espaços destinados à criação artística: o projeto nunca construído para o Fun Palace, elaborado pelo arquiteto Cedric Price, em colaboração com a diretora teatral Joan Littlewood. Em consonância com experiências que surgiam na arte no momento em que foi concebido, na virada da década de 1950 para 1960 - sinalizando o deslocamento do foco do objeto acabado para a noção de participação do público - o Fun Palace não teria uma forma pré-estabelecida, mas estaria em constante transformação de acordo com propostas de utilização definidas livremente pelos usuários. À arquitetura não caberia manifestar-se enquanto resolução formal - tanto que o arquiteto nunca apresentou uma imagem acabada de seu projeto - mas fornecer um abrigo dotado de um sistema infraestrutural flexível, capaz de se adaptar à imprevisibilidade de seus usos futuros, integrando à construção recursos cibernéticos.

O Fun Palace foi tomado por Lacaton \& Vassal como referência para a ampliação do Palais de Tokyo em 2012, por ser considerado "um contêiner aberto e inteligente, que fabrica a liberdade de uso, a flexibilidade, a renovação dos projetos sem conformismo". ${ }^{710}$ Essas noções desenvolvidas no projeto de Price já haviam sido adotadas por Piano \& Rogers no projeto para o Centro Georges Pompidou de Paris, inaugurado em 1977, no qual é possível reconhecer inclusive soluções espaciais e construtivas similares às desenvolvidas no Fun Palace. A abordagem de Lacaton \& Vassal, no entanto, não é literal, mas conceitual, entendendo a estrutura e infraestrutura necessárias aos múltiplos usos não como a instalação de complexos mecanismos tecnológicos programados para diferentes configurações, mas como a disponibilização de uma grande área 
do edifício existente, dotada de condições básicas de utilização - apenas um abrigo amplo e suficientemente variado, aberto à imprevisibilidade. Para a dupla, o orçamento reduzido para a obra não foi uma limitação, mas uma "sorte" para o projeto -o que permitiu que o edifício fosse valorizado no estado em que estava, com a manutenção de suas qualidades essenciais e as marcas de sua história. ${ }^{711}$

O DS+R, por sua vez, remeteu-se ao Fun Palace para justificar o emprego de tecnologia sofisticada em prol da adaptabilidade no projeto para o The Shed de Nova York, concebido, segundo Diller, como "uma máquina de criar espaço para a arte", tratando-se "apenas de estrutura e infraestrutura". ${ }^{712}$ Apesar dessa declaração, vemos que o The Shed, assim como o Centro Pompidou, acaba por manifestar-se com uma resolução formal expressiva ao fornecer, com sua icônica capota móvel, uma imagem arquitetônica espetacular, que acaba por se adequar ao ambiente de ostensiva opulência advinda das recentes transformações urbanas de seu entorno, no bojo das quais o equipamento foi construído.

No projeto do MOMA, o DS+R não procurou agregar mais uma marca arquitetônica ao edifício, mas trabalhar a partir de um contexto dado, com discrição temperada apenas pelo virtuosismo estrutural em elementos pontuais como as novas escadarias e a marquise de entrada. Embora não compareça de modo espetacular como no The Shed, sistemas sofisticados para conferir flexibilidade aos espaços de arte também foram usados no projeto do museu, especialmente no caso da nova sala transformável denominada Studio Gallery, equipada para adaptar-se a uma grande variedade de configurações espaciais.

Refletindo sobre projetos destinados à arte contemporânea, Elizabeth Diller declarou que "a voz do arquiteto precisa ser reduzida para dar aos outros autores a chance de se expressar, pois não é possível 'apagar' a arquitetura e o espaço", ${ }^{713}$ enquanto Anne Lacaton afirmou que "o arquiteto não deve atuar demais para deixar espaço para artistas e para as obras". ${ }^{714} \mathrm{O}$ teor convergente das declarações das arquitetas - ambas mulheres eminentes num meio profissional em que figuras masculinas ainda recebem maior destaque - não deve ser visto como um acanhamento. ${ }^{715}$ Ao contrário,
711 COLUMBIA GSAPP. Lacaton \& Vassal. Youtube. Disponível em: <https://www.youtube.com/ watch?app $=$ desktop\&v=Twiz-dw9-e4\&feature=youtu.be $>$. Acesso em: 30 maio 2021.

712 Diller, Elizabeth. Entrevista concedida a Ana Paula Pontes no escritório da DS+R. Nova York, 18 de julho de 2017. Transcrição e tradução nossa.

713 Ibidem.

714 Anne Lacaton e Jean-Philippe Vassal. Comme une paysage sans limite. In: PALAIS DE TOKYO. Palais 15: Histoire du Palais de Tokyo depuis 1937. Paris: Palais de Tokyo, 2012, p. 104. Tradução nossa.

715 Elizabeth Diller e Anne Lacaton, nascidas respectivamente em 1954 e 1955, estabeleceram suas práticas profissionais em sociedade com seus maridos, como acontece com frequência no campo da arquitetura. Felizmente, o protagonismo de ambas não tem sido eclipsado pelo nome de seus parceiros, como costumava acontecer com a geração anterior. Exemplos disso são Denise Scott Brown (1931-), que não foi premiada com o Pritzker conferido em 1991 unicamente ao seu sócio e marido Robert Venturi (1925-2018), e Sue Rogers, que, sendo esposa e sócia de Richard Rogers na ocasião do concurso do Centro Georges Pompidou em 1971, é raramente mencionada como uma das autoras desse projeto. 
716 Constavam também na categoria “Titãs" da lista de 2018 o jogador de basquete Kevin Durant, o tenista Roger Federer, a apresentadora Oprah Winfrey e os empresários Jeff Bezos e Elon Musk. Cf. BROAD, Eli. Most Influential People 2018: Elizabeth Dilller. Time. Disponível em: <https://time.com/ collection/most-influential-people-2018/5217632/elizabeth-diller>. Acesso em: 15 maio 2021.

717 Ibidem.

718 HeAthcote, Edwin. Elizabeth Diller and Ricardo Scofidio: "The city is a public resource". $R A$ Magazine, 24/05/2019. ed. 2019.

719 THE HyatT Foundation. The Pritzker Architecture Prize Purpose. Pritzker Prize. Disponível em: <https://www.pritzkerprize.com/about>. Acesso em: 15 maio 2021. Tradução nossa. sinalizam uma postura assertiva em prol de uma visão de projeto enquanto processo estratégico de definição de prioridades e pertinências vinculadas a suas contingências, ainda que possa eventualmente resultar num recuo da visibilidade autoral da arquitetura para ceder protagonismo à arte, como vemos tanto no MomA quanto no Palais de Tokyo, apesar das evidentes distinções.

Por diferentes razões, a atuação desses dois escritórios vem ganhando reconhecimento no campo arquitetônico e além dele. Em 2018, Elizabeth Diller figurou pela segunda vez na lista anual das 100 mais influentes personalidades mundiais da revista Time. Além de ser a única representante da arquitetura dessa edição, seu nome foi incluído na categoria "Titãs", ao lado de pessoas ligadas a meios mais midiáticos como esportes, negócios, política e artes em geral. ${ }^{716}$ Para Eli Broad, dono da coleção para quem o DS+R projetara um museu de arte contemporânea inaugurado em 2015 em Los Angeles, a arquiteta seria uma "visionária": "Ela imagina coisas que o resto de nós tem que ver para acreditar. Ela é capaz de transformar uma metáfora em tijolo e argamassa."717 Em 2019, o DS+R recebeu o prêmio anual da Royal Academy of Arts de Londres - RA Architecture Prize. Na opinião do arquiteto e crítico britânico Edwin Heathcote (1968-),

Diller Scofidio + Renfro são um dos raros praticantes que parecem ter negociado com sucesso a jornada de queridinhos da vanguarda a uma atuação global de sucesso comercial sem, aparentemente, perder sua alma ou sua inteligência [...]. Mais importante, porém, eles se ancoraram a uma ideia da cidade como um recurso público, sempre assumindo obras que tenham um aspecto cívico, alguma contribuição para a vida urbana além da construção. ${ }^{718}$

Em 2021, o escritório Lacaton \& Vassal recebeu o principal prêmio internacional da arquitetura, o Pritzker Price, que tem como propósito "homenagear um arquiteto ou arquitetos vivos cuja obra construída demonstra uma combinação das qualidades de talento, visão e comprometimento que produziram contribuições consistentes para a humanidade e o ambiente construído por meio da arte e da arquitetura". ${ }^{719} \mathrm{O}$ anúncio da premiação de 
Lacaton \& Vassal destacou o vínculo de sua atuação profissional com a responsabilidade socioeconômica e ambiental:

Através de seus projetos de habitações particulares e sociais, instituições culturais e acadêmicas, espaços públicos e desenvolvimentos urbanos, Lacaton e Vassal reexaminam a sustentabilidade em sua reverência por estruturas pré-existentes, concebendo projetos fazendo primeiro um inventário do que já existe. Ao priorizar o enriquecimento da vida humana pelo prisma da generosidade e da liberdade de uso, são capazes de beneficiar o indivíduo social, ecológica e economicamente, auxiliando na evolução de uma cidade..$^{720}$

Sobre o Palais de Tokyo, uma das realizações mais importantes da dupla, o anúncio do prêmio apontou para as qualidades oferecidas pelo projeto a seus usuários - artistas, curadores e visitantes:

Afastando-se de galerias tipo cubo branco com percursos dirigidos que são característicos de muitos museus de arte contemporânea, os arquitetos criaram espaços amplos e inacabados. Esses espaços permitem que artistas e curadores criem exposições ilimitadas para todos os meios de arte em uma variedade de ambientes físicos, desde escuros e cavernosos até transparentes e iluminados pelo sol, que incentivam os visitantes à permanência. ${ }^{721}$

É preciso, todavia, reiterar o que foi observado ao longo desta pesquisa: se o Palais de Tokyo obteve êxito, afirmando-se como um dos principais espaços de arte contemporânea do ocidente, isso se deve não apenas à aclamada abordagem arquitetônica de Lacaton \& Vassal, mas à sincronia entre sua forma de atuação e os objetivos da instituição - expressos num projeto curatorial -, e ainda à forma como o centro vem sendo explorado por propostas artísticas. Dialogar com as características essenciais de um lugar existente é uma premissa compartilhada pelos arquitetos, pela instituição e por boa parte da produção contemporânea.

Se, de modo genérico, essa premissa também comparece no MOMA, os objetivos específicos dessa instituição são bastante
720 The HyatT Foundation. Anne Lacaton and Jean-Philippe Vassal Receive the 2021 Pritzker Architecture Prize. Pritzker Prize. Disponível em: $<$ https://www. pritzkerprize.com/laureates/ anne-lacaton-and-jean-philippe-vassal>. Acesso em: 2 maio 2021. Tradução nossa.

721 Ibidem. 
diversos, estando calcados na ambição desenfreada por expandir-se cada vez mais, a partir do acúmulo de objetos para o seu acervo. Esse impulso expansionista explicita as tensões entre as perspectivas mais progressistas que motivaram a revisão curatorial e a consequente ampliação das galerias - visando mostrar a arte moderna e contemporânea de um modo mais abrangente e inclusivo - e a insaciabilidade que repercute os valores consumistas do capitalismo vigente, do qual a arte não fica isenta. É contra esse pano de fundo que poderemos observar de agora em diante de que forma a arte virá a se engajar nos espaços físicos e simbólicos do MOMA, depois da intervenção de Diller Scofidio + Renfro e Gensler.

\section{ARQUITETURA, INSTITUIÇÃO E ARTE NA CONTEMPORANEIDADE}

Vimos ao longo desta tese como museus e centros de arte estão inseridos numa imbricada teia de relações, em permanente transformação. A própria definição de museu estabelecida pelo International Council of Museums (ICOM) está passando por um extenso processo de atualização, iniciado em 2016, "para fazer frente aos novos desafios do mundo contemporâneo. "\$22 Tal é a definição vigente desde 2007:

O museu é uma instituição permanente sem fins lucrativos, ao serviço da sociedade e do seu desenvolvimento, aberta ao público, que adquire, conserva, investiga, comunica e expõe o patrimônio material e imaterial da humanidade e do seu meio envolvente com fins de educação, estudo e deleite. ${ }^{723}$

722 ICOM BRASIL. Nova Definição de museu: consulta aberta. ICOM $B R$. Disponível em: $<$ https://www. icom.org.br/? $\mathrm{p}=2211>$. Acesso em: 6 jun. 2021.

723 Ibidem.
Um comitê designado para esse fim selecionou uma das cinco propostas de revisão levantadas em encontros e oficinas promovidos ao redor do mundo, para submetê-la à aprovação por

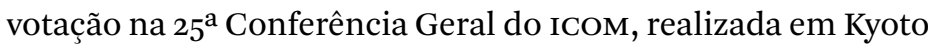
em 2019, com o seguinte teor:

Os museus são espaços democratizantes, inclusivos e polifônicos que atuam para o diálogo crítico sobre os passados e os futuros. Reconhecendo e abordando os conflitos e desa- 
fios do presente, mantêm artefatos e espécimes de forma confiável para a sociedade, salvaguardam memórias diversas para as gerações futuras e garantem a igualdade de direitos e a igualdade de acesso ao patrimônio para todos os povos. Os museus não têm fins lucrativos. São participativos e transparentes e trabalham em parceria ativa com e para as diversas comunidades, a fim de colecionar, preservar, investigar, interpretar, expor e ampliar as compreensões do mundo, com o propósito de contribuir para a dignidade humana e a justiça social, a equidade mundial e o bem-estar planetário. ${ }^{724}$

Mediante os debates suscitados pelas marcantes diferenças entre as duas definições, decidiu-se pela prorrogação até a próxima conferência geral, a ser realizada em Praga, em 2022, e pelo estabelecimento de um amplo processo de consultas junto aos comitês nacionais, liderado por um novo grupo de trabalho central - о ICOM Define. Ainda que não tenha sido aprovada, podemos extrair da redação apresentada em 2019 aspectos que apontam para um novo entendimento sobre o papel social dos museus: um dever de se comprometer com pautas mais progressistas, que vêm ganhando destaque em diferentes esferas da vida contemporânea. Ao enfatizar o objetivo de atuar em prol de um "debate crítico", o texto em discussão apresenta, de modo implícito, uma proposta de diluição da condição tradicional de autoridade dos museus sobre o patrimônio material e imaterial da humanidade.

Não é difícil identificar o alinhamento ou não de uma determinada instituição de arte aos diversos propósitos elencados nessa definição tendo em vista o perfil de sua programação e os modos de relacionamento com o público, mas seria possível pensar em balizas para a arquitetura nesses termos? Como identificar projetos arquitetônicos para espaços de arte contemporânea enquanto "espaços democratizantes, inclusivos e polifônicos"? Algumas das premissas compartilhadas pelos dois casos estudados nesta tese podem, de certa forma, apontar para essas qualidades. De um lado, uma assumida contenção formal - uma "voz rebaixada" da arquitetura para dar espaço à arte e, de outro, uma valorização das características específicas de um lugar - do ponto de vista físico e arquitetônico, 724 Ibidem. 
725 MARINA Abramović: The Artist is Present. Direção: Matthew Akers. Produção: Jeff Dupre. [S.l.]: HBO Documentary Films, MusicBox Films, 2012. 1 DVD (106 min), color. simbólico e institucional. Vemos, assim, que essas qualidades independem de atributos ligados a uma referência estética pré-definida, mas resultam de um entendimento de que o projeto arquitetônico de um espaço dedicado à produção contemporânea é um dos diversos agentes de ação sobre o espaço, compondo a requerida "polifonia" na articulação com a condução institucional e a transformação pela arte, de modo a fomentar de diferentes maneiras o engajamento inclusivo e democrático do público com a produção artística.

Vimos o момA transformar-se num templo-palco para que os visitantes encarassem Marina Abramović nos olhos. A multidão aglomerada ao redor do átrio para participar do ritual permitiu atestar a vocação do museu para conferir valor ao que é apresentado em seus espaços, amplificando o magnetismo da artista e de sua obra - ainda que essa fosse imaterial. Ressaltando seu status de celebridade, Abramović se deixou registrar não apenas durante a ação no museu, mas em diversas situações privadas vivenciadas por ela na época de sua preparação e realização, extensamente documentadas no filme que leva o nome da mostra, fazendo reverberar no tempo parte da experiência originalmente efêmera de sua performance. ${ }^{725}$

Observamos o edifício do Palais de Tokyo totalmente esvaziado de elementos físicos para a mostra de Tino Seghal, convertendo-se num território de interações humanas imprevisíveis entre o público e centenas de participantes realizando as ações desenhadas pelo artista. O estado de rarefação dos amplos salões desocupados durante o evento evidenciou a extrema disponibilidade espacial do edifício, intensificando a proposta do artista de não produzir rastros materiais. Tendo Seghal vetado a produção de qualquer impresso de divulgação ou documentação audiovisual oficial do evento, restam como registro apenas fotos e vídeos produzidos espontaneamente por visitantes, além de desenhos realizados por seu colega Philippe Parreno. $\mathrm{O}$ resgate dessa experiência fica atrelado a relatos pessoais de quem a vivenciou diretamente - uma outra forma de repercutir as interações humanas provocadas pela ação.

Ambos os eventos exemplificam de modo contundente os papeis tanto do Moma como do Palais de Tokyo - com suas respectivas orientações institucionais e molduras arquite- 
tônicas - como agentes determinantes para a produção e a vivência da arte que abrigam em seus domínios. O estudo das duas instituições confirma a hipótese de que a singularidade arquitetônica de espaços de museus e centros de exposição não gera necessariamente uma limitação para exposições de arte contemporânea. Ao contrário, ao propiciar modos variados de integração do conteúdo das propostas artísticas com a arquitetura, a definição de espaços destinados à arte como lugares particulares permite ampliar as oportunidades de interação com o contexto, explicitando, de modo bem-vindo, a polifonia que caracteriza a cultura contemporânea.

\section{EM TEMPO}

Considerando que esta tese trata das relações cruzadas entre arte, arquitetura e instituição como campos que se retroalimentam, englobando ainda conjunturas socioculturais mais amplas, julgo pertinente circunstanciar a particularidade do momento em que foi concluída. O período em que transcorreu a redação, do início de 2020 a meados de 2021, coincidiu com o surgimento e o recrudescimento da pandemia de Covid-19 e com a necessidade de distanciamento social para conter a contaminação pelo novo coronavírus, impactando o funcionamento de museus e exposições do mundo todo, em meio à suspensão ou adaptação de tantas atividades que contávamos como essenciais em nossas vidas. Mediante a interdição de encontros presenciais de toda ordem e de suas consequências para as perspectivas de engajamento do público com a arte no espaço concreto das instituições, é válido indagar em que medida os dados em que se baseiam este doutorado, iniciado em 2017, se mostrarão distantes da realidade social em que nos encontraremos após a sua conclusão. Será apenas momentânea a substituição do contato direto com obras e exposições pela interação restrita a meios virtuais? Continuará o espaço arquitetônico das instituições o local privilegiado ou mesmo essencial para esse encontro? Seguirá relevante a discussão desta tese, que atrela a arquitetura à experiência da arte, no contato físico com o público? 
Enquanto desconhecemos os desdobramentos do porvir, as respostas que podemos dar só podem ser baseadas na reflexão sobre as vivências acumuladas no presente, projetando cenários futuros de modo especulativo. Ao longo deste período excepcional em que ainda estamos, pelo menos no Brasil, temos observado o esforço feito por diversas instituições de arte em manter o diálogo com seu público por meio da intensificação de ações que já vinham ocorrendo antes e que ganharam agora maior urgência, como a disponibilização pela internet de registros fotográficos e audiovisuais de exposições, a promoção de encontros virtuais com agentes como curadores, artistas, produtores e educadores, além da realização de exposições e obras concebidas exclusivamente para meios digitais. Alguns ganhos têm se mostrado notáveis, como a possibilidade de acesso instantâneo a registros e eventos sediados à distância, sem a necessidade de deslocamento físico, ou a divulgação dos processos internos de trabalho dos museus e centros de arte, deixando entrever a complexidade e a multiplicidade de agentes envolvidos em suas realizações. Embora benéficas para os momentos extremos de restrição de encontros presenciais - e com potencial para serem permanentemente incorporadas -, essas medidas acabaram por confirmar o que já suspeitávamos: que a vivência direta com obras e exposições concebidas para espaços físicos ainda está longe de poder ser satisfatoriamente substituída pelos recursos de mediação baseados nas tecnologias digitais de que dispomos atualmente. Sons e imagens registrados de antemão e transmitidos em telas de computador, celular ou tablet conseguem ser apenas fragmentos da experiência multissensorial que uma pessoa pode ter se comparado à possibilidade de estar fisicamente presente num espaço qualquer, o que é particularmente vital nos espaços destinados à arte, de natureza pública e coletiva e cuja linguagem opera no campo do sensível.

Creio ser essa uma das razões pelas quais vimos tantas instituições de arte que, obrigadas a manter suas portas fechadas ao público por longos períodos, preferiram, em vez de simplesmente cancelar sua programação de exposições e migrar essas atividades para a esfera virtual, adaptar suas agendas e implantar complexos protocolos sanitários para reabrir a visita- 
ção a cada oportunidade possível. A ânsia pela possibilidade do reencontro presencial que temos percebido nas mais variadas esferas da vida nos permite seguir apostando na relevância do encontro físico para as trocas humanas e, consequentemente, na pertinência de afirmar que, em instituições destinadas a propostas artísticas, cujo principal propósito é a promoção da cultura contemporânea e seu engajamento com o público, a arquitetura é fator essencial. 



ALTSHULER, Bruce (Ed.). Biennials and Beyond. Exhibitions That Made Art History: 1962-2002. Londres: Phaidon, 2013.

Altshuler, Bruce (Ed.). Salon to Biennial. Exhibitions That Made Art History: 1893-1959. Londres, Nova York: Phaidon, 2008.

APPLE, Jacki. Alternatives in Retrospect: An Historical Overview, 1969-1975. Nova York: The New Museum, 1981. ARKEN MUSEUM OF MODERN ART. The Model: Palle Nielsen. Ishøj: ARKEN Museum of Modern Art, 2015.

ASHER, Michael. Writings 1973-1983 on Works 1969-1979. Halifax e Los Angeles: The Press of the Nova Scotia College of Art and Design e The Museum of Contemporary Art Los Angeles, 1983 .

BARR JR., Alfred H.; JOHNSON, Phillip (Orgs.). Machine art. Nova York: The Museum of Modern Art, 1934.

BATCHELOR, David. Minimalismo. São Paulo: Cosac Naify Edições, 1999.

BIESENBACH, Klaus; FUNCKE, Bettina (Orgs.). MoMA PS1: A History. Nova York: The Museum of Modern Art, 2019.

BISHOP, Claire. Installation Art. Londres: Tate Publishing, 2005.

BOURRIAUD, Nicolas. Estética relacional. São Paulo: Martins Fontes, 1998. Bourriaud, Nicolas. Pós-produção: Como a arte reprograma o mundo contemporâneo. São Paulo: Martins Fontes, 2010.

BURTON, Scott. Artist's Choice: Burton on Brancusi. Nova York: The Museum of Modern Art, 1989.

CLOSE, Chuck. Artist's Choice: Chuck Close, Head-On/The Modern Portrait.
Nova York: The Museum of Modern Art, 1991.

COOLIDGE, John. Patrons and Architects:

Designing Art Museums in the Twentieth Century. Fort Worth: Amon Carter Museum, 1989.

CRIMP, Douglas. Sobre as ruinas do museu. São Paulo: Martins Fontes, 2005.

ELDERFIELD, John (ed.). Imagining the Future of The Museum of Modern Art. Nova York: The Museum of Modern Art, 1998. (Studies in Modern Art). ELligot, Michelle. René D'Harnoncourt and the Art of Installation. Nova York: The Museum of Modern Art, 2018.

FOSTER, Hal. O complexo Arte-Arquitetura. São Paulo: Cosac Naify Edições, 2015.

FOSTER, Hal. O que vem depois da Farsa? São Paulo: Ubu Editora, 2021. FOSTER, Hal; KRAUSS, Rosalind; BOIS, Yves-Alain; et al. Art Since 19oo: Modernism, Antimodernism, Postmodernism. Londres: Thames \& Hudson, 2004.

GOOSSEN, E. C. The art of the real USA, 1948-1968. Nova York: The Museum of Modern Art, 1968.

GREENBERG, Clement. Arte e Cultura. São Paulo: Editora Ática, 1996.

GRYNSZTEJN, Madeleine. Take Your Time: Olafur Eliasson. Nova York e Londres: Thames \& Hudson e San Francisco Museum of Modern Art, 2008.

HOLSINGER, M. Paul (Org.). War and American Popular Culture: A Historical Encyclopedia. Westport: Greenwood Press, 1999.

HUNTER, Samuel. Introduction. In: The Museum of Modern Art, New 
York. 8a. edição. Nova York: Harry N. Abrams e The Museum of Modern Art, 1984, p. 8-41.

HUNTER, Samuel. Jackson Pollock. Nova York: The Museum of Modern Art, 1956.

INSTITUTO MOREIRA SALLES. Anri Sala:

O momento presente. Rio de Janeiro e São Paulo: Instituto Moreira Salles, 2016.

KANTOR, Sybil Gordon. Alfred H. Barr, Jr. and the Intellectual Origins of the Museum of Modern Art. Londres, Nova York: The MIT Press, 2002.

KWON, Miwon. One place after another : site-specific art and locational identity. Boston: Massachusetts Institute of Technology, 2002.

LAMSTER, Mark. The Man in The Glass House. Boston: Little, Brown and Company, 2018.

LICHT, Jennifer. Spaces. Nova York: The Museum of Modern Art, 1969.

LIPPARD, Lucy R. Six years: the dematerialization of the art object from 1966 to 1972. Berkeley e Los Angeles: University of California Press, 2001.

LORENTE, Jesùs Pedro. The Museums of Contemporary Art: Notion and Development. Surrey; Burlington: Ashgate Publishing, 2011.

LÖSCHKE, Sandra Karina. Materials-in-fact: Material aesthetics and ethics in Lacaton \& Vassal's Palais de Tokyo. In: Materiality and Architecture. Nova York: Routledge, 2016.

MCSHINe, Kynaston L. Information. Nova York: The Museum of Modern Art, 1970.

O'DOHERTy, Brian. No Interior do Cubo Branco: a ideologia do espaço da arte. São Paulo: Martins Fontes, 2002.

O'DOHERTY, Brian. Studio and Cube. Nova York: The Temple Hoyne Buell Center for the Study of American Architecture, 2009.
OBRIST, Hans Ulrich. Uma breve história da curadoria. São Paulo: BEI, 2010.

PALAIS DE TOKYO. Palais 15: Histoire $d u$ Palais de Tokyo depuis 1937. Paris: Palais de Tokyo, 2012. (Palais).

PETZET, Muck; HEILMEYER, Florian; VERLAG, Hatje Cantz (Ed.). Surplus - Reduce Reuse Recycle-Architecture as Resource. Ostfildern, Berlim: German Pavilion at the 13 th Venice Architecture Biennale, 2012.

REED, Peter; SILVER-HOHN, Romy. Oasis in the City: The Abby Aldrich Rockefeller Sculpture Garden at The Museum of Modern Art. Nova York: The Museum of Modern Art, 2018. REISS, Julie H. From margin to center: the spaces of installation art. Cambridge, Massachussets: Massachusetts Institute of Technology, 1999. ROSENBERG, Harold. A tradição do novo. São Paulo: Perspectiva, 1974. (Coleção Estudos).

RUBIN, William Stanley. A curator's quest: building the collection of painting and sculpture of the Museum of Modern Art, 1967-1988. Nova York: Harry N. Abrams, 2011.

SANDLER, Irving; NEWMAN, Amy (Orgs.). Defining Modern Art: Selected Writings of Alfred Barr, Jr., . Nova York: Harry N. Abrams, 1986.

SEROTA, Nicholas. Experience or Interpretation: The Dilemma of Museums of Modern Art. Londres: Thames \& Hudson, 2000.

SHAPIRO, Meyer. Arte Moderna Séculos XIX $e$ XX. São Paulo: EDUSP, 1994.

STANISZEWSKI, Mary Anne. The Power of Display: a history of exhibition at the Museum of Modern Art. Cambridge, Londres: The MIT Press, 1998. STONE, Edward Durrel. The Evolution of an Architect. Nova York: Horizon Press, 1962. 
STORR, Robert. Dislocations. Nova York: The Museum of Modern Art, 1991.

TANIGUCHI, Yoshio. The Architecture of Yoshio Taniguchi. Nova York: Harry N. Abrams, 1999.

THE MUSEUM OF MODERN ART. African Negro Art. Nova York: The Museum of Modern Art, 1935.

THE MUSEUM OF MODERN ART. Art in our time: color portfolio. Nova York: The Museum of Modern Art, 1939.

THE MUSEUM OF MODERN ART. Cubism and abstract art. Nova York: The Museum of Modern Art, 1936.

THE MUSEUM OF MODERN ART. Marina Abramovic: The Artist Is Present. Nova York: The Museum of Modern Art, 2010.

THE MUSEUM OF MODERN ART. Modern Architecture: international exhibition.
Nova York: The Museum of Modern

Art, 1932.

THE MUSEUM OF MODERN ART. MOMA

Now. Nova York: The Museum of

Modern Art, 2019.

THE MUSEUM OF MODERN ART. Road to victory, a procession of photographs of the nation at war directed by Lt. Comdr. Edward Steichen, U.S.N.R. Nova York: The Museum of Modern Art, 1942.

THE MUSEUM OF MODERN ART. Timeless Aspects of Modern Art: the first of a series of exhibitions marking the 2oth anniversary of the Museum of Modern Art, New York. Nova York: The Museum of Modern Art, 1948. тотA, Antonio Pedro. O imperialismo sedutor: a americanização do Brasil na época da segunda guerra. São Paulo: Companhia das Letras, 2000.

\section{ARTIGOS}

ARANTES, Otília B. F. Os Novos Museus. Novos Estudos - CEBRAP, n. 31, p. 161169, 1991.

BAYER, Herbert. Aspects of Design of Exhibitions and Museums. Curator: The Museum Journal, v. 4, p. 257-288, 1961. Disponível em: < https://doi. org/10.1111/j.2151-6952.1961.tbo1561. $\mathrm{x}>$. Acesso em: 16 fev. 2020.

BENES, Mirka. Inventing a Modern Sculpture Garden in 1939 at the Museum of Modern Art, New York. Landscape Journal, v. 13, p. 1-20, 1994. Disponível em: <http://lj.uwpress. org/content/13/1/1.full.pdf + html $>$. Acesso em: 15 mar. 2020.

BISHOP, Claire. Antagonism and Relational Aesthetics. October, v. 110, p. 51-79, 2004. Disponível em: $<$ https://doi. org/10.1162/0162287042379810>. Acesso em: 27 maio 2021.
CoHen, Alina. The 5 Biggest Changes to Look for at the New Moma. Artsy, 11/10/2020. ed. 2020. Disponível em: $<$ https://www.artsy.net/article/artsy-editorial-5-changes-new-moma> . Acesso em: 30 out. 2020.

DAVIDSON, Justin. The New Moma Tries to Get Out of Its Own Way. We'll See If It Can. New York Magazine, 9/10/2019. ed. 2019. Disponível em: <https://nymag.com/intelligencer/2019/10/review-of-the-renovated-museum-of-modern-art.html>. Acesso em: 16 out. 2020.

DAVIDSON, Justin; SALTz, Jerry. Two Critics - Art and Architecture Compare Their moma Experiences. New York Magazine, 19/11/2019. ed. 2019. Disponível em: <https:// www.vulture.com/2019/10/jerry-saltz-and-justin-davidson-on-the- 
-new-moma.html>. Acesso em: 16 out. 2020.

Duncan, Carol; Wallach, Alan. Museum Of Modern Art As Late Capitalist Ritual: An Iconographic Analysis. Marxist Perspectives, v. 4, p. 28-51, 1978.

DURBIN, Andrew. What Does the New MomA Mean for Contemporary Art? Frieze Magazine, 16/10/2020. ed. 2020. Disponível em: $<$ https://www. frieze.com/article/what-does-new-moma-mean-contemporary-art>. Acesso em: 2 nov. 2020.

FOOTE, Nancy. The Apotheosis of the Crummy Space. Artforum, p. 28-37, 1976.

FOSTER, Hal. At Dia: Beacon: Fetishistic Minimalist. London Review of Books, v. 25, n. 11, 2003. Disponível em: <https://www.lrb.co.uk/the-paper/v25/n11/hal-foster/at-dia-beacon>. Acesso em: 26 jun. 2021.

FOSTER, Hal. It's Modern but is it contemporary? London Review of Books, v. 26, n. 24, p. n.p, 2004. Disponível em: <https://www.lrb.co.uk/the-paper/v26/n24/hal-foster/it-s-modern-but-is-it-contemporary>. Acesso em: 20 set. 2020.

FOSTER, Hal. Mudança no MOMA. ARS, v. 315, n. 18 (38), p. 315-327, 2020. Disponível em: <https://www.revistas. usp.br/ars/article/view/169115>. Acesso em: 16 out. 2020.

FOSTER, Hal. Museum Tales of Twentieth-Century Art. In: Dialogues in Art History, from Mesopotamian to Modern: Readings for a New Century. Washington: National Gallery of Art, 2009, v. 74, p. 352-375. (Studies in the History of Art). Disponível em: <https://www.jstor.org/stable/42622733>. Acesso em: 23 set. 2019. FOSTER, Hal; HOLLIER, Denis; KOLвоWSKI, Silvia; et al. The момA
Expansion: A Conversation with Terence Riley. October, v. 84, p. 3-30, 1998. Disponível em: <https://www. jstor.org/stable/779206>. Acesso em: 2 out. 2019.

FRANKLIN, Sydney. MOMA reopens with a $\$ 450$ million megaexpansion and slick renovation. The Architects Newspaper, 16/10/2019. ed. 2019. Disponível em: <https://www.archpaper.com/2019/10/moma-reopens/>. Acesso em: 16 out. 2020.

FRASER, Andrea. Da crítica às instituições a uma instituição da crítica. Concinnitas, v. 2, n. 13, p. 178-187, 2008. (Programa de Pós-Graduação em Artes do Instituto de Artes da Uerj). Disponível em: <https:// www.e-publicacoes.uerj.br/index. php/concinnitas/article/view/55510>. Acesso em: 18 maio 2021.

GLUECK, Grace. Abandoned School in Queens Lives Again as Arts Complex. The New York Times, 10/06/1976. ed. p. 38, 1976. Disponível em: <https:// www.nytimes.com/1976/o6/10/archives/abandoned-school-in-queens-lives-again-as-arts-complex.html>. Acesso em: 25 maio 2020.

GOldBerger, Paul. Outside the Box. The New Yorker, 15/11/2004. ed. 2004. Disponível em: <https:// www. newyorker.com/magazine/2004/11/15/outside-the-box $>$. Acesso em: 27 set. 2020.

GRASSKAMP, Walter. The white wall - on the prehistory of the 'white cube'. Oncurating: Curating critique, p. 78-90, 2011. Disponível em: $<$ http://www.oncurating.org/index. php/issue-9.html\#.U2GlX61dV4I $>$. Acesso em: 26 jun. 2016.

GREENBERGER, Alex. Activists Interrupt момА Opening Party, Urging Museum, Trustee to Cut Alleged Ties to Private Prisons. ARTnews, 
18/10/2020. ed. 2020. Disponível em: <https:/www.artnews.com/ art-news/news/moma-opening-party-larry-fink-protest-13420/>. Acesso em: 1 nov. 2020.

GROYS, Boris. Politics of Installation. E-flux, n. Journal \#02, p. 1-8, 2009. Disponível em: <https://www.e-flux.com/journal/o2/68504/ politics-of-installation/>. Acesso em: 28 dez. 2020.

GROYS, Boris. Politics of Installation. E-flux, n. Journal \#02, p. 1-8, 2009. Disponível em: <https://www.e-flux.com/journal/o2/68504/ politics-of-installation/>. Acesso em: 28 dez. 2020.

HALLE, David; TISO, Elisabeth. Lessons from Chelsea. International Journal of the Humanities, v. 3, n. 11, p. 45-66, 2006. Disponível em: <https://books. google.com.br/books?id=BQF5AgAAQBAJ\&pg $=$ PA224\&lpg $=$ PA224\&dq $=-$ firts+galellery+moved+to+Chelsea\&source $=$ bl\&ots $=$ N2StnqOFJ_\&sig $=$ AC $\mathrm{fU}_{3} \mathrm{U}_{1 \mathrm{uVw}}$ 4mB7D7tEF9s9GJYqDC4VMeJg\&hl=pt-BR\&sa=X\&ved=2ahUKEwiB6ralq8jpAhxsh7kg неBoDloQ6AEwE3OECACQAQ\#v=onepage\&$\mathrm{q}=$ firts $\% 2$ ogalellery\%2omoved $\% 20$ to $\% 20$ Chelsea\&f $=$ false $>$.

HEATHCOTE, Edwin. Elizabeth Diller and Ricardo Scofidio: "The city is a public resource". RA Magazine, 24/o5/2019. ed. 2019. Disponível em: $<$ https://www.royalacademy.org. uk/article/magazine-architecture-prize-diller-scofidio>. Acesso em: 21 jun. 2021.

KAUFMAN, Jason Edward. MомA completes merger with PS1. The Art Newspaper, 1/12/2020. ed. 2020. Disponível em: <https://www.theartnewspaper.com/archive/moma-completes-merger-with-ps1>. Acesso em: 18 maio 2021.
KENNICOTT, Philip. The new MoMA is a lot bigger. But you may not learn asmuch about the art. The Washington Post, 10/10/2019. ed. 2019. Disponível em: <https://www.washingtonpost.com/entertainment/ museums/the-new-moma-is-a-lot-bigger-but-you-may-not-learn-as-much-about-the-art/2019/10/o9/ og210c34-eabf-11e9-9306-47cbo324fd44_story.html>. Acesso em: 16 out. 2020.

KIMMELMAN, Michael. With a $\$ 450$ Million Expansion, MomA Is Bigger. Is That Better? The New York Times, 10/10/2019. ed. p. 1, 2019. Disponível em: <https://www.nytimes. com/2019/10/og/arts/design/with-a-450-million-expansion-moma-is-bigger-is-that-better.html>. Acesso em: 16 out. 2020.

KINSELLA, Eileen. What Will the \$500 Million Shed Arts Center Actually Do? No One Seems toKnow. Artnet, 25/05/2017. ed. 2017. Disponível em: $<$ https://news.artnet.com/art-world/ what-will-the-shed-bring-to-new-york-972656>.

KRAUSs, Rosalind. A escultura no campo ampliado. Gávea, v. 1, p. 128137, 1984. (Revista do Curso de Especialização em História da Arte e Arquitetura no Brasil, da PUC-Rio). KUDIELKA, Robert. Objetos da Observação - Lugares da Experiência. Novos Estudos - CEBRAP, v. 82, p. 167178, 2008.

LANGE, Alexandra. Navigating the new момА. New York Magazine, 21/10/2019. ed. 2019. Disponível em: <https://archive.curbed. com/2019/10/21/20924927/moma-reopening-review-building-design $>$. Acesso em: 16 out. 2020.

LANGE, Alexandra. This New House. New York Magazine, 8/10/2004. ed. 
2004. Disponível em: <https://nymag. com/nymetro/arts/features/10057/>. LESSARD, Suzannah. Quietly, He Grew on Them. The New York Times Magazine, 12/04/1998. ed. p. 30, 1998. Disponível em: <https://www.nytimes. com/1998/04/12/magazine/quietly-he-grew-on-them.html>. Acesso em: 8 set. 2020 .

LESSER, Casey. At the New moma, a Fresh Palette of Paint Colors Challenges the White Cube. Artsy, 23/12/2019. ed. 2019. Disponível em: $<$ https://www.artsy.net/article/artsy-editorial-new-moma-fresh-palette-paint-colors-challenges-white-cube>. Acesso em: 31 out. 2020.

LEVY, Valentina G. Revolutionary Instances and Activism in Art Practices at the turn of the 60 s and 7os. Two cases compared: Hi Red Center and Guerilla Art Action Group. Luxflux, v. 54, 2014. Disponível em: <http:// www.luxflux.net/revolutionary-instances-and-activism-in-art-practices-at-the-turn-of-the-6os-and-7os-two-cases-compared-hi-red-center-and-guerilla-art-action-group/>. Acesso em: 25 abr. 2020.

MUSTEATA, Natalie. Defrosting the Icebox: A Contextual Analysis of Andy Warhol's Raid the Icebox 1. Journal of Curatorial Studies, v. 5, n. 2, p. 214-237, 2016. Disponível em: <https://www. academia.edu/39635676/Defrosting the_Icebox_A_Contextual_Analysis_of_Andy_Warhols_Raid_the_Icebox_1_>. Acesso em: 4 jul. 2020.

NAKAMOTO, Michiyo. Yoshio Taniguchi unveils the new момa. The Financial Times, 15/10/2004. ed. 2004. Disponível em: < https://www.ft.com/ content/e7576626-1cec-11d9-abbf-oooooe2511c8>.

O'DOHERTY, Brian. Inside The White Cube, Part I: Notes on the Gallery
Space. Artforum, v. 14, n. 7, 1976. Disponível em: <https://www.artforum.com/print/197603/inside-the-white-cube-notes-on-the-gallery-space-part-i-38508>. Acesso em: 31 maio 2020.

O'DOHERTY, Brian. Inside the White Cube, Part II: The Eye and the Spectator. Artforum, v. 14, n. 8, 1976. Disponível em: <https://www.artforum. com/print/197604>.

O'DOHERTy, Brian. Inside The White Cube, Part III: Context as Content. Artforum, v. 15, n. 3, 1976. Disponível em: <https://www.artforum.com/ print/197609>.

ouroussof, Nicolai. Art Fuses With Urbanity in a Redesign of the Modern. The New York Times, 15/11/2004. ed. 2004. Disponível em: <https://www. nytimes.com/2004/11/15/arts/design/ art-fuses-with-urbanity-in-a-redesign-of-the-modern.html>. Acesso em: 20 set. 2020.

PELLI, Cesar. The Museum of Modern Art Project. Perspecta, v. 16, p. 97-107, 1980. Disponível em: <https://www. jstor.org/stable/1567027>. Acesso em: 2 out. 2019.

PONTES, Ana Paula. Arquitetura para Arte Contemporânea: Longe da Neutralidade. Cadernos de pós-graduação em arquitetura e urbanismo, v. 17, n. 2, p. 151-17o, 2017. Disponível em: <http://editorarevistas. mackenzie.br/index.php/cpgau/ article/view/2017.2.Pontes/6756>.

PONTES, Ana Paula; MARTINS, Patrícia P. Desafios de projetar exposições temporárias em uma casa modernista. In: 90 Fórum de Pesquisa FAU Mackenzie: Projeto e processos em tempos de transição. Timburi: Editora Cia do eBook, 2019, p. 91-102. Disponível em: <https://www.mackenzie.br/ 
fileadmin/user_upload/Ebook_9_ f\% $3 \%$ B 3 rum.pdf $>$. Acesso em: 28 maio 2021.

RÉGNIER, Philippe. Jean de Loisy présente les nouveaux espaces du Palais de Tokyo et ses activités hors les murs. Le Quotidian de l'Art, 126130 mars 2017. ed. 2017. Disponível em: <https:/www.lequotidiendelart. com/articles/10580-jean-de-loisy-presente-les-nouveaux-espaces-du-palais-de-tokyo-et-ses-activites-hors-les-murs.html>. Acesso em: 4 jan. 2019.

REINOLDS, Nigel. Tate Modern chief quits for job in Sweden. The Telegraph, 21/06/2001. ed. 2001. Disponível em: <https://www.telegraph. co.uk/news/uknews/1309420/Tate-Modern-chief-quits-for-job-in-Sweden.html>. Acesso em: 28 set. 2020. RICCIOTTI, Dominic. The 1939 Building of the Museum of Modern Art: The Goodwin-Stone Collaboration. The American Art Journal, v. 17 , n. 3, p. 50-76, 1985. Disponível em: <https://www.jstor.org/stable/1594435 $>$. Acesso em: 23 set. 2019. RUgGiero, Amanda Saba. Hélio Oiticica no момA de Nova York. Arquitextos, v. ano 17, n. 193.01, 2016. Disponível em: <https://www.vitruvius.com.br/revistas/read/arquitextos/17.193/6087>. Acesso em: 15 maio 2020.

SALTZ, Jerry. I Give In, MoмA. You've Won Me Over. Halfway, Anyway. New York Magazine, 27/07/2017. ed. 2017. Disponível em: <https:/www. vulture.com/2017/o7/jerry-saltz-i-give-in-moma.html>. Acesso em: 17 out. 2020.

SALTz, Jerry. What the Hell Was Modernism? The Museum of Modern Art tries to open itself up. New York Magazine, 2/10/2019. ed.
2019. Disponível em: <https://www. vulture.com/2019/10/jerry-saltz-new-moma-modernism.html>. Acesso em: 16 out. 2020.

SHEETS, Hilarie. MOMA's New Curatorial Guard. ARTnews, 1/10/2014. ed. p. 104, 2014. Disponível em: <https:// www.artnews.com/art-news/news/ momas-new-curatorial-guard-2820/>. Acesso em: 14 out. 2014.

SMITH, Roberta. ART REVIEW; More Spacious and Gracious, Yet Still Funky at Heart. The New York Times, 31/10/1997. ed. 1997. Disponível em: <https://www.nytimes. com/1997/10/31/arts/art-review-more-spacious-and-gracious-yet-still-funky-at-heart.html>. Acesso em: 31 maio 2020.

SMITH, Roberta. Hold That Obit; MomA's Not Dead. The New York Times, 02/01/2011. ed. 2011. Disponível em: <https://www.nytimes. com/2011/01/o2/arts/design/o2moma. html>. Acesso em: 12 out. 2020.

SMITH, Roberta. MomA's Art Treasure, No Longer Buried. The New York Times, 18/10/2019. ed. 2019. Disponível em: <https://www.nytimes. com/2019/10/17/arts/design/moma-reopening.html>. Acesso em: 16 out. 2020.

STEPHEns, Suzanne. Museum of Modern Art Addition by Diller Scofidio + Renfro in collaboration with Gensler. Architectural Record, 2/12/2019. ed. 2019. Disponível em: $<$ https://www.architecturalrecord. com/articles/14392-museum-of-modern-art-addition-by-diller-scofidio-renfro-with-gensler>. Acesso em: 16 out. 2020.

THE NEW YORK TIMES. Naked Protesters Burlesque Bronze Nudes at Museum. The New York Times, 25/o8/1969. ed. p. 33, 1969. Disponível em: <https:// 
timesmachine.nytimes.com/ timesmachine/1969/08/25/88859137. html? pageNumber=33>. Acesso em: 25 abr. 2020.

TRUPPIN, Andrea. P.S.1 Contemporary Art Center, Long Island City, New York. Architectural Record, n. agosto de 1998, 1998.

VITELLO, Paul. John Hightower, Besieged Art Museum Director, Dies at 80. The New York Times, 14/07/2013. ed. p. 22, 2013. Disponível em: <https:// www.nytimes.com/2013/o7/14/ arts/john-hightower-besieged-art-museum-director-dies-at-8o. html?_r=1\&>. Acesso em: 26 jul. 2020. vogel, Carol. A Museum Merger: The Modern Meets The Ultramodern. The New York Times, 2/2/1999. ed. p. 1, 1999. Disponível em: <https://www. nytimes.com/1999/02/o2/arts/a-museum-merger-the-modern-meets-the-ultramodern.html>. Acesso em: 19 jul. 2020.

WALLACH, Alan. The Museum of Modern Art: The Past's Future. Journal of Design History, v. 5, n. 3, p. 207215, 1992. Disponível em: <https:// www.jstor.org/stable/1315838>. Acesso em: 2 out. 2019.

\section{COMUNICAÇÕES}

ANDRADE, Marco Pasqualini de. Latin American artists in MOMA's 1970 exhibition "Information". In: LASA Congress 2014. Chicago: LASA, 2014. Disponível em: <https://www.academia.edu/36145576/Latin_American_artists_in_MOMA_S_1970_exhibition_Information_>. Acesso em: 13 maio 2020.

CASCARO, David. Le musée décontracté. Une installation des Lacaton Vassal au Palais de Tokyo. Lacaton \& Vassal. Disponível em: < https:/www.lacatonvassal.com/publications.php?fka $=95^{>}$. Acesso em: 1 out. 2018.

Matsushima, Shiro. MOMA, The Museum of Modern Art, New York. Cambridge: Center for Design Informatics - Harvard Design School, 2003. (Estudo de Caso). Disponível em: <http://www.archidiap. com/beta/assets/uploads/2016/o3/ MOMA__ THE_MUSEUM_OF_ MODERN_ART_NEW_YORK-1.pdf $>$. Acesso em: 8 set. 2020.

MAZUREK, Lily R. MomA and the Museum Tower: Breaking Ground for the Eighties. Nova York: The Museum of Modern Art, 1982.

THE MUSEUM OF MODERN ART. Press release: МомА deepens commitment to collecting, preserving, and exhibiting performance art through a range of pioneering initiatives. момА. Disponível em: <http://press. moma.org/wp-content/press-archives/PRESS_RELEASE_ARCHIVE/ PerformanceRelease.FINAL.pdf $>$. Acesso em: 4 out. 2020.

THE MUSEUM OF MODERN ART. Press release: The Museum of Modern Art anuncia Sur moderno: Journeys of Abstraction - The Patricia Phelps de Cisneros Gift. мома. Disponível em: $<$ https://press.moma.org/wp-content/uploads/2020/o6/MOMA_CisnerosSurmoderno_FINAL_PressRelease-PR_8.17.20.pdf $>$. Acesso em: 1 nov. 2020.

THE MUSEUM OF MODERN ART. PresS release: The Museum of Modern Art completes first phase of major renovation and reveals final design for multi-year expansion 
and renovation project, designed by Diller Scofidio + Renfro in collaboration with Gensler. момА. Disponível em: <https://press. moma.org/wp-content/uploads/2017/o8/6_MOMA_June2017_ PressRelease.pdf $>$. Acesso em: 17 out. 2020.
THE MUSEUM OF MODERN ART. PresS release: The Museum of Modern Art Creates New Curatorial Department. мома. Disponível em: $<$ http://press.moma.org/wp-content/press-archives/PRESS_RELEASE_ARCHIVE/Media.pdf $>$. Acesso em: 3 out. 2020.

\section{WEBSITES}

ADVOCATES FOR PRIVATELY OWNED PUBLIC SPACE, The Municipal Art Society of New York. 31 West 52nd Street. APOPS-MAS. Disponível em: <https://apops.mas.org/pops/ mo50088/>. Acesso em: 6 nov. 2020.

ANDRADE MORETTIN ARQUITETOS. IMS

São Paulo. Andrade Morettin. Disponível em: <https://www.andrademorettin.com.br/projetos/ims/>. Acesso em: 14 jan. 2021.

AWC - ARTISTS WORKERS COATITION.

Open Hearing (1969). Primary Information. Disponível em: <http:// www.primaryinformation.org/product/art-workers-coalition-open-hearing/>. Acesso em: 18 maio 2021.

CARVAlHosa, Carlito. Sum of Days. MомA. Disponível em: <https:// www.moma.org/explore/inside_ out/2011/11/o1/sum-of-days/>. Acesso em: 11 out. 2020.

CENTRE POMPIDOU. Expositions du Centre Pompidou: reportages en argentique (1953-2003). Archives et Documentation du Centre Pompidou. Disponível em: <https:// archivesetdocumentation.centrepompidou.fr/ead.html?id=FRM5050=-0031X0000074_\&cFRM5050-Xo031_0000074_FRM5050-Xoo3189786\#! \{\%22content\%22:[\%22FRM5O5O-X0031_0000074_ FRM $5050-X O O 3189523 \% 22$, - false, $\% 22 \% 22]\}>$. Acesso em: 30 maio 2021.

CENTRE POMPIDOU. L'Histoire des Collections. Centre Pompidou. Disponível em: <https://www.centrepompidou.fr/fr/Collections/L-histoire-des-collections $>$. Acesso em: 27 maio 2021.

CHRISTO; JEANNE-CLAUDE. Wrapped Kunsthalle (Bern, Swittzerland, 1967-68). Christo and Jeanne-Claude. Disponível em: <https:// christojeanneclaude.net/artworks/ wrapped-kunsthalle/>.

CHRISTO; JEANNE-CLAUDE. Wrapped Museum of Contemporary Art (Chicago, 1968-69). Christo and Jeanne Claude. Disponível em: $<$ https://christojeanneclaude.net/ artworks/wrapped-mca/>. Acesso em: 16 abr. 2021.

DILLER SCOFIDIO + RENFRO. Para-site. DSR-NY. Disponível em: <https:// dsrny.com/project/para-site $>$. Acesso em: 6 nov. 2020.

ELLIGOT, Michelle. From the Archives: Faith Ringgold, the Art Workers Coalition, and the Fight for Inclusion at The Museum of Modern Art. мома. Disponível em: <https://www.moma. org/explore/inside_out/2016/07/29/ from-the-archives-faith-ringgold-the-art-workers-coalition-and-the-fight-for-inclusion-at-the-mu- 
seum-of-modern-art/>. Acesso em: 22 abr. 2020.

ENCICLOPÉDIA ITAÚ CULTURAL. Opinião 65. Enciclopédia Itaú Cultural. Disponível em: <https://enciclopedia.itaucultural.org.br/evento81812/ opiniao-65-1965-rio-de-janeiro-rj>. Acesso em: 16 abr. 2021.

Gensler. Services. Gensler. Disponível em: <https://www.gensler. com/about/services $>$. Acesso em: 20 jun. 2021.

GIORNo, John. The Dial-A-Poem Poets, 1972. Ubuweb: Sounds. Disponível em: <http://www.ubu. com/sound/dial.html $>$. Acesso em: 16 maio 2020.

GOLDstein, Bethsheba. Guest Post Series: Bethsheba Goldstein Interviews Carol Goodden about the Origins of FOOD. SoHo Memory Project. Disponível em: <https://sohomemory.wordpress.com/2012/06/30/ guest-post-series-bethsheba-goldstein-interviews-carol-goodden-about-food/>.

HALBReicht, Kathy. Forty Years of Projects. MoмA. Disponível em: <https://assets.moma.org/ momaorg/shared/pdfs/docs/calendar/projects/FortyYearsofProjects. pdf $>$. Acesso em: 13 jun. 2020.

HEISs, Alanna. Alanna Heiss with David Carrier and Joachim Pissarro, with the assistance of Gaby Collins-Fernandez. The Brooklyn Rail. Disponível em: <https://brooklynrail. org/2014/12/art/alanna-heiss $>$. Acesso em: 16 abr. 2021.

HEISs, Alanna. Oral history interview with Alanna Heiss. Smithsonian Archives of American Art. Disponível em: <https://www.aaa.si.edu/collections/interviews/oral-history-interview-alanna-heiss-15902\#transcript>. Acesso em: 25 maio 2020.
ICOM BRASIL. Nova Definição de museu: consulta aberta. ICOM $B R$. Disponível em: $<$ https://www. icom.org.br/? $\mathrm{p}=\mathbf{2 2 1 1}>$. Acesso em: 6 jun. 2021.

instituto MOREIRA SAlles. Anri Sala: O Momento Presente. IMS. Disponível em: <https://ims.com. br/exposicao/anri-sala-o-momento-presente/>. Acesso em: 14 jan. 2021.

INSTITUTO MOREIRA SALLES. Richard Serra: Desenhos na casa da Gávea. IMS. Disponível em: <https://ims. com.br/exposicao/richard-serra-desenhos-na-casa-da-gavea-ims-rio/>. Acesso em: 14 jan. 2021.

KLEIN, Yves. La spécialisation de la sensibilité à l'état matière première en sensibilité picturale stabilisée, "Le Vide". Yves Klein. Disponível em: <http://www.yvesklein. com/en/expositions/view/1158/ la-specialisation-de-la-sensibilite-a-l-etat-matiere-premiere-en-sensibilite-picturale-stabilisee-le-vide-the-specialization-of-sensibility-in-the-raw-material-state-into-stabilized-pictorial-sensibility-the-void/>. Acesso em: 15 mar. 2021.

LACATON, Anne; VASSAL, Jean-Philippe. Palais de Tokyo. Lacaton \& Vassal. Disponível em: <https://www.lacatonvassal.com/index.php?idp=2o\#>. Acesso em: 27 maio 2021.

LIPPARD, Lucy R.; MCSHINE, Kynaston L.; WEINER, Lawrence; et al. 5o Years Later, a Conceptual Art Exhibition Still Courts Controversy. мома. Disponível em: <https:// www.moma.org/magazine/articles/225 $5^{>}$. Acesso em: 14 maio 2020. MAUPIN, Stéphane. SMAC. Stephane Maupin. Disponível em: <https:// www.stephanemaupin.com/>. Acesso em: 27 maio 2021. 
MODERNA MUSEET. Remembering She

- A Cathedral (3.6 2018 - 10.3 2019). Moderna Museet. Disponível em: $<$ https://www.modernamuseet.se/ stockholm/en/exhibitions/remembering-she-a-cathedral/>. Acesso em: 16 abr. 2021.

MOMA PS1. Young Architects Program 1998: Percutaneous Delights by Gelatin (Jun 30-Aug 30, 1998). MомA. Disponível em: <https:// www.moma.org/calendar/exhibitions/3702>. Acesso em: 26 jul. 2020.

PALAIS DE TOKYO. ENFANCE: Encore un jour banane pour le poisson-rêve (Du 22/06/2018 au 09/og/2018). Palais de Tokyo. Disponível em: $<$ https://www.palaisdetokyo.com/ $\mathrm{fr} /$ evenement/enfance $>$. Acesso em: 27 maio 2021.

PALAIS DE TOKYO. Henrique Oliveira: Baitogogo (Du 30/11/2013 au18/12/2016). Palais de Tokyo. Disponível em: <https:/www.palaisdetokyo.com/fr/evenement/henrique-oliveira> Acesso em: 27 maio 2021.

PALAIS DE TOKYO. Le lieu \& son histoire. Palais de Tokyo. Disponível em: <https://www.palaisdetokyo.com/fr/content/lieu-histoire-palais-de-tokyo $>$. Acesso em: 27 maio 2021.

PONTES, Ana Paula. Projeto Expográfico para Anri Sala: o Momento Presente. APP.arq. Disponível em: $<$ https://www.app.arq.br/anri-sala $>$. Acesso em: 14 jan. 2021.

PROGRAMA HELIO OITICICA ITAÚ CULTURAL. Projeto Cães de Caça. Itaú Cultural. Disponível em: <https:// legacy-ssl.icnetworks.org/extranet/ enciclopedia/ho/index.cfm?fuseaction $=$ documentos $\& \operatorname{cod}=152 \&-$ tipo $=2>$. Acesso em: 16 abr. 2021.

SPACE. The Space Story. Space Studios. Disponível em: <https:// spacestudios.org.uk/space-story/>. Acesso em: 25 maio 2020.

STORR, Robert. History of Projects. мома. Disponível em: <https:// assets.moma.org/momaorg/sha$\mathrm{red} / \mathrm{pdfs} / \mathrm{docs} / \mathrm{calendar} /$ projects/ HistoryofProjects.pdf $>$. Acesso em: 13 jun. 2020.

sWARTz, Anne K. Women Artists in Revolution. Oxford Art Online. Disponível em: <https://doi.org/10.1093/ gao/9781884446054.article.T2214396>. Acesso em: 26 abr. 2020.

TATE MODERN. Director appointed for new Tate Gallery of Modern Art. Tate. Disponível em: <https:// www.tate.org.uk/press/press-releases/director-appointed-new-tate-gallery-modern-art>. Acesso em: 28 set. 2020.

TATE MODERN. Olafur Eliasson the Weather Project: about the installation. Tate. Disponível em: $<$ https://www.tate.org.uk/whats-on/ tate-modern/exhibition/unilever-series/unilever-series-olafur-eliasson-weather-project-o>. Acesso em: 6 nov. 2020.

TEMKIN, Ann; HAUPTMAN, Jodi. Gallery 501: 19th-Century Innovators. момA. Disponível em: <https:// www.moma.org/magazine/articles/198>. Acesso em: 31 out. 2020.

THE hyatT Foundation. Anne Lacaton and Jean-Philippe Vassal Receive the 2021 Pritzker Architecture Prize. Pritzker Prize. Disponível em: <https://www.pritzkerprize. com/laureates/anne-lacaton-and-jean-philippe-vassal>. Acesso em: 2 maio 2021.

THE HYATT FOUNDATION. The Pritzker Architecture Prize - Purpose. Pritzker Prize. Disponível em: <https:// www.pritzkerprize.com/about>. Acesso em: 15 maio 2021. 
THE MUNICIPAL ART SOCIETY OF NEW YORK. History: Celebrating more than 125 years of advocacy on behalf of New York and New Yorkers. The Municipal Art Society of New York. Disponível em: <https:// www.mas.org/about-us/history/>. Acesso em: 26 jul. 2020.

THE MUSEUM OF MODERN ART. "Primitivism" in 2oth Century Art: Affinity of the Tribal and the Modern (Sep 27, 1984-Jan 15, 1985). МомA. Disponível em: <https://www.moma.org/ calendar/exhibitions/1907>. Acesso em: 11 abr. 2021.

THE MUSEUM OF MODERN ART. A New Video Frontier. MomA. Disponível em: <https://www.moma. org/interactives/moma_through_ time/1970/a-new-video-frontier/>. Acesso em: 18 jun. 2010.

THE MUSEUM OF MODERN ART. A Virtuoso Pavilion. MOMA. Disponível em: <https://www.moma.org/interactives/moma_through_time/1990/ an-architect-dj-saved-my-life/>. Acesso em: 22 jun. 2021.

THE MUSEUM OF MODERN ART. Abstract Painting and Sculpture in America (Jan 23-Mar 25, 1951). мома. Disponível em: <https:// www.moma.org/calendar/exhibitions/1989? locale=pt $>$. Acesso em: 8 mar. 2020.

THE MUSEUM OF MODERN ART. African Negro Art (Mar 18-May 19, 1935). момА. Disponível em: <https:// www.moma.org/calendar/exhibitions/2937? locale $=$ pt $>$. Acesso em: 5 abr. 2020.

THE MUSEUM OF MODERN ART. American Painting and Sculpture, 18621932 (Oct 31, 1932-Feb 11, 1933). момА. Disponível em: <https://www.moma. org/calendar/exhibitions/2048?loca$\mathrm{le}=\mathrm{pt}>$. Acesso em: 24 jan. 2020.
THE MUSEUM OF MODERN ART. American Paintings from the Museum Collection (Dec 23, 1948-Mar 13, 1949). мома. Disponível em: $<$ https://www.moma.org/calendar/exhibitions $/ 285^{2}$ ? locale $=$ pt $>$. Acesso em: 7 mar. 2020.

THE MUSEUM OF MODERN ART. Americans 1942: 18 Artists from 9 States (Jan 21-Mar 8, 1942). момA. Disponível em: <https://www.moma.org/ calendar/exhibitions/3028?loca$\mathrm{le}=\mathrm{pt}>$. Acesso em: 13 fev. 2020 .

THE MUSEUM OF MODERN ART. Art in Our Time: 1oth Anniversary Exhibition: Painting, Sculpture, Prints (May 10-Sep 30, 1939). момA. Disponível em: <https://www.moma. org/calendar/exhibitions/2743?locale=pt $>$. Acesso em: 5 fev. 2020 .

THE MUSEUM OF MODERN ART. Artist's Choice: Amy Sillman - The Shape of Shape (Oct 21, 2019-Oct 4, 2020). момA. Disponível em: <https:// www.moma.org/calendar/exhibitions/5175 $>$. Acesso em: 1 nov. 2020. THE MUSEUM OF MODERN ART. Artist'S Choice: Burton on Brancusi (Apr 7Jul 4, 1989). мома. Disponível em: $<$ https://www.moma.org/calendar/ exhibitions $/ 2133$ ? locale $=p t>$. Acesso em: 4 jul. 2020.

THE MUSEUM OF MODERN ART. Beaumont Newhall Papers. MOMA. Disponível em: <https://www.moma. org/research-and-learning/archives/finding-aids/Newhallf $>$. Acesso em: 5 jun. 2021.

THE MUSEUM OF MODERN ART. Betye Saar: The Legends of Black Girl's Window (Oct 21, 2019-Jan 4, 2020). момА. Disponível em: <https:// www.moma.org/calendar/exhibitions/5060>. Acesso em: 1 nov. 2020. THE MUSEUM OF MODERN ART. Buckminster Fuller's Dymaxion 
Deployment Unit (Oct 10, 1941-Apr 1, 1942). момA. Disponível em: <https:// www.moma.org/calendar/exhibitions/3015? locale $=\mathrm{pt}>$. Acesso em: 26 mar. 2020.

THE MUSEUM OF MODERN ART. Carlito Carvalhosa: Sum of Days (Aug 24-Nov 14, 2011). момA. Disponível em: <https:/www.moma.org/calendar/exhibitions/1151>. Acesso em: 11 out. 2020.

THE MUSEUM OF MODERN ART. Cézanne, Gauguin, Seurat, van Gogh (Nov 7-Dec 7, 1929). мома. Disponível em: $<$ https://www.moma. org/calendar/exhibitions/1767?locale=pt $>$. Acesso em: 26 jan. 2020.

THE MUSEUM OF MODERN ART. Cubism and abstract art (Mar 2-Apr 19, 1936). момA. Disponível em: <https:// www.moma.org/calendar/exhibitions $/ 2748$ ? locale $=\mathrm{pt}>$. Acesso em: 27 mar. 2021.

THE MUSEUM OF MODERN ART. David Tudor and Composers Inside Electronics Inc.: Rainforest $\mathrm{V}$ (variation 1) (Oct 21, 2019-Jan 5, 2020). момA. Disponível em: <https:// www.moma.org/calendar/exhibitions/5077>. Acesso em: 1 nov. 2020. THE MUSEUM OF MODERN ART. DOrOthy C. Miller Papers. MомA. Disponível em: <https:/www.moma.org/ research-and-learning/archives/finding-aids/dcmillerf $>$. Acesso em: 28 fev. 2020.

THE MUSEUM OF MODERN ART. Energy (Oct 21, 2019-Jan 26, 2020). мома. Disponível em: <https:// www.moma.org/calendar/exhibitions $/ 5100>$. Acesso em: 6 nov. 2020.

THE MUSEUM OF MODERN ART. Exhibition History. MOMA. Disponível em: $<$ https://www.moma.org/calendar/ exhibitions/history $>$. Acesso em: 27 mar. 2021.
THE MUSEUM OF MODERN ART. Fantastic Art, Dada, Surrealism (Dec 9, 1936-Jan 17, 1937). момА. Disponível em: <https://www.moma.org/calendar/exhibitions $/ 2823$ ? locale $=\mathrm{pt}>$. Acesso em: 24 jan. 2020.

THE MUSEUM OF MODERN ART. Fifteen Americans (Apr 9-Jul 27, 1952). MомA. Disponível em: <https:// www.moma.org/calendar/exhibitions/3294? locale=pt $>$. Acesso em: 8 mar. 2020.

THE MUSEUM OF MODERN ART. George Howe, William Lescaze: The Museum of Modern Art, New York (Scheme 4, First Variation), 1930. момA. Disponível em: <https://www. moma.org/collection/works/1017>. Acesso em: 27 mar. 2021.

THE MUSEUM OF MODERN ART. Global research: C-MAP. MOMA. Disponível em: <https:/www.moma.org/research-and-learning/international-program/global-research>. Acesso em: 2 nov. 2020.

THE MUSEUM OF MODERN ART. Goshka Macuga: Exhibition M (2019). MOMA. Disponível em: <https:// www.moma.org/calendar/exhibitions $/ 5170$ ? slideshow $=524 \&$ slide index $=0>$. Acesso em: 3 nov. 2020.

THE MUSEUM OF MODERN ART. Haegue Yang: Handles (Oct 21, 2019Feb 28, 2021). MOMA. Disponível em: $<$ https://www.moma.org/calendar/ exhibitions/5080>.

THE MUSEUM OF MODERN ART. Hard Light (Jun 27-Sep 20, 2004). MомA. Disponível em: <https:// www.moma.org/calendar/exhibitions/4809>. Acesso em: 3 out. 2020. THE MUSEUM OF MODERN ART. Homage to New York: A Self-Constructing and Self-Destroying Work of Art Conceived and Built by Jean Tinguely (Mar 17, 1960). момА. 
Disponível em: <https://www.moma. org/calendar/exhibitions/3369>. Acesso em: 21 mar. 2021.

THE MUSEUM OF MODERN ART. Indian Art of the United States (Jan 22-Apr 27, 1941). МомА. Disponível em: $<$ https://www.moma.org/calendar/exhibitions/2998 locale $=$ pt $>$. Acesso em: 5 abr. 2020.

THE MUSEUM OF MODERN ART. Information (Jul 2-Sep 20, 1970). МомA. Disponível em: <https://www.moma. org/calendar/exhibitions/2686?loca$\mathrm{le}=\mathrm{pt}>$. Acesso em: 15 maio 2020 .

THE MUSEUM OF MODERN ART. Jackson Pollock (Dec 19, 1956-Feb 3, 1957). мома. Disponível em: $<$ https://www.moma.org/calendar/exhibitions/1926? locale $=$ pt $>$. Acesso em: 8 mar. 2020.

THE MUSEUM OF MODERN ART. Japanese Exhibition House (Jun 16, 1954-Oct 15, 1955). мома. Disponível em: <https://www.moma.org/ calendar/exhibitions/2711?locale=pt $>$. Acesso em: 23 mar. 2020.

THE MUSEUM OF MODERN ART. Kerstin Brätsch: Fossil Psychics for Christa (2019). момA. Disponível em: <https://www.moma.org/ calendar/exhibitions/5170?slideshow $=523 \&$ slide $=0>$. Acesso em: 3 nov. 2020.

THE MUSEUM OF MODERN ART. Kynaston McShine Papers in The Museum of Modern Art Archives. MoмA. Disponível em: <https://www.moma. org/research-and-learning/archives/ finding-aids/KynastonMcShinef $>$. Acesso em: 28 mar. 2021.

THE MUSEUM OF MODERN ART. Light Construction (Sep 21, 1995-Jan 2, 1996). мома. Disponível em: $<$ https://www.moma.org/calendar/exhibitions/469>. Acesso em: 30 maio 2021.
THE MUSEUM OF MODERN ART. Lillie P. Bliss's Legacy. момA. Disponível em: <https://www.moma.org/interactives/moma_through_time/1930/ lillie-p-bliss-legacy/>. Acesso em: 27 mar. 2021.

THE MUSEUM OF MODERN ART. Marina Abramović: The Artist Is Present (Mar 14-May 31, 2010). мома. Disponível em: <https://www.moma. org/calendar/exhibitions/964>. Acesso em: 30 maio 2021.

THE MUSEUM OF MODERN ART. Media and Performance. момA. Disponível em: <https://www.moma.org/ collection/about/curatorial-departments/media-performance>. Acesso em: 24 jul. 2020.

THE MUSEUM OF MODERN ART. member: Pope. L, 1978-2001 (Oct 21, 2019Feb 1, 2020). мома. Disponível em: $<$ https://www.moma.org/calendar/ exhibitions/5059>. Acesso em: 1 nov. 2020.

THE MUSEUM OF MODERN ART. Modern Architecture: international exhibition (Feb 9-Mar 23, 1932). момА. Disponível em: <https://www.moma. org/calendar/exhibitions/2044?loca$\mathrm{le}=\mathrm{pt}>$. Acesso em: 21 mar. 2020.

THE MUSEUM OF MODERN ART. Modern Art in Your Life (Oct 5-Dec 4, 1949). момА. Disponível em: <https:// www.moma.org/calendar/exhibitions/2744>. Acesso em: 6 jun. 2021.

THE MUSEUM OF MODERN ART. MOMA Through Time. MOMA. Disponível em: <https://www.moma.org/interactives/moma_through_time $>$. Acesso em: 2 jan. 2020.

THE MUSEUM OF MODERN ART. Neri Oxman: Material Ecology (May 14-Oct 18, 2020). МомA. Disponível em: <https://www.moma.org/calendar/exhibitions/5090 $>$. Acesso em: 25 out. 2020. 
THE MUSEUM OF MODERN ART. NeW American Painting as Shown in Eight European Countries 1958-1959 (May 28-Sep 8, 1959). MомA. Disponível em: <https:// www. moma.org/calendar/ exhibitions/1990>. Acesso em: 20 mar. 2020.

THE MUSEUM OF MODERN ART. Painting \& Sculpture II (Nov 20, 2004Aug 5, 2015). мома. Disponível em: $<$ https://www.moma.org/calendar/ exhibitions/1220 $>$. Acesso em: 22 set. 2020.

THE MUSEUM OF MODERN ART. Painting in Paris (Jan 19-Mar 2, 1930). момA. Disponível em: <https:// www.moma.org/calendar/exhibitions/2024 $>$. Acesso em: 26 jan. 2020.

THE MUSEUM OF MODERN ART. Pipilotti Rist: Pour Your Body Out (7354 Cubic Meters) (Nov 19, 2008-Feb 2, 2009). мома. Disponível em: $<$ https://www.moma.org/calendar/exhibitions/307>. Acesso em: 4 out. 2020.

THE MUSEUM OF MODERN ART. Press-release: American Painting and Sculpture Show to Inaugurate Museum's International Program in Paris Opening on April 24. MOMA. Disponível em: <https://www. moma.org/momaorg/shared/pdfs/ docs/press_archives/1704/releases/ MOMA_1953_oo34_33.pdf $>$. Acesso em: 30 maio 2021.

THE MUSEUM OF MODERN ART. Projects: 100 Boots by Eleanor Antin (May 30-Jul 8, 1973). момA. Disponível em: <https://www.moma.org/ calendar/exhibitions/2540>. Acesso em: 14 jun. 2020.

THE MUSEUM OF MODERN ART. Projects 110: Michael Armitage (Oct 21, 2019-Jan 20, 2020). MOMA. Disponível em: <https://www.moma.org/ calendar/exhibitions/5099>. Acesso em: 25 out. 2020.

THE MUSEUM OF MODERN ART. Projects: Pier 18 (Jun 18-Aug 2, 1971). MOMA. Disponível em: <https:// www.moma.org/calendar/exhibitions $/ 3524$ ?locale $=$ pt $>$. Acesso em: 14 jun. 2020.

THE MUSEUM OF MODERN ART. Projects: Video I (Aug 26-Oct 31, 1974). MомA. Disponível em: <https:// www.moma.org/calendar/exhibitions/2516? locale=pt $>$. Acesso em: 19 jun. 2020.

THE MUSEUM OF MODERN ART. Projects: Video II (Nov 1, 1974-Jan 31, 1975). мома. Disponível em: $<$ https://www.moma.org/calendar/exhibitions/2508>. Acesso em: 18 jun. 2020.

THE MUSEUM OF MODERN ART. Public Space Artist Commissions. MомA. Disponível em: <https:// www.moma.org/calendar/exhibitions/5170>. Acesso em: 20 jun. 2021. THE MUSEUM OF MODERN ART. Rethinking the Modern: Three Proposals for The Museum of Modern Art (Mar 5-Apr 28, 1998). MомA. Disponível em: <https://www.moma. org/calendar/exhibitions/204>. Acesso em: 28 set. 2020.

THE MUSEUM OF MODERN ART. Road to Victory (May 21-Oct 4, 1942). МомА. Disponível em: <https://www.moma. org/calendar/exhibitions/3038?>. Acesso em: 26 fev. 2020.

THE MUSEUM OF MODERN ART. Sculpture of the xxth Century (Apr 28Sep 7, 1953). мома. Disponível em: <https://www.moma.org/calendar/exhibitions $/ 2822$ ? locale $=\mathrm{pt}>$. Acesso em: 21 mar. 2020.

THE MUSEUM OF MODERN ART. Second Floor Permanent Collection (Oct 8, 1958). момА. Disponível 
em: <https://www.moma.org/calendar/exhibitions $/ 2858$ ? locale $=$ pt $>$. Acesso em: 26 mar. 2020.

THE MUSEUM OF MODERN ART. Sheela Gowda's Of All People (Fall 2019Fall 2020). момА. Disponível em: $<$ https://www.moma.org/calendar/galleries/5171>. Acesso em: 1 nov. 2020.

THE MUSEUM OF MODERN ART. Shuzo Azuchi Gulliver's Cinematic Illumination (Aug 27, 2020-Apr 18, 2021). момА. Disponível em: <https:// www.moma.org/calendar/exhibitions/5205>. Acesso em: 1 nov. 2020.

THE MUSEUM OF MODERN ART. Sixteen Americans (Dec 16, 1959-Feb 17, 1960). мома. Disponível em: $<$ https:/www.moma.org/calendar/ exhibitions $/ 2877$ ?locale $=$ pt $>$. Acesso em: 8 mar. 2020.

THE MUSEUM OF MODERN ART. Sleepwalkers: Doug Aitken (Jan 16-Feb 12, 2007). MOMA. Disponível em: $<$ https://www.moma.org/calendar/exhibitions/10>. Acesso em: 3 out. 2020.

THE MUSEUM OF MODERN ART. Sol LeWitt (Feb 3-Apr 4, 1978). мома. Disponível em: $<$ https://www.moma. org/calendar/exhibitions/1971?locale=pt $>$. Acesso em: 26 jul. 2020.

THE MUSEUM OF MODERN ART. SUmmer Exhibition: Painting and Sculpture (Jun 7-Oct 30, 1932). момА. Disponível em: <https:// www.moma.org/calendar/exhibitions/1708? locale $=\mathrm{pt}>$. Acesso em: 24 jan. 2020.

THE MUSEUM OF MODERN ART. Sur Moderno: Journeys of Abstraction - The Patricia Phelps de Cisneros Gift (Oct 21, 2019-Sep 12, 2020). MOMA. Disponível em: <https:// www.moma.org/calendar/exhibitions/5061>. Acesso em: 1 nov. 2020.
THE MUSEUM OF MODERN ART. Surrounds: 11 Installations (Oct 21, 2019-Jan 4, 2020). момА. Disponível em: <https://www.moma.org/calendar/exhibitions/5073 $>$. Acesso em: 28 out. 2020.

THE MUSEUM OF MODERN ART. Take your Time: Olafur Eliasson (Apr 20Jun 30, 2008). мома. Disponível em: <https://www.moma.org/calendar/ exhibitions/31 e https:/www.moma. org/interactives/exhibitions/2008/ olafureliasson/\#/intro/>. Acesso em: 3 out. 2020.

THE MUSEUM OF MODERN ART. Taking a Thread for a Walk (Oct 21, 2019Jan 10, 2021). мома. Disponível em: $<$ https:/www.moma.org/calendar/ exhibitions $/ 5101$ ? locale $=\mathrm{pt}>$. Acesso em: 1 nov. 2020.

THE MUSEUM OF MODERN ART. The Art of Assemblage (Oct 4-Nov 12, 1961). мома. Disponível em: $<$ https://www.moma.org/calendar/exhibitions $/ 1880$ ?locale $=$ pt $>$. Acesso em: 21 mar. 2020.

THE MUSEUM OF MODERN ART. The Art of the Real (Jul 3-Sep 8, 1968). MOMA. Disponível em: <https:// www.moma.org/calendar/exhibitions/1911? locale $=\mathrm{pt}>$. Acesso em: 28 mar. 2020.

THE MUSEUM OF MODERN ART. The Controversial "Primitivism" Exhibition. мома. Disponível em: $<$ https://www.moma.org/interactives/moma_through_time/1980/>. Acesso em: 3 jul. 2020.

THE MUSEUM OF MODERN ART. The Elaine Dannheisser Projects Series. MомA. Disponível em: $<$ https://www.moma.org/calendar/ groups/4>. Acesso em: 14 jun. 2020. THE MUSEUM OF MODERN ART. The House in the Museum Garden (Apr 12-Oct 30, 1949). Мома. Disponível 
em: <https://www.moma.org/calendar/exhibitions/3251?locale $=\mathrm{pt}>$. Acesso em: 26 mar. 2020.

THE MUSEUM OF MODERN ART. The

Machine as Seen at the End of the Mechanical Age (Nov 27, 1968-Feb 9, 1969). момА. Disponível em: <https://www.moma.org/calendar/exhibitions $/ 2776$ ? locale $=\mathrm{pt}>$. Acesso em: 22 abr. 2020.

THE MUSEUM OF MODERN ART. The

Museum Collection of Painting and Sculpture (Jun 20, 1945-Feb 13, 1946). мома. Disponível em: <https://www.moma.org/calendar/exhibitions/2861? locale $=\mathrm{en}>$. Acesso em: 4 mar. 2020.

THE MUSEUM OF MODERN ART. The New American Painting and Sculpture: The First Generation (Jun 18Oct 5, 1969). мома. Disponível em: $<$ https:/www.moma.org/calendar/ exhibitions $/ 1927$ ? locale $=$ pt $>$. Acesso em: 18 abr. 2020.

THE MUSEUM OF MODERN ART. The Responsive Eye (Feb 23-Apr 25, 1965). мома. Disponível em: <https://www.moma.org/calendar/ exhibitions/2914?locale $=$ pt $>$. Acesso em: 28 mar. 2020.

THE MUSEUM OF MODERN ART. Three Centuries of American Art (May 24Jul 31, 1938). мома. Disponível em: < https:/www.moma.org/calendar/ exhibitions $/ 3597$ ? locale $=\mathrm{pt}>$. Acesso em: 28 fev. 2020.

THE MUSEUM OF MODERN ART. Timeless Aspects of Modern Art (Nov 16, 1948-Jan 23, 1949). МомА. Disponível em: <https://www.moma. org/calendar/exhibitions/2845?locale $=$ pt $>$. Acesso em: 11 mar. 2020.

THE MUSEUM OF MODERN ART. Toward the New Museum of Modern Art: Sketchbooks by Ten Architects (May 1-Oct 7, 1997).
MомA. Disponível em: <https:// www.moma.org/calendar/exhibitions/3071? >. Acesso em: 30 maio 2021.

THE MUSEUM OF MODERN ART. Twelve Americans (May 30-Sep 8, 1956). MOMA. Disponível em: <https:// www.moma.org/calendar/exhibitions/3331?locale=pt $>$. Acesso em: 20 mar. 2020.

THE MUSEUM OF MODERN ART. Wolfgang Laib (Jan 23-Mar 11, 2013). MомA. Disponível em: <https:// www.moma.org/calendar/exhibitions/1315 $>$. Acesso em: 11 out. 2020. THE MUSEUM OF MODERN ART. XXVth Anniversary Exhibition: Paintings from the Museum Collection (Oct 19, 1954-Feb 6, 1955). момА. Disponível em: <https://www.moma. org/calendar/exhibitions/280o?locale $=$ pt $>$. Acesso em: 26 mar. 2020. THE MUSEUM OF MODERN ART. Yoko Ono: PEACE is POWER (2019). MOMA. Disponível em: <https://www.moma. org/calendar/exhibitions/5170?slideshow $=527 \&$ slide_index $=0>$. Acesso em: 3 nov. 2020.

THE NEW MUSEum. History. New Museum. Disponível em: <https:// www.newmuseum.org/history>. Acesso em: 26 jul. 2020.

TIME. Most Influential People 2018. Time. Disponível em: $<$ https://time. com/collection/most-influential-people-2018/5217632/elizabeth-diller>. Acesso em: 15 maio 2021. 
ANDERSON, Porter. Commentary:

Inside $М о м A$, art within art (24/11/2004). CNN. Disponível em: <http://edition.cnn.com/2004/ TRAVEL/11/23/inside.moma/index. html>.

COLUMBIA GSAPP. Lacaton \& Vassal. Youtube. [s.l.: s.n., s.d.]. Disponível em: <https://www.youtube. com/watch?app $=$ desktop\&v $=$ Twiz-dw9-e4\&feature=youtu.be>. Acesso em: 30 maio 2021.

LOWRY, Glenn; TANIGUCHI, Yoshio. мома Expansion. In: Charlie Rose. Nova York: PBs Bloomberg Television, 2001. Disponível em: $<$ https:// charlierose.com/videos/271>. Acesso em: 6 nov. 2020.

MARINA Abramović: The Artist is Present. Direção: Matthew Akers. Produção: Jeff Dupre. [S.l.]: Hво Documentary Films, MusicBox Films, 2012. 1 DVD (106 min), color. PONTUAL, Jorge. Entrevista com

Richard Serra. In: Starte. Rio de Janeiro: Globonews, 2014.

RENFro, Charles. The New Moma. Youtube. Disponível em: <https:// www.youtube.com/watch?v=ap$\mathrm{C} 4$ PkiPfiM\&t=303s $>$. Acesso em: 18 out. 2020.

the architectural League. A Conversation on the Museum of Modern Art's Plan for Expansion (28/01/2014). Youtube. Disponível em: <https://www.youtube.com/ watch? $=55$ EEkvA276I $>$. Acesso em: 14 out. 2020.

THE MUSEUM OF MODERN ART. Behind the Scenes with Pipilotti Rist, Pour Your Body Out (7354 Cubic Meters). Youtube. Disponível em: <https:// www.youtube.com/watch?v=89vgdelbVyQ>. Acesso em: 4 out. 2020. THE MUSEUM OF MODERN ART. Behind the Scenes: Carlito Carvalhosa: Sum of Days. Youtube. Disponível em: <https://www.youtube.com/ watch?v=F5jYq10_L14 $>$. Acesso em: 11 out. 2020.

THE MUSEUM OF MODERN ART. Introducing Virtual Views: Amy Sillman -The Shape of Shape. Youtube. Disponível em: <https://www.youtube. com/watch?v=zK2WL75IwzQ>. Acesso em: 31 out. 2020.

\section{PROJETOS}

THE MUSEUM OF MODERN ART ARCHIVES. Planta do projeto expográfico de American Paintings from the museum collection. 1948.

THE MUSEUM OF MODERN ART ARCHIVES. Planta do projeto expográfico de Americans 1942: 18 Artists from 9 States. 1942.

THE MUSEUM OF MODERN ART ARCHIVES. Planta do projeto expográfico de Information. 1970.
THE MUSEUM OF MODERN ART ARCHIVES. Planta do projeto expográfico de Scuplture of the xxth Century. 1954. THE MUSEUM OF MODERN ART ARCHIVES. Planta do projeto expográfico de xxvth Anniversary Exhibition: Paintings from the Museum Collection. 1954 . 


\section{ENTREVISTAS}

CARVAlHosa, Carlito. Entrevista concedida a Ana Paula Pontes em São Paulo, 11 de janeiro de 2019. Apêndice $\mathrm{D}$ desta tese.

CINQUALBRE, Olivier. Entrevista concedida a Ana Paula Pontes no escritório do Centro Georges Pompidou, Paris, 19 de julho de 2018. Apêndice C desta tese.

DILLER, Elizabeth. Entrevista concedida a Ana Paula Pontes no escritório da DS+R, Nova York, 18 de julho de 2017. Apêndice A desta tese.

LAMARCHE-VADEL, Rebecca. Entrevista concedida a Ana Paula Pontes no Palais de Tokyo, Paris, 23 de julho de 2018. Apêndice B desta tese. 



\section{ENTREVISTA COM ELIZABETH DILLER CONCEDIDA A ANA PAULA PONTES NO ESCRITÓRIO DA DS+R, NOVA YORK, 18 DE JULHO DE 2017}

A arquiteta norte americana Elizabeh Diller, nascida em 1954 na Polônia, é sócia do escritório Diller Scofídio + Renfro - DS+R, com o qual vem realizando diversos projetos públicos $\mathrm{e}$ culturais referenciais no cenário contemporâneo, como o High Line Park (2009-2014) e o complexo do Lincoln Center (2003 a 2010), além de numerosos centros de arte. ${ }^{726}$ Dois deles são de especial interesse para esta pesquisa em curso: o MOMA - que passou por mais uma grande reforma e expansão - e o novo centro cultural The Shed, ambos em Nova York e concluídos em 2019 (outubro e abril, respectivamente). Liz Diller, como é conhecida, formou-se pela Cooper Union e é professora na Universidade de Princeton e na Bartlett School of Architecture. Nas primeiras décadas de atuação do escritório, fundado em parceria com Ricardo Scofidio em $1981,{ }^{727}$ o casal dedicou-se a trabalhos envolvendo peças multimídia, instalações site-specific, imagens e objetos que abordam o desejo, o gênero e a apresentação e intervenções eletrônicas mesclando arquitetura e mídia. A aproximação com a arquitetura de edifícios tornou-se mais significativa apenas a partir dos anos 2000. O escritório e a arquiteta em particular vêm recebendo prêmios e ocupando posições de destaque em instituições de arquitetura nos Estados Unidos e na Europa. ${ }^{728}$

A conversa com Liz Diller centrou-se na arquitetura do момA, desde as fases antigas até o projeto atual, e sua relação com as perspectivas curatoriais da instituição. A arquiteta tratou também do contraste entre este projeto e o do The Shed no que diz respeito à concepção de espaços para a arte contemporânea, levantando pontos importantes a serem explorados nesta pesquisa.

A autora tinha contato prévio com a arquiteta por ter coordenado a equipe de desenvolvimento do projeto do MIS - Museu da Imagem e do Som no Rio e Janeiro, de autoria da DS+R, no escritório carioca Índio da Costa A.U.D.T.. A conversa de 30 minutos ocorreu no início da tarde do dia 18 de julho de 2017, no escritório Diller Scofidio + Renfro, no $18^{\circ}$. andar de um edifício comercial no número 601 West da rua 26, no bairro do Chelsea, em Nova York. A transcrição foi feita com a colaboração das estudantes da FAU Mackenzie Gabriela Guerra e Tatiana Colognese e a revisão do texto foi realizada pelo tradutor de língua inglesa Jaime Alberto da Costa Pinto Jr. Por solicitação de Elizabeth Diller, a reprodução parcial ou total do conteúdo desta entrevista não está autorizada fora dos limites estritos desta pesquisa de doutorado.

APP: I'd like to talk to you about the MOMA project and the discussions that are going on between the institution and the architects related to the exhibition areas. How are MOMA's curators taking the actual expansion project as an opportunity to rethink ways of displaying contemporary art, if indeed they are?

ED: Yes, they are. The Moma has, for its history, been a lot about departments. There are right now seven
726 Entre os quais o ICA Intitute of Contemporary Art em Boston (2006), o Center for the Creative Arts da Brown University, em Providence (2011), o The Broad Museum em Los Angeles (2015) e o Berkeley Art Museum and Pacific Film Archive da Universidade da Califórnia, Berkeley (2016).

727 Foramincorporadosposteriormente como sócios os arquitetos Charles Renfro, em 2004, e Benjamin Gilmartin, em 2015.

728 Elizabeth Diller é membro da American Academy of Arts and Letters, da American Academy of Arts and Sciences e do Royal Institute of British Architects (RIBA). Ela liderou o júri para o Prêmio Internacional de Arquitetura do RIBA em 2018. Entre os prêmios que conquistou, estão o Lifetime Achievement Award, da National Academy of Design, o Brunner Prize, da American Academy of Arts and Letters, o Barnard Medal of Distinction e um Honorary Doctorate of the Humanities do Occidental College, além de ter figurado duas vezes na lista anual das 100 mais influentes personalidades mundiais da revista Time, em 2009, ao lado de Ricardo Scofidio, e sozinha em 2018. Em 2019, o DS+R recebeu o prêmio anual da Royal Academy of Arts de Londres - RA Architecture Prize. 
departments and each one has space in the museum: painting and sculpture has space, architecture and design, prints and photography, video and films and so forth. With these departmental groups right there they've collected heavily in these disciplines. There's a fabulous architecture and design collection that has everything - modern and contemporary, all the way. They keep collecting, and, for the first time really in their history, the curators want to establish a new paradigm, where the stories of modernism could be told in a different way, rather than by discipline, more by ideal theme, and in which many disciplines could be together in one space. They also decided for this expansion that rather than have dedicated spaces for each discipline, the way right now you have at MOMA, there would be a much looser fit between the galleries and what's there, so the galleries will be flexible enough to take a lot of different things.

APP: That would apply to the collection, but what about temporary exhibitions or projects for contemporary works, are they thinking about new kinds of space?

ED: I think that MomA has a certain standard. The curators don't like to make tall spaces beyond twenty feet and there are certain kinds of parameters that they work within. It's different from other institutions that we've dealt with. And also it's like a certain art fits into galleries that look like that, but there are pieces that don't look like they belong in that gallery. The relationship of the art and the galleries is very tight in the end, so artists perpetuate making works at that scale because those are the size of the galleries, I think. If there were bigger or taller galleries, artists would make bigger or taller things, or bigger budgets. Of course one doesn't know what the future of art is, so we can only guess our strategies. The Shed is in parallel to MOMA, two very different projects and two very different attitudes about art space.

APP: Considering that MoMA's tradition since Alfred Barr is to show art in seemingly "neutral" spaces, how do you think this "white cube" standard and the attempt to avoid competition with the art works affect the architecture of the building? Is the architecture meant only to work in the circulation, reception and more restricted functional areas?

ED: You mean: where is the place for architecture if it's not the galleries, because the galleries are somewhat reserved for a neutral space. I have to say I genuinely agree with it, even though art can go anywhere and artists can be inspired by all different spaces to make different kinds of site-specific installations. But, generally speaking, I think the voice of the architect needs to be dialed down to give other authors a chance to sign things, because sometimes it's just the opposite and you can't turn off the architect and the space.

APP: Like the Guggenheim Museum, for example?

ED: I love that space and I love it because it does different things, with different kinds of installations, but look at MAXXI, for example. It's a very strong space where you can see the will of the architect everywhere and I think it's hard to occupy those spaces. I'm the last one to complain about that, but it's just my own attitude about being on both sides of the gallery wall, as an artists and as an 
architect - I believe that you need to make room for other people to have strong voices.

APP: Don't you think that flexibility could be more about having different spaces - smaller, taller, or with different geometries - than "one size fits all"?

ED: I believe in both, I think there are two attitudes about flexibility, and we've done both. In the building that we did uptown, the medical education center, it's not for art, but it's a building where there are all different kinds of spaces - small, large, open, outdoor, indoor. Those spaces are all in many different kinds in a vertical topography and the whole idea is that you find the place where you feel comfortable. APP: But MOMA is tight, too tight.

ED: MOMA has a very rigid program, a rigorous program, we really had to expand galleries by $30 \%$. They have a huge collection of modern and contemporary art, ever growing, and they don't have the chance to show the fantastic things, so they needed it. The previous expansions didn't give them enough space. So you think about MOMA - it's not that it's small, but there is not that much space. In the end, there is a lot of public space, but there is not a lot of space for the art. So, this expansion was really about space for galleries and there are some other pieces that we've turned into nice spaces or architectural spaces, there is more of a register of our voice. But this is not like the Taniguchi expansion, where you have a huge piece of site where you can do something really new, the way you do when you really have a lot of territory, new territory. This is much more surgical, it's like a site here, a sliver there, inside of the building over there, a renovation over there, and it's all kind of together, and it's not very heroic, but it's very interesting for us, very complex.

APP: And how about the Projects Room? It's been at the center of many discussions, what was your concept about it? ED: We were the first architects to be invited to do a new installation in the Projects Room and that was in the late 1980's. And so we did it, we used it, we challenged it, and there's the space itself and what was just outside of the space.

APP: Was there a dedicated room in the museum for that?

ED: Yes, it was called the Projects Room and it was the one part of the museum where you would work always by commission. And now, when we did the proposal for this new project for Moma, we put in there what we wanted to have: we thought it would be great to have a street level gallery and to actually bring back the Projects Room, because it was removed during the Taniguchi renovation and it was never reinstalled.

APP: Had they planned to use the big atrium as a Projects Room?

ED: I guess they probably had. When it opened, the atrium had a static sculpture and they couldn't figure out how to use it for a long time. And then they actually started to use it very nicely, with performances, so it became a kind of cool space to use.

APP: A stage.

ED: Yes, mostly a stage, but there is no street level space that's free before admission, that you could just see something that's absolutely new and not make a commitment to go inside. APP: Before the Taniguchi renovation, were there exhibitions on the ground floor and at the glass area of the Philip Johnson's exhibitions building? 
ED: This is the space of the restaurant, but that's where it was. It was a kind of off-piste and it had its own rules. That was the only part of the museum where they wouldn't know what you were doing. Legally they couldn't really say yes or no until they saw it till the end [laughs], because it was really new stuff. So we proposed to bring back the Projects Room, everybody really thought that was a good idea. I think everybody wanted to do a preadmission art space. Now, the way it's going to look: there's a shorter gallery that is on the street side, and there's a double high space to the north, in the same footprint. I think that in the Projects Room they are going to commission new work and they are going to show works of the collection that are too big to show in other places.

APP: But did you have to change anything in the first proposition? What were the discussions with the curators about the features of this room?

ED: At the beginning, in the first six months, we had drawn a lot of ideas, things were published and they weren't really well with that. We had what we called an Art Bay, which was that Projects Room facing the street, it would have been a door that could be opened up. They didn't really want that and it evolved, just like any project. In the first six months you work on your own. For us the general idea of having this very public gallery is unchanged, it just moved to... it's north of where it was.

APP: Another space you proposed for this project was the Grey Box. I suppose the name falls somewhere between the "white cube" and the "black box". What is your concept for it? Is it what it's now becoming the Studio?

ED: Yes, the Studio Gallery. The idea was just that it could do exhibitions or it could do theater, something in between the convention of "black box" and the convention of "white box", so we just called the space that way. We still have the program more or less developed the way we had imagined.

This is the area that the Folk Art Museum used to occupy. In that area it's about 40 feet wide - not very wide, not very deep - it's the space that we need to make the connection from the galleries, so we can get a loop. But also we put a stack of galleries there and there are galleries that MOMA doesn't really have, they're like supplementing the regular galleries that are big footprints that could be subdivided. So the new galleries are going to be very flexible, unlike the current Taniguchi's galleries which are pretty much divided with walls that don't move. So the new spaces are all very flexible. The site for the stack of galleries is limited by its size, but that was really perfect because we can get the street gallery, a Projects Room, a day-lit gallery, and the Grey Box called Studio Gallery. That's connected with the bar just on the top of it so it's open at night, activating that whole space. It's all for art and performance.

APP: Is it the one with a glass panel facing the street?

ED: It's glassy, yes.

APP: In 1996, before Taniguchi's expansion, there was a big discussion involving many curators, architects, artists and so on, and one of the things that called my attention was a speech by Rem Roolhaas. In his provocative style, he said that MomA's main value was the ability to produce "aura", but the museum would have proved that "you can be a successful institution in a mediocre architecture”. Do you agree with him? 
ED: [Laughs] Look, the Museum experience, let's say, first is the work inside them, the work that you're looking at. I mean, I would say that yes, we can have a great experience looking at a painting independent of the room that you're in, independent of how much light is in there etc. You can have a great experience, just you and that painting. It's like going to a concert, you're going to have a great experience hearing the piece of music, even if that it's not regarded as a great concert hall, right? Now, it doesn't hurt to have good architecture. [Laughs] And I would say that it helps to make the experience more than just the connection with the work. Because today the museum is everything, it's a day of your life. You go and you eat there - it would be nice to have a nice meal. It would be nice to see a film while you're there, it would be nice to get some oxygen in between four hours in looking to galleries. The quality of space is important, the quality of the architecture itself, I believe that. We've made several museums and I think it's a responsibility of the architect to contribute to the culture of architecture through making museums, and that's part of the obligation of the museum to expose the public to culture, to information etc. Part of that obligation is the space and so it's part of our obligation to make these spaces really good.

APP: And especially for MoMA, that collects architecture.

ED: And especially Moma, which is especially complicated. I have to say that they've been very good, but in their history, as you know, first you have the Durell - Stone building and - did they pick the best architect in the world to do that? Probably not. Is it mediocre architecture? Probably not.
I mean, it's interesting now that we look back at Stone's, and see some really interesting work for his time. And then Philip Johnson...

APP: Who used to apologize for not having done architecture at MOMA, because flexibility wouldn't be architecture.

ED: Well, we have a different opinion about that today, but they picked Philip Johnson in maybe a good period of his life. So: Stone, Johnson, Cesar Pelli and then Taniguchi - that lineage is really pretty crazy! And now this project that we're doing is at the site of the demolished building of Williams and Tsien and, next door, inside of a shell of a Jean Nouvel's apartment building. It's our work is inside of that framework, so it's super complicated.' APP: A crazy quilt.

ED: Yes, it's a crazy quilt. You have to tie a lot of things together.

APP: A point that was much stressed in the 1990's discussion was the museum's modern identity, the need to reaffirm this tradition and at the same time assert MoMA's engagement with contemporary art. Do you think these two vectors can really be balanced in a contemporary project?

ED: I think so. I mean, I kind of think that the modernist project isn't dead yet. But, first of all, they continue to collect modernism as a historic period, in a more contemporary approach to curating. It's interesting to see what was missing from all those others collections in terms of the absence of certain geographies and demographics. And мома is committed to contemporary works so it does interesting shows backwards and forwards and sometimes with very provocative themes. So I think it's very possible, but if I have to say where MoMA's heart is right now, I'd say it's more in the collection. 
Even though they continue to do contemporary shows, with curators that are looking backwards and forwards, which is part of a project for them. But they just feel like it's their obligation in a way, their legacy is to actually tell their stories. But the new stories are creative, they're thoughtful and it's not only scholarship, it's also interpretation. So, I think it's possible to balance. APP: So the building would be like an instrument that allows them to play many stories in different ways?

APP: You know, our thinking with this project is that it allows them a lot of freedom. When you say that flexibility could be "one size fits all" or could be more about particular, lots of different particularities, this is more on the "one size fits all". I mean there are big galleries and there are also smaller galleries, the stack of galleries is smaller and in different heights so maybe those are unique. But most of the space, the renovated space and the new space, they've just given more space, because what's new for MomA isn't necessarily new for other institutions. So, you look at the Taniguchi galleries, they're all fixed walls, portals, openings, they're all about 40 by 50 feet, they're really big galleries and the circulation is difficult. They really needed flexibility in a literal sense, they want to be able to make small spaces and big spaces, but they want to do it on demand and they don't want to have to say: that small thing always will go on that corner. They just want to kind of rescript the space all the time. It's maybe a more common way of thinking about flexibility. I do believe that one of the biggest problems for us is to figure out in a way what art could look like in the next 20 years or 40 years. Make art spaces when you can't exactly know. And that is where The Shed project comes in. The Shed is speculative in that way, it's really a machine for making space for art, it's just about structure and infrastructure. Structure and power, you know, mutual power and physical structure, and comfort. So, after you have that, you can do anything. 


\section{ENTREVISTA COM REBECCA LAMARCHE-VADEL CONCEDIDA À ANA PAULA PONTES NO PALAIS DE TOKYO, PARIS, 23 DE JULHO DE 2018.}

Rebecca Lamarche-Vadel integrou a equipe de curadoria do Palais de Tokyo de Paris em 2012, quando o centro inaugurou a segunda fase de sua reforma, que reabilitou para uso toda a área de $24.300 \mathrm{~m}^{2}$ do edifício. Foi responsável por diversas exposições no centro, ${ }^{4}$ entre as quais a de Tomás Saraceno - On Air -, que, concluída em 2019, foi a mais visitada na história do Palais até essa data. ${ }^{5}$

Lamarche-Vadel, filha de um artista e de uma colecionadora de arte, cresceu no interior da Bretanha e graduou-se em política e história pela Sorbonne. Iniciou sua atuação de modo independente no meio artístico alternativo de Paris e de Berlim, onde trabalhou em diversos projetos de arte. ${ }^{6}$ Depois de assumir a curadoria no Palais de Tokyo, tem colaborado com diversas instituições internacionais, como o MомA PS1, ${ }^{7}$ coordenado seminários na França e no exterior e publicado estudos sobre arte contemporânea.

A conversa com a curadora forneceu dados importantes sobre o modo de utilização dos espaços do Palais de Tokyo por artistas, tratando de diversos exemplos de interação das obras com a arquitetura em exposições recentes. Lamarche-Vadel apresentou ainda a visão atual do centro no que se refere à sua condição de "instituição" cada vez mais consolidada no universo da arte contemporânea, contribuindo de modo significativo para esta pesquisa.

O contato de Rebecca Lamarche-Vadel foi fornecido pelo artista brasileiro Henrique Oliveira, que realizou uma instalação no Palais de Tokyo em 2013, e que, por sua vez, foi apresentado à autora por seu orientador nesta pesquisa, Agnaldo Farias. A conversa de 45 minutos ocorreu num fim de tarde do dia 23 de julho de 2018 , no terraço do Palais de Tokyo em Paris. A transcrição e a tradução do francês para a língua portuguesa foram realizadas pelas tradutoras Caroline Fretin e Celina Olga.

APP: Nos seis anos em que vem trabalhando na equipe de curadoria do Palais de Tokyo, você viu mudanças na maneira de ocupar os espaços, no sentido de uma institucionalização? RL-v: O Palais de Tokyo foi pensado inicialmente como uma espécie de campo de pesquisa em arte e cultura contemporânea, não apenas nas artes visuais. Cheguei aqui com Jean de Loisy, o atual presidente, em um momento de renovação do espaço, porque estávamos abrindo dois andares inferiores que estavam fechados ao público. Acho que o que sempre mantivemos foi a ideia de que toda exposição vem da vontade do artista e também de uma pesquisa tanto sobre o conteúdo da exposição, ou seja, sobre as obras que vamos mostrar, quanto sobre a maneira como vamos mostrá-las. Então, de fato, para cada projeto em que trabalho, aqui com os artistas, a questão arquitetônica é fundamental, ela é pelo menos tão importante quanto as obras, porque acho que muitos de nós incorporaram a ideia de que uma exposição - falo da arte contemporânea no século XXI - não é
729 Entreseusprojetoscomo curadora no Palais de Tokyo estão as exposições de Tino Sehgal - Carte Blanche (2016) -, a de Marguerite Humeau - FOXP2 (2016) -, a coletiva Le Borde des Mondes (2015), a de Ed Atkins - Bastards (2014) -, a de David Douard Mo'Swallow (2014) -, a de Helen Marten - Evian Disease (2013) - e a de Jon Rafman - Remembering Cartage (2012).

730 AexposiçãoOnAir-Carte Blanche à Tomas Saraceno recebeu 220 mil visitantes entre 17 de outubro de 2018 e 6 de janeiro de 2019 .

731 Tais como Forgotten Bar Project em Kreuzberg (2008) e Based in Berlin (2011).

732 Nas exposições 72 hours of truce: exploring immediate signs (2013) e Bright intervals (2014), nо момА PS1 (Nova York), e nas exposições do artista Fouad Bouchoucha Landscape (2014) -, no Stedelijk Museum e Trouw (Amsterdam) e na coletiva Unfinished Presents (2013), na Bienal de Lyon. 
$733 \mathrm{O}$ artista tailandês Korakrit Arunanondchai (1986-) realizou no Palais de Tokyo a exposição Painting with history in a room filled with people with funny names 3, em 2015.

734 O artista Suíço Thomas Hirshhorn (1957-) realizou no Palais de Tokyo a exposição Flamme Éternelle, em 2014.

735 O artista britânico Tino Sehgal (1976-) realizou no Palais de Tokyo a exposição Carte Blanche à Tino Sehgal, em 2016.

736 O programa Carte Blanche do Palais de Tokyo (Carta Branca em português) consiste em intervenções concebidas por um artista ocupando a área de até $13.000 \mathrm{~m}^{2}$ do edifício. mais apenas ver uma obra à distância, mas é também uma experiência física. E essa experiência física, pelo menos para mim, é fundamental e eu trabalho muito isso com os artistas. Então, se há uma consolidação em favor da institucionalização, da museificação, talvez seja porque as pessoas se sentem mais seguras com essa estética, que, antes de tudo, é desejada pelos artistas. E se há paredes brancas que lembram esses códigos, não é verdade que todos os projetos vão nesse sentido. Aqui, a cada temporada temos uma renovação. Estou pensando em Korakrit Arunanondchai ${ }^{733}$ ou Thomas Hirschhorn, ${ }^{734}$ ou no que fizemos com Tino [Sehgal]. ${ }^{735}$ Havia o desejo de não recorrer ao white cube de modo algum. Além disso, acho que o fato de integrar ou não esses espaços como espaços de reflexão também é uma questão de sensibilidade e de escola artística. Para mim, mais uma vez, isso é absolutamente fundamental, constitutivo. É preciso saber também que todas as exposições são novas produções. Portanto, trabalhamos cada vez sobre um novo projeto com o artista e, para mim, esse momento de reflexão e de mostra do trabalho do artista atende completamente à própria natureza da obra. Daí a necessidade daquilo que fizemos com Tino na época da sua Carte Blanche, ${ }^{736}$ de retirar todas as paredes do Palais de Tokyo, para chegar, ou pelo menos tentar chegar o máximo possível, à essência da arquitetura tal como Lacaton \& Vassal quiseram preservar, ou seja, a um tipo de espaço intermediário. Quanto ao trabalho de Tino, é um trabalho imaterial, então não há nenhum objeto no espaço. Existem apenas obras, enfim, humanos - homens e mulheres- que fazem essas obras - e são chamados de participantes. O princípio é que eles estão vestidos como eu e você, como qualquer pessoa, eles são indetectáveis no espaço da exposição. Mas em um certo momento, quando você está andando em um certo lugar, alguns deles vão vir falar com você e te envolver numa obra.

APP: É uma espécie de performance?

RL-v: Não usamos o termo performance, porque a ideia de performance vem dos anos 70. É a ideia de hora marcada, ou seja, você vai vir num determinado momento para assistir a uma performance, e isso se aproxima da ideia de espetáculo. Além disso, o trabalho de Tino levanta a questão do que seria hoje a possibilidade de fazer objetos imateriais. Então, quando você vai a uma exposição de Tino Seghal, a obra se faz continuamente, ou seja, não há hora marcada, não há um momento em que você espera vivenciar uma espécie de clímax espetacular da obra. Na verdade, ela te envolve, a obra te envolve a qualquer momento quando você entra no espaço. Dessa forma, é apenas uma maneira, para essa obra, de repensar o que são as artes visuais, repensando a ideia de que toda a modernidade escreveu o poder do olhar. E repensar também o que acontece quando se entra numa outra sensação que, nesse caso, é uma sensação imaterial, em que a obra se faz na conversa com o outro. Ainda assim, para essa obra imaterial, havia 400 participantes em todos os espaços do Palais. Retiramos todas as paredes para chegarmos à essência do edifício. Propus isso a Tino porque o edifício do Palais de Tokyo foi criado em 36-37 para a Exposição Universal: foi um momento incrível de exposição da performance dos Estados, da performance do objeto, uma espécie de consagração da 
mecânica, da indústria, etc. Isso é algo completamente contrário ao que Tino defende, porque ele se coloca numa perspectiva de recusa de extração dos recursos naturais do planeta, o que significa criar objetos. Sendo assim, ele não cria mais objetos, nenhum objeto, ou seja, nenhum papel é produzido para uma exposição de Tino Seghal. Fomos proibidos de enviar convites, o que foi feito por e-mail, não tínhamos flyers, não tínhamos nada, nenhum texto para a exposição, nada impresso nos espaços. Tudo estava vazio. E os visitantes eram deixados totalmente por conta própria nesse lugar que era o templo da ideia moderna do progresso. O importante para mim era justamente confrontar esse templo com o pensamento de Tino Seghal, que era o da ociosidade material, para repensar nossos encontros imateriais e como opera a intersubjetividade. Em termos de arquitetura, portanto, não éramos nem institucionais nem não institucionais. Deixamos a instituição se fazer como um espaço que encarna uma ideia, um símbolo. E, efetivamente, o simples fato de as pessoas passarem pela porta era para nós o cenário, $o$ mindset, no qual a pessoa se coloca quando entra nesse espaço. $\mathrm{E}$ isso nos bastava para ativar a exposição e deixar viver o espaço arquitetônico pelo que ele é em termos de referência estética e simbólica para o visitante.

APP: Isso faz parte de um ritual dos espaços expositivos?

RL-v: Sim, exatamente, e a ideia de ritual também é fundamental neste projeto. Para a exposição de Tino, era muito importante para mim imaginar a ideia de ociosidade, porque, de fato, havia uma real pobreza nos espaços uma vez que, justamente, não havia nenhuma parede, nenhuma instalação, nenhuma estetização tal como a instituição normalmente faz. Porque a instituição tem códigos arquitetônicos incríveis para instaurar um poder. Esse é um exemplo deste jogo e um contraexemplo é uma exposição que fizemos em 2015, que se chamava Le Bord des Mondes. ${ }^{737}$ Para mim, a arquitetura era fundamental naquele momento, pelo mesmo motivo, aliás, porque a exposição estava interessada em criadores que não se denominavam artistas. Eram pessoas que tinham criações tão singulares ou poéticas que eu queria integrá-las como ocorre no campo da história da arte ou no campo da arte. Eram pessoas totalmente independentes, que nunca haviam exposto e que não criavam para expor, como, por exemplo, Bridget Polk, que faz pedras em equilíbrio. Ou engenheiros, como Theo Jansen, que cria animais na Holanda para uma espécie de especulação biológica, para tentar repensar o futuro da espécie humana. Eram somente personalidades, 25, em Le Bord des Mondes, que seriam caracterizadas pelo mundo da arte como outsiders, ou como pessoas da arte bruta, que não são artistas. E dessa forma, para mim, todo o jogo com a arquitetura da exposição consistiu em reproduzir uma arquitetura de exposição institucional. Portanto, paredes brancas, enfim, coisas que eu nunca faço. Paredes muito brancas, etiquetas de legendas, para apresentá-las realmente como obras.

APP: Para valorizar coisas que não são consideradas arte.

RL-V: Isso. E especialmente para enganar o olhar. Ou seja: quando apresentamos algo como uma obra, olhamos para isso como uma obra, ou não? E foi muito interessante, porque foi o que aconteceu. As pessoas aceitaram,
737 A Beira dos Mundos em português. 
738 A tradução para o português seria "cenógrafo", mas no Brasil esse termo é mais usado para se referir ao profissional relacionado à criação de cenários teatrais, por isso foi mantida a expressão em francês. O projeto expográfico de Le Bord des Mondes foi desenvolvido pelo arquiteto Stéphane Maupin, que realizou outros projetos no Palais de Tokyo, para o restaurante e a livraria. Ver site do arquiteto: http://www. stephanemaupin.com/\#cbpi=http://www.stephanemaupin.com/cubeportfolio/ librairie/

739 O título Encore un jour banane pour le poisson-rêve - exposição que ficou em cartaz no Palais de Tokyo de 22 de junho a 9 de setembro de 2018, é inspirado no título de um conto do escritor norte americano J.D. Salinger, "A perfect day for bananafish", publicado originalmente em 31 de janeiro de 1948 na revista The New Yorker. o público aceitou totalmente essa apresentação, e a recepção foi extremamente boa. Esses artistas nunca foram caracterizados como outsiders pela imprensa etc., porque foram usados alguns códigos de exposição, o que tornava essa percepção, essa recepção, muito mais simples porque ela usava esses códigos. E foi muito interessante para mim jogar com isso porque havia duas direções fundamentalmente opostas. Uma era fazer uma cenografia um pouco bagunçada, bem "faça você mesmo" ou, ao contrário, fazer algo muito leve. Trabalhei com um scénographe $e^{13}$ para fazer algo extremamente preciso.

APP: Elegante.

RL-v: Extremamente elegante, e tudo correu muito bem. Acho que a questão é um pouco mais complexa do que "isso está se tornando mais institucional ou não?”. Trata-se de pensar no quanto se pode trabalhar com isso. $\mathrm{O}$ que procurei fazer para muitas exposições foi usar a arquitetura como meio simbólico e como ferramenta para conceber o espaço.

APP: Eu digo isso porque a primeira vez que eu vim para cá, dez anos atrás, eu não sabia de nada, exceto que era um espaço de arte contemporânea e, quando entrei, me perguntei: será que eu posso entrar, será que está acabado, será que ainda está em construção, será que está assim de propósito?

RL-v: Sim, imagino.

APP: O Palais dava essa impressão, mas hoje está mais "projetado".

RL-V: Isso.

APP: A entrada, o restaurante, as lojas, a livraria, a recepção, tudo isso.

RL-v: Sim, mas esses espaços, na realidade, não são os espaços de exposição, são os espaços de entrada, etc. É verdade que hoje estamos num espírito muito mais estabelecido do que o que era dez anos atrás, está claro. E isso atende à política da administração do Palais de Tokyo e à sua escolha em termos de prestadores de serviços. É verdade que, nesse ponto, de fato deixamos para trás os antigos restaurantes, as antigas livrarias, que estavam num espírito muito mais leve, frágil. Enfim, havia algo, outro espírito que se destacava.

APP: Informal.

RL-V: Informal, certamente. E isso, acho que tentamos equilibrá-lo em exposições, ou pelo menos tentamos ser, o máximo possível, surpreendentes e inventivos. Acho que acontece com qualquer instituição, infelizmente, que chegue a tamanha escala - o Palais de Tokyo cresceu muitíssimo nos últimos anos, tanto em termos de número de visitantes, de orçamento, quanto de pressão econômica. Então, acho que talvez a estética da instituição seja mais tranquilizadora nesses casos do que movimentos um pouco mais frágeis e mais informais.

APP: A exposição atual - Encore un jour banane pour le poisson-rêve ${ }^{14}$ tem um percurso bem definido. Entrei no sentido contrário, sem saber, e no meio me dei conta que estava na contramão e não sabia como consertar (risos). O percurso é meio labiríntico. RL-V: É verdade.

APP: A gente começa e não tem ideia de onde está o fim. E tem também salas bem separadas, com um ambiente para um artista, outro ambiente para outro. RL-V: Isso mesmo, a separação dos mundos.

APP: É o que estou chamando de mais clássico, mais musealizado.

RL-v: Sim, isso está muito relacionado à natureza da exposição, que é uma exposição coletiva. A exposição 
coletiva, num centro de arte contemporânea, entendo, é mais complexa, porque reunimos obras de artistas que às vezes são muito diferentes, mas que são conectados pelas temáticas, não necessariamente pelas obras ou pela maneira como as obras existem depois. E é por vontade, penso, de não criar diálogos, digamos, indesejáveis ou um pouco perigosos. Esse é realmente o trabalho do curador, assumir ou não essa posição. E então surge outra questão, que é a do curador-autor, ou melhor, do distanciamento do curador para ter uma espécie de objetividade, ou, em todo caso, um ponto de vista um pouco mais destacado em relação à exposição. É verdade que Encore un jour banane pour le poisson-rêve é uma espécie de exposição pensada também em termos de ritual e de etapas, e então tem as passagens, imaginadas por Clément Cogitore, ${ }^{15} \mathrm{e}$ daí passamos de obra em obra.

APP: Como na escada.

RL-v: A escada é uma das passagens imaginadas por Clément. Não fui curadora da exposição, não trabalhei nela em nada, mas sei que foi pensada assim, um pouco como um jogo no qual somos o herói. E assim, de fato, o espírito de labirinto faz totalmente parte da ideia deste projeto. Depois, o que é muito interessante sobre os projetos do Palais nessa escala, é jogar com a perda de rumo, a perda de referências. Aliás, isso funciona muito bem aqui, afinal estamos numa espécie de momento em que é preciso também se deixar levar e se deixar guiar por um caminho que é determinado em grande parte pelos espaços. Mas o interessante é que no começo, em 2012, jogávamos muito mais com a perda de referências, com a desorientação. E fomos muito criticados por isso. Diziam: "A gente se perde o tempo todo", "É incompreensível”, "A gente não consegue”. E de fato vimos nisso um medo real, por parte do visitante, de se perder, de perder referências e perder sinais de orientação claros e distintos. Assim, é verdade que as exposições que guiam os visitantes tendem a tranquilizá-los e a ter mais sucesso.

APP: É verdade. (risos)

RL-V: Isso é impressionante. Em todo caso, o que é interessante é que as pessoas esperam que a instituição as guie ao invés de fazer com que se percam. E, embora não nos definamos aqui como instituição, somos percebidos como tal e as pessoas esperam ser guiadas.

APP: Como vocês, curadores, trabalham em relação ao edifício, que é enorme, para organizar as próximas exposições? RL-v: Depende das temporadas. Esta, por exemplo, é uma temporada bastante tradicional, no sentido de que temos várias exposições que coabitam. Aliás, na exposição de Laure Prouvost, ${ }^{16}$ por exemplo, vemos que a artista realmente usou o espaço, muito mais do que o que foi feito na outra exposição coletiva. Isso tem a ver com o que acabei de dizer, pois, uma vez que o artista realiza uma individual, a arquitetura e o gesto arquitetônico fazem realmente parte da própria exposição. Ela também trabalhou com um scénographe. Por outro lado, eu trabalho nos projetos muito grandes do Palais que ocupam todo o edifício.

APP: Com apenas um artista de cada vez?

RL-v: Sim. E com o Tino Sehgal, como já falamos, foi uma reação diante da obra, da história do edifício, e como poderíamos reagir da maneira mais justa possível num diálogo entre a obra
740 Clément Gogitore é um artista francês, nascido em 1983.

741 A exposição Ring, Sing and Drink for Trespassing, da artista francesa Laure Provost (1978-), ficou em cartaz no Palais de Tokyo de 22 de junho a 9 de setembro de 2018. 
742 A exposição em questão é On Air - Carte Blanche à Tomás Saraceno, que ficou em cartaz de 17 de outubro de 2018 a 6 de janeiro de 2019 e que, tendo recebido 220 mil visitantes, foi a de maior público da história do Palais de Tokyo até aquele momento.

$743 \mathrm{O}$ artista brasileiro Henrique Oliveira (1973-) realizou no Palais de Tokyo a instalação Baitagogo, que ficou de 30 de novembro de 2013 a 18 de dezembro de 2016 .

744 "Suspensão da descrença”, em português. e esse espaço. E me pareceu que seria retirando tudo, esvaziando o edifício. Muitos comentários sobre a exposição de Tino falavam sobre o Palais de Tokyo vazio, enfim, isso se tornou uma coisa que assombrava um pouco os visitantes. Tive essa ideia porque visitei o Palais de Tokyo completamente vazio em 2012, com Jean de Loisy, o atual presidente, e fiquei muito emocionada. Foi incrível, nós dois estávamos nesse espaço que ainda estava em obras, havia buracos de dez metros por toda parte, vazamentos, era um mundo cinzento, completamente sagrado e ao mesmo tempo completamente surreal. Fiquei tão emocionada ao visitar esse lugar que, quando soube que iria trabalhar com Tino, pensei, este é o único artista que vai me permitir mostrar ao público o Palais de Tokyo em sua nudez mais extrema. Agora estou preparando a próxima com Tomás Saraceno, ${ }^{742}$ que é um artista argentino, e estamos tentando usar o espaço de uma maneira talvez mais clássica. Porque o que é impressionante é que o espaço se adapta às obras e não o contrário. Esse gigantismo do Palais nos permite desenhar o espaço arquitetônico para que esteja à altura das obras. Em todo caso, é assim que eu vejo, para Tino, novamente, ou para Le Bord des Mondes, ou para Tomás. $\mathrm{E}$ assim, redesenhamos a cada vez o espaço de modo que a arquitetura responda aos diálogos e não sufoque as obras. Porque é o grande risco, certo? APP: Então vocês procuram convidar artistas que possam usar o espaço, como Henrique Oliveira, ${ }^{743}$ que usou as vigas e as colunas para fazer seu trabalho?

RL-v: Sim e não. Na verdade, acho que cada um reage à arquitetura como pode, não é de forma alguma uma condição para os convidados, mas, muitas vezes, percebemos que as exposições acompanhadas por uma reflexão arquitetônica são de alguma forma mais completas, tornando-se uma ficção, ou seja, a exposição é uma ficção em si. Assim que passamos pela porta da exposição, passamos para um mundo do artista e colocamos de lado nossas dúvidas. Coleridge fala em suspension of disbelief,${ }^{74}$ ou seja, que suspendemos nossas dúvidas para entrar completamente no mundo do artista. $\mathrm{E}$ as exposições que funcionam bem são também aquelas em que o artista está consciente desse movimento, está consciente de que sua obra existe em um conjunto maior, que é uma experiência física de um espaço. $\mathrm{E}$ assim, não é uma condição, mas, na maior parte do tempo, é uma ferramenta. É verdade que, muitas vezes, o problema surge com os jovens artistas: é a maneira como obras ainda pouco maduras, ou que ainda são um pouco frágeis, se confrontam com esse espaço, como podem existir num espaço que tem tamanha autoridade e tamanho poder. Sabemos bem que as obras dos jovens artistas, muitas vezes por razões econômicas, mas também de idade, de momento de carreira, de pesquisa, de vida, nem sempre são capazes de dominar o espaço. $E$ isso faz a obra parecer às vezes muito pobre comparada a esse abismo, a essa imensidão que a cerca. APP: Nesse caso, o trabalho de museografia poderia ajudar.

RL-V: Não temos museographie no Palais. APP: como vocês fazem?

RL-V: Ou trabalhamos com o artista, e isso basta porque é uma reflexão conjunta, ou trabalhamos com scénographes. É muito comum que tenhamos scénographes.

APP: São arquitetos? 
RL-v: Depende da formação. Scenography é a arquitetura da exposição.

APP: É disso que estou falando, em português usamos "museografia" ou "expografia" com esse sentido.

RL-v: Ah.... Há cursos relacionados a isso, mas para o design do espaço. Porque a museographie está mais ligada à conservação, às normas. Trabalhamos com vários scénographes. Não é uma etapa obrigatória, depende realmente do grau de sensibilidade, do grau de investimento do artista nesse ponto.

APP: Você acha que as características do Palais - o espaço monumental interno e cru, um pouco brutal, sem acabamento etc. - permite aos artistas explorar possibilidades que só o Palais pode oferecer?

RL-v: Sim. Acho que tentamos manter o Palais como um terreno de experimentações, ou seja, um espaço aberto que permita se repensar, se reinventar permanentemente, e essa, na realidade, sempre foi uma regra que nos impomos, na maneira como trabalhamos com os artistas. Isso se percebe em cada exposição, como, por exemplo, Laure Prouvost, que fez uma exposição inteira sobre a saída da exposição. Ela fez os vídeos nos espaços do Palais de Tokyo e depois saiu para fora, onde há os jardins compartilhados dos habitantes, os vizinhos do Palais. Ela usa realmente a arquitetura como um lugar de inspiração, um lugar de questionamento do limite, da fronteira, do território e, assim, ela realmente interage com a arquitetura deste lugar. Acho que todos os artistas têm a oportunidade de torná-lo um local de experimentação, porque o edifício não é protegido por lei. Ele não é protegido pelo Bâtiments de France, e isso dá uma certa liberdade que permite mexer no edifício sem prejudicar sua integridade e permite um diálogo entre o contemporâneo e a história. $\mathrm{E}$ isso me parece absolutamente fundamental, uma vez que muitos lidam com essa história, interagem com esses códigos, mesmo que não seja necessariamente o objetivo principal das obras. Mas o que é muito importante, também, é imaginar que estamos diante do paradoxo de trabalhar com objetos que não querem se consolidar, que são as exposições, os momentos temporários, os momentos temporários de habitação do espaço, e cabe a nós, penso, enquanto curadores, enquanto centro de arte, poder fazer existir este temporário em tudo que ele tem de mais ousado, em tudo que ele tem de mais perigoso. É o que tentamos criar, a cada vez, chegando até aos contrafortes do Palais de Tokyo: em todos os corredores, escondidos, temos programas de grafite, de urban art etc. que permitem descobrir outros espaços que não são os espaços oficiais do Palais, espaços de exposição que podem ser visitados com um ingresso. Portanto, há também esse jogo com essa história. Isso me lembra Pierre Huyghe. ${ }^{745}$ Nós o havíamos convidado durante a exposição de Tino Sehgal e ele fez uma sala lá embaixo do Palais, nesse lugar piranesiano que é o nível zero.

APP: Você se refere ao Lasco Project? RL-V: Não, ao último subsolo do Palais. É um espaço onde as pessoas vão muito pouco porque é de difícil acesso, mas é aberto ao público, no nível inferior. Pierre Huyghe, um artista convidado, fez essa sala onde ele integrou completamente a arquitetura do Palais, ou pelo menos a dinâmica do Palais. E, neste espaço que se chama Music Temple, colocamos uma célula humana cancerígena. Os laboratórios, há mais de cinquenta
745 Pierre Huygue é um artista francês nascido em 1962.

\section{8-629}


anos, têm permissão para cultivar células - nesse caso, são células de um humano, uma mulher, que viveu e teve câncer -, e eles as usam para estudar a doença. Esta célula estava dentro de uma estrutura conectada a toda uma série de elementos. Um desses elementos era o batimento cardíaco de uma menininha que estava fazendo uma obra de Tino em outra sala. Então, enquanto ela realizava a obra, ao vivo, as batidas do seu coração eram enviadas para este espaço. Havia também a taxa de $\mathrm{CO}^{2}$ expelida pelos dançarinos que estavam dançando numa sala fechada em outro andar. Havia os movimentos de moscas e camundongos que foram soltos em todo o Palais antes da abertura do vernissage, que até hoje continuamos encontrando e caçando (risos). Todos esses movimentos alimentavam a célula e permitiam que ela se desenvolvesse mais ou menos rapidamente. Em troca, ela transformava a vida do Palais de Tokyo, arquitetonicamente falando, os fluidos da arquitetura. Havia um grande vazamento de água que aumentava ou diminuía de acordo com esses movimentos. Os deslocamentos de um elevador que estava ao lado deste espaço eram desenhados de acordo com a ativação ou não da célula. Havia também os movimentos da eletricidade, com as modificações das intensidades da iluminação. Para Pierre Huyghe, isso foi realmente uma reflexão em torno de toda a arquitetura enquanto fluido em movimento, enquanto matéria movediça. Evidentemente, é uma inspiração permanente e permite jogos, que, esperamos, não sejam comentários literais sobre o Palais de Tokyo, mas uma reflexão sobre como o Palais de Tokyo pode se tornar um espaço simbólico, que inspira artistas. Tem uma célebre história muito falada pelos artistas muitos tentaram iniciar um projeto a respeito, mas nenhum pôde continuar. O que dizem é que pianos teriam sido requisitados e roubados pelos nazistas durante a Segunda Guerra Mundial em Paris, na época da Ocupação, e que esses pianos teriam sido guardados justamente no Music Temple, que é o lugar onde Pierre Huyghe fez esse trabalho. Não há nenhum documento que nos permita atestar isso, mas é uma espécie de mito, de lenda, de história (se é que é verdade), que acompanha o Palais de Tokyo há muitos e muitos anos. Os artistas sempre ouvem falar sobre isso, porque essa história acompanha também, e muito, as pessoas que trabalham no Palais, que a contam para os artistas. Eles querem fazer alguma coisa com isso e nunca deu em nada. Aliás, Pierre Huyghe me perguntou sobre essa história quando trabalhamos juntos e ele começou a pensar nisso, mas, como não havia como verificar essa informação, acabou abandonando a ideia. É muito interessante ver como as histórias que alimentaram essa arquitetura, que alimentaram esse lugar, continuam a assombrá-lo sem que possamos saber se correspondem ou não a fatos históricos.

APP: Não são apenas as características físicas do edifício que instigam os artistas, mas também sua história. RL-v: Sua história, sim, certamente. Os dois andam juntos, de qualquer maneira. Mas, claro, toda a história, todos os momentos também - quando o Palais de Tokyo foi o museu de arte moderna e tivemos aqui obras de Max Ernst, etc -, tudo isso continua dando vida ao lugar. Até os nomes dos espaços, como a Galerie du Capricorne, 
chamada assim por causa de uma exposição do capricórnio feita por Max Ernst. Felizmente, há toda uma história que continua a alimentar os artistas que, hoje, vêm se instalar no Palais por alguns meses.

APP: E as obras do Lasco Project, viraram uma coleção permanente?

RL-v: (risos) Não se sabe. Elas são uma coleção temporária. Estão aqui, preservadas, conservadas por nós, além do mais, o Palais de Tokyo é uma história em movimento permanente. $\mathrm{E}$ também, a maneira como o Palais de Tokyo existe está muito ligada à gestão da presidência.

APP: O Palais de Tokyo está vinculado à qual instituição?

RL-v: O Ministério da Cultura nomeia o presidente. Jean vai embora no ano que vem, então ele deixa o legado do Lasco e também de várias marcas deixadas pelos artistas em todos os lugares, porque também sempre fizemos questão de fazer conviver o passado e o presente. Por isso temos marcas da cinemateca, que também esteve no Palais no século xx. Mantivemos os vestígios dos letreiros de sinalização da cinemateca, que estão lá, e depois de cada exposição dos artistas que intervêm tentamos deixar marcas. Caberá à próxima pessoa que tomar a direção do Palais de Tokyo decidir se manterá, se guardará ou não essas marcas. É realmente uma escolha estética, política e simbólica.

APP: Estou perguntando isso porque, mesmo sendo a Street Art sempre temporária, existem museus dedicados a isso, como por exemplo o Street Art Museum em Amsterdam.

RL-v: Bem, nesse caso, a ideia é que, como as obras são feitas nas paredes, ninguém pode levá-las embora.

APP: Como afrescos.
RL-v: É isso, são afrescos. São um pouco os afrescos dos séculos Xx e XxI. Vão ficar lá de qualquer maneira. Quando sairmos, eles vão ficar. A próxima pessoa que tomar as rédeas desse lugar decidirá se irá ou não integrar aquilo como uma história a ser mantida, preservada ou retirada. Nós não temos coleção, então não podemos considerar isso institucionalmente como uma coleção, porém talvez mais no campo sentimental. São os sentimentos da próxima pessoa que determinarão se esses lugares irão permanecer ou não. APP: E quanto aos arquitetos, vocês ainda têm algum relacionamento com eles para eventuais obras? Ou as relações estão cortadas e vocês estão por conta própria?

RL-v: Temos pouquíssimas relações com Lacaton \& Vassal. Nós nos falamos quando estávamos tentando encontrar as plantas de todo o Palais de Tokyo, porque é uma arquitetura que está mais ou menos sob controle. Ainda não temos as plantas definitivas do edifício, ainda estamos tentando domar este lugar. Por isso estivemos em contato com eles um pouco naquela época e, desde então, não mais. Mas eu acho que o projeto de Lacaton \& Vassal é justamente deixar um lugar que vai ser escrito por todos aqueles que vão habitá-lo depois. E o grande talento, o imenso talento de Lacaton \& Vassal, é aceitar que o gesto arquitetônico não está terminado no momento da entrega. Ele continua, e a maneira como habitamos este lugar vai definitivamente transformar os usos. E a maneira como tentamos categorizar os espaços é a ideia de que esses espaços estão em movimento permanente. Eu acho realmente que o projeto deles foi deixar o lugar como eles o encontraram. Eles foram 
o mais longe possível em seu campo de atividade e, em seguida, cabe a nós - acredito que haja uma história de responsabilidade também -, cabe a nós a responsabilidade pelo modo como damos vida a este lugar. Sempre o fizemos vibrar com os artistas. É um revezamento. Eles intervieram muito pouco e, de algum modo, essa atitude nos encoraja a encontrar soluções por nós mesmos, ou seja, não há mais essa ideia de que a arquitetura se torne o principal mestre de obras para todo o sempre. Ou seja, de repente eles passam o bastão e cabe àqueles que habitam este espaço encontrar soluções, criar um diálogo com este lugar que se reinventa a cada dia conforme as inúmeras dificuldades que se pode encontrar nele. Por outro lado, é um lugar que é realmente impossível de se domesticar, que ainda estamos tentando compreender, mas que nos domina. Eu trabalho num escritório onde a temperatura é de 40 graus no verão e -10 graus no inverno. Realmente, são condições que parecem anacrônicas. E todo mundo está tentando encontrar, coletivamente, soluções para um lugar que é grande demais para nós e para nosso controle. APP: Então a ideia foi bem recebida e continuou?

RL-V: Não sei se foi uma ideia realmente afirmada por Lacaton \& Vassal. É assim que eu analiso, é a passagem, é bem-vinda. De fato, é preciso criar com a vantagem dos inconvenientes desse espaço. Isso nos dá uma enorme liberdade na criação de exposições, na criação de espaços, na transformação etc. e, ao mesmo tempo, restrições enormes, dentro dos limites do controle que se pode ter sobre o espaço. Há vazamentos constantes, o edifício é extremamente difícil de resfriar, extremamente difícil de aquecer etc. Mas ele resiste. É um edifício que resiste e não é um edifício simples. Então eu acho que todas as pessoas que trabalham aqui são extremamente apegadas a este lugar e aceitam, tem de aceitar essa realidade. Penso que Lacaton \& Vassal estavam muito conscientes disso. É por essa razão que ele nunca poderá ser uma instituição, porque imagino que nunca poderemos respeitar as exigências de uma instituição. Isso nos dá mais uma vez muita liberdade e, ao mesmo tempo, muitas restrições. É um jogo. É sempre o mesmo jogo com as leis, com as regras.

APP: Sim, é sempre um jogo entre a arquitetura e a instituição. Devem andar sempre juntas, senão, as coisas não funcionam bem.

RL-V: Isso mesmo. Mas aqui, isso nos permite sermos piratas. Porque é um pouco um edifício pirata.

APP: Uma "ocupação", podemos falar assim em francês?

RL-V: Sim, podemos dizer "ocupação". Dizemos "ocupação temporária do território". É a ZAD [Zona a Defender]. A ZAD em Nantes é um espaço de milhares de $\mathrm{km}^{2}$ que foi ocupado temporariamente para lutar contra a abertura de um aeroporto. Não tem nada a ver com isso, mas em todo caso, é uma zona de ocupação temporária. Pois é, aqui estamos entre paredes grandes demais, de um modo geral. Então temos que aceitar suas regras. $\mathrm{O}$ edifício nos impõe suas regras e fazemos propostas a partir delas. Isso também virou motivo de brincadeira internamente na equipe do Palais de Tokyo. APP: Há uma espécie de improvisação? RL-v: Exatamente. É realmente uma improvisação, ligada, às vezes, a um pouco de desespero também, ligada a um monte de sentimentos. 
APP: Estamos muitos acostumados a isso no Brasil.

RL-v: Existe todo um repertório. É maravilhoso. Há todo um repertório humorístico que se criou em torno desta arquitetura e de todas as surpresas que pode nos reservar. É algo que nem é mais surpresa, na realidade também é um assunto que reforça um pouco os relacionamentos.

APP: Sabemos que a inspiração desse projeto se baseia na ideia de Cedric Price. $^{746}$

RL-v: Exato. Confiei muito nisso. Enfim, eu realmente queria acreditar nisso. Acho que os espaços não são tão móveis e permeáveis, tão transformáveis quanto a ideia do Fun Palace de Cedric Price. Acho que estamos nos aproximando dela. Em todo caso, é um ideal que está longe de ser o que rejeitamos, há algo, pelo menos para mim, que é uma fonte de inspiração muito fértil. Agora, acho que precisamos, para funcionar, no caso da economia que conhecemos hoje de um centro de arte, de lugares que são os locais de exposição, a recepção, o restaurante, etc., No entanto, Cedric Price propunha uma porosidade completa. Passava-se do teatro para o cinema, para a sala de exposição, mas podia-se mudar tudo. Havia uma espécie de porosidade absoluta dos mundos que não é bem o que temos aqui. Penso que estamos tendendo para este modelo, mas acredito que a realização do projeto de Cedric Price.... Eu nunca vi isso nesse planeta.

APP: Havia também muita participação do público com a cibernética etc. RL-v: Exatamente. Havia essa dimensão cibernética extremamente importante. Aqui, estamos tendendo, estamos tendendo, mas não chegamos lá. Está claro. Mas isso faz parte, para mim, dos modelos da instituição, porque há modelos muito interessantes para se pensar uma instituição do século xxI que hoje, sim, está pedindo que se repense uma série de hábitos, de usos, que, no momento, não estão na agenda, mas quem sabe? Isso poderia acontecer. Em todo caso, o Palais de Tokyo tem o tamanho que poderia se prestar a isso. APP: Muito bem, obrigada!

RL-V: É isso? É o suficiente?

APP: Sim, é o suficiente, muito bem, obrigada.

RL-v: Não há de que!

APP: Bom, poderíamos nos estender muito mais!

RL-v: Sim, poderíamos falar disso durantes horas. Então, em que espaços sua tese se concentra?

APP: Estou estudando esses modelos de centros de arte contemporânea em contraste com o MомА, que definiu o padrão de exposição de arte moderna, e que está tentando ser contemporâneo, mas encontrando problemas com, talvez, sua identidade.

RL-v: Definitivamente, e cada vez mais, acho.

APP: Sim. Mas tenho contato com os arquitetos da Diller Scofidio + Renfro, que estão projetando a reforma do MOMA, por ter participado de um projeto com eles no Rio de Janeiro, para o Museu da Imagem e do Som. E durante a pesquisa achei um vínculo interessante desses modelos de espaços de arte contemporânea com outro grande projeto que eles estão fazendo em Nova York, o The Shed.

RL-v: Sim, claro! Eu ia justamente te dizer que, para mim, o modelo que mais se aproxima disso seria The Shed. APP: Exato. Mas vamos ver como vai funcionar. Também é inspirado em Cedric Price. Então, de certa forma fecha-se um círculo.
746 Conforme declaram os arquitetos Lacaton \& Vassal. 
747 O The Shed terá área total de $18.580 \mathrm{~m} 2$, dos quais 2.30om2 serão dedicados a exposições.

748 O Palais de Tokyo tem área total de $24.300 \mathrm{~m}^{2}$, dos quais 22.ooom2 são dedicados a exposições.
RL-v: É por isso que eu pensei nisso quando você me falou de Cedric Price. Porque eles também estão construindo The Shed pensando em Cedric Price. É isso, não é?

APP: É isso, sim. Os arquitetos dizem "Não precisamos de arquitetura, somente de infraestrutura. Estrutura e infraestrutura. " Mas não é bem assim - não é como Lacaton \& Vassal -, eles se preocupam muito com o design. Vai ser em escala americana, o maquinário e tudo mais. Eles estão fazendo as duas coisas ao mesmo tempo, a reforma do мома е o The Shed.

RL-v: Ah, é?

APP: Sim, estão desenvolvendo os dois projetos ao mesmo tempo. E os dois vão ficar prontos em 2019

RL-v: Impressionante! Então tá, OK. Vamos ver. É muito interessante estar em contato com eles para discutir sobre esses dois modelos.

APP: Sim, com certeza.

RL-V: Você está convencida com o projeto The Shed?

APP: É muito impressionante, eu estive lá no ano passado e vi as estruturas que se movem. Mas temos que aguardar para ver se vai realmente ser transformável, ou se vai acabar se fixando mais num sistema. Vai depender muito da programação, veremos. RL-V: Encontrei uma curadora que foi visitar um estúdio de Tomás Saraceno, justamente. Eu estava lá, trabalhando com Tomás, e ela estava passando, acho que queriam lhe convidar para uma exposição.

APP: Era uma curadora que trabalha no The Shed?

RL-v: Sim, ela trabalha para The Shed. Qual é a área?

APP: Não sei dizer. ${ }^{77}$

RL-V: É maior do que o Palais?

APP: Creio que não. ${ }^{748}$ São oito andares de um lado e do outro a cobertura se abre para a praça.

RL-v: Está bem. Ok. Bom, veremos. (risos) Incrível. (risos) 


\section{ENTREVISTA COM OLIVIER CINQUALBRE CONCEDIDA A ANA PAULA PONTES NO ESCRITÓRIO DO CENTRO GEORGES POMPIDOU, PARIS, 19 DE JULHO DE 2018}

$\mathrm{O}$ arquiteto e historiador da arquitetura Olivier Cinqualbre é curador do Centro Georges Pompidou, onde é responsável pelo departamento de arquitetura do Museu Nacional de Arte Moderna - MNAM e do Centro e Criação Industrial - CCI, tendo realizado diversas exposições na instituição. ${ }^{749}$

$\mathrm{O}$ curador relatou à autora algumas das transformações pelas quais o centro passou ao longo das diferentes gestões curatoriais e seu impacto na ocupação dos espaços expositivos. Cinqualbre tratou também do engajamento da instituição com a arte contemporânea, colaborando com informações relevantes para esta pesquisa.

A entrevista com Olivier Cinqualbre foi agendada por intermédio de Valentina Moimas, que lidera o departamento de novas aquisições da coleção de arquitetura do MNAM no Centro Pompidou, e que, por sua vez, foi apresentada à autora pelo colega arquiteto e professor Marcelo Barbosa, de São Paulo. A conversa de 40 minutos ocorreu na tarde do dia 19 de julho de 2018, no escritório do Centro Georges Pompidou, que fica no sétimo andar de um antigo edifício no número 6 da Rue Beaubourg, em frente ao edifício cultural em Paris. A transcrição e a tradução do francês para a língua portuguesa foi realizada pelas tradutoras Caroline Fretin e Celina Olga.

APP: Bom dia, Olivier. Estou interessada nos usos de espaços dedicados à arte contemporânea e escolhi dois exemplos muito diferentes para minha pesquisa. O MOMA de Nova York, porque é um exemplo de padronização de apresentação da arte moderna, e o Palais de Tokyo, que é uma situação completamente diferente, sem coleção e, a princípio, com toda liberdade. O Centro Pompidou encontra-se um pouco no meio de tudo isso, porque sua origem está ligada à história do Palais de Tokyo e também porque é uma proposta de arquitetura que visa a flexibilidade, a transparência etc. Portanto, eu gostaria de saber como você vê a utilização destas qualidades, no período em que trabalhou aqui no Centre.

oc: É uma pergunta bastante ampla. Primeiro porque, apesar de tudo, o Centro hoje tem aproximadamente quarenta anos de existência e, portanto, passou por períodos diferentes, organizações diferentes, espaços diferentes. Existe essa dificuldade. Há outra, para nós, muito significativa, que é o momento no qual, no mundo da história da arte e no mundo dos museus, houve uma ruptura com o período antecedente, em que as disciplinas eram muito mais separadas. Ocorreu esse fenômeno em que os diretores e os curadores de museu não estavam interessados em arquitetura, não entendiam nada de arquitetura, não sabiam ler uma planta. É um fenômeno pouco estudado, mas que terá uma influência na vida do Centro Pompidou. O Centro Pompidou foi criado com dois departamentos: o museu [MNAM - Museu Nacional de
749 Entre as quais Pierre Chareau (1993), Renzo Piano (200o), Robert Mallet-Stevens (2005), Richard Rogers (2007e, associado à Frédéric Migayrou, Le Corbusier Mesures de l'homme (2015). 
Arte Moderna] e o Centro de Criação Industrial [CCI]. O Centro de Criação Industrial, em poucas palavras, é uma invenção pós 68 - jovem, dinâmica -, mas que não se enquadrava na lógica museu - coleção, conservação. E também há o museu, com uma estrutura antiga que, em dado momento, pôde ser um pouco rejuvenescido, e que teve a chance, no início do Centro Pompidou, de ser dirigido por um diretor de museu estrangeiro [o sueco Pontus Hultén], que não teve essa mesma atitude de rejeição em relação à arquitetura. Portanto, vimo-nos diante de um projeto de edifício, de museu, de exposição, que retomava a temática da flexibilidade, da transparência, da mobilidade, com sucessos e com coisas um pouco mais difíceis. Então temos um museu com suportes suspensos e percursos aleatórios, e temos exposições com ambientes em que os suportes mais clássicos eram feitos, toda vez, com os mesmos elementos que eram montados, desmontados, remontados, transportados, guardados, desmontados, movidos. Com o passar do tempo, primeiro Pontus Hultén foi embora, e tivemos diretores de museu cada vez mais tradicionais, clássicos, mas que não foram felizes. Em todo caso, eram pessoas que não tinham um conhecimento pluridisciplinar, o gosto pluridisciplinar das gerações anteriores. Estranhamente, para mim, a ruptura entre a arquitetura e o resto, ou entre o resto e a arquitetura, foi em 68. Havia, na França, a separação nas escolas de arte e de arquitetura e, de certo modo, após 68, cada uma ficou do seu lado. $\mathrm{O}$ mundo da arquitetura do lado da arquitetura e o mundo dos museus do lado dos museus. É isso. E quanto mais o tempo avançava, mais assistíamos ao desaparecimento da flexibilidade, da transparência, do movível. Certamente precisávamos de algo mais perene, mais permanente, mais estável, mais regular, mais barato. E assim chegamos, no que se refere ao museu, a Gae Aulenti e, no que se refere às exposições, a elementos que se tornariam elementos perenes em ambientes que ainda podiam ser mexidos um pouco. Em seguida, haveria o abandono dos suportes móveis. E depois, dos elementos de transparência que, independentemente do museu e dos curadores, iriam ser reduzidos, como por exemplo, no átrio, onde antes havia os espaços de exposição norte e sul com fachadas internas envidraçadas. E, a partir de 1997-2000, ocorreram reformas, em que foram instaladas paredes corta-fogo neste local.

APP: Mas a que você atribui este movimento em direção à tradição? Foram as equipes que mudaram ou foi devido a problemas práticos?

oc: Não, há um outro elemento a ser levado em consideração. Houve as grandes exposições pluridisciplinares, como Paris-Moscou, Paris-Berlim etc. Em seguida, as exposições de artes plásticas, de arquitetura e design, e mesmo as de literatura, e até as de coisas um pouco complexas. Mas, é para as exposições de arquitetura e design que haveria cenografia. A reflexão cenográfica para as exposições de arte viria bem depois, porque eles consideram que as obras se bastam, que as obras-primas não precisam ser valorizadas. Enquanto nós, do lado da arquitetura e do design, sabemos que, para despertar o interesse de uma arquitetura ou a qualidade de um móvel, é preciso dar mais destaque, pois o público não vivencia a emoção 
com um móvel da mesma maneira que vivencia a emoção com um quadro de Matisse. E, consequentemente, para a arquitetura e design, há cenografias que são mais refinadas, mais elaboradas, até mesmo mais caras, e aí temos que compensar com patrocinadores para a cenografia. E, em certo momento, a arte dirá: "Mas por que cenografias refinadas apenas para a arquitetura e design? Nós também queremos!” Haverá esse deslocamento. Um elemento muito importante a se levar em consideração é a questão do dinheiro. Existe a ideia de que se temos algo estável, isso não tem custo, ao passo que se fazemos, desmontamos, remontamos, isso custa dinheiro. $\mathrm{E}$ até mesmo agora que não temos mais os suportes móveis e que construímos, demolimos e reconstruímos, isso custa dinheiro. O problema dos suportes móveis é que, de fato, inicialmente tínhamos uma ferramenta que funcionava bem. Mas surgiram dois problemas. O primeiro, é que isso custava dinheiro, porque era preciso montar, desmontar, guardar, e era uma empresa terceirizada que montava, desmontava, guardava. E ela tinha o monopólio. Portanto, havia o problema do dinheiro. O segundo problema, o técnico, e consequentemente também de dinheiro, é que a gente monta o suporte, coloca um revestimento, pinta, desmonta o suporte, monta novamente, coloca um revestimento e, ao final de vinte anos, eles terão dobrado de peso. E, por exemplo, os suportes eram assim, deformados, porque as camadas de revestimento e de pintura se acumulavam nas extremidades. Todos os suportes eram assim. E, também, havia um outro elemento de mobilidade, de flexibilidade, um ótimo instrumento de trabalho: o piso técnico. Este piso era formado por placas com uma trama de $80 \times 80$, que podiam ser removidas para passar a fiação. Podia-se construir coisas, instalar as obras em rebaixos, havia muitas possibilidades. Por exemplo, com o piso técnico e as placas, tínhamos uma superfície coberta por carpete. $\mathrm{E}$ uma vez um diretor disse: "Não posso trocar o carpete a cada três anos, isto custa muito dinheiro, por isso devemos tirá-lo." Mas ao mesmo tempo em que tiramos o carpete, tiramos também o piso técnico, o que foi uma grande besteira. Portanto temos o elemento "dinheiro", que é muito importante, e é também sobre este elemento "dinheiro" que aqueles que querem um retorno às coisas mais clássicas argumentam: "Gastamos muito dinheiro, é preciso reduzir os custos, retornemos às coisas estáveis etc."

APP: Você conhece algum sistema que tenha conseguido utilizar os recursos de flexibilidade? Por que eu não conheço...

oc: Não. Há um elemento que aparece, aliás, através de um filme, que funciona muito bem: são as divisórias móveis na midiateca, no espaço de exposição da midiateca de Sandai, de Toyo Ito. Mas é japonês e é pequeno. O problema com o Centro Pompidou é a escala, a quantidade, o tamanho dos suportes. Os suportes chegavam às vezes a 3,60 metros, mas podiam chegar a cinco metros de altura. Eram coisas que multiplicavam o peso por dois, ficando muito complicado do ponto de vista logístico. E havia suportes em todos os espaços de exposição. Estamos falando em aproximadamente $4 \mathrm{mil} \mathrm{\textrm {m } ^ { 2 }}$ de área de exposição, além da área do museu contemporâneo que, na época, antes de 1997, ocupava um terço do andar, 
750 No projeto original do Centro Pompidou, o programa ocupava área de total $105.75 \mathrm{Om}^{2}$, das quais 25.34 om $^{2}$ para exposições, distribuídas em 13.450m ${ }^{2}$ para o Museu Nacional de Arte Moderna, 2.930 ${ }^{2}$ para o Centro Nacional de Arte Contemporânea, 2.310m2 para as galerias permanentes do Centro de Criação Industrial e $6.650 \mathrm{~m} 2$ para as exposições temporárias. Fonte: PIANO, Lia (ed.). Centre Pompidou. Piano + Rogers. Gênova: Fondazione Renzo Piano, 2017, pp. 36-37. ou seja, 3 mil m ${ }^{2}{ }^{750}$ Bem, eram muitos suportes. Mas a questão do dinheiro é muito importante. Durante muito tempo, até o final dos anos 1990, ainda encomendavam cenografias de terceiros, as pessoas vinham de fora e faziam as cenografias. A partir do final dos anos 1990, passamos a ter um serviço interno para as cenografias. Também por razões de economia, pois os cenógrafos terceirizados custavam mais caro e o controle das despesas era mais difícil que em um serviço interno.

APP: Você considera que aqui, no Pompidou, a ideia de flexibilidade permanece um pouco utópica?

oc: Não, a noção de flexibilidade não foi utópica, ela existiu. $\mathrm{E}$ o fato de que foi abandonada não foi por ser uma utopia. Ela foi abandonada porque não quiseram levá-la adiante.

APP: Era uma visão institucional?

oc: Sim, é uma visão institucional. E, por exemplo, quando houve as obras de 1997-200o, portanto, com a criação de um piso total, de um andar para o museu, da parte contemporânea, permaneceu o andar realizado por Gae Aulenti. E este andar funcionava bem, conhecíamos seus limites e não o modificamos. Fizemos apenas pequenas alterações, senão custaria muito caro, sem falar na questão dos direitos autorais, pois Gae Aulenti ainda era viva. Porém, tiramos apenas o que era muito ruim, mas conservamos o princípio e até elementos de decoração sobre a arquitetura de Renzo Piano, em especial o sistema de elemento vertical, no que chamamos de La Rue. Nós o conservamos porque isto interferiria no sistema de iluminação, uma vez que as luminárias eram integradas. Mas, se tivéssemos tido todo o dinheiro do mundo, teríamos refeito este andar. Os problemas financeiro e econômico eram os maiores problemas para se fazer reformas.

APP: Você fala em direitos autorais sobre a obra de Gae Aulenti, mas e os direitos autorais sobre o projeto arquitetônico de Piano e Rogers?

oc: Não, o que aconteceu desde o início foi que, toda vez que havia uma modificação interna e externa do edifício, os arquitetos eram informados, eram solicitados e lhes pedíamos sua opinião. Então, quando houve a transformação do museu, dissemos: "Gae Aulenti e Piano e Rogers concordaram”. Mas eu sei que, por ter discutido muitas vezes sobre isso com eles, houve momentos de desentendimento sobre as transformações no Centro. Por exemplo, houve um momento de grande desacordo em relação à orientação das escadas rolantes na Biblioteca Pública de Informação, pois, antes, havia as escadas rolantes, mas elas estavam sempre no sentido longitudinal. E Jean-François Bodin, em 1997-2000, colocou as escadas rolantes no sentido lateral e as sobrepôs como em uma loja de departamentos. Então, houve um desentendimento e Rogers disse: "Não gostei". Com Piano a relação era mais complicada e, de fato, ele sempre dizia: "Você pode fazer mal ao edifício, mas o edifício é mais forte do que isso". E eu acho que eles são mais vigilantes quanto ao aspecto externo do edifício e à arquitetura propriamente ditos, do que com as disposições internas que eles puderam fazer. APP: Portanto, não houve um desentendimento da parte deles em relação ao projeto de Gae Aulenti?

oc: Acho que eles estavam em um outro momento. Fazia praticamente dez anos que o Centro Pompidou tinha aberto suas portas. Acredito que talvez 
o trabalho de Piano para a Fundação de Menil tenha feito com que considerasse sua proposta de museu, em 1997, um pouco complicada demais para se manter. Piano disse que Madame de Menil fez com que ele mudasse seu olhar sobre a apresentação das obras. Penso que não houve um repúdio pela proposta de 1997 para o museu, mas a consideração de que se poderia fazer outra coisa.

APP: O projeto de Gae Aulenti foi concebido como algo permanente? Porque durou mais de 30 anos, e hoje é como se fosse a identidade da coleção. oc: Não, eu acredito que o próprio Centro Pompidou teve dificuldade em pensar a temporalidade. Quero dizer que quando pensávamos nas obras que seriam realizadas entre 1995-1997, na parte externa, e entre 1997-2000, na parte interna, já pensávamos nelas em 1993. Em 1993 fazia dezesseis anos que o Centro estava aberto, e sabíamos que era preciso fazer reformas, que era necessário. Portanto, havia obras de manutenção, de extensão e de transformação. A manutenção consistia na restauração das fachadas, pintura, modificações. A extensão, a partir de 1986, foi no térreo, nas duas alas. Ganhamos $700 \mathrm{~m}^{2}$ de cada lado. Os escritórios saíram do edifício e o espaço foi aproveitado para locais públicos, locais de exposição, mais espaço na biblioteca, coisas deste tipo. Isso também chamamos de extensões, embora não sejam visíveis. Uma outra extensão que modificou as coisas foi, por exemplo, a eliminação do pé direito duplo no museu. Em 1997-200o, para ganhar $300 \mathrm{~m}^{2}$ no sexto andar, fizemos um piso no canto noroeste do museu, onde, na época havia um pé direito duplo. A partir da fachada interna da grande galeria, podia-se ver o museu. E ali ganhamos $300 \mathrm{~m}^{2}$ fazendo um piso.

APP: O problema de área...

oc: Depois houve as transformações. Abandonamos o piso técnico, a estruturação de Gae Aulenti. Mas, de certo modo, a estruturação de Jean-François Bodin foi pouco modificada. No quarto andar do museu, no espaço contemporâneo, foram feitas pequenas modificações de tempos em tempos. Mas, o que foi concebido em 1997-200o, permaneceu: o percurso, a organização das salas, as dimensões das salas, foram poucas modificações. E depois, há essa questão da temporalidade de modo geral, em que não compreendemos que o tempo passa e que é preciso fazer reformas, que, quanto mais esperamos, mais caro e complicado se torna, e que não é grave pensar, vinte anos depois, em transformações. De certo modo, o Musée National d'Art Moderne no Palais de Tokyo tem trinta anos de existência, abriu em 1948 e fechou em 1977. Portanto, não era chocante pensar em transformações no final de vinte anos. E, quando abrimos os dois andares do museu em 2000, a partir desse momento, já começamos a pensar em uma possível extensão. Esta seria, em primeiro lugar, o Centro Pompidou no interior do país, em Metz. O programa pedia um novo andar do museu. Pre-

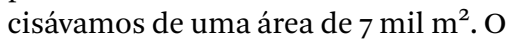
primeiro elemento do Centro Pompidou Metz foi a construção de $7 \mathrm{mil} \mathrm{\textrm {m } ^ { 2 }}$ de exposição.

APP: Então, o problema de área e o problema de orçamento estarão sempre presentes, porque se a coleção cresce constantemente, sempre existirá o problema de extensão. E em relação à decisão de fazer um centro de arte contemporânea no Palais de 
751 As datas não conferem, pois o Palais de Tokyo - Local de Criação Contemporânea, foi inaugurado em 2002 e o Museu do Quai Branly em 2006.

752 Alfred Pacquement (1948-) foi diretor do MNAM de 2000 a 2013.

$753 \mathrm{O}$ atual diretor do MNAM é Bernard Blistène (1955-), tendo assumido o cargo em 2013.
Tokyo, de que modo ela está ligada a esta questão que vemos aqui, de limite do edifício do Centro Pompidou?

oc: Bem, eu não estou falando do Palais de Tokyo, do Museu de Arte Moderna da Cidade de Paris e do Museu Nacional de Arte Moderna. Ocorre o seguinte: em 2000, abrimos os dois andares do museu e, praticamente no final de 2000 , início de 2001, apareceu a ideia de filial, administrativamente falando, que seria o Centre Pompidou Metz, devido à necessidade de extensão para a coleção. Essa história de extensão para a coleção interferiu com uma outra história, que foi a tentativa de impedir o Guggenheim de se instalar na França. Houve tentativas em Lyon, Lille e, toda vez, o Centro Pompidou tentou impedir o Guggenheim de vir, e foi construído o Centro Pompidou Metz. Depois, teve o seminário no museu do Quai Branly, que tinha acabado de abrir. Devia ser o ano de 2005, o Centre Pompidou Metz estava em obras, e antes mesmo de abrir, a conservação do museu disse: "Precisamos de outro local em Paris". E começamos a pensar em que lugar de Paris. Houve uma primeira tentativa de transformar a Galerie do Jeu de Paume em uma filial do Centro Pompidou. Depois desistimos. E, nesse seminário no museu do Quai Branly, estávamos pensando no assunto quando olhamos pela janela e vimos...

APP: Aquele vazio!

oc: O Palais de Tokyo. E então pensamos nisso, pois o edifício estava vazio há muito tempo, desde a transferência da coleção de Arte Moderna em 1977. ${ }^{751}$ A parte do Estado não era ocupada desde então. Houve um projeto de Musée du Cinéma que não foi realizado e o local permaneceu vazio. Teve o fato também de que os curadores do Museu Nacional de Arte Moderna, embora não tivessem utilizado o local, sentiam uma nostalgia desse edifício, inclusive do lado museu verdadeiro, pois houve uma exposição da coleção do Museu Nacional no Museu da Cidade durante o fechamento do Centro Pompidou [para as obras de 1997-200o]. Portanto, havia essa fantasia de museu verdadeiro.

APP: Por que "museu verdadeiro"?

oc: Porque houve uma experiência difícil em relação à arquitetura contemporânea do Centre Pompidou, como eu disse no início.

APP: Você se refere ao lado tradicional do museu "palais"?

oc: Na verdade, a mudança de atitude dos curadores do museu ocorreu com a geração atual de curadores, e isso vem acontecendo nos últimos dez anos. Durante quatorze anos tivemos um diretor que não gostava de arquitetura, ${ }^{752}$ que foi eleito principalmente pela tradição. E, há uns três, quatro anos, temos um novo diretor que se encaixa mais na lógica do edifício de Piano e Rogers. ${ }^{753}$ Então, embora não a tenham vivido, existe essa nostalgia deste museu, cuja arquitetura eu odeio. Além disso, há as operações institucionais e as pessoas que dirigem o Centro não jogam bem e perdem.

APP: Então a ideia era fazer uma filial do Centro Pompidou no Palais de Tokyo e isso não deu certo.

oc: Nós começamos. Durante um ano e meio, nós tivemos a gestão do Palais de Tokyo e iniciamos os projetos de obras e de programação.

APP: Vocês não conseguiram, porém, a ideia, de um modo ou de outro, vingou, pois embora o Palais de Tokyo não fosse uma filial, tornou-se, no final, um espaço de arte.

oc: Não, é um estabelecimento autônomo com uma outra lógica 
econômica, uma outra lógica de programação, sem coleção, é outra coisa. APP: Sim, mas responde a uma demanda por um espaço de arte contemporânea que, aqui no Pompidou é difícil, pois as exposições temporárias talvez sejam mais históricas. Vocês também têm uma galeria no andar térreo que é mais dedicada à arte contemporânea, certo?

oc: Não, o que ocorre é que eles têm mais facilidade para uma programação de arte contemporânea, pois possuem muito espaço e não fazem nada além disso. O que não é o caso do Centro Pompidou, que sofreu uma outra modificação no decorrer do tempo. Havia um outro modelo antes, que era o dos espaços específicos. Ou seja, havia uma galeria para a arquitetura e design, uma galeria para a arte contemporânea, e espaços compartilhados para outras exposições. Os espaços específicos tinham suas lógicas, que eram outras lógicas de troca, de recepção, de exposição, porque havia uma gestão mais autônoma, área por área. E agora não temos mais espaços específicos e, portanto, a programação de todos os espaços é levada em consideração. Devemos fazer a arquitetura em um ano, devemos fazer o design, sem esquecer a fotografia, o histórico... E é verdade que temos muito menos possibilidades do que eles. Depois, o outro fenômeno que ocorre é que há um interesse maior pela arte contemporânea em comparação a tudo o que havia antes. Em 200o, decidimos mudar a entrada do público para o andar contemporâneo, porque as pessoas dificilmente vinham a este andar. E, de fato, a partir de 2005 , mais ou menos, a arte contemporânea estava em toda parte. Há obras de arte contemporânea no Louvre, obras de arte contemporânea no Museu d'Orsay, há fundações privadas, existe isso... $\mathrm{E}$ a arte contemporânea é quase mais reconhecida atualmente do que a arte moderna.

APP: É a produção atual, enfim.

oc: Sim, mas existe esse fenômeno. Eu acho que isso ajudou muito o Palais de Tokyo, o fato de haver essa evolução nos gostos, desejos, visitas. O Palais de Tokyo, como é hoje, com sua programação, se fosse há 20 anos, não funcionaria. Eles são o reflexo do momento. APP: Você acha difícil gerenciar um museu como o Pompidou, que é dedicado a uma coleção importante e que, ao mesmo tempo, seja relevante no cenário contemporâneo da produção atual, engajando artistas que estão produzindo agora?

oc: O que é realmente incrível é que o contemporâneo é cada vez mais desenvolvido, apreciado, apresentado... e, paradoxalmente, as apresentações contemporâneas do museu aqui... nós fazemos o nosso trabalho, é a missão do Centro Pompidou, mas não temos o benefício, a midiatização que se poderia imaginar. Porque, apesar de tudo, há, digamos, cerca de $5 \mathrm{mil} \mathrm{m}^{2}$ de arte contemporânea permanentemente. Eu exagero um pouco porque os limites cronológicos são flutuantes, mas, apesar de tudo, independentemente das exposições, há muitas vezes uma exposição contemporânea de arte, ou de arquitetura, ou de design, ou de novas mídias, ou não sei do quê. Mas, mesmo assim, há uma exposição contemporânea o tempo todo, além do andar contemporâneo do museu, o que é muito, mas não tem a mesma visibilidade. Esses são os nossos problemas. APP: Talvez seja um problema de identidade.

oc: Sim, de identidade, de comunicação. 


\section{APÊNDICE D:}

ENTREVISTA COM CARLITO CARVALHOSA CONCEDIDA A ANA PAULA PONTES

EM SÃO PAULO, 11 DE JANEIRO DE 2019

Nascido em 1961 em São Paulo, Carlito Carvalhosa formou-se na FAU-USP em 1984 e começou a se envolver com a produção artística no início dos anos 1980 , quando integrou o grupo paulistano Casa $7 .{ }^{754} \mathrm{Na}$ ocasião da entrevista, morava e trabalhava no Rio de Janeiro, tendo realizado exposições em diversas instituições culturais no Brasil e no exterior. Sem nunca ter atuado como arquiteto, trabalhou com gravuras e pinturas de grande formato no início de sua carreira e posteriormente passou a produzir esculturas, instalações e performances. $\mathrm{O}$ artista faleceu em maio de 2021, em decorrência de um câncer contra o qual lutou nos últimos oito anos de vida.

Em 2011, realizou no átrio do MoMA a obra Sum of Days, adaptando a obra A Soma dos Dias, realizada um ano antes no Octógono da Pinacoteca em São Paulo. Na conversa com a autora, o artista discorreu sobre a origem do trabalho, as circunstâncias do convite para a exposição no museu nova-iorquino e as questões envolvendo a adaptação da obra ao espaço do átrio do MOMA, diante das semelhanças e diferenças com relação ao Octógono da Pinacoteca. Tratou também da sua impressão sobre o edifício do MoмA em várias épocas e do papel da instituição, tanto na sua formação quanto na sua carreira como artista, mais recentemente. Carlito abordou ainda questões envolvendo as obras site specific e os espaços dos museus dedicados à arte contemporânea, trazendo contribuições importantes para a discussão desta pesquisa em curso.
A autora tinha vínculos de amizade com o artista, pela convivência nos circuitos das artes no Rio de Janeiro, onde morou e trabalhou de 1999 a 2010, e trabalhou de 2011 a 2016. Tiveram também a oportunidade de trabalhar juntos na exposição Iberê Camargo: Diante da Pintura, a autora realizando o projeto expográfico e o artista a identidade visual, sinalização e o projeto gráfico do catálogo. ${ }^{755}$ A conversa de 1 hora e 40 minutos com Carlito Carvalhosa ocorreu na tarde do dia 11 de janeiro de 2019, no apartamento de sua mãe, no Bairro de Cerqueira César, em São Paulo. A transcrição foi feita pela autora com a colaboração de Gabriel Granado, então estudante da FAU-Mackenzie, e o texto foi editado em parceria com o artista, recebendo algumas complementações visando tornar mais claras algumas das ideias discutidas.

APP: A Soma dos Dias é uma instalação montada em dois locais, primeiro na Pinacoteca, em 2010, e em seguida no MOMA, em 2011. Gostaria de começar perguntando como você concebeu a obra em função do espaço do Octógono na Pinacoteca.

Cc: A Soma dos Dias teve origem na exposição Apagador, em Salvador, em 2008, na Igreja do Solar do Unhão, onde fica o Museu de Arte Moderna da Bahia, à beira da Bahia de Todos os Santos, numa antiga sede de engenho restaurada pela Lina Bo Bardi. A Funarte criou um projeto com o nome de "Arte e Patrimônio", que selecionava em todo o Brasil dez propostas 
de trabalhos que relacionassem arte com um conceito amplo de patrimônio, que poderia ser patrimônio imaterial, paisagístico, arquitetônico etc. Eu apresentei um projeto para 2008 que foi escolhido. A ideia do trabalho era essencialmente separar o espaço do lugar. Em cada sala da igreja, em cada espaço, eu construía um cubo com um tecido muito fininho - na verdade tecido não tecido (TNT), um nome que acho espetacular. O cubo ocupava toda a sala, deixando um espaço livre de 40 centímetros entre o tecido e as paredes. Os cubos tinham tamanhos diferentes de acordo com as salas. Mesmo quando o teto era inclinado ou mais curvo, sempre eram cubos, sempre definidos por altura, largura e comprimento. A minha ideia era que com isso se estava tirando o espaço de dentro do lugar. Então, ou você estava dentro do cubo e você tinha o espaço, ou você estava fora - muito perto da parede -, e você tinha o lugar. Havia também um diálogo entre os vários espaços, por que todos eles eram diferentes na dimensão, mas semelhantes na forma - eram todos cubos. Eu pensava que estava retirando uma coisa da outra.

Quando se entra num lugar que já se conhece, não se tem mais uma experiência, nem se olha mais. Mas ao ser obrigado a ter uma experiência diferente, porque você está comprimido junto à parede, começa-se a entender que naquele lugar há um espaço e que aquele lugar é definido por uma realidade e uma história que lhe é própria - e que o espaço pode ser neutro. Havia também outros elementos de deslocamento: quando se entrava num cubo um sensor acendia uma luz num outro local, havia um alto falante onde se ouvia de dia aquilo que havia acontecido à noite, esse som se misturava com o que ocorria na hora. Era um trabalho super simples e que ficou muito legal. Fiquei impressionado com o resultado, por que os panos se moviam e revelavam a presença do ar, daquilo que não se via. O som, mistura do que havia sido gravado e do que estava ocorrendo na hora, criava a mesma ideia de deslocamento que os volumes. A luz também se comportava assim: algumas luzes eram fixas, mas outras acendiam conforme as pessoas se movimentavam.

Eu fiz uma outra versão desse trabalho no Paço Imperial, com o mesmo nome, também em 2008. Alguns projetos daquele ano foram escolhidos pela Funarte para serem adaptados e remontados no Paço e o meu foi um deles. O espaço era a sala do trono na verdade duas grandes salas separadas por um arco -, em que eu fiz cinco corredores também em forma de cubo feito com TNT. Ali os espaços estavam subdivididos, não era um cubo para cada espaço. Os corredores eram compridos e as luzes - relacionadas com o que eu estou fazendo agora, pintando sobre cera - eram blocos de luz que ficavam em algum lugar meio deslocado, às vezes num canto, as vezes no meio da parede, eram como se fossem frestas, aberturas. Fizemos também uma performance: em cada um dos cinco espaços havia um músico tocando, mas o retorno que ele ouvia não era o que ele estava tocando, era o retorno do som de um outro músico em outro cubo de TNT. Os músicos tocavam nessa situação perdida de ouvir alguma coisa diferente do que eles tocavam, sem ter contato com os outros músicos. Como eles não se viam, era uma espécie de desconjunto, do conjunto separado. A união era feita pelo público. Foi incrível, porque 
o som tinha uma coisa espacial, tridimensional. Era um som estranhíssimo por que era como se fosse um território perdido, muito parecido com a ideia da instalação, e muito hipnótico. Era uma coisa que era para durar meia hora e durou duas horas e meia, todo mundo ficou meio alucinado. Foi muito especial, muito forte.

A Soma dos Dias vem dessa ideia de ir somando, acumulando. Também era um sistema muito simples, as coisas que eu faço são geralmente de baixa tecnologia. Havia um microfone que gravava aquilo que acontecia durante a exposição e essa gravação tocava no dia seguinte. Assim a gravação do dia seguinte era uma soma desse som anterior com o que ocorria na hora. Havia também um apagamento, porque conforme os dias iam passando o som dos dias anteriores ia se apagando, o dia anterior era sempre mais forte e os dias mais para trás iam esmaecendo e as performances também. No caso da Pinacoteca, como o espaço é circular e há essa luz muito forte que vem de cima, eu não fiz mais os cubos fechados, com tampa, eu fiz duas espirais intercaladas, porque achava que tinha a ver com a Pinacoteca, que me lembra muito os cárceres do Piranese. Depois da reforma do Paulo Mendes, a parede externa, de tijolo aparente, gasta pelo tempo e a chuva, e a parede interna pintada com detalhes decorativos, se unem dentro do museu. Me lembra muito o Piranese - os labirintos, as escadarias, os cárceres. Eu pensava muito naquilo como uma espécie de labirinto, por que você entra e sai sem saber se está dentro, sem saber se está fora. Pensei em criar no miolo da Pinacoteca um fundo infinito, um descaminho, um vórtex no meio do prédio.
APP: Então já tinha uma conversa do que você propôs na obra, como espiral, como labirinto, com a sua visão do que era o prédio. Não só com relação à geometria do espaço, mas à condição da luz e o que isso evocava pra você. CC: É o que eu vejo que esse prédio tem. É um acerto muito grande essa reforma. Mostra o talento incrível do Paulo Mendes, é muito especial, é muito especial mesmo. O prédio é mais ou menos simétrico, o centro é o Octógono. Minha ideia era criar um infinito no meio do prédio, transformá-lo num verdadeiro labirinto. Como a luz vem de cima, é muito intensa, há uma aspiração para o alto. O resultado me deixou muito surpreso, eu não imaginava que fosse dar tão certo. A luz é impressionante, bate no tecido, que fica brilhando, transparente, uma coisa fenomenal. E de novo o movimento do vento, do ar, da passagem das coisas. Eu tive essa ideia de fazer uma performance meio secreta junto com o Philip Glass. Ele veio tocar, mas ninguém via ele, por que o público ficava fora do trabalho, deitado em tapetes, ou circulando pelo prédio. Podia ser que ele não estivesse lá. Ele sugeriu criar espaços de silêncio entre as músicas, por isso pedimos para o público não aplaudir. Ele tocava uma peça, tinha quatro minutos de silêncio, voltava outra peça, isso ia criando uma espécie de hipnose, porque aquele silêncio era um abismo, você não sabia se ia continuar, se não ia continuar. Ao mesmo tempo, todos os elementos tradicionais do concerto tinham sido retirados - a entrada do músico, o aplauso, a relação com a plateia. Era uma espécie de desconcerto. Foi muito especial.

Para a exposição no MoMA, fiz várias adaptações em relação à Pinacoteca 
- no desenho da forma, na maneira como se adaptava com o espaço, que lá era quadrado e na Pinacoteca octogonal. O MoMA é maior e tem a questão da visitação, que é um problema complicado. A exposição foi das mais visitadas em Nova York naquele ano, acho que teve 500 mil pessoas, algo assim. Eles já tinham me dito que isso era um problema sério, porque é muita gente, então é uma experiência totalmente diferente da Pinacoteca, que tem visitação menor. No caso do MoMA, a luz vem de cima, mas na diagonal, a obra foi montada de uma forma que luz entrasse de lado. Fiz umas linhas de luz na parede que aumentaram muito a luminosidade do lugar, o que é muito importante para o trabalho. Eu pensava que como o museu tem muita visitação, eu poderia criar um espaço de silêncio no meio dele, essa era a ideia. Para isso controlamos o público, por que o trabalho ficava logo na frente da escada de acesso ao museu. Fizemos a saída por aquele lado, assim as pessoas tinham que dar a volta, e o público se espalhava. Isso foi bom, porque dava um tempo maior, era uma experiência mais coletiva - sempre tinha gente dentro, entrando, saindo, no meio do caminho, nos descaminhos que tinha dentro do trabalho. No момA o comportamento do ar também era diferente, era muito mais selvagem. Tinha uma coisa bonita, tinha uma presença mais escultórica do que na Pinacoteca -às vezes o trabalho subia, descia, parecia um pulmão. Você via de longe e tinha uma coisa escultórica. Ele se erguia, aconteciam umas coisas estranhíssimas, que eram muito interessantes - essa coisa de revelar o que não está lá. Ficou lindo lá, eu também fiquei surpreso ao ver que o trabalho também funcionava de um outro jeito.
O prédio do момA traz algumas questões sobre o lugar da arte. Você nunca sabe em que andar você está, porque os andares são muito iguais. É uma consequência da ideia do "cubo branco”: não há um lugar. Não é um labirinto em que você se perde, é um não-lugar: sem lugar não há como a arte confrontar o mundo. Numa igreja italiana, você vê os quadros do Caravaggio, na igreja dos franceses em Roma, eles estão em um lugar escuro, com um altar, uma confusão -, essa é a condição da arte. Você vai em San Rocco, ou no Palácio dos Dodges, e as pinturas estão no mundo. $\mathrm{O}$ cubo branco cria uma situação de um lugar indiferente, onde você no fundo não está confrontando coisa alguma. $\mathrm{O}$ Moma talvez tenha sido ampliado com esse desejo de ser um espaço que desaparecesse.

O que o мома fez, como instituição - seguindo uma leitura que é muito americana, que se vê no Greenberg e também no Barr -, foi consolidar a ideia de uma narrativa mainstream para a arte do século $\mathrm{xx}$. Criou-se um eixo narrativo e evolutivo da arte moderna partindo do Cézanne, passando pelo Picasso, Matisse, pelo surrealismo, pelos mexicanos, chegando obviamente ao ápice no expressionismo abstrato americano - ou seja, uma narrativa que parte da Europa para chegar aos Estados Unidos, uma narrativa que interessava aos americanos. Eu não conheci o MoMA original, eu conheci o Moma nos anos 8o, que obedecia essa narrativa mas era um lugar mais acolhedor. O prédio já era uma reforma mas o espaço guardava uma memória. A sala de Matisse era uma sala só de Matisse, tinha um banco, tinha uma janela. As coisas tinham cara e você se localizava no 
museu, o museu estava ali na rua 53 etc. O момA atual é de gesso, todo feito em paredes de drywall. É uma arquitetura oca. Aquilo poderia estar ali, ou poderia estar em outro lugar. O prédio é inteiro desalinhado, difícil de entender.

APP: É porque é uma colcha de retalhos, ele foi todo sendo remendado em vários pedacinhos.

CC: Exatamente, mas da maneira como isso foi resolvido, o passado foi apagado. A circulação parece de shopping center, o espaço é formado por uma série de galerias brancas, "neutras", que acabam não tendo personalidade.

Outra questão é que eles não podem tirar um Picasso para mostrar um trabalho recente de outro artista, mas ao mesmo tempo precisam mostrar o que está sendo feito hoje. É uma questão que o museu lida da melhor maneira que pode, mas que indica a necessidade de mais espaço. Eles estão pensando nisso, porque o Moma quer ir atrás, ver o que está acontecendo, o que explica eles terem escolhido o meu trabalho.

APP: O convite teve a ver com a visita do Glenn Lowry, diretor do MoмA, à sua exposição na Pinacoteca?

CC: O Brasil estava num bom momento, eles estavam interessados e vieram ver a Bienal. Foram à Pinacoteca ver a exposição do Antônio Dias, não a minha. A Patrícia Cisneros havia visto o trabalho e gostado, acho que falou com eles. Eles viram e se interessaram, foi só isso. Essa capacidade de falar "a gente gosta e a gente quer", poucas instituições têm. Geralmente elas têm aquela coisa, "quem é o curador? ", "qual é a estrutura?", existe toda uma política cultural e o MOMA tem uma atitude de "nós somos o MOMA, tomamos nossas decisões".
APP: Mas o átrio sempre teve muita dificuldade de ser ocupado.

Cc: Eu acho que a minha exposição é uma das poucas que realmente ocupou o espaço inteiro.

APP: Exato. Soube que o Glenn Lowry olhou o seu trabalho e imediatamente lembrou do átrio, provavelmente pela dimensão. Além de serem os dois espaços dedicados à arte contemporânea, o Octógono e o átrio do MOMA são dois espaços verticais.

CC: É isso. Mas era a época do Brasil, e eu acho que isso é a coisa decisiva, eles estavam interessados em mostrar o que estava acontecendo no Brasil, vieram para cá e encontraram um trabalho que deixou eles muito entusiasmados. Aconteceu um negócio ali dentro, eles ficaram muito animados. Na hora o Glenn falou comigo: "a gente pode pensar numa coisa, eu achei interessante, vamos tentar fazer, quero que você vá para lá olhar" e tal. Acho que muitas outras instituições acabam tendo estruturas muito mais rígidas. APP: Como quais, por exemplo?

Cc: Muitas vezes se vê os mesmos artistas fazendo exposições em todos os lugares. Esses artistas estão ligados a galerias e às estruturas de poder do meio de arte. Não é tão comum um trabalho ser exposto numa instituição importante sem absolutamente nenhuma espécie de injunção política. Claro, eu tinha uma história, eles foram atrás para saber quem eu era, o que eu tinha feito etc. Mas a decisão é deles, eles acham que é interessante, "vamos fazer".

Em relação ao outro caso que você está estudando, o Palais de Tokyo, é muito diferente. O Palais de Tokyo é um espaço muito interessante, meio rústico, meio inacabado, mas que se alinha à ideia do Kunsthalle, um 
lugar que pode ser ocupado por exposições monotemáticas ou de um só artista. Tem vários espaços desse tipo no mundo, em Bordeaux tem aquele espaço lindo, o CAPC [Museu de Arte Contemporânea]. ${ }^{756}$

APP: O Nicolas Bourriaud, que foi o primeiro curador do Palais de Tokyo, junto com Jérôme Sans, foi curador justamente do CAPC de Bordeaux nos anos 1990.

CC: Daí realmente depende muito do curador, pegar um espaço desses e ele fazer funcionar. A questão é o cara ser dinâmico, montar uma programação boa, e lá é um espaço incrível que se presta a isso. No MAC Ibirapuera, a ideia era fazer um espaço dessa natureza. Eu fiz a primeira exposição naquele espaço, ${ }^{757}$ no galpão no fundo do museu, que o Tadeu [Chiarelli] tinha pensado reservar para esse tipo de exposição. Ficou incrível a exposição, eu tenho muito orgulho dela. $\mathrm{O}$ Henrique [Oliveira] expôs depois de mim e ficou nisso, nunca mais essa ideia foi pra lugar algum. Porém o MAC tem condições de ter uma atuação muito maior do que ele tem. Em São Paulo não existe um espaço dedicado exclusivamente a isso. Você conseguiria fazer uma exposição a cada 6 meses, dois artistas por ano, há artistas no Brasil pra isso.

APP: O Octógono cumpre um pouco essa função, mas não tem uma escala tão grande.

CC: Cumpre, é exatamente essa a ideia do Octógono. Mas é dentro de um museu, numa escala muito menor. É diferente de um espaço de $2000 \mathrm{~m}^{2}$.

APP: A questão do Palais de Tokyo que me interessa pesquisar é que, pelo fato de ele ser um lugar propositadamente "inacabado" - o que é um statement da arquitetura -, ele obriga a uma tomada de posição com relação ao espaço. Se você quiser fazer lá um espaço como um "cubo branco" você vai fazer, só que isso vai ficar muito escancarado, não vai ficar como no MOMA, como uma espécie de transparência, algo que você não percebe mais, de tanto que você já viu.

CC: É isso que o Taniguchi falava sobre o мома, que se dessem mais dinheiro ele faria o espaço sumir, mas eu acho que não é isso. Acho que ali, como você falou, era uma colcha de retalhos, um espaço muito complicado. Ele se propôs a tentar anular uma condição que era muito presente, o resultado é uma coisa intermediária. Ela é anódina, não tem a pureza - que seria muito difícil - de um espaço límpido e pristino, não é isso.

APP: Mas ele almeja a isso, eu acredito. CC: Mas ele não consegue o que almeja. APP: O Glenn Lowry fala justamente que o que impressionou a equipe do MOMA na visita às obras do Taniguchi no Japão foram as qualidades "pristinas" da sua arquitetura. Era isso o que eles queriam.

Cc: Um dado central do Moma é o público: é possível fazer uma coisa pristina quando você tem uma visitação gigantesca? Eu não sei se isso é viável. Essa é uma transformação que aconteceu nos últimos 20 anos. Quando o prédio foi feito ele era grande, era amplo, hoje em dia está entupido de gente.

APP: Inclusive, no projeto da Diller Scoficio + Renfro, a questão é: eles vão aumentar as circulações e fazer acessos em vários pontos, mas tem o receio de que aconteça aquele "efeito estrada" - quanto mais pistas, mais congestionamento.

CC: Pode mesmo acontecer. O museu mais visitado de Nova York é o
756 Exposição Gibraltar, realizada no CAPC de Bordeaux, França, em 2001.

757 Exposição Sala de Espera, realizada no MAC Ibirapuera de São Paulo, em 2013. 
758 Glenn Lowry assumiu a direção do MOMA em 1995 e em 2018 foi reconduzido ao cargo por mais sete anos. Ficando até 2025, ele completará 30 anos no cargo.
Metropolitan, que tem esse aspecto de colcha de retalhos mas que eu gosto bastante, porque os espaços têm memória. Não é brilhante, mas é verdadeiro. Nova York tem muitos turistas e quanto maior o espaço, mais gente vai. Não acho que seja um problema, é uma condição que é dada. O que eu acho um problema é não se entender que também há espaço para museus distantes e isolados. O problema é tirar a Barnes [Foundation] de onde ela estava para colocar na avenida principal em Filadélfia. Agora, ter um museu gigante onde vai uma multidão, é legal também.

APP: A minha questão com o Moma é que, como eles tem essa coleção que é a maior do mundo, e que não para de crescer, onde é que isso vai parar? Aquela quadra onde eles estão em Nova York se adensa cada vez mais, e quando se acha que já cresceu tudo o que tinha para crescer, ainda tem mais tantos metros quadrados para ocupar. Agora eles vão ocupar os quatro andares de baixo da torre de mais de oitenta andares de apartamentos do Jean Nouvel. Eles começaram com um pequeno lote de uma casa e se expandiram de forma impressionante. Imagino que em algum momento será atingido o potencial construtivo máximo, e então como será? Vão continuar no mesmo endereço? Como se cresce indefinidamente? Mas a minha questão é: como isso se relaciona com o que se oferece para a arte contemporânea? Existe a coleção que toma cada vez mais espaço, e então você pode fazer o que você quiser, mas naquele cantinho. É diferente do Palais de Tokyo onde você tem 22.0oom ${ }^{2}$ de área expositiva para ocupar, ou não. Se você não quiser, você não ocupa aquele canto, deixa ali vazio, porque não se tem o compromisso de ocupar. É muito diferente a dinâmica da instituição.

CC: Eu entendo o que você está falando. É uma questão do museu, que quer se manter contemporâneo e também não pode abrir mão de uma coleção que é extraordinária. Acho que o Glenn Lowry é extremamente competente no que ele faz, ele tem uma capacidade enorme nos dois setores, no setor artístico e no de funcionamento do museu. APP: Agora que ele foi reconduzido, será o diretor mais longevo na instituição. ${ }^{758}$

CC: Mas é por méritos, porque ele é bom mesmo. Obviamente ele não é o curador. Existe toda uma série [de processos], as coisas são todas aprovadas por comissões, há todo um sistema interno. No meu caso, o Luis [Pérez-Orámas] era o curador - o Glenn pediu para ele fazer porque era o responsável pela América Latina. Ele preparou o projeto junto comigo, fez uma defesa, um negócio todo construído, e isso passa por um ritual interno.

APP: Como foi esse trâmite depois que você foi indicado?

CC: Não fui indicado. Eles gostaram da exposição e o Luis veio falar comigo: "gostamos e achamos que pode ser interessante para o Átrio, vamos fazer um projeto". Aí eu fui lá e ficamos conversando, fizemos vários modelos e fizemos um projeto. Ele escreveu um texto que incluía tudo que eu tinha feito antes - é um negócio vasto, um dossiê considerável. Isso é apresentado numa reunião de programação interna, na qual eu não fui. Eles apresentam um monte de coisas e aprovam algumas, é assim que funciona. Aprovaram a minha num prazo muito curto. Eu expus em agosto na Pinacoteca e no agosto seguinte estava expondo no момA. Eles abriram um 
espaço na programação, pois realmente queriam, remanejaram para que o espaço estivesse disponível. Eu não sei exatamente quais são as instâncias, porque é um processo interno. A partir daí é uma montagem de museu, eles são muito bons, competentes. Tem uma coisa engraçada de sindicato, que os horários são totalmente loucos. É meio desesperador: começa às $9 h$, às $11 \mathrm{~h}$ eles param para $\mathrm{o}$ café, voltam ao meio dia, aí eles param para almoçar e você fica como uma barata tonta, tentando trabalhar em torno desses horários meio malucos. Mas os caras são muito competentes e a coisa anda. Eles vestem a camisa, quando tem problema eles vão lá, porque em toda montagem acontecem coisas, e eles estavam lá.

APP: Você sentiu de alguma forma o peso da instituição sobre o seu trabalho?

CC: Não, eu senti apoio absoluto. Todo mundo entusiasmado, eles ficaram supercontentes, eu fiquei supercontente também, foi incrível, foi super legal. Mas, claro, tem que abstrair um pouco o fato de que você está expondo no átrio central do момA. Tem esse lado, a cabeça precisa ficar fria (risos). É um trabalho de risco, por que o tecido era muito frágil - um TNT de 2og, bem fininho -, então tinha várias coisas que eu não sabia. Não sabia se ele iria aguentar o público - a questão do atrito das pessoas -, se ele iria durar - ele ficou 3 meses, com 500 mil pessoas -, mas deu tudo certo. Tem uns medos - esse negócio vai rasgar, vai ser horroroso, como é que vai fazer -, mas não aconteceu nada, tudo funcionou bem. Teve ainda um furacão no meio do caminho, isso foi incrível. Teve um furacão um pouquinho antes da abertura. Aí o vento - eu estava lá, fomos ver de noite -, era lindo, o jeito como aquilo se mexia. Já tinha feito antes, na Pinacoteca e outras vezes, já tinha experiência, mas não naquela escala. Era um pouco mais alto que na Pinacoteca, que tinha $14 \mathrm{~m}$. No MoмA tinha $20 m$ e era maior também.

A questão mais institucional dos museus e das instituições é uma outra coisa. Há uma institucionalização radical, há preços muito altos, custos muito altos. O que seria contestação é acolhido rapidamente nas instituições. O cara vai lá, tira a roupa, se corta inteiro e tal, mas aquilo é institucionalizado. Mesmo quando se propõe a ser uma coisa de ruptura, é muito diferente da performance dos anos 6o, onde o objetivo era fazer algo que não tinha envolvesse dinheiro, uma obra que não podia ser absorvida pelo mercado. Se você pega um cara como Tino Segall, por exemplo, que é um artista incrível. Todo o discurso - que o trabalho não é documentado, que é passado oralmente - não muda o fato de que ele está vendendo esse trabalho. APP: Ele fez uma "Carta Branca" recentemente no Palais de Tokyo. ${ }^{759} \mathrm{O}$ que eles fizeram lá foi deixar o espaço completamente vazio, sem nada. Não tinha um texto de parede, um folder, um convite, nada. Eram 400 participantes que faziam a obra.

Cc: É muito bom o trabalho dele. O que eu quero dizer é que esse discurso - de não ter materialidade etc - se entende dentro do corpo do trabalho, mas sempre se está numa instituição. Essas contradições sempre existiram em arte. Um papa encomenda uma obra, com todas as restrições da igreja, o artista faz um trabalho incrível, que acontece dentro de uma estrutura que é dada. Não estou tentando dizer que não faz sentido fazer isso, pelo
759 O programa Carte Blanche do Palais de Tokyo consiste em intervenções concebidas por um artista ocupando a área de até $13.000 \mathrm{~m}^{2}$ do edifício. 
760 A exposição City Dreams, do artista do Zaire (atualmente República Democrática do Congo), Bodys Isek Kingelez, ficou em cartaz no момA de 26 de maio de 2018 a 1 de janeiro de 2019. contrário, é a condição da arte romper essas limitações. Porém, hoje está muito institucionalizada. O museu se propõe a ser contemporâneo, mas tem esses custos, essa escala, esse número de visitação, acaba tendo que se submeter a essa condição. O PS1, apesar de ser algo a que não foi iniciado pelo момA, é uma tentativa de ter um espaço que tenha menos aura.

APP: Você não acha que essa incorporação permite ao MoMA continuar sendo um pouco mais "establishment”, enquanto a experimentação fica por conta do PS1?

CC: O Mома é establishment, mas há bastante coisa ali, como o meu trabalho, em que eles correm risco. Escolhem artistas menos conhecidos para expor lá. Recentemente houve a exposição do Bodys Isek Kingel, um artista do antigo Zaire. ${ }^{760}$ Ele fez maquetes de cidades possíveis, cidades fantasia. É uma coisa que parece o Artacho Jurado multiplicado por mil, tudo feito com coisas coloridas. Espetacular! É um negócio meio família Jetsons, fascinante. Sabe aquela coisa que a arte tem, que você fica encantado? Você fala: "nossa, que coisa interessante". Estava em alguma daquelas salas. Esse é que é problema do Taniguchi: você não sabe direito onde você está porque os andares se repetem. Eu acho que era no segundo andar, na parte de arquitetura, não sei. Não sei se eles ainda têm uma parte dedicada à arquitetura. APP: No projeto do Taniguchi tem. E isso é uma coisa que eles estão revendo nо момА: existem museus dentro do museu - uma área para o design, outra para arquitetura etc., mas não vai mais ser assim.

CC: Essa ideia de separar em departamentos, introduzida pelo Barr, é uma estrutura que os muitos museus acompanharam - departamento de fotografia, departamento de design etc. Agora essas coisas estão se misturando. APP: E é uma complicação danada, porque tem coisas que você não consegue categorizar na arte contemporânea, mas eles não podem desmanchar essa estrutura por conta da captação de recursos. Tem doador que se dedica a doar obras especificamente para um departamento.

CC: $\mathrm{E}$ os curadores também estão organizados desse jeito.

APP: Mas os curadores novos têm outro perfil. Toda essa reforma que a Diller Scofidio + Renfro está fazendo tem muito a ver com uma nova geração de curadores que trabalha de forma muito menos segmentada, inclusive para olhar a arte moderna. Eles querem contar histórias, não mais "a grande narrativa". Eles querem um espaço que permita contar a história de um jeito mais aberto. Entendi que vai ter uma espécie de grande avenida, com pockets, onde você vai poder expor o que não cabe na "grande narrativa".

CC: Comparando com outros museus, o novo Whitney, por exemplo, é um projeto que gosto. $\mathrm{O}$ antigo era magnífico, mas era um outro museu, muito menor, com uma qualidade que é rara hoje em dia, tudo é desenhado - a escada é incrível, o concreto é incrível, o forro é incrível. Aquela coisa alemã, muito precisa. Hoje não é mais assim. O detalhamento do [novo] Whitney é industrial.

O que eu sinto é que os museus têm que ser um lugar! Tem que ser um lugar e esse é um problema da arquitetura de museus. A ideia de que se vai transformar um edifício num lugar que não existe.... Curiosamente, de certa forma meu trabalho é 
isso, criar um espaço "apagado", mas preciso de um lugar para fazer isso, se não, não há confrontação, não há problema. Nos museus tradicionais, aquelas marcas todas da história do prédio, como as janelas, frisos etc, são importantes. É importante ter janela no museu.

APP: Eu compartilho 100\% dessa sua visão. Mas você acha que essa é uma visão muito de arquiteto, que vem da nossa formação?

CC: Não, essa visão vem da minha experiência como artista. Eu achava o "cubo branco" ótimo quando eu comecei. Achava que as melhores galerias eram aquelas do SoHo, uma parede branca e acabou, sem frescura. Acho que minha visão atual tem a ver com a minha experiência como artista, de já ter exposto em vários tipos de espaço. Por exemplo, o espaço do MAc, que é branco, não é um "cubo branco", ele tem muita personalidade - ele tem umas colunas, ele tem um mezanino, o teto é inclinado. Ele tem personalidade, apesar de não ter janelas.

APP: No sentido em que ele traz a consciência de onde você está, ou seja, você não está em qualquer lugar.

CC: No sentido em que ele é um lugar, no sentido em que ele existe só ali. Essa experiência, hoje em dia, por conta das questões dos computadores, é mais rara. Por exemplo, o que tem de casa de rico que parece o Banco Personnalité.... É uma praga isso, você sente que está entrando dentro daqueles programas de computador de simulação de espaço. Quantas vezes você não tem essa sensação? Você entra num lugar e pensa: é um render, isso aqui não é lugar nenhum, esse lugar não existe, é uma coisa estranhíssima. Eu expus no Palácio da Aclamação em Salvador, que é um palácio de estilo italiano dentro de Salvador - uma coisa também estranhíssima, que podia estar em qualquer lugar. Qualquer lugar do mundo tem prédios desse tipo, do fim do século XIX. Mas o Palácio da Aclamação tem personalidade, porque tem a coisa da manufatura, foi feito ali, não é igual. Eu sinto falta disso em museu. Museu tem que ter caráter. Eu acho que o Whitney novo tem caráter, achei um prédio bacana.

APP: Especialmente porque ele tem as aberturas para fora.

CC: Ele virou o prédio para a cidade, não para o rio - que é uma ideia boa.

APP: A circulação no verão pode ser por fora.

CC: Tem vários tipos de circulação possíveis. Ele tem aquele sofá na frente de um vidro, que você fica vendo a cidade, são coisas que são importantes. No Taniguchi não tem janela!

APP: Mas não é só o Taniguchi, porque os próprios curadores fecham as janelas. Em 2017 foi inaugurada a primeira fase do projeto da Diller Scofidio + Renfro. Eles fizeram algumas galerias envidraçadas e os curadores fecharam. Estou falando das galerias onde estava a exposição do Frank Lloyd Wright, que tinham toda uma parte aberta, mas com um "tapume" na frente. Tem uma coisa que não é só da arquitetura, é o modo de usar o prédio.

CC: Mas isso é uma coisa totalmente diferente. Se o curador quer fechar uma janela, tudo bem.

APP: O que eu quero dizer é que a instituição tem uma visão de como mostrar a arte que me parece um pouco dura. Eles têm um padrão pré-determinado de altura para as salas, a iluminação tem que ter tal temperatura de cor, o piso de madeira estava muito amarelado, decidiram que tinha que 
ter uma cor menos saturada, para ficar mais "neutro". E janela na sala de exposição - que transtorno! É uma negociação, os arquitetos não têm tanta liberdade no projeto. É uma instituição que está muito presente dizendo o que quer, como deve ser. $\mathrm{E}$ o Taniguchi - acho até que foi por isso que ele ganhou o concurso - teve uma atenção enorme para tudo isso. Ele foi escolhido, num processo super concorrido, porque ele entendeu o que o Moma queria. Depois aquilo pode ter ficado excessivo.

CC: O que posso dizer do espaço do Taniguchi é que ao mesmo tempo ele é muito escultórico. É curioso essa coisa de os elementos não se alinharem e no fundo não ter uma lógica.

APP: Mas você só percebe isso trabalhando lá, esse desalinhamento é difícil de perceber.

CC: Mas ele está lá, por isso é que é curioso. Por que é desalinhado, se parece alinhado? O átrio é extremamente complexo, não dá para entender por que é tampado e não é aberto para o céu. Ele fez uma pracinha lá no último andar, onde tem exposições temporárias, mas não precisava ter aquela pracinha. Já que os andares são todos iguais, já que havia uma circulação - a mesma circulação que tem nos andares normais -, podia ter lá em cima, um pouquinho mudada. Mas ele optou por fazer uma coisa um pouco diferente e tampar o teto. Tem aquela pracinha com uma luz zenital, mas que é uma luz que eles fecham com umas persianas. A luz só entra de lado lá embaixo, então o átrio fica escuro. APP: No atual projeto de reforma, que a Diller Scofidio + Renfro está fazendo, eles mexeram em tudo - em todas as circulações, nas áreas de descanso mas o átrio vai ficar do mesmo jeito.
Eles vão unir as galerias do Taniguchi com as novas de uma maneira contínua.

Cc: Então eles não vão tirar os espaços projetados pelo Taniguchi.

APP: Não, mas eles vão mudar a maneira de usar o prédio, a departamentalização dos espaços vai sumir.

CC: Mas e os elevadores e as escadas rolantes?

APP: Eles vão colocar mais. Vai ter outros eixos. O ponto que mais me interessa não é o da coleção, mas a nova Project Room atual. É sala que existia antes, nos anos 8o, dedicada a instalações contemporâneas, onde os curadores júniores podiam fazer projetos, convidar artistas desconhecidos. Não era bem no meio do prédio, como o átrio, então dava para arriscar mais. A própria Liz Diller e o Ricardo Scofidio fizeram uma instalação nessa sala, foram os primeiros arquitetos a serem convidados a fazer uma instalação, segundo ela. E agora eles estão fazendo a sala que vai ser para os artistas, agora eles mudaram de lado. E, se não me engano, a primeira versão da Projects Room deles tinha iluminação natural e o MomA não aceitou. O que estou dizendo é que a instituição é a arquitetura também, o arquiteto não tem essa liberdade toda. É por isso que me interessa essa questão, porque não é como construir um projeto e pensar depois como vai ser usado, eles têm exatamente um script do que eles querem.

CC: Isso é normal.

APP: Não é tão normal assim, às vezes as instituições são mais frágeis, não tem uma visão tão clara sobre como as coisas devem ser. Mas o MoMA tem uma visão muito exata.

CC: É, porque eles têm experiência.

APP: A Pinacoteca, como instituição, 
uma certa sorte. O Octógono foi deixado pelo Paulo [Mendes da Rocha] como um espaço "multiuso", mas não tinha uma ideia muito clara de que ele poderia ser interessante para a arte contemporânea, que parece uma praça etc.

CC: É do Ivo [Mesquita] ou do Marcelo [Araújo] essa ideia de usar para exposição? Porque na época do Emanuel Araújo não era tinha esse programa.

APP: Acredito que ele foi sendo entendido como um lugar interessante para isso, mas não veio da arquitetura, a princípio.

CC: Ele não tinha pensado para isso, mas a arquitetura sugere isso.

APP: O que a arquitetura faz, que eu acho interessante, é deixar uns espaços meio indefinidos. Uns espaços que não se sabe ainda o que vão ser. Enquanto que, quando você loteia demais um projeto, não sobra essa possibilidade. E como não se sabe para onde a arte vai, num museu é muito legal você ter esses espaços meio livres, que não se sabe ainda o que serão, mas que com o uso possam se adaptar a um programa interessante.

cC: Eu concordo totalmente com você, isso é muito mais interessante. Nova York parece um empilhamento de containers. A lógica de Nova York é o seguinte: há uma organização horizontal fixa, com isso a organização vertical é livre. Há um vocabulário, a cidade é compreensível porque tem um grid e os edifícios são todos encostados uns nos outros, como se fossem um monte de containers. Aí a altura é livre, pode variar muito, mas a cidade está estruturada como linguagem. Eu imagino um museu que tenha espaços que possam ser ocupados das mais diferentes formas, acho muito mais legal essa ideia. É o que você está dizendo: existem lá no Palais de Tokyo vinte e tantos mil m2 que vão ser ocupados conforme as coisas forem acontecendo. Ou o que acontece na [Galeria] Pivô - um espaço esquisitíssimo e que justamente por isso é interessante, é ocupado de maneiras distintas. Eu acho muito mais legal isso, ou o Castelo de Rivoli na Itália, em Turim, o antigo L'Orangerie, antes da reforma, que também é um desastre de reforma. É difícil fazer reforma em museu, né? A tendência de piorar é imensa. (risos) Me disseram que o Whitney é flexível, que as paredes andam, não sei se é assim mesmo. E também não acho que isso é necessário, um museu em que tudo se move, não acho que é por aí. Acho que o importante é que o espaço seja interessante.

APP: Um lugar em que tudo move era o Pompidou quando foi feito, que era o anti-palácio, era inteirinho flexível com painéis etc, mas isso rapidamente se mostrou caro, difícil. E aí veio o projeto da Gae Aulenti que criou as salinhas e congelou a parte do acervo. Tinha também muito mais vazios. $\mathrm{E}$ a coleção ainda cresceu muito, virou a segunda maior do mundo - só perde para o мома - e entupiu o prédio. Tanto que eles fizeram o Pompidou Metz, agora tem um braço do Pompidou em Bruxelas, vai ter um em Xangai. Claro, não tem sentido deixar tudo guardado. Para mim surge então uma outra questão: o museu com coleção, no contemporâneo, me parece um problema gigantesco.

CC: Há talvez mais interesse hoje em exposições temporárias do que nos acervos. O museu era um lugar em que você guardava coisas permanentemente para as pessoas irem ver quando quisessem. Mas muitos museus têm mais público quando 
761 http://pinacoteca.org.br/ programacao/situacoes-a-instalacao-no-acervo-da-pinacoteca-de-sao-paulo/

762 https://www.moma. org/explore/inside out/2011/11/o1/sum-of-days/ há exposições temporárias. Claro que museus grandes recebem muitos turistas, têm visitação. Mas, de maneira geral, o que traz vida ao museu é a exposição temporária. Todos os bons museus têm um programa de exposição temporária. No caso dos museus brasileiros, como as coleções geralmente não são tão boas, isso vira uma questão ainda maior, é fundamental um programa forte de exposições temporárias.

APP: É, mas de vez em quando tem umas soluções felizes. Por exemplo, aquele projeto de arte contemporânea da Pinacoteca sobre instalações e acervo. Lembrei do trabalho da Carla Zaccagnini, ${ }^{761}$ em que ela refletia a imagem de um quadro do Almeida Júnior, exposto no andar do acervo, e ia jogando esses reflexos pelo museu com uma série de espelhos até chegar no Octógono, onde tinha um espelhinho pequeno, e a partir de um certo ponto você via o quadro do acervo pelos vários reflexos. É uma maneira de relacionar o acervo com o trabalho atual, achei fantástico esse trabalho. É possível fazer essas relações.

CC: É possível, a Pinacoteca é um exemplo disso. A coleção original da Pinacoteca é de arte brasileira do século XIX e a arte brasileira desse período não é excepcional. A coleção em si é boa, mas a arte não é tão boa. É o que foi feito à época, é importante que seja mostrado, mas não é transcendente. A Pinacoteca soube dar vida à essa coleção fazendo outras coisas que tornam o museu inteiro vivo.

APP: Inclusive eles têm planos de reformar o prédio da escola para projetos de arte contemporânea.

CC: Eu sei, vai ficar muito bom.

APP: Voltando ao seu trabalho, gostaria de discutir um ponto levantado por você, sobre o convite ter sido "uma oportunidade para refletir sobre o modo como o trabalho existe independentemente do seu contexto, observando o que permaneceria igual e o que se transformaria no novo lugar."762 CC: Eu não me interesso muito pela ideia de site specific. Eu acho que os trabalhos devem sempre ser confrontados com sua condição. Eles podem e devem viajar. Eu não acho que o trabalho precisa formar uma unidade indissolúvel com o lugar, acho que o trabalho atua muito contra o lugar, em atrito com o lugar ou em tensão com o lugar. O que me interessa é justamente essa transformação de um espaço com a instalação do trabalho. O trabalho do Moma podia ser visto de longe, na Pinacoteca não. Isso era uma novidade para mim. Era uma relação diferente do que na Pinacoteca - o ruído era diferente, a luz era diferente, a luz lateral era totalmente diferente. Teve um monte de coisas que mudaram por conta da mudança de lugar. O interesse era esse, claro.

APP: Eu fico imaginando que, na visita do pessoal do Moмa ao seu trabalho, eles teriam lembrado do espaço que eles têm lá - um espaço que é difícil de ocupar, que teve muitas coisas que não deram certo, segundo relatos -, e que tinha uma similaridade com o da Pinacoteca. Você tinha $14 \mathrm{~m}$ de altura na Pinacoteca e 2om no Moma. Pensando bem objetivamente: e se você tivesse 10, 8, 7, 6m? Em que momento o trabalho deixaria de fazer sentido com relação às características físicas de um lugar?

cc: Tem isso, claro. Os espaços eram diferentes, mas eles eram suficientemente semelhantes para que você pudesse tentar tensionar uma coisa com a outra. Num outro espaço - por 
exemplo, na igreja da Bahia e no Paço Imperial -, seria um outro desenho. APP: É que você chamou os trabalhos com o mesmo título - A Soma das horas e Sum of days.

CC: Nos trabalhos da Bahia e do Rio também tinha o mesmo título, Apagador, porque eles mantinham a ideia de um espaço que era apagado. Nos trabalhos da Pinacoteca e do MoмA havia essa ideia de acumulo, da experiência ir somando. Estar num lugar e se perder desse lugar - não há horizonte, ver é imaginar. As pessoas me diziam que tinham visões religiosas, ouviam sons, lembravam-se de coisas. O TNT fica se movendo, não é propriamente uma parede, ela se move e de certa forma não está lá. A luz escorre pelo tecido, ele fica iluminado, há uma luz emanada por aquele plano que se move. Quando se está dentro do espaço, há mais luminosidade do que fora. Você está indo para um lugar mais luminoso. Isso era uma grande diferença em relação ao trabalho da Pinacoteca, que tem aquela luz muito forte, uniforme, que já é do espaço.

APP: Mas o trabalho tem um núcleo toda essa experiência com o som você pode reproduzir, a espiral você conseguiu reproduzir. Mas o atrito com o prédio, claro que não, porque cada espaço tem as suas características.

CC: $\mathrm{O}$ atrito com os espaços era muito diferente, principalmente pela questão da luz, a luz da Pinacoteca e a luz de lá. No Moma eu coloquei muito mais luz, coloquei uma quantidade absurda de luz. Isso transformou o lugar, enquanto que na Pinacoteca a luz era natural. Tinha até umas barras de luz, mas de dia elas não modificavam o espaço.

APP: Nas fotos das duas montagens chama a atenção o grid dos tetos
- a claraboia da Pinacoteca e o forro modulado do MOMA -, porque o grid contra a espiral tem uma presença. Achei curioso que, por acaso, os dois tinham essas características.

CC: É a arquitetura moderna, não é por acaso. Mas a pergunta que você fez é: até que ponto um trabalho é site specific e essa é a questão que me interessa. O trabalho é site specific quando ele não pode ser retirado, como aquela coisa do Serra, que se tirou não funciona mais.

APP: Mas não é sempre assim, por exemplo, com as elipses. ${ }^{763}$

CC: Sim, estou falando daquela briga da obra do Federal Plaza. ${ }^{764}$ Esse é o argumento que ele usou ali. Aquele mesmo trabalho não poderia funcionar num outro lugar, seria um outro trabalho, do ponto de vista dele. $\mathrm{O}$ argumento dele era que o fato de a cidade comprar a obriga a respeitar a obra e deixá-la onde foi concebida. Tirá-la de lá seria um desrespeito à liberdade de expressão do artista. Porém o significado da arte não está dado, ele depende de quem vê o trabalho, ele não é uma coisa fixa. Os trabalhos mudam de lugar ou de condição e permanecem tendo uma espécie de integridade que é deles. Há no classicismo uma ideia de que o ápice do trabalho é ser ruína. No Louvre, há duas pinturas feitas pelo arquiteto que adaptou o palácio para ser museu, há 200 anos. Ele fez uma pintura do Louvre pronto de acordo com o seu projeto, e uma outra do Louvre em ruína, com um escravo do Michelangelo meio quebrado. A impressão que se tem é que só como ruína o museu chegaria à plenitude.

Talvez o modernismo seja o oposto disso: ele é incapaz de envelhecer. Lida mal com o tempo. O Memorial da
763 As esculturas da série Torqued Ellipses começaram a ser realizadas por Richard Serra no final dos anos 1990.

764 A escultura Titled Arc foi instalada na Federal Plaza de Nova York em 1981 e removida em 1989, após uma intensa disputa judicial. 
América Latina está sujo, é uma ideia espantosa um edifício precisar ser pintado de branco incessantemente. Muitos dos edifícios modernistas precisam de manutenção permanente porque devem permanecer pristinos, não lidam bem com o desgaste, ambicionam estar fora do tempo. Mais recentemente isso mudou. Mesmo no trabalho SANAA, onde tudo é límpido, a carga simbólica é forte. Com o Frank Gehry ocorre o mesmo, ele cria uma situação insólita, uma experiência única. A Cidade da Música no Rio, onde você trabalhou na construção, eu acho um prédio muito bonito. Apesar do lugar errado, da escala errada e os mil problemas que ele tem, em si ele é magnífico.

APP: Um dos aspectos que me interessa estudar na arquitetura dos espaços de arte é a relação com a visão institucional, curatorial, especialmente nos casos em que a instituição tem voz. De que maneira isso impacta a arquitetura durante o projeto e após, durante o uso. Quais exigências a instituição faz com relação à ocupação dos espaços.

CC: O MомA faz essas exigências porque ele tem experiência. Quando eu conversei com eles, eles falaram de cara: "a visitação é um problema, a gente tem que pensar nisso. A gente não quer fila."

APP: Mas teve fila no final, né?

CC: Mas não era uma fila gigante, apesar de ter muita visitação. A visitação é uma questão complexa, porque é muita gente. Então, se você não tiver um controle de entrada, aquilo vira um caos, não funciona, para de funcionar, porque o trabalho tem uma capacidade de receber um número de pessoas, existe um teto. Por isso é que a gente tirou a entrada da frente, para dar uma dissolvida no público. A entrada era por trás, então já virava uma sala como as outras, que tem vários acessos etc. Funcionou, deu para ter essa visitação muito alta, tinha fila, mas não era uma coisa insuportável. E eu fiquei contente, porque foi possível, o trabalho aguentou o tranco.

APP: Foi uma prova de fogo!

CC: Foi. Meu medo era que rasgasse. E isso não tem como saber, se vai resistir ou não. Eu acho que não rasgou porque era tão leve que o TNT cede, ele não opõe nenhuma resistência. Com isso eu acho que ele não gasta tanto, o atrito não é tão forte assim, porque ele é muito leve. Mas ele se desgastou. Quando a gente desmontou, a condição do tecido mostrava que ele tinha passado por uma prova, você via ele todo meio ralado.

Em relação ao que você falou, do site specific, eu não tenho dúvida. É interessante, por exemplo, esses trabalhos dos postes de madeira. ${ }^{765} \mathrm{Eu}$ fiz aqui e depois fui convidado para fazer na Coréia. Era o mesmo trabalho num espaço muito diferente e ficou bem diferente por que fiz outras coisas, era um pouco mais oriental, era mais desenho, menos pesado. E também tinha o mesmo nome, Sala de espera. É legal você fazer isso, você vê como o trabalho muda em situações diferentes. Acho uma coisa positiva, um desafio interessante.

APP: Tem alguns tipos de trabalho que não tem isso, por exemplo alguns vídeos, que têm mais independência com relação ao espaço.

CC: Essa autonomia começa com a invenção da pintura a óleo. Havia a pintura que era feita na parede e que ficava presa na parede. Há pinturas em encáustica romanas e também no Egito, mas são obras funerárias. A
765 Sala de Espera, realizado no MAC Ibirapuera em 2014. 
pintura a óleo pode ser mercadoria, ela pode viajar, ser vendida e circular. É o que permitiu que o artista que trabalhava só para a igreja pudesse fazer obras que fossem vendidas para burgueses, para nobres, o que deu autonomia para o artista. Há essa questão da arte que circula e da arte que não circula. A instalação é, de certa maneira, uma arte que não circula. Muitas das coisas que eu faço tem essa condição, porque elas não entram pela porta do prédio. Você fica olhando e perguntando "como é que isso veio parar aqui? ". Ele é maior do que a entrada, parece aquela coisa "já estava aqui quando eu cheguei”, "já era assim antes". Então aquilo não é mais um objeto comercializável, é interessante desse ponto de vista. Tem uma coisa bacana que a instalação está propondo uma experiência e não uma coisa que você possa levar com você. Isso é uma maneira de enfrentar toda essa questão comercial. Agora, isso também acontece num circuito institucional, quer dizer, você não está livre das estruturas de poder, porque tem alguém que está pagando essa conta. Eu fiz muita coisa por minha conta, muitas vezes eu paguei para fazer o trabalho, mas sempre há uma estrutura que está te oferecendo um espaço. APP: Expor no MoмA é sempre um acontecimento, traz prestígio e visibilidade. Isso teve um impacto na sua carreira? Como é que você sentiu isso? cc: Claro, enorme, expus no мома. Veio a Sonnabend - uma galeria de Nova York -. Depois fiz isso, fiz aquilo. Abre muitas portas. Também acho que para mim mudou porque eu tive uma experiência plena, com esses trabalhos todos, do que é possível fazer. Eu tenho hoje em dia muita confiança, eu sei o que dá para fazer e o que não dá. Boa parte dessa experiência foi no Brasil, expondo em lugares tombados, você conseguir lidar com condições complicadas. Tem uma coisa no Brasil, que as dificuldades também abrem possibilidades que não existem em outros lugares. A gente acaba tendo coragem. Você chama o cara, ele está de sandália havaiana, com camisa de time de futebol. A flexibilidade que a precariedade traz abre muitas possibilidades interessantes de você fazer coisas que depois te dão coragem de propor. Você ganha muita fé no taco - isso vai dar para fazer, isso vai ficar bom.

APP: Você sentiu na pele a questão do endosso da instituição?

CC: É, é muito raro alguém expor lá assim, então há esse endosso. O que eu acho que acontece comigo é que é o trabalho que traz essas experiências. A exposição do MAC também teve um impacto muito grande. Eu acredito que se você tem condição de trabalhar, é só isso que é necessário. A verdadeira liberdade do artista é poder trabalhar. Essa é a liberdade que você quer. APP: E a instituição é necessária. cc: A gente está em uma sociedade que é capitalista. O museu, quando é formalmente particular, como o MASP, o MAM de São Paulo ou o MAM do Rio, entre outros, é patrocinado por pessoas e empresas que têm dinheiro e portanto é um lugar onde os interesses são conflitantes. Nos museus públicos há também outros conflitos. No fundo todo museu é público, no sentido de que atende a um público, tem função pública. As instituições refletem essa condição da arte, que se propõe a ser uma coisa renovadora, revolucionária, mas que está numa estrutura ligada aos interesses econômicos, públicos e particulares. Porém há frestas nessas estruturas. Um grande empresário 
766 No ano de 1976, antes da reforma de César Pelli.

767 Performance Rio, realizada em 2014 no jardim de esculturas do MOMA de Nova York, baseada no texto "Meu doce rio", de Lygia Clark, escrito em Paris, 1975. Cf. Web site do artista. Disponível em <https:// carlitocarvalhosa.com/ expos/149>. Acesso em 01 jul 2021. também pode ser uma pessoa interessante. Cada experiência tem um valor em si, a tensão entre interesses faz com que as coisas se movimentem. $\mathrm{O}$ lado positivo de uma sociedade como a nossa é que existem muitas aberturas nesse sistema. Existem muitos caminhos, existem muitos descaminhos, há muitas coisas que podem ser feitas. A burguesia tem que assumir o papel dela. Foi o que ocorreu no MASP, foram lá, "nós vamos cuidar desse museu, vamos dar um jeito nisso daqui”, e foi muito positivo. Aí você fala: "Ah, mas é um monte de gente rica querendo aparecer", mas o artista também quer aparecer, a questão não é essa. A questão é que você tem gente que poderia estar colecionando cavalo e que está fazendo uma coisa mais interessante, ou que também é interessante. Cavalo também é legal, não sei. Ninguém sabe direito o que está acontecendo. Muitas vezes olho o mundo a partir de uma formação marxista, mas o mundo mudou muito, talvez esse prisma não seja mais suficiente ou adequado para se entender o que se passa.

APP: E a arte não está isolada, ele está totalmente dentro disso.

CC: A arte sempre existe, mesmo nos países autoritários a arte existe. Um dos ápices da música brasileira é durante a ditadura do Médici. De 70 a 75 , a quantidade discos e shows maravilhosos nesses cinco anos é inacreditável. Na ditadura militar! Uma barra pesada, um ambiente horroroso, mas as coisas estavam acontecendo.

APP: De que maneira sua experiência como visitante no Moma teve impacto na sua formação como artista? Você lembra da primeira vez em que você esteve lá?

CC: Bem, é o maior museu de arte moderna do mundo. Eu lembro exatamente da primeira vez em que eu fui. Você entrava e tinha o mapa dos Estados Unidos do Jasper Johns na parede à esquerda. A escada ficava logo depois que você entrava. Você subia a escada - que era linda - e a parte de pintura começava no Cézanne, no primeiro andar, com o banhista, e ia embora naquela sequência que refletia a leitura deles sobre o modernismo. Tinha uma sala do Matisse que era separada com uma janelinha e um banco grande. Eu tinha 15 anos, foi quando eu fui fazer intercâmbio. ${ }^{766} \mathrm{Eu}$ lembro exatamente como era o museu. Era muito simpático, por que era um prédio bem menor, era um ambiente muito mais íntimo. Muito menos gente, outra escala, não era essa escala do museu atual, a coisa das escadas rolantes, é engraçado, eu acho que há uma referência muito forte de loja.

APP: Pode ser de metrô também.

CC: É, mas não do jeito que está colocado lá. Poderia ser, você tem razão, seria mais interessante. Por exemplo, no Beaubourg a circulação com escadas rolantes é colocada de uma maneira legal, por fora, é muito sacado aquilo. Você vai subindo e vendo a cidade, mudando de posição, maravilhoso. Então, isso, por exemplo, o MomA não explorou, poderia ter explorado. A relação com a cidade eu acho que foi piorando ao longo do tempo. A escala do museu com o jardim também era muito harmônica, agora o jardim ficou pequeno para o tamanho do museu. O jardim era muito presente.

APP: E aquela performance que você fez no jardim, o trabalho Rio? ${ }^{767}$

CC: É, aquilo foi muito importante para mim, pois era uma abertura diferente do meu trabalho, mais imaterial, há 
somente uma fita impressa com 400 metros de comprimento, cabia numa caixa pequena. $\mathrm{O}$ importante era como as falas iam ocupando o espaço, como um rio. Deu muito certo, eu tive muita sorte com os dias de sol - era o maior problema se chovesse. Podia chover, mas não choveu, fizeram dois dias lindos, que era básico. $\mathrm{E}$ as pessoas se engajaram. Tinha bastante conhecidos, tinha uma equipe, que eram umas 10 pessoas, mas o resto eram pessoas que estavam lá e era bastante gente. As pessoas entraram na onda, foi muito legal.

APP: Lembra de algum trabalho mais recente de arte contemporânea, de instalações, expostos no мома que tenham sido marcantes pra você?

APP: De instalação? Essa exposição do Bruce Naumann é muito boa, que está tendo agora lá.

APP: Mas essa é histórica, estou falando de artistas vivos.

CC: Ah! Novas, recentes? No MoMA não me lembro. Porque eu acho que é o que você falou.... No PS1, eu vi várias instalações interessantes.

APP: O PS1 é um espaço interessante, mas ele é muito compartimentado. Salas de aula em sequência, com pé direito básico.

CC: Tem umas salas grandes também. Eu acho espetacular. Eu acho tudo legal lá. A memória de que era uma escola, que aparece nas paredes, nas portas, nos corredores e escadas.

APP: O Palais de Tokyo foi muito inspirado no projeto do PS1.

CC: O PS1 me lembra uma coisa que tem muito na Europa, como o Witte de With em Rotterdam. São prédios que eles adaptam e que guardam a sua história - eu acho muito bacana. Estou lembrando de uma instalação no PS1 do Adrián Rojas, que fez uma exposição linda na Serpentine. Ele faz umas peças gigantes de argila. Ele fez uma escada que no topo tinha umas peças de argila, grandes. ${ }^{768}$

APP: Quando chega num lugar, você fica pensando? (risos)

CC: Claro, você não fica?

APP: Eu fico! Eu fico projetando as reformas dos museus. (risos) CC: Eu fico pensando! (risos)
768 http://www.momaps1. org/expo1/module/adrian-villar-rojas/ 


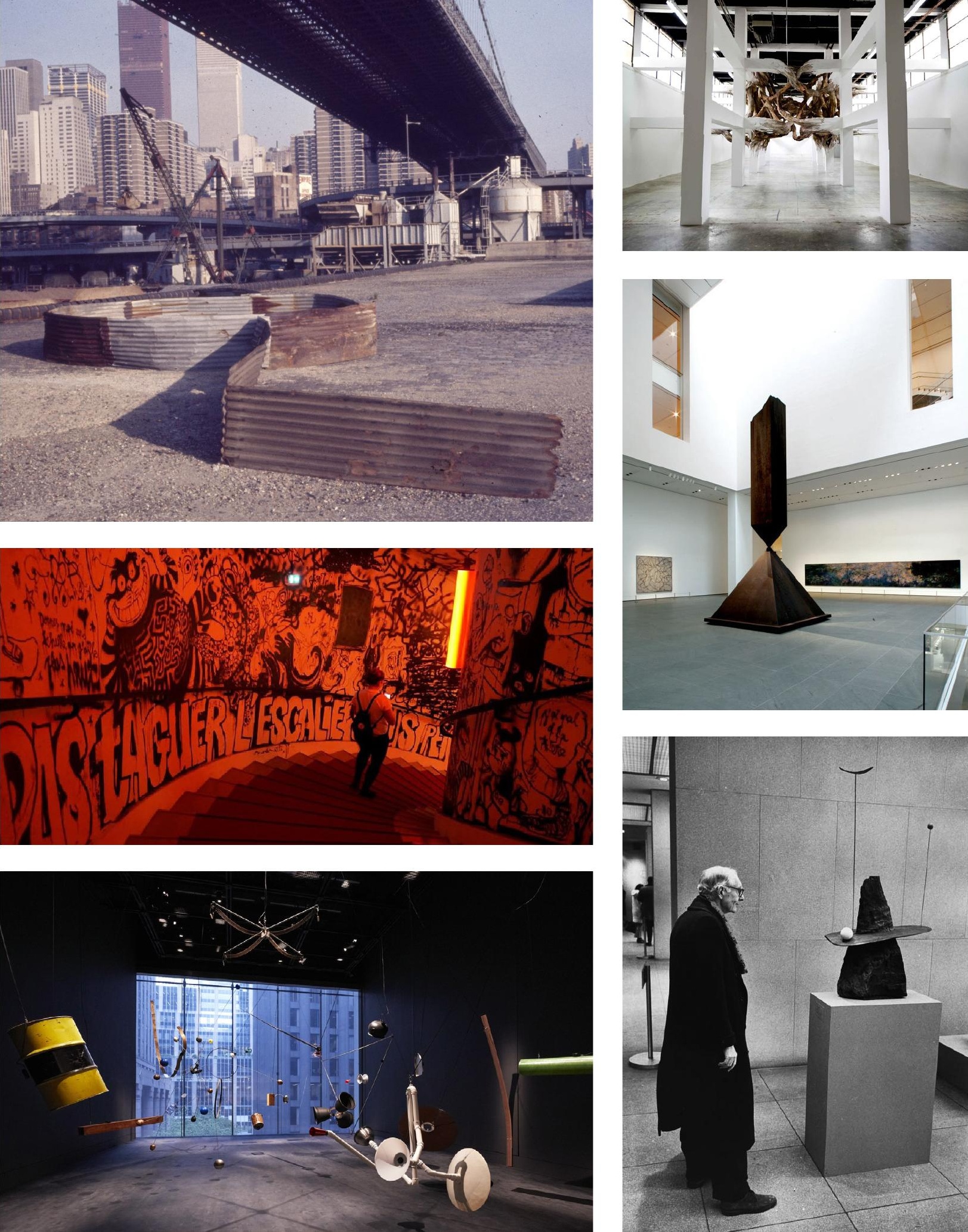

